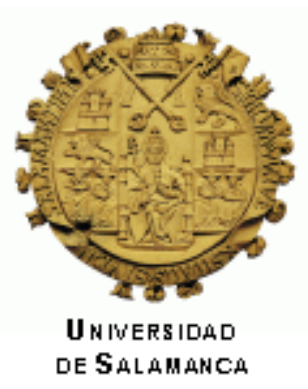

Facultad de Geografía e Historia

Departamento de Historia Medieval, Moderna y Contemporánea Área de Historia de América

\title{
Élites y grupos de poder: \\ Los Hacendados de Santo Domingo (1750-1795)
}

\section{TESIS DOCTORAL}

Ruth Torres Agudo

Directora: Dra. Izaskun Álvarez Cuartero 

La presente Tesis Doctoral ha sido elaborada por Ruth Torres Agudo, bajo la dirección de la Dra. Izaskun Álvarez Cuartero, profesora del Área de Historia de América, en el Departamento de Historia Medieval, Moderna y Contemporánea de la Universidad de Salamanca, con el objetivo de obtener el título de Doctora por la Universidad de Salamanca.

La Directora, La Doctoranda,

Salamanca, Septiembre de 2008. 



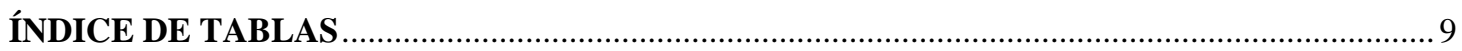

ÍNDICE DE GRÁFICOS, PLANOS, MAPAS Y FIGURAS .......................................................... 11

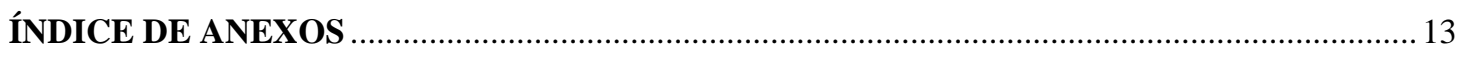

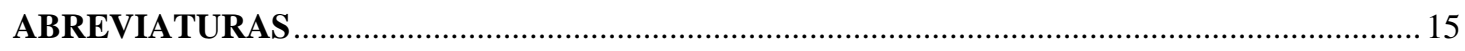

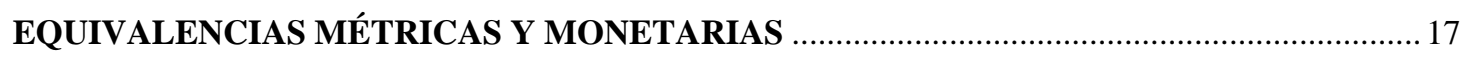

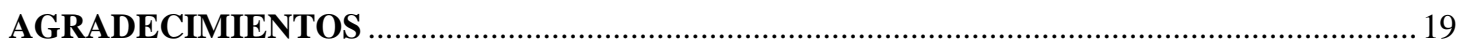

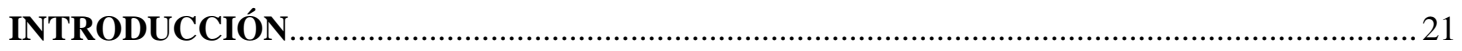

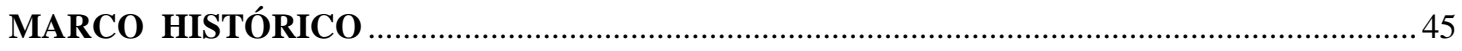

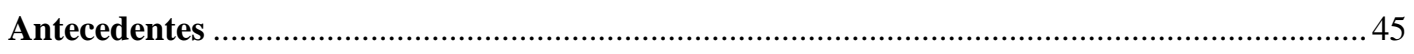

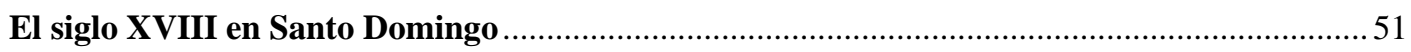

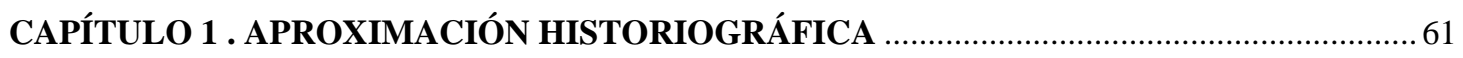

1.1. Historiografía sobre élites en América colonial ................................................................... 61

1.2. Élites en la República Dominicana ................................................................................... 81

CAPÍTULO 2 . EL GOBIERNO POLÍTICO EN SANTO DOMINGO ………………………….... 97

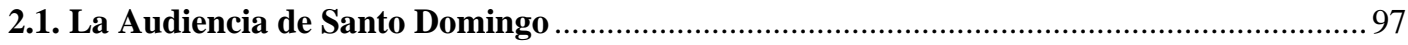

2.1.1. Fundación y marco territorial...................................................................................... 98

2.1.2. La figura del Presidente, Gobernador y Capitán General ........................................ 100

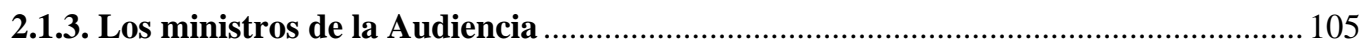

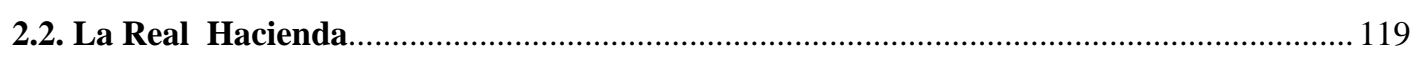

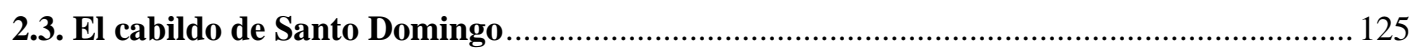

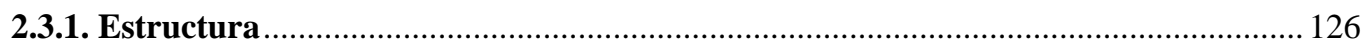

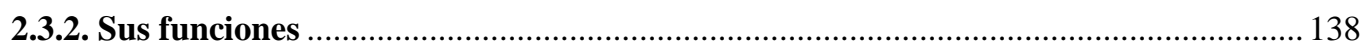

2.3.3. Acceso al cabildo: Antecedentes ……………………........................................... 142

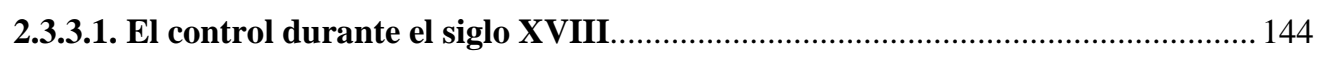

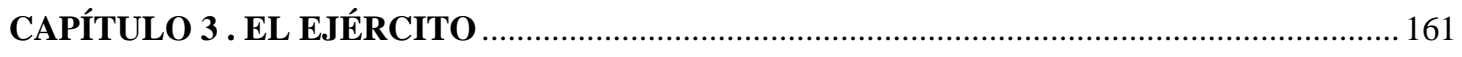

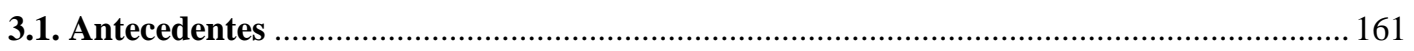

3.2. La guarnición militar de Santo Domingo en el siglo XVIII ............................................ 164 


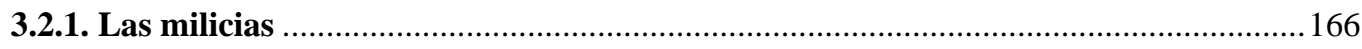

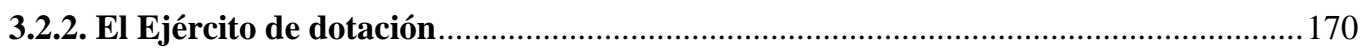

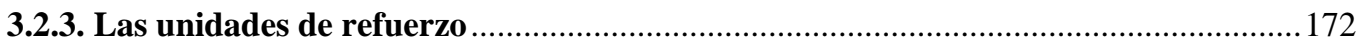

3.3. La oficialidad del Ejército …………............................................................................. 173

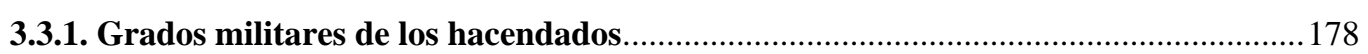

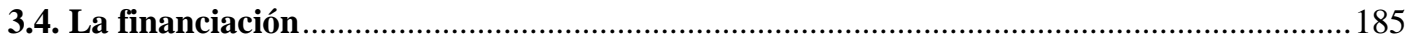

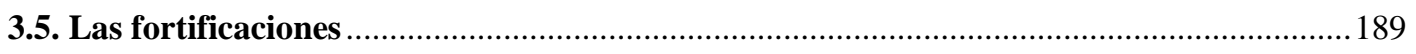

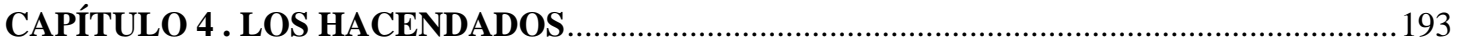

4.1. Orígenes sociales y geográficos de los hacendados............................................................193

4.2. Fórmulas de ascenso e integración de los inmigrantes peninsulares...................................196

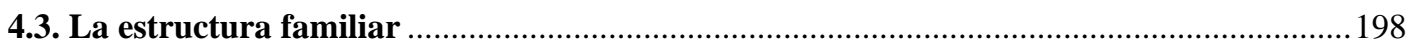

4.3.1. El camino social y profesional de los hijos e hijas .......................................................20

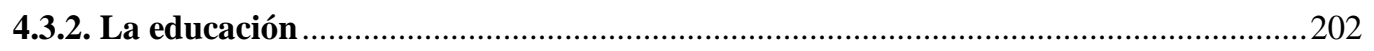

4.3.3. La carrera profesional ..............................................................................................209

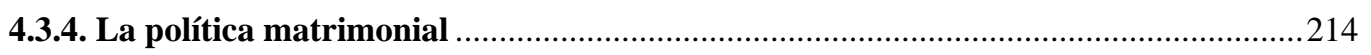

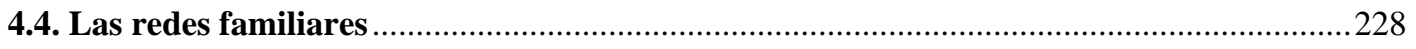

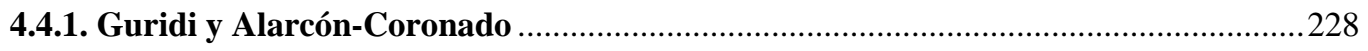

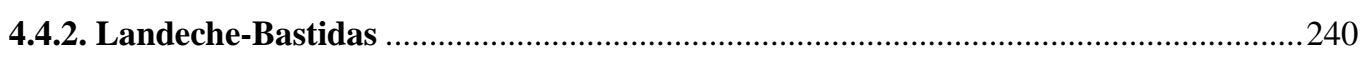

4.4.3. Castro-Rivera y Urdaneta ………………………............................................... 247

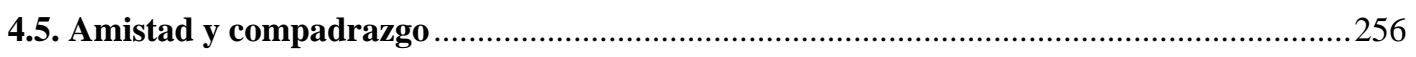

4.5.1. Relaciones de privilegio con la alta administración y la Corte...................................270

4.5.2 Actividades profesionales y asociación económica: la Sociedad de Hacendados.......281

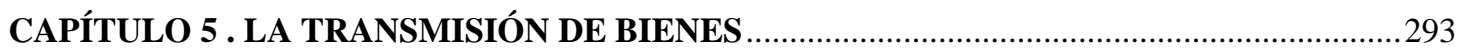

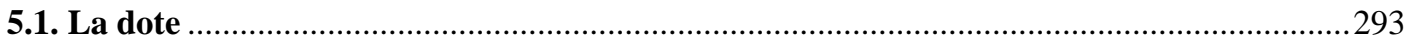

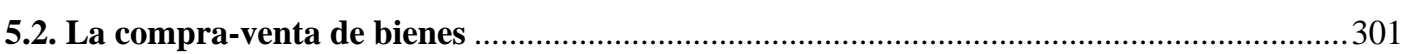

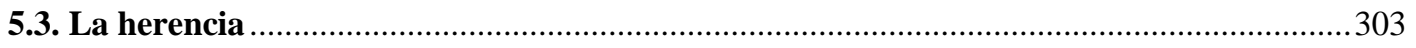

5.3.1. Consecuencias de las transferencias por herencia ........................................................307

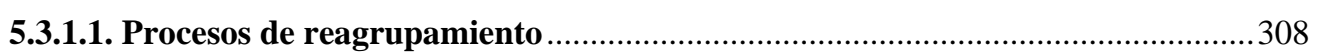

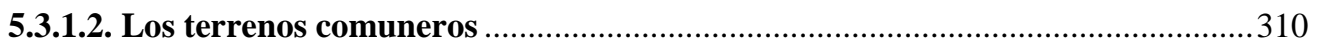

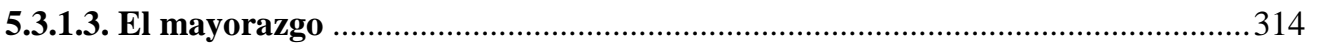

CAPÍTULO 6 . EL ESTILO DE VIDA DE LOS HACENDADOS …………………….................325

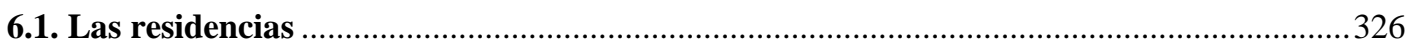

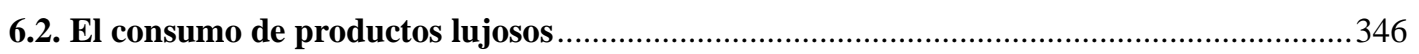

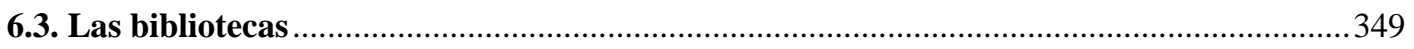

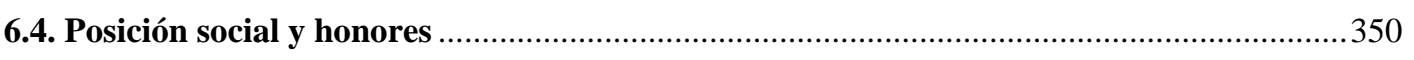

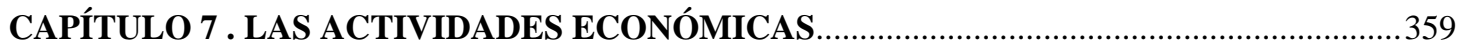

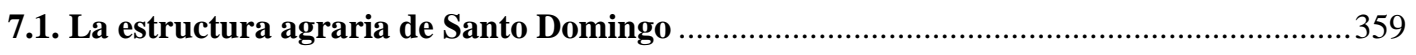




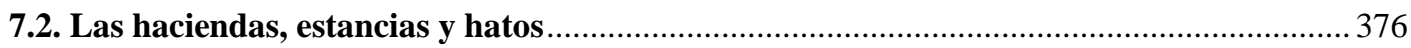

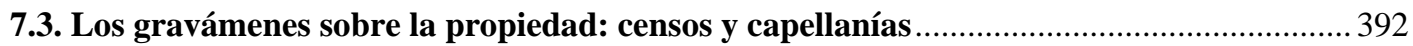

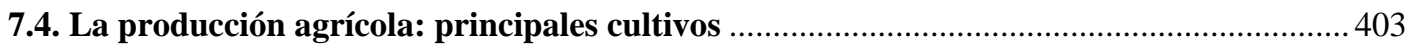

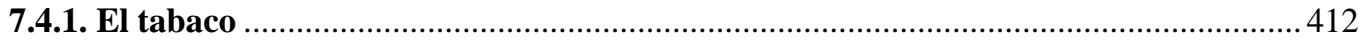

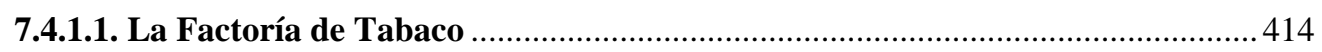

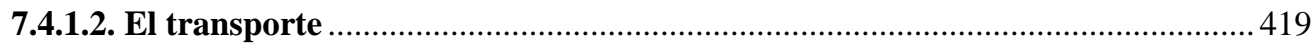

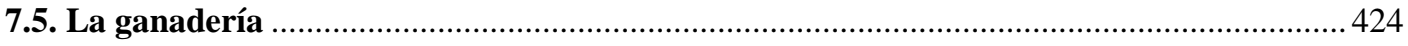

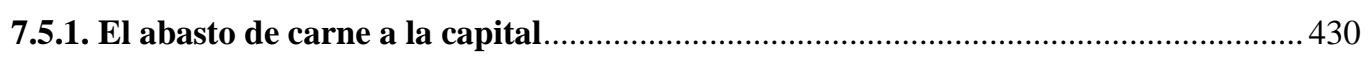

7.5.2. El comercio con Saint Domingue ............................................................................. 437

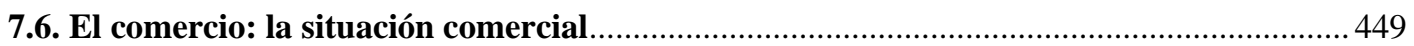

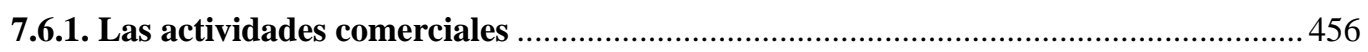

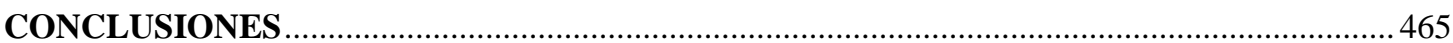

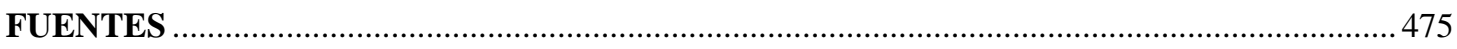

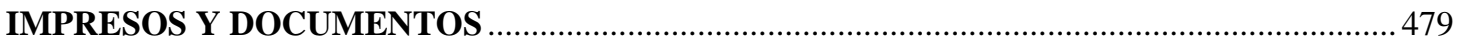

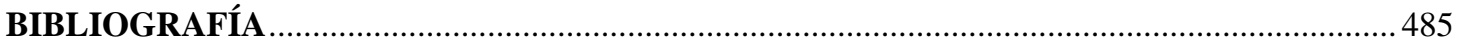

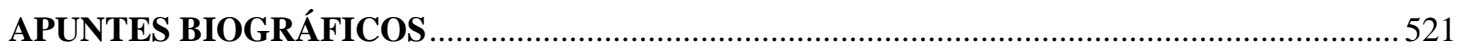

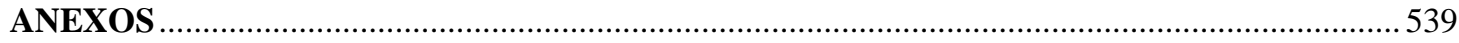





\section{ÍNDICE DE TABLAS}

Tabla 2-1. Relación de Tenientes de rey, 1748-1795

Tabla 2-2. Tiempo en el que José de la Vega estuvo como secretario de la Capitanía

General 104

Tabla 2-3. Relación de alcaldes mayores entre 1750 y 1795 110

Tabla 2-4. Estado de la Audiencia de Santo Domingo, 1771 .....................................................117

Tabla 2-5. Relación de los empleos políticos de la Audiencia de Santo Domingo, 1783 .............118

Tabla 2-6. Estado de las Cajas Reales de Santo Domingo y sus salarios, 1778 ..........................120

Tabla 2-7. Relación de los empleos de la Real Hacienda, 1783 ............................................... 124

Tabla 2-8. Estado de las cajas reales de Santo Domingo y reforma propuesta, 1787 ..................125

Tabla 2-9. Relación de los alcaldes del cabildo de Santo Domingo, 1751-1779...........................128

Tabla 2-10. Relación de alcaldes ordinarios del cabildo de Santo Domingo, 1780-1795 .............130

Tabla 2-11. Relación de alcaldes de visita, 1751-1767 .................................................................134

Tabla 2-12. Relación de los regidores nombrados por los gobernadores en calidad de

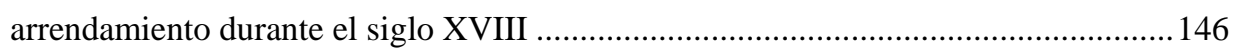

Tabla 2-13. Liquidación de lo que deben los regidores por su arrendamiento ..............................150

Tabla 2-14. Parentesco entre los regidores del cabildo de Santo Domingo ................................153

Tabla 3-1. Sueldos de una Compañía de milicias de infantería, 1775........................................168

Tabla 3-2. Sueldos del Regimiento de infantería y de una Compañía de artillería, 1771..............171

Tabla 3-3. Relación de los cargos y sueldos de los empleos del estado de la plaza de Santo Domingo, 1783.

Tabla 3-4. Grados militares de los hacendados de Santo Domingo, y sus familiares 180

Tabla 4-1. Relación de los grados universitarios y profesión de algunos hacendados y sus familiares. 205

Tabla 4-2. Matrimonios consanguíneos de algunos miembros de las redes familiares

Guridi y Alarcón-Coronado y Landeche-Bastidas

Tabla 4-3. Estado de cobranza de los créditos activos de la testamentaria de Raymundo

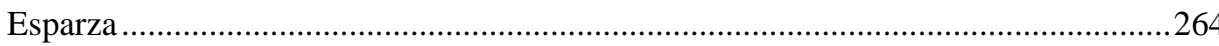

Tabla 4-4. Sociedad de Hacendados, 16 de abril de 1793.

Tabla 4-5. Socios de la Real Sociedad Bascongada de los Amigos del País en Santo

Domingo, 1784-1793 291

Tabla 5-1. Composición y valor de algunas dotes..... 297

Tabla 5-2. Transmisión de la tierra por herencia y recomposición del terreno heredado...............310

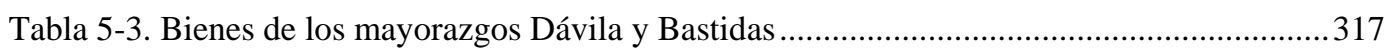

Tabla 6-1. Casas de hacendados en la ciudad de Santo Domingo ...............................................331

Tabla 6-2. Valor de las residencias de algunos hacendados en Santo Domingo ..........................336 
Tabla 7-1. Ingresos realizados en las Cajas Reales de Santo Domingo entre 1769 y $1773 . . . . . . . . . .367$

Tabla 7-2. Propiedades adquiridas por Francisco Espaillat y Virol, 1761-1786 ..........................374

Tabla 7-3. Composición de las haciendas del Marqués de Iranda ...............................................383

Tabla 7-4. Composición de los hatos de Francisco Espaillat y Virol ..........................................390

Tabla 7-5. Relación de gravámenes sobre el ingenio Santa Ana de Engombe .............................400

Tabla 7-6. Relación del valor de las fincas de José de la Vega y sus gravámenes ........................401

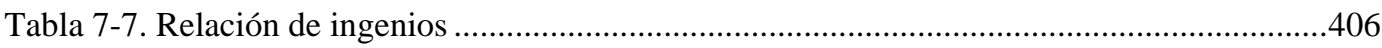

Tabla 7-8. Empleados en las Factorías de Tabaco y sueldos, 1790 ..............................................418

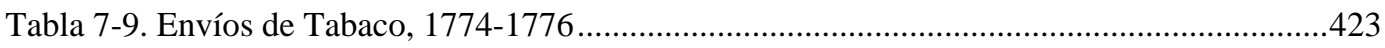

Tabla 7-10. Coste del transporte del tabaco, 1778 y 1779.........................................................424

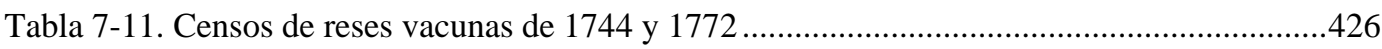

Tabla 7-12. Relación del número de reses consumidas en la ciudad de Santo Domingo en 1782 .432

Tabla 7-13. Resguardo de la isla planificado por el gobernador Manuel Azlor y Urríes 440

Tabla 7-14. Relación de resguardos realizados por los gobernadores Manuel González y Joaquín García .448

Tabla 7-15. Recaudación líquida en concepto de alcabala, 1793-1797 453 


\section{ÍNDICE DE GRÁFICOS, PLANOS, MAPAS Y FIGURAS}

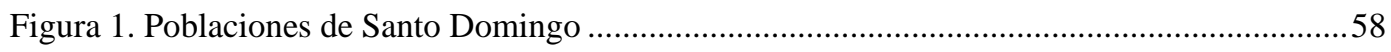

Figura 2. Mapa de provincias de la República Dominicana ......................................................59

Figura 3. Mapa actual de la República Dominicana................................................................60

Figura 2-1. División de la ciudad de Santo Domingo en cuatro cuarteles, 1786............................132

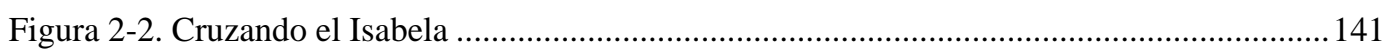

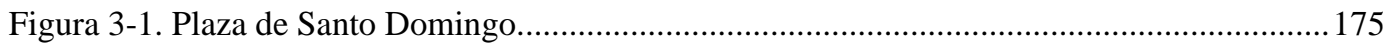

Figura 3-2. Cuantía de los situados recibidos y sus correspondientes gastos entre 1706 y

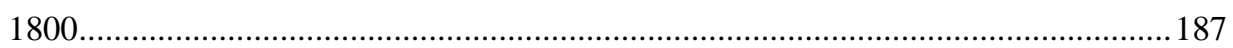

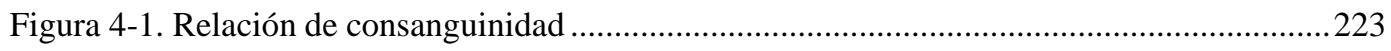

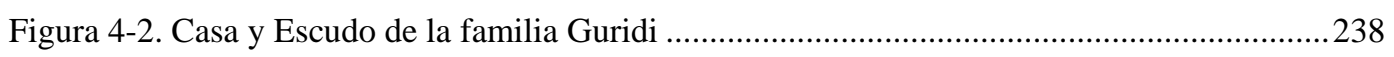

Figura 4-3. Red familiar Guridi y Alarcón-Coronado …………………………………….........239

Figura 4-4. Red familiar Landeche - Bastidas...........................................................................246

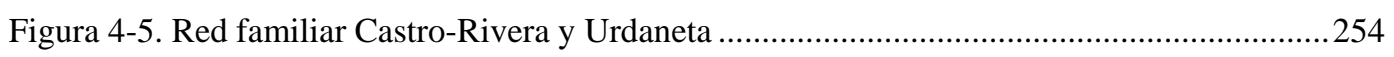

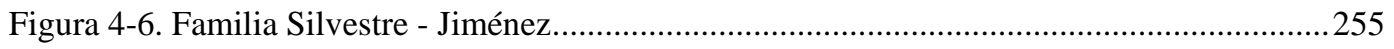

Figura 4-7. Red Social de Raymundo Esparza entre 1766-1786 ...................................................278

Figura 4-8. Red Social de Simón Aragorri y Olavide ...................................................................28

Figura 5-1. Transmisión de los mayorazgos Dávila y Bastidas......................................................321

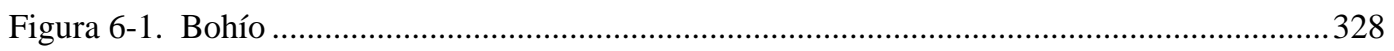

Figura 6-2. Plano de la ciudad de Santo Domingo y localización de las residencias de

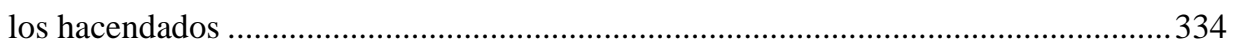

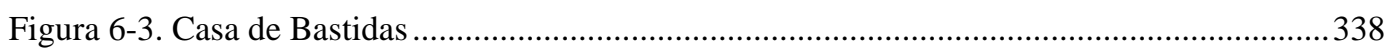

Figura 6-4. Templo privado y escudo nobiliario de los Dávila .......................................................340

Figura 6-5. Residencia rural de Palavé........................................................................................ 342

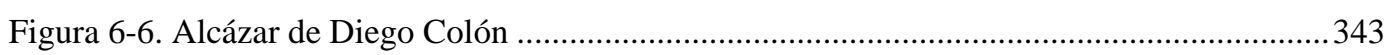

Figura 6-7. Plano de la casa de Engombe................................................................................. 344

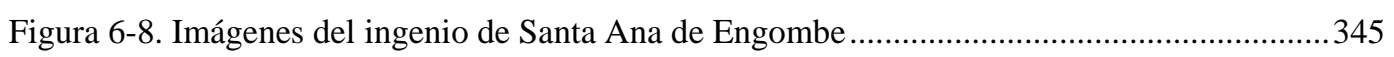

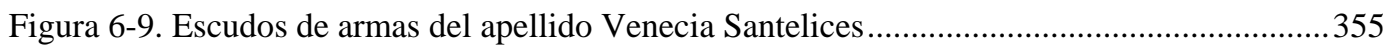

Figura 7-1. Distribución de actividades económicas.......................................................................361

Figura 7-2. Croquis del ingenio Santa Ana de Engombe y alrededores .......................................379

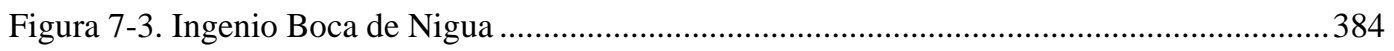

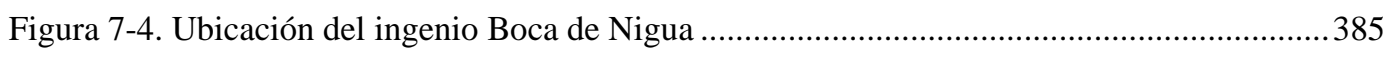

Figura 7-5. Transporte del tabaco en recuas hacia Santiago ........................................................421

Figura 7-6. Distribución del Diezmo .....................................................................................428

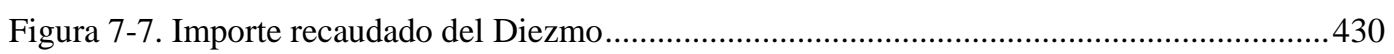

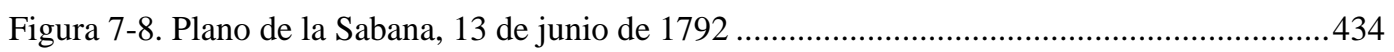




\section{ÍNDICE DE ANEXOS}

Tabla 1. Relación de Presidentes, Gobernadores y Capitanes Generales de Santo

Domingo, 1751-1795 539

Tabla 2. Relación de los escribanos que existen en 1767 ..........................................................541

Tabla 3. Origen geográfico de los hacendados de Santo Domingo ...............................................542

Tabla 4. Origen geográfico de los padres de los hacendados criollos .......................................544

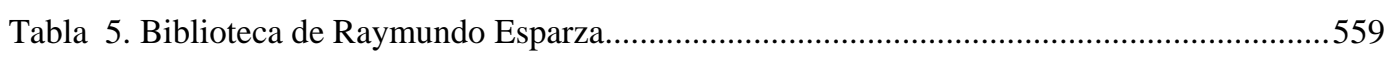

Tabla 6. Biblioteca de Ramón Jover .......................................................................................562

Tabla 7. Inventario de las haciendas de José Guridi y Concha, 1773-1774 ................................569

Tabla 8. Inventario de las haciendas de Lorenzo Angulo Medrano, 1795 .................................581

Tabla 9. Inventario de las haciendas de Francisco Espaillat y Virol, 1787 .................................586

Tabla 10. Inventario de las haciendas de José de la Vega, 1805 ...............................................590

Tabla 11. Relación de licencias de víveres concedidas por el gobernador Manuel Azlor

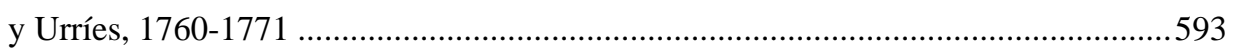

Figura 1. Cronograma de la red familiar Guridi y Alarcón-Coronado .........................................545

Figura 2. Cronograma de la red familiar Landeche - Bastidas (1) ...........................................546

Figura 3. Cronograma de la red familiar Landeche - Bastidas (2) ..............................................547

Figura 4. Cronograma de la familia Campuzano - Polanco......................................................548

Figura 5. Familia Campuzano - Polanco ….........................................................................549

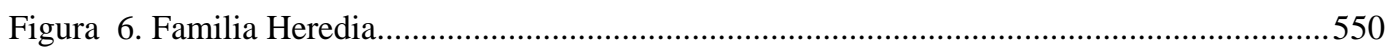

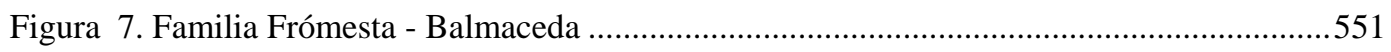

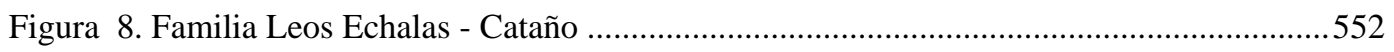

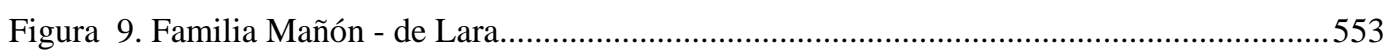

Figura 10. Familia Pérez-Caro y Guerrero ............................................................................554

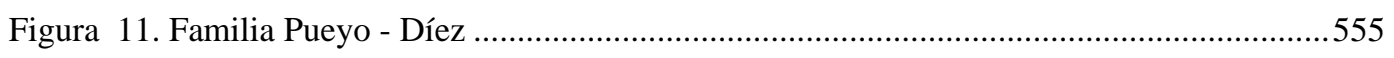

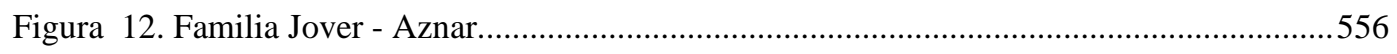

Figura 13. Familia Sterling - del Monte ............................................................................557

Figura 14. Familia Cabrera - Paredes .......................................................................................... 558 



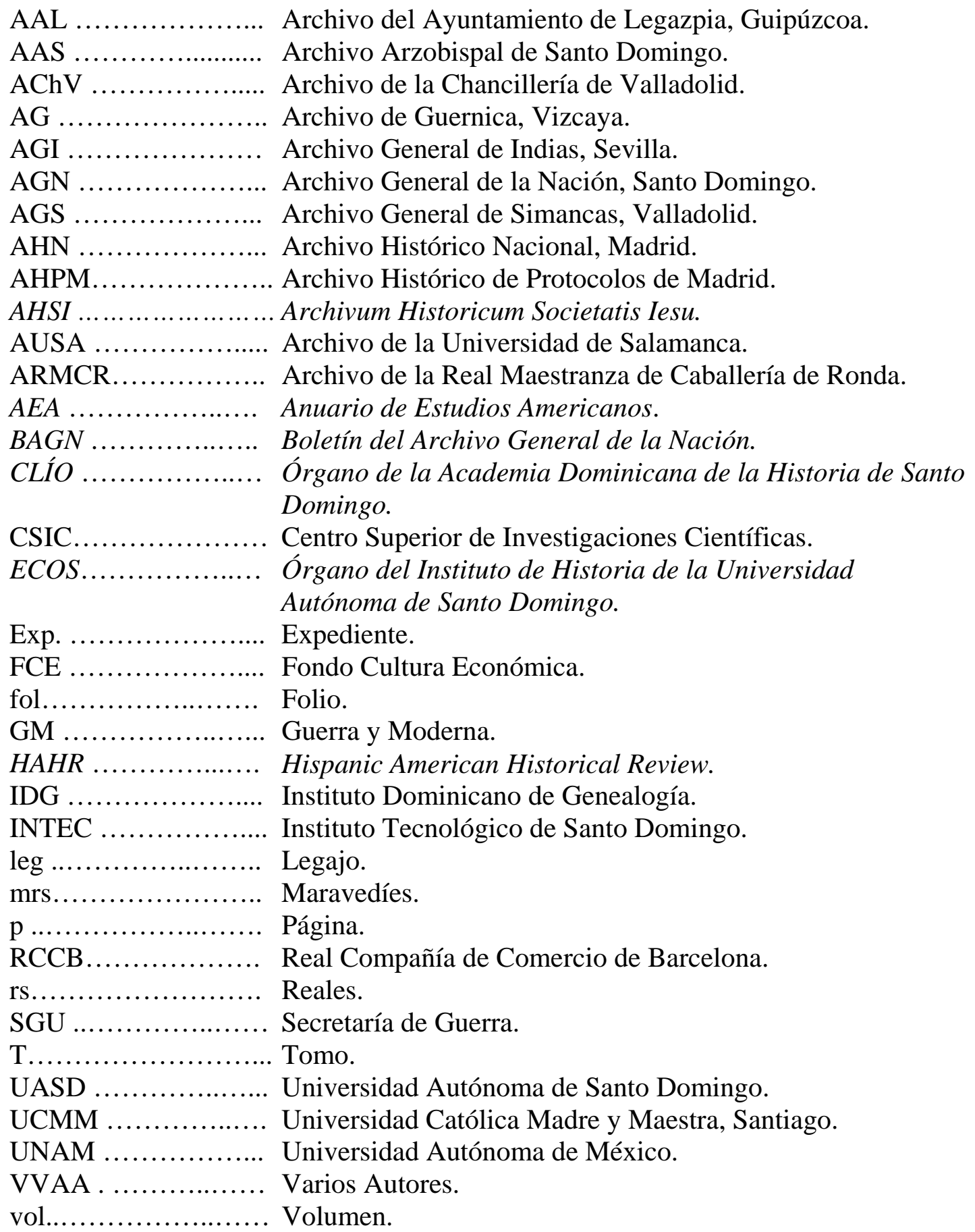





\section{EQUIVALENCIAS MÉTRICAS Y MONETARIAS}

\begin{tabular}{|c|}
\hline Longitud \\
\hline 1 vara................ 0,84 metros \\
\hline 1 caballería............. 645.816,13 varas cuadradas \\
\hline 1 caballería.............. 258,33 cuerdas \\
\hline 1 caballería.............. 45,13 hectáreas \\
\hline 1 tarea .................. 100 varas conuqueras \\
\hline 1 vara conuquera ..... 2,5 metros \\
\hline Peso \\
\hline 1 libra ..................460,25 gramos \\
\hline ..........25 libras \\
\hline 1 quintal ...............100 libras \\
\hline 1 quintal ................ 1 tercio \\
\hline 1 carga ................ 2 quintales \\
\hline 1 carga ............... 8 arrobas \\
\hline 1 carga ............... 40 andrullos de tabaco \\
\hline Moneda \\
\hline 1 peso ................8 reales \\
\hline 1 real ................. 34 maravedíes \\
\hline
\end{tabular}





\section{AGRADECIMIENTOS}

En estas líneas, totalmente necesarias pero insuficientes, quisiera hacer constar mi gratitud a todas aquellas personas que han contribuido a la realización de este trabajo. En primer lugar, debo agradecer la buena diligencia y disposición de los funcionarios de los distintos archivos y bibliotecas que he visitado. En la República Dominicana encontré a una serie de personas con una gran calidad humana que me ayudaron a conocer la historia de este país y, al mismo tiempo, me proporcionaron toda aquella bibliografía que necesité: Salvador Alfau del Valle, Raymundo González, Amadeo Julián y, en particular, Doña Vilma Benzo de Ferrer y el Dr. Emilio Cordero Michel, quienes me atendieron amablemente tanto en el plano académico como en el personal. También debo dar las gracias al Arzobispo Metropolitano de Santiago, Ramón Benito de la Rosa y Carpio que permitió que pudiera acceder al Archivo del Arzobispado de la catedral de Santo Domingo. Asimismo, al director del Centro Interamericano de Microfilmación y Restauración de Documentos, Libros y Fotografías (Centromidca) Manuel Núñez y, Ramón A. Font Bernad del Archivo General de la Nación, que me facilitaron el acceso a la documentación durante el difícil trabajo de archivo. No puedo tampoco olvidar, la colaboración de mis amigos dominicanos que hicieron que los años que residí en ese país y las estancias posteriores fuesen igual de agradables. También quisiera transmitir mi agradecimiento a Thelma Martínez y, en especial, a Josefina Echenique, que continuó prestándome su ayuda a larga distancia, cuando ya estaba en España. Asimismo recordar a la familia de Pedro Pons, lamentablemente fallecido, igualmente a la de Vicinio Moya, con quienes recorrí las tierras de este país.

Mi trabajo de archivo en Sevilla también me obliga a mostrar mi reconocimiento al Dr. Antonio Gutiérrez Escudero, su atención e interesantes sugerencias aportadas sobre Santo Domingo facilitaron la realización de esta investigación. Igualmente al Dr. José Manuel Rodríguez Gordillo, que me permitió consultar el Archivo Histórico de la Fábrica de Tabacos de dicha ciudad. La ayuda que he recibido del Dr. Jacinto Gíl Rodríguez en la Universidad del País 
Vasco, ha sido imprescindible a la hora de solucionarme algunas dudas que han surgido de la documentación consultada en materia normativa, jurídica y sobre distintos asuntos crediticios y de familia. Por supuesto, en esa misma universidad, tengo que dar las gracias al Dr. José María Imízcoz Beunza, a quien debo mucho, ya que sus escritos me han ilustrado sobre el arco de posibilidades que ofrece el enfoque de redes, aportándome propuestas claves para el estudio de un grupo social, como el de los hacendados. También he contado con su amabilidad y gentileza al ponerme en contacto con el Dr. Jean Pierre Dedieu y, a éste, por permitirme consultar la base de datos Fichoz. Del mismo modo, y en la Universidad de Salamanca, a la Dra. Raquel Gómez por su ayuda desinteresada y el apoyo que me ha brindado en la recta final de la tesis, así como al Dr. Francisco Lorenzo Pinar, director del departamento de Historia Medieval, Moderna y Contemporánea, por sus interesantes referencias.

En Madrid, el apoyo de José María Medina Rey y su familia fue fundamental, al permitirme alojarme en su propia casa y facilitarme la visita a las bibliotecas y al Archivo Histórico Nacional. A mis compañeras y amigas de carrera Sara, Ana, Marta y Eva, que me animaron en el transcurso de esta investigación. Igualmente tengo presente y agradezco a Chus y Jaime mis entrañables amigos, su afecto y estímulo en muchos sentidos.

Por último, una gratitud muy especial para la Dra. Izaskun Álvarez Cuartero, mi directora de tesis por toda su ayuda e inestimables recomendaciones que me han ayudado a finalizarla. A mi familia, mis padres y mi hermano por su respaldo incondicional y por compartir conmigo, en todo momento, las alegrías y decepciones en la elaboración de este estudio. Pero con significación propia a José Luis, por su cariño, por su paciencia al soportar las largas ausencias, y por haber aguardado años para verlo terminado. Su comprensión y ánimo han sido fundamentales, facilitando que me pudiera dedicar a tiempo completo a este trabajo. 


\section{INTRODUCCIÓN}

La historiografía analizada nos permite constatar que son pocos los historiadores que se han ocupado de estudiar a fondo la antigua colonia española de Santo Domingo frente a cualquier otra región americana, incluso desde otros ámbitos como la antropología, la política o la sociología. Si bien la bibliografía analizada sobre el siglo XVI y la época contemporánea es abundante, los siglos XVII y XVIII han quedado en un lugar menos favorecido. Para el caso del siglo XVIII que es en el que se centra nuestra investigación, encontramos algunos temas que han sido objeto de mayor atención por parte de la historiografía dominicana tales como la esclavitud, el papel que jugó la Iglesia en relación a ésta, los jesuitas, y otros como la emigración de sus habitantes a Cuba y Puerto Rico (efectuada como consecuencia de la cesión de la parte oriental a Francia en virtud del Tratado de Basilea de 1795) ${ }^{1}$. La historiografía española también se ha interesado por esas cuestiones, así como por las de la frontera, y otros aspectos de la vida económica, política, militar y social de este siglo ${ }^{2}$. Pero en lo que concierne al de las capas sociales altas, carecemos de una monografía de este tipo.

En este trabajo lo que pretendemos es llevar a cabo un estudio de los hacendados de Santo Domingo durante la segunda mitad del siglo XVIII, analizar su participación en las esferas de poder, sus actividades económicas y

\footnotetext{
1 Sobre estos temas concretos, señalamos las siguientes monografías: Silié, R., Economía, esclavitud y población. Ensayos de interpretación histórica del Santo Domingo español en el siglo XVIII. Santo Domingo, 1976. Pérez Memén, F., Iglesia y Estado en Santo Domingo (1700-1853). Santo Domingo, 1984. Deive, C. E., La esclavitud del negro en Santo Domingo (1492-1844). Santo Domingo, 1980, II vols., y Las emigraciones Dominicanas a Cuba (1795-1808). Santo Domingo, 1989. Sáez, J. L., La Iglesia y el negro esclavo en Santo Domingo. Una historia de tres siglos. Santo Domingo, 1994, y La expulsión de los jesuitas de Santo Domingo. Santo Domingo, 2006.

2 Entre las escasas obras publicadas hasta el momento, destacamos: Gutiérrez Escudero, A., Población y economía en Santo Domingo (1700-1746). Sevilla, 1985. Sevilla Soler, Ma. R., Santo Domingo. Tierra de frontera (1750-1800). Sevilla, 1980. Martínez Rebolo, I., Ejército y sociedad en las Antillas Siglo XVIII. Madrid, 1992. Lucena Salmoral, M., Los códigos negros de la América Española. Madrid, 1996. Hernández González, M. V., La colonización de la frontera dominicana (1680-1795). Las Palmas de Gran Canaria, 2005, y Expansión fundacional y desarrollo en el norte dominicano (1680-1795). El Cibao y la Bahía de Samaná. Las Palmas de Gran Canaria, 2006.
} 
asociaciones, la importancia que supone el prestigio social y las redes de relación y, por consiguiente, reconstruir su conformación y funcionamiento como grupo de poder.

Una parte significativa de esta investigación se ha encontrado con una serie de dificultades; entre ellas destacaremos, la falta de fuentes documentales o el mal estado de gran parte de la documentación, resultado de los diversos saqueos e incendios que, a lo largo de su historia, han sufrido los archivos dominicanos y, en particular, el Archivo General de la Nación de la ciudad de Santo Domingo, circunstancia que ha dejado bastantes lagunas en la información. Quizás por ello, este país, dentro del panorama de la historiografía, haya suscitado poco interés y haya tenido como consecuencia una escasa producción bibliográfica. De todos modos, esta situación puede que sea subsanada, en parte, gracias al plan de rehabilitación y reactivación del archivo que se está realizando desde el 2005, con la intención de rescatar la documentación a través de avances tecnológicos como la restauración y digitalización de la misma, así como mejorar las instalaciones del archivo $^{3}$. Estas medidas pueden paliar la pérdida definitiva de la documentación existente y permitir consultarla, facilitando un mayor conocimiento del pasado dominicano.

Otro problema es el ocasionado por la pérdida de los protocolos notariales para la ciudad de Santo Domingo, cuestión que abordaremos más adelante en esta introducción. Si bien esta fuente documental está considerada como la mejor para el conocimiento de las élites, en la actualidad se está complementando con otras fuentes que también nos proporcionan información muy interesante. Si sumamos a esto lo laborioso que resulta para el investigador su dispersión y que, raramente, se conserve íntegra toda la documentación generada acerca de un asunto, se crea un problema, y es que, sólo ocasionalmente, se puede reconstruir por completo la élite y, aún así, puede quedar más de algún cabo suelto. Además todavía no

\footnotetext{
${ }^{3}$ En ese año el Presidente del país Leonel Fernández Reyna nombró al historiador Roberto Cassá para la dirección del proyecto y del archivo, cargos que ambos todavía ejercen en la actualidad. Véase Read, G., "El Archivo General de La Nación, al servicio de la investigación y la cultura", 6/03/1007 en <http://listisdiario.com/app/article.aspx?id=18782.> [con acceso el 1 de junio de 2007], Cassá, R., "Estado de los avances archivísticos en República Dominicana”. Documento presentado en la Exposición y Conferencia Internacional de Archivos (Excol 07, Bogotá, Colombia del 23 al 27 de mayo de 2007, en <http://www.scrib.com/doc/23835/roberto-cassa.> [con acceso el 1 de junio de 2007]. Asimismo agradecemos las informaciones proporcionadas al respecto por el historiador Antonio Gutiérrez Escudero.
} 
Introducción

disponemos de una buena serie de monografías de suficiente amplitud y calado. A diferencia de otros países que cuentan con una trayectoria más dilatada en este tipo de estudios como México, Guatemala, Argentina, Perú o Ecuador; en la República Dominicana ésta es prácticamente inexistente. Tan sólo algunas recientes publicaciones se han acercado a esta temática al estudiar las familias más importantes de la República Dominicana $y$, entre ellas, las élites parlamentarias. Para la época colonial, hasta el momento, contamos con las de Justo del Río Moreno sobre los “señores de ingenios y de ganado” durante el siglo XVI y las de Antonio Gutiérrez Escudero para principios del siglo XVIII, en las que ambos coinciden al señalar la existencia de una élite política y económica que acaparaba los órganos de gobierno y los recursos económicos de la isla ${ }^{4}$; otros investigadores, por el contrario, niegan que haya existido a lo largo de la época colonial de Santo Domingo una "oligarquía económica”. Sin embargo no es así, ya que los mencionados trabajos y otros publicados recientemente ponen de manifiesto que durante el siglo XVIII existieron en cada una de las poblaciones de Santo Domingo élites locales, siendo las más poderosas las de las ciudades de Santiago y Santo Domingo ${ }^{6}$.

De todos modos, aún contando con esta producción bibliográfica, ésta sigue siendo escasa frente a la abundante variedad temática y metodológica existente al respecto en el panorama de la historiografía americanista, que lleva bastantes años comprometida estudiando las élites y en torno a ella los intereses

\footnotetext{
${ }^{4}$ Véase en el capítulo primero el apartado dedicado particularmente a la historiografía sobre élites en la República Dominicana. Cabe destacar, no obstante, los trabajos de Río Moreno, J. del, Los inicios de la agricultura europea en el Nuevo Mundo (1492-1542). Sevilla, 1991, y “'La élite antillana y la economía de conquista en América los intereses ganaderos (1493-1542)” en El Reino de Granada y el Nuevo Mundo. V Congreso Internacional de Historia de América. Granada, 1994, vol. III, pp. 187-204. Gutiérrez Escudero, A., "Élites y poder económico en Santo Domingo (siglo XVIII). Notas para su estudio” en Navarro García, L. (coord.), Élites urbanas en Hispanoamérica: (De la conquista a la independencia). Sevilla, 2005, pp. 241-251. Alguna noticia para la segunda mitad del siglo XVIII puede verse en Sevilla Soler, Mª. R., Santo Domingo..., op. cit., pp. 64-65.

${ }^{5}$ Domínguez, J. J., "La inexistencia de una oligarquía económica en la época colonial”. CLÍO 163 (Santo Domingo, 2002) pp. 171-210. Para el siglo XVIII véase Martínez Rebolo, I., Ejército y sociedad..., op. cit., pp. 186 y 203.

${ }^{6}$ Gascón, M., “The Military of Santo Domingo, 1720-1764”. HAHR 73:3 (Durham, 1993) pp. 431-452, y Rivas, C., “The Spanish Colonial Military: Santo Domingo 1701-1779”. The Americas 60:2 (Washington, 2003) pp. 249-272. Hernández González, M. V., La colonización..., op. cit., y Expansión fundacional..., op. cit. Torres Agudo, R., "Dos catedráticos dominicanos en la Universidad de Salamanca”. CLÍO 168 (Santo Domingo, 2004) pp. 245-264, y "Los CampuzanoPolanco, una familia de la élite de la ciudad de Santo Domingo". Nuevo Mundo Mundos Nuevos, $n^{\circ}$ 7-2007, disponible desde Internet en: <http://nuevomundo.revues.org/document3240.html.> [publicación en línea y con acceso el 5 de enero de 2007].
} 
económicos, políticos y sociales comunes, además de las relaciones de parentesco, clientela, amistad, familia,... en definitiva, formas de sociabilidad que tienden a conformar redes familiares y clientelares, en última instancia, redes de poder locales y transoceánicas.

Como punto de partida, existe una constatación mayoritaria de que la prosopografía es el método más utilizado por los historiadores para el estudio de las capas altas de la sociedad hispanoamericana. Valorando los resultados que ha proporcionado esta metodología dentro de la historiografía americanista, la consideramos como la más apropiada para esta investigación.

Por otro lado, hay que decir que la prosopografía, tal y como se plantea aquí, no es una prosopografía al uso, dedicada a recopilar datos biográficos mensurables sobre un grupo fuertemente cohesionado y homogéneo a partir de los cuáles se establece un perfil que los defina y permita examinar el comportamiento y ligazón entre unos y otros en un contexto determinado ${ }^{7}$, sino que es una prosopografía renovada que ha pasado a reconstruir un grupo o a un individuo a partir, como sugieren Imízcoz y Bertrand, de la observación y comprensión de las relaciones sociales que se entretejen en la sociedad, así como el modo de actuación de sus componentes y la interacción a través de los diferentes contextos en los que se mueven. Esta línea de investigación utiliza la técnica prosopográfica en términos del análisis de redes sociales -network analysis- ${ }^{8}$. Esto, a su vez,

\footnotetext{
${ }^{7}$ En la actualidad este tipo de prosopografía ha pasado a ser denominada como prosopografía tradicional, prosopografía clásica o antigua. Véase en Stone, L., El pasado y el presente. México, 1986, p. 61. Dedieu, J. P., "Un instrumento para la historia social: la base de datos Ozanam”. Cuadernos de Historia Moderna 24 (Madrid, 2000) pp. 185-205, p. 185. Bertrand, M., "Los oficiales reales de Nueva España: una aproximación al estudio de un grupo de poder en la sociedad novohispana (siglos XVII-XVIII)” en Menegus, M. (comp.), Universidad y sociedad en Hispanoamérica. Grupos de poder siglos XVII y XIX. México, 2001, pp. 15-39, p. 16, y Bertrand, M., y Dedieu, J. P., “¿Vino joven en odres viejas? Prosopografía y relaciones sociales en la Monarquía Hispánica” en Cancho Rodríguez, M. (coord.), Historia y perspectivas de investigación. Estudios en memoria del profesor Ángel Rodríguez Sánchez. Mérida, 2002, pp. 3137.

${ }^{8}$ Imízcoz Beunza, J. Ma., "Actores, redes, procesos: reflexiones para una historia más global”. Revista da Facultade de Letras-História, III Série, vol. 5, Porto (Portugal, 2004), pp. 1-28. (En prensa) Imízcoz Beunza, J. Ma ., y Guerrero, R., "Familias en la Monarquía. La política familiar de las elites vascas y navarras en el Imperio de los Borbones” en Imízcoz Beunza, J. Mª (ed.), Casa, familia y sociedad (País Vasco, España y América, siglos XV-XIX). Bilbao, 2004, pp. 177-238. Disponibles ambos artículos en la red: <http:www.ehu.es/grupoimizcoz/jmimizcoz.htm.> [con acceso el 1 de junio de 2007], y “Actores sociales y redes de relaciones en las sociedades del Antiguo Régimen. Propuestas de análisis en Historia social y política” en Barros, C. (ed.), Historia a debate. Retorno del sujeto. Santiago de Compostela, 1995, vol. II, pp. 341-353. Bertrand, M., “De la familia a la red de sociabilidad”. Revista Mexicana de Sociología LXI: 2 (México, 1999) pp. 107-135, y "La élite colonial en la Nueva España del siglo XVIII: un planteamiento en
} 
implica hacer un microanálisis de las relaciones y saber situar a cada persona en relación a los demás en la sociedad; lo cual ha desvelado, como ha señalado Imízcoz, que una persona puede jugar diversos papeles en las relaciones respecto a otra persona, a un colectivo o un sistema y, por lo tanto, estar en distintos niveles en función de la posición que ocupe en la relación ${ }^{9}$.

En este sentido, los trabajos recientes que han aplicado este método a la prosopografía también han constatado que en su mayoría las élites no actúan en un único ámbito, sino que éstas “son polivalentes” al participar, sus miembros, en distintas carreras, actividades, instituciones y actuar distribuidos por lugares geográficamente lejanos unos de otros (desde su localidad, la Corte, o las Indias ${ }^{10}$. Es a través de esos espacios donde convergen, disputan, conectan y articulan las relaciones entre los mismos, siendo éstas las que configuran las redes sociales en las que están inmersos. Sin embargo, esto no significa que no se tengan en cuenta aquellos aspectos exteriores o patrones de actuación común, sino que éstos son complementados con otros que los agrupen por motivos diversos como la desigualdad, la jerarquía, la búsqueda de protección o de objetivos comunes...; o incluso por aquellos elementos "que pueden parecer fuera de la norma” y que, por sí misma, la prosopografía no permite su comprensión, tales como los conflictos familiares, las rupturas y enemistades entre bandos familiares o grupos rivales, el valimiento o patrocinio, la corrupción, etc., ${ }^{11}$. En este punto, lo imprevisible de estas situaciones o los acontecimientos políticos y económicos a los que se ven obligadas las élites a adaptarse y activar sus redes de contacto para la consecución de objetivos, también ofrecen la posibilidad de identificarlas en relación con el ejercicio del poder, los mecanismos de acceso y control del mismo. Un poder que no se circunscribe exclusivamente a la participación directa en el gobierno, ocupando cargos políticos, sino que, a la hora de participar de él y ejercerlo, debe tener en cuenta la red jerárquica de relaciones que establecen las

términos de redes sociales” en Schröter, B. y Büshges, C. (eds.), Beneméritos, aristócratas y empresarios. Identidades y estructuras sociales de las capas altas urbanas en América hispánica. Frankfurt, 1999, pp. 35-51.

9 Imízcoz Beunza, J. Mª, “Actores sociales y redes de relaciones”..., op. cit., pp. 341-353, p. 346.

${ }^{10}$ Imízcoz Beunza, J. Ma., “Actores, redes, procesos”..., op. cit., pp. 1-28, p. 24. Imízcoz Beunza, J. Ma., y Guerrero, R., “Familias en la Monarquía”..., op. cit., pp. 177-238, p. 182.

${ }^{11}$ Idem., y Bertrand, M., "Los oficiales reales de Nueva España: una aproximación al estudio de un grupo de poder en la sociedad novohispana (siglos XVII-XVIII)”..., op. cit., pp. 15-39. 
élites a partir de la capacidad de influencia basada en los vínculos que se articulan entorno al actor que dispone de él o aspira a conseguirlo. En cualquier caso, como señala Imízcoz, no debe perderse de vista que esa jerarquía venía dada en cada vínculo y conllevaba "reglas de funcionamiento propias” y distintos grados de “dependencia, obligaciones y reciprocidades e intercambios”, a partir de los cuales se pueden explicar mejor los comportamientos de los actores sociales ${ }^{12}$.

Este nuevo enfoque prosopográfico más social, que combina los criterios de la prosopografía clásica y los del análisis de redes de relaciones sociales, ha pasado a denominarse prosopografía desplazada o generalizada ${ }^{13}$. Entendemos, en este sentido, que esta forma de utilizar la prosopografía, constituye un instrumento adecuado para el análisis de los hacendados, no sólo de los actores individuales, sino también del grupo, desde sus relaciones en el sentido más amplio hasta su capacidad de influencia, lo que permitirá conocer una porción de la élite de Santo Domingo.

Esto nos conduce a definir y delimitar el objeto de estudio. En este trabajo utilizamos la expresión élite para referirnos a un grupo social preeminente como el de los hacendados ${ }^{14}$. La utilización de este concepto está relacionada con la metodología aplicada a la misma, y lo hace, desde todas aquellas dimensiones en las que actúa el colectivo y no sólo desde un punto de vista, como pudiera ser el jurídico, el socio-profesional o el económico. La amplitud y flexibilidad de este término ha permitido que sea aplicado para definir de manera genérica cualquier grupo que se sitúe en el vértice de la sociedad y, por tanto, sea el de mayor éxito entre los historiadores que se han acercado a reconstruir y analizar esta realidad. Si bien, los criterios utilizados por los investigadores han ido variando y

\footnotetext{
${ }^{12}$ Imízcoz Beunza, J. Ma., “Actores, redes, procesos”..., op. cit., pp. 1-28, p. 19.

${ }^{13}$ Bertrand, M., "De la familia a la red de sociabilidad"..., op. cit., pp. 107-135, y "Los oficiales reales de Nueva España: una aproximación al estudio de un grupo de poder en la sociedad novohispana (siglos XVII-XVIII)”..., op. cit., pp. 15-39. Grendi, E., "Paradojas de la historia contemporánea”. Relaciones XXXIX: 95 (Zamora, 2003) pp. 267-278. También está disponible desde Internet en: <http://www.colmich.edu.mx/relaciones/.095/pdf/Edoardo\%20Grendi-pdf> [con acceso el 10 de enero de 2007].

${ }^{14}$ Según la Real Academia de la Lengua la utilización de la palabra élite o elite se consideran correctas. El término élite de origen francés se define como la "minoría selecta o rectora" de una sociedad, aunque la grafía y pronunciación francesa se extendió durante un tiempo en la actualidad ha pasado a interpretarse como esdrújula. Aunque la historiografía suele emplearla sin acento, nosotros lo hacemos acentuada. En esta misma línea consúltese Portela Miguélez, Ma ${ }^{\text {a }}$ J., “Estrategia matrimonial en la élite del Partido Unión Constitucional de Cuba, 1830-1860". Trocadero 14-15 (Cádiz, 2000-2003) pp. 159-170, p. 159. Real Academia Española. Diccionario Panhispánico de dudas. Madrid, 2006, p. 251.
} 
evolucionando, los aspectos económicos y políticos han continuado siendo hasta nuestros días los elementos más utilizados para identificarlos; hecho que puso de relieve David Brading en su obra de referencia Mineros y comerciantes en el México borbónico, al definirla como aquel "grupo compuesto por aquellos que detentan la riqueza y el poder" 15 .

Sin embargo, a finales de los setenta y ochenta se fue añadiendo otra serie de elementos que también permiten identificar a la élite, que hacen referencia al honor, al control del poder, a la riqueza y al papel de la familia en relación a las estrategias utilizadas para transmitir, a sus descendientes, su posición en la sociedad. El libro de John Kicza, Empresarios coloniales, constituye un buen ejemplo de este cambio. En él, Kicza, estableció otra serie de principios, aparte de la riqueza, para distinguir quién pertenecía a la élite mexicana, como por ejemplo la diversidad de sus actividades económicas, los honores, las estrategias utilizadas para colocar a sus hijos en las instancias de poder civil o eclesiástico a través de una buena política matrimonial, permitiéndole, todo ello, permanecer en la cima de la sociedad ${ }^{16}$. De la misma forma que muchos de estos elementos han sido empleados en investigaciones de otras áreas como Cuba y Guatemala, también se pueden encontrar algunos de ellos aplicados entre los hacendados estudiados ${ }^{17}$. Ahora bien, no debe obviarse el hecho de que los hacendados de Santo Domingo no hubieran alcanzado ni el poder económico-político ni el estatus social que conllevaba el poseer títulos nobiliarios, cosa que obtuvo la élite cubana, mexicana y peruana. Pero, como se podrá comprobar, sí mantuvieron un estilo de vida propio de nobles, que se manifiesta en la representación simbólica de su estatus, por ejemplo mediante el lujo de sus casas, enterramientos y capillas particulares, la preeminencia dada por la posesión de títulos militares o la ocupación de cargos administrativos. Aspectos que demuestran, a su vez, que el prestigio no reside necesariamente en la posesión de un título nobiliario, sino que existen otras

\footnotetext{
${ }^{15}$ Brading, D., Mineros y comerciantes en el México borbónico (1763.1810). México, 1993, p. 403.

${ }^{16}$ Kicza, J., Empresarios coloniales. Familias y negocios en la ciudad de México durante los borbones. México, 1986, p. 27. También merece ser señalado el trabajo de Socolow, S., Los mercaderes del Buenos Aires Virreinal: familia y comercio. Buenos Aires, 1991.

${ }^{17}$ A modo de ejemplo véase: Portela Míguelez, Mª. J., Redes de poder en Cuba entorno al partido constitucional 1878-1898. Cádiz, 2004. Santos Pérez, J. M., Élites, poder local y régimen colonial. El cabildo y los regidores de Santiago de Guatemala 1700-1787. Cádiz, 1999.
} 
variables que los historiadores han ido integrando, tales como los títulos militares, los cargos políticos, la educación y la etnicidad.

Estudios más recientes como los de los antes citados de Imízcoz, Bertrand o los de Langue y Büschges, tienen en cuenta todas estas cualidades que permiten ofrecernos unas caracterizaciones que definen e identifican a las élites y ponen de manifiesto la importancia de conjugarlas, investigando las relaciones sociales que trazan, para explicar las actuaciones concretas en los distintos espacios y tiempos donde estos grupos sociales se configuran, cambian, se distinguen y dominan ${ }^{18}$.

Partiendo de estas proposiciones, entendemos por élite ese sector estudiado, el de los hacendados, y el hecho de que su actividad socioprofesional no se circunscriba a una, sino que tenga una amplia y diversa participación en la vida político-militar y en otras instituciones como la Universidad y la Iglesia. Disponen de una base patrimonial más o menos importante basada en actividades agropecuarias, comerciales y crediticias, así como otros atributos de distinción social que los identifican y les permiten alcanzar y mantener un dominio e influencia local sustentado en una variedad de relaciones que entretejen los mismos hacendados y el resto de la sociedad.

Un análisis de este tipo nos ha llevado a abordar a los hacendados en dos direcciones. Por un lado, tiene que ver con los sujetos: quiénes son esos hombres. Hay que identificar y describir los rasgos principales del conjunto de actores del grupo que lo vivifican -un enfoque prosopográfico clásico-. Para ello, es necesario obtener datos biográficos, lo que permitirá conocerlos con nombres y apellidos, su origen geográfico y social, sus circunstancias personales y familiares, su patrimonio, incluso las ocupaciones económicas y su participación en la vida política y militar. Por otro lado, nos fijaremos en las relaciones sociales, las cuales los vinculan a un grupo o varios grupos sociales, a redes familiares, a intereses económicos y políticos comunes y a lugares de sociabilidad. El conocimiento de las mismas supone explorar la familia que constituye su principal soporte y los círculos de amistad. Su reconstrucción permitirá comprender los mecanismos de poder, ya que su funcionamiento depende del predominio que ejercían en el

\footnotetext{
${ }^{18}$ Langue, F., Aristocracia, honor y subversión en la Venezuela del siglo XVIII. Carcacas, 2000, pp. 19-38 y 45-46, y Langue, F., y Büschges, C., “¿Las élites de la América Española, del éxito historiográfico al callejón interpretativo? Reconsideraciones” en Langue, F., y Büschges, C., (coords.), Excluir para ser. Procesos identitarios y fronteras sociales en la América hispánica (XVII-XVIII). Vervuert, 2005, pp. 9-22.
} 


\section{Introducción}

terreno político y económico, de sus intereses y decisiones, de sus capacidades estratégicas para preservar esos espacios de poder, de su patrimonio y de su estatus social.

En relación con lo primero, debemos concretar que el interés de este trabajo no se centra en todos los hacendados que existieron en Santo Domingo durante la segunda mitad del siglo XVIII, sino sólo en algunos de los más relevantes. Más concretamente, se han seleccionado sesenta y uno en función de la información obtenida de las fuentes, la cual ha permitido reconstruir la trayectoria vital de cada uno de los personajes que componen la estructura social de esta investigación y su entorno. Aunque en algún caso no hemos logrado obtener datos como, por ejemplo, el lugar de dónde procedían. Entre la documentación más provechosa en este sentido destacan: los títulos de nombramiento a los montepíos de ministros, certificaciones de bautismo, matrimonio y defunción, relaciones de méritos y servicios y grados literarios, hojas de servicio militar, licencias de pasajeros a Indias, expedientes de limpieza de sangre y compra-venta y renuncia de cargos, y los extractos o informes de revistas de los gobernadores. Además, se ha utilizado información proveniente de otros materiales ${ }^{19}$.

Primeramente, para completar los datos de los actores, sobre todo los referentes a su dimensión profesional hemos empleado la base de datos Ozanam (Fichoz), llamada así en reconocimiento de su fundador, el historiador Didier Ozaman. Las bases que la componen resultan de un proyecto preconcebido para almacenar información sobre carreras administrativas de los funcionarios españoles del siglo XVIII. En la actualidad, el proyecto conocido como PAPE (Personal Administrativo y Político Español del siglo XVIII) está formado por un grupo de investigación que comprende distintas universidades tanto españolas como europeas bajo la coordinación y dirección de Jean Pierre Dedieu de la Universidad de Bordeaux III $^{20}$.

\footnotetext{
19 En este sentido nos hemos guiado de las reflexiones metodológicas y recomendaciones dadas en las siguientes publicaciones: Bertrand, M., "De la familia a la red de sociabilidad”..., op. cit., pp. 107-135. Imízcoz Beunza, J. Mª “, “Actores, redes, procesos”..., op. cit., pp. 1-28. Pro Ruiz, J., "Socios, amigos y compadres: camarillas y redes personales en la sociedad liberal” en Chacón Jiménez, F., y Hernández Franco, J., (eds.), Familia, poderosos y oligarquías. Murcia, 2001, pp. 153-173.

${ }^{20}$ Sobre su funcionamiento véase la primera presentación realizada en Dedieu, J. P., “El grupo personal político y administrativo español del siglo XVIII” en Carasa Soto, P. (ed.), Elites.
} 
En segundo lugar, hemos utilizado otra de carácter genealógico. La bibliografía que existe en este sentido es abundante, ya que en la República Dominicana la genealogía es una línea de investigación muy importante. Los estudios de genealogía de Emilio Rodríguez Demorizi, Fray Cipriano de Utrera, Carlos Larrazábal Blanco, Julio Genaro Campillo Pérez, Vetillo Manuel Valera Valdez y los del cubano Francisco Javier de Santa Cruz y Mallén sirvieron de guía en el acercamiento a las familias de los hacendados. Igualmente destacamos en este sentido los trabajos de Juan Carlos Guerra y Mogrobejo para identificar aquellos peninsulares vascos que emigraron a Santo Domingo ${ }^{21}$. También han sido de gran ayuda los diccionarios biográfico-políticos de magistrados realizados por Mark Burkholder y Dewitt Chandler y Javier Barrientos Grandon desde una perspectiva prosopográfica, que ofrecen una riquísima información sobre los ministros de la administración colonial y peninsular y, la obra de Juan Marchena Fernández en la que incluye las hojas de servicio del Ejército regular y miliciano de América ${ }^{22}$. Las noticias que las obras de genealogía nos han proporcionado han sido contrastadas con toda la documentación citada anteriormente y con los expedientes de limpieza de sangre, filiación, y ejecutoria de hidalguía, que aportan datos biográficos del individuo y de la familia a la que pertenecía.

La ausencia de protocolos notariales para la época colonial de la ciudad de Santo Domingo que, en otras partes del continente americano y de la Península, han dado tan buenos resultados en el análisis de las élites, fue suplida por alguna documentación notarial dispersa encontrada en el Archivo General de Indias que consta de escrituras de cartas de dote, permisos de casamiento, inventarios postmortem, contratos de compra-venta de bienes, concesión de poderes, donaciones a

Prosopografía contemporánea. Valladolid, 1994, pp. 315-326. Para una descripción más extensa y actualizada de esta base de datos véase Dedieu, J. P., "Un instrumento para la historia social: la base de datos Ozanam”..., op. cit., pp. 185-205. Y Bertrand, M., y Dedieu, J. P., “¿Vino joven en odres viejas? Prosopografía y relaciones sociales en la Monarquía Hispánica”..., op. cit., pp. 3137, en particular las páginas 34-37.

${ }^{21}$ Guerra, J. C. de, Ensayo de un padrón histórico de Guipúzcoa, según el orden de sus familias pobladas. San Sebastián, 1928. Mogrobejo, E. de, Blasones y linajes de Euskalerria. Bilbao, 1991, $\mathrm{X}$ vols.

${ }^{22}$ Marchena Fernández, J., (coord.), El Ejército de América antes de la independencia. Madrid, 2005. Barrientos Grandon, J., “Guía prosopográfica de la judicatura letrada en Indias 1503-1898” en Andrés-Gallego, J., Nuevas aportaciones a la historia jurídica de Iberoamérica. Madrid, 2000. Burkholder, M. A., y Chandler, D. S., Biographical dictionary of audiencia ministers in the Americas: 1687-1821. Wesport, 1982. Asimismo nos ha servido de ayuda la obra de Martínez Robles, M., Los oficiales de las Secretarías de la Corte bajo los Austrias y los Borbones, 15171812. Madrid, 1987. 
testamentos -concretamente cuatro-, y fondos civiles y eclesiásticos localizados en el Archivo Real de Bayaguana y el Archivo Arzobispal de la catedral de Santo Domingo. Por medio de toda esta documentación y la ya mencionada hasta el momento, hemos podido reconstruir acontecimientos concretos individuales y familiares de los hacendados, además de algunas de las estrategias relacionales que utilizaron en el contexto familiar y fuera de éste. Esta información por sí sola no permite explicar el funcionamiento interno como grupo de poder, como bien señalan Bertrand, Imízcoz y Pro, siendo necesario fijarse en la red de relaciones sociales de las cuales forman parte y edifican nuestros actores ${ }^{23}$. En relación a esto, cabe hacerse dos preguntas: ¿cómo y dónde se pueden descubrir relaciones personales y sociales de un personaje concreto o del grupo de hacendados, y qué tipo de vínculos se pueden analizar en la reconstrucción de las relaciones?.

Para responder a estas cuestiones, como ya hemos comentado, hemos examinado los vínculos y, entre éstos la familia que constituye el núcleo más importante de las relaciones sociales ${ }^{24}$. La familia es la pieza clave de la red de relaciones de un hacendado y el grupo familiar al que pertenece. Para analizar en qué familias estaban integrados los hacendados y las estrategias que éstas utilizaban para mantener su poder o ascender en diferentes ámbitos, nos hemos centrado en torno a dos asuntos: la política matrimonial y las prácticas sucesorias, reconstruidas a partir de la documentación notarial y los repertorios de hidalguía o expedientes de pureza de sangre. Si bien, esta información ya se ha utilizado para reconstruir el linaje materno y paterno, también permite conocer las ramificaciones a “escala del imperio" de aquellos peninsulares que, aún establecidos en Santo Domingo y lejos de la metrópoli, lograron mantener conexiones familiares, así como el alcance de las alianzas matrimoniales ${ }^{25}$.

Por su parte, el parentesco espiritual o ritual, es decir, las relaciones de padrinazgo y de compadrazgo, también jugaron un papel muy importante dentro

${ }^{23}$ Bertrand, M., “De la familia a la red de sociabilidad”..., op. cit., pp. 107-135. Imízcoz Beunza, J. M ${ }^{\mathrm{a}}$., “Actores, redes, procesos”..., op. cit., pp. 1-28. Pro Ruiz, J., “Socios, amigos y compadres”..., op. cit., pp. 153-173.

${ }^{24}$ En Pro Ruiz, J., Ibidem., p. 157. Véase también: Imízcoz, J. Mª., "Introducción. Actores sociales y redes de relaciones: reflexiones para una historia global” en Imízcoz, J. Mª, Redes familiares y patronazgo. Aproximación al entramado social del País Vasco y Navarra en el Antiguo Régimen (siglos XV-XIX). Bilbao, 2001, pp. 19-30.

${ }^{25}$ Bertrand, M., "De la familia a la red de sociabilidad”..., op. cit., pp. 107-135, p. 128. Imízcoz Beunza, J. Mª, “Actores, redes, procesos”..., op. cit., pp. 1-28, p. 25. 
de las estrategias familiares, ya que en cierta medida son una prolongación de los lazos familiares. Al tiempo han permitido descubrir relaciones de amistad o de privilegio que forjaron, a lo largo de la vida, los hacendados a través de la elección de padrinos entre miembros importantes de otras familias de hacendados con los que mantenían actividades económicas y negocios, o incluso, entre personas pertenecientes a la alta administración local.

La amistad fue otro vínculo de suma importancia. Para detectar amistades e influencias, hay que añadir a los ya citados testamentos, escrituras dotales e inventarios post-mortem, los contratos de compra-venta de todo tipo de bienes muebles e inmuebles o esclavos-, las escrituras o informes de deudas y de préstamo y los poderes concedidos ante un escribano para servir como albacea testamentario, capellán o patrono de una capellanía, de testigos en los actos públicos y notariales, de socios comerciales, de renuncias de puestos políticos; que permiten desvelar la existencia de una estrecha unión entre los principales implicados en esos actos. Así mediante el estudio de vínculos económicos, tales como las fianzas o el crédito podemos encontrar pistas respecto a las redes económicas.

Lugares de sociabilidad como la Universidad y otras instituciones en las que participan los hacendados, que van desde el cabildo, la audiencia, las cajas reales, Factoría de Tabacos, el Ejército, o asociaciones como la Junta de Agricultura o la Real Sociedad Bascongada de Amigos del País, son espacios en los que, además de estar relacionados familiarmente, se generan lazos solidarios, de compañerismo y de amistad, más o menos intensos, que en algún caso derivaron en relaciones clientelares ${ }^{26}$. Sin duda las relaciones que entablan con personas en esos ámbitos, son relativamente fáciles de conocer ya que tienen un reflejo escrito a través, por ejemplo, de informes que proporcionan los nombramientos de cargos administrativos y militares, estados de los empleos que

\footnotetext{
${ }^{26}$ En este estudio, las relaciones clientelares establecidas entre un patrón y sus clientes están basadas principalmente en la dependencia y desigualdad, aunque se mantuviera una relación recíproca, que estableciera una obligación de intercambios en ambos sentidos. La fidelidad y la confianza era lo que garantizaban que cada uno cumpliera su papel. Las redes clientelares podían organizarse partiendo tanto de relaciones familiares como profesionales, permitiendo a sus integrantes tener prestigio, y ejercer influencia y poder. Dentro de la bibliografía que explica el funcionamiento de las élites coloniales a partir de las variables familia-clientelismo destacan los trabajos pioneros de los ya citados Brading, Kicza y Socolow, más recientes son los de Bertrand, Langue e Imízcoz.
} 
existían en la isla, memoriales de un proyecto concreto, cartas de acusaciones y los pleitos o juicios de residencia que se les hacía a los gobernadores.

En particular, la documentación judicial proporciona una información extraordinaria para reconstruir las redes familiares y clientelares en las que participan los hacendados. También permite encontrar otros grupos de poder y los bandos que existían en el seno de estas redes familiares. Por ejemplo, a partir de los juicios de residencia de los gobernadores es posible identificar a los componentes de la comitiva que les acompañaban cuando viajaron a Santo Domingo y descubrir cómo se integraron en la élite local. Saber ganarse y mantener la lealtad de ésta debió obligar a los gobernadores a llevar un doble juego, dado que a través de ellos y de sus ministros hacían presente el poder del “rey distante”, teniendo que defender los intereses de la Corona al mismo tiempo que el de los hacendados ${ }^{27}$. De ahí que los gobernadores desempeñaran un papel de primer orden en la distribución de favores, actuando como patrones respecto a sus clientes: por una parte, con los miembros de su entorno personal y, por otra, respecto al componente de la élite formada por los hacendados. Estos no descuidaron una posible alianza de amistad -alianza política-, o familiar con los gobernadores del momento o alguien de su séquito, por los beneficios que su apoyo les podía reportar en sus proyectos políticos y actividades agrarias, ganaderas y comerciales, obteniendo prerrogativas como la exención de impuestos, reparto de licencias, además de cargos administrativos y títulos militares de los que eran provistos.

El gobernador también tenía la posibilidad de obtenerlos y de potenciar su prestigio ante la Corte de Madrid mediante las cartas de recomendación que hacían los propios hacendados para que éste siguiera ascendiendo en la Península o incluso, para que permaneciera y se prolongara su periodo de gobierno en la isla. Los propios gobernadores no podían prescindir de los hacendados, lo cual no significa que las relaciones fuesen difíciles (aunque en algunas ocasiones lo fueron) ni que hubiese conflictos con los hacendados, o entre éstos y algunos de los allegados de los gobernadores, que pasaron a convertirse en importantes y ricos personajes.

\footnotetext{
${ }^{27}$ González Enciso, A., "Introducción. Del rey ausente al rey distante” en González Enciso, A., y Usunáriz Garayoa, J. Mª (dirs.), Imagen del rey, imagen de los reinos. Las ceremonias públicas en la España Moderna (1500-1814). Pamplona, 1999, pp. 1-18.
} 
En este sistema relacional, los hacendados también entablaron lazos de solidaridad con los ministros de la Audiencia, los oficiales de la Real Hacienda y personas cercanas al círculo del entorno del rey u otras personalidades influyentes de la época como, por ejemplo, el comerciante y financiero Simón Aragorri y Olavide (Marqués de Iranda), con capacidad de influir y defender sus intereses frente al rey ${ }^{28}$. Entre otros colaboradores cabe destacar también el papel de algunos oidores, como fue el de Agustín Emparán y Orbe y, el del clérigo Antonio Sánchez Valverde, que desempeñaron la función de agentes e impulsores de la innovación agrícola a través de sus escritos, actuando, a su vez, como intermediarios entre los hacendados y la Corte. Su influencia fue, probablemente, decisiva en la concesión de privilegios y prebendas, sin embargo, habría que analizar y realizar un estudio específico sobre estas figuras de gran importancia para Santo Domingo ${ }^{29}$. Por ejemplo, entre muchos interrogantes sin aclarar, está el saber qué papel jugaron realmente en ese sentido y reconstruir su entorno relacional: con qué tipo de relaciones contaban y cuáles entablaron en Madrid, calibrar su influencia y repercusión en Santo Domingo, así como su acción como ilustrados y miembros de la Real Sociedad Bascongada de Amigos del País y la Sociedad Económica Matritense. Es evidente que, a través de este apoyo relacional que recibieron, los hacendados fueron favorecidos en sus actividades y

\footnotetext{
${ }^{28} \mathrm{Al}$ igual que este personaje hubo otros que se dedicaron a la actividad financiera y asentista, convirtiéndose en piezas fundamentales para el funcionamiento de la monarquía española. Aunque aún falta profundizar en ellos y en el papel de sus familias, cabe destacar los estudios que en los últimos años están realizando desde la Universidad de Navarra. Entre ellos citamos los que se han acercado a este financiero vasco francés y a las redes económicas que organizó en torno a sus actividades comerciales y financieras. Sin embargo, no se cuenta todavía con una monografía sobre este personaje. Torres Sánchez, R. (ed.), Capitalismo mercantil en la España del siglo XVIII. Pamplona, 2000, y “Campomanes y el comerciante y financiero Simón Aragorri” en Mateos Dorado, D. (ed.), Campomanes doscientos años después. Oviedo, 2003, pp. 709-718. Véanse también algunas referencias sobre esta figura proporcionadas por Zylberberg, M., Une si douce domination. Les milieux d'affaires français et l'Espgane vers 1780-1808. Paris, 1993. Peralta Ruiz, V., Patrones, clientes y amigos. El poder burocrático indiano en la España del siglo XVIII. Madrid, 2006.

${ }^{29}$ Se sabe que Agustín Emparán y Orbe preparó un escrito sobre el estado de la agricultura de la isla hacia 1785, sin embargo y, como le ha ocurrido a otros investigadores que lo han intentado, no lo hemos encontrado. Este memorial económico probablemente sería clave para comprender la mentalidad y el pensamiento de esos años y la situación de Santo Domingo. Para las referencias respecto a los mencionados personajes que existen hasta el momento consúltese: Malagón Barceló, J., Código Negro Carolino (1784). Código de legislación para el gobierno moral, político y económico de la isla Española. Santo Domingo, 1974, pp. LXI-LXIX. Caro Álvarez, J. A., "Don Agustín Ignacio Emparán y Orbe y el código negro carolino”. Serie Conferencias del Museo del hombre dominicano 4 (Santo Domingo, 1974) pp. 1-16. Cassá, R., "Historiografía de la República Dominicana”. ECOS 1 (Santo Domingo, 1993) pp. 9-39. Rossi, M., Praxis, historia y filosofía en el siglo XVIII. Textos de Antonio Sánchez Valverde (1729-90). Santo Domingo, 1994. Lucena Salmoral, M., Los códigos negros..., op. cit., pp. 63-101.
} 
Introducción

les sirvió para imponer su autoridad en Santo Domingo. Aunque ellos mismos por sí solos también tuvieron capacidad de paralizar reformas y reorientarlas para que les beneficiasen.

La complementariedad de todas estas fuentes ha permitido construir el entorno social y relaciones en las que se sitúan y participan los hacendados estudiados. No obstante, y como se comprobará, no todas al completo, ya que la dispersión de las fuentes, así como el no haber contado con protocolos ni, en particular, con aquella documentación relacionada con las actividades comerciales y financieras o la correspondencia epistolar, son factores que lo han dificultado. Éste es el caso del ya mencionado Marqués de Iranda o el del oficial real Raymundo de Esparza, para los que se ha podido reconstruir, en parte, el núcleo de la red social en Santo Domingo. En cambio, no se ha podido entrar en detalle en sus actividades financieras y mercantiles y, en relación a éstas, el alcance de su participación en la red de comerciantes de Santo Domingo, así como las de fuera de éste espacio. Pero vale la pena mencionar que geográficamente debió distribuirse entre Venezuela, las Antillas mayores y menores, colonias francesas como Saint Domingue e inglesas como Jamaica y, naturalmente, en Madrid. Estas cuestiones pendientes, supondrían investigar en profundidad esas relaciones transatlánticas que mantuvieron y utilizaron personajes de este calibre en esos ejes espaciales.

El marco temporal del estudio comprende cuarenta y cinco años que van desde 1750 hasta 1795. La delimitación cronológica se encuadra dentro del método seguido y las sugerencias, que dan algunos historiadores como Palma, sobre cómo debe ser el tamaño del grupo a investigar. Según este autor ningún sector social es muy pequeño o demasiado grande sino que, lo importante a la hora de realizar un estudio de élites, es elegir un periodo de, al menos, cincuenta años que posibilite la obtención de suficientes datos sobre el núcleo social y al mismo tiempo permita percibir patrones de comportamiento de los personajes, así como de los acontecimientos más notables de la época en la que está inmerso el grupo $^{30}$. No obstante, hay que señalar que en la actualidad la tendencia es la de trabajar con grupos numerosos y amplios que alcanzan periodos muy largos $\mathrm{y}$

\footnotetext{
${ }^{30}$ Véase en Palma Murga, G., "Núcleos de poder local y relaciones familiares en la ciudad de Guatemala a finales del siglo XVIII”. Mesoamérica 12 (Guatemala, 1986) pp. 241-308, p. 242.
} 
cifras altas como, por ejemplo la élite municipal de Recife estudiada por George Félix Cabral de Souza, en su tesis doctoral, que cubre un periodo de 113 años (1710-1822) y estaba conformada por un grupo de 514 individuos. Otro caso ilustrativo es el del ya mencionado Michel Bertrand, quien ha reconstruido las redes clientelares creadas por unos 300 oficiales de la Real Hacienda de las ciudades de México, Guadalajara y Zacatecas, entre los siglos XVII y XVIII, concretamente desde 1660 hasta $1780^{31}$.

Este periodo también responde al interés que puede proporcionar el análisis de los hacendados en el contexto de las reformas borbónicas y, aunque su incidencia se dejó sentir en la primera mitad del siglo XVIII, no fue hasta la segunda mitad de ese siglo cuando se produjeron cambios que reactivaron la estructura socio-económica, política y militar de Santo Domingo. No hemos pretendido realizar una observación exhaustiva de cada una de éstas, pero sí algunos aspectos en relación a cómo participaron los hacendados en esa transformación. De hecho veremos como apoyaron algunas de ellas y las utilizaron en beneficio propio $\mathrm{y}$, al mismo tiempo, eludieron aquellas que les perjudicaban. Para esto, y para conseguir facilidades en sus actividades económicas, los hacendados fueron los principales impulsores, aunque para ello, también se valieron del apoyo de la alta administración local y de la Península.

La investigación concluye en 1795 debido a un hecho particular: la cesión de la parte española de la isla a la colonia francesa, como resultado de la guerra que enfrentaba a España y Francia desde 1792, y que desembocó en la Paz de Basilea por la que se produjo dicho traspaso. Aunque parte de la población permaneció en la isla, su consecuencia inmediata fue la emigración de gran parte de ella y, por tanto, de muchos hacendados que se vieron obligados a vender, alquilar, o abandonar sus bienes y a emigrar a otras colonias españolas como Cuba, Puerto Rico, Venezuela e incluso la propia Península. Muchos de ellos acabaron instalándose en dichos lugares, pero otros regresaron en cuanto pudieron, siendo en algunos casos sus descendientes quienes lo hicieron a lo largo del siglo XIX.

\footnotetext{
${ }^{31}$ Félix Cabral de Souza, G., Elite y ejercicio de poder en el Brasil colonial: la Cámara Municipal de Recife (1710-1822). Salamanca, 2007. Tesis Doctoral inédita. Bertrand, M., Grandeur et misère de l'office. Les officiers de finances de Nouvelle-Espagne XVII-XVIII siècles. Paris, 1999.
} 
Respecto a las fuentes documentales y la bibliografía utilizada, hay que señalar que quedan registradas al final del trabajo. Para la localización de las fuentes necesarias nos ha sido de gran ayuda la bibliografía relativa a la época en la que se enmarca el presente estudio, así como algunos instrumentos de búsqueda y descripción existentes que localizan y describen las fuentes conservadas tanto en archivos y bibliotecas de la República Dominicana como las ubicadas en España o en otros países que, por razones históricas, fueron trasladadas a La Habana una vez cedida la parte oriental de la isla a Francia ${ }^{32}$. Aunque éstas no han sido consultadas son referencias de gran utilidad para los investigadores.

En cuanto a los repertorios dominicanos, destacamos el trabajo realizado por Roberto Cassá. Una primera obra importante que contiene una buena información y, a la vez, una panorámica sobre la organización, la historia institucional de los archivos y bibliotecas, la situación de la documentación y una bibliografía anotada de la República Dominicana. También incluye noticias sobre los archivos y otras instituciones depositarias de documentación de Santo Domingo en España ${ }^{33}$. Otra recopilación de gran calidad e importancia sobre esta temática, es la de Sylvia Hilton e Ignacio González, aparecida en 1995. Se trata de una guía general para la historia iberoamericana, organizada por países, que recoge bibliografía de catálogos de archivos y otros instrumentos descriptivos de los fondos de cada uno de ellos, entre los que nos interesan los referentes al Archivo General de la Nación de la República Dominicana ${ }^{34}$.

El archivo en el que se ha encontrado la mayor parte de la documentación ha sido el Archivo General de Indias, en el cuál se examinó la sección Gobierno, correspondiente a la Audiencia de Santo Domingo. Otros fondos en los que

\footnotetext{
${ }^{32}$ Sobre la documentación que existe en La Habana véanse: “Catálogo de los fondos del Archivo de la Real Audiencia de Santo Domingo que se conservan en el Archivo Nacional de Cuba (17081800)" en Malagón Barceló, J., El distrito de la Audiencia de Santo Domingo en los siglos XVI a XIX. Santiago, 1977, pp. 109-258. Sosa Rodríguez, E., "Importancia del contenido de los fondos del Archivo Nacional de Cuba para la historia de la República Dominicana”. ECOS 2 (Santo Domingo, 1993) pp. 155-182. En este artículo el autor relaciona una serie de manuscritos de Santo Domingo que abarcan el siglo XVIII y el XIX. Entre ellos se encuentra a modo de ejemplo, alguna de la correspondencia mantenida entre los Capitanes Generales de Santo Domingo y Cuba o la promulgación de Reales Cédulas.

${ }_{33}$ Cassá, R., Directorio de Archivos de la República Dominicana. Madrid, 1996. En ella también se puede encontrar la dirección de los archivos y bibliotecas.

${ }^{34}$ Hilton, S. L., y González Casasnovas, I., Fuentes manuscritas para la historia de Iberoamérica. Guía de instrumentos de investigación. Madrid, 1995, pp. 267-270, y Fuentes manuscritas para la historia de Iberoamérica. Guía de instrumentos de investigación: suplemento. Madrid, 1997, pp. 169-170.
} 
también se han hallado información son el de Contaduría, Contratación, Estado, Indiferente General, Escribanía de Cámara, Ultramar y Estado de mapas y planos. De las diversas series documentales contenidas en estas secciones, cabe destacar, las cartas del cabildo y de los gobernadores, los expedientes de compra y renuncia de cargos, las relaciones de méritos y servicios, las hojas militares, los juicios de residencia de los gobernadores, los inventarios de bienes, las escrituras notariales, las licencias de pasajeros y algunos pleitos. Asimismo, el Archivo Histórico Nacional de Madrid, en particular la sección de Consejos Suprimidos, ha proporcionado destacada información sobre las residencias de algunos de los gobernadores y cuestiones como el conflicto que hubo con la Real Compañía de Comercio de Barcelona. En este mismo archivo, también ha sido de utilidad la sección de Ultramar, que ha facilitado datos fiscales, como la alcabala entre otros. En la mencionada ciudad, la consulta de algunas escrituras notariales del Archivo Histórico de Protocolos, permitió sacar algunos datos, especialmente en lo que se refiere a un personaje: el Marqués de Iranda y sus inversiones en Santo Domingo. En la Biblioteca Nacional también encontramos manuscritos coetáneos interesantes, como la memoria descriptiva escrita por el secretario de cámara José Castro Palomino ${ }^{35}$.

Los fondos del Archivo General de Simancas, como la sección de Guerra Moderna y la Dirección General de Rentas, aportaron datos de gran interés que sirvieron para completar la identificación de cargos políticos y militares, así como aspectos militares y económicos. En archivos como el de la Real Chancillería de Valladolid, el Archivo de Guernica de Bilbao, Archivo General de Guipúzcoa de Tolosa y los municipales de Legazpia y Bergara, se encontró información sobre los orígenes de algunos de los hacendados que emigraron a Santo Domingo, especialmente a través de las probanzas de hidalguía. También resultó de gran utilidad la consulta del Archivo de la Real Maestranza de Ronda para confirmar la pertenencia de algunos hacendados a ella. Se realizó una visita al Archivo Histórico de la Fábrica de Tabacos de Sevilla pero, lamentablemente, sólo se pudo consultar unas horas, debido al inmediato cierre con el objeto de trasladar próximamente su documentación al Archivo General de Indias, razón por la cual

\footnotetext{
35 Documento también reproducido en Rodríguez Demorizi, E., Relaciones históricas de Santo Domingo. Santo Domingo, 1957, vol. III, pp. 336-347.
} 
apenas pudimos rastrear la información existente. Esta carencia documental fue complementada con la que nos proporcionó, fundamentalmente, el Archivo General de Indias. Por lo que respecta al Archivo de la Universidad de Salamanca, hemos encontrado datos sobre los estudios realizados por algunos hacendados en dicha Universidad.

En el Archivo General de la Nación de la República Dominicana, la documentación consultada fue más bien escasa en comparación con la ofrecida por el resto de los archivos españoles debido, fundamentalmente, como ya hemos apuntado, a su mal estado y a la supuesta pérdida de documentación tan interesante como la de las actas capitulares de la ciudad de Santo Domingo y sus protocolos notariales del periodo colonial. Avatares históricos como la invasión de Francis Drake a la ciudad de Santo Domingo en 1586, el traslado de parte de la documentación a Cuba en 1796 tras la cesión de la parte occidental de la isla a los franceses, y la invasión haitiana durante veintidós años (1822-1844), no han ayudado a su conservación. De ahí que la mayor parte de la documentación con la que se cuenta para la ciudad de Santo Domingo, parta de la independencia de Haití en 1844. Sin embargo, su lamentable organización y cuidado ha provocado que gran parte se haya deteriorado debido no sólo al clima tropical y a las inclemencias del tiempo tales como el ciclón de 1930, sino también a "las sustracciones de documentos, mutilaciones de otros y destrucción por inadecuado manejo de documentos en mal estado”36.

Retomando el asunto de los protocolos notariales, según Roberto Cassá "no se ha logrado establecer la causa de que no se localicen los libros de protocolos hasta la segunda década del siglo XIX. Probablemente se trasladaron a Cuba o a España, pero no hay informes de su existencia en archivos de esos países”37. Sin embargo, conscientes de todas estas circunstancias desfavorables mencionadas cabe preguntarse si las escrituras notariales de la ciudad de Santo Domingo para la época colonial y, concretamente las del XVIII, existieron en algún momento. Podemos conjeturar que probablemente sí, por lo menos hacia 1950 y 1955, aunque no sepamos dónde se localicen o qué sucedió con éstas

\footnotetext{
${ }^{36}$ En Cassá, R., Directorio de Archivos..., op. cit., pp. 19 y 27. A cerca del Archivo General de la Nación y su situación consúltense las páginas 13-38 y 43-51. Para ver las mejoras que se han realizado y continúan llevándose a cabo véase desde Internet: <http://www.agn.gov.do> [con acceso el 30 de enero de 2008].

${ }^{37}$ Ibidem., véase particularmente la nota al pie 16, p. 19.
} 
posteriormente, ya que para esos años contamos con dos publicaciones muy interesantes con referencias a éstas. La primera de ellas es un libro de Félix Reyes titulado Descripción histórica de las antiguas haciendas, estancias y hatos, que durante la era colonial española, existieron en el partido de los ingenios de Nigua, hoy, San Cristóbal ${ }^{38}$. Esta obra, como bien indica su título, además de localizar y describir un gran número de haciendas que poseyeron algunos de los hacendados estudiados, también aporta datos sobre transacciones de compra-venta y transmisiones de estas propiedades que remiten al escribano que realizó la escritura notarial. Sin embargo, no ofrece datos exhaustivos de dónde procede esta información, lo cuál sería de gran utilidad para los investigadores. La otra referencia bibliográfica es un artículo del historiador Leonidas García Lluberes, que apareció cinco años después que la anterior. En ella el autor presenta una escritura notarial de compra del ingenio Santa Ana de Engombe entre los miembros que pertenecían a una de las familias de hacendados más importantes de aquella época: los Landeche-Bastidas. A diferencia del anterior trabajo, el autor indica que el manuscrito se había conservado durante el siglo XIX en el archivo del historiador José Gabriel García, estando, hacia 1955, en el de la familia capitalina Cruzado ${ }^{39}$.

No obstante, debe mencionarse que en el Archivo General de la Nación se conservan, aunque no en muy buen estado, los protocolos de algunos notarios de finales del siglo XIX y del XX de la ciudad de Santo Domingo. También allí se encuentran los protocolos notariales de otras áreas del país, como por ejemplo los del Seibo, que se inician en las primeras décadas del siglo XIX. Para la época colonial, se cuenta con las escrituras de las poblaciones de Higüey y Bayaguana, que se remontan a la primera mitad del siglo XVII y alcanzan hasta el siglo

\footnotetext{
${ }^{38}$ Reyes, F., Descripción histórica de las antiguas haciendas, estancias y hatos, que durante la era colonial, existieron en el partido de los Ingenios de Nigua, hoy San Cristóbal. Ciudad Trujillo, 1950 .

${ }^{39}$ García Lluberes, L., "Miscelánea histórica. (Extractos de los Cuadernos de Apuntes del Historiador García). El Ingenio Santa Ana de Engonve”. CLÍO 102 (Ciudad Trujillo, 1955) pp. 3944. Posteriormente el artículo fue publicado como capítulo de un libro del mismo autor titulado Crítica Histórica. Santo Domingo, 1964, pp. 98-110. Leonidas García era hijo de José Gabriel García el cúal está considerado como el "padre de la historia dominicana". Parece que reunió fuentes documentales dispersas de la época colonial y el siglo XIX, formando un amplio archivo que le permitió escribir sobre el pasado dominicano y, en particular sobre dicho siglo a través de testimonios directos de este periodo. Para esta figura véanse los siguientes trabajos: Cassá, R., "Historiografía”..., op. cit., pp. 9-39, p. 14 y 15. Roca Friedheim, F. A., "El legado de José Gabriel García y el aporte historiográfico de sus hijos”. CLÍO 173 (Santo Domingo, 2007) pp. 119-173.
} 
Introducción

siguiente aunque, como se ha venido destacando, casi todas ellas también están bastante deterioradas $^{40}$. En ambas series notariales se ha encontrado alguna referencia acerca del patrimonio de haciendas y hatos de los hacendados, así como asuntos de gobierno de la isla. Otro fondo que existe, en dicho archivo, es el que contiene documentación de la época colonial y abarca desde 1735 hasta $1795^{41}$. La consulta de algunos informes de militares, también ha sido de utilidad para el presente estudio; al igual que los registros de bautismos, expedientes de dispensa matrimonial y los libros de capellanías examinados en el Archivo Histórico de la catedral de Santo Domingo ${ }^{42}$.

Entre las principales bibliotecas españolas consultadas, destacan aquellas en las que se localiza la bibliografía correspondiente a Santo Domingo y el periodo histórico en que se inserta este trabajo. Éstas pueden considerarse esenciales para la realización de una investigación sobre la República Dominicana. En Salamanca: la biblioteca de la Facultad de Geografía e Historia, la del Instituto Interuniversitario de Iberoamérica, la de “Francisco de Vitoria”, la de la Universidad Pontificia y el Fondo Antiguo de la biblioteca de la Universidad de Salamanca; en San Sebastián: la biblioteca Koldo Mitxelena y la de la Real Sociedad Bascongada de Amigos del País; en Legazpia, Tolosa y Bergara: las bibliotecas de los respectivos archivos; en Madrid: la Biblioteca Nacional, Biblioteca del Instituto de Cooperación Iberoamericana, Biblioteca del Centro de

\footnotetext{
${ }^{40}$ La documentación de Higüey conforma el Archivo de Higüey y la de Bayaguana el Archivo Real de Bayaguana. En la actualidad una parte de sus fondos reposan en el Centro Nacional de Conservación de Documentos (CENACOD). Este centro está ubicado en el mismo edificio del Archivo General de la Nación y desde su creación, en 1976, operó como Centro Taller Regional de Restauración y Microfilmación de Documentos para el Caribe y Centroamérica, pero a partir de 1986 lo hizo como organismo técnico cultural adscrito a la Secretaría Administrativa de la Presidencia de la República Dominicana. A partir de ese año se le denominó Centro Interamericano de Microfilmación y Restauración de Documentos, Libros y Fotografías (Centromidca) hasta que desde el 2000 se le conoce como CENACOD. Algunos documentos del Archivo de Bayaguana han sido digitalizados y pueden consultarse a través de la red en: <http://www.agn.gov.do> [con acceso el 30 de enero de 2008]. Acerca de la documentación y estado del fondo de Bayaguana véase Moreta Castillo, A., “Análisis jurídico y reponderación del Archivo Real de Bayaguana”. CLÍO 156 (Santo Domingo, 1997) pp. 27-40. Para Higüey consúltese Widmer Sennhauser, R., La propiedad en entredicho. Una historia documental de Higüey, Siglo XVII-XIX. Santo Domingo, 2004.

41 Se trata de aquella documentación que fue trasladada a Cuba tras la cesión de la parte española en 1795 a los franceses y que, años más tarde, parte de ella fue devuelta. Muchos de estos documentos también se encuentran en "pésimo estado". Véase en "Documentos de la Época Colonial, 1733-1795”. BAGN 38-39 (Ciudad Trujillo, 1945) pp. 8-22.

${ }^{42}$ Gran parte de la documentación también se encuentra en mal estado, sobre este archivo véase Sáez, J. L., “Archivo Histórico de la Arquidiócesis de Santo Domingo”. BAGN 115 (Santo Domingo, mayo-agosto 2006) pp. 225-239. También está disponible desde Internet en: $<$ http://www.agn.gov.do/pdf/bagn_115.pdf > [con acceso el 30 de enero de 2008].
} 
Humanidades del Consejo Superior de Investigaciones Científicas y en Sevilla: la Biblioteca de la Escuela de Estudios Hispano-Americanos; esta última con una amplia variedad de revistas dominicanas y bibliografía sobre este país. En República Dominicana: la Biblioteca Nacional, la Biblioteca del Archivo General de la Nación, la Biblioteca del Museo del Hombre Dominicano, Biblioteca Rodríguez Demorizi, Biblioteca del Centro de Altos Estudios Humanísticos y del Idioma Español, y la Biblioteca Enrique Apolinar Henríquez, son fundamentales. La consulta de bibliotecas privadas también ha resultado de gran utilidad.

Este trabajo está estructurado en siete capítulos: En el primero de ellos abordamos el estudio de las élites de la época colonial dentro de la historiografía americanista, y se comprobará cómo en la República Dominicana son mínimos los trabajos que se han acercado a esta temática. Además se constata la rica tradición genealógica, cuyos estudios, completados con la documentación, han permitido el acercamiento a las primeras pistas de las redes sociales de los hacendados y la elaboración de los respectivos árboles genealógicos. El capítulo segundo se dedica al estudio del gobierno de la ciudad de Santo Domingo, centrando la atención sobre varias instituciones: la Audiencia, la Real Hacienda y el cabildo, sus orígenes, su estructura, y funcionamiento durante la segunda mitad del siglo XVIII. La idea es dar una visión panorámica sobre estas instituciones. También adelantamos datos y el papel participativo del sector social estudiado en dichas instancias. En el tercero se hace referencia a distintos aspectos militares como la reorganización realizada por los Borbones, la instauración de las milicias, la jerarquía del Ejército y los grados militares de los hacendados. El cuarto capítulo se centra en los actores sociales que nos ocupan en este trabajo. Tratamos aspectos que van desde el origen social y geográfico, la educación, los medios utilizados por los inmigrantes peninsulares para integrarse en la sociedad local, las redes familiares y clientelares, hasta los intereses económicos y políticos comunes. Para ello, reconstruimos la red social de los hacendados, a través de la política matrimonial y su vinculación, mediante otros lazos como la amistad, el compadrazgo y sus relaciones con otros poderes. Presentamos las principales redes familiares con sus conexiones a otras importantes y la actuación de sus miembros, los hacendados, a través de la ocupación de cargos administrativos,

\footnotetext{
* Situada en la Sociedad Dominicana de Bibliófilos.
} 
universitarios y militares y, en particular, su influencia y eficacia en cuanto a la toma de decisiones desde el cabildo. En el capítulo quinto se analizan las distintas formas de transmisión de los bienes y mecanismos utilizados para evitar su fragmentación. En el sexto se estudian los elementos de distinción social y el estilo de vida noble que llevaban estos personajes, sus propiedades muebles e inmuebles (a pesar de que la mayoría no eran efectivamente nobles de título) e incluso su mentalidad, reflejada en las bibliotecas de algunos a través de inventarios. Finalmente, el último tiene por objeto el análisis de las principales actividades económicas de los hacendados que fueron la agricultura, la ganadería y el comercio, además de la crediticia, tratada en el capítulo cuarto. Se encontrará información sobre la propiedad de la tierra, composición de las haciendas y los gravámenes impuestos sobre éstas y formas de adquirirlas. Asimismo, hacemos una breve presentación del cultivo del tabaco y, en relación a éste, el establecimiento y estructura de la Factoría.

También se puede observar después de la bibliografía, un apartado en el que se incluyen datos biográficos de algunos de los hacendados investigados, así como de otros personajes que tuvieron un destacado papel durante el periodo estudiado, tales como los del oidor Agustín Emparán y Orbe, el Marqués de Iranda y el clérigo Antonio Sánchez Valverde. Los anexos recogen un listado cronológico de los gobernadores, de algunas bibliotecas privadas, inventarios de haciendas, hatos y estancias, licencias de víveres y árboles genealógicos. Elaborado todo ello, a través de la documentación mencionada con la finalidad de completar y comprender mejor lo desarrollado en la tesis. 



\section{MARCO HISTÓRICO}

\section{Antecedentes}

La llegada de Cristóbal Colón a la isla de Quisqueya en diciembre de 1492 significó el comienzo de la historia colonial de lo que luego se llamaría La Española o isla de Santo Domingo ${ }^{1}$. Las “nuevas tierras” estaban habitadas por aborígenes, quienes fueron desapareciendo a medida que la conquista y colonización de la isla se hizo efectiva ${ }^{2}$. La conquista comenzó con la construcción de la primera ciudad en la zona norte de la isla en 1493, llamada La Isabela, y las campañas militares que se hicieron en el interior para controlar a la población indígena. El descubrimiento de minas al sur motivó que en 1498 se fundara, a poca distancia de ese lugar, otra ciudad a orillas del río Ozama, conocida como Santo Domingo ${ }^{3}$.

Colón empezó a utilizar a los indios en la búsqueda y extracción de oro, de forma que los repartió en grupos entre los españoles para ese trabajo. El trato

\footnotetext{
${ }^{1}$ Entre las obras que dan una visión general de la historia dominicana véanse: Cassá, R., Historia social y económica de la República Dominicana. Santo Domingo, 2003-2004, II vols. Bosch, J., Composición social dominicana. Historia e interpretación. Santo Domingo, 1997 (1970). Moya Pons, F., Historia colonial de Santo Domingo. Santiago, 1977, y Manual de historia dominicana. Santo Domingo, 1995.

${ }^{2}$ Para los aspectos económicos y sociales de la conquista y colonización del siglo XVI puede verse: Moya Pons, F., La Española en el siglo XVI. Santiago, 1978, y Después de Colón. Trabajo, sociedad y política en la economía de oro. Madrid, 1987. Acerca de los indios de La Española véanse: Cassá, R., Los taínos de La Española. Santo Domingo, 1990. Deive, C. E., La Española y la Esclavitud del Indio. Santo Domingo, 1995. Esteban Mira Caballos ha publicado numerosos trabajos sobre este tema, entre ellos cabe destacar El indio antillano: repartimiento, encomienda y esclavitud (1492-1542). Sevilla-Bogotá, 1997.

${ }^{3}$ El año de la fundación de la ciudad de Santo Domingo ha variado en la historiografía dominicana dependiendo de la fuente en la que se han basado los investigadores. Así Max Henríquez Ureña y Manuel de Jesús Antonio Mañon Arredondo toman la fecha dada por el cronista Fernández de Oviedo que lo sitúa en 1494, mientras que 1496 es el otro año que utilizan autores como Emilio Rodríguez Demorizi o Úrsula Lamb, los cuales siguen el planteamiento lascasiano. Pese a esta variedad, se toma como definitivo 1498, que fue establecido por Fray Cipriano de Utrera en 1958, y cuya tesis se apoya en la Real Instrucción de 23 de abril de 1497 que dio la facultad al descubridor de fundarla. De acuerdo con él están historiadores como Víctor Garrido, Luis Alamar, Fray Vicente Rubio, o Guillermo Céspedes del Castillo. Sobre este asunto véanse los siguientes trabajos: Chez Checo, J., Veloz Maggiolo, M., y Mateo, A., Santo Domingo. Elogio y memoria de la ciudad. Santo Domingo, 2002, pp. 31-67. Ramos Pérez, D., "El traslado de la ciudad de Santo Domingo, en el cambio de su función y del régimen socio-político”. Casas Reales 12 (Santo Domingo, 1980) pp. 7-39.
} 
abusivo contra éstos hizo que se rebelaran y se sucedieran encuentros bélicos entre los indios y los españoles. A partir de entonces, se llevó una política de sometimiento tras la cuál surgieron rencillas entre los propios españoles, como consecuencia de los nuevos repartimientos de la población indígena. Esta situación provocó una rebelión en contra del descubridor por parte de un grupo de españoles dirigidos por Francisco Roldán, que contó con el apoyo de los indios, lo que obligó a la Corona a sustituirle y su hermano Bartolomé, a quien había encargado el gobierno de la isla mientras estaba en España, por Francisco Bobadilla. Durante su mandato la situación indígena fue empeorando cada vez más debido al trabajo intensivo en la explotación de yacimientos auríferos. Pronto fue destituido porque su administración se vio afectada por la corrupción, por lo que fue reemplazado por Nicolás de Ovando.

La principal actividad económica del gobierno de este último fue la explotación minera para la extracción del oro, centrándose en dos polos: Cotuí y La Buenaventura. Se fomentó la agricultura y ganadería para asegurar el sustento de la población, estableciéndose también un régimen administrativo y burocrático que luego pasaría al resto de colonias españolas en América. Se fundaron nuevas poblaciones y en cada ciudad se instauró un cabildo como institución encargada de la administración local. Respecto a los indios, Ovando llevó a cabo un plan de sometimiento general. Para ello continúo las campañas militares iniciadas por Colón para controlar a los indios y los territorios que todavía no habían sido conquistados. Asimismo, se estableció de forma legal el sistema de repartir indios a los españoles, es decir, el régimen de la encomienda. La encomienda consistió en la cesión a los colonizadores de un grupo de indios, que estaban obligados a prestar servicios al español y recibir a cambio formación religiosa y sobre todo buen trato. Ovando pretendió legalizar lo que llevaba practicándose desde el periodo de Colón, con la peculiaridad de que los aborígenes serían considerados como hombres libres y mejoraría su situación. Sin embargo no fue así, sino que empeoró y la mortandad entre los indios fue cada vez mayor.

El sustituto de Ovando fue el hijo de Cristóbal Colón, Diego, quien tuvo que hacer frente a disputas y bandos entre los propios españoles. Éstas volvieron a surgir como resultado del favoritismo manifiesto a la hora de repartir los indios entre sus acólitos. La reducción de la población indígena hizo que las 


\section{Marco histórico}

reparticiones se reajustasen cada vez más, lo que no impidió que Diego y unos cuantos siguiesen aprovechándose en perjuicio de otros encomenderos. El control por la mano de obra indígena en provecho de los colonizadores produjo una división en dos grupos: por un lado, los que apoyaban al gobernador, y por otro, los que estaban a favor de Miguel de Pasamonte, tesorero real y segundo personaje más importante.

La Corona utilizó la lucha de facciones de los encomenderos para delimitar el poder del gobernador, para lo que se tomaron varias medidas. La primera fue establecer en 1511 una Real Audiencia, de forma que las decisiones del gobernador a partir de entonces no fueron suyas de manera absoluta, y se le quitó la facultad de actuar como juez ${ }^{4}$. La segunda fue la prohibición de repartir y confiscar indios en la colonia. Así se llegó a nombrar a otras personas como Rodrigo de Alburquerque, quien realizó el último repartimiento de indios de forma general para los habitantes de la isla. Para llevar a cabo tal repartición, se confiscaron los indios que Diego Colón había distribuido entre sus allegados, de modo que se beneficiaron aquellos que apoyaron a Miguel de Pasamonte. De ahí que los españoles que salieron perjudicados de tal reparto emigraron hacia Cuba y el continente americano. Este repartimiento supuso la concentración del poder político y económico en manos de un pequeño grupo, que había comenzado a desarrollarse con Ovando y que bajo el gobierno de su sucesor trató de obstaculizar $^{5}$. Junto a esto, se produjo la protesta del Padre Montesinos sobre el abuso que se cometía contra los naturales de aquella isla a través de las encomiendas. La denuncia terminó en la imposición por parte de la Corona de una legislación protectora, las leyes de Burgos de 1512, que trataron de reglamentar y humanizar el trabajo de los mismos.

Al abandonar Diego Colón la administración, se nombró a un grupo de frailes de la orden de los jerónimos para que se encargasen del gobierno y evitaran que la política que se llevara a acabo estuviera por encima de los intereses de los colonos. Pero el punto fundamental de su programa era resolver la situación de la

\footnotetext{
${ }^{4}$ Sobre la Audiencia de Santo Domingo véase: Malagón Barceló, J., El distrito de la Audiencia de Santo Domingo en los siglos XVI a XIX. Santiago, 1977. Polanco Alcántara, T., Las Reales Audiencias en las Provincias Americanas de España. Madrid, 1992.

${ }^{5}$ Sobre el proceso de la encomienda en La Española, y en particular el repartimiento de 1514 véase Arranz Márquez, L., Repartimiento y encomiendas en la Isla Española. (El repartimiento de Alburquerque de 1514). Santo Domingo, 1991. Mira Caballos, E., El indio antillano..., op. cit., pp. 94-157.
} 
población local. Con este fin se elaboró un plan general para quitar de las manos de los encomenderos a los indios. Se pretendió declarar libres a estos últimos de las encomiendas, a cambio del pago de un tributo anual a la Corona sobre el terreno, parte del cual se destinaría a la indemnización de los encomenderos. Otro objetivo fue la creación de aldeas para ellos bajo la tutela de un funcionario español, un sacerdote y un jefe indio. Los nativos estaban obligados a realizar trabajos fijos en las explotaciones auríferas y agrícolas, y las ganancias eran repartidas entre los anteriores y los antiguos encomenderos. El plan fracasó al ser los encomenderos los primeros en oponerse a estas medidas, pues no querían desprenderse de la mano de obra india. Paralelamente, hubo unas epidemias que acabaron reduciendo la pequeña población aborigen.

Esto unido al decaimiento de la economía aurífera, hizo que los padres jerónimos prepararan las condiciones necesarias para poner fin al sistema de las encomiendas. De esta forma, reorientaron la economía de la isla hacia el desarrollo de la agricultura, fomentando el cultivo del azúcar y otros productos agrícolas con destino a las otras colonias españolas. Se establecieron trapiches e ingenios, principalmente en las riberas de los ríos Ozama, Haina, Nizao, Nigua y Yaque del Sur, cerca de la ciudad de Santo Domingo, donde había facilidades de transporte y estaba situado el puerto. Realizaron también una política de préstamos a particulares para la siembra y su procesamiento. Los ingenios se fueron concentrando en aquellos encomenderos que permanecieron en la isla y trasladaron sus inversiones, y en los burócratas de la colonia que procuraron participar también de tal lucrativo negocio. Estos dueños de ingenios acabaron convirtiéndose en los señores más poderosos de la isla, al acaparar no sólo el poder económico sino también el poder político del cabildo y de la Audiencia ${ }^{6}$.

Para llevar a cabo el negocio azucarero, estos hacendados lograron obtener de la Corona permisos para la importación de negros africanos utilizados como mano de obra esclava; el contrabando también fue otro medio por el que la obtuvieron. La importación de esclavos llevó a un aumento del número de negros entre la población, además de a una serie de hechos conflictivos como fueron las

\footnotetext{
${ }^{6}$ Río Moreno, J. del, Los inicios de la agricultura europea en el Nuevo Mundo, 1492-1542. Sevilla, 1991, pp. 470-476.
} 
fugas, rebeliones de esclavos y el cimarronaje*. Estos esclavos que huían a los montes formaron comunidades, conocidas como manieles o palenques, desde donde realizaban ataques a los españoles. Este tipo de levantamientos se convirtió en algo común en la historia colonial de Santo Domingo ${ }^{7}$.

Entre 1520 y 1580 la economía azucarera alcanzó su máxima producción. Sin embargo, ésta empezó a disminuir a partir de 1580 debido al declive de la mano de obra esclava, como resultado de las epidemias, la fuerte competencia de otros productores de azúcar como Cuba y México, el riesgo que conllevaba la exportación, la piratería y la dedicación a otro cultivo como el jengibre, que también se exportaba a Europa. El impulso de su cultivo se debió a que los costos de producción eran bajos, y los precios de su comercialización eran mejores que los del azúcar. A lo que se sumaba el monopolio comercial impuesto por la metrópoli, que impedía a Santo Domingo, al igual que al resto de las colonias, el comercio con otras ciudades de España, a excepción de Sevilla y Cádiz.

Otro punto importante de la economía fue el relacionado con la ganadería. Ya desde el segundo viaje de Colón, se trajeron animales de cría que se multiplicaron y sirvieron de remesas posteriores. Algunos hacendados se dedicaron también a la cría de ganado en hatos, lo que sirvió para proveer de carne a la población y para la exportación de carne salada y cueros a las nuevas poblaciones de la colonia. Este comercio empezó a realizarse clandestinamente en la llamada banda norte. Ante esta intensa actividad, el gobierno metropolitano decidió eliminarlo despoblando toda esa área y trasladando a los vecinos al interior, cerca de la ciudad de Santo Domingo. Esta política realizada entre 1605 y 1606 contó con un gran número de opositores, lo que provocó reacciones de protesta manifestadas en cartas y memoriales. A ello siguieron rebeliones, a las cuales hubo que hacer frente con el apoyo de una guarnición militar de Puerto Rico, que ayudó a obligar a los vecinos al traslado. Los efectos que produjo la despoblación fueron la destrucción de los poblados, la muerte de gran parte del ganado debido a las penurias de su desplazamiento, y la emigración de parte de

\footnotetext{
* Rebelión individual o colectiva de negros o indios contra su situación de servidumbre y opresión al que fueron sometidos por su amo.

${ }^{7}$ Sobre los levantamientos de indios y negros véanse los trabajos de Mira Caballos, E., El indio antillano..., op. cit., pp. 312-329. Y, Deive, C. E., Los cimarrones del maniel de Neiba. Santo Domingo, 1985, y Los guerrilleros negros. Esclavos fugitivos y cimarrones en Santo Domingo. Santo Domingo, 1997.
} 
sus vecinos a Cuba. Como consecuencia, los habitantes que permanecieron y el ganado que sobrevivió fueron reubicados en el interior de la isla en la zona del Cibao y en dos pueblos de nueva fundación. Uno de ellos se creó a partir de Montecristi y Puerto Plata, llamándose Monte Plata, y el otro a partir de Yaguana y Bayajá, denominado Bayaguana; aunque estos pueblos no llegaron a prosperar hasta bien entrado el siglo XVIII ${ }^{8}$.

El abandono de la banda norte facilitó que piratas y extranjeros realizasen de forma continuada incursiones y ataques a La Española. Además los conflictos europeos entre España y países rivales como Francia, Inglaterra y Holanda, obligaron a la Corona a reactivar las defensas españolas en el área del Caribe ante el temor de ataques enemigos, como ya había experimentado Santo Domingo años atrás con la invasión inglesa en 1586. Para ello en 1601 se organizó la Armada de Barlovento, que se encargaría de cubrir el área de las Antillas, escoltando las flotas españolas para evitar los ataques de enemigos, así como las posibles invasiones de extranjeros.

El programa para la defensa de la isla consistió en el aumento del contingente militar y la estructura defensiva. Tal mejora se puso de manifiesto ante el ataque de los ingleses, que intentaron apoderarse nuevamente en 1655; pero éste fue totalmente repelido ${ }^{9}$. A pesar del despliegue defensivo, se siguieron sufriendo incursiones hasta que se establecieron colonos de otros países europeos, en especial franceses, en la isla de La Tortuga. Este lugar fue tomado como base estratégica desde la que estos colonos, conocidos como filibusteros, ejercían la piratería atacando buques, y también como bucaneros, a los que se acercaban a la costa norte de Santo Domingo para cazar y comerciar con el ganado capturado. Los franceses acabaron controlando la isla de la Tortuga, y progresivamente se establecieron en la parte occidental de La Española. En ella desarrollaron las llamadas habitaciones, establecimientos de carácter agrícola, que dieron inicio a lo que luego sería la economía de plantación azucarera de la colonia francesa. Desde entonces fueron constantes los enfrentamientos entre las dos colonias, hasta que

\footnotetext{
${ }^{8}$ Para una visión de la primera mitad del siglo XVII y en concreto sobre las despoblaciones y sus consecuencias véanse: Gíl-Bermejo García, J., La Española. Anotaciones históricas (16001650). Sevilla, 1983, pp. 3-40. Peña Pérez, F., Antonio Osorio: monopolio, contrabando y despoblación. Santiago, 1980. Puede verse también Hernández Tapia, C., "Despoblaciones de la isla de Santo Domingo en el siglo XVII”. AEA XXVII (Sevilla, 1970) pp. 281-320.

9 Moya Pons, F., Historia colonial..., op. cit., pp. 259-263.
} 
con el acuerdo de paz de Ryswick de 1697 entre Francia y España, esta última reconoció la presencia francesa en la isla. La convivencia y las relaciones entre las colonias que compartían la isla, funcionaron a razón de sus necesidades, así como de los acercamientos que tuvieron los dos países ${ }^{10}$.

\section{El siglo XVIII en Santo Domingo}

A principios del siglo XVIII se inició una relativa prosperidad socioeconómica en la parte española. A ello contribuyeron una serie de factores, como fueron las medidas reformadoras tomadas con la subida al trono de la casa de los Borbones, las circunstancias internacionales, y el desarrollo de una economía de plantación en la colonia francesa, que pasó a llamarse Saint Domingue ${ }^{11}$.

Este proceso de reactivación y crecimiento económico fue paralelo al demográfico. El aumento de la población durante el siglo XVIII no sólo fue vegetativo, sino que se debió en parte a la inmigración de esclavos que fueron utilizados como mano de obra en las haciendas y hatos, $\mathrm{y}$ en las residencias de la élite. También la llegada de inmigrantes canarios y extranjeros traídos para continuar la reedificación de los pueblos que habían sido abandonados con las devastaciones, así como para la erección de otros nuevos, contribuyó a ese aumento de la población. A pesar de las discrepancias que existen en las investigaciones que tratan la demografía de este siglo, se aceptan ciertas cifras: 25.000 habitantes para la población entre 1737 y 1739, unos 50.000 o 73.000 para 1769-1772, y para 1784 alrededor de 54.000 habitantes $^{12}$. En lo referente al

\footnotetext{
${ }^{10}$ Sobre bucaneros, filibusteros y el establecimiento de los franceses en la parte occidental de la isla véanse: Peña Batlle, M. A., La isla de La Tortuga. Santo Domingo, 1988 (1951). Bosch, J., Composición social dominicana..., op. cit., pp. 79-108. Apestegui, C., Los ladrones del mar. Piratas en el Caribe. Corsarios, filibusteros y bucaneros 1493-1700. Madrid, 2000. Véase también Lucena Salmoral, M., Piratas, corsarios, bucaneros y filibusteros. Madrid, 2005. En ella se encuentra un amplio y detallado comentario bibliográfico sobre el asunto.

${ }^{11}$ La vida económica, social y política de Santo Domingo durante el siglo XVIII ha sido estudiada por los siguientes autores: para la primera mitad del siglo XVIII Gutiérrez Escudero, A., Población y economía en Santo Domingo (1700-1746). Sevilla, 1985. Para la segunda mitad véase Silié, R., Economía, esclavitud y población. Ensayos de interpretación histórica del Santo Domingo español en el siglo XVIII. Santo Domingo, 1976. Sevilla Soler, Ma . R., Santo Domingo. Tierra de frontera (1750-1800). Sevilla, 1980. También véase la obra de Moya Pons, F., Historia colonial..., op. cit.

12 Entre la bibliografía que se ha acercado a este tema véase: Moya Pons, F., "Notas sobre la primera abolición de la Esclavitud en Santo Domingo". Eme-Eme Estudios Dominicanos 3 (Santiago de los Caballeros, 1974) pp. 3-28, y El pasado dominicano. Santo Domingo, 1986, pp.
} 
número de esclavos es aún más difícil aproximarse, pues gran parte de ellos habían entrado ilegalmente mediante el contrabando y otros huidos de la vecina Saint Domingue. Según el código negro elaborado en 1784 para Santo Domingo, se estima que tenía 15.000 negros y pardos, frente a los 364.196 que habitaban en la parte francesa hacia $1789^{13}$.

La política de inmigración para fundar poblados cuenta con antecedentes en la isla desde el siglo XVII, cuando se creó el pueblo de San Carlos con población canaria ${ }^{14}$. Pero fue en el transcurso del siguiente siglo cuando se completó la fundación de poblados, con el objetivo de terminar de repoblar las áreas con escasa población o aquellas que fueron totalmente abandonadas durante las devastaciones, entre ellos destaca San Juan de la Maguana (1733), Neiba (1735), San Felipe de Puerto Plata (1737) y San Fernando de Montecristi (1751). Otros fueron erigidos para formar una barrera humana en la frontera, con el fin de impedir los deseos franceses de expansión y ocupación: Hincha (1704), San Joaquín de Dajabón (1740), San Rafael de la Angostura (1761), San Gabriel de las Caobas y San Miguel de la Atalaya (1768). Para finalizar el programa poblacional se llevó a cabo la fundación de pueblos en áreas estratégicas como Santa Bárbara de Samaná (1756) y Sabana de la Mar (1760), y en otros lugares con la intención de reunir la población de hateros dispersa como en el valle de Baní, donde se fundó un pueblo con el nombre de Nuestra Señora de Regla de Baní en $1764^{15}$.

En términos generales, hasta fines del siglo XVIII el gobierno metropolitano prohibió a sus colonias americanas comerciar con países extranjeros, pero a raíz de la Guerra de Sucesión española se permitió a los

29-51. Gutiérrez Escudero, A., Población y economía..., op. cit., pp. 45-58. Sevilla Soler, Ma. R., Santo Domingo..., op. cit., pp. 25-47.

${ }^{13}$ Lucena Salmoral, M., Los códigos negros de la América Española. Madrid, 1996, p. 73. Populación de las islas y establecimientos franceses, 1789. AGI, Santo Domingo, 956.

${ }^{14}$ Sobre la fundación del pueblo de San Carlos en el siglo XVII véase Gutiérrez Escudero, A., "Vicisitudes de una villa de canarios en La Española: San Carlos de Tenerife, 1684-1750". Actas del IX Coloquio de Historia Canaria-Americana. Las Palmas de Gran Canaria, 1992, vol. I, pp. 707-716.

${ }^{15}$ Para el estudio de la política de repoblación, y fundación de pueblos, citamos algunos de los trabajos más recientes: Gutiérrez Escudero, A., Población y economía... op. cit., pp. 58-75, y “Colonos, familias pobladoras y fundación de ciudades en La Española, 1684-1768” en El reino de Granada y el Nuevo Mundo. V Congreso Internacional de Historia de América. Granada, 1994, pp. 453-466. Sevilla Soler, Mª R., Santo Domingo...., op. cit., pp. 47-65. A cerca de las villas y pueblos fundados a partir de los inmigrantes canarios véase las siguientes obras: Deive, C. E., Las emigraciones canarias a Santo Domingo (siglos XVII y XVIII). Santo Domingo, 1991. Pérez Guerra, I., Historia y Lengua. La presencia canaria en Santo Domingo. El caso de Sabana de la Mar. Santo Domingo, 1999. 


\section{Marco histórico}

ingleses tener el derecho de llevar anualmente un barco con mercancías a las colonias españolas y el asiento de negros, cuyo trato pasó a monopolizar completamente. Paulatinamente el monopolio español fue resquebrajándose, y los ingleses comenzaron a comerciar tanto legalmente como de forma ilícita con las colonias españolas del Caribe.

De nuevo el contrabando británico y de otras naciones europeas, como el francés y holandés, se generalizó en toda el área del Caribe, en particular en Santo Domingo. La Corona trató de restringir este tráfico mediante el corso, concediendo un permiso especial para que patrullaran el litoral de la colonia y confiscasen cualquier barco extranjero ${ }^{16}$. Muchos habitantes de la isla se dedicaron a esta actividad corsaria, y hubo ocasiones en que los corsarios llegaron a realizar ataques y a detener a los barcos que navegaban de forma legal. Esto provocó serios conflictos entre la Corona española y algunas naciones afectadas, como Inglaterra. Las mercancías capturadas se vendían después en el puerto de Santo Domingo, lo que contribuyó a que hubiera movimiento económico, pues atrajo a muchos comerciantes de las colonias españolas y extranjeras. Estos corsarios también transportaron y proporcionaron a la población local productos básicos como harina, vino y tejidos difíciles de conseguir por las irregularidades del comercio con la metrópoli, así como mano de obra esclava, muy deficitaria y necesaria en los hatos y plantaciones agrícolas. Esta actividad creada para acabar con el comercio ilícito fue algo arbitraria. Al permitirse la venta de las mercancías apresadas, el contrabando entró en las colonias; de hecho muchos de esos corsarios se dedicaron al mismo tiempo al contrabando y al comercio legal ${ }^{17}$.

Asimismo, se intensificó el comercio con la colonia vecina francesa, que para aquel entonces se había convertido en una de las principales colonias europeas por su especialización en la producción de azúcar, café, añil y algodón a gran escala. La fuerte demanda europea de estos productos determinó que aumentase la introducción de la mano de obra esclava en esa colonia. La fuente de abastecimiento era la costa occidental africana, lo que hizo que para fines del siglo

\footnotetext{
${ }^{16}$ Un trabajo muy interesante sobre el corso es el de Stapells Johnson, V., "Los corsarios de Santo Domingo 1718-1779: un estudio socio-económico”. Quaderns del departament de geografia i historia del l'etudi general de Lleida 12 (Lleida, 1992) pp. 3-93. Véase también alguna referencia en Moya Pons, F., Historia colonial..., op. cit. p. 240, y Lucena Salmoral, M., Piratas, corsarios..., op. cit., pp. 277-304.

${ }^{17}$ Stapells Jonson, V., Idem.
} 
XVIII el componente esclavo dentro de su población fuese muy alto. Esta economía de plantación absorbió la mayor parte del espacio, imposibilitando la crianza de ganado que proporcionase carne para la alimentación humana, así como animales para tareas de trabajo.

Esta carencia contribuyó a que Santo Domingo recuperara su economía, al convertirse en abastecedora de ganado a la colonia francesa de Saint Domingue durante el siglo XVIII. A cambio se recibían manufacturas francesas que permitían comprar esclavos, utensilios y herramientas; mientras los habitantes de la parte española proporcionaban tabaco, carne, cueros y animales de transporte como caballos y mulas. La mayoría de los habitantes de la parte española, en especial las capas superiores, se dedicaron a la actividad hatera. Su comercio con la colonia francesa se realizó habitualmente de manera tanto legal como clandestina.

Esta última forma de comercio a través de la frontera fue uno de los principales problemas a los que tuvieron que hacer frente la alta administración. La prohibición de tal comercio dio lugar a episodios conocidos en la historiografía dominicana como los “Tumultos de Santiago” o a la "Revuelta de los Capitanes”, que se produjo entre 1715 y 1723. Este movimiento estuvo encabezado por la élite dirigente de la ciudad de Santiago, que estaba formada fundamentalmente por hateros. Éstos se opusieron a los intentos desde la ciudad de Santo Domingo de paralizar el comercio de ganado con la parte francesa, porque lo consideraban perjudicial para el abastecimiento de dicha ciudad ${ }^{18}$.

En principio todas las ciudades de la isla debían suministrar ganado a las carnicerías de la ciudad de Santo Domingo a través del sistema de pesas, por el cual los cabildos de las distintas poblaciones reunían a los criadores al inicio del año para que declararan el número de reses que poseían. A continuación se establecía por sorteo el número de reses, así como la fecha en que debían enviarselas. Probablemente los fraudes fueron algo común entre los ganaderos de los pueblos fronterizos, y en especial entre los de Santiago, quienes obtenían más beneficios al comerciar las reses con los franceses. Según Antonio Gutiérrez, detrás de la mencionada rebelión se encuentra el intento de las capas altas de

\footnotetext{
${ }^{18}$ Al respecto véase Gutiérrez Escudero, A., Población y economía..., op. cit., pp. 168-170, y "Contrabando en el Caribe: comercio ilícito entre franceses y españoles en Santo Domingo". Estudios de Historia Social y Económica de América 1 (Alcalá de Henares, 1985) pp. 71-90.
} 
Santo Domingo por controlar a la élite ganadera de Santiago ${ }^{19}$. La lucha entre estas dos ciudades fue una constante durante la colonia prolongándose en el siglo XIX, hasta el punto de que en sucesivas ocasiones la ciudad de Santiago trató de independizarse de Santo Domingo ${ }^{20}$.

La alianza entre Francia y España a partir de la guerra de 1739 permitió que el comercio entre ambas colonias se realizase, pero esto no significó que fuese de forma regular, ya que los límites fronterizos todavía no estaban marcados. Los continuos choques e incidentes entre los habitantes de ambas partes en la frontera, fue otro problema que obligó a los gobernadores e ingenieros de ambas colonias a negociar sobre los límites fronterizos durante prácticamente todo el siglo XVIII. Después de toda una serie de convenciones y tratados provisionales, la firma del Tratado de Aranjuez en 1777 puso fin a la lucha legal para la definición de los límites fronterizos; no obstante, en la realidad los problemas continuaron hasta finales del siglo. Junto a este tratado también se firmaron cláusulas que autorizaron el comercio de ganado, frutos, y la captura conjunta de negros fugitivos que habitaban en la frontera ${ }^{21}$.

La población de la parte española no sólo se dedicó al comercio de ganado y corso, sino también a la fabricación de azúcar y al cultivo de otros productos agrícolas como el tabaco, cacao, añil, café y algodón. La mayor parte de la historiografía dominicana coincide al considerar que fue hacia mediados del siglo XVIII cuando el desarrollo agrícola resurgió, siendo en torno a 1780 cuando alcanzó su máximo apogeo. Este auge se vio amparado por el impulso que la Corona dio a la agricultura comercial, así como al esfuerzo y apoyo proporcionado por todos los gobernadores y los propios habitantes de la ciudad de Santo Domingo ${ }^{22}$.

\footnotetext{
${ }^{19}$ Gutiérrez Escudero, A., Población y economía..., ibidem, pp. 148-156.

${ }^{20}$ Acerca de la lucha entre ambas ciudades véase Gutiérrez Escudero, A., "Diferencias entre agricultores y ganaderos en Santo Domingo: siglo XVIII”. ECOS 2 (Santo Domingo, 1993) pp. 45-76. Para el siglo XIX consúltese la obra de Hoetink, H., El pueblo dominicano, 1850-1900. Apuntes para su sociología histórica. Santiago, 1985.

${ }^{21}$ Entre los estudios que tratan el tema fronterizo véase: Peña Batlle, M. A., Historia de la cuestión fronteriza dominico-haitiana. Santo Domingo, 1988 (1946). Gutiérrez Escudero, A., “Cuestión de límites en la Isla Española, 1690-1777”. Temas Americanistas 1 (Sevilla, 1982) pp. 22-24. También véase la obra de Sevilla Soler, Mª. R., Santo Domingo..., op. cit., pp. 341-374.

${ }^{22}$ Historiadores como Frank Moya, Roberto Cassá y Antonio Gutiérrez consideran que a partir de 1780 es cuando hay un resurgimiento en la economía de Santo Domingo. Cassá sitúa el inicio de esa mejora hacia 1730, y Gutiérrez un año más tarde. Al respecto véase Moya Pons, F., Historia colonial..., op. cit., pp. 307-308. Cassá, R., Historia social y económica de la República
} 
De esta forma, muchas tierras se hallaban concentradas y administradas por una minoría formada por un grupo de hombres y mujeres, que además de poseer grandes hatos o hatillos, se dedicaron a la producción del azúcar en ingenios o trapiches localizados en los alrededores de la ciudad de Santo Domingo, y en el sur de la isla, entre el río Nizao y Ozama. También solían contar con estancias en las que plantaban cacao, café, algodón, plátanos o yuca. Estos hacendados que residían en dicha población estuvieron vinculados a la administración, la universidad, la Iglesia y a la vida militar, siendo un importante grupo de presión en la isla. Todos ellos entrelazados y ocupando prácticamente las instituciones de poder, y en particular el cabildo de la ciudad, procuraron que muchas leyes promulgadas por la Corona les favoreciesen.

El resurgimiento de la plantación agrícola conllevó la importación de herramientas de labranza y sobre todo de mano de obra esclava. Todo esto fue proporcionado por varías vías, bien por el comercio que se mantuvo con la colonia francesa, concesiones que la Corona hizo en un principio a particulares y luego se extendieron al resto de la población, o bien por medio de la Real Compañía de Comercio de Barcelona. El papel de esta compañía privilegiada está también relacionado con la activación del comercio interior por el cultivo de tabaco, especialmente en la zona de Santiago y La Vega, donde además de dedicarse a la cría de ganado, cultivaban dicho producto desde hacía años vendiéndolo a la colonia francesa y a las islas vecinas. La toma de La Habana por los ingleses en 1762 supuso que ésta no pudiese proporcionar tabaco a la Península, y a partir de entonces Santo Domingo empezó a jugar un destacado papel en el comercio del producto. La Corona permitió en 1763 el establecimiento de una Factoría de Tabaco, que se encargó de fomentar y acaparar la producción que después se enviaba a las Reales Fábricas de Sevilla, donde era procesado con el tabaco de otras colonias ${ }^{23}$. Alrededor del cultivo del tabaco en la región del Cibao, se creó

Dominicana. Santo Domingo, 1998, vol. I, pp. 115-116. Gutiérrez Escudero, A., “Acerca del proyectismo y del reformismo borbónico en Santo Domingo”. Temas Americanistas 13 (Sevilla, 1997) pp. 17-30.

${ }^{23}$ Entre las publicaciones más importantes sobre el tabaco y papel de la Compañía de Barcelona, se encuentran: Lluberes Navarro, A., "Las rutas del tabaco dominicano". Eme-Eme Estudios Dominicanos 21 (Santiago de los Caballeros, 1975) pp. 3-22, y "Tabaco y catalanes en Santo Domingo durante el siglo XVIII”. Eme-Eme Estudios Dominicanos 28 (Santiago de los Caballeros, 1977) pp. 13-26. Sevilla Soler, Mª. R., Santo Domingo..., op. cit., pp. 104-117. Gutiérrez Escudero, A., Población y economía..., op. cit., pp. 108-113; “Tabaco y algodón en Santo Domingo, 1731-1795” en Sarabia Viejo, Mª. J., Entre Puebla de los Ángeles y Sevilla. 
otro importante grupo formado por grandes cosecheros también conectados entre sí. Poco a poco éstos fueron restando importancia a la actividad hatera a la que se dedicaban con anterioridad, aunque sin abandonarla totalmente.

Esta situación de prosperidad dada durante la segunda mitad del siglo XVIII se truncó con los incidentes provocados por la revolución en Saint Domingue, donde se inició un levantamiento de esclavos en 1791 que pronto produjo un estado de intranquilidad en el resto de América y en su colonia vecina, donde estalló una rebelión similar en el ingenio Boca de Nigua, uno de las más importantes de aquella época. A esto se sumó la situación de Europa, inmersa en una guerra contra Francia que tuvo como resultado la cesión española a dicho país de la parte oriental de la isla tras el acuerdo de paz en Basilea en 1795, para así poder recuperar los territorios que le habían sido arrebatados ${ }^{24}$. La consecuencia inmediata de esto fue la emigración de muchos de esos hacendados y hateros, que se vieron obligados a abandonar sus bienes y trasladarse a otras colonias españolas, sobre todo a Cuba, Puerto Rico y Venezuela, donde acabaron instalándose; aunque algunos de ellos regresaron durante el siglo $\mathrm{XIX}^{25}$.

Homenaje al Dr. J. A. Calderón Quijano. Sevilla, 1997, pp. 151-169; y "El tabaco en Santo Domingo y su exportación a Sevilla (época colonial)” en Vilar Vilar, E., y Kuethe, A. (eds.), Relaciones de poder y comercio colonial: Nuevas perspectivas. Sevilla, 1999, pp. 117-142. Oliva Melgar, J. Ma ., Cataluña y el comercio privilegiado con América en el siglo XVIII: la Compañía de Comercio de Barcelona a Indias. Barcelona, 1987.

${ }^{24}$ Algunas obras que tratan el impacto de la revolución haitiana y su influencia en la parte española véanse: Peña Batlle, M. A., El tratado de Basilea y la desnacionalización del Santo Domingo español. Ciudad Trujillo, 1952. Lovatón, L., "El Tratado de Basilea”. BAGN 68 (Ciudad Trujillo, 1951) pp. 86-119. Andreu Ocariz, J. J., “La rebelión de los esclavos de Boca Nigua”. AEA XXVII (Sevilla, 1970) pp. 551-581. Entre los trabajos más recientes destacamos: Cordero Michel, E., La revolución Haitiana y Santo Domingo. Santo Domingo, 2000 (1975). Sevilla Soler, Mª. R., Santo Domingo..., op. cit., pp. 395-408, y "Las repercusiones de la Revolución francesa en el Caribe español: los casos de Santo Domingo y Trinidad”. Cuadernos Americanos 5 (México, 1989) pp. 117-133. Julián, A., "El ingenio de Boca de Nigua y la rebelión de los esclavos de su dotación en 1796” en Julián, A., Bancos, ingenios y esclavos en la época colonial. Santo Domingo, 1997, pp. 265-335.

${ }^{25}$ Sobre las emigraciones véase: Deive, C. E., Las emigraciones Dominicanas a Cuba (17951808). Santo Domingo, 1989. 
Figura 1. Poblaciones de Santo Domingo

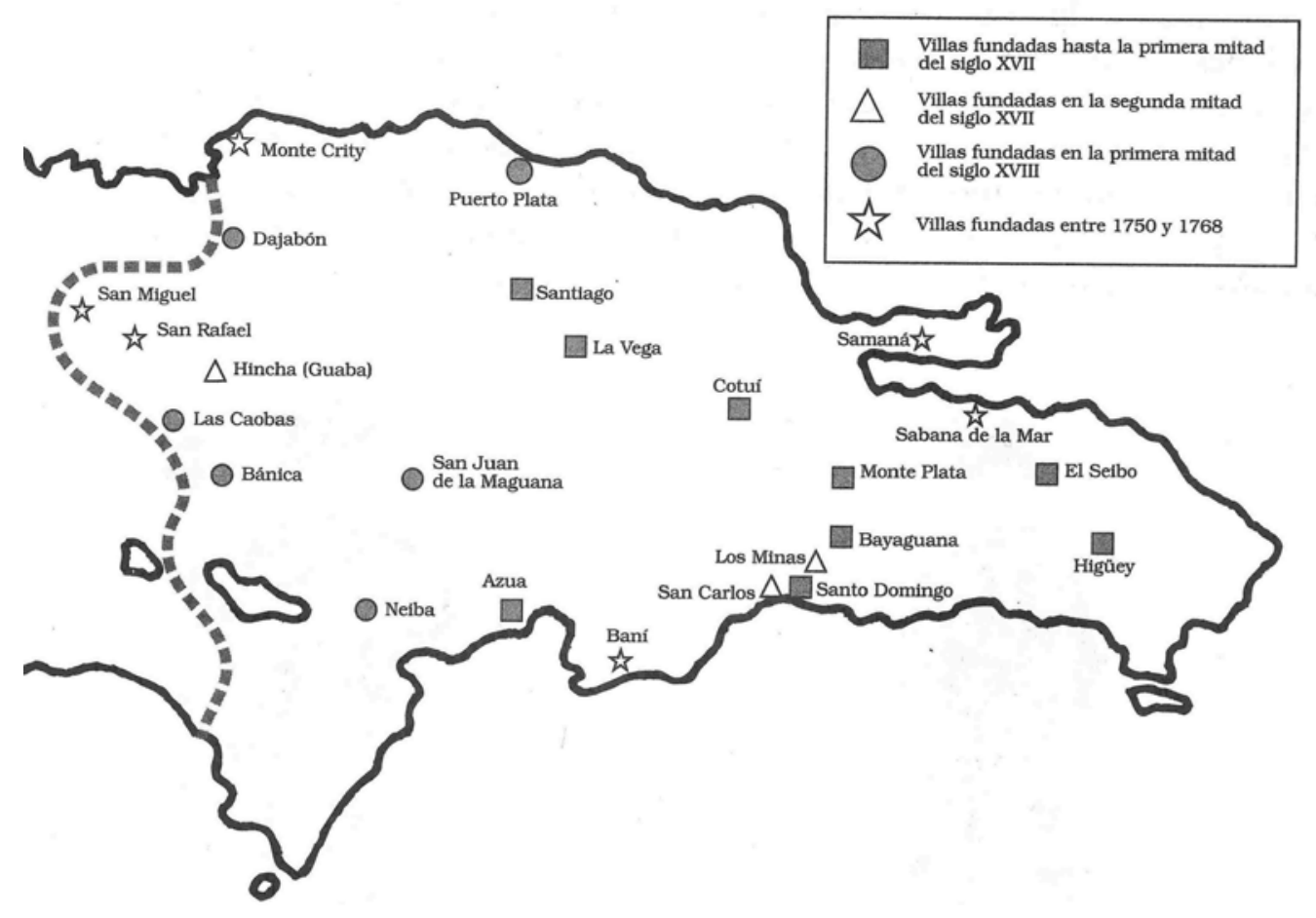

Fuentes: Cassá, R., Historia social y económica de la República Dominicana. Santo Domingo, 2003, vol. I, p. 244. 
Figura 2. Mapa de provincias de la República Dominicana

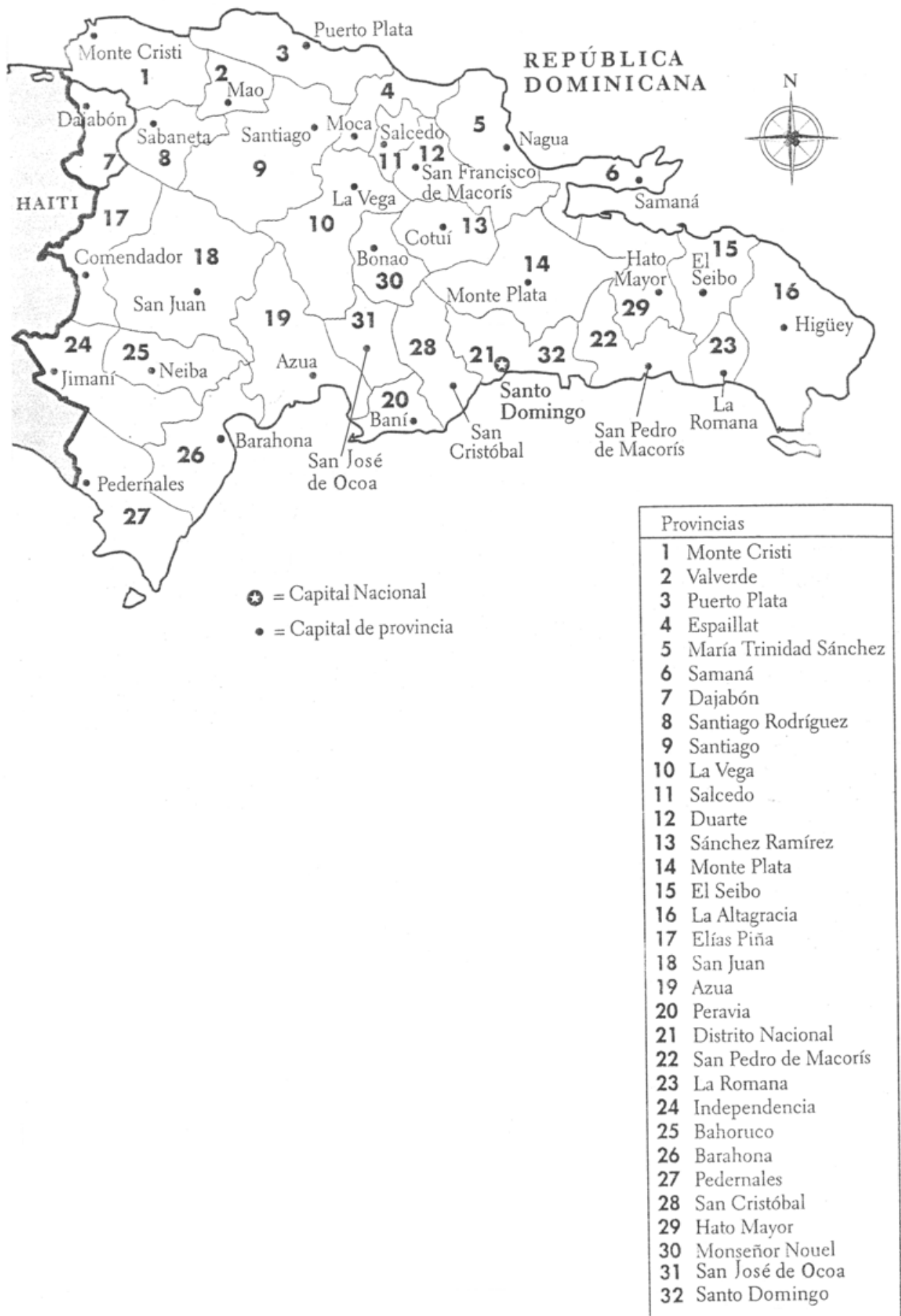

Fuentes: Mapa de elaboración propia a partir del plano de la obra de Hartlyn, J., The Struggle for Democratic Politics in the Dominican Republic. Chapel Hill and London, 1998, p. 2. 
Ruth Torres Agudo

Figura 3. Mapa actual de la República Dominicana

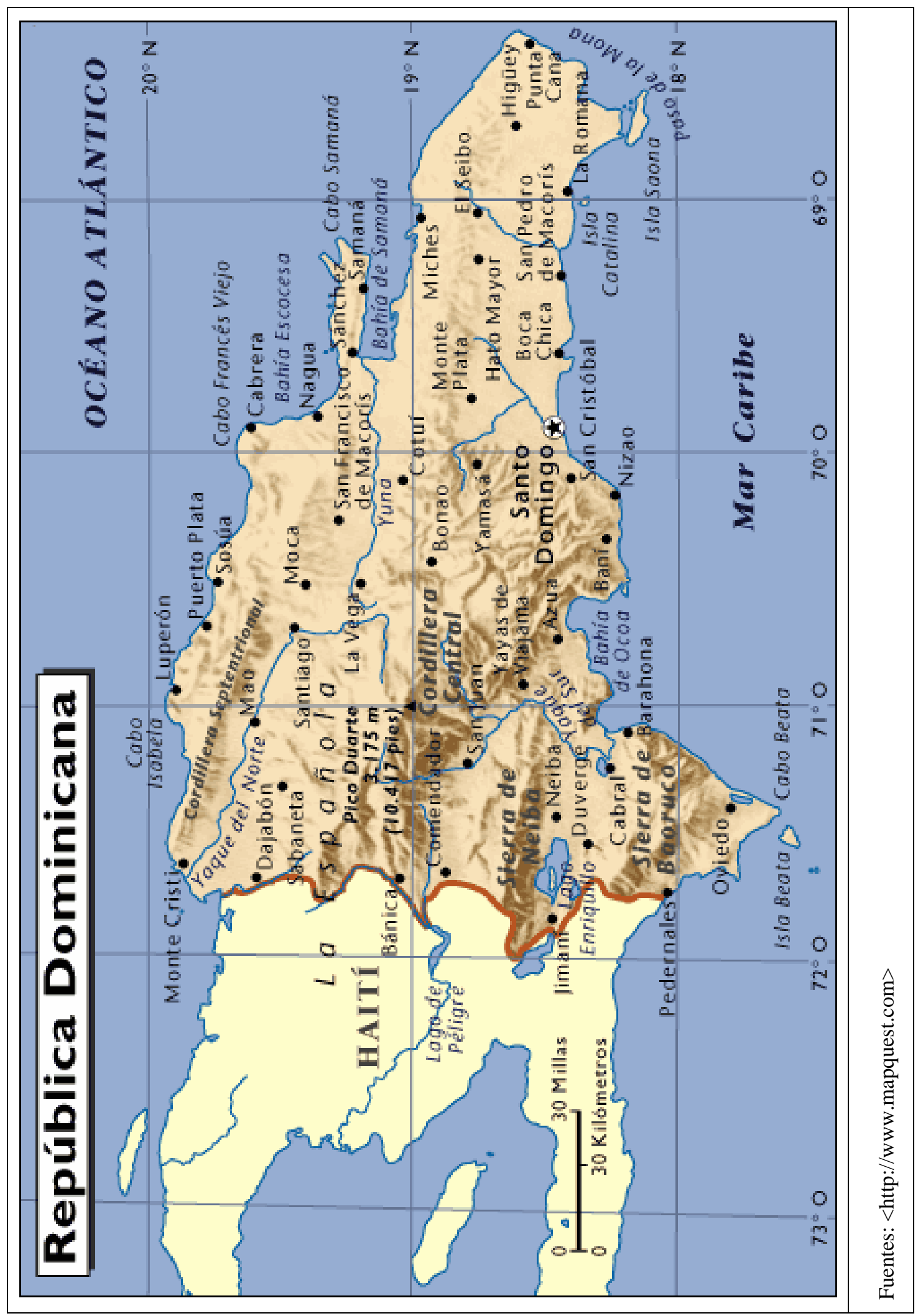




\section{CAPÍTULO 1 \\ APROXIMACIÓN HISTORIOGRÁFICA}

\subsection{Historiografía sobre élites en América colonial}

En los últimos años la investigación histórica se ha acercado, de manera recurrente, a la cuestión de las capas altas de la sociedad, élites o grupos de poder, tanto en el periodo colonial como contemporáneo. Esta temática se ha mostrado a través de una amplia bibliografía en la que se pueden encontrar las diferentes metodologías y enfoques que han ido apareciendo en este tipo de investigaciones. Tomando como punto de partida dichas investigaciones, pretendemos hacer un balance de los trabajos más significativos realizados para las élites durante la época colonial. Asimismo, su elección está relacionada con la utilidad que éstos han proporcionado a la investigación que sigue.

Una de las características que presentan estos trabajos a la hora de abordar el tema es la presencia de ciertas tendencias de diversas disciplinas, como es el caso de la sociología y la antropología, o bien de otras especialidades históricas, como la historia de las mentalidades y la historia política. Otro rasgo común que establece la bibliografía sobre los estratos superiores son las dificultades que existen para definir e identificar estos grupos. Muestra de ello es la cantidad y variedad del léxico utilizado por los historiadores ${ }^{1}$.

\footnotetext{
${ }^{1}$ Entre la variedad de términos utilizados para este grupo social los más empleados son los de estamento y clase, aristocracia, oligarquía, capas sociales altas/dominantes y el de elite o élite. Véase en Mörner, M., "Estratificación social hispanoamericana durante el periodo colonial”. Research Paper Series 28 (Stockholm, 1980) pp. 1-98. Schröter, B., y Büschges, C. (eds.), Beneméritos, aristócratas y empresarios. Identidades y estructuras sociales de las capas altas urbanas en América hispánica. Frankfurt, 1999, pp. 299-300. Langue, F., "Élites Novohispanas versus Leyenda Negra. Los nuevos caminos de la interpretación”. Revista de Historia 13
} 
Prueba del reciente interés surgido por este enfoque son los estudios generales realizados acerca de los diferentes grupos de élites, y los numerosos congresos y seminarios dedicados a esta temática en los últimos años. Ejemplo de ello son los celebrados en Salamanca sobre élites coloniales, en Nicaragua sobre élites, familias, y redes de poder en las sociedades Mesoamericanas, en Colonia sobre las capas altas urbanas (beneméritos, aristócratas y empresarios), en Lima sobre comerciantes, en Sevilla con el título de Élites urbanas en Hispanoamérica, y en Madrid el coloquio sobre las redes mercantiles y de poder transoceánicas e internacionales en la Monarquía hispánica. De todos ellos han surgido diversos trabajos y revistas monográficas que contienen estudios de determinados casos e importantes reflexiones teóricas y metodológicas ${ }^{2}$.

A través de la bibliografía se puede discernir que el método más utilizado para la investigación, identificación y análisis de las élites es la prosopografía. Ésta, surgida en el mundo anglosajón, fue desarrollada por Stone, quien la define como “[...] una biografía colectiva que se basa en el estudio de la vida de un grupo de personas, su identificación político-económica, familiar y su relación con el contexto histórico [...]”3 . La prosopografía es un método que comenzó a utilizarse en los años veinte en el análisis de la historia política, en particular para estudiar el papel desempeñado por los grupos dirigentes en el mundo romano, anglosajón o norteamericano; aunque posteriormente se ha ido aplicando a cualquier otro grupo social ${ }^{4}$.

La aplicación de esta metodología al análisis de las capas altas en la América hispánica colonial ha generado una serie de orientaciones. Una de ellas es la prosopografía política, que se ha encargado del estudio de grupos profesionales. En un principio estas investigaciones tuvieron un enfoque meramente institucional, su objeto de estudio era la historia de las instituciones y

(Nicaragua, 1999) pp. 51-62, y “Las élites en América Española, actitudes y mentalidades”. Boletín Americanista 42-43 (Barcelona, 1992-1993) pp. 123-139.

${ }^{2}$ Véanse las revistas y obras monográficas: “Taller de élites coloniales” en Alcántara, M., (ed.), América Latina. Realidades y perspectivas. Salamanca, 1997, pp. 2-242. "Élites, Familias y Redes de poder en las Sociedades Mesoamericanas”. Revista de Historia 13 (Nicaragua, 1999). Número monográfico. Schröter, B. y Büschges, C. (eds.), Beneméritos, aristócratas y empresarios..., op. cit. Mazzeo de Vivó, C. A. (coord.), Los comerciantes Limeños a fines del siglo XVIII. Capacidad y cohesión de una elite 1750-1825. Lima, 2000. Navarro García, L. (coord.), Élites urbanas en Hispanoamérica: (De la conquista a la independencia. Sevilla, 2005.

${ }^{3}$ Stone, L., "Prosopografía” en Stone, L., El pasado y el Presente. México, 1986, p. 61.

${ }^{4}$ Ibidem., pp. 62-94. Véase también Syme, R., Élites coloniales. Roma, España y las Américas. Málaga, 1993. 
la normativa jurídica de la administración colonial. El estudio de los cabildos, las audiencias, y el Consejo de Indias ha dado lugar a monografías como las de Ots Capdequí, Schäfer y Bayle ${ }^{5}$. Desde los años sesenta y setenta hasta la actualidad, han aparecido trabajos que prestan especial atención a la constitución interna de tal administración, al examen del ejercicio de la autoridad y al estudio particular de los miembros que formaban parte de las instituciones, lo que en historia moderna se ha denominado historia social de la política o de la administración ${ }^{6}$. La primera publicación dentro de la historiografía americanista que aplicó este enfoque fue la obra de Burkholder y Chandler De la Impotencia a la autoridad. Los autores utilizando el método prosopográfico analizan la acción individual de los funcionarios de las audiencias latinoamericanas desde 1687 hasta 1808, y reconstruyen sus caracteres socio-profesionales ${ }^{7}$. Otros estudios más recientes y mucho más específicos sobre la audiencia son los realizados por Bohórquez para la de Caracas, Arnold para México, y Herzog para Quito ${ }^{8}$.

Estas últimas investigaciones que reconstruyen e identifican a aquellos que participan en las instituciones con la reunión de datos de naturaleza económica, política y personales, tratan también de mostrar el modo de actuación de éstos en esos espacios y la interacción con su entorno. Esta perspectiva social del análisis de los integrantes de una institución ha generado nuevos estudios sobre las élites en América que han devuelto su importancia a la historia política. Sin embargo, lo han hecho de forma renovada al abandonar el papel meramente jurídico de las instituciones, para acercarse a los individuos que las ocupan a través de los diferentes contextos en los que éstos se mueven y centrarse en el análisis y

\footnotetext{
${ }^{5}$ Ots Capdequí, J. Ma., El Estado español en las Indias. México, 1946. Schäfer, E. H. J., El Consejo Real y Supremo de Indias. Sevilla, 1935-1947, II vols. Bayle, C., Los cabildos seculares en la América española. Madrid, 1952.

6 Leddy Phelan, J., "Authority and Flexibility in the Spanish Imperial Bureaucracy". Administrative Science Quarterly V:I (Durham, 1960) pp. 47-65. En el contexto de la historiografía de historia moderna véase Molas Ribalta, P., "La historia de la administración. Balance y perspectivas para el siglo XVIII español”. Cuadernos de investigación histórica 6 (Madrid, 1982) pp. 151-168.

${ }^{7}$ Burkholder, M. A, y Chandler, D. S., De la impotencia a la autoridad. La corona española y las Audiencias en América, 1687-1808. México, 1984 (1977). Cabe destacar también otra obra publicada años más tarde por ambos autores y titulada Biographical dictionary of audiencia ministers in the Americas: 1687-1821. Wesport, 1982.

8 López Bohórquez, A. E., Los ministros de la Audiencia de Caracas (1786-1810): caracterización de una élite burocrática del poder en Venezuela. Caracas, 1984. Arnold, L., Burocracia y burócratas en México, 1742-1835. México, 1988. Herzog, T., La administración como fenómeno social: la justicia penal de la ciudad de Quito (1650-1750). Madrid, 1995.
} 
comprensión de las relaciones que entretejen en la sociedad ${ }^{9}$. Esta orientación hacia el estudio de los integrantes de una institución desde un enfoque más social, muestra un especial interés en el análisis de los sistemas relacionales tanto de los componentes de una institución como de otros grupos dominantes. Con este objetivo las investigaciones tienden a seguir tanto a un individuo como al grupo social en el que se inserta “[...] a través de los diferentes contextos en los que se mueven [...]”, analizando a las personas y reconstruyendo alianzas de todo tipo que permitan explicar el funcionamiento grupal en su conjunto ${ }^{10}$.

Son muchos los estudios prosopográficos que investigan la élite desde la reconstrucción de sus relaciones familiares, aunque últimamente se han incluido nuevos vínculos como la amistad y la clientela. En función de la atención prestada a los vínculos se pueden distinguir, dentro del enfoque de la prosopografía social dos perspectivas: por un lado, los estudios de élite en los que predomina la atención a los vínculos familiares, y por otro, aquellos que proponen ir más allá dando gran importancia también a otro conjunto de relaciones que se establecen a partir del parentesco espiritual (padrinazgo/compadrazgo) o en torno a lugares de sociabilidad (reuniones, fiestas, cofradías, partidos políticos, asociaciones, consulados, sociedades económicas de amigos del país...), que permiten reconstruir las redes sociales en las que están inmersos y comprender mejor el funcionamiento de la sociedad colonial. Este modo de acercarse a la realidad social de la élite a través del análisis de las relaciones interpersonales y que además en parte utiliza los pasos utilizados por la prosopografía ha venido ha denominarse prosopografía generalizada o desplazada ${ }^{11}$.

\footnotetext{
${ }^{9}$ Carasa Soto, P., "La recuperación de la historia política y la prosopografía” en Carasa Soto, P. (ed.), Elites. Prosopografía contemporánea. Valladolid, 1994, pp. 41-51, p. 42. Hernández Franco, J., "El reencuentro entre historia social e historia política entorno a las familias de poder. Notas y seguimiento a través de la historiografía sobre la Castilla Moderna”. Studia Histórica 18 (Salamanca, 1998) pp. 179-199.

${ }^{10}$ Pro Ruiz, J., "Las élites de la España liberal: clases y redes en la definición del espacio social (1808-1931)”. Historia social 21 (Alicante, 1995) pp. 47-69, p. 62.

${ }^{11}$ Una síntesis de esta nueva tendencia dentro de la historiografía americanista puede verse, por ejemplo en: Bertrand, M., "De la familia a la red de sociabilidad”. Revista Mexicana de Sociología LXI: 2 (México, 1999) pp. 107-135; “La élite colonial en la Nueva España del siglo XVIII: un planteamiento en términos de redes sociales” en Schröter, B. y Büshges, C. (eds.), Beneméritos, aristócratas y empresarios..., op. cit., pp. 35-51; y "Élites y configuraciones sociales en Hispanoamérica colonial”. Revista de Historia 13 (Nicaragua, 1999) pp.1-15. Véase también Langue, F., "Élites Novohispanas versus Leyenda Negra. Los nuevos caminos de la interpretación”..., op. cit., pp. 51-62. Grendi, E., “Paradojas de la historia contemporánea”. Relaciones XXIV: 95 (Zamora, 2003) pp. 267-278, disponible en la red:
} 
Las investigaciones de élites que se centran en la familia colonial cuentan con una destacada trayectoria historiográfica ${ }^{12}$. Se caracterizan por su tendencia a identificarlas y definirlas con criterios socio-profesionales, y fundamentalmente económicos. Entre los más relevantes estudios latinoamericanos sobre las capas altas de la sociedad hispanoamericana que han marcado esta orientación, destaca la obra de Brading sobre mineros y comerciantes del México de la segunda mitad del siglo XVIII ${ }^{13}$. Esta obra ha tenido y continúa teniendo una notoria influencia en los estudios posteriores que han surgido sobre la élite colonial al identificarla con tales aspectos. De esta forma se ha publicado una abundante bibliografía que contiene una gran variedad de grupos sociales investigados, desde hacendados a mineros, comerciantes, religiosos, militares, nobles, ilustrados o burócratas ${ }^{14}$.

Cabe a su vez destacar que estos trabajos centran sus análisis en las estrategias que las familias de élites utilizaron para consolidar, reforzar o acrecentar su poder político, económico y social. La estrategia es considerada “[...] un conjunto de factores conectados entre sí, que tienen por finalidad construir, conservar o acrecentar, las diversas formas de poder [...]"15. Los investigadores que han trabajado en esta línea han especificado que los tipos de estrategias familiares desarrolladas por la élite giran entorno a dos temas: la política matrimonial y las prácticas sucesorias. La observación de las estrategias diseñadas por estos sectores de la sociedad les ha permitido también percibir parte de las relaciones personales e interacciones de las familias de élite con su entorno.

El matrimonio adquirió en Indias un papel decisivo ante el control y conservación de todo tipo de intereses en los ámbitos político, económico y social. Las relaciones matrimoniales podían tener distintos objetivos, y en función de

$<$ http://www.colmich.edu.mx/relaciones/.095/pdf/Edoardo\%20Grendi-pdf> [con acceso el 10 de enero de 2007].

${ }^{12}$ Las publicaciones sobre este tema son numerosas entre las cuáles se puede destacar: Gonzalbo Aizpuru, P., y Rabell Romero, C. (comps.), La familia en el mundo iberoamericano. México, 1994. Rodríguez Saénz, E., "Historia de la familia en América Latina. Balance de las principales tendencias”. Revista de Historia 26 (Costa Rica, 1992) pp. 145-183. Gonzalbo Aizpuru, P. (coord.), Familias novohispanas: siglo XV al XIX. México, 1991. Balmori, D., Stuart F. V., y Wortman, M., Las alianzas de familias y la formación del país en América Latina. México, 1990.

${ }_{13}^{13}$ Brading, D., Mineros y comerciantes en el México borbónico (1763-1810). México, 1993.

${ }^{14}$ Para una recopilación bibliográfica de las élites en Indias véanse: Langue, F., "Las élites en América colonial (siglos XVI-XIX). Recopilación bibliográfica”. AEA LIV: 1 (Sevilla, 1997) pp. 199-228, y la reciente versión actualizada "Las élites en América colonial (Siglos XVI-XVIII)". Nuevo Mundo Mundos Nuevos $\mathrm{n}^{\circ}$ 1, 2001, artículo que está disponible en la red: $<$ http://nuevomundo.revues.org/documento562.html.> [con acceso el 10 de enero de 2007].

${ }^{15}$ Rodríguez Sánchez, Á., "Métodos de evaluación de las estrategias en el Antiguo Régimen” en Fuentes y métodos de la Historia local: actas. Zamora, 1991, pp. 141-153, p. 142. 
estos algunas familias persiguieron su reproducción social, mientras otras las orientaron para ascender en la escala social. La bibliografía muestra que dentro de la estrategia matrimonial existen dos componentes que ayudan a la consolidación de los objetivos de la élite: la endogamia, es decir, “[...] matrimonios estratégicos y preferenciales entre personas y familias que tienen un oficio en la misma institución, o bien de otra de similar honor [...]”16, y la incorporación de foráneos cuya posición económica, relación personal o su carácter peninsular resultaban de gran utilidad. Estos mecanismos fueron llevados a cabo por los distintos grupos de la élite para mantenerse, ascender dentro del grupo, o incluso para restringir el acceso de nuevos miembros a determinadas instituciones civiles o religiosas.

Los estudios sobre la administración colonial ponen de manifiesto como el ejercicio de cargos administrativos adquirió una dimensión colectiva, donde la familia era primordial ${ }^{17}$. El cabildo es una de las instituciones coloniales que cuenta con mayor número de investigaciones. Estas publicaciones están enfocadas en torno a estudios de casos sobre determinadas ciudades en los que se analizan los aspectos institucionales de los cabildos, su estructura y forma, así como el análisis de sus componentes desde el punto de vista de su trayectoria personal y familiar. De forma que han permitido aclarar el comportamiento de la élite capitular en dicha institución y los mecanismos que desarrollaron para defender sus intereses.

Estos trabajos muestran que la composición del cabildo dependió del ámbito económico en el que estaban inmersos sus actores. Señalan a su vez que la ocupación de un oficio en ese espacio se convirtió en un instrumento de información y control al servicio de los intereses de sus componentes. La bibliografía evidencia además como las prácticas endogámicas permitieron que desde el siglo XVI las familias de encomenderos y descendientes de la conquista coparan el cabildo. Pero la enajenación de los oficios concejiles a partir de ese mismo siglo por parte de la Corona, permitió que se incorporasen nuevos miembros a los cabildos, generalmente comerciantes con posibilidades de

\footnotetext{
${ }^{16}$ Hernández Franco, J., "El reencuentro entre historia social e historia política entorno a las familias de poder”..., op. cit., pp. 179-199, p. 185.

17 Dedieu, J. P., "La familia: ¿una clave para entender la historia política? El ejemplo de la España moderna”. Studia Histórica 18 (Salamanca, 1998) pp. 201-233.
} 
comprar los oficios, y con ello se produjo la ruptura del predominio de los beneméritos ${ }^{18}$.

Este proceso de apertura no fue igual en todos los territorios americanos. Entre los estudios que lo demuestran sobresalen los trabajos realizados por Webre, Palma, y Santos Pérez para Guatemala, Gelman y Saguier para Buenos Aires, de la Peña para Nueva España y Ponce Leiva para Quito, que han hecho patente la pérdida del cabildo de su originario carácter cerrado, y su transformación en un organismo más abierto al admitir a foráneos ${ }^{19}$. Pero también evidencian como algunos beneméritos, lograron mantenerse en el cabildo mediante el matrimonio entre una criolla y un recién llegado. Esta alianza matrimonial facilitó a los foráneos integrarse en la élite local, relacionarse con otras familias, y a los criollos consolidar su situación. Los matrimonios posibilitaron la circulación de individuos y familias dentro del cabildo, aunque la compra de los oficios facilitó también la formación de redes familiares que les garantizaban su presencia en dicha institución durante largo tiempo. Asimismo, esos lazos de parentesco les permitió estar presentes en otras corporaciones, al ocupar miembros de una misma familia puestos en distintas instancias religiosas, militares o en la audiencia, cuyo fin era enriquecerse, acaparar más poder y prestigio social.

\footnotetext{
${ }^{18}$ Véanse los siguientes artículos en los que se hace un balance sobre la bibliografía publicada al respecto: Ponce Leiva, P., "Publicaciones españolas sobre cabildos americanos (1939-1989)". Revista de Indias L: 188 (Madrid, 1990) pp. 77-81. Hijano Pérez, Ma., "El municipio Iberoamericano en la historiografía española”. Revista de Indias L: 188 (Madrid, 1990) pp. 83-94. Para una visión general de los instrumentos que utilizó la élite capitular indiana para defender sus intereses véase en García Bernal, M. C., "Las élites capitulares indianas y sus mecanismos de poder en el siglo XVII”. AEA LVII: 1 (Sevilla, 2000) pp. 89-110.

${ }^{19}$ Webre, S., "Antecedentes económicos de los regidores de Santiago de Guatemala, siglo XVI y XVIII: una élite colonial” en Webre, S., La sociedad colonial en Guatemala: estudios regionales y locales. La Antigua Guatemala, 1989, pp. 189-219, y “El cabildo de Santiago de Guatemala en el siglo XVII: ¿Una oligarquía criolla, cerrada y hereditaria?”. Mesoamérica 2 (Guatemala, 1986) pp.

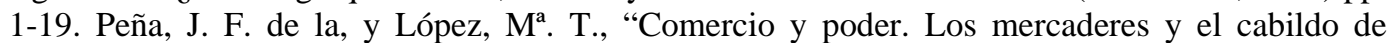
Guatemala, (1592-1623)”. Historia Mexicana XXX: 4 (México, 1981) pp. 469-505. Para el siglo XVIII de Guatemala véase Palma Murga, G., "Núcleos de poder local y relaciones familiares de Guatemala a finales del siglo XVIII”. Mesoamérica 12 (Guatemala, 1986) pp. 241-249. Santos Pérez, J. M., Élites, poder local y régimen colonial. El cabildo y los regidores de Santiago de Guatemala, 1700-1787. Cádiz, 1999, y "Las élites de Santiago de Guatemala y el cabildo colonial, 1700-11770”. Revista de Historia 38 (Costa Rica, 1998) pp. 87-11. Gelman, J. D., “Cabildo y élite local: el caso de Buenos Aires”. HISLA 6 (Buenos Aires, 1985) pp. 3-20. Saguier, E., “El parentesco como mecanismo de consolidación política de un patriciado colonial. El caso de las provincias rioplatenses del virreinato peruano (1700-1776)". Estudios de Historia Social y Económica de América 10 (Alcalá de Henares, 1993) pp. 61-116. Peña, J. F. de la., Oligarquía y propiedad en Nueva España 1550-1624. México, 1983. Ponce Leiva, P., Certezas ante la incertidumbre. Élite y cabildo de Quito en el siglo XVII. Quito, 1998.
} 
No obstante, hubo zonas en las que la apertura a los inmigrantes no tuvo lugar, y donde el dominio de los cabildos continúo en manos de dinastías familiares que se perpetuaron generación tras generación gracias a una fuerte endogamia como estrategia matrimonial. En otras ocasiones, la inversión en otras actividades económicas fue lo que permitió a las familias de élites seguir entre los principales de sus ciudades. Ejemplos de esto son los estudios realizados por Lohmann Villena para Lima, González Muñoz y Martínez Ortega para los cabildos de Mérida, Valladolid, y Campeche en México, y de la Tabla para Quito, entre otros ${ }^{20}$.

Estas estrategias matrimoniales fueron igualmente muy frecuentes entre otro grupo dominante, los comerciantes. Trabajos sobre familias de comerciantes como los de Socolow para Buenos Aires, Kicza para Nueva España, y López Beltrán para La Paz muestran de que manera la elección de pareja para un matrimonio no quedaba a cargo de los novios, sino que eran los padres de los contrayentes quienes intervenían con el fin de reproducir su situación socioeconómica familiar para unos, y aumentar su riqueza y posición para otros ${ }^{21}$.

De este modo, al igual que en muchas otras sociedades de distintas épocas, el matrimonio no era fruto de una decisión personal, sino más bien de una colectiva, de la familia. Así, una buena política matrimonial significó, tanto para los comerciantes como para cualquier otro estrato social alto, no sólo preservar la fortuna familiar, sino también establecer buenas alianzas político-económicas con el resto de grupos dominantes lo que permitió fortalecer la posición social y aumentar las conexiones e influencias en esferas aún más altas. Por el contrario, la incapacidad de lograr una fuerte alianza familiar provocó luchas entre linajes, así como problemas e incluso el fracaso en la obtención de beneficiosos pactos. De

\footnotetext{
${ }^{20}$ Lohmann Villena, G., Los regidores perpetuos del cabildo de Lima (1535-1821): crónica y estudio de un grupo de gestión. Sevilla, 1983. González Muñoz, V., y Martínez Ortega, A. I., Cabildos y élites capitulares en Yucatán (dos estudios). Sevilla, 1989. González Muñoz, V., Cabildos y grupos de poder en Yucatán (siglo XVII). Sevilla, 1994. Ortiz de la Tabla Ducasse, J., Los encomenderos de Quito, 1534-1660. Origen y evolución de una élite colonial. Sevilla, 1993.

${ }^{21}$ Socolow, S., Los mercaderes de Buenos Aires Virreinal: familia y comercio. Buenos Aires, 1991. Kicza, J., Empresarios coloniales. Familias y negocios en la ciudad colonial de México durante los borbones. México, 1986. López Beltrán, C., Alianzas familiares. Élite, género y negocios en La Paz, siglo XVIII. Lima, 1998. Una obra monográfica que trata este tema es la de Seed, P., Amar, honrar y obedecer en el México colonial, conflictos en torno a la elección matrimonial, 1574-1821. México, 1991.
} 
ahí la importancia de poder establecer relaciones estratégicas a través del matrimonio.

La obra de Brading Mineros y Comerciantes en el México Borbónico permite conocer un nuevo aspecto sobre la posición de un inmigrante español en la sociedad mexicana mediante un tipo especial de relación familiar entre tíosobrino o primo. Esta clase de relación de parentesco fue una de las más frecuentes formas de promoción de los inmigrantes que llegaban a Indias. Su integración se realizó porque contaban con algún familiar, generalmente un tío que, a través de una carta hacía un llamamiento a uno de sus sobrinos o primos para que se estableciera con él en el mundo americano ${ }^{22}$. De esta forma se colocaba a un pariente joven en el propio negocio para obtener ayuda en el comercio, la mina o la hacienda. Con frecuencia el joven tendió a heredar la dirección del negocio, y en ocasiones contrajo matrimonio con la viuda de su predecesor o con la hija de éste. Tras esa alianza matrimonial se puede advertir de nuevo una estrategia para reproducir la situación familiar anterior, y por otro lado, para facilitar la integración del inmigrante en la élite local.

La bibliografía que aborda la inmigración a Indias es muy extensa, particularmente en el caso de los vascos y navarros. Por otra parte, uno de los aspectos en los que se han centrado estos estudios son los mecanismos de incorporación a la élite local de cada territorio americano ${ }^{23}$. El hecho de que los inmigrantes procediesen de un mismo lugar, propició que en múltiples ocasiones éstos se reunieran estableciendo relaciones de paisanaje. De esta forma, muchos comerciantes instauraron importantes redes comerciales a través de la familia, mediante alianzas matrimoniales y por paisanaje. Buen ejemplo de ello fueron las distintas casas comerciales que surgieron durante el siglo XVIII en el continente americano, como la de los Aycinena en Guatemala, los comerciantes y mineros Fagoaga de Nueva España, los Elizalde o Torre Tagle en Lima, y la de los Uztáriz

\footnotetext{
22 Brading, D., Mineros y comerciantes..., op. cit, pp. 156-157.

${ }^{23}$ Sobre la importancia de la inmigración del norte de España véase la ya citada obra de Brading, D., Mineros y comerciantes..., idem, y otras como Caro Baroja, J., La hora de Navarra del siglo XVIII (personas, familias, negocios e ideas). Pamplona, 1985. Otazu y Llana, A., Hacendistas navarros en Indias. Bilbao, 1970. Eiras Roel, A. (ed.), La emigración española a Ultramar 1492-1914. Madrid, 1991, pp. 134-166. Andrés Gallego, J. (coord.), Navarra y América. Madrid, 1992. Usunariz Garayoa, J. Ma ., Una visión de la América del siglo XVIII: correspondencia de emigrantes guipuzcoanos y navarros. Madrid, 1992. Escobedo, R, Zaballa, A, y Álvarez Gila, O. (eds.), Emigración y redes sociales de los vascos en América. Vitoria, 1996.
} 
establecidos en Cádiz desde donde comerciaban con América, Asia, África e incluso con Filipinas. Su estudio muestra como estos comerciantes, a través de las conexiones familiares y de amistad, lograron que sus negocios funcionaran con éxito tanto en la Península como en los distintos territorios americanos ${ }^{24}$.

Los estudios referentes a las familias de comerciantes evidencian también otro aspecto notorio, el particular papel que jugaba la mujer en la transmisión del patrimonio. Los comerciantes utilizaban la dote como estrategia sucesoria en la transmisión del patrimonio, pues la mujer transfería a su marido parte de la fortuna familiar. La dote servía de capital inicial para el desarrollo familiar, y así el marido era incorporado en la actividad empresarial de la familia de su mujer, iniciando su actividad junto a su suegro. Sin embargo, en otros casos era el hombre quien disponía del patrimonio y actuaba como rescatador ante los problemas y deudas que pudiera tener la empresa de la familia de su mujer. Además de ser un soporte económico la dote suponía un signo de prestigio social y un indicador de la posición económica de la familia de la mujer. Su composición podía variar, desde objetos de plata a una cantidad de dinero, bienes raíces urbanos o propiedades rurales.

Una gran parte de las principales familias reunieron sus bienes en mayorazgos para evitar la dispersión de sus bienes y conservar la fortuna familiar indivisa durante generaciones. En un análisis detallado, Vargas-Lobsinger demuestra la persistencia del importante mayorazgo del condado de San Pedro del Álamo durante la colonia mexicana. El mayorazgo además de mantener el patrimonio económico también puso de manifiesto el prestigio social de sus fundadores, y por tanto aportaba distinción para sus sucesores ${ }^{25}$.

Esta última consideración refiere otros factores a los que los estudios de élites están prestando atención: las mentalidades e identidades. Estas investigaciones se acercan a las formas y contextos donde las élites manifiestan su

\footnotetext{
${ }^{24}$ A cerca de estas compañías comerciales véanse: Ruíz Rivera, J. B., "La compañía de Uztáriz, las Reales Fábricas de Talavera y el comercio con Indias”. AEA XXVI (Sevilla, 1979) pp. 209245. Kicza, J., Empresarios coloniales..., op. cit., Brading, D., Mineros y comerciantes..., idem. Mazzeo de Vívó, C. A. (coord.), Los comerciantes Limeños a fines del siglo XVIII..., op. cit.

${ }^{25}$ Vargas-Lobsinger, $\mathrm{M}^{\mathrm{a}}$., Formación y decadencia de una fortuna: el mayorazgo de San Miguel de Aguayo de San Pedro del Álamo, 1583-1823. México, 1992.
} 
elevado estatus ${ }^{26}$. Si bien dicho alto rango social es fundamentalmente designado por la riqueza, hay otros elementos como el estilo de vida, la posesión de una residencia ubicada en un buen lugar de la ciudad y de esclavos y carruajes, la indumentaria o la decoración de las casas muestran también al resto de la sociedad la posición social alcanzada.

Los rituales religiosos como el patrocinio y financiamiento de ceremonias, estructuras religiosas, la dedicación de los hijos a la vida eclesiástica, y donaciones de tierras y riqueza que se hacían a través de las capellanías han sido estudiados por Socolow para Buenos Aires, Hoberman y Kicza para México, quienes los conciben como elementos de supremacía social utilizados por la élite $^{27}$. La instauración de capellanías tenía una doble función: la espiritual que consistía en la celebración de una serie de misas para los difuntos, y la económica, para garantizar la posesión de bienes de sus descendientes. Con estos mecanismos la élite pretendía exteriorizar su estatus privilegiado, y asegurar el prestigio y respeto que desprendía ante la sociedad. Pero las capellanías además de facilitar el ingreso de un miembro de la parantela a la Iglesia, también fueron una forma de obtener crédito como pone de manifiesto los trabajos sobre Nueva España de Wobeser y Lavrin ${ }^{28}$.

El uso de apelativos como “don” o “doña”, la posesión de sepulturas familiares, la ocupación de sitios de honor en procesiones o conmemoraciones y los bancos reservados en la Iglesia, eran símbolos que igualmente otorgaban a la élite reconocimiento y que ésta utilizaba como medio de perpetuación. En los actos públicos tenían lugar frecuentemente disputas de protocolo, sobre todo a la hora de ocupar los puestos preeminentes, y a través de esos conflictos la élite está siendo estudiada en relación con otras fracciones de sí misma, civiles o eclesiásticas. Hasta el momento estos enfrentamientos aparecen en las

\footnotetext{
${ }^{26}$ Kicza, J., "Formación, identidad y estabilidad dentro de la élite colonial mexicana en los siglo XVI y XVII” en Schrörter, B., y Büschges, C., Beneméritos, aristócratas y empresarios..., op. cit., pp. 17-34.

${ }^{27}$ Socolow, S., Los mercaderes de Buenos Aires..., op. cit. Hoberman, L. S., "Merchants in seventeenth-century Mexico city. A preliminary portrait”. HAHR LVII: 3 (Durham, 1977) pp. 479-503. Kicza, J., Empresarios coloniales..., op. cit.

${ }^{28}$ Wobeser, G. V., El crédito eclesiástico en la Nueva España. Siglo XVIII. México, 1994. Lavrin, A., "El capital eclesiástico y Las Élites Sociales en Nueva España a Fines del Siglo XVIII”. Estudios Mexicanos I: 1 (California, 1985) pp. 1-28.
} 
investigaciones como un aspecto más, son escasos los estudios de este tipo que han generado alguna monografía al respecto ${ }^{29}$.

La ocupación de cargos administrativos, eclesiásticos y militares, también denominados “empleos de honor”, proporcionaron honor y prestigio a nivel personal y familiar ${ }^{30}$. La relevancia dada a los puestos alcanzados por la élite se asentó en el origen y descendencia familiar en determinadas regiones. De forma que la certificación de la calidad de hidalguía o de la limpieza de sangre de una persona se convirtió en muchos lugares en un requisito imprescindible para poder acceder al cabildo, órdenes religiosas, militares y universidades ${ }^{31}$.

En las relaciones de méritos y servicios de muchos miembros de la élite, la persona que la presenta insiste sobre todo en la antigüedad de su familia y el renombre de esta en el pasado. En la configuración de esa procedencia gloriosa, la memoria tenía un papel esencial. Cuanto más se remontaba el origen familiar, incluso acudiendo a los primeros conquistadores y pobladores de la América hispánica, más posibilidades había de alcanzar el ideal de nobleza. Para poder lograr de forma efectiva ese ideal era necesario poseer un título nobiliario, y una de las condiciones para obtenerlo era que la persona que aspiraba a él y su familia tuvieran pureza de sangre. Ello explica las extensas genealogías que les servían para justificar la preeminencia de la familia, y a los investigadores para elaborar los árboles genealógicos.

Los trabajos más notables acerca de la nobleza americana son los de los historiadores Konetzke, Lohmann Villena, y más recientemente los de Lira Montt. En ellos se tratan los elementos constitutivos de la nobleza americana desde una perspectiva jurídico-institucional, y son de gran utilidad para el estudio de los

\footnotetext{
${ }^{29}$ La importancia del protocolo ya fue expuesto por Leddy Phelan, J., “Authority and Flexibility in the Spanish Imperial Bureaucracy”..., op. cit. Otras publicaciones más recientes véanse: Urquiza, F. C., "Etiquetas y conflictos: El obispo, el virrey y el cabildo en el Río de la Plata en la segunda mitad del siglo XVIII”. AEA L: 1 (Sevilla, 1993) pp. 55-100. Valenzuela Márquez, J., "Rituales y "fetiches" políticos en Chile Colonial: entre el sello de la Audiencia y el pendón del cabildo”. AEA LVI: 2 (Sevilla, 1999) pp. 413-440. Santos, J. M., Élites, poder local y régimen colonial..., op. cit, pp. 304-310.

${ }^{30} \mathrm{Al}$ respecto véase Büschges, C., "Linaje, patrimonio y prestigio. La nobleza titulada de la ciudad de Quito en el siglo XVIII”. AEA LVI: I (Sevilla, 1999) pp. 123-145. Langue, F., “Las élites en América española, actitudes y mentalidades”..., op. cit., pp. 123-139, p. 132 y 133.

${ }^{31}$ Castillo Palma, N. A., "Los estatutos de "pureza de sangre" como medio de acceso a las elites: el caso de la región de Puebla” en Castañeda, C. (coord.), Círculos de poder en la Nueva España. México, 1998, pp. 105-129.
} 
títulos nobiliarios de la élite hispanoamericana ${ }^{32}$. Otra línea de investigación ha limitado su análisis a un grupo de nobles de determinadas regiones hispanoamericanas. La primera investigación realizada en esta dirección fue el estudio de Ladd sobre la nobleza titulada de la ciudad de México de finales del siglo XVIII y principios del $\mathrm{XIX}^{33}$. Recientemente, otros historiadores como Langue han trabajado en la mentalidad aristocrática de la élite a través del estudio de las actitudes y comportamientos de las capas altas en Zacatecas y Caracas durante el siglo XVIII. La autora ofrece información sobre ciertas familias que ostentaron títulos nobiliarios y militares. Según Langue, estas concesiones de nobleza en América sirvieron para premiar a los funcionarios, mineros, terratenientes y comerciantes que hubiesen contribuido a la Corona con préstamos, con el abasto de carne en casos de crisis agrícolas o guerras, y con el mantenimiento de la seguridad y la paz evitando sublevaciones. Este tipo de donaciones por parte de la élite a favor de la Corona fue uno de los motivos que facilitaban la obtención de títulos de nobleza ${ }^{34}$.

Una interpretación similar presenta el trabajo de González-Ripoll en Cuba, La isla de los ensayos, en el que destaca otras formas de ennoblecimiento, como fue la fundación de poblaciones. González-Ripoll sostiene que muchos hacendados de las antillas, en particular los cubanos, llegaron a tramitar con la Corona la creación de pueblos estratégicos para asegurar las costas y fomentar la riqueza. Uno de los títulos más importantes del siglo XVIII fue el Conde Jaruco, concedido por la fundación de la villa de San Juan de Jaruco. Otra condición que permitía la concesión de títulos nobiliarios fue poseer un buen patrimonio económico. De ahí que entre los grandes hacendados cubanos de fines del siglo XVIII, se convirtiera en algo común solicitar la fundación de mayorazgos para

\footnotetext{
${ }^{32}$ Lohmann Villena, G., Los americanos en las órdenes nobiliarias (1529-1900). Madrid, 1947, II vols. Konetzke, R., "La formación de la nobleza en Indias”. AEA III: 10 (Sevilla, 1951) pp. 328358. Lira Montt, L., "La prueba de hidalguía en el Derecho indiano”. Hidalguía 140 (Madrid, 1977) pp. 65-100; "Normas sobre la concesión de títulos de Castilla a los residentes en Indias”. Hidalguía 165 (Madrid, 1981) pp. 629-656, y "Las cédulas auxiliatorias en el Derecho nobiliario indiano”. Hidalguía 178-179 (Madrid, 1983) pp. 479-496.

${ }^{33}$ Ladd, D., La nobleza mexicana ante la independencia, 1780-1826. México, 1984.

${ }^{34}$ Langue, F., Los señores de Zacatecas. Una aristocracia minera del siglo XVIII novohispano. México, 1999, y "El círculo de las alianzas. Estructuras familiares y estrategias económicas de la élite mantuana (siglo XVIII)”. Boletín de la Academia Nacional de la Historia 309 (Caracas, 1995) pp. 97-121.
} 
reunir en manos de un único heredero la fortuna y el título nobiliario ${ }^{35}$. La historiografía ha considerado que la concesión de los títulos significó debilidad por parte de la Corona; sin embargo, estudios como los de Langue y GonzálezRipoll la interpretan como un medio por el que se produjo una convergencia de intereses entre la Corona y la élite. La Corona obtenía dinero preciso, como sucedió con la venta de oficios, y al mismo tiempo se aseguraba el apoyo de importantes familias criollas, que con sus fortunas invertidas en los distintos sectores de la economía, fomentaban la economía colonial aumentando al máximo los ingresos del reino. Por otro lado, la posesión de un título nobiliario revistió de prestigio social a la élite lo que unido a la riqueza, supuso la máxima expresión de nobleza ante la sociedad.

La prosopografía que utiliza los criterios del análisis de redes de relaciones sociales constituye un paso más en la investigación sobre las élites. Este enfoque no es nuevo, sino que tiene su origen en los años cincuenta de manos de sociólogos y antropólogos sajones del network analysis, que se servían de este método para analizar el funcionamiento interno de la sociedad. La adaptación de este método al campo de la sociología, psicología e historia ha generado una amplia bibliografía referente a grupos sociales muy diversos: urbanos, rurales y en particular a los grupos que forman parte de la élite de una sociedad y un periodo histórico $^{36}$. El análisis de redes de relaciones sociales consiste en estudiar a un individuo o un grupo, prestando especial atención a los vínculos existentes entre ellos a través de los contextos en los que se mueven para poder reconstruir la red social de su entorno social, y presentar las acciones e interacciones estratégicas del grupo en su conjunto.

\footnotetext{
${ }^{35}$ González-Ripoll Navarro, Ma ${ }^{a}$ D., Cuba, La isla de los ensayos. Cultura y sociedad (17901815). Madrid, 1999, pp. 130-137.

${ }^{36}$ Este tipo de análisis está utilizándose en la historia moderna y contemporánea para el estudio de las élites. Entre los trabajos más interesantes e innovadores en este asunto destacamos: Imízcoz Beunza, J. M‥, "Actores sociales y redes de relaciones en las sociedades del Antiguo Régimen. Propuestas de análisis en Historia social y política” en Barros, C. (ed.), Historia a debate. Retorno del sujeto. Santiago de Compostela, 1995, vol. II, pp. 341-353, y "Comunidad, red social y élites. Un análisis de la vertebración social en el Antiguo Régimen” en Imízcoz Beunza, J. Mª. (direct.), Élites, poder y red social. Las elites del País Vasco y Navarra en la Edad Moderna. Bilbao, 1996, pp. 13-64. Pro Ruiz, J., "Las élites de la España liberal: clases y redes en la definición del espacio social (1808-1931)”..., op. cit., pp. 47-69, y “Socios, amigos y compadres: camarillas y redes personales en la sociedad liberal” en Chacón Jiménez, F., y Hernández Franco, J. (eds.), Familia, poderosos y oligarquías. Murcia, 2001, pp. 153-173.
} 
Las investigaciones que han empezado a aplicar este método al estudio de las élites se caracterizan por dos aspectos. Por un lado, no utilizan necesariamente las categorías socio-económicas, profesionales o un estatuto social jurídico para definir la sociedad, sino que a partir de la identificación de los vínculos y la reconstrucción de las relaciones se determina la posición que ocupa un individuo en la sociedad. De forma que tal posición será desigual dependiendo del escalafón que ocupe en las relaciones respecto a otra persona, dentro de un grupo, o un grupo respecto a otro grupo. Por otro lado, el concepto de red social es empleado como una herramienta de investigación que permite analizar el entorno de las relaciones de un individuo o un grupo. Bertrand define red social como "[...] un complejo sistema relacional que permite la circulación de bienes y servicios, tanto materiales como inmateriales, dentro de un conjunto de relaciones establecidas entre sus miembros, que los afecta a todos, directa o indirectamente, aunque de manera desigual $[\ldots]^{\text {,37 }}$.

Para la reconstrucción de la red social de una persona o de un grupo de la élite, la bibliografía muestra la necesidad de observar los distintos vínculos que relacionan a las personas. Hasta el momento los vínculos más estudiados han sido los familiares, pero la introducción del concepto de red ha ampliado ese análisis al incluir vínculos como el espiritual o ritual, es decir, relaciones de padrinazgo y compadrazgo, así como de amistad y clientelismo. La identificación de este tipo de lazos ha hecho que los historiadores acudan a las fuentes ya utilizadas en el estudio de las élites, aunque con una visión renovada buscando alguna manifestación, desde el punto de vista relacional, que permita la reconstrucción de la red social.

Entre las fuentes más provechosas en ese sentido, la documentación notarial como testamentos, contratos matrimoniales, dotes o fundaciones de capellanías proporcionan una información muy valiosa contenida en los nombres de los individuos que aparecen como testigos, albaceas, notarios, apoderados, deudores, acreedores, mayordomos, fundadores, capellanes y patronos entre otros, los cuáles tenían generalmente algún vínculo con las personas implicadas en el acto notarial. La documentación judicial, bien sean juicios de residencia realizada

\footnotetext{
${ }^{37}$ Véase Bertrand, M., “De la familia a la red de sociabilidad”..., op. cit., pp. 107-135, p. 119, y “Élites y configuraciones sociales en Hispanoamérica colonial”..., op. cit., pp. 1-15, p. 7.
} 
a un gobernador o a los funcionarios, o pleitos de cualquier materia, puede dar pistas sobre la trama de las relaciones sociales que unen a la élite entre sí y con el resto de la sociedad, lo que permite entender como está estructurado ese círculo de relaciones ${ }^{38}$. El cruzamiento de estas fuentes con la correspondencia epistolar también está siendo de gran utilidad a los historiadores, ya que permite conocer las estrategias relacioneales de los actores en los distintos contextos en los que se mueve y, en particular, el de sus actividades y la trayectoria vital de los grupos familiares $^{39}$.

Respecto a los trabajos históricos que han utilizado el examen de redes para el estudio de las élites todavía es generalmente minoritario; sin embargo, en la historiografía americanista ha supuesto una innovadora forma de abordar el análisis de la élite y su relación con la estructura colonial. Entre los trabajos que han introducido el análisis de redes destaca la obra de Bertrand Grandeur et misère de l'ofiffice. Les officiers de finances de Nouvelle-Espagne XVII-XIII siècles ${ }^{40}$. En ella analiza una parte de la élite novo-hispana, el caso de los oficiales de la real hacienda de los siglos XVII y XVIII. En primer lugar, el autor utiliza la prosopografía para reconstruir los caracteres socio-profesionales de este personal administrativo, fijándose en la forma de su reclutamiento, carrera y formación profesional. El segundo paso es la reconstrucción del sistema de relaciones de estos burócratas; según Bertrand esa red social estaba construida en torno a la familia. Los oficiales reales se integraron en la élite local mediante los casamientos con mujeres criollas, y asimismo terminaron dedicándose a las

\footnotetext{
${ }^{38}$ Sobre las posibilidades que ofrece esta variedad de fuentes para el estudio de las élites véase: Bertrand, M., “De la familia a la red de sociabilidad”..., op. cit., pp. 107-135, en particular las páginas 126-130. Pro Ruiz, J., "Socios, amigos y compadres: camarillas y redes personales en la sociedad liberal”..., op. cit., pp. 153-173, particularmente las páginas 157-166. Flores Galindo, A., Aristocracia y plebe en Lima, 1760-1830: estructura de clases y sociedad colonial. Mosca azul editores, Lima, 1984, p. 19.

${ }^{39}$ Las utilidades que ofrece esta fuente en relación a las redes familiares, véanse: Arroyo, L., "Redes de influencia: relaciones privilegiadas en el comercio colonial a finales del siglo XVIII: los Marticorena y su correspondencia epistolar”. Nuevo Mundo Mundos Nuevos n 7, 2007, disponible en: <http:/nuevo.mundorevues.org/document3213html.> [ publicación en línea y con acceso el 5 de enero de 2007]. Imízcoz, J. Ma ., "Parentesco, amistad y patronazgo. La economía de las relaciones familiares en la hora de Navarra del siglo XVIII” en Fernández, C., y Moreno, A., (eds.), Familia y cambio social en Navarra y País Vasco. Siglos XVIII-XIX. Pamplona, 2003, pp. 165-216, disponible en la red: <http://www.ehu.es/grupoimizcoz/jmimizcoz.htm.> [con acceso el 1 de junio de 2007]. En ella también se puede consultar algunos de los trabajos de este autor sobre las familias vasconavarras del siglo XVIII, así como reflexiones teóricas y metodológicas del análisis de redes sociales y su aplicación para al estudio de éstas.

${ }^{40}$ Bertrand, M., Grandeur et misère de l'office. Les officiers de finances de Nouvelle-Espagne XVII-XVIII siècles. Paris, 1999.
} 
actividades económicas propias de los criollos, como por ejemplo el comercio. Pero estos funcionarios, a pesar de vivir alejados de la metrópoli, supieron mantener los lazos familiares con parientes peninsulares que ocupaban cargos importantes en la Corona.

El autor también presta atención a las relaciones establecidas fuera del marco familiar, como las amistades que tejieron los oficiales. Para estudiar los distintos tipos de estas amistades, el autor se centra en el análisis de los lugares de sociabilidad en los que los oficiales reales podían establecer alguna clase de vínculo. A partir de ahí el autor distingue tres círculos de amistad de los oficiales reales. El primer círculo son las relaciones de compadrazgo, unas de las más estrechas y cercanas a la familia. El segundo el formado por los amigos con los que se mantenían relaciones de negocios comerciales y financieros. $\mathrm{Y}$ el último sería el surgido a partir de una relación de clientelismo en torno al oficial. Para Bertrand tales relaciones suponen unos lazos de dependencia donde la amistad es definida de tipo instrumental, ya que funciona con gran desigualdad entre los individuos interrelacionados. Aunque al mismo tiempo eran recíprocas. De esta forma el puesto del oficial es variable según la posición que ocupe, en ocasiones aparece como protector, y en otras como protegido. Como protector el oficial real lo era de aquellos acólitos que participaban en sus tareas ilícitas, y a cambio les garantizada seguridad. En el caso de los oficiales reales como protegidos, éstos escogían a los que les daban apoyo y protección frente al cargo que ocupaban, sus intereses y actuaciones. Esa protección la obtenían gracias a los lazos familiares y amistades de sus parientes españoles que ocupaban altos cargos en la metrópoli, y a las relaciones y vínculos establecidos con los virreyes, oidores y con la élite local.

La obra muestra de que manera el análisis de redes permite explicar el funcionamiento del aparato administrativo. A través del entramado relacional de los oficiales reales, el autor pone de relieve el papel estratégico que jugaron estos profesionales como intermediarios al lograr establecer conexiones mediante relaciones familiares y de amistad entre dos mundos, la América colonial y la metrópoli. Otros estudios que han utilizado el análisis de redes en la investigación de la élite colonial son los de Calvo para Guadalajara y Lavallé para Cuzco. Gracias a este método han reconstruido las luchas que surgieron dentro de la élite 
de ambas ciudades. Calvo restablece la red social de los Vera y Baeza desde el ámbito familiar centrado en Guadalajara, donde las familias se encontraban enfrentadas, hasta las distintas conexiones de amistad, que éstas tenían con otras regiones como Zacatecas, México, Puebla y Campeche. Siguiendo esa misma línea Lavallé analiza las luchas de poder entre los Esquivel y los Losada surgidas a consecuencia de su deseo de acaparar el cabildo y el cargo de corregidor de la ciudad de Cuzco. Lo que les obligaba a activar esas relaciones familiares así como aquellas que tenían con la administración colonial y de la metrópoli y con los estratos populares de Cuzco, poniendo de manifiesto el papel que jugaban esos aliados en las redes de poder ${ }^{41}$. En esta perspectiva de análisis, Peralta Ruiz y González-Ripoll ofrecen una innovadora visión en sus investigaciones respecto al papel desempeñado por las élites locales vinculadas a la alta administración indiana tanto en la Península como en América a lo largo del siglo XVIII. Peralta Ruiz analiza los manejos políticos, las clientelas, parentelas o redes familiares de cinco secretarios de estado y del despacho de Marina e Indias con actores claves del mundo americano, como virreyes, y gobernadores, y la labor de mecenazgo que estos ministros desempeñaron a la hora de publicar obras relacionadas con la historia, geografía o alguna problemática americana como el comercio. En el caso de González-Ripoll ilustra el funcionamiento de la red social construida entorno a Francisco Arango y Parreño, así como el papel de mediación que asumió respecto a los hacendados para lograr el favor real sobre el proyecto que presentó en Madrid con el objeto de mejorar el comercio de negros y la agricultura en La Habana $^{42}$.

El estudio de la élite a través de las relaciones personales y las redes sociales ha llevado a reconsiderar la cuestión de las reformas borbónicas y la independencia. De manera que los estudios de la élite en relación con las reformas borbónicas muestran como la élite elaboró estrategias basadas en las redes sociales, para contrarrestar la política borbónica de fines del siglo XVIII. Un ejemplo de la utilización de las redes sociales para el control económico y político

\footnotetext{
${ }^{41}$ Calvo, T., Poder, religión y sociedad en la Guadalajara del siglo XVII. México, 1991. Lavallé, B., El mercader y el marqués: las luchas de poder en Cuzco (1700-1730). Lima, 1988.

${ }^{42}$ Peralta Ruiz, V., Patrones, clientes y amigos. El poder burocrático indiano en la España del siglo XVIII. Madrid, 2006. González-Ripoll Navarro, Ma . D., "Vínculos y redes de poder entre Madrid y La Habana: Francisco Arango y Parreño (1765-1837), ideólogo y mediador”. Revista de Indias LXI: 22 (Madrid, 2001) pp. 291-305.
} 
de la élite se halla presente en obras como la del ya citado Bertrand ${ }^{43}$. Estas publicaciones prueban también que la estructura relacional de la élite permitió que los antagonismos entre criollos y peninsulares fueran minimizados. Aunque las reformas borbónicas intentaron restringir la cantidad de criollos que ocupaban puestos en el gobierno colonial, éstas tuvieron un pequeño efecto, pues muchos de ellos llegaron a ejercer cargos importantes incluso después de la independencia. A su vez el tema de la independencia ha comenzado a interpretarse desde la perspectiva de la reconstrucción de los cambios y transformaciones de las redes sociales frente a la propia independencia, y no desde la óptica de la ruptura como hasta hace poco había hecho la historiografía. Estas investigaciones no pretenden analizar los procesos independentistas, sino los comportamientos de las élites coloniales dentro de esas revueltas y sus mecanismos de adaptación ante una nueva situación ${ }^{44}$.

El análisis de las élites en términos de redes de relaciones también ha vuelto a centrar el interés en las prácticas corruptas dentro de la administración y el comercio colonial. Los estudios relacionados con el tema de la corrupción son muy numerosos, así como las interpretaciones que se han desarrollado al respecto. Las explicaciones iniciales sobre la corrupción fueron consideradas como un síntoma del declive del imperio español en América. Según Phelan la corrupción fue como una válvula de escape para la élite frente a una política de recolonización llevada a cabo por los Borbones. Más recientemente, Pietschmann ha interpretado la corrupción como una consecuencia de la degradación de la sociedad y de la crisis creada por la tensión surgida entre el estado español, la burocracia y la sociedad colonial por la distribución del poder y la riqueza ${ }^{45}$.

\footnotetext{
${ }^{43}$ Bertrand, M., Grandeur et misère de l'ofiffice..., op. cit. En esta línea apuntaba ya el trabajo de Lowenthal Felstiner, M., "Kinship Politics in the Chilean Independence Movement". HAHR LVI: 1 (Durham, 1976) pp. 58-80.

${ }^{44}$ Véase Langue, F., “Antagonismos y solidaridades en un cabildo colonial: Caracas 17501810”. AEA XLIX (Sevilla, 1992) pp. 371-393, y “Mineros y poder en Nueva España: Zacatecas en vísperas de la Independencia” en Castañeda, C. (coord.), Círculos de poder en la Nueva España..., op. cit., pp. 205-217. Bertrand, M., "En busca de una identidad social: redes familiares y elite colonial en tiempos de crisis”. Anuario de Estudios Bolivarianos 7-8 (Caracas, 1998-1999) pp. 97-117, y "Las élites sociales de Guatemala en vísperas de la Independencia: estructuras y dinamismos internos” en Álvarez Cuartero, I., y Sánchez Gómez, J. (eds.), Visiones y revisiones de la independencia americana. México, Centroamérica y Haití. Salamanca, 2005, pp. 37-59.

${ }^{45}$ Sobre corrupción véase Leddy Phelan, J., “Authority and flexibility in the Spanish Imperial Bureacracy”..., op. cit. Pietschmann, H., "Burocracia y corrupción en Hispanoamérica colonial. Una aproximación tentativa”. Nova Americana 5 (Turín, 1982) pp. 11-37, y “Corrupción en las Indias Españolas: revisión de un debate en la historiografía hispanoamericana colonial” en
} 
Frente a estas interpretaciones en la actualidad hay otras que consideran la corrupción como el sistema mismo ${ }^{46}$. El trabajo de Moutoukias utiliza el análisis de redes para explicar como a través de prácticas corruptas y vínculos familiares, la élite del Río de la Plata logró organizar las actividades comerciales durante el final del periodo colonial. La élite que el autor analiza son los funcionarios de la Corona, los cuáles se fueron integrando con la élite local, como se ha estado comentado a lo largo de esta reflexión, mediante alianzas familiares y de amistad. Así los magistrados mantuvieron una doble lealtad, hacia la Corona y hacia los grupos locales de Buenos Aires. Según el autor, ésto no significó un debilitamiento de la Corona, ya que gracias a las actividades económicas de la élite, entre ellas el contrabando, se pudo costear el aparato administrativo y militar ${ }^{47}$.

Tanto la corrupción, como la venta de cargos, la concesión de títulos o las donaciones de préstamos que la élite hizo a la Corona son hechos que no se consideran una disminución del poder metropolitano. Al contrario, para poder comprender estos comportamientos de las élites, tanto la prosopografía como el estudio de las redes sociales, así como la utilización de ambas metodologías, permiten interpretar estos funcionamientos tan peculiares dentro del campo de la estructura colonial $^{48}$.

González Jiménez, M., Pietschmann, H., Comín, F. y Pérez, J., Instituciones y corrupción en la historia. Valladolid, 1998, pp. 33-52.

${ }^{46}$ Imízcoz Beunza, J. Mª., “Actores sociales y redes de relaciones en las sociedades del Antiguo Régimen. Propuestas de análisis en Historia social y política”..., op. cit. pp. 341-353, p. 352.

${ }^{47}$ Moutoukias, Z., "Burocracia, contrabando y autotransformación de las elites de Buenos Aires en el siglo XVIII”. Anuario del IESH 3 (Tandil, 1988) pp. 213-247, y “Redes sociales, comportamiento empresario y movilidad social en una economía de no mercado (El Río de La Plata) en la segunda mitad del siglo XVIII” en Zeberio, B., Bjerg, Mª., y Otero, H. (comps.), Reproducción social y sistemas de herencia en una perspectiva comparada. Europa y los países nuevos (siglos XVIII al XX). Tandil, 1998, pp. 63-81.

${ }^{48} \mathrm{La}$ combinación de ambas metodologías ha permitido el estudio de una parte de la élite cubana del siglo XIX, el Partido Unión Constitucional, y al componente social del cabildo de Quito en el siglo XVII, véase en Portela Miguélez, Ma. J., Redes de poder en Cuba entorno al partido constitucional 1878-1898. Cádiz, 2004. Ponce Leiva, P., Certezas ante la incertidumbre..., op. cit. 


\section{2. Élites en la República Dominicana}

En el ámbito de la historiografía dominicana, el tema de las élites coloniales no ha suscitado excesivo interés entre los investigadores. Hasta el momento tan sólo existe una serie de estudios que han sido publicados recientemente. En ellos se analizan algunos grupos familiares que ejercen y detentan el poder en la República Dominicana en la actualidad. El resto de los trabajos existentes consisten en investigaciones realizadas por genealogistas, que se han encargado, y hoy día siguen haciéndolo, de la búsqueda de las raíces de los apellidos de esas familias y de la reconstrucción familiar. Asimismo, entre la bibliografía consultada se encuentran también biografías de personajes que han destacado a lo largo de la historia del país. Su interés se ha hecho patente al publicar, historiadores y genealogistas, sus resultados en revistas, monografías y diccionarios biográficos, aunque sin dar lugar a una publicación específica que estudie las capas altas dominicanas, su funcionamiento e interrelación. Aunque, podremos observar como en los últimos años, este tema ha pasado a recibir la atención de algunos investigadores.

La genealogía cuenta con una larga tradición en Santo Domingo que llega hasta nuestros días, la cual se constata a través de su amplia producción bibliográfica. Los trabajos pioneros por excelencia en esta materia están representados por dos autores fundamentales: Fray Cipriano de Utrera y Emilio Rodríguez Demorizi. Sus investigaciones fueron realizadas entre los años veinte y setenta, y están constituidas por artículos y libros en los que se pueden encontrar noticias referentes a las familias dominicanas que vivieron entre los siglos XVI y XIX.

Fray Cipriano de Utrera es considerado el precursor de los estudios genealógicos en la República Dominicana, y más concretamente gracias a su obra Santo Domingo. Dilucidaciones Históricas, publicada en 1927. Se trata de la recopilación de un conjunto de artículos que abordan diversos temas. Uno de los más interesantes establece la genealogía de algunas familias solariegas de la época colonial, como por ejemplo Bastidas, Fernández de Oviedo, Dávila, Ponce de 
León y Mieses, Pérez Caro, Mañón, o Maldonado entre otras ${ }^{49}$. El mismo autor cuenta con otra serie de artículos y monografías en los que prosigue el análisis genealógico de importantes familias de la época colonial y del siglo XIX, y biografías de personajes, entre las que pueden destacarse la de Don Rodrigo de Bastidas y la del poeta José María Heredia ${ }^{50}$. En su obra titulada Universidades de Santiago de la Paz y de Santo Tomás de Aquino y Seminario Conciliar de la ciudad de Santo Domingo de la isla Española, además de encontrar datos sobre la fundación y funcionamiento de las distintas universidades con las que contó la ciudad de Santo Domingo, también figura información sobre los alumnos y su personal docente ${ }^{51}$.

Emilio Rodríguez Demorizi en su obra Familias Hispanoamericanas continúa los estudios genealógicos de Fray Cipriano de Utrera. En ella se acerca también a la genealogía de los primeros pobladores de Santo Domingo, la familia Colón y sus descendientes. Igualmente incluye algunos documentos como testamentos e instituciones de Mayorazgos, y escudos de armas de la familia Colón y de otras familias de la colonia, como la de Bastidas, los Rocha, los Dávila o los Fernández de Castro ${ }^{52}$. Del mismo autor cabe resaltar la obra Milicias de Santo Domingo (1786-1821) en la que presenta una recopilación de las hojas de servicios de los militares de Santo Domingo. Con estas hojas de servicios aporta

${ }^{49}$ Utrera, F. C. de, "Epigrafía colonial. Genealogía de las familias solariegas de Bastidas, Fernández de Oviedo y Valdés de Fuenmayor, Dávila y entronques (1468-1926)” en Utrera, F. C. de, Santo Domingo. Dilucidaciones Históricas. Santo Domingo, 1927, II vols. Posteriormente fue editada en 1978 y más recientemente en 1995. Para esta investigación se ha utilizado la edición de 1978, vol. I, pp. 425-492.

50 Utrera, F. C. de, Don Rodrigo de Bastidas. Santo Domingo, 1930. En esta obra el autor trata la fundación del mayorazgo Bastidas así como sus líneas sucesoras. Véase también su libro Centenario de José María Heredia (1839-1939). Homenaje de la República Dominicana. Ciudad Trujillo, 1939. La obra es un homenaje a José María Heredia, poeta cubano y descendiente de familias dominicanas importantes que tuvieron que emigrar de Santo Domingo a otras zonas, en este caso Cuba como consecuencia del Tratado de Basilea. El autor analiza la figura de este personaje y su entronque con apellidos de linajes y estirpes dominicanas. Del mismo autor véanse los trabajos: "Dominicanos insignes en el exterior”. CLÍO 33 (Ciudad Trujillo, 1939) pp. 7-13, “El Tapado”. CLÍO 85 (Ciudad Trujillo, 1949) pp. 114-144, y El tapado de México y el de Santo Domingo. Ciudad Trujillo, 1950. Véanse también sus artículos sobre el personaje como indican sus títulos: "Don Luis Franco de Acevedo”. BAGN XII: 61 (Ciudad Trujillo, 1949) pp. 372-385, y “Morell de Santa Cruz”. CLÍO 90 (Ciudad Trujillo, 1951) pp. 57-74.

${ }^{51}$ Utrera, F. C. de, Universidades de Santiago de la Paz y de Santo Tomás de Aquino y Seminario conciliar de la ciudad de Santo Domingo de la Isla Española. Santo Domingo, 1932.

52 Rodríguez Demorizi, E., Familias Hispanoamericanas. Ciudad Trujillo, 1959. Con anterioridad a la publicación de dicha obra el autor había publicado una serie de artículos referentes a esas familias que fueron incluidas posteriormente en ese libro, véanse: "Familias hispanoamericanas”. BAGN 95 (Ciudad Trujillo, 1958) pp. 6-133; "Familias hispanoamericanas". BAGN 96 (Ciudad Trujillo, 1958) pp. 147-236; “Familias hispanoamericanas”. BAGN 97-98 (Ciudad Trujillo, 1958) pp. 269-374. 
información sobre la carrera de los militares, campañas y acciones de guerra, así como su origen, edad y estado civil. La documentación reproducida en la obra procede del Archivo General de Simancas y del Archivo Militar de Segovia ${ }^{53}$.

Otras aportaciones han sido proporcionadas por los investigadores y hermanos Pedro y Max Henríquez Ureña. El primero se centró en el estudio de la cultura de la época colonial de Santo Domingo, mostrando gran interés en el análisis de los dominicanos que destacaron en la literatura e historia. En sus trabajos se hallan, además de referencias a los autores y sus obras, apuntes biográficos sobre estos personajes que aparecen enlazados con importantes familias de la época colonial y contemporánea ${ }^{54}$. Su hermano, Max Henríquez Ureña, compiló y anotó una serie de biografías de algunos dominicanos del siglo XVIII y XIX, que fueron redactadas por el abogado y catedrático José María Morillas a finales del siglo XIX ${ }^{55}$.

Un paso más en los estudios sobre genealogías de familias dominicanas lo constituye la obra de Carlos Larrazábal Blanco, quien ha elaborado una colección de libros en nueve tomos titulada Familias dominicanas, publicada entre 1967 y 1980 por la Real Academia Dominicana de la Historia. En estos libros aparecen las genealogías familiares por medio del apellido o apellidos de sus fundadores, abarcando el período de tiempo comprendido entre los siglos XVI y XIX. Para elaborar su obra el autor ha utilizado, por un lado, las obras anteriormente citadas y por otro, fuentes procedentes de los libros parroquiales del Archivo Arquidiocesano de la catedral de la ciudad de Santo Domingo, y los libros del Estado Civil del Archivo General de la Nación ${ }^{56}$.

\footnotetext{
${ }^{53}$ Rodríguez Demorizi, E., Milicias de Santo Domingo (1786-1821). Santo Domingo, 1978. Para el siglo XIX el autor tiene publicada otra obra similar titulada Hojas del servicio dominicano, 1844-1865. Santo Domingo, 1968-1976, II vols.

${ }^{54}$ Henríquez Ureña, P., La cultura y las letras coloniales. Buenos Aires, 1936, pp. 107-137, y Obra Crítica. México, 1960, pp. 360-444.

${ }^{55}$ José María Morillas en los últimos años de su vida estuvo preparando una obra que no se llegó a publicar titulada Biografías de dominicanos notables. Algunas de esas biografías se recuperaron y han sido publicadas en artículos, véase por ejemplo, la del arzobispo Pedro Valera y Jiménez, y la de José Núñez de Cáceres en Henríquez Ureña, M., "Las biografías de dominicanos notables escrita por José María Morillas”. CLÍO 68-70 (Ciudad Trujillo, 1945) pp. 5-32. Apuntes biográficos sobre Francisco Javier Caro y Torquemada, Juan Vicente Moscoso, José Joaquín del Monte y Maldonado y Tomás de Bobadilla véase en Henríquez Ureña, M., "Biografías de dominicanos notables escritas por José María Morillas”. CLÍO 74-75 (Ciudad Trujillo, 1946) pp. 8-25.

${ }^{56}$ Larrazábal Blanco, C., Familias dominicanas. Santo Domingo, 1969-1980, IX vols. De la misma forma que Emilio Rodríguez Demorizi, Carlos Larrazábal Blanco antes de publicar esta colección fue publicando los resultados de sus investigaciones en artículos como el siguiente en el
} 
Alrededor de los años setenta fueron publicadas nuevas investigaciones dignas de mención, ya que pueden servir de gran utilidad en el estudio de las élites dominicanas coloniales. En 1971 Vetilio Alfau Durán compila unos escritos del historiador José Gabriel García titulados Rasgos biográficos de dominicanos célebres $^{57}$, en los que como indica su título se aportan datos precisos sobre personas destacadas durante el siglo XVIII, como es el caso de los Faura, los Arredondo, o Madrigal, entre otros ${ }^{58}$. Un año más tarde, Manuel Antonio Machado Báez, siguiendo la misma línea que el trabajo citado anteriormente, publica su obra, centrada principalmente en personajes que sobresalieron en el ámbito de las letras coloniales (maestros, abogados, clérigos, poetas) en la ciudad de Santiago ${ }^{59}$.

En los últimos años, el interés por el estudio de familias dominicanas desde el enfoque de la genealogía ha continuado, consagrándose en los ochenta con la creación del Instituto dominicano de genealogía (IDG). En 1983 se funda con el objetivo de ampliar los estudios en este campo, realizando análisis de familias dominicanas desde sus raíces hasta nuestros días. Este instituto edita una revista semestral, Raíces, que sirve como medio de divulgación de las ideas y trabajos sobre genealogía ${ }^{60}$.

que colabora junto a Azpurua, R., “José María de Rojas”. CLÍO 94 (Ciudad Trujillo, 1952) pp. 153-158; y los realizados por el mismo: "Una familia fundadora de San Rafael”. CLÍO 92 (Ciudad Trujillo, 1952) pp. 19-20; "Raimundo Rendón Sarmiento". CLÍO 93 (Ciudad Trujillo, 1952) pp. 106-109; y “Familias de Santo Domingo”. CLÍO 103 (Ciudad Trujillo, 1955) pp. 67-81.

${ }^{57}$ García, J. G., Rasgos biográficos de dominicanoas célebres. Santo Domingo, 1875.

${ }^{58}$ En dicha obra también se puede encontrar noticias de otros destacados personajes del siglo XIX como Juan Sánchez Ramírez y Pedro Alejandrino Pina. Alfau Durán, V. (comp.), Rasgos biográficos de dominicanos célebres. Santo Domingo, 1971. Algunas biografías de los personajes de esta obra fueron publicadas por el mismo autor en artículos como: "Dominicanos ilustres. Biografía de Don Jacobo de Villaurrutia”. CLÍO 88 (Ciudad Trujillo, 1950) pp. 113-117; "Rasgos biográficos de Dominicanos Célebres por José Gabriel García. Agustín de Madrigal”. CLÍO 89 (Ciudad Trujillo, 1951) pp. 27-29. "Documentos históricos. Partida de bautismo del dramaturgo Francisco Xavier Foxá y Lecanda”. CLÍO 90 (Ciudad Trujillo, 1951) pp. 100-102; “Documentos históricos”. CLÍO 83 (Ciudad Trujillo, 1949)” p. 15.

${ }^{59}$ En esta monografía también figuran datos sobre los Arredondo, Del Monte, Pichardo, Campuzano-Polanco o Morel de Santa Cruz. Machado Báez, M. A., Santiagueses ilustres de la colonia. Santo Domingo, 1972. Sobre el célebre obispo Pedro Agustín Morel de Santa Cruz y Lora véase García del Pino, C., La visita eclesiástica (Morel de Santa Cruz). La Habana, 1985.

${ }^{60}$ Últimamente los miembros de dicha institución también están publicando sus resultados en alguna sección periodística como por ejemplo en la sabatina del Diario Hoy conocida como Areíto, los cuáles están disponibles en la página web del Institudo Dominicano de Genealogía: http://www.idg.org.do. Concretamente en el apartado Cápsulas Genealógicas donde puede consultarse los siguientes trabajos: González Hernández, J. A., “¿Existen descendientes de Rodrigo de Bastidas?”. Areíto, 28 de mayo y 4 de junio de 2005. Disponibles desde Internet en: $<$ http://genealogiadominicana.com/idg/capsulas/mayo2005/mayo200528.htm> y también en $<\mathrm{http} / / /$ genealogiadominicana.com/idg/capsulas/junio2005/junio2004.htm> [con acceso el $26 \mathrm{de}$ 
Entre la extensa bibliografía publicada por el instituto mencionaremos aquellos estudios que han tenido mayor relevancia durante nuestra investigación, como el trabajo biográfico realizado por María José Álvarez Gautier sobre un militar del Batallón Fijo de Santo Domingo ${ }^{61}$. Especialmente interesante resulta la obra de Julio Genaro Campillo Pérez Francisco Espaillat y el Desarrollo del Cibao, donde reconstruye la genealogía de Espaillat, personaje distinguido que vivió en Santiago durante la segunda mitad del siglo XVIII y principios del XIX. El autor presenta en el libro una recopilación de documentos como partida de nacimiento, partida de defunción, partida de matrimonio, inventario de bienes y carta de naturaleza otorgada por Carlos III a Francisco Espaillat ${ }^{62}$. Entre los más recientes trabajos de los investigadores del Instituto de Genealogía que han seguido la línea marcada por la enciclopedia de familias de Carlos Larrazábal Blanco, deben ser citados el realizado por Vetilio Manuel Valera Valdez referente a familias de la zona de Baní y el de Ana Concepción Patria Quisqueya, quien ha elaborado un diccionario general de apellidos de familias dominicanas ${ }^{63}$.

Junto a estas obras genealógicas existen otras investigaciones que han sido publicadas en diversas revistas, tanto españolas como dominicanas, y en las que se intenta ir más allá. Por lo general, se trata de pequeños estudios biográficos de algunos personajes que fueron empresarios, mineros, comerciantes o hacendados durante el periodo colonial dominicano. Sin embargo, no se ha propiciado la aparición de una monografía sobre ello. Así, pueden mencionarse trabajos que proporcionan datos genealógicos, pero también otros aspectos como el social,

septiembre de 2005]. Cassá Bernardo de Quirós, C. J., “La unión de los mayorazgos de Oviedo y Bastidas". Areíto, 16 de julio de 2005. Ambos disponibles desde Internet en: <http://genealogiadominicana.com/idg/capsulas/julio2005/julio200516.htm> [con acceso el 16 de septiembre de 2005]. Cassá Bernardo de Quirós, C. J., “El mayorazgo Dávila”. Areíto, 19 de noviembre 2005. Disponible desde Internet a través de la página web: <http://www.idg.org.do/capsulas/noviembre2005/noviembre200519.htm> [con acceso el 7 de agosto de 2006].

${ }_{61}$ Álvarez Gautier, Ma. J., "Esteban Fernández Palomares: su carrera en el Batallón Fijo y su descendencia”. Raíces 7 (Santo Domingo, 1995) pp. 27-30.

${ }^{62}$ Campillo Pérez, J. G., Francisco Espaillat y el desarrollo del Cibao. Santo Domingo, 1985. La documentación procede del Archivo General de Indias, Archivo General de la Arquidiócesis de Santo Domingo, y del Archivo particular de Tomas A. Pastoriza Espaillat. Otras informaciones sobre dicha familia se pueden encontrar en Machado Báez, M. A., Santiagueses ilustres... op. cit., pp. 179-190. Espaillat Cabral, P. R., “Origen de la familia Espaillat”. Eme-Eme Estudios Dominicanos V: 26 (Santiago de los Caballeros, 1976) pp. 53-63.

${ }^{63}$ Valera Valdez, V. M., Baní. Raíces históricas. Genealogías de familias banilejas. Baní, 1998. Patria Quisqueya, A. C., Más familias dominicanas. Investigación genealógica. Santo Domingo, 1995. 
económico y religioso que permiten mostrar la trayectoria personal y la carrera profesional. Las más notorias investigaciones son la de Antonio Gutiérrez Escudero, acerca de la vida de una familia canaria y un minero en Santo Domingo; la de María Magdalena Guerrero Cano, quien a través de la documentación de pruebas de limpieza de un joven dominicano presentada para su admisión en el colegio de Nobles Americanos de Granada reconstruye su entramado familiar; la de María del Mar Barrientos Márquez, que estudia la vida de algunos gaditanos en Santo Domingo a partir de expedientes de bienes de difuntos; y la de Luís Bouché Español, quien a partir de un memorial de Lope Villegas del siglo XVII reconstruye su genealogía y hace una reseña biográfica. Victoria Stapells presta atención a la actividad corsaria en Santo Domingo, poniendo como ejemplo la trayectoria biográfica de tres personas que se dedicaron a esa actividad. Gerard Jori ha estudiado la carrera militar del ingeniero Antonio Álvarez Barba, así como su destacada labor cartográfica al levantar planos de algunas poblaciones y áreas de defensas ${ }^{64}$. Siguiendo la misma línea, algunos historiadores dominicanos como Francisco Moscoso, Anthony Stevens-Acevedo y Emilio Cordero Michel han analizado la vida de algunos hacendados del siglo XVI, además de acercarse al estudio del funcionamiento de los ingenios, su producción y el comercio del azúcar de aquella época ${ }^{65}$.

\footnotetext{
${ }^{64}$ Gutiérrez Escudero, A., "Un canario en la española. Vida, hechos y familia de Pedro Lousel Montero, 1724-1801" en V Coloquio de Historia Canaria-Americana. Las Palmas de Gran Canaria, 1985, pp. 165-201. Sobre este personaje y otros véanse los siguientes artículos del mismo autor: "Tres fuentes españolas sobre Saint-Domingue (1699-1731)” en VVAA., Historiografía y bibliografía americanista. Sevilla, 1980, pp. 23-78; y "Juan Nieto de Valcárcel, minero en Huelva y Santo Domingo". CLÍO 139 (Santo Domingo, 1982) pp. 23-49. Guerrero Cano, Ma. M., "Un dominicano en el colegio de nobles americanos de Granada. Familia y genealogía de Juan Clemente Martínez Saviñón”. Trocadero 8-9 (Cádiz, 1996-1997) pp. 383-400. Barrientos Márquez, $M^{a}$. M., "Presencia gaditana en el Santo Domingo del siglo XVIII. Aspectos culturales: sociales, económicos y religiosos”. Trocadero 8-9 (Cádiz, 1996-1997) pp. 331-349. De la misma autora véase también "Dominga Arambule: una dominicana relacionada con Cádiz" en VII Encuentro de la Ilustración al Romanticismo. Cádiz, América y Europa ante la modernidad. La mujer en los siglos XVIII y XIX. Cádiz, 1993, pp. 165-174. Bouché Español, L., Memorial de Lope de Villegas. Historia del linaje de Villegas. La isla de Santo Domingo a principios del siglo XVII. Madrid, 1997. Stapells Jonson, V., "Los corsarios de Santo Domingo 1718-1779: un estudio socioeconómico". Quaderns del departament de geografia i historia del l'estudi general de Lleida 12 (Lledia, 1992) pp. 3-93. Jori, G., "El ingeniero militar Antonio Álvarez Barba y su proyecto de construcción de una casa para alojamiento de la marina y de una nueva población en la bahía de Ocoa (1771)”. Revista Bibliográfica de Geografía y Ciencias Sociales XII: 10 (Barcelona, 2007), disponible en la red en: <http://www.ub.es/geocrit/b3w-710.htm.> [con acceso el 16 de julio de 2008]. Véase también Capel, H., Los Ingenieros Militares en España (Siglo XVIII). Repertorio biográfico e inventario de su labor científica y espacial. Barcelona, 1983, pp. 29-31.

${ }^{65}$ Moscoso, F., "Un señor de ingenios de Santo Domingo: Francisco Tostado (1520-1528)". ECOS I: 2 (Santo Domingo, 1993) pp. 11-23. Stevens-Acevedo, A., "Esclavos, empresarios
} 
Entre finales de los ochenta y los noventa han surgido algunos trabajos que contienen capítulos dedicados al análisis de la élite colonial. De nuevo estos trabajos no han provocado la aparición de monografías que versen exclusivamente sobre este tema, a pesar de que cuenta con una amplia trayectoria productiva en otros países hispanoamericanos. Sin embargo, contamos con una referencia publicada en 1918 y reeditada en 1991 que puede considerarse un estudio pionero y de innegable calidad. Respecto a esta monografía que trata sobre Los amigos y protectores aragoneses de Cristóbal Colón, su autor Manuel Serrano y Sanz ha demostrado, que el proyecto de expansión comercial de la Corona española y de asentamiento en Santo Domingo se inscribía en un sistema de relaciones e interdependencias, que se apoyaban particularmente en la formación de clientelas. La singularidad de dichas relaciones se articulaban entorno a la Corona y el apoyó de sus funcionarios aragoneses, también presentes en la financiación de los viajes de Colón y, por extensión en puestos de la administración de Santo Domingo. De lo que se desprende la importancia que tuvieron estos ministros dentro de la monarquía desde la cuál se configuró en un grupo de poder conocido en aquella época como el partido aragonés ${ }^{66}$. Posteriormente, en 2002, Arturo Sorhegui D`Mares publicó un artículo en el que continúo el estudio de este tipo de relaciones privilegiadas, con especial atención para Santo Domingo ${ }^{67}$. También vale la pena mencionar la obra de Alice Gould sobre los marineros de Colón en la que recoge datos biográficos de ciento cinco ${ }^{68}$.

Entre esa escasa bibliografía también se incluye la obra de Justo del Río Moreno Los inicios de la agricultura europea en el Nuevo Mundo (1492-1542), en la que analiza los productos agrícolas que se cultivaron y comerciaron en La

azucareros y transacciones económicas en el ingenio Santa Bárbara de la isla Española en 1557.” ECOS III: 4 (Santo Domingo, 1995) pp. 31-55. Cordero Michel, E., "Hernando Gorjón, hombre de empresa y de presa”. CLÍO 155 (Santo Domingo, 1996) pp. 93-113.

${ }^{66}$ Serrano y Sanz, M., Orígenes de la dominación española en América: estudios históricos. Madrid, 1918, y reeditada años más tarde con el título Los amigos y protectores aragoneses de Cristóbal Colón. Barcelona, 1991. Sobre la gestación del “partido aragonés” véase también: Jiménez Fernández, M., Bartolomé de las Casas. Delegado de Cisneros para la reformación de las Indias (1516-1517). Sevilla, 1953, vol. I, p. 9.

${ }^{67}$ Sorhegui D`Mares, A., "Los grupos de poder en América. ¿Se conformó durante el reinado de los Reyes Católicos las primeras formas de patronazgo y clientelismo impuestas por el Estado territorial centralizado español para el dominio de América” en Actas del III Congreso de Historiadores Latinoamericanistas. Santiago de Compostela, 2002.

${ }^{68}$ En un primer momento fueron publicándose en una serie de artículos en el Boletín de la Academia de la Historia entre 1924 y 1944. Gould, A. B., Nueva lista documentada de los tripulantes de Colón en 1492. Madrid, 1984. 
Española durante el siglo XVI. El autor también presta atención a aquellas personas que se dedicaron a la producción del azúcar y la cría de ganado, llamados “señores de ingenios y de ganado" porque supieron mantener, durante mucho tiempo, la mayor parte de los ingenios existentes concentrados en sus manos, así como el poder político, gracias a una fuerte endogamia y configuración de mayorazgos desde el comienzo de la colonización ${ }^{69}$.

El cabildo y la audiencia son cuestiones que los historiadores han tenido muy en cuenta a la hora de estudiar las élites de las ciudades hispanoamericanas. Respecto a Santo Domingo todavía no se cuenta con estudios de este tipo, pero se han publicado varias obras que son recopilaciones de las cartas y memoriales del cabildo de la ciudad de Santo Domingo (siglos XVI y XVII), de los cabildos eclesiásticos de Santo Domingo y Concepción de La Vega, y la Audiencia durante el siglo XVI. Estas colecciones de documentos han sido elaboradas por Genaro Rodríguez Morel y pueden ayudar a la realización de un estudio prosopográfico sobre esas instituciones ${ }^{70}$. También vale la pena mencionar las publicaciones de José Luis Sáez en las que ofrece datos biográficos sobre los jesuitas durante la época colonial ${ }^{71}$. Por otro lado, Fray Cipriano de Utrera ha trabajado acerca del

\footnotetext{
${ }^{69}$ Río Moreno, J. del, Los inicios de la agricultura europea en el Nuevo Mundo (1492-1542). Sevilla, 1991, pp. 470-476. Del mismo autor véanse también los siguientes artículos relativos a la ganadería: "La élite antillana y la economía de conquista en América los intereses ganaderos (1493-1542)" en El Reino de Granada y el Nuevo Mundo. V Congreso Internacional de Historia de América. Granada, 1994, vol. III, pp. 187-204; y López Sebastián, Lorenzo E., "Hombres y ganados en la tierra del oro: comienzos de la ganadería en Indias”. Revista Complutense de Historia de América 24 (Madrid, 1998) pp. 11-45; y "La ganadería vacuna en la isla Española (1508-1587)”. Revista Complutense de Historia de América 25 (Madrid, 1999) pp. 11-49.

${ }^{70}$ Rodríguez Morel, G., Cartas del cabildo de la ciudad de Santo Domingo en el siglo XVI. Santo Domingo, 1999, pp. 15-50. En la introdución el autor menciona a las familias Garay, Dávila, Tapia, Colón, o los Serrano como las que estuvieron al frente del cabildo durante los primeros años, así como algunos conflictos que ésta institución tuvo con la audiencia y la Iglesia. Véase del mismo autor Cartas de los cabildos eclesiásticos de Santo Domingo y Concepción de La Vega en el siglo XVI. Santo Domingo, 2000; Cartas del cabildo de Santo Domingo en el siglo XVII. Santo Domingo, 2007, y Cartas de la Real Audiencia de Santo Domingo (1530-1546). Santo Domingo, 2008. Para el siglo XVIII es interesante el estudio de la estructura interna del cabildo eclesiástico de Santo Domingo de Marrero Castellano, J., "El cabildo eclesiástico en la Iglesia de Santo Domingo en el siglo XVIII". Casas Reales 13 (Santo Domingo, 1982) pp. 99-128.

${ }^{71}$ Sáez, J. L., "Elenco de jesuitas europeos e hispanoamericanos en Santo Domingo (16501767)”. AHSI LXV (Roma, 1996) pp. 31-99, “Los jesuitas en el Caribe insular de habla castellana (1575-1763)”. Paramillo 16 (Táchira, 1997) pp. 5-155, y “Jesuitas nacidos en La Española durante los primeros años de estancia de la Compañía (1658-1767)”. CLÍO 159 (Santo Domingo, 1998) pp. 25-50. Véanse también los siguientes trabajos en los que se proporcionan datos de personas eclesiásticas durante la colonia: Polanco Brito, H. E., "Los cabildos eclesiásticos de Santo Domingo y La Vega, los deanes”. Casas Reales 14 (Santo Domingo, 1987) pp. 121-142. Dobal, C., "Fray Gaspar Gorricio gran amigo del descubridor”. CLÍO 156 (Santo Domingo, 1997) pp. 2226.
} 
cabildo de Santo Domingo durante el siglo XVI, basándose en su estructura interna y funcionamiento. $\mathrm{Y}$ aunque sus escritos han sido publicados en distintos artículos del periódico El Caribe, no han dado lugar a una monografía específica $^{72}$.

A parte de estas monografías y artículos, en los últimos años, el tema del cabildo y su composición ha pasado a recibir la atención de algunos investigadores de los cuáles sólo una monografía está escrita por autores dominicanos. En 1997 se publica la obra colectiva de Pedro Santiago, Julio Genaro Campillo Pérez y Carlos Dobal, que se centra en la ciudad de Santiago, una de las más importantes de la isla incluso en la actualidad. Los autores examinan en primer lugar la economía minera, agrícola y ganadera del Santiago del siglo XVI, lo que les sirve para hacer un análisis de las personas que se dedicaron a esas actividades, y de sus conexiones amistosas y familiares ${ }^{73}$. Con otro enfoque más institucional el historiador Rudolf Widmer ha recopilado en su obra documentación del Archivo de Higüey. Los textos recogidos son muy variados y se puede encontrar en el libro desde inventarios post morten, cartas de arrendamiento hasta decretos del gobernador dictados para la población del Santo Domingo español. El autor también analiza la estructura del cabildo de la población de Higüey ${ }^{74}$.

Las aportaciones más recientes en esta temática son las de los historiadores españoles Antonio Gutiérrez Escudero y Manuel Vicente Hernández González. Para el cabildo de Santiago, y fundamentalmente el de Santo Domingo de principios del siglo XVIII, Gutiérrez en su artículo traza el perfil compuesto de dicha institución por una élite integrada por agricultores-ganaderos con estrechos

\footnotetext{
${ }^{72}$ Utrera, F. C. de, "Concejo, justicia y regimiento era nombre que tenía el ayuntamiento de Santo Domingo". El Caribe, 14 de noviembre de 1987, p. 8; "En qué forma se elegían a los munícipes de Santo Domingo durante el siglo XVI”. El Caribe, 21 de noviembre de 1987, p. 8; y "Elecciones municipales de Santo Domingo sirvieron de modelo para otras colonias". El Caribe, 28 de noviembre de 1987, p. 8. Véase también Ortiz Núñez, D., “Origen de los cabildos en América”. CLÍO 173 (Santo Domingo, 2007) pp. 13-38.

${ }^{73}$ En el capítulo dieciséis se analiza la estructura del cabildo de Santiago, quienes eran sus miembros, sus funciones y las luchas entre bandos para mantener sus puestos y garantizar la defensa de los intereses de su grupo, véase en Santiago, J., Campillo Pérez, J. G., y Dobal, C., El primer Santiago de América, 1495-1995. Santo Domingo, 1997, pp. 211-232.

${ }^{74}$ Widmer Sennhauser, R., La propiedad en entredicho. Una historia documental de Higüey, Siglos XVII-XIX. Santo Domingo, 2004, pp. 23-28.
} 
vínculos familiares ${ }^{75}$. Por su parte, Hernández ha dedicado sus últimas publicaciones al estudio de algunos pueblos situados a lo largo de la frontera con la colonia francesa, y en torno a ellos la problemática del comercio fronterizo. El autor dedica especial atención a los mecanismos de ejercicio del poder de la élite local en esas municipalidades, cómo accedían a los cargos, sus vínculos sociales, las relaciones con los delegados de la Corona, y las disputas entre éstos y la élite local derivados del control por el tráfico comercial fronterizo ${ }^{76}$. La consolidación de algunas familias de la ciudad de Santiago a través de dicho comercio también ha recibido atención de Margarita Gascón en un artículo, centrado entorno a su poder militar. Otra visión sobre la continuidad familiar en el Ejército viene dada en otro artículo por su autora Christine Rivas ${ }^{77}$.

En la obra de Juana Gíl-Bermejo García La Española. Anotaciones históricas (1600-1650) se encuentra información de los más significativos gobernadores, oidores, fiscales, miembros del cabildo, militares y eclesiásticos a través de múltiples referencias, especialmente en el capítulo siete, en el que se recogen apuntes biográficos sobre ellos ${ }^{78}$.

Otro trabajo de gran interés es el de Hugo Eduardo Polanco Brito, dedicado a los escribanos de Santo Domingo. Este es un estudio que puede servir eficazmente de consulta y guía para el conocimiento de la actividad de los escribanos, desde los primeros tiempos históricos hasta el papel que jugaron en la América colonial. En la segunda parte del libro se recogen los nombres, así como

\footnotetext{
${ }^{75}$ Gutiérrez Escudero, A., "Élites y poder económico en Santo Domingo (siglo XVIII). Notas para su estudio" en Navarro García, L. (coord.), Élites urbanas en Hispanoamérica: (De la conquista a la independencia). Sevilla, 2005, pp. 241-251. Véase también alguna referencia en su obra Población y economía en Santo Domingo (1700-1746). Sevilla, 1985, pp. 78-82, y 86-97.

${ }^{76}$ Los pueblos en los que se centra son los de la región norte formada por Montecristi, Dajabón, Bánica, Hincha, San Rafael de la Angostura, Las Caobas y San Miguel de la Atalaya. Y el área sur integrada por Azua, San Juan de la Maguana y Neiba. Hernández González, M. V., "La colonización de la frontera dominicana en la segunda mitad del siglo XVIII. La fundación de San Rafael de la Angostura. Las Caobas y San Miguel de la Atalaya”. CLÍO 167 (Santo Domingo, 2004) pp. 113-146, y sus obras tituladas: La colonización de la frontera dominicana (1680-1795). Las Palmas de Gran Canaria, 2005, pp. 218-232, y Expansión fundacional y crecimiento en el norte dominicano (1680-1795). El Cibao y la Bahía de Samaná. Las Palmas de Gran Canaria, 2006.

${ }^{77}$ Gascón, M., “The Military of Santo Domingo, 1720-1764”. HAHR 73:3 (Durham, 1993) pp. 431-452, y Rivas, C., "The Spanish Colonial Military: Santo Domingo 1701-1779”. The Americas 60: 2 (Washington, 2003) pp. 249-272.

${ }^{78}$ Gíl-Bermejo García, J., La Española. Anotaciones históricas (1600-1650). Sevilla, 1983, pp. 201-246 у pp. 342-356.
} 
noticias personales y profesionales de algunos escribanos de Santo Domingo, abarcando desde 1492 hasta $1865^{79}$.

Hasta ahora no se tiene constancia de la existencia de un estudio que trate los componentes de la Audiencia de Santo Domingo. Tan sólo se cuenta con datos dispersos que proceden de algunas obras como la ya citada de Gíl-Bermejo o la de Burkholder y Chandler De la impotencia a la autoridad, o de artículos en los que se hace una reseña biográfica sobre algún miembro de este cuerpo ${ }^{80}$.

El tratado de Basilea obligó a gran parte de la población de la zona española a emigrar a otros lugares del continente americano. Este hecho hizo que la mayoría de ellos acabaran trasladándose con sus familiares a lugares como La Habana, Puerto Rico y Venezuela donde se establecieron. Respecto a quienes eran esas personas y sus vicisitudes en el traslado a la primera isla, Carlos Esteban Deive lo ha abordado en su obra Las emigraciones dominicanas a Cuba. ${ }^{81}$ Muchos de ellos consiguieron sobresalir e integrarse en la sociedad en la que se instalaron. En las obras de Rafael Nieto Cortadellas y en la de Francisco Javier de Santa Cruz y Mallén se pueden encontrar datos genealógicos sobre aquellos que se asentaron en Cuba. En cuanto a los que orientaron su emigración hacia Puerto Rico, es interesante la información que proporciona sobre algunos personajes el reciente artículo de Ádam Szászdi Nagy ${ }^{82}$.

\footnotetext{
${ }^{79}$ Polanco Brito, H. E., Los escribanos en el Santo Domingo colonial. Santo Domingo, 1989.

${ }^{80}$ Burkholder, M. A., y Chandler, D. S., De la impotencia a la autoridad..., op. cit. En los apéndices V, VI y VII de dicha obra se recoge algunos datos de los miembros que componían la Audiencia de Santo Domingo durante el siglo XVIII, concretamente en las páginas 434-443, y en su otra obra titulada Biographical dictionary..., op. cit. Galíndez, J., "Los vascos en la Audiencia de Santo Domingo”. CLÍO X (Ciudad Trujillo, 1943) pp. 232-237. Para el siglo XVI véase la obra de García Menéndez, A., Los jueces de apelación de La Española y su residencia (1511-1519). Santo Domingo, 1981, pp. 42-50. En esas páginas se encuentra una sucinta biografía de los jueces, Lucas Vázquez de Ayllón y Juan Ortiz de Matienzo. Para el magistrado Gaspar de Espinosa véase: Lohmann Villena, G., "Un hombre de negocios en la colonización de América: el Licenciado Gaspar de Espinosa”. Estudios Americanos 104 (Sevilla, 1960) pp. 131-141, y Les Espinosa. Une famille d'hommes d' affaires en Espagne et aux Indes à l'époque de la colonisation. Paris, 1968, pp. 181-201. Véase también la "Biografía del Licenciado Alonso de Zuazo” en Fernández Navarrete, M., Salvá, M., y Sainz de Baranda, P., Colección de documentos inéditos para la historia de España. Vaduz, 1964, vol. II, pp. 375-379.

${ }^{81}$ Deive, C. E., Las emigraciones dominicanas a Cuba (1795-1808). Santo Domingo, 1989, pp. 42-50.

${ }^{82}$ Nieto Cortadellas, R., Dignidades nobiliarias en Cuba. Madrid, 1954. Santa Cruz y Mallén, F. J. de, Historia de familias cubanas. La Habana, 1940-1980, IX vols. Szászdi Nagy, Á., “Emigrados dominicanos en Puerto Rico, 1796-1812”. CLÍO 164 (Santo Domingo, 2002) pp. 79179. Para Venezuela véase Larrazábal Blanco, C., “Origen hispano-dominicano de algunas familias caraqueñas”. Boletín del Instituto Venezolano de Genealogía 2 (Caracas, 1971) pp. 8-42, también está disponible en la red: <http://www.ivgenealogia.org/boletin02.pdf.> [con acceso el 14 de febrero de 2006].
} 
No obstante, otras familias permanecieron unos años más, hasta que las invasiones haitianas de 1801, 1805 y 1822 acabaron por desvincularlas de Santo Domingo al obligarlas a emigrar a algunos de los lugares anteriormente citados ${ }^{83}$. Aunque hubo algunas ramas de esas familias que regresaron y participaron en la independencia dominicana, así como en la vida política, económica, militar e intelectual del periodo contemporáneo, es decir, ocuparon puestos que previamente habían ostentado ellos o sus familiares. Referencias biográficas sobre estos personajes ya habían sido publicadas en revistas como Clío y monografías entre los años cuarenta $\mathrm{y} \operatorname{setenta}^{84}$. En la actualidad muchos trabajos han continuado en esta misma línea, cabe mencionar los realizados por investigadores ya citados como Julio Genaro Campillo Pérez y Vetillo Alfau Durán ${ }^{85}$. Además han aparecido numerosas monografías biográficas con esta temática, por ejemplo sobre los padres de la independencia, figuras militares, políticas o intelectuales dominicanos del siglo XIX ${ }^{86}$.

Recientemente ha surgido también una serie de diccionarios biográficos de personalidades del siglo XIX y XX, una modalidad que fue iniciada por Rufino Martínez en 1971 al publicar un Diccionario Biográfico-Histórico Dominicano, 1821-1930 que ha seguido reeditándose de manera sucesiva ${ }^{87}$. A partir de este trabajo aumentaron las publicaciones de estas características, entre las que destacan los diccionarios sobre determinadas regiones, como el de Juan Ventura sobre Puerto Plata, o los distintos diccionarios de Cándido Gerón, uno dedicado a

\footnotetext{
${ }^{83} \mathrm{Al}$ respecto véase: "Gaspar de Arredondo y Pichardo, Memoria de mi salida de la isla de Santo Domingo el 28 de abril de 1805” en Rodríguez Demorizi, E., Invasiones haitianas, 1801, 1805 y 1822. Ciudad Trujillo, 1955, pp. 121-160. Robiou Lamarche, S., "Las emigraciones de Santo Domingo y su aportación al desarrollo de Puerto Rico durante el siglo XIX”. CLÍO 151 (Santo Domingo, 1994) pp. 113-126. Reichard Esteves, H., "Presencia dominicana al noroeste de Puerto Rico”. Eme-Eme Estudios Dominicanos 3 (Santiago de los Caballeros, 1975) pp. 135-158.

${ }^{84}$ A modo de ejemplo consúltese Rodríguez Demorizi, E., Juan Isidro Pérez, el ilustre loco. Ciudad Trujillo, 1944. Garrido, V., Los Puello. Santo Domingo, 1974.

${ }^{85}$ Campillo Pérez, J. G., Benigno Filomeno de Rojas. Política y Economía. Santo Domingo, 1993. Años antes el autor había publicado ya un avance sobre este trabajo en su artículo “Genealogía de Benigno Filomeno de Rojas”. CLÍO 123 (Santo Domingo, 1968) pp. 44-106. Alfau Durán, V., "Don Miguel de Lavastida. Apuntes y documentos para su biografía”. CLÍO 139 (Santo Domingo, 1982) pp. 95-125.

${ }^{86}$ Entre la numerosa bibliografía sobre estos personajes nombraremos a modo de ejemplo tan sólo algunas de las publicaciones más recientes, véanse: Alfau Durán, V., Mujeres de la Independencia. Santo Domingo, 1999 (1945). Balcácer, J. D., Juan Pablo Duarte. El Padre de la Patria. Santo Domingo, 2001. Campillo Pérez, J. G., Idem., y Dr. Andrés López Medrano y su legado humanista. Santo Domingo, 1999. Jiménez Hernández, J. A., Manuel Jiménez. Prócer de la Independencia. Santo Domingo, 2001.

${ }_{87}$ Martínez, R., Diccionario Biográfico-Histórico Dominicano, 1821-1930. Santo Domingo, 1971.
} 
políticos y otro a intelectuales de la vida dominicana ${ }^{88}$. De igual forma que se publicaron biografías de las personas más representativas del siglo XIX, también deben citarse obras realizadas desde esa misma óptica sobre personajes que sobresalieron durante el siglo XX, en la historia contemporánea dominicana, como las hermanas Mirabal o Peña Gómez entre otros muchos ${ }^{89}$. Tampoco pueden omitirse trabajos como el de Euclides Gutiérrez, en el que se aúnan distintos retratos biográficos de personajes de la época colonial, pasando también por el periodo de la Independencia, la Restauración y la Guerra de los Seis años hasta desembocar en algunas figuras del Movimiento de abril de $1965^{90}$.

De manera paralela a este interés por las biografías personales, han ido apareciendo una serie de estudios parciales que aportan algunas pinceladas sobre los grupos económicos y políticos más importantes de la República Dominicana. El libro de Juan Bosch, La pequeña burguesía en la historia de la República Dominicana, publicado originariamente entre agosto de 1984 y enero de 1985 en el semanario Vanguardia del Pueblo, perteneciente al Partido de la Liberación Dominicana (PLD); supuso un considerable avance en la investigación de las capas dominantes del siglo XIX. En él se analiza las luchas entre dos grupos, los hateros dirigidos por Pedro Santana y las diferentes capas de la pequeña burguesía bajo el mando de Buenaventura Báez, por participar en la vida política entre 1844 y 1861. Es decir, desde la proclamación de la indepencia de Haití hasta la Anexión a España, periodo histórico conocido como Primera República ${ }^{91}$.

Dentro de esta nueva perspectiva de investigación sobre el tema ha habido una inclinación reciente hacia las élites económicas y políticas del momento. Por primera vez Esteban Rosario en sus escritos se acerca al análisis de algunas de esas principales familias que la integran, y pone de manifiesto como la economía, la política y las asociaciones sin fines de lucro como fundaciones, las

88 Ventura, J., Figuras Puerto Plateñas. Biografías. Santo Domingo, 1997. Gerón, C., Diccionario de autores dominicanos. Santo Domingo, 2001, y Diccionario político dominicano (1821-2000). Santo Domingo, 2001.

${ }^{89}$ Colección Biografías Dominicanas, Minerva Mirabal. Santo Domingo, 2000. Campillo Pérez, J. G., Peña Gómez. Origen y nacimiento. Investigación genealógica. Santo Domingo, 1996.

${ }^{90}$ Gutiérrez Félix, E., Héroes y Próceres Dominicanos y Americanos. Santo Domingo, 2000 (1995).

${ }^{91}$ Bosch, J., La pequeña burguesía en la historia de la República Dominicana. Santo Domingo, 2003. También puede encontrarse información sobre los mencionados enfrentamientos y el papel de los hateros en otra obra suya Composición social dominicana. Historia e interpretación. Santo Domingo, 1997 (1970). 
universidades y centros culturales están dominadas por clanes familiares mediante algún pariente o bien indirectamente “[...] a través de sus técnicos y burócratas alquilados [...]"92 . Aunque este tipo de trabajos están realizados desde un punto de vista periodístico son importantes, pues han abierto una nueva vertiente de investigación en la historiografía dominicana. La obra de Manuel Antonio Sosa Jiménez sobre los orígenes y evolución de la provincia de Hato Mayor, resulta también de gran interés por sus referencias a familias terratenientes y hateras desde el periodo colonial hasta mediados del siglo $\mathrm{XX}^{93}$.

Más específicas son aquellas investigaciones en las que se está teniendo un tratamiento especial al estudiar el rol de las familias empresariales del país, como es el caso del grupo familiar León Jimenes vinculados al cultivo de tabaco y fabricación de cigarros en la región del Cibao. El eje de este trabajo ilustra la evolución empresarial de la firma Aura, perteneciente a la mencionada familia así como su continuidad y el papel de ésta en la organización del negocio ${ }^{94}$.

Por último, desde el Instituto interuniversitario de Iberoamérica de Salamanca se está investigando las élites parlamentarias en América Latina, y entre ellas las de la República Dominicana. Sus investigaciones ubican desde un punto de vista de las ciencias políticas y sociología, las actitudes y valores de la élite política entorno a una amplia temática que va desde la percepción que ésta tiene de la democracia, partidos políticos, elecciones, religión y fuerzas armadas, a través de entrevistas, para posteriormente presentar y explicar la calidad de la democracia en cada uno de los países ${ }^{95}$. En esta misma temática, destaca el trabajo

92 Rosario, E., Los dueños de la República Dominicana. Santo Domingo, 1992, p. 118. Anteriormente Esteban Rosario ya había publicado un trabajo sobre una determinada familia, los Bermúdez. El autor ha continuado trabajando en este campo dando como resultado la publicación de otras obras: La familia Bermúdez: fortuna y crisis. Santo Domingo, 1990, y La oligarquía de Santiago. Santo Domingo, 1997.

93 Sosa Jiménez, M. A., Hato Mayor del Rey, su sitial en la Historia Dominicana. Santo Domingo, 1993.

${ }^{4}$ Alcántara Almánzar, J., y Hernández Caamaño, I., Huella y memoria E. León Jimenes: un siglo en el camino nacional 1903-2003. Santo Domingo, 2003.

${ }^{95}$ Los resultados pueden consultarse en la Colección de documentos-país que el Instituto de Iberoamérica publica. A modo de ejemplo puede verse: Elites parlamentarias iberoamericanas. Equipo de investigación sobre elites parlamentarias. República Dominicana. Salamanca, 1998, vol. X, y "Datos de opinión: Elites Parlamentarias Latinoamericanas. República Dominicana (19942006)”. Estudio que está disponible desde Internet en: <http://iberoame.usal.es/pdfs/BoletinN8.pdf.> [con acceso el 1 de junio de 2007]. 
realizado por el norteamericano Jonathan Hartlyn, que abarca el periodo político desde 1961 hasta $1996^{96}$.

\footnotetext{
${ }^{96}$ Hartlyn, J., The Struggle for Democratic Politics in the Dominican Republic. Chapel Hill and London, 1998, pp. 4-17. El autor ha basado sus fuentes en bibliografía socio-política e histórica, prensa, e informes de la Junta Central Electoral de la República Dominicana. Además es uno de los primeros en utilizar y definir el régimen político dominicano comprendido entre (1961-1996) como neopatrimonialista, tomando como base las peculiaridades dadas por Michael Bratton y Nicholas van de Valle para África, las circunscribe al caso dominicano. Según Jonathan Hartlyn el neopatrimonialismo posee dos características claves: centralización del poder en manos del gobernante que persigue reducir la autonomía de sus seguidores generando lazos de lealtad y dependencia, comúmente generados a través de la relación patrón-cliente. Es con este sistema clientelar como funcionan los intereses privados, públicos, y la administración dominicana, donde además la corrupción está generalizada incluyendo el círculo de allegados al presidente.
} 



\section{CAPÍTULO 2 EL GOBIERNO POLÍTICO EN SANTO DOMINGO}

Mover el complejo engranaje político-administrativo que hacía posible el gobierno de la ciudad de Santo Domingo, exigía la colaboración de un conjunto de personas numéricamente importantes. Algunos nombres de estos hombres que irán apareciendo se encuentran entre los hacendados estudiados, y algunos de sus familiares. En ellos recayó la recaudación fiscal (Real Hacienda), y en gran medida, cada una de las decisiones que hacían posible la vida en el cabildo, o bien mantenían el orden o impartían justicia incluso también desde la Audiencia; otros actuaron como ejecutores de sus órdenes, y en alguna ocasión la participación en el gobierno municipal estaba supeditada, en cierta medida, a aquéllos que los hubiesen nombrado. En este capítulo como en el siguiente, se podrá ir descubriendo quiénes son esos individuos, cómo accedían a los cargos y actuaban en las mencionadas instituciones; y algunos de sus rasgos sociales que los vinculaban a un grupo o varios sociales, a redes familiares o clientelares, a intereses económicos y políticos comunes, cuestiones que serán tratadas detalladamente en el capítulo cuarto.

\subsection{La Audiencia de Santo Domingo}

Las Reales Audiencias fueron establecidas en América con la finalidad de representar a la autoridad real, regular las actividades y el buen gobierno del ámbito territorial de Indias. Su implantación fue de gran importancia para la administración colonial al actuar como tribunal, asesorando a su presidente, gobernador o virrey en los asuntos de gobierno. Tenía una comunicación directa con el rey a través de sus ministros, que se encargaban de informarle sobre los 
más variados aspectos del ámbito de su administración, y controlaban a los funcionarios del gobierno local en beneficio de la Corona.

\subsubsection{Fundación y marco territorial}

La creación de la Real Audiencia de Santo Domingo corresponde a esos factores comunes que motivaron también el origen del resto de las audiencias americanas. Pero la razón determinante de su creación responde a un intento de rescatar la autoridad real en Santo Domingo a consecuencia del conflicto surgido con Diego Colón, quien quiso hacer valer los derechos políticos que había heredado de su padre Cristóbal Colón en perjuicio de la autoridad del monarca. Los continuos abusos de la familia Colón especialmente a través de uno de esos derechos concedidos, la facultad judicial, obligó a la Corona a eliminarla y traspasarla a una institución, la Audiencia. El 5 de octubre de 1511 fue creada con la intención de que su ámbito de influencia no sólo alcanzara Santo Domingo sino toda Indias. A medida que se fueron descubriendo otros territorios y fundando nuevas poblaciones, todas ellas entraron bajo su jurisdicción ${ }^{1}$. Estos sucesivos descubrimientos y conquistas durante el siglo XVI, evidenciaron la imposibilidad de la Audiencia de Santo Domingo de ejercer sus facultades en tierras tan lejanas. De ahí que se determinara la fundación de nuevas audiencias americanas, como la de México en 1527, Panamá en 1535, Lima y Guatemala en 1542, Santa Fe en 1547, Charcas en 1559, Quito en 1563, Chile en 1565 y la de Buenos Aires en 1661. La creación de estas instituciones a principios del siglo XVI hizo que la

\footnotetext{
${ }^{1}$ La bibliografía sobre la Audiencia de Santo Domingo es bien escasa, hasta el momento se cuenta con el único libro de Malagón Barceló, J., El distrito de la Audiencia de Santo Domingo en los siglos XVI a XIX. Santiago, 1977, p. 31. Véanse también los datos que ofrecen otros autores como Herrera Cabral, C. A., "La Real Audiencia de Santo Domingo". CLÍO 118-119 (Santo Domingo, 1961-1962) pp. 3-14. Vega Boyrie, W., "La Real Audiencia de Santo Domingo”. EmeEme Estudios Dominicanos IV: 21 (Santiago de los Caballeros, 1975) pp. 91-104. Moreau de Saint-Méry, M. L. E., Descripción de la parte española de Santo Domingo. Ciudad Trujillo, 1944. El autor de este libro, fue un administrador y político francés que a través de su estancia y viajes por Santo Domingo acabó escribiendo esta obra que fue edita en 1796. En ella describe la geografía, la política y la sociedad de la parte española. También trata sobre su Audiencia, su estructura y funcionamiento, para lo cuál véase pp. 285-311. Una obra más reciente es la de García Menéndez, A., Los jueces de Apelación de La Española y su Residencia. Santo Domingo, 1981. El tema de esta obra es, como ya indica su título, la residencia de los jueces de apelación; en otros capítulos trata la creación de la audiencia y los conflictos entre Diego Colón y estos jueces. En otros trabajos puede encontrarse también alguna referencia al siglo XVI véase en Deive, C. E., La mala vida. Delincuencia y picaresca en la colonia española de Santo Domingo. Santo Domingo, 1997, pp. 175-216; Moreta Castillo, A., La justicia en Santo Domingo. Santo Domingo, 1998, pp. 21-35.
} 
Audiencia de Santo Domingo sufriera una reducción en lo que se refiere a su espacio de influencia, quedando desde entonces bajo su jurisdicción únicamente las Antillas mayores ${ }^{2}$.

Durante el siglo XVIII se le fueron aumentando y reduciendo territorios, de modo que a principios de dicho siglo a la Audiencia de Santo Domingo le correspondía Puerto Rico, Cuba, La Florida y aquellos lugares situados en la zona norte del sur de América (Venezuela, Maracaibo, Nueva Andalucía y la Guayana). En 1717 se creó el Virreinato de Nueva Granada, y la zona de la costa norte del sur de América pasó a depender de la Audiencia de Santa $\mathrm{Fe}^{3}$. Poco después, en 1723 este virreinato desapareció, hasta que en 1739 se restableció quedando de nuevo organizado con los anteriores territorios dentro de él. Pero la reorganización no duró mucho, ya que en 1742 el gobernador de Venezuela solicitó al rey separarse del virreinato y unirse de nuevo a la Audiencia de Santo Domingo, petición que le fue concedida ese mismo año. Hacia mediados del siglo XVIII la audiencia estaba constituida por las islas de Puerto Rico, Cuba, los territorios de Venezuela, La Florida y Luisiana. La Florida fue perdida tras la guerra entablada contra Inglaterra bajo el tercer pacto de familia entre la Corona española y la francesa. Luisiana pasó a depender de la gobernación de Cuba al igual que La Florida, que fue recuperada entre 1780 y 1783, y como consecuencia quedaron bajo la jurisdicción de la Audiencia de Santo Domingo ${ }^{4}$.

En 1777 la jurisdicción territorial de la Audiencia dominicana se vio incrementada al integrarse en ella otras regiones como Cumaná, Trinidad y Margarita. Hasta entonces Venezuela había mantenido su unión a la Audiencia de Santo Domingo; sin embargo, el crecimiento de su población y comercio, y las dificultades de comunicación fueron motivos suficientes para que en 1786 la Corona permitiese a su gobernador crear la Audiencia de Caracas. El distrito de ésta abarcaba aquella región y las de Cumaná, Maracaibo, la Guayana y las islas de Trinidad y Margarita ${ }^{5}$. Con esta nueva audiencia la de Santo Domingo volvió a perder esas regiones. A finales del siglo XVIII su jurisdicción acabó

2 Malagón Barceló, J., El distrito de la Audiencia de Santo Domingo..., op. cit., pp. 39-46.

Ibidem., pp. 31-32.

Ibidem., pp. 33-35.

5 López Bohórquez, A. E., Los ministros de la Audiencia de Caracas (1786-1810): caracterización de una élite burocrática del poder español en Venezuela. Caracas, 1984, pp. 6970 . 
comprendiendo Santo Domingo, Puerto Rico, Cuba, dependiendo La Florida y Luisiana de Cuba. Hasta que por medio del Tratado de Basilea de 1795, Santo Domingo dejó de pertenecer a la Corona española al ser cedida a Francia. Se puso fin así a la primera audiencia de América, que fue trasladada en 1799 a la isla de Cuba, concretamente a Puerto Príncipe y más tarde a la ciudad de Santiago de Cuba ${ }^{6}$.

\subsubsection{La figura del Presidente, Gobernador y Capitán General}

La Audiencia de Santo Domingo contó con un presidente como máxima autoridad. Su figura se caracterizó por la multiplicidad de funciones, pues ostentaba el cargo de capitán general y gobernador de la misma. Además era el superintendente de la Real Hacienda y vicepatrono eclesiástico ${ }^{7}$. Pese a que el gobernador poseía la administración de la justicia de la isla y toda la jurisdicción que dependía de la Audiencia, ésta estuvo en manos de sus ministros. El gobernador se limitaba a presidir, participar en los trabajos de la audiencia y firmar las resoluciones que se tomaban. Como capitán general le correspondía la dirección militar sobre todas las tropas militares de la isla, así como la conservación y defensa del territorio ${ }^{8}$. Dicho mando procedía del tipo de audiencias al que pertenecía la de Santo Domingo, es decir, las denominadas pretoriales en las que el presidente-gobernador llevaba agregado el título militar de capitán general ${ }^{9}$. Asimismo, habría que añadir el carácter militar de Santo Domingo como consecuencia, por un lado, de la situación estratégica que ocupaba Santo Domingo en el Caribe, lo que obligó a la Corona a aumentar las

\footnotetext{
${ }^{6}$ Malagón Barceló, J., El distrito de la Audiencia de Santo Domingo..., op. cit., p. 46. Un estudio detallado sobre el traslado de la Real Audiencia desde la isla de Santo Domingo a la de Cuba como consecuencia del Tratado de Basilea de 1795, y su instauración en La Habana véase en Armas Medina, F., "La Audiencia de Puerto Príncipe (1795-1853)”. AEA XV (Sevilla, 1958) pp. 273-370. Véase también la obra de Rodríguez Demorizi, E., Cesión de Santo Domingo a Francia. Correspondencia de Godoy, García, Roume, Hedouville, Rigaud y otros, 1795-1802. Ciudad Trujillo, 1958. En esta obra el autor recopila documentación respecto a la entrega de la isla a Francia así como del traspaso a Cuba.

${ }^{7}$ Sevilla Soler, Mª. R., Santo Domingo. Tierra de Frontera (1750-1800). Sevilla, 1980, p. 290. Vega Boyre, W., Historia del derecho dominicano. Santo Domingo, 1986, pp. 47-49.

${ }^{8}$ Moreau de Saint-Méry, M. L. E., Descripción de la parte española de Santo Domingo..., op. cit., p. 140. Martín Rebolo, I., Ejército y Sociedad en las Antillas, Siglo XVIII. Madrid, 1992, p. 25.

${ }^{9}$ En Guatemala también existió este modelo de Audiencia, véase en Muro Orejón, A., Lecciones de historia del derecho hispano-indiano. México, 1989, pp. 183-189.
} 
guarniciones militares en esa área debido a las incursiones extranjeras, el contrabando y las sucesivas guerras europeas que tuvieron su reflejo en esa zona, y por lo tanto la necesidad de defenderla y conservarla. Por otro lado, ese carácter militar se debió también a la presencia francesa en la isla y su asentamiento definitivo compartiendo el territorio, influenciado por las continuas disputas en la línea fronteriza entre ambas colonias y el contrabando que se generó en esa zona $^{10}$.

La importancia estratégica de la isla durante el siglo XVIII, probablemente hizo que los gobernadores escogidos para Santo Domingo contaran con un amplio currículo militar (véase en el anexo la tabla 1). El número de gobernadores que tuvo en ese siglo fue menor respecto a otras gobernaciones como Cuba y Puerto Rico, siendo seis los que ejercieron su mandato durante el periodo en el que se centra este trabajo, aunque con algún intervalo de gobierno interino. Estos mandatarios fueron nombrados por periodos de ocho años, pero hubo casos como el de Manuel Azlor y Urríes, en los que se les prorrogó por más tiempo debido a su buena política ${ }^{11}$; mientras que otros mandatarios fueron reemplazados antes de cumplirse los ocho años por traslados a otros cargos, como ocurrió con José Solano y Bote o Manuel González Torres, quien estuvo tan sólo tres años al morir repentinamente ${ }^{12}$. Entre los gobernadores que tuvo Santo Domingo durante la segunda mitad del siglo XVIII tres procedían de otras gobernaciones como Tarifa y Caracas. Su elección como presidentes para la de Santo Domingo estuvo posiblemente motivada por el deseo de propiciar la culminación de sus carreras, debido al carácter meritorio y el prestigio que proporcionaba ocupar la presidencia de la más antigua Audiencia de América ${ }^{13}$. Merecimiento que no fue del agrado del gobernador Manuel González Torres, quien al ser trasladado de la capitanía

\footnotetext{
${ }^{10}$ En Sevilla Soler, Ma . R., Santo Domingo..., op. cit., p. 290, y Martín Rebolo, I., Ejército y Sociedad..., op. cit., pp. 24-26.

${ }^{11}$ Carta del cabildo de Santo Domingo en la que se representa el buen gobierno que Manuel Azlor ha desempeñado promoviendo el bien común, y utilidad pública por lo que suplican a Su Majestad que en atención a los méritos se digne prorrogarlo en su gobierno por ocho años más, 9 de enero de 1767. AGI, Santo Domingo, 944.

${ }^{12}$ Carta del gobernador José Solano y Bote solicitando a la Corte permiso para volver a España luego que efectué el arreglo de límites que están mandos fijar, 23 de octubre de 1775. AGI, Santo Domingo, 945. Carta del cabildo de Santo Domingo en la que representa el buen gobierno de Manuel González, 9 de septiembre de 1790. AGI, Santo Domingo, 953.

${ }^{13}$ En Sevilla Soler, Ma . R., Santo Domingo..., op. cit., pp. 290-291, y Martín Rebolo, I., Ejército y Sociedad..., op. cit., p. 26.
} 
general de Caracas para la de Santo Domingo expresaba sus quejas a la Corona en una carta, en la que dice:

"Me atormenta cruelmente la diferencia de mando que advierto entre Caracas y Santo Domingo: Alli con la extension de cuatro importantes provincias, y dos islas, y aqui limitado a un pedazo de isla poco poblada, indefensa, y pobres, escasa de alimentos y mal sana, cuya triste idea no me ha podido desvanecer a la vista de la realidad el bien dispuesto animo que traia formado, proponiendome lo mas pero sin que me consuele el ejemplar de Solano [... $]^{14}$.

Una Real Cédula de 4 de agosto de 1530 establecía que, en caso de ausencia temporal o muerte del gobernador, su empleo fuese ocupado por el oidor más antiguo de la audiencia llamado decano, y así sucedió en Santo Domingo durante los siglos XVI y XVII ${ }^{15}$. A partir de 1693, se crea un cargo específico para su sustitución, el cabo subalterno o maestre de la plaza, más conocido como teniente de rey ${ }^{16}$. Aunque si ambos faltasen, el auditor de guerra se encargaría de lo político, y del mando militar el más alto oficial de la guarnición ${ }^{17}$. La creación de la figura del teniente de rey produjo molestias en la Audiencia quien hasta la fecha tuvo en sus manos esa prerrogativa. Para evitar conflictos la Corona dictó una Real Cédula el 8 de septiembre de 1736 por la que ratificaba el papel del teniente de rey ${ }^{18}$. Sin embargo, como podrá verse más adelante en los años siguientes siguió habiendo problemas sobre este asunto. El gobernador de Santo Domingo tuvo un sueldo de unos 6.000 pesos anuales en 1771, hasta que por el nuevo reglamento que se estableció sobre la estructura burocrática de las audiencias americanas, y en concreto sobre los sueldos de sus ministros de Indias

\footnotetext{
${ }^{14}$ Carta del gobernador Manuel González manifestando privadamente a Su Majestad sus sentimientos por las continuas traslaciones que ha experimentado, 25 de abril de 1785. AGI, Santo Domingo, 947.

${ }^{15}$ Gíl-Bermejo García, J., La Española. Anotaciones históricas (1600-1650). Sevilla, 1983, pp. 202-210. Vega Boyrie, W., Historia del derecho dominicano..., op. cit., p. 49.

16 El 2 de mayo de 1693 se creó el cargo de teniente de rey de Santo Domingo que fue ocupado por el teniente mariscal de Campo Gíl Correoso. Patentes de teniente de rey de aquella plaza y cabos subalternos desde 1693 hasta 1780. AGI, Santo Domingo, 1087.

17 Marchena Fernández, J., Oficiales y soldados en el ejército de América. Sevilla, 1983, p. 11.

${ }^{18}$ Título teniente de rey de la plaza de Santo Domingo a favor de Luis de Casasola, 13 de junio de 1765. AGI, Santo Domingo, 1087.
} 
en 1776 , se le ascendió a 8.000 pesos anuales ${ }^{19}$. En cambio, el salario del teniente rey durante todo el siglo XVIII fue de 3.000 pesos $^{20}$.

Tabla 2-1. Relación de Tenientes de rey, 1748-1795

\begin{tabular}{|c|c|c|}
\hline Nombre & Fecha de nombramiento & Origen \\
\hline José Sunyes de Basteros & 4 de diciembre de 1748 & Cataluña \\
\hline Pedro López de Osorio & 19 de febrero de 1752 & Ceuta \\
\hline Luís Antonio Casasola & 13 de febrero de 1765 & Sevilla \\
\hline Joaquín García Moreno & 16 de junio de 1780 & Guadalajara \\
\hline Ramón Castro & 30 de marzo de 1789 & Burgos \\
\hline Andrés Heredia y Melgar & 6 de agosto de 1790 & Cuenca \\
\hline Antonio Cancy & 4 de mayo de 1793 & Cádiz \\
\hline
\end{tabular}

Elaboración propia. Fuentes: Patentes de teniente de rey de aquella plaza y cabos subalternos desde 1693 hasta 1780. AGI, Santo Domingo, 1087. Rodríguez Demorizi, E., Milicias de Santo Domingo (1786-1821). Santo Domingo, 1978, pp. 10-12, 80-81, 122-125, 215-216.

Según las leyes de Indias, los gobernadores, una vez terminado su mandato, debían dar cuenta de él a través del juicio de residencia al que se sometían. El primer juicio que se llevó a cabo en Santo Domingo fue en 1509, cuando Nicolás de Ovando fue destituido de su cargo. A partir de ahí los juicios de residencia se sucedieron habitualmente con cada gobernador. En lo que respecta al periodo en que se inserta este trabajo, se cuenta con las residencias de los gobernadores de Francisco Rubio y Peñaranda, Manuel Azlor y Urríes y José Solano y Bote. Ya que los restantes murieron antes de finalizar su mandato o fueron relevados por la Corona de tal procedimiento, como fue el caso de Isidro Peralta y Rojas y Manuel González Torres. No obstante, si se celebró el juicio de residencia de éste último, pues la resolución que anunciaba su relevo llegó después de que se le hubiese realizado ${ }^{21}$.

\footnotetext{
${ }^{19}$ Estado de la Audiencia de la isla Española de Santo Domingo, 21 de junio de 1771. AGI, Santo Domingo, 922.

${ }^{20}$ Patentes de teniente de rey de aquella plaza y cabos subalternos desde 1693 hasta 1780. AGI, Santo Domingo, 1087.

${ }^{21}$ Véase los juicios de residencia de los gobernadores de Santo Domingo: Cuadernos de autos generales obrados sobre la residencia que se ha tomado al mariscal de campo Francisco Rubio y Peñaranda durante el tiempo que sirvió los empleos de presidente y gobernador de la isla, 1759. AGI, Escribanía de Cámara, 16-A. Juicio de residencia del gobernador Manuel Azlor y Urríes, 1771. AHN, Consejos, 21.465. Juicio de residencia del gobernador José Solano y Bote. AHN, Consejos, 20.766. Juicio de residencia del gobernador Manuel González, 1791. AHN, Consejos 20.766. Real Orden de 15 de febrero de 1786 por la que se releva del juicio de residencia al gobernador Isidro Peralta y Rojas. AGI, Santo Domingo, 986.
} 
El gobernador tuvo a su lado como funcionarios auxiliares a un secretario y a un asesor general, que estuvieron a su servicio directo. El primero de ellos era designado por la Corona y se encargaba de escribir la correspondencia, extender las actas, dar fe de los acuerdos y decisiones tomadas, y custodiar los documentos. Aunque a lo largo de la segunda mitad del siglo XVIIII el gobernador eligió tanto a su secretario como al asesor. Entre 1765 y 1787 este cargo estuvo ocupado interinamente por José de la Vega, es decir, unos veintidós años como puede verse en la tabla que sigue, y durante los que no gozó de sueldo. En 1787 se nombró para dicho puesto a Nicolás Toledo, con la asignación de 1.500 pesos anuales ${ }^{22}$.

\section{Tabla 2-2. Tiempo en el que José de la Vega estuvo como secretario de la Capitanía General}

\begin{tabular}{|c|c|c|c|}
\hline Gobernadores & Años & Meses & Días \\
\hline Manuel Azlor y Urríes & 5 & 11 & 29 \\
\hline José Solano y Bote & 7 & 2 & \\
\hline Isidro Peralta y Rojas & 7 & 2 & \\
\hline Joaquín García Moreno & & 7 & 26 \\
\hline Manuel González Torres & 1 & & 5 \\
\hline Total & $\mathbf{2 2}$ & & \\
\hline
\end{tabular}

Elaboración propia. Fuentes: Extracto del mérito contraído por José de la Vega, capitán graduado de infantería de ejército y efectivo de milicias de infantería reglada de Santo Domingo, en el empleo que ejerció de secretario de la Capitanía General e inspección de aquella isla. AGI, Santo Domingo, 964.

El asesor del gobernador era el principal consejero legal. Esta ocupación fue desempeñada habitualmente por el oidor decano de la propia audiencia, que atendía personalmente las consultas del gobernador en causas de gobierno, Real Hacienda, justicia y guerra. Sin embargo en otras ocasiones la ejerció cualquiera de sus ministros. En 1790 el gobernador Joaquín García solicitó a la Corona la creación específica de este puesto con un sueldo anual de 2.000 pesos. La petición le fue concedida pero reduciendo su remuneración a unos 1.500 pesos, 1.000 de los cuales procedían de los propios y arbitrios del ayuntamiento de la ciudad y los

\footnotetext{
${ }^{22}$ Extracto del mérito contraído por José de la Vega, capitán graduado de infantería de ejército y efectivo de milicias de infantería reglada de Santo Domingo, en el empleo que ejerció de secretario de la Capitanía General e inspección de aquella isla. AGI, Santo Domingo, 964.
} 
500 de las Reales Cajas ${ }^{23}$. Bajo el mandato de Francisco Rubio y Peñaranda, el licenciado Antonio Villaurrutia y Salcedo desempeñó la tarea de asesoramiento, mientras que el letrado Vicente Antonio Faura fue el consejero de Isidro Peralta y Rojas, Manuel González Torres y Joaquín García, tanto en su interinidad como gobernador y después cuando fue nombrado oficialmente ${ }^{24}$. En 1797 le sustituye el abogado Leonardo del Monte, quien también desempeñó para esa fecha el de asesor en la plaza de Bayajá ${ }^{25}$.

\subsubsection{Los ministros de la Audiencia}

En cada una de las audiencias que se fueron creando la Corona determinó que la administración y gobierno fuesen conducidas por un personal compuesto por varios oidores y fiscales, alguaciles, tenientes y otros funcionarios. La burocracia de las audiencias desde su creación fue variando en número y salarios durante todo el periodo colonial. Pero fue especialmente en la segunda mitad del siglo XVIII, cuando las audiencias americanas experimentaron una renovación de su estructura burocrática, impulsada por las reformas borbónicas que llevó a cabo la Corona española con el fin de ejercer una mayor efectividad administrativa y extender el control peninsular sobre estos tribunales.

La puesta en venta de los cargos judiciales de las audiencias americanas desde el siglo XVII, posibilitó que en ella participasen los nacidos en el distrito del tribunal. La reforma política de los Borbones, iniciada en 1750, trató de eliminar las ventas en pro de la Corona, al querer elegir a sus funcionarios impidiendo que los criollos entrasen a formar parte de las audiencias. A partir de entonces, los miembros de este órgano fueron seleccionados cuidadosamente. Se exigió contar con una amplia experiencia en el manejo de justicia, lo cual era acreditado por medio de su currículo de méritos y servicios. Además se intentó evitar que estableciesen cualquier tipo de vínculo con la sociedad del lugar. El

\footnotetext{
${ }^{23}$ Carta del gobernador de Santo Domingo en la que informa sobre la asignación del pago del sueldo de asesor de este gobierno en ejecución de la Real Orden de 8 de julio, 25 de diciembre de 1792. AGI, Santo Domingo, 1015.

${ }^{24}$ Carta del gobernador de Santo Domingo a Su Majestad en la que expone la necesidad de un asesor general, 25 de junio de 1790. AGI, Santo Domingo, 953.

${ }^{25}$ Relación de los ejercicios literarios y méritos del doctor Leonardo del Monte, asesor que fue de la plaza de Bayajá en Santo Domingo y abogado de aquella audiencia. AGI, Ultramar, 428.
} 
objetivo era tener un mayor control sobre las audiencias indianas para mejorar la administración de justicia. Si bien esta política se cumplió, no llegó a acatarse de manera estricta en todo el territorio americano. A finales del siglo XVIII, en las audiencias de Chile, México, Lima y Santo Domingo se siguió contando con ministros nativos de sus respectivas jurisdicciones y con peninsulares que acabaron estableciendo nexos locales ${ }^{26}$.

Así por ejemplo, el aragonés Andrés Pueyo y Urríes, obtuvo meritoriamente el cargo de oidor de Santo Domingo. Tanto él como sus hijos conectaron a través de lazos de parentesco con familias locales y con otros miembros peninsulares de la Audiencia dominicana. En cambio, el caso del abogado Domingo de la Rocha-Ferrer y Landeche confirma la política llevada por la Corona para restringir la entrada a los criollos. Éste trató de obtener a principios de 1760 una plaza en la Audiencia de Santo Domingo y le fue denegada, nombrándose en su lugar a un peninsular ${ }^{27}$. Aún así, hubo muchos criollos pertenecientes a importantes familias locales que llegaron a ocupar cargos en la Audiencia de Santo Domingo, sobre todo como abogados de la misma. Igualmente, algunos de sus oidores acabaron estableciendo vínculos con esas familias. Todavía no se cuenta con un estudio sobre la estructura social de la Audiencia de Santo Domingo, tan sólo con informaciones sobre sus integrantes que son datos fragmentados procedentes de obras como la de Burkholder y Chandler en De la impotencia a la autoridad o pequeñas biografías de sus componentes $^{28}$.

Entre los funcionarios o ministros que pertenecían a la Audiencia de Santo Domingo estaban los oidores, en los que recayó la responsabilidad política y jurídica de la audiencia. Una jurisdicción especial que tuvieron estos funcionarios fue la del juzgado de bienes de difuntos, centrado en la figura del oidor-juez de bienes de difuntos. Creado el 16 de abril de 1550, este cuerpo pasó a depender de la propia audiencia, quien desde entonces designaba de entre los oidores a uno para que ejerciera como juez general de los bienes vacantes, más conocido con el título de juez de bienes de los difuntos. La misión de este oidor-juez era custodiar

\footnotetext{
${ }^{26}$ Burkholder, M. A. y Chandler, D. S., De la impotencia a la autoridad..., op. cit., pp. 168-175.

${ }^{27}$ La plaza fue ocupada en 1764 por Vicente Herrera y Rivero (Marqués de Herrera) Ibidem., pp. 131, 134, y 440.

${ }^{28}$ Ibidem., pp. 434-443. Algunas de esas obras y artículos aparecen en la nota al pie ochenta del capítulo primero.
} 
los bienes de aquellos peninsulares que morían en la isla con o sin testamento, debidendo además de liquidar la sucesión en dinero o en especie y remitirla a los herederos en la Península a través de la Casa de la Contratación. El tiempo de duración de este cargo era anual, pero a partir de 1618 fue bianual ${ }^{29}$. Los oidores también actuaban como alcaldes de crimen cuando era necesario, pues no existía ese empleo como tal en esta audiencia. Éstos y el resto de ministros eran escogidos por el Consejo de Indias, quien presentaba al rey los nombres de varios acreditados por su currículo, y el mismo rey nombraba a quien considerase más adecuado $^{30}$. En el momento de su creación el número de jueces u oidores fue de tres, posteriormente se elevó a cuatro o cinco, manteniéndose durante gran parte de la segunda mitad del siglo XVIII, hasta que en 1786 se redujo de nuevo a tres. Su sueldo en 1760 fue de 17.647 reales y 2 maravedíes, mientras que a partir de 1776 se incrementó a 3.300 pesos anuales ${ }^{31}$.

Junto a los oidores hubo otros ministros como los fiscales a quienes les correspondía específicamente la defensa de la ley. Defendían la jurisdicción real en cuestiones de patrono eclesiástico, salvaguardia del patrimonio y la Hacienda Real, así como velar por la ejecución de las leyes y el castigo de los delitos. Parece ser que en los orígenes de la Audiencia sólo existió un fiscal, pero en febrero de 1682 se incorporó otro. De esta manera quedó establecido dos tipos de fiscales: uno encargado de los casos relacionados con lo civil y otro de lo criminal $^{32}$. En 1768 se creó un puesto más, un agente fiscal, que actuó como auxiliar de los dos anteriores. Éste era nombrado por el fiscal de lo civil y tenía un

\footnotetext{
${ }^{29}$ Los colaboradores de este juez fueron un secretario público y un depositario o defensor general de los bienes de difuntos que elegía él mismo entre los abogados de la audiencia, véase: Vega Boyrie, W., Historia del derecho dominicano..., op. cit., pp. 81-82. Moreau de Saint-Méry, M. L. E., Descripción de la parte española de Santo Domingo... op. cit, pp. 325-329. Barrientos Márquez, Ma. M., Gaditanos en las Antillas. Un acercamiento a su realidad socioeconómica a través de los expedientes de Bienes de Difuntos durante el siglo XVII. Cádiz, 2000, pp. 29-30.

${ }^{30}$ En relación a su función como alcalde de crimen, cada oidor tenía la obligación durante tres meses, y más específicamente los martes, jueves y sábados por la tarde de celebrar una audiencia de provincia. Es decir, una reunión para conocer las instancias civiles relativas a un radio de cinco leguas de la ciudad de Santo Domingo. Además en caso de apelación de la Audiencia el oidor no podía estar presente. Al respecto véase Moreau de Saint-Méry, M. L. E., Ibidem., pp. 139 y 305, y García, J. G., Compendio de la Historia de Santo Domingo. Santo Domingo, 1982, vol. I, p. 102.

${ }^{31}$ Cargo de data de salarios de las cuentas de las Cajas Reales de Santo Domingo en los años de 1754, 1755, y 1760. AGI, Contaduría, 1069-A, y B. Carta del gobernador de Santo Domingo en la que dirige relación individual de los empleos perpetuos y temporales políticos, militares y de Real Hacienda que se pagan por las Reales Cajas de Santo Domingo, 12 de marzo de 1783. AGI, Santo Domingo, 946. Véase también Moreta Castillo, A., La justicia en Santo Domingo..., op. cit., pp. 39-41.

${ }^{32}$ Moreta Castillo, A., Ibidem., pp. 43-44.
} 
sueldo anual consignado en 300 pesos anuales de los fondos del ramo de penas de cámara. Los otros dos fiscales tenían un salario de 500 pesos, hasta que en 1776 se les aumentó a 3.300 pesos anuales; sin embargo, el del agente fiscal se mantuvo en la misma cantidad. ${ }^{33}$

El relator era el que redactaba los informes o relatos de los procesos del tribunal. Estos documentos debían contener los puntos principales del procedimiento, las pruebas y sus observaciones. Existía un relator que era nombrado por el Consejo de Indias, pero en 1768 se sumó otro, por lo que la audiencia contó hasta finales del siglo XVIII con dos relatores. El relator tenía un sueldo de 500 pesos al año consignados en penas de cámara, además de otros beneficios económicos que obtenía por las relaciones de su trabajo ${ }^{34}$. La cantidad de dinero que recibía estaba registrada en los aranceles que establecían la cantidad exacta que debía percibir por cada trabajo realizado, así como también lo estaba la normativa que refería como debía redactar y presentar sus informes ${ }^{35}$. A partir del 11 de marzo de 1776, el oficio de relator se obtuvo por oposición. Se pretendía así igualar la forma de acceder al empleo con la del resto de audiencias americanas, en las que ya se hacía de este modo desde el 22 de febrero de $1764^{36}$. En esta calidad fue nombrado el abogado José Jacinto Ramírez al ganar la oposición en 1778. Éste ya contaba con experiencia, pues había sido relator interino en alguna ocasión anteriormente al sustituir a José Frómesta, quien llevaba ejerciendo este

\footnotetext{
${ }^{33}$ Real cédula de 16 de diciembre de 1767 a cerca de la consignación de salarios de un agente fiscal y relator que se crearon en la Audiencia de Santo Domingo. AGI, Santo Domingo, 967. Cargo de data de salarios de las cuentas de las Cajas Reales de Santo Domingo en los años de 1754, 1755, y 1760. AGI, Contaduría, 1069-A, y B. Véase también Moreau de Saint-Méry, M. L. E., Descripción de la parte española de Santo Domingo..., op. cit., pp. 305-306.

${ }^{34}$ Real cédula de 16 de diciembre de 1767 a cerca de la consignación de salarios de un agente fiscal y relator que se crearon en la Audiencia de Santo Domingo. AGI, Santo Domingo, 967.

${ }^{35}$ Testimonio del Real arancel de derechos que llevan los subalternos de la Real Audiencia y Chancillería que reside en esta ciudad de Santo Domingo de La Española, 24 de octubre de 1760. AGI, Santo Domingo, 987.

${ }^{36}$ Real decreto de 11 de marzo de 1776 por el cuál se aumenta el número de algunas plazas en la Audiencia y la creación de que fuese por oposición el oficio de relator, el cual estaba ya mandado por Real Cédula de 22 de febrero de 1764 para el resto de las audiencias americanas. AGI, Santo Domingo, 967.
} 
empleo desde la muerte de su padre Leonardo José Frómesta Montejo en $1748^{37}$. Felipe Mañón de Lara también fue relator interino durante el año de $1752^{38}$.

El alcalde mayor era un funcionario que actuaba como juez de primera instancia en materia civil y criminal en toda la isla durante el siglo XVI. El primero en ocupar la alcaldía fue Francisco Roldán en La Isabela. Posteriormente se creó un cargo de alcalde en la ciudad de Santo Domingo y otro en La Concepción de La Vega, quedando distribuida la administración de la justicia en esas dos circunscripciones ${ }^{39}$. Durante el siglo XVIII existió una sola alcaldía mayor en la isla, cuya atribución siguió siendo estrictamente judicial, y su distrito de actuación correspondía a la ciudad de Santiago, cubriendo todo el área del valle del Cibao, y la frontera norte. Tenía un sueldo anual de 500 ducados y a partir de la Real Cédula de 26 de mayo de 1774 una tercera parte más de los emolumentos $^{40}$. Este empleo estuvo desempeñado por militares como Fernando Martínez Pisón, Pedro Arroyo Guerrero, y letrados distinguidos como Julián Joaquín Pueyo y Urríes, hijo del oidor Andrés Pueyo y Urríes. También puede constatarse que los naturales de la isla tenían prohibido desempeñarlo, aunque entre las personas que ocuparon el puesto de alcalde mayor entre 1750 y 1795, Juan Arredondo y Fernando Morell son las excepciones ${ }^{41}$. En el siguiente cuadro se observa que el resto fueron peninsulares y que Julián Joaquín Pueyo y Urríes lo ocupó durante veinte cinco años, cuando su periodo habitual de permanencia era de cinco años ${ }^{42}$.

\footnotetext{
${ }^{37}$ Informe de la Real Audiencia de Santo Domingo en la que da noticia a Su Majestad con testimonio de las diligencias practicadas para la oposición del segundo relator, 20 de marzo de 1778. AGI, Santo Domingo, 945. Título de relator para José Jacinto Ramírez, San Lorenzo 12 de octubre de 1778, y Título de relator para José Frómesta y Montejo por muerte de Leonardo José Frómesta y Montejo, San Lorenzo, 30 de octubre de 1749. AGI, Santo Domingo, 1006.

${ }^{38}$ Información de calidad y limpieza de sangre de la familia Mañón, 23 de septiembre de 1783. AGI, Santo Domingo, 946.

${ }^{39}$ Vega Boyrie, W., Historia del derecho dominicano..., op. cit., pp. 33-34. Moreta Castillo, A., La justicia en Santo Domingo..., op. cit., p. 51.

${ }^{40}$ Carta a Su Majestad de Julián Joaquín Pueyo y Urríes, alcalde mayor de Santiago de Caballeros, en la que solicita traslado a alguna plaza de este reino, 22 de junio de 1795. AGI, Santo Domingo, 1014.

${ }^{41}$ Carta de la Cámara de Indias en la que informa que se concede a Fernando Morell de Santa Cruz la alcaldía mayor de la ciudad de Santiago de los Caballeros, 3 de junio de 1766. AGI, Santo Domingo, 921.

${ }^{42}$ Entró en dicho cargo el 13 de agosto de 1770 y el 5 de septiembre de 1776 se le prorrogó por cinco años más continuando en él interinamente hasta que se nombrase a otra persona; sin embargo, permaneció en él hasta la cesión de la isla. Carta de Julián Joaquín Pueyo y Urríes, alcalde mayor de Santiago de Caballeros, en la que solicita traslado a alguna plaza de este reino, 22 de junio de 1795. AGI, Santo Domingo, 1014.
} 
Tabla 2-3. Relación de alcaldes mayores entre 1750 y 1795

\begin{tabular}{|l|c|l|}
\hline \multicolumn{1}{|c|}{ Nombre } & \multicolumn{1}{c|}{ Fecha } & \multicolumn{1}{c|}{ Origen } \\
\hline Fernando Martínez Pisón & $1744-1750$ & Peninsular \\
\hline$\dot{¿}$ ? & & \\
\hline Juan Arredondo y Vizcaíno & $1753-1756$ & Criollo \\
\hline Pedro Arroyo Guerrero & $1756-1759$ & Peninsular \\
\hline Miguel Pérez de León & $1759-1764$ & Peninsular \\
\hline Fernando Morell de Santa Cruz & $1764-1770$ & Criollo \\
\hline Julián Joaquín Pueyo y Urríes & $1770-1795$ & Peninsular \\
\hline
\end{tabular}

Elaboración propia. Fuentes: ¿? (desconocido) Títulos de alcaldes mayores de La Española. AGI, Santo Domingo, 940. Confirmación de oficios vendibles y renunciables. AGI, Santo Domingo, 937. AGS, Dirección General del Tesoro, Inv. 2, leg. 181, fol. 113; Inv. 2, leg. 184, fol. 205; Inv. 2, leg. 184, fol. 333; Inv. 2, leg. 185, fol. 324.

Al crearse nuevos poblados y aumentar la población en este siglo fue imposible que el alcalde mayor se encargara de todos ellos. Por ello el gobernador Manuel Azlor y Urríes empleó a diferentes oficiales del Batallón Fijo de la plaza de Santo Domingo en calidad de tenientes de guerra y gobernadores de armas en los puertos de la ciudad de Puerto Plata, Montecristi, Samaná y en la frontera norte y sur, con alguna tropa de la guarnición para "evitar comercio ilicito, y custodiar la frontera” ${ }^{43}$. Aunque éstos no administraban justicia, sólo la militar, ya que la ordinaria la ejercían los alcaldes de cada pueblo, a partir de 1765 también se les facultó cometerla en "causas de todo genero de comercio ilicito y contrabando" ${ }^{44}$, tanto en la zona fronteriza, como en la jurisdicción donde la practicasen. Además llevarían la denominación en sus títulos de “tenientes de gobernador, justicia mayor y jueces de comisos”. La Corona permitió que estos empleos pudieran seguir desempeñándolos los expresados oficiales o cualquier otra persona que el gobernador considerase adecuada ${ }^{45}$. Este cambio supuso que se fijase cuatro administraciones en los siguientes lugares: Dajabón, San Rafael, Las Caobas y Neiba. En cada uno de estos pueblos fronterizos se estableció unas guardias bajo el mando de un oficial militar en calidad de teniente del gobernador con un grupo de soldados para que vigilaran la frontera evitando el contrabando, y además cobrasen el derecho de saca de ganado a la parte francesa. Tarea esta

\footnotetext{
${ }^{43}$ Representación del gobernador Manuel Azlor y Urríes sobre lo que padece la administración de justicia de Santo Domingo, 26 de febrero de 1765. AGI, Santo Domingo, 921.

${ }^{44}$ Real Cédula concediendo al gobernador de Santo Domingo el establecimiento de tenientes de gobernador, justicias mayores y juez de comisos, 20 de julio de 1765. AGI, Santo Domingo, 976.

${ }^{45}$ Ibidem.
} 
última que a partir de 1769 ejercieron los oficiales reales, mientras que los militares continuaron con la vigilancia de sus respectivas jurisdicciones ${ }^{46}$.

Además, durante el gobierno de Manuel Azlor, la isla quedó dividida en dos departamentos, el norte y el sur, estando al cargo de cada uno de ellos por un teniente de gobernador encargado de su resguardo, y con capacidad de actuar como juez de justicia mayor y de comiso. El primero comprendía desde el río Haina hasta el poblado de Dajabón, y el segundo todos los pueblos que quedaban por debajo de ellos. En 1767 el capitán Fernando Manuel de Espinosa y Miranda sirvió de teniente de justicia mayor de la banda sur que comprendía para ese año las villas de Banica, Hincha y San Rafael, ampliándose posteriormente a Neiba, Azua, Baní, Las Caobas, San Juan de la Maguana, y San Miguel de la Atalaya. El capitán Felipe Guridi y Concha reemplazó a Fernando alrededor de 1771, desempeñándolo hasta que el 1 de marzo de 1784 el gobernador Isidro Peralta y Rojas nombró a José Esteban Arredondo y Castro, asignándole el sueldo anual de 1.000 pesos $^{47}$. En cambio la del norte tuvo como juez de comiso al comandante de armas de Santiago Francisco Antonio Velilla y Torres que murió en 1781. Dos años después de su muerte, el cargo fue ocupado por su yerno Francisco Espaillat y Virol hasta que el 1 de agosto de 1786 le sustituye el teniente de infantería Miguel Negrete, estableciéndose que a partir de esa fecha tendría una paga anual de 600 pesos $^{48}$.

El alguacil mayor o primer alguacil de la Audiencia se encargaba de ejecutar las órdenes y ordenanzas, así como de mantener el orden público en la ciudad y en la sala de la audiencia. El mismo alguacil mayor escogía a sus auxiliares, a los carceleros que custodiaban las prisiones y a los tenientes que le acompañaban en sus funciones. El cargo de alguacil estaba considerado como uno de los más prestigiosos. A principios del surgimiento de la colonia existían dos

\footnotetext{
${ }^{46}$ A partir de ese año cada oficial gozaba de sueldo un $10 \%$ de los derechos que cada uno respectivamente recaudase. Certificación del escribano de real hacienda Francisco Martínez de León de la junta de real hacienda, 22 de mayo de 1769. AGI, Santo Domingo, 1059.

${ }^{47} \mathrm{Al}$ morir Felipe Guridi en 1783 el empleo fue ocupado interinamente por Andrés de los Santos, alférez real y regidor del pueblo de San Juan de la Maguana. Carta de Felipe Guridi a Su Majestad, 26 de enero de 1779. AGI, Santo Domingo, 1021. Carta del gobernador Manuel González al rey, 25 de agosto de 1786. AGI, Santo Domingo, 1045. Véase también Hernández González, M. V., La colonización de la frontera dominicana (1680-1795). Las Palmas de Gran Canaria, 2005, p. 261.

${ }^{48}$ Idem. Véase también Campillo Pérez, J. G., Francisco Espaillat y el desarrollo del Cibao. Santo Domingo, 1985, p. 23.
} 
alguaciles, aunque no tenían salario asignado. En cambio, a finales del siglo XVIII sólo existía un alguacil ${ }^{49}$. Al igual que el relator, este empleo y sus dos ayudantes (tenientes de alguacil) tenían como beneficio económico lo obtenido por los aranceles que se cobraban por las funciones de su oficio, como apresar a los delincuentes, maleantes o causantes del desorden público, por hacer rondas para mantener la seguridad o custodiar las cárceles ${ }^{50}$.

Este cargo estuvo desempeñado por tres miembros de una misma familia que lo ocuparon ininterrumpidamente. Matías Guridi Coronado lo compró en 1741 por 600 pesos y renunció a favor de su hijo José Guridi y Concha en 1762, quien no pudo traspasarlo a su hijo al morir repentinamente en $1776^{51}$. Su hijo Nicolás Guridi y Frómesta solicitó comprarlo en ese mismo año, pero no lo obtuvo hasta 1785, manteniéndolo y ejerciéndolo luego en Puerto Príncipe ${ }^{52}$. La familia Guridi, de origen vasco, fue una de las más importantes y acaudaladas de aquella época. Estuvieron vinculados no sólo a la Audiencia, sino que ocuparon también cargos edilicios y militares como se verá más adelante.

La reorganización burocrática iniciada en 1768 con el aumento del número de sus funcionarios en dos componentes más, con un agente fiscal y otro relator, se continúo en todas las audiencias americanas. A partir de 1776, la Corona decretó una nueva estructura para éstas al aumentar sus plazas y sus sueldos, como se ha citado anteriormente. Otro de los cargos que se creó fue el de regente con un salario anual de 6.600 pesos. ${ }^{53}$ En 1776 se nombró como primer regente para la Audiencia de Santo Domingo al oidor más antiguo de la misma, Andrés Pueyo y Urríes, quien en 1780 se jubiló ${ }^{54}$. Un año después, Francisco Xavier de

\footnotetext{
49 Testimonio de las diligencias obradas sobre la averiguación de los oficios que hay vacantes y sin crear en esta isla, 1768. AGI, Santo Domingo, 979. Sobre el oficio de alguacil mayor véase Moreta Castillo, A., La justicia en Santo Domingo..., op. cit., pp. 55-57. Moreau de Saint-Méry, M. L. E., Descripción de la parte española de Santo Domingo..., op. cit., pp. 308-309.

${ }^{50}$ Véase en Testimonio del Real arancel de derechos que llevan los subalternos de la Real Audiencia y Chancillería que residen en esta ciudad de Santo Domingo de La Española. Y Testimonio del arancel que observan los carceleros de esta ciudad de la isla, 24 de octubre de 1760. AGI, Santo Domingo, 987.

${ }^{51}$ Testimonio de los autos obrados sobre la renuncia del oficio de alguacil mayor de la Real Audiencia de la Española hecha por Matías Guridi a favor de José Guridi y Concha, su hijo, 1763. AGI, Santo Domingo, 299 y 937.

${ }^{52}$ Nicolás Guridi y Frómesta pagó 600 pesos por el empleo de alguacil, igual que su abuelo Matías. Confirmación de oficios vendibles y renunciables. AGI, Santo Domingo, 938.

53 “Instrucción de Regentes de 1776" en Sánchez-Arcilla Benal, J., Las ordenanzas de las Audiencias de Indias (1511-1821). Madrid, 1992, pp. 389-399.

${ }^{54}$ Título de nueva creación del cargo de regente de la audiencia de Santo Domingo a favor de Andrés Pueyo y Urríes, 21 de octubre de 1776. AGI, Santo Domingo, 913. Carta del gobernador
} 
Gamboa, antes oidor en México, pasó a ocupar su lugar hasta que en 1787 fue nombrado regente en la Audiencia de México. Su sustituto fue José Antonio de Urízar y Bolívar, quien había sido con anterioridad oidor en la Audiencia de Santo Domingo y más tarde alcalde del crimen y oidor en la de México. Se mantuvo en esta plaza hasta que en 1797 le sucedió Luís Chávez y Mendoza, quien ya en 1777 había sido también oidor en la Audiencia de Santo Domingo ${ }^{55}$.

La figura del regente, se convirtió en el oidor más notable de las audiencias, pues en él se reunieron diversas funciones. Por un lado, las que habían pertenecido al capitán general o virrey como presidente de la audiencia, en caso de ausencia temporal o muerte de alguna de esas autoridades hasta que el rey nombrase otro presidente. Y por otro, las funciones que correspondían al oidor decano o más antiguo, como coordinar al resto de oidores, repartir los trabajos y trámites de las causas entre los oidores y relatores, fallar pleitos y además era el juez conocedor de todos los incidentes que ocurrieran respecto al Sello Real ${ }^{56}$.

Hasta entonces en Santo Domingo la función de ejercer el gobierno de forma interina en ausencia del presidente había correspondido al teniente de rey y no al regente. La creación de dicho cargo permitió que en 1786 la audiencia de Santo Domingo reclamase para sí la sucesión interina, responsabilidad por la que ya se había producido tiempo atrás algún conflicto ${ }^{57}$. La Audiencia entendía que al morir en ese año el gobernador Isidro Peralta y Rojas, debía ocupar la gobernación interina el regente y no el teniente de rey, Joaquín García Moreno,

de Santo Domingo en la que informa se le conceda a Andrés Pueyo y Urríes, regente de la Audiencia el retiro que pide, respecto a no poder continuar concurrir al tribunal por sus continuos achaques y edad, 29 de junio de 1779. AGI, Santo Domingo, 985.

${ }^{55}$ Providencias, informes y títulos desde el establecimiento hasta la traslación de la Audiencia de Santo Domingo. Títulos de regentes desde 1776. AGI, Santo Domingo, 967. Véase también los datos sobre los oidores mexicanos que ofrecen las obras de Burkholder, M. A. y Chandler, D. S., De la impotencia a la autoridad..., op. cit., pp. 182-183, y la de Brading, D., Mineros y comerciantes en el México borbónico (1763-1810). México, 1993, pp. 104-105.

${ }^{56}$ Polanco Alcántara, T., Las Reales Audiencias en las Provincias Americanas de España. Madrid, 1992, pp. 45-52.

${ }^{57}$ En tiempo del gobernador Manuel Azlor y Urríes se planteó un problema semejante al realizar una visita en 1766 por las principales poblaciones de la colonia. A quien correspondía por la ausencia temporal del gobernador era al teniente de rey, pero la Audiencia consideraba que era ella quién debía tomar el mando. A pesar de que por una Real Cédula de diciembre de 1766 declaraba que era el teniente de rey quien debía de ejercer el control del gobierno, capitanía general y presidencia. Sin embargo, el gobernador Manuel Azlor para evitar disensiones, decidió por cuenta propia que la Audiencia se encargaría de las materias de gobierno mientras que el teniente de rey sólo del mando militar. Véase en Carta del gobernador en la que comunica que va a realizar una visita y para determinar sobre gobierno durante su ausencia, 15 de enero de 1766. AGI, Santo Domingo, 921. 
pues en las instrucciones de creación del nuevo cargo de regente se estipulaba que era éste quien debía tomar el mando. La Corona, para seguir en consonancia con la nueva legislación que regía al resto del continente americano, decidió que en lo sucesivo en Santo Domingo sería el regente quien ocupase ese cargo, a pesar de que hasta entonces lo había ocupado el teniente de rey ${ }^{58}$.

La muerte en 1788 del siguiente gobernador Manuel González Torres y la ausencia de un regente, hicieron que el gobierno interino pasara a manos del oidor decano de la Audiencia, Pedro Catani, traspasándolo poco después al regente José Antonio de Urízar. La disputa entre la Audiencia y el teniente de rey por ocupar el gobierno interino continúo. De tal forma que una Real Cédula de 1788 declaraba a favor de la sucesión de los oficiales militares sirvió al teniente rey de Santo Domingo, Joaquín García, para reclamar a la Audiencia el gobierno interino, lo que le fue denegado por la misma. Tanto ésta como el teniente de rey informaron al Consejo de Indias de los conflictos surgidos entre ambos a causa de las pretensiones por obtener el mando interino, a pesar de que desde 1786 se estableció que debía estar en manos del regente. Ante esta situación la Corona expidió otra cédula en 1788. En ella se establecía definitivamente que quien reemplazaría al gobernador en caso de su ausencia y adquiriría el mando sería el teniente de rey de aquella plaza de Santo Domingo, derogando que fuese el regente. Un año después en 1789 se puso en marcha una nueva reforma en Indias. A partir de entonces, se impuso que en los lugares donde no hubiese audiencia, el teniente de rey sería quien sustituiría al gobernador en todos sus cargos, en caso de que no existiese un oficial de mayor graduación. Mientras que en las zonas con un tribunal recaería en este último, aunque esta variación no afectó a Santo Domingo $^{59}$. Así, la autoridad que supuestamente se les confirió a los regentes no tuvo su aplicación en Santo Domingo, donde éstos actuaron como meros funcionarios de la Audiencia. En cambio, el origen español de los que ocuparon tal puesto en este tribunal muestra como su elección estuvo dentro de la política reformista que pretendía reducir la participación criolla, con la excepción de Francisco Xavier de Gamboa que era de Guadalajara (México).

\footnotetext{
${ }^{58}$ Carta del gobernador de Santo Domingo en la que da cuenta que la Real Audiencia de Santo Domingo le ha pasado testimonio de la Real Cédula que se le ha dirigido y en la que informa que en las sucesivas vacantes del gobernador la presidencia recaiga en el regente, 12 de mayo de 1787. AGI, Santo Domingo, 991.

${ }^{59}$ Sevilla Soler, M . R., Santo Domingo..., op. cit., pp. 313-317.
} 
Si hasta ese momento la política reformista había consistido en el aumento de las plazas y sueldos de los ministros de las audiencias americanas, desde 1786 tal política comenzó a cambiar al disminuir el número de sus ministros y el salario del regente que se redujo dos años más tarde a 4.300 pesos $^{60}$. Estas disposiciones fueron entrando en vigor a medida que quedaron vacantes los cargos de cada tribunal. En 1786 la reducción del marco territorial de la Audiencia de Santo Domingo al crearse la Audiencia de Caracas, probablemente influyó a su vez en la disminución de su plantilla de funcionarios. Ese año la Audiencia pasó a tener un regente, tres oidores y un fiscal que se ocupaba tanto de lo civil como de lo criminal. Años después en 1791, ante la imposibilidad por parte del fiscal de realizar el trabajo que le correspondía, se nombró a un agente que le sirviera de ayudante ${ }^{61}$.

$\mathrm{Al}$ igual que el alguacil mayor el salario de los escribanos se regía por los aranceles que fijaban sus honorarios. Los escribanos eran funcionarios que comprobaban e instrumentaban los diversos actos jurídicos y levantaban acta de las sesiones de la Audiencia ${ }^{62}$. En esta institución siempre hubo escribanos, generalmente dos escribanos de cámara que se encargaban de redactar las peticiones y sentencias, custodiar los archivos de la Audiencia, comunicar las ordenanzas reales, distribuir y prevenir al fiscal de los procesos que le correspondiesen, y de que los relatores recibieran los procesos. Asimismo, llevaban el registro de las multas que la Audiencia pronunciaba, pero su cobro era realizado por otro funcionario, conocido como receptor de multas o penas de cámara. Aunque este cargo fue creado específicamente en esta Audiencia para el siglo XVI, durante el siglo XVIII estuvo desempeñado por los oficiales de Real Hacienda $^{63}$. En 1767 existían en la parte española de la isla veintidos escribanos ${ }^{64}$, mientras que en 1778 había veinticuatro escribanos tanto numerarios como reales.

\footnotetext{
${ }^{60}$ Mientras que en Santo Domingo la disminución de los oidores se habían iniciado hacia 1786 en el resto de las audiencias no es a partir del reglamento de Antonio Porlier de 1788 cuando se pone en práctica. Sevilla Soler, Ma . R., Santo Domingo..., op. cit., p. 289. López Bohórquez, A. E., Los ministros de la Audiencia..., op. cit., pp. 42-48.

${ }^{61}$ Sevilla Soler, M${ }^{\mathrm{a}}$. R., Idem.

${ }^{62}$ Testimonio del Real arancel de derechos que llevan los subalternos de la Real Audiencia y Chancillería que reside en esta ciudad de Santo Domingo de La Española, 24 de octubre de 1760. AGI, Santo Domingo, 987. Acerca de los escribanos véase la obra de Polanco Brito, H. E., Los escribanos en el Santo Domingo colonial. Santo Domingo, 1989.

${ }^{63}$ Informe de los oficiales reales, 4 de febrero de 1767. AGI, Santo Domingo, 979.

${ }^{64}$ Ibidem.
} 
De ellos once estaban en la ciudad de Santo Domingo, incluyendo dos de gobierno y uno de Real Hacienda, y los trece restantes distribuidos en los distintos pueblos de la isla ${ }^{65}$. En los orígenes de la Audiencia eran designados por la misma, pero en el siglo XVIII el cargo de escribano se encontraba dentro de la categoría de los oficios vendibles y renunciables (véase en el anexo la tabla 2).

De igual manera se accedía al empleo de canciller, persona que guardaba el Sello Real en la Audiencia, que representaba a la figura del monarca. Además se encargaba de estampar el sello en una carta o cualquier documento donde fuese necesario, por lo que cobraba según lo estipulado por sus aranceles ${ }^{66}$. Junto a éstos hubo otros oficios a los que también se accedía por compra o renuncia. Entre ellos el empleo de intérprete de lenguas, indispensable en los pleitos y a quien se le exigía el conocimiento del castellano y alguna otra lengua, o los dos procuradores de corte con los que contaba esta audiencia. La función de éstos era representar a la ciudad en instancias superiores, como por ejemplo ante el Consejo de Indias. La audiencia contó también entre sus funcionarios con dos porteros, encargados de custodiar su entrada con un sueldo hacia 1783 de 180 pesos anuales, es decir, unos 15 al mes como muestra la tabla 2-5.

\footnotetext{
${ }^{65}$ Informe de la Real Audiencia de Santo Domingo, 18 de julio de 1778. AGI, Santo Domingo, 940.

${ }^{66}$ Testimonio del Real arancel de derechos que llevan los subalternos de la Real Audiencia y Chancillería que reside en esta ciudad de Santo Domingo de La Española, 24 de octubre de 1760. AGI, Santo Domingo, 987.
} 
El gobierno político en Santo Domingo

Tabla 2-4. Estado de la Audiencia de Santo Domingo, 1771

\begin{tabular}{|c|c|c|c|}
\hline Nombre & Cargo & $\begin{array}{c}\text { Fecha desde la que lleva } \\
\text { ejerciendo }\end{array}$ & Sueldo anual \\
\hline José Solano y Bote & Presidente & 6 de septiembre de 1771 & $6.000 \$$ \\
\hline Andrés Pueyo y Urríes & Oidor & 9 de enero de 1755 & $600.000 \mathrm{mrs}$. \\
\hline $\begin{array}{l}\text { Antonio Simón de } \\
\text { Mirafuentes }\end{array}$ & Oidor & 4 de julio de 1771 & $600.000 \mathrm{mrs}$. \\
\hline $\begin{array}{l}\text { José Antonio de Urízar } \\
\text { y Bolívar }\end{array}$ & Oidor & 16 de septiembre de 1771 & $600.000 \mathrm{mrs}$. \\
\hline $\begin{array}{l}\text { José Bernardo de } \\
\text { Osorio Pardo y Llamas }\end{array}$ & Oidor & 27 de abril de 1774 & 600.000 mrs. \\
\hline $\begin{array}{l}\text { Ruperto Vicente } \\
\text { Luyando }\end{array}$ & Oidor & 27 de abril de 1774 & 600.000 mrs. \\
\hline $\begin{array}{l}\text { Diego Martínez } \\
\text { Sánchez de Araque y } \\
\text { Velasco } \\
\end{array}$ & Fiscal & 16 de marzo de 1771 & $600.000 \mathrm{mrs}$. \\
\hline Antolín de Liendo & $\begin{array}{l}\text { Oidor } \\
\text { Supernumerario }\end{array}$ & 2 de febrero de 1761 & $600.000 \mathrm{mrs}$. \\
\hline Manuel de Urrutia & $\begin{array}{l}\text { Oidor } \\
\text { Supernumerario }\end{array}$ & 11 de marzo de 1771 & 600.000 mrs. \\
\hline Salvador Más y Llopis & $\begin{array}{l}\text { Oidor } \\
\text { Supernumerario }\end{array}$ & 28 de marzo de 1763 & 600.000 mrs. \\
\hline Sebastián Maldonado & $\begin{array}{l}\text { Oidor } \\
\text { Supernumerario }\end{array}$ & 3 de octubre de 1767 & $600.000 \mathrm{mrs}$. \\
\hline José Rivera & $\begin{array}{l}\text { Oidor } \\
\text { Supernumerario }\end{array}$ & 24 de junio de 1773 & 600.000 mrs. \\
\hline $\begin{array}{l}\text { Joaquín Julián Pueyo y } \\
\text { Urríes }\end{array}$ & $\begin{array}{l}\text { Alcalde Mayor } \\
\text { de Santiago de } \\
\text { los Caballeros }\end{array}$ & 13 de agosto de 1770 & 500 ducados \\
\hline $\begin{array}{l}\text { José Frómesta y } \\
\text { Balmaceda }\end{array}$ & Relator & 30 de octubre de 1749 & $500 \$$ \\
\hline José Guridi y Concha & Alguacil Mayor & 23 de octubre de 1762 & No tiene \\
\hline
\end{tabular}

Elaboración propia. Fuentes: Estado de la Audiencia de la isla Española de Santo Domingo, 21 de junio de 1771. AGI, Santo Domingo, 922. Burkholder, M. A., y Chandler, D. S., De la impotencia a la autoridad..., op. cit., pp. 434-443. 
Tabla 2-5. Relación de los empleos políticos de la Audiencia de Santo Domingo, 1783

\begin{tabular}{|c|c|c|c|}
\hline Nombre & Cargo & $\begin{array}{c}\text { Fecha de la toma de } \\
\text { posesión }\end{array}$ & $\begin{array}{c}\text { Sueldo } \\
\text { anual en } \\
\text { pesos } \\
\end{array}$ \\
\hline Isidro Peralta y Rojas & \begin{tabular}{|l} 
Presidente, \\
Gobernador y Capitán \\
General \\
\end{tabular} & 3 de agosto de 1778 & 8.000 \\
\hline $\begin{array}{l}\text { Francisco Xavier de } \\
\text { Gamboa }\end{array}$ & Regente & & 6.600 \\
\hline $\begin{array}{l}\text { Luís Chávez y } \\
\text { Mendoza }\end{array}$ & Oidor & \begin{tabular}{|l}
13 de diciembre de \\
1777
\end{tabular} & 3.300 \\
\hline $\begin{array}{l}\text { Agustín de Emparán } \\
\text { y Orbe }\end{array}$ & Oidor & 13 de febrero de 1778 & 3.300 \\
\hline $\begin{array}{l}\text { Ramón Jover y } \\
\text { Ferrandiz }\end{array}$ & Oidor & 13 de enero de 1778 & 3.300 \\
\hline Joaquín Inclán & Oidor & 1 de octubre de 1781 & 3.300 \\
\hline Manuel Bravo & Oidor & 14 de mayo de 1780 & 3.300 \\
\hline $\begin{array}{l}\text { Miguel Cristóbal de } \\
\text { Irizarri }\end{array}$ & Fiscal de lo civil & 13 de febrero de 1778 & 3.300 \\
\hline $\begin{array}{l}\text { Julián Díaz de } \\
\text { Saravia }\end{array}$ & Fiscal del crimen & 14 de marzo de 1782 & 3.300 \\
\hline Francisco de Aybar & Agente fiscal & 17 de febrero de 1782 & 300 \\
\hline Vacante & Alguacil mayor & & No tiene \\
\hline $\begin{array}{l}\text { José Frómesta y } \\
\text { Balmaceda }\end{array}$ & Relator & 30 de octubre de 1749 & 500 \\
\hline José Jacinto Ramírez & Relator & 22 de abril de 1779 & 500 \\
\hline$\dot{2} ?$ & \begin{tabular}{|l|} 
Dos Porteros \\
\end{tabular} & & 180 \\
\hline$\dot{¿} ?$ & $\begin{array}{l}\text { Dos Escribanos de } \\
\text { cámara }\end{array}$ & & No tiene \\
\hline $\begin{array}{l}\text { Julián Joaquín Pueyo } \\
\text { y Urríes }\end{array}$ & $\begin{array}{l}\text { Alcalde mayor de la } \\
\text { ciudad de Santiago }\end{array}$ & $\begin{array}{l}5 \text { de septiembre de } \\
1776\end{array}$ & 500 ducados \\
\hline Juan Tomati & Intérprete de lenguas & 17 de julio de 1777 & 240 \\
\hline
\end{tabular}

Elaboración propia. Fuentes: ¿'? (desconocido) Carta del gobernador de Santo Domingo en la que dirige relación individual y circunstanciada de todos los empleos políticos, militares y de la real hacienda de la jurisdicción de su mando, 21 de mayo de 1783. AGI, Santo Domingo, 946. 


\subsection{La Real Hacienda}

La administración de la Hacienda Real de la parte española de la isla estuvo bajo un grupo de personas conocidas como oficiales reales, que conjuntamente formaban el tribunal de las cajas reales o del tesoro público. Durante el siglo XVI existieron cuatro funcionarios: el tesorero que custodiaba y recibía la parte del oro que le correspondía a la Corona, el contador quien se encargaba de pagar los sueldos al resto de los funcionarios de la isla, el veedor que se cuidaba de recoger, fundir y marcar el oro, y el factor que atendía el almacenamiento y venta de los productos que venían de España. A mediados del siglo XVI, cuando empezó a descender la explotación del oro en la isla, se eliminó el cargo de veedor, quedando reducidos a tres los oficiales reales ${ }^{67}$.

A partir de 1638, al estructurar la administración de las Cajas Reales de Indias se crearon otros tribunales de cuentas en Lima, Bogotá, México y las islas de Barlovento, con asiento en La Habana, que actuaba sobre las cajas de Puerto Rico y Santo Domingo a través de las visitas de los miembros de dicho tribunal ${ }^{68}$. Durante el siglo XVIII hubo varias cajas reales en la isla, una en Santo Domingo, otra en Montecristi habilitada en 1758 y otra en la zona fronteriza que fue creada en 1769 y abarcaba los poblados de Dajabón, San Rafael, Las Caobas, y Neiba. La caja de Montecristi estaba compuesta por un teniente oficial con un sueldo anual de 275 pesos, un guarda mayor que debía visitar, cargar y descargar los productos de las embarcaciones con un salario de 150 pesos, y un escribano de la ciudad. En cada poblado nombrado anteriormente había un administrador que recaudaba los impuestos. Este funcionario no tenía un sueldo fijo, sino que en función de lo recaudado tenía una comisión de un $10 \%$ del producto ${ }^{69}$.

Hacia 1769 las cajas de Santo Domingo estaban al frente de un contador mayor y un tesorero, ambos con un salario anual de 1.102 pesos, 7 reales y 18 maravedíes. Ese año, el primer puesto estaba ocupado por Francisco de Paula Gazcue y Olaiz y el segundo por Raymundo de Esparza, ambos peninsulares ${ }^{70}$.

\footnotetext{
${ }^{67}$ Vega Boyrie, W., Historia del derecho dominicano..., op. cit., pp. 34 y 65-66. Lamb, U., Frey Nicolás de Ovando. Gobernador de las Indias. Santo Domingo, 1977, p. 163.

${ }^{68}$ Vega Boyrie, W., Ibidem., p. 66.

${ }^{69}$ Extractos de la revista de todas las atenciones de la isla de Santo Domingo, 31 de mayo de 1769. AGI, Santo Domingo, 1044.

${ }^{70}$ Título de contador para Francisco Gazcue y Olaiz por fallecimiento de Domingo Ramírez de Arellano, Aranjuez 26 de abril de 1754. AGI, Santo Domingo, 910, y AGS, Dirección General del
} 
Por debajo de ellos se hallaban un oficial mayor con un salario de 300 pesos; un alguacil ejecutor con 337 al año; un sobrestante con 132; y un juez de media annata con $137^{71}$. En 1770, el organigrama se modificó al aumentársele el número de oficiales en tres, un segundo oficial mayor, un oficial supernumerario y un teniente oficial $^{72}$. También se incrementó el sueldo del oficial mayor como puede observarse en la siguiente tabla, estructura que se mantuvo hasta 1778.

Tabla 2-6. Estado de las Cajas Reales de Santo Domingo y sus salarios, 1778

\begin{tabular}{|l|l|}
\hline \multicolumn{1}{|c|}{ Cargos } & \multicolumn{1}{c|}{ Sueldo anual } \\
\hline 1 contador & $1102 \$, 7$ rs. 18 mrs. \\
\hline 1 tesorero & 1102 \$,7 rs. 18 mrs. \\
\hline 1 oficial mayor & $480 \$$ \\
\hline 1 oficial segundo & $360 \$$ \\
\hline 1 oficial supernumerario & $180 \$$ \\
\hline 1 alguacil ejecutor & 331 \$ \\
\hline 1 sobrestante & $132 \$$ \\
\hline 1 juez de media annata & 137 \$ y rs. \\
\hline 1 teniente oficial & 135 \$ \\
\hline
\end{tabular}

Elaboración propia. Fuentes: Estado de la Real Hacienda de Santo Domingo, 1 de agosto de 1778. AGI, Santo Domingo, 1044.

En cuanto al modo de su adquisición, los empleos de contador y tesorero fueron ocupados en función de los méritos o servicios prestados a la Corona, que se encargaba del nombramiento directo de una persona para tales puestos. Estos oficiales a su vez nombraban al sobrestante, mientras que los otros empleos como el segundo oficial mayor, y el supernumerario eran designados por la Corona, que los escogía entre una terna de personas propuestas por los dos oficiales principales. Aunque el gobernador también designó tanto a unos como a otros.

Sin embargo, hubo otros empleos que estaban incluidos en la categoría de vendibles y renunciables, como el alguacil, el escribano o los recaudadores de los derechos reales de alcabala o los diezmos de cada pueblo de la isla, cuestión que

Tesoro, Inv. 2, leg. 184, fol. 841. Título de tesorero oficial real de Santo Domingo a Raymundo Esparza al quedar vacante por ascenso de Francisco Pepín González a las cajas de Puerto Rico, El Pardo 8 de septiembre de 1766. AGI, Santo Domingo, 940.

${ }^{71}$ Extractos de la revista de todas las atenciones de la isla de Santo Domingo, 31 de mayo de 1769. AGI, Santo Domingo, 1044.

${ }^{72}$ Estado de la Real Hacienda de Santo Domingo, 1 de agosto de 1778. AGI, Santo Domingo, 1044. 
será tratada en el capítulo siete. También la administración de la Bula de la Santa Cruzada estaba dentro de esa categoría. Esta tasa de tipo eclesiástico concedía la indulgencia de comer carne en los días de ayuno a aquel que la comprara. Aunque tenía un carácter eclesiástico era administrado por la Real Hacienda a través de un tribunal específico cuyo cuerpo estaba integrado por un comisario, el tesorero, un notario y un alguacil. Estos puestos una vez comprados, podían ser vendidos a otras personas. Así el 2 de agosto de 1775, Antonio Álvarez Barba compró el oficio de tesorero de la Santa Cruzada por 3.000 pesos a José Esteban Arredondo Castro y su mujer Isabel Martínez de Venecia Santelices, que lo había heredado de sus padres ${ }^{73}$. Hacia 1783 se suprimieron los administradores que tenía la Santa Cruzada con la particularidad de que el empleo de tesorero fue puesto a cargo de uno de los oficiales reales, que debía remitir los sumarios a todos los curas, y entregarles sus cuentas finales. Además aparece un nuevo cargo el de marchamador en las cajas de Santo Domingo y Montecristi, aunque se desconoce si existió antes de 1783 en la capital en cambio nos consta que en la segunda ciudad fue creado en 1778. Su misión era la de señalar o marcar los géneros que entraban o salían en los puertos de esas ciudades. En el caso de Montecristi este funcionario era un escribiente que al mismo tiempo ejercía de marchamista. En 1778 se aumentó el sueldo anual del teniente oficial real a 500 pesos, y el del guarda mayor a $300^{74}$. Posteriormente, este último fue aumentado en 60 pesos más como puede observarse en la tabla 2-7 que presenta la estructura administrativa de la Real Hacienda de toda la isla en 1783. Dentro de ella también debe incluirse la Factoría de Tabaco en la que nos centraremos en el capítulo siete.

En 1787 el tesorero Fernando Mauleón intentó realizar una mejora en las oficinas de Santo Domingo, aumentando el número de individuos y su sueldo. Para ese año la real tesorería estaba formada por los empleos ya mencionados en la tabla anterior. A ellos habría que añadir además otros dos escribientes, es decir, que había tres. Estos dos nuevos escribientes habían sido creados temporalmente en el tiempo del gobernador Isidro Peralta y Rojas a petición del tesorero

\footnotetext{
73 Isabel lo heredó de sus padres Manuel Martínez de Mendoza y Margarita Venecia y Santelices, quien se lo había comprado a su hermano Miguel Venecia y Santelices. Cédula Real confirmando el título de tesorero de la Santa Cruzada a favor de Antonio Álvarez Barba, San Lorenzo 15 de octubre de 1778. AGI, Santo Domingo, 913.

${ }^{74} \mathrm{Al}$ haberse habilitado el puerto de Montecristi para el comercio libre en el reglamento de 12 de octubre de 1778 se reformó su cuerpo administrativo. Carta del gobernador Isidro Peralta y Rojas al rey en la que informa de su estado, 26 y 30 de junio de 1779. AGI, Santo Domingo, 1059.
} 
Raymundo Esparza para adelantar trabajo. Además uno de ellos fue asignado a un sargento del Batallón Fijo, quien en calidad de agregado se encargó de ayudar al primer oficial mayor en los ajustes de tropas, hospitales, presidio, maestranza de artillería, fortificación, recaudación de derechos y pago de sueldo del Ejército, recibiendo la gratificación anual de 200 pesos. Mientras que al otro escribano se le encargó liquidar y glosar las cuentas pendientes recibiendo un sueldo anual de 240 pesos. Fernando Mauleón lo que pretendió fue reducir el número de escribientes a dos y aumentar a ese número los oficiales reales por lo que pasarían a ser cinco. Además solicitaba el aumento de los sueldos de todos ellos, a excepción del contador y tesorero que permanecerían igual que en 1783. (Véase tabla 2-8)

Esta nueva configuración suponía más gastos para la Real Hacienda de ahí que la Corona no estuviese de acuerdo, y mandase a través de una Real Orden de 21 de octubre de 1789 la reducción de sus oficiales a tres tal como había ordenado en $1770^{75}$. Sin embargo, las quejas del tesorero Fernando Mauleón ante la imposibilidad de llevar una buena administración con ese número tan reducido permitieron que fuesen finalmente cinco los oficiales. Hacia 1791 las cajas de la capital estaban integradas por el contador, el tesorero y cinco subalternos: cuatro oficiales y un escribano. Además se suprimió la plaza de marchamador y alguacil aunque sus funciones las desempeñaron alguno de los oficiales ${ }^{76}$. En consecuencia, se tuvo que reorganizar el trabajo que debía realizar cada uno de ellos. De forma que a partir de entonces el primer oficial llevaría la administración de diezmos, comisos, alcabalas, papel sellado, naipes, y bulas de la capital y de todos los pueblos de la isla, así como de las administraciones subalternas de Montecristi, Dajabón, San Rafael, Las Caobas y Neiba, con un sueldo anual de 600 pesos. El segundo debía cuidarse de "los libros reales o manuales de cargo y data” en los que debía llevar ordenadamente todas las cuentas cobrando por ello 480 pesos. El tercero se encargaría del "despacho de guias, tomas de razon de titulos y reales ordenes, licencias para ganados que se extraen a la parte francesa, libros de intervencion de almacenes de artilleria y los particulares de liquidaciones

\footnotetext{
${ }^{75}$ Real Orden de 21 de octubre de 1789 en la que se comunica al gobernador Joaquín García, se desapruebe el aumento de subalternos y sueldos que hizo la junta celebrada el 19 de noviembre de 1789 mandando reducir el número de aquellos. AGI, Santo Domingo, 996.

${ }^{76}$ Carta del gobernador al rey, 18 de octubre de 1791. Y, Testimonio de la representación hecha por el tesorero Mauleón para que se tengan en la Real Contaduría los oficiales que en la actualidad existen en ella, 19 de octubre de 1791. AGI, Santo Domingo, 996.
} 
y pagamentos de deudas atrasadas a la corona” con un salario de 420 pesos. Al cuarto le correspondía contar, recibir y pagar todo lo recaudado “en la tesoreria, la formacion de las liquidaciones del Batallon Fijo, artilleria, milicias de infanteria y dragones, retirados o invalidos y [...]”, y los derechos de mar y aduanas, teniendo una paga de 360 pesos. El quinto oficial era el escribano que debía "poner en limpio las cuentas ordenadas, relaciones juradas, las liquidaciones de tropas ajustamientos de derechos y todo lo que los demas trabajaban en borrador” y cuya remuneración anual era de 300 pesos $^{77}$.

Al igual que en el caso de los ministros de la Audiencia, los funcionarios de la Real Hacienda de Santo Domingo no podían estar integrados en la sociedad en la que ejercían sus cargos. La legislación indiana no disponía que se casaran en el distrito donde estaban empleados, así como tampoco poseer casas, tierras o haciendas, entre otras medidas. A pesar de tales prohibiciones por parte de la Corona algunos oficiales reales se establecieron en Santo Domingo, bien a través de conexiones económicas o vinculaciones matrimoniales con hijas de oidores o con familias criollas favoreciendo al desarrollo de nexos locales. También puede comprobarse como adquirieron bienes de gran magnitud, participando en actividades económicas que los situó entre los más acaudalados terratenientes de Santo Domingo. Por citar algunos de esos personajes: Francisco Pepín González, Francisco de Paula Gazcue y Olaiz, Raymundo Esparza y Fernando Mauleón.

\footnotetext{
${ }^{77}$ Ibidem.
} 
Tabla 2-7. Relación de los empleos de la Real Hacienda, 1783

\begin{tabular}{|c|c|c|c|}
\hline \multicolumn{4}{|c|}{ Santo Domingo } \\
\hline Nombre & Cargo & $\begin{array}{c}\text { Fecha de la toma de } \\
\text { posesión }\end{array}$ & $\begin{array}{c}\text { Sueldo anual } \\
\text { en pesos }\end{array}$ \\
\hline $\begin{array}{l}\text { Francisco de Paula } \\
\text { Gazcue y Olaiz }\end{array}$ & Contador & 7 de febrero de 1755 & 1.100 \\
\hline Raymundo Esparza & Tesorero & 4 de febrero de 1767 & 1.100 \\
\hline Pedro Madrigal & Oficial mayor & 1 de enero de 1753 & 480 \\
\hline Juan Lavastida & $\begin{array}{l}\text { Segundo oficial } \\
\text { mayor }\end{array}$ & 1 de enero de 1760 & 360 \\
\hline Francisco Madrigal & $\begin{array}{l}\text { Oficial } \\
\text { supernumerario }\end{array}$ & 10 de abril de 1773 & 180 \\
\hline Félix Guillén & Alguacil & 16 de enero de 1769 & 331 \\
\hline Joaquín Broin & Marchamador & 1 de septiembre de 1777 & 360 \\
\hline Fernando Bello & $\begin{array}{l}\text { Receptor de } \\
\text { alcabala (Santo } \\
\text { Domingo) }\end{array}$ & $\begin{array}{l}19 \text { de septiembre de } \\
1778\end{array}$ & 360 \\
\hline Pedro Juan García & $\begin{array}{l}\text { Guarda mayor del } \\
\text { puerto }\end{array}$ & 20 de febrero de 1724 & $\begin{array}{r}\text { No tiene } \\
\text { sueldo }\end{array}$ \\
\hline Francisco Martínez & Escribano & 2 de diciembre de 1761 & $\begin{array}{r}\text { No tiene } \\
\text { sueldo }\end{array}$ \\
\hline$\dot{c} ?$ & Sobrestante & & 132 \\
\hline$\dot{¿} ?$ & $\begin{array}{l}\text { Receptor de } \\
\text { alcabala de cada } \\
\text { pueblo }\end{array}$ & & $\begin{array}{r}6 \% \text { del } \\
\text { producto }\end{array}$ \\
\hline \multicolumn{4}{|c|}{ Montecristi } \\
\hline Nombre & Cargo & $\begin{array}{c}\text { Fecha de la toma de } \\
\text { posesión }\end{array}$ & $\begin{array}{c}\text { Sueldo anual } \\
\text { en pesos }\end{array}$ \\
\hline José Álvarez & Teniente oficial & 1 de julio de 1779 & 500 \\
\hline Pedro Brito & Marchamador & 1 de julio de 1779 & 360 \\
\hline José Palomino & Guarda mayor & 1 de julio de 1779 & 300 \\
\hline \multicolumn{4}{|c|}{ Zona Fronteriza } \\
\hline Nombre & Cargo & $\begin{array}{c}\text { Fecha de la toma de } \\
\text { posesión }\end{array}$ & $\begin{array}{c}\text { Sueldo anual } \\
\text { en pesos }\end{array}$ \\
\hline Manuel de Aponte & $\begin{array}{l}\text { Recaudador de } \\
\text { Dajabón }\end{array}$ & $\begin{array}{l}19 \text { de noviembre de } \\
1768\end{array}$ & $\begin{array}{r}10 \% \text { del } \\
\text { producto }\end{array}$ \\
\hline Vicente Valera & $\begin{array}{l}\text { Recaudador de } \\
\text { San Rafael }\end{array}$ & $\begin{array}{l}13 \text { de noviembre de } \\
1768\end{array}$ & $\begin{array}{r}10 \% \text { del } \\
\text { producto }\end{array}$ \\
\hline Juan Sánchez & $\begin{array}{l}\text { Recaudador de } \\
\text { Las Caobas }\end{array}$ & 17 de abril de 1778 & $\begin{array}{l}10 \% \text { del } \\
\text { producto }\end{array}$ \\
\hline Nicolás Arias & $\begin{array}{l}\text { Recaudador de } \\
\text { Neiba }\end{array}$ & 3 de noviembre de 1779 & $\begin{array}{l}10 \% \text { del } \\
\text { producto }\end{array}$ \\
\hline
\end{tabular}

Elaboración propia. Fuentes: ¿'? (desconocido) Carta del Gobernador de Santo Domingo en la que dirige la relación individual de los empleos perpetuos y temporales políticos, militares y de Real Hacienda que se pagan por las reales cajas de Santo Domingo, formada en conformidad de las reales ordenes de 25 de agosto de 170 y de 12 de marzo de 1783. AGI, Santo Domingo, 946. 
Tabla 2-8. Estado de las cajas reales de Santo Domingo y reforma propuesta, 1787

\begin{tabular}{|l|r||l|r|}
\hline \multicolumn{1}{|c||}{ Situación actual } & \multicolumn{2}{c|}{ Situación solicitada } \\
\hline 1 oficial mayor & \multicolumn{1}{c||}{$\begin{array}{c}\text { Sueldo anual en } \\
\text { pesos }\end{array}$} & \multicolumn{1}{c|}{ Cargo } & $\begin{array}{c}\text { Sueldo anual en } \\
\text { pesos }\end{array}$ \\
\hline 1 oficial segundo & 480 & 1 oficial mayor & 720 \\
\hline $\begin{array}{l}\text { 1 oficial } \\
\text { supernumerario }\end{array}$ & 360 & 1 oficial segundo & 500 \\
\hline 1escribiente & 180 & 1 oficial tercero & 540 \\
\hline 1 escribiente & 240 & 1 oficial cuarto & 480 \\
\hline 1 escribiente & 240 & 1 oficial quinto & 360 \\
\hline 1 agregado & 240 & 1 escribiente & 300 \\
\hline Total & 200 & 1 escribiente & $\mathbf{3 . 4 2 0}$ \\
\hline
\end{tabular}

Elaboración propia. Fuentes: Relación del tesorero Fernando Mauleón sobre el estado en que al ingreso de su empleo ha hallado aquellas reales cajas en la que informa del número de oficiales de la contaduría principal y real tesorería de la isla de Santo Domingo, con expresión de los sueldos que gozan y de los que se le consideran precisos para su subsistencia, 31 de octubre de 1787. AGI, Santo Domingo, 947.

\subsection{El cabildo de Santo Domingo}

Uno de los primeros pasos en la conquista y colonización americana fue la organización del territorio y su población con la fundación de ciudades y organismos como los cabildos, que sirvieron para su gobierno y administración. La fundación de las primeras ciudades en La Española aportó el establecimiento de los cabildos, que se convirtieron en el órgano rector de todos los aspectos relacionados con ellas. La bibliografía que ha abordado sus orígenes $\mathrm{y}$ funcionamiento es más bien escasa. Además desafortunadamente, son más bien pocos los archivos locales que cuentan con documentación que proporcione información al respecto, o con fuentes tan interesantes como las actas capitulares que ayudarían al estudio de esta institución ${ }^{78}$. Por el momento, según Emilio Rodríguez Demorizi se tiene constancia de que el primer cabildo americano se fundó el 24 de abril de 1494 en La Isabela ${ }^{79}$. Respecto al cabildo de la ciudad de

\footnotetext{
78 Entre la documentación que se ha conservado hasta nuestros días cabe destacar la de los pueblos de Higüey y Bayaguana, localizados en el Archivo General de la Nación, y sobre los que podría realizarse alguna investigación.

79 En 1493 la Corona faculta a Cristóbal Colón crear cabildos en los pueblos que fuesen fundándose en La Española. El primero de ellos fue en La Isabela. Véase en Rodríguez Morel, G., Cartas del cabildo de la ciudad de Santo Domingo en el siglo XVI. Santo Domingo, 1999, p. 15.
} 
Santo Domingo, no se conoce la fecha de su fundación pero sí algunos datos sobre sus funciones y organización proporcionados por sus informes y correspondencia con las autoridades metropolitanas.

\subsubsection{Estructura}

El principal cometido del cabildo de Santo Domingo y del resto de los cabildos coloniales fue la administración de justicia y la organización de la vida y del gobierno municipal de la ciudad. Estas atribuciones se realizaban a través de sus alcaldes ordinarios, que se ocupaban de su cumplimiento dentro de los límites de dicha ciudad. Junto a ellos, los regidores se encargaban de los aspectos de gobierno de la vida diaria, entre otros del abastecimiento de alimentos y servicios como el agua, carnes, limpieza, e iluminación ${ }^{80}$. Durante el siglo XVI este oficio no tuvo salario pero las personas que lo desempeñaron recibieron como recompensa 12 fanegas de sal y 2.000 maravedíes de plata ${ }^{81}$. En cambio durante el siglo XVIII no tuvo ningún emolumento “[...] solo el corto salario de veinte dos pesos anuales $[\ldots]^{, 82}$.

En un principio los alcaldes ordinarios eran elegidos por el propio gobernador, hasta que a partir de 1511 se estableció que serían nombrados anualmente por cada cabildo los primeros días de enero por medio de la votación que realizaban los regidores. En ésta se elegía a un primer alcalde y otro de segundo voto. Entre los requisitos que se exigían para poder ser elegido alcalde estaba ser vecino, preferentemente la pertenencia al grupo de los primeros pobladores, no deber nada a la Real Hacienda y no tener ninguna causa pendiente con la justicia. Sus preeminencias y privilegios iban desde lugares preferentes en actos públicos, como el primer puesto en el recibimiento al gobernador, hasta la tenencia de conocimiento de pleitos, con lo que podían favorecer a una de las

Rodríguez Demorizi, E., El pleito Ovando-Tapia. Comienzos de la vida urbana en América. Santo Domingo, 1978, p. 53.

${ }^{80}$ Bayle, C., Los cabildos seculares en la América española. Madrid, 1952, pp. 175-198. Puede verse también Vega Boyrie, W., Historia del derecho dominicano..., op. cit., pp. 58-60.

${ }^{81}$ Gutiérrez Escudero, A., Población y economía en Santo Domingo (1700-1746). Sevilla, 1985, p. 193.

${ }_{82}$ Carta del cabildo de Santo Domingo al rey informando del estado de éste, 26 de junio de 1724. AGI, Santo Domingo, 284. Auto sobre el verdadero valor del oficio de regidor rematado en Antonio Mañón de Lara, 3 de agosto de 1768. AGI, Santo Domingo, 937. 
partes, sobre todo, siendo los mismos alcaldes parientes o amigos de los delincuentes ${ }^{83}$.

A parte de los alcaldes ordinarios también hubo otros alcaldes con jurisdicciones especiales, como fueron los dos alcaldes de la Santa Hermandad y visita. Éstos se elegían de igual forma que los alcaldes ordinarios, y por lo general la persona escogida para tal función debía haber ejercido con anterioridad algún otro cargo en el cabildo, normalmente como alcalde ordinario o regidor. Estos alcaldes existieron desde los primeros años de la colonia y su función consistía en velar por la seguridad de los campos y caminos de la jurisdicción a la que pertenecían, actuando como una especie de “policía rural” ${ }^{\text {84 }}$. El alcalde provincial de la Santa Hermandad, puesto creado en 1758, estaba por encima de ellos y tenía su responsabilidad. El primero en ocupar el cargo fue José Campuzano y Polanco, siendo nombrado por el gobernador Francisco Rubio y Peñaranda, aunque este oficio fue establecido con el fin de que entrara en la clase de vendible y renunciable ${ }^{85}$.

La repetición de apellidos entre las personas electas para alcaldes ordinarios y de Santa Hermandad entre 1751 y 1779, como muestra la siguiente tabla, evidencia el acaparamiento y la perpetuación de estos puestos por miembros de varios grupos de parentesco que formaban parte de dos redes familiares: la Guridi-Alarcón-Coronado y los Landeche-Bastidas con sus enlaces. Todos ellos eran criollos, exceptuando a Lorenzo Angulo Medrano, José Antonio Zárraga ${ }^{86}$, Antonio Valdemoro y Alcántara, y José Castro Palomino que eran peninsulares.

\footnotetext{
${ }^{83}$ Representación del gobernador Manuel Azlor y Urríes sobre lo que padece la administración de justicia de Santo Domingo, 26 de febrero de 1765. AGI, Santo Domingo, 921.

${ }^{84}$ Moreta Castillo, A., La justicia en Santo Domingo..., op. cit., p. 152. Santos Pérez, J. M., Élites, poder local y régimen colonial. El cabildo de Santiago y los regidores de Santiago de Guatemala, 1700-1787. Cádiz, 1999, p. 53.

${ }^{85}$ Carta de José Campuzano y Polanco, regidor decano de la ciudad de Santo Domingo y alcalde provincial de la Hermandad en la que se solicita la Real confirmación de dicho cargo, 23 abril de 1761. Y Minuta de la Real Cédula de 28 de octubre de 1758 en la que se expidió al gobernador de Santo Domingo que debía ejecutar con el oficio de alcalde provincial, y los regidores de aquella ciudad. Madrid 10 de noviembre de 1760. AGI, Santo Domingo, 937.

${ }^{86}$ José Antonio Zárraga fue electo alcalde de primer voto en 1776, pero a los ocho días de ser elegido tuvo que hacer un viaje a Coro y se quedó en su lugar Antonio Dávila Coca y Landeche. Carta del cabildo al rey, 5 de abril de 1776. AGI, Santo Domingo, 1023.
} 
Tabla 2-9. Relación de los alcaldes del cabildo de Santo Domingo, 1751-1779

\begin{tabular}{|c|c|c|}
\hline Año & Alcaldes ordinarios & $\begin{array}{c}\text { Alcaldes de Santa Hermandad y } \\
\text { visita }\end{array}$ \\
\hline 1751 & $\begin{array}{l}\text { Lorenzo Fernández de Castro } \\
\text { Tomás Leos-Echalas } \\
\end{array}$ & \begin{tabular}{|l|} 
Antonio Caro y Oviedo \\
José Campuzano Polanco
\end{tabular} \\
\hline 1752 & \begin{tabular}{|l|} 
Pedro Campuzano Polanco \\
José Guridi y Concha
\end{tabular} & \begin{tabular}{|l|} 
Tomás Leos-Echalas \\
Nicolás Heredia Maldonado
\end{tabular} \\
\hline 1753 & $\begin{array}{l}\text { Antonio Dávila Coca y Landeche } \\
\text { José Leos-Echalas }\end{array}$ & \begin{tabular}{|l|} 
Pedro Campuzano Polanco \\
José Guridi y Concha \\
\end{tabular} \\
\hline 1754 & $\begin{array}{l}\begin{array}{l}\text { Lorenzo Fernández de Castro } \\
\text { Tomás Heredia }\end{array} \\
\end{array}$ & \begin{tabular}{|l|} 
Antonio Dávila Coca y Landeche \\
Pedro Campuzano Polanco \\
\end{tabular} \\
\hline 1755 & $\begin{array}{l}\text { Miguel de Paredes y Mosquera } \\
\text { Felipe Guridi y Concha }\end{array}$ & $\begin{array}{l}\text { Juan Mieses Ponce de León } \\
\text { Tomás Heredia }\end{array}$ \\
\hline 1756 & $\begin{array}{l}\text { Antonio Dávila Coca y Landeche } \\
\text { Tomás Leos-Echalas } \\
\end{array}$ & \begin{tabular}{|l|} 
Felipe Guridi y Concha \\
José Campuzano
\end{tabular} \\
\hline 1757 & \begin{tabular}{|l|} 
Antonio Caro y Oviedo \\
Tomás Heredia
\end{tabular} & \begin{tabular}{|l} 
Tomás Leos-Echalas \\
José Guridi y Concha
\end{tabular} \\
\hline 1758 & \begin{tabular}{|l|} 
Domingo Heredia Castro-Coronado \\
Domingo de la Rocha-Ferrer Landeche
\end{tabular} & $\begin{array}{l}\text { Antonio Caro y Oviedo } \\
\text { Tomás Heredia } \\
\end{array}$ \\
\hline 1759 & $\begin{array}{l}\text { Lorenzo Fernández de Castro } \\
\text { José de Leos-Echalas }\end{array}$ & $\begin{array}{l}\text { Domingo Heredia Castro- } \\
\text { Coronado } \\
\text { Domingo de la Rocha-Ferrer } \\
\text { Landeche } \\
\end{array}$ \\
\hline 1760 & $\begin{array}{l}\text { Tomás de Leos-Echalas } \\
\text { José Guridi y Concha }\end{array}$ & $\begin{array}{l}\text { Lorenzo Fernández de Castro } \\
\text { José de Leos Echalas }\end{array}$ \\
\hline 1761 & \begin{tabular}{|l|} 
Miguel de Paredes \\
José de Castro \\
\end{tabular} & \begin{tabular}{|l|} 
Tomás de Leos-Echalas \\
José Guridi y Concha
\end{tabular} \\
\hline 1762 & $\begin{array}{l}\text { Antonio Caro y Oviedo } \\
\text { Tomás de Heredia }\end{array}$ & \begin{tabular}{|l} 
Miguel de Paredes \\
José de Castro
\end{tabular} \\
\hline 1763 & \begin{tabular}{|l|} 
Lorenzo Fernández de Castro \\
Felipe Guridi y Concha
\end{tabular} & $\begin{array}{l}\text { Antonio Caro y Oviedo } \\
\text { Tomás Heredia }\end{array}$ \\
\hline 1764 & $\begin{array}{l}\text { Antonio del Monte } \\
\text { Tomás de Leos-Echalas }\end{array}$ & $\begin{array}{l}\text { Lorenzo Fernández de Castro } \\
\text { Felipe Guridi y Concha }\end{array}$ \\
\hline 1765 & $\begin{array}{l}\text { Antonio Dávila Coca y Landeche } \\
\text { José de Leos-Echalas }\end{array}$ & \begin{tabular}{|l|} 
Antonio del Monte \\
Tomás de Leos-Echalas \\
\end{tabular} \\
\hline 1766 & \begin{tabular}{|c|} 
Antonio Caro \\
José del Monte
\end{tabular} & $\begin{array}{l}\text { Antonio Dávila Coca y Landeche } \\
\text { José de Leos-Echalas }\end{array}$ \\
\hline 1767 & $\begin{array}{l}\text { Tomás Leos-Echalas } \\
\text { Felipe Guridi y Concha }\end{array}$ & $\begin{array}{l}\text { Antonio Caro } \\
\text { José del Monte } \\
\end{array}$ \\
\hline 1768 & \begin{tabular}{|l|} 
Lorenzo Fernández de Castro \\
Manuel de Heredia Serrano-Pimentel
\end{tabular} & $\begin{array}{l}\text { Tomás de Leos-Echalas } \\
\text { Felipe Guridi y Concha }\end{array}$ \\
\hline 1769 & $\begin{array}{l}\text { Antonio Caro } \\
\text { Tomás Heredia }\end{array}$ & \begin{tabular}{|l|} 
Lorenzo Fernández de Castro \\
Manuel Heredia Serrano-Pimentel
\end{tabular} \\
\hline 1770 & \begin{tabular}{|l|} 
Antonio Dávila Coca y Landeche \\
José de Leos-Echalas \\
\end{tabular} & \begin{tabular}{|l|} 
Antonio Caro \\
Tomás Heredia \\
\end{tabular} \\
\hline 1771 & \begin{tabular}{|l} 
Lorenzo Fernández de Castro \\
José del Monte y Tapia
\end{tabular} & \begin{tabular}{|l|} 
Pedro Fernández de Castro \\
Nicolás Heredia Serrano-Pimentel
\end{tabular} \\
\hline 1772 & $\begin{array}{l}\text { Pedro Fernández de Castro } \\
\text { Nicolás Heredia Serrano-Pimentel }\end{array}$ & $\begin{array}{l}\text { José de Leos-Echalas } \\
\text { José Garay }\end{array}$ \\
\hline 1773 & $\begin{array}{l}\text { Tomás Heredia } \\
\text { Antonio Mañón de Lara }\end{array}$ & $\begin{array}{l}\text { Francisco Cabral y Maldonado } \\
\text { Antonio del Monte }\end{array}$ \\
\hline
\end{tabular}




\begin{tabular}{|c|l|l|}
\hline Año & \multicolumn{1}{|c|}{ Alcaldes ordinarios } & $\begin{array}{l}\text { Alcaldes de Santa Hermandad y } \\
\text { visita }\end{array}$ \\
\hline 1774 & $\begin{array}{l}\text { Antonio Dávila Coca y Landeche } \\
\text { José de Leos-Echalas }\end{array}$ & $\begin{array}{l}\text { Miguel Paredes } \\
\text { Antonio Valdemoro y Alcántara }\end{array}$ \\
\hline 1775 & $\begin{array}{l}\text { Lorenzo Fernández de Castro } \\
\text { Nicolás Heredia Serrano-Pimentel }\end{array}$ & $\begin{array}{l}\text { Nicolás Heredia Coronado } \\
\text { Luís Franco Guridi }\end{array}$ \\
\hline 1776 & $\begin{array}{l}\text { José Antonio Zárraga } \\
\text { Fernando Heredia }\end{array}$ & $\begin{array}{l}\text { José Jacinto Ramírez } \\
\text { Antonio del Monte }\end{array}$ \\
\hline 1777 & $\begin{array}{l}\text { Tomás Heredia } \\
\text { Damián de Coca }\end{array}$ & $\begin{array}{l}\text { Francisco de Figueroa } \\
\text { Nicolás Heredia Coronado }\end{array}$ \\
\hline 1778 & $\begin{array}{l}\text { José del Monte y Tapia } \\
\text { José de Leos-Echalas }\end{array}$ & $\begin{array}{l}\text { Luís Franco Guridi } \\
\text { Antonio del Monte y Tapia }\end{array}$ \\
\hline 1779 & $\begin{array}{l}\text { Lorenzo Angulo Medrano } \\
\text { Nicolás Guridi y Frómesta }\end{array}$ & $\begin{array}{l}\text { Idelfonso Navarro Leos-Echalas } \\
\text { José Castro Palomino }\end{array}$ \\
\hline
\end{tabular}

Elaboración propia. Fuentes: Certificación de los alcaldes ordinarios y de Santa Hermandad electos desde 1751 hasta 1759. AGI, Escribanía 16A. Certificación del cabildo de la ciudad de Santo Domingo de los sujetos que han sido electos desde el año de 1757 hasta 1779. AGI, Santo Domingo, 1021 y 938. Testimonio de los autos generales del Real despacho y diligencia en su virtud obrada. Vino con carta del oidor de Santo Domingo, Joseph Osorio, de 22 de abril de 1779. AHN, Consejos, 20.766. Carta del cabildo al rey, 5 de abril de 1776. AGI, Santo Domingo, 1023. Rodríguez Demorizi, E., Familias Hispanoamericanas. Ciudad Trujillo, 1959, p. 192.

Durante los años siguientes los puestos de alcaldes ordinarios siguieron en manos de estas familias, aunque hubo un descenso considerable. También se aprecia la introducción de otras personas, miembros de otra red familiar, los Castro-Rivera y Urdaneta, así como un aumento de peninsulares frente al periodo anterior, como puede verse en el siguiente cuadro. 
Tabla 2-10. Relación de alcaldes ordinarios del cabildo de Santo Domingo, 1780-1795

\begin{tabular}{|c|c|c|}
\hline Año & Alcaldes ordinarios & Origen \\
\hline 1780 & $\begin{array}{l}\text { Fernando Heredia Serrano-Pimentel } \\
\text { José Esteban Arredondo Castro }\end{array}$ & $\begin{array}{l}\mathrm{C} \\
\mathrm{C}\end{array}$ \\
\hline 1781 & $\begin{array}{l}\text { Juan Arredondo Vizcaíno } \\
\text { Miguel Bernardo Antonio Ferrer }\end{array}$ & $\begin{array}{l}\mathrm{C} \\
\mathrm{C}\end{array}$ \\
\hline 1782 & $\begin{array}{l}\text { Juan Arredondo Vizcaíno } \\
\text { Miguel Bernardo Antonio Ferrer }\end{array}$ & $\begin{array}{l}\mathrm{C} \\
\mathrm{C}\end{array}$ \\
\hline 1783 & $\begin{array}{l}\text { Tomás Arredondo Castro } \\
\text { Luís Franco Guridi }\end{array}$ & $\begin{array}{l}\mathrm{C} \\
\mathrm{C}\end{array}$ \\
\hline 1784 & $\begin{array}{l}\text { José Aponte } \\
\text { Nicolás Heredia y Serrano-Pimentel }\end{array}$ & $\begin{array}{l}\mathrm{P} \\
\mathrm{C}\end{array}$ \\
\hline 1785 & $\begin{array}{l}\text { Agustín Más y Rubí } \\
\text { Pedro Arredondo Castro }\end{array}$ & $\begin{array}{l}\mathrm{C} \\
\mathrm{C}\end{array}$ \\
\hline 1786 & $\begin{array}{l}\text { Antonio Cumulat } \\
\text { Agustín Más y Rubí }\end{array}$ & $\begin{array}{l}\mathrm{P} \\
\mathrm{C}\end{array}$ \\
\hline 1787 & $\begin{array}{l}\text { Agustín Más y Rubí } \\
\text { Antonio Valdemoro y Alcántara }\end{array}$ & $\begin{array}{l}\mathrm{C} \\
\mathrm{P}\end{array}$ \\
\hline 1788 & $\begin{array}{l}\text { José de la Vega } \\
\text { Pedro Arredondo y Castro }\end{array}$ & $\begin{array}{l}\mathrm{P} \\
\mathrm{C}\end{array}$ \\
\hline 1789 & $\begin{array}{l}\text { Tiburcio José Sterling } \\
\text { Fernando Heredia }\end{array}$ & $\begin{array}{l}\mathrm{C} \\
\mathrm{C}\end{array}$ \\
\hline 1790 & $\begin{array}{l}\text { Miguel Bernardo Ferrer } \\
\dot{¿} \text { ? }\end{array}$ & $\begin{array}{l}\mathrm{C} \\
\dot{i} ?\end{array}$ \\
\hline 1791 & $\begin{array}{l}\text { Francisco Arredondo Castro } \\
\text { Salvador Pí y Piquer }\end{array}$ & $\begin{array}{l}\mathrm{C} \\
\mathrm{P}\end{array}$ \\
\hline 1792 & $\begin{array}{l}\text { Nicolás Heredia y Serrano-Pimentel } \\
¿ \text { ? }\end{array}$ & $\begin{array}{l}\mathrm{C} \\
\dot{i} ?\end{array}$ \\
\hline 1793 & $\begin{array}{l}\text { Pedro Arredondo Castro } \\
\text { Agustín Más y Rubí }\end{array}$ & $\begin{array}{l}\mathrm{C} \\
\mathrm{C}\end{array}$ \\
\hline 1794 & $\begin{array}{l}\text { Francisco Arredondo Castro } \\
\text { Agustín Más y Rubí }\end{array}$ & $\begin{array}{l}\mathrm{C} \\
\mathrm{C}\end{array}$ \\
\hline 1795 & $\begin{array}{l}\text { José Esteban Arredondo Castro } \\
\text { Tiburcio José Sterling }\end{array}$ & $\begin{array}{l}\mathrm{C} \\
\mathrm{C} \\
\end{array}$ \\
\hline
\end{tabular}

Elaboración propia. Fuentes: P (Peninsular). C (Criollo). ¿? (Origen desconocido). AGI, Santo Domingo, 938, 946, 947, 948, 957, 990, 992, 994, 995, 996, 997, 998, 999, 1000, 1005, 1014, 1023, 1025, 1037, 1043. García, J. G., Historia de Santo Domingo. Santo Domingo, 1982, vol. I, pp. 222-223. Documentación del Archivo Real de Higüey, "Ordenanzas del cabildo de Santo Domingo, 1786”. BAGN 46-47 (Ciudad Trujillo, 1946) pp. 157-172, p. 158. Campillo Pérez, J. G., Francisco Espaillat..., op. cit., p. 437.

\footnotetext{
* Procedía de Maracaibo.
} 
Como consecuencia de unas ordenanzas dictadas por el propio cabildo en 1786, se tomó la decisión de crear ocho nuevos puestos de alcaldes de barrio al dividir la ciudad de Santo Domingo en cuatro cuarteles, estando cada uno de esos espacios sujeto a un oidor de la audiencia (véase la figura 2-1). El oidor decano podía elegir el espacio que quisiese, después nombraba a los dos siguientes, quedando para el cuarto el último cuartel. A su vez cada cuartel se dividió en dos barrios habiendo un alcalde por cada barrio. Estos ocho alcaldes de barrio eran elegidos por el ayuntamiento un día después de haber realizado la elección de los alcaldes ordinarios y de Santa Hermandad, y el tiempo de duración de su cargo era de dos años. Los alcaldes y oidores se encargaron de rondar cada cuartel, y en particular su barrio asignado, con el objetivo de mantener la limpieza de las calles y el buen orden en ellas y en las casas, velar por los niños abandonados, así como impedir la vagancia de animales y personas en las vías públicas, entre otras actividades. Un año más tarde la Audiencia acordó reducir el número de oidores pasando a tres, por lo que a partir de entonces se mandó que los dos alcaldes ordinarios del ayuntamiento estuviesen al frente del cuartel vacante. También se crearon otros cuatro alcaldes de este tipo -alcaldes de partidos- para cubrir el partido de Monte Grande que abarcaba La Isabela y La Rama, el de los Llanos que llegaba hasta Bayaguana y el Seibo, el partido de Los Ingenios y el área que iba desde la puerta del Conde hasta el río Haina, zonas que pertenecían a la jurisdicción de la ciudad de Santo Domingo ${ }^{87}$.

\footnotetext{
${ }^{87}$ Diario de las determinaciones de la Real Audiencia de Santo Domingo, 1787. AGI, Santo Domingo, 991. Acerca de las ordenanzas de 1786 véase en Documentación del Archivo Real de Higüey, “Ordenanzas del cabildo de Santo Domingo, 1786”..., op. cit., pp. 157-172, p. 158 y 161. Puede verse también Ugarte, M., “Ordenanzas sobre el régimen y gobierno de la isla (1786)” en Ugarte, M., Estampas Coloniales. Siglos XVII-XIX. Santo Domingo, 1998, vol. II, pp. 275-279.
} 
Figura 2-1. División de la ciudad de Santo Domingo en cuatro cuarteles, 1786

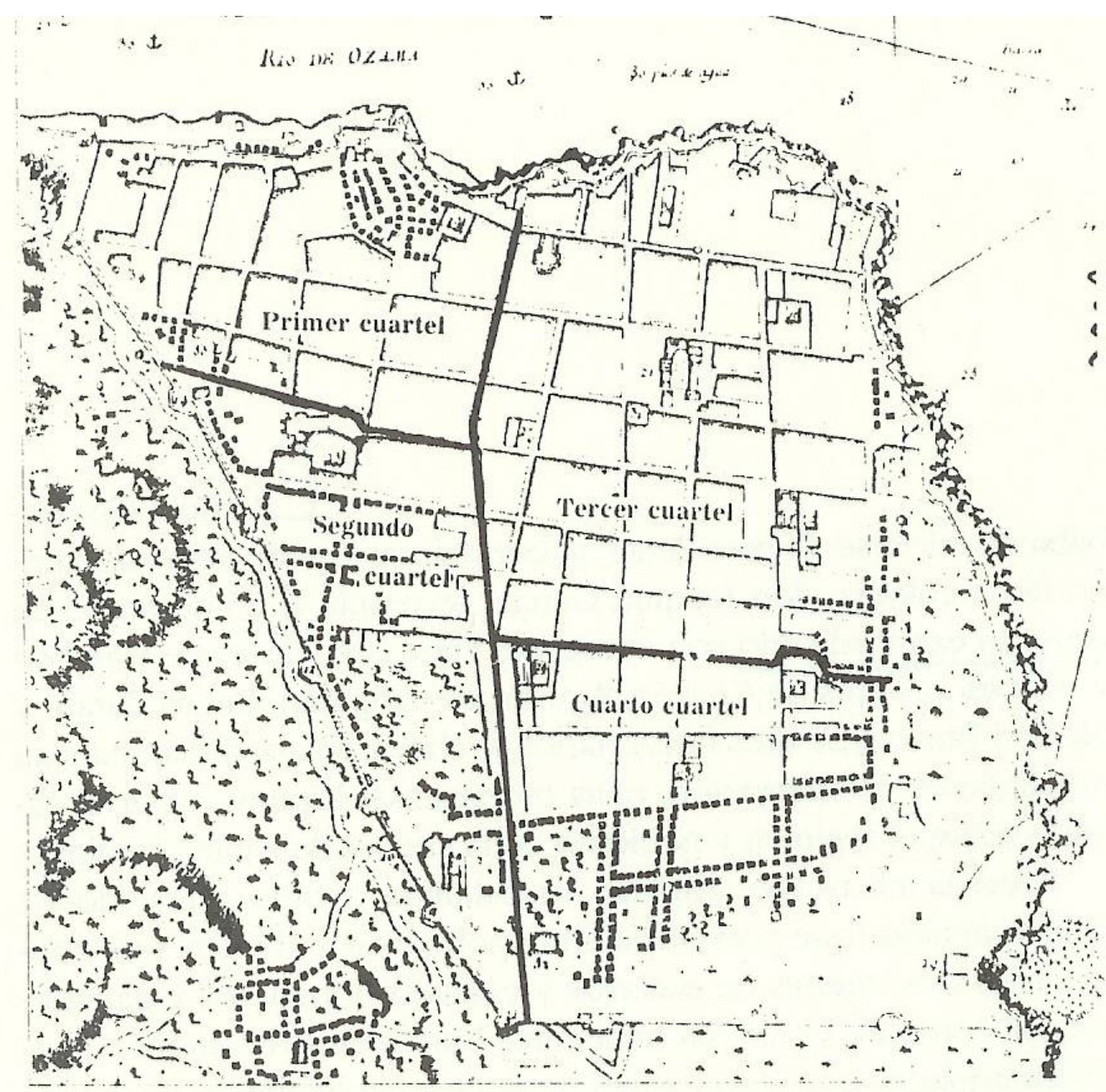

Fuentes: Hacia 1786 el primer cuartel estaba a cargo del oidor Agustín Emparán y Orbe, el segundo de Pedro Catani, el tercero de Manuel Bravo y el cuarto cuartel bajo Luís Chávez. Véase en Diario de las determinaciones de la Real Audiencia de Santo Domingo, 1787..., op. cit. Documentación del Archivo Real de Higüey, "Ordenanzas del cabildo de Santo Domingo, 1786”..., op. cit., pp. 157-172, p. 158 y 161. El plano de la ciudad procede de Ugarte, M., “Ordenanzas sobre el régimen y gobierno de la isla (1786)”..., op. cit., pp. 275-279, p. 276. 
En el cabildo de Santo Domingo, encontramos además de estos alcaldes otro cargo más específico que debió de existir durante el siglo XVIII, fue el alcalde de visita, aunque desconocemos si lo hubo en los siglos anteriores o fue de nueva creación en el mencionado siglo. Las referencias que tenemos por ahora sobre él nos informan de que era cubierto directamente por el propio cabildo en quien recaía la prerrogativa de su elección a principios de cada año ${ }^{88}$. Su atribución era esencialmente la de regular el movimiento de los negros de las haciendas, esto es, tenían la: “[...] obligacion de visitar las haciendas de la jurisdiccion de esta ciudad, y reconocer si los que las havitan asi dueños, como esclavos, y otros agregados viven bien o mal; si usan de sugestiones: si saven la Doctrina Christiana, y cumplen con el precepto annual, teniendo cruces en las Haciendas: y si los curas tienen cuidado de que viven catolicamente y las prisiones necesarias para castigarlos, y contenerles” ${ }^{\text {}}$. En caso de no realizar tal visita el alcalde de visita se le multaba con 100 reales. Además, tenían jurisdicción sobre los hurtos o agravios cometidos por los esclavos.

El término utilizado para designar este cargo fueron varios desde el ya mencionado alcalde de visita a juez de visita, que aparece en la documentación para la segunda mitad del siglo XVIII. Mientras que para principios del mismo se encuentra con la denominación de alcalde de la visita de negros o como visitador de negros ${ }^{90}$. No hay que confundirlo con el empleo citado anteriormente, el alcalde de la Santa Hermandad y Visita que tenía jurisdicción en los alrededores de la ciudad de Santo Domingo, mientras que el alcalde de visita lo tenía específicamente en las haciendas.

Probablemente este tipo de cargo u otros como los alcaldes de indios debieron de surgir como respuesta a la abundante y distinta población étnica que existió en todo el continente americano, permitiendo ejercer un control directo y constante de esos grupos sociales ${ }^{91}$. En el distrito de Santo Domingo, el cargo de

\footnotetext{
${ }^{88}$ Testimonio que presenta Miguel Bernardo Ferrer para justificar la calidad y limpieza de sangre de su mujer María de Castro, 1768. AGI, Santo Domingo, 937.

${ }^{89}$ Certificación de los alcaldes de visita electos desde 1759 hasta 1767, 12 de junio de 1771. AHN, Consejos, 21.465.

${ }^{90}$ Este empleo también existió en la ciudad de Santiago, en Gutiérrez Escudero, A., “Élites y poder económico en Santo Domingo (siglo XVIII). Notas para su estudio” en Navarro García, L. (coord.), Élites urbanas en Hispanoamérica: (De la conquista a la independencia). Sevilla, 2005, pp. 241-251, p. 246, 247 y 248.

${ }^{91}$ Ferreiro, J. P., "Todo queda en familia...política y parentesco entre las familias notables de Jujuy del siglo XVII” en Schröter, B. y Büschges, C. (eds.), Beneméritos, aristócratas y
} 
alcalde de visita fue ocupado por personas que hasta ahora hemos ido mencionando, y que, en consecuencia, eran los propios dueños de esos esclavos, que contaban con la confianza de sus compañeros capitulares y, en general, del sector de los hacendados.

Tabla 2-11. Relación de alcaldes de visita, 1751-1767

\begin{tabular}{|l|l|}
\hline \multicolumn{1}{|c|}{ Año } & \multicolumn{1}{c|}{ Alcalde de visita } \\
\hline 1751 & Luís de Tejada Montenegro \\
\hline 1752 & Luís de Tejada Montenegro \\
\hline 1753 & Francisco Antonio Marín \\
\hline 1754 & Domingo de la Rocha-Ferrer y Landeche \\
\hline 1755 & Antonio Caro \\
\hline 1756 & José de Castro \\
\hline 1757 & José de Leos-Echalas \\
\hline 1758 & Nicolás Heredia \\
\hline 1759 & José Guridi y Concha \\
\hline 1760 & Antonio Coca \\
\hline 1761 & José de Leos-Echalas \\
\hline 1762 & $\dot{¿} ?$ \\
\hline 1763 & $\dot{¿} ?$ \\
\hline 1764 & Nicolás Heredia \\
\hline 1765 & Miguel Bernardo Ferrer \\
\hline 1766 & $\dot{¿} ?$ \\
\hline 1767 & Nicolás Heredia \\
\hline
\end{tabular}

Elaboración propia. Fuentes: ¿'? (desconocido). Certificación de los alcaldes de visita electos desde 1751 hasta 1759. AGI, Escribanía 16A. Certificación de los alcaldes de visita electos desde 1759 hasta 1767, 12 de junio de 1771. AHN, Consejos, 21.465.

empresarios. Identidades y estructuras sociales de las capas altas urbanas en América hispánica. Frankfurt, 1999, pp. 251-273, p. 256. 
Respecto al oficio de regidor, hubo distintas formas de obtenerlo, a través del nombramiento que hacía la Corona o bien los gobernadores en calidad de arrendamiento, y mediante la compra y renuncia del mismo. En la segunda mitad del siglo XVIII el precio de su compra fue de 500 pesos, similar a México que osciló entre 500 y 600 pesos, mientras que en Guatemala fluctuó entre 500 y 1.500 pesos $^{92}$. Los requisitos para ser regidor fueron los mismos que los necesarios para ser alcalde ordinario. El número de regidores fue muy variable durante todo el periodo colonial dominicano. Así en el siglo XVI, en un principio estuvo entre cuatro y seis, pero parece ser que a mediados de siglo los regidores fueron habitualmente diez. La cuestión del rango de arzobispado y ciudad metropolitana que tenía Santo Domingo significaba que le correspondiese doce regidores, pero este número fue considerado excesivo para su población y se mantuvo en diez ${ }^{93}$. Durante el siglo XVIII el número de regidores continuó siendo inestable oscilando entre seis y doce.

En el siglo XVI el desempeñar un cargo municipal o en la administración real como el de factor, veedor o contador, conllevaba un regimiento, ejerciendo distintos oficios, por ejemplo fiel ejecutor, alférez real o alguacil mayor. La puesta en venta de los oficios municipales a partir del siglo XVII, hizo que los funcionarios reales acabasen desligándose del cargo de regidor ${ }^{94}$. En cambio los puestos de fiel ejecutor, alférez real y el alguacilazgo continuaron desempeñándolos los propios regidores. Sin embargo, durante la segunda mitad del siglo XVIII no existió el cargo de alguacil mayor en el cabildo de Santo Domingo, de la misma forma que en el resto de cabildos de la isla, a excepción de los de Higüey, Neiba y San Carlos que contaron con ese puesto ${ }^{95}$.

El fiel ejecutor se encargaba de la política de abastos para la población (pan, vino, frutas, carne...), de regular los pesos y medidas de los productos y de

\footnotetext{
92 Brading, D., Mineros y comerciantes en el México borbónico (1763-1810). México, 1993, p. 425. Santos Pérez, J. M., Élites, poder local y régimen colonial..., op. cit., pp. 80, 82, 92 у 99.

${ }^{93}$ Según Fray Cipriano a partir de 1546 su número de regidores fue diez, mientras que para Wenceslao Vega Boyre fue a partir de 1568. Puede verse en Utrera, F. C. de, "Concejo, justicia y regimiento era nombre que tenía el ayuntamiento de Santo Domingo”. El Caribe, 14 de noviembre de 1987, p. 8. Vega Boyrie, W., Historia del derecho dominicano..., op. cit., p. 59. Ots Capdequí, J. Ma ., España en América: Las instituciones coloniales. Bogotá, 1952, pp. 113-114.

94 Vega Boyrie, W., Ibidem., pp. 58-59 y 65.

95 Testimonio de las diligencias obradas sobre la averiguación de los oficios que hay vacantes $y$ sin crear en esta isla, 1768. AGI, Santo Domingo, 979.
} 
examinar la calidad de los géneros para evitar el fraude. Este oficio fue desempeñado anualmente por turnos por cada uno de los regidores del cabildo ${ }^{96}$.

El cargo de alférez mayor o alférez real era un oficio fundamentalmente honorífico, su misión consistía en custodiar y portar el pendón regio en todas las ceremonias públicas y patronales. El ejercicio del cargo implicaba gastos, ya que las fiestas corrían de su cuenta. Aún así fue un puesto muy codiciado por el gran honor político-social y los privilegios que proporcionaba, como ser la única persona que podía entrar en el cabildo con armas. Además precedía al resto de los regidores en los actos públicos y en el cabildo, por lo que siempre era el primero en ejercer el voto ${ }^{97}$. Este oficio estuvo en posesión de un miembro de la red familiar Landeche-Bastidas, llamado Antonio Dávila Coca y Landeche, durante treinta y cinco años. El gobernador Francisco Rubio y Peñaranda lo nombró para este cargo el 30 de diciembre de 1754, al morir su anterior poseedor Pedro Campuzano Polanco ${ }^{98}$. Antonio murió en 1789, siendo designado Francisco Cabral y Maldonado quien lo mantuvo hasta la cesión de la isla ${ }^{99}$.

El depositario general debía vigilar y guardar con cuidado en un almacén los bienes que eran incautados en un litigio, recibiendo un 2,5\% de esos depósitos ${ }^{100}$. Se accedía por compra y renuncia. En 1753 este cargo fue ejercido por Miguel Bernardo Antonio Ferrer al abdicar en él su cuñado Domingo Lorenzo Zevallos ${ }^{101}$. El escribano o secretario del concejo tenía como función levantar las

\footnotetext{
96 Testimonio de los autos obrados sobre la representación formada por el ilustre ayuntamiento de esta ciudad en orden al remate del oficio de regidor hecho por Francisco Cabral, 21 de enero de 1771. AGI, Santo Domingo, 1004.

97 Bayle, C., Los cabildos seculares..., op. cit., p. 195. Mañón Arredondo, M. J., Crónicas de la Ciudad Primada. Apuntes históricos de la muy noble y lustrosa ciudad de Santo Domingo. Santo Domingo, 1992, p. 215.

98 Con anterioridad el padre de Antonio Dávila Coca y Landeche, también llamado Antonio había sido regidor desde 1725 aunque desconocemos cuando cesó. Certificación del escribano Felipe Peña en la que da cuenta de la toma de posesión de algunos de los oficios del cabildo entre 1751 y 1754, 20 de septiembre de 1756. AGI, Santo Domingo, 1065. Título de alférez real para Antonio Dávila Coca y Landeche por muerte de Pedro Campuzano Polanco, Buen Retiro 24 de diciembre de 1755. AGI, Santo Domingo, 910 y 940. Carta del cabildo al rey, 5 de septiembre de 1740 y 15 de junio de 1741. AGI, Santo Domingo, 972.

99 Francisco Cabral y Maldonado era regidor del cabildo desde el 25 de enero de 1771. Súplica de Francisco Cabral a Su Majestad para que le mande el título del empleo de alférez real de Santo Domingo, 18 de septiembre de 1792. AGI, Santo Domingo, 1007. Título de alférez real para Francisco Cabral Maldonado, 23 de abril de 1793. AGI, Santo Domingo, 940.

100 Bayle, C., Los cabildos seculares..., op. cit., p. 268.

101 Miguel Bernardo Antonio Ferrer pagó 1.800 reales por la tercia parte del valor del oficio de depositario general, más los 52 reales y 14 maravedíes de plata por el derecho de media anata. Título de depositario general a favor de Miguel Bernardo Ferrer, Buen Retiro 21 de febrero de 1756. AGI, Santo Domingo, 940.
} 
actas de sesiones, asistir a juntas, expedir copias autorizadas, registrar contratos de censos, compraventas, y custodiar el archivo municipal. En la ciudad de Santo Domingo este empleo se asimiló casi siempre al de escribano público, y como el de depositario estuvo dentro de los empleos vendibles y renunciables, aunque en sus orígenes era designado por los propios miembros del cabildo ${ }^{102}$. En 1787 tenía un sueldo anual de 87 pesos y 4 reales, y al igual que los escribanos de la audiencia obtenían también alguna ganancia más por cada servicio realizado, que era cobrado según la regulación que establecía su arancel ${ }^{103}$.

El síndico procurador general era quien representaba a la ciudad en cualquier pleito o asuntos que ésta tuviera con la audiencia u otra institución. El puesto se renovaba anualmente y era elegido por los cabildantes. En cambio la ciudad era representada por el procurador de corte o de la audiencia en instancias superiores a las anteriores, como el Consejo de Indias ${ }^{104}$. Éste a su vez podía participar en la defensa de los intereses de los huérfanos o menores de edad, siendo designado por el juez al nombrarlo curador ad litem. Aunque habitualmente tal función fue desempeñada por un regidor a quien el cabildo nombraba anualmente con el título de defensor de menores o padre general de menores $^{105}$.

Junto a estos cargos existieron otros que tuvieron un carácter más auxiliar como el mayordomo elegido por el cabildo entre la población de la ciudad, y se encargaba de la casa del cabildo municipal y de administrar sus gastos, así como de verificar todos los cobros que pertenecían a los propios que eran apuntados en los libros de mayordomías. En un principio el mayordomo tuvo un limitado salario de 2 reales diarios, pero posteriormente atendiendo a las cuentas y al

\footnotetext{
${ }^{102}$ Vega Boyrie, W., Historia del derecho dominicano..., op. cit., pp. 60-61.

103 Carta del gobernador de Santo Domingo en la que suplica se digne aprobar el aumento del salario de escribano del ayuntamiento hasta la cantidad de 300 pesos bajo la precisa calidad de separarse del oficio de escribano público y asistir sólo a las funciones de policía en que incumbe los regidores para la mejor administración de la república, 12 de noviembre de 1787. AGI, Santo Domingo, 990. Arancel de los derechos que han de llevar por razón de sus oficios los ministros de esta Real Audiencia y los escribanos públicos del número, y reales y otros oficiales, 24 de octubre de 1760. AGI, Santo Domingo, 987.

104 Sobre este asunto véase Julián, A., "Fraudes y conflictos en las primeras elecciones celebradas en la isla Española 1512-1513” en Julián, A., Bancos, ingenios y esclavos en la época colonial. Santo Domingo, 1997, pp. 99-121. Moreta Castillo, A., La justicia en Santo Domingo..., op. cit., pp. 63-64.

105 Testimonio de las diligencias obradas sobre la averiguación de los oficios que hay vacantes y sin crear en esta isla, 1768. AGI, Santo Domingo, 979. Véase también Widmer Sennhauser, R., La propiedad en entredicho. Una historia documental de Higüey, Siglo XVII-XIX. Editora Manatí, Santo Domingo, 2004, p. 25.
} 
desempeño de su trabajo se le retiró dicho sueldo y se le contribuyó con un 6\% de lo que se pagaba y recaudaba de los propios del ayuntamiento ${ }^{106}$. En esta categoría entraban los porteros, alarifes, y pregoneros, que también contribuyeron al funcionamiento del ayuntamiento.

\subsubsection{Sus funciones}

El cabildo como máxima autoridad de la ciudad de Santo Domingo se encargó de los aspectos políticos y económicos de ésta. Entre las funciones más importantes de que se encargó el cabildo de Santo Domingo se hallaba la de proporcionar a sus vecinos todo aquello que necesitaran en la ciudad, por ejemplo el reparto de solares entre los primeros vecinos del nuevo mundo; función que fue traspasada en 1519 a la Audiencia y los oficiales reales, aunque años más tarde volvió a intervenir ${ }^{107}$. El cabildo también se ocupó del suministro de agua potable, la cual se encontraba lejos de la ciudad por lo que al principio se transportó en barcas desde el otro lado del río Ozama y más tarde se trajo de una fuente que se encontró al norte de la ciudad, hasta que la construcción de pozos y aljibes por los vecinos en sus casas entre los siglos XVI y XVII permitió su canalización y distribución. Este sistema de aprovisionamiento de agua continuó usándose durante todo el siglo XVIII y principios del XIX ${ }^{108}$.

El abastecimiento de alimentos fue otra de las funciones más importantes del cabildo. Desde el siglo XVI el ayuntamiento de Santo Domingo logró el suministro de carne para la ciudad con las reses proporcionadas por el resto de los pueblos de la isla mediante el sistema de pesas. Esta práctica continuó durante

\footnotetext{
106 Testimonio de las cuentas de los propios de esta ciudad que han presentado sus mayordomos Ignacio Hinojosa, Domingo Velasco, Isidro Cordero, José Ramírez y Juan González, corridas desde 1 de enero de 1769 en que Su Majestad tomó las anteriores hasta 31 de diciembre de 1774. AGI, Santo Domingo, 984.

${ }^{107}$ Las primeras concesiones de tierras realizadas entre los colonos de La Española fueron llevadas a cabo por Cristóbal Colón a través de la licencia real que le fue otorgada en 1497, véase en: Rodríguez Morel, G., Cartas del cabildo..., op. cit., p. 23. Gíl-Bermejo García, J., La Española. Anotaciones históricas..., op. cit., pp. 97-102.

${ }^{108} \mathrm{Al}$ respecto véanse para el siglo XVI los trabajos de Rodríguez Demorizi, E., El pleito Ovando-Tapia..., op. cit., pp. 48-50, Gutiérrez Escudero, A., "El abastecimiento de agua a la ciudad de Santo Domingo (siglo XVI)”. Historia Social y Económica de América 2 (Alcalá de Henares, 1986) pp. 11-49. Para el siglo XVII-XIX véase: Rodríguez Demorizi, E., Viajeros de Francia en Santo Domingo. Santo Domingo, 1979, p. 145. Caro Álvarez, J. A., Las murallas de Santo Domingo. Madrid, 1973, pp. 29-30. Guerrero Cano, M. M., "La ciudad de Santo Domingo a raíz de la anexión a España” en Torres Ramírez, B. (ed.), Andalucía y América. La influencia andaluza en los núcleos urbanos americanos. Sevilla, 1990, pp. 71-108, p. 75 y 76.
} 
todo el siglo XVIII y los ganaderos se reunían en los cabildos de sus pueblos a principios de cada año para declarar el número de ganado que poseían, y a partir de ahí se estableció por sorteo la fecha y la cantidad de reses con las que se debía contribuir a Santo Domingo. Generalmente los ganaderos que poseían pocas reses estaban exentos de contribuir, de esta forma se ayudaba al mantenimiento y crecimiento del hato.

Probablemente el método funcionó, aunque no demasiado bien atendiendo a las referencias de problemas y quejas que proporciona la documentación. Los ganaderos siempre se mostraron contrarios al envío de reses a la capital. Los motivos que alegaban eran la lejanía, el mal estado de los caminos, la pérdida de peso de los animales e incluso la muerte en tan largas travesías hasta la ciudad de Santo Domingo. Sin embargo, según Antonio Gutiérrez Escudero, la verdadera causa eran los escasos beneficios que les proporcionaban en las carnicerías de Santo Domingo, frente a los grandes beneficios económicos que obtenían comerciando a mejor precio con los franceses o con los extranjeros que se acercaban a las $\operatorname{costas}^{109}$. A pesar de sus quejas, durante el siglo XVIII, los ganaderos se vieron obligados a continuar con esa práctica en la que probablemente los fraudes de los ganaderos, en especial entre los de Santiago y los poblados cercanos a la colonia francesa, fueron muy habituales, al igual que el comercio que realizaban a través del contrabando ${ }^{110}$.

Los ingresos del cabildo procedían del alquiler de casas, tiendas y solares que pertenecían al cabildo, como la sabana ${ }^{*}$, o de la aplicación de sisas sobre algunos de los productos alimenticios consumidos en la ciudad de Santo Domingo $^{111}$. Parte de las obras públicas que se realizaron en Santo Domingo fueron financiadas por el ramo de los propios del cabildo, como el reparo de la casa concejil que fue dañada tras el huracán de 1765 y la construcción de un puente para que el ganado de abasto que procedía del otro lado del río Ozama, no tuviera que atravesarlo en canoas con el problema de la facilidad de volteo que

\footnotetext{
109 A cerca de este asunto véase Gutiérrez Escudero, A., Población y economía..., op. cit., pp. 148-156.

${ }^{110}$ Idem.

* La sabana era una llanura de gran extensión cerca de la ciudad de Santo Domingo que estaba cubierta de vegetación y con grupos de árboles donde pastaba el ganado para el abasto de la capital. También fue conocida con el nombre de "sabana del rey”.

${ }^{111}$ Gutiérrez Escudero, A., "El abastecimiento de agua a la ciudad de Santo Domingo (siglo XVI)”..., op. cit., pp. 11-49, p. 21 y 24.
} 
tenían las barcas y los ataques de tiburones que sufrían. Concretamente había que cruzar el Isabela, un brazo del Ozama, que es el río a cuya orilla se encuentra la ciudad de Santo Domingo. En 1754 se determinó la implantación de un impuesto de 2 reales sobre el precio de cada fanega de sal para la fabricación de dicho puente. Pero finalmente no llegó a realizarse porque tanto la construcción del puente como su posterior mantenimiento resultaban demasiado costosos sobre el citado impuesto ${ }^{112}$.

En otros casos, el cabildo tuvo que hacer algunos empeños ya que sus rentas no alcanzaron para sus gastos. Así en 1770 tuvo que tomar prestados 3.800 pesos de las Cajas Reales al no disponer de dinero suficiente para realizar un cercado en la sabana de la ciudad, para que el ganado de abasto estuviese seguro, sin que las reses se extraviasen o introdujesen en el monte o incluso escapasen ${ }^{113}$. Ocasionalmente, fueron los miembros del cabildo quienes sufragaron los gastos de las rentas de propios y arbitrios, como hizo en 1791 Francisco Arredondo y Castro, que en calidad de préstamo presentó 500 pesos al ayuntamiento ${ }^{114}$.

112 Real Cédula de 22 de octubre de 1770 al gobernador de Santo Domingo ordenándole informe en los términos que se refieren, sobre la construcción de un puente de barcos en el río La Ozama de aquella isla, y en cuanto al impuesto de los dos reales en fanega de sal para ella en la forma que se expresa. AGI, Santo Domingo, 1065.

113 Informe sobre haberse practicado en la ciudad de Santo Domingo en la isla Española un cercado grande en la sabana para que el ganado de abasto estuviese con seguridad y sin costo de pastores, Madrid 21 de marzo de 1770. AGI, Santo Domingo, 1065.

${ }^{114}$ Relación de méritos, servicios y empleos de Francisco Arredondo y Castro. AGI, Santo Domingo, 1000. 
Figura 2-2. Cruzando el Isabela

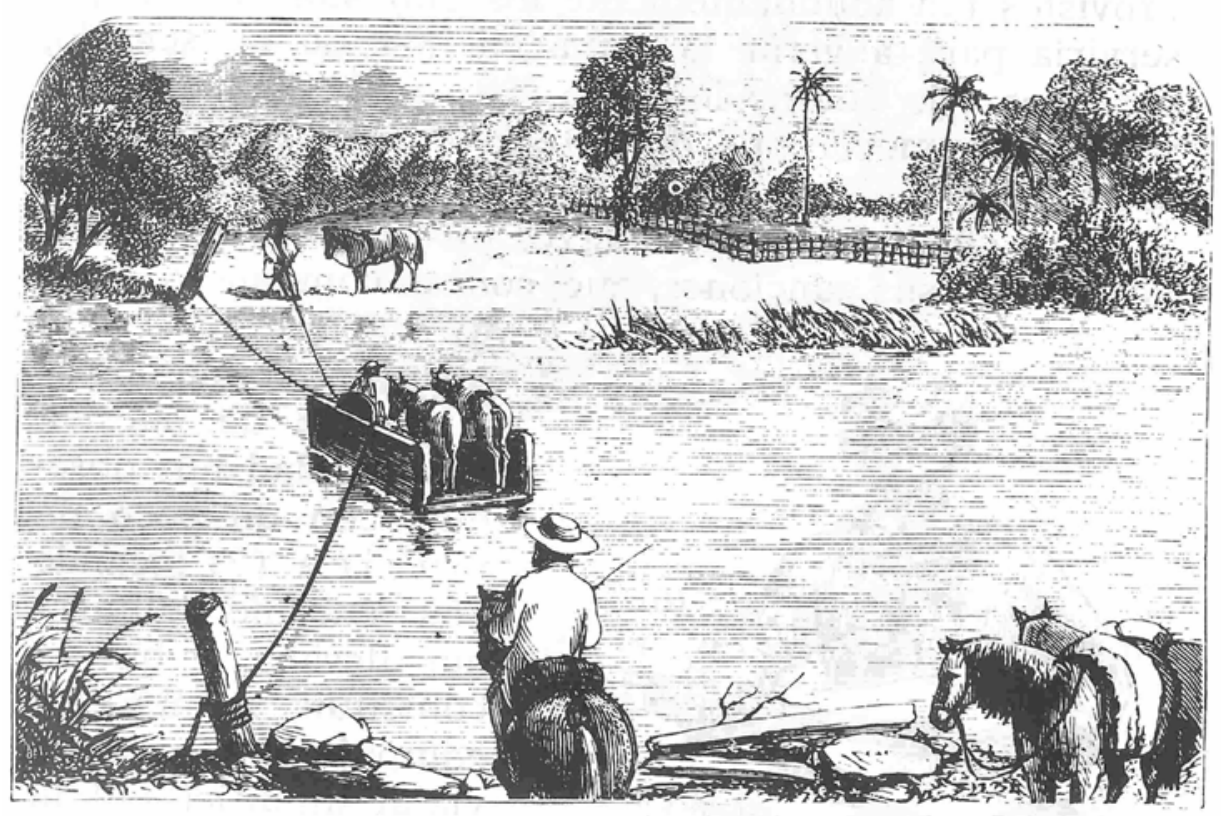

Fuentes: Hazard, S., Santo Domingo. Su pasado y presente. New York, 1873, p. 279.

El cabildo fue un foro de debate desde donde los hacendados de Santo Domingo reivindicaron sus necesidades, buena muestra de ello son las cartas de reclamaciones y peticiones sobre la agricultura. También trataron de invalidar algún dictamen con el que no estaban de acuerdo hasta imponer finalmente su criterio. En el ayuntamiento se formó una Junta de Fomento, entidad desde la que se impulsó el desarrollo de la agricultura de Santo Domingo convirtiéndose en el preámbulo de lo que sería la Sociedad de Hacendados.

En este contexto de sus funciones políticas y económicas, también estaban las sociales; todas ellas se establecieron en las ordenanzas que elaboraba el ayuntamiento para su buen gobierno. A través de ellas este cuerpo municipal también procuró regir el comportamiento de sus vecinos, evitando los escándalos, manteniendo el sosiego en las calles y en los interiores de los hogares, y erradicar los juegos, burdeles, la embriaguez, robos o los excesos delictivos de los esclavos cuyo número había aumentado en la segunda mitad del siglo XVIII. Para regular tal comportamiento el cabildo elaboró unas normas que fueron plasmadas en las ordenanzas de 1786, en las que además de establecer la división en cuarteles de la ciudad y la creación de los alcaldes de barrio anteriormente comentados, también establecía una normativa en cuanto a la cría de ganado, el abasto y venta de carne, 
y una regulación específica para aquellos esclavos que vagaban libres por la ciudad y sus alrededores, y para los jornaleros o negros ganadores ${ }^{115}$.

\subsubsection{Acceso al cabildo: Antecedentes}

La ocupación de un cargo administrativo en La Española estuvo sujeto al nombramiento realizado por la Corona o el gobernador, hasta que posteriormente dichos cargos entraron a formar parte de los denominados oficios vendibles y renunciables. El 17 de abril de 1492, la Corona facultó a Cristóbal Colón para presentar una terna de personas entre las que ella elegiría a los funcionarios que gobernarían el territorio de La Española, tales como regidores, jurados, fieles y procuradores. Más tarde, en mayo de 1493, la Corona otorgó a Colón el poder de nombrar y deponer a los alcaldes, alguaciles, escribanos y otros funcionarios de los cabildos. Los sucesivos gobernadores de Santo Domingo continuaron con esas facultades de forma que los principales cargos administrativos, especialmente los edilicios fueron ocupados por personas allegadas a la figura del gobernador.

A partir de 1508 los cabildos empezaron a tener una mayor autonomía al intentar igualarse a las ciudades castellanas. En primer lugar, consiguieron que a cada una de las poblaciones de la isla se le concediesen armas nobiliarias. Y en segundo lugar, obtuvieron cierta autonomía local al lograr desprenderse del poder que ejercía el gobernador al escoger sus miembros.

La reducción del poder del gobernador comenzó a llevarse a cabo a raíz del gobierno del hijo del descubridor, Diego Colón. En un principio su nombramiento como gobernador de Santo Domingo significó la continuidad de las facultades que habían tenido sus antecesores, sin embargo no se le reconoció el título de virrey que le correspondía como heredero de Cristóbal Colón. Ante la reclamación de Diego Colón para que se le reconociese tal privilegio, se dictó una real provisión el 5 de mayo de 1511 por la que se le reconoció el título, pero a su vez se le despojó del derecho a nombrar y deponer alcaldes, que serían electos por

\footnotetext{
${ }^{115}$ Nombre que recibían aquellos esclavos de los hacendados que "por la voluntad de los amos ejercían distintas actividades y servicios en la ciudad o en los campos [...]”. Además debían entregar a sus dueños una parte del salario recibido. Véase Laviña, J., "Sin sujeción a justicia: Iglesia, cofradías e identidad afroamericana” en García Jordán, P. et al. (coords.), Estrategias de poder en América Latina. Barcelona, 2000, pp. 151-163, p. 155. Véase también Documentación del Archivo Real de Higüey, "Ordenanzas del cabildo de Santo Domingo, 1786”..., op. cit., pp. 157-172.
} 
el ayuntamiento de cada pueblo y no por el gobernador. Asimismo, se le derogó la facultad de proponer ternas para el nombramiento de regidores, procuradores y del resto de los oficios, quedando reservada a la Corona. Otra limitación a su poder fue la creación de la ya citada audiencia como institución rectora de la vida social y política, y fundamentalmente como un poder alternativo al del gobernador al privarle de la facultad de actuar como juez, para lo que la Corona se encargó de nombrar a unos jueces para tal función desde entonces.

La disminución de todas esas atribuciones que había tenido anteriormente el gobernador, generaron una serie de conflictos en algunos cabildos de la isla partidarios de Diego Colón, y por lo tanto, contrarios a la prohibición de que no interviniera en la designación de sus miembros en las elecciones municipales. Todo ello provocó que hacia 1513 la mayoría de los cabildos de la isla se inclinaran por la participación de Diego Colón en la elección, mientras que los de Santo Domingo y Santiago fueron contrarios. Esta división hizo que los jueces de la Audiencia propusieran a Diego Colón una reunión con todos los concejos de la isla para adoptar un único procedimiento de elección. De esta forma, los jueces decidieron que en los cabildos de Santo Domingo y Santiago, en los que todavía no habían tenido lugar las elecciones, se nombrase a doce personas y que entre el gobernador, los jueces y los oficiales se elegirían dos alcaldes y cuatro regidores para cada ciudad. Sin embargo, este sistema tampoco logró solucionar el problema al no conseguir unanimidad en los concejos para la designación de las personas.

En consecuencia, finalmente se impuso la real provisión de 5 de mayo de 1511, que determinó que la elección de alcaldes fuese competencia de los ayuntamientos de cada ciudad y que los regidores fueran nombrados por la Corona de manera perpetua ${ }^{116}$. Pero las necesidades económicas de la Real Hacienda, que desde el siglo XVI venían acuciando a la Corona, hicieron que se pusieran en venta los puestos indianos. Este fenómeno se inició en 1559 al producirse las primeras enajenaciones de las escribanías con carácter vitalicio, y en 1581 se incluyó la posibilidad de que sus titulares pudiesen transmitirlas a

\footnotetext{
${ }^{116}$ Para un acercamiento general al tema véanse los siguientes trabajos: Lamb, U., Frey Nicolás de Ovando..., op. cit., pp. 119, 120, 147, y 148. Julián, A., "Fraudes y conflictos en las primeras elecciones celebradas en la isla Española 1512-1513”..., op. cit., pp. 99-121. García Menéndez, A., Los jueces de apelación..., op. cit. Santiago, J., Campillo Pérez, J. G., y Dobal, C., El primer Santiago de América, 1495-1995. Santo Domingo, 1997, p. 228. Mira Caballos, E., Nicolás de Ovando y los orígenes del sistema colonial español 1502-1509. Santo Domingo, 2000, pp. 101105.
} 
través del sistema de renuncia. A partir de entonces se amplió el campo de manera que cualquiera de los oficios podía ser objeto de venta. La Real Cédula de 1606 asentó este sistema de ventas y renuncias de los oficios indianos, al mismo tiempo estableció su regulación mediante una serie de normas que estipulaban cómo debían realizarse las ventas y renuncias, qué condiciones debían de tener los compradores y sus formas de pago ${ }^{117}$.

Los oficios vendibles y renunciables presentaron habitualmente la siguiente forma de obtención. Primeramente, en el caso de compra de un cargo, éste era objeto de un pregón en el que se informaba sobre el oficio que podía rematarse. Si se trataba de una renuncia, se procedía a una averiguación del valor del oficio mediante la opinión de varios testigos y en función de ésta, el gobernador y los oficiales reales determinaban cuál era el más justo. En ambos sistemas el paso siguiente era el pago, en las Cajas Reales, del importe total por la compra de un oficio y en el caso de la renuncia, de la mitad del valor del oficio si era la primera renunciación y del tercio del mismo en sucesivas transmisiones. El gobernador era quien expedía el título, y en posesión de él, la persona interesada debía presentarse con dicho documento ante el cabildo donde era recibido para el ejercicio del oficio. Posteriormente fue necesario solicitar la confirmación en un plazo de cinco años, y en caso de renuncia, veinte días después de realizar dicha renuncia, que debía ser presentada al gobernador ${ }^{118}$.

\subsubsection{El control durante el siglo XVIII}

Fue a partir de la Cédula de 1606 cuando se accedió a la mayoría de los oficios de los cabildos indianos mediante la compra o renuncia de éstos. En esa condición entraron en el siglo XVIII todos los oficios del cabildo de Santo Domingo, a excepción de los alcaldes ordinarios y de Santa Hermandad, los de visita, el síndico procurador y el padre general de menores que fueron elegidos

\footnotetext{
${ }^{117}$ Sobre este particular asunto puede verse Tomás y Valiente, F., Gobierno e instituciones en la España del Antiguo Régimen. Madrid, 1982, pp. 151-179, y La venta de Oficios en Indias (14921606). Madrid, 1982. El capítulo segundo de esta obra trata del comercio de los oficios hasta 1558, y el tercer capítulo sobre las ventas y renuncias de oficios entre 1558 y 1606.

${ }^{118}$ Idem., Renuncia del oficio de regidor de José de Leos y Echalas en Su Majestad, y remate de Miguel Bernardo Ferrer, 1768. AGI, Santo Domingo, 937.
} 
por los miembros del cabildo, y el fiel ejecutor que rotó anualmente entre los regidores.

En concreto, el cargo de regidor tuvo la particularidad de obtenerse por nombramiento del gobernador durante gran parte del siglo XVIII. El sujeto que servía como regidor lo hacía en calidad de arrendamiento, por lo que debía pagar por él una determinada cantidad de pesos anualmente, en relación a la consideración del valor del regimiento. La renta anual de este oficio durante ese siglo fue de 20 pesos, y el alférez real 40. Mientras que en los concejos de La Vega, Cotuí, Hincha, San Carlos, Montecristi, Monte Plata, Neiba, Banica y Azua se pagaba 5 pesos $^{119}$. A pesar de que este puesto entraba en la categoría de vendible y renunciable, la falta de personas que quisieran comprarlo obligó a la Corona a concederlos en alquiler. La práctica de los arrendamientos de los oficios concejiles de Santo Domingo resultó de dos Reales Cédulas, una de 14 de marzo de 1720 y otra de 13 de septiembre de 1722. Ambas facultaban al gobernador el nombramiento de regidores interinos y el pago de un alquiler por tales oficios, sin que el hecho de estar ocupados cesara los pregones hasta que surgiera un comprador $^{120}$. Sin embargo, en la ciudad de Santo Domingo, hasta la segunda mitad del siglo XVIII, prevaleció más el arrendamiento que la compra de un regimiento.

\footnotetext{
${ }^{119}$ Auto sobre el verdadero valor del oficio de regidor rematado en Antonio Mañón de Lara, 3 de agosto de 1768. AGI, Santo Domingo, 937. Certificación del escribano de la Real Hacienda y registros de esta ciudad, Francisco Martínez de León, sobre lo que deben los regidores de esta ciudad que tomaron sus empleos en arrendamiento por el tiempo que han dejado de satisfacerlos, 9 de febrero de 1779. AGI, Santo Domingo, 1021.

${ }^{120}$ Informe de los oficiales reales, 4 de mayo de 1768. AGI, Santo Domingo, 979.
} 
Tabla 2-12. Relación de los regidores nombrados por los gobernadores en calidad de arrendamiento durante el siglo XVIII

\begin{tabular}{|c|c|c|}
\hline Gobernador & Fecha del nombramiento & Regidores \\
\hline Fernando Constanzo & 5 diciembre de 1720 & \begin{tabular}{|l|} 
Pedro Pimentel \\
Antonio Heredia \\
Juan Esteban Páez \\
\end{tabular} \\
\hline $\begin{array}{l}\text { Francisco de la Rocha- } \\
\text { Ferrer }\end{array}$ & 11 de diciembre de 1723 & \begin{tabular}{|l|} 
Damián del Castillo \\
Antonio Coca \\
Tomás Heredia \\
Pedro Fernández de Castro \\
\end{tabular} \\
\hline \multirow{8}{*}{$\begin{array}{l}\text { Francisco Rubio y } \\
\text { Peñaranda }\end{array}$} & 30 diciembre de 1751 & $\begin{array}{l}\text { Luís Tejada Montenegro } \\
\text { Nicolás Heredia } \\
\text { Miguel Paredes }\end{array}$ \\
\hline & 31 de enero de 1752 & José Campuzano Polanco \\
\hline & 2 de mayo de 1752 & \begin{tabular}{|l} 
Francisco Martínez \\
José Castro \\
Domingo de la Rocha-Ferrer \\
y Landeche
\end{tabular} \\
\hline & 8 de mayo de 1752 & Juan Mieses Ponce de León \\
\hline & 20 de mayo de 1752 & Antonio Caro y Oviedo \\
\hline & 5 noviembre de 1753 & José Guridi y Concha \\
\hline & 4 enero de 1754 & José Leos Echalas \\
\hline & 30 de diciembre de 1754 & $\begin{array}{l}\text { Antonio Dávila Coca y } \\
\text { Landeche }\end{array}$ \\
\hline \multirow[t]{2}{*}{ Manuel Azlor y Urríes } & 15 de octubre de 1765 & \begin{tabular}{|l|} 
Julián Caro \\
Agustín Girón \\
Pedro Fernández de Castro \\
Manuel Heredia \\
\end{tabular} \\
\hline & 22 de marzo de 1767 & \begin{tabular}{|l} 
José del Monte y Tapia \\
Antonio Mañón de Lara
\end{tabular} \\
\hline
\end{tabular}

Elaboración propia. Fuentes: Títulos diversos. AGI, Santo Domingo, 940. Certificación del escribano Felipe Peña de la toma de posesión de algunos de los oficios del cabildo entre 1751 y 1754, 20 de septiembre de 1756. AGI, Santo Domingo, 1065. Carta del gobernador, Manuel Azlor y Urríes, en la que informa haber nombrado a Julián Caro, Agustín Girón, Pedro de Castro y Manuel Heredia, 15 de octubre de 1765. AGI, Santo Domingo, 975. Carta del gobernador, Manuel Azlor y Urríes, en la que informa que confirió a José del Monte y Tapia y Antonio Mañón de Lara los oficios de regidores del ayuntamiento, 22 de marzo de 1767. AGI, Santo Domingo, 978. Informe de los oficiales reales, 4 de mayo de 1768. AGI, Santo Domingo, 979.

Esta forma de elección de los regidores se mantuvo hasta 1767 y probablemente fue una respuesta a la ausencia de ocupación de tales empleos y a que el cabildo tuviera el correspondiente número de sujetos que desempeñasen los cargos concejiles. La escasez de personas interesadas en ocupar tanto el cargo de regidor como el resto de los oficios municipales en Santo Domingo, ha sido manifestada en los informes realizados por los ministros de la Audiencia y oficiales reales durante el siglo XVIII, según los cuales uno de los motivos de esa 
ausencia era la falta de caudal de las personas para comprar y ejercer los oficios $^{121}$.

No obstante, no parece que esto sucediese realmente así en Santo Domingo, donde generalmente hubo personas que se dedicaron al ganado, las haciendas o cualquier otra actividad, es decir, con capacidad económica para pagar un empleo como podrá verse más adelante. De hecho, las escasas referencias bibliográficas que se tienen sobre quién compuso el cabildo de Santo Domingo durante la época colonial, muestran como este órgano estuvo integrado en sus orígenes por los encomenderos, luego por personas ligadas a la economía azucarera, al comercio y a la ganadería, es decir, por los principales participantes en la economía de la isla ${ }^{122}$. Durante la primera mitad del siglo XVIII, los miembros que lo integraron “[...] pertenecían a los grupos sociales distinguidos, poseían tierras, haciendas, ingenios, trapiches, étc.,” ${ }^{123}$. También en la segunda mitad de dicho siglo, la tendencia fue similar al estar compuesto fundamentalmente por hacendados dedicados a la agricultura y a la ganadería, así como por algún comerciante.

Los ministros también exponen la carga que suponía dicho empleo y el tiempo que les quitaba para atender sus haciendas, incluso la falta de incentivos económicos debido a que los regidores tenían el corto salario de “ [...] veintidos pesos anuales, de los que pagan por el arrendamiento veinte, quedandoles solo dos”124. A ello habría que añadir, sin embargo, que sí hubo un interés por ocupar los regimientos y demás oficios del ayuntamiento, sobre todo a partir de 1767, como se verá posteriormente. Esta falta de interés por adquirir los oficios municipales no fue un hecho particular del ayuntamiento de la ciudad de Santo

\footnotetext{
${ }^{121}$ El fiscal de la Real Audiencia de Santo Domingo de la isla Española informa a Su Majestad del deplorable estado del ramo de la Real Hacienda de los oficios vendibles y renunciables, 1767. Y Extracto del expediente del fiscal de la Audiencia de Santo Domingo sobre el deplorable estado del ramo de los oficios vendibles y renunciables, 1767. AGI, Santo Domingo, 979.

${ }^{122}$ Puede verse en Río Moreno, J. del, Los inicios de la agricultura europea en el Nuevo Mundo (1492-1542). Sevilla, 1991, pp. 470-476, y Rodríguez Morel, G., Cartas del cabildo..., op. cit., pp. 14-15.

${ }^{123}$ Gutiérrez Escudero, A., "La propiedad de la tierra en Santo Domingo: del latifundio al terreno comunero”. Temas Americanistas 4 (Sevilla, 1984) pp. 21-26, p. 21.

${ }^{124}$ Carta del gobernador de Santo Domingo, Manuel Azlor y Urríes, en la que informa haber nombrado interinamente a Julián Caro, Agustín Girón, Pedro de Castro y Manuel Heredia, 15 de octubre de 1765. AGI, Santo Domingo, 975. El fiscal de la Real Audiencia de Santo Domingo de la isla Española informa a Su Majestad del deplorable estado del ramo de la Real Hacienda de los oficios vendibles y renunciables, 1767. AGI, Santo Domingo, 979.
} 
Domingo, sino un fenómeno común que se dio en el resto de los cabildos de la América española, como por ejemplo en el de Guatemala ${ }^{125}$.

No es extraño que el gobernador al nombrar a una serie de individuos como regidores se viesen favorecidos criados que llegaban con él, amigos y familiares en tal función e incluso en otros empleos administrativos. Un hecho que se pone de manifiesto en las acusaciones hechas en el juicio de residencia del gobernador José Solano y Bote, así como en las cartas del cabildo de la ciudad en las que se declara que algunos gobernadores, como el ya citado José Solano y Bote, y sus antecesores Manuel Azlor y Urríes y Francisco Rubio y Peñaranda, favorecieron que determinados sujetos ocupasen los oficios de regidores ${ }^{126}$. De esta manera, ciertas familias perpetuaron los regimientos mediante un arrendamiento durante largo tiempo y con una inversión económica mínima, ya que el precio que debían pagar por el alquiler era menor que por la compra. Además, la presencia de un reducido grupo en el cabildo y con algún vínculo de parentesco les permitió manejar a su arbitrio los negocios del ayuntamiento.

El perjuicio que siguió de ello fue la exclusión de otras personas y el escaso ingreso que obtuvo el Real Erario. Los ingresos que tenían que conseguir las Cajas Reales de dichos oficios fueron mermando debido a los atrasos de los pagos que debían hacerse por el arrendamiento de éstos. Asimismo, algunas personas ejercían los cargos sin haber adquirido la real confirmación. Ante esta situación, las autoridades de la Audiencia decidieron informar a la Corona, la cual ordenó que se iniciase una investigación para averiguar en qué situación se encontraban todos los oficios vendibles y renunciables, tanto de la ciudad de Santo Domingo como del resto de las poblaciones de la isla.

A través de los informes de los oficiales reales y demás ministros de la audiencia, se evidencia el mal estado en que se encontraba el ramo de la Real Hacienda de los oficios vendibles y renunciables de las poblaciones de La Española, debido a lo que adeudaban sus poseedores por su arriendo en especial los oficios de regidor del ayuntamiento de Santo Domingo. Así como también se muestra la existencia, en ese cabildo, de determinadas familias que acaparaban los

\footnotetext{
125 Santos Pérez, J. M., Élites, poder local y régimen colonial..., op. cit., pp. 66-110.

126 Sentencia del juicio de residencia del gobernador José Solano y Bote. AHN, Consejos, 20.766. Carta del cabildo de la ciudad de Santo Domingo, 12 de febrero de 1779. AGI, Santo Domingo, 1021 y 1059.
} 
regimientos y otros oficios apoyándose en dispensas de edades, vínculos y eligiendo en las votaciones a algún miembro de su familia ${ }^{127}$.

Para paliar la situación de la Real Hacienda, la Corona promulgó una Real Cédula en 16 de diciembre de 1767, por medio de la que se exigía sacar a pregón los oficios de regidor que se encontraban en arriendo y que no habían pagado lo que debían, aquellos que se encontraban sin real confirmación y los vacantes para que pudieran ser rematados por el mejor postor. Hasta ese momento los regimientos no habían dejado de estar en venta, pero tampoco habían sido comprados por nadie, de manera que los gobernadores continuaron cediéndolos en arrendamiento. El último nombramiento había sido realizado diez meses antes de haberse dictado la citada cédula, como se puede observar en la tabla 2-12.

El ayuntamiento apoyó oficialmente la decisión de la Corona, aunque en la práctica, como podrá verse, se resistió a sacar en pública subasta los oficios de regidor. A pesar de la oposición, la decisión de la Corona tuvo éxito, ya que a partir de entonces hubo un gran interés por ocupar los regimientos hasta el punto de derivar en sucesivas disputas en los remates. Por un lado, un grupo de vecinos empezó a pujar para conseguir cargos municipales. Y por otro, los que habían estado ostentando los cargos trataron de saldar sus deudas de alquiler por el regimiento que llevaban ocupando durante años. Además, hicieron todo lo posible por cambiar su situación de interinidad por la de perpetuos miembros de la institución al intentar comprarlos, tratando de restringir la entrada a cualquiera que no perteneciese a su grupo ${ }^{128}$.

\footnotetext{
127 Testimonio de las diligencias obradas sobre la averiguación de los oficios que hay vacantes $y$ sin crear en esta isla, 1768. Y Testimonio de los inconvenientes que han resultado de haberse servido en arrendamiento los oficios de regidor en la Isla Española, 1768. AGI, Santo Domingo, 979.

${ }^{128}$ En el cabildo de Guatemala también hubo una actitud similar por parte de una facción de la élite que monopolizaba esa institución, cuando otras familias quisieron participar en ella les obligó a cerrarse y restringir la entrada a cualquier elemento externo a la red familiar. Véase en Santos Pérez, J. M., Élites, poder local y régimen colonial..., op. cit., pp. 76-110.
} 
Tabla 2-13. Liquidación de lo que deben los regidores por su arrendamiento

\begin{tabular}{|c|c|c|c|c|}
\hline Regidores & $\begin{array}{c}\text { Año de su } \\
\text { nombramiento }\end{array}$ & $\begin{array}{c}\text { Años sin } \\
\text { pagar }\end{array}$ & $\begin{array}{c}\text { Deben de } \\
\text { arrendamiento }\end{array}$ & $\begin{array}{c}\text { Deben de media } \\
\text { annata }\end{array}$ \\
\hline $\begin{array}{l}\text { Antonio Dávila } \\
\text { Coca y } \\
\text { Landeche }\end{array}$ & 1754 & $1756-1775$ & $760 \$$ & 39\$ y 12 mrs. \\
\hline $\begin{array}{l}\text { José Campuzano } \\
\text { Polanco }\end{array}$ & 1752 & $1754-1776$ & $440 \$$ & 19\$, 4rs. y 6 mrs. \\
\hline $\begin{array}{l}\text { Antonio Caro y } \\
\text { Oviedo }\end{array}$ & 1752 & $1754-1776$ & $440 \$$ & 19\$, 4rs. y 6 mrs. \\
\hline José Guridi & 1753 & $1760-1776$ & 119 \$, 1 rs. y 11 mrs. & \\
\hline José Castro & 1752 & $1753-1770$ & $331 \$$ & 19\$, 4rs. y 6 mrs. \\
\hline Agustín Girón & 1765 & $1766-1772$ & 108 \$,1 rs. y 11 mrs. & \\
\hline Manuel Heredia & 1765 & 1766-1775 & $180 \$$ & \\
\hline $\begin{array}{l}\text { Pedro Fernández } \\
\text { de Castro }\end{array}$ & 1765 & $1766-1775$ & $180 \$$ & \\
\hline Total & \multicolumn{4}{|c|}{2.655 \$, 7 rs. y 8 mrs. } \\
\hline
\end{tabular}

Elaboración propia. Fuentes: En el caso de José Guridi debía cinco años, once meses y quince días. Certificación del escribano de Real Hacienda y registros de esta ciudad, Francisco Martínez de León, 23 de julio de 1776. AGI, Santo Domingo, 1021.

Hacia 1767 algunos de los miembros de este bando como Antonio Caro de Oviedo, Domingo de la Rocha-Ferrer y Landeche, José de Castro, José Guridi, Agustín Girón, Pedro Fernández de Castro, Manuel Heredia, Nicolás Heredia, José Leos-Echalas y Luís Tejada Montenegro. Todos ellos se caracterizaban por formar un grupo fuerte en el cabildo y tenían en común el ser criollos, hacendados y contar con un amplio currículo militar. Estaban emparentados entre sí y pertenecían a algunas de las familias más importantes de aquel entonces, que intrincadas entre sí formaban parte de las redes familiares Guridi-Alarcón Coronado y Landeche-Bastidas. Todos ellos con sus familiares y aliados habían poseído los oficios del cabildo y el gobierno de éste. De ahí que a partir de 1767 elaborasen una estrategia para continuar en el control de la institución municipal.

En cumplimiento de la Real Cédula de diciembre de 1767, el cabildo inició un año después las primeras ventas de los empleos de regidor que debían su arrendamiento y de los que se encontraban sin real confirmación. Los dos primeros oficios de regidor que se sacaron a remate en 1768, fueron los que habían estado ejerciendo en arrendamiento José del Monte y Tapia y Antonio Mañón de Lara durante el año anterior al haberles nombrado el gobernador Manuel Azlor y Urríes. Ambos ocuparon los lugares que quedaron vacantes uno 
por muerte de su antiguo poseedor Julián Caro, y el otro ocupado por Domingo de la Rocha-Ferrer y Landeche, quien tuvo que dejarlo para ejercer su nuevo empleo en México, el de auditor de guerra en las provincias de Yucatán y Campeche ${ }^{129}$. Tanto José del Monte y Tapia como Antonio Mañón de Lara fueron los únicos que se presentaron como postores y remataron cada uno de ellos en 500 pesos ${ }^{130}$.

José Leos y Echalas estaba en posesión de otro oficio de regidor que servía en arrendamiento y lo renunció en la Corona en 1768 debido al mal estado de su salud. Al sacarse a pregón su cargo ese mismo año, se presentó el cubano Miguel Bernardo Antonio Ferrer a rematar el regimiento y lo hizo también en 500 pesos. El grupo de regidores, que hasta entonces había estado ocupando esos empleos, contrarios a él se reunieron antes del remate y acordaron su oposición a la pretensión del referido Miguel. De esta forma el cabildo, encabezado por José del Monte y Tapia, hizo una petición por escrito al gobernador para que se suspendiese el citado remate, al considerar que en la persona de dicho sujeto no concurrían las correspondientes circunstancias de calidad, ni tampoco en la de su mujer, a quien consideraban poco digna por su ascendencia y entronques familiares, que carecían de la distinción que merecía el cabildo. A pesar del intento por parte del cabildo de restringirle su acceso al mismo, las autoridades no suspendieron el remate que hizo Miguel al oficio de regidor ${ }^{131}$.

Siguiendo lo ordenado, se continuaron sacando a pregón los dos oficios de regidor que todavía se encontraban en arrendamiento y que servían Nicolás Heredia y Luís Tejada Montenegro, además el del último carecía de su real título de aprobación. En 1770, Antonio Valdemoro y Alcántara se presentó como único postor a uno de estos oficios de regidor y lo remató en 500 pesos. Al comparecer

${ }^{129}$ Carta del gobernador, Manuel Azlor y Urríes, en la que informa que confirió a José del Monte y Tapia y Antonio Mañón de Lara los oficios de regidores del ayuntamiento, 22 de marzo de 1767. AGI, Santo Domingo, 978 y 979.

${ }^{130}$ Testimonio de los autos obrados sobre la venta del oficio de regidor de la ciudad de Santo Domingo de La Española rematado por Antonio Mañón de Lara, 1768; Testimonio de los autos obrados sobre la venta de un oficio de regidor de esta ciudad de Santo Domingo de La Española rematado en Antonio Mañón de Lara, 1768; y Testimonio de los autos obrados sobre la venta del oficio de regidor de esta ciudad de Santo Domingo rematado por José del Monte y Tapia, 1768. AGI, Santo Domingo, 937. Diligencias practicadas sobre que se saquen al pregón, dos oficios de regidores de esta capital, 1768. AGI, Santo Domingo, 979.

${ }_{131}$ Miguel Bernardo Antonio Ferrer Angulo estaba casado con María Belén Castro-Rivera Urdaneta, hija de Gonzalo de Castro y Micaela Urdaneta, por tanto vinculado a esa red familiar. Renuncia del oficio de regidor de José de Leos y Echalas en Su Majestad, y remate de Miguel Bernardo Ferrer, 1768. AGI, Santo Domingo, 937. Y Testimonio de los inconvenientes que han resultado de haberse servido en arrendamiento los oficios de regidor en la Isla Española. AGI, Santo Domingo, 979. 
ante el gobernador para expedir el título, los ministros de la audiencia consideraron que debía de invalidarse el remate al contar con un familiar en el cabildo. Se trataba del regidor Miguel Bernardo Antonio Ferrer, de quien era cuñado al estar casados ambos con hermanas, por lo que no pudo ejercer el cargo debido al parentesco. Los ministros se basaron en la ley quinta, título diez y libro cuarto de la Recopilación de las leyes de Indias, que prohibía a miembros de una misma familia ocupar puestos dentro del cabildo.

Ante esta situación, el cabildo conjuntamente contrario a su interpretación remitió cartas en las que afirmaba que tal ley sólo se refería a los cargos que eran electivos en los que no se podía nombrar a padres e hijos, ni a los casados con dos hermanas, y que no afectaba a los regimientos que se obtenían en pública subasta mediante su compra. Al mismo tiempo, el cabildo defendía que era normal que los oficios concejiles recayeran en parientes, porque en aquella ciudad estaban emparentados los sujetos de las principales familias de la ciudad de Santo Domingo. De hecho fue una constante en el cabildo de Santo Domingo que los regidores y el resto de los miembros que ocupaban otros empleos, estuviesen emparentados por las mujeres con las que estaban casadas, teniendo generalmente el parentesco de hermano político (cuñados) u otro vínculo, como muestra la tabla 2-14. Finalmente las autoridades del Consejo de Indias rectificaron la interpretación que había dado la Audiencia y se admitió a Antonio Valdemoro y Alcántara como regidor ${ }^{132}$.

\footnotetext{
${ }^{132}$ Expediente del cabildo secular de la ciudad de Santo Domingo sobre la mala inteligencia dada por los ministros de la Audiencia a la ley quinta, título diez, libro cuarto de la Recopilación de Indias, con motivo del remate de un oficio de regidor celebrado en Antonio Valdemoro, 27 de enero de 1771. Y Carta del cabildo de la ciudad de Santo Domingo en la que informa sobre la acumulación de los cargos en determinadas familias, 1771. AGI, Santo Domingo, 983.
} 
Tabla 2-14. Parentesco entre los regidores del cabildo de Santo Domingo

\begin{tabular}{|c|c|c|}
\hline Fecha & Regidores & Parentesco \\
\hline 1743 & $\begin{array}{l}\text { Tomás Heredia } \\
\text { Antonio del Monte }\end{array}$ & $\begin{array}{l}\text { Antonio del Monte yerno de } \\
\text { Tomás Heredia }\end{array}$ \\
\hline 1752 & \begin{tabular}{|l} 
Nicolás Heredia \\
Miguel Paredes \\
Antonio del Monte
\end{tabular} & Hermano político \\
\hline 1752 & $\begin{array}{l}\text { Antonio Caro y Oviedo } \\
\text { Félix Garay }\end{array}$ & Hermano político \\
\hline 1752 & \begin{tabular}{|l|} 
Francisco Martínez \\
Domingo de la Rocha-Ferrer y \\
Landeche
\end{tabular} & Hermano político \\
\hline 1753 & \begin{tabular}{|l|} 
José Campuzano Polanco \\
José Castro
\end{tabular} & Hermano político \\
\hline 1753 & $\begin{array}{l}\text { Juan de Mieses Ponce de León } \\
\text { José Guridi y Concha }\end{array}$ & Hermano político \\
\hline 1753 & \begin{tabular}{|l} 
Nicolás Heredia \\
Antonio del Monte \\
José Leos Echalas
\end{tabular} & Hermano político \\
\hline 1754 & $\begin{array}{l}\text { Antonio Dávila Coca y } \\
\text { Landeche } \\
\text { Domingo de la Rocha-Ferrer y } \\
\text { Landeche } \\
\end{array}$ & Hermano político \\
\hline 1779 & \begin{tabular}{|l} 
Antonio Valdemoro y \\
Alcántara \\
Miguel Bernardo Antonio \\
Ferrer \\
\end{tabular} & Hermano político \\
\hline 1786 & \begin{tabular}{|l|} 
Gregorio Saviñón \\
Miguel Jerónimo Martínez de \\
Venecia Santelices \\
\end{tabular} & $\begin{array}{l}\text { Miguel Martínez yerno de } \\
\text { Gregorio Saviñón }\end{array}$ \\
\hline 1790 & $\begin{array}{l}\text { Francisco Tapia y Castro } \\
\text { Miguel Bernardo Ferrer }\end{array}$ & Primos hermanos \\
\hline
\end{tabular}

Elaboración propia. Fuentes: El regidor de 1790 Miguel Bernardo Ferrer era hijo del regidor del mismo nombre que ocupaba el regimiento en 1779. Carta del cabildo de la ciudad de Santo Domingo a Su Majestad, 21 de enero de 1771. AGI, Santo Domingo, 983. Carta del cabildo de la ciudad de Santo Domingo a Su Majestad, 24 de febrero de 1779. AGI, Santo Domingo, 1021.

El otro oficio de regidor fue rematado en el mismo precio de 500 pesos por Francisco Cabral y Maldonado, y de la misma forma que en el anterior remate de Miguel Bernardo Antonio Ferrer, el cabildo hizo todo lo posible para que no se le concediese la confirmación del mismo. El principal obstáculo que impidió su admisión fue el estar casado con Isabel Herrera Acevedo, cuya familia era considerada descendiente de mulatos. De nuevo la calidad de la mujer de Francisco Cabral y Maldonado fue utilizada como impedimento para que éste no obtuviera el cargo. A partir de ahí se inició un proceso para aclarar la limpieza de 
la familia de la mujer de Isabel Herrera Acevedo. Francisco, su marido, y sus familiares pretendieron afianzar con informaciones de testigos la limpieza de sangre de la ascendencia de su mujer y su buen currículo burocrático. Mientras tanto unos cabildantes se mostraron imparciales y otros se resistieron a la entrada de Francisco; los últimos formaban un grupo opositor entre los que estaban los regidores José del Monte y Tapia, Antonio Mañón de Lara, Antonio Caro de Oviedo y Miguel Bernardo Antonio Ferrer. Estos trataron de denigrar el origen de la familia de Isabel presentando informaciones contrarias a las de Francisco Cabral, acusándole de que lo que él presentaba había sido elaborado clandestinamente para ocultar el origen mulato de su mujer ${ }^{133}$.

El empeño sobre la oscura calidad de la mujer de Francisco Cabral se debió a que ésta tenía descendencia mulata por línea materna. La bisabuela de su mujer, llamada Isabel de la Cid, había sido esclava, pero fue liberada en su infancia tomando el apellido de su madre adoptiva. Este prejuicio racial sirvió para intentar deslustrar a su familia, algo a lo que algunos miembros de la familia Acevedo ya se habían tenido que enfrentar a la hora de optar a algún cargo civil o eclesiástico. Ello a pesar de que la Corona, mediante una Real Cédula de 1715, les habilitó para que pudiesen ostentar cualquier cargo administrativo ${ }^{134}$. Aún así esto no les liberó del lastre racial que conllevaba el mestizaje en aquella época, de hecho muchos de sus familiares se vieron obligados a presentar documentación que justificara la limpieza de su familia para la obtención de algún empleo. No obstante, la utilización de esa descendencia de esclavos no impidió que se le diera confirmación del oficio de regidor a Francisco Cabral y Maldonado, y el grupo de regidores opositores fueron multados cada uno de ellos con 100 pesos y con 200 pesos Antonio Caro y Oviedo por cabecilla ${ }^{135}$.

La Corona, a la hora de optar a un oficio del cabildo, no tenía tan en cuenta la cuestión social y la ascendencia como algunos miembros del mismo, sino que

\footnotetext{
${ }^{133}$ Carta de Juan Lorencín del Castillo, cadete y subteniente interino de una de las compañías del Batallón Fijo de esta plaza, en la que presenta documentación en relación con lo ocurrido al remate del oficio de regidor de este ayuntamiento de Francisco Cabral y Maldonado, 1 de octubre de 1771. AGI, Santo Domingo, 1021. Testimonio de los autos obrados sobre la representación por el ilustre ayuntamiento de esta ciudad en orden al remate del oficio de regidor hecha por Francisco Cabral, 21 de enero de 1771. AGI, Santo Domingo, 1004.

${ }^{134}$ Sobre el asunto véase Saéz, J. L., La Iglesia y el negro esclavo en Santo Domingo. Una historia de tres siglos. Santo Domingo, 1994, p. 64.

${ }^{135}$ Multas, indultos y penas de cámara. AGI, Santo Domingo, 1043.
} 
requería buena conducta, honradez y caudal con el que pagarlo. La cuestión de la ascendencia familiar de las mujeres de los regidores fue utilizada en un intento de restringir la entrada a individuos que no perteneciesen al grupo. Las averiguaciones sobre el origen familiar de las mujeres y el de los que optaban a los oficios de regidor acabaron provocando discordias entre las distintas familias de la ciudad, ya que la calidad trascendía no sólo a la familia a la que se pertenecía sino a muchas más personas debido a las conexiones existentes.

En 1772 la renuncia del oficio que ocupaba José del Monte y Tapia y su puesta en subasta hizo que fuese rematado, en esta ocasión sin problema alguno, por Mateo Firpo, lo que permitió la entrada en el cabildo de un nuevo integrante que mantuvo el cargo hasta que murió en 1791 renunciándolo en sus hijas. Sin embargo éstas no pudieron disfrutarlo a consecuencia del tan conflictivo período que se vivió años después y de la cesión de la isla a los franceses ${ }^{136}$.

Las elecciones capitulares también constituyeron otro importante e interesante momento dentro del cabildo, prueba de ello es lo ocurrido a principios de enero de 1779. Los miembros del cabildo se juntaron el 1 de enero en la casa capitular y tras las votaciones salieron como alcaldes ordinarios José Antonio Zárraga y Nicolás Heredia, a lo que se opuso parte del cabildo encabezada por Antonio Valdemoro y Alcántara y su cuñado Miguel Bernardo Antonio Ferrer, considerando que al estar aún pendientes de la residencia no podían ser electos. De esta manera el cabildo quedó dividido en dos bandos. Uno estaba formado por Antonio Coca, Manuel Heredia, Antonio Mañón y Pedro Fernández de Castro, todos ellos miembros de las redes familiares Guridi y Alarcón-Coronado y Landeche-Bastidas. El otro lo integraban Miguel Bernardo Ferrer, Antonio Valdemoro, Mateo Firpo y Francisco Cabral, pertenecientes a la red familiar Castro-Rivera y Urdaneta. Ante esta situación el gobernador Isidro Peralta y Rojas remitió una orden que anulaba las elecciones y mandaba repetirlas. Pocos días después, el 7 de enero de 1779 se eligió como alcaldes ordinarios a Lorenzo

\footnotetext{
136 Título de regidor concedido a Mateo Firpo el 15 de junio de 1772; Confirmación Real dada en Aranjuez 17 de diciembre de 1775; y Carta de las hijas de Mateo Firpo en la que solicitan a Su Majestad les mantenga por gracia y posesión en el goce del regimiento que en ellas renunció su padre, 9 de abril de 1791. AGI, Santo Domingo, 940.
} 
Angulo Medrano y Nicolás Guridi y Frómesta, y como alcaldes de Hermandad y visita a Idelfonso Navarro Leos-Echalas y José Castro Palomino ${ }^{137}$.

La formación de estos dos bandos venía de tiempo atrás y podría considerarse como el resultado de las distintas luchas entre unos y otros por obtener los regimientos del cabildo. La Real Cédula de 1767, al poner a la venta los oficios de regidor, permitió que accedieran a los remates personas distintas a las que hasta entonces habían ocupado los oficios concejiles, se trataba de algunos miembros de la red Castro-Rivera y Urdaneta. En realidad los oficios siempre estuvieron en venta, pero como se ha podido observar no habían surgido otros sujetos interesados en ellos. La cédula impulsó el interés y abrió la posibilidad a otras personas de entrar en el cabildo. Al mismo tiempo, dicha cédula llevó a los que habían estado dominando interinamente la institución a desplegar una serie de estrategias para asegurarse los oficios municipales, comprándolos y restringiendo la entrada a aquellos que no perteneciesen a su red para no perder el control sobre el cabildo.

Dos nuevos incidentes tuvieron lugar en 1779, y ambos en relación a otros remates que se intentaron sobre distintos regimientos. El primer intento fue el remate de tres puestos vacantes de regidores, dos por muerte de José Guridi y Antonio Caro y Oviedo, y el tercero por renuncia de Nicolás Heredia. Los individuos que hicieron postura a estos tres cargos eran familiares de los anteriores, así José María Mieses Ponce de León era sobrino del primero, José Antonio Zárraga sobrino afín del segundo, y Nicolás Heredia Serrano Pimentel sobrino del último. Esta postura colectiva se realizó mediante una petición escrita en la que solicitaban al gobernador, Isidro Peralta y Rojas, que se suspendiesen los pregones para evitar las discordias que se habían producido anteriormente en las ventas de los oficios de regidor, obstaculizando así la entrada de personas con mala reputación. Asimismo, en el escrito constataba que lo hacían bajo la condición de que los tres oficios de regidor debían ser admitidos juntos. Las autoridades no vieron con buenos ojos el hecho de que tuviesen que paralizarse las almonedas y que se les debiesen adjudicar a ellos los cargos de forma

${ }^{137}$ Carta del gobernador de Santo Domingo, Isidro Peralta y Rojas, informando de la formación de bandos en las elecciones capitulares de dicha ciudad, 25 de enero de 1779. AGI, Santo Domingo, 1021. 
extrajudicial, por ello el gobernador les castigó con arresto domiciliario para que no pudieran acceder el día que se sacasen a pregón los oficios de regidor ${ }^{138}$.

El intento de compra colectiva presenta un aspecto importante, el interés de las dos redes, Guridi y Alarcón-Coronado y Landeche-Bastidas, por controlar la institución. Tras la postura colectiva que estas tres personas realizaron se encontraban otros miembros de dichas redes familiares que procuraban, como indicaron en su escrito, "evitar que otros individuos accediesen al cabildo para mantener los oficios que habian poseido sus mayores”139. Esta estrategia muestra que tras ella había unos cabecillas Felipe Guridi Concha, Nicolás Guridi y Frómesta y Antonio Dávila Coca y Landeche, que trataron por todos los medios de preservar los oficios que poseían en el cabildo y obtener los regimientos que habían quedado desocupados. Nicolás Guridi y Frómesta quiso obtener el regimiento que había ocupado su padre José Guridi, pero al haber sido elegido alcalde ordinario en 1779 no pudo presentarse a rematarlo por la incompatibilidad que había entre ambos oficios. Por ello Nicolás Guridi y Frómesta sugirió, en un escrito que envió a su tía Ana Guridi, que su primo José María de Mieses participase en la postura conjunta a uno de los oficios de regidor, comprándoselo él más tarde al mismo precio. Se trataba probablemente de una futura compra encubierta. Asimismo, otros miembros de la red como Antonio Dávila Coca y Landeche y Antonio Mañón de Lara animaron a Manuel Heredia y a su hermano Nicolás a que rematasen los dos oficios de regidor, proporcionándoles el dinero necesario para su compra y dificultando por tanto la entrada de otros en el cabildo $^{140}$.

La anulación de esta posible compra conjunta hizo que los oficios de regidor fuesen sacados de nuevo a pregón. Los perjudicados en el anterior remate acordaron que Manuel Heredia, hermano del citado Nicolás Heredia, se presentase al remate del oficio de regidor y así en 1779 ofreció 550 pesos. También se presentó Gregorio Saviñón, un cubano casado con Micaela Antonia Tapia, sobrina de Miguel Bernardo Antonio Ferrer e hijastra de Antonio Valdemoro y Alcántara, que ofreció 600 pesos. Según Manuel Heredia, los oficios de regidores no podían

\footnotetext{
${ }^{138}$ Carta del gobernador de Santo Domingo Isidro Peralta y Rojas a Su Majestad informando de lo ocurrido en la presentación que hicieron varios vecinos a tres oficios de regidores vacantes y sus incidencias, 28 de febrero de 1779. AGI, Santo Domingo, 1021.

139 Ibidem.

140 Ibidem.
} 
caer en manos de sujetos de inferior calidad, como presumía que era el caso de Gregorio Saviñón y su mujer, sino que debían corresponder a los beneméritos a pesar de que otros individuos ofreciesen más dinero. Gregorio Saviñón llevaba intentando rematar uno de los oficios de regidor desde 1770, sin embargo el rechazo de su remate no se apoyaba en la calidad de su familia y su mujer, sino en el hecho de no ser considerado benemérito. Nuevamente el remate fue anulado y volvió a sacarse en almoneda, acordándose que le correspondería al mayor postor. El 3 de abril de 1781 tanto Nicolás Heredia como Gregorio Saviñón se presentaron como los únicos postores. Se inició una puja entre los dos hasta que fue rematado en Gregorio Saviñón en 3.050 pesos, el precio más alto ofrecido hasta entonces por el oficio de regidor, pues desde que se inició la venta durante la segunda mitad del siglo XVIII se había estado pagando por él 500 pesos ${ }^{141}$.

Los otros dos oficios de regidores que quedaron vacantes en 1779 por defunción de José Guridi y Antonio Caro y Oviedo, fueron rematados sin conflictos en 1785, uno por Francisco Tapia y Castro y el otro por Esteban Sáez Vásquez en 500 pesos $^{142}$. De igual forma se siguieron rematando los regimientos que iban quedando desocupados por sus titulares, así en el mismo año Luís Franco Guridi obtuvo el oficio de regidor por renuncia de Antonio Valdemoro y Alcántara. Pedro Fernández de Castro llevaba ocupando un regimiento desde 1765 y en 1784 lo renunció al rey por estar enfermo. Unos años después comenzó a hacerse posturas al cargo, que fue adjudicado en 1786 en el remate que hizo Miguel Jerónimo Martínez de Venecia Santelices, yerno de Gregorio Saviñón, en la cantidad de 500 pesos $^{143}$.

Al morir el regidor Miguel Bernardo Antonio Ferrer su puesto pasó por renuncia de éste a su hijo Miguel en 1785, quien era abogado de la Real Audiencia y poco después lo renunció a la Corona al dejar dicho oficio en 1789. Ese mismo año se sacó a pregón el cargo y se produjo de nuevo otro conflicto en el remate de dicho regimiento, el último del siglo XVIII. Se presentó Pedro

\footnotetext{
${ }^{141}$ Expediente en cuanto a lo ocurrido en la presentación que hicieron varios vecinos a los oficios de regidor vacante y sus incidencias, 1779-1781. AGI, Santo Domingo, 1021.

${ }_{142}$ Testimonio del gobernador Isidro Peralta y Rojas del remate de dos oficios de regidor, 16 de junio de 1785. AGI, Santo Domingo, 940.

${ }^{143}$ Testimonio de los autos de renuncia del oficio de regidor de la capital hecha por Antonio Valdemoro y Alcántara a favor de Luís Franco, 1785-1789. AGI, Santo Domingo, 938. Título de regidor del cabildo, justicia y regimiento de la ciudad de Santo Domingo a favor de Miguel Martínez de Venecia Santelices, 1786. AGI, Santo Domingo, 938.
} 
Arredondo y Castro e hizo postura a él, pero se le anuló por ocupar uno de sus hermanos otro puesto de regidor, Francisco Arredondo y Castro. El tema del parentesco que ya anteriormente había suscitado enfrentamientos entre los capitulares resurgió. Al igual que sucedió con la invalidez del remate de Antonio Valdemoro y Alcántara, el poderoso grupo de las redes Guridi y AlarcónCoronado y Landeche-Bastidas siguió utilizando el parentesco para continuar con el proceso de limitar el acceso al cabildo. De esta manera el puesto se volvió a sacar a almoneda y fue rematado por uno de sus miembros, Silvestre Ramírez Guridi, en 1.000 pesos $^{144}$.

De lo expuesto puede deducirse cuáles fueron los intereses de las personas que querían comprar los cargos municipales, en particular el de regidor. Durante el periodo de tiempo en que se inserta este trabajo fueron varios. El más frecuente entre los cabildos americanos fue la obtención de prestigio social. Aunque hubo otros motivos más específicos, como el interés que tuvo una parte de la élite de Santo Domingo, formada por algunos hacendados, por controlar el organismo a través del que reivindicaron sus necesidades. Los nombramientos de muchos de ellos como regidores por los gobernadores y sus enlaces familiares permitieron que siempre eligieran a algún pariente en las elecciones capitulares. De manera que también las relaciones familiares y el apoyo de sus acólitos les sirvió de respaldo, especialmente después de la Real Cédula de 1767, que facilitó la entrada en la institución a otras personas y obligó a los que hasta entonces se habían mantenido como mayoría en el cabildo a movilizarse, haciendo resistencia ante cualquier intento de compra por parte de alguien externo a su grupo.

Las líneas trazadas a partir de 1768 muestran la presencia de dos grupos rivales pero emparentados todos ellos entre sí, formando una gran red familiar que comprendía a tres: los Guridi y Alarcón-Coronado, los Landeche-Bastidas y los Castro-Rivera y Urdaneta. Los conflictos surgieron al reclamar algunos miembros de la última red, que cuando pretendían adquirir un regimiento los candidatos eran considerados por el resto de los cabildantes (las dos primeras familias) como personas poco aptas por la ascendencia de su mujer o por tener algún pariente en

\footnotetext{
${ }^{144}$ Carta del cabildo de Santo Domingo en la que da cuenta de haber excluido de un oficio de regidor a Pedro Arredondo, 20 de abril de 1791. AGI, Santo Domingo, 1006. Expediente causado con motivo de la renuncia que hizo a favor de la Real Hacienda Miguel Ferrer de un oficio de regidor de la ciudad de Santo Domingo, el cual fue rematado por Silvestre Ramírez 1785-1790. AGI, Santo Domingo, 1008.
} 
el cabildo. El otro modo de acción que presentó resistencia a estos candidatos fueron los apoyos utilizados por los hacendados, quienes se basaban en leyes que conservaran la exclusividad de sus miembros, pero aún así no lograron evitar la entrada en la política local de un grupo de personas que en virtud de su dinero pudieron comprar regimientos. Por otro lado, la facción de la élite establecida (las dos primeras familias) vio disminuir el monopolio absoluto que había poseído en dicha institución a fines del siglo XVIII. A pesar del cambio que sufrió el cabildo en su composición, algunos de sus miembros siguieron estando presentes en este organismo, aunque minoritariamente y compartiendo la parcela de poder con los otros. 


\section{CAPÍTULO 3 EL EJÉRCITO}

En este capítulo vamos a ver la evolución del Ejército, que podemos sintetizar en dos aspectos. Por un lado se estudiará todo lo relavito al gobierno militar, analizando la evolución de las fuerzas militares, tanto las regulares como las milicianas, el estado, su financiación y el de las fortificaciones. El otro aspecto está relacionado con lo anterior, y se refiere al currículo militar de algunos de los hacendados estudiados: los empleos y grados obtenidos como recompensa a su trayectoria militar o al contrario, sin experiencia militar, por sus prestaciones económicas y personales a la Corona. También fueron recibidos a través de las relaciones privilegiadas que mantuvieron con el gobernador y presidente de la Audiencia, quien en ocasiones los otorgó a personajes de las principales familias de hacendados o algún miembro que formaba parte de su comitiva, cuando llegó a la isla.

\subsection{Antecedentes}

La Española fue el primer lugar donde los españoles pusieron en práctica las medidas de autodefensa ante los posibles ataques de los indios que poblaban la isla. Las fuerzas utilizadas para la defensa estaban formadas por varios grupos de personas, uno de ellos integrado por soldados profesionales recluidos en fortalezas dispersas a lo largo de la isla, y otros por los encomenderos así como por las milicias formadas por los propios isleños, los cuales eran obligados a prestar servicio militar en caso necesario. Una vez instalados los primeros asentamientos en Santo Domingo y sometidos los indígenas, empezó a surgir el peligro desde el exterior de la isla con los eventuales ataques de piratas realizados por mar, algunos de ellos llegando a tierra firme. Y así en 1586 la ciudad de Santo Domingo fue saqueada por Francis Drake. 
Durante el siglo XVII los ataques desde el exterior continuaron, siendo los enemigos de la Corona Española, es decir, los franceses, ingleses y holandeses, quienes desde el mismo momento de su descubrimiento habían iniciado también su colonización en América. Su presencia se dejó sentir en Santo Domingo, sobre todo en la zona norte de la isla, dedicándose al contrabando y comercio ilícito, lo que forzó a la Corona a abandonar dicha área con el objetivo de que cesaran esas actividades, proceso conocido como las Devastaciones (1605-1606).

Esta constante amenaza y la oposición de los habitantes a desocupar la zona obligaron a traer un contingente de militares de Puerto Rico para perseguir y reducir a los alzados. Asimismo se encargaron de combatir a los piratas y contrabandistas acostumbrados a hacer negocios en la parte norte de la isla. Con el tiempo, una de las consecuencias que produjeron las Devastaciones fue el intento de asentamiento de esas potencias extranjeras en los lugares despoblados, así como de apoderarse de la isla. De hecho a partir de entonces, la plaza de Santo Domingo reactivó la defensa arquitectónica de la ciudad y poblados de la isla, y se fue aumentando cada cierto tiempo el número de sus soldados. A pesar de la fuerte militarización de Santo Domingo, los éxitos de las tropas militares frente a los ataques fueron más bien escasos. Entre los numerosos asaltos que sufrieron cabe destacar los sucesivos intentos de ingleses y franceses desde 1630 por establecerse en la isla La Tortuga, situada en el noroeste de La Española. Su asentamiento en tal isla permitió que se realizasen numerosos ataques a buques españoles e incursiones en otros territorios del norte de la isla en busca de ganado para aprovechar el cuero y sebo que después vendían. Poco a poco de ambas actividades fueron surgiendo grupos especializados en esas tareas, a los dedicados a los ataques se les llamó filibusteros mientras los que realizaron incursiones fueron bucaneros.

Las tropas militares de Santo Domingo acometieron a éstos organizándose en cuadrillas y “cincuentenas” hasta lograr desalojarlos ${ }^{1}$. Pero el traslado de este contingente militar a la ciudad de Santo Domingo ante el riesgo de que se produjera en ella un ataque de alguna potencia enemiga, obligó a abandonar la isla

\footnotetext{
${ }^{1}$ Las cincuentenas fueron unidades compuestas por la propia población de Santo Domingo generalmente "personas de baja condición social” que combatían con lanzas y machetes por medio de ataques inesperados. Véase en Cassá, R., Historia económica y social de la República Dominicana. Santo Domingo, 2003, vol. I, p. 215.
} 
de La Tortuga y la zona norte de la isla. Ello permitió que finalmente los franceses se apoderasen de La Tortuga, desde la que accedieron a la parte occidental de la isla formando en ella la colonia francesa. Alrededor de 1650, los rumores de un posible ataque inglés con el objetivo de apoderarse de Santo Domingo y demás posesiones americanas, forzaron a la Corona Española a prepararla incrementando el número de fuerzas auxiliares y la pequeña tropa del presidio de Santo Domingo. En 1655 los ingleses lograron desembarcar en la desembocadura del río Haina y en las playas de Najayo, pero el conjunto de fuerzas militares venidas de fuera y las milicias consiguieron derrotarlos.

A partir de entonces se hizo necesario contar con más soldados y con un Ejército regular que se organizó en compañías de caballería y artillería compuestas por "gente noble y caballeros de la ciudad de Santo Domingo", además de las milicias integradas por la propia población ${ }^{2}$. Sin embargo, el establecimiento de los franceses en la parte occidental de la isla, así como sus continuos ataques sobre distintas partes de la isla, demostró que la organización militar con la que contaba Santo Domingo no era lo suficientemente fuerte, a pesar de la victoria española en la batalla de Sabana Real o La Limonade celebrada en 1691.

Otra de las características del Ejército de Santo Domingo era la precaria instrucción de los componentes de las milicias y las guarniciones de las fortalezas. La inexistencia de reuniones entre ellos, la falta de coordinación y el escaso material de armamento que poseían para realizar el servicio contribuyó a esa insuficiencia en la defensa de la isla. Esta limitada preparación y organización del aspecto militar se dio tanto en Santo Domingo como en el resto de los territorios americanos, y se puso de manifiesto de nuevo durante el siglo XVIII cuando una escuadra inglesa tomó La Habana en 1762. Como consecuencia de este hecho, la preocupación de la Corona hizo que se llevara a la práctica un nuevo programa de reestructuración de la defensa y lo militar que afectó a toda América ${ }^{3}$.

\footnotetext{
2 Moya Pons, F., "La defensa militar de Santo Domingo" en III Congreso Venezolano de Historia. Caracas, 1979, vol. II, pp. 311-332, p. 332.

${ }^{3}$ Sobre el sistema defensivo de Santo Domingo durante los siglos XVI y XVII véanse: Moya Pons, F., Historia colonial de Santo Domingo. Santiago, 1977, pp. 259-263. Utrera, F. C. de, Historia militar de Santo Domingo (Documentos y noticias). Ciudad Trujillo, 1953, III vols. Rodríguez Demorizi, E., “Invasión inglesa de 1655”. BAGN 88-89 (Ciudad Trujillo, 1956) pp. 6161. Peña Batlle, M. A., La isla de La Tortuga. Santo Domingo, 1988. Gíl-Bermejo García, J., La Española. Anotaciones históricas (1600-1650). Sevilla, 1983, pp. 202-210. Martín Rebolo, I.,
} 


\subsection{La guarnición militar de Santo Domingo en el siglo XVIII}

A principios del siglo XVIII la defensa de la ciudad de Santo Domingo estuvo en manos de ocho compañías de infantería, una compañía de artillería también conocida con el nombre de artilleros, dos compañías de patricios encargadas de custodiar las costas y fronteras del norte y sur de la isla, y las milicias, formadas por la propia población que acudía en caso de necesidad. La composición de estas guarniciones militares fue variable en cuanto al número de soldados con los que contaba cada una de ellas. Generalmente todas sus plazas no estuvieron cubiertas al completo debido a la escasez de población y de personas interesadas en participar. Asimismo, al igual que en el siglo XVII, continuaron faltando coordinación y normas que regulasen las guarniciones militares, por lo que cada una de ellas actuaba con gran independencia ${ }^{4}$. Estas deficiencias fueron habituales en todo el continente americano hasta que a mediados del siglo XVIII se fueron introduciendo algunas modificaciones con el objeto de mejorar la defensa militar en Indias.

Los pilares básicos de esos cambios siguieron siendo los arreglos de las murallas que protegían las ciudades y el aumento de las obras de fortificación en puntos estratégicos, que permitieron mejorar la defensa. Esto se completó con el perfeccionamiento de las guarniciones militares y su regulación a través de reglamentos específicos para cada lugar. El primero que recibió esta normativa fue Buenos Aires en 1718, Cuba en 1719, Cartagena en 1721 y la cuarta ciudad fue Santo Domingo en 1738, extendiéndose sucesivamente esta organización a las guarniciones de Puerto Rico en 1739, Perú y Chile en 1753 y Yucatán en 1754, entre otras ${ }^{5}$. Según el reglamento de 1738, la mejora del sistema defensivo de Santo Domingo se centró en la creación de un Batallón de Infantería que estuvo compuesto por siete compañías, seis compañías sencillas y una compañía de

Ejército y Sociedad en las Antillas, Siglo XVIII. Madrid, 1992, pp. 63-65, y 93. Cassá, R., Historia económica y social..., op. cit., vol. I, pp. 102-107. En estas dos últimas obras también se encuentran referencias al siglo XVIII, así como en el trabajo de Sevilla Soler, Mª R., Santo Domingo. Tierra de Frontera (1750-1800). Sevilla, 1980, pp. 323-329. Véase también Gascón, M., “The Military of Santo Domingo, 1720-1764”. HAHR 73:3 (Durham, 1993) pp. 431-452, y Rivas, C., "The Spanish Colonial Military: Santo Domingo 1701-1779". The Americas 60: 2 (Washington, 2003) pp. 249-272.

${ }^{4}$ Martín Rebolo, I., Ejército y Sociedad... op. cit., pp. 64-65.

${ }^{5}$ Marchena Fernández, J., Oficiales y soldados en el Ejército de América. Sevilla, 1983, pp. 5255. 
granaderos. Sus jefes militares fueron un capitán, puesto que generalmente ejercía el teniente de rey, un teniente y un subteniente. La tropa de estas compañías la formaba un total de 637 plazas, siendo el cuerpo militar más importante de Santo Domingo $^{6}$. Su uniforme se compuso de casaca, chupa y calzón de lienzo en color blanco igual que el botón, y una buelta y collarín azul ${ }^{7}$.

La compañía de artillería aumentó su número de tropa hasta alcanzar 61, más los tres oficiales, un capitán, un teniente y un subteniente. Su uniforme estaba formado por una casaca y calzón azul, botón dorado, chupa blanca de lienzo y sombrero con galón de seda amarillo $^{8}$. A su vez, el reglamento estableció la sustitución de las compañías de patricios con la creación de dos compañías de caballería que cubrirían las mismas zonas que las anteriores, cada una de ellas debía estar compuesta por 50 hombres y tres oficiales encargados de su mando: un capitán, un teniente y un subteniente. A diferencia del resto de las compañías militares este último grado recibía el nombre de alférez ${ }^{9}$. Hacia 1769 cada compañía contaba con 43 soldados montados, estando la del norte bajo las órdenes del capitán y teniente coronel Gaspar Leos-Echalas, el teniente Ignacio de la Rocha y el alférez Francisco Zervero. Mientras que en la del sur, el capitán fue Fernando Manuel de Espinosa y Miranda, el teniente José Pepín González y el alférez Nicolás Montenegro. Tanto la compañía del norte como la del sur tenían la misma vestimenta, una casaca azul con cuellezuelo y solapa encarnados, calzón azul y chupa blanca de lienzo con sombrero de galón de plata. En cuanto al armamento, exceptuando las espadas y las sillas no había uniformidad, además los caballos utilizados debían ser mantenidos por ellos mismos ${ }^{10}$.

A partir de la aparición del reglamento, la defensa de la isla estuvo a cargo de dicho batallón, las citadas compañías de artillería y de caballería, y las milicias. No obstante, la gran reforma de estos cuerpos militares que se encargaban de la

\footnotetext{
${ }^{6}$ Reglamento del Batallón de la guarnición de la plaza de Santo Domingo, 12 de septiembre de 1738. AGI, Santo Domingo, 237.

${ }^{7}$ Carta del gobernador de Santo Domingo Isidro Peralta y Rojas de 6 de abril de 1783, dando cuenta del estado de las tropas veteranas y de milicias que hay en aquella isla. AGI, Santo Domingo, 946.

${ }^{8}$ Estado que manifiesta la tropa que se presentó en la revista e inspección pasada por el capitán general de la isla Manuel Azlor y Urríes, 15 de diciembre de 1766. AGI, Santo Domingo, 932.

${ }^{9}$ Reglamento del Batallón de la guarnición de la plaza de Santo Domingo, 12 de septiembre de 1738. AGI, Santo Domingo, 237.

${ }^{10}$ Extractos de la revista de todas las atenciones de la isla de Santo Domingo, 31 de mayo de 1769. AGI, Santo Domingo, 1044.
} 
defensa militar en Santo Domingo, así como de los de cada zona del continente americano, se produjo después de la toma de La Habana por los ingleses en 1762. Este hecho fue el verdadero factor que desencadenó la reordenación militar y de la marina de América. Tras la recuperación de La Habana, Carlos III inició un plan de reforma en Cuba para reorganizar las fuerzas regulares y las milicias, siendo éstas el objetivo principal con la intención de convertirlas en cuerpos profesionales capaces de la defensa de la isla. Esta labor fue desarrollada bajo el mando de Alejandro O’Reilly, y una vez encauzada en esta isla acabó implantándose en el resto del continente americano. Si bien tanto las fuerzas regulares como las milicias sufrieron una reorganización interna, también se les proporcionó nuevos uniformes, medios y personal necesario para hacer frente a cualquier situación de ataque y defensa. Además se les dotó de una reglamentación propia para su instrucción, disciplina y buen funcionamiento interno. En lo sucesivo, las milicias se convirtieron en el grueso del Ejército militar americano, es decir, en los cuerpos principales para resguardar y defender cada territorio. Hacia la segunda mitad del siglo XVIII, el Ejército de Santo Domingo quedó formado por las milicias, el Ejército de dotación y las unidades de refuerzo.

\subsubsection{Las milicias}

Los primeros pasos en la organización de las milicias dominicanas fueron dados por los gobernadores Manuel Azlor y Urríes y José Solano y Bote, este último altamente experimentado ya que en Venezuela había dirigido las reformas de las unidades de milicias de aquella provincia ${ }^{11}$. Fue a partir de 1769 cuando se inició la reestructuración de las antiguas unidades de milicias existentes, las cuales se organizaron en batallones y regimientos, asignados cada uno de ellos a oficiales veteranos e instructores que vinieron desde España y Cuba como colaboradores para adoctrinar a las milicias y ponerlas en funcionamiento.

Esta política se plasmó en Santo Domingo con la creación de varias compañías de voluntarios regladas o disciplinadas, tanto de infantería como de

\footnotetext{
${ }^{11}$ García, J. G., Compendio de la historia de Santo Domingo. Santo Domingo, 1982, vol. I, p. 204. Reglamento instructivo para las milicias de Venezuela propuestas por José Solano y Bote, 1 de octubre de 1766. AGS, SGU, 7198.
} 
caballería. En 1769 se fundaron quince compañías de milicias de infantería. El propósito fue que la isla contara con una tropa formada por la población de la misma, para que defendiera su territorio en caso de ataque inmediato, de ahí que también se les conocieran como compañías de voluntarios. Se reunían los domingos para tomar el ejercicio doctrinal militar y el demás tiempo lo empleaban en sus tareas personales ${ }^{12}$. En función del color de la piel de quienes las componían estuvieron divididas en dos, una compañía de blancos y la otra de morenos. Tanto una como la otra tenían tres oficiales que las dirigían (capitán, teniente y subteniente) aunque los sueldos variaban, siendo mayores los de la primera compañía como muestra la tabla 3-1. Además los oficiales cobraban mensualmente, mientras que los sargentos y tambores lo hacían diariamente y su sueldo era conocido como prest ${ }^{*}$.

La compañía de blancos estaba integrada por doce compañías, que a su vez debían estar compuestas por 100 hombres, aunque en ocasiones no estuvieron al completo. Se distribuían por la isla de manera que la ciudad de Santo Domingo tenía cuatro, Santiago dos, y una los pueblos de San Carlos, el Seibo, La Vega, Hincha, Azua y otra que cubría Montecristi y Puerto Plata. La compañía de morenos estuvo formada por el mismo número de hombres y por tres cuerpos, uno en Santo Domingo y los otros en La Vega y Santiago ${ }^{13}$. Su uniforme era costeado por cada soldado, estando compuesto por una casaca, chupa, botón y calzón blanco de lienzo, buelta, collarín y alamares encarnados ${ }^{14}$.

\footnotetext{
${ }^{12}$ Estado que manifiesta el número de compañías y domicilios en que están establecidas las milicias disciplinadas, 25 de abril de 1790. AGI, Santo Domingo, 954.

* El "prest" es un término de origen francés y se refiere en el Ejército a la paga diaria y el pan que recibían algunos de sus miembros.

${ }^{13}$ Estado que manifiesta la tropa que se presentó en la revista de inspección pasada por el brigadier de los Reales Ejércitos, Gobernador y Capitán General de la isla Española e Inspector de la tropa reglada y milicia de ella, Isidro Peralta y Rojas, con noticia de su armamento y demás conducentes al perfecto conocimiento y disciplina del cuerpo de Voluntarios de Infantería de Santo Domingo, 17 de septiembre de 1784. AGI, Santo Domingo, 1088.

${ }^{14}$ Carta del gobernador de Santo Domingo Isidro Peralta y Rojas de 6 de abril de 1783, dando cuenta del estado de las tropas veteranas y de milicias que hay en aquella isla. AGI, Santo Domingo, 946. Estado que manifiesta el número de compañías y domicilios en que están establecidas las milicias disciplinadas, 25 de abril de 1790. AGI, Santo Domingo, 954.
} 
Tabla 3-1. Sueldos de una Compañía de milicias de infantería, 1775

\begin{tabular}{|c|l|c|}
\hline $\begin{array}{c}\text { Número de } \\
\text { plazas }\end{array}$ & \multicolumn{1}{|c|}{ Clase } & $\begin{array}{c}\text { Sueldos mensuales en } \\
\text { pesos }\end{array}$ \\
\hline 1 & Comandante & 142 \\
\hline 2 & Ayudantes mayores & 50 \\
\hline 1 & Tambor mayor & 14 \\
\hline 1 & Primer pífano & 14 \\
\hline 1 & Segundo pífano & 11 \\
\hline 9 & Capitanes blancos & 34 \\
\hline 11 & Capitanes morenos & 10 \\
\hline 3 & Tenientes blancos & 20 \\
\hline 3 & Tenientes morenos & 7 \\
\hline 12 & Subtenientes blancos & 16 \\
\hline 3 & Subtenientes morenos & 5 \\
\hline 12 & Sargentos blancos & 13 \\
\hline 13 & Sargentos morenos & 4 \\
\hline 12 & Tambores blancos & 8 \\
\hline 3 & Tambores morenos & $2 \$$ y 4 rs. \\
\hline
\end{tabular}

Elaboración propia. Fuentes: Ajustamiento que se hizo en las Milicias de Infantería arregladas en esta isla para el ahorro, 20 de octubre de 1775. AGN, Documentación colonial, leg. 10, exped. 6. Relación que instruye el número de tropa de milicias de Infantería de la isla de Santo Domingo, 24 de noviembre de 1789. AGS, SGU, 7164.

En 1769 también se crearon seis compañías de caballería de milicias disciplinadas que sustituyeron a las dos existentes hasta entonces situadas una en la frontera norte y la otra en la del sur. Estas seis nuevas compañías estaban formadas por 50 hombres cada una, es decir, un total de 300 miembros. La oficialidad de cada compañía también estaba integrada por un capitán, un teniente y un alférez. Hacia 1789 estos oficiales cobraban su sueldo mensualmente, recibiendo el primero 36 pesos, el segundo 25 y el tercero 22, cantidades de dinero más altas que las percibidas por los oficiales de las milicias de infantería; en cambio los primeros sargentos gozaron de un prest de 18 pesos y 16 los tambores ${ }^{15}$.

Sus soldados conocidos como “dragones” podían trasladarse con rapidez a cualquier lugar de la isla donde fuesen necesarios, y tenían una gran capacidad de combate, a diferencia de los de infantería que debido a su pesado armamento y al mal estado de los caminos entre los poblados eran más lentos. Además este tipo de soldados podían realizar sus servicios alternativamente a pie o a caballo,

\footnotetext{
${ }^{15}$ Estado que manifiesta el número de compañías y domicilios en que están establecidas las milicias disciplinadas de Santo Domingo, 25 de abril de 1790. AGI, Santo Domingo, 954.
} 
aunque era mucho más frecuente el segundo caso $^{16}$. Estas compañías de voluntarios de dragones estaban destinadas en pueblos cercanos a la frontera, así una de ellas estuvo en Dajabón, otra en Baní, en San Juan de la Maguana, en San Miguel de la Atalaya y dos en Santiago, con el fin de vigilar la zona fronteriza. Esta última ciudad contó con un total de cinco compañías, tres de milicias de infantería, y las dos ya citadas de caballería. El motivo por el que se establecieron más unidades militares fue con el objeto de evitar que su población realizase comercio ilícito con los franceses. El uniforme que llevaban las compañías de milicias de caballería era uno de los más lujosos del Ejército americano, el de Santo Domingo se componía de casaca, chupa y calzón de lienzo blanco, buelta, collarín y solapa azul y botón blanco ${ }^{17}$.

Existieron otras unidades de milicias, las llamadas guardias urbanas, formadas por aquellos vecinos de la isla que no fueron integrados en las anteriores compañías de milicias debido a "[...] su edad, achaques, distancia del domicilio, rusticidad y poca calidad [...]”, de manera que estuvieron agrupados en este tipo de compañías sueltas ${ }^{18}$. Todos los pueblos de la isla contaron con este modelo de milicias; sus miembros vivían en sus propias casas y en el campo, y sólo en caso de necesidad se recurría a ellos. La mayor parte de sus integrantes era gente de color, aunque también había blancos. Se reunían una vez al año para la revista general y sus armas eran el machete y las lanzas. Hacia 1789 estuvieron compuestas por una fuerza efectiva de 5.715 hombres, distribuidos unos 986 en las 12 leguas del contorno de la capital, mientras que el resto, 4.729, residían en el interior de la isla; ello sin contar a los oficiales que no tuvieron sueldo, sólo el grado militar correspondiente ${ }^{19}$.

En 1782 se creó otra unidad militar de este estilo, la compañía suelta de fieles prácticos, formada por vecinos que vivían cerca de la frontera. Su misión fue realizar rondas a lo largo de la frontera con los franceses, celando el trato ilícito y furtivo e introducción de ganados en ella. Estas unidades se establecieron en los pueblos de Dajabón, San Rafael, Caobas y Neiba. Cada una de ellas se

\footnotetext{
${ }^{16}$ Marchena Fernández, J., Oficiales y soldados..., op. cit., p. 66.

${ }^{17}$ Carta del gobernador de Santo Domingo, Isidro Peralta y Roja,s de 6 de abril de 1783, dando cuenta del estado de las tropas veteranas y de milicias que hay en aquella isla. AGI, Santo Domingo, 946. Véase también Sevilla Soler, Mª . R., Santo Domingo..., op. cit., pp. 332-333.

${ }^{18}$ Relación que instruye el número de urbanos que componen la isla de Santo Domingo, 24 de noviembre de 1789. AGS, SGU, 7164.

${ }^{19}$ Ibidem.
} 
componía de 120 hombres y su mando estuvo bajo un capitán, un teniente y un alférez. Su uniforme distintivo constó de chupa corta, calzón azul y solapa encarnada $^{20}$.

\subsubsection{El Ejército de dotación}

La tropa regular de Santo Domingo encargada de defender su plaza estuvo compuesta por el Batallón Fijo de infantería y la compañía de artillería, ambas al igual que las milicias experimentaron cambios pero tan sólo en el número de sus componentes. Así, siguiendo la política de reforma militar de los Borbones, en 1771 el Batallón Fijo presentó los primeros cambios al ascender a nueve frente a las siete de antes, una de granaderos y el resto fusileros o sencillas. También se aumentó su número al crearse tres puestos, un sargento como oficial en cada compañía sencilla y dos subtenientes abanderados situados en la plana mayor. De manera que la plana mayor del Batallón Fijo estaba compuesta por el comandante, el sargento mayor, el ayudante mayor, y dos subtenientes. En cambio cada compañía estaba integrada por tres oficiales: un capitán, un teniente y un subteniente, luego le seguía dos sargentos y los cabos, aunque en cada compañía de fusileros o sencilla hubo tres sargentos ${ }^{21}$. Además también se les incrementó los sueldos, siendo más alto el de los oficiales de la compañía de granaderos ${ }^{22}$. Un año más tarde, en 1772, el número de las compañías fue aumentado de nuevo llegando a doce ${ }^{23}$. De entre estas compañías, nueve fueron las encargadas de la defensa militar de la ciudad de Santo Domingo. Las otras tres guarnecieron la zona fronteriza, que hacia 1781 se alternaron con las nueve restantes mientras que en 1789 fueron cuatro los destacamentos que salieron semanalmente hacia esa

\footnotetext{
${ }^{20}$ Carta del gobernador de Santo Domingo Isidro Peralta y Rojas de 6 de abril de 1783, dando cuenta del estado de las tropas veteranas y de milicias que hay en aquella isla. AGI, Santo Domingo, 946. Sevilla Soler, Mª. R., Santo Domingo..., op. cit., pp. 333-334. Martín Rebolo, I., Ejército y Sociedad..., op. cit., p. 94.

${ }^{21}$ Rodríguez Demorizi, E., Milicias de Santo Domingo (1786-1821). Santo Domingo, 1978, pp. 9 y 101.

${ }^{22}$ Reglamento de los goces mensuales, que deberá tener los oficiales, y demás individuos Batallón Fijo y la Compañía de Artillería, Aranjuez 18 de junio de 1771. AGI, Santo Domingo, 1089.

${ }^{23}$ Sevilla Soler, Ma . R., Santo Domingo..., op. cit., pp. 326-327. Martín Rebolo, I., Ejército y Sociedad..., op. cit., p. 69.
} 
área. La dotación total de la unidad debía ser de 847 según el reglamento, sin embargo hacia 1789 su fuerza efectiva era de $658^{24}$.

La compañía de artillería también sufrió algunos cambios, concretamente en 1779 al verse aumentada con la creación de dos nuevas plazas, por lo que su guarnición pasó de 61 a 63 hombres, más los tres oficiales ${ }^{25}$. Frente al resto de las compañías existentes en la isla, ésta estuvo compuesta por los soldados más cualificados y sus oficiales tuvieron sueldos idénticos a los de la compañía de granaderos del Batallón Fijo de igual graduación, como muestra la tabla 3-2. Sin embargo, los oficiales de ambas compañías constituían el grupo social militar más elevado $^{26}$.

Tabla 3-2. Sueldos del Regimiento de infantería y de una Compañía de artillería, 1771

\begin{tabular}{|l|r|r|r|}
\hline \multicolumn{1}{|c|}{ Clases } & $\begin{array}{c}\text { Compañía de } \\
\text { granaderos }\end{array}$ & $\begin{array}{c}\text { Compañía } \\
\text { de fusileros }\end{array}$ & $\begin{array}{c}\text { Compañía de } \\
\text { artillería }\end{array}$ \\
\hline Capitán & 70 & 60 & 70 \\
\hline Teniente & 44 & 40 & 44 \\
\hline Subteniente & 34 & 32 & 34 \\
\hline Sargento de primera & 18 & 16 & 18 \\
\hline Sargento de segunda & 16 & 14 & 15 \\
\hline Tambor & 11 & 10 & 11 \\
\hline Cabos primeros & 12 & 11 & 14 \\
\hline Cabos segundos & 11 & 10 & 12 \\
\hline Soldados & 10 & 9 & 10 \\
\hline Soldados artilleros & & & 12 \\
\hline Soldados minadores & & & 12 \\
\hline Soldados bombarderos & & & \\
\hline
\end{tabular}

Elaboración propia. Fuentes: El sueldo mensual está reflejado en pesos. El cabo primero de la compañía de artillería recibía el nombre de bombardero y el segundo artillero. Reglamento de los goces mensuales, que deberán tener los oficiales, y demás individuos del Batallón Fijo y la Compañía de Artillería, Aranjuez18 de junio de 1771. AGI, Santo Domingo, 1089.

\footnotetext{
${ }^{24}$ Relación que instruye el pie y fuerza con que se halla el Batallón Fijo de Infantería de la isla de Santo Domingo, 24 de noviembre de 1789. AGS, SGU, 7164.

${ }^{25}$ Sevilla Soler, Ma . R., Santo Domingo..., op. cit., 329. Martín Rebolo, I., Ejército y Sociedad..., op. cit., p. 69.

${ }^{26}$ Marchena Fernández, J., Oficiales y soldados..., op. cit., p. 65.
} 


\subsubsection{Las unidades de refuerzo}

Junto a estos cuerpos militares hubo en Santo Domingo otros que sirvieron de refuerzo a los ya existentes. Estas unidades, también conocidas como “ejército de operación en Indias”, fueron enviadas desde la Península para incrementar la guarnición de la isla en caso de conflicto con otras potencias y de situaciones de peligro, y una vez concluida su labor regresaban a España. En cambio, la mayoría de las que llegaron a Santo Domingo lo hicieron de paso, pues su destino eran otros lugares del continente americano. Tal fue el caso de la llegada de los batallones de los regimientos de Granada y Murcia en 1762 como consecuencia del conflicto con Inglaterra, pero la toma de La Habana hizo que estas dotaciones militares permanecieran por poco tiempo en la isla y fuesen enviadas a Cuba para impedir un ataque completo sobre dicha isla.

En 1780 otra unidad de refuerzo llegó a Santo Domingo, el regimiento de infantería de Enghien, compuesta por un batallón con diez divisiones y un total de 635 hombres. La novedad de esta tropa de refuerzo era que procedía de la parte occidental de la isla. Su entrada estuvo motivada por el temor de una invasión inglesa como resultado de la intervención conjunta que habían llevado a cabo las Coronas Española y Francesa en la guerra de Independencia de los Estados Unidos contra Inglaterra. Poco después, el 20 de febrero de 1783, regresaron a la parte francesa. Pero antes de ello se produjo la llegada desde la Península de otras tres unidades de refuerzo, los regimientos de Zamora, León y Extremadura, que sustituyeron a las anteriores aunque también por poco tiempo, pues su destino eran las campañas del Guarico, Providencia, Lucayas y Lima. A finales del siglo XVIII hubo otro grupo de unidades militares de refuerzo que llegaron a la isla, con el fin de defender las posesiones españolas ante los posibles ataques de las fuerzas que defendían la independencia de Haití. Estas unidades americanas procedían de Cuba, Puerto Rico y Nueva España, y se establecieron en la isla hasta la cesión de la parte española de la isla a Francia. El resto de las tropas de Santo Domingo fueron ordenadas abandonar la isla, pero el retraso en la entrega de la parte española y la declaración de guerra a Inglaterra, que atacó el puerto de Neiba en 1797, obligó a que tan sólo una parte de éstas se trasladasen a Puerto Rico, permaneciendo el regimiento de infantería y el de artillería en la isla. Al 
realizarse en 1801 la entrega de la parte española, los miembros de las tropas abandonaron la capital de Santo Domingo teniendo como destino Cuba o Puerto Rico $^{27}$.

\subsection{La oficialidad del Ejército}

El mando sobre este conjunto militar pertenecía a un grupo de jefes militares conocidos como oficiales. Dentro de este cuerpo se distinguían los altos oficiales que integraban el Estado Mayor de la Plaza de Santo Domingo, es decir, el grupo social militar más elevado encargado de coordinar la defensa de dicha plaza. Los otros eran los oficiales que dirigían directamente los destacamentos militares regulares de la isla, las milicias y aquellos que venían con las unidades de refuerzo para el mando de éstas.

El cuerpo del Estado Mayor de esta plaza estaba formado por el gobernador, que se situaba a la cabeza con el título de capitán general, tras él el teniente de rey, que al mismo tiempo era el comandante o coronel del Batallón Fijo de infantería por estar unido un empleo al otro ${ }^{28}$. Les seguía el sargento mayor, que a principios del siglo XVIII desempeñaba el mando de una de las compañías de infantería, pero a partir del reglamento de 1738 se le prohibió tener mando sobre alguna unidad, y sólo podía ejercerlo como ayudante del coronel en casos excepcionales. Su función desde entonces fue meramente administrativa, era el encargado de llevar la contabilidad, distribuir órdenes, el santo y seña, y vigilar el comportamiento y la disciplina ${ }^{29}$. Luego estaba el ayudante mayor, quien coordinaba el sistema defensivo y actuaba como un auxiliar administrativo del sargento mayor. Este colectivo estaba a su vez al frente del Batallón Fijo de infantería de la ciudad de Santo Domingo constituyendo su plana mayor. De igual forma la compañía de artillería, las unidades de milicias de infantería y caballería contaban en su plana mayor con algunos de estos miembros y con un inspector

\footnotetext{
${ }^{27}$ Hasta el momento las únicas referencias bibliográficas a cerca de estas unidades militares se encuentran en las siguientes obras: Martín Rebolo, I., Ejército y Sociedad..., op., cit., pp. 69-70, y Marchena Fernández, J., Oficiales y soldados..., op. cit., pp. 52 y 56-58.

${ }^{28}$ Extracto del estado de las tropas y milicias en la Isla Española de Santo Domingo, 20 de enero de 1783. AGI, Santo Domingo, 946.

${ }^{29}$ Al respecto véase el artículo treinta y seis del reglamento, ya citado, para Santo Domingo de 1738. AGI, Santo Domingo 237. Acerca del grado de Sargento Mayor en el Ejército americano véase en Marchena Fernández, J., Oficiales y soldados..., op. cit., pp. 25, 67 y 72.
} 
general. Debe destacarse que este grupo directivo que conformaba la alta oficialidad ejerció un mando más político-administrativo que militar sobre la tropa. Las personas que ocuparon tales graduaciones dentro del Ejército hispanoamericano fueron habitualmente peninsulares, sin embargo en Santo Domingo los puestos de sargento mayor y ayudante estuvieron en general en manos de criollos ${ }^{30}$.

A estos seguían otros cargos complementarios que conformaban el Estado Mayor de la Plaza de Santo Domingo, como los ingenieros encargados de dirigir las obras arquitectónicas militares y el sobrestante mayor de fábricas que llevaba las cuentas de los materiales y de las fortificaciones. El servicio religioso estaba integrado por dos capellanes que velaban por la religiosidad de los militares, y el sanitario por un médico (cirujano) y su colaborador, conocido como protomedicator o practicante mayor, un controlador y mayordomo encargado de administrar el Hospital Real militar de San Nicolás de Bari. A estos se añadían los responsables de los Reales Almacenes, el guardalmacén y sus ayudantes, cuya función era resguardar y llevar el estado de los pertrechos militares y los víveres: el capitán era el responsable del almacén de armas y el maestro armero estaba empleado en custodiar, recomponer y limpiar las mismas. Otros oficios eran el castellano de la fortaleza de San Jerónimo, encargado de dirigir dicho fortín situado en la desembocadura del río Haina, un tambor mayor y cuatro músicos que tenían la denominación de chirimías y cuya función era "tocar en las procesiones del Santisimo Sacramento"31. Cada regimiento o compañía militar contaba también en su plana mayor con sus propios servicios, así por ejemplo las compañías de milicias de infantería tenían un cirujano y dos pífanos, mientras que el Batallón Fijo un capellán, un cirujano, un maestro armero, un tambor mayor y dos pífanos, y la compañía de artillería un armero, un tambor, un herrero y un carpintero $^{32}$.

\footnotetext{
${ }^{30}$ Martín Rebolo, I., Ejército y Sociedad..., op. cit., p. 181.

${ }^{31}$ Carta del gobernador de Santo Domingo en la que dirige relación individual de los empleos perpetuos y temporales políticos, militares y de real hacienda que se pagan por las Reales Cajas de Santo Domingo, de los que se sirven sin pagarse y de los que no tienen señalamiento fijo, formada en conformidad de las reales ordenes de 25 de agosto de 1780 y de 12 de marzo de 1783. AGI, Santo Domingo, 922. Estado mayor de la plaza e inválidos, 6 de abril de 1783. AGI, Santo Domingo, 946.

${ }^{32}$ Estado de la tropa que se presentó en la revista de inspección a las milicias de Infantería de Santo Domingo realizadas por el gobernador y capitán general Isidro Peralta y Rojas, con noticia de sus armas y demás conducente al perfecto conocimiento y disciplina de este cuerpo, 17 de
} 
El Ejército

Figura 3-1. Plaza de Santo Domingo

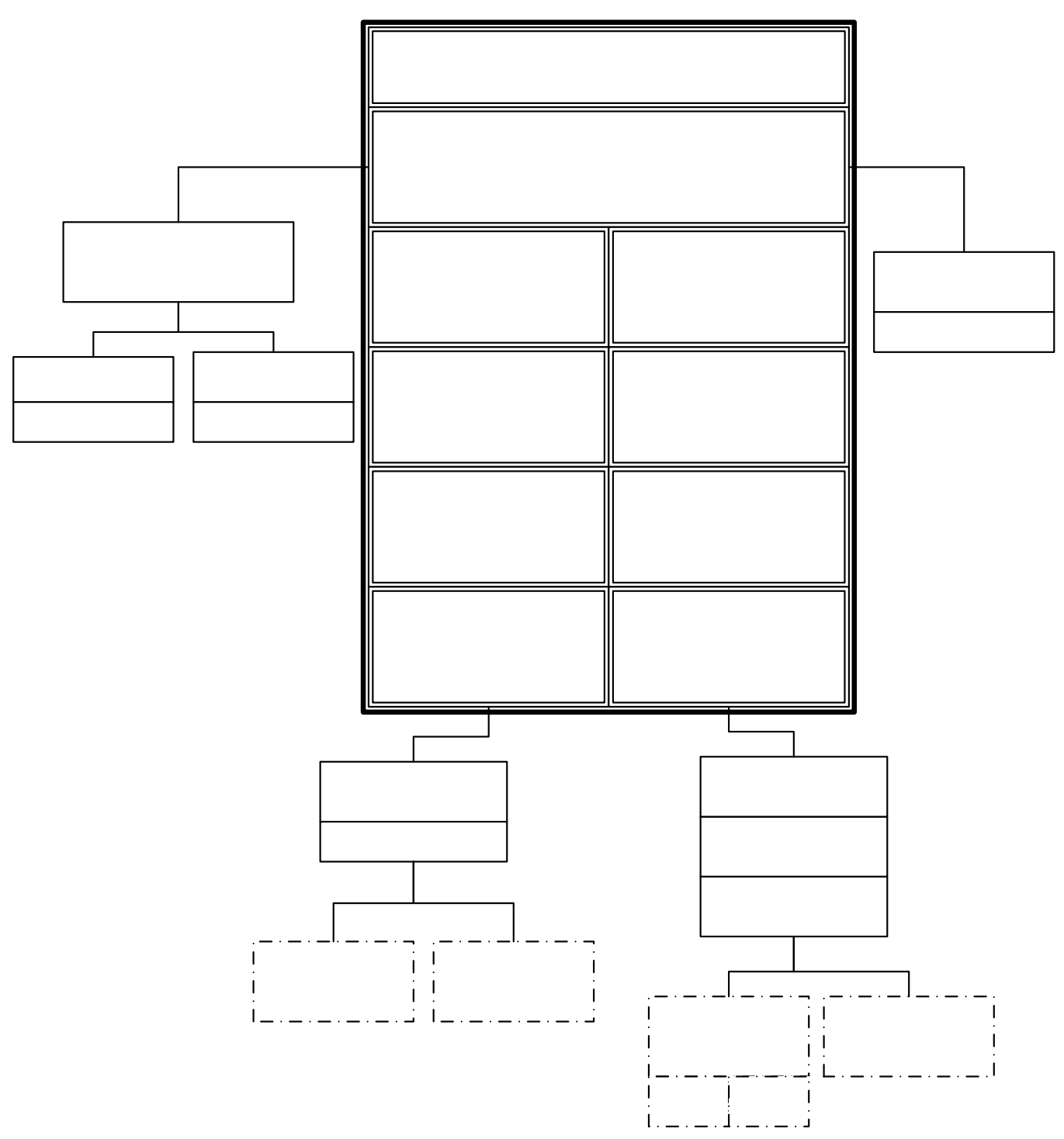

Elaboración propia. Fuentes: El cuerpo de artillería era el más antiguo, pues había sido creado en 1710. Estado del ejército que hay en la isla Española de Santo Domingo, 20 de Enero de 1783. AGI, Santo Domingo, 946. Organigrama elaborado a partir de la obra de Marchena Fernández, J., Oficiales y soldados..., op. cit., p. 87.

\section{Colaboradores no}

septiembre de 1784. AGI, Santo Domingo, 1088. Y, Extracto de la revista que pasó el gobernador José Solano y Bote al cuerpo de artillería, 1 de diciembre de 1775. AGN, leg. 9, exped. 14. 
Tabla 3-3. Relación de los cargos y sueldos de los empleos del estado de la plaza de Santo Domingo, 1783

\begin{tabular}{|c|c|c|c|}
\hline Nombre & Cargo & $\begin{array}{c}\text { Fecha de la toma } \\
\text { del cargo }\end{array}$ & $\begin{array}{c}\text { Sueldo } \\
\text { anual }\end{array}$ \\
\hline $\begin{array}{l}\text { Isidro Peralta y } \\
\text { Rojas }\end{array}$ & $\begin{array}{l}\text { Presidente, Gobernador } \\
\text { y Capitán General }\end{array}$ & 3 de agosto de 1778 & 8.000 \\
\hline Joaquín García & $\begin{array}{l}\text { Teniente de rey, y } \\
\text { comandante del } \\
\text { Batallón Fijo }\end{array}$ & 25 de enero de 1780 & 3.000 \\
\hline Ignacio Caro & Sargento Mayor & $\begin{array}{l}23 \text { de noviembre de } \\
1755\end{array}$ & 1.200 \\
\hline Agustín Girón & Ayudante Mayor & $\begin{array}{l}24 \text { de diciembre de } \\
1772\end{array}$ & 600 \\
\hline Antonio Ladrón & Ingeniero & $\begin{array}{l}24 \text { de diciembre de } \\
1779\end{array}$ & $\dot{d} ?$ \\
\hline $\begin{array}{l}\text { Pedro Roig de } \\
\text { Lluís }\end{array}$ & Ingeniero Delineador & $\begin{array}{l}10 \text { de diciembre de } \\
1779\end{array}$ & $\dot{i} ?$ \\
\hline$\dot{i} ?$ & Sobrestante de fábricas & & 180 \\
\hline$\dot{\imath} ?$ & Armero & & 1.200 \\
\hline $\begin{array}{l}\text { Andrés de } \\
\text { Lecanda }\end{array}$ & Guarda almacén & 28 de junio de 1765 & 300 \\
\hline$\dot{¿} ?$ & $\begin{array}{l}\text { Castellano de San } \\
\text { Jerónimo }\end{array}$ & & 300 \\
\hline$\dot{¿} ?$ & $\begin{array}{l}\text { Capellán del Hospital de } \\
\text { San Lázaro }\end{array}$ & & 132 \\
\hline José de la Vega & $\begin{array}{l}\text { Controlador del } \\
\text { Hospital San Nicolás de } \\
\text { Bari }\end{array}$ & $\begin{array}{l}30 \text { de septiembre de } \\
1777\end{array}$ & 600 \\
\hline Juan Pimentel & $\begin{array}{l}\text { Capellán del Hospital de } \\
\text { San Nicolás de Bari }\end{array}$ & $\begin{array}{l}11 \text { de septiembre de } \\
1777\end{array}$ & 150 \\
\hline Pedro Tevenas & Médico (cirujano) & 11 de junio de 1782 & 300 \\
\hline$\dot{i} ?$ & Practicante Mayor & & 180 \\
\hline ¿? & Comisario de entradas & & 144 \\
\hline$\dot{\imath} ?$ & Mayordomo & & $\dot{2} ?$ \\
\hline $\begin{array}{l}\text { Francisco Pepín } \\
\text { González }\end{array}$ & Inspector General & $\begin{array}{l}26 \text { de diciembre de } \\
1782\end{array}$ & 1.200 \\
\hline$\dot{2} ?$ & Tambor mayor & & \\
\hline$\dot{\imath} ?$ & Chirimías & & 132 \\
\hline
\end{tabular}

Elaboración propia. Fuentes: ¿ ? (desconocido). Las cantidades expresadas están reflejadas en pesos. Carta del gobernador de Santo Domingo en la que dirige relación individual y circunstanciada de todos los empleos políticos, militares y real hacienda de la jurisdicción de su mando, 21 de mayo de 1783. AGI, Santo Domingo, 946. Ajustamiento al estado mayor de esta plaza y su cuerpo, 1775-1777. AGN, Documentación colonial, leg. 10, exped 6.

El segundo grupo de oficiales estaba compuesto por aquellos que mandaban directamente a la guarnición militar, se encargaban de dirigir, ordenar su instrucción y coordinar a la tropa. De modo que cada compañía o batallón estaba compuesto por los siguientes jefes militares que se correspondían con los 
grados medios dentro de la jerarquía militar: el capitán, que era la cabeza de cada compañía; el teniente, que era el ayudante del anterior y podía incluso sustituirle; y por último el subteniente-alférez, quien era a su vez el auxiliar del teniente ${ }^{33}$. En lo que respecta a este grado, hay que señalar que en las unidades de infantería lo que aparece son subtenientes, de hecho con el reglamento de 1738 se produce un cambio de nombre, así el que antes era alférez aparece como subteniente. Mientras que en las compañías de caballería y las de fieles prácticos no hay subtenientes sino sólo alféreces ${ }^{34}$.

Después de este cuerpo que formaba la oficialidad de las distintas unidades militares estaban los jóvenes que se iniciaban en la carrera militar. Se les conocía como cadetes, y generalmente eran hijos de militares que se educaban sirviendo en algún regimiento o batallón al lado de un capitán o teniente; solía haber dos en cada uno de ellos y estaban exentos del servicio mecánico. La presencia de criollos en estos escalones también fue muy abundante, sobre todo en el caso de familias importantes de hacendados de la ciudad de Santo Domingo así como de otros pueblos de la isla.

Por debajo de éstos estaban los subalternos, un grupo también muy notorio formado por los sargentos y la tropa (cabos y soldados). A los sargentos no se les consideraba oficiales propiamente, se situaban entre la oficialidad y los soldados, ya que eran mandados por los jefes citados anteriormente pero los soldados estaban bajo sus órdenes. Procedían habitualmente de la tropa regular en la que habían destacado por su aplicación y conducta, de ahí que fueran ascendidos y premiados con esta graduación. Sin embargo, tenían vedado ocupar cualquier otro puesto dentro de la oficialidad, por ello se mantenían en ese puesto durante toda su carrera militar ${ }^{35}$.

A parte de estos grados, cabría resaltar otra figura dentro de ese escalafón militar, la del oficial graduado. Se trataba de “[...] aquel oficial al cual se le ascendía nominalmente de grado, pero desempeñaba funciones y mando de su

\footnotetext{
${ }^{33}$ Los grados militares en orden ascendente son: soldado, sargento, cadete, subteniente-alférez, ayudante mayor, teniente, capitán, teniente coronel, sargento mayor, coronel, brigadier y mariscal de campo. Estos dos últimos grados generalmente fueron concedidos a los gobernadores o ingenieros. Puede verse en Marchena Fernández, J., Oficiales y solados..., op. cit., pp. 69-79, y 86.

${ }^{34}$ Ibidem., pp. 74-75.

${ }^{35}$ Ibidem., pp. $69-79$.
} 
grado antiguo [...]”36. Es decir, podía darse el caso de que los jefes de una compañía figurasen con "grado de teniente coronel” cuando en realidad eran capitanes. Esto solía suceder cuando había que ascender a un oficial por sus méritos, pero al no existir una vacante en el grado que le correspondía en la unidad, se le elevaba nominalmente porque en la práctica el empleo que ejercía era el que poseía. Como ejemplo, el hacendado José de la Vega fue durante 1783 “capitán graduado” de Ejército de las milicias de infantería de Santo Domingo, cuando en realidad aunque tenía ese título ejercía de teniente. Igualmente, el hacendado José Arata a pesar de poseer el título de “teniente coronel graduado" del regimiento de granaderos del Batallón Fijo de Santo Domingo era en realidad un capitán más dentro de esa compañía, de hecho era uno de los capitanes más antiguos con los que contaba ${ }^{37}$. También podía ocurrir que los oficiales ascendieran de empleo pero no de grado militar, se les conocía entonces como oficiales reformados o interinos ${ }^{38}$. De nuevo José de la Vega sirve de ejemplo. Fue teniente interino de caballería en 1770, es decir, a pesar de ejercer las funciones como teniente no había sido ascendido a esa graduación ${ }^{39}$.

\subsubsection{Grados militares de los hacendados}

El aumento de los criollos en el grupo de la oficialidad se debió a la creación de las milicias, lo que para los vecinos significó la oportunidad de integrarse en el cuerpo militar, así como en el resto de las tropas de la isla. Muchos hacendados se alistaron en las milicias y colaboraron en su formación alcanzando los más altos grados de ellas. Para finales del siglo XVIII las tres redes familiares estudiadas de la ciudad de Santo Domingo, contaban con varios miembros en alguna de las unidades militares de defensa de la isla, bien fuese en las milicias o en las regulares, e incluso en ambas. En su mayoría estos

\footnotetext{
${ }^{36}$ Ibidem., p. 76.

37 José de la Vega durante 1812 tenía el título de “teniente coronel graduado” de milicias de infantería de Coro, ciudad a la que emigró, cuando realmente era un capitán más dentro de esa compañía. Extracto de los méritos y servicios de José de la Vega, 15 de noviembre de 1805 y 22 de noviembre de 1812. AGI, Santo Domingo, 964. Carta de José Arata en la que solicita merced, 8 de mayo de 1796. AGI, Estado 18.

${ }^{38}$ A cerca de ese tipo de graduaciones militares véase Marchena Fernández, J., Oficiales y soldados...op. cit., pp. 76-77.

${ }^{39}$ Extracto de los méritos y servicios de José de la Vega, 15 de noviembre de 1805 y 22 de noviembre de $1812 . .$. , op. cit.
} 
hacendados seleccionados lograron elaborarse un buen currículo militar, empezando desde abajo hasta llegar a obtener no sólo los grados militares más importantes de la oficialidad de una compañía, sino también del Estado Mayor de la plaza de Santo Domingo, o prestaron algún servicio en ella, como se recoge en la tabla siguiente. Aunque hubo algunos que fueron soldados o cadetes sin continuar la carrera militar, por ejemplo José Jacinto Ramírez que estuvo en el Batallón Fijo de la plaza durante once años como cadete, desde el 1 de junio de 1754 hasta el 31 de enero de 1764 antes de seguir la carrera de letras ${ }^{40}$. A pesar de ser un escalafon bajo para ingresar en el Ejército, este proporcionaba prestigio individual y a su grupo familiar, así como seguridad en el Fuero y para continuar la carrera militar. El empleo inicial de cadete significaba una diferencia social que distiguía aquellos que lo ejercían de los demás vecinos, ya que generalmente fue desempeñado por nobles o hidalgos al exigirse acreditar un origen social alto, y por miembros que abarcaba dos o más generaciones de una importante familia que poseía una amplia participación militar. El capitán del batallón Jerónimo Figueroa en el que José Jacinto estuvo expone este hecho del siguiente modo: “[...] ha hecho cuerpo con los estados de noble en cuya virtud el presidente Francisco Rubio le admitio a la plaza de cadete que solo se da a los hombres nobles” ${ }^{\text {41. }}$

Sin embargo, otros miembros de la red Guridi y Alarcón-Coronado a la que pertenecía José Jacinto se dedicaron a la profesión militar, alcanzando el grado de capitán. De hecho el fundador de ésta había participado en la conquista de Venezuela y México hasta que recibió tal designación en una compañía de la plaza de Santo Domingo ${ }^{42}$. (Véase en el anexo la figura 1 el cronograma de esta red familiar)

\footnotetext{
${ }^{40}$ Testimonio de información producida por Antonia Ramírez sobre su distinción y limpieza de sangre en 1770, que amplió su legítimo hermano Manuel en 1783 y 1784. AGI, Santo Domingo, 990.

${ }^{41}$ Ibidem.

${ }^{42}$ Relación de los servicios militares del alférez Antonio de Guridi, cabo de la Infantería de una fragata de la Armada de Barlovento, 10 de noviembre de 1685. AGI, Indiferente General, 130, N1, 22.
} 
Tabla 3-4. Grados militares de los hacendados de Santo Domingo, y sus familiares

\begin{tabular}{|c|c|c|}
\hline Hacendado & Grado militar & Otros \\
\hline $\begin{array}{l}\text { Antonio Guridi y } \\
\text { Echeandia }\end{array}$ & Capitán de infantería & $\begin{array}{l}\text { Sargento Mayor de la } \\
\text { plaza }\end{array}$ \\
\hline Nicolás Guridi y Coronado & $\begin{array}{l}\text { Capitán de infantería y } \\
\text { Coronel de milicias }\end{array}$ & \\
\hline Matías Guridi y Coronado & $\begin{array}{l}\text { Capitán de milicias de } \\
\text { infantería y de caballería }\end{array}$ & \\
\hline Luís Franco Acevedo & $\begin{array}{l}\text { Capitán de milicias } \\
\text { caballería }\end{array}$ & \\
\hline Mateo Franco Guridi & $\begin{array}{l}\text { Soldado distinguido del } \\
\text { Batallón Fijo }\end{array}$ & $\begin{array}{l}\text { Ayudante de la plaza en } \\
\text { dragones }\end{array}$ \\
\hline Luís Franco Guridi & Teniente del Batallón Fijo & \\
\hline José Jacinto Ramírez & Cadete del Batallón Fijo & \\
\hline Silvestre Ramírez Guridi & $\begin{array}{l}\text { Subteniente del Batallón } \\
\text { Fijo }\end{array}$ & \\
\hline José Guridi y Concha & $\begin{array}{l}\text { Capitán de milicias de } \\
\text { infantería }\end{array}$ & \\
\hline Nicolás Guridi y Frómesta & $\begin{array}{l}\text { Cadete del regimiento de } \\
\text { infantería de Saboya }\end{array}$ & \\
\hline $\begin{array}{l}\text { Manuel Heredia Serrano } \\
\text { Pimentel }\end{array}$ & $\begin{array}{l}\text { Capitán de milicias de } \\
\text { infantería y de urbanos }\end{array}$ & \\
\hline Antonio Mañón de Lara & $\begin{array}{l}\text { Capitán de milicias de } \\
\text { infantería y de urbanos }\end{array}$ & \\
\hline $\begin{array}{l}\text { José Mañón de Lara } \\
\text { Mieses }\end{array}$ & $\begin{array}{l}\text { Capitán de milicias de } \\
\text { infantería }\end{array}$ & \\
\hline $\begin{array}{l}\text { Esteban Fernández } \\
\text { Palomares }\end{array}$ & $\begin{array}{l}\text { Comandante de milicias } \\
\text { de infantería }\end{array}$ & \\
\hline Manuel de Peralta & $\begin{array}{l}\text { Capitán de milicias de } \\
\text { infantería }\end{array}$ & Ayudante Mayor \\
\hline Antonio Landeche & Teniente de rey & \\
\hline $\begin{array}{l}\text { Nicolás Leos-Echalas } \\
\text { Heredia }\end{array}$ & $\begin{array}{l}\text { Subteniente del Batallón } \\
\text { Fijo }\end{array}$ & \\
\hline Antonio Coca Landeche & $\begin{array}{l}\text { Teniente del Batallón Fijo } \\
\text { de infantería }\end{array}$ & \\
\hline Antonio Coca Landeche & $\begin{array}{l}\text { Capitán de milicias de } \\
\text { infantería }\end{array}$ & \\
\hline $\begin{array}{l}\text { Damián Coca Landeche y } \\
\text { Oviedo }\end{array}$ & $\begin{array}{l}\text { Capitán de milicias de } \\
\text { infantería y de urbanos }\end{array}$ & \\
\hline $\begin{array}{l}\text { Antonio Coca Landeche y } \\
\text { Oviedo }\end{array}$ & $\begin{array}{l}\text { Coronel de los Reales } \\
\text { Ejércitos }\end{array}$ & \\
\hline Lorenzo Angulo Medrano & $\begin{array}{l}\text { Capitán de urbanos y } \\
\text { teniente de milicias de } \\
\text { infantería }\end{array}$ & \\
\hline $\begin{array}{l}\text { Antonio Angulo Coca } \\
\text { Landeche }\end{array}$ & Cadete del Batallón Fijo & \\
\hline $\begin{array}{l}\text { Andrés Angulo Coca } \\
\text { Landeche }\end{array}$ & $\begin{array}{l}\text { Subteniente de milicias de } \\
\text { infantería }\end{array}$ & \\
\hline Andrés Angulo Cabrera & Cadete en el Batallón Fijo & \\
\hline
\end{tabular}




\begin{tabular}{|c|c|c|}
\hline Hacendado & Grado militar & Otros \\
\hline Francisco Pepín González & $\begin{array}{l}\text { Teniente coronel del } \\
\text { Batallón Fijo }\end{array}$ & \\
\hline $\begin{array}{l}\text { Francisco Pepín González } \\
\text { Coca }\end{array}$ & $\begin{array}{l}\text { Coronel de los Reales } \\
\text { Ejércitos }\end{array}$ & $\begin{array}{l}\text { Inspector General de } \\
\text { frontera y Ayudante } \\
\text { Mayor }\end{array}$ \\
\hline Martín José de Miura & $\begin{array}{l}\text { Teniente del Batallón Fijo } \\
\text { de infantería }\end{array}$ & \\
\hline Joaquín Cabrera & $\begin{array}{l}\text { Coronel de los Reales } \\
\text { Ejércitos y Comandante de } \\
\text { las milicias de infantería }\end{array}$ & $\begin{array}{l}\text { Sargento Mayor de la } \\
\text { plana mayor del Batallón } \\
\text { Fijo }\end{array}$ \\
\hline $\begin{array}{l}\text { Juan Miguel de la Rocha- } \\
\text { Ferrer y Landeche }\end{array}$ & $\begin{array}{l}\text { Alférez retirado del } \\
\text { Batallón Fijo }\end{array}$ & \\
\hline $\begin{array}{l}\text { Ignacio de la Rocha-Ferrer } \\
\text { y Landeche }\end{array}$ & $\begin{array}{l}\text { Graduado de teniente } \\
\text { coronel del Batallón Fijo }\end{array}$ & $\begin{array}{l}\text { Sargento Mayor de la } \\
\text { plaza }\end{array}$ \\
\hline $\begin{array}{l}\text { Rodrigo Macedonio de la } \\
\text { Rocha-Ferrer y Coca } \\
\text { Landeche }\end{array}$ & $\begin{array}{l}\text { Capitán del batallón } \\
\text { veterano de infantería de } \\
\text { Castilla fijo de Campeche } \\
\text { y (continúa agregado al } \\
\text { Batallón Fijo de Santo } \\
\text { Domingo }\end{array}$ & $\begin{array}{l}\text { Ayudante de la plaza y } \\
\text { Sargento Mayor y del } \\
\text { primer batallón de Castilla } \\
\text { fijo (Campeche) }\end{array}$ \\
\hline Antonio Álvarez Barba & Mariscal de campo & Ingeniero \\
\hline Francisco Álvarez Barba & Capitán del Batallón Fijo & $\begin{array}{l}\text { Ayudante mayor de las } \\
\text { milicias }\end{array}$ \\
\hline $\begin{array}{l}\text { Miguel Bernardo Antonio } \\
\text { Ferrer Angulo }\end{array}$ & $\begin{array}{l}\text { Capitán graduado de } \\
\text { Ejército }\end{array}$ & \\
\hline $\begin{array}{l}\text { Domingo Lorenzo } \\
\text { Zevallos }\end{array}$ & $\begin{array}{l}\text { Teniente de milicias de } \\
\text { caballería }\end{array}$ & \\
\hline Antonio Rojas & $\begin{array}{l}\text { Comandante de milicias } \\
\text { urbanas }\end{array}$ & \\
\hline José Tadeo Zevallos & $\begin{array}{l}\text { Teniente de milicias de } \\
\text { caballería }\end{array}$ & \\
\hline Pedro Roig y Lluís & Teniente coronel & Ayudante de ingenieros \\
\hline $\begin{array}{l}\text { Andrés Lecanda y } \\
\text { Andirengoechea }\end{array}$ & & $\begin{array}{l}\text { Guarda-almacén de víveres } \\
\text { y pertrechos }\end{array}$ \\
\hline Joaquín María de Foxá & Coronel de infantería & $\begin{array}{l}\text { Sargento mayor del } \\
\text { regimiento de Cantabria }\end{array}$ \\
\hline $\begin{array}{l}\text { Francisco Xavier Foxá } \\
\text { Lecanda }\end{array}$ & Teniente & \\
\hline $\begin{array}{l}\text { Luís Pérez Guerra y } \\
\text { Trespalacios }\end{array}$ & $\begin{array}{l}\text { Capitán de milicias de } \\
\text { caballería }\end{array}$ & \\
\hline Francisco Espaillat y Virol & & $\begin{array}{l}\text { Médico y cirujano mayor } \\
\text { de las milicias de } \\
\text { Infantería, Caballería y de } \\
\text { Urbanos de Santiago, la } \\
\text { Vega, Montecristi y Puerto } \\
\text { Plata. } \\
\text { Mayordomo, } \\
\text { Administrador y Médico } \\
\text { oficial del Hospital de } \\
\text { Nuestra Señora de la } \\
\text { Asunción y San Sebastián } \\
\text { en Santiago }\end{array}$ \\
\hline
\end{tabular}


Ruth Torres Agudo

\begin{tabular}{|c|c|c|}
\hline Hacendado & Grado militar & Otros \\
\hline $\begin{array}{l}\text { Francisco Antonio Velilla } \\
\text { y Torres }\end{array}$ & $\begin{array}{l}\text { Capitán de las milicias } \\
\text { regladas de Santiago }\end{array}$ & \\
\hline José de la Vega & $\begin{array}{l}\text { Capitán de milicias de } \\
\text { infantería }\end{array}$ & $\begin{array}{l}\text { Inspector General y } \\
\text { Controlador del Hospital } \\
\text { Real de la plaza }\end{array}$ \\
\hline José Arata & $\begin{array}{l}\text { Capitán del Batallón Fijo } \\
\text { de infantería }\end{array}$ & \\
\hline Antonio Cumulat & $\begin{array}{l}\text { Capitán de milicias } \\
\text { urbanas }\end{array}$ & \\
\hline $\begin{array}{l}\text { Ignacio Pérez Caro y } \\
\text { Oviedo }\end{array}$ & Coronel del Batallón Fijo & $\begin{array}{l}\text { Sargento Mayor de la } \\
\text { plaza }\end{array}$ \\
\hline
\end{tabular}

Elaboración propia. Fuentes: AGI, Santo Domingo, 927, 928, 932, 933, 948, 949, 975, 990, 1021, 1087, 1088, 1089 y 1095. Empleos y retiros. AGS, SGU, 7149, 7152, 7154, 7155, 7156, 7290. AGI, Indiferente General, 130, 131, 145, 146, 166. AGI, Indiferente General, 130, 131, 132, 136, 143, 145, 146, 166, 1609, 3001. AGI, Estado 5, 18. AGI, Ultramar 9. AGI, Contratación, 5478, 5452. AGI, Pasajeros, L.14, E.155. Rodríguez Demorizi, E., Familias Hispanoamericanas. Ciudad Trujillo, 1959, y Milicias de Santo Domingo..., op. cit., Campillo Pérez, J. G., Francisco Espaillat y el desarrollo del Cibao. Santo Domingo, 1985. Base de datos Fichoz.

Habitualmente los grados militares eran concedidos por el gobernador o el rey como recompensa a un comportamiento distinguido a lo largo de su carrera militar, y en algunas ocasiones como premio por los servicios prestados a la Corona. Así la concesión de algún alto mando dentro de la oficialidad de una compañía, como el de capitán o cualquier otro rango más elevado dentro de la jerarquía militar como pudiese ser el de coronel o brigadier, o la introducción de algún hijo de éstos en el Ejército, debieron estar también probablemente influenciados al contar con algún familiar en dicha institución. Lo mismo pudo ocurrir con las numerosas colaboraciones que estos militares y hacendados realizaron para la Corona en algún momento de su vida, que generalmente coincidieron con el establecimiento de las milicias o con situaciones de conflicto y escasez de las arcas reales. En estos casos casos se trata de mercedes que el Rey concedía algún individuo de las familias ilustres de Santo Domingo en recompensa a los servicios prestados, aunque hubiese sido realizado por sus ascendientes tiempo atrás.

Al igual que el resto de la población de la isla, éstos siempre estuvieron dispuestos a conceder ayudas a las arcas de la Corona con dinero y alimento en época de guerra, como realizó el acaudalado hacendado Nicolás Guridi y Frómesta, que con motivo de la guerra con Francia iniciada en 1792 ofreció no sólo su persona sino también la de su hijo para que sirviera sin sueldo alguno, 
prest, ni gratificación en el regimiento de Cantabria; esclavos de los que el capitán general pudiera disponer y la manutención de los Reales Hospitales Militares de carne por seis meses. Durante la guerra con los ingleses, ayudó en la subsistencia de la guarnición militar con 2.000 reses vacunas pertenecientes a su hato Yabacao. Además el 1 de junio de 1797 entregó 4.000 pesos a las Cajas Reales, al hallarse éstas exhaustas de caudales por la falta de situados que permitiesen atender los gastos de tropas y hospitales, aunque dicha cantidad se le devolvió porque no fue necesaria $^{43}$. El hacendado Adrián Campuzano Polanco ofreció en calidad de donativo para los gastos de la mencionada guerra con Francia, doscientos pesos cada año hasta que finalizase el conflicto, además de su persona, la casa de su morada para cuartel u hospital de la tropa ${ }^{44}$.

Antonio Mañón de Lara, también hacendado, colaboró en el establecimiento de las milicias adelantando dinero para pagar los sueldos y 70 uniformes de los soldados de una Compañía de Milicias de la ciudad de Santo Domingo. Además en tiempos de guerra suministró 2.000 pesos a la Real Hacienda, recibiendo como recompensa al final de su carrera militar el grado de capitán en una de esas compañías ${ }^{45}$.

Otro personaje, Francisco Espaillat, realizó un préstamo de 9.120 pesos a las Cajas Reales y en 1780, como médico, ayudó a los enfermos de Santiago de los Caballeros, Puerto Plata y Montecristi. Asimismo gastó 5.722 pesos y 2 reales en la reconstrucción y dotación de utensilios como sábanas, colchones, alimentos, medicina y una enfermera negra de un Hospital en la ciudad de Santiago. A cambio se le premió nombrándole médico y cirujano mayor de las milicias de la zona norte del país y mayordomo y administrador del Hospital mencionado líneas más arriba. Sin embargo, la recompensa más importante que recibió seguramente fue la Carta de naturaleza de español que le otorgó Carlos III en $1787^{46}$.

\footnotetext{
${ }^{43}$ Relación de los méritos y servicios de Nicolás Guridi y Frómesta, Alguacil Mayor de la Real Audiencia de la isla de Cuba. AGI, Estado 18.

${ }^{44}$ Relación de los méritos, y ejercicios Literarios del Dr. en Leyes, y Lic. en Cánones Adrian Campuzano y Polanco, Abogado de la Real Audiencia de Santo Domingo. AGI, Santo Domingo, 929.

${ }^{45}$ Carta del Gobernador de Santo Domingo Joaquín García, de 25 de octubre de 1789 en la que informa sobre la instancia del capitán de milicias Antonio Mañón de Lara, que implora el grado de capitán de ejército. AGI, Santo Domingo, 949.

${ }^{46}$ Campillo Pérez, J. G., Francisco Espaillat..., op. cit., pp. 31 y sig.
} 
Como caso excepcional -en relación a la forma de obtener la oficialidadencontramos aquellos hacendados que accedieron a las armas obteniendo directamente como primer empleo el de capitán y en algún caso el de teniente. Se trata de un nombramiento que el propio gobernador y Capitán General concedía a algunos de los hombres que le habían acompañado como séquito junto a él, y a los cuáles distribuía favores concediéndoles los mencionados empleos u cualquier otro. Este tipo de concesiones permitió por ejemplo a los peninsulares Francisco Antonio Velilla y Torres obtener el título militar de capitán de milicias de Santiago, y a José de la Vega el de teniente ascendiendo hasta alcanzar el de capitán de milicias de infantería de la ciudad de Santo Domingo.

Estos hacendados y sus descendientes además de acaparar títulos militares con los que tuvieron cierto control sobre el Ejército, también participaron en la administración colonial, en especial en el cabildo, algunos incluso en la Real Hacienda y en la Audiencia. Así por ejemplo, hubo tenientes del Batallón Fijo que durante muchos años fueron electos como alcaldes ordinarios del cabildo de Santo Domingo, pero no cobraron el sueldo que tenían asignados como militares ${ }^{47}$. Sin embargo, hubo otros casos en los que no se les suprimió el sueldo como militares mientras desempeñaron el cargo de regidor, como sucedió con el cadete Agustín Girón en 1765 o el del alcalde ordinario José de la Vega, capitán de milicias de infantería en 1788, quienes continuaron recibiendo el sueldo correspondiente a su categoría militar $^{48}$. Algunos incluso ocuparon al mismo tiempo otros puestos administrativos en la Real Hacienda y la Audiencia como fue el caso del ya mencionado José de la Vega, quien sirvió la plaza de controlador del hospital desde el 30 de septiembre de 1777, el de segundo factor para la compra de tabacos desde enero de 1770, y la secretaría de la presidencia desde $1759^{49}$.

Aunque hubo una criollización en el Ejército de Santo Domingo, esto no significó la ausencia de peninsulares, los hubo a pesar de que Santo Domingo no

\footnotetext{
${ }^{47}$ Martín Rebolo, I., Ejército y Sociedad..., op. cit., p. 191.

${ }^{48}$ Respuesta a una consulta de los oficiales reales de Santo Domingo en la que se les ordena que continúen pagando el sueldo de cadete a Agustín Girón, a pesar de haber sido nombrado regidor, San Idelfonso 11 de agosto de 1766. AGI, Santo Domingo, 1094. Extracto de los empleos de José de la Vega, capitán graduado de infantería de exército y efectivo de milicias de infantería reglada de Santo Domingo, ha ejercido en lo político, 15 de noviembre de 1805. AGI, Santo Domingo, 964. Véase también Marchena Fernández, J., Oficiales y soldados..., op. cit., p. 11.

49 Extracto de los empleos en la Real Hacienda que José de la Vega, capitán graduado de infantería de exército, y efectivo de milicias de infantería reglada de Santo Domingo, obtubo y desempeñó en ella, 15 de noviembre de 1805. AGI, Santo Domingo, 964.
} 
era una zona apetecible para aquellos militares que trataban de mejorar su currículo militar o buscar fortuna en América. Los militares peninsulares que llegaron a Santo Domingo lo hicieron con grados de oficiales o simples soldados. Los primeros formaron el Batallón Fijo de Santo Domingo para instruir a las nuevas milicias y apoyar a las unidades de refuerzo, mientras que los segundos completaron la tropa. Tanto unos como otros constituyeron un importante contingente de hombres, muchos de los cuales se establecieron en Santo Domingo. Los enlaces matrimoniales entre éstos y las principales familias de hacendados les permitió continuar su carrera militar y a su vez participar en la vida política y económica de la isla. Si bien el aspecto de su inserción en la sociedad local será tratado en el capítulo cuarto puede avanzarse el nombre de algunos de ellos: Joaquín María Foxa Montúfar, Joaquín Cabrera, Martín José de Miura, Antonio Álvarez Barba, Pedro Roig y Lluís, José Arata, Manuel Peralta o Esteban Fernández Palomares, entre otros.

\subsection{La financiación}

El sistema de financiación de todo el aparato militar de La Española se realizó a través del situado y de los préstamos de particulares. El dinero que se enviaba anualmente desde México era conocido como situado. Este sistema que se venía utilizando desde el siglo XVI lo gozaron sus islas vecinas Cuba y Puerto Rico. En cambio es a partir de 1608 cuando a La Española se le otorga esa ayuda, a consecuencia de la escasez de recursos de las reales cajas y de las despoblaciones de la banda norte de la isla. En un principio esta ayuda económica se destinó a cubrir los gastos defensivos, pero desde junio de ese mismo año hasta el siglo XVIII también sirvió para hacer frente a los salarios del presidente y ministros de la Audiencia, miembros del cabildo de Santo Domingo, viudas, huérfanos, etc ${ }^{50}$.

Una de las características de este situado fueron los continuos retrasos de su llegada a la isla, motivados por el trayecto de su transporte al no venir directamente a Santo Domingo, sino que pasaba primero por la isla de Cuba, luego era conducido hasta la bahía de Ocoa y finalmente hasta la ciudad de Santo

\footnotetext{
${ }^{50}$ Gíl-Bermejo García, J., La Española. Anotaciones históricas..., op. cit., pp. 281-282. Martín Rebolo, I., Ejército y Sociedad..., op. cit., p. 111.
} 
Domingo. A esto hay que añadir otras dificultades que complicaron su llegada, como fueron los ataques de piratas y los momentos críticos de guerra que no permitían su traslado y obligaban a paralizar el transporte del situado ${ }^{51}$. La cuantía del situado de cualquier ciudad hispanoamericana fue muy variable y dependió de las necesidades o los gastos que tuvieran que ser cubiertos. El siguiente cuadro muestra las cantidades de situado recibidas en Santo Domingo durante algunos años del siglo XVIII y lo gastado en el aspecto militar, siendo esto último superior a los ingresos del situado durante todo ese periodo, con la excepción de los años 1740 y 1770 en los que se observa como la diferencia entre lo recibido y gastado no fue tan grande.

${ }^{51}$ Idem. 
Figura 3-2. Cuantía de los situados recibidos y sus correspondientes gastos entre 1706 y 1800

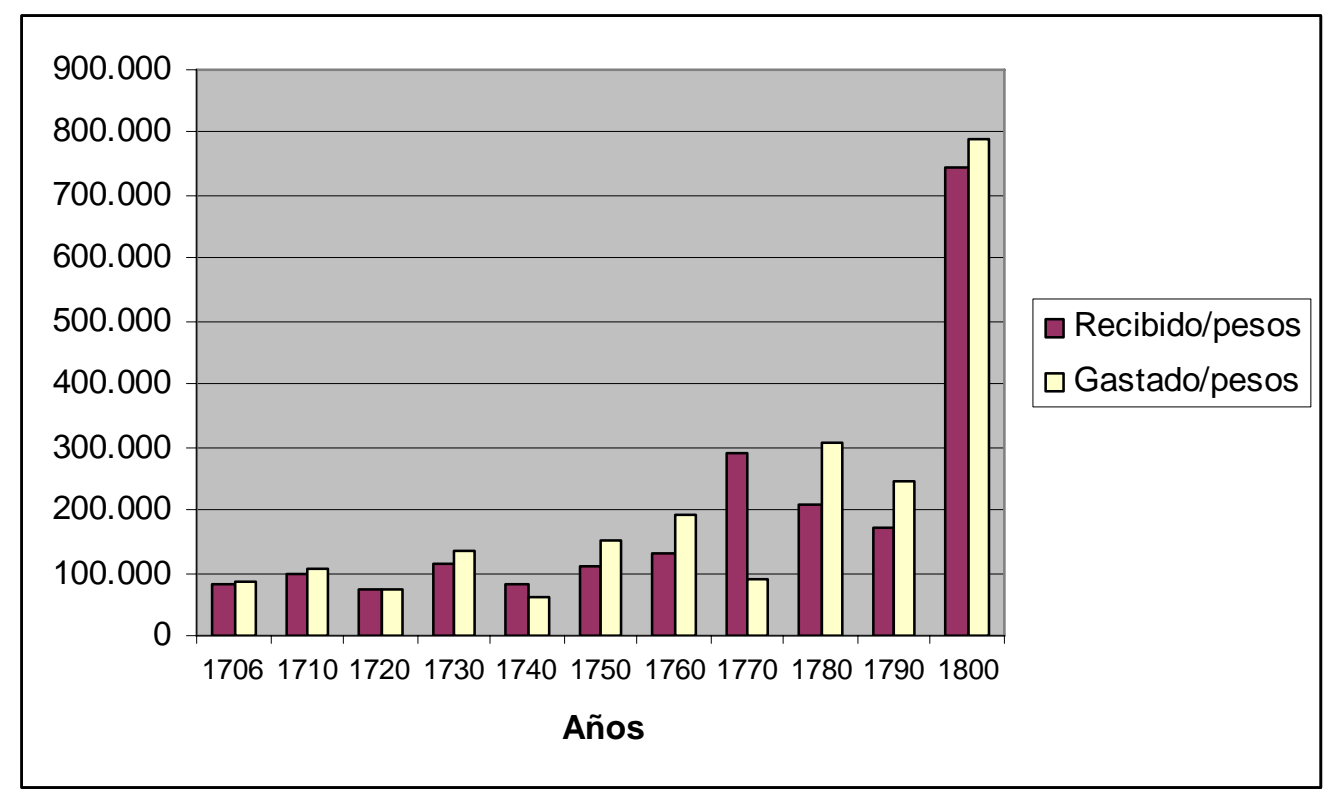

\begin{tabular}{lrr}
\hline Años & Recibido/pesos & Gastado/pesos \\
\hline 1706 & 80.000 & 86.759 \\
1710 & 98.775 & 105.310 \\
1720 & 73.667 & 73.800 \\
1730 & 113.668 & 134.965 \\
1740 & 80.429 & 62.768 \\
1750 & 112.467 & 152.201 \\
1760 & 131.859 & 194.301 \\
1770 & 289.138 & 91.517 \\
1780 & 208.409 & 307.471 \\
1790 & 170.272 & 245.707 \\
1800 & 742.667 & 788.837 \\
Total & $\mathbf{2 . 1 0 1 . 3 5 1}$ & $\mathbf{2 . 2 4 3 . 6 3 6}$ \\
\hline
\end{tabular}

Fuentes: En Martín Rebolo, I., Ejército y Sociedad..., op. cit., pp. 112-113.

Los retrasos en la percepción del situado fueron habituales a lo largo de todo el siglo XVIII, un hecho que ya venía dándose en los siglos anteriores. Mientras llegaba el situado, esta situación obligó a buscar otras formas que permitieran la subsistencia de las tropas y de la administración de la isla. De manera que al igual que sucedió en Cuba, Puerto Rico, Panamá, o Chile se 
recurrió a los propios habitantes de Santo Domingo para que realizasen préstamos y estos fueron reembolsados con la llegada del siguiente situado ${ }^{52}$.

En el caso de Santo Domingo fueron los hacendados quienes financiaron esas aportaciones. En relación a esto, según Martín Rebolo, durante el siglo XVIII se efectuaron estas aportaciones mediante préstamos a las Cajas Reales por un valor de más de 1.998 .390 pesos, mientras que lo devuelto fue de 1.843 .040 pesos. Lo que significa la existencia de una deuda acumulada de 155.350 pesos contra la Real Hacienda dominicana, que no pudo erradicarse a pesar del intento de subsanarla desde principios del siglo XVIII mediante el remite de cantidades extraordinarias de dinero que hiciesen frente a esos atrasos ${ }^{53}$.

No sólo el sector hacendado colaboró con tales aportaciones, sino que también el resto de los vecinos de la isla prestaron su ayuda, que se incrementaba en los momentos de guerra con préstamos, y en ocasiones con los donativos gratuitos que hacía la población a la Corona, una acción que se convirtió en algo habitual y en un medio para la supervivencia de la defensa. A parte de cantidades de dinero también se ofrecía como donativo desde animales, reses para alimentar a los soldados, misas rezadas, agua o leña, a la presentación como soldado voluntario $^{54}$.

La ausencia y retrasos de dinero afectaron de tal manera a la economía de La Española, que en 1757 se produjo la sublevación del Batallón Fijo de Santo Domingo al debérsele el pago de veintiocho meses de su sueldo ${ }^{55}$. Otra de las consecuencias más graves fue la escasa circulación de moneda en la economía de Santo Domingo. Ello llevó a las autoridades a elaborar unas papeletas por el valor de 100.000 pesos en sustitución de la moneda. Estos billetes serían retirados cuando se fuera produciendo la llegada de los situados con sus atrasos, pero el recibo de los auxilios no fue suficiente para hacer frente a la situación por lo que

\footnotetext{
${ }^{52}$ Sevilla Soler, Ma. R., Santo Doming..., op. cit., pp. 224-226. Marchena Fernández, J., Oficiales y soldados..., op. cit p. 25. Y Martín Rebolo, I., Ejército y Sociedad..., op. cit., pp. 104108 y 114-119.

53 Martín Rebolo, I., Ibidem., p. 112.

${ }^{54}$ Lista de los dones gratuitos que han ofrecido a Su Majestad y Real Servicio los vecinos de las ciudades de Santiago y Montecristi, 25 de noviembre de 1793. AGI, Santo Domingo, 956. Informe del regente de Santo Domingo José Antonio Urízar en el que acompaña la relación de los donativos que han continuado los vecinos de la isla, 22 de mayo de 1794. AGI, Santo Domingo, 957.

${ }^{55}$ Sevilla Soler, Ma . R., Santo Domingo..., op. cit., pp. 96 y 338. Marchena Fernández, J., Oficiales y soldados..., op. cit., p. 366.
} 
el sistema de billetes se mantuvo. El uso de estos billetes en lugar de dinero provocó que empezasen también a circular numerosas falsificaciones, ya que el desgaste del papel obligó a producir más papeletas. Este fraude fue realizado por el propio personal de las Cajas Reales, que contó con la facilidad de emisión de los billetes y de la falsificación de su sello al disponer de los medios necesarios. Todas estas circunstancias agravaron las deudas de las Cajas Reales de Santo Domingo, que contaron con una mala administración que estuvo ligada a la irregularidad con que continuaron llegando los situados ${ }^{56}$.

\subsection{Las fortificaciones}

En cuanto a las obras de fortificación de la isla, al contrario de lo que sucedió en Cuba y Puerto Rico la arquitectura militar defensiva fue más modesta. Durante el siglo XVIII no acontecieron grandes obras de fortificación sino que se produjo fundamentalmente la recomposición y conservación de obras antiguas realizadas por los ingenieros militares. Estos ingenieros formaban un cuerpo que englobaba no sólo a Santo Domingo, sino también a Cuba, Puerto Rico y La Florida. Durante la primera mitad del siglo XVIII tan sólo existía un ingeniero, pero a partir de 1752 hubo dos en Santo Domingo, Lorenzo de Córdoba y Antonio Álvarez Barba, quienes realizaron la mayor parte de los trabajos de defensa de la isla ${ }^{57}$. Este último se estableció en la isla alcanzando el título de brigadier y comandante de ingenieros y enlazó con una de las familias más importantes de la ciudad de Santo Domingo, los Leos-Echalas. Su matrimonio le permitió conectar con la red familiar de los Guridi ${ }^{58}$. Otros de los ingenieros que destacaron en su actividad durante la segunda mitad del siglo XVIII en Santo Domingo, fueron el ingeniero comandante Antonio Ladrón de Guevara y Pedro Roig de Lluís,

\footnotetext{
${ }^{56}$ Sobre este asunto véase Sevilla Soler, M a R., Ibidem, pp. 224-227. Martín Rebolo, I., Ejército y Sociedad..., op. cit., p. 114. Rodríguez Gautreau, F. A., Los Oficiales Reales y su Tiempo. Santo Domingo, 2001, pp. 30-36.

${ }^{57}$ Véase Martín Rebolo, I., Ibidem, pp. 68 y 72. Rodríguez Demorizi, E., Viajeros de Francia en Santo Domingo. Santo Domingo, 1979, p. 18.

58 Antonio Álvarez Barba fue destinado en 1770 durante once meses a Cádiz para ejercer la dirección de ingenieros de Andalucía al morir el director ingeniero de tal cargo. Durante su ausencia en Santo Domingo, su sustituto fue otro peninsular, Alonso González de Villalar. A su vuelta a La Española continúo su carrera con el cargo de ingeniero de detalle de las fortificaciones de la plaza de Santo Domingo. Relación de los servicios y méritos del Teniente Coronel $e$ Ingeniero segundo Antonio Álvarez Barba. AGI, Santo Domingo, 933. Véase también "Plan de defensa de la plaza de Santo Domingo, 1772” en Rodríguez Demorizi, E., Relaciones Geográficas de Santo Domingo. Santo Domingo, 1977, vol. II, pp. 7-51.
} 
nombrado este último en 1779 como ayudante de ingenieros, servicio en el que permaneció hasta 1799. Gracias a su matrimonio emparentó con otra de las familias más importantes de la élite dominante local de aquel entonces, los Saviñón, una rama de la red Castro-Rivera y Urdaneta. Después emigró con su familia a Puerto Rico, donde permaneció como ingeniero ordinario y alcanzó el grado de teniente coronel e ingeniero de detalle ${ }^{59}$.

La protección de la ciudad de Santo Domingo empezó con la muralla que la rodeaba, construida en los inicios de su fundación. La muralla estaba guarnecida por pequeños baluartes para centinelas encargados de la vigilancia. Esas garitas fueron bautizadas en su mayoría con nombres de santorales como la de los Estudios, San Gil, La Concepción, San Lázaro, La Merced, San Miguel, San Francisco, San Antonio, Santa Bárbara y San Diego. Los terrenos inmediatos a las murallas que dominaban la ciudad tenían distintas alturas y todos ellos se encontraban cubiertos de árboles y malezas.

Le seguían otras dos construcciones defensivas de la ciudad, una formada por el conjunto formado por La Fuerza o Fortaleza Ozama que se situaba en la propia ciudad. Fue construida en el siglo XVI y su función era defender la entrada y salida al puerto y al desembarcadero. En ese recinto se encontraban los edificios militares más importantes, como la Torre de Homenaje o del vigía, el almacén de pólvora y efectos, y la cárcel militar. En 1787 se construyeron en su interior dos cuarteles, destinados al alojamiento de la tropa, y una enorme puerta de entrada a este recinto que fue reconstruida y se conoce por el nombre de Puerta de Carlos III o de La Fortaleza. La otra obra defensiva de la ciudad se situaba a extramuros de ésta y estaba compuesta por varias fortificaciones que impedían la entrada en el puerto como en el Castillo de San Jerónimo, y otras establecidas en puntos más distantes de la ciudad de Santo Domingo pero igualmente estratégicos para la protección de la isla, como fueron aquellos en los puertos de Samaná, Montecristi y la bahía de Ocoa distante de Santo Domingo a unas veinte leguas ${ }^{60}$.

El cinturón defensivo del área de la ciudad de Santo Domingo se completaba con las baterías y trincheras alrededor de sus costas, que servían de

\footnotetext{
${ }^{59}$ Martín Rebolo, I., Ejército y Sociedad..., op. cit., p. 72.

${ }^{60}$ Véase Pérez Montás, E., Monumentos históricos y arqueológicos. México, 1984, pp. 345-356. Gutiérrez Escudero, A., "La defensa y las fortificaciones del Caribe español durante la época colonial” en VVAA., Puertos y Fortificaciones en América y Filipinas. Madrid, 1985, pp.152-154.
} 
defensa de entrada en el puerto y contra posibles ataques y susceptibles desembarcos de extranjeros. Estas construcciones fueron perfeccionándose continuamente a lo largo de la segunda mitad del siglo XVIII. Se reconstruyeron algunas como la de Güibia, situada en una playa que recibe tal nombre y era la que se hallaba más cerca de la ciudad. También se construyeron otras, entre ellas la batería de Haina, que estaba considerada como una de las más importantes y fue mandada edificar por el gobernador Manuel Azlor y Urríes. Los posteriores gobernadores continuaron en la misma línea de defensa de Santo Domingo, dedicando especial atención a la fortificación de sus playas, y de un modo permanente en el expresado punto de Haina, ya que en su memoria aún permanecía el ataque inglés sufrido en el siglo XVII ${ }^{61}$.

\footnotetext{
${ }^{61}$ Carta del regente de la Audiencia de Santo Domingo José Antonio de Urizar en la que dirige las copias de las juntas de guerra celebradas para la defensa de aquella capital y de la cuenta de las providencias que en ella se acordaron, 25 de octubre 1794. AGS, SGU, 7161. Véase también Rodríguez Demorizi, E., Viajeros de Francia en Santo Domingo..., op. cit., p. 22.
} 



\section{CAPÍTULO 4 LOS HACENDADOS}

“[...] Los moradores de La Española eran ostentosos en sus funciones públicas y privadas, y tan celosos de la nobleza de su origen que no se confundían las clases. Existía de hecho la diferencia más marcada. El noble llevaba el calificativo de Señor, Don, el blanco de Don, el sospechoso de Señor, y el pardo o moreno ningún dictamen. La diferencia también era marcada en los trajes, sobre todo entre las mujeres. Sin que todo esto alejase a los unos de los otros, pues al contrario no había noble que no tuviese una clientela numerosa de aficionados, ahijados y compadres, por quienes abogaba y a quienes patrocinaba cordialmente, sucediendo lo mismo con los pardos y morenos libres que eran muchos" 1 .

\subsection{Orígenes sociales y geográficos de los hacendados}

Este trabajo se inserta en el marco temporal que va desde 1750 a 1795 y los protagonistas seleccionados son algunos de los hacendados más importantes que participaron en la formación y consolidación de una poderosa red de relaciones. Aquellos que formaron parte de este grupo estuvieron ocupando cargos edilicios en la Audiencia como los de abogado, oidor, relator, alguacil mayor o funcionario de la Real Hacienda, desde tesoreros y contadores de las Cajas Reales a administradores de la Real Factoría de Tabacos y de la Compañía de Comercio de Barcelona.

La trayectoria de todos ellos presenta algunos rasgos comunes, siendo uno de ellos, como se ha podido apreciar en los capítulos anteriores, contar con una nutrida representación en el control gubernativo de la isla y en los más altos

\footnotetext{
${ }^{1}$ En Monte y Tejada, A. del, Historia de Santo Domingo. Ciudad Trujillo, 1953, vol. III, p. 77. La cursiva es nuestra.
} 
grados del cuerpo militar. Sus actividades estaban directamente relacionadas con la agricultura y ganadería, y algunas con el comercio. Su patrimonio de riqueza se componía de tierras, haciendas, hatos, esclavos, barcos y propiedades urbanas, entre otros. Asimismo, para todos fueron muy importantes las relaciones sociales, pues su éxito se debió en gran medida a la consecución de buenas alianzas matrimoniales y al hecho de contar con numerosas relaciones y allegados.

En cambio, los orígenes sociales y geográficos de los hacendados estudiados fueron muy diversos. De entre los 61 hacendados estudiados se ha encontrado que 37 eran criollos, 20 peninsulares, y 4 procedían de lugares como África, Italia y Francia, como puede verse en las tablas de datos relativos al origen geográfico (anexos tabla 3 y 4). Dentro del primer grupo de criollos, 3 habían nacido en territorios americanos (La Habana y Venezuela), mientras que de los peninsulares aparecen 4 cuyo origen nos es desconocido aunque se intuye que probablemente eran peninsulares. De los criollos también se ha investigado el origen de sus padres, dando como resultado que de éstos eran 10 peninsulares, 24 criollos de los cuáles 7 eran de otras partes del continente americano, y otros 2 de Francia; en cambio las madres de todos ellos a excepción de 1 peninsular eran criollas, y de ellas 4 de origen cubano.

Estos hacendados que destacaron a fines del siglo XVIII tuvieron sus orígenes sociales en familias que descendían de matrimonios entre criollas, hijas de prominentes personajes de la ciudad de Santo Domingo y peninsulares que llegaron a Santo Domingo a finales del siglo XVII y principios del XVIII, así como los que siguieron llegando durante la segunda mitad de este último siglo. Los primeros en llegar iniciaron una serie de clanes familiares como los Guridi, clan que procedía del matrimonio entre el vasco Antonio Guridi y Echeandia y Leonor Alarcón-Coronado; los Mañón a partir del enlace del francés Antonio Mañón con Ángela de Lara y Mieses; los Heredia a través del casamiento entre Antonio Heredia Portes y María Melo Silva y Delgado; los Rocha de la unión de María del Rosario Landeche con Antonio Francisco de la Rocha-Ferrer y de las Barces ${ }^{2}$; los Landeche del enlace entre el vasco Antonio Landeche y Ana María Bastidas; los Coca de la boda celebrada entre el gaditano Antonio Coca-Landeche

\footnotetext{
${ }^{2}$ El apellido parece que derivó en Labarces. En la documentación aparece indistintamente ambas grafías.
} 
y Josefa Lucía Landeche Bastidas; la familia de los Frómesta a raíz de la unión entre Leonardo José Frómesta Montejo y Felipa Balmaceda ${ }^{3}$; los Leos-Echalas del casamiento del navarro José Leos Echalas con Lucía Cataño y Mosquera; los Arredondo del enlace entre Tomás Arredondo Simancas y María de Rojas; los Pérez-Caro ${ }^{4}$ del matrimonio entre el sevillano Juan Pérez-Caro Guerrero y Ana Teresa Fernández de Oviedo, y los Campuzano del enlace entre Gregorio Semillán Campuzano y María Josefa Pérez Polanco. (Véase en el anexo los árboles genealógicos). Todos ellos y sus descendientes acabaron ocupando el poder político y económico de Santo Domingo, e incluso algunos en la ciudad de Santiago. Igualmente estuvieron vinculados por relaciones de parentesco y negocios, lo que les permitió formar una poderosa red familiar de hacendados que se subdividía en otras subredes: los Guridi-Alarcón-Coronado, los LandecheBastidas, y los Castro-Rivera Urdaneta.

La segunda oleada de emigrantes que pasaron a formar parte del grupo de hacendados fueron aquellos peninsulares que llegaron estimulados por la corriente de las Reformas Borbónicas, que arrancaron con la reforma militar, la instalación de la Real Compañía de Comercio de Barcelona y la Factoría de Tabaco; así como también la continúa llegada de ministros para la Audiencia, oficiales reales y militares, que venían para ocupar sus empleos. Esta apertura hizo que muchos de los peninsulares se avecindaran accediendo así al grupo dominante de hacendados. Por citar algunos ejemplos: Andrés Lecanda y Andirengoechea, José de la Vega, Ruperto Vicente Luyando, Pedro Catani, Lorenzo Angulo Medrano, Salvador Pí y Piquer, Francisco de Paula Gazcue y Olaiz, Raymundo Esparza, Francisco Pepín González, Juan Bautista Oyarzábal y Olavide, Antonio Álvarez Barba, Esteban Fernández Palomares, Pedro Roig y Lluís, Joaquín Cabrera, Martín José de Miura, Francisco Antonio Velilla y Torres, el francés Francisco Espaillat Virol y Joaquín María Foxá Montúfar, entre otros. Todos ellos al igual que los anteriores peninsulares acabaron integrándose en una de las redes familiares a través del compadrazgo, negocios o el matrimonio con algún descendiente de los que habían forjado las familias ya mencionadas.

\footnotetext{
3 En este caso ambos procedían de la isla de Cuba. El apellido Balmaceda también suele aparecer en las fuentes como Balmaseda.

4 En ocasiones los miembros de esta familia figuran en la documentación sólo como Caro, probablemente para acortar el apellido Pérez-Caro.
} 


\subsection{Fórmulas de ascenso e integración de los inmigrantes peninsulares}

El paso decisivo para muchos de estos inmigrantes para integrarse con la élite local, acceder al patrimonio y a las relaciones sociales fue el matrimonio. Si bien esto debió ser un aliciente para los peninsulares éstos fueron escogidos en muchas ocasiones por las familias criollas ya establecidas como candidatos para casar con sus hijas. Así mismo hubo peninsulares que llegaron a la ciudad de Santo Domingo con su sus familias, y será a través del casamiento de sus hijos o hijas con miembros de la élite local como acaban integrándose.

El matrimonio por tanto fue el primer escalón y medio más eficaz de los peninsulares para ascender socialmente y al mismo tiempo para reclutar a nuevos miembros entre los hacendados. Pero esto no fue algo exclusivo de la ciudad de Santo Domingo, sino un hecho que se dio en las distintas regiones del Nuevo Mundo. La mayoría de los trabajos sobre élites hispanoamericanas que han tratado este aspecto, estiman que el éxito de un inmigrante y su inserción en la sociedad local dependieron fundamentalmente de dos aspectos. El primero se refiere al prestigio de la familia y la red de vínculos que derivaba del matrimonio con una hija de una familia acaudalada, y en segundo lugar los enlaces que el inmigrante podía tener en la metrópoli. Además estos trabajos ponen de manifiesto que el nexo llevado a cabo entre los recién llegados de la Península y las familias establecidas suponía beneficios para ambas partes. Habitualmente los recién llegados conseguían un ascenso social, y por su parte, las familias locales garantizaban las posiciones políticas y económicas ${ }^{5}$.

A este respecto, el caso de las familias Guridi, Mañón, Heredia, Rocha, Pérez-Caro, Campuzano, Frómesta, y Leos-Echalas es ilustrativo, pues sus fundadores eran peninsulares que llegaron a Santo Domingo, y a través de su matrimonio con la hija de un personaje principal de la ciudad lograron su ascenso social e integración dentro de la élite local. Un ejemplo de esta fórmula la ofrece el gaditano Antonio Coca-Landeche, cuyo despegue económico-social se debió a

\footnotetext{
${ }^{5}$ Son destacables en este aspecto los trabajos de Santos Pérez, J. M., y Mira, G., "Estrategias de integración y ascenso social de emigrantes españoles a América en el siglo XVIII" en Alcántara, M. (ed.), América Latina. Realidades y perspectivas. I Congreso Europeo de Latinoamericanistas. Salamanca, 1997, pp. 216-242. Vázquez de Ferrer, B., y Ferrer, N., "Propuesta de análisis y fuentes para el estudio de las redes sociales de poder" en Martinez Ruiz, E. (coord.), Poder y mentalidad en España e Iberoamérica. Madrid, 2000, pp. 35-57. Marchena Fernández, J., Oficiales y soldados en el Ejército de América. Sevilla, 1983, p. 30.
} 
la ayuda social y monetaria de su suegro, aportada esta última por la herencia de haciendas, así como su inserción en el ámbito de la administración local al ser elegido alcalde ordinario. Probablemente, a Antonio no sólo le movieron los impulsos amorosos cuando en 1720 se casó con Josefa Lucía Landeche Bastidas, hija de uno de los hombres más ricos de la isla. Sin duda, la fortuna y destacada posición social de la familia de Josefa, al descender por línea materna de una de las familias más antiguas de Santo Domingo, fue determinante para el enlace. Como también lo fue el hecho de que Antonio procediese de una familia gaditana acaudalada y con nobleza.

Para los poderosos personajes locales, como el padre de su mujer, llamado también Antonio Landeche, esta alianza matrimonial significó el mejor medio de encontrar una amplia parentela en la que apoyarse, ya que el peninsular se convertía fácilmente en un sujeto dependiente y leal a la red familiar de su esposa. Esto sucedía especialmente cuando el inmigrante no contaba con vínculos locales ni caudal, entonces no le queda más opción que integrarse en el grupo familiar de su mujer. Habría que añadir que Antonio Landeche era vasco, y al igual que su yerno su riqueza y posición en la isla se la debía en parte a su unión con Ana María Bastidas, perteneciente a una rica familia criolla ${ }^{6}$. En la misma línea el tesorero Antonio Francisco de la Rocha-Ferrer y de las Barces al casarse con María del Rosario Landeche Bastidas, otra hija del anterior matrimonio, debía en parte su posición social a su mujer, y la de su hermano Antonio de la RochaFerrer y de las Barces, gobernador de Santo Domingo entre 1723 y 1731 ${ }^{7}$. De igual forma, su posición económica se la había proporcionado su mujer, que aportó una dote “pingüe y de las mas gruesas del pais” asignada en bienes de plata y oro, joyas, esclavos, ropa de vestir, haciendas de campo y muebles ${ }^{8}$. También recibieron una donación monetaria de 2.310 pesos y $127 / 216$ avos de real en plata

\footnotetext{
6 Testimonio de los autos obrados con motivo de haberse pedido a Antonio Coca, vecino de la ciudad de Santo Domingo cien pesos para completar el socorro mensual del mes de agosto de 1721. AGI, Santo Domingo, 257. Véase también Larrazábal Blanco, C., Familias dominicanas. Santo Domingo, 1978, vol. IV, pp. 153-154.

${ }^{7}$ Testimonio de la información de vida, y costumbre de Antonio Francisco de la Rocha, tesorero de las cajas de Santo Domingo, 13 de diciembre de 1744. AGI, Santo Domingo, 1046.

${ }^{8}$ Ibidem.
} 
acuñada, y una esclava. Antonio Francisco, llevó al matrimonio 1.000 pesos en concepto de arras ${ }^{9}$.

Los descendientes de esta familia, como los de las otras anteriormente citadas, tendieron a continuar con este patrón típicamente colonial basado en el matrimonio entre un peninsular y una criolla o viceversa. Esta dinámica se repitió en la segunda mitad del siglo XVIII entre los peninsulares de la segunda oleada, como se verá en un epígrafe de este capítulo dedicado a la política matrimonial. En él también se podrá advertir cómo los descendientes de estas redes familiares recurrieron a enlaces con criollos considerados como iguales o incluso con parientes.

\subsection{La estructura familiar}

Si bien el matrimonio fue un mecanismo de integración para los inmigrantes peninsulares, para los hacendados ya asentados y los criollos de Santo Domingo constituía la pieza clave sobre la que se sostenían sus familias. De hecho, tanto el matrimonio como las distintas funciones de cada miembro de la familia estaban delimitados y establecidos desde la conveniencia familiar, y articuladas a través de la patria potestad, que se vió reforzada con leyes borbónicas como la Real Pragmática de matrimonios de 1776. De manera que el padre puede considerarse "el punto de referencia familiar" entre los hacendados ${ }^{10}$.

La estructura de las familias de los hacendados del Santo Domingo del siglo XVIII responde al modelo de familia extensa que habita en un mismo espacio. Según este modelo, las personas que residen en la casa familiar son el matrimonio y sus hijos con o sin sus cónyuges, y en ocasiones los parientes más o menos cercanos, es decir, abuelos, tíos, sobrinos, además del servicio doméstico de esclavos. Todos ellos se sometían a la autoridad del cabeza de la familia, cuyo mando quedaba legitimado a través del ejercicio de la patria potestad. Según Ángel Rodríguez, el desarrollo de la patria potestad se reflejaba en distintos

\footnotetext{
${ }^{9}$ Ibidem., Y Escritura de carta y recibo de dote hecha a favor de María del Rosario Landeche por el capitán Antonio de La Rocha y Labarces, 17 de febrero de 1725. AGI, Santo Domingo, 1046.

${ }^{10}$ En Turiso Sebastián, J., Comerciantes españoles en la Lima Borbónica. Anatomía de una elite de poder (1701-1761). Lima, 2002, p. 160. García Fernández, M., Herencia y patrimonio familiar en la Castilla del Antiguo Régimen (1650-1840): efectos socioeconómicos de la muerte y la partición de bienes. Valladolid, 1995, p. 239.
} 
espacios, como el doméstico donde el padre se encargaba de la función económica y tenía el poder decisorio respecto al control patrimonial y a la estrategia familiar, mientras que a la madre le correspondía la crianza de hijos y el cuidadado de la casa. En el espacio jurídico, el dirigismo y el poder del padre se apoyaba en la propia legislación que prohibía a la mujer por sí sóla enajenar o comprar bienes, celebrar contratos o presentarse a un juicio sin el permiso de su marido. Así mismo queda reflejado en la incapacidad de tutelar a sus hijos menores que podía ser desempeñado por el padre, en caso de muerte de su esposa hasta que alcanzasen su mayoría de edad $^{11}$. Pero si el padre era quien fallecía, la mujer tan sólo podía ser tutora y curadora de sus hijos, así como administradora de los bienes, siempre que su marido lo dejara escrito, como se constata en los testamentos de algunos hacendados ${ }^{12}$. La autoridad del padre se manifestaba también a la hora de repartir el patrimonio entre sus hijos, en la elección de los que recibirían una mejora de su legítima, o de quien heredaría el mayorazgo familiar $^{13}$. Los padres se encargaban de que algunos de sus hijos varones continuasen con la carrera que ellos habían ejercido, y de que otros entraran en una orden religiosa, así como de elegir con quien debían casarse. De ahí que desde muy pequeños, los padres fueran preparando y mentalizando a sus hijos a cerca del futuro social y profesional que les estaba destinado. Por su puesto, cabía la posibilidad de que ese proyecto fuese incumplido al tomar los hijos una decisión contraria a lo promovido por la autoridad doméstica. En algunos casos, tal hecho tuvo consecuencias importantes para el infractor, como podía ser la expulsión del grupo familiar. Como bien enfatizan Imízcoz y Moutoukías, tan importante es observar en las relaciones sociales la dependencia de las normas y costumbres que regían al grupo que pertenecía el individuo como “[...] los márgenes de libertad e incertidumbre dentro de los cuales los individuos pueden manipular las reglas y las representaciones, reactualizándolas” y creando situaciones nuevas no

\footnotetext{
${ }^{11}$ Rodríguez Sánchez, A., “El poder familiar: la patria potestad en el Antiguo Régimen” en VVAA., Estructuras y formas de poder en la Historia. Salamanca, 1991, pp. 105-116, p. 107 y 109; y La familia en la Edad Moderna. Madrid, 1996, pp. 25-30 y 51-52.

12 Escritura del testamento de Miguel Bernardo Ferrer, 30 de abril de 1784. AGI, Santo Domingo, 947. Escritura del testamento de Juan Mieses Ponce de León, 5 de enero de 1759. AChV, Pleitos civiles, La Puerta Olvidados 1378.

${ }^{13}$ Ibidem.
} 
previstas $^{14}$. Así sucedió, como se verá al detalle más adelante, en el caso de la expulsión de Julián Joaquín Pueyo y Urríes de su círculo familiar al contraer matrimonio en contra de su parentela con una persona supuestamente no idónea.

\subsubsection{El camino social y profesional de los hijos e hijas}

Si para los padres de las primeras generaciones de hacendados supieron conseguir una destacada posición en la sociedad de Santo Domingo para sí y su familia, sus descendientes debían reproducirlo y mantenerlo. Con este objetivo los padres elaboraron un plan para que sus hijos desde muy tierna infancia perpetuaran el linaje familiar. Este propósito se desarrolló en primer lugar, proporcionándoles una educación que les permitiera situarse en los grados más altos de la administración civil y militar; y en segundo lugar, a través de la formación de una tupida red de alianzas con otras familias, elaborada con matrimonios estratégicos y relaciones de amistad y fidelidad, que les sirviera para defender su elevada posición e intereses.

Los hijos eran por tanto los encargados de salvaguardar la continuidad y el futuro familiar, de ahí la numerosa cantidad de hijos que se procreaban para aquella época y la importancia de tenerla en cuenta. En relación al número de hijos que debió tener cada matrimonio, la información se ha tomado de las referencias bibliográficas que proporcionan algunas obras genealógicas y de las que aparecen en la documentación. De esta manera se tiene conocimiento no sólo de los hijos que vivieron, sino también de aquellos que no llegaron a la edad adulta. Aunque respecto a estos últimos la información suele ser bastante escasa, pues tan sólo aparece su nombre y que murieron párvulos ${ }^{15}$. Sin embargo con los datos que se tienen puede confirmarse que el número de hijos de algunos hacendados fue elevado. Esta práctica fue frecuente en aquella época entre la élite

\footnotetext{
${ }^{14}$ Imízcoz Beunza, J. Ma., “Actores, redes, procesos. Reflexiones para una historia más global”. Revista da Facultade de Letras-História, III Série, vol. V, Porto (Portugal, 2004) pp. 1-28, p. 21 y 22. Moutoukías, Z., "Narración y análisis en la observación de vínculos y dinámicas sociales: el concepto de red personal en la historia social y económica” en Bjerg, Mª y Otero, H. (comps.), Inmigración y redes sociales en la Argentina Moderna. Tandil, 1995, pp. 221-241, p. 229 y 235.

15 Escritura del testamento de Miguel Bernardo Ferrer, 30 de abril de 1784. AGI, Santo Domingo, 947.
} 
y el resto de la población debido también a la alta tasa de mortalidad infanti ${ }^{16}$. El resultado obtenido de la contabilidad realizada entre 32 parejas da una media de 4,4 hijos por familia ${ }^{17}$. Susan Socolow en su estudio de 115 familias de comerciantes de Buenos Aires determinó que el número medio de descendientes fue de 7 hijos por familia. Otro trabajo sobre los regidores de Guatemala realizado por José Manuel Santos, destaca como caso excepcional que la cantidad más alta de hijos por pareja fue de veinte ${ }^{18}$. De entre los hacendados estudiados también hubo algunos que tuvieron una alta descendencia, como Gregorio Saviñón y Francisco Espaillat con catorce hijos, o Andrés Lecanda que tuvo trece en su matrimonio $^{19}$.

En relación con el número de hijos estaba la edad de casamiento, pero desafortunadamente no se ha encontrado información sobre las edades, tan sólo algún ejemplo que permite constatar que se dieron matrimonios entre parejas muy jóvenes y que las mujeres lo hicieron a una edad más temprana que la de sus maridos, una tendencia bastante habitual también entre la población del Antiguo Régimen ${ }^{20}$. Obviamente, cuanto más jóvenes las posibilidades de fertilidad eran más altas. Sin embargo, la avanzada edad de los hombres e incluso la de la mujer no fue un impedimento para tener descendencia. Así por ejemplo, el hacendado Rodrigo de la Rocha se casó a la edad de cuarenta y dos años, mientras que su

\footnotetext{
${ }^{16}$ Según Antonio Gutiérrez Escudero, la media de hijos para la población de otros lugares de la isla como El Seibo, Higüey, Bayaguana, Monte Plata, Boyá, Baní, Azua, Neiba, San Juan, Banica, Hincha, y Samaná era de 6,29, véase en su obra Población y economía en Santo Domingo. Sevilla, 1985, p. 50.

${ }^{17}$ El número de hijos es relativo ya que de los sesenta y un hacendados sólo hemos podido establecer la cantidad de hijos que hubo en treinta dos matrimonios dado que la documentación utilizada como expedientes de limpieza de sangre, relaciones de méritos, o testamentos y la bibliografía genealógica o biográfica no nos proporciona datos precisos.

${ }^{18}$ Socolow, S., Los mercaderes del Buenos Aires virreinal: familia y comercio. Buenos Aires, 1991, pp. 60-61. Santos Pérez, J. M., Élites, poder local y régimen colonial..., op. cit., p. 153.

${ }^{19}$ Del primer matrimonio de Francisco Espaillat sobrevivió un hijo, y del segundo tuvo trece, aunque de ellos tres murieron a muy temprana edad, en Campillo Pérez, J. G., Francisco Espaillat y el desarrollo del Cibao. Santo Domingo, 1985, pp. 155-161. Instancia de Gabriela Sánchez Moreno, viuda de Andrés Lecanda, en la que solicita varias gracias a Su Majestad a su favor y el de sus hijos, 23 de agosto de 1799. AGI, Santo Domingo, 960. Larrazábal Blanco, C., Familias dominicanas..., op. cit., vol. IV, p. 178.

${ }^{20}$ Miguel Jerónimo Martínez de Venecia Santelices y María Antonia Saviñón se casaron el 7 de agosto de 1780 con dieciocho y veinte años respectivamente, en Guerrero Cano, Ma. M., "Un dominicano en el colegio de nobles americanos de Granada. Familia y genealogía de Juan Clemente Martínez Saviñón”. Trocadero 8-9 (Cádiz, 1996-1997) pp. 383-400, p. 390.
} 
mujer y prima hermana Petronila Angulo tenía treinta seis, una edad también avanzada para aquella época sobre todo siendo su primer casamiento ${ }^{21}$.

\subsubsection{La educación}

En líneas generales, el camino social y profesional que prepararon los padres para lograr la estabilidad y mejora familiar empezó por el especial interés que mostraron por dar a sus hijos una buena educación. Dada la conciencia que tenían respecto al valor de los conocimientos y su utilidad, los padres procuraron que sus hijos entrasen en alguna de las más reputadas instituciones educativas de ciudad de Santo Domingo, como la Universidad de Santo Tomás de Aquino o la Universidad de Santiago de la Paz, también conocida como Gorjón, e incluso algunos enviaron a sus descendientes a España con ese fin $^{22}$.

Pero antes de acceder a la Universidad los jóvenes recibían sus primeros conocimientos en conventos religiosos o en casas particulares. En ellos les enseñaban a leer y escribir, y se les introducía a la gramática latina. Tanto en la ciudad de Santiago como en la de Santo Domingo los religiosos se encargaron de esta tarea. En la primera de esas ciudades, el padre jesuita Luís Vergel inició en 1679 la modalidad de dar clases particulares de gramática, filosofía y teología en la escuela que había creado en el atrio de su casa. Tiempo después, entre 1738 y 1767, Blas López continúo la obra del anterior, aunque probablemente en un lugar distinto. Durante el siglo XVIII, en la ciudad de Santiago también existió una escuela, dirigida por el padre Juan Escoto, en la que la juventud de esa ciudad

${ }^{21}$ Carta del gobernador de Santo Domingo en la que da curso al memorial y documentos con que solicita real permiso para casarse el capitán Rodrigo de la Rocha con su prima hermana Petronila Angulo, 24 de mayo de 1797. AGI, Santo Domingo, 961.

${ }^{22}$ La Universidad de Santo Tomás de Aquino fue establecida por los dominicos el 28 de octubre de 1583 y para la segunda mitad del siglo XVIII estaba situada en el Convento Imperial de los Predicadores. La Universidad de Santiago de la Paz pertenecía a los jesuitas y fue fundada el 23 de febrero de 1558 y erigida como colegio en la ciudad de Santo Domingo. Se le agregó el nombre de Gorjón para invocar la memoria del hacendado español Hernando Gorjón, con cuyos bienes subvencionó dicha institución. Tras la expulsión de los jesuitas en 1767 el Colegio se cerró, y años más tarde mediante una Real Cédula de 10 de agosto de 1778 se mandó que volviera a abrirse creándose otro nuevo. Sin embargo, éste no se abrió hasta doce años más tarde bajo el nombre de San Fernando, en reconocimiento a su fundador el arzobispo Fernando Portillo y Torres y al de su antiguo fundador Hernando Gorjón. Al respecto puede verse: Utrera, F. C. de, Universidades de Santiago de la Paz y de Santo Tomás de Aquino y Seminario Conciliar de la ciudad de Santo Domingo de La Española. Santo Domingo, 1932. Pérez Memen, F., Iglesia y Estado en Santo Domingo (1700-1853). Santo Domingo, 1984, p. 105. Y también Cordero Michel, E., "Hernando Gorjón, hombre de empresa y de presa”. CLÍO 155 (Santo Domingo, 1996) pp. 93-113. 
aprendía sus primeras letras, también tenían la opción de hacerlo en el convento de los mercedarios ${ }^{23}$.

Después de haber estudiado en esas escuelas particulares, los padres enviaban a sus hijos a estudiar a una de las universidades de la ciudad de Santo Domingo. Aquellos que no residían en la capital contaron con el apoyo de los parientes que vivían en ella, quienes se encargaron de dar alojamiento, cuidado y educación a sus hijos. Así, por ejemplo, Gaspar Arredondo y Pichardo después de haber estudiado con el ya mencionado padre Juan Escoto marchó a la capital “al abrigo del doctor don Juan de Arredondo”, su abuelo paterno, para continuar sus estudios de leyes en la Universidad de Santo Tomás de Aquino ${ }^{24}$. En esta universidad como en la de Gorjón la educación fue exclusiva de dos órdenes religiosas, los dominicos en la Universidad de Santo Tomás y los jesuitas en la de Gorjón. Tanto en una como en otra su estructura administrativa estaba representada por el rector, que era la cabeza de la Universidad, el vicerrector y los consiliarios, es decir, sus colaboradores. Les seguía el maestrescuela, encargado de la jurisdicción académica, la colación de los grados y de admitir a los estudiantes. Los conservadores cumplían la función de proteger el estudio, y los catedráticos eran los que impartían la docencia. Entre los oficiales con que contaba la Universidad destacan el secretario o notario, los contadores, mayordomos, además de los capellanes, bibliotecarios, bedeles y los estudiantes. Muchos de los hijos de los hacendados que fueron a estudiar a estas universidades, jugaron también un importante papel en ellas desempeñando uno o varios de esos cargos. Algunos incluso llegaron a ocupar el puesto de rector, responsabilidad que sólo una minoría de los que estudiaron en universidades de la Península llevó a cabo ${ }^{25}$.

\footnotetext{
${ }^{23}$ Machado Báez, M. A., Santiagueses ilustres de la colonia. Santo Domingo, 1972, p.12. Sáez, J. L., La formación sacerdotal en Santo Domingo desde el Concilio de Trento a la Fundación de la República. Santo Domingo, 1999, p. 45.

24 "Gaspar de Arredondo y Pichardo, Memoria de mi salida de la isla de Santo Domingo, 28 de abril de 1805” en Rodríguez Demorizi, E., Invasiones haitianas de 1801, 1805 y 1822. Ciudad Trujillo, 1955, pp. 121-160, p. 124.

${ }^{25}$ El rector era el que regía y gobernaba a la Universidad, siendo sus funciones principales administrar la jurisdicción académica, convocar y presidir claustros, dirigir la marcha de su desarrollo y procurar su eficacia. Era elegido anualmente por votación sacando mayoría, sin poder ser reelegido en las dos siguientes. Las reformas de Carlos III exigieron más preparación al rector, por lo que para poder serlo se requería estar graduado de doctor o licenciado, tener al menos veinte cuatro años cumplidos, y se le aumentó el periodo rectoral a dos años. El rectorado en Santo Domingo fue desempeñado en alternancia entre eclesiásticos y seglares. Al respecto véase en
} 
Las universidades de la ciudad de Santo Domingo siguieron el modelo académico de tradición escolástica de la universidad medieval al enseñar artes, nombre con el que se designaba al estudio del Trivium, que abarcaba la gramática, retórica y la lógica; mientras que en el Cuatrivium se estudiaba la aritmética, música, geometría y astronomía. En ellas existía un total de cuatro facultades, divididas en facultades mayores en las que se estudiaba Teología, Derecho civil y canónico y Medicina, y facultades menores de Artes o Filosofía. Los títulos que concedía las universidades eran tres: el de Bachiller, Licenciado y el de Doctor en Teología, Derecho o Medicina. Para poder estudiar estas carreras fue imprescindible haber estudiado previamente artes. Más tarde esto sólo se exigió para estudiar Medicina, mientras que para Teología y Derecho conocer la dialéctica. La obtención de cada grado tenía un significado que estaba relacionado con las posibilidades que éste abría profesionalmente, tanto en la educación como en cualquier puesto administrativo. El grado de bachiller servía para el ejercicio profesional, así como el de licenciado, con el que además se podía obtener algún puesto en la Universidad. El de doctor era el máximo prestigio que podía alcanzar un estudiante, y tuvo un significado fundamentalmente honorífico. Las materias que se impartían en las facultades recibieron el nombre de cátedras. Según la hora en que se impartiesen las materias recibían el nombre de prima (a primera hora de la mañana) o vísperas (a primera hora de la tarde). Otras llevaban el nombre de los principales autores, textos o un nombre relacionado con la materia que en ella se explicaba $^{26}$. Entre las personas que egresaron de las universidades, se ha encontrado que 26 personas de las tres redes familiares 4 obtuvieron el título de bachiller, 5 la licenciatura y 17 el de doctor, coincidiendo todos ellos en la misma especialidad, Derecho, sólo cinco en Teología, y uno en Medicina, el cuál se había trasladado a la Península. También habría que destacar que sus estudios les permitieron ejercer los cargos de abogado, alguacil mayor, y relator de la Audiencia o la alcaldía mayor de Santiago.

Rodríguez Cruz, Á. M., El oficio de Rector en la Universidad de Salamanca y en las Universidades Hispanoamericanas. Salamanca, 1979, pp. 68-70.

${ }^{26}$ Así por ejemplo, en la facultad de Cánones había cátedras de Decreto, Sexto, Clementinas, de Código o Instituta, que hacen referencia al Derecho romano, en Utrera, F. C. de, Universidades..., op. cit., pp. 259-262, y 276-284. A cerca de la enseñanza y sus centros de estudios véase Pérez Memen, F., Iglesia y Estado en Santo Domingo (1700-1853)..., op. cit., pp. 42-49. 
Tabla 4-1. Relación de los grados universitarios y profesión de algunos hacendados y sus familiares

\begin{tabular}{|l|l|l|c|}
\hline \multicolumn{1}{|c|}{ Nombre } & \multicolumn{1}{|c|}{ Grado } & Profesión & Año \\
\hline $\begin{array}{l}\text { Antonio Francisco de la Rocha- } \\
\text { Ferrer Landeche }\end{array}$ & Bachiller & Clérigo & 1748 \\
\hline Nicolás Frómesta Montejo & Doctor & Relator, clérigo & 1743 \\
\hline José Frómesta Montejo & Doctor & $\begin{array}{l}\text { Abogado y } \\
\text { relator }\end{array}$ & 1744 \\
\hline José Núñez de Cáceres & Doctor & Clérigo & 1746 \\
\hline $\begin{array}{l}\text { Antonio Francisco de la Rocha- } \\
\text { Ferrer y Landeche }\end{array}$ & Bachiller & Clérigo & 1749 \\
\hline José Mañón de Lara & Doctor & Clérigo & 1751 \\
\hline $\begin{array}{l}\text { Domingo de la Rocha-Ferrer y } \\
\text { Landeche }\end{array}$ & Bachiller & Abogado & 1751 \\
\hline Felipe Mañón de Lara & Doctor & Relator & 1752 \\
\hline José Guridi y Concha & Doctor & $\begin{array}{l}\text { Abogado, } \\
\text { procurador }\end{array}$ & 1758 \\
\hline Felipe Guridi y Concha & Doctor & Abogado & 1758 \\
\hline José Jacinto Ramírez & Licenciado & $\begin{array}{l}\text { Abogado y } \\
\text { relator }\end{array}$ & 1764 \\
\hline Julián Joaquín Pueyo y Urríes & Licenciado & $\begin{array}{l}\text { Alcalde mayor } \\
\text { de Santiago }\end{array}$ & 1770 \\
\hline Félix Ferrer y Castro & Doctor & Abogado & 1771 \\
\hline Miguel Bernardo Ferrer y Castro & Doctor & Abogado & 1775 \\
\hline José Esteban Arredondo Castro & Doctor & $\begin{array}{l}\text { Abogado, } \\
\text { relator, y fiscal }\end{array}$ & 1779 \\
\hline Vicente Antonio Faura & Doctor & Abogado & 1779 \\
\hline $\begin{array}{l}\text { Adrián Campuzano Polanco } \\
\text { Fernández de Lara }\end{array}$ & Doctor & Abogado & 1781 \\
\hline Pedro Arredondo Castro & Doctor & Abogado & 1782 \\
\hline Tiburcio José Sterling del Monte & Bachiller & Abogado & 1783 \\
\hline Nicolás Guridi y Frómesta & Doctor & Alguacil mayor & 1785 \\
\hline Tomás Arredondo Castro & Licenciado & Abogado & 1788 \\
\hline Francisco Arredondo Castro & Licenciado & Abogado & 1791 \\
\hline Francisco Cabrera & Doctor & Abogado & 1793 \\
\hline José Francisco Heredia Mieses & Doctor & Abogado & 1795 \\
\hline $\begin{array}{l}\text { Francisco Xavier Caro de Oviedo y } \\
\text { Torquemada }\end{array}$ & Licenciado & $\begin{array}{l}\text { Rector de la } \\
\text { Universidad de } \\
\text { Salamanca }\end{array}$ & 1798 \\
\hline José Espaillat Tabarez & Doctor & Médico & 1805 \\
\hline
\end{tabular}

Elaboración propia. Fuentes: La fecha hace referencia al año en que empezaron a desempeñar el empleo. AGI, Santo Domingo, 317, 929, 967, 975, 990, 1015, 1025, 1038, AGI, Estado, 18. AGI, Indiferente General, 3001, 232. Utrera, F. C. de, Universidades..., op. cit., pp. 514-522. Campillo Pérez, J. G., Francisco Espaillat..., op. cit., pp. 454-459, y 470. 
El haber recibido una educación era algo muy preciado por aquel entonces, hasta el punto de que en las relaciones de méritos que se enviaban a la Corte para obtener un cargo en la administración u otros beneficios, aparecían detalladamente los estudios que estas personas hubiesen realizado. Buen testimonio de ello es el memorial de méritos del abogado Vicente Antonio Faura, en el que daba cuenta de sus estudios y de los distintos cargos que ocupó en la universidad en que estudió: “[...] Leyes en la Real, y Pontificia Universidad de Santo Tomas de Aquino de la expresada Ciudad de Santo Domingo, en cuyo tiempo [...] tuvo los varios, y repetidos actos de sabatinas públicas, y otros Académicos [...]”, ejercicios literarios, y recibió los grados de Bachiller, Licenciado, Doctor y el de Bachiller en Cánones. En la misma Universidad suplió con aplicación, y esmero las Cátedras de Instituta y Vísperas: en tres ocasiones se opuso a la Prima de Leyes del Derecho Civil, la cual se le confirió en todas ellas, y la regentó nueve años “con la mayor utilidad, aplicación y esmero, habiendo sacado muchos Discípulos que dan lustre a aquella Universidad, y otros de aprovechamientos para el Público [...]. En el año de mil setecientos setenta y siete fue electo Consiliario Sinodial de la propia Universidad: en el de mil setecientos seteta y nueve Fiscal de ella; y en los de mil setecientos ochenta, mi setecientos ochenta y uno, setecientos ochenta y dos, setecientos ochenta y tres, y setecientos ochenta y quatro, reelecto Consiliario, cuyos cargos desempeñó con la mayor satisfacción [...]. En primero de septiembre de mil setecientos ochenta y cinco se le nombró Vice-Rector de la misma Universidad; y por enfermedad del Rector se hizo cargo de ella, y la gobernó con mucha satisfaccion, y aprovechamiento de sus individuos”27.

De igual forma que Vicente Antonio Faura, hubo otros personajes que estudiaron en la Universidad de Santo Tomás de Aquino. José Guridi y Concha estudió Derecho, obteniendo el título de abogado, y además llegó a ser rector de dicha universidad en $1758^{28}$. Otros hacendados como Tiburcio José Sterling, y José Francisco de Heredia y Mieses también se formaron allí. El primero se

\footnotetext{
${ }^{27}$ Relación de los méritos y ejercicios literarios del doctor Vicente Antonio Faura, abogado de la Real Audiencia de la Isla Española, que reside en la Ciudad de Santo Domingo, y Asesor General del Gobierno de ella. AGI, Santo Domingo, 1015.

${ }^{28}$ El presidente y oidores de la Real Audiencia de Santo Domingo informan con testimonio de los méritos de José Guridi y Concha, alguacil mayor y abogado de ella, 15 de marzo de 1764. AGI, Santo Domingo, 975.
} 
graduó como bachiller en Derecho civil, y como abogado en 1783. El segundo obtuvo los grados de bachiller en Cánones en 1792, el de licenciado en 1793 y el de doctor en 1794, año en que obtuvo la posición en la cátedra de Cánones en tal universidad, y en 1795 fue recibido como abogado ${ }^{29}$. José Esteban Arredondo fue otro de los que realizaron sus estudios en la Universidad de Santo Tomás de Aquino. Cursó las clases de Derecho y recibió los grados de bachiller, licenciado y doctor en Derecho civil. Regentó las cátedras de Leyes, Instituta y Cánones, y además desempeñó los cargos universitarios de consiliario, letrado, fiscal y rector en $1778^{30}$. Adrián Campuzano y Polanco recibió el grado de bachiller, licenciado y doctor en leyes por aquella universidad el 10 de enero de 1778, en ella obtuvo la cátedra prima de Leyes y la Instituta Justiniani. Fue admitido como abogado de la Audiencia el 1 de marzo de 1781, y posteriormente se graduó como licenciado en Cánones por la misma universidad el 21 de marzo de 1787, siendo electo rector en $1795^{31}$.

José Frómesta Montejo obtuvo las insignias de doctor en cánones y la cátedra Instituta en otra prestigiosa institución, la Universidad de Gorjón. También su hermano Nicolás alcanzó tal preeminente grado académico pero en la Universidad de Santo Tomás de Aquino, donde su padre se había licenciado en Cánones y Leyes ${ }^{32}$. En la de Gorjón, José Jacinto Ramírez regentó las cátedras de Derecho civil y se graduó como doctor también en Derecho civil el 1 de mayo de 1766, mientras que sus hijos Juan y José Ramírez Guridi estudiaron leyes en la

\footnotetext{
${ }^{29}$ Relación de los méritos del bachiller Tiburcio José Sterling, abogado de la Audiencia y Real Chancillería que fue de Santo Domingo, y síndico procurador general de aquella isla. AGI, Santo Domingo, 1038. Para José Francisco Heredia y Mieses véase la obra de López-Bohórquez, A. E., Los ministros de la Audiencia de Caracas (1786-1810): caracterización de una élite burocrática del poder en Venezuela. Caracas, 1984, p. 159.

${ }^{30}$ Relación de los méritos y ejercicios literarios del doctor José Esteban Arredondo, abogado de la Real Audiencia de Santo Domingo en la Isla Española. AGI, Santo Domingo, 1012.

${ }^{31}$ Relación de los méritos y ejercicios Literarios del Dr. en Leyes, y Lic. en Cánones Adrián Campuzano y Polanco, Abogado de la Real Audiencia de Santo Domingo. AGI, Santo Domingo, 929.

${ }^{32}$ Relación de los méritos y servicios del doctor José de Frómesta, Relator de la Real Audiencia de Santo Domingo en la Isla Española. AGI, Santo Domingo, 1025. Relacion de los méritos y ejercicios literarios del Doctor Nicolas de Fromesta y Montejo, Catedrático de Visperas de la Real, y Pontificia Universidad, sita en el Convento de Predicadores de la ciudad de Santo Domingo de la Isla Española. AGI, Indiferente General 232, N34.
} 
Universidad de Santo Tomás de Aquino donde obtuvieron sendos grados de doctores $^{33}$.

En 1744, Domingo de la Rocha-Ferrer Landeche, inició sus estudios en la Universidad de México, donde recibió el grado de bachiller en derecho canónico. Fue admitido como abogado en la Audiencia de dicha ciudad en 1750, y un año después fue incorporado a la de Santo Domingo ${ }^{34}$.

Otros lograron estudiar en la Península, en instituciones con gran reputación como la Universidad de Salamanca. En ella estudiaron dos hijos miembros de importantes familias de hacendados. Uno de ellos fue Francisco Xavier Caro de Oviedo y Torquemada, sobrino de Adrián Campuzano y Polanco, quien con diecisiete años fue enviado por sus padres a estudiar jurisprudencia en la mencionada universidad. Aunque había iniciado sus estudios en la Universidad de Santo Tomás de Aquino, en la de Salamanca logró los siguientes grados y ejercicios literarios: primero realizó estudios mayores en las Facultades de Filosofía y de Leyes graduándose como bachiller en Leyes el 29 de julio de 1793, y como licenciado el 12 de abril de 1796, tras lo que fue nombrado rector el 10 de noviembre de 1798 , responsabilidad que desempeñó hasta $1800^{35}$.

El otro dominicano que estudió en la Universidad de Salamanca fue José Espaillat. Allí estudió Ciencias y se graduó en Medicina, continuando con la carrera de médico que su padre Francisco Espaillat había ejercido en su ciudad natal Santiago. Para poder acceder a Medicina era necesario haber estudiado anteriormente artes o filosofía natural durante cuatro años, algo que José había hecho en el colegio San Carlos de Madrid aunque sin obtener el título de bachiller, que alcanzó el 3 de diciembre de 1802 en Salamanca, donde se trasladó para continuar sus estudios. Logró también el título de licenciado el 19 de diciembre de

\footnotetext{
${ }^{33}$ Testimonio de información producida por Antonia Ramírez, sobre su distinción y limpieza de sangre en 1770, que amplió su legítimo hermano Manuel en 1783 y 1784. AGI, Santo Domingo, 990.

${ }^{34}$ Burkholder, M. A., Biographical dictionary of audiencia ministers in the Americas: 16871821. Westport, 1982, pp. 291-292.

${ }^{35}$ Véase las noticias biográficas que proporciona los siguientes trabajos: Morillas, J. $\mathbf{M}^{\mathrm{a}}$., "Biografía de dominicanos notables. Francisco Javier Caro y Torquemada, ministro del Real y Supremo Consejo de la Cámara de Indias y Consejero de Estado”. CLÍO 74-75 (Ciudad Trujillo, 1946) pp. 8-17. Más reciente son los de González Guerra, M., Seis rectores americanos de la Universidad de Salamanca. Salamanca, 1992, pp. 33-37. Y, Torres Agudo, R., "Dos catedráticos dominicanos en la Universidad de Salamanca”. CLÍO 168 (Santo Domingo, 2004) pp. 245-264.
} 
1804 y el de doctor el 22 de abril de 1805, año en que obtuvo a su vez la cátedra de Partida Mayor en Medicina ${ }^{36}$.

Nicolás Guridi y Frómesta, hijo de hacendados, tuvo igualmente la oportunidad de formarse fuera de Santo Domingo, y lo hizo en 1775 en el Real Seminario de Nobles en Madrid, donde estudió matemáticas, álgebra, geometría, trigonometría, aplicación del álgebra a la trigonometría, secciones cónicas y delineación $^{37}$. En el caso de Juan Clemente Martínez Saviñón, su padre Miguel Jerónimo Martínez de Venecia Santelices trató de que fuese a estudiar al prestigioso Colegio de Nobles de Granada, que estaba en proyecto de creación a finales del siglo XVIII con la intención de que la élite dominante de la Península y de Indias realizase allí sus estudios. A pesar de que el joven fue admitido en dicha institución, parece ser que no hubo fondos suficientes para llevar a cabo el proyecto del colegio, que fue suspendido en 1795, de manera que Juan Clemente no llegó a trasladarse a la Península ${ }^{38}$.

\subsubsection{La carrera profesional}

Una vez pasada la etapa estudiantil, la mayor parte de los hijos de los tres grupos familiares de hacendados (Guridi y Alarcón-Coronado, LandecheBastidas, y Castro-Rivera y Urdaneta) continuaron los pasos profesionales de los padres realizando la carrera militar, y obteniendo así varios miembros de una misma familia una gran variedad de títulos militares. (Véase en el anexo las figuras 1, 2 y 3)

Pero los hacendados procuraron que además de contar con algún título militar en su cursus honorum, sus hijos ocuparan los cargos políticos que ellos ejercieron. En su mayoría siguieron el ejemplo de sus padres, e incluso el de sus abuelos al beneficiarse de algún cargo en el cabildo. La ocupación de cualquiera de los puestos por varios miembros de una familia resultaba un éxito para sus

\footnotetext{
${ }^{36}$ Libro de Bachiller. AUSA, 766. Libro de Licenciado y Doctor. AUSA, 802. Procesos de Cátedras. AUSA, 1020. Acerca de la familia Espaillat y la figura de José Espaillat véanse los datos que ofrece la obra de Campillo Pérez, J. G., Francisco Espaillat..., op. cit., pp. 150, 342, y 454-459. Y, Torres Agudo, R., Idem.

${ }^{37}$ Relación de los méritos y servicios de Nicolás Guridi y Frómesta, alguacil mayor de la Real Audiencia de Cuba. AGI, Estado 18.

${ }^{38}$ Sobre este asunto véase Guerrero Cano, $\mathbf{M}^{\mathrm{a}}$. M., "Un dominicano en el Colegio de Nobles Americanos de Granada”... op. cit., pp. 383-400.
} 
intereses, ya que el cabildo se convirtió en el lugar de sus operaciones y reivindicaciones. Estas familias acapararon todos los puestos de este cuerpo, como quedó constatado en el capítulo segundo. Sin embargo, éstas también trataron de que sus hijos ocuparan cargos administrativos más relevantes en la Real Hacienda o en la Audiencia, como el de alguacil mayor, abogado o relator; aunque esto último supusiese infringir la legislación indiana existente, que prohibía a los ministros de ésta desempeñar un puesto en el distrito de nacimiento.

En cambio, no parece que la legislación fuese seguida fielmente. Véase el caso de la familia Guridi y Alarcón-Coronado, que mantuvo durante tres generaciones el puesto de alguacil mayor, desde 1741 cuando Matías Guridi Coronado lo compró hasta la cesión de la isla en 1795, ocupándolo para tal fecha Nicolás Guridi y Frómesta. Otro ejemplo lo constituyen los Frómesta, quienes ejercieron el cargo de relator durante dos generaciones. Leonardo José Frómesta llegó a finales del siglo XVII para ocupar dicho empleo, que desempeñó hasta su muerte en 1748. Su hijo, José Frómesta, lo ejerció desde entonces. Sin embargo, como ya se ha mencionado su otro hijo Nicolás le había sustituido durante el año de 1743. La creación de otro puesto de relator en 1778 permitió que éste fuese desempeñado por José Jacinto Ramírez, miembro de la ya nombrada red Guridi y Alarcón-Coronado y con la que los Frómesta estaban emparentados ${ }^{39}$. Asimismo, a través de los casamientos de sus hijas con miembros de otras familias que también ocupaban puestos en la Audiencia, lograron que su presencia en esas instancias fuese preeminente. Los miembros de esta familia y sus enlaces tuvieron una participación muy alta en el cabildo, hasta el punto de coincidir generalmente varios de sus miembros, como ya se pudo observar en el capítulo segundo.

De igual forma, la familia Landeche-Bastidas trató de que sus descendientes desempeñaran cargos en la administración local. Su presencia en la audiencia fue menor, aunque regentaron empleos en la Real Hacienda. Así, por ejemplo Francisco Pepín González desempeñó el empleo de tesorero desde 1756, pero al tener que realizar un viaje a la Península en 1760 le sustituyó interinamente Lorenzo Angulo Medrano, su cuñado ${ }^{40}$. El tercer grupo familiar

\footnotetext{
39 Títulos de relatores y alguaciles mayores de la Audiencia de Santo Domingo. AGI, Santo Domingo, 967.

${ }^{40}$ Carta de Francisco Pepín González a SM en la informa de la necesidad de ir a España por la avanzada edad de sus padres y pide licencia y facultad para nombrar su teniente en su ausencia
} 
constituido por los Castro-Rivera y Urdaneta también tuvo un destacado papel dentro de las actividades del gobierno municipal, no sólo de la ciudad de Santo Domingo sino también de la de Santiago, en las Cajas Reales como administradores de la Real Factoría de Tabaco y en la Audiencia como abogados.

Entre los miembros de la red Castro-Rivera y Urdaneta destaca José Esteban Arredondo y Castro por haber ocupado cargos administrativos en otras partes de Indias como La Habana y Venezuela. En 1772 fue elegido contador y fiscal de la Real Hacienda en la contaduría de la isla de Cuba, donde también ejerció el cargo de asesor general del Real Cuerpo de Artillería durante tres años. Fue nombrado en tres ocasiones para juez de residencia, una al Marqués de CasaCaigal por el tiempo que sirvió al gobierno de la ciudad de Santiago de Cuba y a sus ministros, la segunda vez para tomar la residencia a otro gobernador de Cuba, Lorenzo de Madariaga, y la tercera al gobernador de Cumaná Pedro José de Urrutia y demás ministros. En esa provincia obtuvo el empleo de teniente gobernador, auditor de guerra y asesor, cargos que ejerció desde el 20 de junio de 1777 hasta el 21 de noviembre del mismo año $^{41}$. Otros miembros de las familias Guridi y Alarcón-Coronado y Landeche-Bastidas aparecen desempeñando oficios en otras regiones, como Francisco Heredia Mieses que llegó a ser oidor y regente en la Audiencia de Caracas, y Vicente Antonio Faura que fue oidor honorario en la misma audiencia ${ }^{42}$. También cabe destacar que Domingo de la Rocha-Ferrer Landeche, miembro de la segunda red familiar, fue abogado de la Audiencia de México durante el año de 1750, auditor de guerra en la provincia de Yucatán y Campeche desde 1767, oidor de la Audiencia de Guadalajara hacia 1794 y fiscal en la de Guatemala para la que fue nombrado el 10 de septiembre de $1796^{43}$. Otros hacendados llegaron alcanzar diversos puestos administrativos dentro de la monarquía española ya a principios del XIX. Así, Francisco Xavier Caro de

Lorenzo Angulo, 12 de abril de 1760. Y, Concesión a su petición, Madrid 24 de diciembre de 1760. AGI, Santo Domingo, 1011.

${ }^{41}$ Relación de méritos y ejercicios literarios del doctor José Esteban Arredondo, abogado de la Real Audiencia de Santo Domingo en la Isla Española. AGI, Santo Domingo, 1015.

${ }^{42}$ Véase López-Bohórquez, A. E., Los ministros de la Audiencia de Caracas..., op. cit., p. 159. Carta de María Ramírez, viuda de Vicente Antonio Faura, en la que informa de los méritos y servicios de su esposo, 13 de diciembre de 1792. AGI, Santo Domingo, 1015.

${ }^{43}$ Carta del gobernador de Santo Domingo, Manuel Azlor y Urríes en la que da cuenta del nombramiento que confirió a José del Monte y Antonio Mañón de Lara los oficios de regidores, 22 de marzo de 1767. AGI, Santo Domingo, 979. Véase también: Burkholder, M. A, y Chandler, D. S., Biographical dictionary..., op. cit., p. 292. 
Oviedo y Torquemada fue electo vocal de la Junta Suprema Central y Gubernativa por la provincia de Castilla la Vieja (1808-1810), y Adrián Campuzano Polanco Fernández de Lara como diputado para América y Filipinas en las elecciones de $1810^{44}$. A partir del seguimiento de estos personajes se podría examinar el papel que desarrollaron en la Corte metropolitana y su proyección en Santo Domingo, aspectos que requerirían futuros análisis. (Véase en el anexo la figura 4)

Por otro lado, algunos hijos eran orientados al servicio de la Iglesia. La carrera eclesiástica ofrecía el beneficio del ejercicio de poder y privilegios, así como prestigio social para ellos y su familia. El clero de Santo Domingo estaba formado por los mercedarios, los franciscanos, los dominicos, los jesuitas y las monjas de Santa Clara y Santa Catalina de Sena, cuyo convento era conocido como Regina Angelorum, situados ambos conventos en la ciudad de Santo Domingo. Los mercedarios también contaban con un convento en la ciudad de Santo Domingo, y otros en las ciudades de Azua, Santiago y La Vega. Los franciscanos sólo tenían uno en la capital, y los dominicos en ésta última y en Santiago ${ }^{45}$.

Los hijos de los hacendados que se consagraron a esta profesión son más bien pocos si los comparamos con los que se dedicaron a la carrera políticomilitar. Aunque sería necesario realizar un estudio prosopográfico sobre quiénes fueron y cómo funcionaban los cabildos y los conventos ${ }^{46}$. Aquellos que se decidieron por la opción eclesiástica o fueron obligados a ello recibieron igualmente una formación universitaria en algunas de las universidades de la ciudad de Santo Domingo ya mencionadas. Tras finalizar los estudios estaban preparados para comenzar su ascenso en la jerarquía de la Iglesia. Así por ejemplo, José Guridi de la Concha, miembro de la familia Guridi y AlarcónCoronado, hizo tonsura el 11 de junio de 1738. Estudió en la Universidad de los dominicos, en la facultad de Teología, donde se graduó de bachiller, licenciado y

\footnotetext{
${ }^{44}$ Morillas, J. Mª., “Excelentísimo e Ilustrísimo”..., op. cit., pp. 8-17.

45 Véase Pérez Memén, F., Iglesia y Estado en Santo Domingo..., op. cit., pp. 49-52.

46 Se puede encontrar algunos datos al respecto en los siguientes trabajos: Rodríguez Morel, G., Cartas de los cabildos eclesiásticos de Santo Domingo y Concepción de La Vega en el siglo XVI. Santo Domingo, 2000. Marrero Castellano, J., "El cabildo eclesiástico en la Iglesia de Santo Domingo en el siglo XVIII”. Casas Reales 13 (Santo Domingo, 1982) pp. 99-128. Polanco Brito, H. E., "Los cabildos eclesiásticos de Santo Domingo y La Vega, los deanes". Casas Reales 14 (Santo Domingo, 1987) pp. 121-142. Utrera, F. C. de, "Constituciones del cabildo eclesiástico de Santo Domingo”. CLÍO 88 (Ciudad Trujillo, 1958) pp. 85-93.
} 
maestro en Filosofía en 1744, y en 1746 obtuvo el título de bachiller y doctor en Teología. Un año después, el 16 de septiembre de 1747, recibió las cuatro órdenes menores y se presentó para opositar a una prebenda eclesiástica, pero no salió electo. No volvió a intentarlo, es más, abandonó la carrera eclesiástica, se casó y acabó dedicándose a la política como habían hecho sus antecesores. Continúo sus estudios en Leyes en dicha universidad, donde alcanzó en 1755 la cátedra de prima Cánones, y en 1758 fue aceptado como abogado y procurador de la Real Audiencia de Santo Domingo, hasta que en 1762 obtuvo el empleo de alguacil mayor por la renuncia que en él hizo su padre ${ }^{47}$.

Dentro de la red Landeche-Bastidas habría que señalar a Antonio Francisco de la Rocha-Ferrer y Landeche que recibió las órdenes menores el 16 de septiembre de 1746, luego en 1748 fue subdiácono y un año después diácono, hasta que en marzo de 1750 alcanzó el de presbítero en el obispado de Puebla de los Ángeles, México. En ese mismo año se le confirió interinamente el empleo de cura interino, vicario y juez eclesiástico del Partido de Sangolica ${ }^{48}$.

Entre los que ingresaron en alguna orden religiosa destaca Juan Frómesta, quien fue prebendado, miembro de la orden de los predicadores y rector de la universidad. De igual forma, su hermano Nicolás Frómesta fue dignidad tesorero (1756-1758), maestreescuela (1760-1767), prebendado en 1767, además de canónigo de la catedral, juez provisor y vicario general del arzobispado de la ciudad de Santo Domingo. Antes de realizar su carrera eclesiástica hay que señalar que había estudiado leyes en la Universidad de Santo Tomás de Aquino obteniendo el grado de bachiller, lo que le permitió que durante el año de 1743 sustituyese como relator a su padre Leonardo, quien estaba enfermo ${ }^{49}$. Un cuñado de ambos, José Núñez de Cáceres, vistió el hábito talar en 1731. Éste estudió en la Universidad de los jesuitas un curso de Filosofía y cuatro años de Teología,

\footnotetext{
${ }^{47}$ El presidente y oidores de la Real Audiencia de Santo Domingo informan con testimonio de los méritos de José Guridi y Concha, alguacil mayor y abogado de ella, 15 de marzo de 1764. AGI, Santo Domingo, 975.

${ }^{48}$ Relacion de méritos de Antonio Francisco de la Rocha y Landeche, Presbítero Domiciliario del Arzobispado de Santo Domingo en la Isla Española. AGI, Indiferente General, 3001.

${ }^{49}$ Expediente de la causa matrimonial seguida por Francisca de Frómesta contra Andrés de Ibarra, 1788. AGI, Santo Domingo, 1025.
} 
obteniendo el título de doctor en Teología el 1 de febrero de 1744, años más tarde, en 1769, alcanzó la posesión del arzobispado de la ciudad ${ }^{50}$.

El camino social de las hijas fue mucho más restringido que el de los hijos: casarse o ingresar en un convento. Entre aquellas que se dedicaron a la vida religiosa cabe mencionar a dos jóvenes miembros de la familia Guridi y AlarcónCoronado, que tomaron los hábitos de una de las congregaciones existentes en la ciudad de Santo Domingo. Éstas fueron Ana Guridi y Leos-Echalas y María Guridi y Concha, que recalaron como monjas clarisas en el convento de Santa Clara $^{51}$.

\subsubsection{La política matrimonial}

La preocupación de los padres por encontrar el partido adecuado para sus hijos e hijas queda reflejada en el cuidado con el que escogieron a sus parejas. En esta época el matrimonio fue normalmente un contrato realizado por los padres, y en él se consideraban muchos aspectos, desde los económicos hasta los sociales. Además el margen de libertad de elección que tenían los contrayentes fue muy limitado, ya que el consentimiento paterno para celebrar un casamiento fue imprescindible. Según las leyes indianas, el consentimiento paterno fue una condición necesaria para que un enlace se llevara a buen término ${ }^{52}$. En el caso de que los padres no se encontrasen en el lugar del enlace, el permiso paterno podía ser sustituido por una autorización judicial o realizada por algún familiar ${ }^{53}$. No

\footnotetext{
${ }^{50}$ Inició su carrera religiosa en el cabildo catedralicio de Santo Domingo como teniente cura (1746), y penitenciario (1747), pasando por las dignidades de tesorero (1754), maestrescuela (1756), chantre (1757), arcediano (1762), deán (1765) y ascender a arzobispo interino (1789). Véase en Carta del rector y regente de la Universidad de los dominicos informando de la obtención del título de Doctor en Teología de José Núñez de Cáceres, 1744. AGI, Santo Domingo, 317. Véase también Polanco Brito, H. E., "Los cabildos eclesiásticos de Santo Domingo y La Vega, los deanes”..., op. cit., pp. 121-142, p. 138.

${ }^{51}$ Carta de Nicolás Guridi y Frómesta, alguacil mayor de la audiencia, en la que suplica a Su Majestad se digne moderarle la redempción del capital que reconoció a favor de las temporalidades de los regulares expulsos, 14 de febrero de 1791. AGI, Santo Domingo, 954. Véase también Larrazábal Blanco, C., Familias dominicanas..., op. cit., vol. III, pp. 446-448. Santa Cruz y Mallén, F. J. de, Historia de familias cubanas. La Habana, 1942, vol. III, pp. 22-23.

${ }^{52}$ Acerca de la legislación indiana véase: Ots Capdequí, J. Mª., El Estado español en las Indias. México, 1946. Ripodas Ardanaz, D., El matrimonio en Indias: realidad social y regulación jurídica. Buenos Aires, 1977.

${ }^{53}$ Así sucedió con Rodrigo de la Rocha quien, en ausencia de su padre, recibió licencia de su tío Ignacio de la Rocha el 21 de abril de 1797 para que pudiera contraer matrimonio con Petronila Angulo. Memorial y documentos que solicita el gobernador de Santo Domingo para que pueda casarse el capitán Rodrigo de la Rocha, 24 de mayo de 1797. AGI, Santo Domingo, 960.
} 
obstante, esto no significó que no se diesen matrimonios fuera de la línea trazada por la autoridad paterna, sin duda los hubo, tanto en Santo Domingo como en cualquier otra región del continente hispanoamericano ${ }^{54}$.

En general puede decirse que los padres buscaron para sus hijos personas que estuviesen dentro de su mismo grupo, con la idea de que entre ambos contrayentes no existiera una gran desigualdad social. El matrimonio endogámico cumplía a la perfección este cometido, y por ello resultó tan frecuente entre las familias de hacendados. El objetivo de esta práctica se tradujo en una actitud cuyo propósito cumplía una doble función. Por un lado, resguardaba y aumentaba el patrimonio económico y el poder político-militar, y por otro, permitía preservar y afianzar la calidad y el estatus social de la familia. De ahí que los grupos familiares de hacendados procuraran impedir cualquier enlace desigual. En el caso de que un joven se enamorase de una persona que no perteneciese a su condición, los miembros de su familia entrarían inmediatamente en acción. En particular lo harían los familiares más directos, es decir, los padres y hermanos, quienes con el apoyo legal de la Real Pragmática sobre matrimonios y la presentación de documentación de limpieza de sangre tratarían de defender su rango social de principales de la ciudad ${ }^{55}$. Su intervención tenía como objetivo impedir su casamiento, y en consecuencia el desprestigio que podía producir respecto a la calidad de la familia, así como las rencillas entre ambas partes y con otras familias dependiendo de las conexiones que hubiese entre éstas. Son varios los ejemplos que se han encontrado y que ilustran este hecho, correspondiéndose cada uno de ellos con una de las tres redes familiares.

En 1783 José Jacinto Ramírez conoció las pretensiones esponsalicias de su hijo Juan Ramírez con Petronila Ariza y Sayas. Sin embargo el entusiasmo del joven no fue compartido por el padre, quien era miembro destacado de una de las

\footnotetext{
54 A modo de ejemplo véase para el caso argentino y mexicano: Socolow, S., “Aceptable partners: marriage choice in colonial Argentina, 1778-1819” en Lavrin, A. (ed.), Sexuality \& Marriage in colonial Latin America. Lincon \& Londo, 1989, pp. 209-246. Seed, P., Amar, honrar y obedecer en el México colonial: conflictos entorno a la elección matrimonial, 1571-1821. México, 1991.

${ }^{55}$ La Real Pragmática sobre matrimonios fue promulgada el 23 de marzo de 1776 y en las Indias en Real Cédula de 7 de abril de 1778 con el objeto de que la calidad de los contrayentes a la hora de contraer matrimonio debía ser la misma. En caso contrario se permitía a los familiares oponerse a matrimonios desiguales, hasta el punto de que se concedió poder a los padres para desheredar a sus hijos si realizaban un casamiento de esas características sin su permiso. Véase el documento en Konetzke, R., Colección de documentos para la historia de la formación social de Hispanoamérica (1691-1779). Madrid, 1962, vol. III, t. I, pp. 406-413.
} 
principales familias de la ciudad, los Guridi y Alarcón-Coronado, siendo esto el motivo de su oposición al deseo al que aspiraba su hijo. Ante el disentir del padre, Petronila también se movilizó y puso una demanda en el tribunal eclesiástico contra Juan. En ella solicitaba que le fuera cumplida la promesa de esponsales impedida por la negación del padre, quien consideraba que no podía celebrarse tal enlace por la gran desigualdad de fortuna y calidad que existía entre la pareja. Según José Jacinto Ramírez “[...] hay una grandisima desigualdad entre la familia de dicha Ariza y mi hijo, por ser descendientes y estar enlazada con las familias mas altas y distinguidas de la ciudad cuya calidad no goza Ariza, por ser de la ínfima plebe [...] y por haberse prostituido a un sacerdote y otros [...]"56. El padre y otros parientes como los hermanos de Juan defendieron su linaje familiar haciendo valer su notoria calidad en contraposición a la documentación presentada por la enamorada de Juan respecto a su familia. Para demostrarlo ambas partes introdujeron testimonios donde constaban sus orígenes y sus vínculos con los miembros más principales de la sociedad, lo cual dejó patente la elevada posición de los Guridi y Alarcón-Coronado. En este caso el disenso del padre fue aprobado como racional y se impuso la notabilidad social de su hijo, por lo que se evitó la unión con Petronila ${ }^{57}$.

El mismo principio por resguardar la calidad de la familia ante un posible matrimonio desigual, animó a la familia Landeche-Bastidas cuando Josefa Coca en 1791 se opuso a la boda de su hijo Antonio Angulo con Ana Caballero. De nuevo fue la joven quien demandó al noble muchacho para que le cumpliese la promesa de matrimonio que le había hecho ante la interposición de la madre de éste. Negación que se apoyaba en lo mandado por la Real Pragmática de 1776, en la que la Corona había prevenido que no se aceptasen matrimonios entre personas de notable desigualdad, y en sucesivas Reales Cédulas en las que se reiteraba la prohibición de admitir en los tribunales eclesiásticos demandas de esponsales celebrados sin el consentimiento paterno, como había sucedido en el caso de

\footnotetext{
${ }^{56}$ Autos que José Jacinto Ramírez sigue en oposición al matrimonio que Petronila de Ariza pretende contraer con Juan Ramírez, su hijo, 4 de noviembre de 1786. AGI, Santo Domingo, 990.

${ }^{57}$ Testimonio de información producida por Antonia Ramírez sobre su distinción y limpieza de sangre en 1770, que amplió su legítimo hermano Manuel en 1783, y 1784; Información de calidad promovida por Pedro José de Ariza, perteneciente a la de su consorte e hija, Francisca de Sayas Bazán y Villanueva, 1784; Y Testimonio pedido por Pedro José de Ariza de la información de calidad y limpieza de sangre producida por Pedro de Sayas, padre legítimo de Francisca, mujer de aquel, 1784. AGI, Santo Domingo, 990.
} 
Antonio Angulo ${ }^{58}$. Sin embargo, la documentación muestra que sí pidió permiso y que a pesar de poseer ambas familias igual calidad en cuanto al rango militar, a la madre “[...] no le gustaba que se casase con ella [...]"59. Finalmente acabó casándose con otra persona más conveniente para la familia, la rica criolla María de los Ángeles Heredia Campuzano, hija del gran hacendado Nicolás Heredia y Serrano Pimentel, cuya familia participaba activamente en la Audiencia, el cabildo y en el Ejército de la ciudad de Santo Domingo ${ }^{60}$. En el año de 1775, nos encontramos con otro caso dentro de esta red familiar en donde, María Petronila Coca hermana de Josefa solicitó una constancia de legimitimad y limpieza de sangre, para que su hija Josefa contrajera matrimonio con el subteniente del Batallón Fijo Martín José de Miura ${ }^{61}$. Es así que para aprobar o negar una unión matrimonial, la limpieza de sangre o el obtener una licencia paterna fue utilizado como mecanismo de exclusión o integración.

Diferente desenlace tuvo el caso de Julián Joaquín Pueyo y Urríes, hijo del oidor y regente de la Audiencia de Santo Domingo Andrés Pueyo y Urríes, quien se casó clandestinamente con Jerónima Tapia y Castro, miembro de la red familiar Castro-Rivera y Urdaneta ${ }^{62}$. Ante esta situación el oidor interpuso una demanda

\footnotetext{
${ }^{58}$ Las Reales Cédulas dictadas el 26 y 31 de mayo de 1783 seguían las líneas trazadas de la Pragmática de 1776 de prohibir casamientos a aquellos jóvenes que no hubiesen pedido consentimiento a sus padres, y en caso de hacerlo desheredarlos. Las nuevas cédulas añadían además la "privación del goce de los honores familiares y la inhabilitación para obtener empleos civiles”. A partir de entonces todo esponsal debía quedar registrado en una escritura notarial en la que debía aparecer específicamente el consentimiento paterno, así como la firma de los contrayentes, sus padres y los testigos. Véase en Ripodas Ardanaz, D., El matrimonio en Indias..., op. cit., p. 272.

${ }^{59}$ Testimonio de los autos en que Ana Caballero demanda al cadete, Antonio Angulo para que le cumpla la palabra esponsalicia; Y Expediente de Ana Caballero, natural y vecina de Santo Domingo, para que Josefa Coca prestase consentimiento para que su hijo Antonio Angulo se casase con ella, 22 de febrero de 1792. AGI, Santo Domingo, 1008.

${ }^{60}$ Larrazábal Blanco, C., Familias dominicanas..., op. cit., vol. I, p. 142.

${ }^{61}$ Rodríguez Demorizi, E., Milicias de Santo Domingo (1786-1821). Santo Domingo, 1978, pp. 369-381.

${ }^{62}$ Sobre este caso particular la información procede: Expediente sobre haberse casado sin precedente real un hijo de Andrés Pueyo y Urríes, oidor de aquella Audiencia de la isla La Española, 1765; Carta del gobernador y capitán general de la isla Española y presidente de la Real Audiencia de Santo Domingo, en la que informa a Su Majestad de haber celebrado matrimonio clandestino un hijo del oidor Andrés Pueyo y dirige testimonio de las diligencias practicadas sobre este asunto, 7 de abril de 1765; Y Extracto del expediente de la Audiencia de La Española sobre el recurso de fuerza introducido en ella por el oidor Andrés Pueyo y Urríes, con motivo de haberle declarado el juez eclesiástico, por no parte en los autos que seguía de oficio contra Joaquín Pueyo, su hijo, por el matrimonio que contrajo clandestinamente, 1766. AGI, Santo Domingo, 975. Expediente del gobernador de Santo Domingo sobre la aprobación de la providencia dada en asunto al matrimonio clandestino contraído por Joaquín Pueyo y Urríes con Jerónima Tapia, y la instancia de éste en cuanto a que se le levante el destierro que se le impuso por el referido exceso, 28 de septiembre de1768. AGI, Santo Domingo, 979.
} 
en 1765 ante la Audiencia y el tribunal eclesiástico para que fuese anulado dicho matrimonio. Según Andrés su hijo había contraído matrimonio sin el debido permiso paterno y en desigualdad de calidad y condiciones respecto a la mujer. Asimismo se quejaba del procedimiento seguido por el sacerdote, quien debía haberse informado a cerca de si los jóvenes tenían las licencias requeridas antes de celebrar la ceremonia y no después, como sucedió.

Durante el periodo de tiempo en que se deliberaron los hechos acontecidos, la pareja estuvo separada y prisionera, él en la cárcel de la Real Fuerza y ella en el convento religioso de Santa Clara. En 1768 el juez eclesiástico declaró válido el casamiento y que Andrés no era dirimente para poder impedir ese matrimonio contraído en la Iglesia. Aunque el hecho de no tener las licencias y el atentado que cometieron al omitirlas y engañar al cura, hizo que la pareja fuese condenada al destierro fuera de la ciudad al arbitrio de la apelación que hizo Andrés ante el dictamen de aceptación de dicho enlace. Finalmente el matrimonio acabó establecido en la ciudad de Santiago, donde Julián Joaquín Pueyo y Urríes ocupó la alcaldía mayor de dicha ciudad, y fue excluido del clan familiar al considerar su padre que se había mezclado con "[...] una de las familias de poco lustro [...]”, cuando tenía casadas al resto de sus hijas con el "bando poderoso" 63.

Éste y otros ejemplos de matrimonios clandestinos celebrados demuestran que el amor podía tener prioridad a la hora de escoger pareja entre la élite dominante, aunque probablemente todavía en aquella época fuese una práctica restringida. Además el caso de Julián Joaquín y Jerónima es muy significativo, porque muestra que este tipo de enlaces al margen de la autoridad paterna podía tener como consecuencia la exclusión de los contrayentes de su clan familiar. Detrás de este disenso estaba la división de las tres grandes familias de hacendados, como resultado de los conflictos surgidos por el deseo de ocupar los oficios del cabildo y la elección de alcaldes. Así un bando estaba formado por los Guridi y Alarcón-Coronado y los Landeche-Bastidas, al que pertenecía el regente Andrés Pueyo y Urríes, y el otro por la familia Castro-Rivera y Urdaneta, con quien Julián Joaquín había emparentado pese a la oposición de los suyos.

\footnotetext{
${ }^{63}$ Carta del gobernador de Santo Domingo, Isidro Peralta y Rojas a Su Majestad informando sobre la pretensión hecha por varios individuos a los oficios vacantes de regidor, 28 de febrero de 1779, AGI, Santo Domingo, 1021.
} 
A pesar de la rebeldía de estos jóvenes, los hijos de los hacendados presentaron un comportamiento común a la hora de contraer matrimonio. Entrando en su análisis propiamente dicho, se advierte que una de las características de los casamientos de estas familias fueron los matrimonios de conveniencia. Tenían como objetivo establecer alianzas económicas y políticas con otras familias del grupo dominante, es decir, con miembros de la propia familia o con destacados linajes criollos de la jurisdicción de la ciudad.

La siguiente tabla muestra la existencia de al menos seis matrimonios endogámicos y consanguíneos entre los hacendados estudiados. Estos casamientos fueron un mecanismo eficiente, pues garantizaron el mantenimiento del rango social de la familia y el engrandecimiento del matrimonio. Pero además estas uniones sirvieron para paliar los efectos que podía tener el sistema hereditario de división de la herencia a partes iguales entre los hijos, es decir, la dispersión patrimonial. De manera que se utilizaron para recomponer la separación de bienes que pudiera haberse producido en generaciones precedentes. La red familiar Guridi y Alarcón-Coronado y los Landeche-Bastidas constituyen un claro ejemplo de la eficacia de este tipo de matrimonios entre primos hermanos o incluso entre cuñados con matrimonios dobles, cuya elección estuvo motivada por las razones expuestas anteriormente. Hubo otros hacendados estudiados que también utilizaron el casamiento entre tío-sobrina o viceversa como sucedió en la familia de los Heredia y Campuzano conectados a las dos anterirores. Ana Heredia Castro-Coronado se casó con su sobrino Tomás Leos Echalas Heredia, mientras que el hacendado Adrián Campuzano lo hizo con su sobrina Rosa Pérez-Caro Campuzano-Polanco ${ }^{64}$.

${ }^{64}$ Santa Cruz y Mallén, F. J. de, Historia de familias cubanas..., vol. V, pp. 17-20. 
Tabla 4-2. Matrimonios consanguíneos de algunos miembros de las redes familiares Guridi y Alarcón-Coronado y Landeche-Bastidas

\begin{tabular}{|l|l|l|}
\hline \multicolumn{1}{|c|}{ Marido } & \multicolumn{1}{|c|}{ Mujer } & \multicolumn{1}{c|}{$\begin{array}{c}\text { Grado de } \\
\text { parentesco }\end{array}$} \\
\hline José Francisco Heredia Mieses & $\begin{array}{l}\text { María Merced Heredia y } \\
\text { Campuzano }\end{array}$ & Primos hermanos \\
\hline Nicolás Leos-Echalas Heredia & $\begin{array}{l}\text { Josefa María Fernández de } \\
\text { Castro Guridi }\end{array}$ & Primos segundos \\
\hline $\begin{array}{l}\text { Domingo de la Rocha-Ferrer } \\
\text { Landeche }\end{array}$ & Isabel Coca Landeche & Primos hermanos \\
\hline $\begin{array}{l}\text { Rodrigo Macedonio Rocha- } \\
\text { Ferrer Coca }\end{array}$ & $\begin{array}{l}\text { Petronila Angulo Coca- } \\
\text { Landeche }\end{array}$ & Primos hermanos \\
\hline $\begin{array}{l}\text { Domingo de la Rocha-Ferrer } \\
\text { Angulo }\end{array}$ & Manuela Coca-Figueroa & Primos hermanos \\
\hline Andrés Angulo Cabrera & $\begin{array}{l}\text { Francisca Guridi Leos- } \\
\text { Echalas }\end{array}$ & Primos terceros \\
\hline
\end{tabular}

Elaboración propia. Fuentes: Utrera, F. C. de, Centenario de José María Heredia (1839-1939). Homenaje de la República Dominicana. Ciudad Trujillo, 1939, pp. 111-142, y Santo Domingo. Dilucidaciones Históricas. Santo Domingo, 1978, pp. 437-492.

Si bien la Iglesia consideró los matrimonios entre parientes como incestuoso esto fue solventado a través de las dispensas matrimoniales que ella misma concedió. Entre las prohibiciones matrimoniales que establecían las reglas canónicas dentro de los tipos de relaciones de parentesco, se distingue el espiritual, es decir, el bautismal fundamentalmente y, el de consanguinidad por una familiaridad de hasta el tercer y cuarto grado. Aunque en tiempos anteriores al periodo en el que se inserta este trabajo, la Iglesia llegó a requerir dispensa hasta en un séptimo grado de consanguinidad. Así, a la hora de solicitar la dispensa la justicia eclesiástica exigía presentar, con justa causa y, a instancia de una parte de los futuros contrayentes documentación que justificara y explicase el impedimento de consaguinidad o afinidad existente entre la pareja ${ }^{65}$. Generalmente este tipo de

\footnotetext{
${ }^{65}$ La literatura sobre la reglamentación matrimonial dictada por la Iglesia establece dos grupos de impedimentos o prohibiciones. Los absolutos para referirse a situaciones de carácter biológico, como la falta de edad o la impotencia del marido y, las de carácter religioso, por lo general, en el caso de celebrar matrimonios entre infieles o con un hereje. Los impedimentos relativos "se basaban en la afinidad que se lograba con el parentesco, en el temor al incesto y en el problema que planteaban las promesas incumplidas”. Las principales limitaciones remiten al parentesco espiritual, que contraía a los padrinos de bautizados y confirmados y, en particular, el de consaguinidad en determinados grados. Sobre estas teorías justificativas de las prohibiciones matriomiales, véase: Rodríguez Sánchez, A., La familia en la Edad Moderna..., op. cit., pp. 19-25. Bestard Camps, J., "La estrechez del lugar. Reflexiones en torno a las estrategias matrimoniales cercanas” en Chacón Jiménez, F., y Hernández Franco, J. (eds.), Poder, familia y consanguinidad en la España del Antiguo Régimen. Barcelona, 1992, pp. 107-175. Ripodas Ardanaz, D., El matrimonio en Indias..., op. cit., p. 169 y sig.
} 
documentación solía venir acompañada con un deslinde genealógico que servía para aclarar el grado prohibido que ligaba al pretendiente con su pretendida. Un buen ejemplo es la que presentó Andrés Angulo, cuando tenía contraído esponsales con Francisca Guridi Leos-Echalas, y en la que nos encontramos el árbol genealógico, que parte del antepasado común, del que va desglosando las líneas de sucesión hasta llegar a los protagonistas, tal como vemos en la figura 41. De forma que queda perfectamente especificado que la ligazón era en tercero con cuarto grado de consanguinidad. Una vez reconocido el grado de parentesco que existía entre los novios se formulaba la dispensa que finalmente era firmada confirmando que ésta había sido concedida. Obtenida dicha dispensa se celebraba el casamiento.

La forma utilizada para determinar el parentesco existente entre dos individuos que afirman descender de un antepasado común se expresa en términos de líneas y los grados. Dentro de las líneas, estas se clasifican en la línea recta “que une ascendientes con descendientes”, mientras que la colateral liga aquellos que "tienen un ascendiente común, sin estar ellos en línea recta”“66. El grado, por su parte, está en relación con cada una de las posiciones o generaciones de parentesco que vinculan en mayor o menor distancia a dos personas. A partir de esa determinada distancia, variable según cada tipo de sociedad y época, los grados prohibidos también son cambiables en función a la forma de calcular el parentesco. El modo definido y utilizado por la Iglesia Católica para computar los grados de parentesco fue el cómputo romano o civil hasta que a partir del siglo IX adoptó el sistema germánico o eclesiástico. Mientras en la computación romana el cálculo se hacía contando tantos grados como posiciones de parentesco existentes en el trayecto familiar entre dos individuos hasta el antepasado común. En el germánico, se hacía remontándose al antepasado por el número tanto de grados como de generaciones que los separaba ${ }^{67}$.

\footnotetext{
${ }^{66}$ Sánchez Baena, J. J., y Chaín Navarro, C. M., "La persistencia del antiguo régimen en la esructura matrimonial mediterránea: el análisis del parentesco en Cartagena (1750-1850)” en Chacón Jiménez, F., y Hernández Franco, J. (eds.), Poder, familia y consanguinidad..., op. cit., pp. 177-214, p. 180.

${ }^{67}$ Sobre la historia de la evolución de los grados y el cómputo utilizado por la Iglesia véase: Idem. Y, Bestard Camps, J., "La estrechez del lugar. Reflexiones en torno a las estrategias matrimoniales cercanas” en Chacón Jiménez, F., y Hernández Franco, J. (eds.), Poder, familia y consanguinidad..., op. cit., pp.107-175. Arthur Noel, V. J., “Vínculos y grados de parentesco”. Areíto, 19 de marzo de 2005. Este artículo también está disponible desde Internet en:
} 
Volviendo ha tomar el caso que hemos expuesto de los novios Andrés Angulo y Francisca Guridi, este sirve para demostrar que se trata de una consanguinidad combinada al mezclar dos diferentes grados, un tercer con cuarto grado de consanguinidad, debido a que los contrayentes aún teniendo un antepasado común, su posicionamiento los situaba en líneas desiguales y grados distintos. Tal situación implica que debió de existir un salto generacional. Como se puede ver en la figura, Andrés, el novio, es tataranieto del antepasado, mientras que Francisca es biznieta. Este ejemplo, también ilustra que existía al mismo tiempo otro salto generacional grande en cuanto a la edad de casamiento. Mientras Andrés era un hombre bastante mayor, la mujer con la que se casa era probablemente mucho más joven.

<http://genealogiadominicana.com/idg/capsulas/marzo2005/marzo200519.htm>[con acceso el 16 de septiembre de 2005]. 
Figura 4-1. Relación de consanguinidad

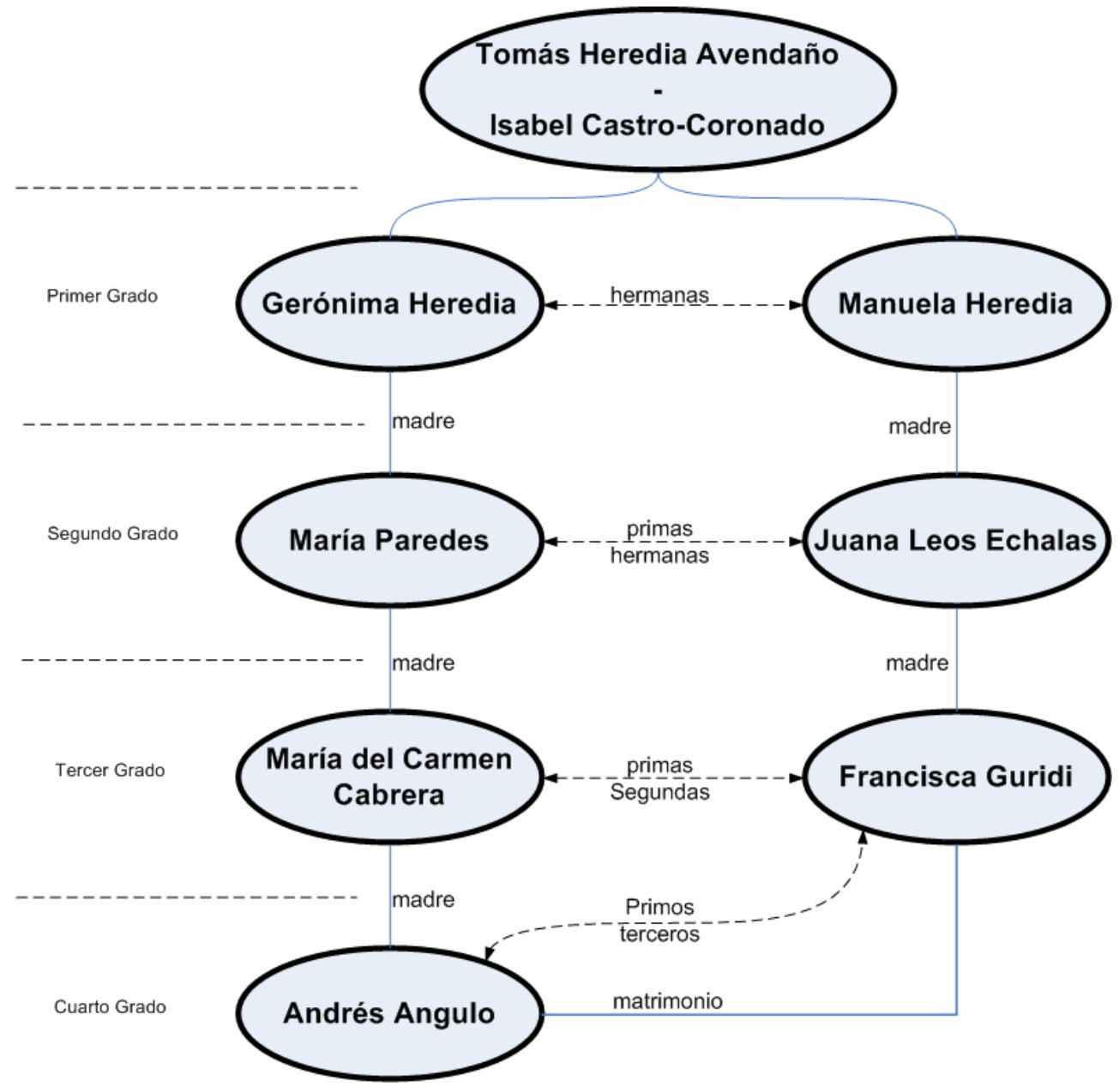

Elaboración propia. Fuentes: Dispensa matrimonial concedida a Andrés Angulo y Francisca Guridi, 14 de marzo de 1811. AASD, Dispensa matrimonial I (1801-1811).

Dejando a un lado estos ejemplos, lo cierto es que los hacendados no sólo optaron sistemáticamente por las nupcias entre parientes, sino que además de la endogamia familiar y consanguínea practicaron otro tipo de endogamia, la ocupacional o profesional. Ésta consistía en la tendencia a casarse entre los miembros de una misma ocupación, lo que también implicó en algunos casos endogamia económica, es decir, casamientos realizados dentro de su misma esfera social y de recursos similares. Los niveles detectados de endogamia ocupacional entre los hacendados son muy significativos. Tanto los hijos como las hijas de esas familias de hacendados, miembros de la Audiencia o del cabildo, emparentaron con apellidos de propietarios de haciendas que al mismo tiempo 
estaban representados en dichas instituciones así como en el Ejército, la Iglesia, la Universidad y la Real Hacienda. Estos casamientos permitieron que las familias Guridi y Alarcón-Coronado, Landeche-Bastidas y Castro-Rivera y Urdaneta estuvieran vinculadas entre sí, y monopolizasen la vida local de la ciudad de Santo Domingo en todos los ámbitos, a través de la presencia de varios de sus miembros en aquellas instancias. La vinculación de estas familias a su vez con otros clanes familiares de poderosos hacendados, como fueron los Mañón, Leos-Echalas, Frómesta, Heredia, Campuzano, Pérez-Caro, y Fernández de Castro entre otros, fue lo que determinó que éstas retuvieran a lo largo de varias generaciones tal concentración de poder.

No obstante, esto no significa que estas familias no aceptaran a los peninsulares como futuros cónyuges para sus hijos. Así, además de la endogamia familiar y profesional, los hacendados, sobre todo en el caso de los matrimonios de sus hijas, escogieron mayoritariamente a sus maridos entre los peninsulares, o los hijos de éstos, que fueron llegando a la ciudad de Santo Domingo durante la segunda mitad del siglo XVIII para ocupar la plaza de oidor, como oficiales reales, militares, comerciantes, administradores de la Factoría de Tabacos y de la Compañía de Comercio de Barcelona. Todos ellos acabaron integrándose en los negocios familiares como hacendados, y en algunos casos obtuvieron cargos en el gobierno local de la ciudad de Santo Domingo, y grados militares.

A diferencia de algunos lugares del continente americano, donde este tipo de matrimonios se dio a través de contratos realizados antes de la llegada del peninsular a Indias con una familia local o entre individuos procedentes de la misma región, en Santo Domingo parece que no fue frecuente entre los hacendados esta endogamia geográfica. Esta solidaridad regional fue bastante habitual entre los comerciantes de Guatemala, Lima y México, y más concretamente entre los peninsulares vascos ${ }^{68}$. Sin embargo, en Santo Domingo también se dieron matrimonios entre los propios peninsulares que procedían de distintos lugares de la Península.

\footnotetext{
${ }^{68}$ Sobre los vascos destacamos: Santos Pérez, J. M., Élites, poder local y régimen colonial..., op. cit., p. 144. Turiso Sebastián, J., Comerciantes españoles en la Lima Borbónica..., op. cit., pp. 135 y 143. Brading, D., Mineros y comerciantes en el México borbónico (1763-1810). México, 1993, pp. 149-159. Escobedo Mansilla, R., Zaballa Beascoechea, A. de y Álvarez Villa, O. (eds.), Emigración y redes sociales de los vascos en América. Vitoria, 1996.
} 
Según las leyes de Indias, los peninsulares que llegaron como ministros no podían entablar lazos de parentesco con la sociedad local, aunque la Corona les eximió de tales restricciones a través de una contribución económica a cambio de la que se les concedían dispensas matrimoniales. En un principio las reformas Borbónicas obligaron a dejar de conceder las dispensas matrimoniales, sin embargo éstas volvieron a concederse de forma gratuita a condición de que la persona que las recibiera aceptase de forma inmediata el traslado a otro distrito ${ }^{69}$. A pesar del deseo de la Corona de controlar a sus ministros, éstos supieron hacer prevalecer sus intereses frente a los suyos. Así por ejemplo, el oidor de la Audiencia Andrés Pueyo y Urríes recibió en 1768 licencia para casar a sus hijas con personas empleadas en el distrito de la Audiencia de Santo Domingo, bajo la condición de abandonarla y trasladarse a otra. Pero Andrés Pueyo y Urríes permaneció junto a su familia en la ciudad de Santo Domingo, y continuó participando en las actividades económicas de la ciudad como hacendado ${ }^{70}$. Sus dos hijas se unieron a personas que ocupaban cargos importantes en la Audiencia y en la Real Hacienda. María se casó con el oidor y juez de realengos y almonedas Ruperto Vicente Luyando y Beltrán, trasladándose en 1772 a Guadalajara para ocupar el empleo de oidor, y seis años más tarde a México. Y Joaquina se casó con otro oidor, el limeño Nuño Navia Bolaños, quien años después fue nombrado para el mismo empleo en la Audiencia de Guatemala. Su otra hija Josefa estuvo casada con el contador de las Cajas Reales Francisco de Paula Gazcue y Olaiz, quien llegó a convertirse en un destacado hacendado ${ }^{71}$. (Véase en el anexo la Figura 11)

Otro ejemplo de casamiento entre peninsulares es el caso del teniente coronel de las milicias de Santo Domingo José de la Vega, natural de Plasencia, quien estuvo casado primeramente con Antonia de Galandier y Velez Carrión, y en segundas nupcias con María Teresa Jover Aznar, hija del oidor Ramón Jover

\footnotetext{
${ }^{69}$ Burkholder, M. A., y Chandler, D. S., De la impotencia a la autoridad..., op. cit., pp. 137-138.

${ }^{70}$ Carta del fiscal en la que informa que Andrés Pueyo y Urríes quiere casar a sus hijas con naturales de aquel distrito y solicita licencia, 11 de julio de 1766. AGI, Santo Domingo, 921.

${ }^{71}$ Carta de Ruperto Vicente Luyando en la que solicita licencia para contraer matrimonio con persona natural del distrito, 28 de julio de 1766. AGI, Santo Domingo, 921. Instancia del oidor Nuño Navia Bolaños para contraer matrimonio con una hija de Andrés Pueyo y Urríes, 13 de enero de 1770. AGI, Santo Domingo, 921 y 922. Expediente en cuanto a lo ocurrido en la presentación que hicieron varios vecinos a los oficios de regidor vacante y sus incidencias. AGI, Santo Domingo, 1021.
} 
Ferrandiz y de Joaquina Aznar. Francisca Antonia Jover, la hermana de María Teresa, se unió en matrimonio a otro oidor, Pedro Catani, un catalán que había llegado en 1783 para ejercer dicho empleo en la Audiencia, en la que acabó instalándose tras ese enlace matrimonial ${ }^{72}$.

Como se ha podido observar, después de la muerte de uno de los cónyuges, las segundas nupcias no fueron excepcionales. Además de los casamientos entre peninsulares, otros tendieron a los enlaces dentro de la propia familia, como sucedió con Joaquín Cabrera que se casó en segundas nupcias con una hermana de sus nueras María de la Concepción Angulo Coca Landeche al quedarse viudo. Tres de los hijos de su primer matrimonio se habían casado anteriormente con personas que eran hermanos entre sí y a su vez de María de la Concepción. Esta forma de integrar parientes a través de estos matrimonios encadenados triples que unen a hermanas con hermanos y, el del padre de éstos con otra hermana de las anteriores expresan claramente una elección explícita de cónyuges preferenciales dentro de la propia parentela y, el deseo de renovar las alianzas entre ambas partes e integrarse a través de matrimonios con un parentesco de afinidad a la red de los Landeche-Bastidas. Estos matrimonios eran lícitos por lo que no necesitaban dispensa eclesiástica. (Véase en el anexo las figuras 6 y 14)

En el caso de María de los Santos Leos-Echalas, al morir su marido en 1752, el regidor Felipe Frómesta y Montejo, se volvió a casar con el salmantino e ingeniero militar Antonio Álvarez Barba. Ambas familias los Leos-Echalas y los Frómesta estaban emparentados con la familia Guridi-Alarcón y Coronado y los Castro-Rivera y Urdaneta, como se verá en el siguiente epígrafe. Este hecho muestra que los enlaces entre peninsulares y criollas fueron también un patrón matrimonial muy común entre las tres redes de familias de hacendados.

Los miembros de las familias Landeche-Bastidas y Castro-Rivera y Urdaneta, tampoco tuvieron ningún problema en encontrar maridos de prestigio para sus hijas, y en alguna ocasión fue un hijo el que conectó el casamiento con una peninsular. De esta manera varios miembros de una misma familia lograron que sus hijas casaran con peninsulares, como hizo Gonzalo de Castro-Rivera que

\footnotetext{
${ }^{72}$ Escritura de dote de María Teresa Jover, 15 de marzo de 1788. AGI, Santo Domingo, 948. Véase también Larrazábal Blanco, C., Familias dominicanas..., op. cit., vol. II, p. 158, y del vol. IX, p. 46.
} 
casó a Micaela con el canario y corsario Domingo Lorenzo Zevallos, y a Ana con Antonio Valdemoro y Alcántara. Otro miembro de esta familia, el hacendado y regidor Gregorio Saviñón tuvo catorce hijos, de los cuales tres se casaron con peninsulares que llegaron a Santo Domingo durante la segunda mitad del siglo XVIII: así Jacinta lo hizo con el tesorero de las Cajas Reales Fernando Mauleón ${ }^{73}$, Juana con el teniente de ingenieros Pedro Roig y Lluís, y Bárbara con el catalán Salvador Pí y Piquer, empleado en la Real Compañía de Comercio de Barcelona. Las dos únicas hijas que se casaron con criollos fueron: María Antonia que se desposó con Miguel Jerónimo Martínez de Venecia Santelices, y María Vicenta con Joaquín Fernández de Castro. De igual manera la hija de este último matrimonio María de la Cruz contrajo nupcias con el criollo Francisco Xavier Foxá Lecanda. Los padres, abuelos y tíos de Francisco contaban con uniones entre criollas y peninsulares que ocupaban cargos en la vida político-militar y en el comercio de Santo Domingo ${ }^{74}$.

En esta misma línea, la familia Landeche-Bastidas además de contar con matrimonios dentro de su propio círculo familiar y con otras familias criollas, también elaboró una política matrimonial mediante la cual incorporó a peninsulares que llegaron como militares u oficiales reales. Así por ejemplo, Josefa Coca-Landeche se casó con un navarro que llegó como teniente militar, Lorenzo Angulo Medrano. Dos de sus hermanas siguieron ese patrón. Una de ellas, Ana se casó con el peninsular Francisco Martínez, y María Petronila se unió al gaditano y oficial de las Cajas Reales de Santo Domingo Francisco Pepín González. Este matrimonio hizo un contrato para que su hija Josefa se casara con el pamplonés Martín José de Miura, un subteniente del Batallón Fijo ${ }^{75}$.

Estos matrimonios estratégicos con funcionarios de la administración sirvieron a las familias de los hacendados como respaldo a sus intereses

\footnotetext{
${ }^{73}$ Fernando Mauleón estuvo casado en segundas nupcias con Ana Cabrera y Paredes, hija de Joaquín Cabrera y María Paredes. Carta del gobernador de Santo Domingo, Joaquín García, dando cuenta a Su Majestad por medio de un expediente obrado para el casamiento y licencia que dio al tesorero de aquellas cajas Fernando Mauleón celebrado con Jacinta Saviñón, 20 de enero de 1791. AGI, Santo Domingo, 954. Carta de Ana Cabrera, viuda de Fernando Mauleón, solicitando pensión, 1800. AGI, Santo Domingo, 1037.

${ }_{74}$ Véase en Larrazábal Blanco, C., Familias dominicanas..., op. cit., vol. II, pp. 131-132 y del vol. VIII, pp. 105-106. Guerrero Cano, M" . M., "Un dominicano en el colegio de nobles americanos de Granada. Familia y genealogía de Juan Clemente Martínez Saviñón”..., op. cit., pp. 383-400.

${ }^{75}$ Larrazábal Blanco, C., Ibidem., vol. I, pp. 141-142. Rodríguez Demorizi, E., Milicias de Santo Domingo..., op. cit., pp. 369-381.
} 
económicos y para predominar en la esfera política, la Real Hacienda, y militar, además de prestigiarlas. Por otro lado, como se ha venido explicando, permitieron a los peninsulares integrarse en las redes familiares y participar en la vida política y económica de Santo Domingo. Sin embargo, a pesar de las ventajas que reportaba un buen matrimonio, hubo peninsulares que quedaron solteros, desconociéndose el motivo. Entre ellos destaca el tesorero de las Cajas Reales Raymundo Esparza, por la fortuna que tuvo y el reconocimiento social y el poder que llegó a tener, y Juan Bautista Oyarzábal y Olavide, administrador del ingenio Boca de Nigua. Ambos se incorporaron a las familias de hacendados a través de otro tipo de conexiones que se explicaran más adelante.

\subsection{Las redes familiares}

Hasta ahora se ha podido observar que estas familias de hacendados realizaron uniones entre sí y entre peninsulares. Pero también hubo una apertura social hacia los peninsulares, lo que les permitió mantenerse y reforzar su actuación en las instancias de poder. Para facilitar el análisis de las políticas matrimoniales de las tres grandes familias, éstas se presentan a continuación indicándose más detalladamente sus filiaciones, conexiones entre sí, y con otras familias.

\subsubsection{Guridi y Alarcón-Coronado}

De entre las familias más importantes de hacendados y su red de enlaces destacan los Guridi y Alarcón-Coronado. El apellido Guridi es originario del País Vasco, y representa a un linaje guipuzcoano que tuvo su antigua casa solar en la villa de Legazpia, perteneciente al partido judicial de Bergara. De esta casa salieron distintas ramas que se establecieron y fundaron nuevas familias en las villas de Zegama y Azpeitia. Una de esas ramas tuvo presencia en tierras americanas desde finales del siglo XVII y estuvo representada por Antonio Guridi y Echeandia, el fundador de la familia Guridi en la ciudad de Santo Domingo ${ }^{76}$.

\footnotetext{
${ }^{76}$ Antonio Guridi y Echeandia era hijo de Francisco Guridi Echeandia y de María de Aguirre Burualde. Sobre esta familia véase los siguientes trabajos: Guerra, J. C. de, Ensayo de un padrón histórico de Guipúzcoa, según el orden de sus familias pobladas. San Sebastián, 1928, pp. 257-
} 
Este guipuzcoano, antes de asentarse en esta ciudad, estuvo en Venezuela y México participando en las expediciones de conquista y reducción de indios en Cumaná, Campeche y Yucatán. En Venezuela poseyó el grado de alférez en una de las compañías de la fuerza de Araya, y en Yucatán sentó la plaza de soldado en la compañía de caballos de coraza y fue arcabucero de aquella provincia, en la que también ascendió a alférez. Después de haber estado tres años en la última compañía, entró como cabo de infantería en una fragata que navegaba como guarnición a la Armada de Barlovento, hasta que pasó a Santo Domingo donde se avecindó y se casó con Leonor Alarcón-Coronado, hija del capitán Nicolás Alarcón-Coronado y de Isabel Gazo Carrillo ${ }^{77}$. En esta ciudad continuó con su carrera militar, siendo nombrado por el gobernador Guillermo Morfi para el puesto de sargento mayor en interinidad por la ausencia de su propietario, Juan del Barranco. Este cargo lo desempeñó desde el 9 de septiembre de 1708 hasta el 22 de octubre de 1710. En 1721 fue capitán propietario de una de las compañías militares de esa plaza $^{78}$. Se convirtió en un importante hacendado al adquirir el ingenio Camba Santa Lucía, el cual pasó a sus descendientes, siendo sus poseedores a finales del siglo XVIII Josefa María Fernández de Castro Guridi y Nicolás Leos-Echalas Heredia.

El matrimonio entre ambos engendró tres hijos, dos chicos llamados Nicolás y Matías, y una chica, Antonia. Ésta se casó con Luís Franco Acevedo, un peninsular oriundo de las Canarias que emigró a La Española, donde ejerció el cargo de capitán de caballería. Además se dedicó al contrabando a principios del siglo XVIII, y tuvo el apodo de "el Tapado", porque siempre que trataban de apresarlo lograba escapar, para lo cual parece que contó con cómplices como el gobernador de aquel entonces, Francisco de la Rocha y Ferrer, y sus allegados ${ }^{79}$.

259. Y las obras de Mogrobejo, E. de, Blasones y linajes de Euskalerria. Bilbao, 1991, vol. VII, pp. 72-73. Zelaia, I. (coord.), Legazpi. Itxaropena, 1979, pp. 63-65. Ugarte, J. L., Mandinabeitia, T., y Ugalde, $\mathrm{M}^{\mathrm{a}}$. J., (coords.), Brinkola gogoan: apunte historiko eta etnografikoak. Donostia, 1999, pp. 83-88 y 251-255.

${ }^{77}$ Larrazábal Blanco, C., Familias dominicanas..., op. cit., vol. III, p. 446.

${ }^{78}$ Relación de los servicios militares del alférez Antonio de Guridi, cabo de la Infantería de una fragata de la Armada de Barlovento, 10 de noviembre de 1685. AGI, Indiferente General, 130, N1, 22.

${ }^{79}$ Luís Franco Acevedo era hijo de Luís Franco Delgado y Acevedo y de Inés Herrera de Oliva, todos ellos originales de la villa de Orotava de Tenerife. Luís Franco Delgado y Acevedo al enviudar marchó a La Española con sus hijos, donde se volvió a casar con Antonia de Ourive. Testimonio de los autos de renuncia del oficio de regidor de la capital hecha por Antonio Valdemoro y Alcántara a favor de Luís Franco, 1785-1789. AGI, Santo Domingo, 938. Véase 
Este matrimonio también tuvo una sola hija y tres hijos varones: Enrique, Mateo, Luís e Isabel. Mateo y Luís Franco Guridi realizaron servicios militares en el Batallón Fijo de Santo Domingo. El primero lo hizo como soldado distinguido, y el segundo como teniente del mismo regimiento, además este último fue alcalde ordinario en 1778, y obtuvo el empleo de regidor en $1785^{80}$. Mateo se casó con María Pérez Caro Fernández, nieta del contador Julián Fernández Pérez, enlazando con la distinguida familia Pérez-Caro ${ }^{81}$.

La única hija, Isabel Franco Guridi, se casó con el licenciado José Jacinto Ramírez, un criollo que estuvo como cadete en el batallón de la plaza de Santo Domingo durante once años, desde 1754 hasta 1764. En 1764 se le concedió el título de abogado, oficio que ejerció en la Audiencia y desde 1778 también desempeñó el empleo de relator ${ }^{82}$. Tuvieron seis hijos: Silvestre, Juan, María Mercedes, Antonia, Manuel y José María. Entre los varones, Silvestre Ramírez Guridi ocupó un cargo de regidor al comprarlo en 1789. Su hija María Mercedes Ramírez Guridi contrajo matrimonio con otro miembro de la Audiencia, el abogado, asesor de gobierno y también criollo Vicente Antonio Faura ${ }^{83}$. Siguiendo la línea de este tipo de matrimonios endogámicos "socioprofesionales”, otro de sus hijos, José María Ramírez, también abogado de la Audiencia, se casó con Antonia Marca Quevedo y Villegas, cuya familia participaba activamente en este cuerpo ${ }^{84}$.

también el artículo de Utrera, F. C. de, "Don Luís Franco de Acevedo". BAGN XII: 61 (Ciudad Trujillo, 1949) pp. 372-385.

${ }^{80}$ Hoja de servicios militares de Mateo Franco Guridi, 1 febrero de 1756. AGI, Santo Domingo, 933.

${ }^{81}$ La familia Pérez-Caro era originaria de Sevilla, su fundador en Santo Domingo fue Ignacio Pérez-Caro, quien llegó a finales del siglo XVIII como gobernador, capitán y presidente de esta ciudad, donde acabo estableciéndose. Ignacio Pérez-Caro era el bisabuelo paterno de María PérezCaro Fernández, y sus padres fueron Francisco Caro y Oviedo y María Manuela Fernández de Lara, la cual era hija del contador real Julián Fernández Pérez y de Catalina de Lara y Figueroa. Los descendientes de la familia Pérez-Caro fueron hacendados y contaron con un currículo político y militar muy amplio. Véase en Santa Cruz y Mallén, F. J. de, Historia de familias cubanas..., op. cit., vol. V, pp. 17-20.

82 José Jacinto Ramírez era hijo de Manuel Ramírez y de Úrsula González. Véase en Testimonio de información producida por Antonia Ramírez sobre su distinción y limpieza de sangre en 1770, que amplió su legítimo hermano Manuel en 1783 y 1784. AGI, Santo Domingo, 990.

${ }^{83}$ El apellido Faura es originario de Orihuela (Alicante) de donde eran los padres de Vicente Antonio Faura, que fueron Antonio Faura y Josefa Rodríguez-Agudo, aunque él había nacido en Santo Domingo. Véase en Informe de justificación de calidad y antigüedad de los progenitores del abogado Vicente Antonio Faura, abogado de la Audiencia, vecino y natural de la misma. AGI, Santo Domingo, 990.

${ }^{84}$ Antonia desciende de la familia Villegas, establecida en Santo Domingo desde principios del siglo XVII ocupando cargos en la administración de la ciudad. Su hermano Juan Quevedo y 
El segundo hijo del matrimonio entre Antonio Guridi y Echeandia y Leonor Alarcón-Coronado fue Nicolás, quien comenzó a servir en el Ejército el 1 de enero de 1709, logrando con el paso de los años ser capitán en propiedad de una de las compañías de dotación, como lo fue su padre, y ascender al título de coronel de milicias de Santo Domingo ${ }^{85}$. También participó en el gobierno de la ciudad de Santo Domingo al ser elegido alcalde ordinario en 1727. Se casó en primeras nupcias con Ana Micaela Frómesta Balmaceda, y por segunda vez con otra criolla Beatriz Leos-Echalas ${ }^{86}$. Parece que tanto en uno como en otro matrimonio no hubo hijos. Ambas uniones permitieron enlazar con otras familias dominantes de Santo Domingo, los Frómesta y los Leos-Echalas, que poseían haciendas y cuyos miembros contaban con grados militares y ocupaban cargos en la Audiencia y el cabildo. Además con estas familias estuvieron emparentados a través de otros matrimonios que se establecieron con miembros de los Guridi. Así, una hermana de la primera mujer de Nicolás, llamada Isabel, estuvo casada con José Guridi Concha. Y una hermana de su segunda mujer, Ana Buenaventura Leos-Echalas, se unió a un hermano del anterior, Felipe Guridi de la Concha ${ }^{87}$.

Matías Guridi Coronado, el segundo hijo varón de Antonio Guridi y de Leonor Alarcón-Coronado, fue como su padre y su hermano, capitán del batallón

\footnotetext{
Villegas fue escribano de cámara y de gobierno, y estaba casado con Antonia Piña Urdaneta, hija de Gabriel Urdaneta y Piña y Úrsula Arambule, miembros de la red Castro-Rivera y Urdaneta. Sobre el linaje Villegas véase Gíl-Bermejo García, J., La española. Anotaciones históricas (16001650). Sevilla, 1983, pp. 220 y 344. Bouché Español, L., Memorial de Lope de Villegas. Historia del linaje de Villegas. La isla de Santo Domingo a principios del siglo XVII. Madrid, 1997.

${ }_{85}$ Relación de los servicios del capitán de infantería Nicolás Guridi Coronado, que lo es en propiedad de una de las cuatro compañías de la dotación antigua del presido de Santo Domingo en la isla Española. AGI, Indiferente General, 166. Y Carta del Gobernador en la que da cuenta del memorial de Nicolás Guridi y Coronado, para que se le conceda el título de coronel de milicias de Santo Domingo, 2 de marzo de 1767. AGI, Santo Domingo, 932.

${ }^{86}$ Demanda puesta por Leonor Coronado, viuda del capitán Antonio Guridi que lo fue de este presidio a los bienes del mariscal de Campo Guillermo Morfy, presidente, gobernador y capitán general que fue de esta isla y la siguió el alférez Nicolás Guridi su hijo por los gajes, y tablajes de los juegos que debió percibir del tiempo que fue dicho capitán sargento mayor, 1725. AGI, Escribanía 30. Expediente de la causa matrimonial seguida por Francisca Frómesta contra Andrés de Ibarra, 1784. AGI, Santo Domingo, 1025.

${ }^{87}$ La familia Leos-Ehalas procede de Murazával (Navarra). José Leos-Echalas se estableció en Santo Domingo a finales del siglo XVII, e inició la saga de esta familia al casarse con la criolla Beatriz Lucía Cataño y Mosquera. Sus descendientes se convirtieron en terratenientes, obtuvieron grados militares y empleos en el cabildo de la ciudad de Santo Domingo. Además de los Guridi, estaban emparentados con otras familias como los Heredia, Coca-Landeche y Castro-Rivera Urdaneta a través de los matrimonios de sus hijos. Tanto Beatriz como Ana Buenaventura LeosEchalas eran hijas de Francisco Javier Leos Echalas y Jerónima Heredia Castro-Coronado. Escritura del testamento de Beatriz Leos Echalas, 28 de noviembre de 1783. AGI, Santo Domingo, 960. Véase también Santa Cruz y Mallén, F. J. de, Historia de familias cubanas..., op. cit., vol. V, p. 138.
} 
de milicias de la ciudad de Santo Domingo en 1726, y en 1732 de la compañía de caballería. Se casó en 1726 con María Merced Rivera de la Concha Solano, hija del capitán y secretario de cámara de la Audiencia, José Rivero de la Concha, natural del Valle de Carriendo (Santander), y de Ana Solano Garavito ${ }^{88}$. Más tarde, en 1741, compró el oficio de alguacil mayor de la Audiencia, y a partir de ese momento este oficio permaneció en la familia durante dos generaciones más hasta la cesión de la isla ${ }^{89}$. Entre sus descendientes tuvieron dos hijas: María que fue monja clarisa, y Ana que contrajo matrimonio el 30 de junio de 1748 con Juan Mieses Ponce de León y Pérez-Caro, un criollo y hacendado que fue alcalde de Santa Hermandad y regidor en el cabildo de Santo Domingo, muriendo el 5 de enero de 1759. Este enlace significó otra conexión con la ya citada familia PérezCaro y los Mieses Ponce de León. Ana y Juan Mieses tuvieron cinco hijos: María, Francisca Justa, Rosalía, José María y María de la Concepción ${ }^{90}$. El matrimonio de dos de sus hijos permitió emparentar con otras dos familias importantes de la ciudad, los Campuzano y los Heredia. Así el hijo varón mayor José María Mieses se casó con Josefa Campuzano y Fernández de Lara, hija del regidor venezolano José Campuzano Polanco Morillo y de la criolla Rosa Fernández de Lara. Los Campuzano ocuparon cargos edilicios, en el Ejército, la Universidad y la Audiencia $^{91}$.

\footnotetext{
${ }^{88}$ María Merced Rivera de la Concha tuvo un hermano, Antonio, que fue prebendado, dignidad de tesorero y maestro de escuela del cabildo de la catedral de Santo Domingo. La madre de ellos Ana Solano y Garavito fue hija de Antonio Solano, secretario de dicha audiencia y de Magdalena Garavito. Estos también tuvieron otro hijo, Lorenzo, que fue vicario general del Arzobispado de Santo Domingo, véase en Expediente de José Rivero y la Concha, vecino de Santo Domingo, solicitando la confirmación del oficio de escribano de cámara y gobierno de la Real Audiencia, 21 de febrero de 1705. AGI, Santo Domingo, 298.

${ }^{89}$ Relación de los méritos y servicios del capitán Matías Guridi y Coronado, que lo es con actual ejercicio del batallón de las milicias de la ciudad de Santo Domingo de la isla Española, y de su padre y abuelos. AGI, Indiferente General, 166. Confirmación de oficios vendibles y renunciables. AGI, Santo Domingo, 299 y 938.

${ }^{90}$ Juan Mieses era hijo del teniente coronel y capitán de infantería Francisco Mieses Ponce de León Quero y de Francisca Luisa Pérez-Caro y Fernández de Oviedo. Escritura del testamento de Juan Mieses, 5 de enero de 1759. AChV, Pleitos civiles, La Puerta Olvidados 1378. Véase también Santa Cruz y Mallén, F. J. de, Historia de familias cubanas..., op. cit., vol. V, pp. 17-20.

${ }^{91}$ Entre los hijos que tuvieron José Campuzano Polanco Morillo y Rosa Fernández de Lara cabe destacar a María Magdalena Catalina casada con Ignacio Pérez Caro y Oviedo con el que tuvo como hijo a Francisco Xavier Caro, y al abogado Adrián casado con su sobrina Rosa Pérez Caro Campuzano. Los abuelos paternos de ellos fueron el mariscal de campo Francisco Campuzano Polanco y la venezolana María Francisca Morillo de Ayala. Los bisabuelos paternos de Josefa fueron el abogado de la Audiencia Gregorio Semillán Campuzano y la criolla María Josefa Pérez Polanco, que tuvieron a Francisco y también al clérigo Francisco Gregorio Semillán Campuzano, al corsario y teniente coronel José, y al capitán de caballería Pedro. Sobre esta familia pueden verse las siguientes publicaciones: "Memorial del Licenciado Gregorio Semillán Campuzano, 16
} 
Mientras que su hermana Francisca Justa Mieses Guridi contrajo matrimonio con el regidor Manuel Heredia Serrano Pimentel. Esta unión significó emparentar con otra de las más acaudaladas familias de aquel entonces, con haciendas e ingenios y con participación de sus miembros en el cabildo y el Ejército. Manuel Heredia procedía por línea materna de los Serrano-Pimentel, una de las estirpes más importantes del siglo XVII. Por parte paterna, también provenía de una familia ilustre, cuyos orígenes se remontan al conquistador de Cartagena de Indias, Pedro Heredia ${ }^{92}$. Francisca Justa Mieses y Manuel Heredia tuvieron cinco descendientes, un hijo y cuatro hijas, los cuales se casaron con criollos, personas cercanas a su círculo, lo que les permitió enlazar con otras familias de hacendados. Joaquina Heredia Mieses se casó con el hacendado José Antonio Zárraga Caro de Oviedo, conectando de nuevo con la familia PérezCaro $^{93}$. María Dolores Heredia Mieses enlazó matrimonialmente con otro hacendado, Tiburcio José Sterling del Monte, quien además fue abogado de la Audiencia desde 1783, así como alcalde ordinario en los años de 1789 y 1795, y síndico procurador general en $1799^{94}$. Su otra hija María Altagracia Heredia Mieses celebró matrimonio con José Antonio Peralta Mañón, enlazando con la familia Mañón, de origen francés, asentada en la ciudad de Santo Domingo desde

de agosto de 1687” en Rodríguez Demorizi, E., Relaciones históricas. Ciudad Trujillo, 1957, vol. III, pp. 273-295. Machado Báez, M. A., Santiagueses ilustres de la colonia..., op. cit., pp. 27-34. Larrazábal Blanco, C., Familias dominicanas..., op. cit., vol. II, pp. 63-64. Utrera, F. C. de, Centenario de José María Heredia..., op. cit., pp. 135-138. Stapells Johnson, V., "Los corsarios de Santo Domingo 1718-1779: un estudio socio-económico”. Quaderns del departament de geografia i historia del l'estudi general de Lleida 12 (Lleida, 1991) pp. 3-93, particularmente las páginas 4251. Torres Agudo, R., "Los Campuzano-Polanco, una familia de la élite de la ciudad de Santo Domingo”, Nuevo Mundo Mundos Nuevos, $\mathrm{n}^{\circ}$ 7-2007. Artículo que está disponible desde Internet en: <http://nuevomundo.revues.org/document3240.html.> [publicación en línea y con acceso el 5 de enero de 2007].

${ }^{92}$ Manuel Heredia Serrano Pimentel era hijo de Domingo Heredia Castro-Coronado y de Isabel Serrano Pimentel y Paredes. Esta familia enlaza con los Leos-Echalas, Campuzano, Caro y del Monte. Para obtener información sobre la familia Heredia y sus enlaces véanse las siguientes obras: Utrera, F. C. de, Centenario de José María Heredia..., op. cit., Valera Valdez, V. M., Baní: Raíces Históricas. Genealogía de Familias Banilejas. Baní, 1998, pp. 209-211. Larrazábal Blanco, C., Familias dominicanas..., op. cit., vol. IV, pp. 17-22. Y, Santa Cruz y Mallén, F. J. de, Historia de las familias cubanas..., op. cit., vol. V, pp. 136-150.

93 José Antonio Zárraga Caro de Oviedo, era hijo del bilbaíno José Antonio Zárraga y de la criolla Felipa Pérez-Caro y Oviedo. Libro de bautismos. AASD, Acta 946, fol. 207, libro 11.

${ }^{94}$ Tiburcio José Sterling era hijo del francés Nicolás Sterling, quien fue teniente de caballería de dragones, y de la criolla Bernarda del Monte y Luna, perteneciente a una familia de Santiago. Bernarda era hija de Tiburcio del Monte y de Ana Luna, los abuelos de ella contaban con una amplia presencia en el Ejército. Tiburcio José estuvo casado en primeras nupcias con Jacinta Arredondo Castro, miembro de la red Castro-Rivera y Urdaneta. Expediente con motivo de dirigir la Real Audiencia de Santo Domingo testimonio de los méritos y servicios del licenciado José Sterling, 11 de diciembre de 1795. AGI, Santo Domingo, 999. 
finales del siglo XVII. Sus miembros destacaron como hacendados y ocuparon importantes cargos políticos tanto en el cabildo como en la Audiencia, la Iglesia y en el Ejército ${ }^{95}$.

El hijo varón de Francisca Justa Mieses y Manuel Heredia se llamó José Francisco Heredia Mieses y nació el 1 de diciembre de 1776. Fue abogado de la propia Audiencia de Santo Domingo en 1795, y profesor de derecho en la Universidad de Santo Tomás de Aquino. Tras el Tratado de Basilea emigró a Venezuela, aunque no de manera inmediata sino a principios del siglo XIX donde fue oidor y regente de la Audiencia de Caracas ${ }^{96}$. Allí contrajo matrimonio con su prima hermana María Merced Heredia y Campuzano, nacida en Venezuela, ya que sus padres también habían emigrado ha dicho país. Este matrimonio consanguíneo facilitó de nuevo su enlace con los Campuzano ${ }^{97}$. José Francisco Heredia Mieses y María Merced fueron los padres del célebre poeta dominicano José María Heredia y Heredia, autor del Cantor del Niágara ${ }^{98}$.

Además de la ya mencionada Ana, Matías Guridi Coronado y María Merced Rivera de la Concha y Solano tuvieron dos hijos varones que se casaron con criollas, hijas de otras importantes familias de Santo Domingo con las que enlazaron y así consolidaron su posición. Uno de ellos fue Felipe Guridi Concha, quien contrajo nupcias con Ana Buenaventura Leos-Echalas, hermana de Beatriz

\footnotetext{
${ }^{95}$ José Antonio Peralta Mañón era hijo del granadino Manuel de Peralta que había llegado a la isla como militar del regimiento de Zamora en 1782 y se estableció al casarse con la criolla María de la Concepción Mañón de Lara Mieses. Ésta joven era hija del hacendado Antonio Mañón de Lara y Ana Teresa Mieses Ponce de León. Este matrimonio tuvo otros hijos, como José María Mañón Mieses que estuvo casado con María de la O Sánchez del corral, y tuvieron como hija a María Merced casada con Juan Castro Palomino, y María Petronila Mañón casada con el militar Esteban Fernández Palomares. Los bisabuelos de José Peralta Mañón fueron el francés Antonio Mañón y Angelina de Lara y Mieses. Para obtener información de la familia Mañón véase: Álvarez Gautier, M. J., "Esteban Fernández Palomares. Su carrera en el Batallón Fijo y su descendencia”. Raíces 7 (Santo Domingo, 1995) pp. 27-30. Y, Larrazábal Blanco, C., Familias dominicanas..., op. cit., vol. V, pp. 35-37.

${ }^{96}$ Después de su salida de Santo Domingo, José Francisco de Heredia y Mieses desempeñó el cargo de asesor de gobierno e intendencia de Pensacola en la Florida Occidental, luego fue electo oidor de la Audiencia de Caracas en 1809 aunque no ocupó el puesto hasta 1812. En 1817 es trasladado a México como alcalde de crimen de la Audiencia de dicha ciudad, donde falleció. La información de este personaje procede de las siguientes obras: López-Bohórquez, A. E., Los ministros de la Audiencia de Caracas..., op. cit., p. 159. Utrera, F. C. de, Centenario de José María Heredia..., op. cit., pp. 26-27.

${ }_{97}$ María Merced Heredia y Campuzano era hija de Nicolás Heredia Serrano Pimentel, hermano de Manuel Heredia, y de María Magdalena Campuzano Fernández, quien era hija del venezolano José Campuzano Polanco y de la dominicana Rosa Fernández de Lara, hija del contador Julián Fernández Pérez y de Catalina de Lara. Véase en Larrazábal Blanco, C., Familias dominicanas..., op. cit., vol. II, pp. 63-64, y Utrera, F. C. de, Ibidem., pp. 135-138.

${ }_{98}$ Utrera, F. C. de, Ibidem., pp. 15-16, y pp. 26-27.
} 
Leos-Echalas y mujer de su tío Nicolás Guridi Coronado. La única hija de este matrimonio María Guridi Leos-Echalas se casó con el criollo y regidor Pedro Fernández de Castro Coca-Landeche, hijo de Lorenzo Fernández Castro y de Antonia Coca-Landeche. Este enlace matrimonial permitió conectar con otra distinguida familia, los Coca-Landeche, perteneciente a la red Landeche-Bastidas, que contaba con una de las mayores fortunas locales. Pero lo realmente significativo fue la conexión entre ambas y constitución en una de las redes más poderosas. Este matrimonio tuvo como hija a Josefa María Fernández de Castro Guridi, que se unió a su primo Nicolás Leos-Echalas Heredia, hijo de Tomás Leos-Echalas Heredia, gobernador de Baní en 1772, y de Ana Heredia CastroCoronado. Ambos también eran parientes aunque en segundo grado, pues Tomás era sobrino de Ana ${ }^{99}$.

El otro hijo de Matías Guridi y María Merced Rivera de la Concha Solano fue José, quien siguiendo la carrera política de esta familia fue abogado y procurador de la Audiencia en 1758. Ese mismo año fue rector de la Universidad de Santo Tomás de Aquino, donde había realizado sus estudios en Leyes. Más tarde obtuvo el cargo de alguacil mayor de la Audiencia por renuncia que en él hizo su padre Matías Guridi al morir en 1762. También participó en la política municipal siendo electo en dos ocasiones alcalde ordinario, una en 1752 y otra en 1760, así como regidor perpetuo desde 1753. De igual forma que sus ascendientes, ejerció el cargo de capitán de milicias del batallón de la plaza de Santo Domingo $^{100}$. José Guridi y Concha fue un poderoso hacendado, adquirió sus propiedades en la subasta de temporalidades. Su matrimonio con Isabel Frómesta y Balmaceda condujo a la conexión con otra de esas principales e influyentes familias de hacendados que ocuparon cargos en la Audiencia y el cabildo. Los padres de Isabel fueron el abogado y relator de la Audiencia Leonardo José de Frómesta y Montejo, y Felipa Balmaceda Rexas y Arteaga, de conocida nobleza

\footnotetext{
${ }^{99}$ Memorial y documentación que en la que el subteniente retirado Nicolás Echalas solicita real permiso para casarse con Josefa Fernández Castro Guridi, 25 de octubre de 1785. AGI, Santo Domingo, 949. Véase también la obra de Valera Valdez, V. M., Baní: Raíces históricas..., op. cit., p. 17.

${ }^{100}$ El presidente y oidores de la Real Audiencia de Santo Domingo informan con testimonio de los méritos de José Guridi y Concha, alguacil mayor y abogado de ella, juzgándole digno de ser empleado en plaza togada de alguna de las audiencias de aquellos reinos, 15 de marzo de 1764. AGI, Santo Domingo, 975.
} 
en Cuba al descender por ambas líneas de los primeros pobladores de dicha isla $^{101}$.

Fruto del matrimonio entre José Guridi y Concha e Isabel Frómesta y Balmaceda nacieron varios hijos, de los cuales destaca Nicolás Guridi y Frómesta, personaje muy activo en la vida política, económica y militar de la ciudad de Santo Domingo. Al igual que sus antecesores empezó a elaborarse un currículo militar siendo cadete del regimiento de infantería de Saboya entre 1773 y 1775. Durante este último año fue caballero seminarista en el Real Seminario de Nobles en Madrid, donde fue a estudiar. Regresó a Santo Domingo y allí, al igual que su padre y su abuelo, ejerció el cargo de alguacil mayor de la Audiencia desde 1785 hasta después de la cesión de la isla a los franceses. También participó en la política local siendo alcalde ordinario de segundo voto en 1779 , y director de la Sociedad de Hacendados que se formó en la ciudad de Santo Domingo ${ }^{102}$. Fue uno de los hacendados de fines del siglo XVIII dominicano más importantes y ricos de Santo Domingo, componiéndose su patrimonio de numerosas haciendas y hatos que heredó de sus padres. Contrajo dos matrimonios, el primero con Juana Leos-Echalas y Heredia, hija del regidor José Leos-Echalas y Manuela de Heredia y Castro-Coronado, enlazando de nuevo con las ya citadas familias y sus ramas Leos-Echalas y Heredia. Con este matrimonio tuvo tres hijos y dos hijas, de los cuales Ana fue monja clarisa, Matías clérigo tonsurado y Francisca se casó con su primo tercero Andrés Angulo y Cabrera, lo que supuso una nueva unión con una rama de la familia Coca-Landeche (red Landeche-Bastidas) ${ }^{103}$. Su segunda mujer

\footnotetext{
${ }^{101}$ Leonardo José Frómesta Montejo fue el fundador de esta familia en Santo Domingo, donde llegó para estudiar en la Universidad de Santo Tomás de Aquino. De su matrimonio con Felipa nacieron otros cinco hijos más, entre los que destaca Nicolás y Juan Antonio que se dedicaron a la vida religiosa, mientras que José y Felipe fueron abogados y relatores de la Audiencia de Santo Domingo. De estos dos últimos, el segundo también fue regidor del cabildo de Santo Domingo. Además de Isabel tuvieron otra hija la ya mencionada Ana Micaela que estuvo casada con Nicolás Guridi Coronado. Los enlaces matrimoniales de todos ellos y sus descendientes permitieron conectar con las familias Leos-Echalas y otros apellidos como Pérez-Caro, Girón, Núñez de Cáceres y Lauzel-Cid. Expediente de la causa matrimonial seguida por Francisca Frómesta contra Andrés de Ibarra, 1784. AGI, Santo Domingo, 1025. Puede verse también Gutiérrez Escudero, A., "Un canario en La Española, vida, hechos y familia de Pedro Lousel Montero, 17241801” en V Coloquio de Historia Canario-Américana. Las Palmas de Gran Canaria, 1985, pp. 165-201.

${ }^{102}$ Relación de los méritos y servicios de Nicolás Guridi y Frómesta, alguacil mayor de la Real Audiencia de Cuba. AGI, Estado 18, N86.

103 Andrés Angulo Cabrera era hijo del subteniente Andrés Angulo y Coca y de María del Carmen Cabrera y Paredes, hija del peninsular Joaquín Cabrera, que alcanzó los grados militares de brigadier de los reales ejércitos y comandante de milicias, y la criolla María Paredes Heredia, en Larrazábal Blanco, C., Familias dominicanas..., op. cit., vol. II, p. 28, y vol. III, pp. 447-448.
} 
fue Teresa Uztáriz y Arranz, hija del gobernador de Puerto Rico Miguel Antonio de Uztáriz y Tadea Arranz Martínez de Arizala. Finalmente esta familia acabó instalada en La Habana, donde emigraron tras el Tratado de Basilea, aunque al principio se trasladaron a Puerto Rico muriendo allí Teresa en $1807^{104}$.

${ }^{104}$ Real Cédula concediendo a Tadea de Arranz, viuda de Miguel Antonio de Uztáriz la pensión que solicita a Su Majestad para ella y sus seis hijos, Aranjuez 19 de junio de 1803. AGI, Ultramar, 428. 


\section{Figura 4-2. Casa y Escudo de la familia Guridi}

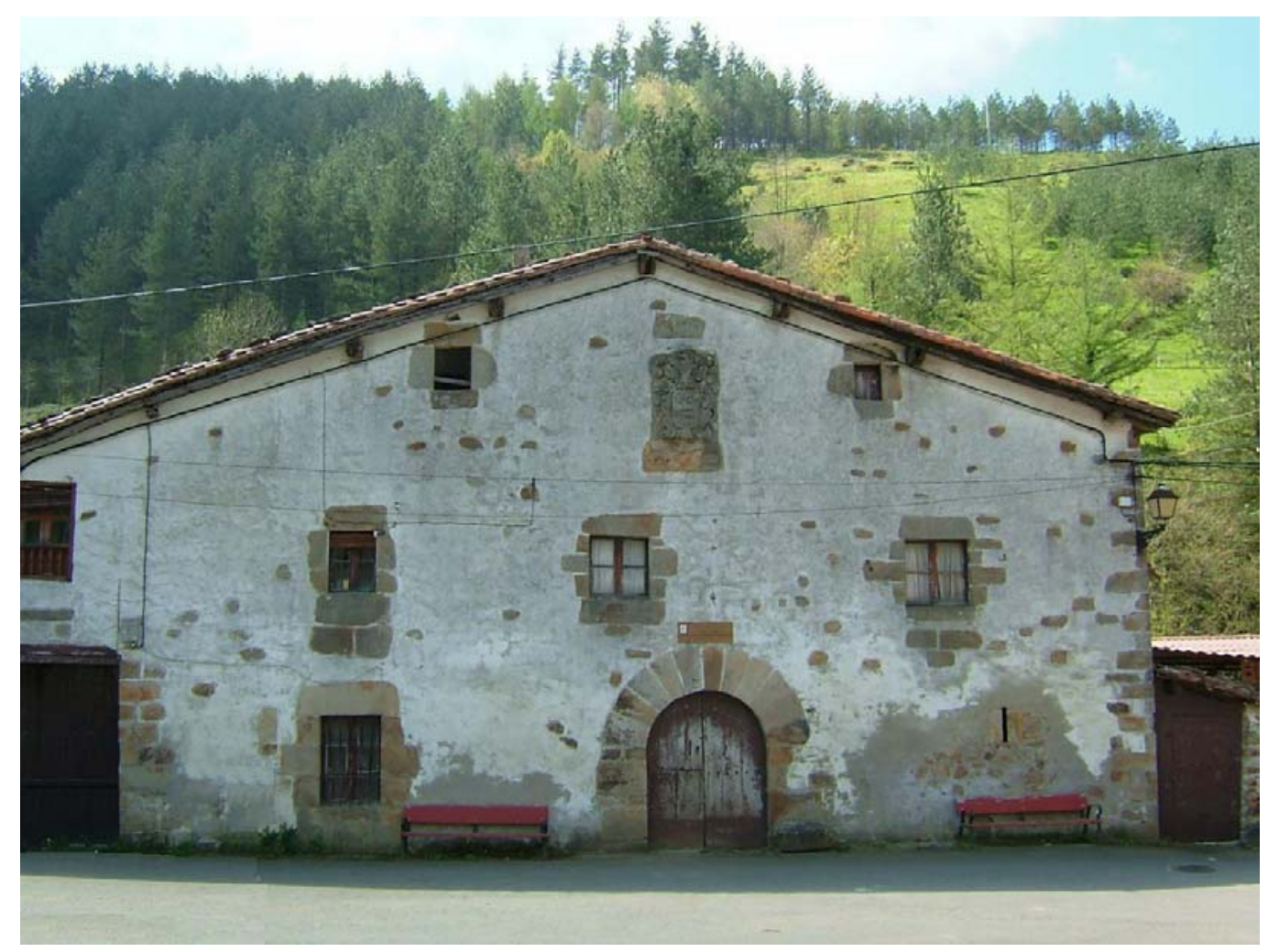

Casa y solar situada en Arabaolaza, jurisdicción de Legazpia (barrio Brinkola)

Escudo de armas del linaje de los Guridi ubicado en la parte superior de la fachada de la casa. En el expediente de hidalguía de Antonio Guridi de 1701 aparece inserto un testimonio de la ejecutoria de blasón de esta familia, expedida por sus ascendientes el 9 de octubre de $1654 \mathrm{y}$, en el que aparece descrito como: "[...] un escudo en campo de oro con un Arbol berde y al pie de el una Baca colorada paziendo en un Prado, y un Ternerito que le esta

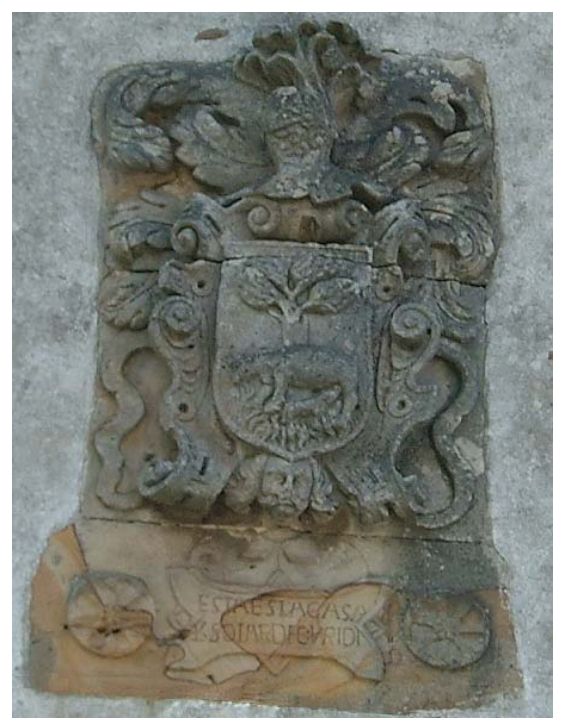
mamando [...]"105.

Fotos: autora

${ }^{105}$ Probanza de hidalguía del capitán Antonio de Guridi, residente en Santo Domingo de la Isla Española, originario de la casa de Guridi Etxeandia, 1701. AAL, Hidalguía C/199/6. 
Los Hacendados

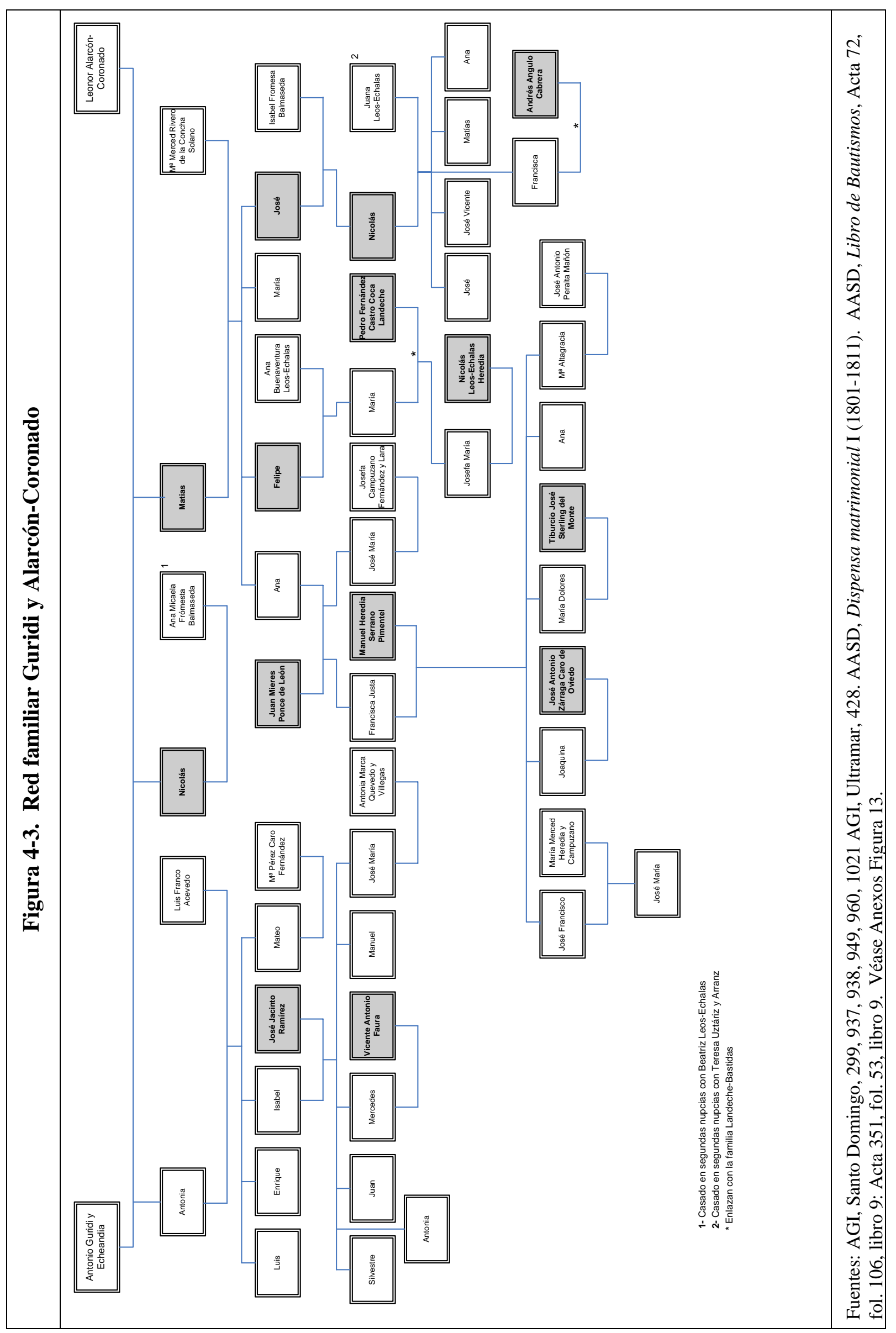




\subsubsection{Landeche-Bastidas}

Otra de las familias de más renombre y acaudaladas de Santo Domingo fue la de los Landeche-Bastidas. Los Landeche procedían del País Vasco, eran una familia de abolengo. Fue Antonio Landeche el que marchó a Indias en el siglo XVII, embarcándose en la Armada de Barlovento con diferentes empleos pasando por el de gobernador de un tercio de ella y el de almirante interín. Se estableció en La Española, donde obtuvo el título de coronel y cabo subalterno. Asumió el mando de Santo Domingo de manera interina al morir el brigadier Pedro Niela y Torres en 1714, ejerciéndolo hasta la llegada en 1715 del gobernador Fernando Constanzo y Ramírez ${ }^{106}$. Se casó el 29 de septiembre de 1698 con Ana María Bastidas, una criolla descendiente de una familia de Santo Domingo con una gran fortuna y cuya estirpe se remonta al siglo XVI. Este matrimonio tuvo una larga descendencia, destacando los entronques que crearon sus dos hijas: Josefa Lucía y María del Rosario ${ }^{107}$.

Josefa Lucía Landeche Bastidas contrajo matrimonio el 20 de octubre de 1720 con el gaditano Antonio Coca Landeche ${ }^{108}$. A pesar de la coincidencia en la posesión del apellido Landeche, esta pareja no tenía ningún grado de parentesco. Este matrimonio permitió a Antonio Coca Landeche convertirse en uno de los vecinos más ricos de la isla al formar parte de la familia de su mujer, y heredar tras la muerte de su suegro y de su cuñado una porción de la fortuna familiar compuesta por haciendas. Entre ellas destacaba el ingenio Santa Ana de Engombe y el hato Higüero con numerosos esclavos, utensilios y caballerías de tierras, que administró hasta su repartición, así como los mayorazgos Dávila y Bastidas que poseía su familia política. Participó también en la política local ocupando los

106 Título al coronel Antonio Landeche de cabo subalterno del gobierno en atención a sus méritos, Madrid 7 de diciembre de 1707. AGI, Santo Domingo, 1087. Véase también García, J. G., Compendio de la Historia de Santo Domingo. Santo Domingo, 1982, vol. I, pp. 184-185. Base de datos Fichoz.

107 Además de Josefa y María del Rosario tuvieron a Francisco Antonio y Ana María que murieron a temprana edad, en Larrazábal Blanco, C., Familias dominicanas..., op. cit., vol. IV, pp. 153-154.

${ }^{108}$ Antonio Coca Landeche era hijo del regidor perpetuo de Cádiz Juan Bruno Coca y Gatica, y de María Petronila de Landeche y Bevers, hija de Juan Bevers del Hierro y del capitán Antonio Landeche. Carta del gobernador de Caracas para que precediendo la justificación que previene en este despacho disponga que se entreguen a la viuda e hija de Antonio Landeche la cantidad que está depositado en estas cajas reales de aquella contaduría, 20 de enero de 1605. AGI, Santo Domingo, 626. Puede verse también en Larrazábal Blanco, C., Familias dominicanas..., op. cit., vol. II, p. 181. 
cargos de alcalde ordinario en 1727 y 1747, y el de regidor de la ciudad de Santo Domingo en 1725 y 1731.

Del matrimonio de Antonio Coca Landeche con Josefa Lucía Landeche Bastidas merecen ser mencionados los siguientes entronques creados por sus seis hijos, un varón y cinco mujeres. Su hijo Antonio Coca Landeche fue alférez real del cabildo de Santo Domingo desde 1754 hasta 1789. Se casó con Juana Fernández de Oviedo. Este matrimonio tuvo tres hijos, dos chicos y una chica María del Carmen. Damián nació en Santo Domingo en 1740 y murió en 1820. Fue Maestrante de Ronda y capitán de voluntarios de la plaza de Santo Domingo hasta que emigró a España, a Jerez de la Frontera, para administrar el mayorazgo Bevers que había heredado de su padre y procedía de sus abuelos gaditanos. Fue allí donde se casó con la navarra Josefa Figueroa González Torres ${ }^{109}$. Posteriormente volvió a La Española, pero el Tratado de Basilea le forzó a emigrar a Coro, desde donde regresó de nuevo a España muriendo en Jerez de la Frontera. Tuvieron una hija María Manuela que se casó con Domingo de la Rocha-Ferrer Angulo. Este matrimonio propició el enlace con una distinguida familia, los Rocha, que contaba con una extensa carrera política y con la cual la rama Coca-Landeche estuvo unida a través de otros enlaces matrimoniales, como se irá viendo en este epígrafe ${ }^{110}$. El otro hijo varón de Antonio y Juana fue Antonio, quien al igual que su hermano fue caballero de la Real Maestranza de Ronda, obtuvo el grado de coronel de los reales Ejércitos, y parece que murió soltero $^{111}$.

Una de las hijas de Antonio Coca Landeche y de Josefa Lucía Landeche Bastidas, también se llamaba como su madre Josefa y se casó con Lorenzo Angulo Medrano, un peninsular natural del pueblo de Alfaro ${ }^{112}$. Su unión selló su entrada en el núcleo de hacendados, como queda reflejado en las típicas pautas de

\footnotetext{
${ }^{109}$ Utrera, F. C. de, Santo Domingo. Dilucidaciones históricas..., op. cit., p. 446.

${ }^{110}$ Domingo de la Rocha-Ferrer Angulo era hijo de Rodrigo Macedonio de la Rocha-Ferrer Coca y de Petronila Angulo Coca-Landeche. El matrimonio de Domingo de la Rocha-Ferrer Angulo y María Manuela Coca Figueroa tuvieron una única hija María de la Merced Severina, quien se casó con el americano Jonathan Elliot y por segunda vez con Esteban Fernández y González. Véase en Larrazábal Blanco, C., Familias dominicanas..., op. cit., vol. VII, pp. 119121.

111 Según Utrera ésta era pariente del gobernador Manuel González Torres, aunque no hemos encontrado documentación que lo certifique. Utrera, F. C. de, Santo Domingo. Dilucidaciones históricas..., op. cit., p. 446.

${ }^{112}$ Lorenzo Angulo Medrano era hijo de Hermenegildo Angulo y de Esperanza Medrano, en Larrazábal Blanco, C., Familias dominicanas..., op. cit., vol. I, pp. 141-142.
} 
matrimonio que hemos estado señalando, según las cuales la hija de un hacendado establecido se casaba con un recién llegado de España. De este modo se integró a la red familiar con amplias vinculaciones con otros hacendados, permitiéndole además el acceso al cabildo al ser elegido alcalde ordinario en 1779. Lorenzo Angulo estuvo empleado como capitán de urbanos desde el 16 de abril de 1768 hasta el 3 de abril de 1779, y como teniente del cuerpo de milicias desde 1771 hasta $1778^{113}$.

Lorenzo y Josefa tuvieron siete descendientes, cuatro hijas y tres hijos. Uno de los hijos fue Antonio Angulo Coca* , contador de la Real Hacienda, que al casarse con María de los Ángeles Heredia Campuzano conectó con los Heredia, una de las familias más acaudaladas y poderosas políticamente ya citadas ${ }^{114}$. Ésta tenía además una amplia participación en el Ejército y la Iglesia, y al mismo tiempo estaba emparentada con los Guridi. Otro hijo, Andrés Angulo Coca, fue subteniente de una de las compañías de milicias de Santo Domingo. Se casó en 1787 con María del Carmen Cabrera Paredes, hija del brigadier de los reales Ejércitos y comandante de las milicias Joaquín Cabrera, natural de Escalona (Toledo), y de la criolla María Paredes Heredia. Este matrimonio tuvo nueve hijos, entre los que Andrés Angulo y Cabrera, siguiendo el patrón en el que los hijos se casaban con criollas de familias ya instaladas en Santo Domingo, contrajo nupcias con la ya nombrada Francisca Guridi Leos-Echalas, hija de Nicolás Guridi y Frómesta y Juana Leos-Echalas Heredia, miembros de la red familiar de los Guridi y Alarcón-Coronado ${ }^{115}$.

Tres de las hermanas de Andrés Angulo Coca estuvieron también casadas con miembros de la familia Cabrera. Así María Josefa Angulo Coca lo estuvo con el abogado Francisco Cabrera Paredes, conocido como Francisco Mosquera Cabrera Paredes al recaer en él el mayorazgo Mosquera ${ }^{116}$. Josefa Vicenta se casó

\footnotetext{
${ }^{113}$ Hoja de servicios militares de Lorenzo Angulo. AGI, Santo Domingo, 1095.

En ocasiones también aparece en la documentación como Antonio Angulo Coca-Landeche, es decir con el apellido completo de la madre.

${ }^{114}$ María de los Ángeles Heredia Campuzano era hija del teniente y regidor Nicolás Heredia y Magdalena Campuzano Polanco, en Larrazábal Blanco, C., Familias dominicanas..., op. cit., vol. IV, p. 19, y del vol. I, p. 142.

${ }^{115}$ Larrazábal Blanco, C., Familias dominicanas..., op. cit., vol. I, p. 142, y del vol. II, pp. 28.

${ }^{116}$ El mayorazgo lo heredó de su madre María Paredes Heredia, hija del teniente coronel Miguel Paredes-Carreño y de Jerónima de Heredia Castro-Coronado. Miguel Paredes fue alcalde ordinario de primera elección en los años de 1755 y 1761 en el ayuntamiento de Santo Domingo. Expediente con motivo de haber remitido el gobernador de la isla la instancia de Francisco Mosquera y
} 
con Joaquín Tomás Cabrera Paredes, también abogado, y María de la Concepción se unió en matrimonio con el suegro de sus hermanos Joaquín Cabrera, siendo para él su segundo matrimonio ya que había estado casado, como se indicó líneas más arribas, con María Paredes Heredia ${ }^{117}$. (Véase en el anexo la figura 14)

La cuarta hija de Lorenzo Angulo Medrano y Josefa Coca fue Petronila Angulo Coca Landeche, quien contrajo matrimonio con su primo hermano Rodrigo Macedonio de la Rocha-Ferrer Coca. Éste era hijo de Isabel Coca Landeche, que al igual que su hijo se había casado con un primo hermano, Domingo de la Rocha-Ferrer y Landeche, abogado de la Audiencia, regidor del cabildo de Santo Domingo desde 1752 hasta 1767. Dejó estos empleos ya que por real decreto de 2 de mayo de 1766 fue nombrado auditor de guerra en las provincias de Yucatán y Campeche, donde se trasladó con su familia un año despúes ${ }^{118}$. Este matrimonio permitió también conectar con los Rocha.

De las cinco hijas del matrimonio de Antonio Coca Landeche con Josefa Lucía Landeche Bastidas, tan sólo dos se unieron matrimonialmente a criollos de familias ya establecidas, siguiendo el resto la tendencia de casarse con peninsulares. Además de las ya mencionadas Isabel Coca Landeche, esposa de Domingo de la Rocha-Ferrer Landeche y madre de Rodrigo Macedonio RochaFerrer Coca, y Josefa casada con Lorenzo Angulo Medrano las otras tres hijas fueron, Antonia, María Petronila y Ana.

La primera de ellas, Antonia Coca Landeche se casó con el regidor y hacendado Lorenzo Fernández de Castro Pimentel, hijo del regidor Pedro Fernández de Castro y Luisa Pimentel Figueroa. Tuvieron como hijo a Pedro Fernández de Castro, quien también fue regidor y estuvo casado con María Guridi Leos-Echalas, hija de Felipe Guridi Concha y Ana Buenaventura Leos-Echalas, emparentando así con una de las redes más prósperas económicamente y más

Cabrera vecino de aquella ciudad, pidiendo al rey la licencia para vender el vínculo que posee del propio apellido de ella y trasladarlo a cualquiera otra parte de sus dominios, 23 de julio de 1798. AGI, Santo Domingo, 1000.

${ }^{117}$ Para la familia Paredes-Cabrera y Angulo-Coca véase Larrazábal Blanco, C., Familias dominicanas..., op. cit., vol. I, pp. 141-142, y del vol. II, p. 28. Santa Cruz y Mallén, F. J. de, Historia de familias cubanas..., op. cit., vol. V, p. 138.

${ }^{118}$ Domingo de la Rocha-Ferrer y Landeche era hijo de María del Rosario Landeche Bastidas y del tesorero Antonio Francisco de la Rocha-Ferrer y de las Barces. Isabel Coca Landeche era hija del ya citado gaditano Antonio Coca Landeche y Josefa Lucía Landeche Bastidas. Carta del gobernador de Santo Domingo dando curso al memorial y documentos en los que el capitán Rodrigo de la Rocha solicita casarse con Petronila Angulo, 24 de mayo de 1797. AGI, Santo Domingo, 960. 
poderosas políticamente, la red de los Guridi ${ }^{119}$. Las otras dos hijas enlazaron con peninsulares. De manera que María Petronila Coca Landeche estuvo casada con el gaditano, teniente coronel y tesorero oficial de las Reales Cajas de Santo Domingo, Francisco Pepín González, quien más tarde fue promovido como contador de las Cajas Reales de Puerto Rico, donde murió. Respecto a sus hijos, Josefa contrajo matrimonio con el pamplonés Martín José de Miura, subteniente del Batallón Fijo de la plaza de Santo Domingo; y Francisco continuó con la carrera militar de su padre alcanzando el grado de coronel ${ }^{120}$. Ana Coca Landeche se casó con otro peninsular, Francisco Martínez que fue regidor de Santo Domingo entre 1753 y 1759.

El segundo tronco de esta familia lo formó María del Rosario Landeche Bastidas, quien como ya se ha comentado se había casado con el tesorero real Antonio Francisco de la Rocha-Ferrer y de las Barces, hermano del que había sido gobernador y capitán general de la parte española de la isla (1723-1731), Francisco de la Rocha-Ferrer y de las Barces ${ }^{121}$. Su unión significó el principal entronque con esta familia, pues los casamientos entre miembros de los RochaFerrer y los Coca Landeche se deben a los descendientes de éste matrimonio. Esta pareja tuvo numerosos hijos, concretamente trece, de los cuales tres, a través de sus matrimonios, se vincularon a familias criollas de hacendados que se han ido mencionando, como los Fernández de Castro y los Pérez-Caro: Ignacio de la Rocha-Ferrer Landeche, teniente y coronel se casó con Agustina Ferández de Lara, y Juana con el ayudante mayor de milicias Juan Pérez-Caro. Su otro hijo Domingo de la Rocha-Ferrer y Landeche se unió con su prima hermana Isabel Coca Landeche, cuyo hijo Rodrigo Macedonio se casó con su prima hermana Petronila Angulo Coca-Landeche. Otros hijos de María del Rosario Landeche y

\footnotetext{
${ }^{119}$ Memorial y documentación en la que el subteniente retirado Nicolás Echalas solicita real permiso para casarse con Josefa Castro, 25 de octubre de 1785. AGI, Santo Domingo, 949.

${ }^{120}$ Rodríguez Demorizi, E., Milicias de Santo Domingo..., op. cit., pp. 369-381.

${ }^{121}$ El gobernador Francisco de la Rocha-Ferrer y su hermano el tesorero Antonio Francisco, nacieron en Cartagena de Indias, ciudad en la que se casaron sus padres el 25 de marzo de 1684. Los progenitores de ambos fueron la asturiana Juana Clemencia de las Barces y Pando y el extremeño Domingo de la Rocha-Ferrer, que fue oidor en la Audiencia de Santa Fé. Relación de méritos y servicios del coronel de los reales ejércitos Francisco de la Rocha-Ferrer, gobernador, capitán general que fue de la Provincia del Espíritu Santo de la Grita y de la ciudad de Maracaybo, y actual presidente de la Audiencia de Santo Domingo de la Isla Española. AGI, Santo Domingo, 941. Sobre la familia Rocha-Landeche y las Barces y Pando, puede verse Larrazábal Blanco, C., Familias dominicanas..., op. cit., vol. VII, pp. 119-121. Restrepo Lince, P., Genealogía de Cartagena de Indias. Bogotá, 1993, p. 169. Base de datos Fichoz.
} 


\section{Los Hacendados}

Antonio de la Rocha-Ferrer fueron Juan Miguel, alférez del Batallón Fijo, que murió soltero en el hospital de San Lázaro, y Antonio Francisco que fue cura ${ }^{122}$.

${ }^{122}$ Larrazábal Blanco, C., Idem. 
Ruth Torres Agudo

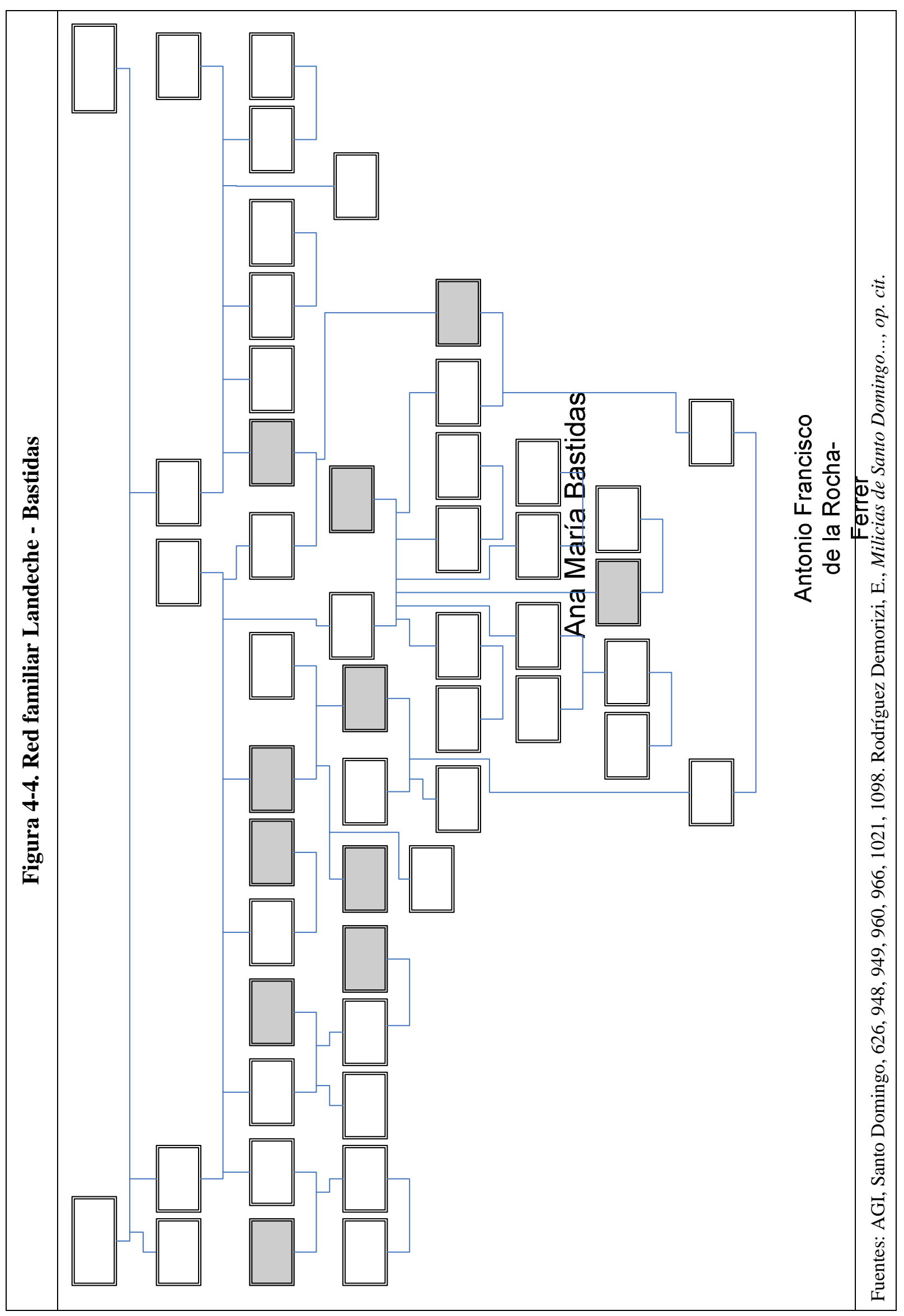




\subsubsection{Castro-Rivera y Urdaneta}

Esta red familiar la inició Gonzalo Castro-Rivera Castilla, capitán de infantería, al contraer matrimonio con Micaela Piña Urdaneta ${ }^{123}$. Fruto de este matrimonio nacieron cuatro hijas, dos se casaron con criollos y las otras dos con peninsulares. La primera de ellas, María Belén Castro-Rivera Urdaneta, se casó el 16 de agosto de 1744 con el cubano Miguel Bernardo Antonio Ferrer Angulo, quien había llegado años antes a la ciudad para proseguir sus estudios en la universidad y vestir los hábitos clericales, los cuales finalmente abandonó. En 1779 obtuvo el título de capitán de infantería del Ejército de la ciudad de Santo Domingo. Entre los cargos políticos que ejerció destaca el de depositario general en el cabildo de dicha ciudad, que consiguió gracias a la renuncia que en él hizo su cuñado Domingo Lorenzo Zevallos en 1753. También fue regidor desde 1768 hasta que lo traspasó al renunciarlo en su hijo Miguel en $1784^{124}$. El matrimonio entre María Belén y Miguel Bernardo Antonio Ferrer tuvo varios hijos aunque sólo sobrevivieron tres, el ya citado Miguel, Félix y María de la Concepción. Los dos jóvenes fueron abogados de la Audiencia. Miguel Ferrer contrajo matrimonio con María de la Columna Leos-Echalas, conectando con esta familia ${ }^{125}$. Su hija María de la Concepción Ferrer estuvo casada con el peninsular Antonio Rojas, dedicado al comercio, fue asentista de tabacos y también hacendado.

La segunda hija de Gonzalo Castro-Rivera y Micaela Piña Urdaneta fue Jacinta, quien se unió el 20 de mayo de 1743 al criollo Juan Arredondo Vizcaíno, un ministro de la Audiencia en cuya institución ejerció como abogado. Él y su familia materna procedían de Santiago, ciudad en la que fue alcalde mayor. En cambio su padre el capitán de artillería Tomás Arredondo y Simancas era de la Península. Tanto los ancestros como los hijos de Juan Arredondo Vizcaíno

\footnotetext{
${ }^{123}$ Gonzalo de Castro era hijo del regidor y alcalde ordinario Gonzalo de Castro y de Jerónima Alarcón-Coronado. Micaela Urdaneta era hija de Gabriel Urdaneta y Piña y de Úrsula Arambule. Micaela tuvo dos hermanos, Gabriel que fue presbítero y cura rector de Baní, y Antonia, que estuvo casada con el escribano de cámara y gobierno de la Audiencia de Santo Domingo Juan de Quevedo y Villegas. Información correspondiente a la limpieza, habilidad y suficiencia para ocupar el oficio de regidor Miguel Bernardo Antonio Ferrer, 26 de noviembre de 1768. AGI, Santo Domingo, 937.

${ }^{124}$ Ibidem., y, Diligencias practicadas por María de Castro, viuda del capitán graduado de ejército Miguel Ferrer para la obtención del Monte Pío, 1784. AGI, Santo Domingo, 947.

${ }^{125}$ María de la Columna Leos-Echalas era hija de Francisco Javier Leos-Echalas y de Jerónima Heredia Castro-Coronado. La familia Leos-Echalas estaba a su vez unida, a través de otras conexiones matrimoniales, con la ya citada red familiar Guridi y Alarcón-Coronado.
} 
participaron de manera activa en la vida de las ciudades de Santiago y de Santo Domingo. En esta última Juan fue rector de la Universidad de Santo Tomás de Aquino y electo alcalde ordinario en dos ocasiones por su cabildo, en 1781 y en $1782^{126}$.

De los diez hijos de Jacinta Castro-Rivera y Juan Arredondo Vizcaíno, uno murió de pequeño, y el resto sobrevivieron. Dos de ellos enlazaron con algunas de las familias más influyentes de ambas ciudades. En consecuencia, su hijo Francisco Arredondo y Castro, contrajo matrimonio en 1771 en la ciudad de Santiago con Francisca Pichardo Zerezeda, hija del capitán de milicias Antonio Pichardo Vinuesa y de Rosa Zereceda Cruzado, otra distinguida familia de esa ciudad $^{127}$. En ella Francisco ejerció el cargo de regidor en 1778 y 1779, y más tarde, entre 1786 y 1796, fue regidor perpetuo en el cabildo de Santo Domingo. Durante ese tiempo fue nombrado síndico procurador general en 1788, y en 1789 y 1790 le correspondieron los cargos de fiel ejecutor y comisario general de abastos. También fue elegido alcalde ordinario en 1791 y 1794, y alcalde de la Santa Hermandad en $1795^{128}$. Este matrimonio tuvo ocho hijos, los cuales se trasladaron a la isla de Cuba a causa de la cesión de la parte española a los franceses, donde acabaron estableciéndose ${ }^{129}$.

José Esteban Arredondo Castro ocupó varios empleos administrativos en la isla. Fue relator y fiscal de la Audiencia, y en 1769 fue tesorero y administrador de la limosna de la Bula de la Santa Cruzada del arzobispado de Santo Domingo. Entre 1772 y 1777 fue designado en tres ocasiones para tomar la residencia a los

\footnotetext{
${ }^{126}$ Juan Arredondo Vizcaíno era hijo de Tomás Arredondo Simancas y la criolla María Vizcaíno y Guzmán de Rojas. Para obtener información sobre la familia Arredondo véanse: Santa Cruz y Mallén, F. J. de, Historia de familias cubanas..., op. cit., vol. V, pp. 60-62. Larrazábal Blanco, C., Familias dominicanas..., op. cit., vol. I, pp. 174-175. Véase también el artículo de “Gaspar Arredondo y Pichardo, Memoria de mi salida de la isla de Santo Domingo, 28 de abril de 1805”..., op. cit., pp. 121-160.

${ }^{127}$ El capitán José Antonio Pichardo y Vinuesa fue uno de los más reputados y ricos vecinos de Santiago. Para obtener información de la familia Pichardo y de la Zereceda véase Espinal Hernández, E., Nosotros. La familia Pichardo-Román. Estudio Genealógico. Santo Domingo, 1990. También el artículo de "Gaspar Arredondo y Pichardo, Memoria de mi salida de la isla de Santo Domingo, 28 de abril de 1805”..., ibidem., p. 124.

${ }^{128}$ Testimonio de las diligencias obradas sobre la renuncia que José de Contreras y Medrano hizo en Francisco Arredondo y Castro del oficio de regidor de la ciudad de Santiago, 1777. AGI, Santo Domingo, 937. Relación de méritos, servicios y empleos de Francisco Arredondo y Castro, regidor perpetuo de Santo Domingo, capital de la Isla Española. AGI, Santo Domingo, 1000.

${ }^{129}$ Entre los hijos que tuvieron cabe destacar a Gaspar, quien escribió su experiencia ante las invasiones haitianas de 1801 y 1805, en "Gaspar Arredondo y Pichardo, Memoria de mi salida de la isla de Santo Domingo, 28 de abril de 1805”..., op. cit., pp. 121-160.
} 
gobernadores de La Habana y Cumaná. El 1 de marzo de 1784 fue nombrado por el gobernador de Santo Domingo, Isidro Peralta y Rojas, teniente de justicia mayor y juez de comisos de los pueblos interiores de Santo Domingo. Fue alcalde ordinario del ayuntamiento de Santo Domingo durante el año de $1795^{130}$. Se desposó con Isabel Martínez de Venecia Santelices, hija de Manuel Martínez de Mendoza, que había llegado en torno a 1751 con la comitiva del gobernador Francisco Rubio y Peñaranda, y la criolla Margarita Venecia Santelices ${ }^{131}$.

Los otros tres hijos de Juan Arredondo Vizcaíno y Jacinta Castro-Rivera fueron Lorenza, Pedro, y Tomás. Los dos chicos al igual que su padre fueron abogados de la Audiencia y obtuvieron empleos en el cabildo de la ciudad de Santo Domingo: Tomás fue alcalde ordinario en 1783 y Pedro en 1788. Lorenza se desposó con el abogado Tiburcio José Sterling que poseía un amplio currículo político y procedía de una importante familia de Santiago ${ }^{132}$.

La tercera hija de Gonzalo Castro-Rivera y Micaela Piña Urdaneta fue Micaela que se casó con el canario Domingo Lorenzo Zevallos, miembro importante dentro del ámbito del comercio y del corso. Llegó a ocupar el cargo de depositario general renunciando, como ya se ha comentado, en 1753 a su cuñado Miguel Bernardo Antonio Ferrer Angulo ${ }^{133}$. También obtuvo el empleo de anotador de hipotecas, ejerciéndolo desde 1763 hasta que antes de morir en 1775 lo traspasó a su hijo Domingo Vicente ${ }^{134}$.

La cuarta fue Ana Castro-Rivera que estuvo casada en primer lugar con el canario Pedro Tapia, quien fue agente fiscal de la Audiencia y secretario de

${ }^{130}$ Relación de los méritos y ejercicios literarios del doctor José Esteban Arredondo, abogado de la Real Audiencia de la isla de Santo Domingo en la Isla Española. AGI, Santo Domingo, 1015.

131 Manuel Martínez de Mendoza había sido alguacil mayor en la ciudad de Guadalajara (Toledo) y agregado a una de las secretarías del Despacho Universal de Indias. Margarita Venecia Santelices era hija del santanderino, Miguel Martínez Santelices y la criolla Bárbara Figueroa, hija del capitán Francisco Figueroa e Isabel Rodríguez. Tanto los abuelos como los bisabuelos paternos y maternos de Isabel Martínez Santelices ocuparon cargos políticos, militares y religiosos en la Península, y sus entronques familiares llegaban incluso hasta el siglo XV. Para obtener datos genealógicos véase Guerrero Cano, Ma . M., "Un dominicano en el colegio de nobles americanos de Granada. Familia y genealogía de Juan Clemente Martínez Saviñón”..., op. cit., pp. 383-400. Y, Larrazábal Blanco, C., Familias dominicanas..., op. cit., vol. I, pp. 174-176, y vol. V, pp. 75-76.

${ }^{132}$ AASD, Libro de bautismo, Acta 364, fol. 133, libro 14.

${ }^{133}$ En la documentación el apellido Zevallos o Cevallos aparece indistintamente con ambas grafías. Stapells Johnson, V., "Los corsarios de Santo Domingo 1718-1779: un estudio socioeconómico”..., op. cit., pp. 3-93, particularmente las páginas 52-57.

134 Domingo Vicente Zevallos lo renunció en 1791 en Juan Ventura Aguirre. Diligencias practicadas por Juan Ventura de Aguirre, anotador de hipotecas de esta ciudad de Santo Domingo, 1791. AGI, Santo Domingo, 939. 
gobierno en el tiempo del gobernador Alfonso Castro y Mazo. Al morir contrajo segundas nupcias con el peninsular, hacendado y regidor del cabildo de Santo Domingo, Antonio Valdemoro y Alcántara ${ }^{135}$. Los tres hijos que tuvo Ana fueron de su primer matrimonio, un hijo llamado Francisco Tapia que fue regidor del ayuntamiento, y dos hijas cuyos cónyuges pertenecieron a las principales familias de la ciudad de Santo Domingo. De sus dos hijas, una se casó con un criollo y la otra con un peninsular. Sus descendientes siguieron la línea de unirse a peninsulares que llegaron a Santo Domingo para ocupar los cargos militares o burocráticos a los que habían sido destinados, como oficiales de las Cajas Reales o ministros de la Audiencia.

La primera en contraer matrimonio fue Micaela Tapia-Castro. Lo hizo con un cubano, Gregorio Saviñón, que descendía de las primeras generaciones de familias canarias que llegaron a la isla de Cuba, y en ella sus familiares habían ocupado cargos políticos y militares. Fue regidor de la ciudad de Santo Domingo y hacendado. Tuvieron catorce hijos, seis chicos, y ocho chicas, de las cuales las siguientes se casaron con peninsulares: Jacinta con el tesorero de las Cajas Reales Fernando Mauelón, Juana con el teniente de ingenieros Pedro Roig Lluís, y Bárbara con el catalán Salvador Pí y Piquer, miembro de la Real Compañía de Comercio de Barcelona.

Las otras dos de las hijas de Micaela Tapia-Castro y de Gregorio Saviñón se unieron en matrimonio con criollos. De esta manera María Antonia con se casó con Miguel Jerónimo Martínez de Venecia Santelices, hermano de la ya citada Isabel Martínez de Venecia Santelices ${ }^{136}$. La otra hija, María Vicenta con Joaquín Fernández de Castro y Pérez Caro, enlazando con las familias de éstos apellidos $^{137}$. Su hija, María de la Cruz, se desposó con el criollo Francisco Xavier Foxá Lecanda, hijo de Joaquín Foxá y Montúfar y de María Altagracia Raymunda Lecanda Sánchez ${ }^{138}$. Su enlace matrimonial permitió establecer alianzas con los

\footnotetext{
135 Expediente sobre las pretensiones hechas por varios individuos a los oficios vacantes de regidor, 1779. AGI, Santo Domingo, 1021.

${ }^{136}$ Véase en Guerrero Cano, M M $^{\mathrm{a}}$. M., "Un dominicano en el colegio de nobles americanos de Granada. Familia y genealogía de Juan Clemente Martínez Saviñón”..., op. cit., pp. 383-400, en particular las páginas 389-393.

${ }^{137}$ Joaquín Fernández de Castro y Pérez-Caro era hijo de Lorenzo Fernández de Castro Pimentel y de Belén Pérez-Caro, en Rodríguez Demorizi, E., Familias Hispanoamericanas. Ciudad Trujillo, 1959, pp. 339-343.

${ }^{138}$ Joaquín Foxá y Montúfar era originario de Orán. Llegó a Santo Domingo como sargento mayor del regimiento de infantería de Cantabria en 1794, estableciéndose en aquella ciudad tras su
} 
Silvestre-Jiménez, una destacada familia dedicada a las actividades mercantiles, a la agricultura y con una amplia participación en empleos de la administración de Santiago y Santo Domingo. De hecho María Altagracia Raymunda Lecanda Sánchez era hija de Gabriela de la Cruz Sánchez Firpo, miembro a su vez de dicha familia distinguida, y del bilbaíno Andrés de Lecanda y Andirengoechea, que había llegado a Santo Domingo como paje del gobernador Manuel Azlor y Urríes. Fue guarda almacén, primer factor de la Real Renta de Tabacos de la ciudad de Santo Domingo en 1770, y llegó a convertirse en un poderoso hacendado ${ }^{139}$.

Las hermanas de Gabriela de la Cruz Sánchez Firpo, y por tanto, cuñadas de Andrés de Lecanda, se casaron con peninsulares que ocuparon cargos en la Audiencia, la Real Hacienda y el Ejército, así: María de luz se casó primero con José Gallegos y por segunda vez con un abogado de la Audiencia, Nicolás Padrón; Tomasa con el administrador de la Real Hacienda de la frontera de Dajabón Manuel de Aponte Hinojosa; Rosa con el burgalés Luís Pérez Guerra y Trespalacios, que fue capitán del Ejército y de voluntarios de dragones, así como comandante de las armas y juez de comisos de Santiago ${ }^{140}$. María se casó en primeras nupcias con el aragonés Francisco Antonio Velilla y Torres, guarda mayor y administrador de la Real Renta de Correos de la ciudad de San Fernando de Montecristi, y segundo factor de tabacos de la ciudad de Santiago. Y por segunda vez con el teniente de voluntarios de dragones, José Tadeo Zevallos. Entre los hijos que tuvo de su primer matrimonio cabe destacar a Petronila Velilla Sánchez debido a la importancia de su casamiento, ya que se unió a uno de los hacendados más ricos de la ciudad Santiago, un francés llamado Francisco

matrimonio. Su hijo Francisco Xavier Foxá y Lecanda fue dramaturgo literario, y entre los hijos que tuvo también destaca Narciso, que fue poeta. Véase en Alfau Durán, V., "Documentos históricos. Partida de bautismo del dramaturgo Francisco Xavier Foxá y Lecanda”. CLÍO 90 (Ciudad Trujillo, 1951) pp. 100-102. Rodríguez Demorizi, E., Milicias de Santo Domingo..., op. cit., pp. 331-360.

${ }^{139}$ Gabriela de la Cruz Sánchez Firpo era hija de Rosa Manuela Firpo Jiménez, natural de la ciudad de Santo Domingo, y del canario Domingo de la Cruz Sánchez Moreno. Los abuelos paternos fueron Lorenzo José Moreno y Úrsula Francisca Sánchez, naturales de las canarias, y los maternos, Juan Silvestre Firpo, natural de Génova (Italia), y María Gabriela Jiménez, natural de Santo Domingo. Este último matrimonio tuvo un hijo Mateo Firpo que fue regidor en el cabildo de Santo Domingo, en Larrazábal Blanco, C., Familias dominicanas..., op. cit., vol. III, p. 208 y vol. VIII, p. 49. Súplica del permiso y licencia de embarque para salir de Cádiz a Andrés Lecanda, 21 de octubre de 1761. AGI, Santo Domingo, 1011.

${ }^{140}$ Luís Pérez Guerra se había casado en primeras nupcias con María Pichardo y Zereceda, en segundas con Rosa Sánchez, y en terceras con Catalina Portes, en Rodríguez Demorizi, E., Invasiones haitianas de 1801, 1805 y 1822..., op. cit., p. 127. Campillo Pérez, J. G., Francisco Espaillat..., op. cit., pp. 410, 412, 419, y 421. 
Espaillat Virol, para quien era su segundo matrimonio, pues anteriormente había estado casado con Catalina Tabarez Zapata ${ }^{141}$. Francisco Espaillat fue nombrado en 1780 médico cirujano de las milicias regladas de infantería, caballería, así como de los urbanos de Montecristi, Puerto Plata, La Vega y Santiago. En la última ciudad fue nombrado también mayordomo, administrador y médico del hospital militar en 1783. Paralela a su labor como médico, desempeñó otros cargos como el de factor del ramo de tabacos, empleo que había ejercido previamente su suegro y que ocupó en 1783, dos años después de la muerte de éste. A partir de esa fecha también ejerció el cargo de juez subdelegado de comisos para la región norte, hasta que fue sustituido en 1786. Tuvo una amplia descendencia, aunque de su primer matrimonio sólo sobrevivió un hijo, José Espaillat Tabarez, que estudió medicina en la Universidad de Salamanca. De su segundo matrimonio nacieron trece hijos, muriendo algunos de ellos a muy temprana edad y emigrando los restantes a Puerto Rico tras el Tratado de Basilea $^{142}$.

La segunda hija del matrimonio de Ana Castro y Pedro Tapia fue Jerónima Tapia-Castro. Ésta se casó con el aragonés Julián Joaquín Pueyo y Urríes, alcalde mayor de Santiago e hijo del regente de la Audiencia, Andrés Pueyo y Urríes, y de Josefa Díez de Aux y la Marca ${ }^{143}$. Con este matrimonio los Tapia-Castro emparentaron con otra notable familia de la ciudad que contaba con una extensa parentela en la Audiencia, y la Real Hacienda. Ello a pesar de la ya mencionada oposición del padre de Julián Joaquín a dicho matrimonio, al considerar que se había celebrado en contra de su consentimiento y la distinta calidad entre ambas familias. Julián Joaquín Pueyo y Jerónima tuvieron como hija a Juana que se casó

\footnotetext{
${ }^{141}$ De origen francés Francisco Espaillat Virol, nació en el pueblo de Masclat. Marchó a la colonia francesa de Saint Domingue y de ésta pasó a la parte española de la isla hacia 1754, estableciéndose en la ciudad de Santiago. Puede verse en Campillo Pérez, J. G., Ibidem., pp. 9, 23-28 y 155-161.

${ }^{142}$ Algunos de los descendientes del la familia Espaillat regresaron a lo largo del siglo XIX a Santo Domingo, donde destacaron como médicos y políticos, como por ejemplo Ulises Francisco Espaillat, que fue presidente desde el 29 de abril al 5 de octubre de 1876. Gerón, C., Diccionario político dominicano (1821-2000). Santo Domingo, 2001, p. 192.

${ }^{143}$ Expediente de información y licencia de pasajeros a Indias de Andrés Pueyo y Urríez, 28 de septiembre de 1756. AGI, Contratación 5498, N40.
} 


\section{Los Hacendados}

con el subteniente del Batallón Fijo Mariano Caro-Oviedo y Fernández de Lara, conectando con las familias de los mencionados apellidos ${ }^{144}$.

\footnotetext{
${ }^{144}$ Mariano era hijo del teniente del Batallón Fijo Francisco Pérez-Caro y Oviedo, y de María Manuela Fernández de Lara. Expediente del gobernador de Santo Domingo en la que dirige los documentos y memorial que le ha presentado el teniente del batallón de Santo Domingo solicitando real licencia para casarse con Juana Pueyo, 1794. AGI, Santo Domingo, 1089.
} 
Ruth Torres Agudo

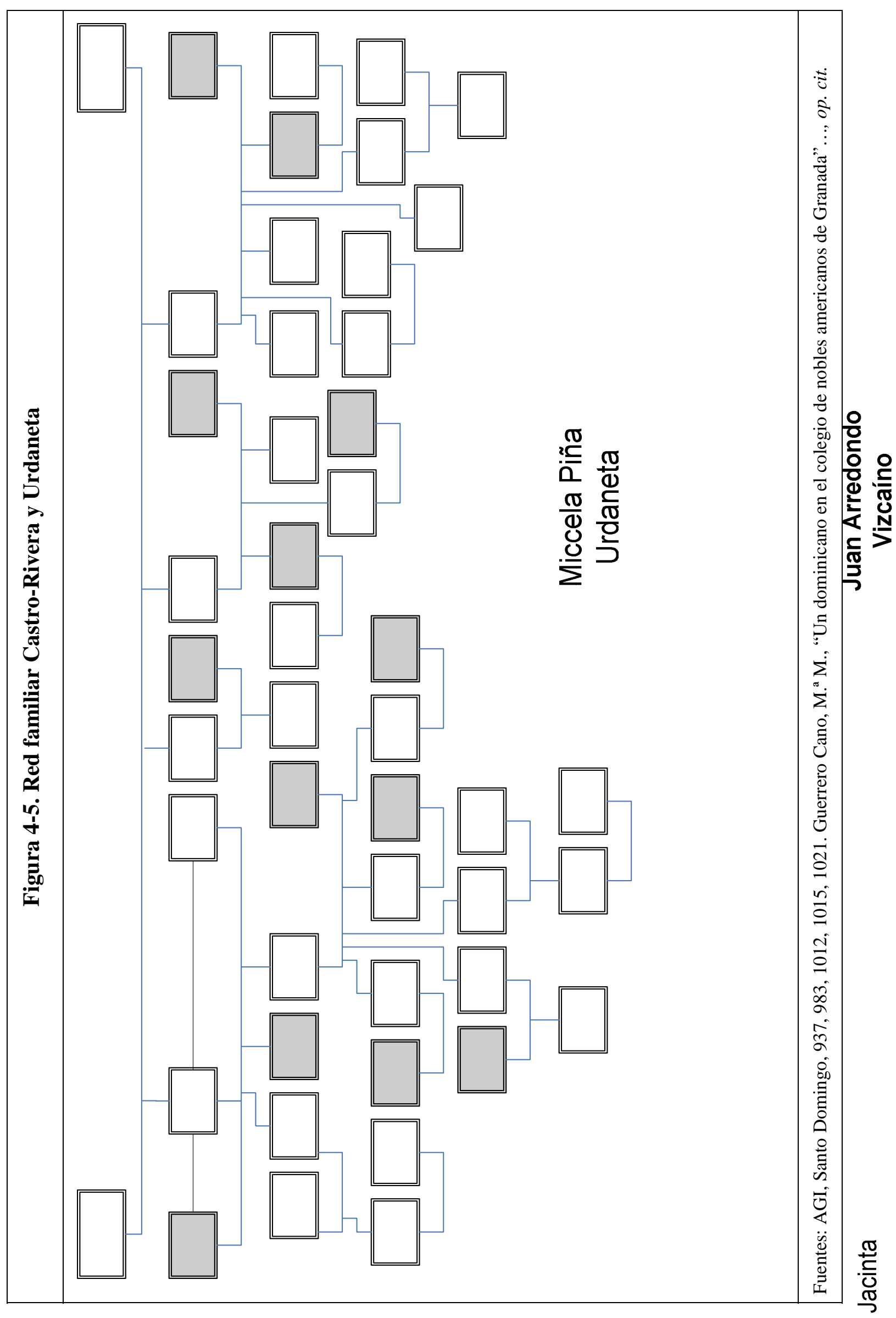


Los Hacendados

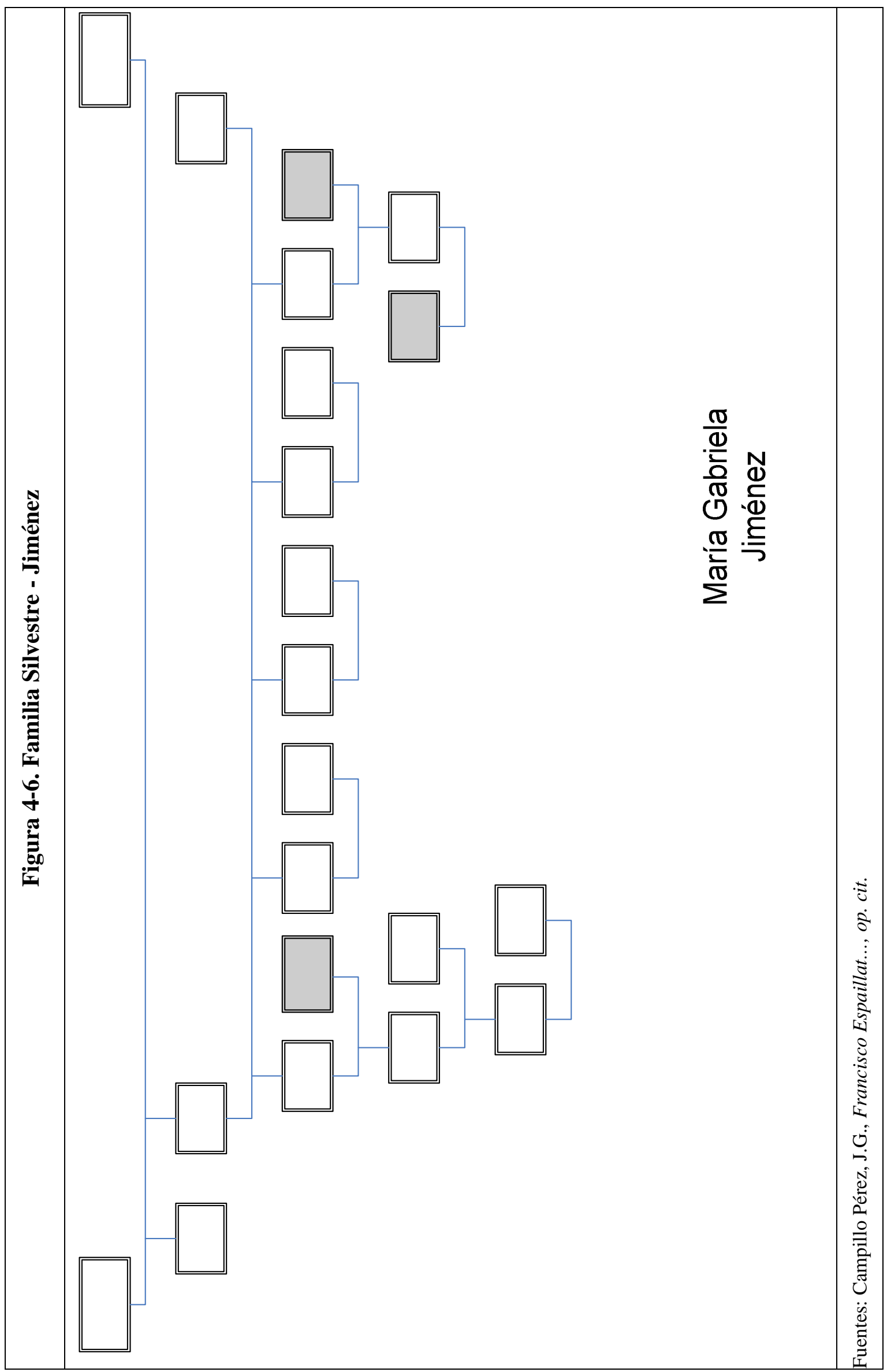




\subsection{Amistad y compadrazgo}

A parte de los lazos familiares, existieron otros tipos de vínculos utilizados por los hacendados que completarían el conjunto de relaciones de este grupo dominante. Entre las más evidentes, el compadrazgo o padrinazgo fue una de esas alianzas creadas tanto dentro como fuera del núcleo familiar con el objeto de obtener algún tipo de lealtad, protección o apoyo del personaje elegido, lo que además permitió conectar con otra red de relaciones.

Si bien los hacendados planearon estratégicamente los matrimonios de sus hijos, obraron de modo similar a la hora de escoger a un padrino o madrina. Esta figura, al igual que en el caso de las capas elevadas hispanoamericanas, tuvo un muy importante papel entre la élite de Santo Domingo, así como en el resto de la sociedad, pues además de afianzar la lealtad entre ambas partes, el padrino o madrina tenía obligaciones morales y familiares con el ahijado que eran atribuidas por la Iglesia. De esta manera tenía que colaborar en la educación religiosa que debía recibir su ahijado, además de hacerse cargo de él en caso de muerte de los padres. El lazo establecido creaba una determinada relación, y en función de sus características se pueden distinguir tres tipos.

El primer tipo de relación sería el parentesco estricto entre padres e hijos, el segundo referiría el parentesco espiritual o ritual, es decir, un vínculo religioso entre padrinos e hijos, y un tercer tipo consistiría en una relación de amistad que podía existir entre los padres y padrinos. Dependiendo de cómo fuese esa relación espiritual entre ambas partes, ésta podía ser simétrica o asimétrica. Aunque generalmente fue desigual, pues la función protectora que tenía el padrino respecto al ahijado implicaba que los padres siempre estuviesen agradecidos por tal generosidad ${ }^{145}$.

El compadrazgo que ejercieron los hacendados de Santo Domingo se llevó a cabo tanto dentro como fuera del seno familiar. En este sentido, cuando se elegía a un miembro de una misma familia, bien fuesen abuelos, tíos, cuñados o primos, la relación venía definida por simetría. Sin embargo, dentro de este marco se escogieron habitualmente a los abuelos, lo que suponía un reconocimiento de la supremacía del papel de los patriarcas, y al mismo tiempo se contribuía a la

\footnotetext{
${ }^{145} \mathrm{Al}$ respecto véase Langue, F., Los señores de Zacatecas. Una aristocracia minera del siglo XVIII. México, 1999, pp. 330-333.
} 
cohesión familiar. Pero probablemente la elección de los abuelos como padrinos fue una estrategia para evitar problemas con la Iglesia, ya que según su legislación estaba prohibido el matrimonio entre personas que tenían lazos espirituales, como el padrinazgo ${ }^{146}$. No obstante, como ya se pudo ver, esta regla fue más teórica que práctica, pues los casamientos entre tíos-sobrinas y primos fueron frecuentes en la red Landeche-Bastidas, destacando que entre estos contrayentes no existía parentesco espiritual. Tanto esta red familiar como los Guridi y AlarcónCoronado, y los Castro-Rivera y Urdaneta recurrieron a buscar padrinos dentro de su propio $\operatorname{clan}^{147}$.

Otro caso de este tipo de relación simétrica sería el compadrazgo que unía al grupo de los hacendados en sus negocios y en la política. Es decir, hubo hacendados que eligieron como padrinos a amigos que al mismo tiempo eran sus socios o compañeros en alguna institución. Se trató de personas muy cercanas a ellos, de hecho en la documentación aparecen denominados como "amigos intimos” ${ }^{148}$, relación que se vio reforzada con este parentesco ritual. El grado de intensidad de esta amistad recíproca quedó reflejado incluso en el momento de la muerte. No es raro así encontrar entre los albaceas de los hacendados a alguien que al mismo tiempo era compadre del difunto o viceversa, y que además de compañero de empleo lo era en sus actividades agrarias y comerciales.

Así por ejemplo, el oficial real Raymundo Esparza fue elegido padrino de Raymundo, hijo del factor de tabacos Andrés de Lecanda y Andirengoechea y Gabriela Sánchez, el cual fue bautizado en la catedral de Santo Domingo el 17 de

\footnotetext{
146 Fernández Pérez, P., El rostro familiar de la metrópoli. Redes de parentesco y lazos mercantiles en Cádiz, 1700-1812. Madrid, 1997, p. 156.

${ }^{147}$ A modo de ejemplo María de la Concepción Mieses Guridi (hija de Ana Guridi y Juan Mieses) fue apadrinada por su abuelo Matías Guridi el 14 de diciembre de 1758, y Nicolás Guridi y Frómesta (hijo de Isabel Frómesta y José Guridi) por su tía Beatriz Leos-Echalas el 21 de mayo de 1755. Dentro de la familia Landeche-Bastidas, Rodrigo Macedonio de la Rocha Coca (hijo de Isabel Coca y Domingo de la Rocha) fue bautizado el 5 de octubre de 1754, siendo Josefa Coca su madrina, quien más tarde se convertiría en su suegra. Otro miembro de esta red, Antonio Dávila Coca-Landeche, ofició como padrino el 18 de julio de 1760 en el bautizo de Petronila Angulo de quien era abuelo. Algo similar se puede encontrar entre los miembros de los Castro-Rivera y Urdaneta, que captaron padrinos dentro del propio entorno. El 3 de octubre de 1749 Domingo Lorenzo Zevallos apadrinó a su sobrino Francisco Arredondo Castro hijo de Juan Arredondo Vizcaíno y Jacinta Castro-Rivera. Uno de los hijos de Miguel Bernardo Antonio Ferrer Angulo y María Belen Castro-Rivera fueron apadrinados por su abuela Micaela Piña Urdaneta que lo fue de María de la Concepción, y de Miguel su tío-abuelo Juan de Quevedo y Villegas. AASD, Libros de Bautismos, Acta 699, fol. 95, libro 5; Acta 72, fol. 112, libro 9; Acta 516, fol. 80, libro 9; Acta 818, fol. 109, libro 5; Acta 1030, fol. 115, libro 3: Acta 1747, fol. 264, libro 9.

${ }^{148}$ Carta de José Frómesta en la que suplica a Su Majestad se sirva mandar en las causas que han dado algunos a las torpezas de sus esclavas, 20 de enero de 1787. AGI, Santo Domingo, 990.
} 
julio de $1775^{149}$. Raymundo Esparza también fue padrino del resto de los hijos de esta pareja, quienes además del nombre propio llevaban agregado el de Raymunda o Raymundo dependiendo si era un chico o una chica ${ }^{150}$. Por otro lado, Andrés fue uno de los albaceas testamentarios de Raymundo. La elección como albacea también es un hecho notorio, porque denotaba la confianza que el difunto depositaba en él al concederle el poder de gestionar el patrimonio al morir éste, su liquidación así como la tutoría para dirigir su casa. Aunque respecto a esto último parece que no debió suceder en el caso de Raymundo, pues murió soltero, dejando su patrimonio a la Corona y el remanente que quedase de todos sus bienes, derechos y acciones al gobernador Joaquín García Moreno, a quien además de haberle nombrado como albacea también le hizo heredero fideicomisario por “[...] su fiel y antigua amistad [...]"151 . Raymundo fue a su vez padrino de una de las hijas de Joaquín García Moreno, María Josefa que nació el 24 de abril de 1779. Otra de las hijas de Joaquín tuvo como madrina a María del Carmen Coca y Oviedo, miembro de la red Landeche-Bastidas ${ }^{152}$.

La tercera persona elegida por Raymundo Esparza como albacea fue el abogado de la Audiencia Rufino Suárez de Rivera y Manrique, al que poco después se le trasladó a Manila para ocupar el empleo de auditor de guerra, y con quién lógicamente debió mantener una estrecha amistad ${ }^{153}$. Estos ejemplos ilustran como la elección de uno o varios albaceas revela ese grado de amistad íntima y solidaridad que se va forjando a lo largo de la vida de todo individuo.

149 AASD, Libro de Bautismos, Acta 581, fol. 128, libro 9.

${ }^{150}$ De los trece hijos que tuvo Andrés de Lecanda, nueve tuvieron como padrino a Raymundo Esparza, y otros dos al oidor Rufino Suárez y al hacendado Francisco Espaillat. El nombre de Raymundo o Raimundo añadido a los bautizados aparece en la documentación indistintamente con ambas grafías, puede verse en: AASD, Libro de Bautismos, Acta 349, fol. 162, libro 12; Larrazábal Blanco, C., Familias dominicanas..., op. cit., vol. IV, p. 178; y Campillo Pérez, J. G., Francisco Espaillat..., op. cit., p. 247.

${ }^{151}$ Escritura del testamento de Raymundo Esparza, 23 de enero de 1786. AGI, Santo Domingo, 992.

${ }^{152}$ La hija de Joaquín García se llamaba igual que su madrina María del Carmen Josefa Joaquina. Nació el 2 de abril de 1765 y fue bautizada el 4 de mayo de 1765. AASD, Libro de Bautismos, Acta 495, fol. 110, libro 9. Véase también Larrazábal Blanco, C., Familias dominicanas..., op. cit., vol. III, pp. 268-269.

${ }^{153}$ Rufino Súarez era hijo de Juan Manuel Suárez de Rivera y Manrique y de Teresa Rosa Sevillano Bernardo de Quirós. Llegó a Santo Domingo alrededor de 1772 como pasante junto a Diego Martínez de Araque, que había sido nombrado fiscal para la Audiencia de Santo Domingo. Escritura del testamento de Raymundo Esparza, 23 de enero de 1786..., op. cit. Expediente de información y licencia de pasajeros a Indias, 17 de noviembre de 1772. AGI, Contratación, 5517, N2, R21. 
Los hacendados podían ser también los padrinos de los hijos de sus propios esclavos. Además a través de la documentación se ha comprobado que muchos de ellos aparecen bautizados con el nombre de los dueños e incluso con sus apellidos; en este caso el origen social y étnico determina que la relación sea asimétrica. Sin embargo, su cooperación y lealtad hacia su amo podía ser recompensada al final de la vida de éste al concederle la libertad en su testamento, una costumbre muy recurrente utilizada por los hacendados, sobre todo en agradecimiento a sus esclavos domésticos por el servicio prestado ${ }^{154}$.

Junto a estos dos tipos de compadrazgos, los hacendados también mantuvieron entre sí relaciones de ayuda, es decir, de solidaridad. Así los hacendados se prestaron dinero unos a otros, actuando como fiadores, o incluso como agentes o representantes de ellos mismos en determinadas situaciones. Entre varios casos de éstos, el papel que desempeñó el abogado y relator José Jacinto Ramírez ejempliza este comportamiento de apoyo que se proporcionaban los hacendados tanto dentro de la familia como fuera de ésta. En 1785, José Jacinto es elegido por su cuñado, Luís Franco Guridi como su representante, en la obtención del cargo de regidor ${ }^{155}$. José Jacinto también tuvo una participación activa en la defensa particular de Narciso Subirás y Barra -director de la Real Compañía de Comercio de Barcelona y amigo de su familia los Guridi-, cuando surgió el conflicto con ésta en relación a las acusaciones que la implicaba en la realización de comercio ilítico, y en particular a Narciso ${ }^{156}$.

En cuanto a los préstamos de dinero, los hacendados de Santo Domingo los realizaron para comprar un bien inmueble o bien para la ocupación de algún cargo público. Si en un momento dado un hacendado no contaba con el dinero suficiente para la compra de un empleo en el cabildo, otro se lo podía prestar. Eso fue lo que le sucedió a Manuel Heredia cuando fue a comprar un regimiento,

\footnotetext{
${ }^{154}$ Ibidem. Escritura del testamento de Beatriz Leos-Echalas, 28 de noviembre de 1783. AGI, Santo Domingo, 960. Escritura del testamento de Juan Miguel de la Rocha, 5 de mayo de 1778. AGI, Santo Domingo, 989. "Testamento de Jacinta de Castro y Urdaneta, 2 de junio de 1807" en Sáez, J. L., La Iglesia y el negro esclavo en Santo Domingo. Una historia de tres siglos. Santo Domingo, 1994, pp. 510-511, y las páginas 45-48, y 70-71. Utrera, F. C. de, “Don Luís Franco de Acevedo”..., op. cit., pp. 372-385, p. 378.

${ }^{155}$ Pedimento de Luis Franco para las diligencias que acusan dar poder a su cuñado, el relator José Jacinto Ramírez, 11 de marzo de 1785. AGI, Santo Domingo, 938.

156 Oliva Melgar, J. Ma., "Contrabandistas, criollos y mercantilismo español en el siglo XVIII: la resistencia a la compañía de Barcelona en Santo Domingo”. Pedralbes 4 (Barcelona, 1984) pp. 233-271, p. 264.
} 
quien a pesar de ser un rico hacendado no contaba con él, por lo que Antonio Mañón de Lara y Antonio Dávila Coca y Landeche se ofrecieron a prestárselo ${ }^{157}$. Los parientes también podían actuar facilitándoselo, es el caso de Nicolás Guridi y Frómesta, quien en 1779 a través de una compra encubierta intentó adquirir un cargo de regidor pero por mediación de su primo José María de Mieses, que se encargaría de hacerla ${ }^{158}$.

Otro caso sería el préstamo que los hacendados hacían a algún funcionario público, un hecho que se vio acentuado por los sucesivos retrasos del situado. Si bien para los funcionarios era un favor que aliviaba su situación crítica, para el hacendado era una forma de obtener a la larga una ayuda en caso de necesidad. Esta ayuda que aceptaban los funcionarios de los hacendados probablemente comprometía su imparcialidad y los privilegiaba. En concreto, en cuanto a los empleados en la Real Hacienda de Santo Domingo, hubo personas que ejercieron de fiadores respecto al administrador responsable de algún ramo de hacienda en caso de hacer quiebra o no estar exactas sus cuentas. De manera que a la hora de entrar en el cargo, debían presentar un listado de personas que ejercerían como sus fiadores. El número de éstos oscilaba entre uno y veinte, pudiendo el funcionario ir renovándolos durante el ejercicio de su empleo ${ }^{159}$.

El nombramiento de Fernando Mauelón como tesorero de las Cajas de la ciudad de Santo Domingo en 1786 muestra lo dicho. En un principio, puso como fianza 3.308 pesos, 6 reales y 20 maravedís, siendo entre sus fiadores el hacendado José Antonio Zárraga y su mujer Felipa Pérez-Caro y Oviedo, y José Coll y Solá ${ }^{160}$. En 1793 Fernando Mauleón volvió afianzar la administración de las reales cajas, pero en esta ocasión se trataba de la ciudad Valladolid (Michoacán) a la que había sido ascendido como contador. Antes de su salida ofreció entregar la fianza en el tribunal de cuentas de La Habana y aumentarla

\footnotetext{
${ }^{157}$ La mujer de Manuel Heredia se llamaba Francisca Justa Mieses Guridi, y era sobrina de Antonio Mañón de Lara por parte de su mujer Teresa Mieses Ponce de León. Carta del gobernador de Santo Domingo, Isidro Peralta y Rojas, 28 de febrero de 1779. AGI, Santo Domingo, 1021.

158 Ibidem.

${ }^{159}$ Esto fue habitual en los empleos de este tipo como por ejemplo en México, véase al respecto los interesantes artículos de Bertrand, M., "En torno a una problemática de la administración colonial: la real hacienda de Nueva España (1680-1770)”. AEA XLVI (Sevilla, 1989) pp. 195-217, en particular las páginas 204 y 205, y "Élites, parentesco y relaciones sociales en Nueva España”. Tiempos de América 3-4 (Alicante, 1999) pp. 57-66, p. 64.

${ }^{160}$ Escritura de fianza de José Antonio Zárraga y Joseph Coll realizada por el escribano José Abad, 14 y1 6 de julio de 1787. AGI, Santo Domingo, 1045.
} 
hasta la cantidad de 6.000 pesos. De ellos 3.000 fueron aportados por Nicolás Guridi Coronado y su mujer Beatriz Leos-Echalas; 306 el capitán de ingenieros Pedro Roig y Lluís mancomunado con su mujer; 1.000 por Ignacio Pérez-Caro y Oviedo y otros 1.000 Félix Guillén, con sus respectivas esposas, y el resto los 694 pesos con “distintas personas"161 . Los 3.000 pesos que proporcionaron Nicolás Guridi y Beatriz Leos-Echalas los habían puesto como fianza sobre su casa morada, cuyo valor ascendía a la mencionada cantidad. Al morir Nicolás este vínculo remunerativo pasó a manos de su mujer Beatriz, que ante las circunstancias de evacuación de la isla en 1795 trató de cancelar la fianza y liberar la casa hipotecada. Para tal fin dio poder a su cuñado, Antonio Álvarez Barba, quien como heredero del gravamen en que se constituyó de la fiadora Beatriz, hizo todo lo posible para que Fernando Mauleón contribuyera por su parte. Sin embargo, la cesión de la isla obligó a suspender no sólo esta fianza, sino también otras muchas que poseían los vecinos sobre sus bienes ${ }^{162}$.

Las necesidades de la fianza nos han llevado a descifrar varias cuestiones muy importantes. En primer lugar, conocer las relaciones sociales que entablaron estos funcionarios con sus fiadores y el resto de la sociedad local. En un segundo momento, el poder que proporcionaba desempeñar un cargo de este tipo en relación con el clientelismo, tomando el caso anterior y de un personaje del que venimos mencionando y tratamos a lo largo de este epígrafe y el siguiente, el del ya mencionado tesorero Raymundo de Esparza.

La integración de estos funcionarios en la ciudad de Santo Domingo, viene dada por ese primer contacto con aquellas personas que les ofrece su apoyo financiero, en su mayoría como hemos visto hacendados que los irán integrando en su círculo. Con esto se les concede una especie de carta de presentación en la ciudad, donde son unos completos desconocidos y, sean considerados como vecinos de ella. Sin embargo, fueron los matrimonios entre éstos y las hijas de algunos de los hacendados más importantes de la ciudad de Santo Domingo la mejor forma de integración, como sucedió con los ministros de la Audiencia o los

\footnotetext{
${ }^{161}$ La mujer de Pedro Roig y Lluís era Juana Saviñón Tapia, la de Ignacio Pérez-Caro y Oviedo María Magdalena Catalina Campuzano, y la de Félix Guillén Jerónima Viage. Escritura de fianza de Ignacio Caro y Félix Guillén realizada por el escribano Martín Mueses, 28 de marzo de 1793. AGI, Santo Domingo, 1045.

162 Testimonio de las diligencias seguidas por el mariscal de campo Antonio Barba contra Fernando Mauleón, sobre que liberte la casa de la fianza que le otorgó Beatriz Leos y Echalas, a las resultas de la administración de su empleo de tesorero, 1796. AGI, Santo Domingo 960.
} 
militares. Si bien en un principio el hecho de que sus mujeres sean más ricas que él implicaba en cierta medida un grado de desigualdad y dependencia respecto a la familia de ella al menos en el sentido socioeconómico, en contrapartida a la larga el funcionario les ofrecía fidelidad y seguridad en los negocios familiares en los que rápidamente se adaptaba. Podemos presumir que el oficial no tomaría decisiones que afectasen a los intereses familiares o los de sus aliados, protegidos o protectores, al fin y al cabo eran los suyos propios. Además de esta manera indirecta por la que los hacendados usufructuaban de dicho cargo, también lo hicieron directamente, cuando el oficial les delegaba el poder que les confería un cargo del ramo de la Hacienda con el nombramiento que hacía en ínterin a algún pariente o bien en amigos, o siendo su sustituto. De tal forma que la posición de este funcionario dentro del gobierno de Santo Domingo constituye un centro de poder nada despreciable por parte de los hacendados, quienes estimaron que su colaboración les era útil para completar su dominio. En el mismo sentido, como veremos más adelante las conexiones con los minististro de la Audiencia, o los gobernadores les proporcionaban ese apoyo que les sirvio para ir imponiendo su autoridad local y defender sus intereses socioeconómicos. Por su parte, para que los oficiales reales pudieran rentabilizar este cargo "tan apetecido por aquellos naturales”163 y obtener beneficios económicos a través de la participación en actividades agropecuarias y comerciales; también necesitaron del apoyo familiar y las relaciones clientelares construidas por y en torno a ellas, así como aquellas que los propios funcionarios fueron creando una vez que habían hechado raíces o bien incluso con las que seguían manteniendo en la Península.

Un ejemplo de esta forma de actuar nos lo ofrece el caso de Fernando Mauleón: en líneas anteriores señalábamos que entre los fiadores que contó Fernando Mauleón se encuentra algunos de los hacendados más importantes que les sirvieron de aval para presentarse ante la sociedad. Entre los favores que pudieron obtener los hacendados destacamos el nombramiento como contador interino de Ignacio Pérez-Caro y Oviedo durante el año de $1791^{164}$. Aunque fueron sus matrimonios los que le integraron de manera definitiva. Lo singular de

\footnotetext{
${ }^{163}$ Informe del fiscal de la representación realizada por Lorencis del Castillo, natural de estos reinos y avencidado en Santo Domingo, 19 de julio de 1771. AGI, Santo Domingo, 1004.

${ }^{164}$ Informe del regente y del gobernador de la isla, 18 de enero de 1796. AGI, Santo Domingo, 1044.
} 
éstos fue que en primer lugar se casó con Jacinta Saviñón, emparentando con la red familiar Castro-Rivera y Urdaneta. En ella encontró el apoyo para su segunda fianza, ya que entre los fiadores aparece su hermano político Pedro Roig y Lluís. En segundas nupcias con Ana Cabrera y Paredes, conectando con la de los Landeche-Bastidas $^{165}$.

Tampoco fue extraño en estas Cajas que el oficial real hiciese préstamos con dinero que no le pertenecía, como hizo el tesorero Raymundo Esparza, quien además de hacendado y comerciante prestó dinero a personas con las que al mismo tiempo mantenía relaciones de negocios, es decir, eran socios. La estrechez de este vínculo económico queda constatada en una parte del testamento de Raymundo Esparza, en el que hace una relación de algunos de sus deudores, acreedores, intermediarios de otros puertos e intereses que tenía con ellos. Aparecen sus nombres y sólo en alguna ocasión contiene los contratos, cartas o relaciones financieras así como fechas y cantidades adeudadas, referencias que se encuentran en la documentación de forma global y más específicamente remitiendo a papeles personales de Raymundo a los que no hemos tenido acceso. Los individuos que contrajeron deudas con este personaje fueron: Antonio Rojas, Antonio Cumulat, Andrés de Lecanda, Juan Miguel Arozena, Juan José Barrios, Félix Guillén, Domingo Sánchez, José Lazerre, Francisco Antonio Irisarri, Ramón Arbeliz, Francisco Sasturre y Felipe Guridi Concha, entre otros ${ }^{166}$.

Este listado de doce personas desvela con quien mantenía negocios Raymundo, y que en su mayoría eran comerciantes, siendo algunos de origen vasco, catalán y canario. Su estudio supondría realizar una investigación más profunda sobre este componente social y los negocios mercantiles del que a penas existe ningún trabajo y, particularmente su funcionamiento a través de las redes sociales entabladas en los distintos lugares de la geografía de hispanoamericana y la Península. Por ello, de ese listado cabe resaltar la buena relación que debió mantener Raymundo Esparza con algunos de los hacendados peninsulares y

\footnotetext{
165 Carta del gobernador de Santo Domingo, Joaquín García, dando cuenta a Su Majestad por medio de un expediente obrado para el casamiento y licencia que dio al tesorero de aquellas cajas Fernando Mauleón celebrado con Jacinta Saviñón, 20 de enero de 1791. AGI, Santo Domingo, 954. Carta de Ana Cabrera, viuda de Fernando Mauleón, solicitando pensión, 1800. AGI, Santo Domingo, 1037.

166 Reconocimiento e imbentario de los papeles, de creditos derecho, y acciones activas, $y$ pasivas pertenecientes a la testamentaria del difunto tesorero, Raymundo Esparza, 22 de diciembre de 1787. AGI, Santo Domingo, 992.
} 
criollos estudiados: el asentista de tabacos Antonio Rojas, el ya mencionado factor de tabacos Andrés Lecanda, los empleados de la Compañía de Comercio de Barcelona Narciso Subirás y Antonio Cumulat, y el criollo abogado Felipe Guridi Concha. Junto a ellos hubo otros como Francisco Antonio Velilla, José Guridi, Miguel Ferrer, Domingo Sánchez, Felipe Mañón o Joaquín Cabrera, que también fueron deudores de Raymundo Esparza. Como ejemplo mostramos a continuación el estado de la liquidación de algunas deudas, cuentas y cobro de éstas hacia 1790.

\section{Tabla 4-3. Estado de cobranza de los créditos activos de la testamentaria de Raymundo Esparza}

\begin{tabular}{|l|c|}
\hline \multicolumn{1}{|c|}{ Nombre } & Cantidad \\
\hline Francisco Antonio Velilla y Torres & 1.785 \$ 1rs. 17mrs. \\
\hline Domingo Sánchez & 2.136 \$ \\
\hline José Guridi Concha & 2.015 \$ 5rs. 17 mrs. \\
\hline Pedro Echegarate & Liquidada \\
\hline Pedro Petreña & 40.420 \$ 1rs. \\
\hline Juan Miguel Arozena & No aparece y está en estado de concluirse \\
\hline Félix Guillén & No aparece y está en estado de concluirse \\
\hline Manuel de Poveda & 477 7rs. \\
\hline José Belzunce y Laureano Chacón & 549 \$ 7rs. \\
\hline $\begin{array}{l}\text { Rafael Menocal, Jacinto Tomás Barreto, } \\
\text { Clemente de la Guardia e Ignacio } \\
\text { Peñalver }\end{array}$ & 400 \$ \\
\hline Narciso Subirás & 40 \$ \\
\hline Pedro Betancurt & 219 4rs. \\
\hline Miguel Ferrer & 889 \$ \\
\hline Joaquín Cabrera & \\
\hline $\begin{array}{l}\text { José Manuel Rodríguez, Felipe Mañón, } \\
\text { Juan Marcano, Pedro Barriere, Antonio } \\
\text { Sánchez, Antonio de Castro, María } \\
\text { Ximénez, Manuel Bazán, y Pedro } \\
\text { Bermudes }\end{array}$ & No aparece y están en estado de \\
\hline
\end{tabular}

Elaboración propia. Fuentes: En el caso de Domingo Sánchez, Francisco Antonio Velilla, José Guridi, y José Belzunce y Laureano Chacón, ya difuntos las cuentas fueron liquidadas por sus albaceas y herederos. Estado de cobranza de los créditos activos de la testamentaria de Raymundo Esparza, 24 de enero de 1790. AGI, Santo Domingo, 1045. La cursiva es nuestra.

Hay que señalar que, algunos de estos hacendados con los que Esparza dirigía sus negocios eran también oficiales reales, personas vinculadas al tráfico comercial y cohesionados familiarmente entre ellos, así como con aquél. Particularmente con la red clientelar que asociaba a distintas generaciones de la rama familiar Silvestre-Jiménez, y que entronca con la red familiar Castro-Rivera 
y Urdaneta: suegro-yerno, hermanos políticos y tío-sobrino. Este fue el caso de los factores de tabaco Francisco Antonio Velilla-Francisco Espaillat, Velilla-Andrés de Lecanda y de Lecanda-Francisco Espaillat. Junto a este núcleo, el parentesco espiritual entre Lecanda y Esparza, ya presentado es un buen ejemplo de este comportamiento. En suma, puede decirse que los lazos políticos, los de tipo espiritual y los económicos convergían uniendo familia, riqueza e intereses que permitían negocios.

Los servicios prestados por Esparza abarcaban hechos tan diversos como la negociación de letras o el adelanto de dinero, administración del tabaco, y cultivo del cacao en su estancia Guayabal. En el desarrollo y operación de estas actividades intervinieron otros compañeros "amigos y paniaguados”, tales como los que menciona en una carta el gobernador Isidro Peralta y Rojas, refiriéndose al oficial Pedro Madrigal, el alguacil ejecutor Félix Guillén, y particularmente al contador Francisco de Paula Gazcue y Olaiz ${ }^{167}$. Esa dependencia o colaboración entre Esparza y el resto de los oficiales reales era lógica ya que al fin y al cabo debían entenderse, si querían evitar contratiempos.

La muerte de Esparza en 1786 destapó el desfalco de las cajas reales como consecuencia de la conducta inapropiada de los funcionarios reales ${ }^{168}$. En concreto sobre cómo Raymundo de Esparza se aprovechó de su posición privilegiada para realizar un fraude, tanto en el contrabando de "efectos clandestinos” que escondían en tiendas de comerciantes o almacenes de los propios oficiales, los cuáles habían sido adquiridos: "parte por compra a las embarcaciones del franco comercio en las reales almonedas de apresamientos y comisos y, parte por consignaciones y confianzas de varios individuos de esos reinos y de muchos de los mismos patrones y sobrecargos de las embarcaciones”, como en la manipulación de la documentación que se debía presentar anualmente del estado de cuentas ${ }^{169}$. De hecho en su testamento declaró que tenía finiquitado sus cuentas desde 1766 hasta las de 1777, faltando desde ese año hasta 1785, para lo cuál encargaba su ajuste a Gazcue y, a los albaceas el ingreso en las cajas reales

${ }^{167}$ Carta del gobernador, Isidro Peralta y Rojas, al rey dando cuenta de la mala conducta de los oficiales reales de las cajas de la isla, 12 de diciembre de 1781. AGI, Santo Domingo, 986.

${ }^{168}$ Expediente tramitado en el Consejo de Indias relativo al desfalco producido en las Cajas Reales de la isla de Santo Domingo por los oficiales, Raymundo Esprza, tesorero de Hacienda y Caja Real de Santo Domingo, Francisco Gascue y Olaiz, oficial contador. AGI, Santo Domingo, 1069.

${ }^{169}$ Carta del gobernador, Isidro Peralta y Rojas..., op. cit. 
de los beneficios anuales de su estancia ${ }^{170}$. Otros datos que se habían obtenido en el periodo de investigación hacen referencia a la falsificación de poderes facilitando para ello el papel sellado que sacaban de la contaduría o incluso sobre las papeletas falsas de dinero, que circulaban desde 1782 para facilitar el comercio $^{171}$.

Los resultados de las investigaciones determinaron también responsables del fraude por negligencia y participación activa al resto de los funcionarios, aunque no llegaron a ser procesados ni destituidos de sus cargos. El más perjudicado fue Francisco Gazcue que fue encarcelado y, por las pérdidas materiales que le supuso: la confiscación de su sueldo y el embargo de sus bienes, entre ellos una estancia y joyas que pertenecían a su mujer. Gazcue pudo ir haciendo luz en el caso al recuperar aquellos que eran la legítima de su mujer y, por tanto, pertenecían a sus hijos, el resto era para restituir a la tesorería parte de lo defraudado. Por su parte, Raymundo ya muerto había dejado al rey todos sus bienes, nombrándole como su único heredero. Además, se encomendó al oidor Pedro Catani y, después a Melchor Foncerrada la labor de recuperar para la Real Hacienda la cobranza de los créditos que resultaban a favor de Esparza, la puesta en alquiler de la estancia Guayabal, y retirada del papel moneda falso que circulaba en la isla.

Otro aspesto que se cuestionaba era la actitud del gobernador de aquel entonces Manuel González, a quien se le reprobó el haber mantenido a Gazcue por quince meses en su puesto y no haber separado al sospechoso tardíamente hasta 1788. El 26 de marzo de 1788, Nicolás Toledo, fue nombrado interinamente por el gobernador Joaquín García para el puesto de contador, un sujeto de su confianza ya que era su secretario de gobierno. Lo cuál molestó al oficial Juan Lavastida a quien por el escalafón de la Real Hacienda le debía corresponder tal empleo. Las cartas de protesta que envió al rey lograron que por una Real Orden de 21 de octubre de 1789 fuese destituido Nicolás. Sin embargo, el tesorero Fernando Mauleón se opuso a ese mandato, y por tanto a su elección por la desconfianza que le inspiraba en el manejo de caudales, y porque había sido el

\footnotetext{
${ }^{170}$ Escritura del testamento de Raymundo Esparza, 23 de enero de 1786. AGI, Santo Domingo, 992.

${ }^{171}$ Bando del gobernador Isidro Peralta y Rojas para habilitar papeletas, 13 de mayo de 1782. AGI, Santo Domingo, 946.
} 
instrumento que valió al gobernador Isidro Peralta para el tanteo de las cajas de las que resultaron principales sospechosos Esparza y Gazcue. El gobernador interino Joaquín García y Nicolás Toledo apoyaron estos motivos, añadiendo el impedimento de desempeñar un cargo dentro de la Real Hacienda si existía otro pariente como se daba el caso. Pues tenía un hijo que era administrador en San Rafael, logrando que se diera provisión del empleo de contador al teniente de infantería Ignacio Pérez-Caro por "ser sujeto de los mas benemeritos de este pueblo, de los mas arraigados en patrimonio, y en quien concurren las mas notorias circunstancias de habilidad, y de suficiencia para desempeñar con mas ardua comision” ${ }^{172}$. Aunque sólo lo mantuvo por un año, ya que desde 1792 hasta 1796 fue ocupado finalmente por Juan Lavastida mientras que Nicolás Toledo entró en el oficio de tesorero ${ }^{173}$. Detrás de este conflicto por nombrar a una persona para tal puesto se descubre los intentos del gobernador Joaquín García y sus aliados por contar con alguien de suma confianza para seguir encubriendo los manejos de Esparza de quien era connivente y la implicación del propio gobernador.

El trato de privilegio que Esparza recibió en sus negocios por los gobernadores no significa que también tuviera desavenencias y tirantez con alguno de ellos como Isidro Peralta y Rojas, quien durante su gobierno había intentado destituirle y, al que consideraba “encubridor" del "ilicito comercio”, que se prodigó en aquellos años. El gobernador centraba sus críticas en la política comercial llevada a cabo en cuyas directrices reconocía los personales y turbios manejos de Esparza: "hace catorce años que maneja los considerables intereses reales con increible despotismo supliendo a unos, no cobrando a otros y adquiriendo fincas de mucho valor, con lo que ha logrado hacerse temible e invulnerable" ${ }^{174}$.

172 Sobre este asunto véase: Expediente tramitado en el Consejo de Indias relativo al desfalco producido en las Cajas Reales de la isla de Santo Domingo por los oficiales, Raymundo Esparza, tesorero de Hacienda y Caja Real de Santo Domingo, Francisco Gascue y Olaiz, oficial contador, 1789-1807. AGI, Santo Domingo, 1069.

173 El hijo de Juan tenía el mismo nombre que su padre. El apellido Lavastida o Labastida aparece escrito en la documentación indistintamente con ambas grafías. Relación de empleos de la Real Hacienda, 15 de febrero de 1796. AGI, Santo Domingo, 1039.

${ }^{174}$ Carta del gobernador, Isidro Peralta y Rojas, al rey dando cuenta de la mala conducta de los oficiales reales de las cajas de la isla, 12 de diciembre de 1781. AGI, Santo Domingo, 986. 
Este suceso desvela que los hacendados además contaron con otro tipo de amistades en las que la relación funcionaba como un vínculo de dependencia. Esta amistad solía ser de tipo instrumental, ya que implicaba una gran desigualdad entre ambas partes relacionadas al disponer una de ellas de "[...] posibilidades claramente superiores para conceder favores, bienes y servicios [...]” a la otra ${ }^{175}$. En este sentido, en función de dónde se situara el individuo en la relación, podía ser protector o protegido. Por su parte, los hacendados tuvieron la posición de protectores respecto algunos oficiales reales como fue el caso del ya mencionado Fernando Mauleón, o de Nicolás Guridi y Frómesta al actuar como fiador del tesorero Juan González Terino en 1794. Mientras que el oficial Esparza actuó como protector respecto a los subalternos de la caja real, los hacendados y particularmente los comerciantes. Los hacendados también escogieron entre sus deudos a personas que estaban por debajo de ellos social y económicamente. Se trataba frecuentemente de empleados elegidos por los propios hacendados, entre los cuales destaca la figura del criado o mayordomo. Sin embargo, aquellos peninsulares que emigraron a Santo Domingo trajeron consigo a sus dependientes, un hecho que se constata mediante las licencias de embarque en las que aparecen inscritos. Por ejemplo, en 1784 se le concedió la licencia a los asturianos Gabriel Collar y Tomás de la Riva para pasar a Santo Domingo junto al hacendado Juan Bautista Oyarzábal y emplearse como mayordomos en el ingenio que éste había comprado en nombre de su primo Simón Aragorri y Olavide, el Marqués de Iranda $^{176}$.

La función principal de estas personas era dirigir la casa o la hacienda agrícola en ausencia de su amo. Pero además actuaban como apoderados y solían llevar la contabilidad de los negocios, así como de las tareas ilegales: redacción de documentación falsa, transportar los productos agrícolas fuera del registro, esconder los productos, etc. En contrapartida, el hacendado les aseguraba la responsabilidad de tales trabajos, además les alimentaba y cobijada en su propia

\footnotetext{
175 Wolf, E., "Relaciones de parentesco, de amistad y de patronazgo en las sociedades complejas” en Banton, M. (comp.), Antropología social de las sociedades complejas. Madrid, 1996, pp. 13-39, p. 34.

${ }^{176}$ Expediente de informacion y licencia de pasajero a Indias de Juan Bautista de Oyarzabal, Aranjuez 8 de junio de 1784. AGI, Contratación, 5527, N1, R35.
} 
casa donde normalmente vivían con ellos ${ }^{177}$. En este sentido en el ingenio del Marqués de Iranda se fueron integrando otra serie de peninsulares, que además participaban en la casa de comercio de Aragorri, del que también era dueño el Marqués. Se trata del vasco Simón de Iriarte que "se mantuvo en el ingenio de Boca de Nigua como agregado a la casa” y a la fábrica de azúcar y, del barcelonés Pedro Abadía destinado a la de aguardiente ${ }^{178}$. Estas relaciones de protección y servicios resultan efectivas porque tenían como base la confianza que les proporcionaba las relaciones familiares y financieras. El escrito siguiente expresa la necesidad de contar con este tipo de relaciones:

“[...] si el señor Marques y el señor Martin de Aragorri su hermano llegaran a fallecer antes que estubiese concluida la fundacion de la Hacienda de Santa Maria o después de fenecida, en el tiempo que su manejo o direccion corriese al cargo de Juan Bautista Oyarzabal, los subcesores de los precitados señores, han de estar atenidos a pasar y conformarse con las cuentas que les diese, sin precisarle a producir mas documentos justificatibos de gastos e imbersion de dinero, que los que el mismo presente, en atencion a la confianza y seguridad que tienen de que en este particular no abusara ni pondra en las citadas cuentas partida alguna que no sea veridica; y ultimamente confiesa y declara don Juan Bautista Oyarzabal, que no pretendera retribucion ni gratificacion alguna por razon de su trabajo, y asistencia personal a la fundacion de la sobre dicha Hazienda de Santa Maria o de Andiarena propia del señor Marques y subcesores, en consideracion a los benefizios que le tiene hechos hasta ahora y se propone continuarle, ausiliandole en sus dependencias particulares, y que despues que sea concluida (que se reputara por tal quando en el termino y curso de un año produgese dos mil

177 Al efectuar el inventario de la hacienda Guayabal tras la muerte de su dueño Raymundo Esparza, su mayordomo declaraba que "no existia libro de cuentas" de ella, aludiendo además a que tampoco lo tenían los dueños de haciendas de aquella isla, quienes "no llevaban mas formalidad por no tener que dar cuenta a nadie". Expediente sobre lo presentado por el gobernador y oficiales reales y otros subalternos a las cajas de Santo Domingo, en cuanto al deplorable estado en que dejó el tesorero de ellas Raymundo de Esparza a su fallecimiento por defecto de cuanta y razón. AGI, Santo Domingo, 992.

${ }^{178}$ Información de soltería practicada por Fermín Patricio San Quintín, 12 de abril de 1806. AASD, Dispensa matrimonial I (1801-1811). Licencia dada a Pedro Abadía para pasar a Santo Domingo para emplearse en el ingenio del Marqués de Iranda, que está a nombre de Juan Bautista Oyarzábal, 26 de octubre de 1787. AGI, Santo Domingo, 1099. 
quintales de Azucar blanco y moreno), se arreglara amistosamente el tanto por ciento que se le aia de bonificar o abonar por causa de su administración [...]”179.

En este caso, Juan Bautista de Oyarzábal, primo del Marqués de Iranda fue el que operaba en Santo Domingo para sus asuntos comerciales y administrativos de las propiedades que poseía. De igual manera que en otros negocios familiares de América, el contar con un pariente de total confianza en un lugar distante le aseguró que llevara a cabo una buena gestión. Esta confianza lógicamente estaba probada a lo largo de los años en negocios que Juan Bautista había participado. Es más vivió y se inició desde joven en "su Casa y Compañía”180. Finalmente, cuando muere en 1806 el Marqués le recompensa nombrándole apoderado y segundo testamentario general, así como director de la Casa. De ese modo manifestaba un reconocimiento a la persona que lo había acompañado sin falla durante su carrera. El propio Juan Bautista también se rodeó de personas de confianza, los ya mencionados mayordomos y dependientes, que probablemente conocería en ese tiempo de aprendizaje y, la élite local de Santo Domingo. En particular, sus primeros contactos parece ser que fueron a través del hacendado Felipe Mañón de Lara, quién actuó como intermediario en la compra del ingenio Boca de Nigua y valedor ante los hacendados.

\subsubsection{Relaciones de privilegio con la alta administración y la Corte}

El amparo que garantizaba el hacendado en sus relaciones se debía también en cierta medida a otras conexiones que le servían de apoyo. La protección era generalmente proporcionada a través de los círculos de amistad que el hacendado tenía con la alta administración de Santo Domingo o de España. Entre esas relaciones se encuentran aquellas alianzas que se establecieron con los gobernadores del momento, o con los descendientes de aquellos que habían ocupado ese cargo durante la primera mitad del siglo XVIII, y que en lugar de regresar a la Península acabaron estableciéndose en Santo Domingo. Los

\footnotetext{
${ }^{179}$ Escritura de declaracion, que otorgan el señor Marques de Iranda, y don Juan Bautista de Oyarzabal, 7 de octubre de 1783. AHPM, protocolo $\mathrm{n}^{\circ}$ 21650, fols. 792-793. La cursiva es nuestra.

${ }^{180}$ Ibidem.
} 
hacendados no desaprovecharon la ventaja que les podía proporcionar la posesión de una amistad o un parentesco con esos personajes.

Varios miembros de la red familiar Landeche-Bastidas estuvieron conectados con ellos a través de diversas relaciones. María del Rosario Landeche se había casado con el tesorero Antonio de la Rocha-Ferrer, hermano de Francisco de la Rocha-Ferrer que había sido gobernador durante 1723 y 1731. Un hijo de este matrimonio, Domingo de la Rocha-Ferrer regidor del ayuntamiento, mantuvo una estrecha amistad con el gobernador Manuel Azlor y Urríes. Muestra de ello es la descripción que hacían los ministros de la Audiencia al llamar a Domingo “[...] asesor mercenario del presidente y comensal, comiendo en su mesa todos los días [...]”181. Esta familia y la red Guridi y Alarcón-Coronado estuvieron vinculadas a través de matrimonios con los descendientes del gobernador Ignacio Pérez-Caro (1690-1696) ${ }^{182}$. También mantuvieron una estrecha relación con el gobernador Manuel Azlor y Urríes, quien los había favorecido en la obtención de los empleos de regidores igual que su antecesor Francisco Rubio y Peñaranda.

Los Castro-Rivera y Urdaneta también contaron con este tipo de alianzas, aunque con la peculiaridad de que su conexión con los gobernadores venía dada a través de aquellas personas que formaban parte de la comitiva con la que los gobernadores se trasladaban al lugar donde eran destinados para ejercer su puesto. Éstos se vieron favorecidos al concederles empleos y facilidades para insertarse en las actividades locales. Un hecho que a primera vista podría suponer una amenaza para la élite local, y aunque probablemente se diese en algún momento, estos recién llegados acabaron casándose con hijos de hacendados, como fue el caso de algunos miembros de la red Castro-Rivera y Urdaneta. El hacendado José Esteban Arredondo se casó con Isabel Martínez de Venecia Santelices, hija de Manuel Martínez de Mendoza, quien llegó junto con el gobernador Francisco Rubio y Peñaranda, con el que debía mantener una estrecha amistad incluso antes de su llegada a la isla. Buena muestra de ello es el regalo que tanto él como su mujer, Josefa de Godar, le dieron para su boda, el vestido de novia para la mujer de

\footnotetext{
${ }^{181}$ Carta de la Audiencia de Santo Domingo en la que informa a Su Majestad con testimonio del expediente formado para arreglar el dictamen dado a su presidente sobre el punto de abastos para esta ciudad, 13 de febrero de 1766. AGI, Santo Domingo, 976.

182 También fue gobernador de 1702 a 1706, aunque interinamente tras la muerte de Juan Barranco, en Utrera, F. C. de, Santo Domingo. Dilucidaciones históricas..., op. cit., pp. 446-447. Santa Cruz y Mallén, F. J. de, Historia de familias cubanas..., op. cit., vol. V, pp. 17-20.
} 
Manuel $^{183}$. El hermano de Isabel, Miguel Jerónimo estuvo casado con María Antonia Saviñón Tapia, una rama de la ya citada red Castro-Rivera y Urdaneta. Otro caso es el de Andrés de Lecanda y Andirengoechea, quien había llegado a la isla como paje del gobernador Manuel Azlor y Urríes. Al poco tiempo fue nombrado guardalmacén y después primer factor de la Renta de Tabacos de la ciudad de Santo Domingo ${ }^{184}$. De igual manera Francisco Antonio Velilla y Torres había ascendido de “[...] page a comandante de voluntarios de Santiago, subdelegado de comisos y administrador de tabacos [...]"185.

La distribución que el gobernador realizaba de cargos municipales, militares o en la Real Hacienda constituye un elemento importante del gobierno local, así como en la formación de una clientela. El caso protagonizado por el gobernador Manuel Azlor y Urríes nos sirve para ilustrar, el intercambio de mercedes y servicios propio de toda relación clientelar. Azlor, como hemos señalado, contaba con una importante clientela en la que destacan las tres redes familiares estudiadas. Así fue benefactor y protector de los intereses de los hacendados y el concejo de la ciudad de Santo Domingo a lo largo de su gobierno, representado por miembros de la red Guridi y Alarcón-Coronado y Landeche Bastidas. Tal como queda reflejado en la carta que éste órgano local escribió al Rey, en la que solicita que se le prorrogue por ocho años más por "el buen gobierno acreditado por su particular deseo de fomentarla y restituirla a su antigua ser" dándole el título de "verdadero Padre de la Patria"186. Ante la respuesta favorable del Monarca el gobernador reiteró su deseo de permanecer. La actitud asumida por ambas partes demuestra que la base sobre la que funcionaba esta relación era la reciprocidad y el reconocimiento. En el otro círculo de agraciados se encuentran algunos de los peninsulares mencionados que llegaron con él a la isla, a quienes compensaba y favorecía y a su entorno. Para ello influyó en el

\footnotetext{
${ }^{183}$ Guerrero Cano, M . M., "Un dominicano en el colegio de nobles americanos de Granada. Familia y genealogía de Juan Clemente Martínez Saviñon”..., op. cit., pp. 383-400, p. 391 y 392.

${ }^{184}$ Súplica del permiso y licencia de embarque para salir de Cádiz a Andrés Lecanda, 21 de octubre de 1761. AGI, Santo Domingo, 1011.

${ }^{185}$ Carta de Jose del Monte y Tapia, vecino de Santo Domingo a Su Majestad, 25 de marzo de 1779. AGI, Santo Domingo, 1021.

${ }^{186}$ Carta del cabildo de la ciudad de Santo Domingo en la que interpuso suplica a Su Majestad a fin de que se sirva continuar el gobierno de la isla de Manuel Azlor, 9 de enero de 1767. AGI, Santo Domingo, 944. La cursiva es nuestra.
} 
proceso de ascenso social de la familia política (rama Silvestre-Jiménez) de estos individuos integrados en la red familiar Castro-Rivera y Urdaneta.

Por el contrario, el favorecer a unos u otros miembros de estas familias provocó en alguna ocasión que los capitulares se agruparan en torno a bandos y parcialidades, como el articulado por el regidor José Campuzano Polanco, quien llegó a expresar duras críticas contra el gobierno de Azlor a través de un anónimo pasquín que circulaba por Santo Domingo. Las protestas estaban dirigidas también al comandante de artillería Benito Lisle a quien protegía y relacionaban determinados intereses, expresados en la situación de Santo Domingo durante el año de 1762, en el que los ingleses tomaron La Habana. José Campuzano alegaba que la ciudad de Santo Domingo no había estado abastecida de suficientes víveres y de no haber resguardado la plaza, cuando no fue así como quedó constatado años después en el juicio de residencia del gobernador. En realidad sacaba a la luz el apoyo dado por Azlor a Lisle en la junta de guerra celebrada el 12 de abril de 1762 ante la posiblidad de que los ingleses atacaran la ciudad. El expresado Lisle proponía que en tal caso sería conveniente que la población se retirase con todos los vecinos tierra adentro, mientras que otros como el ingeniero Antonio Álvarez Barba y los del bando Campuzano proponían defender la plaza. Además del motivo expresado José Campuzano tenía el de que había nombrado a Nicolás Guridi Coronado coronel de las milicias de Santo Domingo, cuando él se había ofrecido a tomar su dirección y por eso "no se acomodaba a estar subordinado"187. Como consecuencia de este disturbio Campuzano fue castigado con una multa de 500 pesos, la retirada del cabildo y el destierro a la ciudad de Coro por diez años sin que pudiera regresar sin licencia. Es posible que a pesar de su expulsión permaneciese por lo menos hasta 1768 en Santo Domingo. De hecho para esa fecha colaboró junto con el regidor Antonio Dávila Coca y Landeche en la elaboración de unas ordenanzas para regular la vida de los esclavos. Posteriormente, lo más probable fue que marchara a Coro, pues a partir de esta fecha, no aparece mencionado en la documentación hasta que, hacia 1781, su mujer Rosa Fernández de Lara, solicita permiso para su regreso. Finalmente en 1783 no sólo se le concede sino que fue acreditada su inocencia de las injurias

\footnotetext{
187 Carta del gobernador Manuel Azlor y Urríes a Su Majestad, 30 de septiembre de 1762. AGI, Santo Domingo, 927.
} 
verbales a las que se le había imputado ${ }^{188}$. Estas manifestaciones de malestar se revelan en el contexto de la llegada de un nuevo gobernador que al favorecer a unos u otros produjo este cambio drástico como la expulsión de un miembro de entre la élite local, pero al mismo tiempo permiten medir la estabilidad de ésta en los oficios capitulares ya que Azlor se convirtió en un aliado que gestionó las peticiones de ésta representada en el cabildo de Santo Domingo.

La amistad con un gobernador también ponía en contacto a los hacendados con los oidores. Se retoma así la buena relación existente entre el hacendado Raymundo Esparza y el gobernador Joaquín García Moreno. Probablemente esta amistad se fundamentó en la libertad concedida por el gobernador a Raymundo, a la hora de llevar a cabo sus actividades comerciales y corruptivas en las Cajas Reales. Pero todo esto no podría haberse realizado sin las relaciones de privilegio que mantuvo el gobernador con sus ministros, a quienes a través de “[...] su refinada politica, ha sabido ganarlos, y a proporcion de la anterior reciproca emulacion con que se trataban, es en el dia la mas estrecha union [...]”, prueba de ello es "de lo mucho que les necesita [...]" para que pasaran por alto las gracias y justicias que cedía a Raymundo Esparza y su círculo, así como a otras personas ${ }^{189}$. Una muestra de la amistad que Joaquín García mantenía con los funcionarios de la audiencia es la descripción que sigue realizada por el cabildo en 1792:

“[...] es publico, y notorio que el Vuestro Regente es su mas intimo amigo, y que aquel le saca todas las tardes de paseo en el coche, dandole el lado derecho, algo que los presidentes jamas han practicado. Este Ministro es el juez comisionado en la testamentaria del citado Tesorero Raymundo Esparza. Asimismo los Vuestros oydores Melchor Foncerrada, Don Manuel Bravo y el

188 El "bando de Campuzano" estaba integrado por su cuñado el alcalde de santa hermandad José Fernández de Castro y el alcalde ordinario Tomás de Heredia. También estaban implicados dos oidores de la audiencia Antonio Villaurrutia, y José Gómez Buelta, a quienes igualmente se les impusieron multas. Torres Agudo, R., "Los Campuzano-Polanco, una familia de la élite de la ciudad de Santo Domingo". Nuevo Mundo Mundos Nuevos, $\mathrm{n}^{\circ}$ 7, 2007. Disponible desde Internet en: <http://nuevomundo.revues.org/document3240.html.> [publicación en línea y con acceso el 5 de enero de 2007].

189 Carta del cabildo de la ciudad de Santo Domingo a Su Majestad en la que hacen presentación de los recursos que tienen pendientes contra este presidente, gobernador y capitán general de la isla, Joaquín García, para lo cual acompañan documentos en los que se informa sobre el origen de donde se derivan y otros hechos, 25 de julio de 1792. AGI, Santo Domingo, 997. La cursiva es nuestra. 
Fiscal Don Andres de Alvares, guardan finamente la misma intimidad, especialmente el primero como comisionado que tambien fue de aquella testamentaria, y despues removido. Y en una palabra de los cinco Ministros, que componen este Real acuerdo, solo el Vuestro Decano Don Pedro Catani, se ha separado de esta parcialidad [...]"190.

Entre las numerosas prerrogativas que recibió Raymundo Esparza del gobernador, y otros de sus compañeros como Andrés de Lecanda, destacan licencias para traer víveres y ropa de las colonias extranjeras, así como para extraer ganado a la colonia francesa. Las licencias eran concedidas directamente a ellos o a sus compañeros de negocios, si se daban a éstos entonces los hacendados aparecían como intermediarios. Éstas no eran concedidas gratuitamente, sino que como se refleja en la documentación "se han atrevido a vender”, Joaquín García, y su mujer, Eulalia Jacinta Cadrecha y Amat, quien también aparece implicada en la documentación y a la que se le conocía como “señora presidenta”"191. La forma de pago fue generalmente dinero, pero en otras ocasiones se recibieron regalos, como alhajas, ropa, juegos de café y loza refinada, o en dinero tanto para la mujer del gobernador como para sus hijas.

Bajo este comercio legal no es extraño que esas licencias fuesen aprovechadas además para introducir productos de contrabando. Aquellos que lo hicieron estaban sostenidos por el presidente y su mujer, quienes parece que también participaban, pues colaboraban en el transporte de los productos introduciéndolos en su calesa y guardándolos en su propia casa, "sin ser reconocidos y sin pagar ningun Derecho Real [...]” y otros en "algunas casas del Pueblo de los Isleños $[\ldots]^{192}$. Los productos eran vendidos posteriormente en una tienda de lencería, y otros géneros que poseían en la ciudad de Santo Domingo, y a través de "algunas negras que benden por las calles, los generos de aquel”193. La concesión de estas licencias era algo que ya se había producido con anterioridad. Otros gobernadores como Manuel Azlor y Urríes también lo hicieron. A través de su juicio de residencia, se constata que éste concedió muchas licencias de este tipo

\footnotetext{
190 Ibidem. Hacia 1792 el regente era José Antonio de Urízar y Bolívar. La cursiva es nuestra.

${ }^{191}$ Informe sobre la conducta de los ministros de la Audiencia y la de su presidente, Joaquín García, 22 de mayo de 1785. AGI, Santo Domingo, 1012.

${ }^{192}$ Ibidem. Se refiere a la villa de San Carlos fundada con canarios.

193 Ibidem.
} 
que favorecieron a sujetos de su confianza como Francisco Antonio Velilla, Antonio Rojas y Narciso Subirás ${ }^{194}$.

Dentro de esta red de relaciones también entran en juego aquellas que los hacendados mantenían con las autoridades más cercanas a la Corona, como las que tuvo Raymundo Esparza de quien se dice que “[...] esta sostenido en la corte y de algunos señores del Consejo y Secretaria del Consejo de Indias [...]”"195; entre éstos figuran nombres como los de José Antonio de la Cerda y Soto, Bernardo Iriarte, Ignacio Hermosilla y Sandoval y Pedro Aparici ${ }^{196}$. Raymundo, valiéndose de estas relaciones que proporcionaban capacidad de influencia y actuación consiguió reforzar su posición en Santo Domingo, consiguiendo que prosperaran sus intereses comerciales. Para ello también utilizó a su clientela de Santo Domingo para que se trasladaran a la Corte como agentes y corresponsales para promover sus pretensiones. Este tipo de relación de intermediario de la que se valió Raymundo aparece el hacendado Felipe Guridi y Concha, que había pasado a España "para asuntos propios [...] y para lo del enunciado Esparza, quien libro a favor de aquel dos cartas libranzas que fueron efectivas en esta corte, en la casa de comercio de Drouilhet [...]"197. La implicación de esta firma francesa en el comercio colonial hispano-francés cubrió distintas modalidades: desde los seguros marítimos, la concesión de créditos, pasando por la participación en el tráfico negrero, y el monopolio gaditano entre otros. Todo ello significa que la red relacional de Raymundo tenía también una extensión transoceánica.

Si bien el análisis de estas relaciones evidencia la importancia y eficacia de estas conexiones, además muestran la existencia de otros medios para conseguir

\footnotetext{
${ }^{194}$ Expediente del juicio de residencia del gobernador Manuel Azlor y Urríes, 1771. AHN, Consejos, 21.465.

${ }^{195}$ Informe sobre la conducta de los ministros de la Audiencia y la de su presidente, Joaquín García, 22 de mayo de 1785. AGI, Santo Domingo, 1012.

${ }^{196}$ Estos tres personajes fueron oficiales del Consejo de Indias: José Antonio de la Cerda fue nombrado en 1774, Ignacio Hermosilla en 1785, y Bernardo Iriarte en 1793. Pedro Aparici logró ascender a director de la Real Hacienda para la América septentrional en 1790, y cuatro años más tarde obtuvo el título de oficial honorario. Bernard, G., Le Secrétariat D'Etat et le Conseil Espagnol des Indes (1700-1808). Paris, 1972, pp. 221-224, y 233. Martínez Robles, M., Los oficiales de las Secretarías de la Corte bajo los Austrias y los Borbones, 1517-1812. Madrid, 1987, p. 157. Burkholder, M. A., Biographical Dictionary of Councilors of the Indies, 1717-1808. New York, 1986, pp. 29, 55, y 62.

${ }^{197}$ Informe del regente de la Audiencia de Santo Domingo para entender en la testamentaria de los oficiales de las cajas reales y capital de Raymundo, 18 de enero de 1796. AGI, Santo Domingo, 1044.
} 
los objetivos trazados, según exponía el alguacil ejecutor Félix Guillén en una declaración que había oído una conversación en la que Raymundo recomendaba a Felipe Guridi que: “en Madrid no anduviera con menudencias y que asi, a quellas personas a quienes debiera gratificar, como a lo agentes fiscales de esa. La costumbre era darles quatro o seis doblones, le diera diez o doce para que los asuntos se adelantasen por aquel medio, y que tambien diera dinero a todos los que ocupase”

Un actor importante en la Corte madrileña fue el Marqués de Iranda, quien a través de sus relaciones de amistad con algunos ministros de la Corte madrileña como el Conde de Aranda, Pedro López de Lerena, y José Gálvez, entre otros, logró introducirse en el comercio colonial, y una serie de prerrogativas para poner en funcionamiento el ingenio que había comprado en Santo Domingo ${ }^{199}$. No sólo eso sino que contribuyó a que éstas también fuesen concedidas al resto de los hacendados. Al tiempo también acudió al gobernador Manuel González, para que defendiera sus intereses en la isla y tuviera trato de favor hacia su primo Juan Bautista de Oyarzábal para que le protegiera en cuanto a todo aquello que necesitase $^{200}$.

Si bien fue algo normal que los hacendados se ligaran con estos altos mandatarios y los representantes locales de la Corona, esto no significó que fueran obedientes a la autoridad que éstos tenían. Por el contrario, en algunas ocasiones en la documentación aparecen tildados de desobedientes y presuntuosos, sobre todo en casos puntuales de protocolo de alguna celebración religiosa, cuando se

\footnotetext{
${ }^{198}$ Expediente tramitado en el Consejo de Indias relativo al desfalco producido en las Cajas Reales de la isla de Santo Domingo por los oficiales, Raymundo Esparza, tesorero de Hacienda y Caja Real de Santo Domingo, Francisco Gascue y Olaiz, oficial contador, 1789-1807. AGI, Santo Domingo, 1069.

199 Este personaje también contaba con una amplia parentela dispersa geográficamente por América, Europa y Madrid que ocupaban cargos importantes y lógicamente con conexiones de influencia. Puede destacarse de él que fue miembro del consejo de la Real Hacienda y participó en la Junta Extraordinaria de Comercio de Indias que funcionó entre 1764 y 1765. Fue un influyente banquero, financiero y comerciante de la segunda mitad del siglo XVIII. Véase Álvarez Cuartero, I., "Amigos desde La Habana: confabulaciones de una Sociedad” en Risco, A., y Urkia, J. M. (eds.), I Seminario Peñaflorida "Amistades y sociedades en el siglo XVIII. Real Sociedad Bascongada de los Amigos del País”. San Sebastián, 2000, pp. 185-200. Torres Sánchez, R., "Campomanes y el comerciante y financiero Simón Aragorri” en Mateos Dorado, D. (ed.), Campomanes doscientos años después. Oviedo, 2003, pp. 709-718. Peralta Ruiz, V., Patrones, clientes y amigos. El poder burocrático indiano en la España del siglo XVIII. Madrid, 2006, pp. 149-181.

${ }^{200}$ Julián, A., Bancos, ingenios y esclavos en la época colonial. Santo Domingo, 1997, p. 300.
} 
retraían a cumplir alguna ley relativa a la forma de acceso al cabildo o la Real Cédula de 1754 acerca de la composición de la propiedad de la tierra. Era entonces cuando, aún habiendo alguna rivalidad entre los propios hacendados, se unían para defender sus intereses y reorientar las leyes en beneficio propio, siendo el cabildo el espacio desde donde actuaban.

Figura 4-7. Red Social de Raymundo Esparza entre 1766-1786 


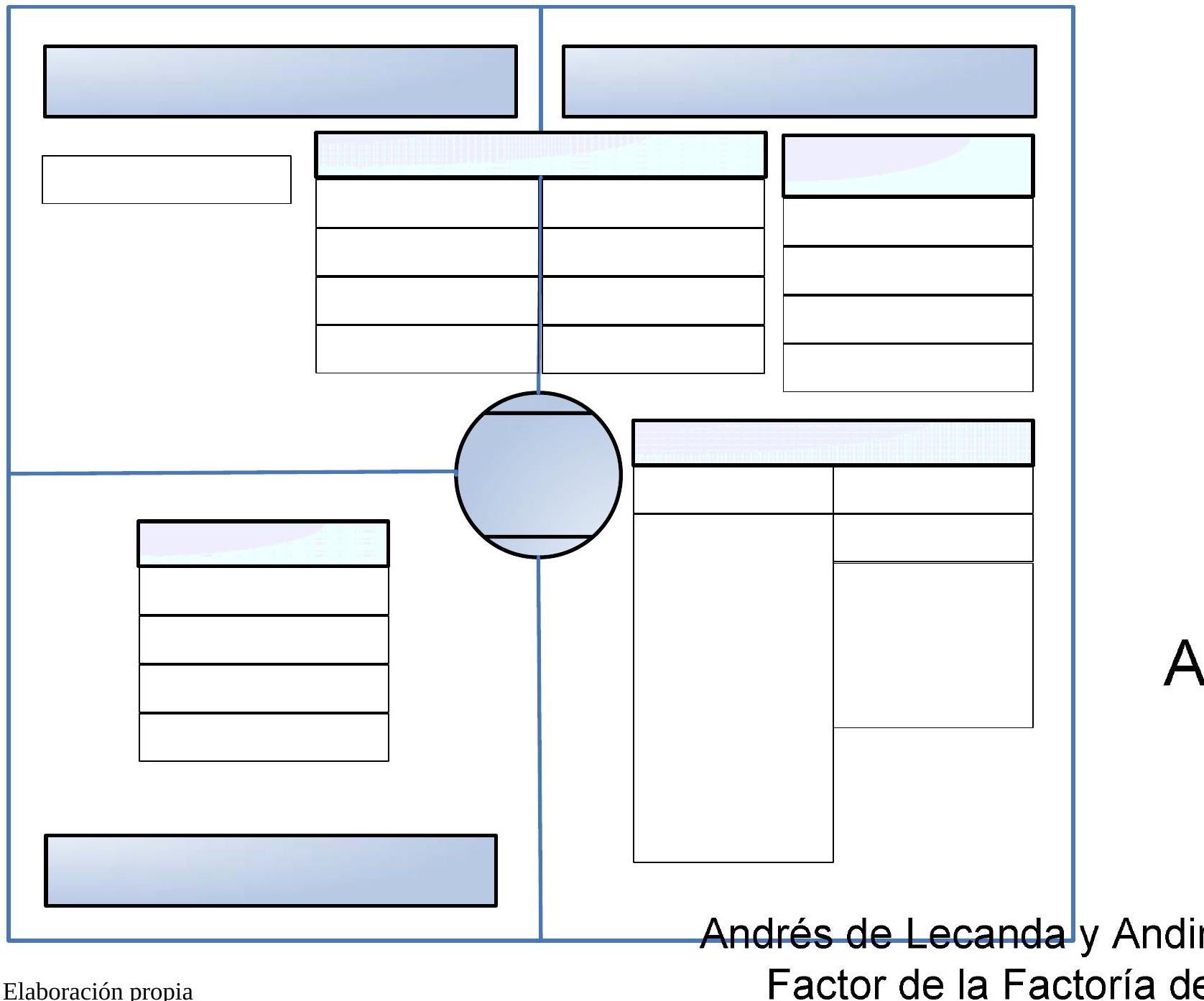


Ruth Torres Agudo

Figura 4-8. Red Social de Simón Aragorri y Olavide

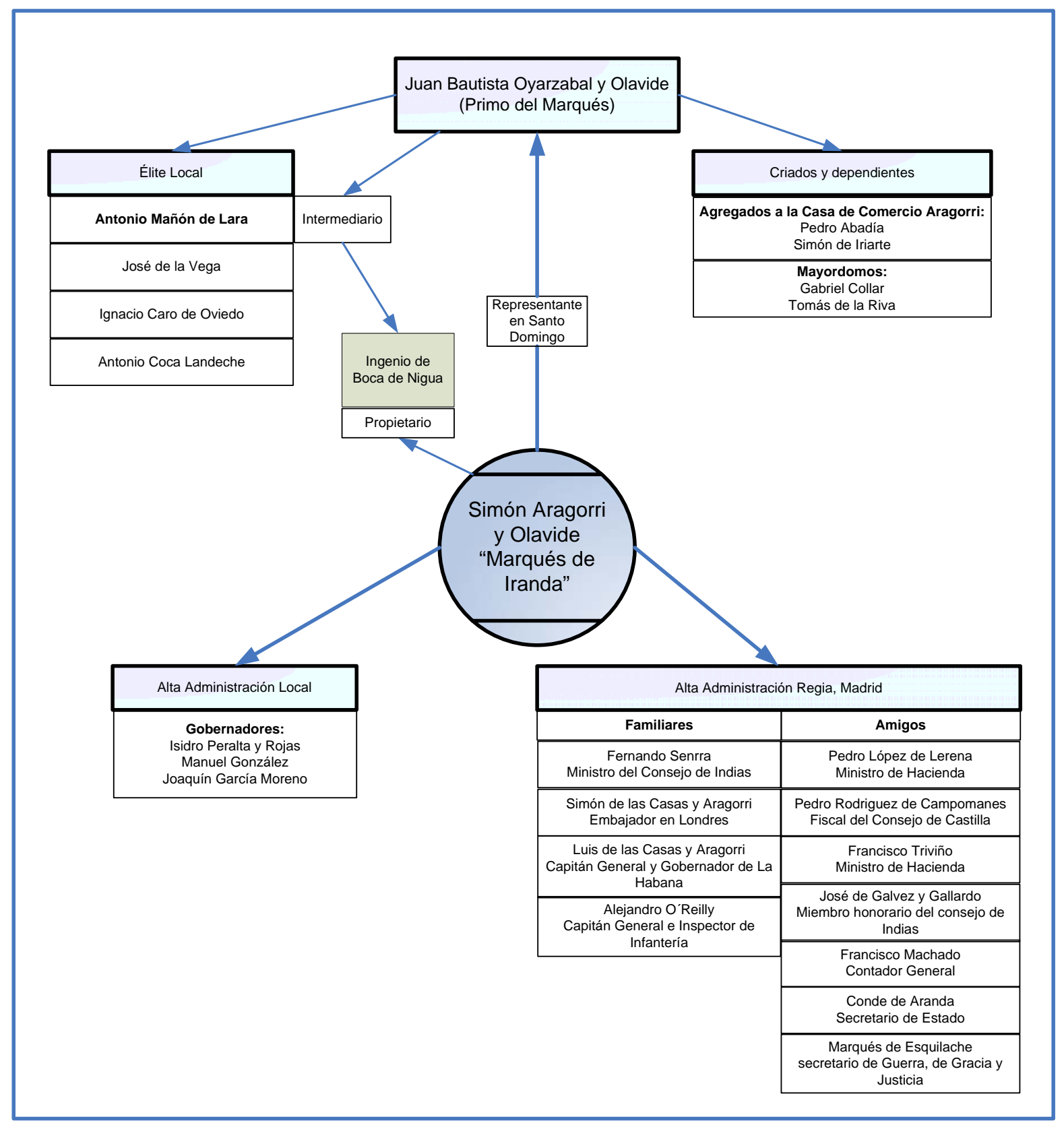

Elaboración propia 


\subsubsection{Actividades profesionales y asociación económica: la Sociedad de} Hacendados

Desde el cabildo los hacendados trataron de solicitar mejoras para la agricultura y adquirir recursos. El contexto internacional de la época, y la política reformista de los Borbones, que estimuló la plantación esclavista, se vio completada con la actitud favorable de los hacendados de Santo Domingo a dar un impulso al fomento del cultivo. Por tanto, los socios en la agricultura eran también aliados políticos, y en 1767 dieron el primer paso reivindicativo al enviar a la Corona una carta en la que planteaban como objetivo principal el fomento de la agricultura. El gobernador Manuel Azlor y Urríes mandó también una representación de apoyo al cabildo, en el que informaba sobre la fertilidad de la tierra de Santo Domingo y la necesidad de importar esclavos y facilidades de precios y pago para los hacendados ${ }^{201}$. La respuesta del Consejo de Indias en 1768, en la que informaba que estudiaría la proposición, animó al cabildo ante la posible entrada de tal contingente humano a elaborar unas ordenanzas para negros, similares a las francesas para su gobierno y reprimir el cimarronaje. Éstas fueron redactadas por dos de sus miembros, los regidores y hacendados Antonio Dávila Coca y Landeche y José Campuzano, quienes lo hicieron en base a las ya existentes en el cabildo, que databan de principios del siglo XVI. Sin embargo, no fueron concluidas ni aprobadas por la Corona, de manera que permanecieron en el olvido hasta que en 1783, bajo mandato real, volvieron a tenerse en cuenta para la elaboración de un código negro ${ }^{202}$.

En 1769 la petición del cabildo fue atendida con una Real Cédula dirigida al gobernador de Santo Domingo, para que creara una Junta que se encargara de

\footnotetext{
${ }^{201}$ Hacia 1767 el cabildo estaba formado por Tomás Leos Echalas y Felipe Guridi Concha como alcaldes ordinarios. Antonio Caro y José del Monte ejercían de alcaldes de Santa Hermandad. Los regidores eran: Antonio Dávila Coca y Landeche, José Guridi Concha, Domingo de la Rocha Bastidas, Agustín Girón, Antonio Caro de Oviedo, Julián Caro, Manuel Heredia, y Nicolás Heredia. A partir de marzo Antonio Mañón de Lara y José del Monte Tapia ocuparon los regimientos de Domingo y Julián. Carta del gobernador, capitán general y presidente de Santo Domingo en la que da cuenta de la representación que le ha hecho el cabildo para que remita a Su Majestad sobre los medios convenientes para su fomento, 18 de enero de 1767. AGI, Santo Domingo, 978.

${ }^{202}$ Al respecto véanse los siguientes trabajos: Malagón Barceló, J., Código Negro Carolino (1784). Código de legislación para el gobierno moral, político y económico de la isla Española. Santo Domingo, 1974, pp. 117-154. Lucena Salmoral, M., Los códigos negros de la América Española. Madrid, 1996, pp. 28-48.
} 
elaborar un informe sobre el estado de la agricultura de la isla y un plan de fomento agrícola de Santo Domingo, con el fin de aumentar las cosechas de azúcar, añil, cacao, algodón y demás productos que produjese ${ }^{203}$. En cambio, no fue hasta 1772, bajo el gobernador José Solano y Bote, cuando se encauzó su constitución, además de intentar mejorar los medios de comunicación y transporte, establecer un comercio regular y proporcionar mano de obra tan necesaria e insuficiente, y por cuya carencia existían quejas desde años atrás.

Este organismo también aparece en la documentación con el nombre de Junta de Agricultura, probablemente debido a que el gobernador José Solano y Bote, conocedor de la naturaleza de los Consulados de Agricultura y Comercio de otras partes del continente americano, consideró que la Junta de Santo Domingo podía emularlas en su dedicación por adelantar no sólo la agricultura sino también el comercio. Para ello puso como ejemplo imitar a la ya adelantada Junta de la parte francesa, compuesta por dos cámaras situadas en los dos puertos principales, Puerto Príncipe y Cabo Francés, cada una de ellas integrada por cuatro hacendados y cuatro comerciantes, encargados de promover en Saint Domingue, y un representante en París ${ }^{204}$.

A principios de octubre de 1772 se celebró la Junta en el cabildo y en ella se solicitó al rey la concesión de una serie de gracias con el objeto de auxiliar y fomentar la agricultura. En el intento de igualarse a la colonia francesa de Saint Domingue, los diputados del cabildo concretaron sus aspiraciones en ocho puntos: permiso para entrar 1.500 esclavos libres de impuestos y posteriormente durante los cinco años siguientes 4.000 esclavos más que serían comprados por cuenta de la Real Hacienda; abolir los derechos que gravaban los productos alimenticios que se exportasen de la isla y los importados de España, así como los instrumentos de labranza, pagando sólo un 3\% de derechos; se les exonerase de los artículos primero y segundo del Reglamento de Comercio libre; reducir el rédito de los censos del 5 al 3\%, y reunir a los vagos y aquellas personas que vivían de la caza

${ }^{203}$ Representación del fiscal del Consejo de Indias sobre el expediente del fomento de la agricultura en la isla de Santo Domingo, 23 de diciembre de 1784. AGI, Santo Domingo, 969.

${ }^{204}$ Expediente formado, sobre que a la Isla Española de Santo Domingo, se conceda el fomento, y auxilios, que necesita para recobrarse de la infeliz situación, a que se halla reducida su población, agricultura, industria y comercio, 23 de diciembre de 1784. AGI, Santo Domingo, 969. Véase también Moreau de Saint-Méry, M. L. E., Descripción de la parte española de Santo Domingo. Ciudad Trujillo, 1944, p. 159. 
atacando a las haciendas en pueblos; quedando todo ello establecido en unas ordenanzas que se harían para la ciudad de Santo Domingo ${ }^{205}$.

Paralelamente la audiencia también preparó un informe que fue realizado por el fiscal Diego Martínez de Araque en el que se “[...] proponia los medios que creia adecuados para restablecer la poblacion y la industria de la isla Española”206. En 1774 ambos informes enviados al Consejo de Indias fueron entregados a uno de sus ministros, José Pablo de Agüero, quien había sido fiscal de la Audiencia de Santo Domingo, y por tanto, como conocedor de la isla podría dar una resolución más adecuada. Sin embargo, su repentina muerte no le permitió ejecutar un dictamen, dejando un escrito incompleto en el que sólo le había dado tiempo ha revisar las peticiones de la Junta pero no el expediente de la audiencia. Antes de tomar una decisión al respecto, la Corona dio una Real Cédula el 22 de octubre de 1779 a la Audiencia de Santo Domingo, para que enviase otro informe actualizado sobre la situación de la agricultura.

La obra que no hemos podido localizar fue mandada a uno de sus oidores, Agustín de Emparán y Orbe, quien tuvo que compaginarlo con otro trabajo que se le había asignado en 1783, la elaboración de un reglamento para el gobierno económico, político y moral de los esclavos al estilo del Código negro francés. Para la realización de dicho código tuvo en cuenta la opinión de “[...] los hacendados de mejor nota y a otros sujetos imparciales e inteligentes en la materia [...]” quienes también participaron en su elaboración ${ }^{207}$. Esta comisión estuvo formada por diez personas, el teniente de rey Joaquín García, y los hacendados Antonio Dávila Coca y Landeche, Antonio Mañón, Ignacio Caro, Francisco Tapia y Castro, Miguel Bernardo Ferrer, Francisco Cabral, José Aponte, Andrés Heredia y Melgar, y el deán José Núñez de Cáceres, algunos de ellos miembros de las tres

\footnotetext{
${ }^{205}$ En 1772 el cabildo estaba compuesto por los alcaldes ordinarios Pedro Fernández de Castro y Nicolás Heredia, y los de Santa Hermandad José de Leos Echalas y José Garay. Las personas que ejercían como regidores eran: José Guridi Concha, Pedro Fernández de Castro, Antonio Caro y Oviedo, Manuel Heredia, José del Monte y Tapia, Antonio Mañón de Lara, Miguel Bernardo Antonio Ferrer, Nicolás Heredia, Francisco Cabral, Antonio Valdemoro, Mateo Firpo, y Antonio Dávila Coca y Landeche como alférez real. Carta del cabildo y del gobernador, José Solano y Bote, informando a la Corte de las decisiones tomadas en la Junta de Auxilio y Fomento de la Española, 8 de octubre de 1772. AGI, Santo Domingo, 969. Testimonio de los autos generales del Real despacho y diligencia en su virtud obrada. Vino con carta del oidor de Santo Domingo, Joseph Osorio, de 22 de abril de 1779. AHN, Consejos, 20766.

${ }^{206}$ Expediente formado, sobre que a la Isla Española de Santo Domingo, se conceda el fomento, y auxilios, que necesita para recobrarse de la infeliz situación, a que se halla reducida su población, agricultura, industria y comercio, 23 de diciembre de 1784. AGI, Santo Domingo, 969.

${ }^{207}$ Lucena Salmoral, M., Los códigos negros..., op. cit., p. 63.
} 
redes familiares estudiadas ${ }^{208}$. Agustín de Emparán y Orbe también se sirvió para la elaboración del código de las ordenanzas existentes en los archivos del cabildo, donde se encontraban las formadas en 1528, 1535, 1542, 1544, y las de 1768. A esto hay que añadir los conocimientos que tenía de Derecho y Leyes sobre la esclavitud, como el Código negro francés. En 1785 tanto el Código negro como el informe sobre la agricultura fueron mandados al Consejo de Indias para su aprobación $^{209}$. Sin embargo, los trabajos permanecieron sin ser ratificados ni consultados, hasta que en 1788 el Código negro fue solicitado por el ministro Antonio Porlier, a quien el monarca había ordenado la formación de un código parecido pero con un carácter general para todas las Indias. Un año más tarde, a través de una Real Cédula de 1789 se mandaba el cumplimiento de unas Instrucciones sobre la educación, trato y ocupación de los esclavos de todos los dominios de Indias e islas Filipinas ${ }^{210}$. Los trabajos de Agustín de Emparán sirvieron de base para dictar la citada cédula, aunque ésta no llegó aplicarse por la oposición de los hacendados de Cuba, Caracas, Puerto Rico, Luisiana, Quito, Nuevo reino de Granada e incluso los de Santo Domingo, que lograron suspenderla $^{211}$.

Mientras el Consejo de Indias y sus ministros deliberaban sobre las reivindicaciones formuladas a través de la Junta, al hacendado Juan Bautista Oyarzábal y Olavide, un vasco que había comprado hacia 1781 el ingenio Boca de Nigua muy cerca de la capital, se le daba en 1783 permiso a sus peticiones realizadas ese mismo año. Entre las gracias que le fueron concedidas: la introducción de 400 esclavos y utensilios como calderas, pailas, cilindros o moledores, estufas, barretones de hornillas, azadas, hachas y otros de las colonias extranjeras libres de todos impuestos, pudiendo incluso vender o ceder a otros, sin tener que pagar los derechos correspondientes, así como la exención del diezmo durante diez años ${ }^{212}$. Para la consecución de esos beneficios perseguidos por

\footnotetext{
${ }^{208}$ Malagón Barceló, J., Código Negro Carolino (1784)..., op. cit., pp. 88-113.

${ }^{209}$ Lucena Salmoral, M., Los códigos negros..., op. cit., pp. 63-64.

${ }^{210}$ Ibidem., pp. 279-284.

${ }^{211}$ Ibidem., pp. 89-94 y 95-123. Malagón Barceló, J., Código Negro Carolino (1784)..., op. cit., pp. LXIX-LX. Véase también Deive, C. E., Los guerrilleros negros. Esclavos fugitivos y cimarrones en Santo Domingo. Santo Domingo, 1997, p. 245. Leal, I., "La aristocracia criolla venezolana y el código negro de 1789”. Boletín de la Academia Nacional de la Historia 336 (Caracas, 2001) pp. 27-47.

${ }^{212}$ Carta del gobernador Isidro Peralta y Rojas con fecha de 21 de abril de 1784, en la que participa estar enterado de la Real Orden de 23 de diciembre de 1783 en la que se ha concedido
} 
Oyarzábal fue necesario contar con la confirmación del Consejo de Indias, quien consideró tener encuenta el criterio de la Contaduría y del fiscal. La receptividad para el otorgamiento de las referidas gracias fue posible a que Oyarzábal contaba con el apoyo de un personaje clave en la Corte madrileña, su primo el Marqués de Iranda, quien además de ser uno de los banqueros más poderosos, emparentaba con figuras relevantes y poseía aliados en las altas instancias gubernativas como la Contaduría. Así la opinión del contador general Francisco Machado y el ministro José Gálvez del Consejo de Indias pudo influir en el dictamen final. Sin embargo, hacia 1788 Oyarzábal se quejaba de que tan sólo había podido adquirir sesenta esclavos a través del Guarico debido a que el número de embarcaciones que proveía de esclavos era escaso. Nuevamente Oyarzábal dirigió al rey una súplica para que pudiera proveerse comerciando directamente con los ingleses, dispensa que le fue otorgada en ese mismo año ${ }^{213}$.

A raíz de las concesiones mencionadas, en junio de 1784 José de la Vega, dueño del ingenio Manoguayabo, e Ignacio Caro de Oviedo, del de Cumba, solicitaron las mismas libertades que habían sido concedidas a Juan Bautista Oyarzábal. Así se les permitió introducir a cada uno 200 esclavos de las colonias extranjeras, 40 fondos de pailas, 4 juegos de molinos completos y 500 azadas $^{214}$. Un mes después, Antonio Dávila Coca y Landeche y Antonio Mañón de Lara, también solicitaron la libertad de derechos en la introducción de utensilios, y 400 esclavos, concediéndosela igualmente ${ }^{215}$. Tras estas concesiones particulares, las siguientes que se dieron afectaron por igual a toda la población de la isla, aunque

las gracias a Juan Bautista Oyarzábal para fomentar su ingenio de azúcar en aquella isla. AGI, Santo Domingo, 946 y 1012.

${ }^{213}$ Los sesenta esclavos habían sido introducidos en Santo Domingo el 13 de agosto de 1785 a través de una licencia concedida por el gobernador Manuel González a Francisco Robaina. También se trajeron "herrajes y utensilios" para el ingenio. Ibidem., Certificaciones del escribano de Real Hacienda, de registro y de esta ciudad de los barcos registrados desde el 9 de julio que existian fondeados en este puerto, 24 de agosto de 1785. AGI, Santo Domingo, 947. Informes solicitando auxilios para un ingenio de azucar administrado por Juan de Oyarzabal, 1783. AGI, Santo Domingo, 930. Carta de Juan Bautista de Oyarzabal a Su Majestad, 25 de febrero de 1788. Y, Real Cédula ampliando el permiso de compra a los ingleses, Aranjuez 21 de junio de 1788. AGI, Indiferente General, 2821. Julián, A., Bancos, ingenios y esclavos..., op. cit., pp. 280-303.

${ }^{214}$ Carta del gobernador Isidro Peralta y Rojas con fecha de 21 de junio de 1784 apoyando una instancia de dos propietarios de ingenios y resolución de la misma, San Lorenzo 30 de octubre de 1784. AGI, Santo Domingo, 1012.

${ }^{215}$ Carta de Antonio Dávila Coca, regidor y alférez real de Santo Domingo, y el capitán Antonio Mañón de Lara, regidor también, en la que solicitan que por lo proveído con Juan Bautista Oyarzábal se les conceda la libertad de derechos en la conducción e instrucción de aquella isla de las máquinas y utensilios necesarios para los ingenios de azúcar, 9 de julio de 1784. AGI, Santo Domingo, 928. 
el que se beneficio especialmente fue el sector de los hacendados, quienes a través de la Real Cédula de 12 de abril de 1786 vieron como lo que habían reivindicado a través de la Junta de Agricultura era concedido en exclusividad para Santo Domingo. Además se incluía otros privilegios que les eximían del pago de los derechos de aguardiente de caña y el diezmo durante diez años ${ }^{216}$.

El cabildo adelantándose a la Real Cédula mencionada dictó una serie de ordenanzas en las que se establecía: una división de la ciudad de Santo Domingo en cuatro cuarteles, reducción de los negros libres al poblado de San Lorenzo de las Minas, normas para la cría de ganado y el abasto público, y dando una especial protección a la agricultura ante las quejas que causaban los ganados a los labradores en sus tierras ${ }^{217}$. De ahí se estableció que no hubiera “[...] cría de ganado en tierras de labor, ni labores en tierras de crianza”, pudiendo matar aquellos animales que se introdujeran en las propiedades o reclamarle al dueño los perjuicios ocasionados ${ }^{218}$. Sin embargo, ésta medida no fue del agrado del Consejo de Indias, quien ordenó a la audiencia que las ordenanzas debían regirse por lo prevenido en la cédula de 12 de abril de 1786 en la que se hacía hincapié sobre la agricultura, aunque con la previsión de no "perder de vista” la cría de ganados $^{219}$.

El protagonismo que tuvieron los hacendados en la elaboración de la Junta hace que pueda hablarse de un cuerpo de hacendados, asociados por unos intereses que se reflejan desde 1767, y que fueron gestionadas en la ya mencionada Junta de Agricultura de 1772. Esto nos permite presumir que fue en ella donde se gestionó la Cámara o Sociedad de Hacendados, aunque no es hasta el 16 de abril de 1793, cuando se constata oficialmente la asociación a través de una reunión celebrada en esa fecha. El motivo por el que se formó fue una serie de levantamientos de esclavos que se estaban dando en sus plantaciones. Probablemente estuvieron influenciados por la rebelión de esclavos de 1791 en la

\footnotetext{
${ }^{216}$ Real Cédula de Su Majestad, a consulta de su supremo Consejo de Indias, por la cual se conceden varias gracias, y prerrogativas en beneficio de todos los vecinos de la Isla Española de Santo Domingo, para el fomento de su Agricultura, Industria y Comercio, Madrid 12 de abril de 1786. AGI, Santo Domingo, 1012.

${ }^{217}$ Las ordenanzas fueron elaboradas el 25 de febrero de 1786. Documentación del Archivo Real de Higüey, “Ordenanzas del Cabildo de Santo Domingo, 1786”. BAGN 46-47 (Ciudad Trujillo, 1946) pp. 157-172.

${ }^{218}$ Ibidem., pp. 165-166.

${ }^{219}$ Sevilla Soler, M . R., Santo Domingo. Tierra de frontera (1750-1789). Sevilla, 1980, p. 127.
} 
parte francesa, que generó un ambiente de intranquilidad y agitación en Santo Domingo. Esto obligó a los hacendados a establecer tres cuadrillas para vigilar las zonas de Los Llanos y las riberas de los ríos Haina y Ozama, con el objeto de colaborar en "la captura y exterminio de las personas mal entretenidas [...]” y así lograr “[...] aquel reposo con que siempre se ha mantenido esta ciudad, y toda su jurisdiccion [...]”220. Las cuadrillas estuvieron formadas por ocho hombres y un cabo cada una. Éstas fueron subvencionadas por los propios hacendados, quienes crearon una caja con un fondo necesario para cubrir los gastos ${ }^{221}$. Se eligieron a dos administradores, uno de ellos fue Andrés de Lecanda, quien como tesorero de la caja debería llevar las cuentas en un libro. Mientras que José de la Vega fue electo contador revisor, siendo su misión la de registrar las cuentas y dar visto bueno o anotar los reparos. Como se podrá ver más adelante, ambos contaban con amplia experiencia, pues habían ejercido el empleo de factores de tabacos.

En este documento aparece por primera vez elaborada una lista de las personas que constituían la sociedad para esa fecha y su directiva, entre los que se encuentra algunos de los hacendados estudiados (véase tabla 4-4). Aunque hay que tener en cuenta que ésta había emergido años atrás mediante una red de sociabilidad, en la que además de las relaciones familiares y de amistad, se mantuvieron de manera conjunta acciones para reactivar no sólo la agricultura sino también el comercio, actuando como una especie de Consulado de Agricultura y Comercio, a pesar de que la Corona en su Real Cédula de 1786 apuntaba “[...] he tenido a bien reservarme el establecimiento de un Consulado de Agricultura, y Comercio [...]”,222.

\footnotetext{
${ }^{220}$ Testimonio del expediente en que consta la Junta y Sociedad celebrada por los hacendados de la ciudad de Santo Domingo, con el fin de redimirse de las atrocidades y excesos que se experimentan en Santo Domingo, 16 de abril de 1793. AGS, SGU, 7157.

${ }^{221}$ Tanto las cuadrillas como la caja fueron creadas conforme al capítulo treinta y siete del Código negro que había elaborado Agustín Emparán y Orbe, y el cúal había sido tomado de las ordenanzas de 1768. Cada cabo recibiría de jornal quince pesos, mientras que los cuadrilleros ocho, cantidades inferiores frente a lo que dictaba el capítulo mencionado del Código negro que establecía como salario del jefe veinte pesos y el de cada cuadrillero diez, además de la gratificación que éstos podían llevar de ocho a diez pesos por cada cimarrón capturado. La regulación del Código también variaba respecto del de la Junta al número de cuadrilleros que mandaba que estuviese compuesta por nueve hombres. Ibidem., y Lucena Salmoral, M., Los códigos negros..., op. cit., pp. 84-85.

${ }^{222}$ Real Cédula de Su Magestad, a consulta de su supremo Consejo de Indias, por la qual se conceden varias gracias, y prerrogativas en beneficio de todos los vecinos de la Isla Española de Santo Domingo, para el fomento de su Agricultura, Industria y Comercio, Madrid 12 de abril de 1786. AGI, Santo Domingo, 1012.
} 
Para ello, como élite ilustrada, debieron desarrollar actividades basadas en el estudio, la discusión y el debate. La documentación muestra que esas reuniones fueron celebradas en el cabildo de la ciudad de Santo Domingo, y probablemente en lugares de sociabilidad informales, difíciles de reconstruir puesto que las fuentes no han dejado rastro directo sino sólo alguna alusión a que se llevaran a cabo en espacios como algunas casas de estos hacendados. Además también participaron como colaboradores en la elaboración de informes centrados alrededor de cuestiones económicas y sociales, como el realizado por el oidor Agustín Emparán y Orbe. Su trabajo y la obra del clérigo Antonio Sánchez Valverde, publicada en 1785, debieron de servir de apoyo y respaldo a los hacendados en la emisión de Reales Cédulas que garantizasen las transformaciones agrarias que solicitaban ${ }^{223}$. El papel que jugaron estos dos personajes como agentes de la innovación agrícola en Santo Domingo requeriría un estudio específico.

A todo esto habría que añadir su intervención como miembros de la Real Sociedad Bascongada de Amigos del País, lo que constituye otra manifestación de su sociabilidad. De hecho en el capítulo veintisiete del Código negro de Agustín Emparán y Orbe, se proponía como complemento para el impulso agrícola fundar una Sociedad Patriótica de Amigos del País a imagen de la Bascongada, la cual sería asumida por la Junta de Agricultura y estaría dirigida por el presidente de la Audiencia y sus ministros como socios beneméritos. Esta Sociedad se encargaría de la instrucción agrícola de los hacendados, informándoles acerca de los terrenos, las plantaciones, la maquinaria y los medios más convenientes que facilitaran el trabajo agrícola. Además comunicaría cuál era el momento adecuado para el derribo del monte y roza de la tierra ${ }^{224}$. No sabemos si finalmente ésta llegó a erigirse, ya que no hemos encontrado documentación alguna que nos constate de su existencia. Sin embargo, hacia 1784 aparecen como socios no sólo todos los miembros que componían para ese año la Audiencia, sino también algunos hacendados que habían participado en la Junta de Agricultura y en la elaboración del Código negro, así como otros inmigrantes peninsulares que habían llegado por

\footnotetext{
${ }^{223}$ Sánchez Valverde, A., Idea del valor de la Isla Española y utilidades que de ella puede sacar su monarquía. Santo Domingo, 1988 (1785). Antonio Sánchez Valverde se preocupó también de introducirse en el círculo de los ilustrados al ingresar en la Sociedad Económica Matritense.

${ }^{224}$ Lucena Salmoral, M., Los códigos negros..., op. cit., p. 81.
} 
esa época y que se dedicaban igualmente a la agricultura y los negocios mercantiles, como muestra la tabla 4-5. La admisión de todos ellos como miembros de esa Sociedad debió estar influenciada probablemente por el propio Agustín Emparán y Orbe, quien era miembro desde 1783, y pertenecía a una importante familia de Azpeitia, los “Emparanes”, que mantenían una buena amistad con el Conde de Peñaflorida, fundador de la Bascongada ${ }^{225}$. Aunque el Código negro que realizó Agustín Emparán no fue aprobado por la Corona, parece que algunos de sus puntos fueron puestos en práctica por los hacendados de Santo Domingo. Además les sirvió para dar el último empujón para reactivar y mejorar la agricultura que había sido perfilada desde el cabildo.

${ }^{225}$ Tellechea Idígoras, I. J., La ilustración vasca: Cartas de Xavier María de Munibe, Conde de PeñaFlorida a Pedro Jacinto de Álava. Vitoria, 1987, pp. 301-304, 474-475, 656, y 740. 
Tabla 4-4. Sociedad de Hacendados, 16 de abril de 1793

\begin{tabular}{|l|l|}
\hline \multicolumn{1}{|c|}{ Oficios } & \multicolumn{1}{c|}{ Nombres } \\
\hline Regente & José Antonio de Urízar \\
\hline $1^{\circ}$ Alcalde & Pedro Arredondo y Castro \\
\hline $2^{\circ}$ Alcalde & Agustín Más y Rubí \\
\hline \multirow{5}{*}{ Regidores } & Francisco Cabral y Maldonado \\
& Gregorio Saviñón \\
& Francisco Tapia y Castro \\
& Luís de Tapia \\
& Luís Franco Guridi \\
& Miguel Jerónimo Martínez de Venecia \\
& Santelices \\
& José del Monte \\
& Silvestre Ramírez Guridi \\
\hline Directores & Nicolás Guridi y Frómesta \\
& Juan Bautista Oyarzábaly Olavide \\
& José de Castro \\
& Francisco Tapia y Castro \\
& Félix Guillén \\
& Andrés de Lecanda y Andirengoechea \\
\hline & Nicolás Guridi y Frómesta \\
& Miguel Bernardo Ferrer \\
& Adrián Campuzano \\
& José de la Vega \\
& José Tiburcio Sterling \\
& Pedro de Castro \\
& Andrés de Lecanda y Andirengoechea \\
& Nicolás de Mota \\
& Félix Guillén \\
& Juan Bautista Oyarzábal y Olavide \\
& Antonio Cumulat \\
& Manuel Sarmiento \\
& Fernando Heredia \\
& Domingo de Castro \\
& Casimiro Bello \\
& Gregorio Núñez \\
& Miguel Pérez \\
& José Sánchez \\
& José Fermín Ximénez \\
\hline & \\
\hline &
\end{tabular}

Elaboración propia. Fuentes: Testimonio del expediente en que consta la Junta y Sociedad celebrada por los hacendados de la ciudad de Santo Domingo, con el fin de redimirse de las atrocidades y excesos que se experimentan en Santo Domingo, 16 de abril de 1793. AGS, SGU, 7157. La cursiva es nuestra. 
Tabla 4-5. Socios de la Real Sociedad Bascongada de los Amigos del País en Santo Domingo, 1784-1793

\begin{tabular}{|c|c|c|c|c|}
\hline Nombre & Oficios & Tipo de socio & Cargo RSBAP & Origen \\
\hline $\begin{array}{l}\text { Isidro Peralta y } \\
\text { Rojas }\end{array}$ & $\begin{array}{l}\text { Gobernador, } \\
\text { presidente y } \\
\text { capitán }\end{array}$ & $\begin{array}{l}\text { Benemérito } \\
(1784-1787)\end{array}$ & & $\mathrm{P}$ \\
\hline Luís Chaves & $\begin{array}{l}\text { Oidor de la } \\
\text { Audiencia }\end{array}$ & $\begin{array}{l}\text { Benemérito } \\
\text { (1784-1787) }\end{array}$ & & $\mathrm{P}$ \\
\hline $\begin{array}{l}\text { Agustín Emparán y } \\
\text { Orbe }\end{array}$ & $\begin{array}{l}\text { Oidor de la } \\
\text { Audiencia }\end{array}$ & $\begin{array}{l}\text { Benemérito y } \\
\text { Mérito (1783- } \\
1785 \text { y 1787- } \\
1793)\end{array}$ & $\begin{array}{l}\text { Comisionado } \\
\text { (1783 y 1786) y } \\
\text { Vice-recaudador } \\
(1786)\end{array}$ & $\mathrm{P}$ \\
\hline Manuel Bravo & $\begin{array}{l}\text { Oidor de la } \\
\text { Audiencia } \\
\end{array}$ & $\begin{array}{l}\text { Benemérito } \\
(1784-1793)\end{array}$ & & $\mathrm{P}$ \\
\hline $\begin{array}{l}\text { Ramón Jover y } \\
\text { Ferrandiz }\end{array}$ & $\begin{array}{l}\text { Oidor de la } \\
\text { Audiencia }\end{array}$ & $\begin{array}{l}\text { Benemérito } \\
(1784-1785) \\
\end{array}$ & & $\mathrm{P}$ \\
\hline Miguel Irisarri & $\begin{array}{l}\text { Fiscal de la } \\
\text { Audiencia } \\
\end{array}$ & $\begin{array}{l}\text { Benemérito } \\
\text { (1784-1793) }\end{array}$ & & $\mathrm{P}$ \\
\hline $\begin{array}{l}\text { Melchor José de } \\
\text { Foncerrada y } \\
\text { Ulivarri }\end{array}$ & \begin{tabular}{|l} 
Oidor y \\
Fiscal de la \\
Audiencia \\
\end{tabular} & $\begin{array}{l}\text { Benemérito } \\
(1788-1793)\end{array}$ & & $\mathrm{P}$ \\
\hline Raymundo Esparza & $\begin{array}{l}\text { Oficial real } \\
\text { de las Cajas } \\
\text { Reales }\end{array}$ & $\begin{array}{l}\text { Benemérito } \\
\text { (1784-1786) }\end{array}$ & & $\mathrm{P}$ \\
\hline $\begin{array}{l}\text { Francisco de Paula } \\
\text { Gazcue y Olaiz }\end{array}$ & $\begin{array}{l}\text { Oficial real } \\
\text { de las Cajas } \\
\text { Reales } \\
\end{array}$ & $\begin{array}{l}\text { Benemérito } \\
(1784-1791)\end{array}$ & & $\mathrm{P}$ \\
\hline $\begin{array}{l}\text { Francisco Javier } \\
\text { Gamboa }\end{array}$ & $\begin{array}{l}\text { Regente de la } \\
\text { Audiencia }\end{array}$ & $\begin{array}{l}\text { Benemérito } \\
(1781-1787) \\
\text { Mérito (1787- } \\
1788)\end{array}$ & & $\mathrm{P}$ \\
\hline $\begin{array}{l}\text { José Núñez de } \\
\text { Cáceres }\end{array}$ & $\begin{array}{l}\text { Deán y } \\
\text { arzobispo de } \\
\text { la catedral }\end{array}$ & $\begin{array}{l}\text { Benemérito } \\
(1784-1788) \\
\text { Mérito (1788- } \\
1789)\end{array}$ & $\begin{array}{l}\text { Comisionado y } \\
\text { Vice-recaudador } \\
(1788-1789)\end{array}$ & $\mathrm{C}$ \\
\hline $\begin{array}{l}\text { Ignacio Pérez-Caro } \\
\text { de Oviedo }\end{array}$ & Coronel & $\begin{array}{l}\text { Benemérito } \\
\text { (1784-1793) }\end{array}$ & & $\mathrm{C}$ \\
\hline $\begin{array}{l}\text { Antonio Dávila } \\
\text { Coca y Landeche }\end{array}$ & $\begin{array}{l}\text { Alférez real } \\
\text { del cabildo }\end{array}$ & $\begin{array}{l}\text { Benemérito } \\
(1784-1789)\end{array}$ & & $\mathrm{C}$ \\
\hline $\begin{array}{l}\text { Joaquín García } \\
\text { Moreno }\end{array}$ & $\begin{array}{l}\text { Gobernador, } \\
\text { presidente y } \\
\text { capitán } \\
\end{array}$ & $\begin{array}{l}\text { Benemérito } \\
\text { (1784-1793) }\end{array}$ & & $\mathrm{P}$ \\
\hline $\begin{array}{l}\text { Andrés de Lecanda } \\
\text { y Andirengoechea }\end{array}$ & \begin{tabular}{|l|}
$\begin{array}{l}\text { Factor de } \\
\text { tabacos }\end{array}$ \\
\end{tabular} & $\begin{array}{l}\text { Benemérito } \\
(1784-1793)\end{array}$ & & $\mathrm{P}$ \\
\hline $\begin{array}{l}\text { Juan Bautista } \\
\text { Oyarzábal y } \\
\text { Olavide }\end{array}$ & & $\begin{array}{l}\text { Benemérito y } \\
\text { Mérito (1784- } \\
1793)\end{array}$ & $\begin{array}{l}\text { Comisionado y } \\
\text { Vice-recaudador } \\
\text { (1788-1793) }\end{array}$ & $\mathrm{P}$ \\
\hline $\begin{array}{l}\text { Antonio Mañón de } \\
\text { Lara }\end{array}$ & $\begin{array}{l}\text { Capitán y } \\
\text { regidor }\end{array}$ & $\begin{array}{l}\text { Benemérito } \\
\text { (1784-1793) }\end{array}$ & & $\mathrm{C}$ \\
\hline
\end{tabular}


Ruth Torres Agudo

\begin{tabular}{|l|l|l|l|l|}
\hline \multicolumn{1}{|c|}{ Nombre } & \multicolumn{1}{|c|}{ Oficios } & Tipo de socio & Cargo RSBAP & Origen \\
\hline $\begin{array}{l}\text { Nicolás Guridi y } \\
\text { Frómesta }\end{array}$ & $\begin{array}{l}\text { Alguacil } \\
\text { mayor de la } \\
\text { Audiencia }\end{array}$ & $\begin{array}{l}\text { Benemérito } \\
(1784-1793)\end{array}$ & C \\
\hline $\begin{array}{l}\text { Pedro Fernández } \\
\text { de Castro }\end{array}$ & Regidor & $\begin{array}{l}\text { Benemérito } \\
(1784-1793)\end{array}$ & & C \\
\hline Mateo Pérez & $\begin{array}{l}\text { Teniente } \\
\text { coronel }\end{array}$ & $\begin{array}{l}\text { Benemérito } \\
(1784-1793)\end{array}$ & & $\mathrm{C}$ \\
\hline José de la Vega & $\begin{array}{l}\text { Factor de } \\
\text { tabacos }\end{array}$ & $\begin{array}{l}\text { Benemérito } \\
(1784-1793)\end{array}$ & & $\mathrm{P}$ \\
\hline Antonio Cumulat & $\begin{array}{l}\text { Factor de la } \\
\text { RCCB }\end{array}$ & $\begin{array}{l}\text { Benemérito } \\
1784-1793)\end{array}$ & & $\mathrm{P}$ \\
\hline
\end{tabular}

Elaboración propia. Fuentes: P (Peninsular) C (Criollo). Martínez Ruiz, J., Catálogo General de individuos de la R.S.B. de los Amigos del País (1765-1793). San Sebastián, 1985, vol. XII, pp. 36, 39, 41-42, 44, 49, 51, 53-56, 65, 67, 70, 75, 85, 90, 92, y 111; "Sección Primera. Resumen de actas de la Sociedad Bascongada de los Amigos del País, En sus juntas celebradas en Vergara por julio de 1788” en Extractos de las Juntas Generales celebradas por la Real Sociedad Bascongada de los Amigos del País (1786-1788). San Sebastián, 1985, vol. IX, p. 10; Tellechea Idígoras, I. J., La ilustración vasca..., op. cit., pp. 784-785. Polanco Brito, H. E., "Los cabildos eclesiásticos de Santo Domingo y La Vega, los deanes”..., op. cit., pp. 121-142, p. 138. 


\section{CAPÍTULO 5 LA TRANSMISIÓN DE BIENES}

El estudio del modo en que los hacendados transmitían los bienes a sus descendientes permite conocer cómo mantuvieron su posición social y el patrimonio. Su continuismo y reproducción social no sólo dependieron de los matrimonios y en consecuencia de las alianzas que éstos podían realizar, sino también de los mecanismos que utilizaron para traspasar sus bienes. En Santo Domingo, entre los hacendados estudiados, hemos encontrado dos formas de transmitir su patrimonio: una realizada en vida en la que destacan la dote y la compra-venta; y otra que se daba al fallecer éstos a través del sistema de herencia y las donaciones, que también podían hacerse entre vivos.

\subsection{La dote}

La dote fue un medio por el que las mujeres recibían una aportación económica en el momento del enlace. Este mecanismo sirvió para aportar una ayuda al nuevo matrimonio, para satisfacer las necesidades de la futura familia, y también podía aumentar un poco más el capital de un patrimonio mayor. La dote tenía otras funciones, como la de proporcionar protección a la mujer en caso de disolución matrimonial, viudez, abandono o mal uso de los bienes conyugales por parte del marido. Sólo en caso de quedar viudo y sin hijos que pudiesen heredar, el marido pasaba a apropiarse de los bienes dotales. Además la dote fue un importante indicador del nivel económico disfrutado por los miembros de la élite ${ }^{1}$.

\footnotetext{
${ }^{1}$ Entre la amplia bibliografía que trata el tema de la dote destaca: Ots Capdequí, J. Ma ., Historia del Derecho Español en América y del Derecho Indiano. Madrid, 1969, pp. 54-56. Socolow, S., Los mercaderes del Buenos Aires Virreinal: familia y comercio. Buenos Aires, 1991, pp. 54-57. Fernández Pérez, P., El rostro familiar de la metrópoli. Redes de parentesco y lazos mercantiles en Cádiz. Madrid, 1997, pp. 251-257. López Beltrán, C., Alianzas familiares. Élite, género y negocios en La Paz, siglo XVII. Lima, 1998, pp. 167-204. Santos Pérez, J. M., Élites, poder local y régimen colonial. El cabildo y los regidores de Santiago de Guatemala, 1700-1787. Cádiz, 1999, pp. 147-
} 
En las Indias, desde el punto de vista jurídico, se distinguían dos tipos de dote: la necesaria y la voluntaria. La primera se daba cuando era exigida al padre o a algún familiar que bien podía ser un abuelo, un tío o un individuo que se lo hubiese prometido ${ }^{2}$. Se trataba en definitiva de un adelanto de la legítima herencia que correspondía a la hija, siendo descontada en el momento del reparto del patrimonio. Mientras que la segunda era la dote otorgada por cualquier pariente de manera espontánea, aunque generalmente fue concedida con el objeto de completar la dote necesaria, o para que una novia sin los medios requeridos pudiera casarse ${ }^{3}$.

En la sociedad colonial la dote se convirtió en una obligación a la hora de realizar un contrato matrimonial, en especial entre las familias dominantes, que solían hacerlo por escrito y ante notario para dejar constancia legal del hecho. Este acto notarial se presentaba a través de los recibos y cartas dotales. Por tradición y ley, la dote era entregada por los padres, parientes, tutores o donadores al futuro marido antes de la ceremonia religiosa, o bien una vez efectuado el matrimonio. En ese documento aparecía con mayor o menor detalle la cuantía de los bienes dotales, sus variedades, así como el nombre de la persona que efectuaba de la entrega. Estos bienes aunque pertenecían a la mujer, eran consignados en el marido en el momento de realizarse el documento notarial, mediante el cual pasaban a ser administrados por él obteniendo su usufructo.

Las cantidades entregadas supusieron un desembolso de los bienes de la familia de la novia. Ahora bien, este gasto también significaba una inversión, sobre todo cuando el marido entraba en los negocios de su suegro y se dedicaba a generar beneficios, que posteriormente aumentaban la empresa familiar y que a la larga se convertirían en bienes gananciales. En la documentación se advierte que cuando estos bienes eran cedidos a un hijo la pareja hablaba de "nuestros bienes",

152. Turiso Sebastián, J., Comerciantes españoles en la Lima Borbónica. Anatomía de una elite de poder (1701-1761). Lima, 2002, pp. 144-149.

${ }^{2}$ Ots Capdequí, J. Mª., Historia del Derecho Español..., op. cit., pp. 54-55.

${ }^{3}$ Esto debió suceder con la dote que tenía Felicita Garay y Maldonado de 20.000 reales, la cuál no era suficiente para contraer matrimonio y fue ayudada por su tío, Gaspar Maldonado y LeosEchalas, quien la llegó aumentar en 40.000 reales más. La dote final fue de 60.000 reales, afianzada dicha cantidad con la estancia de Capotillo, situada en "la sierra que divide y forma parte de la guarda raya con la colonia francesa”. Con esta dote Felicita se desposó con el subteniente del Batallón Fijo Juan Vicente Salazar y Valenzuela. Escritura de dote de Felicita Garay y Maldonado para su matrimonio con Juan Vicente Salazar, subteniente del Batallón Fijo, 26 de febrero de 1789. AGI, Santo Domingo, 948. 
lo que afirma que los bienes gananciales pertenecían al marido y a la mujer ${ }^{4}$. En otros casos el patrimonio se vio aumentado al casarse dentro de su propio círculo, bajo el patrón endogámico.

Pero al mismo tiempo la dote fue un instrumento de sometimiento para la autoridad paterna, como queda reflejado en el caso de Antonio Angulo CocaLandeche, que al casarse con María de los Ángeles Heredia Campuzano pasó a vivir bajo el techo de su suegro Nicolás Heredia Serrano Pimentel. Y además se convirtió en el administrador de numerosas propiedades que su suegro tenía, como la hacienda de cacao Palavé y cuatro hatos: Árbol Gordo, Madrigal, Reparadero y La Cruz. Tal era la dependencia, que tras la cesión de la parte española a los franceses y estando en La Habana tras su emigración a esta isla, Antonio Angulo comentó encontrarse en situación crítica debido al abandono de los bienes que poseía su familia en Santo Domingo y a que “[...] su suegro no le puede dispensar las ayudas que antes le hacia [...]"

Otro de los aspectos interesantes que hay que tener en cuenta es la composición de los bienes dotales. Entre las dotes que hemos localizado de algunos hacendados de Santo Domingo, éstas estuvieron compuestas por un reducido capital monetario si se comparan con las de otros lugares como Guatemala, Perú o Bolivia, donde las dotes fueron bastante altas ${ }^{6}$. En Santo Domingo su valor osciló entre 2.500 o 3.000 pesos, como se puede observar en la tabla que sigue, en la que hay una excepción cuyo valor fluctuó entre 13.000 y 14.000 pesos.

Como se observa en la tabla las cantidades de dinero recibidas en concepto de dote fueron cuatro y de ellas dos llevaban además otros enseres como ropa de vestir, muebles y alhajas. Mientras que las diez restantes eran el equivalente de los

\footnotetext{
${ }^{4}$ Testimonio del expediente promovido por Ana Osorio, reclamando los bienes embargados a su marido Manuel Del Monte, los dotales de ella y los gananciales durante su consorcio, 1811. AGI, Santo Domingo, 961.

${ }^{5}$ Instancia de Antonio Angulo, relativa a solicitar de Su Majestad que le conceda los honores de oficial real con opción a ser colocado en la primera plaza vacante, a fin de que Su Majestad sirva ponerle en conocimiento, 27 de enero de 1815. AGI, Santo Domingo, 964.

${ }^{6}$ La dote en Guatemala ascendía entre 2.500 y 15.000 pesos, siendo la mayor la que llevó Ana María Carrillo a su matrimonio con Juan Fermín Aycinena, cuya cantidad fue de 178.000 pesos. En Lima osciló entre 6.000 y 200.000 pesos, mientras que en La Paz entre 1.000 y 5.000 pesos, y las más privilegiadas entre 15.000 y 20.000 pesos. Véase las obras de Santos Pérez, J. M., Élites, poder local y régimen colonial..., op. cit., pp. 150-152 y 332-334. Turiso Sebastián, J., Comerciantes españoles en la Lima Borbónica..., op. cit., p. 146. López Beltrán, C., Alianzas familiares..., op. cit., p. 193.
} 
bienes que cedían las familias de hacendados a sus hijas, los cuales se encontraban afianzados sobre haciendas, hatos y sus utensilios así como sobre residencias en la ciudad. Sólo hay tres casos en los que se desconoce el tipo de bienes que compusieron las dotes, debido a que la documentación no proporciona más información, aunque probablemente fueron haciendas y hatos. En consecuencia, la dote de estas familias de hacendados estuvo compuesta de bienes inmuebles, en los que había desde las ya citadas estancias y hatos, con sus esclavos, ganado, herramientas y muebles, o casas hasta alhajas y plata labrada; estos bienes fueron menos frecuentes que la transferencia de tierra. Un caso que representaría una excepción entre las dotes estudiadas fue la copiosa dote de alhajas que recibió Ana Osorio y Pérez-Caro, entre las que destacan un rosario y un relicario de oro que le donó su madrina Isabel Frómesta. Y por parte de su madre, una cadena de oro, una sortija con nueve diamantes, unos pendientes también con diamantes, un dedal de oro, una hebilla de oro y dijes de pañuelo, además de muebles destacando sillas, mesitas, una cama con su armadura y herraje, dos espejos, colchones y ropa para la casa ${ }^{7}$.

\footnotetext{
${ }^{7}$ Escritura de dote de Ana de Osorio, 10 de julio de 1783. AGI, Santo Domingo, 961.
} 
Tabla 5-1. Composición y valor de algunas dotes

\begin{tabular}{|c|c|c|c|}
\hline Novio & Novia & Composición & Dote \\
\hline $\begin{array}{l}\text { José de la } \\
\text { Vega }\end{array}$ & $\begin{array}{l}\text { María Teresa } \\
\text { Jover Aznar }\end{array}$ & Dinero & 2.500 \\
\hline $\begin{array}{l}\text { Esteban } \\
\text { Fernández } \\
\text { Palomares }\end{array}$ & $\begin{array}{l}\text { María Petronila } \\
\text { Mañón de Lara }\end{array}$ & $\begin{array}{l}\text { Hato Chacuey (tierras, pastos y } \\
\text { abreviadores con } 200 \text { reses vacunas, } 15 \\
\text { bestias caballares y un mayoral) }\end{array}$ & 2.500 \\
\hline \begin{tabular}{|l|} 
Pedro Roig de \\
Lluís
\end{tabular} & \begin{tabular}{|l|} 
Juana Saviñón y \\
Tapia
\end{tabular} & $\begin{array}{l}\text { Hatillo Casamancebo (tierras y } 50 \text { reses) } \\
\text { y dos casas altas y bajas }\end{array}$ & 2.500 \\
\hline \begin{tabular}{l|} 
Nicolás Leos- \\
Echalas \\
Heredia
\end{tabular} & \begin{tabular}{|l|} 
Josefa María \\
Fernández de \\
Castro Guridi \\
\end{tabular} & Ingenio Santa Lucía Camba & 3.000 \\
\hline $\begin{array}{l}\text { Rodrigo } \\
\text { Macedonio de } \\
\text { la Rocha }\end{array}$ & $\begin{array}{l}\text { Petronila } \\
\text { Angulo }\end{array}$ & Dinero & 3.000 \\
\hline $\begin{array}{l}\text { Francisco } \\
\text { Mieses Ponce } \\
\text { de León }\end{array}$ & \begin{tabular}{|l} 
Francisca Luisa \\
Pérez-Caro y \\
Fernández de \\
Oviedo \\
\end{tabular} & Dinero, ropa de vestir y alhajas & 3.000 \\
\hline $\begin{array}{l}\text { María } \\
\text { Petronila } \\
\text { Coca- } \\
\text { Landeche }\end{array}$ & $\begin{array}{l}\text { Francisco Pepín } \\
\text { González }\end{array}$ & $\begin{array}{l}\text { Ingenio Engombe ( } 9 \text { caballerías de tierra, } \\
\text { capilla, casa habitación y de trabajo, } \\
\text { herramientas, bestias mulares y } \\
\text { caballares, y esclavos) }\end{array}$ & $\dot{¿} ?$ \\
\hline $\begin{array}{l}\text { Ana Coca- } \\
\text { Landeche }\end{array}$ & \begin{tabular}{|l|} 
Francisco \\
Martínez \\
\end{tabular} & Idem & $\dot{¿} ?$ \\
\hline $\begin{array}{l}\text { Martín José } \\
\text { Miura }\end{array}$ & \begin{tabular}{|l|} 
Josefa Pepín \\
González
\end{tabular} & $\begin{array}{l}\text { Estancia Cañaboba (1 caballería de tierra } \\
\text { con peones y aperos) }\end{array}$ & 2.500 \\
\hline $\begin{array}{l}\text { Manuel del } \\
\text { Monte Cabral } \\
\end{array}$ & $\begin{array}{l}\text { Ana Osorio y } \\
\text { Pérez-Caro } \\
\end{array}$ & Dinero, alhajas, y muebles & 2.200 \\
\hline $\begin{array}{l}\text { Francisco } \\
\text { Espaillat y } \\
\text { Virol } \\
\end{array}$ & $\begin{array}{l}\text { Catalina } \\
\text { Tabarez Zapata }\end{array}$ & "Varios bienes" & 600 \\
\hline $\begin{array}{l}\text { Francisco } \\
\text { Espaillat y } \\
\text { Virol } \\
\end{array}$ & $\begin{array}{l}\text { Petronila Velilla } \\
\text { Sánchez }\end{array}$ & "Bienes apreciables" & 7.000 \\
\hline José Arata & $\begin{array}{l}\text { Micaela Sterling } \\
\text { del Monte }\end{array}$ & 4 casas & 2.500 \\
\hline Antonio Rojas & \begin{tabular}{|l|} 
María de la \\
Concepción \\
Ferrer Castro- \\
Rivero \\
\end{tabular} & $\dot{i} ?$ & $\begin{array}{c}13.000 \\
/ \\
14.000\end{array}$ \\
\hline
\end{tabular}

Elaboración propia. Fuentes: ¿ ? (desconocido). Las cantidades están expresadas en pesos. AGI, Santo Domingo, 946, 948, 949, 960, 961, 1037, 1038. Testamento de Francisco Mieses Ponce de León, 28 de junio de 1758. AChV, Pleitos civiles, La Puerta Olvidados 1378. "Escritura de dote de Josefa Pepín González, 17 de enero de 1775” en Rodríguez Demorizi, E., Milicias de Santo Domingo (1786-1821). Santo Domingo, 1978, pp. 377-381. García Lluberes, L., "Miscelánea histórica. (Extractos de los Cuadernos de Apuntes del Historiador García). El ingenio Santa Ana de Engonve”. CLÍO 102 (Ciudad Trujillo, 1955) pp. 39-44. Campillo Pérez, J. G., Francisco Espaillat y el desarrollo del Cibao. Santo Domingo, 1985, pp. 150-151. 
En las escrituras de dote no siempre se describió al detalle su contenido, así los esclavos aparecen individualizados por sus nombres, y rara vez su procedencia, que es más habitual en los inventarios de haciendas o hatos. De igual forma el ganado se halla categorizado según la especie a la que pertenecían los animales. En el caso de Santo Domingo no hemos encontrado la inclusión de oficios públicos o vestimenta, bienes presentes en mayor medida en lugares como México, Guatemala o Perú ${ }^{8}$. Sin embargo, aparecen ajuar, vestidos y joyas como regalos de bodas, que aún siendo éstos notorios no tuvieron el mismo significado que la dote. Entre los obsequios que los hacendados se hacían, pueden servir de ejemplo los que recibió Josefa Pueyo y Urríes los días inmediatos a la celebración de su boda con Francisco de Paula Gazcue y Olaiz: alhajas de oro de la mujer del gobernador José Solano y Bote, y del hacendado y comerciante Antonio Rojas una frasquerita con frascos de cristal, varias piezas de plata sobre dorado y una pirámide de cristal para un reloj de sobremesa. En otras ocasiones, los regalos se recibían en los bautismos de los hijos como recibieron algunos de Josefa por parte de Felipa Pérez-Caro y Oviedo ${ }^{9}$.

La transferencia de propiedades a través de la dote fue un medio por el que los inmigrantes pudieron incorporarse a la actividad familiar, y apuntalar el patrimonio hasta convertirse en hacendado, para rescatar las deudas del negocio de su suegro que podían estar pendientes o para extender sus actividades; aunque estos dos últimos aspectos fueron más frecuente entre el grupo de los comerciantes de La Paz, Lima o Buenos Aires. ${ }^{10}$ Para el caso de los emigrantes peninsulares que llegaron a Santo Domingo la dote fue más bien un respaldo para poner a punto la nueva casa en la que iba a vivir, pero sobre todo significó el

\footnotetext{
${ }^{8}$ Santos Pérez, J. M., Élites, poder local y régimen colonial..., op. cit., p. 151. Turiso Sebastián, J., Comerciantes españoles en la Lima Borbónica..., op. cit., p. 149. Sólo hemos encontrado un caso, el de Francisca Luisa Pérez-Caro quien además de aportar 3.000 pesos llevaba ropa de vestir y algunas alhajas, aunque la documentación no da más detalles. Testamento de Francisco Mieses Ponce de León, 28 de junio de 1758. AChV, Pleitos civiles, La Puerta Olvidados 1378.

${ }^{9}$ La mujer del gobernador José Solano y Bote se llamaba Rafaela Ortiz de Rojas, tanto él como ella eran de Zorita, Cáceres. Felipa Pérez-Caro y Oviedo estaba casada con el bilbaíno José Antonio Zárraga. Testimonio de las diligencias practicadas por Francisca Pueyo sobre que se le entreguen los usufructos de la hacienda embargada al contador Francisco Gazcue para alimentos de los hijos de éste. AGI, Santo Domingo, 997.

${ }^{10}$ La dote en el ámbito de los comerciantes sirvió para incrementar sus capitales, agilizar sus transacciones, ampliar sus actividades, e invertirlo en comercio o en un préstamo comercial, o como carta que certificase liquidez económica en sus negocios financieros. Véase en López Beltrán, C., Alianzas familiares..., op. cit., p. 173. Turiso Sebastián, J., Comerciantes españoles en la Lima Borbónica..., op. cit., p. 147. Socolow, S., Los mercaderes del Buenos Aires Virreinal..., op. cit., pp. 55-57.
} 
acceso a la propiedad rural, la integración en el círculo de los hacendados y por tanto el convertirse en uno de ellos.

Para ilustrar este hecho se presentan cuatro casos que sirven como ejemplo de las tres redes familiares de hacendados estudiadas. Todos ellos tienen en común la asignación de la dote sobre una propiedad rústica y que las personas con las que se casan estas hijas de hacendados son peninsulares que llegaron a Santo Domingo como militares. Así, una de las hijas de Gregorio Saviñón y de Micaela Antonia de Tapia, miembros de la red Castro-Rivera y Urdaneta, llamada Juana Saviñón al contraer matrimonio con el alférez del cuerpo de ingenieros Pedro Roig de Lluís, llevó como dote 2.500 pesos asignados sobre el hatillo Casamancebo y dos casas cercanas al ayuntamiento de Santo Domingo ${ }^{11}$. De la misma forma para uno de los enlaces familiares con los que contaba la red Guridi, el matrimonio entre María Petronila Mañón de Lara y el alférez del Batallón Fijo Esteban Fernández Palomares, se recibió en calidad de dote el hato Chacuey, situado en la jurisdicción de Santo Domingo y valorado en 3.000 pesos $^{12}$.

En la red familiar de los Landeche-Bastidas, otro militar, el subteniente del Batallón Fijo de la plaza Martín José de Miura, al casarse con Josefa Pepín González recibió como dote 2.500 pesos designados en la estancia Cañaboba, fundada en una caballería de tierra y compuesta por “[...] una arboleda de cacao, y otros frutos con suficiente número de peones, tierras, y aperos para su cultivo y labor [...]”13. En este caso el hermano de Josefa Pepín González, Francisco, renunció al derecho de posesión y dominio por el que le pertenecía parte de esa propiedad en beneficio de su hermana para que no pereciera la dote ${ }^{14}$. Este hecho muestra como el querer mantener un patrimonio íntegramente pudo llevar a utilizar la dote como un mecanismo que privilegiara a uno de los hijos, para que la

\footnotetext{
${ }^{11}$ Carta del gobernador de Santo Domingo, Isidro Peralta y Rojas, en la que informa que Pedro Roig de Lluís, ayudante de ingenieros de aquella plaza solicita licencia para contraer matrimonio con Juana Saviñón y Tapia, así como la documentación relativa a la calidad y dote, 13 de mayo de 1782. AGI, Santo Domingo, 946.

${ }^{12}$ María Petronila Mañón de Lara tenía un sobrino José Antonio Peralta Mañón que se casó con María Altagracia Heredia Mieses Guridi. Carta del gobernador de Santo Domingo, Isidro Peralta y Rojas, en la que dirige instancia de Esteban Fernández Palomares, subteniente del Batallón Fijo de esta plaza en la que pide licencia a Su Majestad para contraer matrimonio con María Petronila Mañón de Lara, y en la que acompaña los documentos de su calidad y dote como previenen las reales ordenanzas, 24 de septiembre de 1783. AGI, Santo Domingo, 946.

13 “Escritura de dote de Josefa Pepín González, 17 de enero de 1775” en Rodríguez Demorizi, E., Milicias de Santo Domingo..., op. cit., pp. 377-381, p. 378.

14 Idem.
} 
propiedad no se dividiera ${ }^{15}$. Es interesante resaltar que la madre de Josefa y Francisco Pepín González, María Petronila Coca y Landeche y su hermana Ana habían recibido como “bienes dotales hereditarios” uno de los ingenios más importantes del siglo XVIII, Santa Ana de Engombe, cuyo valor según un “inventario extrajudicial” realizado en 1762 ascendía a 20.610 pesos y 6 reales ${ }^{16}$. Aunque no se tiene constancia del valor que tuvo en el momento de la entrega, probablemente debió ser una jugosa dote y una de las de mayor volumen de propiedad agrícola recibida. Asimismo, para sus respectivos esposos, el oficial de la Real Hacienda Francisco Pepín González y el regidor Francisco Martínez, fue una aportación importante para acceder a la propiedad de la tierra y al grupo de hacendados.

Estos ejemplos indican que las dotes constituyeron en algunos casos el soporte económico de estos matrimonios. Igualmente destacan el carácter desigual en cuanto al nivel económico entre la pareja, pues los bienes de sus esposas fueron más importantes que los de sus maridos. No obstante, hay que subrayar que si para los peninsulares fue una buena inversión también lo fue para la familia de la mujer criolla, pues la dote supuso un instrumento de sometimiento a la autoridad paternal. Aceptar a estos inmigrantes como yernos sin una buena posición económica convertía a éstos en personas dependientes, y por tanto en fieles a la familia de su mujer; más aún cuando no contaban con ningún pariente instalado en Santo Domingo. De esta manera también se conseguía que el patrimonio de bienes no se dispersara, y al mismo tiempo permitía a los peninsulares trabajar y administrar las propiedades del suegro, las cuales serían luego transmitidas a sus hijos.

Sin embargo, también hubo peninsulares que a la hora de casarse contaron con un amplio capital. Esta contribución que el hombre hacía se conocía como arras, y responde a la contribución recíproca de la décima parte del capital que hace el esposo a la mujer. Aunque este dato es interesante para conocer cuál era el patrimonio que poseía el novio antes de casarse, no hemos hallado en la documentación datos al respecto, por lo que quizás su importancia en Santo

\footnotetext{
15 Aunque las leyes hereditarias castellanas mandaban repartir equitativamente el patrimonio entre los hijos, la dote y las mejoras dependían de la voluntad paterna. Ots Capdequí, J. Ma ., Historia del Derecho Español..., op. cit., p. 63.

${ }^{16}$ García Lluberes, L., "Miscelánea histórica”..., op. cit., pp. 39-44.
} 
Domingo debió ser menor que en otras partes del continente americano. Aún así a través de otras fuentes se puede constatar aproximadamente el monto de sus bienes. De hecho, hay dos casos, el de un peninsular y un francés, que cuando subieron al altar ya contaban con una amplia fortuna. José de la Vega, al casarse en segundas nupcias con María Teresa Jover, poseía ya una casa en la ciudad de Santo Domingo, y varias haciendas entre ellas, una estancia Guaximía y un hatillo unidos al ingenio de azúcar nombrado Mata Naranjo. También Francisco Espaillat, desposado primeramente con Catalina Tabarez, tenía una amplia fortuna rústica compuesta por numerosas haciendas y hatos valorados en 8.000 pesos. En su segundo matrimonio celebrado el 24 de julio de 1780 con Peronila Velilla, aportó unos 200.000 pesos. El patrimonio había aumentado al ampliarlo mediante la compra de terrenos, y en parte a la herencia de su primera esposa ${ }^{17}$.

En los casos de matrimonio celebrado entre criollos, la situación económica fue generalmente más igualitaria, lo que permitió que el patrimonio engrosara y fuese aún más importante. Así lo muestra el casamiento realizado entre los hijos de las familias de hacendados con las hijas de éstos, y entre propios familiares. Tendencia que siguieron casi todos los miembros de las familias registradas en el capítulo anterior.

\subsection{La compra-venta de bienes}

Un segundo tipo de transferencia de los bienes que llevaron a cabo los hacendados fue la compra-venta de bienes rurales entre familiares. Este sistema no conllevaba la partición de un terreno sino su mantenimiento y transmisión mediante las ventas realizadas entre parientes: hermanos, cuñados, padres-hijos, yernos-suegros, tíos-sobrinos, etc. Este comportamiento también se dio en el resto de países hispanoamericanos durante la época colonial, como por ejemplo en Perú y Argentina, donde parece que fue bastante común ${ }^{18}$.

\footnotetext{
${ }^{17}$ Carta de esponsales entre José de la Vega y María Teresa Jover, 15 de marzo de 788. AGI, Santo Domingo, 948. Campillo Pérez, J. G., Francisco Espaillat..., op. cit., pp. 20-22 y 150-151.

18 Sobre este punto véase la siguiente bibliografía: Ramírez, S., Patriarcas provinciales. La tenencia de la tierra y la economía del poder en el Perú colonial. Madrid, 1991, p. 150. Saguier, E., El mercado inmobiliario rural y su incidencia en la estructura social rioplatense. Buenos Aires, 1993, pp. 35-37. Canedo, M., “Tierra sin gente y gente con tierra. La dinámica del acceso y de la transferencia de la tierra en una zona de colonización temprana de la Campaña de Buenos Aires. (Los Arroyos, 1600-1850)” en Zeberio, B., Bjerg, Mª, y Otero, H. (comps.), Reproducción
} 
Este tipo de transmisiones se dieron frecuentemente en los alrededores de la ciudad de Santo Domingo y en la zona de Bayaguana ${ }^{19}$. En lo que respecta a las familias de hacendados estudiadas, existen dos casos que lo ejemplifican. Uno es el de la ya citada familia Landeche-Bastidas poseedora del ingenio Engombe. Sus dueños en 1762 eran María Petronila Coca Landeche con su marido Francisco Pepín González, y su hermana Ana Coca Landeche viuda de Francisco Martínez. Todos ellos en "mancomún", ante la posibilidad de que el ingenio que habían recibido como bien dotal pudiese fragmentarse si se dividía entre sus herederos, decidieron venderla en ese mismo año "por sí y por el todo insolidum” a su hermana Josefa Coca Landeche y su marido el teniente de milicias y coronel Lorenzo Angulo y Medrano ${ }^{20}$. En realidad lo que se hizo en 1762 fue la escritura de venta, ya que dos años antes se había realizado "la entrega y posesión que tomó del citado ingenio, y no se había formado la presente por la confianza en que como hermanos hemos vivido [...]"21. Se trataba de una estrategia mediante la cual el ingenio de moler se traspasó y mantuvo indiviso en la propia familia, sin generar una dispersión del terreno heredado a principios del siglo XVIII. Así en 1796 tras la muerte de su marido, Josefa Coca Landeche aparece como única propietaria y su hijo Andrés Angulo Coca-Landeche como su administrador, quien trató de venderlo o alquilarlo al verse obligados a emigrar de Santo Domingo ante la cesión de la isla a los franceses ${ }^{22}$.

social y sistemas de herencia en una perspectiva comparada. Europa y los países nuevos (siglos XVIII al XX). Tandil, 1998, pp. 83-119.

${ }^{19}$ Gutiérrez Escudero, A., Población y economía en Santo Domingo (1700-1746). Sevilla, 1985, p. 141. Para la región del Cibao durante el siglo XIX véase la obra de San Miguel, P., Los campesinos del Cibao. Economía de mercado y transformación agraria en la República Dominicana 1880-1960. Puerto Rico, 1997, p. 229.

${ }^{20}$ El término jurídico mancomún se utiliza en "aquellos actos y contratos" en los que existen varias personas "ligados unitariamente, o en común" como muestra el ejemplo. La expresión insolidum o in solidum se refiere a la solidaridad, es decir, al "cumplimiento de determinadas obligaciones que corresponden a varias personas y puede a cada una de ellas reclamarsele por entero". En este contrato de compra-venta las leyes de la mancomunidad aluden a que las tres personas que venden el ingenio concurren solidariamente para proteger a Josefa Coca Landeche, renunciando a todas las leyes de indivisiblidad, omisión y todos se obligan para responder ante los posibles defectos que pudiera tener el ingenio. García Lluberes, L., "Miscelánea histórica”..., op. cit., pp. 39-44, p. 39. Gómez de Liaño y González, F., Diccionario jurídico. Oviedo, 1991, pp. 117,168 y 142.

${ }^{21}$ García Lluberes, L., Ibidem., p. 40.

${ }^{22}$ Carta de Andrés Angulo en la que solicita gracia a Su Majestad para permanecer por tres años en Santo Domingo para efectuar la venta o arrendamiento de un ingenio que administraba de su madre, 3 de junio de 1796. AGI, Estado 5B, N75. 
El otro caso es el del hacendado Francisco Espaillat y Virol, quien a finales del siglo XVIII compró a su suegro José Tadeo Zevallos un ingenio que le costó 15.000 pesos $^{23}$.

\subsection{La herencia}

En Santo Domingo también coexistieron junto a la dote otros patrones de comportamiento que los hacendados utilizaron a la hora de transmitir sus bienes, la sucesión testamentaria. En América, y por tanto en Santo Domingo, el derecho castellano a través de las Leyes de Toro de 1505 fueron las que regularon, entre otras cosas, las normas a seguir en el reparto de la herencia y las partes en que debía dividirse. Esta legislación no determinaba una única práctica sucesoria, sino que dejaba abierta la posibilidad de transmitir a través de distintas formas, desde la gran parte del patrimonio a un único heredero, la mejora del tercio y el quinto de libre disposición, hasta la realización de una división igualitaria del patrimonio entre todos los herederos ${ }^{24}$. Los testamentos estudiados muestran que en Santo Domingo la práctica común fue la división igualitaria del patrimonio entre los hijos, bien fueran varones o mujeres. Sin embargo, esto no significa que no existieran casos en los que se mejorara la herencia a alguno de los herederos favoritos, o bien que fuese un solo hijo el que recibiese la mayor parte de la fortuna familiar.

Hubo casos en los que no se realizó testamento. Se trata de las sucesiones del tipo $a b$ intestato o intestado, es decir, no existe un testamento escrito. Esta situación la ilustra Ramón Jover Ferrandiz, oidor y alcalde del crimen de la Audiencia de Santo Domingo, ya que murió sin haber elaborado su testamento. Ramón Jover, falleció en el Hospicio de los padres de Belén en Cuba en 1785, donde estaba hospedado. Se encontraba en dicha isla porque había sido

\footnotetext{
${ }^{23}$ Campillo Pérez, J. G., Francisco Espailltat..., op. cit., pp. 21 y 128. Deive, C. E., La esclavitud del negro en Santo Domingo (1492-1844). Santo Domingo, 1980, vol. II, p. 619.

${ }^{24}$ Entre algunas obras que tratan el aspecto jurídico del sistema hereditario español e indiano destacan: Casey, J., y Hernández Franco, J. (eds.), Familia, Parentesco y Linaje. Siglos XV-XIX. Murcia, 1997. García Fernández, M., Herencia y patrimonio familiar en la Castilla del Antiguo Régimen (1650-1840): efectos socioeconómicos de la muerte y la partición de bienes. Valladolid, 1995. Dérouet, B., y Goy, J., "Transmitir la tierra. Las inflexiones de una problemática de la diferencia” en Zeberio, B., Bjerg, $\mathrm{M}^{\mathrm{a}}$., y Otero, H. (comps.), Reproducción social..., op. cit., pp. 15-50. Ots Capdequí, J. Mª., Historia del Derecho Español..., op. cit., pp. 60-65 y 67-70. Vega Boyrie, W., Historia del derecho colonial dominicano. Santo Domingo, 1979, pp. 97-98.
} 
comisionado para hacer cumplir ciertos reales mandatos librados por el Consejo de Indias para solucionar unos pleitos. El gobernador de Cuba y los oficiales de la misma hicieron un inventario de sus bienes, entre los que se hallaban ropa y libros, que fueron remitidos a su mujer Joaquina Aznar e hijos que se encontraban en Santo Domingo ${ }^{25}$.

Respecto a los casos en que los hacendados hicieron testamento, la documentación proporciona una amplia variedad de situaciones. Hubo sucesiones en las que no existieron hijos o cónyuges, como muestra el testamento realizado en 1793 por Beatriz Leos-Echalas, viuda de Nicolás Guridi y Coronado. En él había unas cláusulas de donación que especificaban que dejaba sus bienes inmuebles a sus sobrinos: la mitad de la hacienda de cacao llamada Cambita pasaría a su sobrina María Guridi Leos-Echalas, y la otra mitad a su sobrino Nicolás Leos-Echalas Heredia, y a su sobrino Enrique Franco Guridi le donaba tres casas que poseía en la ciudad de Santo Domingo (una en la calle el Caño, otra en la de Santo Domingo y la tercera en la Nueva Merced). A su hermana Francisca le dejó una casa que hacía esquina en la calle Plateros y en la que atraviesa la capilla Dávila al Hospital Real, y a su otra hermana María y su marido el Mariscal Antonio Álvarez Barba los nombró como albaceas. Además instituía a su hermana María como heredera universal del resto de sus bienes, y que muriendo ella pasase a sus hijos legítimos de ambos matrimonios ${ }^{26}$.

En su testamento Beatriz Leos-Echalas estableció que se le otorgara la libertad a sus esclavas Irene, Julia y Guadalupe, a condición de que mientras ella viviera le debían de seguir sirviendo con la lealtad que hasta entonces habían desarrollado, y que de lo contrario quedaría nula. Asimismo concedió la libertad a otro esclavo, Isidro, que trabajaba en la hacienda. Tres años más tarde en 1796 hizo cobadicilo, donde estableció que se conservasen a su favor los caudales de

\footnotetext{
${ }^{25}$ Testimonio de los autos de inventario y avalúo de los bienes que quedaron por fallecimiento de Ramón Jover oidor que fue de esta Real Audiencia y murió intestado en la ciudad de Santiago de Cuba, 25 de noviembre de 1786. AGI, Santo Domingo, 992.

${ }^{26}$ María de los Santos Leos-Echalas estuvo casada en primeras nupcias con Felipe Frómesta Balmaceda quien murió en 1752, después en 1757 contrajo matrimonio por segunda vez con Antonio Álvarez Barba. Véase en Larrazábal Blanco, C., Familias dominicanas. Santo Domingo, 1978, vol. IV, p. 198.
} 
sus bienes, y que los futuros legatarios sólo recibiesen los usufructos y las propiedades al morir ella ${ }^{27}$.

El caso del tesorero de las Cajas de la Real Hacienda, Raymundo Esparza, es más peculiar porque a pesar de afincarse en Santo Domingo no se casó y tampoco llegó a contar con familia directa en Santo Domingo. Murió el 29 de abril de 1786 pero cuatro meses antes había realizado su testamento, en el que nombró como albaceas al teniente de rey Joaquín García, al factor de la administración de tabacos Andrés Lecanda, y al abogado de la Audiencia Rufino Suárez. Ellos fueron los encargados de mandar hacer el inventario de sus bienes, y de que se vendiesen en almoneda los muebles, casa, alhajas y esclavos, sin perjuicio de la libertad que Raymundo concedía a varios de sus sirvientes, como al mayordomo de la estancia y a su mujer, al cocinero Nicolás, al calesero y criado Juan Luís y al panadero Julián, ni de las alhajas que legaba a personas de su estimación. Entre ellas estaba su compañero de trabajo, Francisco de Paula Gazcue y Olaiz, a quien donaba un reloj inglés, y Rufino Suárez, que recibió la papelera que había en la sala con una cajita con piezas de plata y un caballo.

Raymundo Esparza mandaba a sus albaceas que se encargaran de administrar la estancia que poseía llamada Guayabal, estableciendo como condición que ésta no podía enajenarse y que los frutos que produjese fuesen utilizados para la manutención de los salarios de los esclavos de sementera, cultivo, subsistencia y compostura de las tierras. También debía servir para finiquitar las cuentas de las Cajas Reales desde 1777 hasta diciembre de 1785. Es decir, legó a la Corona cuanto existía en dicha hacienda ya que “[...] al no tener heredero queria hacer este voluntario servicio a Su Majestad en demostracion de su amor y gratitud, con la precisa calidad que el valor de toda la estancia, sus frutos y los muebles de la casa de aquella ciudad, sirvieran para satisfacer el alcance o resulta que pudiesen haber en las cuentas reales $[\ldots . .]^{, 28}$. El remanente que quedase de todos sus bienes, derechos y acciones fue para Joaquín García, a quien había nombrado como heredero fideicomisario ${ }^{29}$.

\footnotetext{
${ }^{27}$ Escritura de testamento de Beatriz Leos-Echalas, 28 de noviembre de 1793. Y, Cobadicilo, 27 de mayo de 1796. AGI, Santo Domingo, 960.

${ }^{28}$ Escritura del testamento de Raymundo Esparza, 23 de enero de 1786. AGI, Santo Domingo, 992.

${ }^{29}$ Ibidem.
} 
El alférez del Batallón Fijo de Santo Domingo, Juan Miguel de la RochaFerrer Landeche murió, también soltero, nombró al Hospital de San Lázaro como único heredero para que “[...] lo distribuya entre los pobres de dicho hospital como tambien en edificaciones y habitaciones [...]”30. A diferencia del caso anterior Juan Miguel sí contaba familia, pues pertenecía a la red LandecheBastidas. De hecho nombró como sus albaceas a dos familiares, Lorenzo Angulo y a Antonio Dávila Coca, para que pagasen el remanente de sus bienes, deudas, derechos, acciones, liberasen a algunos de sus esclavos, entregasen 200 pesos a su hermana Juana, y para que se encargaran de su enterramiento y celebrasen las misas rezadas acostumbradas en aquella época en la Iglesia del hospital ${ }^{31}$.

Un caso interesante que refleja la importancia de contar con hijos a quienes transmitir los bienes es el de un miembro de la familia Gonzalo-Tapia y Urdaneta. En 1785 muere Miguel Bernardo Antonio Ferrer, quien un año antes había nombrado como únicos herederos a sus tres hijos; sin embargo, el documento no proporciona datos de su partición ni del patrimonio familiar ${ }^{32}$.

El modelo de la familia Pueyo y Urríes puede ser más ilustrativo al facilitar la documentación más datos. Por su parte, el padre de la familia, el regente Andrés Pueyo y Uríes, estuvo casado con Josefa Díez, con la que tuvo siete hijos. El 15 de enero de 1782 elaboró su testamento en el que adjudicaba lo que correspondía a cada uno de sus hijos. Su hija Francisca fue la albacea y tenedora de los bienes, y en función de los deseos de su padre se dividieron entre sus hijos. Según la legislación de las Leyes de Toro la herencia quedaba sujeta a la división en cuatro quintas partes de transmisión obligatoria y una quinta parte de libre disposición. Dentro de la porción destinada a la transmisión obligatoria, dos tercios de la misma debían repartirse igualitariamente entre los hijos, es decir, como hizo Andrés Pueyo y Urríes con cada uno de sus hijos, quienes recibieron una parte de la herencia o legítima. El tercio restante quedaba para mejorar las legítimas de uno o de varios hijos, o incluso de los nietos. Este fue el deseo final de Andrés Pueyo y Urríes, que mejoró en la mitad el remanente del quinto y tercio de todos sus bienes en el codicilo que realizó un año después de hacer su

\footnotetext{
${ }^{30}$ Escritura del testamento de Juan Miguel de la Rocha, 5 de mayo de 1778. AGI, Santo Domingo, 989.

${ }^{31}$ Ibidem.

${ }^{32}$ Escritura del testamento de Miguel Bernardo Ferrer, 30 de abril de 1784. AGI, Santo Domingo, 947.
} 
testamento, y cuya partida sumaba 7.745 pesos, 7 reales $y^{7} / 10$ avos. Esta mejora fue reiterada y entregada en 1786 a favor de sus ocho nietos debido al fallecimiento de su hija Josefa ese mismo año. Su marido, el contador Francisco de Paula Gazcue y Olaiz, fue quien se encargó de administrarlo ${ }^{33}$.

\subsubsection{Consecuencias de las transferencias por herencia}

El análisis de la distribución y partición de los bienes entre los herederos, ha llevado a muchos investigadores a relacionar la aplicación del sistema hereditario castellano con la dispersión de los patrimonios en el traspaso de unas generaciones a otras, y en particular sobre la fragmentación de la propiedad de la tierra en el territorio americano durante la época colonial. Son numerosos los trabajos que han tratado este aspecto así como todo lo relacionado con el agro hispanoamericano, por lo que se citarán algunos realizados sobre México y Buenos Aires.

Así por ejemplo en el caso de Nueva España, según David Brading, la única causa del cambio de los propietarios en las haciendas de León y Rincón entre 1700 y 1860 fue el sistema testamentario español ${ }^{34}$. Por su parte, Eduardo Saguier ha trabajado sobre las propiedades rurales de Buenos Aires. Este investigador señala que si bien el régimen hereditario fue una de las causas de la fragmentación de la propiedad agraria, también incidieron otros aspectos como los censos y el régimen de capellanías a los que estaban sometidos las propiedades, así como otros sistemas de partición basados en el derecho de abolengo ${ }^{35}$. Todo esto tuvo como consecuencia la movilidad de sus propietarios, y por tanto el debilitamiento de los terratenientes ${ }^{36}$. Sin embargo, hay otros estudios que prueban que la transferencia por herencia no contribuyó necesariamente a la fragmentación de la propiedad rural. Trabajos como los de Garavaglia y Grosso para México y Canedo para Buenos Aires muestran que las propiedades rurales de

\footnotetext{
33 Josefa Pueyo y Díez murió el 30 de agosto de 1786. Testimonio de las diligencias practicadas por Francisca Pueyo sobre que se le entreguen los usufructos de la hacienda embargada al contador Francisco Gazcue para alimentos de los hijos de éste. AGI, Santo Domingo, 997.

${ }^{34}$ Brading, D., Haciendas and Ranchos in the Mexican Bajío. León 1700-1860. Cambridge, 1978, pp. 118-119.

35 Saguier, E., El mercado inmobiliario rural y su incidencia en la estructura social rioplatense..., op. cit., pp. 21-38.

Idem.
} 
algunas regiones de esos países fueron más estables que las del resto de Indias. A través del seguimiento de algunas familias de la élite de hacendados, sus propiedades y su transmisión, estos autores manifiestan como lograron mantenerlas durante muchos años evitando su fragmentación, lo que permitió que hubiese una mayor estabilidad entre los propietarios ${ }^{37}$. Estas investigaciones ponen de relieve la gran variedad de consecuencias que podía conllevar el sistema hereditario en los bienes rurales dentro de un país.

En Santo Domingo donde la sucesión igualitaria fue la forma más habitual, cabría preguntarse si llevó a la subdivisión del patrimonio familiar, y en particular de la propiedad de la tierra. La respuesta no es sencilla, pues sería necesario realizar un estudio en profundidad sobre la tierra y todo lo concerniente a ella. Pero en función de la documentación consultada respecto a los hacendados estudiados y el patrón hereditario utilizado, puede decirse que algunas familias mantuvieron en sus manos su patrimonio durante varias generaciones. Para ello utilizaron diversas estrategias que les sirvieron para contrarrestar y evitar la fragmentación, y en consecuencia para mantener la unidad de las propiedades familiares. Una de ellas fue el sistema de compra-venta, que además de ser una forma de transmisión puede considerarse como una estrategia para prevenir una división de la propiedad como se vio en el caso de la familia Landeche-Bastidas; así como otros mecanismos que serán explicados a continuación.

\subsubsection{Procesos de reagrupamiento}

En primer lugar, se puede constatar la existencia de procesos de reagrupación, que solían hacerse después de distintas particiones de un patrimonio durante varias generaciones. El cuadro siguiente muestra como las sucesivas transferencias de la propiedad rural de la estancia de cacao Cambita, perteneciente a la familia Guridi y Alarcón-Coronado, acabó dividiéndose y como a finales del

\footnotetext{
37 Puede verse en Garavaglia, J. C., y Grosso, J. C., Puebla desde una perspectiva microhistórica. Tepeaca y su entorno agrario: población, producción e intercambio (1740-1870). México, 1994, pp. 166-182, y 222-242. Canedo, M., “Tierra sin gente y gente con tierra. La dinámica del acceso y de la transferencia de la tierra en una zona de colonización temprana de la campaña de Buenos Aires. (Los Arroyos, 1600-1850)” en Zebeiro, B., Bjerg, Ma., y Otero, H. (comps.), Reproducción social..., op. cit., pp. 83-119.
} 
siglo XVIII se recompuso casi totalmente a través de la elaboración de una buena política matrimonial.

A principios del siglo XVIII la estancia fue propiedad de Antonio Guridi y Echeandia y de Leonor Alarcón-Coronado, quienes además tenían al lado de ésta un ingenio de azúcar llamado Santa Lucía de Camba. La estancia de cacao fue distribuida entre sus dos hijos varones, Nicolás Guridi casado con Beatriz LeosEchalas, y Matías Guridi con María Merced Rivero de la Concha Solano. Nicolás Guridi no tuvo hijos, y murió antes que su mujer, por lo que fue ésta la que donó una mitad de la propiedad a su sobrino Nicolás Leos-Echalas Heredia y la otra a su sobrina María Guridi Leos-Echalas ${ }^{38}$.

María Guridi transmitió esta porción de la estancia Cambita a su hija Josefa María Fernández de Castro Guridi, a lo que se sumaba la otra parte de dicha finca que había heredado su padre Felipe Guridi de su abuelo Matías Guridi. El matrimonio de conveniencia entre Josefa María Fernández de Castro Guridi y Nicolás Leos-Echalas Heredia refleja como sirvió para recomponer la fragmentación de la propiedad rústica. Además de esos dos trozos, ella aportó al matrimonio una dote de 3.000 pesos y 8 reales consignados “[...] en valor de las tierras, animales, negros y utiles del ingenio de moler azucar [...]” Santa Lucía de Camba, que lo había heredado su madre María Guridi como hija única del abogado de la Audiencia Felipe Guridi ${ }^{39}$. Por su parte, Nicolás Leos-Echalas Heredia aportó la otra parte de la estancia de cacao que heredó de su tía Beatriz Leos-Echalas, así como “[...] otras haciendas y fincas de su propiedad, que exceden en mucho el capital de 3.000 pesos [...]” y acerca de las cuales la documentación no especifica más datos ${ }^{40}$. Sin embargo, la estancia no quedó completamente unificada, ya que una parte de ella estuvo en manos de Ana Guridi, quien al igual que su hermano Felipe Guridi, recibió sus legítimas que llegaban “a 20.000 pesos fincados en una hacienda de cacao que el alguacil mayor de esta real audiencia Matías Guridi, mi padre mando por clausula de su

\footnotetext{
${ }^{38}$ Nicolás Leos-Echalas era hijo de Tomás Leos-Echalas y Ana Heredia Castro-Coronado, mientras que María Guridi era hija de Felipe Guridi Concha y Ana Buenaventura Leos-Echalas. Escritura del testamento de Beatriz Leos-Echalas, 28 de noviembre de 1783. AGI, Santo Domingo, 960.

39 Ibidem.

${ }^{40}$ Ibidem, y Memorial y documentación en la que se solicita real permiso para casarse el subteniente retirado Nicolás Echalas con Josefa Castro, 25 de octubre de 1789. AGI, Santo Domingo, 949.
} 
testamento [...]" que cuando él falleciese y se dividieran sus bienes fuese entregada a Ana Guridi ${ }^{41}$. (Véase del capítulo 4 la figura 4-3. Red familiar Guridi y Alarcón-Coronado, y del anexo la figura 8. Familia Leos Echalas-Cataño)

Tabla 5-2. Transmisión de la tierra por herencia y recomposición del terreno heredado

\begin{tabular}{|l|l|l|l|}
\hline \multicolumn{1}{|c|}{ Otorgante } & \multicolumn{1}{|c|}{ Adquiriente } & Parentesco & \multicolumn{1}{c|}{ Forma } \\
\hline $\begin{array}{l}\text { Antonio Guridi y } \\
\text { Echeandia }\end{array}$ & $\begin{array}{l}\text { 1-Nicolás Guridi Coronado } \\
\text { 2-Matías Guridi Coronado }\end{array}$ & Padre-hijos & Herencia \\
\hline Beatriz Leos-Echalas & $\begin{array}{l}\text { 1-María Guridi Leos-Echalas } \\
\text { 2-Nicolás Leos-Echalas Heredia }\end{array}$ & Tía-sobrinos & Donación \\
\hline $\begin{array}{l}\text { Matías Guridi } \\
\text { Coronado }\end{array}$ & $\begin{array}{l}\text { 1-Felipe Guridi Concha } \\
\text { 2-Ana Guridi Concha }\end{array}$ & Padre-hijos & Herencia \\
\hline $\begin{array}{l}\text { Felipe Guridi Rivera- } \\
\text { Concha }\end{array}$ & María Guridi Leos-Echalas & Padre-hija & Herencia \\
\hline $\begin{array}{l}\text { María Guridi Leos- } \\
\text { Echalas }\end{array}$ & $\begin{array}{l}\text { Josefa María Fernández de } \\
\text { Castro Guridi }\end{array}$ & Madre-hija & Herencia \\
\hline
\end{tabular}

Elaboración propia. Fuentes: Escritura del testamento de Beatriz Leos-Echalas, 28 de noviembre de 1783. AGI, Santo Domingo, 960. Memorial y documentación en la que se solicita real permiso para casarse el subteniente retirado Nicolás Echalas con Josefa Castro, 25 de octubre de 1789. AGI, Santo Domingo, 949.

\subsubsection{Los terrenos comuneros}

Debe destacarse igualmente otro tipo de comportamiento que estaba relacionado con la adjudicación de la tierra y que en un principio tampoco llevaba a la partición de la propiedad. Este medio se correspondía con una forma de tenencia de tierra conocida en Santo Domingo como terrenos comuneros ${ }^{42}$. Esta

\footnotetext{
${ }^{41}$ Cláusula del testamento de Matías Guridi inserto en el Pedimento que hace Ana Guridi, viuda del regidor Juan de Mieses para que se le discierne el cargo de tutora de sus hijos. ACh, Pleitos civiles, La Puerta Olvidados, 1378.

${ }^{42}$ La mayoría de los estudios sobre terrenos comuneros están realizados fundamentalmente desde un ángulo jurídico véanse: Ruíz Tejada, R., Estudio sobre la propiedad inmobiliaria en la República Dominicana. Ciudad Trujillo, 1952. Alburquerque, A., Títulos de los terrenos comuneros de la República Dominicana. Ciudad Trujillo, 1961. Vega Boyrie, W., "Historia de los Terrenos Comuneros en la República Dominicana”. CLÍO 162 (Santo Domingo, 2000) pp. 81-108. Entre los trabajos que han tratado el origen y la evolución histórica de las tierras comuneras dominicanas destacamos: Hoetink, H., El pueblo dominicano, 1850-1900. Apuntes para su sociología histórica. Santiago, 1985. Fernández Rodríguez, A. C., “Origen y evolución de la propiedad y de los terrenos comuneros en la República Dominicana”. Eme-Eme Estudios Dominicanos 51 (Santiago de los Caballeros, 1980) pp. 5-45. Moreno, G., "De la propiedad comunera a la propiedad privada moderna, 1844-1924”. Eme-Eme Estudios Dominicanos 51 (Santiago de los Caballeros, 1980) pp. 47- 129. Gutiérrez Escudero, A., "La propiedad de la tierra en Santo Domingo: del latifundio al terreno comunero”. Temas Americanistas 4 (Sevilla, 1984) pp. 21-26, y su obra Población y economía..., op. cit., pp. 92-97. Para una aproximación más detallada
} 
clase de propiedad fue también característica de otros lugares como Cuba y Puerto Rico $^{43}$.

Los terrenos comuneros empezaron a utilizarse en el siglo XVII extendiéndose a los siglos XIX y XX. Durante el siglo XVIII también eran denominados sitios, porque hacían referencia al nombre del lugar en el que estaban situados. Si bien la mayoría de los autores que los han estudiado coinciden en localizar temporalmente este sistema en el siglo XVII, no hay unanimidad entre ellos a la hora de explicar cuál fue su origen, existiendo varias hipótesis. No obstante, todas ellas constatan que los terrenos comuneros surgieron del régimen hatero. Conviene detenerse aquí brevemente para explicar los dos planteamientos -de carácter polémico- que existen acerca de cómo y porqué surgió este tipo de propiedad.

El primero de ellos se refiere a los estudios que explican los orígenes a partir del marco jurídico de la herencia. Éstos ponen de manifiesto la dificultad y la imprecisión a la hora de conocer los límites reales de los terrenos, que existió durante la época colonial hasta el punto que la documentación pone de manifiesto como en alguna ocasión el propio dueño también los desconocía. Además, consideran que las sucesivas ventas de una parte de una propiedad produjeron múltiples subdivisiones de ésta ${ }^{44}$. Por su parte, la segunda postura representada por Roberto Cassá, Wenceslao Vega, y Aura Celeste Fernández abogan que los terrenos comuneros surgieron como “consecuencia de la partición hereditaria entre sucesores (descendientes y cónyuges) a la muerte del propietario” y a que con el paso del tiempo y generaciones la propiedad no quedó dentro del círculo familiar, sino que fue pasando a manos de personas ajenas a ella ${ }^{45}$. Esta explicación fue ya expresada con nitidez por coetáneos de finales del siglo XIX

sobre los terrenos comuneros en la región del Cibao, específicamente en la provincia de Santiago véase el capítulo VI de la obra de San Miguel, P., Los campesinos del Cibao..., op. cit., pp. 189256. Widmer Sennhauser, R., "El Higüey en el siglo XVIII. Los inicios de la industria maderera en Santo Domingo (1780-1800)”. Estudios Sociales 123 (Santo Domingo, 2001) pp. 63-78. Con un carácter descriptivo también son muy útiles los trabajos publicados en el siglo XIX de: Hazard, S., Santo Domingo. Su pasado y presente. New York, 1873. Monte y Tejada, A. del, Historia de Santo Domingo. Ciudad Trujillo, 1952 (1890), vol. II, p. 19.

${ }^{43}$ Le Riverend, J., Historia económica de Cuba. La Habana, 1981, pp. 5-6. Amores Carredano, J. B., Cuba en la época de Ezpeleta (1785-1790). Pamplona, 2000, pp. 184-192. Cassá, R., Historia social y económica de la República Dominicana. Santo Domingo, 2003, vol. I, pp. 261262.

${ }^{44}$ Ruíz Tejada, R., Estudio sobre la propiedad inmobiliaria..., op. cit.

${ }^{45}$ Fernández Rodríguez, A. C., “Origen y evolución de la propiedad y de los terrenos comuneros en la República Dominicana”..., op. cit., pp. 5-45, p. 23. 
como Samuel Hazard en su obra escrita en 1873. En esta dirección, se ha desarrollado también otra posible explicación, el propio Samuel Hazard y posteriormente el sociólogo Hoetink plantean que el mayorazgo, y en relación a esta institución el sistema de primogenitura también pudo haber influído en su aparición $^{46}$.

Si bien la segunda hipótesis también está de acuerdo en la repercusión que tuvieron las sucesivas transmisiones de la propiedad en la creación de los terrenos comuneros, añade argumentos a favor de otros motivos como el costo de la agrimensura, el poco valor de la tierra y el de la producción que venía dado por la propia naturaleza de la crianza del ganado, ya que ésta requería amplias llanuras. Estas tesituras defendidas por los propios investigadores citados anteriormente, y en particular por Roberto Cassá, Wenceslao Vega y Samuel Hazard, nos conducen a que en ambos casos se trata de sucedáneos, y a proponer los terrenos comuneros como un tema abierto a la investigación.

Habitualmente los terrenos comuneros eran grandes extensiones de tierra dedicadas a la cría de ganado vacuno, caballar y de cerdos. Según Pedro Francisco Bonó, estos predios tuvieron la particularidad de contener una parte de praderas, matas y sabanas con ríos y lagunas, que formaban la parte más importante del hato, y por otro lado, sitios con arbustos, montes y extensiones boscosas, conocidas como ranchos o monterías. Las primeras áreas se utilizaban fundamentalmente para la crianza de ganado vacuno y caballar, y allí se encontraban los bohíos y conucos ${ }^{*}$; mientras que las segundas se dedicaban a la crianza y alimentación del ganado de cerda, el pastoreo de los caballos y para cortar la madera ${ }^{47}$.

Estos terrenos se caracterizaron a su vez porque a la muerte del dueño de la tierra, sus herederos mantenían una parte de la propiedad indivisa, utilizándola

\footnotetext{
${ }^{46}$ Apuntado ya por Hazard en 1873 fue Hoetink quien lo desarrolló ampliamente en su obra de 1985. Hazard, S., Santo Domingo..., op. cit., pp. 485-488. Hoetink, H., El pueblo dominicano, 1850-1900..., op. cit., pp. 15-16.

* Los bohíos fueron edificios, bien fuesen casas, almacenes e incluso iglesias fabricadas de madera, más específicamente de tablas de palmas y cubiertas con las hojas de éstas. En cambio el conuco era un trozo de tierra dedicado al cultivo.

47 Sobre este asunto véase Rodríguez Demorizi, E., Papeles de Pedro Francisco Bonó. Barcelona, 1980, p. 218. Pedro Francisco Bonó fue un personaje muy importante del siglo XIX dominicano. Se dedicó al comercio y a la política, aspectos sobre los que escribió ensayos así como sobre la sociedad de su época. Parte de sus trabajos fueron recopilados por Emilio Rodríguez Demorizi. Está considerado como el padre de la sociología dominicana.
} 
en común como copropietarios. Aunque lo hacían con la peculiaridad de tener cada uno de ellos una ocupación individual, lo que producía era una relativa concentración familiar.

Sin embargo, existía la posibilidad de que una propiedad privada se convirtiese en un terreno comunero en caso de que los herederos no realizasen la partición e hicieran un uso común de ella. La adjudicación y valoración de la parte correspondiente a cada uno se hacía a través del sistema de acciones de pesos o títulos de pesos, que consistía en utilizar la unidad monetaria de aquella época, es decir, el peso, para referirse a la valoración específica de la unidad o unidades que tenía cada acción, mientras que la acción era el derecho proporcional que cada copropietario tenía sobre un terreno comunero. Con el paso del tiempo, los pesos que un copropietario tenía en un terreno comunero se denominaron acciones o títulos de pesos. Esto significó que la posesión de una determinada cantidad de pesos, daba a sus poseedores el derecho de la utilización de la parte del conjunto de tierras del bosque y pastos, así como de las aguas.

Si con este sistema se trató de mantener unificada una propiedad, a la larga produjo una dispersión y fragmentación del terreno, pues personas ajenas a la familia acabaron obteniendo derechos sobre esos terrenos mediante los matrimonios y las ventas que los herederos copropietarios del sitio realizaban, dando lugar a su comercialización y circulación de condueños, y por tanto a su fragmentación ${ }^{48}$. En cambio, este sistema también permitió que a través de la compra de derechos de tierras sobre un terreno, éste acabara en manos de una persona o familia. Ello sucedió con los sitios de Enmedio, la otra banda del río Yaque y Las Matas de Santa Cruz, dedicados a la cría de ganado y que fueron adquiridos en varias compras y en distinto tiempo por Francisco Espaillat y Virol. Los dos primeros estaban ubicados en la jurisdicción de Santiago y el segundo en la jurisdicción de Montecristi. El hato de Enmedio perteneció originariamente a Francisco Muñoz del Monte, Jerónima de Villar, Pedro del Rosario y Quiñones y Mauricia Pacheco, cada uno de ellos tenía unos derechos sobre esas tierras, aunque se desconoce cómo las obtuvieron. Éstos los vendieron a Francisco Espaillat: el primero en 1761 por un valor de 4.500 pesos, la segunda en 1766 por

\footnotetext{
${ }^{48}$ Vega Boyrie, W., "Historia de los terrenos comuneros en la República Dominicana”..., op. cit., pp. 81-108. San Miguel, P., Los campesinos del Cibao..., op. cit., pp. 190-193.
} 
400 pesos, el tercero en 1768 por 150 pesos, y el cuarto derecho de tierra en 1782 por 400 pesos $^{49}$.

El terreno situado en la otra banda del río Yaque lo adquirió también Francisco Espaillat en seis sucesivas compras. De esta manera en 1783 hizo la compra de una parte de tierra en 300 pesos a José Silvestre de Peña y su mujer, y otro pedazo a Gregorio Aybar en el mismo valor. Un año más tarde, a primeros de julio, compró de nuevo dos derechos de tierras, uno a Mariana de Vargas en 300 pesos y otro a Sebastián Borbón en 45 pesos. En agosto del mismo año lo hizo a Catarina de Aybar, y el 10 de diciembre cincuenta y cinco pies de tierra a Francisco de Bargas y su mujer Isabel Borbón en 55 pesos. En mayo de 1784 obtuvo en el paraje de Las Matas de Santa Cruz, un derecho de tierra de Gregorio Pérez en 600 pesos y en septiembre otro de Juan Núñez en 350 pesos $^{50}$.

\subsubsection{El mayorazgo}

Por último, otra forma utilizada por los hacendados para la conservación de la riqueza familiar fue el mayorazgo. La fundación de un mayorazgo en Indias a principios de la colonia, se realizó con el objetivo de premiar a los conquistadores por los servicios prestados a la Corona. Pero la intención fundamental del mayorazgo fue perpetuar en la familia la propiedad de ciertos bienes con arreglo a las condiciones que el fundador dejaba escritas, y en las que se establecía generalmente la línea de sucesión en la que debía transmitirse. Los mayorazgos integraron desde bienes inmuebles como casas y tierras hasta rentas, títulos nobiliarios o empleos, entre otros. Junto a todo ello, el mayorazgo también tuvo como objeto que el apellido del fundador fuese apropiado por aquella persona que lo heredase, lo cual aportaba prestigio social a él y su familia ${ }^{51}$.

Los mayorazgos que existieron en Santo Domingo en la segunda mitad del siglo XVIII habían sido creados durante el siglo XVI. A diferencia de otras partes del continente americano donde a finales del siglo XVIII hubo un aumento de este tipo de vinculaciones, en el caso de Santo Domingo no se ha encontrado

\footnotetext{
49 Campillo Pérez, J. G., Francisco Espaillat..., op. cit., p. 123.

50 Ibidem., pp. 126-127.

${ }^{51}$ Para el mayorazgo indiano véase Lira Montt, L., "La fundación de mayorazgos en Indias”. Hidalguía 230 (Madrid, 1992) pp. 561-581, y Clavero, B., Mayorazgo. Propiedad feudal en Castilla, 1369-1836. Madrid, 1989, pp. 181-207.
} 
alguno que fuese de nueva creación. Los trabajos que existen sobre este aspecto son más bien escasos. Entre estas investigaciones cabe destacar los estudios genealógicos realizados por Emilio Rodríguez Demorizi y Fray Cipriano de Utrera sobre el mayorazgo Dávila y Bastidas, así como otras dos obras más recientes escritas por Melchor Contin Alfau y Manuel Antonio Sosa Jiménez en las que se puede encontrar información a cerca del mayorazgo Dávila ${ }^{52}$. Además de estos dos mayorazgos fundados en el siglo XVI, existieron otros como el instituido por Gonzalo Fernández de Oviedo y Valdés, que estuvo asociado al de Bastidas, el de Mosquera, así como el de Garay o el de Veragua, al que se añadía el título y bienes del Ducado del mismo nombre ${ }^{53}$. Todos ellos fueron creados con licencia real y dispuestos en una escritura testamentaria en la que explicaban detalladamente cuáles eran sus bienes, y los deseos de asegurar el futuro de sus hijos y mantener el apellido. Algunos de estos mayorazgos que se mantuvieron hasta finales del siglo XVIII llegaron a las manos de algunos de los hacendados estudiados.

Se sabe que la familia Landeche-Bastidas poseyó varios mayorazgos, como el de Bastidas, el de los Dávila y el Mosquera. El primero fue fundado conjuntamente por el obispo Rodrigo de Bastidas y su madre el 24 de mayo de 1551. Sus bienes estuvieron compuestos por su casa principal, situada en la calle Las Damas, doce casas y unos siete solares, y numerosos hatos e ingenios distribuidos por distintos lugares de la isla ${ }^{54}$. El mayorazgo Dávila fue creado el 23 de agosto de 1554 por Francisco Dávila, un rico terrateniente miembro del cabildo de la ciudad de Santo Domingo que había llegado junto al gobernador Nicolás de Ovando. De igual forma que el anterior mayorazgo, su fortuna estaba

\footnotetext{
${ }^{52}$ Rodríguez Demorizi, E., Familias Hispanoamericanas. Ciudad Trujillo, 1959. Utrera, F. C. de, Don Rodrigo de Bastidas. Santo Domingo, 1930. Las publicaciones más recientes son las siguientes: Contin Alfau, M., El Hato Mayor del Rey. Reseña Histórico-Geográfica Tradicional y Religiosa. Santo Domino, 1991. Sosa Jiménez, M. A., Hato Mayor del Rey, su sitial en la Historia Dominicana. Santo Domingo, 1993. Véase también alguna referencia en Pérez Montás, E., Casas Coloniales de Santo Domingo. Colonial Houses of Santo Domingo. Santo Domingo, 1980, pp. 180-181.

${ }^{53}$ Miralles de Imperial y Gómez, C., "Del linaje y armas del primer cronista de Indias, el madrileño Gonzalo Fernández de Oviedo”. Revista de Indias 71 (Madrid, 1958) pp. 73-126.

${ }_{54}$ Rodrigo de Bastidas era hijo del capitán de mismo nombre que descubrió Colombia y Panamá, y de Isabel Rodríguez de Romero Tamaris. El obispo fundador del mayorazgo se convirtió en un gran terrateniente en Santo Domingo, donde fue Administrador Apostólico de Santo Domingo, además de obispo de Coro y de San Juan de Puerto Rico. Véase en Utrera, F. C. de, Don Rodrigo..., op. cit., pp. 5-8. Rodríguez Demorizi, E., Familias Hispanoamericanas..., op. cit., p. 328.
} 
integrada por numerosos hatos en la actual provincia de Hato Mayor ${ }^{55}$, haciendas en la jurisdicción de La Vega, Puerto Plata, San Juan de la Maguana, y en la ciudad de Santo Domingo. En ella tenía una casa principal en la calle Las Damas con su fuerte y capilla privada, además de otras veinte tres casas. En las tablas siguientes se puede observar detalladamente cuáles fueron los bienes vinculados de ambos mayorazgos en el momento de su fundación.

\footnotetext{
${ }^{55}$ En el momento del descubrimiento el área de Hato Mayor formaba parte de los cazicazgos de Higüey y Maguá, al este de la República Dominicana. En 1984 mediante la ley 245 se creó la provincia de Hato Mayor, quedando constituido por los municipios de Hato Mayor del Rey, Sabana de la Mar y El Valle. Sosa Jiménez, M. A., Hato Mayor del Rey..., op. cit., pp. 605-611.
} 
Tabla 5-3. Bienes de los mayorazgos Dávila y Bastidas

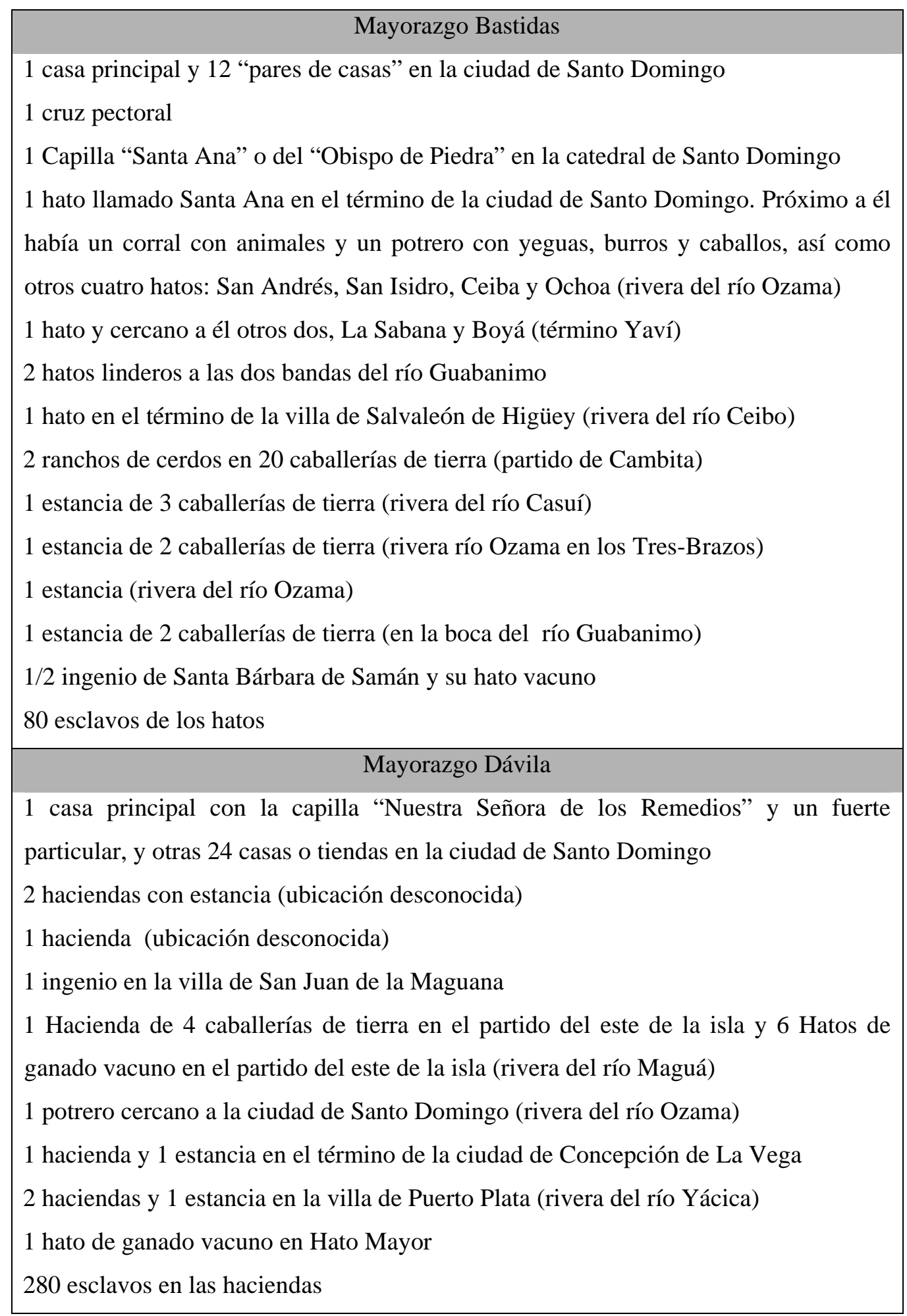

Elaboración propia. Fuentes: Utrera, F. C. de, Don Rodrigo..., op. cit., pp. 238-248. Rodríguez Demorizi, E., Familias Hispanoamericanas..., op. cit., pp. 197-214. Sosa Jiménez, M. A., Hato Mayor..., op. cit., pp. 35-41. 
Ambos mayorazgos se instituyeron con una serie de cláusulas entre las que destaca aquella que refiere el hecho de que debía heredarlo el hijo varón mayor. Sin embargo, en ambos casos se dio de otra manera, ya que Francisco Dávila sólo tuvo un hijo que murió antes de instituirse el vínculo, y Rodrigo de Bastidas al ser obispo tampoco tuvo hijos, por lo que recurrieron a sus respectivos sobrinos no sólo para transmitir la fortuna vinculada, sino también como medio para conservar sus apellidos, el honor y reputación familiar ${ }^{56}$.

Las siguientes generaciones que accedieron a estos mayorazgos, lo hicieron a través de la descendencia masculina. Pero años más tarde, en el mayorazgo Dávila esta línea se extinguió y a mediados del siglo XVII se recurrió finalmente a las hijas, siendo los maridos de éstas quienes lo administraron y transmitieron a sus hijos. Mariana Dávila Benavides fue la primera mujer que heredó el mayorazgo. A la edad de veintitres años se casó con Rodrigo de Bastidas, significando esto la unión de ambos mayorazgos. Siguiendo lo trazado por los fundadores, al primogénito de este matrimonio, Ignacio, le correspondía heredarlos, pero su repentina muerte en 1694 obligó de nuevo a la entrada de una mujer. De esta manera pasó a su hermana Ana María Dávila Bastidas, que estaba casada con el vizcaíno Antonio Landeche, quien se encargó de ambos mayorazgos hasta la muerte de su mujer en 1715, cuando fueron transmitidos a su hijo Francisco Antonio Landeche Bastidas. Francisco Antonio poseyó los mayorazgos desde 1716 hasta 1721, año en que murió. Ese año entró en él su hermana Josefa Lucía Landeche, casada con el gaditano Antonio Coca Landeche. Él los administró y cuidó hasta que fueron traspasados a sus respectivos hijos, así como otros bienes familiares formados por un ingenio en la ribera del río Haina, el hato Higüero y otras haciendas, cuya tasación ascendió a unos 56.429 pesos, 5 reales y 6 maravedíes, y deudas a su favor de 62.459 pesos, 5 reales y 6 maravedíes ${ }^{57}$.

El mayorazgo Dávila en posesión de Josefa Lucía Landeche y Antonio Coca Landeche fue sucedido en su hijo Antonio en 1746. Al morir éste en 1789 pasó a sus hijos Antonio y Damián Coca Landeche y Oviedo, y su hermana María del Carmen. Ambos jóvenes se hicieron cargo de él hasta que Damián hacia 1779

\footnotetext{
${ }^{56}$ Para la fundación y condiciones de ambos mayorazgos véase Utrera, F. C. de, Don Rodrigo..., op. cit., pp. 212-237. Rodríguez Demorizi, E., Familias Hispanoamericanas..., op. cit., pp. 191214 y $220-239$.

${ }^{57}$ Certificación de los bienes del coronel Antonio de Landeche, cabo subalterno que fue de esta plaza, 24 de agosto de 1721. AGI, Santo Domingo, 257.
} 
obtuvo el permiso para marcharse a Jeréz de la Frontera y atender el mayorazgo Bevers que poseía su padre en dicha ciudad. A partir de entonces fue Antonio quien se encargó de él ${ }^{58}$.

La cesión de la parte española a los franceses obligó a sus poseedores a intentar enajenar los bienes, otros en cambio los abandonaron o los dejaron al cargo de alguien con la expectativa de regresar y recuperarlos. A pesar de que la legislación prohibía que los mayorazgos fuesen vendidos, en esta ocasión una Real Cédula de 1801 lo autorizó, y así “[...] vender las fincas, bienes, acciones y derechos correspondientes al mayorazgo, con facultad de subrogar su valor integro en cualquier otra parte de mis dominios [...]"59. Sin embargo, parece que no llegaron a ser vendidos y que los descendientes, pese a las circunstancias críticas posteriores, mantuvieron como pudieron su fortuna. La invasión haitiana en 1822 suprimió todos los mayorazgos, secuestrando la mayor parte de los bienes de los habitantes, que en su mayoría habían emigrado a otras partes del continente americano o hacia la Península, entre los que se encontraban los del mayorazgo Dávila $^{60}$. Esta situación no debió ser fácil al producirse una litis discusión dentro de la familia entre Felipe Fernández de Castro y los hermanos Antonio y María Manuela de Coca Figueroa, que se extendió entre 1820 y mediados del siglo $\mathrm{XIX}^{61}$. Finalmente pactaron el reparto de los bienes que conservaban, correspondiéndole el Hato Mayor y demás hatos que se incluían a los Coca, entre

\footnotetext{
${ }^{58}$ Real Orden concediendo a Damian Bevers Coca y Landeche, vecino y capitán de milicias de la infantería de Santo Domingo, para que vaya a domiciliarse en España para atender los mayorazgos que posee, El Pardo 20 de febrero de 1779. AGI, Santo Domingo, 1095.

${ }^{59}$ Real Cédula de 14 de junio de 1801 concediendo a Antonio Dávila y Coca la facultad para que pueda vender las fincas del mayorazgo que posee en la isla de Santo Domingo y subrogar otras en la conformidad que se expresa. AGI, Indiferente General, 1609.

${ }^{60}$ Dos años antes de la invasión haitiana, la Corona había emitido una Real Cédula el 11 de octubre surprimiendo los mayorazgos. Sobre el tema de la tierra durante la dominación haitiana, véase en Moya Pons, F., La dominación haitiana, 1822-1844. Santiago, 1978, pp. 45- 79. Utrera, F. C. de, Don Rodrigo..., op. cit., p. 247.

${ }^{61}$ Carta de María Manuela de Coca pidiendo licencia para pasar a Santo Domingo, donde el referido su padre era natural y siendo indispensable marchar a ella ya sea sola, o acompañada de su único hermano a arreglar y dividir los bienes que les pertenecen, Xerez de la Frontera 17 de marzo de 1820; Licencia concedida a María Manuela de Coca, natural de Xerez de la Frontera y de estado honesto para pasar a la isla y ciudad de Santo Domingo con su criado Bernardo Picasso, para arreglar los bienes que le pertenecen en ella por fallecimiento de su padre, Cádiz 18 de octubre de 1820. Y Felipe Dávila Fernández de Castro suplica a S.M Real Licencia para que su hijo Felipe pase a Santo Domingo embarcándose, para recuperar sus bienes o parte, Madrid 29 de octubre de 1822, y Concesión del Real Permiso el 4 de noviembre de 1822. AGI, Santo Domingo, 1099.
} 
los que destaca el hato La Pringamosa, y el resto de los terrenos a los Fernández de Castro ${ }^{62}$.

Es interesante resaltar que María Manuela, en quien había recaído el mayorazgo de Dávila contrajo matrimonio en 1821 con su primo hermano Domingo de la Rocha-Ferrer Angulo ${ }^{63}$, quien también poseía el mayorazgo Bastidas, por lo que de nuevo volvieron a unirse los mayorazgos. Los bienes de ambos bastante reducidos por las circunstancias de la época pasaron en parte a su hija María de las Mercedes Severiana de la Rocha, que heredó de su madre algunos terrenos del ya extinguido mayorazgo Dávila, donando gran parte de ellos en 1888 para la fundación del pueblo de Hato Mayor ${ }^{64}$. (Véase figura 5-1)

En lo que respecta a la posesión y transmisión del mayorazgo Bastidas, como se ha mencionado líneas más arriba, hacia principios del siglo XIX estaba en manos de Domingo de la Rocha-Ferrer Angulo, quien lo había heredado de su padre Rodrigo Macedonio de la Rocha-Ferrer Coca Landeche, y éste a su vez del abogado y regidor Domingo de la Rocha-Ferrer y Landeche, que lo heredó de su madre María del Rosario Landeche, habiendo entrado en él en 1721. El abogado Domingo de la Rocha-Ferrer y Landeche estuvo en posesión del mayorazgo, pero al trasladarse a México en 1767 para ejercer el empleo de auditor de guerra en las provincias de Yucatán y Campeche, fue su hermano Ignacio quien se responsabilizó de representarle y administrar los bienes. Estos consistían en numerosas casas en la ciudad de Santo Domingo, concretamente veinticuatro en la calle que va desde el Convento de San Francisco a la plaza del Contador y da la vuelta a la calle Santa Bárbara, y la casa principal situada en la calle Las Damas, así como un hato de grandes dimensiones conocido como Santa Ana, y otros hatos menores ${ }^{65}$.

\footnotetext{
${ }^{62}$ Según Emilio Rodríguez Demorizi y Manuel Antonio Sosa Jiménez se resolvió el 4 de enero de 1826, mientras que Vetilo Alfau Durán y Emiliano Tejera lo sitúan el mismo día pero en distinto año, 1862. Rodríguez Demorizi, E., Familias Hispanoamericanas..., op. cit., p. 191. Sosa Jiménez, M. A., Hato Mayor del Rey..., op. cit., pp. 45-50. Tejera, E., "Documentos antiguos”. La Cuna de América 10 (Santo Domingo, 1915) pp. 1-10.

${ }^{63}$ También conocido como Domingo de la Rocha Bastidas.

${ }^{64}$ María de las Mercedes Severiana nació en Santo Domingo en 1822, estuvo casada en primer lugar con el agente norteamericano Jonathan Elliot, que murió en 1872. Se volvió a casar por segunda vez con un inmigrante cubano de la Guerra Chica (1868) llamado Esteban Fernández y González. Para los datos biográficos y sobre el acta notarial de la donación de los terrenos véase en Sosa Jiménez, M. A., Hato Mayor del Rey..., op. cit., pp. 204-212, y 220-225.

${ }^{65}$ Utrera, F. C. de, Don Rodrigo..., op. cit., pp. 242-245. Rodríguez Demorizi, E., El pleito Ovando-Tapia. Comienzos de la vida urbana en América. Santo Domingo, 1978, p. 69-70.
} 


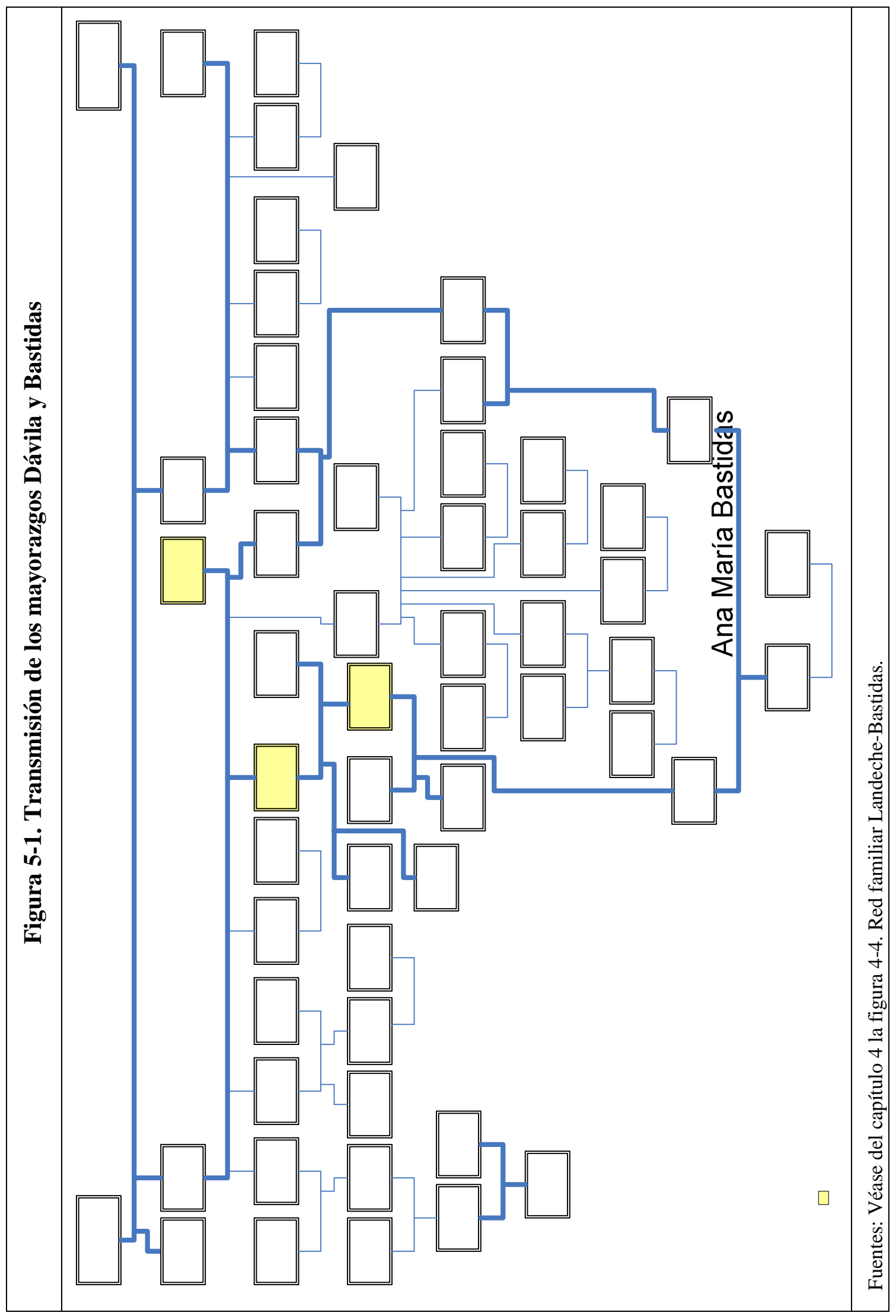


El mayorazgo Dávila y Bastidas además de proporcionar a los hacendados un sustancioso patrimonio, tenía por objeto preservar la continuidad del apellido y la preeminencia de su fundador. Se logró dicha permanencia gracias a la memoria familiar y a través de la utilización de algunos símbolos, como las sepulturas privilegiadas que poseían en la catedral y la exposición de escudos en sus casas y capillas privadas, que les sirvieron para recordar y evocar a sus antepasados, así como para demostrar su estatus social, pues no todos gozaban de tales insignias.

Aunque las capillas tenían una finalidad funeraria, cumplieron de igual forma la función propagandística. De hecho los poseedores del mayorazgo Dávila contaban con una capilla privada conocida como Nuestra Señora de los Remedios o de los Dávila, y con otras dos en la catedral (la capilla de las Ánimas y la Anunciación) y una en el convento Imperial de los Predicadores (la capilla de San Luís Beltrán). Mientras que los del mayorazgo Bastidas poseían en la catedral la capilla Santa Ana, también denominada la del obispo de piedra, ya que presentaba un panteón con la figura de un obispo de cuerpo entero representando a su fundador, Rodrigo de Bastidas ${ }^{66}$.

Otro miembro de la red familiar Landeche-Bastidas, Francisco Cabrera y Paredes, poseyó el mayorazgo Mosquera, de ahí que fuese conocido como Francisco Mosquera y Cabrera al anteponer el apellido de su fundador. Este mayorazgo era uno de los más antiguos. Fue fundado en 1546 por Juan Mosquera y Eufrasia de Pasamonte, con real licencia que les concedió la Corona en 1539. Tras numerosas transmisiones entró en este vínculo su madre María Paredes (Mosquera) y Heredia, quien al morir en 1783 lo sucedió en él. En el momento de su fundación este mayorazgo debía contar con numerosas fincas rústicas, pero hacia finales del siglo XVIII se "[...] hallaban disminuidas, detrimentadas y de mucho menor valor [...]"67. Igual que al dueño del mayorazgo Dávila, se le concedió a Francisco Mosquera y Cabrera permiso para venderlo y subrogarlo en

\footnotetext{
${ }^{66}$ Las capillas de las Ánimas y la Anunciación las habían heredado por vía materna y paterna, la primera había sido fundada por Ruiz Fernández de Fuenmayor, y la segunda por Gonzalo Fernández de Oviedo. Mientras que la del convento les recayó por ser descendientes por línea materna de Lope de Bardecí, su fundador. Véase en Rodríguez Demorizi, E., Familias Hispanoamericanas..., op. cit., pp. 228-239.

${ }^{67}$ Expediente con motivo de haber remitido el gobernador de la isla la instancia de Francisco Mosquera y Cabrera, vecino de aquella ciudad, pidiendo al rey la licencia para vender el vínculo que posee del propio apellido de ella y trasladarlo a cualquier otra parte de sus dominios, 23 de julio de 1798. AGI, Santo Domingo, 1000.
} 
otras fincas o imposiciones que asegurasen su permanencia en cualquier otro lugar del continente americano, aunque por el momento se desconoce lo que sucedió posteriormente ${ }^{68}$.

En 1799 también se concedió tal permiso al hacendado Nicolás Guridi y Frómesta, dueño de dos vínculos que fundó a principios del siglo XVIII el deán Lorenzo Solano Garavito ${ }^{69}$. Éstos estuvieron integrados por “[...] varias casas, y fincas rayces [...]" entre ellos un hato de ganado denominado Arroyo Hondo, en el valle de Baní; sobre los que además había impuesto unas capellanías a favor de su sobrino, y también deán Antonio de la Concha Solano ${ }^{70}$. Al morir éste pasaron a su madre Ana Solano Garavito, quien posteriormente traspasó a su hija María Merced, casada con Matías Guridi Coronado, transmitiéndose dentro de los Guridi hasta pasar a Nicolás Guridi y Frómesta.

Juan Mieses Ponce de León, miembro de esta familia, también poseyó dos mayorazgos y el patronazgo de una capellanía que había heredado de su padre, Francisco Mieses Ponce de León, cuando murió el 14 de junio de 1758 siendo capitán de una de las compañías del Batallón Fijo de la ciudad de Santo Domingo. La particularidad de estos vínculos es que estaban formados por huertas y tierras que se localizaban en la Península, concretamente en la villa Fuentelapeña, Zamora. Uno de ellos fue erigido por el clérigo Gonzalo de Mieses el 17 de abril de 1608, mientras que el otro por Alonso González Paz más tarde, el 11 de enero de 1628. Al morir Juan Mieses Ponce León un año después que su padre, su mujer Ana Guridi Concha pleiteó con otro familiar del mencionado pueblo, José de Mieses, quien los reclamaba como suyos. Ana, como tutora y curadora de su hijo mayor José María, defendió los derechos que les correspondían en la sucesión de

\footnotetext{
${ }^{68}$ Real Cédula de 18 de mayo de 1799 en la que se concede a Francisco Mosquera y Cabrera, vecino de Santo Domingo, la facultad para que pueda vender las fincas del mayorazgo que posee en dicha ciudad y que con su importe subrogue otras en la conformidad que expresa. AGI, Indiferente General, 1609.

${ }^{69}$ Lorenzo Solano Garavito era natural de Santo Domingo, y sus padres fueron el capitán y secretario de la Audiencia Antonio Solano Tovar y Magdalena Garavito, en Polanco Brito, H. E., “Los cabildos eclesiásticos de Santo Domingo y La Vega. Los deanes”. Casas Reales 14 (Santo Domingo, 1987) pp. 121-142, p. 135 y 136.

${ }^{70}$ Real Cédula de 9 de junio de 1799 concediéndole a Nicolás Guridi la facultad para que pueda vender las fincas de dos vínculos que posehe en la ciudad de Santo Domingo, y subrogar su importe en otras, según y en la forma que se expresa. AGI, Indiferente General, 1609.
} 
Ruth Torres Agudo

dichos mayorazgos, y por los que su suegro ya había pleiteado en 1720, otorgándole sentencia favorable en Valladolid el 1 de diciembre de $1737^{71}$.

${ }^{71}$ Autos en grado de apelación a la Chancillería de Valladolid de Manuel de Arbarza, escribano de cámara de ella a pedimento de José de Mieses quien litiga con el apoderado de Ana Guridi como madre, tutora y curadora de José María Mieses, vecino de Santo Domingo, isla Española sobre el goce de diferentes mayorazgos sitos en esta villa de Fuentelapeña, 1761-1764. AChV, Pleitos civiles, La Puerta Olvidados, 1378. 


\section{CAPÍTULO 6 EL ESTILO DE VIDA DE LOS HACENDADOS}

En la sociedad de aquella época el prestigio y el honor fueron aspectos propios de la condición de pertenencia al grupo dominante. Tan importante era ser uno de ellos como demostrarlo. Los principales hacendados de Santo Domingo llevaron una vida en la que la ostentación y la apariencia fueron elementos básicos, que los definía y distinguía dentro de su círculo de principales así como del resto de la población. En este sentido, el vivir noblemente, fue un hábito no sólo de los hacendados de Santo Domingo, sino también de la élite de la América colonial $^{1}$. Para alcanzar tan deseada distinción, los hacendados se sirvieron de varios atributos que manifestaron externamente el alto estatus que correspondía a los dominantes, por ejemplo la vestimenta, las casas en las que vivían, el consumo de productos, tales como joyas, alimentos, mobiliario, telas, carruajes, esclavos y otros símbolos. Si bien la riqueza proporcionaba un estilo de vida acomodado y de apariencia, también les proporcionaba prestigio social. El cual además emanaba de los grados universitarios, de los empleos administrativos, religiosos y militares,

\footnotetext{
${ }^{1}$ Este modo de vivir típico de la élite hispanoamericana ha sido destacado en distintas investigaciones, entre las cuales se puede señalar la obra clásica de Sanchíz Ochoa, P., Los hidalgos de Guatemala. Realidad y apariencia de un sistema de valores. Sevilla, 1976. Trabajos más recientes que señalan este tipo de comportamiento puede verse en Ramírez, S., Patriarcas provinciales: la tenencia de la tierra y la economía del poder en el Perú colonial. Madrid, 1991, pp. 145 y 196. Santos Pérez, J. M., Élites, poder local y régimen colonial. El cabildo y los regidores de Santiago de Guatemala, 1700-1787. Cádiz, 1999, pp. 154-164. Kicza, J., "Formación, identidad y estabilidad dentro de la élite colonial mexicana en los siglos XVI y XVII" en Schröter, B., y Büschges, C. (eds.), Beneméritos, aristócratas y empresarios. Identidades y estructuras sociales de las capas altas urbanas en América hispánica. Frankfurt, 1999, pp. 17-34, p. 25 y 26. Langue, F., Los señores de Zacatecas. Una aristocracia minera del siglo XVIII. México, 1999, pp. 368-391.
} 
del hecho de ser miembro de una familia distinguida, y de la posesión de títulos nobiliarios o la pertenencia a una orden de Caballería.

\subsection{Las residencias}

La posesión de una casa y un buen mobiliario fue una buena insignia de distinción de los hacendados de Santo Domingo. Aunque la finalidad de la casa era la residencia, su construcción y ubicación espacial proyectaba el estatus social de los que vivían en ella. La pervivencia de algunas de esas casas, muchas de ellas reformadas, permite que aún puedan ser admiradas hoy día. Su reconstrucción ha permitido conocer cómo fue su edificación, así como la traza y planta. Dentro de ese tipo de construcciones pueden distinguirse dos tipos de residencias que poseyeron los hacendados: la casa morada en la ciudad, también conocida como casa principal, y la casa-hacienda o casa de campo en los alrededores de ésta o en algún paraje alejado de la ciudad ${ }^{2}$. En cuanto al primer tipo, la vivienda de los hacendados situada en la ciudad era el espacio donde se desarrollaba la vida cotidiana. En ella además de vivir la familia propiamente dicha, padres e hijos, en algunas ocasiones también residían los hijos con sus respectivos cónyuges así como los esclavos domésticos, que tenían habitaciones apartadas del resto de la familia o en edificios contiguos a las casas de sus dueños. La posesión de esclavos era un símbolo de prestigio y una manera de marcar la diferencia entre las personas que pertenecían al grupo de las capas altas y las que no. Sin embargo, la mayor parte de la población hacía todo lo posible por tener al menos un esclavo negro como criado ${ }^{3}$.

Las casas solían disponer de una planta, y las más grandes e importantes contaban con dos pisos. Durante el siglo XVIII prevalecieron las residencias de dos pisos, como indica el viajero francés Moreau de Saint-Méry “[...] las casas de

\footnotetext{
${ }^{2}$ Las casas rurales recibieron distinta denominación según el país, así en Perú se conocían como haciendas o quintas, en Colombia y Brasil como hacienda, en Chile fundos, y en Argentina y México haciendas y estancias. A cerca de este tipo de arquitectura véase en Gutiérrez, R., Arquitectura y urbanismo en Iberoamérica. Madrid, 1984, pp. 321-341.

${ }^{3}$ Según Carlos Esteban Deive “[...] la posesión de un esclavo doméstico era hasta tal punto un símbolo de estatus que incluso aquellos blancos que vivían en la pobreza hacían malabarismos económicos para conseguir por lo menos uno. La casa podía carecer de ajuar o tener sólo lo indispensable, pero nunca o casi nunca faltaba en ella el criado negro [...]” en su obra, $L a$ esclavitud del negro en Santo Domingo (1492-1844). Santo Domingo, 1980, vol. I, p. 306.
} 
Santo Domingo, son bastante hermosas, de dos pisos, de un gusto sencillo y casi uniforme [...]”, frente al siglo XIX donde la tendencia arquitectónica fue la construcción de casas de un solo piso ${ }^{4}$. Las residencias de dos pisos debieron ser frecuentes durante casi toda la época colonial, pues ya en el siglo XVI existían y se les conocía con el nombre de "pares de casas”, mientras que durante el siglo XVIII aparece en la documentación con la denominación de “casas altas” o “casas altas y bajas”, y a las de una planta como “casas bajas” ${ }^{5}$.

Se distinguían también dos tipos de viviendas, por un lado aquellas que tenían dos habitaciones centrales (sala y comedor), que podían situarse en el primer piso o bien en el segundo, y a su alrededor estaban el resto de las habitaciones. Las casas más importantes solían tener un patio que se situaba en el centro de la casa o en un ala de la misma, generalmente cerrado por las paredes que se abrían con arcadas tanto en la planta baja como en la superior. El otro tipo de vivienda era aquella en la que las habitaciones centrales eran independientes y no contaban con luz. Se caracterizaba sobre todo por la posesión de elementos andaluces, como el patio y el traspatio, aunque con la peculiaridad de que en Santo Domingo estaban separados por un pasillo cubierto de bóvedas, por el que se llegaba a la cocina y demás estancias ${ }^{6}$.

Las residencias del hacendado en la ciudad se construían con cantería, piedra labrada o mampostería, es decir, una mezcla de piedra y ladrillo, materiales que fueron utilizados de forma aislada o conjunta para las paredes y solados de las casas principales ${ }^{7}$. Otro material utilizado para la fabricación de las casas fue la madera, que se empezó a emplear en la segunda mitad del siglo XVII y continúo

\footnotetext{
${ }^{4}$ Véase en su obra Descripción de la parte española de Santo Domingo. Ciudad Trujillo, 1944, p. 138.

${ }^{5}$ Escritura de venta de Andrés Lecanda y Gabriela Sánchez de una casa a Juan Francisco Pons, 10 enero de 1797. AASD, leg. 49, cajón 32, estante B. Véase también la siguiente bibliografía: Palm, E. W., Los monumentos arquitectónicos de La Española: con una introducción a América. Barcelona, 1955, vol. I, p. 152. Guerrero Cano, M․ M., "La ciudad de Santo Domingo a raíz de la anexión a España” en Torres Ramírez, B. (ed.), Andalucía y América. La influencia andaluza en los núcleos urbanos americanos. Sevilla, 1990, pp. 71-108, p. 77. Pérez Montás, E., Casas Coloniales de Santo Domingo. Colonial Houses of Santo Domingo. Santo Domingo, 1980, p. 123.

${ }^{6}$ Para un análisis amplio de las casas coloniales, véase Palm, E. W., Ibidem., pp. 150-154.

${ }^{7}$ Lescalier, D., "Itinerario de un viaje por la parte española de la isla de Santo Domingo (1764)" en Rodríguez Demorizi, E., Relaciones Geográficas de Santo Domingo. Santo Domingo, 1970, vol. I, pp. 111-141, p. 127. El sistema de mampostería siguió utilizándose durante el siglo XIX. Al respecto véase Hazard, S., Santo Domingo. Su pasado y presente. New York, 1873, p. 224, y Guerrero Cano, Ma. M., “La ciudad de Santo Domingo”..., op. cit., pp. 71-108, p. 81.
} 
utilizándose durante todo el siglo siguiente ${ }^{8}$. Los techos estaban levantados “[...] ordinariamente en plataforma, destinados a recoger las aguas fluviales para las cisternas [...]”9 . Asimismo estaban cubiertos de tejas o vigas, a diferencia de las casas de los mayordomos, esclavos, y en definitiva del resto de la población, que estaban fabricadas de madera y con un tejado de guano, yaguas, o cogollo* . Este tipo de construcción de casas era denominado bohío o bohío ramada ${ }^{10}$.

Figura 6-1. Bohío

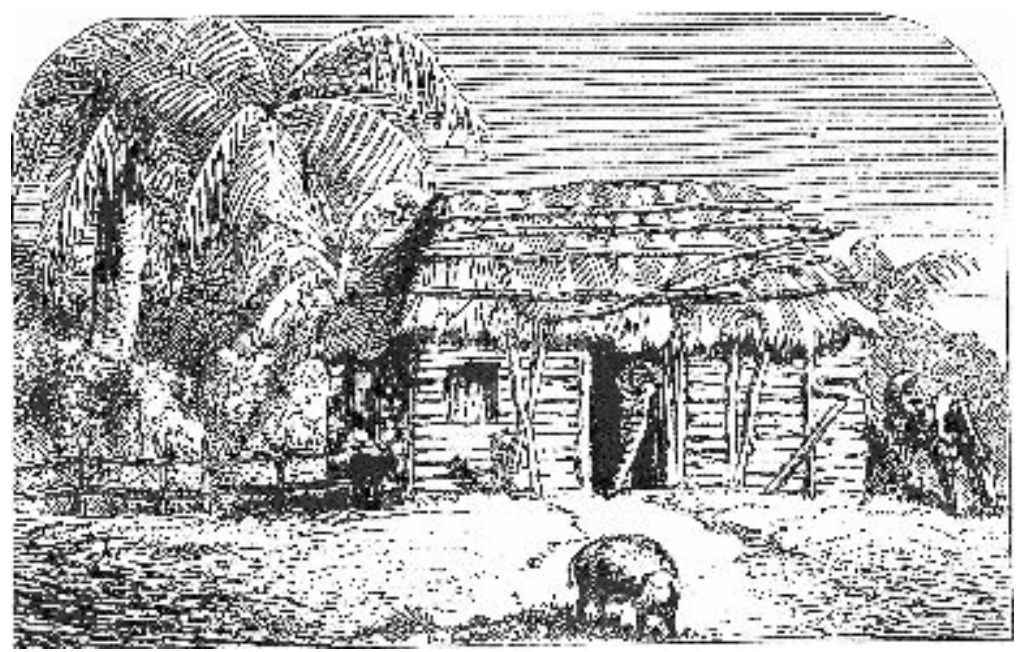

Fuentes: Hazard, S., Santo Domingo. Su pasado y presente. New York, 1873, p. 286.

Las ventanas y balcones de las viviendas de los hacendados estaban amparados normalmente con rejas de hierro, aunque también las había de madera. La descripción de como estaba construida la casa del hacendado Gregorio Saviñón ejemplifica a la perfección lo hasta ahora comentado:

\footnotetext{
${ }^{8}$ Moreau de Saint-Méry, M. L. E., Descripción de la parte española de Santo Domingo..., op. cit., pp. 137-138. Sánchez Valverde, A., Idea del valor de la Isla Española y utilidades que de ella puede sacar su monarquía. Santo Domingo, 1988, p. 109.

${ }^{9}$ Moreau de Saint-Méry, M. L. E., Ibidem., p. 38.

* Brotes de hojas de las palmeras o de otros árboles que sirven para diversos usos desde techar chozas o casas hasta envolver el tabaco en rama.

${ }^{10}$ En ocasiones bohío aparece en la documentación con varias grafías como bojío y bujío (o bogío). Se trata de una palabra de origen taína que se utilizaba para definir la vivienda indígena antillana, y que ha perdurado hasta los años cuarenta y cinco del siglo XX con el significado genérico para referirse a una casa pajiza, edificada tanto en el ámbito urbano como rural de la República Dominicana. Aunque en la actualidad este tipo de vivienda continúa edificándose en el área rural y enclaves turísticos. Sobre la evolución histórica del bohío véase en Cordero, W., "El bohío dominicano: de lo real a lo simbólico”. CLÍO 165 (Santo Domingo, 2003) pp. 103-128.
} 


\section{El estilo de vida de los Hacendados}

“[...] la casa tiene veinte varas y tercia, y de fondo por linea recta veinticinco varas, sus paredes maculadas y techadas de ladrillo, las paredes del costado de la casa y el sitio son de mediania con los lindantes, y la del fondo lo mismo. Fabrica en el patio, aposentos y cocina son todas techadas de ladrillo y de texas, igual que el medio pozo, pila, solado de la casa y del patio, y toda la casa por su frente esta adornada de rejas de fierro, calzada de la calle, sumidero, oficina y demas servidumbre [...]"11.

Otros elementos que distinguían las viviendas de los hacendados de las del resto de la población eran su ornamentación, su mobiliario y su ubicación espacial respecto del centro de la ciudad de Santo Domingo ${ }^{12}$. Es decir, donde estaba situada la plaza mayor, lugar concebido, al igual que en otras ciudades americanas, como elemento organizador y generador del entramado urbano. En la plaza mayor de Santo Domingo y sus alrededores era donde se asentaba el poder civil (cabildo) y eclesiástico (catedral), y desde ella partía “[...] ocho calles espaciosas tiradas a cordon que corren paralelas de Este al Oeste, y otras diez que las cruzan de Norte a Sur” ordenadas a modo de cuadras ${ }^{13}$. En calles cercanas a la plaza se encontraban otros poderes de gobierno, como el palacio de los gobernadores y las casas de los principales vecinos de la ciudad, entre las que había alguna de los hacendados estudiados ${ }^{14}$. Así las residencias de los hacendados y sus familiares se localizaban en la zona cercana a la catedral y en torno a los edificios de gobierno de la ciudad. Entre las calles más importantes de aquella época destacan la calle Las Damas, por ser una de las más antiguas, o la

\footnotetext{
${ }^{11}$ Escritura de reconocimiento a cargo de Gregorio Saviñón y Micaela Tapia sobre una capellanía que mandó fundar Aldonza Maldonado, 16 de enero de enero de 1793. AASD, leg. 45, cajón 33, estante B.

${ }_{12}$ Palm, E. W., Los monumentos arquitectónicos de La Española..., op. cit., vol. I, pp. 150-155 y vol. II, pp. 99-112.

${ }^{13}$ Breve Descripción de la Isla Española de Santo Domingo realizada por el Secretario de Cámara y Gobierno Joseph Castro Palomino, 25 de abril de 1783. BN, Manuscritos, 11.030, fol. 18.

${ }^{14}$ Sobre la importancia de la plaza mayor en las ciudades americanas véase Gutiérrez, R., Arquitectura y urbanismo en Iberoamérica..., op. cit., pp. 91-99. Para la plaza de Santo Domingo destacamos: Mañón Arredondo, M. J., Crónicas de la Ciudad Primada. Apuntes históricos de la muy noble y lustrosa ciudad de Santo Domingo Primada de Indias. Santo Domingo, 1992, pp. 5761, y Solano, F. de, "La plaza mayor hispanoamericana o la difusión del urbanismo en Santo Domingo”. Casas Reales 14 (Santo Domingo, 1987) pp. 93-118.
} 
calle Conde, también conocida como Imperial ${ }^{15}$. En el siguiente mapa de la ciudad de Santo Domingo aparecen reflejados los edificios más significativos de la ciudad. En él también se encuentran ubicadas las residencias de algunos hacendados en función de la calle en la que estuviesen, y en la tabla el número de casas que poseían en cada una de ellas. Domingo de la Rocha-Ferrer y Landeche era el que más tenía al contar con veinticinco casas, de entre las cuales la situada en la calle de Las Damas era su morada principal ${ }^{16}$. Le sigue Antonio Rojas con once propiedades (ocho casas, dos solares, y un bohío) y Nicolás Guridi y Frómesta con siete casas y un solar.

15 “Testamento de Jacinta de Castro y Urdaneta, 2 de junio de 1807” en Sáez, J. L., La Iglesia y el negro esclavo en Santo Domingo. Una historia de tres siglos. Santo Domingo, 1994, pp. 510511. Salvador Gautier, M., "Fundación de la ciudad de Santo Domingo". CLÍO 154 (Santo Domingo, 1996) pp. 135-144.

${ }^{16}$ Utrera, F. C. de, Don Rodrigo de Bastidas. Santo Domingo, 1930, pp. 240-241. 
Tabla 6-1. Casas de hacendados en la ciudad de Santo Domingo

\begin{tabular}{rcc}
\multicolumn{2}{c}{ Calle Baracaldo } \\
\hline Hacendado & $\mathbf{N}^{\mathbf{0}}$ de casas \\
Antonio Rojas & 2 (solares y \\
& & paredes)
\end{tabular}

\begin{tabular}{|c|c|}
\hline \multicolumn{2}{|c|}{ Calle Conde } \\
\hline Hacendado & $\mathrm{N}^{\circ}$ de casas \\
\hline José Tiburcio Sterling del Monte & 1 \\
\hline Juan Arredondo Vizcaíno & 1 \\
\hline José Jacinto Ramírez & $\begin{array}{l}2 \text { (una baja y un } \\
\text { bohío) }\end{array}$ \\
\hline \multicolumn{2}{|c|}{ Callejón del Hospital } \\
\hline Hacendado & $\mathrm{N}^{\circ}$ de casas \\
\hline
\end{tabular}

Calle Caño o de las Cuatro Calles

Hacendado $\quad N^{0}$ de casas

Nicolás Guridi y Coronado 1

Pedro Fernández de Castro 1

Andrés de Lecanda y Andirengoechea 1 (alta)

Antonio Rojas 4 (bajas)

\begin{tabular}{|cc|}
\multicolumn{1}{c}{ Calle Clavijo } \\
\hline \multicolumn{1}{c}{ Hacendado } & $\mathbf{N}^{\mathbf{0}}$ de casas \\
\hline Pedro Roig y Lluís & 1 \\
Julián Joaquín Pueyo y Urríes & 1 \\
Francisco Tapia y Castro & 1
\end{tabular}

\begin{tabular}{|cc}
\multicolumn{2}{c}{ Calle Cuesta de la Atarazana } \\
\hline Hacendado & $\mathbf{N}^{\mathbf{0}}$ de casas \\
\hline Nicolás Guridi y Frómesta & 1 (alta) \\
Marqués de Iranda & 5 (bajas)
\end{tabular}

\begin{tabular}{lc}
\multicolumn{2}{c}{ Calle Cuesta del Vidrio } \\
\hline \multicolumn{1}{c}{ Hacendado } & $\mathbf{N}^{\mathbf{0}}$ de casas \\
\hline Nicolás Guridi y Frómesta & 1 \\
Diego Antonio Ximénez & 1 (baja) \\
Antonio Álvarez Barba & 1 (alta)
\end{tabular}


Gregorio Saviñón ${ }^{17}$

1 (baja)

Ignacio Pérez-Caro y Oviedo

1

\begin{tabular}{lc}
\multicolumn{2}{c}{ Calle Las Damas } \\
\hline \multicolumn{1}{c}{ Hacendado } & $\mathbf{N}^{\mathbf{0}}$ de casas \\
\hline \multicolumn{1}{c}{ Antonio Landeche-Coca } & 1 \\
Domingo de la Rocha-Ferrer y Landeche & 1 \\
Fernando Mauleón & 1 (baja) \\
Marqués de Iranda ${ }^{18}$ & 1 (baja) \\
\hline \multicolumn{1}{c}{ Hacendado La Merced } & $\mathbf{N}^{\mathbf{0}}$ de casas \\
\hline Nicolás Guridi y Frómesta & 3 (dos altas y una \\
& baja) \\
\hline
\end{tabular}

Calle Nueva de la Merced

\begin{tabular}{rc}
\hline Hacendado & $\mathbf{N}^{\mathbf{0}}$ de casas \\
\hline Nicolás Guridi y Coronado & 1
\end{tabular}

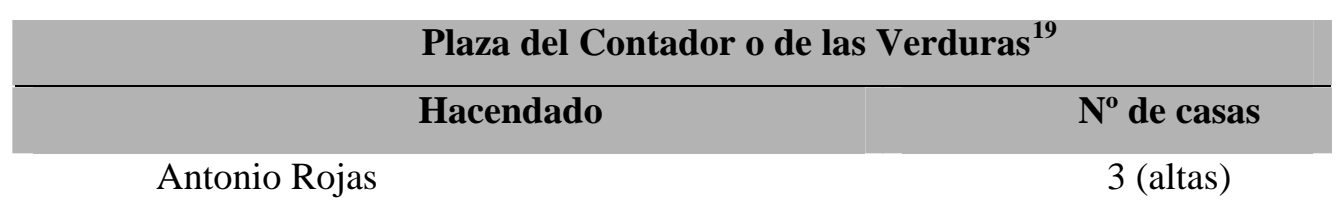

\begin{tabular}{|c|c|}
\multicolumn{2}{|c|}{ Plazuela del Carmen } \\
\hline Hacendado & $\mathbf{N}^{\mathbf{0}}$ de casas \\
\hline José Esteban Arredondo y Castro & 3 (una grande y \\
& dos pequeñas)
\end{tabular}

\begin{tabular}{rc}
\multicolumn{2}{c}{ Calle Plateros } \\
\hline Hacendado & $\mathbf{N}^{0}$ de casas \\
\hline Nicolás Guridi y Frómesta & 1 (alta) \\
Nicolás Guridi y Coronado & 1
\end{tabular}

\begin{tabular}{cc}
\multicolumn{2}{c}{ Calle Regina } \\
\hline Hacendado & $\mathbf{N}^{\mathbf{0}}$ de casas \\
\hline Nicolás Guridi y Frómesta & 1 (baja) \\
& \multicolumn{2}{c}{ Calle San Andrés ${ }^{20}$} \\
\hline
\end{tabular}

17 Situada concretamente en la placeta del Convento de Santo Domingo frente a su Iglesia.

18 La casa estaba situada en la esquina que forman dos calles, de una una parte la calle del Arquillo que conduce a la Catedral y a la Real Fuerza, y la otra la de Las Damas.

${ }^{19}$ Plaza también conocida como Plaza vieja y Mercado antiguo. 


\begin{tabular}{|c|c|}
\hline Hacendado & $\mathbf{N}^{0}$ de casas \\
\hline José de la Vega & 1 \\
\hline \multicolumn{2}{|c|}{ Calle Santa Bárbara } \\
\hline Hacendado & $\mathbf{N}^{0}$ de casas \\
\hline Antonio Rojas & 1 \\
\hline \multicolumn{2}{|c|}{ Calle Santa Clara } \\
\hline Hacendado & $\mathrm{N}^{0}$ de casas \\
\hline José Mañón de Lara & 1 \\
\hline Ignacio Pérez-Caro y Oviedo & 1 \\
\hline \multirow[t]{2}{*}{ Nicolás Guridi y Frómesta } & \\
\hline & 1 (solar) \\
\hline \multicolumn{2}{|c|}{ Calle San Diego } \\
\hline Hacendado & $\mathbf{N}^{0}$ de casas \\
\hline Domingo de la Rocha-Ferrer y Landeche & 24 \\
\hline \multicolumn{2}{|c|}{ Calle Santo Domingo } \\
\hline Hacendado & $\mathrm{N}^{0}$ de casas \\
\hline Nicolás Guridi y Coronado & 1 \\
\hline Pedro Campuzano Polanco & 1 \\
\hline Diego Antonio Ximénez & 1 \\
\hline
\end{tabular}

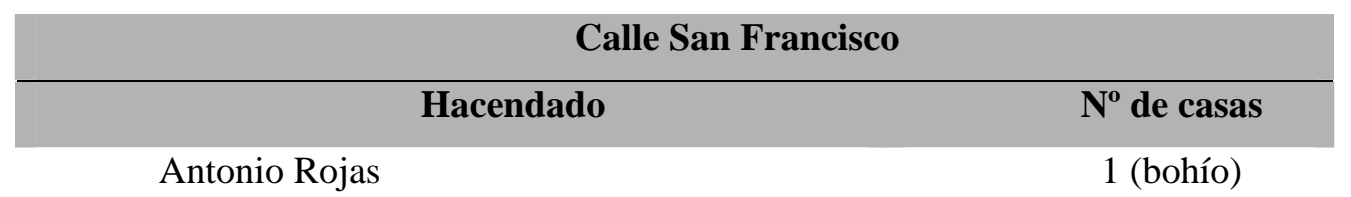

Elaboración propia. Fuentes: AASD, leg 47, cajón 32, estante B, y leg 49, cajón 32, estante B. AGI, Ultramar, 9. AGI, Santo Domingo, 946 947, 948, 960, 1015, 1037, 1038, 2683. Relación del Real derecho de alcabala cobrada en Santo Domingo, 1794. AGN, Documentación colonial, leg. 27, exp. 3. Rodríguez Demorizi, E., “Apuntes y documentos: el real derecho de alcabala. Libro de cargo y data de 1793”. CLÍO 108 (Ciudad Trujillo, 1956) pp. 165-185, p. 179. “Testamento de Jacinta de Castro y Urdaneta, 2 de junio de 1807” en Sáez, J. L., La Iglesia y el negro esclavo..., op. cit., pp. 510-511. Escriptura de fianza otorgada por parte de la testamentaria del Exmo. Señor Marques de Iranda con barias ypotecas, para satisfacer a diferentes acreedores 4.897 .676 reales de vellon el termino de tres años, en virtud de Real Orden de S. M., 30 de noviembre de 1806. AHPM, protocolo n ${ }^{\circ} 21764$, fols. 656 y 673.

${ }^{20}$ Ésta calle actualmente se llama Arzobispo Nouel, y era conocida en aquella época como los Nichos o del Arquillo, pero también recibió otros nombres. Así, las dos primeras cuadras hacia el este se conocía como los Nichos, mientras que el tramo siguiente al oeste calle de San Andrés. En ésta era donde estaba situada la casa de José de la Vega, haciendo esquina con la cuesta de San Miguel. 


\section{Figura 6-2. Plano de la ciudad de Santo Domingo y localización de las residencias de los hacendados}

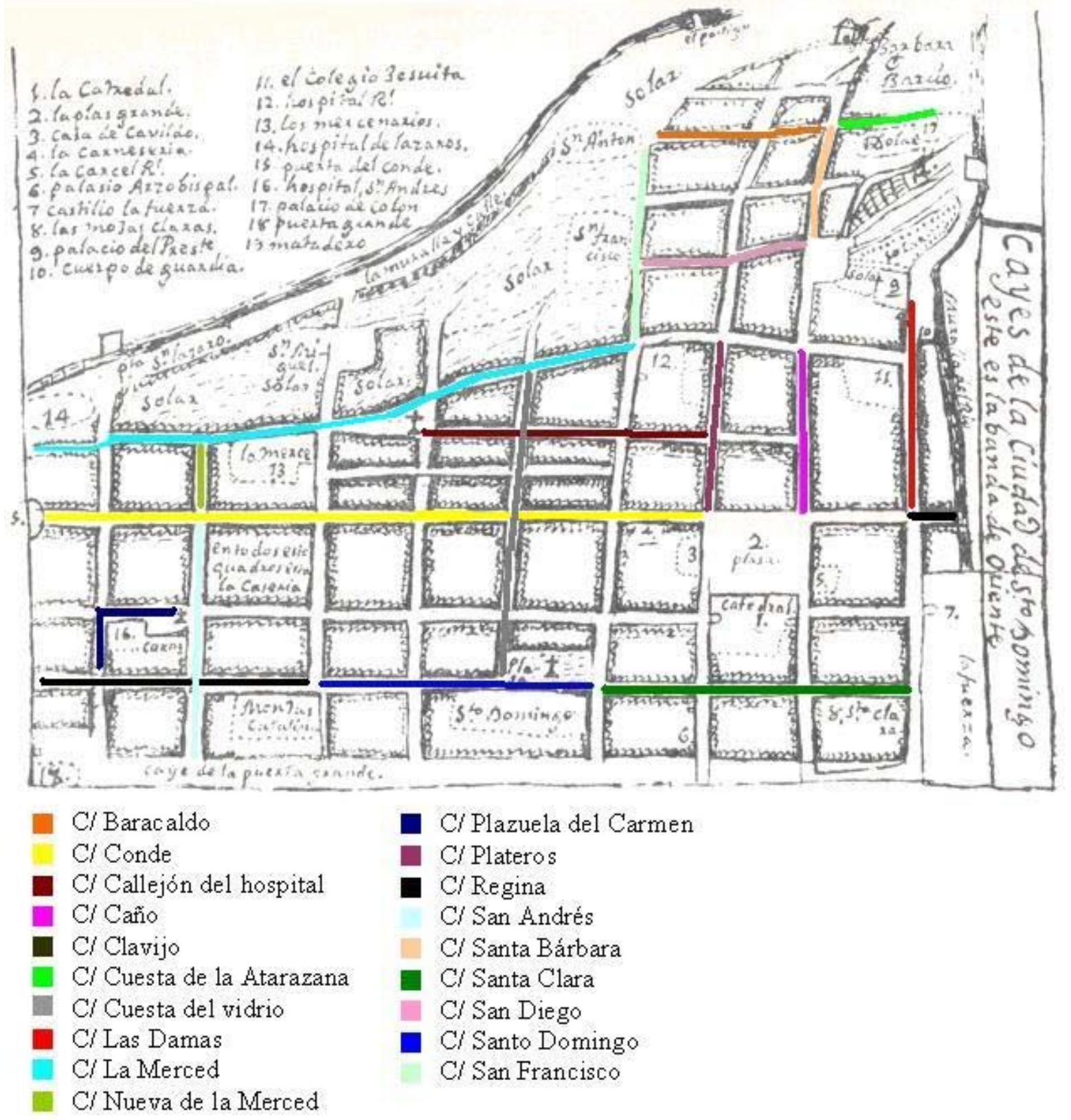

Elaboración propia. Fuentes: El plano de la ciudad procede de la obra de Peguero, L. P., Historia de la conquista de la isla Española de Santo Domingo. Trasumptada el año de 1762. Santo Domingo, 1975, vol. II, p. 19. Ugarte, M., Estampas coloniales. Siglos XVII-XIX. Santo Domingo, 1998, vol. II, pp. 169-174. Arnaiz, F. J., Más luces que sombras. Santo Domingo, 1989, pp. 189194. Salvador Gautier, M., "Fundación de la ciudad de Santo Domingo”..., op. cit. También véase tabla 6-1. 
Además de la casa morada en la que residían los hacendados, también tuvieron otras casas que solían alquilar. Entre los inquilinos figuran personas que estaban de paso en Santo Domingo, como comerciantes o ministros de la Audiencia. A modo de ejemplo, Antonio Dávila Coca y Landeche alquiló una casa al comerciante Francisco Irisarri por el que le pagaba mensualmente 16 pesos, mientras que Nicolás Guridi y Frómesta había arrendado una de las casas que poseía en la calle La Merced al regente José Antonio Urízar ${ }^{21}$.

Sin embargo, el alquiler fue algo transitorio para aquellos que acabaron instalándose en la ciudad. El arrendamiento de una o varias casas proporcionaba un ingreso adicional, como pone de manifiesto el hacendado José Arata, según el cual los alquileres de las cuatro casas que había aportado como dote su mujer, Micaela Sterling, les había permitido “[...] vivir con decencia a toda su familia [...]”antes de su salida de Santo Domingo hacia La Habana después de la cesión de esta parte de la isla a los franceses ${ }^{22}$. Pero el arriendo también presentaba el peligro de que el inquilino dejara de pagar la cantidad acordada. Esta morosidad podía ser motivo de desalojo o la necesidad del dueño de adquirir su casa. Tal fue el caso de Domingo de la Rocha-Ferrer y Landeche, dueño de una casa que había alquilado a Antonio Rojas situada en "[...] la calle que desciende del Convento de San Francisco a la Plaza del contador [...]” por 18 pesos anuales ${ }^{23}$. Sin embargo, desde 1772, año en el que fue alquilada, hasta 1791, Antonio Rojas no efectuó el pago del alquiler, por lo que Domingo le interpuso una demanda, pero fue Ignacio, su hermano, quien actuó como su representante ya que él se encontraba en Yucatán. Ante la declaración de Antonio Rojas como insolvente, pues tenía todos sus bienes embargados, la Audiencia tomó la decisión de vender un bohío

\footnotetext{
${ }^{21}$ Nicolás Guridi y Frómesta tenía su residencia frente a la casa alquilada, concretamente en el tramo de la calle La Merced donde estaba la capilla de la Altagracia. De ahí que también fuese conocida con ese nombre, calle de la Altagracia. Diarios de las providencias dadas por el superior Tribunal de la Audiencia de Santo Domingo, 1788. AGI, Santo Domingo, 994. Testimonio de justificación de una casa propiedad de Nicolás Guridi y Frómesta, 1798. AGI, Santo Domingo, 2683.

${ }^{22}$ Eran tres casas altas y una baja. Expediente de diferentes instancias del coronel José Arata y su mujer, en solicitud de que se les conceda alguna gracia por la pérdida considerable de bienes como consecuencia de su emigración de Santo Domingo, 20 de agosto de 1804. AGI, Santo Domingo, 1038.

${ }^{23}$ Se trata de la calle San Diego. Testimonio de la instancia seguida por el teniente Ignacio de la Rocha con poder de su hermano Domingo contra Antonio Rojas, sobre el cobro de unos pesos procedentes del arrendamiento del suelo y paredes correspondientes al mayorazgo Bastidas que posee Domingo, 1791. AGI, Santo Domingo, 1006.
} 
que poseía al lado de la casa alquilada, para que del dinero que se sacase se pudiera pagar lo que se debía a Domingo de la Rocha-Ferrer y Landeche ${ }^{24}$.

En cuanto al valor económico de los alquileres y de las casas, tan sólo se cuenta con esas dos referencias de alquiler y ciertas valoraciones para las casas de algunos de los hacendados estudiados, como muestra la siguiente tabla.

Tabla 6-2. Valor de las residencias de algunos hacendados en Santo Domingo

\begin{tabular}{|l|l|l|}
\hline \multicolumn{1}{|c|}{ Hacendado } & Número de casas & \multicolumn{1}{c|}{ Valor en pesos y reales } \\
\hline Andrés Lecanda y Andirengoechea & 1 & 8.045 \$ y 3 rs. \\
\hline Antonio Rojas & 11 & 31.555 \$ y 3 rs. \\
\hline Diego Antonio Ximénez & 2 & 13.830 \$ \\
\hline Fernando Mauleón & 1 & 3.780 \$ \\
\hline Gregorio Saviñón & 1 & $2.150 \$$ \\
\hline José Jacinto Ramírez & 1 & $2.200 \$$ \\
\hline José Esteban Arredondo y Castro & 3 & $6.600 \$$ \\
\hline José de la Vega & 1 & 8.608 \$ y 3 rs. \\
\hline José Tiburcio Sterling del Monte & 1 & $7.300 \$$ \\
\hline José Arata & 4 & 2.500 \$ \\
\hline Marqués de Iranda & 6 & $14.885 \$$ \\
\hline Nicolás Guridi y Frómesta & 8 & $37.000 \$$ \\
\hline
\end{tabular}

Elaboración propia. Fuentes: Véase tabla 6-1.

Los valores de las casas que se reflejan en la tabla se refieren a cuando éstas fueron compradas, menos en el caso de José Arata que las había aportado su mujer al matrimonio como dote, y las que poseía Nicolás Guridi y Frómesta en parte heredadas de su padre, y otras adquiridas por él. Entre otros, el Marqués de Iranda a través de su primo Juan Bautista Oyarzábal había comprado una casa baja en la calle Las Damas por un valor de 300 pesos en 1785, posteriormente reedificó la vivienda haciéndola de dos plantas para lo que expendió 12. 232 pesos. Las otras cinco casas cerca del muelle y que utilizaba como almacén lo había hecho en el precio de 2.353 pesos. Sólo en el caso de Antonio Rojas está incluido además el valor de los muebles. La residencia de José de la Vega con sus esclavos y muebles estaba tasada en 12.723 pesos, la de Nicolás Guridi y Frómesta situada en la calle

\footnotetext{
24 Ibidem.
} 
La Merced en 13.354 pesos y la de Gregorio Saviñón en 2.804 pesos y 2 reales hacia 1792, y siete años más tarde fue apreciada en 3.572 pesos $^{25}$.

Entre los hacendados que tuvieron su residencia habitual en otros lugares como la ciudad de Santiago destaca Francisco Espailltat y Virol, quien poseía tres casas y un solar que con toda su servidumbre estaban valoradas hacia 1786 en 28.800 pesos $^{26}$. En cambio, hubo algunos que al desempeñar un empleo fuera de la jurisdicción de la ciudad de Santo Domingo compraron o construyeron su propia casa en el pueblo, donde eran destinados. Así el teniente de justicia mayor de la banda sur, Felipe Guridi y Concha edificó su casa en Azua, pueblo cabecera de dicha área. Mientras que su sustituto José Esteban Arredando y Castro la compró $^{27}$.

Algunas casas de los hacendados fueron auténticas mansiones, entre las más representativas y que todavía hoy pueden contemplarse en la ciudad de Santo Domingo destacan la casa de los Bastidas y la de los Dávila. La primera de ellas fue construida por su dueño Rodrigo de Bastidas, un importante personaje de los primeros años de la colonia. Estaba situada en una de las calles más antigua de la ciudad, Las Damas, al lado del conjunto militar de La Fuerza. Durante la segunda mitad del siglo XVIII su poseedor fue Domingo de la Rocha-Ferrer y Landeche. Tras la invasión haitiana sufrió algunos destrozos por lo que tuvo que ser restaurada, aunque mantuvo el aspecto de las casas coloniales, como las naves

\footnotetext{
${ }^{25}$ Escriptura de fianza otorgada por parte de la testamentaria del Exmo. Señor Marques de Iranda con barias ypotecas, para satisfacer a diferentes acreedores 4.897 .676 reales de vellon el termino de tres años, en virtud de Real Orden de S. M., 30 de noviembre de 1806. AHPM, protocolo $\mathrm{n}^{\circ} 21764$, fols. 656 y 673. Resumen de los vienes que comprende el antecedente abaluo propios del capitán Joseph de la Vega, 15 de junio de 1805. AGI, Santo Domingo, 964. Escritura de reconocimiento de fianza realizada por José Francisco Hidalgo, 22 de octubre de 1774. AGI, Santo Domingo, 954. Gregorio Saviñón compró la casa el 23 de mayo de 1782 al regidor Francisco Cabral en 2.150 pesos, en Certificación de la escritura de venta de la casa realizada por José Abad, 19 de diciembre de 1792. AASD, leg. 45, cajón 32, estante B, y Certificación y tasación de los bienes de la casa de Gregorio Saviñón realizado por el escribano Martín Mueses, 1 de octubre de 1799. AASD, leg. 47, cajón 32, estante B.

${ }^{26}$ Su residencia era una casa de dos plantas situadas en la calle del Sol, donde también tenía un solar. Mientras que las otras dos en la calle Colón. Parece que también poseyó una cuarta casa en la plaza mayor, pleno centro de la ciudad de Santiago, en Campillo Pérez, J. G., Francisco Espaillat y el desarrollo del Cibao. Santo Domingo, 1985, pp. 19-20 y 139-140.

${ }^{27}$ Testimonio de los autos obrados por el licenciado Thomas Arredondo y Castro, abogado de la Real Audiencia y juez comisionado en la residencia tomada a Phelipe Guridi, teniente de justicia que ha sido de esta villa de Azua, y demas pueblos de esta banda sur, 1779. Y Testimonio de las diligencias practicadas sobre la suspensión del juicio de residencia del brigadier Manuel Gonzalez en consecuencia de la Real Cedula de 20 de diciembre de 1790. AHN, Consejos, 20.766.
} 
alargadas en plano rectangular alrededor del patio adornadas con arcos de distinto tipo. En las mencionadas naves se encontraban las habitaciones ${ }^{28}$.

Figura 6-3. Casa de Bastidas

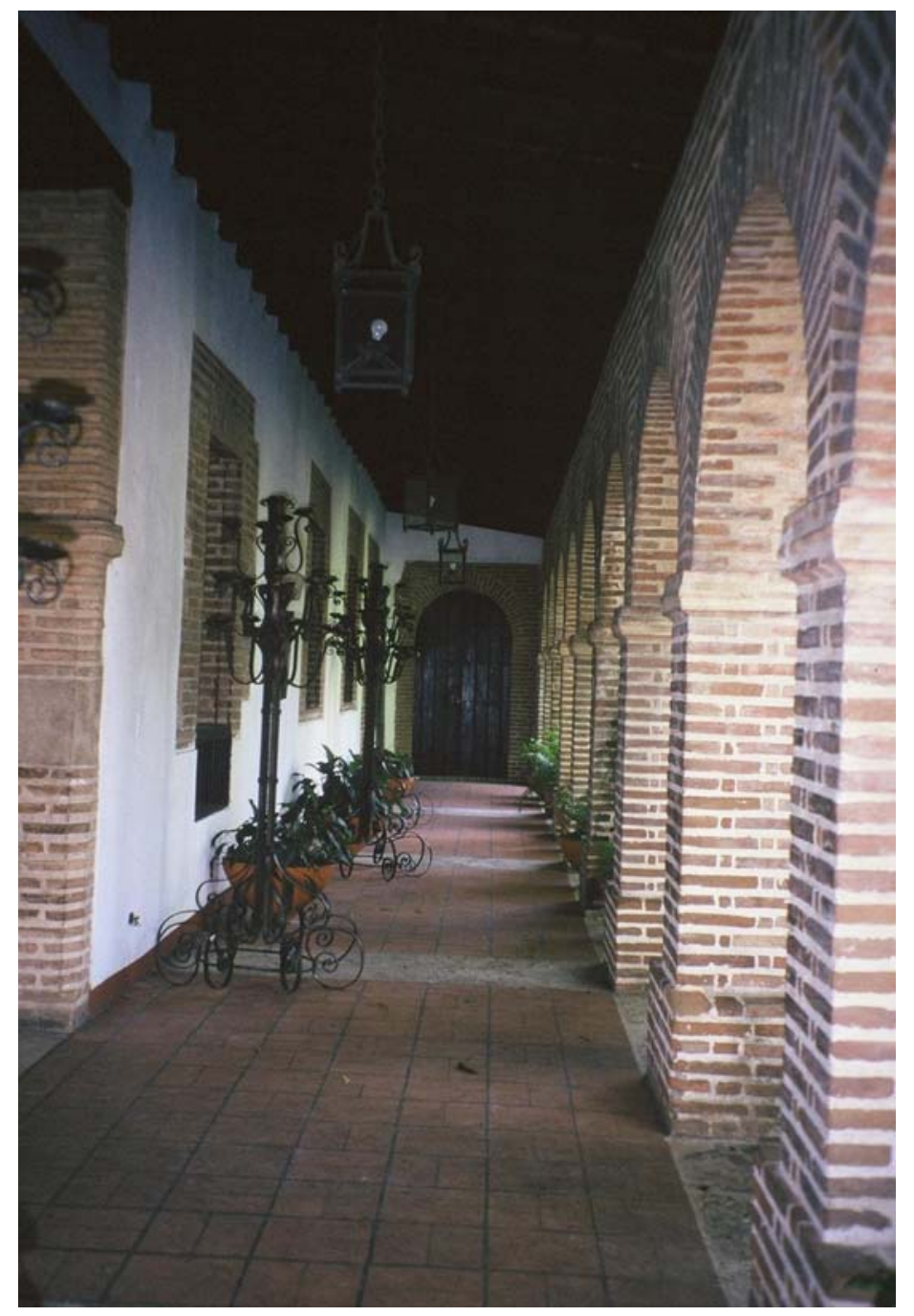

Pasillo lateral formado por arcos que dan acceso al patio central, y a las dependencias

Foto: autora

El dueño de la segunda casa fue Francisco Dávila, regidor y oidor de la Audiencia. Está considerada como un símbolo del éxito y riqueza de los encomenderos, y de la grandeza del Santo Domingo del siglo XVI. En el siglo XVIII el descendiente y heredero Antonio Dávila Coca y Landeche fue quien la

\footnotetext{
${ }^{28}$ En la actualidad esta casa ha sido transformada en un museo infantil. Respecto a esta casa colonial véase Ugarte, M., Monumentos coloniales. Santo Domingo, 1977, pp. 226-231. Pérez Montás, E., Casas Coloniales..., op. cit., pp. 175-187.
} 
poseyó. Esta residencia se levantó en los terrenos del mayorazgo de la propia familia y estuvo situada en la calle de Las Damas. Fue una de las casas más completas, y la única que contó durante el periodo colonial con su propio fuerte, una ermita privada, conocida como Nuestra Señora de los Remedios o Capilla de los Dávila, y un mirador que dominaba la desembocadura del río Ozama ${ }^{29}$.

Esta construcción constaba de dos plantas y en su interior un patio con arcadas, alrededor del cual se disponían las dependencias existentes en ambas plantas. La portada de su entrada estaba decorada con dos puertas con dovelas de arco plano. En uno de los portales debió reposar el escudo de la familia, cuyos detalles parece que desaparecieron tras la invasión haitiana. En cambio, tras su restauración se hallaron “[...] vestigios de dos figuras quiméricas en posición rapante, con cuerpo de león y alas y cabeza de águila [...]” de ese escudo ${ }^{30}$.

El fuerte, llamado Invencible, también era conocido como el Fuerte de Don Antonio. Esta fortificación se construyó en el siglo XVII, cuando la Corona pidió a sus súbditos de La Española que contribuyesen para completar la muralla de la ciudad iniciada en el siglo XVI. Su propietario no sólo colaboró con la obra, sino que levantó su propio bastión de sólidos sillares de piedra en su casa, el cual tuvo doce troneras para cañones. La capilla de los Remedios estaba situada al final de la ya citada calle de Las Damas, frente al inicio de la calle de las Mercedes. El templo se articulaba en planta de cruz latina, y aunque fue reconstruida con ladrillo, pareció estar hecha en sus orígenes de piedra. En la parte superior de la fachada se podía observar un nicho vacío que servía para contener la imagen de la Virgen de los Remedios o el escudo de armas de los Dávila, cuestión sobre la que aún no hay unanimidad entre los investigadores ${ }^{31}$.

\footnotetext{
${ }^{29}$ Actualmente esta casa es un hotel de la compañía Sofitel. A cerca de la casa Dávila véase Ugarte, M., Ibidem., pp. 129 y 210.

${ }^{30}$ Ibidem., pp. 210-213.

${ }^{31}$ A cerca del templo privado véase Ugarte, M., Ibidem., pp. 125-129. Otra obra de la misma autora Iglesias, capillas y ermitas coloniales. Santo Domingo, 1995, pp. 207-212. Véase también algunos datos que ofrece Rodríguez Demorizi, E., Familias Hispanoamericanas..., op. cit., pp. 228-239.
} 


\section{Figura 6-4. Templo privado y escudo nobiliario de los Dávila}

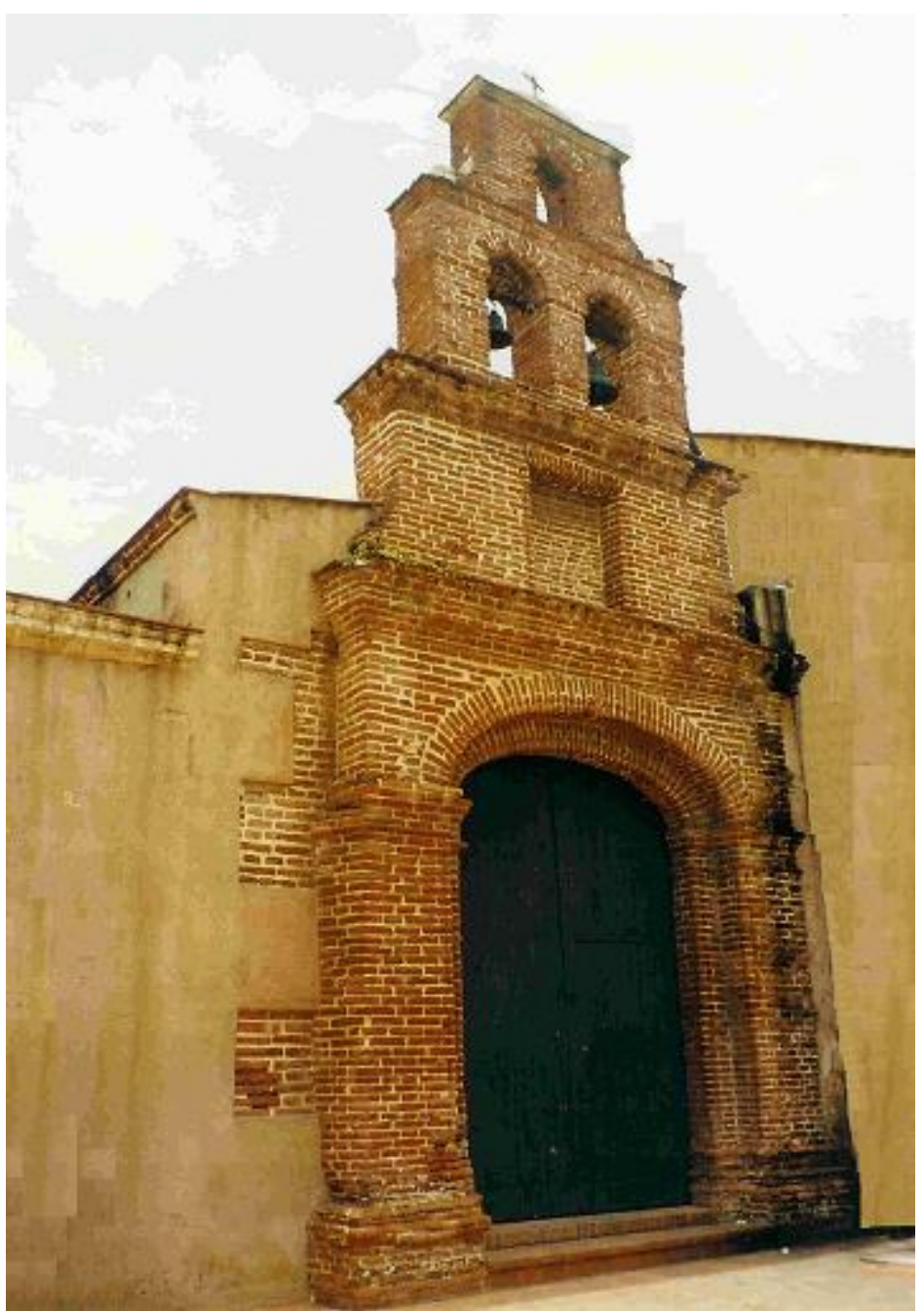

Fachada de la

Capilla de Nuestra

Señora de los Remedios o de los Dávila

Escudo de armas situado sobre la fachada de la casa de los Dávila

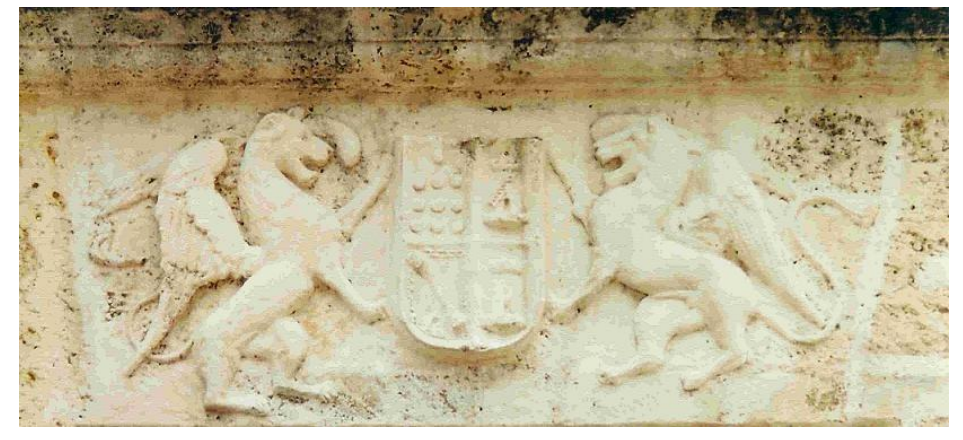

Fotos: autora

En cuanto a la casa-hacienda, sus orígenes se remontan a los inicios del auge de la economía azucarera en Santo Domingo. Se trataba de una casa de campo con amplio espacio, que solía edificarse en las cercanías de alguna orilla de un río, y en alguna ocasión se elevaba sobre el terreno lo que permitía tener 


\section{El estilo de vida de los Hacendados}

visibilidad de los caminos, el jardín, conucos y las tierras de cultivo. La dimensión de esta casa era mayor que la de las urbanas, y constaba de varias habitaciones destinadas a dormitorios, cocina, despensa y los despachos dedicados a tertulias de sobremesa y reuniones. En estas salas había normalmente un pequeño dormitorio. Los materiales utilizados en su construcción eran la piedra y el ladrillo, también utilizados para el solado, reservándose la madera para los techos, vigas, puertas y ventanas que presentaban cerraduras, bisagras, pasadores y rejas de hierro. En torno a la casa se organizaban otros edificios: la ermita privada y el oratorio público, la noria, los depósitos de herramientas y utensilios de trabajos, los almacenes para los productos agrícolas, las casas de trabajo integradas por las carpinterías, herrerías, el ingenio, la de purga y calderas, y los bohíos del mayordomo y de los esclavos. Sólo algunas de estas propiedades contaron con un hospital y una botica e incluso una cárcel, como fue el caso de la finca La Angostura, propiedad de Francisco Espaillat y Virol $^{32}$.

Buenos ejemplos de este tipo de vivienda, y que todavía hoy pueden visitarse, son la casa grande de Palavé y el Palacio de Engombe. La primera está sobre una pequeña colina, del lado occidental del río Haina. La casa estaba situada en los terrenos de la estancia de cacao cuyo nombre era San José, aunque la mansión tomó el nombre del paraje del lugar, de ahí que se la conozca en la actualidad como casa de Palavé. Se desconocen sus orígenes, tan sólo se sabe que en el siglo XVII debió ser la morada de Rodrigo Pimentel, un rico propietario de ingenios de aquella época. Durante el siglo XVIII estuvo en manos de la familia Heredia, su propietario fue Nicolás Heredia Serrano Pimentel, luego pasó a su yerno Antonio Angulo Coca-Landeche, siendo su último propietario el poeta José María de Heredia hacia finales de dicho siglo ${ }^{33}$.

\footnotetext{
${ }^{32}$ Campillo Pérez, J. G., Francisco Espaillat..., op. cit., pp. 137-138.

33 Sobre el conjunto de la casa Palavé y sus dueños véanse las informaciones dadas en las siguientes obras: Pérez Montás, E., Monumentos históricos y arqueológicos. México, 1984, p. 390. Mañón Arredondo, M., Crónicas de la Ciudad Primada..., op. cit., pp. 161-167. Ugarte, M., Estampas coloniales..., op. cit., vol. II, pp. 67-99.
} 


\section{Figura 6-5. Residencia rural de Palavé}

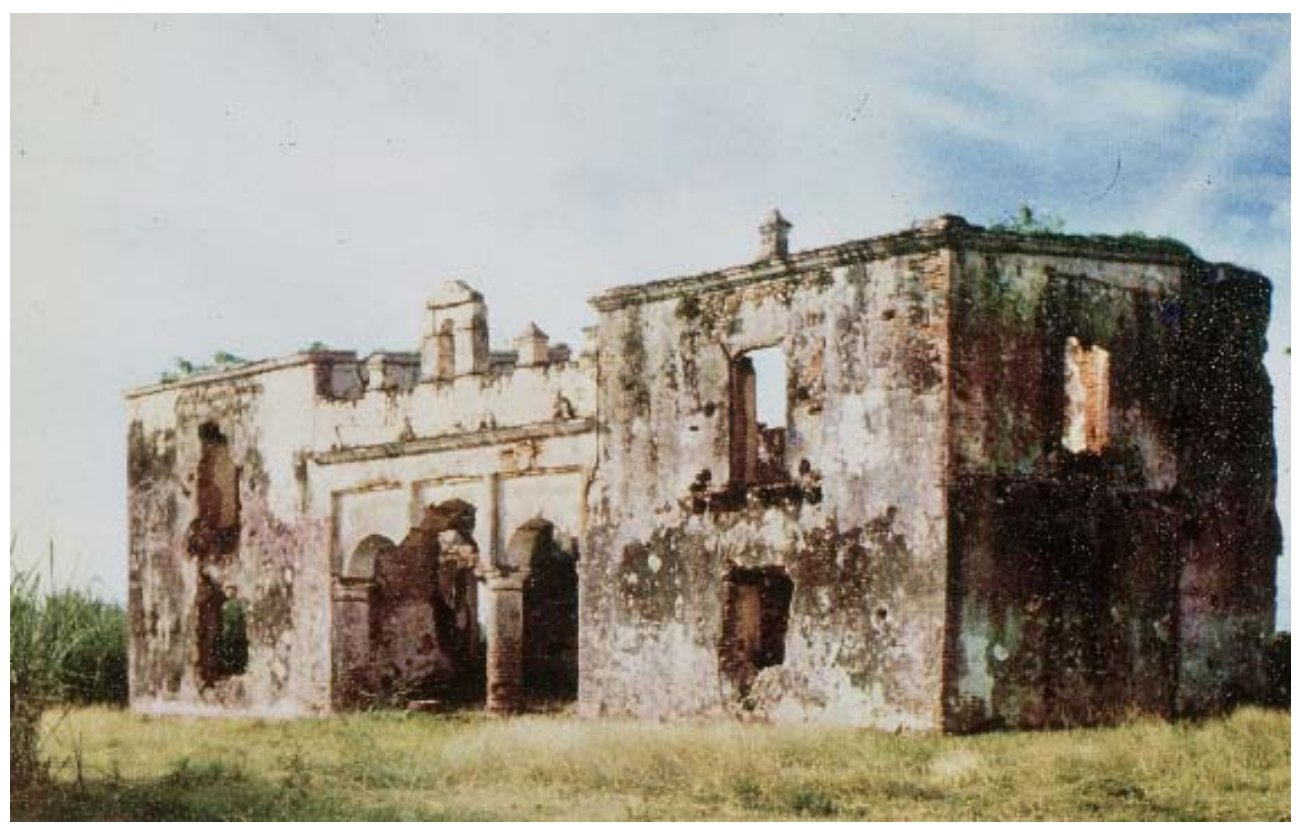

Fuentes: Pérez Montas, E., Casas coloniales de Santo Domingo..., op. cit., p. 54.

El Palacio de Engombe está situado en el margen izquierdo del río Haina, cerca de su desembocadura, dista a unos quince kilómetros de la ciudad de Santo Domingo. Este palacio fue la vivienda de los propietarios del ingenio de azúcar que llevaba el nombre de Santa Ana de Engombe. Perteneció de igual forma que la anterior casa descrita a la familia Dávila, hasta que en el siglo XVIII pasó a sus descendientes, los Coca-Landeche y los Angulo ${ }^{34}$. Construido en la primera mitad del siglo XVI, el palacete constaba de dos plantas y en cada piso de varias habitaciones, siendo dos las centrales flanqueadas por cuartos más pequeños. En uno de ellos se encontraba el hueco de la escalera. La fachada principal tenía dos ventanas grandes, una en cada planta, sencilla la del primer piso y más adornada la del segundo. En los laterales del edificio también se han conservado las ventanas, las cuales debieron tener balcones. La mayoría de las investigaciones arquitectónicas e históricas consideran que este monumento tiene una acentuada

\footnotetext{
${ }^{34}$ El Palacio de Engombe y sus alrededores fue propiedad del dictador Leónidas Rafael Trujillo. Posteriormente una parte pasó a manos del gobierno que lo donó a la Universidad Autónoma de Santo Domingo (UASD), a la que pertenece en la actualidad. En dicho terreno se creó una finca experimental para dar prácticas a los estudiantes de agronomía y veterinaria. Al respecto véase Ugarte, M., Monumentos coloniales..., op. cit., p. 194. Jiménez, P. E., Los negros esclavos en la historia de Bayona, Manoguayabo y otros poblados. Santo Domingo, 1993, pp. 215-224.
} 
similitud con el Alcázar de Diego Colón, situado en la ciudad de Santo Domingo $^{35}$.

\section{Figura 6-6. Alcázar de Diego Colón}

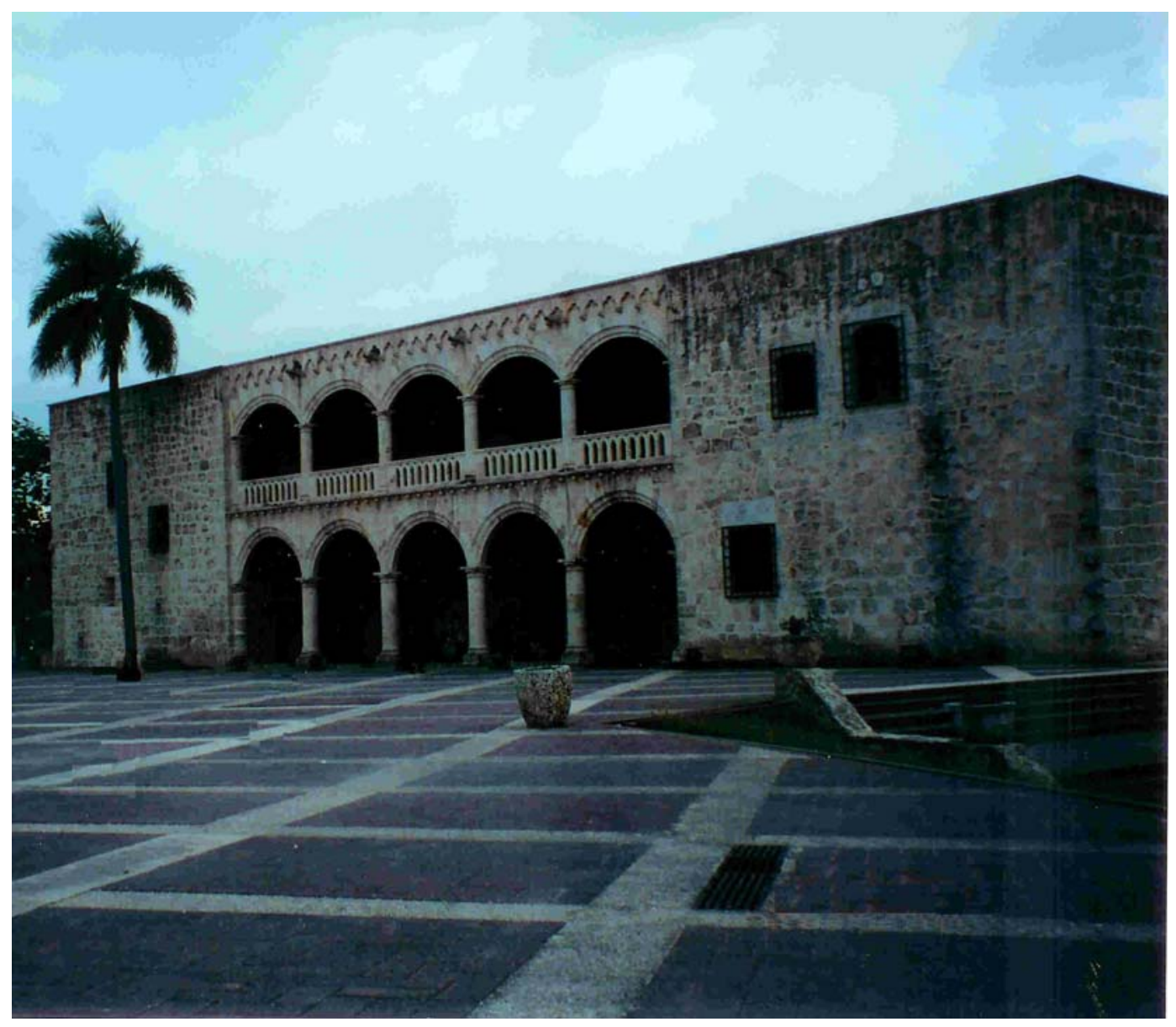

Foto: autora

En el área de espacio del ingenio se ha conservado también la ermita, que debió estar ricamente adornada, pues según un inventario realizado en 1795 aparecen en la capilla imágenes y adornos como una cruz, dos vinagreras de plata, un platillo y una campanilla de metal, un cáliz y una patena, un campanario con su campana, dos candeleros de metal, un misal, una esterita, cuatro candeleros dorados y un frontal de lienzo pintado cuyo valor era de 1.196 pesos $^{36}$.

\footnotetext{
${ }^{35}$ Ugarte, M., Ibidem., pp. 194-199. Véase también Ugarte, M., Iglesias, capillas y ermitas coloniales..., op. cit., pp. 233-237. Jiménez, P. E., Ibidem., pp. 29-30.

${ }^{36}$ García Lluberes, L., "Miscelánea histórica. (Extractos de los Cuadernos de Apuntes del Historiador García). El ingenio Santa Ana de Engonve”. CLÍO 102 (Ciudad Trujillo, 1955) pp. 3944, p. 42.
} 
El templo estaba construido de cal y canto de piedra sobre una sola nave, con un ábside poligonal cubierto por una cúpula de media naranja. Tenía amplias ventanas y una entrada con un portal que sostenía un dintel formado por grandes dovelas, además contaba con un campanario con su campana ${ }^{37}$.

Junto a la casa y la ermita, parece ser que también existieron otras estructuras pertenecientes al complejo del ingenio, como las casas de trabajo (de purga, herrería, ingenio y calderas) construidas de cal y canto y con techo de yaguas o de cogollo, y la casa del mayordomo. Entre otras construcciones que hubo destaca un edificio cuyo destino se desconoce, pero se piensa que probablemente sirvió como galpón de esclavos o almacén de productos. De este último tan sólo quedan restos, y se encuentra sin restaurar a diferencia de la casa y la ermita, como se puede observar en las imágenes que siguen ${ }^{38}$.

\section{Figura 6-7. Plano de la casa de Engombe}

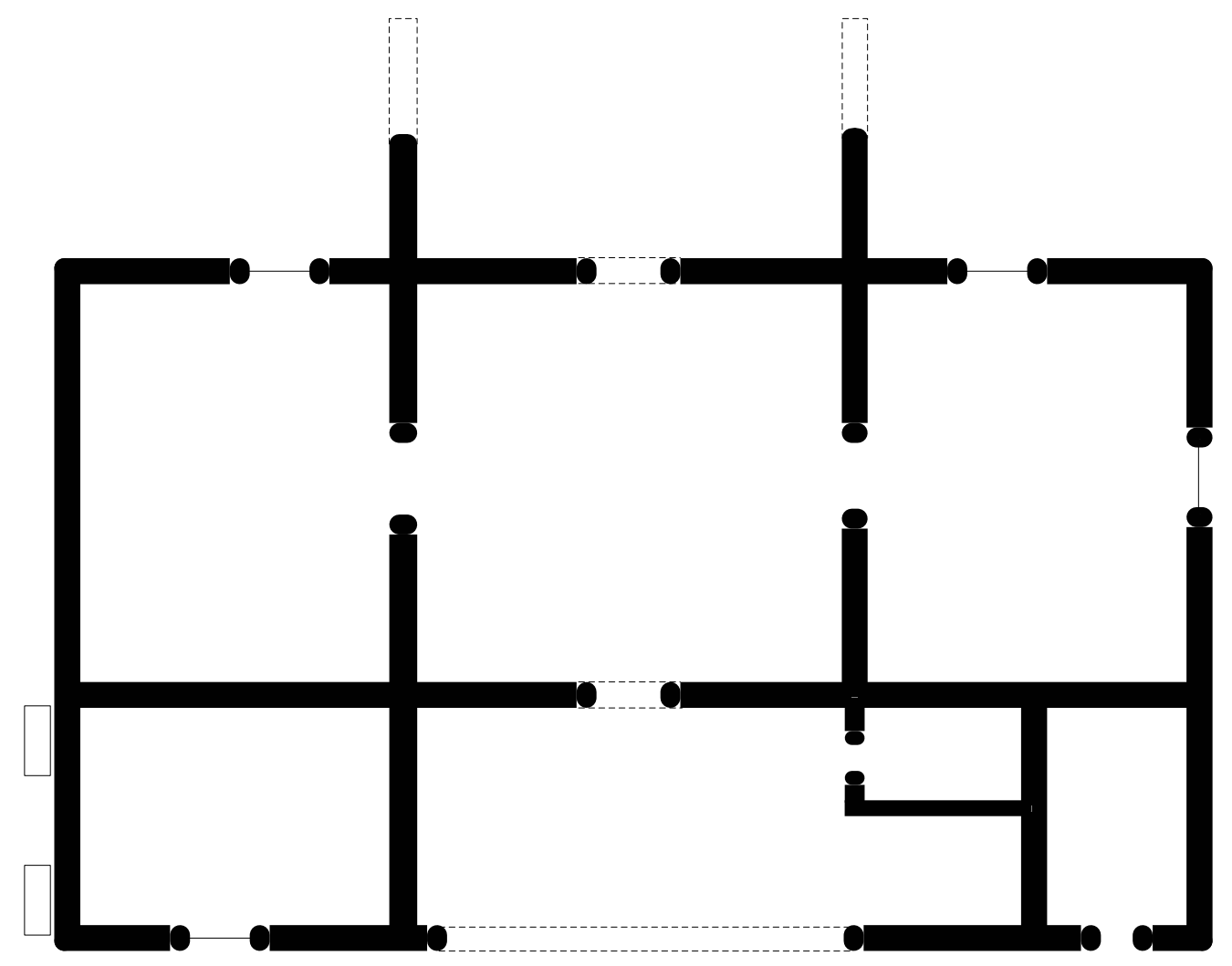

Fuentes: Palm, E. W., Los monumentos arquitectónicos de La Española..., op. cit. vol. I, p. IX.

\footnotetext{
${ }^{37}$ Ugarte, M., Iglesias, capillas y ermitas coloniales..., op. cit., pp. 233-237. Pérez Montás, E., Monumentos históricos y arqueológicos..., op. cit., pp. 388-389.

${ }^{38}$ Idem., y Ugarte, M., Monumentos coloniales..., op. cit., pp. 194-199.
} 
Figura 6-8. Imágenes del ingenio de Santa Ana de Engombe
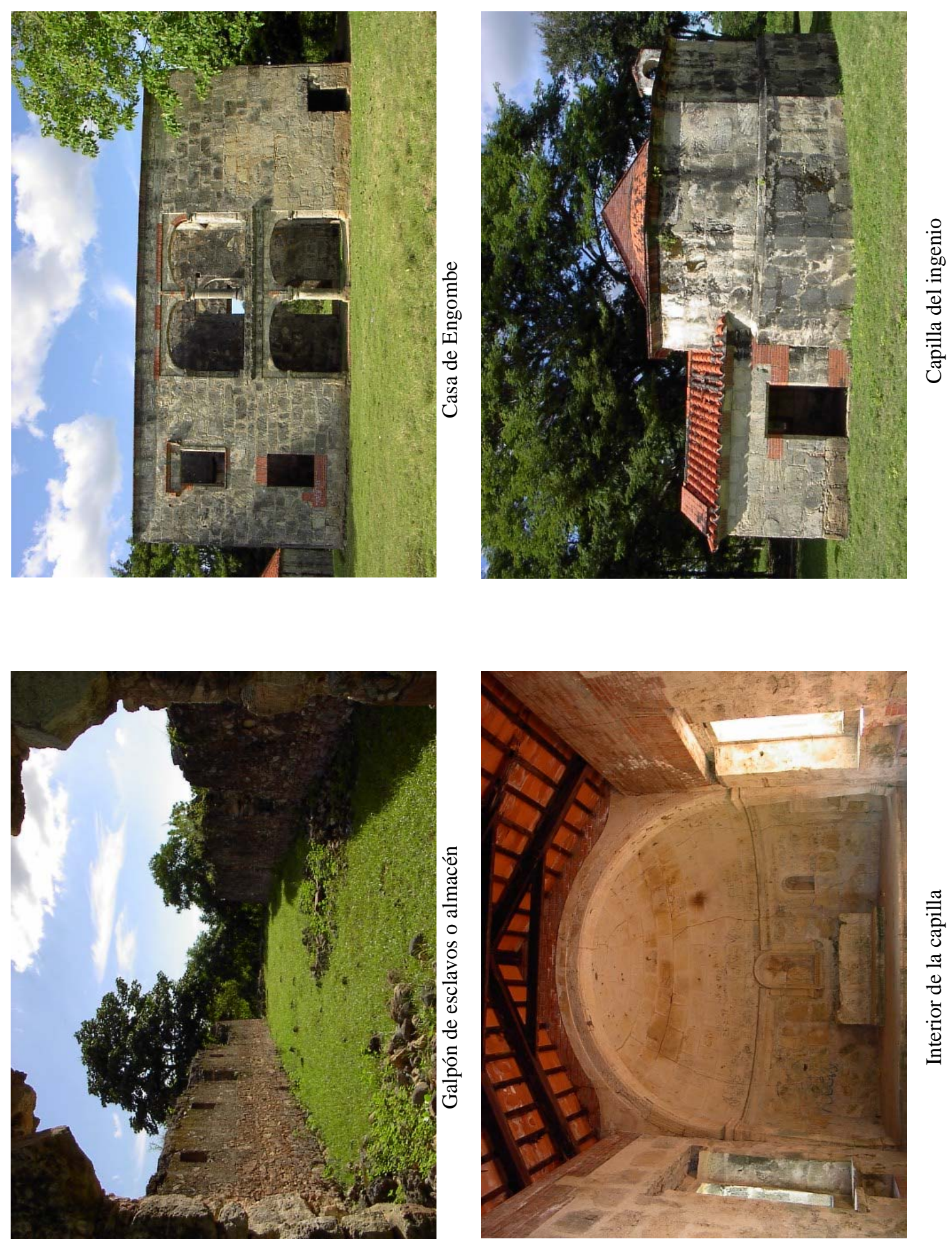

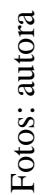




\subsection{El consumo de productos lujosos}

Los hacendados incorporaron a su vida el lujo y la ostentación, como puede verse en el ambiente interior de sus casas a través de la decoración de pinturas en sus paredes, grandes piezas de mobiliario y el consumo de productos de lujo para comer y vestir. Para tener en cuenta estos aspectos de los hacendados se han utilizado algunos de los inventarios de sus bienes realizados en la segunda mitad del siglo XVIII, en concreto el del tesorero oficial de las cajas de Santo Domingo, Raymundo Esparza. Éste permite apreciar la riqueza suntuaria del interior de sus residencias, tanto de la casa que poseía en la ciudad de Santo Domingo como de su casa-hacienda llamada El Guayabal, situada al otro lado del río Ozama de la ciudad de Santo Domingo.

Al igual que la casa de Engombe, la casa del campo era de dos plantas y estaba construida toda ella de ladrillo. En la primera planta se hallaban la sala principal o comedor, un gabinete y dos aposentos, uno el despacho y otro un dormitorio, y en la de arriba dos gabinetes más. La escalera que permitía el acceso a la segunda planta era de rosca, contaba con veinte escalones y en su pie había un pilar con dos arcos pequeños y tres bóvedas. Al lado de la casa se encontraba una ermita con una portada de pilastras y un arco de ladrillo, y del otro lado un bohío con dos habitaciones. En una de ellas debía estar la cocina y en la otra la despensa. Cerca de la casa principal también estaba la casa del mayordomo con cobija de tablas, y cuatro bohíos más, uno para el almacén de frutas, otro utilizado de gallinero, y los dos restantes como ingenio de yuca y para guardar sus avíos. La casa también contaba con una noria fabricada de plomo muy cerca del huerto. En la estancia principal los muebles eran de maderas nobles y su valor ascendía a 1.650 pesos. En las paredes de los cuartos había colgaduras de láminas y mapas ${ }^{39}$. Sin embargo, fue en la residencia de la ciudad de Santo Domingo donde la decoración y los bienes representaban el gusto refinado y suntuoso del propietario. La casa de la ciudad contó con tres aposentos, una sala principal comedor, un

\footnotetext{
${ }^{39}$ Testimonio de las diligencias del inventario y avalúo de los bienes que quedaron por muerte de Raymundo Esparza, tesorero oficial real de estas cajas de Santo Domingo. Y Testimonio de la pieza comprensiva del inventario y avalúo de la casa estancia de labrar frutos nombrada El Guayabal, sita en el otro lado del río de esta ciudad perteneciente al difunto Raymundo Esparza. AGI, Santo Domingo, 992.
} 
gabinete de reuniones con un dormitorio, una cochera, una biblioteca, una cocina y una despensa ${ }^{40}$. Entre los artículos de buena calidad que poseía se encuentran los muebles de madera de caoba que simboliza opulencia, y el espinillo considerado de menor calidad. En los aposentos existieron mesas y sillas, con gran variedad de formas y tamaños, destacando una de mármol en la sala principal y escritorios en las salas destinadas a reuniones, llamados en aquella época gabinetes. Los asientos más utilizados fueron las sillas de brazo, de paja, las poltronas con almohadones y cojines forrados de damasco, y taburetes con canapé. Los objetos para el servicio de la mesa mostraron gran variedad de loza inglesa, francesa y china, cristalería fina, y cubertería de plata compuesta por cucharas, tenedores, cuchillos, platos, bacinas, flamenquillas, lebrillos, bandejas y cafeteras, entre otros. Las paredes de la casa estaban cubiertas por cuadros y láminas de retratos en los que predomina la temática hagiográfica como por ejemplo, la imagen de Santa Clara, la efigie de Nuestra Señora de Guadalupe y la de Nuestra Señora de la Soledad, con marcos de plata y vidriera. Junto a este tema también aparecen otros como láminas del dios Baco, el retrato del Conde de Aranda, así como pinturas italianas, retratos de reyes, y varios de temática pastoril.

En las alcobas se encontraban los catres, especie de armadura de cama, con el colchón de tafetán, sábanas y sobrecamas de algodón y lienzo. El dormitorio se completaba con mesitas de noche, silla, taburete o canapé, espejo, lavadero y armarios roperos. Al igual que los esclavos domésticos para la casa eran signo de riqueza, también lo era la posesión de esclavos dedicados al trabajo del cultivo de la tierra y cuidado de los animales. Raymundo Esparza tuvo un número notable de ellos, como otros hacendados estudiados. En total, en el inventario practicado en 1786, vienen señalados nueve esclavos para el servicio doméstico de la casa de la ciudad y cincuenta y cinco esclavos en la estancia, habiendo de todas las edades y de ambos sexos, y oscilando su precio entre los 125 y 400 pesos.

Otro aspecto importante que cabe resaltar dentro de la casa de la ciudad para conocer el ambiente de lujo en el que vivía este hacendado, es el que refiere

\footnotetext{
${ }^{40}$ Para no repetir continuamente la información que se proporciona procede del Testimonio de las diligencias del inventario y avalúo de los bienes que quedaron por muerte de Raymundo Esparza, tesorero oficial real..., Ibidem.
} 
el consumo de productos de importación. En el inventario se encuentran gran cantidad de telas de importación, tejidos y ropas de altas calidades y de todo tipo, lo que permite conocer como se vestía y su casa. Raymundo Esparza como tesorero de la Real Hacienda llevó un uniforme compuesto de casaca, chupa, calzón de grana y volantes, chalecos y calzones de angarípolas de lienzo, seda o tafetán de distintos colores. La mayor parte de las camisas, corbatines, pañuelos, peinadores, sábanas, colchas, mantelerías, delantales, cortinas y paños importados de Asia eran de algodón, morcelina, raso, seda y tafetán; mientras que los que eran traídos de la Península eran de hilo y lienzo.

Los productos comestibles también presentaron gran variedad y cantidad, pueden mencionarse: barricas de aceite y aguardiente de Orleans, vino de Burdeos y de Grenoble, vino blanco de Jerez, cerveza, aceitunas, alcaparras, ciruelas pasas, jamones y queso. Otro aspecto significativo que demostró la ostentación de los hacendados fue la posesión de carruajes y alhajas. Siguiendo con el inventario de Raymundo Esparza, se hallaron dos calesas, y respecto a las joyas un relicario de plata, pendientes de vidrio, una sortija de piedras blancas, varios relojes franceses de oro, una cadena de oro para reloj, hebillas de oro y piedras para el corbatín, a parte de la cubertería y loza de plata ya citadas.

A este respecto, otros inventarios de bienes de hacendados también recogieron la posesión de calesas y joyas, como el del oidor Ramón Jover, quien a su vez poseyó dos calesas. En cuanto a las joyas destacan un rosario con una gran cruz de oro francés y otros más de cuentas negras y sin cruz, aretes franceses de piedras verdes y azules, esmeraldas, mancornas de botones de oro de filigrana y hebillas de piedras entre otras ${ }^{41}$. El inventario del contador Francisco de Paula Gazcue y Olaiz contenía con una amplia variedad de objetos de oro y plata, desde una cubertería hasta relicarios, pulseras, jarrones, alfileres, rosarios, anillos, hebillas y relojes, valorados todos ellos en 1.075 pesos y 1 real $^{42}$. De la nómina de alhajas de oro que poseyó el comerciante y hacendado Antonio Rojas, destacan aretes, mancornas, cadenitas, terno de hebillas tanto para hombre como para

\footnotetext{
${ }^{41}$ Testimonio de los autos de inventario y avalúo de los bienes que quedaron por fallecimiento de Ramón Jover, oidor que fue de esta Real Audiencia y murió intestado en la ciudad de Santiago de Cuba, 26 de noviembre de 1786. AGI, Santo Domingo, 992.

${ }^{42}$ Testimonio de tasación y peso de un cajón con prendas de oro y plata que poseía Francisco Gazcue, 16 de marzo de 1790. AGI, Santo Domingo, 997.
} 
mujer, un dedal, dijes para pañuelos y relojes. Entre las de plata había cuatro candeleros grandes con sus brazos, cuyo monto conjuntamente, además de algunos esclavos y una balandra, rondaba los 3.836 pesos y 7 reales ${ }^{43}$.

\subsection{Las bibliotecas}

Si bien las relaciones de bienes ofrecen una idea aproximada de la opulencia en la que vivían los hacendados, los libros son un buen indicativo cultural. En los inventarios de Raymundo Esparza y Ramón Jover se encuentran unas listas detalladas de libros que conformaron destacadas bibliotecas, lo que permite conocer las inquietudes intelectuales de estos hacendados. Además dan idea de que éstos estaban puestos al día desde el punto de vista literario, pues entre las numerosas obras se hallan libros muy representativos de la Ilustración ${ }^{44}$. (Véase en el anexo las tablas 5 y 6 )

La biblioteca de Raymundo Esparza estaba en su casa de la ciudad de Santo Domingo y debió contar con un número de 171 libros. Éstos mostraban una gran variedad temática desde literatura, política, derecho o idiomas, a Ejército, historia y educación. Dentro de las obras literarias destacan cuatro tomos de Quevedo y ocho de Benito Feijoo con su Teatro Crítico y Cartas. Sobresalen los libros de cursos de gramática, diccionarios y aprendizaje de los idiomas inglés y francés, y de historia como La Historia General de España del padre Juan de Mariana. También deben mencionarse las cuarenta y seis obras de relatos de la Historia General de los Viajes del abate Prévost, presentes en las bibliotecas

\footnotetext{
${ }^{43}$ Testimonio de lo últimamente obrado en el asiento de la contrata de tabacos de Su Majestad, 14 de mayo de 1785. AGI, Santo Domingo, 947.

${ }^{44}$ A cerca de las bibliotecas privadas en la ciudad de Santo Domingo durante el siglo XVI y XVIII véanse las siguientes publicaciones: Mira Caballos, E., “Algunas consideraciones en torno a la primera biblioteca de Santo Domingo”. ECOS 3 (Santo Domingo, 1994) pp. 147-153. Deive, C. E., "Las bibliotecas privadas en la ciudad de Santo Domingo durante el periodo colonial" en VVAA., La ciudad de Santo Domingo en la literatura. Santo Domingo, 1996, pp. 135-147. Véase también las lecturas de Gregorio González de Cuenca, presidente de la Audiencia hacia 1581 en Martínez Hampe, T., "Lecturas de un jurista del siglo XVI”. AEA XLI (Sevilla, 1984) pp. 143-193, y en su obra Bibliotecas privadas en el mundo colonial. La difusión de libros e ideas en el Virreinato del Perú (siglos XV-XVII). Madrid, 1996, pp. 107-117.
} 
privadas tanto europeas como indianas durante la segunda mitad del siglo $\mathrm{XVIII}^{45}$

Mucho mayor que la biblioteca de Raymundo Esparza fue la del oidor Ramón Jover, quien murió en Cuba en 1785. El inventario de los bienes que poseyó en dicha ciudad y en su casa de Santo Domingo contiene una relación de unos 301 volúmenes. Al igual que la biblioteca de Raymundo Esparza, la de Ramón Jover estuvo compuesta por obras de muy diversas materias, destacando especialmente las referentes a su profesión, es decir, estudios y tratados de derecho. Obras de autores clásicos como Séneca, Aristóteles, Cicerón, Virgilio, Tácito, Tertuliano Quinto Septimio y sobre la legislación indiana poseía Política Indiana de Solórzano, la Nueva Recopilación de Indias, así como la obra de Ribadeniera, Patronato Indiano. También los tratados sobre Arte de cartas, y Arte de escribir. Las obras literarias que más sobresalen son las de autores españoles como Fray Luis de León, La Perfecta Casada, y de Salazar Las Poesías. Entre los autores americanos destacan los textos de Sor Juana Inés de la Cruz ${ }^{46}$.

Estas bibliotecas son buena muestra de la cultura y el grado de conocimiento de los hacendados, pues la variedad de volúmenes que había les servían para su deleite e instrucción personal o como guía profesional. Pero también suponen otro indicativo social de su estatus, ya que la posesión de libros era privilegio de una minoría debido a su elevado costo, así como por las dificultades de su transporte al continente americano desde España.

\subsection{Posición social y honores}

La élite además de expresar su distinción y posición social a través del modo de vida, también se sirvieron para ello de otros elementos como la posesión de un título nobiliario o la pertenencia a alguna de las órdenes de Caballería. Exhibir algún título de este tipo constituía una diferencia más dentro de los de su misma calidad. Pero al contrario de lo que ocurría en México, Perú y La Habana,

\footnotetext{
${ }^{45}$ Testimonio de las diligencias del inventario y avalúo de los bienes que quedaron por muerte de Raymundo Esparza, tesorero oficial real de estas cajas de Santo Domingo. AGI, Santo Domingo, 992.

${ }^{46}$ Testimonio de los autos de inventario y avalúo de los bienes que quedaron por fallecimiento de Ramón Jover, oidor que fue de esta Real Audiencia y murió intestado en la ciudad de Santiago de Cuba, 26 de noviembre de 1786. AGI, Santo Domingo, 992.
} 
donde su obtención fue una práctica común entre los miembros de la élite, en Santo Domingo fue más bien escasa, prácticamente inexistente ${ }^{47}$. Algunos de los títulos que existían habían sido concedidos en los primeros tiempos de la colonia, como el que tuvo la familia Colón, conocido como el Ducado de Veragua ${ }^{48}$. En la época en que se centra este trabajo fueron más bien pocos los personajes que disfrutaron de un título nobiliario. Por ahora tan sólo se tiene conocimiento del título de Barón de la Atalaya, concedido en 1771 como recompensa al hatero, Juan Guzmán, quien había fundado a costa de su dinero y tierras un poblado llamado San Miguel de la Atalaya, cercano a la frontera con los franceses ${ }^{49}$. Otros que contaron con un título fueron los gobernadores, como Francisco Rubio y Peñaranda y José Solano y Bote, caballeros de la Orden de Santiago, o el teniente de rey Luís Casasola, miembro también de la misma orden.

Entre los hacendados estudiados que lograron obtener un título en alguna orden de Caballería destaca Damián Coca Landeche y Oviedo, quien fue admitido como caballero en la Real Maestranza de Caballería de Ronda el 14 de mayo de 1786. Su hermano Antonio, también fue aceptado como caballero maestrante en dicha orden ingresando el 12 de octubre de $1795^{50}$. Otro hacendado, Nicolás Guridi y Frómesta, solicitó a la Corona obtener la cruz supernumeraria en la Real

\footnotetext{
${ }^{47}$ Entre la abundante bibliografía hispanoamericana al respecto destacamos algunos de los trabajos más representativos sobre México, Perú y Cuba. Flores Galindo, A., Aristocracia y plebe en Lima, 1760-1830: estructura de clases y sociedad colonial. Lima, 1984. González-Ripoll Navarro, Ma. D., Cuba, la isla de los ensayos. Cultura y Sociedad (1790-1815). Madrid, 1999, pp. 131-137. Langue, F., Los señores de Zacatecas..., op. cit.

${ }^{48}$ Acerca del Ducado de Veragua véanse: Mañón Arredondo, M. J., Crónicas de la Ciudad Primada..., op. cit., pp. 27-34. Veragua, D. de, "El Archivo de la Casa ducal de Veragua”. Hidalguía 28 (Madrid, 1958) pp. 413-424; “La creación del duque de Veragua”. Hidalguía 37 (Madrid, 1959) pp. 785-800, y “Ducado de Veragua”. CLÍO (Santo Domingo, 1975) pp. 14-18. Luque Talaván, M., Bibliografía española de genealogía, heráldica, nobiliaria y derecho nobiliario en Iberoamérica y Filipinas (1900-1997). Madrid, 1999, pp. 29-30 y 35.

49 Para obtener noticias sobre el Barón de la Atalaya véanse las siguientes referencias bibliográficas: Moya Pons, F., Historia colonial de Santo Domingo. Santiago, 1977, p. 290. Sánchez Valverde, A., Idea del valor de la Isla Española y Utilidades que de ella puede sacar su monarquía. Santo Domingo, 1988, pp. 207-208. Sevilla Soler, Ma. R., Santo Domingo. Tierra de Frontera (1750-1800). Sevilla, 1980, p. 62. Hernández González, M. V., "La colonización de la frontera dominicana en la segunda mitad del siglo XVIII. La fundación de San Rafael de la Angostura. Las Caobas y San Miguel de la Atalaya”. CLÍO 167 (Santo Domingo, 2004) pp. 113146, y La colonización de la frontera dominicana (1680-1795). Las Palmas de Gran Canaria, 2005, pp. 218-232.

${ }^{50}$ Primer Libro Maestro. ARMCR, fols. 39, y 11.
} 
y distinguida orden española de Carlos III $^{51}$. No obstante, no hemos tenido la oportunidad de encontrar documentación que nos confirme de su ingreso.

La escasez de títulos entre los hacendados no significó que éstos no gozasen de prestigio social entre la élite de la ciudad, pues como ya se ha expuesto en los epígrafes anteriores, basaron su estatus en la reputación pública a través del mantenimiento de un estilo de vida en cierto modo noble, atendiendo a su vestimenta, la decoración de sus casas y el consumo de productos. Además los hacendados hicieron uso de otros elementos con los que proyectarse socialmente y justificar su elevada posición.

Los grados militares y académicos de los hacendados les proporcionaban honorabilidad, pero también el desempeñar un empleo eclesiástico o civil. Ocupar y ejercer algún cargo de esos tipos estuvo considerado como una manera de demostrar no sólo la capacidad de una persona para ejercer un puesto, sino también sobre todo el estatus social del grupo familiar al que se pertenecía. No hay que olvidar que para ocupar un cargo en la administración de la ciudad de Santo Domingo, en especial en el cabildo, una de las condiciones exigidas a sus miembros era ser vecino, honesto y honrado. De modo que la ocupación de un cargo estaba vinculada a un reconocimiento de prestigio social ${ }^{52}$.

En Santo Domingo la pertenencia a un linaje puro se determinaba mediante la presentación de informaciones de calidad y de limpieza de sangre. Esta documentación servía para certificar la calidad de una persona y la de su familia, así como la de sus cónyuges en caso de estar casados. Para poder ejercer algunos empleos en el cabildo, y más específicamente el oficio de regidor, este tipo de información se convirtió en indispensable durante la segunda mitad del siglo XVIII ${ }^{53}$. A través de dicha documentación se puede observar que uno de los

\footnotetext{
${ }^{51}$ Carta de Nicolás Guridi y Frómesta en la que adjunta relación de sus méritos y servicios para ser condecorado con la cruz de la orden de Carlos III, 12 de febrero de 1799. AGI, Estado 18.

${ }^{52}$ De ahí que según Büschges la ocupación de este tipo de puestos estaban considerados como “empleos de honor”, en Büschges, C., "Las leyes del honor. Honor y estratificación social en el distrito de la Audiencia de Quito (siglo XVIII)”. Revista de Indias 209 (Madrid, 1997) pp. 68-77, y "La formación de una nobleza colonial. Estructura e identidad de la capa social alta de la ciudad de Quito (siglos XVI-XVIII)” en Schröter, B., y Büschges, C. (eds.), Beneméritos, aristócratas y empresarios..., op. cit., pp. 215-231, p. 228.

53 Este hecho se dio habitualmente en los cabildos americanos, como por ejemplo en la región de Puebla, Nueva España, donde para poder obtener alguna regiduría también fue necesario presentar documentación que acreditase la limpieza de sangre. Véase al respecto en Castillo
} 
requisitos exigidos para ser aceptado era tener un estatus étnico de blanco o español, demostrar que una persona y su familia no eran moros o judíos, o mulatos o pardos. Ante la movilidad social y mezcla de razas en la América colonial, y en concreto en Santo Domingo donde la población esclava era tan abundante, los mulatos tenían prohibida la participación en los cargos públicos y clericales. Sin embargo, en ciertos casos la Corona concedió certificaciones que habilitaron a un individuo y a sus descendientes para ocupar algún oficio público $^{54}$. Pero esto no significó que la familia evitara el estigma de la mancha de sangre que conllevaba que un miembro de la familia tuviera ascendencia negra, como ya se puso de manifiesto en el segundo capítulo, cuando Francisco Cabral y Maldonado quiso obtener el oficio de regidor. Se evidencia así la importancia del color en aquella sociedad y el rechazo que suponía, pero fundamentalmente se muestra como el color de la piel se convirtió en un elemento diferencial y de prestigio social entre los hacendados ${ }^{55}$. Además fue utilizado como un modo de restringir la entrada en el cabildo.

La verificación de la ascendencia hispánica o española también aparece en las probanzas de limpieza de sangre presentadas por los regidores. Estas informaciones trataban de exponer la calidad y capacidad de los demandantes, así como de sus ascendientes. A veces también se describían los lazos de sus hermanos, tíos y familiares de su mujer mediante la legitimación de casamientos de sus parientes, lo cual era probado con las partidas de matrimonios y bautismos de los padres, abuelos y bisabuelos. Asimismo aclaraban en lo posible los méritos y servicios conseguidos por éstos. En ellas también aparecía certificado el estatus de nobleza peninsular, que podía manifestarse a través de dos formas. Una era la demostración de que por alguna línea, generalmente la de la mujer, se descendía de los conquistadores y primeros pobladores de Santo Domingo, los cuales fueron ennoblecidos por las hazañas y servicios que prestaron a la Corona. La otra

Palma, N. A., "Los estatutos de "pureza de sangre” como medio de acceso a las elites: el caso de la región de Puebla” en Castañeda, C. (coord.), Círculos de poder en la Nueva España. México, 1998, pp. 105-129. Sobre este tipo de documentación en Santo Domingo véase Deive, C. E., Heterodoxia e inquisición en Santo Domingo, 1492-1822. Santo Domingo, 1983, pp. 213-236.

${ }^{54}$ Saéz, J. L., La Iglesia y el negro esclavo..., op. cit., pp. 60-65.

55 En el resto del continente americano el color de la piel también fue un elemento diferencial que determinaba la posición social. Para el caso de Guatemala y México puede verse en Santos Pérez, J. M., Élites, poder local y régimen colonial..., op. cit., p. 154. Brading, D., Mineros y comerciantes en el México borbónico (1763-1810). México, 1993, pp. 153-154. 
consistía en una certificación jurídica, que se conseguía promoviendo pleitos de hidalguía o a través de la presentación de documentación que demostrase legalmente su condición de noble, como la que mostró Miguel Jerónimo Martínez de Venecia y Santelices para obtener el oficio de regidor en 1786. En ella además de reflejar los méritos y servicios de sus antepasados, se subrayaba la antigüedad e hidalguía de la familia de Miguel hasta el punto de que en la genealogía presentada enlazaba con peninsulares que fueron condes y marqueses de renombre del siglo XV. También se hacía referencia a la posesión de un escudo familiar, insignia típica de la honorabilidad y distinción de la nobleza ${ }^{56}$.

\footnotetext{
${ }^{56}$ Algunos de los linajes con los que los Santelices estaban entroncados eran los Condes de Oñate, y los de Feria, correspondiente al linaje de los Figueroa, y los Guevara que descendían de la casa de Escalante de Santander. Tanto el título de Conde de Feria como el de Oñate fueron otorgados por Enrique IV. El primero a Lorenzo Suárez de Figueroa en 1468, y a Iñigo Velez de Guevara, un año después. Origen, armas, hidalguía y nobleza de Miguel Martínez de Venecia y Santelices para obtener uno de los oficios de regidor de esta ciudad de Santo Domingo, 1786. AGI, Indiferente General, 1723. Origen, armas, hidalguía y nobleza de Miguel de Venecia Santelices, natural de la villa de Santander, arzobispado de Burgos, 1739. AGI, Indiferente General, 1621.
} 
Figura 6-9. Escudos de armas del apellido Venecia Santelices

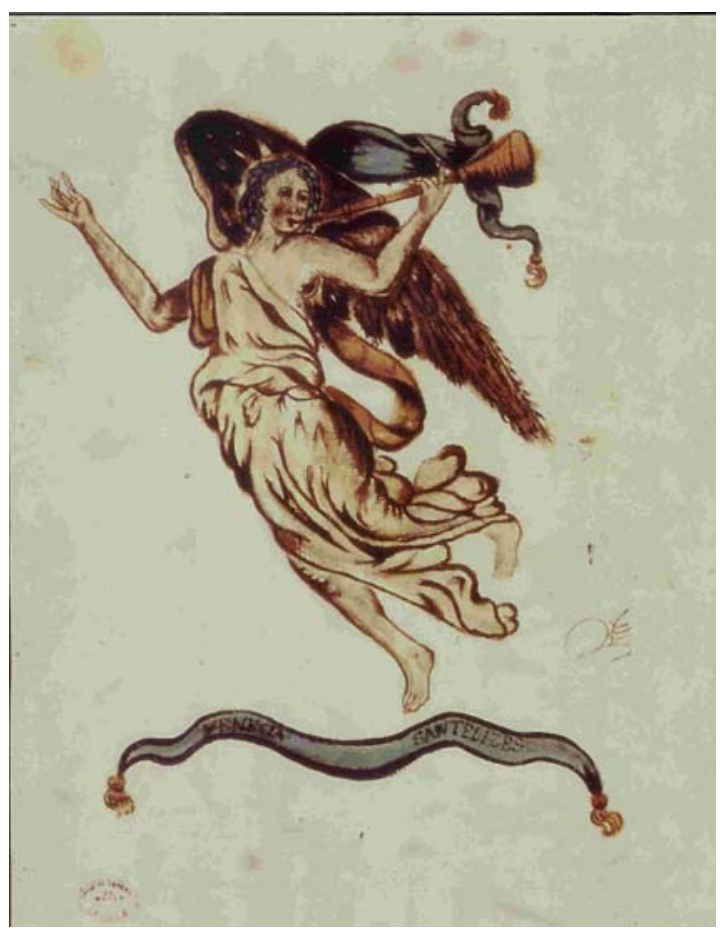

Dibujo de ángel trompetero sobre apellidos Venecia Santelices

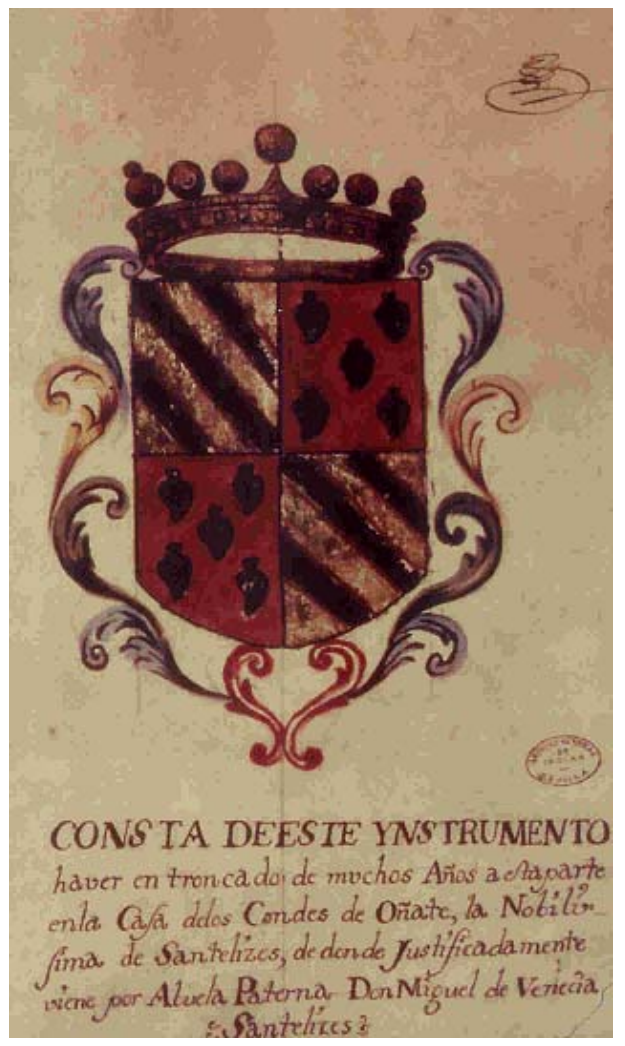

Escudo de armas de los Condes de Oñate

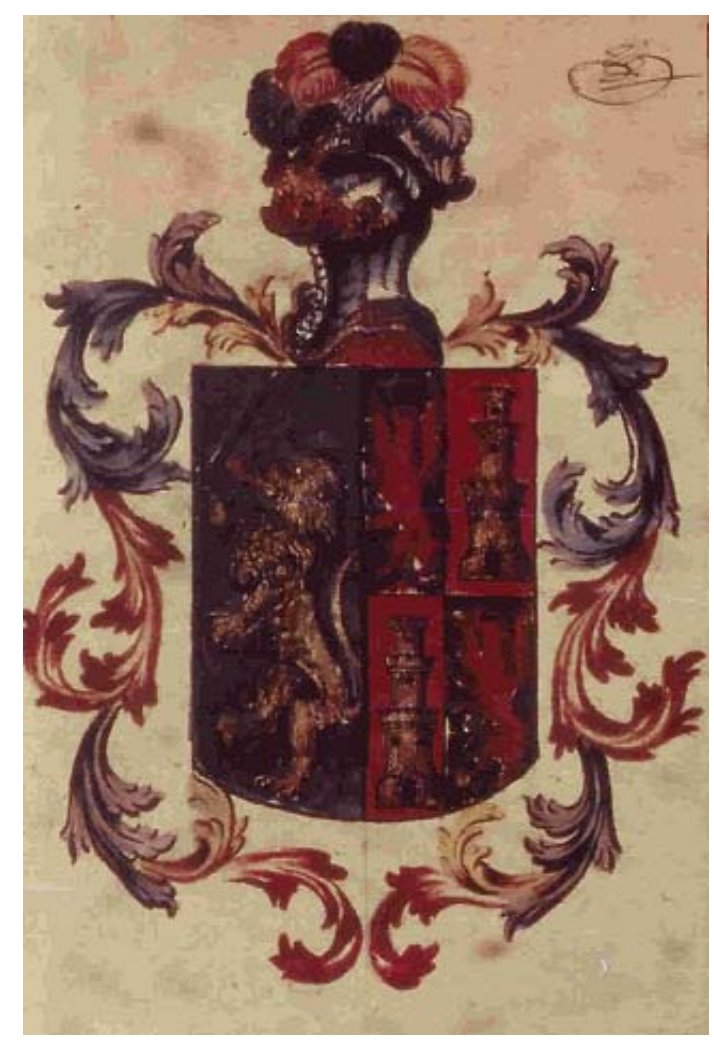

Escudo de armas del apellido Venecia Santelices

Fuentes: AGI, Mapas y planos, escudos 114-114bis, 115-115bis, y AGI, Mapas y planos, estampas 9-9bis. 
Respecto a las certificaciones jurídicas del estatus de nobleza, algunos hacendados peninsulares promovieron desde Santo Domingo pleitos de hidalguía ante los concejos de las villas de donde provenían, con el objeto de obtener una ejecutoria que demostrase legalmente su nobleza. La aprobación se recibía una vez que la documentación fuese ratificada por la Chancillería de Valladolid o la de Granada. Sus familiares residentes en la Península eran los encargados de que la reputación de su pariente en Indias recibiese la aprobación jurídica. Así se implicaba prestigio social no sólo a su persona sino al resto de su familia, tanto a la de la Península como a sus nuevos parientes en Santo Domingo. Probablemente a muchos peninsulares que emigraron a América, tales comprobaciones les sirvieron como cartas de presentación ante la sociedad local para probar la pertenencia a una familia que aseguraba su ascendencia y limpieza de sangre. Entre estos peninsulares que se convirtieron en importantes hacendados en Santo Domingo destaca Antonio Guridi y Echeandia, quien una vez establecido en la ciudad, formalizó en 1701 su hidalguía en la villa de Legazpia ${ }^{57}$.

Esta documentación sirvió igualmente tanto a los descendientes de estos peninsulares como a los que fueron llegando durante la segunda mitad del siglo XVIII, para optar a algún cargo administrativo que no estuviese en el cabildo. De esta manera, a Matías Guridi y Coronado, hijo del anterior, se le exigió probar su estatus y certificar la notoria calidad de toda su familia para obtener el oficio de alguacil mayor de la Audiencia. Para ello presentó las probanzas de hidalguía que poseía de su padre Antonio Guridi y Echeandia. Y por parte materna, las concedidas a su bisabuelo Luís Coronado ante la Audiencia de Granada en 1589 y $1592^{58}$. De igual forma, el vasco Andrés Fernando de Lecanda y Andirengoechea presentó la información sobre su genealogía de nobleza vizcaína y limpieza de

\footnotetext{
57 Antonio Guridi otorgó poder a favor de Jorge Amaran, su corresponsal en la villa de Legazpia, para que se encargara de dicho tema. Probanza de hidalguía del capitán Antonio de Guridi, residente en Santo Domingo de la Isla Española, originario de la casa de Guridi Etxeandia, 1701. AAL, Hidalguía C/199/6.

${ }^{58}$ Expediente sobre la confirmación del oficio de alguacil mayor de la Audiencia de Santo Domingo a favor de Matías Guridi y Coronado, 3 de junio de 1744. AGI, Santo Domingo, 299. Y relación de méritos y servicios del capitán Matías Guridi y Coronado, que lo es con actual ejercicio del Batallón de la Milicia de la ciudad de Santo Domingo de la Isla Española, y de su padre y abuelos. AGI, Indiferente General, 166.
} 
sangre en noviembre de 1770, año en el que fue nombrado primer factor de tabacos de la ciudad de Santo Domingo ${ }^{59}$.

Esta formalidad previa que debían realizar los candidatos al ocupar un empleo en la administración, también fue obligada en los conventos religiosos, instancias militares y universidades. En este sentido, Francisco Xavier Caro de Oviedo y Torquemada, al ingresar en la Universidad de Salamanca tuvo que presentar al claustro la debida documentación que certificase su nobleza y limpieza de sangre. Tal información se la envío su padre, el coronel Ignacio Pérez-Caro y Oviedo, y en ella se especificaba como “[...] sus ascendientes han sido y son tenidos por hijosdalgos, notarios de sangre en cuya virtud han obtenido los empleos más esclarecidos de la Republica, politica y militar, ejerciendo los actos positivos que ejercen los que gozan de nobleza”60 . Asimismo se confirmaba que “[...] sus padres y abuelos son limpios de mala raza de los judios, penitenciarios y nulos nuevamente convertidos a la Santa fe catolica” ${ }^{61}$. También Juan Clemente Martínez Saviñón, hijo del hacendado Miguel Jerónimo Martínez tuvo que presentar este tipo de documentación para poder acceder al Colegio de Nobles de Granada ${ }^{62}$.

Aquellos que eran extranjeros y querían obtener los mismos derechos que los españoles tuvieron que hacerse con una licencia especial, la llamada Carta de Naturaleza de Indias, que les permitía residir, obtener un empleo administrativo e incluso les autorizaba comerciar en aquellos territorios. La concesión de esta Carta exigía el cumplimiento de una serie de requisitos, como haber residido en América durante veinte años sucesivos, estar casado con una mujer natural o hija de extranjeros residentes, y estar en posesión de bienes raíces en una cantidad que no fuese inferior a los 4.000 ducados $^{63}$.

\footnotetext{
59 La acreditación de nobleza fue promovida por su hermana María Agustina de Lecanda. Genealogía de Andrés Fernando de Lecanda y Andirengoechea. AG, Hidalguía 87/1164.

${ }^{60}$ Libro de grado de Bachiller. Salamanca, 29 de julio de 1793. AUSA, Libro 768, fol. 140. Claustro presentado para el licenciamiento en leyes del bachiller Francisco Xavier Caro. Salamanca, 1 de abril de 1796. AUSA, Libro 805, fols. 278-279.

61 Ibidem.

${ }^{62}$ Guerrero Cano, Ma . M., “Un dominicano en el colegio de nobles americanos de Granada. Familia y genealogía de Juan Clemente Martínez Saviñón”. Trocadero 8-9 (Cádiz, 1996-1997) pp. 383-400.

${ }^{63}$ Morales Álvarez, J. M., Los extranjeros con carta de naturaleza de las Indias, durante la segunda mitad del siglo XVIII. Caracas, 1980, pp. 147-148, 170-173, y 205-208.
} 
Junto a esto debían presentar información que acreditase su genealogía familiar y la de su mujer, su calidad de cristianos y sus cualidades personales, que serían constatadas por la Audiencia. Luego se enviaba al Consejo de Indias, que era el que despachaba este tipo de mercedes. Entre los hacendados seleccionados sólo el francés Francisco Espaillat y Virol deseó obtener el estatus y las posibilidades que concedía el tener una carta de este tipo. Francisco contaba además con las condiciones necesarias que prevenía la legislación indiana: residía desde hacía más de treinta años en Santiago, ejercía la profesión de médico y cirujano, había contraído matrimonio con dos mujeres de origen español y de distinción, y poseía una gran fortuna de bienes raíces y casas valoradas en 166.280 pesos y 4 reales, sin contarse los ajuares de las casas y haciendas que superaban la cantidad exigida por las leyes. Se daba la circunstancia añadida de haber realizado distintas donaciones a hospitales de la referida ciudad y a la Corona ${ }^{64}$. En vista de lo cual, el 17 de agosto de 1787 ésta le concedió mediante una Real Cédula la Carta de Naturaleza para “[...] residir libremente y obtener cualquier empleo honorífico de justicia, guerra o hacienda [...]”65. Pero el proceso no acababa ahí, ya que por último debía pagar a la Corona por haberle concedido tal licencia. Así, Francisco pagó, como la mayoría de los extranjeros a los que se otorgó esta merced, 5.100 maravedíes de vellón ${ }^{66}$.

\footnotetext{
${ }^{64}$ Campillo Pérez, J. G., Francisco Espaillat..., op. cit., p. 22. Véase también Leyes 31-34, título 27, libro 9 de la Recopilación de Indias.

${ }^{65}$ Campillo Pérez, J. G., Ibidem., pp. 31-146.

${ }^{66}$ Idem., y Morales Álvarez, J. M., Los extranjeros..., op. cit., pp. 313-314.
} 


\section{CAPÍTULO 7}

\section{LAS ACTIVIDADES ECONÓMICAS}

"La jurisdicción de Santo Domingo era extensa, poblada y rica en hatos, cacaotales e ingenios de azúcar, entre los cuales distinguían por sus grandes dotaciones, máquinas y productos, el de Boca de Bocanigua, fundado por el Marques de Iranda [...]. El de Camba que fue de los jesuitas y poseyó después Nicolás Guridi y el de San José, de Antonio Dávila Coca”¹.

\subsection{La estructura agraria de Santo Domingo}

La población de Santo Domingo se dedicó en la época colonial a la ganadería y la agricultura, actividades que configuraron el paisaje rural dominicano. Durante casi la totalidad del siglo XVIII la ganadería fue la base de su economía, estando formada por ganado vacuno, caballar, ovino, caprino y cerda. El más abundante fue el vacuno, que era aprovechado para el abastecimiento de carne de los habitantes de Santo Domingo, y al mismo tiempo era exportado a Saint Domingue, donde era utilizado para alimentar a su población esclava. Sin embargo, a partir de la segunda mitad del siglo XVIII resurgió con gran impulso la dedicación a la agricultura, que fue recortando la importancia de la ganadería, lo que no significó en cambio que ésta dejase de existir. Esta alteración se debió a las circunstancias económicas de aquel momento. A este respecto, especial relevancia tuvo la consonancia que se dio entre la política reformista de los Borbones, que favorecía la transformación de la economía agrícola de abastecimiento en una agricultura comercial basada en la

\footnotetext{
${ }^{1}$ En Monte y Tejada, A. del, Historia de Santo Domingo. Ciudad Trujillo, 1953, vol. III, pp. 105-106. La cursiva es nuestra.
} 
organización de grandes explotaciones, y los hacendados dueños y administradores de tales concentraciones.

Según el lugar y a lo que se dedicaban las explotaciones, éstas recibieron diferentes nombres. Las destinadas al cultivo de cualquier producto eran denominadas haciendas o estancias en la mayoría de Hispanoamérica. Aquellas que lo hacían a la ganadería eran conocidas con distintos nombres; así en Argentina, Perú, Chile y Uruguay se utilizaba el término estancia, mientras que en Santo Domingo, Venezuela y Cuba se prefería hato ${ }^{2}$. En Santo Domingo pueden distinguirse diversos tipos de posesiones rurales: las haciendas, que eran grandes extensiones de tierra dedicadas a la plantación de azúcar, café, algodón, añil, y tabaco orientada a la exportación, y las estancias y los hatos, que proveían a las haciendas de alimentos y ganado. No obstante, a través de la documentación se constata que el término hacienda aparece utilizado en numerosas ocasiones, para referirse tanto a una propiedad dedicada a la agricultura como a la ganadería, o incluso a ambas actividades ${ }^{3}$. Así lo muestra Pedro Catani, oidor decano de la Audiencia, en un informe que realizó en 1788, donde describe las haciendas compuestas tanto por crías de ganados, como por ingenios de azúcar, trapiches, u otras dedicadas al cultivo de cualquier fruto ${ }^{4}$.

Aunque las estancias y hatos se desarrollaron en estrecha relación con las haciendas, también hubo propietarios que se dedicaron exclusivamente a aquellos, encargándose de suplir el mercado local de la villa más próxima y de la ciudad de Santo Domingo, donde se ubicaba la mayor parte de la población. Asimismo se dio la circunstancia de que el producto de algunas de estas estancias y hatos era destinado especialmente al comercio exterior. Éstas estuvieron localizadas en

\footnotetext{
${ }^{2}$ Véase al respecto: Sorhegui, A., "Élite o aristocracia en La Habana entre los siglos XI y XVII" en Schröter, B. y Büschges, C. (eds.), Beneméritos, aristócratas y empresarios. Identidades y estructuras sociales de las capas altas urbanas en América hispánica. Frankfurt, 1999, pp. 201213, p. 201. Ramírez, S., Patriarcas provinciales: la tenencia de la tierra y la economía del poder en el Perú colonial. Madrid, 1991, pp. 14-15 y 139. Peguero, L. P., Historia de la conquista de la isla Española de Santo Domingo. Trasumptada el año de 1762. Santo Domingo, 1975, vol. I, pp. XIX y XXV-XXVII.

${ }^{3}$ También en Guatemala el concepto de hacienda estaba identificado con las tierras dedicadas a la ganadería, a la agricultura o incluso a ambas actividades, en Santos Pérez, J. M., Élites, poder local y régimen colonial. El cabildo y los regidores de Santiago de Guatemala 1700-1787. Cádiz, 1999, p. 215.

${ }^{4}$ Estado de los medios para el fomento de la isla realizado por el oidor decano de la Audiencia de Santo Domingo Pedro Catani, 15 de noviembre de 1788. AGI, Santo Domingo, 1012. Documento también reproducido en González, R., "Dos relaciones inéditas del siglo XVIII". ECOS 2 (Santo Domingo, 1993) pp. 183-203, particularmente las páginas 185-193.
} 
parcelas cercanas a la ciudad de Santo Domingo y en lugares lejanos a este centro, como fue el caso de los hatos que existían en la zona norte, este y oeste de la isla, y las estancias de tabaco y café en Santiago y la Vega Real. Al lado de estas grandes propiedades se hallaban otras con un carácter más familiar cuya producción era simplemente de autoabastecimiento.

Figura 7-1. Distribución de actividades económicas

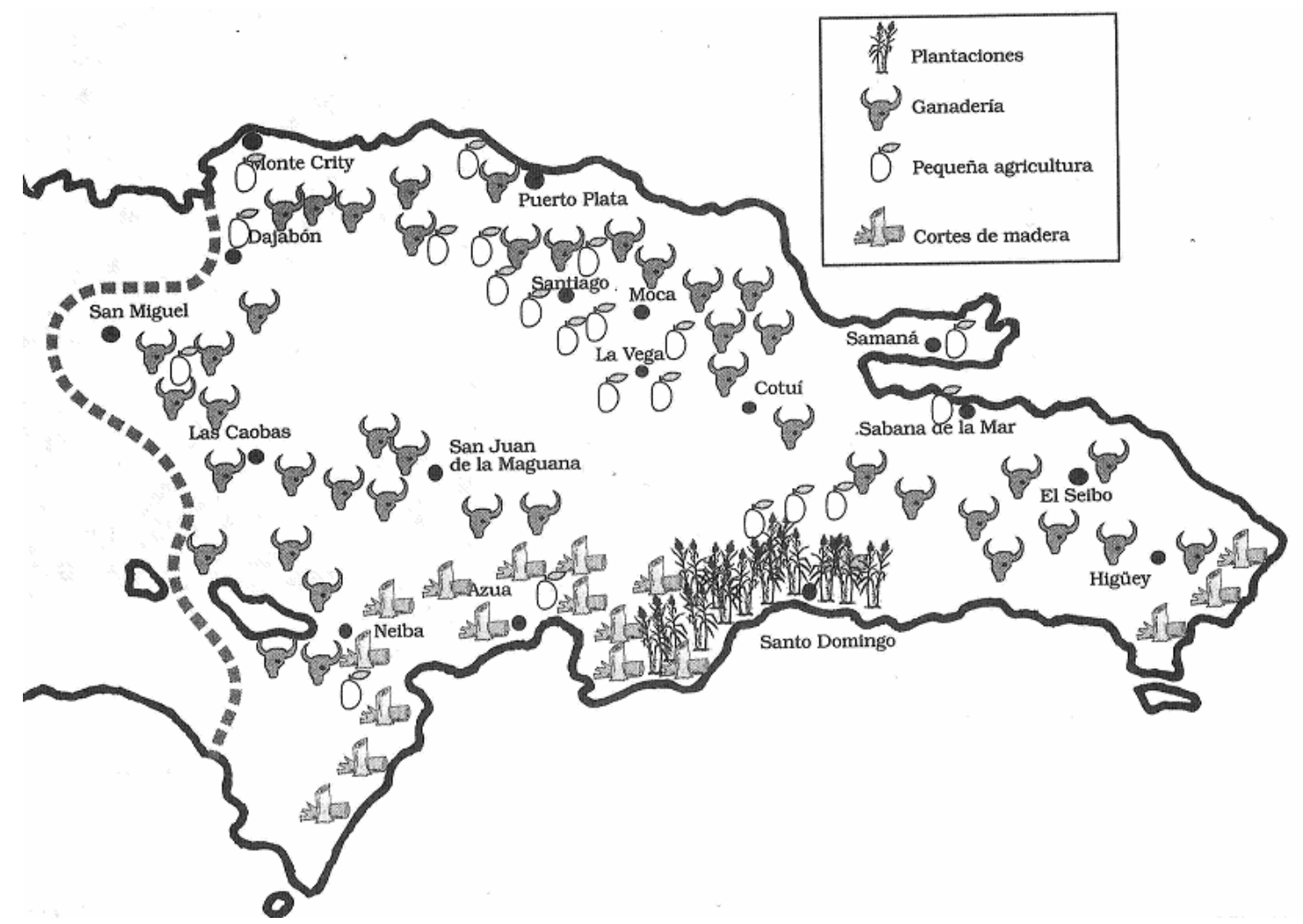

Fuentes: Cassá, R., Historia social y económica de la República Dominicana. Santo Domingo 2003, vol. I, p. 247.

La mayor parte de las propiedades estuvieron fundamentalmente en manos de dos sectores: la Iglesia y particulares que se convirtieron en hacendados y hateros $^{5}$. La obtención de un trozo de tierra en la segunda mitad del siglo XVIII debió ser bastante difícil, al menos en la jurisdicción de la ciudad de Santo Domingo según la descripción de Daniel Lescallier, un viajero francés, quien en 1764 explicaba:

\footnotetext{
${ }^{5}$ Gutiérrez Escudero, A., "La propiedad de la tierra en Santo Domingo: del latifundio al terreno comunero”. Temas Americanistas 4 (Sevilla, 1984) pp. 21-26, p. 24.
} 
“[...] desde hace mucho tiempo no queda ni una pulgada de tierra que no tenga dueño, de modo que toda esta vasta tierra está repartida entre los principales señores de la capital que las explotan y son los propietarios de ellas. De esta manera, un particular que quiera establecerse aquí tiene la obligación de comprar un terreno que le será vendido muy caro o de alquilar el que sea [...]”6.

Esta tendencia de acaparamiento de tierras fue un proceso que se inició en el siglo XVI. La adquisición de propiedades por parte de la élite de Santo Domingo durante ese periodo se realizó a través de las mercedes de tierras, y posteriormente con la compra, aunque ésta se realizó en muchas ocasiones de manera fraudulenta, adquiriéndose los terrenos con dinero de las Arcas Reales o amañando las almonedas, y siendo adjudicadas a un individuo u otro en función de los vínculos de tipo personal ${ }^{7}$. En el siglo siguiente, las Devastaciones de la zona norte de la isla ocurridas entre 1605 y 1606, obligaron a gran parte de la población de ese lugar a establecerse en la zona sur de la isla o a emigrar a otras partes del continente americano. El abandono de las tierras permitió que fuesen adquiridas mediante compra o directamente acaparadas por familias adineradas o cualquier persona. La apropiación de la tierra fue un fenómeno que continuó teniendo lugar durante el siglo XVIII por todo el territorio dominicano, aunque con más frecuencia en lugares lejanos de las ciudades, pues en las cercanías de éstas el terreno estaba ocupado con o sin título de propiedad. Esto hizo que cuando se inició la política de repoblación de las zonas abandonadas y la fundación de otras, las autoridades se encontrasen con que muchas tierras estaban ya ocupadas por particulares y dedicadas bien a la agricultura o a la crianza de ganado, e incluso a ambas. Tal fue el caso de los terrenos del poblado de San Carlos, cercano a la ciudad de Santo Domingo, el de San Lorenzo de los Minas y en el área norte la población de Puerto Plata y Montecristi, donde se produjeron disputas por la propiedad ${ }^{8}$.

\footnotetext{
6 "Nociones sobre los principales lugares de la colonia Española por un ingeniero francés que la ha visto en 1764" en Rodríguez Demorizi, E., Viajeros de Francia en Santo Domingo. Santo Domingo, 1979, pp. 9-29, p. 16. La cursiva es nuestra.

${ }^{7}$ López y Sebastián, L., y Río Moreno, J. del, “La ganadería vacuna en la isla Española (15081587)”. Revista Complutense de Historia de América 25 (Madrid, 1999) pp. 11-49, p. 23 у 24.

${ }^{8}$ Gutiérrez Escudero, A., "La propiedad de la tierra en Santo Domingo: del latifundio al terreno comunero”..., op. cit. pp. 21-26. Hernández González, M. V., La colonización de la frontera dominicana (1680-1795). Las Palmas de Gran Canaria, 2005, pp. 48-72.
} 
En consecuencia, con el objeto de evitar este tipo de conflictos y regular la propiedad de la tierra se sucedieron una serie de Reales Cédulas. En realidad estas fueron una continuación del proceso que se había iniciado con la publicación de una Real Cédula el 1 de noviembre de 1591 sobre la posesión de la tierra, que según José María Ots Capdequí significó la primera reforma agraria para todo el continente hispanoamericano ${ }^{9}$. Se sometieron a revisión todos los títulos de tierra expedidos hasta entonces, reconociéndose aquellos que los poseyeran legalmente. Mientras que en el caso de que la tierra hubiese sido apropiada indebidamente o en demasía debería ser restituída a la Corona para que fuese puesta a subasta y rematada al mejor postor. Además de este modo la cédula estableció otros medios para resolverlo. Si bien los que presentasen títulos originales podían ampararse en ellos y en su posesión legítima, por su contra los que no contaban con éstos podrían hacerlo a través de la justa prescripción que suponía demostrar la antigua posesión, población y cultivo de la tierra. El otro medio fue la composición, es decir, la compra al fisco de la porción de tierra que hubiese sido ocupado ya fuese sin justo título o aquella que aún teniéndolo el titular se había excedido de la concedida ${ }^{10}$.

La siguiente cédula fue dictada en 1694, y en ella se ordenaba la presentación de los títulos de propiedad por parte de todo aquel que poseyera tierras. Cuando no se presentaran aquellas serían declaradas como realengas, y la Real Hacienda se encargaría de ponerlas en arrendamiento o en venta ${ }^{11}$. En contraposición el cabildo de Santo Domingo trató por todos los medios de suspender la disposición, al tiempo que adelantaba un problema dominicano que ha perdurado hasta la actualidad: la inexistencia de títulos de propiedad o su falsificación. De acuerdo con el ayuntamiento, la mayoría de los vecinos habían adquirido los terrenos comprándolos a otros que previamente los habían obtenido por merced real por lo que “[...] carecían de los justificantes debido a los años transcurridos o por no haberlos recibido en su día [...]”12. El cabildo alegaba también el mal estado de los archivos debido a la humedad, por lo que sólo se

\footnotetext{
9 Ots Capdequí, J. Mª ., España en América. El régimen de tierras en la época colonial. México, 1959, pp. 29-36.

${ }^{10}$ Aunque la composición se estableció con la mencionada cédula ésta fue reiterada en otra hacia 1631, que fue incorporada a la Recopilación de Indias de 1680. Ibidem., pp. 37-38, y 122-124.

${ }^{11}$ Gutiérrez Escudero, A., "La propiedad de la tierra en Santo Domingo: del latifundio al terreno comunero”..., op. cit., pp. 21-26, p. 22.

${ }^{12}$ Ibidem., p. 23.
} 
conservaba documentación reciente. A los hacendados representados en él lógicamente no les interesaba que se formalizara, pues muchos clanes familiares que ocupaban puestos en esa institución probablemente se habrían aprovechado de tal situación, comprando tierras que se ofertaban en públicas subastas donde eran favorecidos por sus familiares y amistades, y en otros casos usurpándolas ${ }^{13}$.

Un siglo más tarde siguió una serie de nuevas cédulas con el mismo objetivo que provocaron igualmente contrariedades y molestias a los cabildantes, quienes finalmente lograron paralizarlas. La primera de esas cédulas dictadas para el siglo XVIII fue la del 24 de noviembre de 1735. Las condiciones que imponían eran las mismas que las que hasta entonces se habían ordenado con un capítulo especial en el que se obligaba a recurrir al rey para la obtención de la confirmación de las posesiones, un requisito que resultaba gravoso por la distancia y los gastos que suponía ${ }^{14}$. Años después, en 1741, otra Real Cédula daba la posibilidad de obtener la propiedad y su título demostrando haberlas trabajado por lo menos durante treinta años, previo pago de éstas y con la posibilidad de que a partir de entonces éstas no serían declaradas como realengas ${ }^{15}$. Sin embargo, parece que esta cédula tampoco tuvo mucho efecto.

La ineficacia de éstas y de las anteriores disposiciones hizo que el 15 de octubre de 1754 de nuevo otra Real Cédula estableciera de manera firme la averiguación de la propiedad de la tierra y, en particular, las tierras realengas que existían desde principios del siglo XVIII, es decir, su situación y su acreditación ${ }^{16}$. Entre las innovaciones y disposiciones más interesantes de sus capítulos cabe destacar que sólo debían presentarse los títulos de tierras que habían sido otorgados a partir de 1700, mientras que los expedidos con anterioridad a la fecha serían respetados aunque no estuviesen confirmados. La obtención de su confirmación se realizaría en la Audiencia, por lo que ya no era necesario recurrir

\footnotetext{
13 Idem.

${ }^{14}$ Real Cédula de 24 de noviembre de 1735 sobre bienes realengos para que se confirmen en el tiempo asignado con pena de perderlas. AGI, Santo Domingo, 978.

${ }^{15}$ Sevilla Soler, Ma . R., Santo Domingo. Tierra de frontera (1750-1800). Sevilla, 1980, p. 97.

16 Para los hacendados cubanos el "descubrimiento" de tierras realengas fue una "forma de acrecentar su patrimonio” rural, y convertirse en propietarios de éstas. Los medios que utilizaron fundamentalmente fueron a través del corrimiento de tierras, usurpaciones, y premios que recibían aquellos que denunciaron a los que poseían tierras realengas lo que provocó importantes litigios. Al respecto véase Balboa Navarro, I., "El asalto a los realengos 71750-1839)" en Balboa Navarro, I., y Piqueras, J. A. (eds.), La excepción americana. Cuba en el ocaso del imperio continental. Valencia, 2006, pp. 55-78.
} 
al rey. Además se creó la figura del juez subdelegado de realengos, quien era responsable de llevar a cabo la composición de tierras realengas y su venta en toda la isla ${ }^{17}$. Para tal función se nombró al fiscal de la Audiencia, José Pablo de Agüero, quien empezó a trabajar en ello. Pero no pudo hacer mucho, ya que el cabildo de la ciudad de Santo Domingo logró paralizarla hasta que trece años más tarde otra cédula de 1767 la puso en vigencia ${ }^{18}$.

En esta ocasión además del juez de realengos se creó otro puesto, el de defensor, encargándose los dos de poner en práctica las disposiciones de la cédula de 1754. Para el primer puesto, el gobernador Manuel Azlor y Urríes nombró al oidor Ruperto Vicente Luyando, quien había llegado un año antes para ocupar su plaza en la Audiencia. Éste eligió a su vez para el segundo puesto al abogado José del Monte, siendo a partir de entonces su asistente en este trabajo ${ }^{19}$.

Hacia 1767 el panorama de la propiedad de la tierra lejos de aclararse en virtud de las disposiciones de 1754, entró nuevamente en una etapa de conflicto con los hacendados, quienes con anterioridad y a través de su posición en el cabildo habían logrado dirimirlas. El cabildo recurrió a la Corona para suplicarle la suspensión de tal medida. Dicha petición dio lugar a una serie de representaciones que se desarrollaron durante ese año de la siguiente forma. En primer lugar, los hacendados recordaron la inexistencia de títulos de propiedad, y por tanto, la imposibilidad de mostrar "los titulos con que poseyeron los primeros pobladores, ni tampoco aquellos con que han ido pasando las posesiones de unos a otros hasta la fecha: 1586 invadio y tomo Drake la ciudad, pereciendo titulos e instrumentos. A los ochenta años, en 1665 arribo a estas costas la armada de Cromwell, tambien huracanes y terremotos que han desplomado muchos edificios, sepultando muchos documentos. Se ha padecido sucesivamente varias viruelas, y

\footnotetext{
${ }^{17}$ Ots Capdequí, J. Ma., España en América. El régimen de tierras..., op. cit., pp. 102-111.

${ }^{18}$ Carta del cabildo de Santo Domingo a Su Majestad solicitando en testimonio de los autos obrados por José Agüero sobre la venta y composición de tierras, se suspendiese el bando mandado publicar. Vino con carta del oidor de la Audiencia Ruperto Luyando, 30 de septiembre de 1767. AGI, Santo Domingo, 978.

19 Título librado por el presidente Manuel Azlor a Ruperto Luyando por cuanto las leyes y cédulas de estos reinos tiene ordenado la venta y composición de las tierras realengas. Santo Domingo, 31 de agosto de 1767. AGI, Santo Domingo, 978. Real Cédula para Ruperto Vicente Luyando, oidor de la Audiencia de Santo Domingo y Juez subdelegado de realengos de aquella isla, participándole lo resuelto en las ocurrencias dimanadas de la práctica de su comisión, con el ayuntamiento de aquella ciudad, y ordenándole su cumplimiento en la forma que se expresa, Aranjuez 17 de abril de 1771. AGI, Santo Domingo, 892, L61.
} 
polillas enemigas de los documentos [...]"20. Pero la finalidad de estos propietarios, según Ruperto Vicente Luyando, era evitar “el descubrir como posehian” las tierras ${ }^{21}$. En resumen, estas motivaciones eran meras excusas para conocer cómo las habían adquirido y su extensión.

En segundo lugar, en otra carta el argumento del ayuntamiento era que “[...] los vecinos y cabildo estaban empeñados en el reanimo y ferviente cultivo de los campos antes de las ultimas tormentas padecidas que ya no solo se provea el Pais de sus cacahuales, ingenios de azucar y melado, y labores de tabaco, sino que sobraba muchos frutos para hacer un pequeño comercio. Pero sera inutil si los vecinos pierden las tierras que poseian, cuyo efecto causaba precisamente la comision de V. M. [...]"22.

A pesar de la oposición de éstos y sus intentos de anularla se continuó la tarea que tenía asignada el juez de realengos, la cual se extendió a todo el territorio de la isla. Para finales del año 1767 Ruperto Vicente Luyando presentó una relación de aquellas tierras que fueron declaradas realengas. Entre éstas cita algunas de las que poseían varios hacendados, como Nicolás Guridi Coronado en los sitios de Cambita, parte de un terreno de un ingenio fundado por Miguel Bernardo Antonio Ferrer, y por las tierras que poseía Luisa Pimentel ${ }^{23}$. El siguiente paso fue legalizar esas propiedades y por tanto, obtener el título de propiedad para aquellos que no lo poseían y en caso contrario una certificación que reconociese unos derechos sobre la tierra, para lo que se utilizaron dos medios.

El primero de ellos no era novedoso. Se trataba de la composición de tierras, es decir, el pago de una determinada cantidad al fisco por la posesión de unos terrenos que en su mayoría habían sido apropiados ilícitamente, tras lo cual se concedía el título correspondiente. Fue una manera de consolidar un hecho que

\footnotetext{
${ }^{20}$ Representación de Tomás Leos-Echalas, alcalde ordinario, y José Guridi, regidor perpetuo en la que el cabildo pide a Su Majestad los testimonios de los autos obrados por José Agüero sobre la venta y composición de tierras que entretanto se suspendiese el bando mandado publicar, Santo Domingo 16 de septiembre de 1767. AGI, Santo Domingo, 978.

${ }^{21}$ Cartas del oidor y juez subdelegado de realengos Ruperto Vicente Luyando al rey, 30 de septiembre y 28 de diciembre de 1767. AGI, Santo Domingo, 978.

${ }_{22}$ Carta del cabildo de la ciudad de Santo Domingo que recurre a la representación de Su Majestad para que escuche la voz de este triste vecindario, 12 de octubre de 1767. AGI, Santo Domingo, 978.

${ }^{23}$ González, R., "De la reforma de la propiedad a la reforma rural”. ECOS 4 (Santo Domingo, 1995) pp. 179-192, p. 184.
} 
hasta entonces no se había resuelto. Así por ejemplo, el 24 de febrero de 1768 Luisa Pimentel tuvo que pagar 554 reales por 55.428 varas de tierras realengas del que era su ingenio ${ }^{24}$. Entre 1769 y 1773 se ingresaron en las Reales Cajas en tal concepto la cantidad de 166.999 reales como se puede observar en la tabla siguiente.

\section{Tabla 7-1. Ingresos realizados en las Cajas Reales de Santo Domingo entre 1769 y 1773}

\begin{tabular}{|c|c|c|}
\hline \multirow{2}{*}{ Año } & \multicolumn{2}{|c|}{ Cantidad } \\
\hline & Reales & Maravedíes \\
\hline 1769 & 49.631 & 21 \\
\hline 1770 & 7.120 & \\
\hline 1771 & 53.101 & 21 \\
\hline 1772 & 862 & 11 \\
\hline 1773 & 56.283 & 32 \\
\hline Totales & \multicolumn{2}{|c|}{166.999 rs. y medio mrs } \\
\hline
\end{tabular}

Elaboración propia. Fuentes: Sevilla Soler, Mª. R., Santo Domingo..., op. cit., pp. 268 y 471475.

En segundo lugar, otros hacendados prefirieron resolverlo a través de peticiones de amparo real, un instrumento jurídico que tenía por objeto proporcionar la protección de las personas en sus derechos sobre bienes muebles o inmuebles, cuando éstos eran alterados. Entonces, éstas acudían a la máxima autoridad local (Audiencia) o al rey en demanda de amparo. El proceso se resolvía, cuando una de las autoridades mencionadas dictaban un mandamiento de amparo en el que se protegía “[...] los derechos de una persona frente a la agresión actual o futura que en su detrimento realizan otras personas [...] o no, ordenándose, según el caso, la reparación de los daños causados o la suspensión de aquellos actos que puedan causarlos [...]”25. En relación a la propiedad de la tierra, y en especial con lo que mandaba la cédula de 1754, el amparo real sirvió a aquellos hacendados que no tenían el título de propiedad pero sí una posesión de mucho tiempo sobre ésta, ya que era una forma de reconocer los derechos sobre su tierra. Según José María Ots Capdequí el proceso de amparo "presupone la

\footnotetext{
${ }^{24}$ Soler Sevilla, Ma. R., Santo Domingo..., op. cit., p. 268.

${ }^{25}$ Lira, A., El amparo colonial y el juicio de amparo mexicano (antecedentes novohispanos del juicio de amparo). México, 1971, p. 35.
} 
existencia de un título” que en algún momento debió de existir ${ }^{26}$, aunque como ha señalado Antonio Gutiérrez “de la documentación se deduce” que eran más bien pocos los que lo poseyeron en Santo Domingo ${ }^{27}$. El propio Ruperto Vicente Luyando apunta al respecto: [...] la prueba de posesion que, era el unico asilo de todos los acendados pues en ninguno o muy pocos se encontraba titulo Real, sino la plena libertad de usar del terreno como propio [...]”28. En caso de haberlo perdido, para poder cumplir los derechos del demandante, éste podía presentar una serie de testigos que avalasen su posesión y los linderos, una escritura de un censo instituido a favor de una capellanía, e incluso una certificación de amparo realizada anteriormente a la causa ${ }^{29}$.

El real amparo cubría la posesión pero no el dominio sobre una propiedad. Además la posesión se amparaba en un hecho que ya se recogía en las cédulas de 1591 y 1741, y se fundamentaba en el hecho de que la propiedad debía estar dedicada al cultivo o a la ganadería a partir de un periodo largo de tiempo. La cédula de 1754 concretaba tres meses para los hatos y de seis para las haciendas. Esto implicaba, como ha indicado Ots Capdequí, “una expectativa de dominio” que se concedía a la propiedad si se cumplía con lo anteriormente mencionado, o si se demostraba que el terreno había sido ocupado por un periodo de tiempo de cuarenta años sin interrupción alguna ${ }^{30}$. No obstante, en caso de haber transcurrido ese tiempo y de encontrarse la propiedad abandonada, ésta podía ser arrendada o comprada por otra persona ${ }^{31}$.

Entre las diversas peticiones de amparo real con delimitación de las posesiones que se hicieron en Santo Domingo citaremos las solicitudes de varios hacendados. Ignacio Francisco Pérez Caro y Oviedo poseía dos ingenios llamados San Cristóbal y Santiago, situados ambos en las riveras del río Nigua, de los que pidió deslinde en 1767 ante la reclamación de una porción de éstas que le hacía su

\footnotetext{
${ }^{26}$ Ots Capdequí, J. Ma., España en América. El régimen de tierras..., op. cit., p. 38.

${ }^{27}$ Sobre este asunto, puede verse Gutiérrez Escudero, A., "La propiedad de la tierra en Santo Domingo: del latifundio al terreno comunero”..., op. cit., pp. 21-26, p. 23. Y su obra, Población y economía en Santo Domingo (1700-1746). Sevilla, 1985, p. 88.

${ }^{28}$ Real Cédula a Ruperto Vicente Luyando, oidor de la Audiencia de Santo Domino y Juez Subdelgado de Realengos de aquella Isla, participandole lo resuelto en las difamadas de la practica de su comision, con el Ayuntamiento de aquella Ciudad, y ordenandole su cumplimiento, Aranjuez 17 de abril de 1771. AGI, Santo Domingo, 892, L61.

${ }^{29}$ Véase Ots Capdequí, J. Mª., España en América. El régimen de tierras..., op. cit., p. 38-41. Rodríguez Demorizi, E., Familias Hispanoamericanas. Ciudad Trujillo, 1959, pp. 37-41.

${ }^{30}$ Ots Capdequí, J. Mª., Ibidem., p. 39.

31 Ibidem., pp. 106-107 y 122-124.
} 
colindante Damián del Castillo. Finalmente se estableció que pertenecían a Ignacio. La sentencia sirvió para obtener su título y confirmar que en lo sucesivo el hacendado no fuese molestado ni se le reclamase las tierras ${ }^{32}$.

Asimismo, Nicolás Guridi Coronado ese mismo año puso una demanda contra Nicolás Sterling sobre las tierras de la Loma, que se encontraban a espaldas de la hacienda de dicho Guridi nombrada Cambita. El litigio sobre estas tierras obligó a ambas partes a presentar algún documento que acreditase su propiedad. Nicolás Guridi Coronado declaró haberla heredado de su padre y no contar con papeles que la acreditasen. Mientras, Nicolás Sterling presentó la escritura de venta realizada el 21 de febrero de 1756 en la que Dominga Fernández, viuda de Antonio González, le vendía esa porción. Las averiguaciones sobre los datos presentados para alegar la confirmación de éstas dieron como resultado que la referida escritura de venta era falsa, por lo que se anuló el procedimiento, quedando protegidos los derechos de propiedad de Guridi ${ }^{33}$.

A pesar de que la comisión mantenía a los hacendados temerosos de que algunas de sus tierras fuesen declaradas realengas y puestas a la venta, en agosto de 1768 aquellos volvieron a suplicar a la Corona que ésta cesase, algo que no sucedió $^{34}$. En cambio sí lograron que en 1771 se moderasen los capítulos tercero y cuarto de la cédula de 1754, reduciendo la justificación que hicieran aquellos propietarios que poseyeran tierras de antigua ocupación de cuarenta años a treinta. Además se suprimió el cargo de defensor, y se mandó que se nombraran subdelegados para lugares distantes de la capital ${ }^{35}$. Probablemente la Corona quiso que continuara no sólo por los fines fiscales de aumentar los ingresos de las arcas reales, sino también para realizar una ordenación agraria con la intención de

\footnotetext{
${ }^{32}$ Ignacio Francisco Pérez Caro y Oviedo era para ese año teniente coronel graduado y sargento mayor de la plaza. Estaba casado con Ana María de Oviedo y Castillo Torquemada. Testimonio de las sentencias y tasaciones de los autos obrados en el tribunal del señor Ruperto Vicente Luyando, juez subdelegado de realengos, 1767. AGI, Santo Domingo, 978.

${ }^{33}$ Ibidem.

${ }^{34}$ Según Raymundo González los hacendados lograron “la suspensión de la medida en 1769” y que ésta fuese “conmutada por la formación de una Junta de Hacendados”, así como el traslado del juez Luyando “fuera de la colonia en 1773”. Véase en González, R., “De la reforma de la propiedad a la reforma rural”..., op. cit., pp. 179-192, y "La figura del montero en la formación histórica del campesinado dominicano (Discurso de ingreso como miembro de número de la Academia Dominicana de la Historia)”. CLÍO 168 (Santo Domingo, 2004) pp. 75-96.

${ }^{35}$ Real Cédula a Ruperto Vicente Luyando, oidor de la Audiencia de Santo Domino y Juez Subdelgado de Realengos de aquella Isla, participandole lo resuelto en las difamadas de la practica de su comision, con el Ayuntamiento de aquella Ciudad, y ordenandole su cumplimiento, Aranjuez 17 de abril de 1771. Y, Real Cédula a la Ciudad de Santo Domingo, Aranjuez 17 de abril de 1771. AGI, Santo Domingo, 892, L61.
} 
fomentar la agricultura, para lo que era necesario distribuir la tierra concentrada en unos pocos. De esta forma, la propia Corona aceptó que los hacendados utilizaran la composición de tierras para legalizar sus propiedades.

Todo esto se sitúa en la orientación reformista que tomó la Corona de impulsar la economía del continente americano y en especial aquellos lugares a los que no se les había prestado atención hasta entonces, como era el caso de Santo Domingo. La propuesta de fomentar la agricultura había sido iniciada paralelamente a la comisión de realengos por los propios hacendados desde el cabildo. Al tiempo que reclamaban terminar con dicha comisión, elevaban instancias para mejorar e incrementar la agricultura. Para tal fin la Corona mandó crear por la Real Cédula el 29 de octubre de 1769 la ya mencionada Junta de Fomento. A partir de entonces, el interés de los hacendados se centró en obtener todo aquello que necesitaban para sus haciendas. Además habían logrado que el juez de realengos, Ruperto Vicente Luyando se incorporase a ellos. Su matrimonio con María Pueyo y Urríes, hija del regente de la Audiencia Andrés Pueyo y Urríes y allegado a los hacendados, probablemente les permitió establecer algún compromiso en relación a la propiedad de la tierra. En 1772 Ruperto Vicente Luyando fue trasladado como oidor a la Audiencia de Guadalajara, donde fue con su familia, y en 1778 como fiscal a la de México ${ }^{36}$. Esto no significó que concluyera la cuestión de la composición de tierras, pues aún desconociendo quién continuó en dicha tarea, los ingresos en las Cajas Reales siguieron, así en 1792 se entró por este concepto la cantidad de 4.743 reales y 8 maravedíes $^{37}$.

La inexistencia de los títulos de propiedad de la tierra y los litigios por ésta prosiguieron, pues para finales del siglo XVIII se encuentran entre la documentación ejemplos respecto a estos dos asuntos. Un caso ilustrativo es el pleito iniciado en 1776 entre los hacendados Antonio Valdemoro y Alcántara, Antonio Sánchez, Juan Antonio Peña y sus respectivas consortes, y el demandante Juan Manuel Castellón, procurador de la Audiencia, que representaba a Jacobo

\footnotetext{
${ }^{36}$ Burkholder, M. A., y Chandler, D. S., De la impotencia a la autoridad. La Corona española y las Audiencias en América, 1687-1808. México, 1984, pp. 336 y 390; y, Biographical dictionary of audiencia ministers in the Americas, 1687-1821. Westport, 1982, pp. 191-192.

${ }^{37}$ Estado de la entrada y salida de caudales que ha habido en las reales cajas principales de la isla de Santo Domingo desde 1 de enero hasta 31 de diciembre de 1792 y de la existencia en el día de la fecha. AGI, Santo Domingo, 956.
} 
Estuardo, Duque de Bervick y de Veragua, quien reclamaba a los anteriores las tierras situadas entre el río la Isabela y el Higuero. En ellas, el primer hacendado era dueño del ingenio Las Monjas, el segundo del de Miraflor y el tercero de cinco caballerías en la rivera del río Higuero, tierras que Jacobo reclamaba como suyas en virtud de la Real Cédula del 19 de enero de 1637, por la que el rey le había confirmado "las tierras, labranzas, y pastos que el Almirante Don Luis Colon y la Birreyna su Madre poseían en esta Ysla” ${ }^{38}$. Junto a esta cédula presentó también una serie de testigos que se encargaron de corroborarlo. Los demandados consideraban que la información que presentaba para reclamar el terreno como suyo no le daba derecho para sentenciar la posesión que pretendía, alegando además concretamente Antonio Valdemoro y Alcántara “la inmemorial posesión” que poseía su mujer de las tierras del ingenio Las Monjas ${ }^{39}$. También presentaron una serie de declaraciones de testigos para certificar el derecho de la posesión que tenían sobre esas tierras, y como respaldo jurídico los escritos de amparo que poseían éstos. Todo ello les sirvió para que en 1777 fuesen declarados “a todos por legítimos poseedores de los terrenos a que se ha contrahido esta disputa $[\ldots]^{, 40}$.

Tiempo después se pudo confirmar que algunos hacendados no tenían los títulos de propiedad de sus tierras. Esto queda constatado en la declaración del oficial real Juan González Terino en 1794, cuando para ocupar el cargo de tesorero se le exigió que presentase el título de propiedad del hato Arroyo Hondo. El dueño de esta hacienda era el hacendado Nicolás Guridi y Frómesta, quien como fiador de Juan la había ofrecido para seguridad de la Real Hacienda. En dicha declaración Juan dice:

“[...] no solamente dificulta tenerla en su posesion, y solicitarla por lo pronto, sino tambien que exista por ser un documento tan antiguo como los de la

\footnotetext{
38 Rodríguez Demorizi, E., Familias Hispanoamericanas..., op. cit., p. 384.

${ }^{39}$ Tanto Antonio Sánchez como Juan Antonio Peña, alegaban lo mismo que Antonio Valdemoro y Alcántara. Ibidem., p. 385.

40 Juan Antonio Peña fue amparado en febrero de 1771 por el juez de realengos las cinco caballerías de tierra en la rivera del río Higuero. En septiembre de 1767, dos caballerías del ingenio Miraflor de Antonio Sánchez, y en 1769 cuatro caballerías del ingenio las Monjas perteneciente a Antonio Valmero y Alcántara. Ibidem., pp. 383 y 387-390.
} 
posesion de los terrenos y animales del hato en su familia, que segun un mediano computo, debe pasar de ciento y cincuenta años [...]"41.

Para justificar la posesión que tenía el hacendado sobre dicho hato el fiscal de la Audiencia, mandó a Juan González Terino que lo probase competentemente. Así, a través de la información proporcionada por el anotador de hipotecas y el testimonio de una serie de personas, sirvieron para confirmar el caudal que notoriamente poseía el fiador de Juan Terino, y que dicho hato lo había heredado Nicolás Guridi y Frómesta de su padre José Guridi Concha ${ }^{42}$.

A parte de estos problemas en torno a los títulos de propiedad y las ya citadas formas de acceso a la propiedad de la tierra que utilizaron los hacendados, hay que tener en cuenta algunas otras. Una de ellas fue la compra-venta de propiedades. Algunos hacendados accedieron a la tierra a través de la compra de las haciendas y hatos de los jesuitas, que fueron vendidos tras su expulsión de Santo Domingo en $1767^{43}$. Fueron varios los hacendados que se aprovecharon de su confiscación. Uno de ellos fue José Guridi y Concha, quien acudió a la subasta de temporalidades que se celebró el 13 de diciembre de 1773. En ella compró la hacienda La Jagua y los hatos Yaguete y Pizarrete con el potrero Bardecia, y las monterías de Nizao por un valor de 31.357 pesos, 3 reales y 17 maravedíes. En el mismo día y mes, José Frómesta adquirió en la subasta de los bienes de los jesuitas, la estancia de cacao Sainaguá, en el paraje de San Antonio, y los hatos de Sabana Grande y Catalina, y el ingenio de Camba ${ }^{44}$. Los hatos Pizarrete y

\footnotetext{
${ }^{41}$ Pedimento de Juan Gonzalez, 20 de noviembre de 1794. AGI, Santo Domingo, 1045.

${ }^{42}$ Los testigos fueron los hacendados Manuel Heredia, su hermano Nicolás, Juan Francisco Soto y el alférez militar Manuel de Echevarría, en Representación del fiscal a Su Majestad, 22 de noviembre de 1794. AGI, Santo Domingo, 1045.

43 Acerca de los jesuitas y su expulsión así como el remate de sus bienes véase: Sáez, J. L., “Impacto real de la salida de los jesuitas de Santo Domingo (19-23 de agosto de 1767)". Estudios Sociales XXXI: 112 (Santo Domingo, 1998) pp.73-91, y La expulsión de los jesuitas de Santo Domingo. Santo Domingo, 2006. González, R., "Copia de 1787 del expediente sobre inventario, tasación y almoneda de los bienes materiales que fueron de la Compañía de Jesús en Santo Domingo (año 1768) (incompleto)”. Estudios Sociales XXXIII: 122 (Santo Domingo, 2000) pp. 79-123. Según González, el expediente originario relativo a la expulsión y sus bienes "se ha perdido", y lo que se conserva es tan sólo un fragmento de una copia de 1787 ubicada en la sección Época Colonial del Archivo General de la Nación. Este documento se encuentra incompleto y en "avanzado estado de deterioro".

${ }^{44}$ Carta del rey al gobernador de Santo Domingo para que le informe de las diligencias practicadas sobre los bienes de los jesuitas, Real Cédula de 26 de septiembre de 1772. AGI, Santo Domingo, 954. Véase también Reyes, F., Descripción histórica de las antiguas haciendas, estancias y hatos, que durante la era colonial, existieron en el partido de los Ingenios de Nigua, hoy San Cristóbal. Ciudad Trujillo, 1950, p. 53.
} 
Catalina debieron estar situados en los mismos lugares que en la actualidad, se conservan en la jurisdicción de Baní, mientras que la hacienda La Jagua, la estancia Sainaguá, así como los hatos de Sabana Grande y Yaguete, pertenecieron al partido de los Ingenios de Nigua, en San Cristóbal.

Los peninsulares Raymundo Esparza, José de la Vega y Andrés Lecanda y Andirengoechea también debieron comprar sus haciendas y estancias; sin embargo, no hemos encontrado información al respecto. En cambio si se tiene conocimiento de otros, como el contador Francisco de Paula Gazcue y Olaiz, que adquirió su estancia inmediata a la ciudad de Santo Domingo comprándosela a Diego Camarena $^{45}$. Otro caso es el del vasco Juan Bautista Oyarzábal y Olavide, quien compró en 1781 el ingenio denominado Boca de Nigua, situado en la rivera del río Nigua ${ }^{46}$.

Entre 1761 y 1786, Francisco Espaillat y Virol adquirió numerosas propiedades rurales como puede verse en la siguiente tabla. Situadas en la banda norte, concretamente en la jurisdicción de Santiago, Montecristi y Puerto Plata. Estaban dedicadas a la ganadería y al cultivo de productos comerciables como el azúcar, café y añil. Generalmente en ellas también se cultivaba una parte para el consumo propio.

\footnotetext{
${ }^{45}$ Testimonio de las diligencias practicadas por Francica Pueyo sobre que se le entregue los usufructos de la hacienda embargada al contador Francisco Gascue para alimentos de los hijos de este. AGI, Santo Domingo, 997.

${ }^{46}$ Escritura de venta real que Isabel Maldonado hace a Antonio Mañón de Lara en representación de Juan Bautista de Oyarzabal y Olavides residente en la villa de Madrid, Santo Domingo, 2 de octubre de 1781. AGI, Santo Domingo, 969.
} 
Tabla 7-2. Propiedades adquiridas por Francisco Espaillat y Virol, 1761-1786

\begin{tabular}{|c|c|c|c|c|}
\hline Año & Terreno & Explotación & $\begin{array}{l}\text { Anterior } \\
\text { propietario }\end{array}$ & $\begin{array}{c}\text { Precio } \\
\text { en pesos }\end{array}$ \\
\hline 1761 & $\begin{array}{l}\text { Dos terrenos en el hato de } \\
\text { Enmedio }\end{array}$ & Crianza de ganado & $\begin{array}{l}\text { Francisco Muñoz } \\
\text { del Monte }\end{array}$ & 4.500 \\
\hline 1764 & Tierras la Angostura & $\begin{array}{l}\text { Ingenio de azúcar, } \\
\text { añil y crianza de } \\
\text { ganado }\end{array}$ & Pedro Jesús Paredes & 2.000 \\
\hline 1766 & $\begin{array}{l}\text { Terreno en el hato de } \\
\text { Enmedio }\end{array}$ & Crianza de ganado & Jerónima de Villar & 400 \\
\hline 1768 & $\begin{array}{l}\text { Terreno en el hato de } \\
\text { Enmedio }\end{array}$ & Crianza de ganado & $\begin{array}{l}\text { Pedro del Rosario y } \\
\text { Quiñones }\end{array}$ & 150 \\
\hline 1779 & Terreno Baytoa & Crianza de ganado & Juan Reyes Terreros & 215 \\
\hline 1780 & $\begin{array}{l}\text { La mitad de la estancia Nueva, } \\
\text { conocida como finca Los } \\
\text { Ciruelos } \\
\end{array}$ & Siembra de café & Lucas Pichardo & 800 \\
\hline \multirow{3}{*}{1782} & $\begin{array}{l}\text { Terreno en el hato de } \\
\text { Enmedio }\end{array}$ & Crianza de ganado & Mauricia Pacheco & 400 \\
\hline & Terreno Gurabo (Gurabito) & $\begin{array}{l}\text { Ingenio de azúcar y } \\
\text { crianza de ganado }\end{array}$ & Bartolomé Rivas & 800 \\
\hline & Estancia Sabana Grande & Ingenio de azúcar & Juan Basilio de Vera & 650 \\
\hline \multirow{4}{*}{1783} & Estancia Pontezuela & & Pedro de Vera & 425 \\
\hline & Maguana & Crianza de ganado & Manuel Villafaña & 500 \\
\hline & $\begin{array}{l}\text { Terreno en la otra banda del } \\
\text { río Yaque }\end{array}$ & Crianza de ganado & $\begin{array}{l}\text { José Silvestre de } \\
\text { Peña y su mujer }\end{array}$ & 300 \\
\hline & $\begin{array}{l}\text { Terreno en la otra banda del } \\
\text { río Yaque } \\
\end{array}$ & Crianza de ganado & Gregorio Aybar & 300 \\
\hline \multirow{8}{*}{1784} & $\begin{array}{l}\text { Terreno en la otra banda del } \\
\text { río Yaque }\end{array}$ & Crianza de ganado & Mariana de Vargas & 300 \\
\hline & $\begin{array}{l}\text { Terreno en la otra banda del } \\
\text { río Yaque } \\
\end{array}$ & Crianza de ganado & Sebastián Borbón & 45 \\
\hline & $\begin{array}{l}\text { Terreno en la otra banda del } \\
\text { río Yaque }\end{array}$ & Crianza de ganado & Catarina de Aybar & 300 \\
\hline & $\begin{array}{l}\text { Terreno en la otra banda del } \\
\text { río Yaque }\end{array}$ & Crianza de ganado & $\begin{array}{l}\text { Francisco de Bargas } \\
\text { e Isabel Borbón }\end{array}$ & 55 \\
\hline & \begin{tabular}{|l|} 
Terreno en el paraje Las \\
Matas de Santa Cruz \\
\end{tabular} & Crianza de ganado & Gregorio Pérez & 600 \\
\hline & $\begin{array}{l}\text { Terreno en el paraje Las } \\
\text { Matas de Santa Cruz }\end{array}$ & Crianza de ganado & Juan Núñez & 350 \\
\hline & La mitad del sitio La Gozuela & Crianza de ganado & Leonarda Zevallos & 6.600 \\
\hline & $\begin{array}{l}\text { La mitad de una tercia parte } \\
\text { del sitio de La Larga }\end{array}$ & Crianza de ganado & Juan del Monte & 2.300 \\
\hline 1785 & $\begin{array}{l}\text { Un terreno de Las Lagunas e } \\
\text { Isabela }\end{array}$ & Crianza de ganado & José Cid de Chávez & 300 \\
\hline 1786 & $\begin{array}{l}\text { Un terreno en el sitio de La } \\
\text { Isabela }\end{array}$ & Crianza de ganado & Juan de Casacau & 280 \\
\hline
\end{tabular}

Elaboración propia. Fuentes: Las tierras de la Angostura fueron compradas junto a una casa en la ciudad de Santiago. Campillo Pérez, J., Francisco Espaillat y el desarrollo del Cibao. Santo Domingo, 1985, pp. 20-21 y 123-140. 
Todas estas tierras formaban 9 hatos (Enmedio, Baytoa, Maguana, Yaque, Las Matas de Santa Cruz, Las Lagunas, La Isabela, La Larga, La Gozuela), 2 estancias (Los Ciruelos, La Pontezuela) y 3 ingenios (Angostura, Gurabito, Sabana Grande). A lo que habría que añadir seis hatos más: La Salada, y el sitio Nueva Fundación, y el Herradura y Dicayagua, estos últimos continuos a la rivera del río Yaque, y los otros dos que habían aportado sus mujeres, situados ambos en las cercanías de Santiago. Tras el fallecimiento de la primera de ellas, Catalina Tavarez, Francisco Espaillat heredó un pedazo de tierra en el sitio Macabón, y de su segunda mujer, Petronila Velilla, una caballería de tierra en Hato Mayor (Santiago), que le había legado su padre. A finales del siglo XVIII Francisco Espaillat adquirió otro ingenio que compró al padrastro de su segunda mujer, José Tadeo Zevallos, por un precio de 15.000 pesos $^{47}$. Así aquel poseyó un total de 15 hatos, 2 estancias y 4 ingenios.

La compra-venta de un terreno entre familiares fue algo muy habitual como ya pudo verse en el capítulo quinto, donde también se destacó el papel que tuvo la dote como forma de acceder a la propiedad agraria para aquellos peninsulares que se casaron con criollas que llevaban como prenda una hacienda, hato o ingenio. Entre los criollos, la herencia que los padres dejaban a sus hijos u otros parientes les permitió continuar siendo ricos hacendados. Éstos tampoco dudaron en ampliar su patrimonio bien a través del matrimonio dentro de su círculo o comprando y vendiendo terrenos como hizo Nicolás Guridi y Frómesta, quien heredó de su padre la hacienda Santa Ana de La Jagua, los hatos Yaguete, Pizarrete con el potrero Bardecia, Yabacao, Arroyo Hondo, y de su madre el ingenio Santa Ana de la Parra y los hatos Las Damas y Montones ${ }^{48}$. Entre las propiedades que compró destaca el ingenio Santa Cruz del Dajao, por el que pagó a Domingo Fernández y Ana Fernández de Castro 7.320 pesos $^{49}$.

\footnotetext{
${ }^{47}$ José Tadeo Zeballos fue el segundo marido que tuvo la madre de Petronila Sánchez Velilla, mujer de Francisco Espaillat. El primer marido fue el aragonés Francisco Antonio Velilla y Torres. Véase en Campillo Pérez, J. G., Francisco Espaillat..., op. cit., pp. 21 y 128. Y, Deive, C. E., La esclavitud en Santo Domingo, 1492-1844. Santo Domingo, 1980, vol. II, p. 619.

${ }^{48}$ Escritura de reconocimiento de fianza ante el escribano José Francisco Hidalgo, 22 de octubre de 1774. AGI, Santo Domingo, 954.

${ }^{49}$ Hacia 1755 el ingenio fue propiedad del teniente coronel y alférez real Pedro Campuzano. Lo vendió el 27 de noviembre de ese mismo año al regidor José Fernández de Castro y su mujer Antonia Clemencia Fernández, quienes lo transmitieron a Domingo Fernández y su esposa. Certificación de escritura de venta realizada por el escribano Martín de Mueses, 23 de abril de
} 


\subsection{Las haciendas, estancias y hatos}

Las informaciones sobre las propiedades que pertenecieron a algunos de los hacendados estudiados pueden considerarse como las más representativas de aquella época. A través de sus inventarios se observa que las haciendas estaban formadas por elementos comunes, aunque con diferencias en cuanto a su composición y volumen, como puede observarse detalladamente en los anexos (tablas 7, 8, 9 y 10). En primer lugar, los edificios que existían eran tanto construcciones para la residencia del propietario, como casas de los empleados y barracones para los esclavos. También había edificios ligados a la elaboración del o de los productos, bien fuese azúcar u otro fruto con todos los instrumentos necesarios. En aquella época éstos eran conocidos como casas de trabajo. La mayoría de las haciendas contaban con una ermita propia, y sólo la finca de La Angostura de Francisco Espaillat llegó a tener un hospital.

En segundo lugar, estaban las tierras cultivadas de estas fincas, distinguiéndose dos tipos. Aquellas que eran de grandes extensiones y donde eran cultivados los productos de exportación: caña de azúcar, café, cacao, añil, etc. Y las tierras en las que había cultivos de alimentos y árboles frutales para el abastecimiento del propietario y familiares así como para los esclavos. También solían tener reservas forestales y lagunas que les servían para el pastoreo de animales y recolección de madera, frutos silvestres, caza y pesca. En tercer lugar, todas las fincas tenían animales, que eran aprovechados tanto para la alimentación como para el transporte y trabajo, y la mano de obra formada por esclavos.

El ingenio de Santa Ana de La Jagua perteneció a partir de 1776 a Nicolás Guridi y Frómesta. Éste lo había heredado de su padre José Guridi y Concha quien, como ya se comentó, había pertenecido a los jesuitas y tras su expulsión fue comprado por él. En el inventario correspondiente a los años 1773 y 1774 consta que el ingenio La Jagua estaba compuesto por las siguientes edificaciones: la casa vivienda, una ermita y las casas de trabajo de purga y aguardentería, de carpintería, de ingenio y de calderas, todas ellas construidas de piedra y ladrillo. En estos edificios se encontraban los alambiques, canoas, espumaderas, pilones, fondos de cobre, etc. En la descripción de los utensilios de trabajo había desde los 
instrumentos para trabajar el azúcar como de labranza, entre los que pueden citarse planas, pailas, colador de cobre, pernos, coas, hachas, fondos de cobre, guayos, botijas, bateas, almireces, parrillas de hierro, sierras, burenes, barrenas, y otras múltiples herramientas.

En cuanto a las tierras de labranza el ingenio contaba con 13 extensas partes de sembraduras de barbecho de caña, 1 de maíz, 25 tareas de plátano, 700 árboles de café, 22 tareas de yuca, y 1.120 árboles de cacao. Además presentaba 1.774 varas de palizada de madera y javilla entremetida con algunos naranjos y limoneros. Los animales de los que dispuso la finca estaban representados por 31 mulas, 17 caballos, 8 yeguas, 6 potros, 12 yuntas de bueyes, 2 burros, 11 ovejas, 11 gallinas, 5 pollos, 1 gallo, 1 capón y 7 patos. El personal de trabajo se componía de unos 111 esclavos entre hombres, mujeres y niños. Tenía un rendimiento anual de 8.000 pesos $^{50}$. Nicolás Guridi y Frómesta tuvo también otros dos ingenios, llamados Santa Ana de la Parra y Santa Cruz del Dajao, este último situado al otro lado del río Ozama y formado “con negros, herramientas y demas especies de que esta fundado en seis caballerias de tierra [...] con pastos y abrevaderos $[\ldots]^{\text {"51. }}$.

Hacia 1795 el ingenio Santa Ana de Engombe era de Josefa CocaLandeche y su marido Lorenzo Angulo Medrano. Localizado en el margen izquierdo del río Haina estaba compuesto de 9 caballerías de tierra, con su ermita y las distintas casas. La vivienda estaba construida de piedra de cantería, la de purga de cal y canto con techo de yaguas; la casa de herrería también de cal y canto pero con techo caído; la de aguardentería igual que las anteriores pero sin techo; la de ingenio con el techo de cogollo, y la de calderas de yaguas. En todas ellas se encontraban los instrumentos necesarios para la fabricación del azúcar y aguardiente. Tuvo un bohío de vivienda para el mayordomo, y corrales para los animales. Disponía de una plantación de 15 barbechos con 55 tareas de caña de hoja, 184 de caña soca, 116 de caña plantona, 64 de caña resoca, y de 1.061 varas de palizada firme ${ }^{52}$. Para realizar las faenas tuvo 31 esclavos (uno de ellos

\footnotetext{
${ }^{50}$ Certificación del inventario corregida con el expediente original realizada por el escribano José María Rodríguez, 12 de noviembre de 1796. AGI, Santo Domingo, 2683.

${ }^{51}$ Certificación de escritura de venta realizada por el escribano Martín de Mueses, 23 de abril de 1792. AGI, Santo Domingo, 1045.

${ }^{52}$ En función de los cortes que debía recibir la caña de azúcar durante su cultivo ésta tiene un nombre determinado: caña de planta se llama la caña que se corta por primera vez, soca de planta o
} 
maestro de azúcar) y entre los animales: 4 yeguas, 1 caballo, 10 mulas, 1 burro, 5 yuntas de bueyes, 3 vacas, 60 ovejas, y 11 reses. También contaba para su aprovechamiento con la estancia llamada Cocos fundada en 2 caballerías de tierra y con 2.575 árboles de cacao, 34 palmas de coco, una palizada de 330 varas y 2 esclavos $^{53}$.

socaplanta la que se corta por segunda vez, la caña soca a la que proviene de la socaplanta y la caña resoca aquella que nace en los terrenos de soca. Véase al respecto en Moreno Fraginals, M., El ingenio. Complejo económico social cubano de azúcar. Barcelona, 2001, p. 159.

${ }^{53}$ García Lluberes, L., "Miscelánea histórica. (Extractos de los Cuadernos de Apuntes del Historiador García). El ingenio Santa Ana de Engonve”. CLÍO 102 (Ciudad Trujillo, 1955) pp. 3944. 
Figura 7-2. Croquis del ingenio Santa Ana de Engombe y alrededores

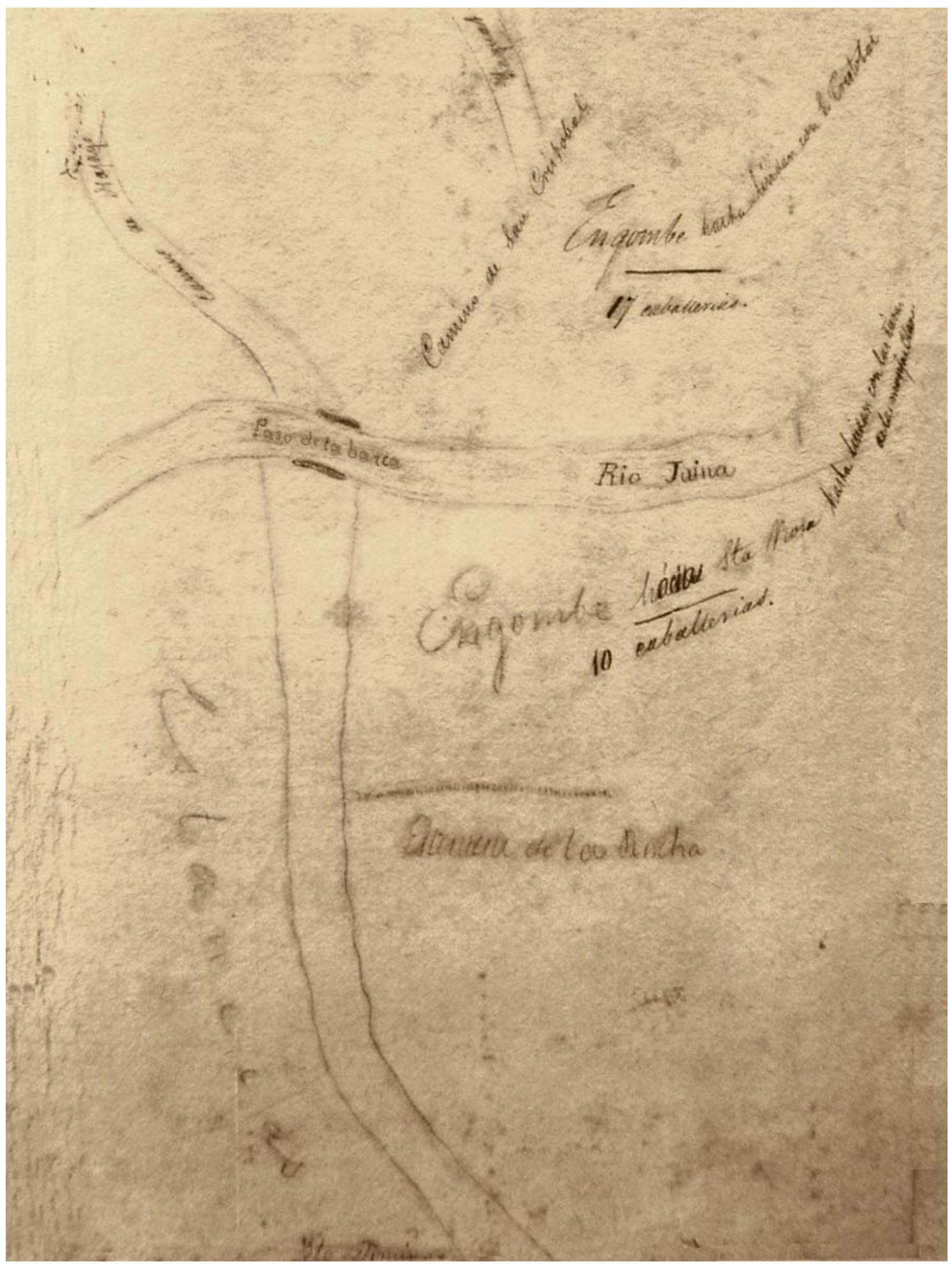

Fuentes: Mapa de finales del siglo XIX en Rodríguez Demorizi, E., Mapas y planos de Santo Domingo. Santo Domingo, 1979, p. 365. 
Entre otros ingenios importantes para aquella época destacan los de los peninsulares José de la Vega, Juan Bautista Oyarzábal y del francés naturalizado español Francisco Espaillat. Todos ellos lograron formar parte de los hombres más ricos e importantes de Santo Domingo. José de la Vega logró reunir un capital de 52. 697 pesos, una cuantía de bienes entre los que tuvo el ingenio Mata Naranjo de 3 caballerías de tierra distante a cinco leguas al oeste de Santo Domingo, en la jurisdicción de esta ciudad. De la misma manera que los anteriores ingenios descritos, éste poseía todos los elementos necesarios, desde los edificios hasta los instrumentos para extraer azúcar y aguardiente. Sus cañaverales consistían en 2.135 varas de cerca viva de javilla y limón, y otros terrenos en los que también se cultivaba yuca, maíz, batata. Entre las tierras de labranza destacan 2.607 árboles de cacao, 309 pies de café y 3.107 matas de plátanos. La ganadería de la que disponía esta finca estaba representada por mulas, caballos, yeguas de cría, potros, burros, vacas, bueyes y becerros. Unida al ingenio estaba la estancia Guaximía de 1 caballería de tierra, la cual se hallaba cercada y en ella había árboles frutales, cocos y un bohío con cocina. También estaban ubicados cerca del ingenio dos hatos de que disponía José de la Vega para su aprovechamiento. Uno era el hato Yacó de 7 caballerías de tierra, compuesto de un bohío, 2 esclavos, 186 reses, 6 bestias y 17 puercos de crianza, y el hatillo Mata Naranjo que se componía de 6 caballerías de tierra ${ }^{54}$.

Del ingenio de azúcar de Juan Bautista Oyarzábal y Olavide se sabe que se denominaba Santa María del Rosario de Andiarena, aunque era conocido "vulgarmente con el nombre de Boca Nigua", por estar situado en la orilla meridional del río Nigua como su nombre indica, y "en el parage por donde este rio entra en el mar” nombrado Ingenio Viejo de Nigua ${ }^{55}$. Distaba entre tres y cinco leguas de la ciudad de Santo Domingo y estaba formado por una casa vivienda, las instalaciones del ingenio de azúcar, así como las tierras necesarias para el cultivo

\footnotetext{
54 Resumen de los vienes que comprehende el antecedente abaluo propios del Capitán Joseph de la Vega, 15 de junio de1805. AGI, Santo Domingo, 964.

${ }^{55}$ Escriptura de fianza otorgada por parte de la testamentaria del Exmo. Señor Marques de Iranda con barias ypotecas, para satisfacer a diferentes acreedores 4.897.676 reales de vellon el termino de tres años, en virtud de Real Orden de S. M., 30 de noviembre de 1806. AHPM, protocolo $\mathrm{n}^{\mathrm{0}} 21764$, fol. 656 .
} 
de la caña compuesta de 12 caballerías de tierra a las cuáles fue añadiéndose otras contiguas a ellas alcanzando la extensión total de 19 y 3/4 de caballerías ${ }^{56}$.

Hasta hace poco no se había constatado quien fue el dueño de este ingenio ya que se pensaba que era de Juan Bautista Oyarzábal, pero en realidad no fue su propietario sino su administrador y representante en Santo Domingo. Su dueño fue su primo, el Marqués de Iranda, que residía en Madrid ${ }^{57}$. Juan Bautista Oyarzábal, de origen vasco, también vivía en esa ciudad, desde la que compró dichas caballerías, concretamente las 12 lo hizo a través de un intermediario en la ciudad de Santo Domingo. Se trataba del hacendado Antonio Mañón de Lara, quien en representación de Juan Bautista Oyarzábal las adquirió el 2 de octubre de 1781 pagando a su vendedora Isabel Maldonado "2.400 pesos de ocho reales de plata cada uno” ${ }^{58}$. Para la puesta en marcha del referido ingenio, Juan Bautista Oyarzábal solicitó una serie de gracias y exenciones fiscales que le fueron concedidas, y posteriormente al resto de los hacendados como ya se vio en el capítulo cuarto. Además debió invertir en él “como doscientos mil pesos, más o menos" ${ }^{59}$. No se ha encontrado el inventario que detalle minuciosamente la composición de este ingenio, pero por las referencias que ofrece la documentación y los restos de éste que aún hoy se conservan, puede afirmarse que debió formar parte de los ingenios más grandes e importantes de aquella época. En 1796 el regente José Antonio Urízar lo definía como “[...] una Hacienda, que si no excede a la mejor de estas Islas, se puede afirmar, que en el conjunto de sus circunstancias no hay otra que la aventaje $[\ldots]]^{\prime 60}$.

\footnotetext{
${ }^{56}$ Según el regente José Antonio de Urízar el ingenio se encontraba a una distancia de tres leguas de la capital, mientras que en una relación del gobernador Joaquín García y del oidor Manuel Bravo la distancia que dan es de cinco leguas, véase en Carta del oidor José de Urízar al Príncipe de la Paz sobre la rebelión de los esclavos de Boca-Nigua, 1 de noviembre de 1796; Informe del gobernador Joaquín García al Príncipe de la Paz, sobre la abortada sublevación de Boca Nigua, 31 de diciembre de 1796, reproducidos en Sáez, J. L., La Iglesia y el negro esclavo en Santo Domingo. Una historia de tres siglos. Santo Domingo, 1994, pp. 488-493.

${ }^{57}$ Se trata del comerciante y financiero vasco Simón de Aragorri y Olavide. Licencia dada a Pedro Abadía para pasar a Santo Domingo para emplearse en el ingenio del Marqués de Iranda, que está a nombre de Juan Bautista Oyarzábal, 26 de octubre de 1787. AGI, Santo Domingo, 1099. Escriptura de declaracion, que otorgan el señor Marques de Iranda, y don Juan Bautista de Oyarzabal, Madrid 7 de octubre de 1783. AHPM, protocolo $\mathrm{n}^{\circ}$ 21650, fols. 792-793. Véase también Julián, A., Bancos, ingenios y esclavos en la época colonial. Santo Domingo, 1997, pp. 299-300.

${ }^{58}$ Idem., y Escritura de venta real que Isabel Maldonado hace a Antonio Mañón de Lara en representación de Juan Bautista de Oyarzabal y Olavides residente en la villa de Madrid, 2 de octubre de 1781. AGI, Santo Domingo, 969.

59 Julián, A., Bancos, ingenios y esclavos en la época colonial..., op. cit. p. 330.

${ }^{60}$ Idem.
} 
Otra descripción de este ingenio la ofrece un viajero francés llamado Vicent que visitó la isla en 1798. En su relato admite haber estado en esta finca de la que comenta:

"Yo salí el día 22, a las cinco de la tarde, de Santo Domingo para venir a dormir a un ingenio perteneciente a un español, hombre muy meritorio, llamado Aria Saba (Oyarzábal). Este establecimiento es, sin duda, el más magnífico y el mayor de la Parte Española, aunque las construcciones atestiguan por doquier que el propietario tenía mucho dinero y el arquitecto mucha pesadez en sus ideas y estilo de construcción”,

Esta finca también es conocida por la rebelión de negros que hubo en ella en 1796, siendo una de las más importantes de finales del siglo XVIII dominicano. Anteriormente a ella ya se habían producido unos conatos de sublevación en otros lugares como Hincha, San Juan de la Maguana, Samaná y en las haciendas situadas entre los ríos Haina y Nizao entre 1791 y 1796. Probablemente todos ellos estuvieron influenciados por el levantamiento de esclavos que sufrió la colonia francesa en $1791^{62}$.

Desde 1781 hasta 1793, probablemente el ingenio había experimentado importantes transformaciones en su dotación técnico-material. Aunque no se cuente con el número y el valor de los esclavos, el siguiente cuadro permite apreciar el monto de las instalaciones más importantes así como el de las tierras, evaluado en conjunto hacia 1793. Además de este ingenio el Marqués de Iranda poseyó en la isla otras tierras de labor y cría de ganado vacuno, que fue adquiriendo entre 1785 y 1796 de igual manera que el de Boca Nigua a través de su pariente y administrador Juan Bautista Oyarzabal.

\footnotetext{
61 "Resumen del viaje hecho del Cabo a Santo Domingo a comienzos del mes de Brumario del año 7 (1798) por el C. Vincent, director de las fortificaciones de las islas de Sotavento" en Rodríguez Demorizi, E., Viajeros de Francia en Santo Domingo..., op. cit., pp. 135-160, p. 151.

${ }^{62}$ Sobre el levantamiento de negros en el ingenio de Boca de Nigua véase: Andreu Ocariz, J. J., “La rebelión de los esclavos de Boca Nigua”. AEA XXVII (Sevilla, 1970) pp. 551-581. Julián, A., Bancos, ingenios y esclavos en la época colonial... op. cit., pp. 317-328.
} 
Tabla 7-3. Composición de las haciendas del Marqués de Iranda

\begin{tabular}{|c|c|c|c|c|}
\hline \multicolumn{5}{|c|}{ Ingenios } \\
\hline Hacienda & Ubicación & Extensión & Composición & Valor total \\
\hline \multirow[t]{2}{*}{$\begin{array}{l}\text { Ingenio Boca } \\
\text { Nigua }\end{array}$} & \multirow[t]{2}{*}{$\begin{array}{l}\text { Paraje el } \\
\text { Ingenio } \\
\text { Viejo de } \\
\text { Nigua (río } \\
\text { Nigua) }\end{array}$} & \multirow[t]{2}{*}{$\begin{array}{l}19 \text { y 3/4 } \\
\text { caballerías }\end{array}$} & $\begin{array}{l}\text { Casa vivienda, } \\
\text { azucarería, el } \\
\text { molino de la casa, } \\
\text { aguardientería sin } \\
\text { enseres }\end{array}$ & $28.825 \$$ \\
\hline & & & Terrenos & 4.827\$ y 3rs. \\
\hline \multicolumn{5}{|c|}{ Tierras incultas } \\
\hline Hacienda & Ubicación & Extensión & Composición & Valor total \\
\hline Un terreno inculto & $\begin{array}{l}\text { Paraje el } \\
\text { Ingenio } \\
\text { Viejo de } \\
\text { Yuca }\end{array}$ & $\begin{array}{l}\text { 18,5 } \\
\text { caballerías }\end{array}$ & & $7.650 \$$ \\
\hline Hato Santa Ana & $\begin{array}{l}\text { Entre los } \\
\text { ríos } \\
\text { Ozama y } \\
\text { Cabon }\end{array}$ & $\begin{array}{l}23 \text { o } 24 \\
\text { caballerías }\end{array}$ & $\begin{array}{l}1 \text { bohío, } 426 \\
\text { reses, } 8 \text { bestias } \\
\text { caballares, } 33 \\
\text { esclavos y otros } \\
\text { enseres }\end{array}$ & $4.432 \$$ \\
\hline Hatillo de la Seiba & $\begin{array}{l}\text { Norte del } \\
\text { hato Santa } \\
\text { Ana }\end{array}$ & $\begin{array}{l}12 \text { y } 1 / 4 \\
\text { caballerías }\end{array}$ & $\begin{array}{l}26 \text { cabezas de } \\
\text { bestias caballares, } \\
\text { buros, } 6 \text { esclavos, } \\
\text { canoa de navegar } \\
\text { y otros enseres }\end{array}$ & \multirow[t]{2}{*}{$6.148 \$$} \\
\hline \multicolumn{4}{|l|}{$\begin{array}{l}\text { Tierras de Moxica, } \\
\text { Rincón dorado, } \\
\text { Guabina y las } \\
\text { Caobas }\end{array}$} & \\
\hline $\begin{array}{l}\text { La mitad de los } \\
\text { terrenos del hato y } \\
\text { monterías de } \\
\text { Sierra Prieta }\end{array}$ & & & & $1.000 \$$ \\
\hline Un terreno & $\begin{array}{l}\text { Paraje } \\
\text { Boca } \\
\text { Haina } \\
\end{array}$ & 4 caballerías & & $1.000 \$$ \\
\hline Suma total & & & & $53.882 \$$ \\
\hline
\end{tabular}

Elaboración propia. Fuentes: Escriptura de fianza otorgada por parte de la testamentaria del Exmo. Señor Marques de Iranda con barias ypotecas, para satisfacer a diferentes acreedores 4.897.676 reales de vellon el termino de tres años, en virtud de Real Orden de S. M., 30 de noviembre de 1806. AHPM, protocolo n ${ }^{\circ} 21764$, fols. 656 y 673. 


\section{Figura 7-3. Ingenio Boca de Nigua}
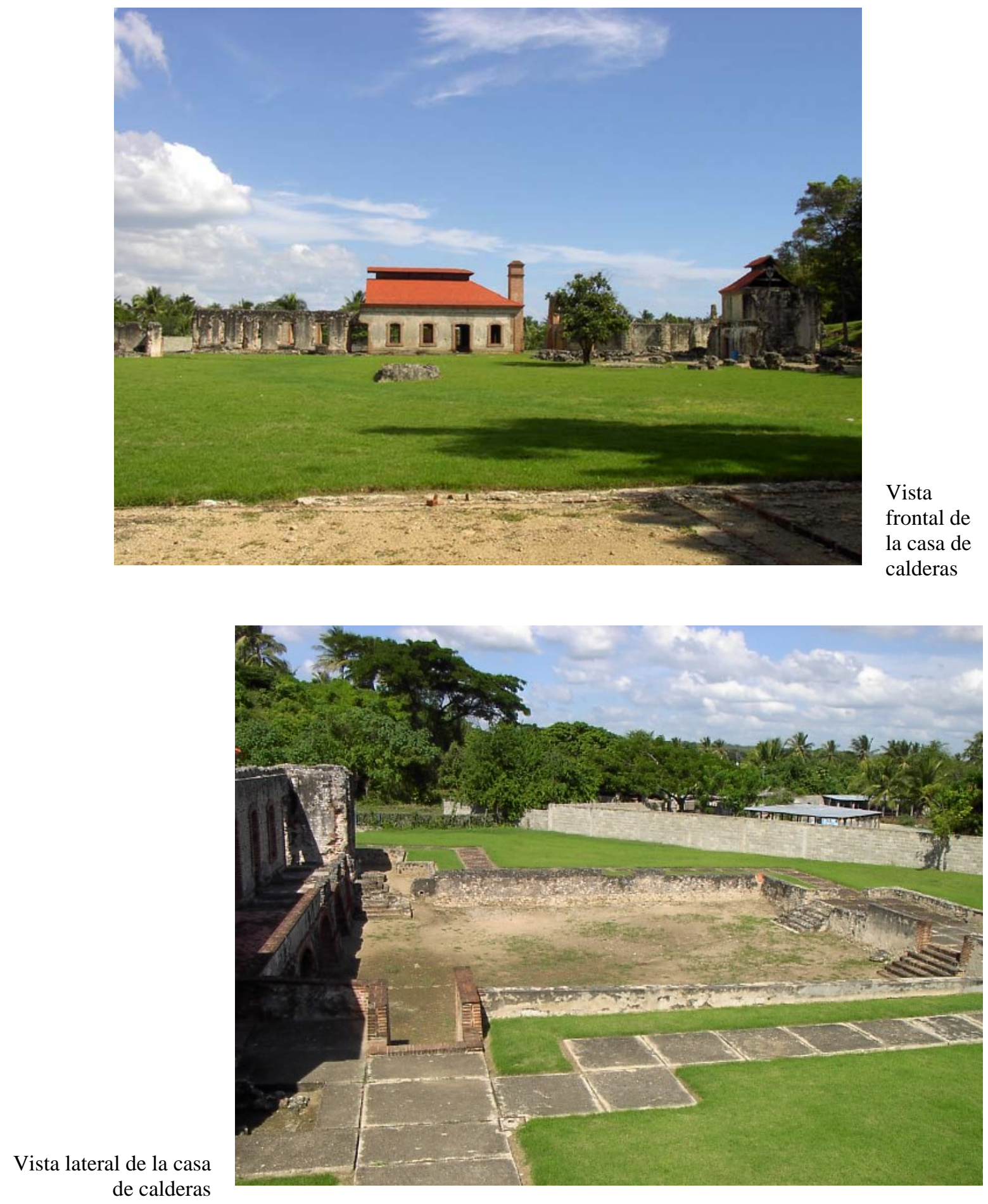

Fotos: autora 
Figura 7-4. Ubicación del ingenio Boca de Nigua

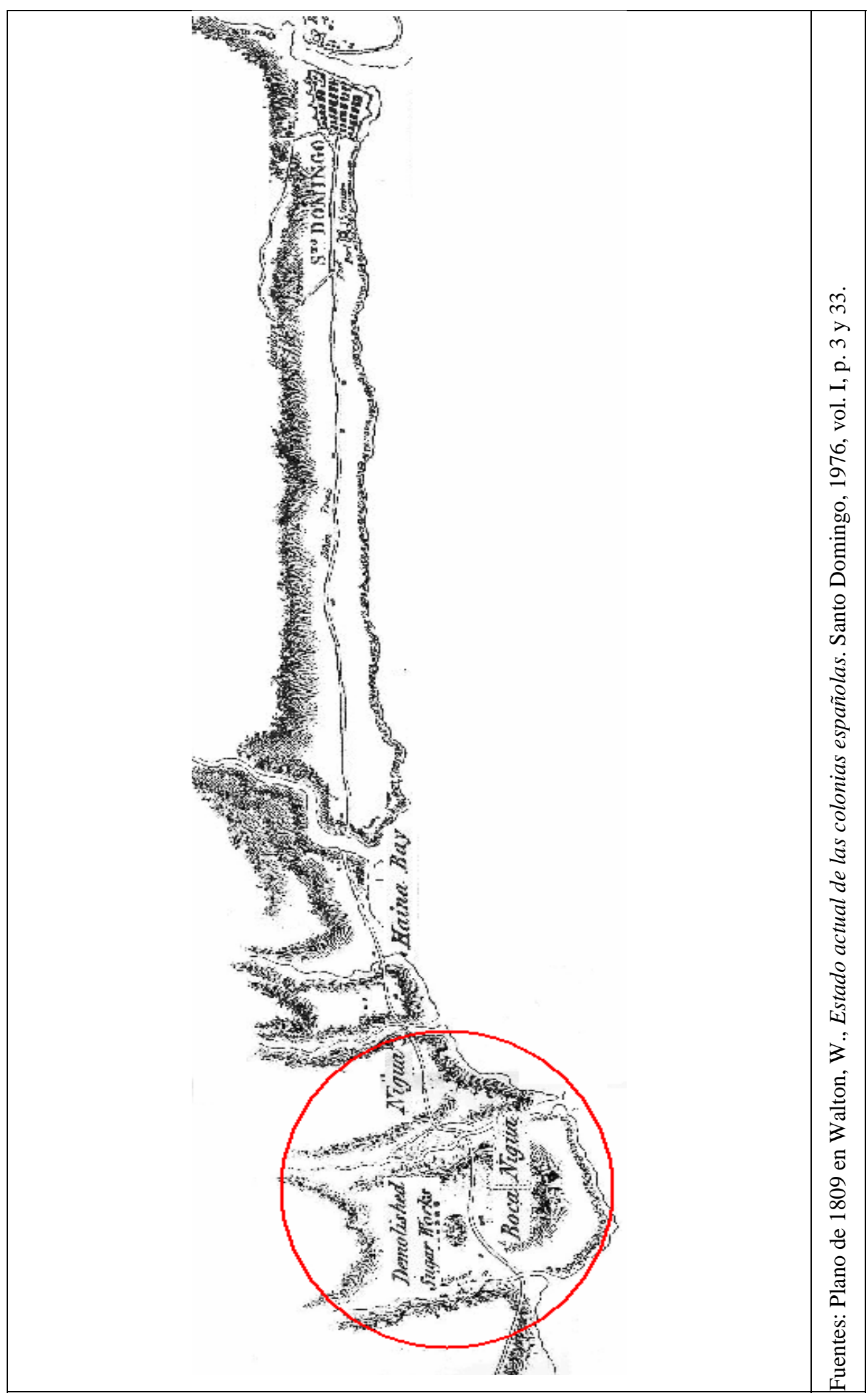


Los ingenios Gurabito, Sabana Grande y La Angostura pertenecientes al francés Francisco Espaillat, están considerados también como unos de los más opulentos y completos en la elaboración de azúcar. De hecho la descripción que da el inventario de su patrimonio realizado en 1787 lo revela ${ }^{63}$. Estas fincas estaban ubicadas en la jurisdicción de Santiago, a diferencia de las que hasta ahora se han ido señalando.

De acuerdo con el inventario, la casa vivienda del ingenio Gurabito estaba edificada de madera y cubierta de teja de barro y soladura de ladrillo, medía 20 varas de largo y 10 de ancho, y tenía 25 esclavos. A su lado estaba otra serie de edificios, como dos almacenes grandes, uno en el que había una cocina y un cuarto, y en el otro donde se guardaban los burenes. Además contaba con un bohío cubierto de yaguas para el mayordomo, y una prisión con rejas. Entre las instalaciones de trabajo destaca la casa de molienda construida con madera de candelón $^{*}$ y cubierta de yagua, mientras que la de calderas estaba edificada sobre cimientos de pared, viga entablada de palma y con una cubierta de teja de barro y hornallas de pared. Ésta última tenía una longitud de 16 varas de largo y 8 de ancho. Sus tierras de labranza eran 4 barbechos de caña de todos los tiempos, 40 tareas de platanar con 4.000 matas, y una palizada de más de media legua de tierra que contaba con agua y desmonte. Los animales utilizados para las faenas de trabajo eran 80 reses, 18 mulas, 55 bestias y 5 burros.

En la descripción del ingenio de Sabana Grande puede verse que la extensión del área cultivada era de 8 barbechos de caña madura de 40 tareas conuqueras, 4.000 pies de café y 60 tareas de plátanos. Las casas de trabajo de este ingenio aparecen trazadas detalladamente. Así la casa de ingenio disponía de 3 tambores de moler y 4 mazas que daban movimiento a las piezas elásticas o resorte para escupir el bagazo sin operario, 11 parrillas de hierro para las hornallas de 6 pailas, 8 carretas con cadenas y ejes de hierro y un alambique con 3 barricas para extraer aguardiente. La casa de molienda constaba de 22 varas de diámetro de paredes de cal y piedra para el interior, y el exterior al estilo inglés. Tenía una

\footnotetext{
${ }^{63}$ Campillo Pérez, J., Francisco Espaillat..., op. cit., pp. 123-140. Todo lo que sigue procede de este libro.

* La madera de candelón abunda en el área del parque natural de los Haitises (sitios de Mejía y Rojas) y en las lomas del Seibo. "Es un árbo alto y de madera muy dura, que se usaba mucho para la confección de trapiches de azúcar y horcones de viviendas y para las viguerías de casas coloniales”, en Mañón Arredondo, M. J., Crónicas de la Ciudad Primada..., op. cit., p. 193.
} 
altura de 7 pies con 16 pilares de ladrillo y unas bóvedas para introducir la caña y sacar el bagazo. La madera utilizada para el interior de la cubierta fue la caoba, que estaba aserrada y labrada, mientras en el exterior estaba revestida de teja de barro. El área de calderas también disponía de gran amplitud al contar con 66 varas de largo con un corredor de 30 sobre pilares, y unas 9 varas y dos tercios de ancho. Su altura fue menor que la anterior al ser de 4 pies y una profundidad de 4 varas. La casa de purga, o área donde se realizaba el trabajo de purgado de la meladura, disponía de una pila para recibir miel y una alambiquera separada por 12 pipas hechas de ladrillo molido. Estaba cobijada por un techo de teja de barro sobre carpintería a la francesa, constaba de 13 ventanas con rejas de hierro y 10 puertas de caoba. El número de esclavos era de 55 y el de animales de trabajo de 110 entre mulos, caballos, bestias y yuntas de bueyes.

La finca de La Angostura era una unidad agrícola en la que se cultivaba azúcar así como añil, producción a la que se dedicó más específicamente. Al igual que toda hacienda contó con la casa de vivienda principal en la que residía el propietario, y una ermita. A ambos lados de la ermita se hallaba el hospital, que tenía una longitud de 17 varas de largo por 7 de ancho. Estaba construido sobre cimientos de pared y soladura de ladrillo y la cubierta de techo, y en su interior había un cuarto que era la botica donde se almacenaban las medicinas. Las casas de trabajo de la hacienda mantenía las mismas instalaciones que cualquier otra de las ya mencionadas, y estando todas ellas soladas de ladrillo y cubiertas de teja. Pero además existieron otras construcciones, como una cocina al lado de la casa principal, una conejera, un gallinero en simetría al de los palomares, una cárcel, una casabera*, una fragua y carpintería con 3 divisiones y con los utensilios de ambos oficios, y un pozo de 8 varas de profundidad y una bomba para llevar el agua que servía para el riego. Tenía 1.400 matas de plátano, y entre los animales 250 reses, 50 bestias y 200 cerdos de crianza. Llama la atención que sólo tuviera 8 esclavos como mano de obra, un número escaso frente a la dimensión de la hacienda y el trabajo que debía haber en ella.

Algunos de los hacendados también se dedicaron de manera específica a la explotación de estancias y hatos. Hasta ahora los hacendados poseían ingenios, y junto a éstos existió el cultivo de ambos tipos de explotaciones. Entre algunas de

\footnotetext{
${ }^{*}$ Lugar común.
} 
las estancias que se dedicaron a la plantación de café destaca una propiedad que tenía Francisco Espaillat en Santiago llamada los Ciruelos, otras como Cambita y San Isidro de Cambita estaban cerca de Santo Domingo a orillas del río Nizao ${ }^{64}$. El dueño de la primera de ellas era Nicolás Guridi Coronado y el de la segunda Nicolás Sterling.

La estancia de la que se posee más noticias es la de Guayabal, que pertenecía al oficial real Raymundo Esparza. Estaba dedicada tanto al cultivo del azúcar como al de la yuca, casabe, maíz, y arroz, según los objetos, las casas de trabajo y las tierras de labranza que aparece descrito en su inventario de 1786. Concretamente sus tierras estaban formadas por 16.000 varas de tierra que para dicho año estaban “aviadas para poder sembrar”, 32 varas de yuca, 6.000 varas de caña, 600 matas de plátanos, 933 varas de palizada, y otras tierras dedicadas a hortalizas $^{65}$. Para el regadío de las tierras disponía de una noria y una pila que estaban en el huerto. Además había tres bohíos. Uno de ellos servía de almacén para los frutos, otro era para el mayordomo de la estancia, y el último para el mayoral encargado del cuidado de los animales. Las edificaciones de trabajo que tenía eran la casa de ingenio y la casa de molino de yuca. La casa vivienda era muy amplia, y estaba amueblada confortablemente con gran variedad de muebles, libros y cuadros, como se vio en el capítulo sexto. También contaba con las herramientas y utensilios necesarios para trabajar en la hacienda como hachas, palas, azadas, espiochas, pilones, calderos, pilones, fondos, bateas, a pailas, un alambique y espumaderas entre otros. En cuanto al número de mano de obra ésta contó con 55 esclavos ${ }^{66}$.

Entre los hacendados que también se dedicaron a las explotaciones ganaderas destaca el ya citado Francisco Espaillat, que tuvo 15 hatos. Otro de los hacendados que se dedicó a la ganadería fue Nicolás Guridi y Frómesta, quien como ya se comentó había heredado de su padre los hatos Pizarrete, Yaguete, Yabacao, el potrero Bardecia y Sabana Buey. Pero además tuvo otros cuatro hatos de mayor magnitud y valor. Dos de ellos, el nombrado Yabacao y Arroyo Hondo también los había heredado de su padre. El primero estaba situado en jurisdicción

\footnotetext{
${ }^{64}$ La estancia San Isidro de Cambita también era conocida como Cambita-Sterling.

65 Testimonio de la pieza comprensiva del inventario y avalúo de la casa estancia de labrar frutos nombrada El Guayabal, sita en el otro lado del río de esta ciudad perteneciente al difunto Raymundo Esparza. AGI, Santo Domingo, 992.

${ }^{66}$ Ibidem.
} 
de la ciudad de Santo Domingo, contaba con 1.100 reses y 70 caballos y junto al mobiliario valía 14.900 pesos $^{67}$. El segundo hato llamado Arroyo Hondo tenía ganado menor y bestias caballeras, estaba en la jurisdicción de Baní y su valor ascendía a 3.000 pesos. El hato las Damas y Montones, los había heredado de su madre e importaban 11.128 pesos $^{68}$.

\footnotetext{
${ }^{67}$ Según la documentación cada res estaba tasada en diez pesos, mientras que el caballo en veinte por lo que el valor total del hato era de 12.900 y no la cantidad ya citada debido probablemente a un error del escribano. Relacion jurada de Nicolás Guridi y Frómesta del valor actual de las fincas, Santo Domingo terminador año Once Francés. AGI, Ultramar 9.

${ }^{68}$ El hato las Damas estaba "dentro de las confrontaciones del ingenio Santa Ana de la Parra” en Escritura de reconocimiento de fianza realizada por el escribano José Francisco Hidalgo, Santo Domingo, 22 de octubre de 1774. AGI, Santo Domingo, 954.
} 
Ruth Torres Agudo

Tabla 7-4. Composición de los hatos de Francisco Espaillat y Virol

\begin{tabular}{|c|c|c|c|c|}
\hline Hato & Ubicación & Composición & Animales & $\begin{array}{l}\text { Valor total } \\
\text { en pesos }\end{array}$ \\
\hline Maguana & $\begin{array}{l}\text { Valle del } \\
\text { Cana }\end{array}$ & & $\begin{array}{l}200 \text { reses } \\
11 \text { betias } \\
9 \text { yeguas de parto } \\
2 \text { caballos }\end{array}$ & 2.330 \\
\hline Enmedio & & $\begin{array}{l}3 \text { esclavos ( } 2 \\
\text { de ellos } \\
\text { mayorales) }\end{array}$ & $\begin{array}{l}550 \text { reses } \\
30 \text { bestias } \\
18 \text { burros } \\
250 \text { cabras y ovejas }\end{array}$ & 7.441 \\
\hline La Salada & & 2 esclavos & $\begin{array}{l}250 \text { reses } \\
12 \text { bestias }\end{array}$ & 3.150 \\
\hline La Larga & & 1 esclavo & $\begin{array}{l}500 \text { reses } \\
15 \text { bestias }\end{array}$ & 5.675 \\
\hline $\begin{array}{l}\text { La } \\
\text { Gozuela }\end{array}$ & Montecristi & 1 esclavo & $\begin{array}{l}420 \text { reses } \\
28 \text { bestias } \\
41 \text { cabras } \\
33 \text { ovejas }\end{array}$ & 5.711 \\
\hline Macabón & Montecristi & & $\begin{array}{l}200 \text { reses } \\
68 \text { bestias } \\
56 \text { cabras } \\
49 \text { ovejas }\end{array}$ & 4.357 y 4 rs. \\
\hline $\begin{array}{l}\text { Las Matas } \\
\text { de Santa } \\
\text { Cruz }\end{array}$ & Montecristi & 2 esclavos & $\begin{array}{l}180 \text { reses } \\
18 \text { bestias } \\
3 \text { burros } \\
31 \text { cerdos de crianza }\end{array}$ & 2.926 \\
\hline Yaque & $\begin{array}{l}\text { Ribera del río } \\
\text { Yaque }\end{array}$ & $\begin{array}{l}1 \text { esclavo, y } \\
\text { un bohío } \\
\text { cubierto de } \\
\text { teja, cocina, } \\
\text { corral y } \\
\text { chiquero }\end{array}$ & $\begin{array}{l}50 \text { reses } \\
6 \text { bestias } \\
100 \text { cabras } \\
100 \text { ovejas }\end{array}$ & 1.530 \\
\hline $\begin{array}{l}\text { La } \\
\text { Herradura }\end{array}$ & $\begin{array}{l}\text { Ribera del río } \\
\text { Yaque }\end{array}$ & 1 esclavo & 66 reses & 920 \\
\hline Dicayagua & $\begin{array}{l}\text { Ribera del río } \\
\text { Yaque }\end{array}$ & & & $\dot{¿}$ ? \\
\hline $\begin{array}{l}\text { Sitio } \\
\text { Baytoa }\end{array}$ & & & 100 cerdos & 200 \\
\hline $\begin{array}{l}\text { Sitios Las } \\
\text { Lagunas e } \\
\text { Isabela }\end{array}$ & Puerto Plata & & $\begin{array}{l}20 \text { reses } \\
4 \text { yuntas de bueyes } \\
500 \text { cerdos }\end{array}$ & 900 \\
\hline $\begin{array}{l}\text { Sitio } \\
\text { Fundación } \\
\text { Nueva }\end{array}$ & & $\begin{array}{l}\text { bohío, } \\
\text { pocilgas y } \\
\text { cercado de } \\
\text { tablas }\end{array}$ & & 100 \\
\hline $\begin{array}{l}\text { Hato } \\
\text { Mayor }\end{array}$ & $\begin{array}{l}\text { Alrededores } \\
\text { de Santiago }\end{array}$ & $\begin{array}{l}1 \text { caballería de } \\
\text { tierra }\end{array}$ & & 600 \\
\hline Total & & & & 35.840 y 4 rs. \\
\hline
\end{tabular}

Elaboración propia. Fuentes: Campillo Pérez, J., Francisco Espaillat..., op. cit., pp. 20-21 y 123-140. 
Los hatos estaban representados en una extensión de tierra que contenía montes y lagunas, y por un número de cabezas de ganado vacuno, aunque también se criaban cerdos, caballos, burros, cabras, ovejas, etc. En el desglose de los inventarios se observa que las instalaciones de éstos, en comparación con las haciendas y estancias, eran bastantes sencillas. Lo habitual era que existiese un bohío en el que vivía el mayoral, normalmente negro o mulato, encargado de cuidar el ganado, los corrales y los chiqueros; además de algún que otro empleado, un sub-mayoral, peones o lanceros, o esclavos, que le ayudaban. Asimismo hubo hatos en los que el propietario junto con sus familiares realizaba los trabajos. No obstante éste no fue el caso de los hacendados que aquí se estudian, quienes contaban con la ayuda de mayorales para su administración y cuidado.

Los hateros aparecen descritos por diferentes viajeros franceses del siglo XVIII como personas toscas y conformistas, y con una muy baja calidad de vida si se compara con la lujosa existencia de Saint Domingue. Respecto a la forma de la vivienda, Moreau de Saint-Méry apunta lo siguiente:

"El albergue en que se abriga, tanto él como su familia, es una choza, construida de estacas y tablas mal unidas, cubierta de paja, con una sala de 12 o 18 pies en cuadro, en la cual hay una mesa, dos o tres taburetes y una hamaca. Para acostarse hay una segunda pieza, menos grande que la primera y uno o varios lechos, tales como los he descrito antes. Si llueve, las goteras que forman los agujeros, dejan caer el agua adentro y muy pronto el suelo en el interior que no está enladrillado y que no se diferencia del campo sino en que los pasos han matado la hierba, está cubierto de lodo [... $]^{\text {"69 }}$.

Esta descripción y otras de la época se corresponden con aquellos hatos que se mantenían en un régimen familiar y un nivel de vida precario, contrastando con el de los hacendados estudiados, que muestran una realidad diferente a la ofrecida por estos viajeros. Ya que los hacendados no solían vivir en los hatos sino en las ciudades, y cuando iban a la casa de campo lo hacían a aquella que

\footnotetext{
${ }^{69}$ En Moreau de Saint-Méry, M. L. E., Descripción de la parte española de Santo Domingo. Ciudad Trujillo, 1944, p. 102.
} 
tenían en su ingenio o estancia, donde, como se apreció en el capítulo sexto, destacaba la riqueza interior de sus residencias.

En la documentación existen referencias a otras propiedades, entre ellas se encuentran las de Nicolás Heredia. Éste era dueño de la hacienda de cacao Palavé, cuyo valor ascendía a unos 22.000 pesos, y cuatro hatos de ganado: Árbol Gordo, Madrigal, Reparadero y La Cruz. Su hermano Manuel Heredia fue el propietario del hato Novillero, José Antonio Zárraga era dueño del ingenio San Cristóbal, Francisca Pueyo y Urríes del hato La Candelaria, María Petronila Mañón de Lara del hato Chacuey, Juana Saviñón y Tapia del hatillo Casamancebo, Beatriz LeosEchalas de la estancia de cacao Cambita y del hato Mata de la Iglesia, José Esteban Arredondo del hato Papayo y la estancia Las Pastillas, Lorenzo Fernández de Castro del hato Anamá, José Campuzano-Polanco del hato de ganado e ingenio Barbaroja, y Gregorio Saviñón del ingenio Monte Grande. Existen noticias de que otros hacendados poseyeron estancias, haciendas y hatos, pero la documentación no indica los lugares, nombres ni cualquier otra característica de las fincas. Entre aquellos estarían Andrés Lecanda, Miguel Bernardo Antonio Ferrer y Antonio Cumulat.

\subsection{Los gravámenes sobre la propiedad: censos y capellanías}

Muchos de los bienes rurales y urbanos de lo hacendados estuvieron gravados con censos en mayor o menor cuantía. Un censo era "un contrato mediante el cual se pagaba un interés anual en concepto de devolución de un

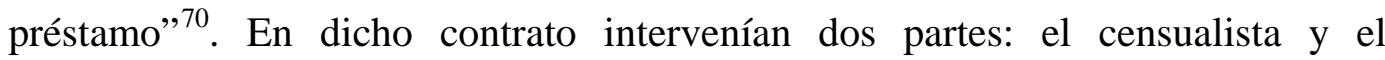
censuario. El primero (prestamista) entregaba una cantidad determinada de dinero u otro bien al censuario (prestatario), y éste a su vez tenía la obligación de pagar al anterior unos réditos anuales sobre tal cantidad. Para garantizar la operación se imponía un gravamen sobre una propiedad del censuario.

La falta de dinero líquido, lo cual fue bastante habitual en Santo Domingo, debió influir en la existencia de este tipo de operaciones, que fueron utilizadas en la compra-venta y arrendamiento de propiedades inmobiliarias, obtención de

\footnotetext{
${ }^{70}$ También podían constituirse a través del testamento. Kamen, H., Vocabulario básico de la Historia Moderna. España y América, 1450-1750. Barcelona, 1986, p. 40. Véase también Ots Capdequí, J. Mª ., España en América: Las instituciones coloniales. Bogotá, 1952, p. 47.
} 
préstamos y la realización de obras pías. Existieron distintos tipos de censos: enfitéutico, reservativo y consignativo. El censo enfitéutico era aquel en el que el dueño de un bien transmitía a otro el dominio útil de una cosa, mediante el pago de un canon o pensión anual. En cambio, el contrato por el cual el dueño transfería a otra persona tanto el dominio directo como útil de una propiedad, reservándose sólo para sí el derecho de recibir una pensión, era denominado reservativo. Este censo podía ser irredimible con obligación perpetua de pagarlo, o redimible, es decir, se podía quitar. Estos dos tipos de censos se emplearon para adquirir casas, haciendas, terrenos o dotaciones de aguas y tierras ${ }^{71}$.

Un ejemplo del censo reservativo es el que tuvo sobre sus haciendas José Guridi y Concha, cuando en 1773 compró el ingenio La Jagua, hato Pizarrete, Yaguete, y potrero Bardecia por un valor de 31.357 pesos, 3 reales y 17 maravedíes a dicho censo y redimible a voluntad del mismo, estableciendo que debía pagarse en tres plazos "con la condicion de pagar un cinco por ciento, anualmente por razon del total en que remato dichas haciendas"72. Para su seguridad se afianzó con las mismas fincas y con otras de su pertenencia: el ingenio Santa Ana de la Parra, los hatos las Damas y Los Montones, y una casa en la ciudad de Santo Domingo situada en la calle La Merced ${ }^{73}$. Al morir José Guridi y Concha, las haciendas pasaron a su hijo Nicolás Guridi y Frómesta, quien en 1781 reconoció el censo junto a su mujer Juana Leos-Echalas. Conjuntamente en 1792 éstos solicitaron redimir el capital de la venta en octavas partes en vez de en tres, como se había establecido en el contrato compra-venta. Un año después se les dio el permiso de hacerlo con la condición de que los cuatro primeros plazos fuesen entre dieciocho meses cada uno para la redención de cada octava parte, y los cuatro restantes hasta ocho serían por año ${ }^{74}$. La cesión de la parte española de

\footnotetext{
${ }^{71}$ Sobre estos dos tipos de censos véase Idem., y Ots Capdequí, J. Ma ., España en América. El régimen de tierras..., ibidem., pp. 43-44. Wobeser, G. V., "Mecanismos crediticios en la Nueva España. El uso del censo consignativo”. Estudios Mexicanos V: 1 (California, 1989) pp. 1-23, específicamente las páginas 7-9.

${ }^{2}$ Certificación de nueva escritura realizada por Nicolás Guridi y Frómesta bajo la misma contrata que su padre ante el escribano Antonio Pérez, 30 de septiembre de 1796. AGI, Santo Domingo, 2683.

${ }^{73}$ Los citados bienes pertenecían a Isabel Frómesta, mujer de José Guridi y Concha de quien los había heredado. Escritura de reconocimiento de fianza ante el escribano José Francisco Hidalgo, 22 de octubre de 1774. AGI, Santo Domingo, 2683.

${ }^{74}$ Real Orden en que concedio S. M a Nicolás Guridi, la gracia de redimir por menores partes de las que se comprenhendian en el contrato, Madrid 20 de agosto de 1792. Y, Certificacion de la
} 
la isla a los franceses obligó a Nicolás Guridi y Frómesta a trasladarse a Cuba con 150 esclavos tanto del ingenio La Jagua como de otras de sus propiedades. De la citada cantidad vendió 106 a tres importantes hacendados de aquella isla, Manuel del Manzano (Marqués Justiz de Santa Ana), Miguel de Cárdenas Santa Cruz y Domingo de Ugarte en la cantidad de 27.497 pesos, mientras que el resto quiso mantenerlos, pues su intención era establecer un ingenio en el paraje de La Magdalena $^{75}$. El dinero que obtuvo con la venta de los esclavos fue utilizado para pagar parte de la cantidad que había costado las referidas haciendas en razón de los 31.982 pesos $^{76}$. Por lo que así canceló la escritura de compra, y se le otorgó otra para que respondiera de los 4.485 pesos que restaban, cuya seguridad afianzó sobre una casa que tenía en alquiler frente a la que él residía en la calle de la Merced en lugar de las haciendas sobre las que estaban ${ }^{77}$.

Instaurados los franceses en Santo Domingo, alegaron que al ceder la soberanía también se habían cedido las propiedades así como las acciones y derechos de éstas, hasta el punto que se consideró que Nicolás Guridi y Frómesta no debía haber sacado los esclavos, y que la redención del censo que hizo de las haciendas de los jesuitas no debía haberlo hecho en La Habana por pertenecer dicha suma a la República francesa. El gobierno francés exigió a Nicolás Guridi y Frómesta reconocer nuevamente el censo sobre las referidas haciendas con las mismas condiciones a favor de la administración francesa. Aquel reemplazó su pago hipotecando otros bienes de su propiedad que había heredado de sus padres: varias casas en la calle Santa Clara, los hatos Yabacao y Arroyo Hondo, y 3 casas

Junta de Temporalidades en la ciudad de Santo Domingo ante el escribano Francisco Mueses, 4 de septiembre de 1793. AGI, Santo Domingo, 2683.

75 Estos personajes pertenecían a la élite azucarera de Cuba y eran miembros de la Sociedad Patriótica entre 1793-1795. Además, Manuel del Manzano fue contador mayor del tribunal de cuentas y suscriptor del Papel Periódico de La Habana, Miguel Cárdenas teniente coronel, y Domingo Ugarte capitán del regimiento de infantería y suscriptor del Papel Periódico en La Habana. En cuanto al número de esclavos que Nicolás Guridi sacó y vendió a los citados personajes varía en la documentación oscilando entre 150 y 200. Idem., y véase también: González-Ripoll Navarro, Ma . D., Cuba, la isla de los ensayos. Cultura y sociedad (1750-1815). Madrid, 1999, pp. 224, 226 y 229. Amores Carredano, J. B., Cuba en la época de Ezpeleta (17851790). Pamplona, 2000, pp. 53, 66, y 489-499.

${ }^{76}$ A los 31.357 pesos, 3 reales y 17 maravedíes que en un principio costaron las haciendas se le agregaron 625 pesos de las monterías sobre el río Nizao y Ocoa. Testimonio de las diligencias obradas en precaución de los bienes pertenecientes al ramo de Temporalidades: Reclamación de los propios bienes hechos por el agente de la República Francesa e instancia de Nicolás Guridi, sobre devolución de las Haciendas, 1797. AGI, Santo Domingo, 2683.

77 Testimonio de la escritura de fianza mancomunada con su mujer Juana Leos-Echalas ante el escribano José María Rodríguez sobre una casa que tienen en la calle La Merced, 28 de abril de 1798. AGI, Santo Domingo, 2683. 
que obtuvo en pago de la venta de la hacienda La Jagua, hatos Pizarrete y Yaguete, y el potrero Bardecia que compró el padre Bernardo Correa y Girón en $1800^{78}$.

El tercer tipo de censo, el consignativo, era un contrato mediante el cual una persona recibía una determinada cantidad de dinero llamada principal, por la que debía de pagar a aquel que se la hubiese prestado una renta de un cinco por ciento anual. La transacción solía asegurarse con bienes raíces del que tomaba dicha cantidad. A diferencia de los otros dos censos donde el bien se traspasaba, en este censo no se daba tal cesión sino un traspaso de dinero. En general estos contratos se hicieron por un largo tiempo, habiendo casos en que fueron perpetuos o redimibles ${ }^{79}$. El censo consignativo está considerado como el más importante, ya que se utilizó durante toda la época colonial para hacer inversiones de capital, debido a que producía notables cantidades de réditos que fueron empleados, al igual que los censos enfiteútico y reservativo en la adquisición y arrendamiento de bienes raíces, pero también en la concesión de préstamos y la realización de obras pías, cuando los donantes de las mismas no contaban con dinero en efectivo ${ }^{80}$.

La Iglesia fue una de las instituciones que contó con mayor capital líquido y por tanto se convirtió en la fuente crediticia más destacada ${ }^{81}$. En Santo Domingo además de la Iglesia y conventos hubo otras corporaciones como los hospitales San Nicolás de Bari, San Andrés y San Lázaro que también concedieron este tipo créditos. Esta función se debía fundamentalmente a la acumulación de capital procedente de las ganancias que se obtenían de los legados testamentarios,

\footnotetext{
${ }^{78}$ En la escritura de compra-venta se estableció como condición que el propio padre Bernardo Correa y Girón debía de liberar los gravámenes que tenían las casas que cedía. Escritura de venta de las haciendas La Jagua, hatos Pizarrete y Yaguete, y potrero Bardecia a favor del padre Bernardo Correa y Girón, 20 de marzo de 1800. AGI, Santo Domingo, 2683.

${ }^{79}$ El censo consignativo de igual forma que el reservativo podía ser irredimible y redimible. Véase Wobeser, G. V., "Mecanismos crediticios en la Nueva España. El uso del censo consignativo”..., op. cit., pp.1-23, y El crédito eclesiástico en la Nueva España. Siglo XVIII. México, 1994, pp. 39-43.

80 Idem.

${ }^{81}$ Sobre este asunto hay abundante bibliografía a modo de ejemplo véase: Martínez LópezCano, Mª. P., y Valle Pavón, G. del (coords.), El crédito en Nueva España. México 1998. Wobeser, G.V., El crédito eclesiástico en la Nueva España..., op. cit. Lavrin, A., "El capital eclesiástico y Las Élites Sociales en Nueva España a Fines del Siglo XVIII”. Estudios Mexicanos I:1 (California, 1985) pp. 1-28. En estas obras se considera que junto a la Iglesia los comerciantes fueron otra fuente de crédito importante, sobre todo durante la segunda mitad del siglo XVIII.
} 
limosnas, diezmos y la fundación de obras pías, como por ejemplo las capellanías. Todo ello en su conjunto constituyó los fondos para préstamos ${ }^{82}$.

Según José María Ots Capdequí las capellanías consistían en "la celebración de cierto número de misas anuales en determinada capilla, iglesia o altar, afectando para su sostenimiento las rentas de los bienes que se especificaban”83. En la fundación de una capellanía participaban el fundador, el capellán, el patrón y la institución encargada de administrarla. El fundador era la persona que establecía la capellanía, que podía realizarse de distintas formas: con una cantidad de dinero en efectivo, donando algún bien, a través del depósito irregular o mediante un censo ${ }^{84}$. La donación que hacía el fundador servía para pagar al capellán, quien debía decir un número de misas periódicas en su memoria. De esta manera, el fundador mediante los rezos que hacía por su alma el capellán podía redimir sus pecados y obtener la salvación después de muerto. A través del testamento o de cualquier escritura notarial se decretaba la forma en que debía establecerse la capellanía: el número de misas, el lugar y día, la persona a la que le correspondía recaer el patronato, la cantidad de dinero o los bienes sobre los que se imponía la fundación, y en alguna ocasión se mandaba donar una parte del dinero para fomentar el culto de un santo o una advocación mariana particular del fundador ${ }^{85}$. Finalmente quedaba regulado cómo debía de sucederse. Habitualmente se siguieron las reglas de los mayorazgos al preferir la línea masculina sobre la femenina, y a los mayores sobre los menores en la transmisión ${ }^{86}$.

En ocasiones el patrono fue el propio fundador, y en otras una persona nombrada por él, que se encargaba de que las reglas que había mandado su fundador se cumplieran, y de elegir a los futuros capellanes y patronos, cuando la

\footnotetext{
${ }^{82}$ Sobre el tema de los censos y capellanías en Santo Domingo véanse: Cassá, R., Historia social y económica de la República Dominicana. Santo Domingo, 1998, vol. I, pp. 134-137. Rodríguez Morel, G., Cartas de los cabildos eclesiásticos de Santo Domingo y Concepción de La Vega en el siglo XVI. Santo Domingo, 2000, pp. 58-77.

${ }_{83}$ Ots Capdequí, J. Ma., Historia del Derecho Español en América y del Derecho Indiano. Madrid, 1969, p. 67, y España en América. El régimen de tierras..., op. cit., pp. 46-47.

${ }^{84}$ Wobeser, G.V., "Las fundaciones piadosas como fuentes de crédito en la época colonial". Historia Mexicana XXXVIII: 4 (México, 1989) pp. 779-792, p. 783 y 784.

${ }^{85}$ Pensión del señor Lorenzo Solano Garavito para la fiesta del Apóstol San Pedro en la Iglesia de la Catedral, 19 de mayo de 1728. ASD, Libro de Capellanías II (1749-1753).

${ }^{86}$ Algunas de las capellanías que establecían ese orden de sucesión: Capellanía que mandó fundar Francisco Dávila, 25 de agosto de 1555. Capellanía que mandó fundar el deán Lorenzo Solano Garavito, 19 de mayo de 1728. Capellanía que mandó fundar Gregorio Bazan, 15 de noviembre de 1715. AASD, Libro de Capellanías II (1749-1753).
} 
capellanía quedase vacante. El cargo podía ser desempeñado tanto por un hombre como por una mujer ${ }^{87}$. El interés por desempeñarlo provocó en alguna ocasión que se produjese conflictos dentro de la propia familia. Hacia 1786 Miguel Jerónimo Martínez de Venecia Santelices y su cuñado José Esteban Arredondo, quien en representación de su mujer Isabel, lucharon para obtener el patronato de unas capellanías que habían fundado su abuela Bárbara Figueroa y tíos-abuelos Francisco y Jerónimo. Finalmente los derechos sobre ellas fueron dados a Isabel ${ }^{88}$. Asimismo debió haber abusos por parte de los patronos, quienes no pagaban a los capellanes al no realizar las misas mandadas. Los propios curas tampoco cumplieron sus obligaciones, quienes se enriquecieron apropiándose como los patronos de los capitales en que se habían fundado las capellanías y a través de la acumulación de varias capellanías ${ }^{89}$.

Los bienes sobre los que se podía imponer un censo capellánico fueron muy variados desde inmuebles, muebles e incluso sobre ingresos que podían obtenerse en el futuro, como por ejemplo la administración del derecho de la alcabala $^{90}$. La gran mayoría de las propiedades agropecuarias de los hacendados estuvieron gravadas con censos consignativos, establecidos a favor de una o varias capellanías, y algunas de esas se remontan al siglo XVI y principios del XVIII. Así por ejemplo, en la catedral de la ciudad de Santo Domingo, Francisco Dávila mandó fundar en 1555 una capellanía de cinco misas rezadas, que debían celebrarse semanalmente en la capilla de su propiedad* ${ }^{*}$ con la cantidad de 1.560

\footnotetext{
${ }^{87}$ Así por ejemplo en el testamento de Beatriz Leos-Echalas manda que del remanente de sus bienes se tome 3.000 pesos como principal para una capellanía de doce misas anuales, que sería administrada por su cuñado Fernando Mauleón a quien nombraba como patrono junto a su esposa y hermana María de Leos-Echalas. Escritura del testamento de Beatriz Leos-Echalas, 28 de noviembre de 1783. AGI, Santo Domingo, 960.

${ }^{88}$ Guerrero Cano, Ma . M., "Un dominicano en el colegio de nobles americanos de Granada. Familia y genealogía de Juan Clemente Martínez Saviñón”. Trocadero 8-9 (Cádiz, 1996-1997) pp. 383-400, p. 391.

${ }^{89}$ El cura Ignacio Alarcón, padre de Higüey, poseyó a mediados del siglo XVIII numerosas capellanías con cuyos beneficios tuvo una actividad muy amplia prestando dinero a los hacendados, y también comprando y vendiendo esclavos. Véase Pérez Memén, F., "La Iglesia y la Economía en el siglo XVIII". Boletín del museo de historia dominicana 17 (Santo Domingo, 1999) pp. 113-148, particularmente las páginas 123-126, y 134.

${ }^{90}$ En 1780 los oficiales de las Cajas Reales y hacendados, Raymundo de Esparza y Francisco de Paula Gazcue y Olaiz, fueron inquilinos de la capellanía de Juana Manuel de Acuña fundada en un principal de 600 pesos, para lo cuál hipotecaron el ramo de alcabalas. Escritura de obligación de alquiler del principal de la capellanía de Juan Manuela de Acuña realizada por el escribano José Abad, 22 de marzo de 1780. ASS, Libro de Capellanías III (1772-1785).

* Se trataba de la Capilla de Nuestra Señora de los Remedios, también conocida como Capilla de los Dávila.
} 
pesos de principal, cantidad que debía producir un doce por ciento anual, es decir, que el capellán recibiría una renta de 187 pesos al año ${ }^{91}$. El principal se impuso a censo consignativo sobre todas las tierras y haciendas de su mayorazgo. El patrono fue adjudicado al poseedor del mayorazgo, en cambio no consta quien debía ser el capellán. Hacia 1780 la capellanía y las posesiones estaban en manos de sus descendientes, miembros de la familia Landeche-Bastidas. Entre los que ejercieron de capellanes destaca el presbítero Antonio Francisco de la RochaFerrer Landeche y Andrés Angulo ${ }^{92}$. Otro ejemplo de la fundación de capellanía con este tipo de censo es la que el deán Lorenzo Solano Garavito dejó escrita en 1728 en una cláusula de su testamento. En ella mandaba que se fundara una capellanía de misas rezadas con 2.000 pesos de principal sobre el hato de vacas, cabras y ovejas que tenía en el valle del Baní, nombrado Arroyo Hondo. Encomendaba a los capellanes de la catedral la celebración de 25 misas anuales, quienes a razón de un cinco por ciento debían recibir 100 pesos. Para administrar la capellanía y la hacienda nombró a su sobrino Antonio de la Concha, aunque bajo la condición de que "jamás pueda ser vendido ni enajenado el hato" ${ }^{93}$. $\mathrm{Al}$ morir Antonio pasó a su madre Ana Solano, quien lo transmitió a su hija María Merced y de ésta lo heredó su hijo José Guridi y Concha, pasando luego a su descendiente Nicolás Guridi y Frómesta. Estos ejemplos muestran cómo las capellanías podían mantenerse durante un largo tiempo, y a su vez que las propiedades no se subdividieran.

En el caso de que un propietario quisiera vender o rentar sus bienes, se establecía una certificación en la que se informaba a cerca del tipo de gravámenes que presentaba esa propiedad. Tal informe era realizado por el anotador de hipotecas. Fue común que en la compra de una hacienda se entregase parte en dinero en efectivo y parte librando el censo que tuviese la propiedad. El hacendado Antonio Mañón de Lara, cuando compró el hatillo Chacuey a Lorenzo

\footnotetext{
${ }^{91}$ Durante la década cuarenta del siglo XVI en Santo Domingo los intereses de los censos se pagaban a un $14 \%$ anual, a mediados del mismo a un $12 \%$ y luego a un $10 \%$, hasta que a partir de una Real Cédula de 1565 se redujo a un 7\%. Véase en Rodríguez Morel, G., Cartas de los cabildos eclesiásticos..., op. cit., pp. 72 y 76.

${ }^{92}$ Con el paso del tiempo el número de misas fueron reducidas, así en 1623 a tres a la semana, en 1678 a dos y a partir de 1710 setenta y ocho misas cada año. Capellanía mandada fundar por Francisco Dávila, 25 de agosto de 1555. AASD, Libro de Capellanías II (1749-1753).

${ }^{93}$ Capellanía mandada fundar por Lorenzo Solano Garavito, 19 de mayo de 1728. AASD, Libro de Capellanías II (1749-1753).
} 
Natera por 625 pesos, lo hizo pagándole 425 pesos al contado y los 200 restantes los reconoció y redimió a favor de la capellanía impuesta sobre el hato y que servía el presbítero Manuel $\mathrm{Cid}^{94}$. Sin embargo, la liberación de una propiedad también podía realizarse mediante la sustitución de un censo por otro. Eso fue lo que hicieron Pedro Fernández de Castro y María Guridi cuando cancelaron la capellanía de misas impuestas sobre su casa en la calle el Caño y la traspasaron al hato Anamá, en la jurisdicción del Seibo, el 21 de marzo de $1783^{95}$. La redención de censos no debió ser una tarea fácil, pues suponía desembolsar elevadas cantidades, como sucedió con la venta del ingenio Santa Ana de Engombe realizada en 1762. Sus propietarios Francisco Pepín González, su mujer María Petronila Coca Landeche y la hermana de ésta, Ana Coca Landeche, lo traspasaron a Lorenzo Angulo y Josefa Coca Landeche por 20.610 pesos y 6 reales. Dicha cantidad fue pagada de la siguiente forma: 6.760 pesos y 1 real en dinero, mientras que el resto, los 13.850 pesos y 5 reales en que estaban gravadas, fueron redimidas por los compradores así como el rédito que de ellos se debía pagar “[...] a razón de veinte mil el millar [...]”" como muestra la tabla siguiente.

\footnotetext{
${ }^{94}$ Certificación del la escritura de venta real que hizo Lorenzo Natera a Antonio Mañón de Lara realizada por el escribano José Abad, 20 de octubre de 1783. AGI, Santo Domingo, 946.

${ }^{95}$ Pedro Fernández de Castro había heredado de sus padres, Antonia Coca Landeche y Lorenzo Fernández de Castro, esta capellanía que estaba impuesta sobre la mencionada casa. Ésta y la capellanía la había heredado Antonia Coca Landeche de Francisco Serrano Arias, quien además de sucederle sus bienes le encargó la celebración de misas por su alma y la de sus padres. Capellanía mandada fundar por Francisco Serrano Arias, 6 de junio de 1744. AASD, Libro de Capellanías I (1732-1754).

${ }_{96}$ Término de la época para referirse al cinco por ciento de interés anual. García Lluberes, L., “Miscelánea histórica”..., op. cit., pp. 39-44, p. 41.
} 
Tabla 7-5. Relación de gravámenes sobre el ingenio Santa Ana de Engombe

\begin{tabular}{|c|c|}
\hline Institución & $\begin{array}{c}\text { Principal en pesos y } \\
\text { reales }\end{array}$ \\
\hline Manuales de la Iglesia de la Catedral & $930 \$$ y 6 reales \\
\hline Convento de San Francisco & $2.104 \$$ \\
\hline Convento de Santo Domingo & $1.292 \$$ y 2 reales \\
\hline Convento Nuestra Señora de la Merced & $754 \$$ y 5 reales \\
\hline Propios y rentas de la ciudad de Santo Domingo & $125 \$$ \\
\hline Capellanía que mandó fundar Ana Quesada & $1.000 \$$ \\
\hline Capellanía que mandó fundar Luis Mateo Vallejos & $502 \$$ y 4 reales \\
\hline Capellanía que mandó fundar María Aliaga & $780 \$$ \\
\hline Capellanía que mandó fundar Juan Méndez Caraballo & $300 \$$ \\
\hline Capellanía que mandó fundar Ana Ponce & $687 \$$ y 4 reales \\
\hline Capellanía que mandó fundar García de Torre & $300 \$$ \\
\hline Capellanía que mandó fundar Francisco Marocho & $1.000 \$$ \\
\hline Capellanía que mandó fundar Fernando Landeche & $429 \$$ \\
\hline Capellanía que mandó fundar María Petronila & $100 \$$ \\
\hline Capellanía que mandó fundar Catalina de Bastidas & $200 \$$ \\
\hline Capellanía que mandó fundar Leonor de Aliaga & $150 \$$ \\
\hline Capellanía que mandó fundar María Pastrana & $100 \$$ \\
\hline Capellanía que mandó fundar José Fernández & $100 \$$ \\
\hline Hospital San Andrés & $1.495 \$$ \\
\hline Hospital San Lázaro & $200 \$$ \\
\hline Curato de la villa del Seibo & $200 \$$ \\
\hline Curato de la villa de Higüey & $100 \$$ \\
\hline
\end{tabular}

Elaboración propia. Fuentes: García Lluberes, L., “Miscelánea histórica”..., op. cit., pp. 39-44.

Esta relación de gravámenes de la propiedad nos permite apreciar que también fue habitual que el bien acumulara más de un censo y estuviese situado en distintas capellanías, corporaciones eclesiásticas e incluso en el fondo de propios del cabildo. Otro ejemplo significativo de ello es el caso del hacendado José de la Vega, quien contó con numerosos gravámenes sobre sus propiedades, ascendiendo la cantidad adeudada a 10.389 pesos como se expresa en la siguiente tabla. La documentación presenta esa relación, en cambio no específica si los gravámenes proceden de un préstamo o de la fundación de obra pía; aunque en este último caso sólo aparecen las derivadas de capellanías. 
Tabla 7-6. Relación del valor de las fincas de José de la Vega y sus gravámenes

\begin{tabular}{|l|r|r|}
\hline \multicolumn{1}{|c|}{ Fincas } & \multicolumn{1}{c|}{ Valor en pesos } & \multicolumn{1}{c|}{ Gravámenes en pesos } \\
\hline Ingenio Mata Naranjo & $\mathbf{3 3 . 3 5 3}$ & $\mathbf{4 . 6 8 0}$ \\
\hline Convento Santa Clara & & 1.200 \\
\hline Hospital San Nicolás & $\mathbf{5 8 7}$ & 1.200 \\
\hline Real Hacienda & $\mathbf{4 . 4 3 8}$ & 2.280 \\
\hline Estancia Guaximía & & $\mathbf{0}$ \\
\hline Hatillo Yacó & & $\mathbf{1 . 3 4 7}$ \\
\hline Convento San Franisco & $\mathbf{1 . 5 6 0}$ & 1.017 \\
\hline Sacristán mayor del Seibo & & 330 \\
\hline Hatillo Mata Naranjo & & $\mathbf{1 . 2 5 0}$ \\
\hline Hospital San Andrés7 & & 250 \\
\hline $\begin{array}{l}\text { Capellanía que servía Fray } \\
\text { Manuel Morales, dominico }\end{array}$ & $\mathbf{3 5}$ & 700 \\
\hline Convento de San Francisco & $\mathbf{1 2 . 7 2 3}$ & $\mathbf{0}$ \\
\hline $\begin{array}{l}\text { Tierra en la campiña del } \\
\text { Seibo }\end{array}$ & & 3.112 \\
\hline $\begin{array}{l}\text { Casa en Santo Domingo y } \\
\text { servidumbre de ella }\end{array}$ & & 425 \\
\hline Convento San Francisco & & 147 \\
\hline $\begin{array}{l}\text { Manuales de la Iglesia de la } \\
\text { Catedral }\end{array}$ & & 140 \\
\hline Capellanía de Juana de Robles & & 600 \\
\hline Capellanía de Baltasar Castro & & 500 \\
\hline $\begin{array}{l}\text { Capellanía de Magdalena } \\
\text { Ávila }\end{array}$ & & $\mathbf{1 0 . 3 8 9}$ \\
\hline $\begin{array}{l}\text { Capellanía del coro, que fundó } \\
\text { el arzobispo Isidoro Rodríguez }\end{array}$ & & $\mathbf{4 2 . 3 0 8}$ \\
\hline $\begin{array}{l}\text { Capellanía del Hospital San } \\
\text { Andrés }\end{array}$ & & 575 \\
\hline Sacristán mayor de La Vega & & 500 \\
\hline Suma total & & \\
\hline Caudal líquido & & \\
\hline & & \\
\hline
\end{tabular}

Elaboración propia. Fuentes: Resumen de los vienes que comprehende el antecedente abaluo propios del Capitán Joseph de la Vega, 15 de junio de 1805. AGI, Santo Domingo, 964.

Las capellanías podían clasificarse en dos tipos: las eclesiásticas también llamadas colativas o gentilicias y, las mercenarias conocidas además como profanas y laicas. En las primeras se requería para su fundación una autorización de la Iglesia, que tenía el derecho de elegir al patrono cuando la capellanía quedaba vacante, dándose generalmente a un eclesiástico. También se encargaba

\footnotetext{
${ }^{97}$ Estaba mancomunado con la casa.

${ }^{98}$ Los gravámenes de las capellanías de Baltasar Castro, Magdalena Ávila, y la del Hospital de San Andrés estaban mancomunados con el Hatillo Mata Naranjo.
} 
de la conservación de los bienes asignados para su mantenimiento. En cambio las capellanías mercenarias, profanas o laicas no necesitaban del permiso de la Iglesia, ya que dependían de la jurisdicción civil y, por tanto eran más abiertas en cuanto a su manejo. De hecho el patrono podía ser tanto lego como eclesiástico ${ }^{99}$.

No es habitual que la documentación indique ante qué clase de capellanía estamos. Entre los escasos ejemplos podemos mostrar la modalidad de una del tipo laical. En una escritura, Gregoria Heredia, antes de morir en 1784, dejó mandado que se erigiesen varias capellanías de misas a favor de las familias Heredia y Pérez-Caro ${ }^{100}$. Un año después, el 4 de febrero, se fundaron dos capellanías dotadas cada una de ellas con 3.325 pesos. La primera estuvo a favor de los Heredia. Fue realizada por su sobrino, el teniente de infantería del Batallón Fijo Ignacio Pérez-Caro de Oviedo, y su mujer María Magdalena Catalina Campuzano Fernández para “cuya seguridad hipotecaron todos los bienes habidos y por haber en especial un ingenio de moler azucar llamado Cumba, sito en la jurisdiccion de Santo Domingo”"101 . La segunda capellanía, para la familia PérezCaro, fue establecida por el cuñado de Gregoria, el coronel Ignacio Francisco Pérez-Caro, quien “reconocio 3.000 pesos para lo que hipoteco unas casas altas y bajas, sitas en la calle que corre de la capilla del mayorazgo de Davila para el convento de Nuestra Señora Merced y hace frente a la capilla de Nuestra Señora Altagracia [...]”, y una estancia de cacao llamada Yubasá, situada también dentro de la jurisdicción de Santo Domingo ${ }^{102}$. Los 325 pesos restantes los impuso de nuevo su sobrino Ignacio junto con su mujer María Magdalena Catalina, hipotecándolo sobre el ya mencionado ingenio Cumba. El 13 de julio de 1786, dicha cantidad que gravaba el ingenio fue redimida por su nuevo propietario Fabián Rodríguez, quien lo había comprado por 8.453 y 1 real $^{103}$.

Aun teniendo los hacendados gran parte de sus bienes gravados, a su vez otros les debían cantidades de dinero; lo que pone de manifiesto que éstos fueron

\footnotetext{
99 Ots Capdequí, J. Ma., España en América: Las instituciones coloniales..., op. cit., pp. 46-47.

100 También había mandado fundar otra capellanía a favor de la Santa Cruzada con un principal de 150 pesos. Capellanía mandada fundar por Gregoria Heredia, 1784. AASD, Libros de Capellanías III (1772-1785).

${ }^{101}$ Ignacio Pérez-Caro de Oviedo era hijo del coronel Ignacio Francisco Pérez Caro de Oviedo y de Ana María Oviedo y Castillo Torquemada. El coronel Ignacio Francisco era hermano del capitán de milicias regladas Antonio Pérez-Caro, y marido de Gregoria Heredia. Ibidem.

102 Ibidem.

${ }^{103}$ Idem. Véase también Reyes, F., Descripción histórica de las antiguas haciendas, estancias y hatos..., op. cit., pp. 55-56.
} 
al mismo tiempo tanto acreedores como deudores. No hay que olvidar que hubo casos en que los propios hacendados actuaron como fiadores para comprar alguna propiedad o bien, a fin de obtener algún cargo civil en el cabildo o un empleo de la Real Hacienda. Incluso en ocasiones prestaron dinero a las arcas reales e hicieron donaciones voluntarias, en un intento de contribuir a los gastos que suponía defender a la monarquía de la agresión bélica de algunas naciones europeas durante la segunda mitad del siglo XVIII. En esta actividad también participaron el resto de la población, como se pudo observar en el capítulo tercero, y las ya citadas instituciones eclesiásticas, como el convento Regina Angelorum al que la Corona debía 85.899 pesos en 1792 en concepto de dinero prestado años atrás ${ }^{104}$. Asimismo, puede decirse que a través de los censos se logró evitar el fraccionamiento de la tierra, ya que la legislación prohibía que cualquier propiedad que tuviese censos se subdividiera, favoreciendo en este sentido a los hacendados ${ }^{105}$. Además habría que señalar que de las numerosas reivindicaciones llevadas desde el cabildo, entre otras cosas se logró que el tipo de interés de los censos se concediese a un tres por ciento en vez de a un cinco a partir de $1786^{106}$.

\subsection{La producción agrícola: principales cultivos}

Muchos de los productos que se cultivaron durante la segunda mitad del siglo XVIII en la parte española de la isla existían desde el siglo XVI. Hubo una gran variedad de productos agrícolas: desde azúcar, cacao, café, algodón, añil, arroz, yuca, batatas, achiote, jengibre, alubias hasta distintos árboles frutales que daban naranjas, cocos y plátanos entre otros, que fueron aprovechados para la exportación y el consumo propio de la población.

El cultivo básico de la alimentación de la población de Santo Domingo se basó en una agricultura de subsistencia, la cual estaba determinada por las necesidades y gustos del propio pueblo, además de por el medio natural de dicho

\footnotetext{
${ }^{104}$ Pérez Memén, F., “La Iglesia y la Economía en el siglo XVIII”..., op. cit., pp. 113-148, p. 127 y 128.

${ }^{105}$ Ots Capdequí, J. Mª., España en América: Las instituciones coloniales..., op. cit., p. 47. Wobeser, G. V., "Mecanismos crediticios en la Nueva España. El uso del censo consignativo”..., op. cit., 1-23, p. 21.

${ }^{106}$ Real Cédula de Su Majestad, a consulta de su supremo Consejo de Indias, Por la qual se conceden varias gracias, y prerrogativas en beneficio de todos los vecinos de la Isla Española de Santo Domingo, para el fomento de su Agricultura, Industria, y Comercio, Madrid 12 de abril de 1786. AGI, Santo Domingo, 1012.
} 
territorio que posiblitaba la naturaleza de los cultivos. De entre los frutos más habituales pueden distinguirse aquellos tubérculos indígenas o de procedencia africana que se consumían desde el siglo XVI como las batatas, yuca, los plátanos, y otros como el arroz, el maíz, verduras y árboles frutales que daban naranjas, piñas, guayabas, lechosas, etc. Todo ello podía encontrarse en cualquier zona de la isla, especialmente en los alrededores de las ciudades.

El pueblo de San Carlos fue el encargado de proveer a la capital de tales productos, en particular del casabe, un pan que era elaborado con la harina que se extraía de la raíz de la yuca. Este tipo de pan ya era consumido por los indios de La Española y los propios españoles debido a la falta de harina. Aunque se elaboraba fundamentalmente para el consumo interno, en ocasiones el casabe fue también exportado a Venezuela y Puerto Rico ${ }^{107}$. A principios del siglo XVIII se trató en vano de incentivar la siembra de trigo, de ahí que la frecuente práctica de importar la harina de lugares de la costa venezolana como Coro, La Guaira, Veracruz y otras colonias extranjeras como Curazao, Jamaica, Saint Thomas y Saint Domingue continuase durante la segunda mitad de ese mismo siglo ${ }^{108}$.

Las nuevas concepciones económicas y administrativas propias de los Borbones trajeron aparejado un viraje en la política colonial. Este cambio se caracterizó por fomentar nuevos cultivos y explotaciones que aparecerían en sus colonias, como también sucedió en otros imperios, así el inglés y el francés. Esto unido al impulso de los propios hacendados explica que se intentase cultivar algodón, café, añil y tabaco, y revivir los productos que hasta entonces se habían estado cultivando, como el cacao o la caña de azúcar, ofreciendo a unos y otros ciertas medidas para su estímulo y protección. Entre éstas se encuentran las ya mencionadas prerrogativas que les fueron concedidas a los hacendados en 1786, como la exención de diezmos y los derechos sobre el aguardiente de caña, o la libre entrada de aperos de labranzas.

Dentro del marco de la agricultura de Santo Domingo, la caña de azúcar era uno de los cultivos tradicionales por excelencia desde principios de la colonia. La caña fue introducida en Santo Domingo desde las islas Canarias y comenzó a

\footnotetext{
${ }^{107}$ A Caracas fue exportada en época de crisis de dicha ciudad entre 1700 y 1709 . En cambio el casabe enviado a Puerto Rico estaba motivado por distintas plagas que atacaron ese cultivo, en Gutiérrez Escudero, A., Población y economía..., op. cit., pp. 106-107 y 228-229.

${ }^{108}$ Ibidem., pp.114-116.
} 
cultivarse alrededor de la capital, en los márgenes del río Ozama y de los ríos Haina, Nigua y Nizao. Pero la competencia y calidad con la que se producía en México y Brasil en el siglo XVI hizo que la producción azucarera decayera en Santo Domingo. Su dedicación que recibió durante el siglo XVII fue mínima, experimentando un resurgimiento en la segunda mitad del siglo siguiente bajo el patrocinio que se dio a la agricultura en esta época. Las haciendas volvieron a estar situadas en los lugares circundantes a la capital, donde ya en el siglo XVI se habían ubicado las explotaciones más importantes. También se cultivó en otras partes de la isla, como en la Vega Real y Puerto Plata.

Hasta el momento no se cuenta con una relación exacta del número de ingenios que existieron en la segunda mitad del siglo XVIII. De acuerdo con Moya Pons debían funcionar en torno a treinta o treinta y uno, once entre los ríos Ozama y Nizao, y otros diecinueve o veinte alrededor de la capital ${ }^{109}$. Autores de la época como el francés Moreau de Saint-Méry y el clérigo Antonio Sánchez Valverde citan que pudieron existir veintidos ingenios de gran consideración, aunque no relacionan los nombres en sus obras ${ }^{110}$. Por su parte, los trabajos de Fray Cipriano de Utrera y Félix Reyes completan la anterior información indicando los nombres de las propiedades y de los dueños, entre los que destacan algunos de los hacendados estudiados ${ }^{111}$. A través de otras fuentes se ha podido precisar la existencia de dichos y nuevos ingenios, como se observa en el siguiente cuadro, algunos de los cuales ya han sido mencionados a lo largo de este capítulo. Hay que señalar que sólo uno de ellos era un trapiche, el que poseía Gregorio Saviñón en el paraje Monte Grande.

\footnotetext{
109 Ya hacia 1527 existían alrededor de la ciudad de Santo Domingo diecinueve ingenios, en Ratekin, M., “The early sugar industry in Española”. HAHR XXXIV (Duke, 1958) pp. 1-20, y Moya Pons, F., Historia colonial de Santo Domingo. Santiago, 1977, p. 308.

${ }^{110}$ Moreau de Saint-Méry, M. L. E., Descripción de la parte española de Santo Domingo..., op. cit., pp. 96-97. Sánchez Valverde, A., Idea del valor de la Isla Española y utilidades que de ella puede sacar su monarquía. Santo Domingo, 1988, p. 113. En este último trabajo aparecen algunos nombres de haciendas y su correspondiente dueño, aunque los nombres de los ingenios, sus propietarios, y demás aclaraciones son anotaciones realizadas por Emilio Rodríguez Demorizi y Fray Cipriano de Utrera.

${ }^{111}$ Fray Cipriano de Utrera menciona once ingenios y once trapiches. Véase en Utrera, F. C. de, “Carlos III en Santo Domingo”. Revista de la Fundación García Arévalo 2 (Santo Domingo, 1988) pp. 13-31, particularmente las páginas 23-24. Reyes, F., Descripción histórica de las antiguas haciendas, estancias y hatos..., op. cit. Para la primera mitad del siglo XVIII Antonio Gutiérrez señala la existencia de veinte nueve ingenios. Gutiérrez Escudero, A., Población y economía..., op. cit., pp. 103-104.
} 
Tabla 7-7. Relación de ingenios

\begin{tabular}{|c|c|c|c|}
\hline Hacendado & Ingenio & Ubicación & Fuente \\
\hline $\begin{array}{l}\text { Antonio Coca } \\
\text { Landeche }\end{array}$ & San José & Los LLanos & $\begin{array}{l}\text { AASD, Libro de } \\
\text { Capellanías III } \\
(1772-1785)\end{array}$ \\
\hline $\begin{array}{l}\text { Lorenzo Angulo } \\
\text { Medrano }\end{array}$ & $\begin{array}{l}\text { Santa Ana de } \\
\text { Engombe }\end{array}$ & Rivera del río Haina & $\begin{array}{l}\text { García Lluberes, L., } \\
\text { “Miscelánea } \\
\text { histórica”..., op. cit. }\end{array}$ \\
\hline \multirow{3}{*}{ José de la Vega } & Sanabotana & $\begin{array}{l}\text { Orilla derecha de río } \\
\text { Haina }\end{array}$ & \multirow{3}{*}{$\begin{array}{l}\text { AGI, Santo } \\
\text { Domingo, } 1012\end{array}$} \\
\hline & Manoguayabo & Arroyo Manoguayabo & \\
\hline & Mata Naranjo & Oeste de Santo Domingo & \\
\hline \multirow{3}{*}{$\begin{array}{l}\text { Francisco Espaillat y } \\
\text { Virol }\end{array}$} & Gurabito & \multirow{3}{*}{ Santiago } & \multirow{3}{*}{$\begin{array}{l}\text { Campillo Pérez, } \\
\text { J.G., Francisco } \\
\text { Espaillat..., op. cit. }\end{array}$} \\
\hline & Sabana Grande & & \\
\hline & La Angostura & & \\
\hline $\begin{array}{l}\text { Juan Bautista } \\
\text { Oyarzábal } \\
\end{array}$ & Boca de Nigua & Rivera del río Nigua & \begin{tabular}{|l|} 
AGI, Santo \\
Domingo, 969 \\
\end{tabular} \\
\hline José Frómesta & Camba Arriba & $\begin{array}{l}\text { Orilla derecha del río } \\
\text { Nizao }\end{array}$ & AGI, Santo \\
\hline Felipe Guridi Concha & Camba Abajo & $\begin{array}{l}\text { Orilla izquiera del río } \\
\text { Nizao }\end{array}$ & Domingo, 954 \\
\hline \multirow{3}{*}{$\begin{array}{l}\text { Felipe Guridi } \\
\text { Frómesta }\end{array}$} & $\begin{array}{l}\text { Santa Ana de la } \\
\text { Jagua }\end{array}$ & $\begin{array}{l}\text { Boca del arroyo la Jagua } \\
\text { que sale frente al río } \\
\text { Nizao }\end{array}$ & \multirow{3}{*}{$\begin{array}{l}\text { AGI, Santo } \\
\text { Domingo, } 954\end{array}$} \\
\hline & $\begin{array}{l}\text { Santa Ana de la } \\
\text { Parra }\end{array}$ & $\begin{array}{l}\text { Orilla derecha del río } \\
\text { Haina }\end{array}$ & \\
\hline & $\begin{array}{l}\text { Santa Cruz del } \\
\text { Dajao }\end{array}$ & Otro lado del río Ozama & \\
\hline $\begin{array}{l}\text { Juan Mieses Ponce } \\
\text { de León }\end{array}$ & La Venta & ¿? & \begin{tabular}{|l|} 
AGI, Santo \\
Domingo, 275
\end{tabular} \\
\hline $\begin{array}{l}\text { José Campuzano- } \\
\text { Polanco }\end{array}$ & Barbaroja & Bayaguana & $\begin{array}{l}\text { ARB, leg. } 25 \text { (1773- } \\
\text { 1824) }\end{array}$ \\
\hline \multirow{2}{*}{$\begin{array}{l}\text { Ignacio Francisco } \\
\text { Pérez Caro y Oviedo }\end{array}$} & San Cristóbal & \multirow{2}{*}{ Rivera del río Nigua } & \multirow{2}{*}{$\begin{array}{l}\text { AGI, Santo } \\
\text { Domingo, } 978\end{array}$} \\
\hline & Santiago & & \\
\hline $\begin{array}{l}\text { Ignacio Pérez Caro y } \\
\text { Oviedo }\end{array}$ & Cumba & \begin{tabular}{|l|} 
Orilla izquierda del río \\
Nizao (14 leguas de \\
Santo Domingo) \\
\end{tabular} & $\begin{array}{l}\text { AGI, Santo } \\
\text { Domingo, } 1012\end{array}$ \\
\hline $\begin{array}{l}\text { Francisco Tapia } \\
\text { Castro }\end{array}$ & $\begin{array}{l}\text { Sabana Perdida de } \\
\text { Nuestra Señora de } \\
\text { las Mercedes }\end{array}$ & $\begin{array}{l}\text { Paraje Tablazo (del otro } \\
\text { lado del río Ozama) }\end{array}$ & $\begin{array}{l}\text { AGI, Santo } \\
\text { Domingo, } 964\end{array}$ \\
\hline Gregorio Saviñón & Trapiche ( $\dot{d} ?)$ & Monte Grande & $\begin{array}{l}\text { AASD, leg. 47, } \\
\text { cajón 32, estante B }\end{array}$ \\
\hline $\begin{array}{l}\text { Antonio Valdemoro } \\
\text { y Alcántara }\end{array}$ & Las Monjas & $\begin{array}{l}\text { Entre los ríos Isabela e } \\
\text { Higuero }\end{array}$ & $\begin{array}{l}\text { Rodríguez } \\
\text { Demorizi, E., } \\
\text { Familias } \\
\text { Hispanoamericanas } \\
\text {..., op. cit., } \\
\end{array}$ \\
\hline $\begin{array}{l}\text { Antonio Mañón de } \\
\text { Lara }\end{array}$ & Enjuagador & Rivera del río Ozama & $\begin{array}{l}\text { Larrazábal Blanco, } \\
\text { C., Familias } \\
\text { dominicanas..., op. } \\
\text { cit., vol. V, p. } 37 .\end{array}$ \\
\hline
\end{tabular}


En los inicios del siglo XVIII la industria azucarera era muy similar a la del siglo anterior, presentando una escasa producción debido a la falta de mano de obra y al instrumental deficiente. Lo poco que se produjo fue por lo general azúcar blanca y parda o mascabada. También fue transformada en bebida de aguardiente, y tanto una como otra fueron consumidas en la isla, y sólo en contadas ocasiones se exportó. Algunas veces para satisfacer el consumo local se tuvo que recurrir a la importación de Cuba o Saint Domingue ${ }^{112}$. El aguardiente de caña fue conocido en aquella época con el nombre de tafia, bebida que gustaba mucho a los habitantes de Santo Domingo, según describe el francés Moreau de Saint-Méry: “A ellos les gustaría mucho tomar el tafia, que es un aguardiente fabricado con la caña de azúcar, pero, como éste sólo entra allí de contrabando, es sumamente raro y muy caro, pues cuesta treinta centavos torneses la pinta”113.

Aunque durante el periodo colonial la Corona prohibió su producción en todo el continente americano con el objeto de que fuese importado de la Península, éste se obtuvo a través del contrabando o elaborándose de manera clandestina. Fueron numerosas las reales cédulas que se sucedieron a lo largo del siglo XVIII prohibiéndolo, sin embargo no se cumplieron. La primera Real Cédula dictada en este siglo se dio el 10 de agosto de 1714 para toda Hispanoamérica. Esta medida se infringió hasta el punto de que en algunos lugares de las colonias, como Nueva Granada, fue anulada en 1736, estableciéndose una renta real sobre su producción ${ }^{114}$.

En Santo Domingo una Real Cédula de 15 de junio de 1720 vedó la fabricación del aguardiente de caña en toda la isla. El 9 de octubre del mismo año llegaron a la ciudad las instrucciones en las que se mandaba a las autoridades visitar todo el territorio para averiguar quién fabricaba y requisar así el material utilizado en su elaboración. A través de dicha documentación se ha establecido que entre 1715 y 1720 existieron en los alrededores de Santo Domingo veintinueve ingenios y dos trapiches dedicados a esta actividad. La prohibición de que se fabricase aguardiente trajo como consecuencia que éste continuase elaborándose y vendiéndose clandestinamente, tal como describe en 1724 el fiscal

\footnotetext{
112 Gutiérrez Escudero, A., Ibidem., p. 105.

113 Moreau de Saint-Méry, M. L. E., Descripción de la parte española de Santo Domingo..., op. cit., p. 88.

${ }^{114}$ Le Riverend, J., Historia económica de Cuba. La Habana, 1981, p. 59.
} 
de la Audiencia sobre cómo los militares estaban dedicados a esta actividad ${ }^{115}$. Tres años más tarde el teniente coronel Manuel Revenga informó a la Corona de que pese a lo mandado por la cédula de 1720 seguía produciéndose, incluso después de establecer multas, como la que se impuso a los jesuitas en $1734^{116}$.

Nuevamente, una Real Cédula del 6 de agosto de 1747 reiteró el veto en toda Hispanoamérica, en especial en Nueva España y las Islas de Barlovento. En ella se mencionaba al respecto los anteriores documentos referentes a las cédulas de 1714 y 1720. En Santo Domingo se tuvo conocimiento de ésta el 3 de enero de 1749, dos años después de promulgarse. La cédula también insistió en la obligación que tenían las autoridades de hacer cumplir lo exigido a los hacendados, pero ésta tampoco logró que cesase la producción de aguardiente ${ }^{117}$.

A partir de 1760 hubo una mejora debido a las grandes reformas administrativas y económicas de la época. Así en 1765 una Real Cédula declaró la abolición de los derechos que hasta entonces se cobraban al azúcar en Cuba, Puerto Rico, Margarita, Trinidad y Santo Domingo. La cédula también dictaba la reducción a un 6\% del impuesto de alcabala sobre el azúcar, que sería pagado sólo una vez, bien en el momento de la venta o a la salida de sus puertos. En ese mismo año se estableció el derecho de 2 pesos por barril de aguardiente de caña y de 1 real de plata en el de zambumbia, que afectaba de igual manera a los lugares mencionados ${ }^{118}$. No obstante, en Santo Domingo el impuesto sobre el aguardiente no fue implantado hasta 1777 por una Real Orden. En ella quedaba además decretado que el cobro de la alcabala se haría a razón de un 1\% durante cinco años a partir del año siguiente ${ }^{119}$. Si bien estaba prohibida la fabricación de aguardiente, en cierta medida esta disposición reconocía a los hacendados su elaboración; aunque el permiso les fue concedido dos años más tarde, cuando el gobernador José Solano y Bote estableció el 1 de agosto en un bando la exacción

\footnotetext{
115 Sobre este asunto véase Gutiérrez Escudero, A., Población y economía..., op. cit., pp. 103105. Chez Checo, J., El ron en la historia dominicana. Desde los antecedentes hasta finales del siglo XIX. Santo Domingo, 1988, pp. 143-152.

116 Chez Checo, J., Idem.

117 Ibidem., p. 154.

118 Real Orden al gobernador de Santo Domingo reduciendo los derechos cobrados en el azúcar, imposición de un derecho sobre el aguardiente y reducción del real derecho de marca, 8 de noviembre de 1765. AGI, Santo Domingo, 1065.

${ }^{119}$ Ibidem. Véase también Documentación del Archivo Real de Bayaguana, "Reducción a la mitad del derecho de alcabala por cinco años en el comercio interior de la Isla Española, 1778”. BAGN 46-47 (Ciudad Trujillo, 1946) pp. 173-190.
} 
de los 2 pesos por barril, habilitando la fábrica y venta de esta bebida. Para ello sería también necesario contar con una licencia que concedía el gobernador ${ }^{120}$. Esta gracia ya había sido promovida por los propios hacendados desde el cabildo de la ciudad de Santo Domingo.

El cacao fue junto al azúcar uno de los cultivos más preciados en esta isla y fuera de ella. Pero a diferencia del azúcar, el cacao fue un fruto propio de Santo Domingo, que se producía en la mayor parte de la isla, sobre todo en los alrededores de la capital y en la Vega Real. Era consumido por los propios colonos en chocolate bebido con azúcar o puro, es decir, amargo o cerrero, como se hacía en tiempos prehispánicos. También se exportaba a España y México, donde estuvo considerado durante mucho tiempo como uno de los mejores por su calidad. Fue durante el siglo XVII cuando tuvo su máxima expansión coincidiendo con la decadencia que había sufrido la producción del azúcar. Sin embargo, una plaga de epidemias en 1666, y los temporales de 1672 destruyeron los árboles de cacao, y por tanto su producción disminuyó ${ }^{121}$. A partir de entonces Venezuela ocupó el lugar de Santo Domingo, pero en el primer tercio del siglo XVII comenzó de nuevo cierta recuperación, aunque no fue lo suficiente para el consumo de la población de la isla, que tuvo que importar 22.445 fanegas de cacao venezolano entre $1700-1739^{122}$. A lo que habría que añadir que a la población le gustaba el chocolate que se preparaba mezclando la almendra del cacao de Santo Domingo con la de Venezuela. A pesar de la recuperación constatada a través de los veinte envíos que se hicieron a Cádiz entre 1753 y 1794, su cultivó descendió al destrozar los huracanes de 1754 y 1764 la mayoría de los árboles $^{123}$. Aquellos que lograron salvarse tardaron en restablecerse, pues el cultivo del cacao requería varios años de labor y espera antes de que el árbol

\footnotetext{
${ }^{120}$ El contador general de Santo Domingo informa sobre lo representado por el gobernador de esta isla acerca del establecimiento de alcabala que ha verificado en aquella isla consecuente con una Real Orden de 19 de abril de 1777 e imposición de 2 pesos en cada barril de aguardiente de caña, habilitando su fábrica y expendio, 2 de mayo de 1779. Y Carta y testimonio del gobernador de Santo Domingo que la acompaña del 1 de agosto último dando cuenta del modo y circunstancia con que se había establecido en aquella isla el derecho de alcabala, en cumplimiento de la Real Orden de 19 de abril de 1777 y así mismo el de aguardiente de caña. AGI, Santo Domingo, 927.

${ }^{121}$ Gutiérrez Escudero, A., Población y economía..., op. cit., p. 101.

122 Lucena Salmoral, M., Vísperas de la independencia americana: Caracas. Madrid, 1986, p. 109.

${ }^{123}$ Moreau de Saint-Méry, M. L. E., Descripción de la parte española de Santo Domingo..., op. cit., pp. 98-99. Sevilla Soler, Ma. R., Santo Domingo..., op. cit., pp. 455-458.
} 
pudiese dar fruto. Por ello quedaron “pocas haciendas” dedicadas a este producto, así se recurrió nuevamente a su importación de otros lugares como Venezuela y Puerto Rico ${ }^{124}$.

Otros cultivos de importancia, aún siendo su comercio más limitado que los anteriores, fueron el achiote o bija, y el jengibre. No se cultivaron en explotaciones agrarias especializadas sino en aquellas mixtas o diversificadas en las que además se cultivaban otros productos. Durante el siglo XVI fueron de gran importancia y estuvieron destinados al comercio exterior, en cambio dos siglos más tarde su producción fue mínima, aunque según describen algunos coetáneos su cultivo no requería mucho esfuerzo al nacer por todas partes al igual que el añil ${ }^{125}$.

La historia del cultivo del café en Santo Domingo se inicia en el siglo XVIII ya que esta planta fue traída del Dondón e introducida por sus vecinos los franceses ${ }^{126}$. La planta se debió aclimatar fácilmente a la parte española, extendiéndose su cultivo por toda la isla, preferentemente en las poblaciones de Santiago y La Vega Real, donde también se cultivaba tabaco, así como en algunas haciendas de los alrededores de Santo Domingo. La calidad de este café y los intentos que se venían realizando para que se incrementase su cultivo tuvieron como resultado su intensificación y exportación a España. Este último hecho empezó a darse a partir de una Real Cédula de 8 de junio de 1768 favorable a la labranza del producto, y que eximía de todos los derechos a sus cosecheros durante cinco años. También se ordenaba al gobernador la elaboración de un informe a través del cual pudieran conocerse los lugares en que se cultivaba y su calidad $^{127}$.

${ }^{124}$ Estado de los medios para el fomento de la isla realizado por el oidor decano de la Audiencia de Santo Domingo Pedro Catani, 15 de noviembre de 1788. AGI, Santo Domingo, 1012.

${ }^{125}$ Breve Descripción de la Isla Española de Santo Domingo realizada por el Secretario de Cámara y Gobierno Joseph de Castro Palomino, 25 de abril de 1783. BN, Manuscritos, 11.030, fol. 21. Sobre estos productos véase también Gutiérrez Escudero, A., Población y economía..., op. cit., p. 106. Gíl-Bermejo García, J., La Española. Anotaciones históricas (1600-11650). Sevilla, 1983, pp. 65-59.

${ }^{126}$ Moreau de Saint-Méry, M. L. E., Descripción de la parte española de Santo Domingo..., op. cit., p. 97. Sevilla Soler, Ma . R., Santo Domingo..., op. cit., p. 100.

${ }^{127}$ Expediente del gobernador de Santo Domingo en asunto a la extensión de la siembra del café en aquella isla, y recordación de una carta de 18 de enero de 1768 en la que hizo presentes los medios propuestos por aquel cabildo secular para el restablecimiento de aquella isla. AGI, Santo Domingo, 979. 
En 1771 el gobernador recolectó muestras de grano de café y las envió a Cádiz en dos embarcaciones de la Real Compañía de Barcelona. Los ejemplares fueron recogidos de cuatro haciendas cercanas a Santo Domingo, algunas pertenecientes a varios de los hacendados estudiados, como la de Cambita de Nicolás Guridi y la de San Isidro de Cambita de Nicolás Sterling. Las otras dos eran la hacienda de Lorenzo Daniel y la estancia Caucino, en la que su dueño Julián Fernández había plantado más de 31.000 árboles de café. Asimismo, se recolectaron muestras de otras haciendas situadas en los partidos de Gurabo, Licey, Canca, Exido y Jacagua dentro de la jurisdicción de Santiago, siendo sus dueños Juan Antonio Méndez, Juan del Monte, Juan Acevedo, Francisco Reina y Francisco Pichardo ${ }^{128}$. La llegada de éstas y su consideración como de buena calidad sirvió para que las siembras de café aumentasen, aunque se tuvo que luchar con la competencia del café de Saint Domingue y de otras islas francesas, a lo que se sumaba la predilección de los habitantes de Santo Domingo por el chocolate.

Dentro de este espíritu de fomento se estimuló el cultivo del algodón, otro fruto importante. Según algunos coetáneos de la época destacaba por su “espontáneo crecimiento y buena calidad” por toda la isla ${ }^{129}$. Mencionan también que hacia la segunda mitad del siglo XVIII se cultivaba en la ribera oeste del río Nizao. Durante esa época y para ayudar al desarrollo de la industria textil catalana, la Corona exentó de derechos al algodón americano que fuese destinado a dicha manufactura. Esta situación fue aprovechada por el gobernador José Solano y Bote para enviar en 1775 un cargamento de este producto al Consejo de Indias, con el fin de obtener una respuesta favorable para su comercio e intercambiarlo por “distintas mercancías peninsulares”"130. Sin embargo, a pesar del reconocimiento de su calidad y el apoyo de instituciones como la Sociedad Económica de Madrid, el proyecto no se llevó a cabo ${ }^{131}$.

\footnotetext{
${ }^{128}$ Ibidem., y Nómina de las muestras de café que dirige a Su Majestad el gobernador y capitán general de la isla La Española, 11 de febrero de 1771. AGI, Santo Domingo, 981.

${ }^{129}$ Moreau de Saint-Méry, M. L. E., Descripción de la parte española de Santo Domingo..., op. cit., p. 97. Sánchez Valverde, A., Idea del valor de La Española..., op. cit., p. 115.

${ }^{130}$ Ibidem. Para este cultivo véase Gutiérrez Escudero, A., Población y economía..., op. cit., pp. 116-118, y “Tabaco y algodón en Santo Domingo, 1731-1795” en Sarabia Viejo, Ma. J (ed.), Entre Puebla de los Ángeles y Sevilla: estudios americanistas en Homenaje al Dr. J. A. Calderón Quijano. Sevilla, 1997, pp. 151-169.

${ }^{131}$ Idem.
} 
El añil empezó a cultivarse en el siglo XVI, siendo "víctima de la despoblación y aniquilamiento por el abandono” hasta que se incentivó nuevamente su cultivo en el siglo XVIII ${ }^{132}$. Entre los hacendados que dedicaron alguna de sus propiedades a este cultivo cabe destacar a Francisco Espaillat y Virol en su finca La Angostura. De igual forma que los restantes productos, se trató de darle facilidades para que conjuntamente mejorase la economía agraria, sin embargo se ignora qué producción llegó alcanzar.

\subsubsection{El tabaco}

La Corona promovió igualmente el tabaco, convirtiéndose éste en uno de los productos que más resultados proporcionó y del que más noticias se tienen. Su estudio daría lugar a una investigación particular, de modo que en el siguiente apartado se tratará a grandes rasgos.

La dedicación a la labranza del tabaco tiene una larga tradición en Santo Domingo, pues se cultivaba desde el siglo XVI, extendiéndose fundamentalmente alrededor de Santiago y en el llamado valle de la Vega Real ${ }^{133}$. Parte de la producción de tabaco era consumida por la propia población como medicina, sobre todo entre los esclavos, quienes hacían uso del producto para aliviar enfermedades y el cansancio. Otra parte de la producción era exportada a Sevilla, vendiéndose una porción en comercio de contrabando a los barcos que se acercaban a la costa de La Española, en especial al norte de la isla. El notable provecho que obtuvieron los extranjeros hizo que la Corona tomase medidas para evitar el contrabando, así se llegó a prohibir la siembra de tabaco en Santo Domingo de la misma forma que se prohibió en las islas y zona costera continental del Caribe. Sin embargo, tal restricción no tuvo éxito, al consentirse de nuevo en 1614 su cultivo y su exportación, impidiendo su comercio con cualquier otra nación. En cambio el siglo XVII se caracterizó por la disminución de su producción y comercio a causa de la competencia del tabaco cubano y el de la colonia británica de Virginia, que por sus cualidades y facilidades en medios de

\footnotetext{
${ }^{132}$ Moreau de Saint-Méry, M. L. E., Descripción de la parte española de Santo Domingo..., op. cit., p. 98.

${ }^{133}$ Zona localizada entre Santiago, Cotuí y La Vega. Actualmente se corresponde con dichos municipios así como los de San Francisco Macorís y Moca.
} 
comunicación acabaron dominando el mercado y provocando el declive tabacalero de La Española ${ }^{134}$.

Pese a esta crisis, los intentos de fomentar este cultivo a finales del siglo XVII y la primera mitad del XVIII en Santo Domingo continuaron. Con ese fin se elaboraron numerosos proyectos que tendrían su culminación en la segunda mitad del siglo XVIII. En 1687 la Corona puso empeño en impulsar la siembra del tabaco en La Española, con la intención de hacer frente a los competidores extranjeros. Para ello encargó al gobernador la búsqueda de las tierras más propicias para su cultivo, pero la falta de comercio hizo que sólo se produjese el mínimo para el consumo interno. Bajo el mando del gobernador Alfonso de Castro (1731-1741) se trató una vez más de incentivar su siembra. Aquel elaboró un plan que tenía por objeto aumentar los terrenos dedicados al cultivo del tabaco, abaratar su coste, establecer el estanco e incrementar su comercio, para todo lo cual estaba dispuesto a costear de su peculio el importe de los barcos necesarios para su envío a la metrópoli. El único resultado que se obtuvo de este proyecto fue la extensión del cultivo del tabaco, que continuó produciéndose para consumo interno y comercio con los franceses ${ }^{135}$.

Más tarde, en 1753, el gobernador Francisco Rubio y Peñaranda solicitó permiso a la Corte para embarcar en los registros que venían de la Península y devolvían a ésta el tabaco que se estaba produciendo en aquella isla. Pero la propuesta no fue exitosa, ya que las Reales Fábricas de Sevilla consideraron que con el tabaco de Cuba era más que suficiente, además estaba estimado de mejor calidad que el de Santo Domingo. Fue durante el gobierno de Manuel de Azlor y Urríes (1759-1771) y de los siguientes gobernadores cuando la producción y el mercado del tabaco dominicano experimentaron un cambio significativo al crearse la Factoría de Tabacos en 1763. Su establecimiento coincidió con la nueva legislación de la Corona, que estaba destinada a extender la producción agrícola de sus colonias americanas, e incrementar sus ingresos fiscales con el restablecimiento del estanco de tabaco en lugares como Cuba, y ampliarlo a otros territorios de América como Nueva España. No obstante, su creación también fue

\footnotetext{
134 Véase Gutiérrez Escudero, A., "El tabaco en Santo Domingo y su exportación a Sevilla (época colonial)” en Vilar Vilar, E., y Kuethe, A. J. (eds.), Relaciones de poder y comercio colonial. Sevilla, 1999, pp. 117-142. Sevilla Soler, Mª R., Santo Domingo..., op. cit., pp. 104-117.

${ }^{135}$ Idem., véase también Gutiérrez Escudero, A., Población y economía..., op. cit., pp. 108-110.
} 
consecuencia directa de la ocupación de La Habana por parte de los ingleses en 1762, que paralizó el comercio de esta isla, y por tanto el tabaco que ésta proporcionaba a España. Esta situación fue aprovechada por el gobernador Manuel Azlor y Urríes, quien siguiendo las líneas de su antecesor, de querer introducir el producto dominicano dentro del comercio español, envió a la Península un cargamento de tabaco de distintas calidades con la intención de que éste se permitiese remitir desde Santo Domingo, como hasta entonces se había hecho desde La Habana. La buena calidad de las hojas y otras circunstancias, tales como el descenso de tabaco cubano que llegaba a la Factoría sevillana antes de la toma de los ingleses, también debieron de favorecer su instauración ${ }^{136}$.

\subsubsection{La Factoría de Tabaco}

La respuesta favorable a la petición de Manuel Azlor y Urríes dio lugar a la creación de una Factoría de Tabacos en la ciudad de Santo Domingo, que respondía a la Real Orden de 12 de octubre de 1763. La función de esta Factoría fue la de estimular el cultivo del tabaco, pero fundamentalmente se encargó de comprarlo y remitirlo a las Factorías Reales de Sevilla. Los fondos asignados para tales operaciones supusieron 25.000 pesos, que debían de llegar junto con el situado procedente de México. La primera cantidad llegó en 1765, pero las posteriores lo hicieron con bastante irregularidad ${ }^{137}$.

El mando de la Factoría estaría a cargo del primer factor o principal y de un segundo o un interventor-contador. El primer factor tenía la obligación de recibir los tabacos que se remitían anualmente desde la ciudad de Santiago a Santo Domingo, su reconocimiento, examen, separación y empacamiento para embarcarlos a España. Debía también recibir los caudales para los costos y gastos que se originaran en la oficina de su cargo, dando cuenta de todo ello a la Corte, adonde debía remitir las cuentas detalladamente. El segundo factor o interventorcontador tenía que asistir a las faenas de todos los trabajos que se realizasen en la Factoría y certificar su ejecución, y como interventor, debía ayudar en lo que fuese necesario al trabajo de pluma, encargándose de llevar los libros de cuentas

\footnotetext{
136 Sobre este asunto véase Gutiérrez Escudero, A., "El tabaco en Santo Domingo y su exportación a Sevilla (época colonial)”..., op. cit., pp. 117-142, p. 124 y 125.

137 Idem.
} 
generales y facturas que debía anotar. Además en caso de ausencias y enfermedades del factor principal o del escribiente le suplía ${ }^{138}$. Respecto a aquellos que se encargaron del funcionamiento de la Factoría, en un principio fueron escogidos valorando su experiencia laboral. De igual forma que en el resto del continente americano, las personas elegidas para ocupar los dos oficios para la Factoría de Santo Domingo fueron empleados de la Real Fábrica de Sevilla ${ }^{139}$. Para el primer puesto se escogió a José de la Cid Paz, teniente fiel y sobre-estante mayor, y para el de interventor-contador a José de Carranza, oficial escribiente de la Contaduría General de la fábrica sevillana. Pero finalmente estas personas no se trasladaron a Santo Domingo al no resultarles atractiva esta isla, habiendo otros lugares más interesantes como México y al limitado sueldo que se le ofrecía ${ }^{140}$. A partir de 1768 se buscaron de nuevo otras personas para ocupar los empleos de la Factoría. Para el puesto de primer factor se nombró a Pedro de la Concepción Álvarez, quien ya había trabajado en la Factoría de Sevilla como oficial de primera intervención del Fielato principal entre 1753 y 1760, y como máximo responsable de ésta entre 1760 y 1767. Para la segunda plaza se eligió a Joaquín de Irundarena, entonces secretario de la Intendencia de la Fábrica de Sevilla ${ }^{141}$. Probablemente éstos tampoco llegaron a ir a Santo Domingo, de ahí que se dejase en manos del gobernador Manuel Azlor y Urríes la elección y nombramiento de las personas que él considerase más idóneas para ocupar tales puestos, eligiendo entre ellas a Andrés de Lecanda y Antonio Velilla, quienes habían llegado en comitiva con él a la isla.

Estos problemas entorno al personal de la Factoría hicieron que no fuese hasta 1770 cuando realmente se crease y empezase a funcionar. El 1 de enero de ese mismo año Manuel Azlor nombró como factor principal al bilbaíno Andrés de

\footnotetext{
${ }^{138}$ Reglamento que manifiesta los empleados en el Real Ramo de Tabacos en esta isla Española, sus ocupaciones, sueldos que gozan, con las que deberán continuar: sueldos que se proponen, y aumento de otro empleado de Reconocedor, según lo prescribe la Real Orden de 19 de marzo de este año dirigida por Pedro Lerena a este gobierno, 25 de junio de 1790. AGI, Santo Domingo, 954.

139 Gutiérrez Escudero, A., "El tabaco en Santo Domingo y su exportación a Sevilla (época colonial)”..., op. cit., pp. 117-142, p. 125.

${ }^{140}$ Probablemente, la elección de José de la Cid Paz se debió a los méritos de su padre Cristóbal de la Cid Paz que fue fiel principal de la Fábrica de Tabacos de Sevilla. Carta al Marqués Esquilache, Sevilla 7 de septiembre de 1763. Y Carta del Exc. S. Marqués de Esquilate a José de Carranza, San Loenzo 11 de octubre de 1763. AHFT, leg. 606, exped. 9.

${ }^{141}$ Gutiérrez Escudero, A., "El tabaco en Santo Domingo y su exportación a Sevilla (época colonial)”..., op. cit., pp. 117-142, p. 125.
} 
Lecanda y Andirengoechea, entonces guardalmacén de la plaza, y como segundo factor e interventor-contador a José de la Vega, teniente de caballería de milicias arregladas $^{142}$. Al quedar vacante en 1777 este puesto, por ascenso de José de la Vega a controlador del hospital militar, el gobernador Isidro Peralta eligió en 1778 a Melchor Ximénez. Sin embargo la renuncia de éste un año después hizo que se nombrara a Mariano Ortega y Soto ${ }^{143}$.

Produciéndose la mayor parte del tabaco en Santiago y sus proximidades, el gobernador Manuel Azlor y Urríes creyó conveniente establecer en esa ciudad otra factoría, que estaría al mando de un factor principal. Éste se encargaría de la compra del tabaco y su remisión a la capital, así como de la compra de los serones y enseres necesarios para su custodia. Además debía dar cuenta de los caudales que entregaba en cada remesa. También fue a principios de 1770 cuando el gobernador designó para tal empleo a Francisco Antonio Velilla y Torres, desempeñándolo hasta que murió en 1781. Posteriormente el puesto fue ocupado por su yerno Francisco Espaillat y Virol $^{144}$.

En ambas factorías hubo otros empleados subalternos, como el escribiente a quien le estaba encomendado el trabajo material de pluma, por lo que debía anotar todo cuanto ocurría en dicha oficina y hacerse cargo como guardalmacén de los tabacos y demás enseres de la factoría. En un primer momento existió uno en la factoría de Santo Domingo, mientras que en la de Santiago hubo dos “[...] con la obligacion de asistir a todas las Faenas de dicha Factoria, y escribir quanto ocurriese en ella [...]”145. A partir de 1790 a uno de éstos se le añade el encargo

\footnotetext{
${ }^{142}$ Carta del gobernador Manuel Azlor y Urríes, para que se concediese a Andrés Lecanda la comisión de factor para la compra de tabacos, 7 de enero de 1768. AGI, Indiferente General, 1745. Certificación del gobernador Manuel Azlor y Urríes, 29 de julio de 1771. AGS, SGU, 7149, exped. 61.

${ }_{143}$ Carta del gobernador, Isidro Peralta y Rojas, informando del nombramiento de Melchor Ximénez como factor contador, 24 de agosto de 1778. Y Carta del gobernador, Isidro Peralta y Rojas, informando de la renuncia de Melchor Ximénez y del nombramiento que hace en Mariano Ortega, 24 de febrero de 1779. AGI, Santo Domingo, 1055.

${ }^{144}$ Campillo Pérez, J. G., Francisco Espaillat..., op. cit., p. 23. Cartas del gobernador, Isidro Peralta y Rojas, en las que participa haber nombrado a Francisco Espaillat para factor de la real factoría de Santiago de los Caballeros con el sueldo de 30 pesos mensuales y su asignación por fallecimiento de Francisco Velilla, 24 de marzo y 24 de noviembre de 1783. AGI, Santo Domingo, 1055.

${ }^{145}$ Reglamento que manifiesta los Empleados en el Real Ramo de Tabacos en esta Isla Española, sus ocupaciones, sueldos que gozan, con las que deberán continuar: sueldos que se proponen, y aumento de otro Empleado de Reconocedor, segun lo prescribe la Real Orden de 19 de marzo de este año dirigida por Pedro de Lerena a este Gobierno, 25 de junio de 1790. AGI, Santo Domingo, 954.
} 
de guardalmacén, aumentándole además el sueldo. En la citada factoría de Santo Domingo existió también un maestro enfardelador. Estaba encargado de asistir al recibo de tabacos, pesarlos, cuidar de las prensas y del empaque, así como ayudar al escribiente en la guarda, custodia y aseo de los almacenes. El empleo de reconocedor fue creado específicamente por Real Orden de 19 de marzo de 1790 para la factoría de Santiago. Su función era la de revisar los tabacos, separarlos según sus clases, y ayudar al factor principal en todas las faenas de la oficina. Tuvo un sueldo de 600 pesos anuales ${ }^{146}$.

Respecto a los salarios que el personal percibió, al principio se trató de que al menos el del primer factor y del interventor se equiparasen con los de empleados en La Habana con el objetivo de que les sirviese de estímulo. Así, al primer factor se le asignaron anualmente 3.750 pesos y al interventor 1.500 pesos, cantidades que finalmente no recibieron ${ }^{147}$. La remuneración del primer y del segundo factor fue de 360 pesos anuales, igual salario tuvo el factor de Santiago. Este sueldo como el del resto de los empleados se mantuvo invariable hasta que todos ellos fueron incrementados en 1790, como se observa en la siguiente tabla.

\footnotetext{
146 Ibidem.

147 Gutiérrez Escudero, A., "El tabaco en Santo Domingo y su exportación a Sevilla (época colonial)”..., op. cit., pp. 117-142, p. 126.
} 
Tabla 7-8. Empleados en las Factorías de Tabaco y sueldos, 1790

\begin{tabular}{|c|c|c|c|}
\hline \multicolumn{4}{|c|}{ Factoría Principal de Santo Domingo } \\
\hline Cargo & Nombre & Sueldo & Nuevo sueldo \\
\hline Factor Principal & Andrés Lecanda & 30 & 80 \\
\hline $\begin{array}{l}\text { Segundo Factor e } \\
\text { interventor-contador }\end{array}$ & $\begin{array}{l}\text { Francisco Camilo } \\
\text { Riofrio }\end{array}$ & 30 & 40 \\
\hline Escribiente & Marcos Sánchez & 15 & 25 \\
\hline Maestro enfardelador & Francisco Tamayo & 12 & 20 \\
\hline \multicolumn{4}{|c|}{ Factoría de Santiago } \\
\hline Cargo & Nombre & Sueldo & Nuevo sueldo \\
\hline Factor principal & Francisco Espaillat & 30 & 60 \\
\hline Escribiente & José Hernández & 15 & 25 \\
\hline Escribiente & $\begin{array}{l}\text { Juan Valderas } \\
\text { Bustamante }\end{array}$ & 15 & \\
\hline Reconocedor & José de la Cruz & & 50 \\
\hline
\end{tabular}

Elaboración propia. Fuentes: El sueldo mensual está expresado en pesos. Carta del gobernador de Santo Domingo en la que dirige individual de los empleos perpetuos y temporales políticos, militares y de Real Hacienda que se pagan por las cajas reales de Santo Domingo, formada en conformidad de las reales órdenes de 25 de agosto de 1780 y de 12 de marzo de 1783. AGI, Santo Domingo 946; Reglamento que manifiesta los empleados en el Real Ramo de Tabacos en esta isla Española..., op. cit. Y Carta del gobernador de Santo Domingo cumpliendo Real Orden de 19 de marzo, 25 junio de 1790. AGI, Santo Domingo, 954.

El tabaco se cultivaba fundamentalmente en Santiago, pero la instalación de la factoría hizo que la producción aumentase al extenderse su cultivo a los alrededores de dicha ciudad y a toda la Vega Real. Específicamente los lugares más destacados fueron los siguientes: Licey, Pontezuela, Guazumal, Limonal, Puñal, Canca, Guravo, Buenavista, Jacagua, Moca, Sabana Grande, Las Charcas, Viojo, Estancia Nueva, Canavacoa, Palmar, Peladeros, Angostura, Rincon Largo, Baitoa, Madera, Cienega, Guravito, La Torre, La Penda, Las Palomas, Exido, Zarambamba, Papayo, Matanzas, Guayabal, Babosico, Quinigua, Hato mayor, Hoya del Caimito, Caymito, Diezmo, Bonagua, Santa Rosa, Emboscada, Hincha, Rafael, Algarrovo, Mirador, Río Verde, Charcas, Mari Lopez, Mamey, La Soledad, Tabava, Arroyo Hondo, Manga Larga, Mirador, Alta Mira, Vega, entre otros. También llegó a cultivarse en la jurisdicción de la ciudad de Santo Domingo, en Los Llanos y Yabacao, aunque en menor proporción ${ }^{148}$.

Según el gobernador Manuel Azlor y Urríes la producción de tabaco en 1770 fue de unas 10.000 arrobas, mientras que en 1772 alcanzó unas 2.000 más y se estimaba que la posibilidad de aumentar en el año siguiente a más de 18.000 y

\footnotetext{
${ }^{148}$ Ibidem., p. 133.
} 
en 1774 incluso llegar a la cantidad de unas 24.000. Sin embargo, una Real Orden de 1774 ordenaba según las Reales Fábricas de Sevilla, que debía reducirse la producción anual a 12.000 arrobas y ser recogida del partido de Licey porque era el de mejor calidad. Asimismo, para evitar que se perdiese lo producido ese año se mandaba pagarlo a través de una remisión especial de dinero desde México. Esta medida fue consecuencia de la sobreproducción, ya que las fábricas seguían abasteciéndose fundamentalmente del tabaco cubano. Esto produjo que algunas tierras fuesen abandonadas hasta el punto que los envíos descendieron, así en 1777 no llegó ningún cargamento con tabaco a Sevilla. Finalmente, con ánimo de ayudar a aquellos agricultores que siguieron cultivándolo, una Real Orden de noviembre de 1778 les permitió la venta de ese tabaco que las fábricas de Sevilla consideraban de baja calidad a la colonia vecina de Saint Domingue, recibiendo a cambio de él dinero o esclavos. A partir de este año se normalizó la producción relativamente, ya que en los años siguientes no se llegó a completar el cargamento de las 12.000 arrobas que se había determinado ${ }^{149}$. Hacia 1785 el gobernador Isidro Peralta y Rojas alegaba distintos motivos, como fueron la falta de dinero para su compra, la disminución de su producción debido a la restricción impuesta y las destrucciones producidas por la gran sequía que sufrieron en 1779 y la tormenta padecida el 15 de octubre de $1780^{150}$. A lo que podría añadirse el contrabando, medio por el que probablemente también se comerció de manera paralela. Según Sevilla Soler entre 1780 y 1796 las exportaciones de tabaco ascendieron a 9.9679 arrobas, una media anual de $5.864^{151}$.

\subsubsection{El transporte}

Una vez recogido el tabaco se pesaba y empaquetaba en pequeños manojos de doce hojas, con ocho de éstos se formaba otro manojo más grande que era atado con majaguas ${ }^{*}$ y rociado “[...] para la mejor unión y conservación, con

\footnotetext{
${ }^{149}$ Gutiérrez Escudero, A., Población y economía..., op. cit., pp. 111-112. Sevilla Soler, Ma. R., Santo Domingo..., op. cit., pp. 110-115.

${ }_{150}$ Informe del gobernador Isidro Peralta y Rojas, 1781-1782. AGI, Santo Domingo, 1055.

151 Sevilla Soler, Ma. R., Santo Domingo..., op. cit., p. 116

* La majagua es un árbol americano de la familia de las malváceas, su madera se utiliza para lanzas y jalones, y del líber de los vástagos nuevos se obtenían cordajes. Gutiérrez Escudero, A., "El tabaco en Santo Domingo y su exportación a Sevilla (época colonial)”..., op. cit., pp. 117-142, p. 132.
} 
Zambumbia clara con buen temple, que es el nombre que se le da en la América al agua miel, con el fin de conservarle el jugo natural y que los manojos puedan llegar frescos y tal vez en disposición de que sin humedecerlos se logre su conservación en cigarros [...]”152 . Con grupos de cien manojos se formaba un tercio o fardo que era prensado y enfundado en lienzo o bien esteras ${ }^{153}$. Cada tercio de tabaco, cuyo peso era aproximadamente de 100 libras, debía estar sellado con las armas reales y una marca según su calidad. De esta forma se distinguían varias clases de tabaco. El primer tipo llamado “tienda” (T) estaba considerado como de muy buena calidad y bien tratado, se parecía al de La Habana. El segundo era el "rescogido” (R) y estaba considerado peor que el anterior, pero ambos eran estimados de mejor calidad que los de Virginia para la elaboración de cigarros. El tercer tipo nombrado "libra” (L) era muy inferior a los otros dos, pues contenía “[...] hojas bastante dañadas por haber estado las matas más cerca de la tierra”. Para cada uno de ellos existía un tipo de mejor calidad que se denominaba “con premio",154.

Inicialmente el traslado de tabaco se hizo por vía terrestre y recuas a Santiago y luego a Santo Domingo, desde dónde se embarcaba a Cádiz. El transporte terrestre que se utilizaba en la isla era un medio duro por las malas condiciones y su largo traslado de Santiago a la ciudad de Santo Domingo. La medida tomada ante esta situación fue la de cambiar la vía terrestre de transporte del tabaco por la fluvial. Para ello el gobernador José Solano y Bote dispuso en 1774 que se hiciesen navegables los ríos Yuna y Camú. Ambos ríos atraviesan parte del valle del Cibao y desembocan en la bahía de Samaná, además el primero es afluente del segundo ${ }^{155}$. En ese mismo año se construyó a orillas del río Camú un establecimiento que se llamó San Rafael de Angelina ${ }^{156}$, donde se guardaban

\footnotetext{
152 Idem.

153 Las esteras eran sacos elaborados con plantas filamentosas. Ibidem., p. 133.

154 Cada uno de estas variedades con premio eran denominados de la siguiente forma: Tienda con Premio (TP), Rescogido con Premio (RP) y Libra con Premio (LP). Sevilla Soler, $\mathrm{M}^{\mathrm{a}}$. R., Santo Domingo..., op. cit., p. 109.

155 En Lluberes Navarro, A., "Tabaco y catalanes en Santo Domingo durante el siglo XVIII". Eme-Eme Estudios Dominicanos 28 (Santiago de los Caballeros, 1977) pp. 13-26, p. 15, y "Las rutas del tabaco dominicano”. Eme-Eme Estudios Dominicanos 21 (Santiago de los Caballeros, 1975) pp. 3-22.

${ }^{156}$ También era conocido como San Rafael de Angélica. El nombre de este lugar se debía a que el gobernador José Solano y Bote lo escogió en honor a su mujer, Rafaela Ortiz de Rojas. Hernández González, M. V., Expansión fundacional..., op. cit., p. 181. Ferreras, R. A., Breve
} 
las mulas, bueyes, carretes y champanes ${ }^{*}$ que ayudaban al transporte. Había un personal formado por esclavos y operarios que se encargaban de la limpieza de ambos ríos, pero sobre todo de más de 30 leguas del curso del río Camú. En ese lugar también hubo un almacén en el que se depositaba el tabaco que era comprado en la ciudad de Santiago, donde a su vez se creó un local para guardar el que llegaba de los alrededores y realizar las operaciones comerciales. Después este tabaco era transportado por vía terrestre hasta el puesto de San Rafael de Angelina, desde el cual se llevaba en champanes a Samaná, donde era revisado por un comisionado o por el propio factor principal de tabacos de Santo Domingo.

Dado el visto bueno era enfardelado y otra embarcación mayor se encargaba de llevarlo al puerto de Santo Domingo ${ }^{157}$.

\section{Figura 7-5. Transporte del tabaco en recuas hacia Santiago}

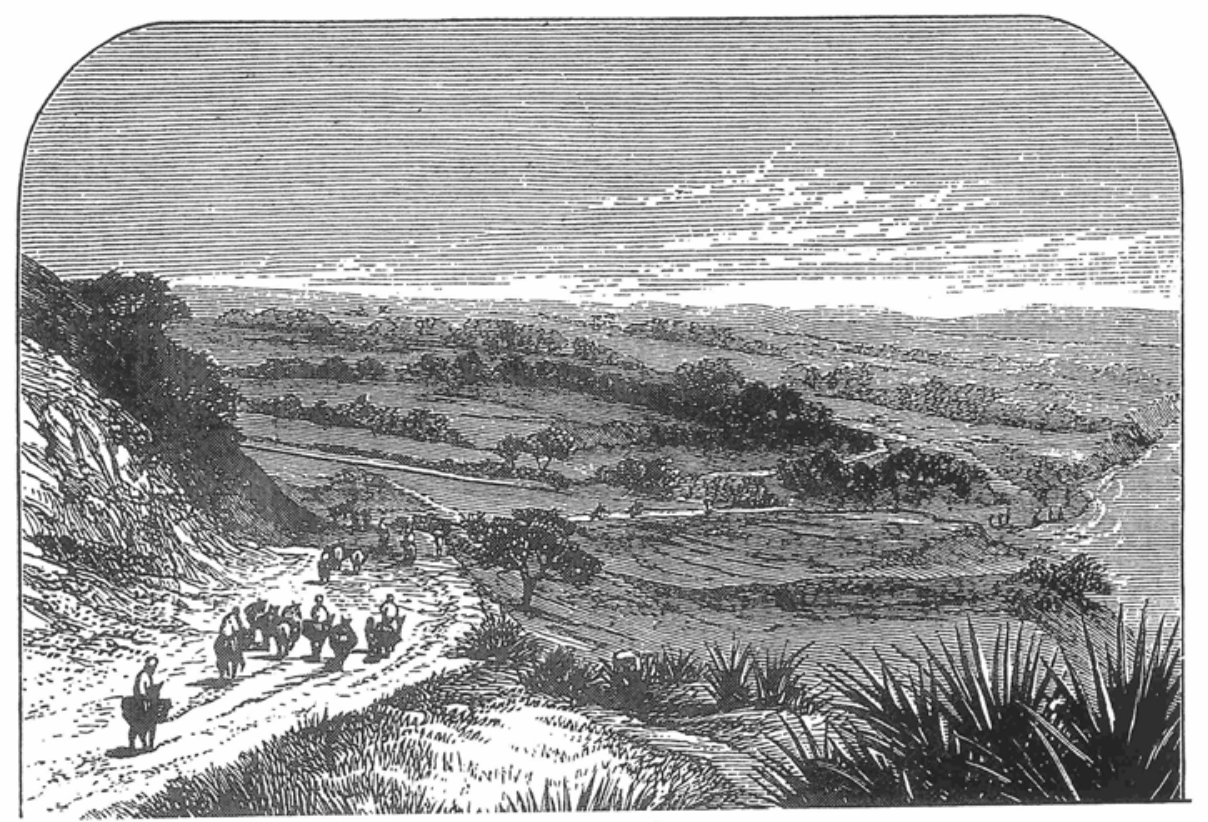

Fuentes: Hazard, S., Santo Domingo. Su pasado y presente. New York, 1873, p. 324.

Este transporte era realizado por la Real Compañía de Comercio de Barcelona, que además corría con los gastos de la puesta a punto de los caminos,

historia de Santo Domingo. Desde la orogénesis hasta el año 1992. Santo Domingo, 1992, pp. 156-157.

* Tipo de embarcación grande, de fondo plano que se utiliza para navegar por los ríos.

${ }^{157}$ Incidencia a lo últimamente obrado en el asunto de tabaco, 23 de mayo de 1785. AGI, Santo Domingo, 947. 
ríos y acondicionamiento de los locales que servían de almacén, así como de las tiendas donde se vendían los productos que traía la compañía de la metrópoli. Los buenos resultados obtenidos en Cumaná con la apertura de varias tiendas hicieron que la dirección de la compañía decidiera lo mismo para Santo Domingo. Hacia 1776 tanto el establecimiento de Santiago como el de San Rafael de Angelina estuvieron bajo el mando de Francisco Ferrer y Alás, segundo factor de la compañía en la ciudad de Santo Domingo. Los responsables directos de éstas fueron José de la Cruz y Francisco Levina. Su apertura se realizó cuatro años después de la del que operaba en la ciudad de Santo Domingo, abierto desde 1771 y administrado para esa fecha por Francisco Báez ${ }^{158}$.

La inversión realizada por la compañía en la puesta en marcha de esta ruta interior e iniciación de los dos nuevos establecimientos, fue recompensada al concederle la Corona en exclusividad la conducción del tabaco a través de las mencionadas vías hasta el puerto de Santo Domingo, y después a Cádiz por medio de sus barcos. Narciso Subirás y Barra, primer factor de la compañía por entonces (1767-1774), contribuyó a la firma de un contrato entre ésta y el gobernador José Solano y Bote. Se le concedía oficialmente la "privativa transportacion de ellos por el termino de tres años” que empezaría a partir de noviembre de 1774, corriendo por su cuenta toda avería y riesgo ${ }^{159}$. Además la Real Compañía recibiría el mismo precio que hasta ese momento se había pagado por el transporte terrestre desde que era entregado en la Factoría del tabaco de la ciudad de Santiago hasta que se depositaba en la ciudad de Santo Domingo, la cantidad de seis pesos y medio ${ }^{160}$. Durante este contrato los envíos de tabaco a Cádiz alcanzaron un volumen de 9.318 tercios.

\footnotetext{
${ }^{158}$ Oliva Melgar, J. Mª, Cataluña y el comercio privilegiado con América en el siglo XVIII: la Real Compañía de Comercio de Barcelona a Indias. Barcelona, 1987, pp. 105-106 y 110.

159 Representación de Narciso Subirás y Barra, 26 de septiembre de 1774. AGI, Santo Domingo, 1055.

${ }^{160}$ Ibidem.
} 
Tabla 7-9. Envíos de Tabaco, 1774-1776

\begin{tabular}{|l|l|l|r|}
\hline \multicolumn{1}{|c|}{ Fecha } & \multicolumn{1}{|c|}{ Embarcación } & \multicolumn{1}{c|}{ Capitán } & $\begin{array}{r}\text { Cantidad } \\
\text { en tercios }\end{array}$ \\
\hline 8 Noviembre de 1774 & Saetía Espíritu Santo & Joseph Buter & 1.171 \\
\hline 6 Febrero de 1775 & Saetía Espíritu Santo & Josef Boté & 1.171 \\
\hline 13 Octubre de 1775 & $\begin{array}{l}\text { Paquebote Nuestra Señora } \\
\text { del Pilar }\end{array}$ & Antonio Tutzó & 2.148 \\
\hline 10 Enero de 1776 & $\begin{array}{l}\text { Paquebote Nuestra Señora } \\
\text { del Pilar }\end{array}$ & Antonio Tutzó & 2.148 \\
\hline 20 Enero de 1776 & $\begin{array}{l}\text { Bergantín San Joaquín y } \\
\text { Santa Ana }\end{array}$ & Martín Sopeña & 1.137 \\
\hline 9 Agosto de 1776 & $\begin{array}{l}\text { Saetía Nuestra Señora del } \\
\text { Carmen }\end{array}$ & $\begin{array}{l}\text { Francisco de } \\
\text { Pruna }\end{array}$ & 1.543 \\
\hline Total & \multicolumn{3}{|l}{} \\
\hline
\end{tabular}

Elaboración propia. Fuentes: Facturas de tabaco, 1174, 1775, 1776. AGI, Santo Domingo, 1055. Lluberes Navarro, A., “Tabaco y catalanes en Santo Domingo durante el siglo XVIII”..., op. cit., pp. 13-26, p. 20.

Si bien hacia 1777 debió vencer la contrata con la compañía, probablemente Narciso Subirás continuó con este negocio aunque por su propia cuenta, pues para la fecha estaba desvinculado de la Real Compañía como consecuencia del problema en el que se vio envuelta en 1771. En 1777 el gobernador José Solano y Bote y Narciso Subirás firmaron un nuevo contrato, en esta ocasión por cinco años. Sin embargo, la declaración de guerra a Inglaterra en 1779 obligó a paralizarlo, pues en el convenio se había ajustado que se realizaría exclusivamente en tiempo de paz. A partir de 1781 el comerciante y también hacendado Antonio Rojas se encargó de remitir a Cádiz los tabacos, al no hallarse otro comerciante en disposición de hacer este asiento mientras durase la guerra ${ }^{161}$. Éste firmó tres contratos: el primero el 16 de febrero de 1780 por el que recibió 2.923 quintales el 30 de mayo de 1781. El segundo el 1 de julio de 1781, para transportar 1.700 quintales que envió en octubre de 1781, y el tercero en 1 de diciembre de 1782 por 3.500 quintales que fueron remitidos en enero de 1783. Por el primer contrato se estableció que el asentista Antonio Rojas debía transportarlos hasta Samaná por los ríos Camú y Yuna, siempre y cuando no lo impidiesen "las

\footnotetext{
${ }^{161}$ Carta del gobernador de Santo Domingo Isidro Peralta y Rojas informando con documento las Razones en que se ha fundado para la remesa de tabacos que hace por vía extraña a las Reales Fábricas de Sevilla, asegurados con competentes fianzas, 1 de mayo de 1780. AGI, Santo Domingo, 1055.
} 
fuertes avenidas o la escasez de agua"162. En cambio se le permitió que desde Samaná hasta el puerto de Santo Domingo y de éste al de Cádiz, pudiera hacerlo con bandera neutral para evitar el riesgo del contexto bélico. Además el cambio de ruta fue necesario para la elección de aguas seguras, por ese motivo la conducción hasta Cádiz se realizó vía Curazao. Los dos siguientes transportes se hicieron por el Guarico*. Adjunto al cobro por el transporte del tabaco, se añadió una partida por los riesgos de mar, enemigos de la Corona, piratas y demás, por el que cobró de un 26 a un 35\% del importe de flete.

Respecto al coste del transporte, en la siguiente tabla se muestra información de dos facturas donde se notifican los fletes desde Santiago a Santo Domingo y de ahí al puerto de Cádiz. A pesar de la gran diferencia de distancia de las dos rutas, el precio era similar debido probablemente a la complejidad del transporte dentro de la isla a causa de las dificultades orográficas.

Tabla 7-10. Coste del transporte del tabaco, 1778 y 1779

\begin{tabular}{|c|r|r|r|r|r|}
\hline \multirow{2}{*}{$\begin{array}{c}\text { Fecha } \\
\text { Factura }\end{array}$} & \multirow{2}{*}{$\begin{array}{c}\text { Quintales } \\
\text { (arrobas) }\end{array}$} & $\begin{array}{c}\text { Santiago- } \\
\text { Santo } \\
\text { Domingo }\end{array}$ & $\begin{array}{c}\text { Reales } \\
\text { por } \\
\text { arroba }\end{array}$ & $\begin{array}{c}\text { Santo } \\
\text { Domingo- } \\
\text { Cádiz }\end{array}$ & $\begin{array}{c}\text { Reales } \\
\text { por } \\
\text { arroba }\end{array}$ \\
\hline 1778 & $\begin{array}{r}3.000 \\
(12.000)\end{array}$ & $9.675 \$$ & 6,5 & $11.250 \$$ & 7,5 \\
\hline 1779 & $\begin{array}{r}5.500 \\
(22.000)\end{array}$ & $16.500 \$$ & 6 & $17.875 \$$ & 6,5 \\
\hline
\end{tabular}

Elaboración propia. Fuentes: Manifiesto exacto del costo que causa una remesa de tabaco de tres mil quintales con arreglo a las que de quenta de S. M (que Dios guie), se ha hecho en los años antezedentes, 31 de agosto de 1778. Y, Manifiesto del costo que causará una remesa de cinco mil y quinientos quintales de tabaco, que se haga de quenta de S. M (que Dios guie) a Cadiz, variando el método de el de enfrente, con arreglo a este en la forma siguiente, 15 de enero de 1779. AGI, Santo Domingo, 1055.

\subsection{La ganadería}

Durante el siglo XVI la ganadería se desarrolló en la isla de manera paralela al cultivo de la caña de azúcar. Traído de la Península, el ganado que existió era el vacuno, caballar, porcino, caprino y ovino. Los dos primeros tipos

\footnotetext{
${ }^{162}$ Expediente que sigue el fiscal de Santo Domingo ante el gobernador sobre el cumplimiento de las contratas de tabaco del asentista Antonio Rojas, 1784. AGI, Santo Domingo, 968.

Se trata del puerto del área norte de Saint Domingue, también conocido como Cabo Francés, y actualmente como Cabo haitiano.
} 
sirvieron de complemento a la plantación azucarera, pues los bueyes eran utilizados como instrumento de transporte, mientras que el resto del ganado fue aprovechado como alimento para la población. En los dos siglos siguientes la ganadería se convirtió en una de las actividades más importantes para la economía de Santo Domingo, y en ambos siglos su desarrollo estuvo motivado por una demanda externa. Durante el siglo XVII el interés estuvo en los cueros de las reses que eran vendidas en las costas de la isla, sobre todo en el norte a extranjeros; incluso algunos como los franceses (bucaneros) lo cazaban directamente. En cambio, en el siglo XVIII fueron las bestias y reses de lo que más provecho sacaron los franceses, instalados en la parte occidental de la isla. A partir de entonces entre ambas colonias se creó una dependencia por partida doble. La parte española se convirtió en fuente abastecedora de ganado vacuno, caballar, y tabaco, y la francesa proporcionaba esclavos, herramientas agrarias, productos de lujo, dinero y alimentos ${ }^{163}$.

Los beneficios que se obtenían de este comercio motivaron que se expandiera la actividad ganadera por toda la isla, pero en especial fueron las áreas norte y oeste los principales lugares de producción ganadera y los que mantuvieron los intercambios con los franceses. En el este también existieron grandes hatos, sobre todo en el Seibo y Hato Mayor. No obstante, si se comparan los datos de los dos únicos censos de ganado con los que por el momento se cuenta para el siglo XVIII, puede observarse que en el de 1772 las ciudades de Santiago y La Vega sufrieron un descenso frente al de 1744. Según Antonio Gutiérrez Escudero ello se debió al impulso agrícola que tuvo el cultivo de tabaco en esos lugares, provocando que algunos ganaderos dedicasen sus terrenos a este producto $^{164}$. Aún así, el resto de localidades como Hincha, Cotuí, Puerto Plata, Neiba o San Juan de la Maguana aumentaron su número gracias al auge comercial establecido entre ambas colonias. También se dio un alto incremento de ganado en el Seibo, zona bastante alejada de la frontera. Hay que destacar que en el censo de 1744 no aparecen Montecristi, Sabana de la Mar y San Rafael, ya que estas poblaciones fueron fundadas posteriormente. Tampoco figura Azua y Baní, lugares de gran importancia para la ganadería, o Banica que por el contrario no se

\footnotetext{
163 Silié, R., Economía, esclavitud y población. Ensayos de interpretación histórica del Santo Domingo español en el siglo XVIII. Santo Domingo, 1976, pp. 35-37.

${ }^{164}$ Gutiérrez Escudero, A., Población y economía..., op. cit., p. 147.
} 
encuentra en el estadillo de 1772. Según el informe de 1788 realizado por el oidor Pedro Catani en la isla existían alrededor de 13.515 cabezas de ganado, una cifra bastante baja si se compara con el censo de $1772^{165}$.

Tabla 7-11. Censos de reses vacunas de 1744 y 1772

\begin{tabular}{|c|c|c|}
\hline Lugares & $\begin{array}{c}1744\left(n^{0} \text { de }\right. \\
\text { reses) }\end{array}$ & $\begin{array}{c}1772\left(\mathrm{n}^{0} \text { de }\right. \\
\text { reses })\end{array}$ \\
\hline \multicolumn{3}{|l|}{ Ciudades } \\
\hline \multicolumn{3}{|l|}{ Santo Domingo } \\
\hline Santiago & 26.467 & 15.000 \\
\hline La Vega & 12.685 & 12.000 \\
\hline Monte Cristi & & 3.000 \\
\hline Monte Plata & 2.076 & 3.000 \\
\hline Puerto Plata & & 25.000 \\
\hline Bayaguana & 4.171 & 16.000 \\
\hline \multicolumn{3}{|l|}{ Samaná } \\
\hline \multicolumn{3}{|l|}{ Villas } \\
\hline San Carlos & & 1.000 \\
\hline Cotuí & 10.187 & 18.000 \\
\hline Baní & & 20.000 \\
\hline Azua & & 14.000 \\
\hline $\begin{array}{l}\text { San Juan de la } \\
\text { Maguana }\end{array}$ & 8.687 & 25.000 \\
\hline Hincha & 19.335 & 30.000 \\
\hline Banica & 6.674 & \\
\hline Neiba & 5.550 & 9.000 \\
\hline Higüey & 2.516 & 6.000 \\
\hline Seibo & 13.750 & 28.000 \\
\hline Boyá & & 500 \\
\hline \multicolumn{3}{|l|}{ Pueblos } \\
\hline $\begin{array}{l}\text { San Lorenzo de } \\
\text { Los Minas }\end{array}$ & & 500 \\
\hline San Rafael & & 2.000 \\
\hline $\begin{array}{l}\text { Sabana de la } \\
\text { Mar }\end{array}$ & & 1.000 \\
\hline \multicolumn{3}{|l|}{ Curatos } \\
\hline Los Ingenios & & 8.000 \\
\hline Haina & & 11.000 \\
\hline Los Llanos & & 23.000 \\
\hline Totales & 112.098 & 271.000 \\
\hline
\end{tabular}

Elaboración propia. Fuentes: Gutiérrez Escudero, A., Población y economía..., op. cit., p. 143. Sevilla Soler, Mª. R., Santo Domingo..., op. cit., pp. 132-134. Silié, R., Economía, esclavitud y población..., op. cit., pp. 35-37.

${ }^{165}$ Estado de los medios para el fomento de la isla realizado por el oidor decano de la Audiencia de Santo Domingo Pedro Catani, 15 de noviembre de 1788. AGI, Santo Domingo, 1012. 
En función de la producción ganadera de cada propietario, ésta se distribuía de la siguiente forma: una parte estaba dedicada al consumo de la ciudad de Santo Domingo, otra podía servir bien para el consumo propio, bien para vender a la colonia francesa, y la tercera para la reproducción del ganado. Su aumento dependió tanto del cuidado de los dueños como de las inclemencias del tiempo. Según Antonio Sánchez Valverde, dentro del ganado vacuno se distinguían distintas clases: corraleras, mansas, extravagantes y alzadas, también conocidas como bravías o montaraces. Las primeras estaban agrupadas en los corrales del hato, a diferencia de las mansas que vivían en los alrededores y andaban sueltas. Las extravagantes pastaban en las monterías (bosques), y cuando se quería hacer uso de éstas para reconocerlas y contar el número de reses debía hacerse con el sistema de rodeo, que consistía en la reunión del ganado en una sabana o pradera con el objeto de marcarlas o escogerlas para su venta o abasto. Las alzadas eran aquellas que lograban escaparse de la circunscripción que cubría un hato y se adentraban en el campo, o las que andaban y vivían libres en él. Éstas fueron generalmente cazadas y vendidas en contrabando por gran parte de la población, pero sobre todo por aquellos que vivían dispersos por los montes, de ahí que fuesen conocidos como monteros ${ }^{166}$.

Los hacendados tuvieron que pagar una serie de impuestos. Uno de ellos fue el diezmo, que se aplicó en La Española sobre la producción agropecuaria y consistía en el pago de una parte de cada diez a la Iglesia. Originariamente el diezmo fue patrimonio de la Corona, pero el Papa Alejandro VI a través de la bula del 16 de diciembre de 1501 concedió a los Reyes Católicos el diezmo de las Indias. Posteriormente, en 1512 los reyes renunciaron a ella y lo cedieron a la Iglesia. Durante la primera mitad del siglo XVI, los diezmos fueron recaudados y suministrados mediante su arrendamiento, sistema que fue prohibido en 1539. A partir de esa fecha fue administrado enteramente por cuenta de la Real Hacienda, aunque la Iglesia fue la encargada de establecer su organización y sentó las bases de la división de los diezmos: un cuarto del total estaba destinada al Arzobispo (mesa arzobispal), otra cuarta parte al Cabildo catedralicio (mesa capitular), y el resto se subdividía en nueve partes, de las que cuatro novenos eran para el clero parroquial, dos novenos iban para el rey, uno y medio para la parroquia (la fábrica

\footnotetext{
${ }^{166}$ Sánchez Valverde, A., Idea del valor de la Isla Española..., op. cit., pp. 272-274.
} 
y los gastos del culto), y otro tanto igual para el hospital. Anexo a éstos estaba el diezmo de cada comunidad, que recibía el nombre de excusado y se aplicaba a los feligreses de cada parroquia ${ }^{167}$.

Figura 7-6. Distribución del Diezmo

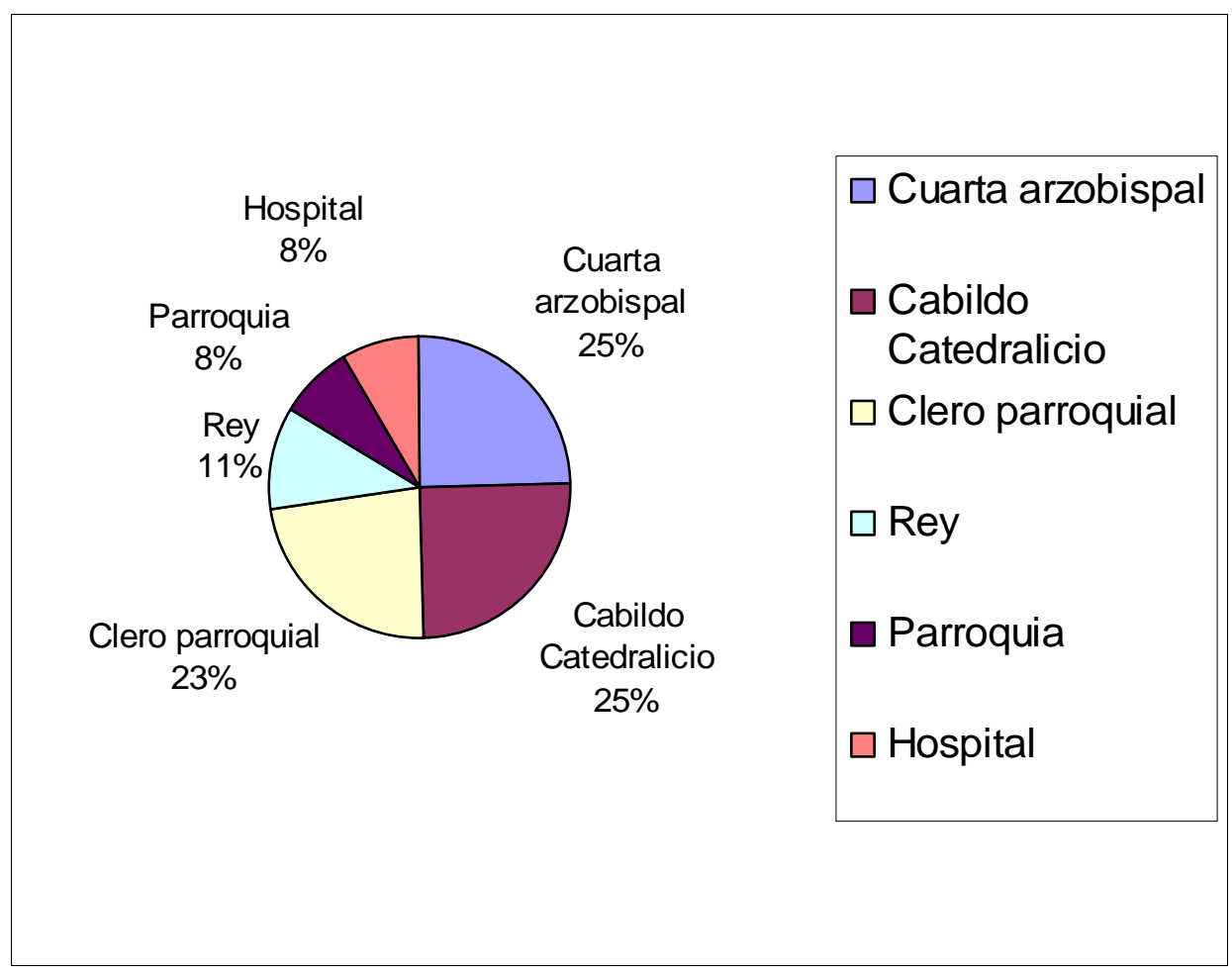

Elaboración propia

Durante el siglo XVIII la Real Hacienda continuó con la tarea de fiscalizar las rentas decimales del diezmo, pero a través de la documentación se deduce que para la segunda mitad su cobro volvió a ser arrendado. Entre las personas que decidieron hacerse cargo de este ramo destacan algunos de los hacendados estudiados, como José Guridi y Concha por la villa de Baní los años de 17701775, Francisco Espaillat por La Vega en 1781 y por Santiago entre 1785-1786.

\footnotetext{
167 Al respecto véase Casa Rivas, J. M". de la, "Los diezmos como fuente de ingresos de la Iglesia Dominicana (1492-1577)”. Casas Reales 12 (Santo Domingo, 1980) pp. 43-73. González Díaz, R., "Estado financiero de la Iglesia dominicana. Los diezmos (1578-1650)”. Casas Reales 12 (Santo Domingo, 1980) pp. 77-93. Pérez Memén, F., "El clero y la economía colonial en el siglo XVIII”..., op. cit., pp. 97-121. Rodríguez Morel, G., Cartas de los cabildos eclesiásticos..., op. cit., pp. 42-58.
} 
En ese mismo bienio, Juan Arredondo tomó asiento por Montecristi y Diego Antonio Ximénez por la población de San Juan de la Maguana ${ }^{168}$.

Los oficiales reales se encargaban de supervisar que los arrendadores cumplieran con sus obligaciones y de que pagaran de manera puntual cada año, algo que según sus informes no parece que se produjera regularmente, bien por la morosidad de los arrendadores bien por la de los propios feligreses. Para los primeros, de acuerdo con las informaciones de los oficiales, la morosidad se debía en parte a las justicias ordinarias de cada localidad, quienes no se cercioraban de si los rematadores estaban autorizados para tal cobro, o si habían cumplido con el pago adjudicado en la subasta. Por ejemplo, hacia 1787 el oficial real Fernando Mauleón informa entre los morosos que deben cantidades de dicho tributo los hacendados mencionados anteriormente, aunque finalmente para ese año sólo uno de ellos seguía debiendo. De ellos consta que los 1.800 pesos que debía José Guridi del cuatrienio 1770-1773 los pagó en 1777; los 125 pesos que debía Francisco Espaillat por La Vega los entregó en 1787; el deudor Juan Arredondo devolvió los 8.100 pesos entre el 23 de julio de 1785 y el 21 de julio de 1787; mientras que hacia 1787 Diego Antonio Ximénez había ingresado 3.390 pesos de los 4.520, quedando todavía por pagar 1.130 pesos. Por su parte, la actitud de los feligreses estaría motivada probablemente con el objeto de pagar menos diezmos y aumentar los beneficios agropecuarios ${ }^{169}$. Este comportamiento fue probablemente seguido por los hacendados encargados de recaudar los diezmos, aplicándolos sobre sus propias haciendas, como hizo José Guridi y Concha por los de Baní, y Francisco Espaillat por los de Santiago, lugares donde tenían varias de sus explotaciones agropecuarias. Por otro lado, no hay que olvidar que a partir de 1783 a Juan Bautista Oyarzábal, y un año después a José de la Vega, Ignacio Caro de Oviedo, Antonio Coca Landeche y Antonio Mañón de Lara se les había eximido del pago de diezmos de sus haciendas agrícolas; extendiéndose este beneficio al resto de la población desde 1786, lo que significó que este tributo continuara cobrándose sobre la producción ganadera.

\footnotetext{
168 Testimonio del expediente promovido por Francisco Gascue sobre cobranza de varias cantidades que se están debiendo por distintos sujetos al ramo de diezmos, formada hasta fin de diciembre de 1787. AGI, Santo Domingo, 954.

${ }^{169}$ Idem., y Pérez Memén, F., “El clero y la economía colonial en el siglo XVIII”..., op. cit., pp. 97-121, p. 106.
} 
En la siguiente gráfica podemos observar como el diezmo recaudado desde 1754 hasta 1788 fue aumentando. La información obtenida de algunos años procede de la cuarta arzobispal, pero para una mejor interpretación se ha extrapolado el valor al diezmo, según la relación de la figura 7-6 ${ }^{170}$.

\section{Figura 7-7. Importe recaudado del Diezmo}

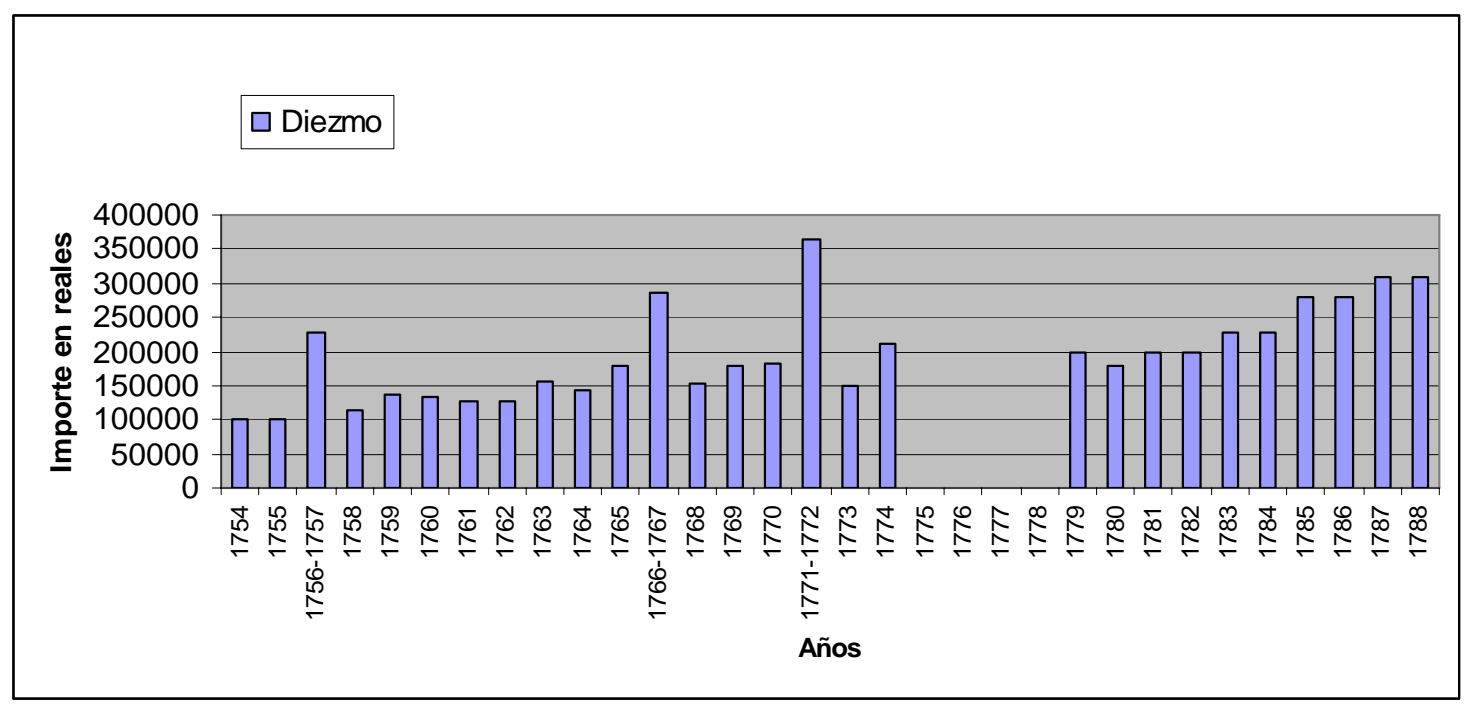

Elaboración propia. Fuentes: Sevilla Soler, Ma. R., Santo Domingo..., op. cit., pp. 459-487. Certificación de Fernando Mauleón tesorero propietario y Nicolás Toledo, contador interino de la Real Hacienda del monto de los cinco bienios contados desde el año de 1779 hasta 1788 que han tocado a la mitra por su cuarta arzobispal, 22 de noviembre de 1789. AGI, Santo Domingo, 994.

\subsubsection{El abasto de carne a la capital}

La mayoría de las poblaciones estaban obligadas a suministrar ganado a la ciudad de Santo Domingo. Como ya se ha comentado, los lugares en los que más se produjo fueron las zonas norte, oeste y este. Entre las ciudades y villas situadas en esa área, hay que señalar que estuvieron relevadas las villas de Hincha y

${ }^{170}$ La información obtenida para 1754-1769 procede de la cuarta arzobispal, expresada en reales. De igual forma que las cifras de los años 1768-1770, aunque éstas están tomadas de los dos novenos del rey, cantidad que había sido cedida al cabildo eclesiástico de la isla durante 17541769. En cambio para 1775-1778 no hemos obtenido información. Los datos de los años 17791788 están tomados de la cuarta arzobispal, que venían expresados en pesos y han sido convertidos en reales. También hay que destacar que las cifras de algunos años como 1756-1757, 1766-1767 y 1771-1772 se han obtenido de forma bienal como queda relejado en la gráfica. 
Banica desde $1747^{171}$. En este año el gobernador Pedro Martín Zorrilla los indultó ante los reclamos que éstas hicieron para que las exonerase de tal contribución, alegando la lejanía de ochenta a noventa leguas que existía entre éstas y la capital. En el área norte, también estuvo libre de esta obligación la población de Santiago, exceptuando la ciudad de La Vega y la villa del Cotuí ${ }^{172}$. No obstante, Hincha, Banica y Santiago debían aportar carne salada, cuando el cabildo capitalino lo requiriese. En momentos de escasez de carne en la capital, los gobernadores trataron de que los criadores de esos lugares, en especial los de Hincha debido a su abundancia, enviasen ganado para el abasto de la ciudad. En 1762 y 1765, Manuel Azlor y Urríes, y en 1785, Isidro Peralta y Rojas, intentaron que esa villa colaborase completando el número de reses para la provisión de dichos años. Aunque no lo lograron, pues éstas acudieron a la Audiencia para defender su excepción en esta materia, que dictó sentencia favorable en ellas ${ }^{173}$.

El sistema de pesas fue el que se utilizó para abastecer a la capital. Durante el mes de octubre de cada año, el cabildo de la ciudad de Santo Domingo “formaba un extracto general de todos los criadores de la Parte Española, y sobre la suerte principal de sus haciendas por un tanto por ciento repartia a cada uno lo que correspondia para que abasteciese la ciudad de carne, señalandose dia, o dias en que debia verificarlos: en cuyo repartimiento lo pasaba al gobernador que aprobandolo como lo hacia, lo pusiese en execucion” ${ }^{174}$. Tras ello el fiel ejecutor del cabildo de cada población junto al resto de los capitulares realizaba el cálculo de los sujetos en que debían de repartirse las pesas ${ }^{175}$. Mediante un sorteo se determinaba el orden y la fecha de entrada de las reses que le correspondía llevar a cada ganadero a la ciudad de Santo Domingo ${ }^{176}$. A lo largo del siglo XVIII una pesa equivalía a un máximo de 80 reses semanales, no debiendo pasar cada res de

${ }^{171}$ Carta del gobernador, Manuel Azlor y Urríes al rey, informando de los perjuicios que resultan por la introducción clandestina de ganados a la colonia francesa, 12 de octubre de 1760 . AGI, Santo Domingo, 1059.

${ }^{172}$ Ibidem.

${ }^{173}$ Gutiérrez Escudero, A., Población y economía..., op. cit., p. 149. Junta de abastos y fomento de Santo Domingo, 6 de julio de 1785. AGI, Indiferente General, 1579.

${ }^{174}$ Carta del cabildo de Santo Domingo al rey, 28 de enero de 1801. AGI, Santo Domingo, 1045.

${ }^{175}$ Relación de los sujetos en que se han de repartir las ochenta reses al abasto de la capital, Villa de Higüey 13 de febrero de 1793. ARH, leg. 23, exp. 17.

${ }^{176}$ El sistema de rueda o pesa también fue utilizado en Cuba. Gutiérrez Escudero, A., Población y economía..., op. cit., p. 148. Amores Carredano, J. B., Cuba en la época de Ezpeleta..., op. cit., pp. 383-389. 
tres años ${ }^{177}$. Sin embargo hubo determinados momentos en que la pesa fue incrementada a algunos pueblos. Por ejemplo, entre 1760 y 1761 al llegar dos batallones de España, se adjudicó a Puerto Plata una pesa de 100 reses para completar los repartimientos que se realizaron entre el resto de las poblaciones de la isla ${ }^{178}$.

Hasta el momento no se tiene información seriada de varios años que permita conocer la cantidad de reses que entraba en la capital y cómo fue su evolución. Tan sólo se cuenta con algunas fechas: en 1773 entraron 4.805 reses vacunas, 4.686 en $1774^{179}$, y en 1782 unas 5.476, como puede observarse de manera más detallada en la siguiente tabla.

Tabla 7-12. Relación del número de reses consumidas en la ciudad de Santo Domingo en 1782

\begin{tabular}{|c|c|c|c|}
\hline \multirow{2}{*}{ Meses } & \multirow{2}{*}{ Número de reses } & \multicolumn{2}{|c|}{ Peso } \\
\cline { 3 - 4 } & & arrobas & libras \\
\hline Enero & 463 & 4.631 & 4 \\
\hline Febrero & 366 & 3.335 & 11 \\
\hline Marzo & 332 & 3.226 & 24 \\
\hline Abril & 471 & 4.251 & 7 \\
\hline Mayo & 500 & 4.435 & 22 \\
\hline Junio & 478 & 4.814 & 15 \\
\hline Julio & 555 & 5.120 & 2 \\
\hline Agosto & 518 & 5.174 & 11 \\
\hline Septiembre & 456 & 4.367 & “ \\
\hline Octubre & 445 & 4.395 & 16 \\
\hline Noviembre & 447 & 4.273 & 3 \\
\hline Diciembre & 445 & 4.131 & “ \\
\hline Totales & $\mathbf{5 4 7 6}$ & $\mathbf{5 2 . 1 5 6}$ & $\mathbf{1 5}$ \\
\hline
\end{tabular}

Elaboración propia. Fuentes: Estado que manifiesta el numero de Reses, que se han consumido en el abasto del publico de la Ciudad de Santo Domingo de la Isla Española, en todo el año próximo passado de 1782, con expresión de Reses, su peso de arovas, y libras mensualmente, que han producido todas ellas, y a quanto cada una, 22 de enero de 1783. AGI, Indiferente General, 1579.

Fueron varios los inconvenientes a los que tuvieron que hacer frente los criadores cuando trasladaban su ganado a la capital. Para llegar a ella, los de la parte este como Bayaguana, Higüey y el Seibo, tenían que atravesar el río Ozama,

\footnotetext{
177 Informe del gobernador Manuel Azlor y Urríes, 8 de noviembre de 1765. AGI, Santo Domingo, 976.

${ }^{178}$ Razón de los expedientes de gobierno sobre el abasto de carnes, 18 de diciembre de 1765. AGI, Santo Domingo, 976.

${ }^{179}$ Sevilla Soler, Ma . R., Santo Domingo..., op. cit., p. 148.
} 
muriendo ahogadas muchas de las reses al volcar las canoas, y otras por los ataques que sufrían de los tiburones. En 1754 el gobernador Francisco Rubio y Peñaranda decidió implantar un impuesto de 2 reales sobre el precio de cada fanega de sal, con el objeto de construir un puente que permitiese el tránsito no sólo de los animales sino también de los frutos que traían los hacendados de dichas jurisdicciones y los de la capital, pues algunos tenían sus haciendas en ellas $^{180}$.

Sin embargo, el puente no llegó a construirse, ya que en 1769 el cabildo de Santo Domingo había proyectado la creación de un cercado en la sabana que pertenecía a los propios de la ciudad. Éste daría más seguridad al ganado de abasto que pastaba en él, evitando que se escapara y adentrase en el bosque. Para poder fabricarlo el cabildo tomó prestado 3.800 reales de las Cajas Reales ${ }^{181}$. Más tarde manifestó que el dinero recaudado por la sisa impuesta sobre la sal también podría serles útil en la construcción del cercado, pero finalmente esta propuesta fue denegada ${ }^{182}$. En 1789 se levantó este impuesto y su producto fue utilizado en obras públicas para la ciudad ${ }^{183}$. Hacia 1791 el gobernador Joaquín García mandó abrir un terreno con el que se pretendió ampliar la sabana. El trozo del prado se extendía “desde las proximidades de la noria hasta la vereda que va a la playa de Güiba”, y estaba cubierta “con un bosque de espinas de maleza que hizo inservible e inutil aquella porcion de terreno" ${ }^{\# 4}$. Para poder utilizarlo se tuvo que limpiar, algo que ya habían hecho con anterioridad sus antecesores, Isidro Peralta y Rojas y Manuel González, al realizarse una limpieza general por toda la ciudad en navidad. En esta ocasión, el costo de la puesta apunto de ese terreno y la reparación de la antigua cerca no supuso ningún gasto para el cabildo, pues corrió a cuenta del regidor y hacendado Gregorio Saviñón ${ }^{185}$.

\footnotetext{
${ }^{180}$ Real Cédula de 22 de octubre de 1770 al gobernador de Santo Domingo ordenándole informe en los términos que se refieren, sobre la construcción de un puente de barcos en el río La Ozama de aquella isla, y en cuanto al impuesto de los dos reales en fanega de sal para ella en la forma que expresa. AGI, Santo Domingo, 1065.

${ }^{181}$ Informe sobre haberse practicado en la ciudad de Santo Domingo en la isla Española un cercado grande en la sabana para que el ganado de abasto estuviese con seguridad y sin costo de pastores, Madrid 21 de marzo de 1770. AGI, Santo Domingo, 1065.

${ }_{182}$ Carta del cabildo de Santo Domingo al rey, 29 de julio de 1769. AGI, Santo Domingo, 980.

183 Carta del cabildo de Santo Domingo al rey, 25 de enero de 1789. AGI, Santo Domingo, 994.

${ }^{184}$ Carta del gobernador, Joaquín García, al rey informando sobre las particulares quejas elevadas por el ayuntamiento, 19 de julio de 1792. AGI, Santo Domingo, 997.

${ }^{185}$ Ibidem.
} 
Ruth Torres Agudo

Figura 7-8. Plano de la Sabana, 13 de junio de 1792

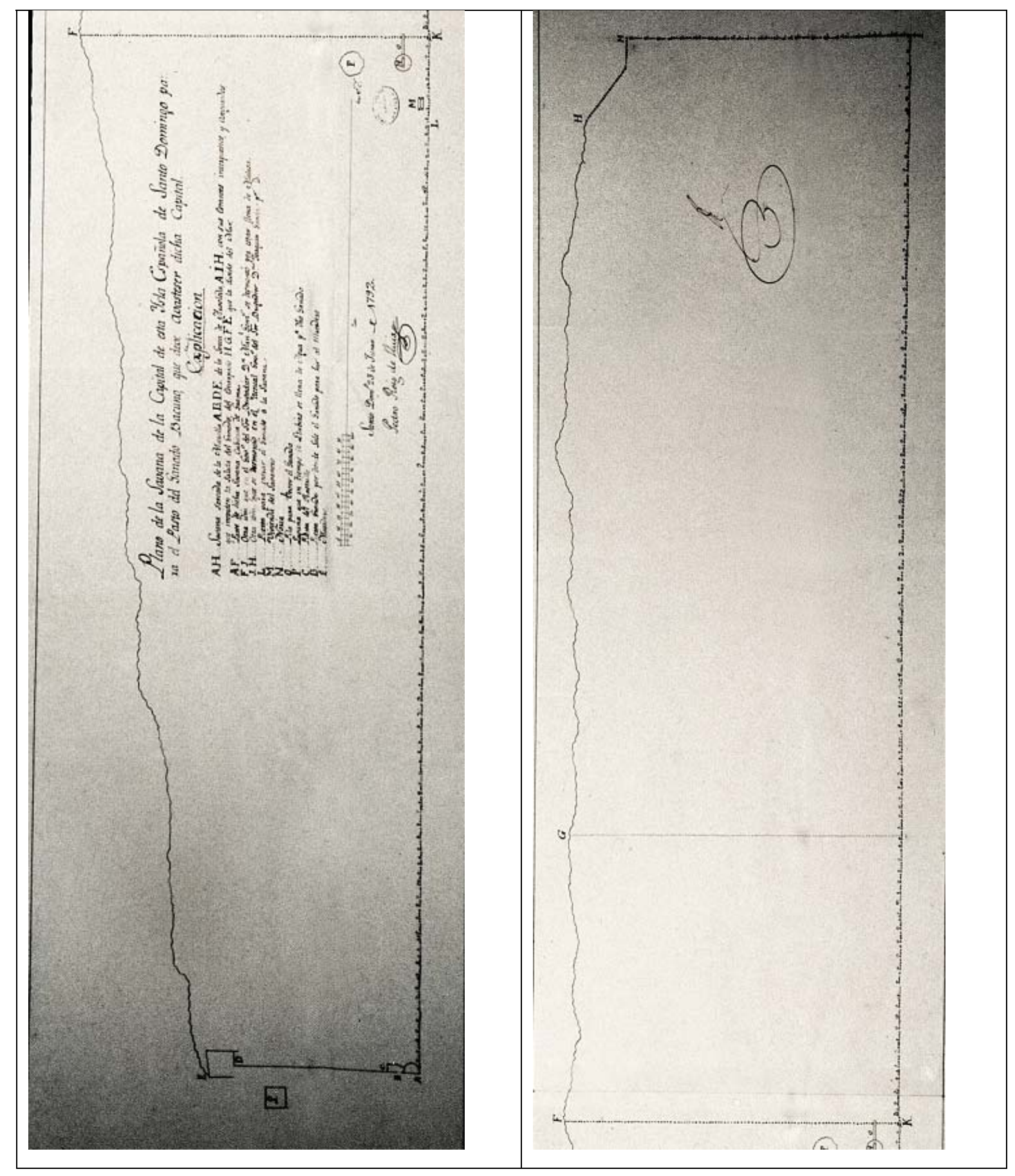


Las actividades económicas

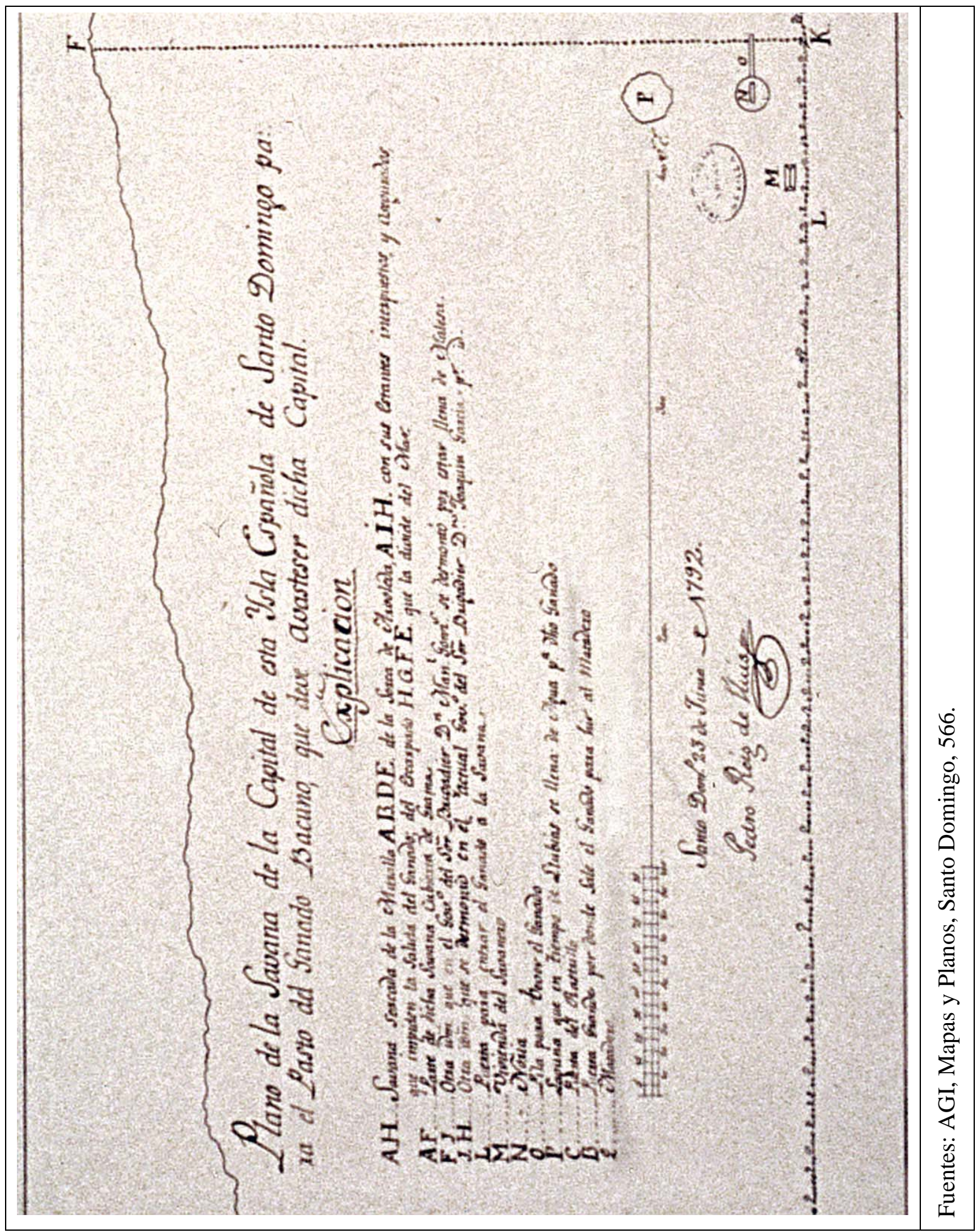


El recorrido del ganado que procedía desde la zona oriental a la ciudad de Santo Domingo era mucho más largo que los anteriores lugares en cuanto tiempo, lo que suponía gastos y la posible pérdida del ganado por enfermedad o muerte. Además en ocasiones, los animales llegaban con un peso bastante inferior con respecto al que presentaban antes de salir. Esto obligó a los propios criadores del interior a realizar contratos por "vía de arrendamiento" con aquellos que tenían hatos más cercanos a la capital (el Seibo, Higüey, Bayaguana o Monte Plata), para que éstos suministrasen las pesas que a ellos les correspondían ${ }^{186}$. A partir de las ordenanzas de 1786, quedó establecido que los que realizaban este tipo de contratos debían tener en la ciudad de Santo Domingo un apoderado, agente o personero de su confianza que lo representara y se cuidase de entregar el ganado. Se seguía exigiendo que las reses contasen con tres años de edad, pero además tendrían que pesar alrededor de diez arrobas. Aquellos sujetos a los que les correspondiera la contribución de reses y no la cumpliesen serían multados con 200 pesos $^{187}$.

Los ganaderos tenían que tributar a la entrada de la ciudad medio real por cada cabeza de ganado vacuno ${ }^{188}$, y pagar un alquiler al cabildo por el transporte de las reses del matadero a las carnicerías ${ }^{189}$. Asimismo, el precio por el que se vendían las reses en la capital era menor que si se hiciera en la parte francesa, bien fuese legal o ilícitamente. Durante la primera mitad del siglo XVIII el precio osciló entre 2 y 10 pesos, en cambio los franceses en 1744 pagaban la pareja de reses a 35 pesos en el comercio legal ${ }^{190}$. Esta cantidad, al igual que la que se pagaba en la capital se mantuvo estable para 1762, mientras que hacia 1780 en la parte francesa se llegó a pagar 16 pesos por cada res de tres años, a pesar de que los hateros de Hincha habían solicitado al gobernador que se aumentase la

\footnotetext{
186 En Gutiérrez Escudero, A., Población y economía..., op. cit., p. 150.

187 Ya con anterioridad se multaba la falta de pesas, así entre 1760 y 1764 la sanción era de 50 pesos y además debían de reintegrar con igual número que les hubiese tocado llevar a la capital. Documentación del Archivo Real de Higüey, "Ordenanzas del cabildo de Santo Domingo, 24 de enero de 1786”. BAGN 46-47 (Ciudad Trujillo, 1946) pp. 157-172, p. 167. Razón de los expedientes de gobierno sobre el abasto de carnes, 18 de diciembre de 1765. AGI, Santo Domingo, 976.

188 Carta del cabildo al rey, 17 de septiembre de 1756. AGI, Santo Domingo, 1065.

189 Gutiérrez Escudero, A., Población y economía..., op. cit., p. 155.

190 Ibidem., p. 156. Sevilla Soler, Ma . R., Santo Domingo..., op. cit., pp. 137-138, y 166.
} 
cantidad a 20 pesos $^{191}$. Aún no siendo mucha la diferencia de precios se obtenían más ganancias, ya que el transporte no les suponía ningún coste. La diferencia de precios y las dificultades mencionadas fueron motivos utilizados por los ganaderos para intentar evitar su envío de ganado a la capital. No obstante, como ha indicado Antonio Gutiérrez Escudero, el motivo fundamental estaba en el bajo precio que los criadores conseguían en la ciudad de Santo Domingo, frente a los mayores beneficios que se alcanzaban en la parte francesa, sobre todo al venderlo clandestinamente, donde además de dinero se obtenían esclavos, manufacturas y víveres. La capital consideraba que ese comercio de ganado era perjudicial para el abastecimiento de dicha ciudad ya que la escasez de ganado se debía al comercio que realizaban los hateros del norte y oeste con los franceses. Si bien hubo momentos determinados, como los huracanes o sequías, que perjudicaron tanto al ganado como a la agricultura, también es cierto que los ganaderos del interior utilizaron las inclemencias del tiempo como excusa para eludir la pesa, llegando a mentir al respecto, e incluso sobre el número de hatos que poseían realmente. Sin embargo, esto no significó que dejasen de remitir lo que tenían asignado, sólo en casos excepcionales no llegaron a completarse las pesas como sucedió en 1735, 1762, y 1765. En tal situación se tenía que recurrir a los hatos de la élite capitalina, aunque supusiese una molestia, y a los de la Iglesia, a la que no se le exigía habitualmente la contribución que se pedía al resto de las poblaciones ${ }^{192}$. Además como puede observarse a continuación, algunos hacendados que desempeñaron puestos militares y justicias rurales de los pueblos fronterizos también participaron en la exportación de ganado a la colonia francesa.

\subsubsection{El comercio con Saint Domingue}

A pesar de que la venta de ganado a la colonia francesa se llevaba realizando desde que los franceses se instalaron en la parte occidental de la isla aún estando prohibido, no fue hasta mediados del siglo XVIII cuando empezó a

\footnotetext{
${ }^{191}$ Carta del gobernador, Isidro Peralta y Rojas al rey, 30 de enero de 1783. AGI, Indiferente General, 1579.

${ }^{192}$ A principios del siglo XVIII se obligó a varios miembros del cabildo capitalino así como a los jesuitas a aportar reses de sus respectivos hatos. Gutiérrez Escudero, A., Población y economía..., op. cit., pp. 149, 151 y 154-155. Hernández González, M. V., La colonización..., op. cit., pp. 197-198.
} 
regularse. La apertura legal de este comercio se inició en 1742, cuando la Corona española estableció un trato con la francesa, comprometiéndose a suministrarle 200 reses mensuales. A raíz de este convenio, el gobernador Pedro Zorrilla de San Martín planteó a la Corona un proyecto a fin de evitar el contrabando. Se establecerían dos aduanas en la frontera, una en el norte y otra en el sur, por las cuales deberían pasar todas las reses destinadas a los franceses. El precio estipulado fue de 35 pesos por mancuerna o par de reses. Además los hateros pagarían un impuesto de dos pesos y medio por cada animal. Su plan incluyó también la elaboración de un censo vacuno, que se realizó en 1742. El Consejo de Indias contrario a dicho plan lo desaprobó. Por su parte, el gobernador lo llevó a cabo al tiempo que intentaba que fuese admitido, hasta que en 1745 se le ordenó que cesase pese a que entre 1742-1743 se habían ingresado importantes cantidades de dinero en las Cajas Reales ${ }^{193}$. Pero fue la llegada del gobernador Manuel Azlor y Urríes lo que hizo que el comercio de ganado con la colonia vecina fuese retomado nuevamente de manera legal.

Hasta entonces la prohibición no había logrado que desapareciese dicho comercio, que continuó realizándose a través del contrabando. Ante esta situación, en 1760 Manuel Azlor sugirió al Consejo de Indias su legalización, lo cual fue autorizado siempre y cuando no escasease en la parte española. A partir de 1765 aquellos hateros que extrajeran ganado a la parte francesa lo harían por una de las cuatro aduanas que se establecieron en las siguientes localidades fronterizas: Dajabón, Las Caobas, San Rafael o Neiba ${ }^{194}$. En la línea colindante con los franceses existía una compañía de caballería que cubría el norte y otra el sur, pero Manuel Azlor aumentó su resguardo estableciendo además en cada aduana una guardia que estuvo bajo el mando de un militar con el título de teniente de gobernador, que se encargó de la percepción y cobro de los derechos establecidos sobre el ganado, cantidad que para ese año era de 5 pesos por cada mancuerna, la misma que se había establecido bajo Pedro Zorrilla. El precio de venta tampoco

\footnotetext{
193 Según Rosario Sevilla se había recaudado para la banda norte la cantidad de 13.977 pesos y la del sur 7.464'5. En cambio Antonio Gutiérrez da la cantidad total de unos 9.269 pesos. Gutiérrez Escudero, A., Ibidem., pp. 162-165. Sevilla Soler, Mª R., Santo Domingo..., op. cit., pp. 150-156.

${ }^{194}$ Carta del gobernador Manuel Azlor y Urríes, informando sobre el derecho de extracción que se había establecido según Su Majestad por la Real Orden de 18 de octubre de 1761, 25 de febrero de 1769. AGI, Santo Domingo, 1059.
} 
varió, 35 pesos por pareja de res ${ }^{195}$. A su vez, para poder pasar el ganado fue imprescindible tener una licencia o pasaporte, que era concedida por el propio gobernador $^{196}$. Los oficiales militares también debían resguardar el área fronteriza y no permitir la clandestina extracción, contando para ello con la ayuda de una cuadrilla de soldados en cada lugar. De igual manera en la ciudad de Santiago y en la Santo Domingo, así como en el puerto de ésta última localidad y en el de Montecristi se establecieron cuerpos de guardia. A partir de entonces en ambos puertos existieron unos cabos que se encargaron de asistir en sus falúas los barcos y reconocer el cargamento. Por su parte, los guardas permanecían en la embarcación velando hasta que se verificase la descarga. Unos y otros debían recorrer la costa y caletas evitando el contrabando. Se creó también una compañía militar que tuvo carácter volante al emplearse en rondar continuamente la frontera y costa del departamento norte, para impedir las introducciones de ganado de toda especie a la colonia francesa, arrestando a los introductores y a los negros, mulatos y fugitivos. Frente a ella estuvo el hacendado y comandante de armas de Santiago, Francisco Antonio Velilla y Torres con el título de juez subdelegado de comisos, confiriéndole además "las facultades de alcalde provincial como las tenia Jose Campuzano” quien desempeñaba dicho cargo en el cabildo de la ciudad Santo Domingo ${ }^{197}$. Mientras que la zona fronteriza estuvo bajo el mando del teniente de justicia mayor Fernando Manuel de Espinosa y Miranda, sustituido después por el hacendado Felipe Guridi y Concha.

\footnotetext{
${ }^{195}$ Hacia 1769 la aduana del norte estuvo bajo el mando del comandante y capitán de caballería Gaspar Leos-Echalas, el cual fue sustituido por Domingo Sierra y al morir éste ocupó el puesto el alférez Francisco Zervero. La responsabilidad de la banda sur recayó en Fernadno Manuel de Espinosa, encargado a su vez de la administración de San Rafael, y el teniente de caballería José Pepín de la de Neiba. Éstos militares también se encargaban de la guardia de los pueblos de Hincha, y Banica, cercanos a la frontera. Informe del contador José Antonio Gelabert, Santo Domingo 27 de febrero de 1769. AGI, Santo Domingo, 1059.

${ }^{196}$ Informe del derecho de extracción que se había establecido según Su Majestad por la Real Orden de 18 de octubre de 1761. AGI, Santo Domingo, 1059.

${ }^{197}$ Extracto del gobernador de Santo Domingo sobre lo conveniente que sera a la isla la formación de una Compañía para resguardo de ella, 4 de junio de 1768. AGI, Santo Domingo, 979.
} 
Tabla 7-13. Resguardo de la isla planificado por el gobernador Manuel Azlor y Urríes

\begin{tabular}{|c|c|c|}
\hline Lugar & Número de plazas & Sueldo mensual \\
\hline \multirow{2}{*}{ Santo Domingo } & 1 cabo & 18 \\
\hline & 9 guardas & 135 \\
\hline \multirow{2}{*}{ Puerto de Santo Domingo } & 1 cabo para la falúa & 18 \\
\hline & 9 guardas & 135 \\
\hline \multirow{2}{*}{ Puerto de Montecristi } & 1 cabo para la falúa & 18 \\
\hline & 4 guardas & 60 \\
\hline \multirow{2}{*}{$\begin{array}{l}\text { Zona Fronteriza (Dajabón, San } \\
\text { Rafael, Las Caobas, Neiba) } \\
\end{array}$} & 4 cabos & 72 \\
\hline & 16 guardas & 240 \\
\hline \multirow{2}{*}{ Compañía volante en la frontera } & 1 cabo volante & 30 \\
\hline & 2 guardas volantes & 30 \\
\hline \multirow{2}{*}{ Santiago } & 1 cabo & 18 \\
\hline & 2 guardas & 30 \\
\hline Total & 51 Plazas & 804 \\
\hline
\end{tabular}

Elaboración propia. Fuentes: Los cabos cobraban 18 pesos cada uno mientras que los guardas 15. En Sevilla Soler, Mª. R., Santo Domingo.., op. cit., p. 216.

A lo largo del gobierno de Manuel Azlor se realizaron varios convenios con los franceses, acordándose que se les abastecería de ganados. El primero de ellos se determinó el 21 de julio de 1762 y se debió a la firma del pacto de familia entre España y Francia. Conforme a él quedaba estipulado no sólo cuidarse y asistirse mutuamente en caso de un ataque inglés, sino que en situación de escasez de carne en la colonia francesa, los españoles les proporcionarían unas 800 reses al mes o todas aquellas que fuesen necesarias. Al finalizar la guerra, los franceses consideraron que al no haberse efectuado la entrega del ganado se podría aumentar su cantidad a 1.000 e incluso enviarles ese mismo número de caballos. A pesar de que tras la paz el acuerdo quedaba suspendido, el gobernador no concedió el paso de 1.000 reses sino de las que habían sido acordadas en un principio. En lo que respecta a los caballos, Manuel Azlor no consideró oportuno proporcionarles tal número, ya que éstos eran imprescindibles en la parte española como medio de transporte y en las tareas de labranza ${ }^{198}$.

El segundo convenio tuvo lugar a raíz de la solicitud que los franceses hicieron en 1763 a la Corona española para que no cesase el paso de ganado a su colonia. El permiso fue concedido a través de una Real Orden el 5 de octubre de 1763, por la que además se comunicaba al gobernador de Santo Domingo que se

\footnotetext{
198 Sevilla Soler, Ma. R., Santo Domingo..., op. cit., pp. 158-160. Moreau de Saint-Méry, M. L. E., Descripción de la parte española de Santo Domingo..., op. cit., pp. 374-376.
} 
debía firmar un nuevo acuerdo, para lo cual se nombró como representante al hacendado y tesorero de las Cajas Reales Francisco Pepín González; aunque no se firmó hasta 1766. Las reglas que se establecieron fueron las mismas que las del tratado de 1762, con la diferencia de que en esta ocasión se permitía a los carniceros o representantes franceses acercarse a los hatos españoles a comprar el ganado. Junto a ello, según el artículo quinto, el impuesto que debían pagar por mancuerna fue rebajado a 3 pesos frente a los 5 anteriores, o un peso y medio en vez de los dos pesos y medio por cada cabeza de ganado ${ }^{199}$.

El tercer tratado fue firmado en 1770 con el objeto de establecer unos límites fronterizos fijos entre ambas colonias. De los ocho capítulos que presentaba, el tercero y el sexto hacían referencia al comercio de ganado y al de caballos. En ellos se establecía que el tráfico continuaría como hasta entonces, con la novedad de que se permitiría que uno o varios hombres en representación de los franceses fuesen a la parte española a comprar 300 caballos para su Ejército. Los hacendados españoles que los vendiesen deberían hacerlo de igual forma que con el ganado, con una licencia, y a cambio podrían recibir dinero o víveres ${ }^{200}$.

Paralela a este comercio legal, la introducción clandestina de ganado a la colonia francesa continuó realizándose, como describe el propio Manuel Azlor en 1769:

“[...] por caminos y veredas extraviados, siguiendose de ellos gravisimos daños: el primero en defraudar la real hacienda de los derechos que deben exigir por los ganados que se introduzcan segun lo estipulado. Lo segundo que los ganados asi se introducen por ladrones, los cuales se alientan para ejecutar su maldad por el asilo que encuentran en las colonia y a su causa de la facilidad con que vender a menos precios las reses asi por eximirse de pagar los derechos que no les cuesta más que hurtarlas, y lo tercero que con una extraccion, tan exorbitante y desordenada, respecto a que la saca de ganados es por dos partes, la una clandestina, como llevo dicho y la otra con licencias segun lo estipulado, llegaria muy en breve la destruccion total de los hatos y por consiguiente a mendigar su sustento" ${ }^{201}$.

\footnotetext{
${ }^{199}$ Sevilla Soler, Mª R., Ibidem., pp. 357. Moreau de Saint-Méry, M. L. E., Ibidem., p. 379.

${ }^{200}$ Sevilla Soler, Ma . R., Ibidem., pp. 164 y 358-360.

${ }^{201}$ Carta del gobernador, Manuel Azlor y Urríes al rey en la que da cuenta con testimonio de los motivos porque se ha visto precisado a estrechar las órdenes a los comandantes de frontera
} 
Para hacer frente a este comercio ilegal Manuel Azlor y Urríes tomó varias medidas. En primer lugar, el gobernador junto a los ministros de la Audiencia elaboraron unas instrucciones dirigidas a los cabildos que recogían cómo debía realizarse el paso a la parte francesa. De los once puntos destaca el primero, en el que se reitera que las licencias para su extracción sólo podían ser dadas por el gobernador, "sin que los capitanes, subalternos de la frontera ni ninguna persona pueda dar”202. En caso contrario sería confiscado el ganado. El tercero y el cuarto establecían que los cabildos debían formar anualmente un estado de todos los hatos de su jurisdicción, expresando quiénes eran los dueños, las calidades del ganado, la obligación del abasto a la capital y las licencias que hubiesen sido despachadas. Todo esto tenía que quedar anotado en un libro becerro que se guardaría en sus archivos ${ }^{203}$.

En segundo lugar, los militares ya no se encargarían de recaudar la tasa en las aduanas, sino que lo harían los oficiales reales. Este cambio fue consecuencia del descubierto que encontró el contador del tribunal de cuentas de Barlovento, José Antonio Gelabert, en la revisión de las cuentas reales que realizó desde 1 de enero de 1765 hasta 31 de diciembre de 1768. En ellas quedaba reflejado que el derecho de ganado produjo la cantidad de 10.030 pesos, cuando según su cálculo, deducido de las noticias que había obtenido en la zona fronteriza sobre el tráfico de ganado, debió haber rendido 47.550 pesos $^{204}$. A partir de 1769 la administración del referido derecho pasó a manos del ramo de la Real Hacienda, por lo que se elegiría para cada una de las poblaciones fronterizas una persona “de

para que celen el grave desorden que se experimenta en la introducción clandestina de ganado a la colonia francesa, 30 de junio de 1769. AGI, Santo Domingo, 1059. La cursiva es nuestra.

${ }^{202}$ Instrucción que con arreglo del dictamen de la Real Audiencia de 8 de noviembre del año pasado y de lo que en su consecuencia deberá obrar las justicias para la extracción de ganado a la colonia francesa bajo las penas que se expresan y se impondrán a los contraventores por considerarse su precisa observancia de la mayor utilidad al servicio del rey, causa pública, beneficio de la isla y fomento de su crianza, 25 de marzo de 1769. AGI, Santo Domingo, 930.

${ }^{203}$ Ibidem. No sabemos si finalmente los cabildos elaboraron el libro becerro o se han perdido como ya ha apuntado Antonio Gutiérrez Escudero en su trabajo Población y economía..., op. cit., p. 137. Moreta Castillo, A., "El Santo Domingo del siglo XVIII a través del Libro Becerro". CLÍO 174 (Santo Domingo, 2007) pp. 43-66. Hasta el momento este artículo es la única publicación de referencia. El autor ha utilizado el Libro Becerro de 1778 en el que se insertan noticias de los propios de la ciudad de Santo Domingo para ese año, así como noticias del siglo XIX. Sin embargo, no hay referencias para la ganadería. Este documento pertenece al historiador dominicano Raymundo González.

${ }^{204}$ Sevilla Soler, Mª ${ }^{\mathrm{a}}$ R., Santo Domingo..., op. cit., p. 163. 
toda fidelidad y abono”, asignándole como sueldo el $10 \%$ del producto ${ }^{205}$. Para el puesto de San Rafael se nombró a Vicente Valera, Fernando Bello para Las Caobas, José Álvarez en Neiba y Manuel Aponte en Dajabón ${ }^{206}$. Los nuevos administradores también recibieron unas instrucciones por las que debían regirse para el cobro del derecho de ganado y su saca a la parte francesa. Cabe destacar aquellas que referían que estos debían llevar relación de las reses, su dueño, número, edad, calidad y presentación de la licencia o guía ${ }^{207}$. En el período comprendido entre 1765 y el 31 de junio de 1775 se recaudaron en la Real Hacienda 341.603 reales $^{208}$. En cuanto a cifras concretas, se ha calculado que en 1779 desde la aduana de San Rafael se exportó a la colonia francesa 3.855 reses, que dejaron 46.250 reales; mientras que para 1782 se registraron 4.937 vacas con un beneficio de 59.687 reales $^{209}$.

Durante el gobierno de José Solano y Bote hubo algunos cambios significativos en el comercio con los franceses al permitirse la venta de mulos y caballos. A partir de 1777 también se amplió a los vecinos de la frontera y costa de Montecristi la posibilidad de vender otros productos como cerdos, cabras, ovejas, aves, caza, pesca y madera, y al resto de la población frutos de cualquier parte de la isla sin que pudieran ser cacao, café, azúcar, tabaco y añil. Al igual que en el caso del ganado deberían llevar su correspondiente licencia, y pasar por los “puertos secos” de Dajabón, San Rafael, Las Caobas o Neiba, y sólo por el único puerto marítimo de Montecristi ${ }^{210}$. Los pueblos de Puerto Plata, Samaná y Sabana de la Mar podrían transportar por mar los frutos y ganados hasta el mencionado

\footnotetext{
205 Informe del contador José Antonio Gelabert, La Habana 11 de septiembre de 1769. AGI, Santo Domingo, 1059.

${ }^{206}$ Carta del gobernador y oficiales de la Real Hacienda dando cuenta a Su Majestad de la junta celebrada para nombrar cuatro oficiales reales para el cobro del real derecho de saca de ganado a la colonia francesa, 16 de octubre de 1769. AGI, Santo Domingo, 1059.

${ }^{207}$ Instrucciones formadas por la real contaduría para la saca de ganado a la colonia francesa, y cobro de sus derechos por los administradores, 16 de agosto de 1769. AGI, Santo Domingo, 1059.

${ }^{208}$ En Sevilla Soler, Ma . R., Santo Domingo..., op. cit., p. 263.

${ }^{209}$ Hernández González, M. V., La colonización..., op. cit., pp. 187-194, y 300. Manuel Hernández, muestra la importancia del comercio fronterizo a través de algunos libros de la administración de San Rafael, Las Caobas, y Dajabón conservados en el Archivo Histórico Nacional, que contienen datos aislados, y de los que no constan relaciones seriadas.

${ }^{210}$ Carta del gobernador a Su Majestad en la que expone que convendría se les permitiese a los pueblos fronterizos vender a los franceses vecinos su caza, pesca, víveres y las maderas, 20 de septiembre de 1776. Y Real Cédula permitiendo a varios pueblos fronterizos de La Española puedan llevar a vender su caza, pesca, víveres, carne fresca y maderas a los franceses vecinos, El Pardo 8 de enero de 1777. AGI, Santo Domingo, 1059.
} 
puerto. Otra novedad fue el hecho de que los colonos españoles pudiesen cobrar lo vendido no sólo en dinero sino también en esclavos, tan necesarios en la parte española de la isla. Además se logró que la Corona concediese a los habitantes de Santo Domingo una rebaja de un $20 \%$ sobre su valor en el derecho de marca ${ }^{211}$. Un año antes el permiso para extraer frutos y maderas a los franceses había sido concedido a Cumaná, Guayra y Luisiana, con la diferencia de que lo harían con las islas francesas de Barlovento y el pago se les realizaría sólo en dinero o letras de cambio. En los puertos de las citadas ciudades residían dos comisionados franceses que se encargaban de la compra de aquello que necesitaban, y de igual modo se haría en Santo Domingo ${ }^{212}$. Con la ampliación de este comercio propuesto por José Solano y Bote pretendía “exterminar el medio ilicito”, y que la colonia francesa también se hiciese "dependiente de nosotros en esto, como la tenemos en carnes para su abasto" 213 .

También habría que señalar que este gobernador utilizó la dependencia que tenían los franceses del ganado español, para contrarrestar su política de sobrepasar los límites fronterizos que realizaban estableciendo bohíos o cultivando terrenos, mediante la suspensión de ganado. En consecuencia, los franceses abandonaban el territorio ocupado, así utilizó este método en varias ocasiones con dicha finalidad. Sin embargo, no fue hasta la firma del tratado de Aranjuez en 1777, cuando se estableció oficialmente la frontera entre ambas colonias. Paralelo a él se signó un acuerdo policía por el que se comprometían mutua ayuda a la hora de capturar delincuentes, y devolución de los esclavos que se escapasen de cada parte ${ }^{214}$.

La política seguida por Isidro Peralta y Rojas fue bastante más rígida que la de sus antecesores. Se ignora la cantidad de licencias y reses que llegaron a pasar a la parte francesa, pero por las quejas de algunos hateros se deduce que los

\footnotetext{
${ }^{211}$ Real Orden permitiendo el pago del comercio con los franceses además de dinero y letras de cambio en negros, pagando el derecho de marca a la introducción moderado a un 20\%, El Pardo 9 de enero de 1777. AGI, Santo Domingo, 1059.

${ }^{212}$ Real Orden a los gobernadores y oficiales reales de Cumaná, Guayra y Luisiana permitiendo la extracción de frutos y maderas que expresan a los franceses de aquellas colonias, San Ildefonso 24 de julio de 1776; Instrucción reservada que deben observar exactamente los respectivos gobernadores, y oficiales reales de las Provincias de Venezuela, Cumaná, Guayra y Luisiana, Madrid 8 de julio de 1776. AGI, Santo Domingo, 1059.

${ }^{213}$ Carta del gobernador José Solano y Bote al rey, 20 de septiembre de 1776. AGI, Santo Domingo, 1059.

${ }^{214}$ Gutiérrez Escudero, A., Población y economía..., op. cit., p. 166.
} 
permisos fueron reducidos ${ }^{215}$. Entre las licencias que fueron concedidas a los vecinos de la ciudad de Santiago para vender al comisionado francés en 1780, destacan las 200 reses de ganado del hacendado Francisco Espaillat y las 700 de Francisco Antonio Velilla ${ }^{216}$. Entre 1777 y 1790 Espaillat había exportado a través de la aduana de Dajabón un total de 2.398 reses, mientras que su suegro Velilla $485^{217}$. El sistema de defensa establecido por Manuel Azlor continúo, pero al morir en 1783 el teniente de justicia mayor del departamento sur Felipe Guridi se nombró a José Esteban Arredondo y Castro. Ambos también participaron en tal lucrativo negocio, el primero con 1.748 vacas entre $1773 \mathrm{y}$ 1779, y el segundo por cuenta de su hermano Francisco Arredondo con $123^{218}$.

Si hasta el momento la compra de ganado se había realizado a través de dos comisionados franceses, a partir del mandato del siguiente gobernador, Manuel González, el sistema cambió. Desde 1786 el método empleado sería el de las ferias públicas. Las autoridades de Santo Domingo establecerían el número de reses de que podía disponer cada ganadero. Se podría presentar cualquiera, y el pago se seguiría realizando en dinero, esclavos, herramientas y utensilios para la agricultura. Los militares de las administraciones estarían presentes para evitar cualquier irregularidad $^{219}$. En ese mismo año el gobernador, ante el continuo tráfico ilegal en la frontera, reformó el resguardo modificando algunos puntos del que había adoptado y dispuesto Manuel Azlor. Se formaron dos compañías volantes, una en el norte y otra en sur, compuesta cada una de ellas por un cabo y dieciséis guardas que debían ayudar a los dos subdelegados del área norte y sur como cabeza del resguardo. La del norte continuó estando bajo el mando de una persona en calidad de juez subdelegado de comiso, con la diferencia de que tanto la guardia de la capital como la de Montecristi estuvieron “a las inmediatas

\footnotetext{
215 Sevilla Soler, Mª. R., Santo Domingo..., op. cit., pp. 168-169.

216 Certificación del secretario de cámara de real hacienda y chancillería, José Castro Palomino de las licencias que concedió el 11 de enero de 1780 el superior gobierno a los vecinos de la ciudad de Santiago de los Caballeros al comisionado francés de la parte norte, 16 de enero de 1783. AGI, Indiferente General, 1579.

217 Hernández González, M. V., Expansión fundacional..., op. cit., pp. 54-57.

218 Hernández González, M. V., La colonización..., op. cit., pp. 254, 262, y 302.

219 Este nuevo plan se encuentra en la undécima cláusula de las gracias concedidas a Santo Domingo en 1786. Real Cédula de Su Majestad, a consulta de su supremo Consejo de Indias, Por la cual se conceden varias gracias, y prerrogativas en beneficio de todos los vecinos de la Isla Española de Santo Domingo, para el fomento de su Agricultura, Industria, y Comercio, Madrid 12 de abril de 1786. AGI, Santo Domingo, 1012.
} 
ordenes” del teniente de infantería Miguel Negrete, nombrado para este puesto ${ }^{220}$. Según el gobernador Manuel González el motivo de su establecimiento fue "evitar las conexiones que produce la larga residencia de los guardas en las poblaciones de la isla [...]”, para lo que cada ronda se mantendría “[...] errante sin detenerse en los lugares poblados mas tiempo que su preciso descanso y el de proveerse de viveres para su marcha que se hara con regulacion a la distancia de uno a otro pueblo"221. En la zona sur el control siguió estando en manos del teniente de justicia mayor José Esteban Arredondo y Castro. Asimismo, los guardas del puerto de la capital y de Montecristi subsistieron, sufriendo sólo una ligera variación en cuanto al número de plazas y sueldo ${ }^{222}$.

Sin embargo, parece que estos cambios tampoco debieron tener buenos resultados a la hora de contrarrestar el contrabando que producía según el gobernador Joaquín García Moreno “el perjuicio y la rebaja de los reales derechos de la frontera $[\ldots]]^{223}$. Ante tal situación este gobernador, el último del siglo XVIII, propuso otra serie de cambios. Si bien los comandantes de los cuatro puestos administrativos de la frontera y Montecristi tenían la facultad de decomisar, desde 1790 también podrían hacerlo los recaudadores así como los comandantes, o en su defecto los tenientes de todos los pueblos de la isla. La excepción fueron Hincha y Banica, para las que comisionó temporalmente al cabo José Antonio de Rosas, y el área de Bayaguana, Puerto Plata, Boyá, Los Llanos y costa de ellos a Manuel Santana. El término de Santiago estaría cubierto por el alcalde mayor, Julián Joaquín Pueyo y Urríes, y el comandante Luís Pérez Guerra y Trespalacios, con el título de juez subdelegado de comiso de dicha ciudad y del área norte. Igualmente estarían bajo subdelegados diversos territorios: el teniente Vicente Díaz o en su defecto Ignacio Batista en la villa de Azua, para Higüey Rafael González Fernández, en el valle de Baní, la villa de San Carlos y la del Seibo, y en los puertos de Samaná, Sabana de la mar y Puerto Plata sus

\footnotetext{
${ }^{220}$ Con anterioridad el mando del departamento estuvo desempeñado por Francisco Antonio Velilla y Torres, y su yerno Francisco Espaillat. Instrucción que deberá observar el juez de comisos subdelegado de esta superintendencia para el resguardo de las partes sur y norte de esta isla, 1 de agosto de 1786. AGI, Santo Domingo, 1045.

${ }^{221}$ Ibidem.

${ }^{222}$ Carta del gobernador Joaquín García informando a Su Majestad de los defectos del manejo del resguardo ha meditado con prolixo examen de todos los anteriores, 25 de marzo de 1790. AGI, Santo Domingo, 953.

${ }^{223}$ Ibidem.
} 
respectivos comandantes. Se suprimieron todos los demás subdelegados que hasta entonces habían existido, quedando así el celo y resguardo bajo estos subdelegados locales. El teniente de justicia mayor fue apartado del área fronteriza, y su jurisdicción abarcaría los pueblos interiores ${ }^{224}$.

Buscando su buen funcionamiento Joaquín García elaboró unas normas para éste y aquellos que actuasen como subdelegados de comisos, en las que se les especificaba cómo debían actuar contra el contrabando y los comisos. A modo de ejemplo, los comandantes y los administradores de frontera debían prestarse ayuda sin que hubiese disputas entre ellos a la hora de realizar una denuncia. En el caso de que el que realizase el comiso fuese personalmente uno de los subdelegados, se le adjudicaría la cuarta parte, pero si hubiese sido por los cabos "haciendo sus rondas en virtud de la orden de su jefe” les corresponderían tres cuartas partes de la cuarta, quedando el resto a beneficio del subdelegado ${ }^{225}$. En cambio, todo aquello que aprendiese la tropa en los puestos fronterizos o haciendo rondas se repartiría: una parte al comandante y las tres para la tropa que hubiese hecho el decomiso. Por el contrario, si lo hiciesen bajo una orden serían “[...] las tres quartas partes a favor del comandante comisionado de quien dimano la diligencia, y una para la tropa”226. Aunque las reglas que estableció para los administradores y los cabildos, a fin de frenar los abusos en la extracción de ganados y frutos permitidos, no se diferenciaban mucho de las de sus antecesores $^{227}$.

\footnotetext{
${ }^{224}$ De las introducciones licitas de la Parte francesa a la nuestra y del modo de proceder en los comisos, y contrabando, 25 de octubre de 1790. AGI, Santo Domingo, 953.

${ }^{225}$ Ibidem.

${ }^{226}$ Ibidem.

${ }^{227}$ Instrucciones de extracción de ganados, 25 de octubre de 1790. AGI, Santo Domingo, 953.
} 
Tabla 7-14. Relación de resguardos realizados por los gobernadores Manuel González y Joaquín García

\begin{tabular}{|c|c|c|c|c|}
\hline \multirow[b]{2}{*}{ Lugares } & \multicolumn{2}{|c|}{ Manuel González } & \multicolumn{2}{|c|}{ Joaquín García } \\
\hline & $\begin{array}{l}\text { Número de } \\
\text { plazas }\end{array}$ & $\begin{array}{c}\text { Sueldo } \\
\text { mensual }\end{array}$ & $\begin{array}{l}\text { Número de } \\
\text { plazas }\end{array}$ & $\begin{array}{c}\text { Sueldo } \\
\text { mensual }\end{array}$ \\
\hline \multirow{3}{*}{$\begin{array}{l}\text { Compañía volante en la } \\
\text { banda norte }\end{array}$} & $\begin{array}{l}1 \text { juez de } \\
\text { comisos }\end{array}$ & 50 & & \\
\hline & 1 cabo & 30 & & \\
\hline & 16 guardas & 256 & & \\
\hline \multirow{2}{*}{$\begin{array}{l}\begin{array}{l}\text { Compañía volante en la } \\
\text { banda sur }\end{array} \\
\end{array}$} & 1 cabo & 30 & 1 cabo & 30 \\
\hline & 16 guardas & 256 & 3 guardas & 48 \\
\hline \multirow[b]{2}{*}{ Santo Domingo } & & & 1 cabo & 30 \\
\hline & & & \begin{tabular}{|l} 
g guardas \\
para las \\
puertas
\end{tabular} & 128 \\
\hline \multirow[t]{2}{*}{ Puerto de Santo Domingo } & $\begin{array}{l}1 \text { cabo para } \\
\text { la falúa }\end{array}$ & 18 & $\begin{array}{l}1 \text { cabo para la } \\
\text { falúa }\end{array}$ & 18 \\
\hline & 6 guardas & 90 & 6 guardas & 96 \\
\hline \multirow[t]{2}{*}{ Puerto de Montecristi } & $\begin{array}{l}1 \text { cabo para } \\
\text { la falúa }\end{array}$ & 18 & \begin{tabular}{|l}
1 cabo para la \\
falúa
\end{tabular} & 18 \\
\hline & 4 guardas & 60 & 5 guardas & 80 \\
\hline Santiago & & & 4 guardas & 64 \\
\hline $\begin{array}{l}\text { Zona Fronteriza } \\
\text { (Dajabón, San Rafael, Las } \\
\text { Caobas, Neiba) }\end{array}$ & & & 18 guardas & 288 \\
\hline Total & 47 plazas & 808 & 48 plazas & 800 \\
\hline
\end{tabular}

Elaboración propia. Fuentes: Cada guarda cobraba 16 pesos, pero bajo el gobierno de Manuel González los del puerto de Santo Domingo y Montecristi recibían 15 pesos. En Sevilla Soler, Ma R., Santo Domingo..., op. cit., p. 217-218. 


\subsection{El comercio: la situación comercial}

“[...] esta Ysla sufre un comercio solamente pacivo, y que sus caudales, y los que vienen para el situado pasan a los extranjeros, y porque no viniendo de España viveres, ni efectos necesarios al sustento de estos habitantes, es preciso que los soliciten de aquellos o ya por medio de algunas licencias que por la necesidad se conceden o ya por medio de la introduccion clandestina, difícil de evitar totalmente por lo abierto de las costas” ${ }^{228}$.

Las reformas que se producen durante el siglo XVIII en toda América ayudaron a reactivar el comercio de la zona. Estas tendieron a dar una mayor libertad económica, aunque siempre bajo la activa intervención de la Corona. Los primeros cambios que se experimentaron a comienzos del siglo XVIII se iniciaron con el proyecto de galeones de 1720, que prohibía el uso de barcos extranjeros en el comercio y la posibilidad de utilizar navíos de registro. También se modificaron las medidas fiscales volviendo al impuesto de palmeo, de manera que las mercancías eran gravadas con un tanto por ciento sobre su valor. A partir de 1735 desapareció el sistema de flotas, el cual fue relevado por los navíos de registro. El objetivo de estos cambios era reactivar el comercio español y americano para hacer frente al inglés. Pero el mantenimiento del sistema monopolista y de puerto único no ayudó a tal reactivación, a pesar de que en Santo Domingo se llegó a eximir de algunos derechos como el de avería, armada y almojarifazgo a las naves procedentes de este puerto, y a exentar del abono del tonelaje a quienes viajasen de registro a dicho puerto ${ }^{229}$. Esta práctica de eximir el pago de esas tasas no era nueva, pues durante los siglos XVI y XVII la isla había disfrutado de esta gracia en muchas ocasiones para el caso del almojarifazgo e incluso el de la alcabala; también con el objetivo de estimular la llegada de embarcaciones al puerto de Santo Domingo.

El almojarifazgo era un impuesto que se pagaba por aquel género que entraba y salía de Santo Domingo. Durante la segunda mitad del siglo XVIII se

\footnotetext{
${ }^{228}$ Estado de los medios para el fomento de la isla realizado por el oidor decano de la Audiencia de Santo Domingo Pedro Catani, 15 de noviembre de 1788. AGI, Santo Domingo, 1012. La cursiva es nuestra.

${ }^{229}$ Gutiérrez Escudero, A., Población y economía..., op. cit., p. 199.
} 
cobraba un $5 \%$ sobre los productos importados de las colonias españolas, un $10 \%$ a los de Europa y colonias extranjeras, un 20\% sobre la harina, y 22,5 reales por cada pipa de vino. Desde 1769, año en el que empieza a funcionar el decreto de 1765 sobre el Libre Comercio entre la Península y las islas de Barlovento, el impuesto sobre lo importado fue de un 15 o un 20\%, y en concreto un $5 \%$ a lo que procedía de la Península o de las Antillas. En cuanto a la tasa cobrada sobre las exportaciones, fue de 2,5\% entre 1750 y 1769. Posteriormente se continuó cobrando igual, aunque sólo a aquellas mercancías que partían hacia las colonias extranjeras. Además se pagaba la alcabala de viento, que gravaba los artículos desembarcados en Santo Domingo con un 2\% de su valor total y un $4 \%$ la harina hasta 1769. A partir de ese momento, se estipuló un 4\% sobre lo extranjero y un 2\% sobre lo español, con excepción de aquella mercancía que procedía de la Península, Puerto Rico, Cuba y Margarita que estaba exenta. Desde finales de ese mismo año quedaron libres no sólo de la alcabala sino también del almojarifazgo y el derecho de armada, al ser sustituidos por un arancel conjunto que consistía en el cobro de un $6 \%$ sobre géneros peninsulares y un $7 \%$ sobre los extranjeros ${ }^{230}$. Ya en tiempos de guerra como en 1762 y 1763, se permitió la rebaja en Santo Domingo de cobrar la mitad de los derechos de alcabala, almojarifazgo y armada a aquellas embarcaciones que fuesen a las colonias extranjeras o neutrales a por víveres y municiones ${ }^{231}$.

La alcabala de tierra fue otro impuesto que se cobraba en las transacciones comerciales de casas, esclavos, tierras, joyas, productos agrícolas y el ganado que estaba destinado al abasto público. Una mitad era pagada por el vendedor y la otra por el comprador, salvo que ambas partes establecieran un pacto de permuta. En un principio, la alcabala no se aplicó a fin de dar facilidades a los pobladores de la isla mientras se organizaban, hasta que a partir de 1592 se estableció un 2\% como había instruido la Real Cédula de 1 de noviembre de 1591. Poco después de su implantación se trató de que la relevación temporal que hasta entonces había gozado continuase de manera perpetua o se rebajase. En 1595 se consigue la exoneración por cinco años a los vecinos de la isla, una práctica que se convirtió

\footnotetext{
${ }^{230}$ Sevilla Soler, Ma . R., Santo Domingo..., op. cit., pp. 246-253.

${ }^{231}$ Informe de José Antonio Gelabert, 20 de febrero de 1769. AGI, Santo Domingo, 980.
} 
en habitual durante casi toda la época colonial ${ }^{232}$. De esta forma los vecinos de la ciudad de Santo Domingo estuvieron libres de ese arancel durante gran parte del siglo XVIII “[...] en atencion a su misero estado, fidelidad en las frecuentes invasiones de Enemigos y prestamos al Erario para manutención del Presidio, y en postergaciones de Situados [...]”233.

También los reclamos de los hacendados desde el cabildo ante los destrozos de las haciendas, y pérdida de sus frutos y ganados como consecuencia de un terremoto, huracán o sequía, les sirvió para conseguir la dispensa, que dejó de prorrogarse a principios de 1762, aunque a finales del mismo se les eximió durante diez años más. Cumplido en 1772, nuevamente volvió a ser ampliado por cinco años más. En 1776, un año antes de su cumplimiento, el cabildo volvió a realizar una petición para que continuase la relevación, pero no obtuvo los resultados deseados, pues a partir de un año más tarde se instauró su cobro a razón de $1 \%$ durante cinco años, mitad del $2 \%$ que prescribía la ley catorce, título trece, libro ocho de la Recopilación de Indias. En 1778 el gobernador José Solano y Bote lo hizo público en un bando, y junto a él las instrucciones y un reglamento por el que se regía el tribunal de cuentas de La Habana para su recaudación y cobro, así como las demás cajas de las islas de Barlovento y Luisiana, y por el que a partir de entonces lo haría Santo Domingo ${ }^{234}$.

De este modo quedó establecido que el cobro del derecho de alcabala en la ciudad de Santo Domingo lo haría un oficial real con un sueldo anual de 360 pesos, mientras que en el resto de las poblaciones estaría en manos de los receptores, que eran nombrados por los oficiales reales, de quienes eran “sobstituos para la recaudacion del derecho de Alcavala”235. Como salario tuvieron el 6\% del total de lo recaudado. Las personas que se encargaban del cobro del derecho de ganado en las aduanas del área fronteriza también fueron propuestas para el cobro de este impuesto. Para el resto de las poblaciones se

\footnotetext{
${ }^{232}$ Rodríguez Demorizi, E., “Apuntes y documentos. El Real derecho de alcabala. Libro de cargo y data de 1793”. CLÍO 108 (Ciudad Trujillo, 1956) pp. 165-185, particularmente las páginas 165-169.

${ }^{233}$ Expediente sobre la instancia de la ciudad de Santo Domingo para la prorrogación de no pagar el derecho de alcabala, 1777-1779. AGI, Santo Domingo, 985.

${ }^{234}$ Ibidem., y Documentación del Archivo Real de Bayaguana, "Reduccion a la mitad del derecho de alcabala por cinco años en el comercio interior de la Isla Española, 1778”. BAGN (Ciudad Trujillo, 1946) pp. 173-190.

${ }^{235}$ Ibidem., p. 182.
} 
prefirió a destacados jefes militares de cada localidad, entre los que sobresale el hacendado con el título de capitán de milicias de caballería Francisco Antonio Velilla y Torres para la ciudad de Santiago ${ }^{236}$. Así, la recaudación de la alcabala estuvo al cargo de estos administradores y los oficiales de la Real Hacienda, a diferencia de otros lugares como México y Guatemala donde la Corona los arrendó a un particular o una institución como el cabildo y el consulado ${ }^{237}$. Pese que a partir de 1778 se había establecido que el cobro se haría con la mira de ponerlo en arrendamiento, no fue hasta 1791 cuando se puso en práctica. Según los oficiales reales hasta entonces los ingresos producidos por la alcabala en cada pueblo eran escasos ${ }^{238}$, asimismo encontraban dificultades a la hora de buscar personas que quisiesen hacerse cargo de su cobro, ya que las que lo hacían "estan pidiendo continuamente su relevo debido a que el seis por ciento de la recaudacion no les produce ni aun para el costo del papel, tinta, portes y cartas”239. Por todo ello decidieron que lo mejor seria ponerlo en arrendamiento por trienios porque “[...] el rematador o deudor pondria interes en averiguar todas las ventas o coste, y asi su celo puede ser mejor que el de un receptor que mira como carga o gravamen una mision que solo produce trabajo y una utilidad despreciada de seis, doce o veinte pesos al año"240. En cambio la cobranza en la ciudad de Santo Domingo continuaron realizándola los oficiales reales. Entre 1793 y 1797 se recaudaron 84.178 reales y 21 maravedíes, es decir una media anual de 16.835 reales y 24 maravedíes. Pero los hacendados no pagaron la

\footnotetext{
${ }^{236}$ Para Cotuí se nombró el gobernador de armas Miguel Sánchez, en La Vega el capitán de milicias de infantería Antonio Ramírez, para Montecristi y Dajabón el teniene José Álvarez, Puerto Plata el capitán comandante Juan del Monte, Samaná y Sabana de la Mar el sargento Lope Lucenal, Baní el teniente de caballería José Montero, Azua el capitán de milicias de infantería Alejandro Barrero, San Juan el teniente de milicias de caballería José Galán, Neiba Juan Feliz, Banica, Caobas y San Miguel el administrador Juan Sánchez, San Rafael el administrador Vicente Álvarez, Hincha el capitán de milicias de infantería Juan de Aranda, para la parte de Bayaguana, Monte Plata y Boyá el gobernador de dicha área Alejandro Mejía, en el Seibo el capitán de milicias de infantería Miguel Carrillo, y para Higüey el subdelegado de comisos Juan Hidalgo. Nomina de los sugetos que lo oficiales reales presentan al Presidente, Capitán General de esta isla para servir en las ciudades, villas, pueblos y partidos los empleos de receptores del Real Derecho de alcavala, 8 de julio de 1778. AGI, Santo Domingo, 985.

${ }^{237}$ Santos Pérez, J. M., Élites, poder local y régimen colonial..., op. cit., pp. 253-269.

${ }^{238}$ Durante el quinquenio 1786-1790 la colecta de alcabala en los pueblos de la isla había sido bastante irregular debido, según los oficiales reales, a que los receptores no lo habían llevado minuciosamente año por año. De ahí que sólo se hubiese ingresado 3.297 pesos, 5 reales y 31 maravedíes. Calculo de lo que produce la Alcabala en cada pueblo de esta Isla regulado por un quinquenio, 1790. AHN, Ultramar, Libro 724.

${ }^{239}$ Libro de arrendamiento de alcabalas de los pueblos del interior de la isla de Santo Domingo. AHN, Ultramar, Libro 724.

${ }^{240}$ Ibidem.
} 
alcabala correspondiente a los frutos de sus haciendas desde 1786 hasta 1797, alegando que la Real Cédula de fomento de 1786 les había liberado de tal contribución. En 1791 Nicolás Guridi, Manuel Heredia y Gregorio Saviñón propusieron a la Corona continuar con dicha gracia, decisión que hacia 1799 todavía estaba pendiente por determinar ${ }^{241}$.

Tabla 7-15. Recaudación líquida en concepto de alcabala, 1793-1797

\begin{tabular}{|r|r|}
\hline Año & Importe recaudado \\
\hline 1793 & 13.013 rs. y 5 mrs. \\
\hline 1794 & 17.500 rs. y 7 mrs. \\
\hline 1795 & 16.333 rs. y 13 mrs. \\
\hline 1796 & 15.213 rs. y 27 mrs. \\
\hline 1797 & 22.118 rs. y 3 mrs. \\
\hline Total & $\mathbf{8 4 . 1 7 8}$ rs. 21 mrs. \\
\hline
\end{tabular}

Elaboración propia. Fuentes: Relación de lo que han producido las alcavalas de esta ciudad en un quinquenio corrido desde enero de noventa y tres hasta fines de noventa y siete según las cuentas presentadas por José Fernández a cuyo cargo está su recaudación por cuenta de la real hacienda con declaración de lo que es liquido. AHN, Ultramar, Libro 724.

Si bien el reglamento de 1765 abrió el comercio libre entre las colonias del Caribe y los puertos de Cádiz, Sevilla, Alicante, Cartagena, Málaga, Barcelona, Santander, Coruña y Gijón, el de 1778 lo extendió a todas las colonias españolas americanas. Este Reglamento habilitó nuevos puertos americanos entre los que cabe destacar el de Montecristi, situado al noroeste de la isla que junto al de Santo Domingo estaba incluido dentro de los denominados “puertos menores”. En 1758 y 1762 el puerto de Montecristi ya fue habilitado en calidad de neutral durante la guerra entre Francia e Inglaterra ${ }^{242}$. La apertura de Montecristi en esos años permitó convertirla en una zona de abastecimiento y como puerto intermediario pues se obtenían productos procedentes de España y provincias americanas ${ }^{243}$.

En cuanto a los derechos, además de los específicos para cada mercancía, la mayor parte de los productos peninsulares estuvieron libres a su entrada en América, contribuyendo sólo con uno global de un 3\% en los puertos mayores y

241 Informe de los oficiales reales, Santo Domingo 13 de noviembre de 1799. AHN, Ultramar, Libro 724. Rodríguez Demorizi, E., “Apuntes y documentos. El Real derecho de alcabala. Libro de cargo y data de 1793”..., op. cit., pp. 165-185, p. 185.

242 Informe de los oficiales reales, 30 de junio de 1779. AGI, Santo Domingo, 1059.

243 Acerca de este puerto, las actividades comerciales y el papel que jugaron algunos comerciantes canarios puede consultarse: Hernández González, M. V., La colonización..., op. cit., pp. 78-108. 
de $1,5 \%$ en los menores. Por otra parte, el reglamento de comercio no abrió las colonias al comercio extranjero, ya que su propósito era eliminar el incesante contrabando y dar vigor al comercio metropolitano. Pero la realidad es que en Santo Domingo y todo el Caribe se practicaba este tipo de comercio desde el siglo XVII, pues resultaba más provechoso tanto para los extranjeros y peninsulares como para los habitantes de la isla. En cierta medida esta actividad ilícita estuvo autorizada por los propios gobernadores de la segunda mitad del siglo XVIII, desde el momento en que concedieron permisos para ir a otras colonias a por comestibles para el abasto de Santo Domingo y adquirir mano de obra esclava dando lugar a toda clase de abusos. Al estar permitida la concesión de este tipo de licencias en caso de necesidad extrema o durante un conflicto bélico, se recurrió no sólo a colonias americanas sino también extranjeras como las islas holandesas, danesas, y francesas, y en particular a la vecina de Saint Domingue, con la que a partir de 1778 se permitió comerciar ganado vacuno así como cabras, ovejas, cerdos, madera y frutos.

Por el contrario, la represión del contrabando acaparó cada vez más la atención de las autoridades locales quienes, como se ha podido observar, dispusieron resguardos en las localidades más propicias para este tipo de intercambio o redoblaron la vigilancia costera. La Corona también tomó como medida la concesión de patentes a corsarios para que formaran patrullas por el litoral, a fin de evitar que las embarcaciones extranjeras se acercasen a las costas, pudiendo apresar el cargamento ilegal que transportaban y venderlo en pública subasta. Lo cierto es que fue una manera de aprovisionamiento de todo tipo de productos en sus colonias, pero lo que se hacía era dar entrada libre al contrabando. Al tiempo, esta actividad proporcionaba un nuevo ingreso en las cajas reales, ya que los corsarios tenían que pagar una serie de impuestos sobre las presas realizadas. No obstante, sucedió lo mismo que con las licencias de víveres, el contrabando no se eliminó, y de acuerdo con Stapells las "actividades corsarias corrieron paralelas a las del comercio ilegal. No sólo las mismas personas y 
barcos participaban en ambas cosas, sino que, frecuentemente, éstas se dieron simultáneamente”244.

Efectivamente, al amparo de licencias, y a través del corso y otro tipo de intercambios comerciales se habían realizado operaciones clandestinas. La prueba más gráfica puede ser la introducción fraudulenta a la isla de negros que no fueron registrados y por los cuáles no se pagaron impuestos. El hecho era conocido por las propias autoridades locales y el Consejo de Indias, cuestión de la que da fe los distintos indultos otorgados por la Corona a la isla para normalizar ese tipo de adquisiciones. El 15 de mayo de 1776, y bajo el amparo de la Real Orden de 12 de mayo de 1756, el gobernador José Solano y Bote dictó un bando que mandaba conocer la concesión del indulto en todas las villas de la isla mediante pregones. Además se les informaba que esa gracia se les hacía a todos los propietarios que presentasen los “negros de mala entrada” para sellarlos, previo pago de los derechos correspondientes ${ }^{245}$. Aunque hasta ahora no sabemos el número real de negros que se introdujeron por esta vía y la recaudación de la marca en las cajas reales, la cifra legal recaudada en el indulto de 1756 para las poblaciones de la parte sur asciende a 19.699 pesos, 1 real y 20 maravedíes, mientras que en el de 1776 se ingresaron 8.000 pesos, cantidad bastante inferior ${ }^{246}$. Además entre 1776 y 1777 se había ingresado en las cajas de la Real Hacienda la suma total de 192.023 reales y 16 maravedíes ${ }^{247}$.

\footnotetext{
244 Stapells Jonson, V., "Los corsarios de Santo Domingo 1718-1779: un estudio socioeconómico”. Quaderns del departament de geografia i historia del l'estudi general de Lleida 12 (Lleida, 1992) pp. 3-93, p. 71.

${ }^{245}$ Hernández González, M. V., La colonización..., op. cit., pp. 133, 252, y 270; y Expansión fundacional..., op. cit., pp. 50, y 97-99. Julián, A., "Negros de mala entrada. El contrabando de esclavos en la Colonia Española de Santo Domingo en la segunda mitad del siglo XVIII" en La ruta del esclavo. Santo Domingo, 2006, pp. 25-56.

${ }^{246}$ En 1756 la responsabilidad de la zona sur recayó en el visitador de negros Antonio Angulo, mientras que en 1776 el encargado fue el teniente de justicia mayor Felipe Guridi, y para el norte el subdelegado de comisos Francisco Antonio Velilla. Según Amadeo Julián el número total de negros que fueron presentados entre 1776 y 1777 en ambas jurisdicciones ascendió a 1.169. Idem. Instancia de Antonio Angulo, relativa a solicitar de Su Majestad que le conceda los honores de oficial real con opción a ser colocado en la primera plaza vacante, a fin de que Su Majestad sirva ponerle en conocimiento, 27 de enero de 1815. AGI, Santo Domingo, 964. Libro de indulto de Negros de Mala Entrada, Comenzando Día 16 de Diciembre de este presente año de 1776. AHN, Ultramar, Libro 764.

${ }^{247}$ En Julián, A., "Negros de mala entrada. El contrabando de esclavos en la Colonia Española de Santo Domingo en la segunda mitad del siglo XVIII” en La ruta del esclavo..., op. cit., pp. 2556, p. 56.
} 


\subsubsection{Las actividades comerciales}

La participación de los hacendados en este tráfico comercial también fue notoria, aunque habría que señalar que antes que hacendados eran comerciantes, en su mayoría peninsulares, que acabaron establecidos en la isla. Su integración a la élite local se dio a través del matrimonio con una de sus hijas, lo que les permitió a su vez participar en actividades agropecuarias y obtener puestos políticos y grados militares. En cambio, otros peninsulares ya establecidos actuaron como colaboradores de esos. Una característica particular de estos comerciantes era que pertenecían a la misma red familiar: los Castro-Rivera y Urdaneta, y su rama Silvestre-Jiménez. El ámbito de sus actividades abarcó tres áreas: el comercio peninsular, el intrarregional y el comercio interno de Santo Domingo.

A lo largo del siglo XVIII, fueron muchos los individuos que lograron una patente de corso y se dedicaron a esta actividad, permitiendo al mismo tiempo que llegasen productos de abastecimiento a los habitantes de esta isla. Uno de ellos fue Domingo Lorenzo Zevallos, de origen canario. Se desconoce la fecha en que pudo llegar a Santo Domingo, pero a través de la documentación se constata que hacia 1750 empezaría a comerciar. La embarcación que utilizó para su actividad corsaria se llamaba El Dichoso, siendo su copropietario Juan Beltrand. Estaba formada por una tripulación de veinte personas, que estuvo bajo el mando de su hermano Pedro José Zevallos. Durante 1751 capturó dos barcos ingleses, uno era el bergantín Bonito, que había salido de Jamaica con destino Nueva York y transportaba armamento, harina, y carne salada. El segundo, fue una corbeta que se dirigía hacia Curazao. Ambas capturas produjeron un conflicto diplomático entre España e Inglaterra al realizarse en un periodo de paz entre ambas naciones. Finalmente se tuvo que abonar los daños causados en el primer caso ya que la embarcación se había hundido, y en el segundo a devolverla ${ }^{248}$.

En el período que abarca 1753 y 1760, Domingo Lorenzo Zevallos empezó a participar en otros negocios relacionados con intercambios comerciales entre Santo Domingo y el puerto de Coro y las Islas de Barlovento, adonde llevaba

\footnotetext{
${ }^{248}$ Sobre este comerciante consúltese: Stapells Jonson, V., “Los corsarios de Santo Domingo”..., op. cit., 52-57. Hernández González, M. V., La colonización..., op. cit., pp. 79-81; y Expansión fundacional..., op. cit., pp. 75-76.
} 
frutos y traía de vuelta víveres en dos balandras en las que participaba al 50\% con su socio. Entre los productos que introdujo de Coro pueden destacarse trece docenas de cordobanes grandes y ochenta y siete y media más pequeñas que entró el 19 de agosto de 1759. Mientras que el 9 de marzo de 1760, su otra balandra que venía de las Islas de Barlovento estaba cargada de mantequilla, harina, bacalao, queso, hierro, sebo, cerveza, clavos, salchichones y anguilas saladas ${ }^{249}$. En ese mismo año también colaboró transportando familias de canarios que habían sido enviadas para fundar el pueblo de Samaná. Su currículum se completó con el empleo de depositario general en el cabildo de Santo Domingo, que traspasó en 1753 a su cuñado Miguel Bernardo Antonio Ferrer. También desempeñó el empleo de anotador de hipotecas renunciándolo en su hijo Domingo Vicente Zevallos antes de morir en $1775^{250}$. Las ganancias obtenidas en el corso y comercio permitieron que su patrimonio contara con dos casas en la ciudad de Santo Domingo, viviendo en una de ellas en la que tenía a su servicio tres esclavos domésticos. Debió invertir también en tierras, pues poseyó una hacienda de la que por el momento no se tienen más datos, y un ingenio nombrado La Venta $^{251}$. Su matrimonio con Micaela Castro-Rivera y Urdaneta le llevó a integrarse a esa red familiar, dedicada a actividades agropecuarias y en la que además hubo otros individuos, en su mayoría peninsulares, que también se dedicaron al comercio.

El sobrino político de Domingo Lorenzo Zevallos, Antonio Rojas, fue otro destacado comerciante de la segunda mitad del siglo XVIII ${ }^{252}$. En este caso, también se desconoce la fecha en que este peninsular se encontraba en Santo Domingo. Fue asentista en el transporte de tabaco, y su ingreso en el comercio de importación y exportación, está relacionado con el problema del abastecimiento de víveres y otros productos que escaseaban en la isla, como ya se ha comentado.

\footnotetext{
${ }^{249}$ Relación de entrada de embarcaciones en el puerto de Santo Domingo, 16 de agosto de 1771. AGI, Santo Domingo, 968.

${ }^{250}$ Diligencias practicadas por Juan Ventura de Aguirre, anotador de hipotecas de esta ciudad de Santo Domingo, 1791. AGI, Santo Domingo, 939.

${ }^{251}$ El 5 de noviembre de 1749 el ingenio fue vendido a Juan Mieses Ponce de León Pérez Caro y su mujer Ana Guridi Concha. Certificación de los bienes que posee Domingo Cevallos y Micaela de Castro, realizada por el escribano Francisco Rendon Sarmiento. Y Certifiación de Andrés de Gordon y Barcena, anotador de hipotecas y tributos de esta isla, 1755. AGI, Santo Domingo, 275.

${ }^{252}$ Estuvo casado con María Concepción Ferrer Castro-Rivera, hija del hacendado y regidor del cabildo de la ciudad de Santo Domingo Miguel Bernardo Antonio Ferrer Angulo y María Belén Castro-Rivera Urdaneta.
} 
Parece que la Compañía de Comercio de Barcelona, que hacia 1757 empezó a funcionar, no suministraba todo aquello que necesitaban los habitantes de Santo Domingo, como queda reflejado en la correspondencia del gobernador Manuel Azlor y Urríes de 1759. A través de ella manifiesta a la Corona la insuficiencia de víveres y ropas que traían las embarcaciones de la Compañía, y el valor tan elevado al que se vendían ${ }^{253}$. Esta situación propició que el comercio ilícito continuase, ya que con él se surtían de lo mismo y a mejor precio. Ante esta situación, el gobernador tomó la decisión de conceder "licencias de viveres" a otros barcos españoles para que pudieran traerlos de "las colonias amigas", término que aparece en la documentación para referirse a las colonias americanas tanto españolas como extranjeras. Este sistema estaba amparado por la propia Corona, que permitía a las autoridades locales conceder este tipo de licencias, pero sólo en caso de severa necesidad. Entre 1760 y 1771 el gobernador adjudicó alrededor de noventa y ocho licencias, entre ellas tres a Antonio Rojas: una el 14 de mayo de 1762, otra el 4 de julio del mismo año y la tercera el 10 de noviembre de $1768^{254}$. Cabe señalar que once de ellas fueron dadas a embarcaciones extranjeras, tres holandesas, tres inglesas y otras cinco de Curazao (véase tabla 11 del anexo).

El gobernador Manuel Azlor y Urríes no dudo incluso en conceder algunas de ellas al factor de la Compañía de Barcelona, Narciso Subirás y Barra, quien las facilitaba a los capitanes de dicha compañía para traer esclavos y algunos víveres como harina, arroz, jamones, quesos y piezas de coleta. En noviembre de 1769 se dio permiso a Juan Gatell para traer al menos cien esclavos, llevando dinero para su compra. Asimismo, podía conducir algunos víveres para el abasto de esta plaza. El 30 de marzo de 1770 regresó al puerto de la ciudad de Santo Domingo con ciento seis esclavos de Barbados, harina, arroz y aguardiente ${ }^{255}$.

Como consecuencia de la concesión de estas licencias, en 1771 Manuel Azlor tuvo que hacer frente a las acusaciones que se le hicieron en el juicio de

\footnotetext{
253 Juicio de residencia del gobernador Manuel Azlor y Urríes, 1771. AHN, Consejos, 21.465. Oliva Melgar, J. $\mathrm{M}^{\mathrm{a}}$., "Contrabandistas, criollos y mercantilismo español en el siglo XVIII: la resistencia a la compañía de Barcelona en Santo Domingo”. Pedralbes 4 (Barcelona, 1984) pp. 233-271.

${ }^{254}$ Relación de entrada de embarcaciones en el puerto de Santo Domingo, 16 de agosto de 1771. AGI, Santo Domingo, 968.

${ }^{255}$ Testimonio de la entrada en este puerto de la balandra nombrada San Luís, con negros al cargo de Juan Gatells. Año 1771. AHN, Consejos Suprimidos, 21.058.
} 
residencia. Se consideró que tales licencias habían sido excesivas, y entregadas sin realizar previamente una petición a través del procurador general y recibir el visto bueno del fiscal de la Audiencia ${ }^{256}$. También se abrió una causa por presunto contrabando contra la Compañía, por haber introducido productos extranjeros ilícitamente con el pretexto de traer víveres a esta plaza, cuando estaba prohibido. Como preveía el capítulo primero de su Real Cédula de erección, la Compañía podía comerciarlos, pero sólo en caso de que vinieran de la Península. Por otra parte, la introducción de esclavos permitió a los hacendados proveerse de mano de obra $^{257}$.

Tanto el gobernador como la Compañía fueron absueltos, el primero en 1771 y la segunda el 1 de septiembre de 1774. Hay que tener en cuenta que estas licencias respondieron no sólo a las necesidades de abastecimiento de Santo Domingo, sino también a la ajustada situación de la monarquía, y puede que sirvieran igualmente para su recuperación con el ingreso al fisco de los impuestos que debían pagar. Sin embargo, al amparo de estas licencias se estaba dando cobertura a operaciones comerciales anormales incluso con el consentimiento de las autoridades locales y metropolitanas ${ }^{258}$.

Posterior a esta situación, entre 1778 y 1779, otro conflicto surgió, esta vez en Santiago y contra de algunos de los empleados de la Factoría de Tabacos y asentistas de este fruto, entre los que nuevamente se encontraba Narciso Subirás. Las quejas provenían de los labradores y la élite capitular de Santiago, quienes reunidos en la casa del cura confirieron poder al abogado José del Monte y Tapia para que los representara, y redactara una carta en la que ponían de manifiesto como la administración del ramo de tabacos en Santiago, con Francisco Antonio Velilla y Torres a la cabeza, utilizaba pesos distintos a la hora de entregar los tabacos, quedando a su favor todos los excesos y convirtiendo "la mayor parte de nuestro tabaco en calidad de libras y rescogido lo pasa a VM por rescogido y tienda para lucrar de este modo la diferencia que hay de unos precios a otros” e

\footnotetext{
${ }^{256}$ Sentencia del juicio de residencia del gobernador Manuel Azlor y Urríes, 19 de julio de 1771. AHN, Consejos, 21.465.

${ }^{257}$ Oliva Melgar, J. Mª., "Contrabandistas, criollos y mercantilismo español en el siglo XVIII: la resistencia a la compañía de Barcelona en Santo Domingo”..., op. cit., pp. 233-271.

${ }^{258}$ Otros gobernadores continuaron concediendo este tipo de licencias. Por ejemplo, en 1787 Manuel González concedió una al comerciante Francisco Ferrer y Alás para que extrajese de sus cortes de madera cuartones de caoba llevándolas a las colonias extranjeras y retornase con ropas y víveres. Testimonio del expediente de los oficiales reales, 1791. AGI, Santo Domingo, 1045.
} 
incluso "pasando por bueno el tabaco que no lo es el de sus amigos y deudores”259. También se quejaban de los personales y turbios manejos de los asentistas Antonio Rojas y Narciso Subirás, que destituido de su cargo en la Compañía permaneció en la isla. A éstos se les acusaba de introducir efectos de ilícito comercio que transportaban a través de los ríos Yuna y Camú con el pretexto de conducir tabaco, y vendían en el establecimiento de San Rafael de Angelina y Santiago. Otras de las quejas era la mala calidad de las harinas que introducían, y el excesivo precio de los géneros que vendían, produciendo la falta de abastecimiento y víveres que había sufrido la ciudad de Santiago para esos años $^{260}$. Aunque probablemente las acusaciones de contrabando eran ciertas, la intención de los agricultores era que se les permitiera comerciar con la vecina colonia francesa, que le ofrecía los productos a mejor precio y con la que llevaba comerciando desde su instalación en la isla. A partir del gobernador Manuel Azlor se había legalizado ese tráfico mercantil, por el contrario, fue prohibido por José Solano e Isidro Peralta y Rojas. Bajo el gobierno de este último se sitúa esta reivindicación de Santiago en la que el gobernador para facilitar el comercio de harina y víveres había continuado con el trato de privilegio que Azlor había dado a la Compañía de Barcelona, así como en el transporte del tabaco, y a los peninsulares encargados de ese negocio.

Como contrapartida, Francisco Antonio Velilla informó de forma alarmista al gobernador Isidro Peralta y Rojas de que en Santiago se estaba produciendo una rebelión con el abogado José del Monte y Tapia como cabecilla. En respuesta, éste fue encarcelado, y se envió al capitán Mateo Pérez para realizar una pesquisa y averiguar que estaba sucediendo. En esta investigación se encontró que en 1778 hubo abundancia de víveres, y que la necesidad que padecía Santiago era una mera escusa para comerciar con los franceses. El gobernador envió un informe a la Corona relatando los acontecimientos y esperando una decisión sobre los posibles abusos de la factoría sobre los labradores ${ }^{261}$. Sin embargo, las sospechas

\footnotetext{
${ }^{259}$ Carta de los labradores de Santiago a Su Majestad, 21 de enero y 25 de junio de 1779. AGI, Santo Domingo, 1021.

${ }^{260}$ Carta de los labradores de Santiago a Su Majestad, 2 de febrero de 1779. Y, Carta del cabildo de Santiago a Su Majestad, 18 de mayo de 1778. AGI, Santo Domingo, 1021. Testimonio de las diligencias obradas en la ciudad de Santiago por mandato del presidente, 1779. AGI, Santo Domingo, 1022.

${ }^{261}$ Idem. Sobre esta rebelión consúltese: Hernández González, M. V., Expansión fundacional..., op. cit., pp. 76-97, y 104-137.
} 
no influyeron a los factores a pesar de que en la denuncia éstas se habían extendido a sus familiares como el factor Andrés de Lecanda, quienes pertenecían a la familia Silvestre-Ramírez, una de las ramas más fuertes de la red familiar Castro-Rivera y Urdaneta. Éstos fueron considerados probablemente libres de toda responsabilidad ya que no fueron castigados de alguna forma ni destituidos de sus cargos y siguieron gozando del estatus anterior. Es más al morir Francisco Velilla su yerno Francisco Espaillat le sustituyó siendo nombrado por el propio gobernador Isidro Peralta y Rojas. La importancia de este problema deja al descubierto nuevamente la facilidad con que se podía defraudar a las arcas reales y, puede ser un exponente de las relaciones y rivalidades entre la élite de Santiago por controlar tal vez el tráfico comercial de la región del Cibao y, en particular, de esa ciudad. Este conflicto revela que en ella se había formado dos “partidos” bien claros. Uno formado por Francisco Antonio Velilla y otro por Julián Joaquín Pueyo y Urríes, quien guiado por José del Monte prestó a los agricultores y al cabildo su apoyo. Ambos ocupaban dos de los empleos con más prestigio y poder, el primero como juez subdelegado de comisos y el segundo como alcalde mayor y, en su entorno social y familiar mostraban diversas conexiones de diversa índole con la élite de Santo Domingo. Aunque pertenecían al mismo grupo familiar entorno a Francisco Antonio se había tejido una extensa red de poder que le había permitido no sólo formar una considerable fortuna, sino el control socioeconómico y administrativo de esa región. También es sabido, que el comercio tanto legal como ilegal continuó realizándose entre las dos colonias ${ }^{262}$.

El joven catalán Antonio Cumulat fue sucesor de Narciso Subirás, Antonio Cumulat. Había iniciado la carrera comercial en la casa barcelonesa de AlegreGibert. Ocupó el cargo de primer factor entre 1774 y 1786, siendo el que más tiempo estuvo en ese puesto, pues, para 1789 la Compañía de Barcelona desaparece de Santo Domingo. La Compañía nombró en ese intervalo de dos años a unos delegados que se encargaron de cerrar sus cuentas ${ }^{263}$. A pesar de la desaparición de la Compañía, Antonio Cumulat permaneció en la isla. Desde su llegada empezó a granjearse un cierto prestigio, consiguiendo un cargo en la

\footnotetext{
${ }^{262}$ Idem. Sobre la élite de Santiago véase: Hernández González, M. V., Ibidem., pp. 54-76. José del Monte contaba con una amplia parentela en Santiago, concretamente su tío Pedro del Monte y Tapia era procurador del cabildo e instigador de la protesta.

${ }^{263}$ Oliva Melgar, J. Mª., Cataluña y el comercio..., op. cit., p. 108.
} 
milicia, el de capitán de la segunda compañía de las milicias urbanas de la ciudad de Santo Domingo. Su conocimiento del idioma inglés y francés le sirvió para ser nombrado intérprete de lenguas en la expedición a Bayajá, por la que cobró 40 pesos al mes. También ocupó en el cabildo de Santo Domingo el cargo de alcalde ordinario al ser elegido en 1786. Es importante destacar que en ese año se promulgaron las ordenanzas para la ciudad de Santo Domingo, en las que Antonio colaboró en compañía del alférez real Antonio Dávila Coca y Landeche ${ }^{264}$.

Antonio Cumulat fue reuniendo una pequeña fortuna, fruto de sus contactos y la posición que le otorgaba el ser primer factor de la Compañía. Ello le permitió adquirir haciendas y hatos, y casarse con una criolla hija de “[...] los descendientes de los primeros pobladores españoles [...]”265 y entablar negocios con personajes importantes como el ya citado oficial real Raymundo Esparza. También le posibilitó socorrer a las reales cajas en 1780 con la cantidad de 33.000 pesos, que adelantó en efectivo para la paga de las tropas, y en géneros y víveres para la provisión de hospitales y habilitación de barcos del real servicio.

Como responsable de la factoría de la compañía se encargó de que se limpiasen los ríos Yuna y Camú para mantenerlos navegables. Además se abrieron caminos carreteros desde estos ríos hasta la ciudad de Santiago, con el objeto de facilitar el transporte del tabaco que se acopiaba en esa ciudad. Paralelamente a su empleo en la Compañía, Antonio Cumulat tuvo otras actividades como el corso. Desde 1780 a 1783 mantuvo con su peculio tres barcos armados al corso, con los que abasteció de víveres a la ciudad, al Batallón Fijo, las milicias y al regimiento francés de Enghien, que había llegado a la ciudad de Santo Domingo en 1780. Cuatro años más tarde ingresó como miembro benemérito en la Real Sociedad Bascongada de los Amigos del País ${ }^{266}$.

Dejando a un lado los ya señalados, otro importante peronaje en la red familiar Castro-Rivera y Urdaneta fue el barcelonés Salvador Pí y Piquer, que

\footnotetext{
${ }^{264}$ Carta del gobernador de Santo Domingo, Joaquín García, en la que acompaña un memorial de Antonio Cumulat que suplica a S.M se le conceda alguna gracia en remuneración de sus servicios, 25 de octubre de 1794. AGI, Santo Domingo, 957.

${ }^{265}$ Ibidem. No hemos logrado averiguar con quién estuvo casado, pero según Carlos Larrazábal lo estuvo con María Merced Guerrero, en Larrazábal Blanco, C., Familias dominicanas. Santo Domingo, 1969, vol. II, p. 266.

${ }^{266}$ Carta del gobernador de Santo Domingo, Joaquín García..., op. cit. Martínez Ruiz, J., Catálogo General de Individuos de la R.S.B. de los Amigos del País (1765-1793). San Sebastián, 1985, vol. XII, p. 51.
} 
ejerció el cargo de segundo factor junto a los principales factores, Pau Orry Caralt y Narciso Subirás y Barra, con el que tuvo que hacer frente al problema en que se vio envuelta la Compañía en 1771. Se encargó principalmente del trato directo de los clientes de la Compañía ${ }^{267}$. De la misma forma que Antonio Cumulat, este segundo factor acabó instalado en la ciudad de Santo Domingo. Se casó con la criolla Bárbara Saviñón Tapia, hija del hacendado y regidor Gregorio Saviñón y de Micaela de Tapia, miembros de la ya mencionada red familiar Castro-Rivera y Urdaneta. Su enlace matrimonial permitió que fuese elegido para ejercer algún empleo administrativo, así en 1779 fue vicesecretario y notario del arzobispado de la catedral, y en 1791 alcalde ordinario y síndico procurador del ayuntamiento de la ciudad de Santo Domingo ${ }^{268}$.

El análisis de estos casos evidencia la interconexión de distintos intereses en el circuito comercial de la isla, y cómo a través de las relaciones se influyó o determinó en su evolución. Sin embargo, habría que profundizar más en el comercio prestando especial atención a los grupos de mercaderes que existieron, sus estrategias comerciales y redes familiares. Así, tal vez conociendo estas relaciones, se pueda comprender mejor el papel que jugó la Real Compañía de Comercio, la controversia de las licencias que otorgó el gobernador Manuel Azlor y Urríes y alguno de sus sucesores, y la importancia que el puerto de Montecristi tuvo dentro de la estructura comercial colonial de la segunda mitad del siglo XVIII.

\footnotetext{
${ }^{267}$ Oliva Melgar, J. Mª, Cataluña y el comercio..., op. cit., p. 109.

${ }^{268}$ Carta del cabildo de la ciudad de Santo Domingo dando cuenta de los pleitos que ha recibido del gobernador, 25 de julio de 1791. AGI, Santo Domingo, 997. Véase también Larrazábal Blanco, C., Familias dominicanas..., op. cit., vol. VI, pp. 197-198.
} 



\section{CONCLUSIONES}

A lo largo de este trabajo hemos estudiado a un grupo de hacendados que controlaron la vida de Santo Domingo durante la segunda mitad del siglo XVIII, y pertenecieron a las familias más significativas y poderosas como los Coca, Landeche, Campuzano-Polanco, Guridi, Frómesta, Heredia, Leos-Echalas, Mañón de Lara, Pérez-Caro, Rocha-Ferrer, o Arredondo. Estos grupos familiares se encontraban involucrados en la agricultura, ganadería, y comercio, y acaparaban los cargos de mayor relevancia dentro del organigrama de la administración local, y en el Ejército, desde donde podían hacer uso de toda su influencia. El control de las relaciones sociales también fue fundamental parar el afianzamiento de estas familias, y este hecho se manifiesta en las alianzas matrimoniales y su utilización endogámica, ya que ello supuso el entronque entre ellas, creándose una tupida red de parentesco que les permitió mantener y aumentar el estatus alcanzado. La consecuencia de estas sólidas relaciones fue la constitución de una amplia red de hacendados que se englobaban en tres grandes familias: los Guridi-AlarcónCoronado, los Landeche-Bastidas, y los Castro-Rivera y Urdaneta.

La relación de parentesco constituye un elemento de integración de éstas, que les permitía identificarse y cohesionarse, al tiempo que excluía del acceso a esas instancias de poder a aquellos que no perteneciesen al grupo familiar. Ello no significó, que fuera cerrado, pues el estudio de estas redes familiares demuestra que también incorporaron nuevos miembros, fueran peninsulares, criollos de otras regiones del imperio español o extranjeros que, por sus relaciones personales o su posición económica-política y social resultaron de utilidad para garantizar la consolidación como grupo dominante. La aparición de estos inmigrantes se inscribe en dos oleadas de llegada. Los primeros lo hacen entre finales del siglo XVII y principios del XVIII para ocupar un cargo burocrático o en el Ejército. La particularidad de muchos de ellos es que fueron los fundadores de los clanes ya 
mencionados, cuyo origen se había establecido en el matrimonio celebrado entre éstos y una criolla, que en algún caso descendía de los primeros conquistadores. La segunda oleada se ubica durante nuestro periodo de estudio -la segunda mitad del siglo XVIII-, los cuáles lo hicieron estimulados por las Reformas Borbónicas, con la instalación de la Real Compañía de Comercio de Barcelona, la Factoría de Tabaco, la reactivación económica, y aquellos funcionarios y militares que continuaron llegando para ocupar sus empleos, o bien como pajes de los gobernadores. Algunos de estos personajes llegaron a desempeñar un papel decisivo en esas familias que conformaban la élite de Santo Domingo, revitalizándolas y dándoles continuidad familiar dentro de la administración.

Un balance sobre el destino de estos recién llegados nos permite observar que la forma de integrarse a la élite local se desarrolló bajo dos formas. Por norma general fue mediante alianzas matrimoniales sobre todo a partir de las segundas y terceras generaciones de las tres redes familiares. Cuando llegaban casados eran sus hijos quienes conectaban con esas familias o incluso entre ellos mismos, aunque en ocasiones los progenitores también lo hiciesen a través de segundos matrimonios. La importancia de estos matrimonios reside en las dotes que obtenían los peninsulares ya que constituyeron el soporte económico gracias al cuál se insertaron en las actividades agropecuarias y comerciales por lo que quedaban absorbidos por la familia de la esposa. Además el matrimonio garantizaba a la élite local tener entre sus miembros otro pariente leal y dependiente, teniendo en cuenta que no tenía familia directa en la isla. Esto no significa que se desligaran de sus parientes de la metrópoli, sino que contaron con su ayuda, por ejemplo para la obtención de la ejecutaria de hidalguía, que les proporcionaba prestigio y limpieza de sangre.

Otra forma de inserción con la élite criolla fue a través de relaciones contractuales como las fianzas o cartas de poder establecidas entre un peninsular y un hacendado criollo. Por medio del dinero que adelantaba el hacendado, capital necesario para pagar la fianza de toma de posesión de un puesto en las cajas reales. En algún caso este vínculo económico se superpuso a una alianza matrimonial, pasando el oficial real a formar parte de la familia criolla. El caso del contador Raymundo de Esparza es más singular porque lo hizo sin pasar por el casamiento y, apoyándose principalmente en su círculo de amistades. De hecho, 
sus primeras amistades se formaron dentro de la Real Hacienda en la que sirvió durante veinte años, y paralelamente con algunos miembros de las redes familiares Guridi y Alarcón-Coronado y Castro-Rivera y Urdaneta. A la vez el manejo arbitrario de Esparza que no separó claramente sus negocios comerciales y crediticio de los de las cajas le permitieron acumular una fortuna respetable, y un vertiginoso ascenso social, influencia política e intervención.

Juan Bautista de Oyarzábal y Olavide, también llegó a situarse en la misma cúspide social. Su llegada e integración fue posible a través de su apoderado, el hacendado y criollo Antonio Mañón de Lara. Oyarzábal operó bajo la firma comercial Aragorri en combinación con actividades agropecuarias, representando a su primo el Marqués de Iranda, quien confió en su pariente para la dirección del negocio y lo convirtió en socio. La capacidad de liderazgo que gozó Oyarzábal dentro de los hacendados se manifestó al ser nombrado miembro directivo de la Sociedad de Hacendados en 1793.

Otras relaciones, como la de servir de albacea testamentario, de testigos en juicios e informes, o de socios, también les servían para integrarse y, a la élite local para salvaguardar su posición dominante, y aumentar su poder. Lo mismo se puede decir del parentesco espiritual, donde se buscaban entre ellos para establecer relaciones de compadrazgo en bautizos. Estas relaciones se desarrollaron de manera paralela dentro de los mismos grupos familiares de los hacendados que explican las buenas relaciones mantenidas en las sucesivas generaciones. El casamiento fue sin duda el lazo que las reforzaba, y buen reflejo de ello son los matrimonios de jóvenes de un mismo núcleo familiar con varias hermanas de otro, y consanguíneos renovados de cara a la generación siguiente, lo que permitió la concentración del patrimonio y evitó la dispersión de la fortuna. Este tipo de enlaces se constatan sobre todo en las redes familiares Guridi y Alarcón-Coronado y Landeche-Bastidas. En este sentido resulta lógico que se celebrasen habitualmente segundas nupcias. Esto a su vez, tenía consecuencias para las actividades agropecuarias comunes a las que se dedicaban: engrandeciendo y manteniendo su patrimonio, colaborando con su pariente en la administración de las haciendas y compartiendo afinidad ideológica políticaeconómica, lo que se traduce por la participación en las mismas instancias de poder, en particular el cabildo. 
Los hacendados además contaron con otros apoyos claves obtenidos a través de relaciones de amistad heredadas del marco familiar como aquellas mantenidas entorno a sus actividades profesionales y otros ámbitos como la Universidad o el Ejército. Una característica específica de estas relaciones es que con frecuencia aparecen ambos elementos recubriéndolas o superpuestas a otras que hemos mencionado. Las amistades observadas pueden clasificarse en varios tipos. Unas se refieren al grupo de amigos con los que mantenían relaciones de negocios, y se inscribe dentro de sus actividades profesionales, cuando actuaban prestándose dinero, o como intermediarios o agentes, fiadores, apoderados o testaferros realizando contratos por cuenta de otro; es el caso de la compra de una propiedad rústica o un cargo político. Dentro de éstas estaban aquellos con los que la relación fue más estrecha. En algún caso se trata del grupo de "amigos intimos” con los que además mantenía una relación especial formalizada con un parentesco espiritual o una mención en un testamento que revelaba el grado máximo de confianza y fidelidad.

Las últimas son del tipo clientelar y se concreta en una cooperación basada en la desigualdad entre los individuos relacionados. La especificidad de los hacendados es que podían estar integrados en una misma red clientelar o en distintas por lo que en función de dónde se situaron, y de acuerdo a los intereses que entraban en juego, tenían el papel de protector o protegido. Entre los dependientes que contaron los hacendados se encuentran los criados, los mayordomos o administradores que se encargaron de administrar la casa, las haciendas agrícolas y ganaderas, el negocio comercial, llevar los libros de cuentas, y obtener información privilegiada. Por debajo de ellos, se encontraban los esclavos domésticos con quienes establecieron relaciones de parentesco espiritual.

Los hacendados también disfrutaron de las relaciones privilegiadas que mantuvieron con los altos funcionarios de la administración local, desde los oidores al gobernador, o con los oficiales reales, hasta en España, ya fuesen miembros de la burocracia española, como los miembros del Consejo de Indias o poderosos de la Corte madrileña. Conseguir su apoyo y protección les permitió ocupar puestos en las mencionadas instancias o en aquellos de nueva creación a través de nombramientos directos, y en el cabildo concretamente a través de la designación de las regidurías que hicieron los gobernadores. También sirvió para 


\section{Conclusiones}

movilizar relaciones a favor de ellos para obtener mercedes para sus distintas actividades, y que a menudo adquirieron un perfil de fraude o parcialidad a favor de determinados hacendados que, implicaron que se produjera en connivencia con las propias autoridades locales, principalmente por los propios gobernadores. Aunque esta relación de clientelismo político fue motivo en alguna ocasión de conflicto, por ejemplo cuando los gobernadores colocaban a sus allegados en puestos políticos o militares pasando por encima a los ya establecidos, los gobernadores también trataron de favorecerles en este sentido y, de manera grupal a la hora de defender sus intereses, actuando como intermediario ante la Corona. Ello también les servía para tenerlos a su favor.

Además del clientelismo las formas que se dieron para la provisión de puestos fueron el cursus honorum, la compra y renuncia, y los matrimonios endogámicos. A través de ellas, los hacendados pudieron mantenerse y afianzar su representación en la Audiencia, en la que además ocuparon puestos como el de relator, abogado o alguacil mayor. Acompañó a este proceso la formación académica de sus miembros, desempeñando también algún cargo en la universidad donde estudiaron y en la Iglesia. El cuerpo militar tuvo igualmente destacados representantes dentro de ese núcleo social. Lo mismo ocurrió en la Real Hacienda actuando como contadores, tesoreros, factores del tabaco o administrando los diezmos y la Bula de la Santa Cruzada. Aunque se han comprobado dichas relaciones sociales, sería preciso realizar un estudio más profundo sobre estas cinco instituciones: la Audiencia, la Universidad, el Ejército, la Real Hacienda y la Iglesia.

Este dominio ejercido en todas las esferas de poder que se prolonga a toda la isla, y en particular la ciudad de Santo Domingo, les permitió que la administración estuviese en sus manos y maniobrar en cuestiones locales en función de sus propios intereses. Los hacendados fueron capaces de retraer algunas de las reformas de la Corona como la Real Instrucción de 1754, que afectaba a la propiedad de la tierra y el pago de la alcabala a través de los sucesivos relevos que habían gozado desde su implantación. Así, trataron desde el cabildo de extender su fuerza en el contexto de la estructura colonial, e imponer su criterio por encima de los intereses de la metrópoli durante bastantes años. 
Finalmente tuvieron que acatar esas reformas y ponerlas en práctica. No obstante, éstos mantuvieron su poder en la vida local.

Muchas de las decisiones tomadas en el sector comercial, y fundamentalmente en el agrario, fueron impulsadas por los hacendados. Lograron el apoyo de los gobernadores que, básicamente, fueron los portavoces de su discurso a la hora de reivindicar aquello que necesitaban para sus explotaciones agrícolas, y argumentos para conseguir exenciones, y que solicitaron a la Corona en 1767 de acuerdo con la política borbónica de fomento de la agricultura. Para ello siete años después establecieron una Junta de Fomento, suponiendo en cierta medida el preámbulo de lo que para fines del siglo XVIII sería la Sociedad de Hacendados. Las gestaciones de esta asociación tuvieron como resultado la Real Cédula de 1786, que concedía medidas concretas a las solicitudes de los hacendados que giraban entorno a la agricultura: exención de derechos en la introducción de esclavos e importación de utensilios, así como en el cobro del diezmo, y la alcabala. Sin embargo, antes de obtener estas gracias con carácter general para toda la sociedad local, habían sido dadas a título personal a varios hacendados, entre estos a Juan Bautista Oyarzábal, quien contaba en la Corte de Madrid con la protección de su pariente el Marqués de Iranda, que se encontraba inserto en solidaridades, lo que facilitó hacerse conceder mercedes, que contribuyeron a que se extendiera al resto de la población a través de la mencionada cédula.

El cabildo de Santo Domingo, se va a convertir en un cuerpo dinamizador de la vida económica de esa ciudad, y el núcleo del poder local en el que la mayoría de los hacendados principales estuvieron representados. A través del rastreo del origen de sus componentes, y el conocimiento de las distintas conexiones mantenidas hemos podido analizar el predominio que tuvieron determinadas familias en periodos concretos al copar sus miembros buena parte de los oficios. De hecho fue la institución en la que el vínculo familiar estuvo presente y, por tanto, donde se produjo el mayor grado de coincidencia entre familiares. Este organismo estuvo monopolizado durante gran parte de la segunda mitad del siglo XVIII por las redes Guridi-Alarcón y Coronado y LandecheBastidas, emparentados a su vez con otras familias criollas. Se ha comprobado también que hacia 1779 los empleos fueron ocupados por miembros de la red 


\section{Conclusiones}

Castro-Rivera y Urdaneta y por algún comerciante. La razón más inmediata de este cambio fue la modificación del sistema de acceso al cargo de regidor que hasta entonces se había hecho a través del nombramiento que hacía el gobernador, al decretar la Corona la puesta en venta de los regimientos a partir de la Real Cédula de 1767. Este hecho supuso un conflicto y como consecuencia que el control de las regidurías y las alcaldías en el cabildo municipal cambiasen para 1780-1795, aunque las otras dos familias siguieron participando en la institución. De su importancia nos habla el hecho de que, sus nombres figuran entre los miembros que fueron consultados para la elaboración del código negro que había mandado preparar la Corona hacia 1783. Asimismo, un año después éstos ingresaron como miembros de la Real Sociedad Bascongada de los Amigos del País. Su participación en ella constituye una notoria manifestación de sociabilidad. Lo llamativo es que dentro del grupo de hacendados, sólo una minoría gozó de tan prestigiosa institución económica. Los Amigos del País de Santo Domingo estaba agrupada por veintidós, de los cuáles quince eran peninsulares. En su mayoría se trataba de Socios que desempeñaban cargos claves en la alta administración local: el gobernador y presidente de la Audiencia, sus ministros, la dirección de la Real Hacienda, y parte de la comunidad mercantil de Santo Domingo. Entre los criollos de las más antiguas familias figuran aquellos que habían puesto en marcha la Junta de Agricultura, y en algún caso los descendientes de éstos. El pasado tenía todavía presencia, pues Nicolás Guridi y Frómesta miembro de la red familiar Guridi y Alarcón-Coronado figuraba además presidiendo la Sociedad de Hacendados en 1793.

La composición del cabildo de Santo Domingo a fines del siglo XVIII, demuestra tanto los cambios, como la relativa estabilidad de su composición. También refleja la evolución económica y las actividades a las que se dedicaron los hacendados. Durante la segunda mitad del siglo XVIII, tuvo lugar en Santo Domingo una serie de importantes cambios que mejoraron su economía. Dicha recuperación se afianzó con el aumento demográfico y la fundación de nuevas poblaciones. Este auge estuvo respaldado por las actividades agropecuarias a las que se dedicaron mayoritariamente nuestros hacendados. Aunque parte de la producción era utilizada para el consumo local, otra era exportada. El principal negocio de las haciendas dedicadas a la agricultura era el cultivo de cacao, café, 
azúcar y tabaco. En torno al cultivo del último producto, se formó un grupo social localizado en la ciudad de Santiago y sus alrededores. Área que presentaba también una intensa dedicación a la ganadería. La importancia de éste requeriría por si sola un estudio más pormenorizado. A pesar de haber constatado que algunos hacendados de la capital tenían relaciones con destacados miembros de la ciudad de Santiago, que se dedicaban tanto al cultivo del tabaco como a la ganadería sería necesario prestar mayor atención a sus conexiones y posibles rivalidades. La expansión de la ganadería se debió a una gran demanda de reses por parte de la colonia vecina francesa, que eran utilizadas como alimento y animales de carga. Nuestros hacendados también se dedicaron a tan lucrativo negocio. El crédito también aparece entre los campos de interés de los hacendados, prestándose entre ellos e incluso a la propia monarquía, que recurrió a ellos para hacer frente a sus gastos en momentos de estrechez económica, aunque en ocasiones fueron donativos. Otras actividades como la recaudación de impuestos o el abastecimiento de víveres fueron practicadas por el grupo de estudio.

En cuanto al comercio, fue otra de las principales actividades de los hacendados estudiados, sobre todo por los advenedizos comerciantes llegados de España, los cuáles obtuvieron importantes fortunas acaparando el comercio transoceánico y el regional. En particular, algunos miembros de la red familiar Castro-Rivera y Urdaneta, quienes mantuvieron además negocios con los factores de la Real Compañía de Comercio de Barcelona, hasta el punto de que unos cuantos acabaron integrados a través del matrimonio. La corporación catalana debía realizar el intercambio comercial entre esta isla y las vecinas del Caribe con la Península, y otros puertos como el de Cumaná. Además se le había otorgado permiso para transportar tabaco desde el interior al puerto de Santo Domingo y de éste al de Cádiz. Se le concedieron también licencias para introducir mercancías y esclavos, lo que aprovechó para incluir productos extranjeros y españoles. En realidad, el principal problema que encontró fue la oposición de los labradores de Santiago, quienes se quejaban de su actuación acusándoles de contrabando junto a los factores de tabaco de dicha ciudad, y de imponer altos precios. Algunos cargos de dicha factoría como los de la de la capital, fueron desempeñados por individuos pertenecientes a la familia Silvestre-Jiménez, conectada a la red Castro-Rivera y 


\section{Conclusiones}

Urdaneta. Pese a la extralimitación de sus funciones, la Compañía continúo actuando hasta que fue extinguida. No obstante, antes y después de su fundación debieron de existir otras asociaciones mercantiles o particulares que realizaron el comercio de Santo Domingo, entre las que se encontraban algunos miembros de la red mencionada. A pesar de nuestra contribución al conocimiento de esta actividad, sería necesario realizar un estudio más profundo, y específicamente sobre quién componía el sector mercantil de esta isla, lo cuál podría ayudar a completar las conexiones de los hacendados y aclarar un punto fundamental que no ha sido tratado en esta investigación: quiénes les proporcionaban la mano de obra. Aunque se ha apuntado que una parte se introdujo a través de las licencias que concedió el gobernador Manuel Azlor y Urríes a la Real Compañía de Comercio y particulares, otros medios fueron el corso y el intercambio con la parte francesa. Por otro lado la documentación y la escasa bibliografía al respecto sugieren que debieron existir otras vías, como la realizada por comerciantes británicos y el contrabando. La prueba más contundente de este último tipo de aprovisionamiento, sea las concesiones de indulto que la Corona otorgó en 1756 y 1776 a Santo Domingo. También se deja sin respuesta otras preguntas: ¿cuál y cómo fue el tráfico portuario de Santo Domingo, y el de Montecristi?. La designación y apertura del puerto de Montecristi como otro puerto alternativo para la isla desde donde se podía comerciar probablemente supuso un importante incentivo para que prosperaran muchos comerciantes. La consecuencia inmediata fue que Montecristi se convirtiera en centro intermediario, distribuidor de mercaderías para los territorios americanos, sobre todo en tiempos bélicos con licencias que permitían comerciar con neutrales. Estas vías de aprovisionamiento constatan que aún queda mucho por investigar.

Nuestro estudio se detiene en 1795, un momento clave ya que tras el Tratado de Basilea la parte este de la isla es cedida a los franceses, truncando las expectativas de expansión, y obligó a que gran parte de los hacendados emigrasen y se instalaran en otras zonas del continente como Cuba, Puerto Rico y Venezuela, además de la Península. Pocos fueron los que permanecieron. Sus descendientes, algunos de los cuales regresaron a lo largo del siglo XIX, se convirtieron en figuras de primer rango en la guerra dominico-haitiana y en la vida política, económica y cultural de dicho siglo. Estudiar estos temas, su salida e integración 
Ruth Torres Agudo

en esos territorios, así como el regreso de sus descendientes, entre otros son cuestiones pendientes por aclarar de la historia de Santo Domingo, que continúa siendo un lugar periférico dentro de la historiografía americanista. 


\section{FUENTES}

\section{FUENTES DOCUMENTALES}

\section{ESPAÑA}

\section{Archivo General de Indias (Sevilla)}

Sección Gobierno. Audiencia de Santo Domingo. Legajos: 626, 237, 257, 298, 299, 275, 910, 913, 918, 920, 921, 922, 930, 931, 932, 937, 938, 939, 940, 941, 942, 943, 944 ,945,946,947, 948, 949, 950, 951, 952, 953, 954, 955, 956, 957, 958, 959, 960, 961, 962, 963, 964, 965, 966, 967, 968, 969, 970, 971, 972, 973, 974, 975, 976, 977, 978, 979, 980, 981, 982, 983, 984, 985, 986, 987, 988, 989, 990, 991, 992, 993, 994, 995, 996, 997, 998, 999, 1000, 1001, 1002, 1003, 1004, 1005, 1006, 1007, 1008, 1009, 1010, 1011, 1012, 1013, 1014, 1015, 1021, 1022, 1023, 1024, 1025, 1026, 1034, 1035, 1036, 1037, 1038, 1039, 1043, 1044, 1045, 1046, 1053, 1054, 1055, 1058, 1059, 1065, 1069, 1087, 1088, 1089, 1095, 1099, 1100, 1107, 1108, 1109, 2633, 2833.

Contaduría. Legajos: 1069.

Contratación. Legajos: 5524N1,R43; 5527N1,R35; 5437,N2R38; 5466N1R22; 5452N47; 5456N1R12; 5478N1R14; 5488N1,R2; 5498 N40; 5790L3; 5509 N3, R47; 5524N1; 5452, N108.

Escribanía de Cámara. Legajos: 15, 16, 30.

Estado. Legajos: 2 N63; 5B N75; 5A N51; 15,N89; 16 N12; 17N12; 18 N86; 18 N99.

Indiferente General. Legajos: 130N3; 135,N129; 145N8; 145N52; 153N1; 175; 192N195; 232N34; 242N6; 250; 1308; 1579; 1621; 1723; 136N39; 143N60; 2821. 
Mapas y planos: escudos y armas 114-114 bis, 115-115 bis; estampas 9-9bis; Santo Domingo, 552, 566.

Pasajeros. L13,E141; L13,E1091; L14,E889.

Ultramar. Legajos: 9 N5; 16 N19; 94; 165N70; 338; 428.

\section{Archivo Histórico de la Fábrica de Tabacos (Sevilla)}

Legajo 606, Expediente. 9.

\section{Archivo Histórico Nacional (Madrid)}

Sección. Consejos Suprimidos. Legajos: 21.058, 21.465, 21.466, 21.766.

Sección. Ultramar. Libros: 683, 724, 764, 766, 767.

\section{Biblioteca Nacional (Madrid)}

Manuscritos, 11.030.

\section{Archivo de la Universidad de Salamanca}

Libro 802. Libro de licenciado y doctor.

Libro 766. Libro de Bachiller.

Libro 1020. Proceso de Cátedras.

\section{Archivo General de Simancas (Valladolid)}

Secretaría del Consejo de Guerra. Sección Guerra Moderna. Legajos: 7146, 7149, 7150, 7151, 7152, 7253, 7157, 7161, 7162, 7164, 7169, 7198, 7514, 1514.

Dirección General del Tesoro: Inv.2, leg.2; Inv. 2, leg.3; Inv.2, leg.92; Inv.2, leg.6; Inv.24, leg.266; Inv.181, leg.113; Inv. leg.184, leg. 205 у 333; Inv.185, leg. 324. 
Archivo Real de Chancillería (Valladolid)

Real Audiencia y Chancillería de Valladolid. Pleitos Civiles. Escribanía Lapuerta.

Pleitos Olvidados 1378/1.

Archivo de la Real Maestranza de Caballería (Ronda)

Primer Libro Maestro.

Archivo del Ayuntamiento de Legazpia (Guipúzcoa)

Hidalguía C199/6.

Archivo de Guernica (Vizcaya)

Hidalguía Reg. 87, General 1164. 


\section{REPÚBLICA DOMINICANA}

\section{Archivo General de la Nación (Santo Domingo)}

Documentos de la Época Colonial, 1733-1795:

Legajo 9, expediente 6, Comprobantes originales de Datas y Tabacos, 1775; y comprobantes de datas de fortificaciones, 1775.

Legajo 10, expediente 6, Comprobantes de Fortificaciones de Plaza, 1780.

Archivo Real de Bayaguana: Legajo 25 (1773-74).

Archivo de Higüey: Legajo 23, expediente 17.

\section{Archivo del Arzobispado (Santo Domingo)}

Capellanías:

Libro de Capellanías I (1732-1754).

Libro de Capellanías II (1749-1753).

Libro de Capellanías III (1772-1785).

Escrituras de reconocimiento de capellanías:

Legajo 45, estante B, cajón 32.

Legajo 47, estante B, cajón 32.

Legajo 49, estante B, cajón 32.

Libros de Bautismos:

Libros: 3, 5, 6, 7, 9, 11, 12, 13, 14, 15, 17.

Matrimonios y Dispensas matrimoniales:

Expedientes de dispensas matrimoniales (1765-1800).

Ibidem (1800-1806).

Ibidem (1801-1810).

Ibidem (1815). 


\section{IMPRESOS Y DOCUMENTOS}

Alburquerque, Alcibíades, Títulos de los terrenos comuneros de la República dominicana. Ciudad Trujillo, Impresora dominicana, 1961.

Alfau Durán, Vetilio, “Documentos históricos”. CLÍO 83 (Ciudad Trujillo, 1949) p. 15.

, “Dominicanos ilustres. Biografía de Don Jacobo de Villaurrutia”. CLÍO 88 (Ciudad Trujillo, 1950) pp. 113-117.

" "Rasgos biográficos de Dominicanos Célebres por José Gabriel García. Agustín Madrigal”. CLÍO 89 (Ciudad Trujillo, 1951) pp. 27-29.

"Documentos históricos. Partida de bautismo del dramaturgo Francisco

Xavier Foxá y Lecanda”. CLÍO 90 (Ciudad Trujillo, 1951) pp. 100-102.

Armas Medina, Fernando, "La Audiencia de Puerto Príncipe (1795-1853)". AEA XV (Sevilla, 1958) pp. 273-370.

Bayle, Constantino, Los cabildos seculares en la América española. Madrid, Sapientia, 1952.

“Biografía del Licenciado Alonso de Zuazo” en Fernández Navarrete, Martín, Salvá, Miguel y Sainz de Baranda, Pedro, Colección de documentos inéditos para la historia de España. Vaduz, Kraus reprint, 1964, vol. II, pp. 375-379.

Campillo Pérez, Julio Genaro, “Genealogía de Benigno Filomeno de Rojas”. CLÍO 123 (Santo Domingo, 1968) pp. 44-106.

Castro Palomino, José Antonio de, "Breve descripción de la isla española de Santo Domingo, 1783” en Rodríguez Demorizi, Emilio, Relaciones históricas de Santo Domingo. Ciudad Trujillo, Editora Montalvo, 1957, vol. III, pp. 336-347.

Documentos del Archivo General de Indias, "Méritos de Joaquín Pueyo y Leonardo del Monte. Real Audiencia. Batallón de Infantería de Santo Domingo. Fortificaciones y almacenes militares. Restablecimiento del fuero militar". BAGN XI: 11 (Ciudad Trujillo, 1948) pp. 70-87.

, "Súplica de Manuel Heredia y Pimentel a Su Majestad, Cuba 8 febrero de 1804”. BAGN XX: 93 (Ciudad Trujillo, 1957) pp. 175-206.

"Vicente Antonio Faura, abogado de la Real Audiencia. Documento para su biografía”. BAGN XXIV: 104 (Santo Domingo, 1962) pp. 3-45. 
, "Carta de naturaleza otorgada por el rey de España, Carlos III a

Francisco Espaillat”. BAGN XVI: 76 (Ciudad Trujillo, 1953) pp. 101-106.

“Documentos de la Época Colonial, 1733-1795”. BAGN 38-39 (Ciudad Trujillo, 1945) pp. 8-22.

Documentación del Archivo Real de Bayaguana, "Reducción a la mitad del derecho de alcabala por cinco años en el comercio interior de la isla española, 1778”. BAGN 46-47 (Ciudad Trujillo, 1946) pp. 173-190.

Documentación del Archivo Real de Higüey, “Ordenanzas del cabildo de Santo Domingo, 1786”. BAGN 46-47 (Ciudad Trujillo, 1946) pp. 157-172.

Galíndez, Jesús, “Los vascos en la Audiencia de Santo Domingo”. CLÍO 10 (Ciudad Trujillo, 1943) pp. 232-237.

García, José Gabriel, Rasgos biográficos de dominicanos celebres. Santo Domingo, Imprenta García Hermanos, 1875.

García Lluberes, Leonidas, “Miscelánea histórica. (Extractos de los Cuadernos de Apuntes del Historiador García). El ingenio Santa Ana de Engonve”. CLÍO 102 (Ciudad Trujillo, 1955) pp. 39-44. Posteriormente el artículo fue publicado como capítulo en su obra Crítica Histórica. Santo Domingo, Editora Montalvo, 1964, pp. 98-110.

"Gaspar de Arredondo y Pichardo, Memoria de mi salida de la isla de Santo Domingo el 28 de abril de 1805" en Rodríguez Demorizi, Emilio, Invasiones haitianas, 1801, 1805 y 1822. Ciudad Trujillo, Editora Montalvo, 1955, pp. 121160.

Guerra, Juan Carlos de, Ensayo de un padrón histórico de Guipúzcoa, según el orden de sus familias pobladas. San Sebastián, Casa Baroja, 1928.

Hazard, Samuel, Santo Domingo, su pasado y su presente. New York, Harper \& Brothers, publishers, 1873.

Henríquez Ureña, Max, “Las biografías de dominicanos notables escritas por José María Morillas”. CLÍO 68-70 (Ciudad Trujillo, 1945) pp. 5-32.

, “Biografías de dominicanos notables escritas por José María Morillas”. CLÍO 74-75 (Ciudad Trujillo, 1946) pp. 8-25.

Henríquez Ureña, Pedro, La Cultura y las letras coloniales. Buenos Aires, Universidad de Buenos Aires, 1936.

, Obra Crítica. México, FCE, 1960.

Herrera Cabral, César A., “La Audiencia de Santo Domingo”. CLÍO 118-119 (Santo Domingo, 1961-1962) pp. 3-14. 
Jiménez Fernández, Manuel, Bartolomé de las Casas. Delegado de Cisneros para la reformación de las Indias (1516-1517). Sevilla, Escuela de Estudios HispanoAmericanos, 1953, vol. I.

Konetzke, Richard, “La formación de la nobleza en Indias”. AEA III: 10 (Sevilla, 1951) pp. 328-358.

Colección de documentos para la historia de la formación social de Hispanoamérica (1493-1810). Madrid, Instituto Jaime Balmes-CSIC, 1953-1962, III vols.

Larrazábal Blanco, Carlos y Azpurua, Ramón, “José María de Rojas”. CLÍO 94 (Ciudad Trujillo 1952) pp. 153-158.

Larrazábal Blanco, Carlos, “Una familia fundadora de San Rafael”. CLÍO 92 (Ciudad Trujillo, 1952) pp. 19-20.

106-109. , “Raimundo Rendón Sarmiento”. CLÍO 93 (Ciudad Trujillo, 1952) pp. 67-81.

, “Familias de Santo Domingo”. CLÍO 103 (Ciudad Trujillo, 1955) pp.

Leddy Phelan, John, “Authority and Flexibility in the Spanish Imperial Bureaucracy”. Administrative Science Quarterly V: I (Durham, 1960) pp. 47-65.

Lohmann Villena, Guillermo, Los americanos en las órdenes nobiliarias (15291900). Madrid, CSIC, 1947, II vols.

" "Un hombre de negocios en la colonización de América: el Licenciado Gaspar de Espinosa”. Estudios Americanos 104 (Sevilla, 1960) pp. 131-141.

, Les Espinosa. Une famille d'hommes d' affaires en Espagne et aux Indes à l'époque de la colonisation. Paris, École Practique des Hautes Études, 1968.

Lovatón, Lugo, “El Tratado de Basilea”. BAGN 68 (Ciudad Trujillo, 1951) pp. 86119.

(Colección), “Archivo General de Indias”. BAGN III: 13 (Ciudad Trujillo, 1940) pp. 368-392.

143-161. “Archivo General de Indias”. BAGN III: 10 (Ciudad Trujillo, 1940) pp. 
"Memorial del Licenciado Gregorio Semillán Campuzano, 16 de agosto de 1687” en Rodríguez Demorizi, Emilio, Relaciones históricas. Ciudad Trujillo, Editora Montalvo, 1957, vol. III, pp. 273-295.

Miralles de Imperial y Gómez, Claudio, “Del linaje y armas del primer cronista de Indias, el madrileño Gonzalo Fernández de Oviedo”. Revista de Indias 71 (Madrid, 1958) pp. 73-126.

Monte y Tejada, Antonio del, Historia de Santo Domingo. Ciudad Trujillo, Secretaría de Estado y Educación y Bellas Artes, 1952-1953 (1890), III vols.

Moreau de Saint-Méry, Méderic Louis Élie, Descripción de la parte española de Santo Domingo. Ciudad Trujillo, Editora Montalvo, 1944.

Morillas, José María, "Biografía de dominicanos notables. Francisco Javier Caro y Torquemada, ministro del Real y Supremo Consejo de la Cámara de Indias y Consejero de Estado”. CLÍO 74-75 (Ciudad Trujillo, 1946) pp. 8-17.

"Excelentísimo e Ilustrísimo, señor Francisco Javier Caro y Torquemada”. CLÍO 74-75 (Ciudad Trujillo, 1946) pp. 8-17.

Nieto Cortadellas, Rafael, Dignidades nobiliarias en Cuba. Madrid, Cultura Hispánica, 1954.

Ots Capdequí, José María, Manual de historia del derecho español en las Indias y del derecho propiamente indiano. Buenos Aires, Editorial Losada, 1945.

, El Estado español en las Indias. México, FCE, 1946.

España en América: Las instituciones coloniales. Bogotá, Universidad Nacional de Colombia, 1952.

, España en América. El régimen de tierras en la época colonial. México, FCE, 1959.

Historia del Derecho Español en América y del Derecho Indiano. Madrid, Aguilar, 1969.

Palm, Edwin Walter, Los monumentos arquitectónicos de La Española: con una introducción a América. Barcelona, Seix y Barral, 1955, II vols.

Peña Batlle, Manuel Arturo, El tratado de Basilea y la desnacionalización del Santo Domingo español. Ciudad Trujillo, Impresora dominicana, 1952.

Polanto Brito, Hugo Eduardo, Recuerdos de familia. Ciudad Trujillo, Santo Domingo, 1948.

Ratekin, Mervyn, “The early sugar industry in Española”. HAHR XXXIV (Duke, 1958) pp. 1-20. 
Reglamento para el comercio libre 1778. Sevilla, Escuela de Estudios HispanoAmericanos, 1978.

Reyes, Félix, Descripción histórica de las antiguas haciendas, estancias y hatos, que durante la era colonial española, existieron en el partido de los Ingenios de Nigua, hoy San Cristóbal. Ciudad Trujillo, Editora Montalvo, 1950.

Rodríguez Demorizi, Emilio, "Edificaciones de Santo Domingo". BAGN I: 3 (Ciudad Trujillo, 1940) pp. 201-210.

1944.

Juan Isidro Pérez, el ilustre loco. Ciudad Trujillo, Editora Montalvo, Invasiones haitianas de 1801, 1805 y 1822. Ciudad Trujillo, Editora Montalvo, 1955.

_, “Invasión inglesa de 1655”. BAGN 88-89 (Ciudad Trujillo, 1956) pp. 6161.

"Apuntes y documentos: el real derecho de alcabala. Libro de cargo y data de 1793”. CLÍO 108 (Ciudad Trujillo, 1956) pp. 165-185.

, Relaciones históricas de Santo Domingo. Ciudad Trujillo, Editora Montalvo, 1957, vol. III.

, Cesión de Santo Domingo a Francia. Correspondencia de Godoy, García, Roume, Hedouville, Rigaud y otros, 1795-1802. Ciudad Trujillo, Impresora Dominicana, 1958.

133.

, “Familias Hispanoamericanas”. BAGN 95 (Ciudad Trujillo, 1958) pp. 6$\overline{147-236}$ pp. 269-374.

“Familias Hispanoamericanas”. BAGN 97-98 (Ciudad Trujillo, 1958) Familias Hispanoamericanas. Ciudad Trujillo, Editora Montalvo, 1959.

Ruíz Tejada, Ramón, Estudio sobre la propiedad inmobiliaria en la República Dominicana. Ciudad Trujillo, Editora del Caribe, 1952.

Serrano y Sanz, Manuel, Orígenes de la dominación española en América: estudios históricos. Madrid, Bailly/Baillére, 1918.

Schäfer, Ernst Hermann Johann, El Consejo Real y Supremo de Indias. Sevilla, Escuela de Estudios Hispano-Americanos, 1935-1947, II vols. 
Tejera, Emiliano,"Documentos antiguos”. La Cuna de América 10 (Santo Domingo, 1915) pp. 1-10.

Utrera, Fray Cipriano de, Don Rodrigo de Bastidas. Santo Domingo, Padres Franciscanos Capuchinos, 1930.

, Universidades de Santiago de la Paz y de Santo Tomás de Aquino y Seminario Conciliar de la Ciudad de Santo Domingo de la Isla Española. Santo Domingo, Padres Franciscanos Capuchinos, 1932.

, Centenario de José María Heredia (1839-1939). Homenaje de la República Dominicana. Ciudad Trujillo, Editorial Franciscana, 1939. 1939) pp. 7-13.

“Dominicanos insignes en el exterior”. CLÍO 33 (Ciudad Trujillo, , “Don Luís Franco de Acevedo”. BAGN XII: 61 (Ciudad Trujillo, 1949) pp. 372-385.

, “El Tapado”. CLÍO 85 (Ciudad Trujillo, 1949) pp. 114-144.

, El tapado de México y el de Santo Domingo. Ciudad Trujillo, Tipografía Franciscana, 1950.

, “Morell de Santa Cruz”. CLÍO 90 (Ciudad Trujillo, 1951) pp. 57-74.

, Historia militar de Santo Domingo (Documentos y noticias). Ciudad Trujillo, Tipografía Franciscana, 1953, III vols.

, “Constituciones del cabildo eclesiástico de Santo Domingo”. CLÍO 88 (Ciudad Trujillo, 1958) pp. 85-93.

, "Epigrafía colonial. Genealogía de las familias solariegas de Bastidas, Fernández de Oviedo y Valdés de Fuenmayor, Dávila y entronques (1468-1926)” en Utera, Fray Cipriano de, Santo Domingo. Dilucidaciones Históricas. Santo Domingo, Secretaría de Estado de Educación, Bellas Artes y Cultos, 1978 (1927), vol. I, pp.425-492.

Veragua, Duque de, "El Archivo de la Casa ducal de Veragua”. Hidalguía 28 (Madrid, 1958) pp. 413-424.

“El ducado de Veragua”. Hidalguía 37 (Madrid, 1959) pp. 785-800. 


\section{BIBLIOGRAFÍA}

Alcántara Almánzar, José, y Hernández Caamaño, Ida, Huella y memoria E. León Jimenes: un siglo en el camino nacional 1903-2003. Santo Domingo, Grupo León-Jimenes, 2003.

Alcántara, Manuel (ed.), América Latina. Realidades y perspectivas. I Congreso Europeo de Latinoamericanistas. Salamanca, Universidad de Salamanca, 1997, Colección Aquilafuente $n^{0} 7$.

Alfau Durán, Vetilio, Rasgos biográficos de dominicanos célebres. Santo Domingo, Editora del Caribe, 1971.

" "Don Miguel de Lavastida. Apuntes y documentos para su biografía". CLÍO 139 (Santo Domingo, 1982) pp. 95-125.

(1945).

Mujeres de la Independencia. Santo Domingo, Editora Búho, 1999

Álvarez Cuartero, Izaskun, “Amigos desde La Habana: confabulaciones de una Sociedad” en Risco, Antonio y Urkia, José María (eds.), I Seminario Peñaflorida "Amistades y sociedades en el siglo XVIII. Real Sociedad Bascongada de los Amigos del País”. San Sebastián, RSBAP-Université de Toulouse Le Mirail, 2000, pp. 185-200.

Álvarez Gautier, María José, “Esteban Fernández Palomares: su carrera en el Batallón Fijo y su descendencia”. Raíces 7 (Santo Domingo, 1995) pp. 27-30.

Amores Carredano, Juan B., Cuba en la época de Ezpeleta (1785-1900). Pamplona, Eunsa, 2000.

Ana Concepción, Patria Quisqueya, Mas familias dominicanas. Investigación genealógica. Santo Domingo, IDG, 1995, vol. V.

Andreu Ocariz, Juan José, "La rebelión de los esclavos de Boca Nigua”. AEA XXVII (Sevilla, 1970) pp. 551-581.

Andrés Gallego, José (coord.), Navarra y América. Madrid, Mapfre, 1992.

Apestegui, Cruz, Los ladrones del mar. Piratas en el Caribe. Corsarios, filibusteros y bucaneros 1493-1700. Madrid, Lunwerg, 2000. 
Arnaiz, Francisco José, Más luces que sombras. Santo Domingo, Comisión Dominicana Permanente para la celebración del Quinto Centenario, 1989.

Arnold, Linda, Burocracia y burócratas en México, 1742-1835. México, Grijalbo, 1988.

Arranz Márquez, Luís, Repartimiento y encomiendas en la Isla Española. (El repartimiento de Alburquerque de 1514). Santo Domingo, Fundación García Arévalo, 1991.

Arroyo, Lara, "Redes de influencia: relaciones privilegiadas en el comercio colonial a finales del siglo XVIII: los Marticorena y su correspondencia epistolar”. Nuevo Mundo Mundos Nuevos n ${ }^{0}$ 7, 2007, disponible en: $<$ http:/nuevo.mundorevues.org/document3213html.> [con acceso el 5 de enero de 2007].

Arthur Noel, Víctor José, "Vínculos y grados de parentesco”. Areíto, 19 de marzo de 2005. Artículo que está disponible desde Internet: <http://genealogiadominicana.com/idg/capsulas/marzo2005/marzo200519.htm> [con acceso el 16 de septiembre de 2005].

Balboa Navarro, Imilcy, "El asalto a los realengos 71750-1839)” en Balboa Navarro, Imilcy, y Piqueras, José A. (eds.), La excepción americana. Cuba en el ocaso del imperio continental. Valencia, Historia Social, 2006, pp. 55-78.

Balcácer, Juan Daniel, Juan Pablo Duarte. El Padre de la Patria. Santo Domingo, Editora Amigo del Hogar, 2001.

Balmori, Diana, Stuart F. Voss y Wortman, Miles, Las alianzas de familias y la formación del país en América Latina. México, FCE, 1990.

Barrientos Grandon, Javier, "Guía prosopográfica de la judicatura letrada en Indias 1503-1898” en Andrés-Gallego, José, Nuevas aportaciones a la historia jurídica de Iberoamérica. Madrid, Fundación Histórica Tavera, 2000. [CD-ROM]

Barrientos Márquez, María del Mar, "Dominga Arambule: una dominicana relacionada con Cádiz" en VII Encuentro de la Ilustración al Romanticismo. Cádiz, América y Europa ante la modernidad. La mujer en los siglo SXVIII y XIX. Cádiz, Universidad de Cádiz, 1994, pp. 165-174. 
"Presencia gaditana en el Santo Domingo del siglo XVIII. Aspectos culturales: sociales, económicos y religiosos”. Trocadero 8-9 (Cádiz, 1996-1997) pp. 331-349.

, Gaditanos en las Antillas. Un acercamiento a su realidad socioeconómica a través de los expedientes de Bienes de Difuntos durante el siglo XVII. Cádiz, Universidad de Cádiz, 2000.

Baud, Michel, "El surgimiento de un campesinado criollo. La producción tabacalera en La Española, 1500-1870”. ECOS 5 (Santo Domingo, 1996) pp. 9-41.

Bernard, Gildas, Le Secrétariat D’Etat et le Conseil Espagnol des Indes (17001808). Paris, Centre de recherches d’histoire et de philologie, 1972.

Bertrand, Michel, "En torno a una problemática de la administración colonial: la real hacienda de Nueva España (1680-1770)”. AEA XLVI (Sevilla, 1989) pp. 195-217.

"En busca de una identidad social: redes familiares y elite colonial en tiempos de crisis.” Anuario de Estudios Bolivarianos 7-8 (Caracas, 19981999) pp. 97-117.

, Grandeur et misère de l'office. Less officiers de finances de Nouvelle-Espagne XVII-XVIII Siécles. Paris, Publications de la Sorbonne, Paris, 1999.

"Élites y configuraciones sociales en Hispanoamérica colonial". Revista de Historia 13 (Nicaragua, 1999) pp. 1-15.

, "La élite colonial en la Nueva España del siglo XVIII: Un planteamiento en términos de redes sociales” en Schröter, Bernd y Büschges, Christian (comps.), Beneméritos, aristócratas y empresarios. Identidades y estructuras sociales de las capas altas urbanas en América Hispánica. Frankfurt, Iberoamericana, 1999, pp. 35-51.

, "Élites, parentesco y relaciones sociales en Nueva España.” Tiempos de América 3-4 (Castellón, 1999) pp. 57-66.

, "De la familia a la red de sociabilidad". Revista Mexicana de Sociología LXI: 2 (México, 1999) pp. 107-135.

"Los oficiales reales de Nueva España: una aproximación al estudio de un grupo de poder en la sociedad novohispana (siglos XVII-XVIII)" en Menegus, Margarita (comp.), Universidad y sociedad en Hispanoamérica. Grupos de poder siglos XVIII y XIX. México, UNAM, 2001, pp. 15-39. 
y Dedieu, Jean Pierre,“¿Vino joven en odres viejas? Prosopografía y relaciones sociales en la Monarquía Hispánica” en Cancho Rodríguez, Miguel (coord.), Historia y perspectivas de investigación. Estudios en memoria del profesor Ángel Rodríguez Sánchez. Mérida, Editora Regional de Extremadura, 2002, pp. 31-37.

"Los hombres de la Real Hacienda en Veracruz: ¿burócratas o empresarios? en Acosta Rodríguez, Antonio, González Rodríguez, Adolfo y Vila Vilar, Enriqueta (coords.), La Casa de Contratación y la navegación entre España y las Indias. Sevilla, CSIC-Fundación El Monte, 2004, pp. 863-883.

"Las élites sociales de Guatemala en vísperas de la Independencia: estructuras y dinamismos internos” en Álvarez Cuartero, Izaskun, y Sánchez Gómez, Julio (eds.), Visiones y revisiones de la independencia americana. México, Centroamérica y Haití. Salamanca, Universidad de Salamanca. Aquilafuente, 2005, pp. 37-59.

"Poder, negocios y familia en Guatemala a principios del siglo XIX". Historia Mexicana LVI: 3 (México, 2007) pp. 863-917.

Boshc, Juan, Composición social dominicana. Historia e interpretación. Santo Domingo, Editora Alfa \& Omega, 1997 (1970).

La pequeña burguesía en la historia de la República Dominicana. Santo Domingo, Editora Alfa \& Omega, 2003 (1984-1985).

Bestard Camps, Joan, "La estrechez del lugar. Reflexiones en torno a las estrategias matrimoniales cercanas” en Chacón Jiménez, Francisco, y Hernández Franco, Juan (eds.), Poder, familia y consanguinidad en la España del Antiguo Régimen. Barcelona, Anthropos, 1992, pp. 107-175.

Bouché Español, Luís, Memorial de Lope de Villegas. Historia del linaje de Villegas. La isla de Santo Domingo a principios del siglo XVII. Madrid, Impresión Luís Español Bouché-Breve descripción de la colección Semprún Fernández de Lara, 1997.

Brading, David, Mineros y comerciantes en el México borbónico (1763-1810). México, FCE, 1993 (1971).

Haciendas and Ranchos in the Mexican Bajío. León 1700-1860. Cambridge, Cambridge University Press, 1978.

Burkholder, Mark A., y Chandler, D. S., De la impotencia a la autoridad. La Corona española y las Audiencias en América, 1687-1808. México, FCE, 1984 (1977). 
, Biographical dictionary of audiencia ministers in the Americas: 16871821. Westport, Greenwood Press, 1982.

Burkholder, Mark A., Biographical Dictionary of Councilors of the Indies, 17171808. New York, Greenwood Press, 1986.

Büschges, Christian, "Las leyes del honor. Honor y estratificación social en el distrito de la Audiencia de Quito (siglo XVIII)”. Revista de Indias 209 (Madrid, 1997) pp. 68-77.

"Linaje, patrimonio y prestigio. La nobleza titulada de la ciudad de Quito en el siglo XVIII”. AEA LVI: I (Sevilla, 1999) pp. 123-145.

, "La formación de una nobleza colonial. Estructura e identidad de la capa social alta de la ciudad de Quito (siglos XVI-XVIII) en Schröter, Bernd, y Büschges, Christian (eds.), Beneméritos, aristócratas y empresarios. Identidades y estructuras sociales de las capas altas urbanas en América hispánica. Frankfurt, Iberoamericana, 1999, pp. 215-231.

y Langue, Frédérique, “¿Las élites de la América española, del éxito historiográfico al callejón interpretativo? Reconsideraciones” en Büschges, Christian y Langue, Frédérique (coords.), Excluir para ser. Procesos identitarios y fronteras sociales en la América hispánicaa (XVII-XVIII). Vervuert, AHILAIberoamericana, 2005, pp. 9-22.

Calvo, Tomás, Poder, religión y sociedad en la Guadalajara del siglo XVII. México, CEMCA-H, Ayuntamiento de Guadalajara, 1991.

Campillo Pérez, Julio Genaro, Francisco Espaillat y el desarrollo del Cibao. IDG, Santo Domingo 1985.

Benigno Filomeno de Rojas. Política y Economía. Santo Domingo, Editora Alfa \& Omega, 1993.

Peña Gómez. Origen y nacimiento. Investigación genealógica. Santo Domingo, Editora de Colores, 1996.

, Dr. Andrés López Medrano y su legado humanista. Santo Domingo, Editora Corripio, 1999.

Canedo, Mariana, “Tierra sin gente y gente con tierra. La dinámica del acceso y de la transferencia de la tierra en una zona de colonización temprana de la Campaña de Buenos Aires. (Los Arroyo, 1600-1850)" en Zebeiro, Blanca, Bjerg, María, y Otero, Hernán (comps.), Reproducción social, y sistemas de herencia en una perspectiva comparada. Europa y los países nuevos (siglos XVIII al XX). Tandil, Instituto de Estudios Históricos-Sociales, 1998, pp. 83-119. 
Capel, Horacio, García, Lourdes, Omar Moncada, José, Olive, Francesc, Quesada, Santiago, Rodríguez, Antonio, Sánchez, Joan-Eugeni, y Tello, Rosa, Los Ingenieros Militares en España (Siglo XVIII). Repertorio biográfico e inventario de su labor científica y espacial. Barcelona, Universidad de Barcelona, 1983.

Carasa Soto, Pedro, "La recuperación de la historia política y la prosopografía” en Carasa Soto, Pedro (ed.), Elites. Prosopografía contemporánea. Valladolid, Universidad de Valladolid, 1994, pp. 41-51.

Caro Álvarez, José Antonio, Las murallas de Santo Domingo. Madrid, Gráficas Martín, 1973.

, "Don Agustín Ignacio Emparán y Orbe y el código negro carolino". Serie Conferencias del Museo del hombre dominicano 4 (Santo Domingo, 1974) pp. 1-16.

Caro Baroja, Julio, La hora de Navarra del siglo XVIII (personas, familias, negocios e ideas). Pamplona, Institución Príncipe de Viana, 1985 (1969).

Casa Rivas, José María de la, "Los diezmos como fuente de ingresos de la Iglesia Dominicana (1492-1577)”. Casas Reales 12 (Santo Domingo, 1980) pp. 43-73.

Cassá, Roberto, Los taínos de La Española. Santo Domingo, Editora Búho, 1990.

“Historiografía de la República Dominicana”. ECOS 1 (Santo Domingo, 1993) pp. 9-39. También publicada en inglés "Historiography of the Dominican Republic" en Higman, B.W. (ed.), General history of the Caribbean. Methodology and historiography of the Caribbean. London, Unesco publishing, 1999, vol. VI, pp. 388-416.

y Rodríguez, Genaro, "Consideraciones alternativas acerca de las rebeliones de esclavos en Santo Domingo”. ECOS 3 (Santo Domingo, 1994) pp. 155-191.

Directorio de Archivos de la República Dominicana. Madrid, Fundación Histórica Tavera, 1996, Documentos Tavera $\mathrm{n}^{0} 1$.

Historia social y económica de la República Dominicana. Santo Domingo, Editora Alfa \& Omega, 1996-1998, II vols. Publicados recientemente con alguna ampliación pero con el mismo título y editora, 2003-2004, II vols.

, "Estado de los avances archivísticos en República Dominicana". Documento presentado en la Exposición y Conferencia Internacional de Archivos (Excol 07, Bogotá, Colombia del 23 al 27 de mayo de 2007), en <http://www.crib.com/doc/23835/roberto-cassa> [con acceso el 1 de junio de 2007]. 
Cassá Bernardo de Quirós, Constantino José, "La unión de los mayorazgos de Oviedo y Bastidas". Areíto, 16 de julio de 2005. Disponible en: $<$ http://genealogiadominicana.com/idg/capsulas/julio2005/julio200516.htm> [con acceso el 16 de septiembre de 2005].

, y “El mayorazgo Dávila”. Areíto, 19 de noviembre de 2005. En:

<http://www.idg.org.do/capsulas/noviembre2005/noviembre200519.htm.> [con acceso el 7 de agosto de 2005].

Cassaús Arzú, Marta Elena, "Las redes familiares vascas en la configuración de la élite de poder centroamericana" en Escobedo Mansilla, Ronald, Zaballa Beascoechea, Ana y Álvarez Gila, Óscar (eds.), Emigración y redes sociales de los vascos en América. Vitoria, Universidad del País Vasco, 1996, pp. 285-315.

Casey, James, y Hernández Franco, Juan (eds.), Familia, Parentesco y Linaje. Siglos XV-XIX. Murcia, Universidad de Murcia, 1997.

Castañeda, Carmen (coord.), Círculos de poder en la Nueva España. México, Porrúa, 1998.

Castillo Moreta, Américo, La justicia en Santo Domingo del siglo XVI. Santo Domingo, Colección Banreservas, 1998.

Castillo Palma, Norma Angélica, "Los estatudos de "pureza de sangre" como medio de acceso a las elites: el caso de la región de Puebla” en Castañeda, Carmen (coord.), Círculos de poder en la Nueva España. México, Porrúa, 1998, pp. 105-129.

"Catálogo de los fondos del Archivo de la Real Audiencia de Santo Domingo que se conservan en el Archivo Nacional de Cuba (1708-1800)” en Malagón Barceló, Javier, El distrito de la Audiencia de Santo Domingo en los siglos XVI a XIX. Santiago, UCMM, 1977, pp. 109-258.

Chacón Jiménez, Francisco, "Hacia una redefinición de la estructura social en la España del Antiguo Régimen a través de la familia y las relaciones de parentesco”. Historia social 21 (Alicante, 1995) pp. 75-104.

Chez Checo, José, El ron en la historia dominicana. Desde los antecedentes hasta finales del siglo XIX. Santo Domingo, Centenario de Brugal \& CO., C. Por A., 1888-1988, 1988.

La familia Montás en la historia dominicana 1716-1995. Santo Domingo, Fundación Montás, 1996, pp. 9-26.

Chez Checo, José, Veloz Maggiolo, Marcio y Mateo, Andrés, Santo Domingo. Elogio y memoria de la ciudad. Santo Domingo, Codetel, 2002.

Clavero, Bartolomé, Mayorazgo. Propiedad feudal en Castilla, 1369-1836. Madrid, Siglo XXI, 1989. 
Colección Biografías Dominicanas, Minerva Mirabal. Santo Domingo, Editora Alfa \& Omega, 2000.

Colección César Herrera, Tratado de límites con franceses 1772. Santo Domingo, Patronato de la Ciudad Colonial de Santo Domingo, 1995.

Colección de documentos-país del Instituto de Iberoamérica y Portugal, "Datos de opinión: Elites Parlamentarias Latinoamericanas. República Dominicana (19942006)” en <http://iberoame.usal.es/pdfs/BoletinN8.pdf.> [con acceso el 1 de junio de 2007].

Cordero, Walter, "El bohío dominicano: de lo real a lo simbólico". CLÍO 165 (Santo Domingo, 2003) pp. 103-128.

Cordero Michel, Emilio, La revolución haitiana y Santo Domingo. Santo Domingo, Editora Búho, 2000 (1975).

, “Hernando Gorjón, Hombre de Empresa y de Presa”. CLÍO 155 (Santo Domingo, 1996) pp. 93-113.

Contin Alfau, Melchor, El Hato Mayor del Rey. Reseña Histórico-Geográfica Tradicional y Religiosa. Santo Domingo, Editora Taller, 1991.

"Datos de opinión: Elites Parlamentarias Latinoamericanas. Republica Dominicana (1994-2006)”, disponible desde Internet en: $<$ http://iberoame.usal.es/pdf/BoletinN8.pdf.> [con acceso el 1 de junio de 2007 ].

Dedieu, Jean Pierre, "El grupo personal político y administrativo español del siglo XVIII” en Carasa Soto, Pedro (ed.), Elites. Prosopografía contemporánea. Valladolid, Universidad de Valladolid, 1994, pp. 315-326.

, "La familia: ¿Una clave para entender la historia política? El ejemplo de la España moderna”. Studia Histórica 18 (Salamanca, 1998) pp. 201-233.

"Un instrumento para la historia social: la base de datos Ozanam". Cuadernos de Historia Moderna 24 (Madrid, 2000) pp. 185-205.

"Procesos y redes. La historia de las instituciones administrativas de la época moderna, hoy” en Castellano, Juan Luis, Dedieu, Jean Pierre y LópezCordón, María Victoria (eds.), La pluma, la mitra y la espada. Madrid, Marcial Pons, pp. 13-30.

Deive, Carlos Esteban, La esclavitud del negro en Santo Domingo (1492-1844). Santo Domingo, Museo del hombre dominicano, 1980, II vols.

Heterodoxia e inquisición en Santo Domingo, 1492-1822. Santo Domingo, Editora Taller, 1983. 
, Los refugiados franceses en Santo Domingo. Santo Domingo, Universidad Nacional Pedro Henríquez Ureña, 1984.

, Los cimarrones del maniel de Neiba. Santo Domingo, Banco Central de la República Dominicana, 1985.

, Las emigraciones Dominicanas a Cuba (1795-1808). Santo Domingo, Fundación Cultural Dominicana, 1989.

Las emigraciones canarias a Santo Domingo (siglos XVII y XVIII) Santo Domingo, Fundación Cultural Dominicana, 1991.

, La Española y la Esclavitud del Indio. Santo Domingo, Fundación García Arévalo, 1995.

, Vodu y Magia en Santo Domingo. Santo Domingo, Fundación Cultural Dominicana, 1996.

"Las bibliotecas privadas en la ciudad de Santo Domingo durante el periodo colonial” en VVAA., La ciudad de Santo Domingo en la literatura. Santo Domingo, Comisión municipal para la conmemoración del V Centenario de la ciudad de Santo Domingo, 1996, pp. 135-147.

Los guerrilleros negros. Esclavos fugitivos y cimarrones en Santo Domingo. Santo Domingo, Fundación Cultural Dominicana, 1997.

, La mala vida. Delincuencia y Picaresca Española de Santo Domingo. Santo Domingo, Fundación Cultural Dominicana, 1997.

Dérouet, Bernard y Goy, Joseph, “Transmitir la tierra. Las inflexiones de una problemática de la diferencia” en en Zebeiro, Blanca, Bjerg, María, y Otero, Hernán (comps.), Reproducción social, y sistemas de herencia en una perspectiva comparada. Europa y los países nuevos (siglos XVIII al XX). Tandil, Instituto de Estudios Históricos-Sociales, 1998, pp. 15-50.

Dobal, Carlos, “Fray Gaspar Gorricio gran amigo del descubridor”. CLÍO 156 (Santo Domingo, 1997) pp. 22-26.

Domínguez, Jaime de Jesús, "La inexistencia de una oligarquía económica en la época colonial”. CLÍO 163 (Santo Domingo, 2002) pp. 171-210.

Domínguez Company, Francisco, "Elementos históricos determinantes en el estudio de las instituciones locales de América”. Revista de Historia de América 75-76 (Sevilla, 1973) pp. 179-195.

“Élites, Familias y Redes de poder en las Sociedades Mesoamericanas”. Revista de Historia 13 (Nicaragua, 1999) Número monográfico. 
Elites Parlamentarias iberoamericanas. Equipo de investigación sobre las elites parlamentarias. República Dominicana. Salamanca, Instituto de Estudios de Iberoamérica y Portugal, 1998, vol. X.

Eiras Roel, Antonio (ed.), La emigración española a Ultramar 1492-1914. Madrid, Tabapress, 1991.

Escobedo Mansilla, Ronald, Zaballa Beascoechea, Ana y Álvarez Gila, Óscar (eds.), Emigración y redes sociales de los vascos en América. Vitoria, Universidad del País Vasco, 1996.

“Escritura de dote de Josefa Pepín González, 17 de enero de 1775” en Rodríguez Demorizi, Emilio, Milicias de Santo Domingo (1786-1821). Santo Domingo, Editora del Caribe, 1978, pp. 377-381.

Espaillat Cabral, Pedro Ramón, “Origen de la familia Espaillat”. Eme-Eme Estudios Dominicanos V: 26 (Santiago de los Caballeros, 1976) pp. 53-63.

Espinal Hernández, Edwin, "Presencia catalana en Santiago". Eme-Eme Estudios Dominicanos 86-88 (Santiago de los Caballeros, 1990-1991) pp. 9-24.

Nosotros. La familia Pichardo-Román. Estudio Genealógico. Santo Domingo, IDG, 1990.

Extractos de las Juntas Generales celebradas por la Real Sociedad Bascongada de los Amigos del País (1786-1788). San Sebastián, Caja de Ahorros Municipal de San Sebastián, 1985, vol. IX.

Fernández Pérez, Paloma, El rostro familiar de la metrópoli. Redes de parentesco y lazos mercantiles en Cádiz, 1700-1812. Madrid, Siglo XXI, 1997.

Fernández Rodríguez, Aura Celeste, “Origen y evolución de la propiedad de los terrenos comuneros en la República Dominicana”. Eme-Eme Estudios Dominicanos 51 (Santiago de los Caballeros, 1980) pp. 5-45.

Félix Cabral de Souza, George, Elite y ejercicio de poder en el Brasil colonial: la Cámara Municipal de Recife (1710-1822). Salamanca, Universidad de Salamanca, 2007. Tesis Doctoral inédita.

Ferreiro, Juan Pablo, "Todo queda en familia...política y parentesco entre las familias notables de Jujuy del siglo XVII” en Schröter, Bernd y Büschges, Christian (eds.), Beneméritos, aristócratas y empresarios. Identidades y estructuras sociales de las capas altas urbanas en América hispánica. Frankfurt, Iberoamericana, 1999, pp. 251-273.

Ferreras, Ramón Alberto, Breve historia de Santo Domingo. Desde la orogénesis hasta el año 1992. Santo Domingo, Editorial del Nordeste, 1992. 
Flores Galindo, Alberto, Aristocracia y plebe en Lima, 1760-1830: estructura de clases y sociedad colonial. Lima, Mosca azul editores, 1984.

García Bernal, Manuela Cristina, "Las élites capitulares indianas y sus mecanismos de poder en el siglo XVII”. AEA LVII: 1 (Sevilla, 2000) pp. 89-110.

García, José Gabriel, Rasgos biográficos de dominicanos célebres. (Compilación y notas de Vetillo Alfau Durán). Santo Domingo, Editora del Caribe, 1971.

Compendio de la Historia de Santo Domingo. Santo Domingo, Central de Libros, 1983, (1878), IV vols.

García Fernández, Máximo, Herencia y patrimonio familiar en la Castilla del Antiguo Régimen (1650-1840): efectos socioeconómicos de la muerte y la partición de bienes. Valladolid, Universidad de Valladolid, 1995.

Garavaglia, Juan Carlos, y Grosso, Juan Carlos, Puebla desde una perspectiva microhistórica. Tepeaca y su entorno agrario: población, producción e intercambio (1740-1870). México, Editorial Claves Latinoamericanas, 1994.

García del Pino, César, La visita eclesiástica (Morel de Santa Cruz). La Habana, Editorial de Ciencias Sociales, 1985.

García Menéndez, Alberto, Los jueces de apelación de La Española y su residencia (1511-1519). Santo Domingo, Museo de las Casas Reales, 1981.

García Muñiz, Humberto, “El bufete corporativo Peynado \& Peynado en la República Dominicana y su importancia para los estudios caribeños”. CLÍO 170 (Santo Domingo, 2005) pp. 235-282.

Garrido, Víctor, Espigas históricas. Santo Domingo, Academia Dominicana de la Historia, 1972.

Los Puello. Santo Domingo, Secretaría de Estado de Educación, Bellas Artes y Cultos, 1974.

Gascón, Margarita, “The Military of Santo Domingo, 1720-1764”. HAHR 73:3 (Durham, 1993) pp. 431-452.

Gelman, Jorge Daniel, "Cabildo y élite local. El caso de Buenos Aires en el siglo XVII”. HISLA 6 (Buenos Aires, 1985) pp. 3-20.

Gellner, Ernest, Patronos y clientes. Gijón, Ediciones Jucar, 1986.

Gerón, Cándido, Diccionario de autores dominicanos. Santo Domingo, Editora de Colores, 2001.

, Diccionario político dominicano (1821-2000). Santo Domingo, Editora de Colores, 2001. 
Gíl-Bermejo García, Juana, La Española. Anotaciones históricas (1600-1650). Sevilla, Escuela de Estudios Hispano-Americanos, 1983.

Gómez de Liaño y González, Fernando, Diccionario jurídico. Oviedo, Forum, 1991.

González Enciso, Agustín, "Introducción. Del rey ausente al rey distante” en González Enciso, Agustín, y Usunáriz Garayoa, Jesús Ma . (dirs.), Imagen del rey, imagen de los reinos. Las ceremonias públicas en la España Moderna (15001814). Pamplona, 1999, pp. 1-18.

González, Raymundo, "Ideología del progreso y campesinado en el siglo XIX”. ECOS 2 (Santo Domingo, 1993) pp. 25-43.

, “Dos relaciones inéditas del siglo XVIII”. ECOS 2 (Santo Domingo, 1993) pp. 183-203.

"De la reforma de la propiedad a la reforma rural”. ECOS 4 (Santo Domingo, 1995) pp. 179-192.

, “La leva de 1782”. CLÍO 161 (Santo Domingo, 1999) pp. 26-80.

, “Copia de 1787 del expediente sobre el inventario, tasación y almoneda de los bienes materiales que fueron de la Compañía de Jesús en Santo Domingo (año 1768) (incompleto)”. Revista Estudios Sociales XXXIII: 122 (Santo Domingo, 2000) pp. 79-123.

"La figura del montero en la formación histórica del campesinado dominicano (Discurso de ingreso como miembro de número de la Academia Dominicana de la Historia)”. CLÍO 168 (Santo Domingo, 2004) pp. 75-96.

Gonzalbo Aizpuru, Pilar y Rabell Romero, Cecilia (comps.), La familia en el mundo iberoamericano. Mexico, UNAM, 1994.

Gonzalbo Aizpuru, Pilar (coord.), Familias novohispanas: siglo XV al XIX. México, Colegio de México, 1991.

González Díaz, Rafaela, "Estado financiero de la Iglesia dominicana. Los diezmos (1578-1650)”. Casas Reales 12 (Santo Domingo, 1980) pp. 77-93.

González Hernández, Julio Amable, “¿Existen descendientes de Rodrigo de Bastidas?”. Areíto, 28 de mayo y 4 de junio de 2005. Disponibles en la red: $<$ http://genealogiadominicana.com/idg/capsulas/mayo2005/myo200528.htm y http://genealogiadominicana.com/idg/capsulas/junio2005/junio2004.htm> [con acceso el 16 de septiembre de 2005].

González Guerra, Miguel, Seis rectores americanos de la Universidad de Salamanca. Salamanca, Ediciones Universidad de Salamanca, 1992. 
González Muñoz, Victoria y Martínez Ortega, Ana Isabel, Cabildos y élites capitulares en Yucatán (dos estudios). Sevilla, Escuela de Estudios HispanoAmericanos, 1989.

González Muñoz, Victoria, Cabildos y grupos de poder en Yucatán (siglo XVII). Sevilla, Diputación Provincial de Sevilla, 1994.

González-Ripoll Navarro, María Dolores, Cuba, La isla de los ensayos. Cultura y Sociedad (1790-1815). Madrid, CSIC, 1999.

, "Vínculos y redes de poder entre Madrid y La Habana: Francisco Arango y Parreño (1765-1837), ideólogo y mediador”. Revista de Indias LXI: 222 (Madrid, 2001) pp. 291-305.

Gould, Alice B., Nueva lista documentada de los tripulantes de Colón en 1492. Madrid, Real Academia de la Historia, 1984.

Grendi, Edoardo, “Paradojas de la historia contemporánea”. Relaciones XXIV: 95 (Zamora, 2003) pp. 267-278. También disponible desde Internet: $<$ http://www.colmich.edu.mx/relaciones/.095/pdf/Edoardo\%20Grendi-pdf> [con acceso el 10 de enero de 2007].

Guerrero Cano, María Magdalena, Santo Domingo (1795-1865). Cádiz, Universidad de Cádiz, Cádiz, 1986.

"La ciudad de Santo Domingo a raíz de la anexión a España” en Torres Ramírez, Bibiano (ed.), Andalucía y América. La influencia andaluza en los núcleos urbanos americanos. Actas de las VII Jornadas de América y Andalucía. Sevilla, Consejería de Obras Públicas y Transportes, 1990, pp. 71-108.

"Un dominicano en el colegio de nobles americanos de Granada. Familia y genealogía de Juan Clemente Martínez Saviñón”. Trocadero 8-9 (Cádiz, 1996-1997) pp. 383-400. Artículo publicado también con alguna ampliación como: "La representación dominicana en el colegio de nobles americanos de Granada. Familia y genealogía de Juan Clemente Martínez Saviñón”. Crónica Nova 24 (Granada, 1997) pp. 149-169.

Gutiérrez, Ramón, Arquitectura y urbanismo en Iberoamérica. Madrid, Cátedra, 1984.

Gutiérrez Escudero, Antonio, “Tres fuentes españolas sobre Saint-Domingue (1966-1731)" en VVAA., Historiografía y bibliografía americanista. Sevilla, Escuela de Estudios Hispano-Americanos, 1980, vol. XXIV, pp. 23-78.

"Juan Nieto de Valcárcel, minero en Huelva y Santo Domingo" en Primeras jornadas de Andalucía y América. Huelva, Instituto de Estudios Onubenses "Padre Marchena”, CSIC, Universidad Santa María de la Rábida, 
1981, vol. II, pp. 135-149. Posteriormente este artículo fue revisado y ampliado con el mismo título en CLÍO 139 (Santo Domingo, 1982) pp. 23-49.

, “Cuestión de límites en la isla Española, 1690-1777”. Temas Americanistas 1 (Sevilla, 1982) pp. 22-24.

"La propiedad de la tierra en Santo Domingo: del latifundio al terreno comunero”. Temas Americanistas 4 (Sevilla, 1984) pp. 21-26.

, "Un canario en la española: vida, hechos y familia de Pedro Lousel Montero, 1724-1801" en V Coloquio de Historia Canaria-Americana. Las Palmas de Gran Canaria, Ediciones del cabildo insular de Gran Canaria, 1985, pp. 165201.

Población y economía en Santo Domingo (1700-1746). Sevilla, Diputación Provincial de Sevilla, 1985.

, "Contrabando en el Caribe: comercio ilícito entre franceses y españoles en Santo Domingo". Estudios de Historia Social y Económica de América 1 (Alcalá de Henares, 1985) pp. 71-90.

"La defensa y las fortificaciones del Caribe español durante la época colonial” en VVAA., Puertos y fortificaciones en América y Filipinas. Madrid, CEHOPU, 1985, pp. 152-154.

"El abastecimiento de agua a la ciudad de Santo Domingo (Siglo XVI)". Estudios de Historia Social y Económica de América 2 (Alcalá de Henares, 1986) pp. 11-49.

"Vicisitudes de una villa de canarios en La Española: San Carlos de Tenerife, 1684-1750" en Actas del IX Coloquio de Historia Canaria-Americna. Las Palmas de Gran Canaria, Ediciones del Cabildo insular de Gran Canaria, 1992, vol. I, pp. 707-716.

, "Diferencias entre agricultores y ganaderos en Santo Domingo: siglo XVIII”. ECOS 2 (Santo Domingo, 1993) pp. 45-76.

"Nuevas consideraciones sobre la inmigración canaria a Santo Domingo en el siglo XVIII" en $X$ Coloquio de Historia Canaria-Americana. Las Palmas de Gran Canaria, Cabildo insular de Gran Canaria, 1994, vol. I, pp. 447466.

, "Colonos, familias pobladoras y fundación de ciudades en La Española, 1684-1768” en El Reino de Granada y el Nuevo Mundo. V Congreso Internacional de Historia de América. Granada, Diputación Provincial de Granada, 1994, pp. 453-466. 
“Acerca del proyectismo y del reformismo borbónico en Santo Domingo”. Temas Americanistas 13 (Sevilla, 1997) pp. 17-30.

“Tabaco y algodón en Santo Domingo, 1731-1795” en Sarabia Viejo, María Justina (ed.), Entre Puebla de los Ángeles y Sevilla: estudios americanistas en Homenaje al Dr. J. A. Calderón Quijano. Sevilla, Escuela de Estudios Hispano-Americanos, 1997, pp. 151-169. Este mismo trabajo ha sido publicado también con alguna ampliación en CLÍO 158 (Santo Domingo, 1998) pp. 103-125.

"El tabaco en Santo Domingo y su exportación a Sevilla (época colonial)" en Vilar, Enriqueta y Kuethe, Allan (eds.), Relaciones de poder y comercio colonial: Nuevas perspectivas. Sevilla, Escuela de Estudios HispanoAmericanos, 1999, pp. 117-142. Este mismo trabajo ha sido publicado también con alguna ampliación en CLÍO 161 (Santo Domingo, 1999) pp. 114-153.

"La Casa de la Contratación y el comercio de la Española: azúcar, tabaco y otros productos exportables” en Acosta Rodríguez, Antonio, González Rodríguez, Adolfo y Vila Vilar, Enriqueta (coords.), La Casa de Contratación y la navegación entre España y las Indias. Sevilla, CSIC-Fundación El Monte, 2004, pp. 511-539.

"Élites y poder económico en Santo Domingo (siglo XVIII). Notas para su estudio" en Navarro García, Luís, (coord.), Élites urbanas en Hispanoamérica: (De la conquista a la independencia); grupo de investigación sobre élites urbanas en Hispanoamérica y el Caribe en el siglo XVII; edición al cuidado de Julián B. Ruíz Rivera y Manuela Cristina García Bernal. Sevilla, Universidad de Sevilla, 2005, pp. 241-251.

Santo Domingo colonial. Estudios históricos. Siglos XVI al XVIII. Santo Domingo, Academia Dominicana de la Historia, 2007. En esta obra el autor recoge doce artículos publicados en revistas españolas o presentados en congresos nacionales e internacionales entre 1980 y 1990.

Gutiérrez Félix, Euclides, Héroes y Próceres Dominicanos y Americanos. Santo Domingo, Editora Nueva Diaria, 2000 (1995).

Hartlyn, Jonathan, The Struggle for Democratic Politics in the Dominican Republic. Chapel Hill and London, The University of Nort Carolina Press, 1998.

Hernández Franco, Juan, "El reencuentro entre historia social e historia política en torno a las familias de poder. Notas y seguimiento a través de la historiografía sobre la Castilla Moderna”. Studia Histórica 18 (Salamanca, 1998) pp. 179-199.

Hernández González, Manuel Vicente, "La vida cotidiana en un pueblo de bohíos: Higüey en los siglos XVII y XVIII”. CLÍO 165 (Santo Domingo, 2003) pp. 129141.

"Conflictos en la Universidad de Santo Domingo en la segunda mitad del siglo XVIII”. CLÍO 166 (Santo Domingo, 2003) pp. 87-112. Este mismo 
trabajo ha sido publicado también con alguna ampliación: "La vida cotidiana en la Universidad de Santo Domingo en la segunda mitad del siglo XVIII”. Tiempos de América 11 (Castellón, 2004) pp. 3-14.

, "La colonización de la frontera dominicana en la segunda mitad del siglo XVIII. La fundación de San Rafael de la Angostura. Las Caobas y San Miguel de la Atalaya”. CLÍO 167 (Santo Domingo, 2004) pp. 113-146.

La colonización de la frontera dominicana (1680-1795). Las Palmas de Gran Canaria, Ediciones Idea, 2005. Obra también publicada con el mismo título por el Archivo General de la Nación y la Academia Dominicana de la Historia, Santo Domingo, 2006.

, "Los estudios de la Universidad de Santo Domingo en el siglo XVIII a través del inventario de su archivo”. CLÍO 171 (Santo Domingo, 2006) pp. 63-84.

, Expansión fundacional y crecimiento en el norte dominicano (16801795). El Cibao y la Bahía de Samaná. Las Palmas de Gran Canaria, Ediciones Idea, 2006.

"Repoblación y expansión económica en la frontera dominicana. El desarrollo de Azua en el siglo XVIII". Revista de Indias LXVI: 238 (Madrid, 2006) pp. 659-678. Este mismo trabajo ha sido publicado en BAGN 117 (Santo Domingo, 2006) pp. 145-173. También disponible en la red: <http://www.agn.gov.do/pdf/bagn_117.pdf.> [con acceso el 30 de enero de 2008].

Hernández Tapia, Concepción, “Despoblaciones de la isla de Santo Domingo en el siglo XVII”. AEA XXVII (Sevilla, 1970) pp.281-320.

Hernández Franco, Juan, "El reencuentro entre historia social e historia política entorno a las familias de poder. Notas y seguimiento a través de la historiografía sobre la Castilla Moderna”. Studia Histórica 18 (Salamanca 1998) pp. 179-199.

Herzog, Tamar, La administración como fenómeno social: la justicia penal de la ciudad de Quito (1650-1750). Madrid, Centro de Estudios Constitucionales, 1995.

Hijano Pérez, María, “El municipio Iberoamericano en la historiografía española”. Revista de Indias L: 188 (Madrid, 1990) pp. 83-94.

Hilton, Sylvia Lyn y González Casasnovas, Ignacio, Fuentes manuscritas para la historia de Iberoamérica. Guía de instrumentos de investigación. Madrid, Fundación Mapfre América-Instituto Histórico Tavera, 1995.

Fuentes manuscritas para la historia de Iberoamérica. Guía de instrumentos de investigación: suplemento. Madrid, Fundación Mapfre AméricaInstituto Histórico Tavera, 1997.

Hoberman, Louisa Schell, "Merchants in seventeenth-century Mexico city. A preliminary portrait”. HAHR LVII: 3 (Durham, 1977) pp. 479-503. 
Hoetink, Harry, El pueblo dominicano, 1850-1900. Apuntes para su sociología histórica. Santiago, UCMM, 1985.

Imízcoz Beunza, José María*, “Actores sociales y redes de relaciones en las sociedades del Antiguo Régimen. Propuestas de análisis en Historia social y política” en Barros, Carlos (ed.), Historia a debate. Retorno del sujeto. Historia a debate, Santiago de Compostela, 1995, vol. II, pp. 341-353.

"Comunidad, red social y élites. Un análisis de la vertebración social en el Antiguo Régimen” en Imízcoz Beunza, José María (direct.), Élites, poder y red social. Las élites del País Vasco y Navarra en la Edad Moderna. Bilbao, Universidad del País Vasco, 1996, pp. 13-64.

"Introducción. Actores sociales y redes de relaciones: reflexiones para una historia global” en Imízcoz, José María, Redes familiares y patronazgo. Aproximación al entramado social del País Vasco y Navarra en el Antiguo Régimen (siglos $X V$-XIX). Bilbao, Universidad del País Vasco, 2001, pp. 19-30.

"Parentesco, amistad y patronazgo. La economía de las relaciones familiares en la hora de Navarra del siglo XVIII” en Fernández Romero, Cayetano y Moreno Almárcegui, Antonio (eds.), Familia y cambio social en Navarra y País Vasco. Siglos XVIII-XIX. Pamplona, Instituto de Ciencias para la familia, 2003, pp. 165-216.

“Actores, redes, procesos. Reflexiones para una historia más global”. Revista da Facultade de Letras-História, III Série, vol. 5, Porto (Portugal, 2004), pp. 1-28.

y Guerrero, Rafael, “Familias en la Monarquía. La política familiar de las elites vascas y navarras en el Imperio de los Borbones” en Imízcoz Beunza, José María (ed.), Casa, familia y sociedad (País Vasco, España y América, siglos $X V$-XIX). Bilbao, Universidad del País Vasco, 2004, pp. 177-238.

“Instrucción de Regentes de 1776" en Sánchez-Arcilla Benal, José, Las ordenanzas de las Audiencias de Indias (1511-1821). Madrid, Dykison, 1992, pp. 389-399.

Jiménez, Pedro Encarnación, Los negros esclavos en la historia de Bayona, Manoguayabo y otros poblados. Santo Domingo, Editora Alfa \& Omega, 1993.

Jiménez Hernández, José Antonio, Manuel Jiménez. Prócer de la Independencia. Santo Domingo, Editora Corripio, 2001.

Jori, Gerard, "El ingeniero militar Antonio Álvarez Barba y su proyecto de construcción de una casa para alojamiento de la marina y de una nueva población en la bahía de Ocoa (1771)”. Revista Bibliográfica de Geografía y Ciencias

\footnotetext{
* Las publicaciones de este autor también están disponibles desde Internet en: <http://www.ehu.es/grupoimizcoz/jmimizcoz.htm> [con acceso el 1 de junio de 2007].
} 
Sociales XII: 10 (Barcelona, 2007), disponible en la red en: <http://www.ub.es/geocrit/b3w-710.htm.> [con acceso el 16 de julio de 2008].

Julián, Amadeo, "Fraudes y conflictos en las primeras elecciones celebradas en la isla Española 1512-1513” en Julián, Amadeo, Bancos, ingenios y esclavos en la época colonial. Santo Domingo, 1997, pp. 99-121.

, "El ingenio de Boca de Nigua y la rebelión de los esclavos de su dotación en 1796" en Amadeo, Julián, Bancos, ingenios y esclavos en la época colonial. Santo Domingo, 1997, pp. 265-335.

Bancos, ingenios y esclavos en la época colonial. Santo Domingo, Colección Banreservas, 1997.

, "Negros de mala entrada. El contrabandote esclavos en la Colonia Española de Santo Domingo en la segunda mitad del siglo XVIII" en Comisión Nacional Dominicana de la Ruta del Esclavo, La ruta del esclavo. Santo Domingo, Editora Búho-UNESCO-Comisión de las Naciones Unidas para la Educación, la Ciencia y la Cultura, 2006, pp. 25-56.

Kamen, Henry, Vocabulario básico de la Historia Moderna. España y América, 1450-1750. Barcelona, Grijalbo, 1986.

Kicza, John, Empresarios coloniales. Familias y negocios en la ciudad de México durante los borbones. México, FCE, 1986.

"Formación, identidad y estabilidad dentro de la élite colonial mexicana en los siglos XVI y XVII” en Schröter, Bernd, y Büschges, Christian (eds.), Beneméritos, aristócratas y empresarios. Identidades y estructuras sociales de las capas altas urbanas en América hispánica. Frankfurt, Iberoamericana, 1999, pp. 17-34.

Ladd, Doris, La nobleza mexicana ante la independencia, 1780-1826. México, FCE, 1984.

Lamb, Úrsula, Frey Nicolás de Ovando. Gobernador de las Indias. Santo Domingo, Sociedad Dominicana de Bibliófilos, 1977.

Langue, Frédérique, "Antagonismos y solidaridades en un cabildo colonial: Caracas 1750-1810”. AEA XLIX (Sevilla, 1992) pp. 371-393.

“Las élites en América Española, actitudes y mentalidades”. Boletín Americanista 42-43 (Barcelona, 1992-1993) pp. 123-139.

, "El círculo de las alianzas. Estructuras familiares y estrategias económicas de la élite mantuana (siglo XVIII)”. Boletín de la Academia Nacional de la Historia 309 (Caracas, 1995) pp. 97-121. 
"Las élites en América colonial (siglos XVI-XIX). Recopilación bibliográfica”. AEA LIV: 1 (Sevilla, 1997) pp. 199-228, y la reciente versión actualizada "Las élites en América colonial (Siglos XVI-XVIII)". Nuevo Mundo Mundos Nuevos $\mathrm{n}^{\circ}$ 1, 2001, disponible en la red: $<$ http://nuevomundo.revues.org/documento562.html.> [con acceso el 10 de enero de 2007].

, "Mineros y poder en Nueva España: Zacatecas en vísperas de la Independencia” en Castañeda, Carmen (coord.), Círculos de poder en la Nueva España. México, Porrúa, 1998, pp. 205-217.

, "Élites Novohispanas versus Leyenda Negra. Los nuevos caminos de la interpretación”. Revista de Historia 13 (Nicaragua, 1999) pp. 51-62.

Los señores de Zacatecas. Una aristocracia minera del siglo XVIII novohispano. México, FCE, 1999.

, Aristocracia, honor y subversión en la Venezuela del siglo XVIII. Caracas, Academia Nacional de la Historia, 2000.

, y Büschges, Christian, “¿Las élites de la América Española, del éxito historiográfico al callejón interpretativo? Reconsideraciones” en Langue, Frédérique y Büschges, Christian (coords.), Excluir para ser. Procesos identittarios y fronteras sociales en la América hispánica (XVII-XVIII). Vervuert, AHILA-Iberoamericana, 2005, pp. 9-22.

Larrazábal Blanco, Carlos, Los negros y la esclavitud en Santo Domingo. Santo Domingo, Editora Amigo del Hogar, 1967.

IX vols.

Familias dominicanas. Santo Domingo, Editora del Caribe, 1969-1980,

"Origen hispano-dominicano de algunas familias caraqueñas". Boletín del Instituto Venezolano de Genealogía 2 (Caracas, 1971) pp. 8-42, también disponible en la red: <http://www.ivgenealogia.org/boletin02.pdf.> [con acceso el 14 de febrero de 2006].

Lavallé, Bernard, El mercader y el marqués: las luchas de poder en Cuzco (17001730). Lima, Banco Central de Reservas del Perú, 1988.

Laviña, Javier, "Sin sujeción a justicia: Iglesia, cofradías e identidad afroamericana” en García Jordán, Pilar et al. (coords.), Estrategias de poder en América Latina. Barcelona, Universidad de Barcelona, 2000, pp. 151-163.

Lavrin, Asunción, “El capital eclesiástico y Las Élites Sociales en Nueva España a Fines del siglo XVIII”. Estudios Mexicanos I: 1 (California, 1985) pp. 1-28.

(ed.), Sexuality \& Marriage in colonial Latin America. Lincon \& London Univesity of Nebraska, 1989. 
Leal, Idelfonso, "La aristocracia criolla venezolana y el código negro de 1789". Boletín de la Academia Nacional de la Historia 336 (Caracas, 2001) pp. 27-47.

Le Riverend, Julio, Historia económica de Cuba. La Habana, Editorial Pueblo y Educación, 1981.

Lescalier, Daniel, "Itinerario de un viaje por la parte española de la isla de Santo Domingo (1764)” en Rodríguez Demorizi, Emilio, Relaciones Geográficas de Santo Domingo. Santo Domingo, Editora del Caribe, 1970, vol. I, pp. 111-141.

Levaggi, Abelardo. Las capellanías en la Argentina. Buenos Aires, Instituto de Investigaciones Jurídicas y Sociales “Ambrosio L. Gioja”, 1992.

Levi, Giovanni, La herencia inmaterial. La historia de un exorcista piamontés del siglo XVIII. Madrid, Nerea, 1990.

Lira, Andrés, El amparo colonial y el juicio de amparo mexicano (antecedentes novohispanos del juicio de amparo). México, FCE, 1971.

Lira Monnt, Luís, “La prueba de hidalguía en el Derecho indiano”. Hidalguía 140 (Madrid, 1977) pp. 65-100.

, "Normas sobre la concesión de títulos de Castilla a los residentes en Indias”. Hidalguía 165 (Madrid, 1981) pp. 629-656.

, "Las cédulas axiliatorias en el Derecho nobiliario indiano”. Hidalguía 178-179 (Madrid, 1983) pp. 479-496.

pp. 561-581.

“La fundación de mayorazgos en Indias”. Hidalguía 230 (Madrid, 1992)

Lohmann Villena, Guillermo, Los regidores perpetuos del cabildo de Lima (15331821): crónica y estudio de un grupo de gestión. Sevilla, Diputación Provincial de Sevilla, 1983, II vols.

López Beltrán, Clara, Alianzas familiares. Élite, género y negocios en La Paz, siglo XVII. Lima, Instituto de Estudios Peruanos, 1998.

López Bohórquez, Alí Enrique, Los ministros de la Audiencia de Caracas (17861810): caracterización de una élite burocrática del poder español en Venezuela. Caracas, Academia Nacional de la Historia de Caracas, 1984.

López y Sebastián, Lorenzo E., y Río Moreno, Justo del, "La ganadería vacuna en la isla Española (1508-1587)”. Revista Complutense de Historia de América 25 (Madrid, 1999) pp. 11-49.

Lowenthal Felstiner, Mary, "Kinship Politics in the Chilean Independence Movement”. HAHR LVI: 1 (Durham, 1976) pp. 58-80. 
Lucena Salmoral, Manuel, Vísperas de la independencia americana: Caracas. Madrid, Alambra, 1986.

Unesco, 1996.

Los códigos negros de la América Española. Madrid, Ediciones , Piratas, corsarios, bucaneros y filibusteros. Madrid, Síntesis, 2005.

Luque Talaván, Miguel, Bibliografía española de genealogía, heráldica, nobiliaria y derecho nobiliario en Iberoamérica y Filipinas (1900-1997). Madrid, Fundación Histórica Tavera, 1999.

Lluberes Navarro, Antonio, "Las rutas del tabaco dominicano". Eme-Eme Estudios Dominicanos 21 (Santiago de los Caballeros, 1975) pp. 3-22.

, “Tabaco y catalanes en Santo Domingo durante el siglo XVIII”. EmeEme Estudios Dominicanos 28 (Santiago de los Caballeros, 1977) pp. 13-26.

Machado Báez, Manuel Antonio, Santiagueses ilustres de la colonia. Santo Domingo, Ediciones Centurión, 1972.

Malagón Barceló, Javier, Código Negro Carolino (1784). Código de legislación para el gobierno moral, político y económico de la isla Española. Santo Domingo, Editora Taller, 1974.

, El distrito de la Audiencia de Santo Domingo en los siglos XVI a XIX. Santiago, UCMM, 1977 (1942).

Mañón Arredondo, Manuel de Jesús, Crónicas de la Ciudad Primada. Apuntes históricos de la muy noble y lustrosa ciudad de Santo Domingo Primada de Indias. Santo Domingo, Editora Corripio, 1992.

Marrero Castellano, Josefina, "El cabildo eclesiástico en la Iglesia de Santo Domingo en el siglo XVIII”. Casas Reales 13 (Santo Domingo, 1982) pp. 99-128.

Marchena Fernández, Juan, Oficiales y soldados en el Ejército de América. Sevilla, Escuela de Estudios Hispano-Americanos, 1983.

(coord.), El Ejército de América antes de la independencia. Ejército regular y milicias americanas. 1750-1815. Hojas de servicio, uniformes y estudio histórico. Madrid, Fundación Mapfre-Tavera, 2005. [CD-ROM].

Martínez, Rufino, Diccionario Biográfico-Histórico Dominicano. Santo Domingo, UASD, 1971.

Martínez Hampe, Teodoro, “Lecturas de un jurista del siglo XVI”. AEA XLI (Sevilla, 1984) pp. 143-193. 
Bibliotecas privadas en el mundo colonial. La difusión de libros e ideas en el Virreinato del Perú (siglo XV-XVII). Madrid, Iberoamericana, 1996.

Martínez López-Cano, María del Pilar y Valle Pavón, Guillermina del (coord.), El crédito en Nueva España. México, Instituto de Investigaciones HistóricasUNAM, 1998.

Martín Rebolo, Isabelo J. F., Ejército y Sociedad en las Antillas, Siglo XVIII. Madrid, Ministerio de Defensa, 1992.

Martínez Robles, Miguel, Los oficiales de las Secretarías de la Corte bajo los Austrias y los Borbones, 1517-1812. Madrid, Instituto Nacional de administración pública, 1987.

Martínez Ruiz, Julián, Catálogo General de individuos de la R.S.B de los Amigos del País (1765-1793). San Sebastián, Caja de Ahorros Municipal de San Sebastián, 1985, vol. XII.

Marrero Castellano, Josefina, "El cabildo eclesiástico en la Iglesia de Santo Domingo en el siglo XVIII”. Casas Reales 13 (Santo Domingo, 1982) pp. 99-128.

Mazzeo de Vivó, Cristina Ana (coord.), Los comerciantes Limeños a fines del siglo XVIII. Capacidad y cohesión de una elite 1750-1825. Lima, Universidad Católica del Perú, 2000.

Mira Caballos, Esteban, “Algunas consideraciones en torno a la primera biblioteca de Santo Domingo”. ECOS 3 (Santo Domingo, 1994) pp. 147-153.

El indio antillano: repartimiento, encomienda y esclavitud (1492-1542). Sevilla-Bogotá, Muñoz Moya, 1997.

Nicolás de Ovando y los orígenes del sistema colonial español 15021509. Santo Domingo, Patronato de la Ciudad Coloniald de Santo Domingo, 2000.

Mogrobejo, Endika de, Blasones y linajes de Euskalerria. Bilbao, Amigos del Libro Vasco, 1991, X vols.

Molas Ribalta, Pedro, "La historia de la administración. Balance y perspectivas para el siglo XVIII español”. Cuadernos de investigación histórica 6 (Madrid, 1982) pp.151-168.

Morales Álvarez, Juan M., Los extranjeros con carta de naturaleza de las Indias, durante la segunda mitad del siglo XVIII. Caracas, Academia Nacional de la Historia, 1980.

Moreno, Guillermo, "De la propiedad comunera a la propiedad privada moderna 1844-1924”. Eme-Eme Estudios Dominicanos 51 (Santiago de los Caballeros, 1980) pp. 47-129. 
Moreta Castillo, Américo, “Análisis jurídico y reponderación del Archivo Real de Bayaguana”. CLÍO 156 (Santo Domingo, 1997) pp. 27-40.

, La justicia en Santo Domingo del siglo XVI. Santo Domingo, Colección Banreservas, 1998.

“El Santo Domingo del siglo XVIII a través del Libro Becerro". CLÍO 174 (Santo Domingo, 2007) pp. 43-66.

Moreno Fraginals, Manuel, El Ingenio. Complejo económico social cubano del azúcar. Barcelona, Crítica, 2001.

Moscoso, Francisco, “Un señor de ingenios de Santo Domingo: Francisco Tostado (1520-1528)”. ECOS I: 2 (Santo Domingo, 1993) pp. 11-23.

Moutoukias, Zacarías, "Burocracia, contrabando y autotransformación de las élites, Buenos Aires en el siglo XVII”. Anuario del IEHS 3 (Tandil, 1988) pp. 213-247.

"Narración y análisis en la observación de vínculos y dinámicas sociales: el concepto de red personal en la historia social y económica” en Bjerg, María y Otero, Hernán (comps.), Inmigración y redes sociales en la Argentina Moderna. Tandil, Instituto de Estudios Histórico-Sociales, 1995, pp. 221-241.

, "Redes sociales, comportamiento empresario y movilidad social en una economía de no mercado (El Río de la Plata en la segunda mitad del siglo XVIII) en Zebeiro, Blanca, Bjerg, María, y Otero, Hernán (comps.), Reproducción social, y sistemas de herencia en una perspectiva comparada. Europa y los países nuevos (siglos XVIII al XX). Tandil, Instituto de Estudios Históricos-Sociales, 1998, pp. 63-81.

Mörner, Magnus, "Estratificación social hispanoamericana durante el periodo colonial”. Research Paper Series 28 (Stockholm, 1980) pp. 1-98.

Moya Pons, Frank, "Notas sobre la primera abolición de la Esclavitud en Santo Domingo". Eme-Eme Estudios Dominicanos 3 (Santiago de los Caballeros, 1974) pp. 3-28.

, Historia colonial de Santo Domingo. Santiago, UCMM, 1977.

, La Española en el siglo XVI. Santiago, UCMM, 1978.

, La dominación haitiana, 1822-1844. Santiago, UCMM 1978.

"La defensa militar de Santo Domingo" en III Congreso Venezolano de

Historia. Caracas, Academia Nacional de la Historia, 1979, vol. II, pp. 311-332. 

1986.

El pasado dominicano. Santo Domingo, Fundación J. A. Caro Álvarez,

Después de Colón. Trabajo, sociedad y política en la economía del oro. Madrid, Alianza-América, 1987.

, “Introducción al Caribe. Dominación y fragmentación colonial.” AEA 2 (Sevilla 1994) pp. 17-24.

Manual de historia dominicana. Santo Domingo, Caribbean Publishers, 1995.

Muro Orejón, Antonio, Lecciones de historia del derecho hispano-indiano. México, Editorial Porrúa, 1989.

Navarro García, Luís (coord.), Élites urbanas en Hispanoamérica: (De la conquista a la independencia); grupo de investigación sobre élites urbanas en Hispanoamérica y el Caribe en el siglo XVIII; edición al cuidado de Julián B. Ruiz Rivera y Manuela Cristina García Bernal. Sevilla, Universidad de Sevilla, 2005.

"Nociones sobre los principales lugares de la colonia Española por un ingeniero francés que la ha visto en 1764" en Rodríguez Demorizi, Emilio, Viajeros de Francia en Santo Domingo. Santo Domingo, Editora Montalvo, 1979, pp. 9-29.

Oliva Melgar, Jose María, Cataluña y el comercio privilegiado con América en el siglo XVIII: la Real Compañía de Comercio de Barcelona a Indias. Barcelona, Universidad de Barcelona, 1987.

, “Contrabandistas, criollos y mercantilismo español en el siglo XVIII:

la resistencia a la compañía de Barcelona en Santo Domingo”. Pedralbes 4 (Barcelona, 1984) pp. 233-271.

Ortiz Núñez, Dantes. “Origen de los Cabildos en América”. CLÍO 173 (Santo Domingo, 2007) pp. 13-38.

Ortiz de la Tabla Ducasse, Javier, Los encomenderos de Quito, 1534-1660. Origen y evolución de una élite colonial. Sevilla, Escuela de Estudios HispanoAmericanos, 1993.

Otazu y Llana, Alfonso, Hacendistas navarros en Indias. Bilbao, Ellacuria, 1970.

Palma Murga, Gustavo, "Núcleos de poder local y relaciones familiares en la ciudad de Guatemala a finales del siglo XVIII”. Mesoamérica 12 (Guatemala, 1986) pp. 241-308.

Patria Quisqueya, Ana Concepción, Más familias dominicanas. Investigación genealógica. Santo Domingo, IDG, 1995. 
Peguero, Luís Joseph, Historia de la conquista de la isla Española de Santo Domingo. Trasumptada el año de 1762. Santo Domingo, Museo de las Casas Reales, 1975, II vols.

Peguero, Valentina y Santos, Danilo de los, Visión general de la historia dominicana. Santiago, UCMM, 1983.

Peña, José Francisco de la, y López, María Teresa, "Comercio y poder. Los mercaderes y el cabildo de Guatemala, (1592-1623)”. Historia Mexicana XXX: 4 (México, 1981) pp. 469-505.

Peña, José Francisco de la, Oligarquía y propiedad en Nueva España 1550-1624. México, FCE, 1983.

Peña Batlle, Manuel Arturo, Historia de la cuestión fronteriza dominico-haitiana. Santo Domingo, Sociedad Dominicana de Bibliófilos, 1988 (1946). , La isla de La Tortuga. Santo Domingo, Editora Taller, 1988 (1951).

Peña Pérez, Frank, Antonio Osorio: monopolio, contrabando y despoblación. Santiago, UCMM, 1980.

Peralta Ruiz, Víctor, Patrones, clientes y amigos. El poder burocrático indiano en la España del siglo XVIII. Madrid, CSIC, 2006.

Pérez Guerra, Irene, Historia y Lengua. La presencia canaria en Santo Domingo. El caso de Sabana de la Mar. Santo Domingo, Patronato de la Ciudad Colonial de Santo Domingo, 1999.

Pérez Memén, Fernando, "El clero y la economía colonial en el siglo XVIII”. Casas Reales 12 (Santo Domingo, 1980) pp. 97-121.

, “La mentalidad dominicana en el siglo de las luces”. Casas Reales 13 (Santo Domingo, abril 1982) pp. 47-96. UASD, 1984.

Iglesia y Estado en Santo Domingo (1700-1853). Santo Domingo, "La Iglesia y la Economía en el siglo XVIII". Boletín del museo de historia dominicana 17 (Santo Domingo, 1999) pp. 113-148.

Pérez Montás, Eugenio, Casas Coloniales de Santo Domingo. Colonial Houses of Santo Domingo. Santo Domingo, Museo de las Casas Reales, 1980.

, Monumentos históricos y arqueológicos. México, Instituto Panamericano de Geografía e Historia, 1984. 
Pietschmann, Horst, "Burocracia y corrupción en Hispanoamérica colonial. Una aproximación tentativa”. Nova Americana 5 (Turín, 1982) pp. 11-37.

, “Corrupción en las Indias Epañolas: revisión de un debate en la historiografía hispanoamericana colonial” en González Jiménez, Manuel, Pietschmann, Horst, Comín, Francisco y Pérez, Joseph, Instituciones y corrupción en la historia. Valladolid, Universidad de Valladolid, 1998, pp. 33-52.

“Plan de defensa de la plaza de Santo Domingo, 1772” en Rodríguez Demorizi, Emilio, Relaciones Geográficas de Santo Domingo. Santo Domingo, Editora Taller, 1977, vol. II, pp. 7-51.

Polanco Alcántara, Tomás, Las Reales Audiencias en las Provincias Americanas de España. Madrid, Mapfre, 1992.

Polanco Brito, Hugo Eduardo, “Los cabildos eclesiásticos de Santo Domingo y La Vega, los deanes”. Casas Reales 14 (Santo Domingo, 1987) pp. 121-142.

Taller, 1989.

Los escribanos en el Santo Domingo colonial. Santo Domingo, Editora

Ponce, Maraniela, El control de la gestión administrativa en el juicio de residencia del gobernador Manuel González Torres de Navarra. Caracas, Biblioteca de la Academia Nacional de la Historia, 1985, vol. II.

Ponce Leiva, Pilar, "Publicaciones españolas sobre cabildos americanos (19391989)”. Revista de Indias L: 188 (Madrid, 1990) pp. 77-81.

Certezas ante la incertidumbre. Élite y cabildo de Quito en el siglo XVII. Quito, Abya-Yala, 1998.

y Amadori, Arrigo. "Élites en la América Hispánica: Balance bibliográfico (1992-2005)”. Nuevo Mundo Mundo Nuevos, $n^{\circ} 1$, 2006, disponible en: <http://nuevomundo.revue.org/document1576.html> [con acceso el 1 de junio de 2007].

Portela Miguélez, María José, "Estrategia matrimonial en la élite del Partido Unión Constitucional de Cuba, 1830-1860”. Trocadero 14-15 (Cádiz, 2000-2003) pp. 159-170.

Redes de poder en Cuba entorno al partido constitucional 1878-1898.

Cádiz, Universidad de Cádiz, 2004.

Pro Ruiz, Juan, “Las élites de la España liberal: clases y redes en la definición del espacio social (1808-1931)”. Historia Social 21 (Alicante, 1995) pp. 47-69.

, "Socios, amigos y compadres. Camarillas y redes personales en la sociedad liberal” en Chacón Jiménez, Francisco y Hernández Franco, Juan (eds.), 
Familia, poderosos y oligarquías. Murcia, Universidad de Murcia, 2001, pp. 153173.

Ramírez, Susan, Patriarcas provinciales. La tenencia de la tierra y la economía del poder en el Perú colonial. Madrid, Alianza, 1991.

Ramos Pérez, Demetrio, "El traslado de la ciudad de Santo Domingo, en el cambio de su función y del régimen socio-político”. Casas Reales 12 (Santo Domingo, 1980) pp. 7-39.

Read, Gabriela, “El Archivo General de La Nación, al servicio de la investigación y la cultura”, 6/03/2007 disponible en la red <http://listisdiario.com/app/article.aspx?id=18782.> [con acceso el 1 de junio de 2007].

Real Academia Española. Diccionario Panhispánico de dudas. Madrid, Santillana, 2006.

Reichard Esteves, Herman, "Presencia dominicana al noroeste de Puerto Rico". Eme-Eme Estudios Dominicanos 3 (Santiago de los Caballeros, 1975) pp. 135158.

Restrepo Lince, Pastor, Genealogía de Cartagena de Indias. Bogotá, Instituto Colombiano de la Cultura Hispánica, 1993.

"Resumen del viaje hecho del Cabo a Santo Domingo a comienzos del mes de Brumario del año 7 (1798) por el C. Vincent, director de las fortificaciones de las islas de Sotavento" en Rodríguez Demorizi, Emilio, Viajeros de Francia en Santo Domingo. Santo Domingo, Editora Montalvo, 1979, pp. 135-160.

Río Moreno, Justo del, Los inicios de la agricultura europea en el Nuevo Mundo (1492-1542). Sevilla, Asaja, 1991.

" "La élite antillana y la economía de conquista en América los intereses ganaderos (1493-1542)” en El Reino de Granada y el Nuevo Mundo. V Congreso Internacional de Historia de América. Granada, Diputación Provincial de Granada, 1994, vol. III, pp. 187-204.

y López y Sebastián, Lorenzo E., "Hombres y ganado en la tierra del oro: comienzos de la ganadería en Indias”. Revista Complutense de Historia de América 24 (Madrid, 1998) pp. 11-45. También reproducido en la revista CLÍO 160 (Santo Domingo, 1999) pp. 53-104.

Complutense de Historia de América 25 (Madrid, 1999) pp. 11-49.

Ripodas Ardanaz, Daisy, El matrimonio en Indias: realidad social y regulación jurídica. Buenos Aires, Fundación para la Educación, la Ciencia y la Cultura, 1977. 
Rivas, Christine, “The Spanish Colonial Military: Santo Domingo 1701-1779”. The Americas 60:2 (Washington, 2003) pp. 249-272.

Robiou Lamarche, Sebastián, "Las emigraciones de Santo Domingo y su aportación al desarrollo de Puerto Rico durante el siglo XIX”. CLÍO 151 (Santo Domingo, 1994) pp. 113-126.

Roca Friedheim, Frank Alejandro, "El legado de José Gabriel García y el aporte historiográfico de sus hijos”. CLÍO 173 (Santo Domingo, 2007) pp. 119-173.

Rodríguez Cruz, Águeda María, El oficio de Rector en la Universidad de Salamanca y en las Universidades Hispanoamericanas. Salamanca, Universidad de Salamanca, 1979.

Rodríguez Demorizi, Emilio, Hojas del servicio dominicano, 1844-1865. Santo Domingo, Editora del Caribe, 1968-1976, II vols.

, Las murallas de Santo Domingo. Madrid, Gráficas Martín, 1973.

, Samaná, pasado y porvenir. Santo Domingo, Editora Arte y Cine, 1973.

, Nueva fundación de Puerto Plata. Santo Domingo, Editora Arte y Cine, 1975.

, Noticias de Puerto Plata. Santo Domingo, Editora Arte y Cine, 1975.

, Relaciones Geográficas de Santo Domingo. Santo Domingo, Editora del Caribe, 1970, vol. I.

, Relaciones Geográficas de Santo Domingo. Santo Domingo, Editora Taller, 1977, vol. II.

, El pleito Ovando-Tapia. Comienzos de la vida urbana en América. Santo Domingo, Editora del Caribe, 1978. Caribe, 1978.

, Milicias de Santo Domingo (1786-1821). Santo Domingo, Editora del Caribe, 1979.

Viajeros de Francia en Santo Domingo. Santo Domingo, Editora del 1979.

Mapas y planos de Santo Domingo. Santo Domingo, Editora Taller, Papeles de Pedro Francisco Bonó. Barcelona, Gráficas Pareja, 1980. 
Rodríguez Gautreau, Fabio A., Los Oficiales Reales y su Tiempo. Santo Domingo, Editora Búho, 2001.

Rodríguez Morel, Genaro, “Cartas privadas de Hernando Gorjón”. AEA 2 (Sevilla, 1995) pp. 204-233.

Cartas del cabildo de la ciudad de Santo Domingo en el siglo XVI. Santo Domingo, Patronato de la Ciudad Colonial de Santo Domingo, 1999.

Cartas de los cabildos eclesiásticos de Santo Domingo y Concepción de La Vega en el siglo XVI. Santo Domingo, Patronato de la Ciudad Colonial de Santo Domingo, 2000.

, Cartas del cabildo de Santo Domingo en el siglo XVII. Santo Domingo, Archivo General de la Nación-Academia Dominicana de la Historia, 2007.

Cartas de la Real Audiencia de Santo Domingo (1530-1546). Santo Domingo, Archivo General de la Nación-Academia Dominicana de la Historia, 2008.

Rodríguez y Rodríguez, Alberto, El azúcar como hacedor de historia y de comunidades. Santo Domingo, UASD, 1985.

Rodríguez Sáenz, Eugenia, "Historia de la familia en América Latina: Balance de las principales tendencias”. Revista de Historia 26 (Costa Rica, 1992) pp. 145183.

Rodríguez Sánchez, Ángel, "El poder familiar: la patria potestad en el Antiguo Régimen” en VVAA., Estructuras y formas de poder en la Historia. Salamanca, Ediciones Universidad de Salamanca, 1991, pp. 105-116.

, "Métodos de evaluación de las estrategias en el Antiguo Régimen” en Fuentes y métodos de la Historial local: actas. Zamora, Instituto de Estudios Zamoranos “Florián de Ocampo”, 1991, pp. 141-153.

, La familia en la Edad Moderna. Madrid, Arco, 1996.

Rosario, Esteban, La familia Bermúdez: fortuna y crisis. Madrid, Editorial Mariel, 1990.

Búho, 1992.

Los dueños de la República Dominicana. Santo Domingo, Editora La oligarquía de Santiago. Santo Domingo, Editora Central, 1997.

Rosario Rivera, Raquel, Efectos de las revoluciones de 1791-1848 en el Poblamiento de Puerto Rico. Universidad de Valladolid, Facultad de Filosofía y Letras, 1988. Tésis Doctoral inédita. 
Rossi, Maximo, Praxis, historia y filosofía en el siglo XVIII. Textos de Antonio Sánchez Valverde (1729-90). Santo Domingo, Editora Taller, 1994.

Rubio, Fray Vicente, “Carlos III en Santo Domingo”. Revista de la Fundación García Arévalo 2 (Santo Domingo, 1988) pp. 13-31.

Ruíz Rivera, Julián Bautista, "La compañía de Uztáriz, las Reales Fábricas de Talavera y el comercio con Indias”. AEA XXVI (Sevilla, 1979) pp. 209-245.

Sáez, José Luis, La Iglesia y el negro esclavo en Santo Domingo. Una historia de tres siglos. Santo Domingo, Patronato de la Ciudad Colonial de Santo Domingo, 1994.

, "Los jesuitas y esclavos negros en el Santo Domingo colonial (16581767)”. Paramillo 15 (Táchira, 1996) pp. 493-525.

, "Elenco de jesuitas europeos e hispanoamericanos en Santo Domingo (1650-1767)”. AHSI LXV (Roma, 1996) pp. 31-99.

"Los jesuitas en el Caribe Insular de habla castellana (1575-1767)". Paramillo 16 (Táchira, 1997) pp. 5-155.

, "Jesuitas nacidos en La Española durante los primeros años de estancia de la Compañía (1658-1767)”. CLÍO 159 (Santo Domingo, 1998) pp. 25-50.

, "Impacto real de la salida de los jesuitas de Santo Domingo (19-23 agosto 1767)”. Estudios Sociales XXXI: 112 (Santo Domingo, 1998) pp. 73-91.

La formación sacerdotal en Santo Domingo desde el Concilio de Trento a la Fundación de la República. Santo Domingo, Editora Amigo del Hogar, 1999.

, “Archivo Histórico de la Arquidiócesis de Santo Domingo”. BAGN 115 (Santo Domingo, mayo-agosto 2006) pp. 225-239, disponible desde Internet en: <http://www.agn.gov.do/pdf/bagn_115.pdf> [con acceso el 30 de enero de 2008].

La expulsión de los jesuitas de Santo Domingo. Santo Domingo, Academia Dominican de la Historia, 2006.

Saguier, Eduardo, "La corrupción administrativa como mecanismo de acumulación y engendrador de una burguesía comercial local”. AEA XLVI (Sevilla, 1989) pp. 269-303.

El mercado inmobiliario rural y su incidencia en la estructura social rioplatenese. Buenos Aires, Centro Editor de América Latina, 1993. 
"El parentesco como mecanismo de consolidación política de un patriciado colonial. El caso de las provincias rioplateneses del virreinato peruano (1700-1776)". Estudios de Historia Social y Económica de América 10 (Alcalá de Henares, 1993) pp. 61-116.

Salvador Gautier, Manuel, "Fundación de la ciudad de Santo Domingo”. CLÍO 154 (Santo Domingo, 1996) pp. 135-144.

Sánchez Valverde, Antonio, Idea del valor de la Isla Española y Utilidades que de ella puede sacar su monarquía. Santo Domingo, Editora Corripio, 1988 (1785).

Sánchez Baena, Juan José y Chaín Navarro, Celia M., "La persistencia del antiguo régimen en la esructura matrimonial mediterránea: el análisis del parentesco en Cartagena (1750-1850)” en Chacón Jiménez, Francisco y Hernández Franco, Juan (eds.), Poder, familia y consanguinidad en la España del Antiguo Régimen. Barcelona, Anthropos, 1992, pp. 177-214.

Sanchíz Ochoa, Pilar, Los hidalgos de Guatemala. Realidad y apariencia de un sistema de valores. Sevilla, Universidad de Sevilla, 1976.

Santa Cruz y Mallén, Francisco Javier de, Historia de familias cubanas. La Habana, Editorial Hércules, 1940-1980, IX vols.

Santiago, Pedro Julio, Campillo Pérez, Julio Genaro y Dobal, Carlos, El primer Santiago de América, 1495-1995. Santo Domingo, Editora Amigo del Hogar, 1997.

Santos Pérez, José Manuel, Élites, poder local y régimen colonial. El cabildo y los regidores de Santiago de Guatemala 1700-1787. Cádiz, Universidad de Cádiz, 1999.

, "Las élites de Santiago de Guatemala y el cabildo colonial, 17001770)”. Revista de Historia 38 (Costa Rica, 1998) pp. 87-111.

, y Mira, Guillermo, "Estrategias de integración y ascenso social de emigrantes españoles a América en el siglo XVIII” en Alcántara, Manuel (ed.), América Latina. Realidades y Perspectivas. I Congreso Europeo de Latinoamericanistas. Salamanca, Universidad de Salamanca, 1997, Colección Aquilafuente $n^{\circ}$ 7, pp. 216-242.

San Miguel, Pedro, Los campesinos del Cibao. Economía de mercado y transformación agraria en la República Dominicana, 1880-1960. Puerto Rico, Universidad de Puerto Rico, 1997.

Seed, Patricia, Amar, honrar y obedecer en el México colonial, conflictos en torno a la elección matrimonial, 1574-1821. México, Alianza Editorial, 1991. 
Serrano y Sanz, Manuel, Los amigos y protectores aragoneses de Cristóbal Colón. Barcelona, Riopiedras, 1991.

Sevilla Soler, María del Rosario, Santo Domingo. Tierra de frontera (1750-1800). Sevilla, Escuela de Estudios Hispano-Americanos, 1980.

"El comercio entre Santo Domingo y Andalucía (1750-1795)” en Primeras jornadas de Andalucía y América. Huelva, Instituto de Estudios Onubenses "Padre Marchena", CSIC, Universidad Santa María de la Rábida, 1981, vol. I, pp. 139-148.

"Las repercusiones de la Revolución francesa en el Caribe español: los casos de Santo Domingo y Trinidad”. Cuadernos Americanos 5 (México, 1989) pp. 117-133.

Silié, Rubén, Economía, esclavitud y población. Ensayos de interpretación histórica del Santo Domingo español en el siglo XVIII. Santo Domingo, UASD, 1976.

"El hato y el conuco: contexto para el surgimiento de la cultura criolla" en VVAA., Ensayos sobre cultura dominicana. Santo Domingo, Fundación Cultural Dominicana, 1997, pp. 143-168.

Schröter, Bernd, y Büschges, Christian (eds.), Beneméritos, aristócratas y empresarios. Identidades y estructuras sociales de las capas altas urbanas en América hispánica. Frankfurt, Iberoamericana, 1999.

Socolow, Susan, "Marriage, Birth and Inheritance: The Merchants of EighteenthCentury Buenos Aires”. HAHR 60: 3 (Duke, 1980) pp. 389-405.

"Aceptable partners: marriage choice in colonial Argentina, 17781819” en Lavrin, Asunción (ed.), Sexuality \& Marriage in colonial Latin America. Lincon \& Londo, 1989, pp. 209-246.

Los mercaderes del Buenos Aires Virreinal: familia y comercio. Buenos Aires, Editora de La Flor, 1991.

Solano, Francisco de, "La plaza mayor hispanoamericana o la difusión del urbanismo de Santo Domingo”. Casas Reales 14 (Santo Domingo, 1987) pp. 93118.

Sorhegui D`Mares, Arturo, “Élite o aristocracia en La Habana entre los siglos XI y XVII” en Schröter, Bernd y Büschges, Christian (eds.), Beneméritos, aristócratas y empresarios. Identidades y estructuras sociales de las capas altas urbanas en América hispánica. Frankfurt, Iberoamericana, 1999, pp. 201-213.

"Los grupos de poder en América. ¿Se conformó durante el reinado de los Reyes Católicos las primeras formas de patronazgo y clientelismo impuestas por el Estado territorial centralizado español para el dominio de 
América” en Actas del III Congreso de Historiadores Latinoamericanistas. Santiago de Compostela, 2002. [CD-ROM]

Sosa Jiménez, Manuel Antonio, Hato Mayor del Rey, su sitial en la Historia Dominicana. Santo Domingo, Editora Taller, 1993.

Sosa Rodríguez, Enrique, "Importancia del contenido de los fondos del Archivo Nacional de Cuba para la historia de la República Dominicana”. ECOS 2 (Santo Domingo, 1993) pp. 155-182.

Stapells Johnson, Victoria, "Los corsarios de Santo Domingo 1718-1779: un estudio socio-económico". Quaderns del departament de geografia i historia del l'estudi general de Lleida 12 (Lleida, 1992) pp. 3-93.

Stevens-Acevedo, Anthony, "Esclavos, empresarios azucareros y transacciones económicas en el ingenio Santa Bárbara de la isla Española en 1557”. ECOS III: 4 (Santo Domingo, 1995) pp. 31-55.

Stone, Lawrence, El pasado y el presente. México, FCE, 1986.

Syme, Ronald, Élites coloniales. Roma, España y las Américas. Málaga, Algazara, 1993 (1958).

Szásszdi Nagy, Ádám, “Emigrados dominicanos en Puerto Rico, 1796-1812”. CLÍO 164 (Santo Domingo, 2002) pp. 79-179.

Tellechea Idígoras, Ignacio J., La ilustración vasca: Cartas de Xavier María de Munibe, Conde de PeñaFlorida a Pedro Jacinto de Álava. Vitoria, Parlamento Vasco, 1987.

“Testamento de Jacinta de Castro y Urdaneta, 2 de junio de 1807” en Sáez, José Luis, La Iglesia y el negro esclavo en Santo Domingo. Una historia de tres siglos. Santo Domingo, Patronato de la Ciudad Colonial de Santo Domingo, 1994, pp. 510-511.

Tomás y Valiente, Francisco, Gobierno e instituciones en la España del Antiguo Régimen. Madrid, Alianza, 1982.

, La venta de Oficios en Indias (1492-1606). Madrid, Instituto Nacional de Administración Pública, 1982.

Tornero Tinajero, Pedro, "Hacendados y desarrollo azucarero cubano (17631818)”. Revista de Indias 153-154 (Madrid, 1978) pp. 715-736.

Torres Agudo, Ruth, "Dos catedráticos dominicanos en la Universidad de Salamanca”. CLÍO 168 (Santo Domingo, 2004) pp. 245-264.

"Los Campuzano-Polanco, una familia de la élite de la ciudad de Santo Domingo", Nuevo Mundo Mundos Nuevos, ${ }^{\circ}$ 7, 2007. Disponible en: 
<http://nuevomundo.revues.org/document3240.html.> [publicación en línea y con acceso el 5 de enero de 2007].

Torres Sánchez, Rafael (ed.), Capitalismo mercantil en la España del siglo XVIII. Pamplona, Eunsa, 2000.

, "Campomanes y el comerciante y financiero Simón Aragorri” en Mateos Dorado, Dolores (ed.), Campomanes doscientos años después. Oviedo, Universidad Oviedo-Instituto Feijoo de Estudios del siglo XVIII, 2003, pp. 709718.

Tovar Pinzón, Hermes, “El estado colonial frente al poder local y regional”. Nova americana 5 (Turín, 1982) pp. 39-77.

Turiso Sebastián, Jesús, Comerciantes españoles en la Lima Borbónica. Anatomía de una elite de poder (1701-1761). Lima, Universidad de Valladolid, 2002.

Ugarte, María, Monumentos coloniales. Santo Domingo, Museo de las Casas Reales, 1977.

Banreservas, 1995.

Iglesias, capillas y ermitas coloniales. Santo Domingo, Colección Estampas coloniales. Santo Domingo, Comisión Permanente de la Feria Nacional del Libro, 1998, II vols.

Ugarte, Jose Luis, Mandinabeitia, Tere, y Ugalde, María José (coords.), Brinkola gogoan: apunte historiko eta etnografikoak. Donosita, Colección Landiketzan, Eusko Ikaskuritza, 1999.

Urquiza, Fernando Carlos, "Etiquetas y conflictos: El obispo, el virrey y el cabildo en el Río de la Plata en la segunda mitad del siglo XVIII". AEA L: 1 (Sevilla, 1993) pp. 55-100.

Usunariz Garayoa, Jesús María, Una visión de la América del siglo XVIII: correspondencia de emigrantes guipuzcoanos y navarros. Madrid, Mapfre, 1992.

Utrera, Fray Cipriano de, "Epigrafía colonial. Genealogía de las familias solariegas de Bastidas, Fernández de Oviedo y Valdés de Fuenmayor, Dávila y entronques (1468-1926)" en su obra Santo Domingo. Dilucidaciones Históricas. Santo Domingo, Secretaría de Estado de Educación, Bellas Artes y Cultos, 1978, vol. I, pp. 425-492.

, "Concejo, justicia y regimiento era nombre que tenía el ayuntamiento de Santo Domingo”. El Caribe, 14 de noviembre de 1987, p. 8.

"En qué forma se elegían a los munícipes de Santo Domingo durante el siglo XVI”. El Caribe, 21 de noviembre de 1987, p. 8. 
"Elecciones municipales de Santo Domingo sirvieron de modelo para otras colonias". El Caribe, 28 de noviembre de 1987, p. 8.

, “Carlos III en Santo Domingo”. Revista de la Fundación García Arévalo 2 (Santo Domingo, 1988) pp. 13-31.

Valera Valdez, Vetilio Manuel, Baní: raíces históricas. Genealogía de familias banilejas. Santo Domingo, Editora taller, 1998.

, “Baní: orígenes históricos”. Raíces 6 (Santo Domingo, 1994) p. 12.

Valenzuela Márquez, Jaime, "Rituales y "fetiches" políticos en Chile Colonial: entre el sello de la Audiencia y el pendón del cabildo". AEA LVI: 2 (Sevilla, 1999) pp. 413-440.

Vargas-Lobsinger, María, Formación y decadencia de una fortuna: el mayorazgo de San Miguel de Aguayo de San Pedro del Álamo, 1583-1823. México, UNAM, 1992.

Vázquez de Ferrer, Belin, y Ferrer, Nereyda, "Propuesta de análisis y fuentes para el estudio de las redes sociales de poder” en Martinez Ruiz, Enrique (coord.), Poder y mentalidad en España e Iberoamérica. Madrid, Universidad de Zulia y Complutense de Madrid, 2000, pp. 35-57.

Vega Boyrie, Wenceslao, "La Real Audiencia de Santo Domingo". Eme-Eme Estudios Dominicanos IV: 21 (Santiago de los Caballeros, 1975) pp. 91-104.

Taller, 1979.

Historia del derecho colonial dominicano. Santo Domingo, Editora Historia del derecho dominicano. Santo Domingo, INTEC, 1986.

, "Historia de los Terrenos Comuneros en la República Dominicana". CLÍO 162 (Santo Domingo, 2000) pp. 81-108.

y Esteban Deive, Carlos, "Topónimos dominicanos vinculados a esclavos y a África”. Boletín del museo de historia dominicana 14 (Santo Domingo, 1980) pp. 147-164.

Ventura, Juan, Figuras Puerto Plateñas. Biografías. Santo Domingo, Editora Cantera Gráfica, 1997.

Veragua, Duque de, “Ducado de Veragua”. CLÍO (Santo Domingo, 1975) pp. 1418.

Walton, William, Estado actual de las colonias españolas. Santo Domingo, Editora de Santo Domingo, 1976, vol. I. 
Webre, Stephen, "El cabildo de Santiago de Guatemala en el siglo XVII: ¿Una oligarquía criolla cerrada y hereditaria?”. Mesoamérica 2 (Guatemala, 1986) pp. $1-19$.

"Antecedentes económicos de los regidores de Santiago de Guatemala, siglo XVI y XVIII: una élite colonial” en Webre, Stephen (ed.), La sociedad colonial en Guatemala: estudios regionales y locales. Guatemala, CIRMA, 1989, pp. 189-219.

Widmer Sennhauser, Rudolf, "El Higüey en el siglo XVIII. Los inicios de la industria maderera en Santo Domingo (1780-1800)”. Estudios Sociales 123 (Santo Domingo, 2001) pp. 63-78.

, "El hato ganadero del Este en la economía dominicana del siglo XVIII. Con Antonio Sánchez Valverde en San Dionisio de Higüey”. CLÍO 165 (Santo Domingo, 2003) pp. 143-158.

La propiedad en entredicho. Una historia documental de Higüey, Siglo XVII-XIX. Santo Domingo, Editora Manatí, 2004.

Wobeser, Gisela Von, "Mecanismos crediticios en la Nueva España. El uso del censo consignativo". Estudios Mexicanos V: 1 (California, 1989) pp. 1-23.

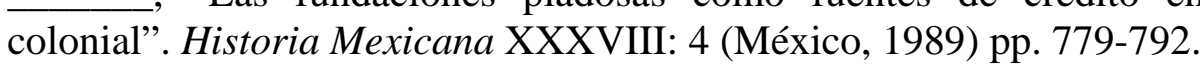
UNAM, 1994.

El crédito eclesiástico en la Nueva España. Siglo XVIII. México,

Wolf, Eric, "Relaciones de parentesco, de amistad y de patronazgo en las sociedades complejas” en Banton, Michael (comp.), Antropología social de las sociedades complejas. Madrid, Alianza, 1996, pp. 13-39.

Zeberio, Blanca, Bjerg, María, y Otero, Hernán (comps.), Reproducción social y sistemas de herencia en una perspectiva comparada. Europa y los países nuevos (siglos XVIII al XX). Tandil, Instituto de Estudios Históricos-Sociales, 1998.

Zelaia, Iñaki (coord.), Legazpi. Ayuntamiento de Legazpi, Itxaropena, 1979.

Zylberberg, Michel, Une si douce domination. Les milieux d'affaires français et l'Espgane vers 1780-1808. Paris, Comité pour l'histoire économique et finacière, Ministère des Finances, 1993. 


\section{APUNTES BIOGRÁFICOS}

\section{Nota explicativa:}

El objetivo en este apartado es el de presentar un resumen prosopográfico que facilite la obtención de datos de algunos hacendados y personajes notables. Para aligerar estos apuntes biográficos hemos optado por no citar las fuentes y bibliografía detallada a lo largo del trabajo. La información más específica está anotada fundamentalmente en el capítulo cuarto, así como en las fuentes citadas para la elaboración de los árboles genealógicos y cronogramas familiares.

\section{ÁLVAREZ BARBA, Antonio.}

Natural de Salamanca. Se trasladó a Santo Domingo para ejercer como Ingeniero militar de su plaza, obteniendo el título de Brigadier y Comandante de ingenieros. Se casó con María de los Santos Leos-Echalas para quien era ya su segundo matrimonio, pues estuvo casada anteriormente con Felipe Frómesta Balmaceda. María de los Santos era hija de Francisco Javier Leos-Echalas y Juana Coronado. Entre los hijos que tuvieron destaca María de la Concepción que se unió en matrimonio a José Fernández de Castro, y Antonio con María Josefa Zárraga y Pérez-Caro.

Hacendado.

\section{ARATA, José.}

Nacido en Génova, Italia. Se incorporó a la Guardia de Corps el 17 de febrero de 1771, estando cinco años, hasta que hacia 1776 se trasladó a Santo Domingo. Durante once años, desempeñó el cargo de teniente de una compañía de granaderos del Batallón Fijo. En ella ascendió a capitán en 1788, y a graduado de teniente coronel el 28 de diciembre de 1793. Tras la firma del tratado de policía entre la parte española y los franceses, fue elegido el 7 de junio de 1786 para que se encargara como comisario en el comercio de ganado y de vigilar y reclamar a los desertores fugitivos. También fue comandante de 
armas en pueblos fronterizos como Las Caobas, donde estuvo desde noviembre de 1789 hasta enero de 1794, y en Dajabón desde marzo de 1795 hasta enero de 1796.

Se casó con la criolla Micaela Sterlin del Monte, hija del francés Nicolás Sterling y de Bernarda del Monte Luna, una importante familia de la ciudad de Santiago.

Hacendado.

\section{ARAGORRI Y OLAVIDE, SIMÓN.}

Nacido en Hendaya alrededor de 1725, sus padres fueron Nicolás de Aragorri y Larremburu, y Jeanne de Olavide y Michelena. Está considerado como un personaje clave de la Corte madrileña de la segunda mitad del siglo XVIII, ya que fue un importante y poderoso banquero, financiero, comerciante, y terrateniente de su tiempo. Poseyó una Casa de Comercio llamada “Aragorri Hermanos” con la que se dedicó a múltiples negocios: importó mercancías para otros comerciantes y autoridades militares a quienes provisionó de víveres y armamento para el Ejército español, y de harinas para Madrid, promovió asientos para la Armada, y actuó en el comercio colonial como intermediario entre los comerciantes madrileños y gaditanos, así como directamente a través de su participación en la Compañía de La Habana y la de Filipinas. En Santo Domingo adquirió numerosas propiedades rústicas que fueron administradas por su primo Juan Bautista de Oyarzábal y Olavide, quien heredó la dirección de la compañía.

Además logró la protección política y estableció vínculos con figuras relevantes, llegando a emparentar con algunas de ellas como el embajador en Londres Simón de las Casas, su hermano Luís, que fue Gobernador de Cuba y Capitán General de Cádiz, entre otros. Hacia 1777 se casó con Josefa de la Torre, hija del noble vasco Antonio de la Torre, para quien era su segundo matrimonio; ya que en primeras nupcias fue con Fernando de Llano, miembro de la Orden de Santiago y Tesorero general de las sisas regias del ayuntamiento de Madrid.

En 1769 obtiene el título nobiliario de Marqués de Iranda, y el de Vizconde de Azcubeda, suprimido en 1770. Mientras que el de Iranda lo mantuvo el resto de su vida hasta que murió en 1806. 


\section{ARREDONDO CASTRO, José Esteban de.}

Nació en Santo Domingo. Hijo de Juan Arredondo Vizcaíno y de Jacinta de CastroRivera Urdaneta. Estuvo casado con Isabel Martínez de Venecia Santelices.

Estudió en la Universidad de Santo Tomás de Aquino cursando las clases de derecho, y dónde recibió el grado máximo de Doctor en derecho civil. En dicha Regentó las cátedras de Prima de Leyes durante tres años interinamente, la Instituta en propiedad durante un quinquenio, y la de Prima de Cánones cerca de un año en sustitución, recibiendo el grado de Doctor en Cánones. Además fue electo Consiliario letrado por el Claustro de dicha Universidad, y fiscal, así como rector el 1 de septiembre de 1778.

Fue abogado de la Audiencia de Santo Domingo desde el 8 de noviembre de 1748, y luego fue electo como relator, promotor fiscal y asesor de ella. El 25 de septiembre de 1769 obtuvo el empleo de Tesorero y Administrador de la limosna de la Bula de la Santa Cruzada de aquel Arzobispado.

Ejerció de juez de residencia en dos ocasiones: la primera para tomar la residencia al Marqués de Casa-Cagigal del tiempo que fue Gobernador de la ciudad de Santiago de Cuba, y a sus ministros de justicia. Para esa época el Intendente General de Guerra y Hacienda de Cuba le nombra en 1772 Contador y Fiscal de la Real Hacienda de aquella Contaduría. También ejerció el cargo de Asesor General del Real Cuerpo de Artillería y el de Comandante del mismo cuerpo. La segunda, para tomar residencia al Gobernador Lorenzo de Madariaga.

En Santo Domingo desempeñó distinto empleos como el de Defensor de las Temporalidades de los bienes de los expulsados jesuitas, y alcalde ordinario de primera elección hacia 1782. El 1 de marzo de 1784 Isidro Peralta y Rojas le despachó el título de teniente de justicia mayor y juez de comisos de los pueblos interiores de la isla con un sueldo de 1.000 pesos anuales.

Hacendado.

\section{CAMPUZANO POLANCO MORILLO, José.}

Nacido en Santo Domingo. Sus padres fueron Francisco Campuzano Polanco y la venezolana María Francisca Morillo de Ayala. Fue regidor decano en el ayuntamiento de la ciudad de Santo Domingo, y el de alcalde provincial que había sido creado en 1758. En 1768 participó en la elaboración de unas ordenanzas para negros.

Se casó con Rosa Fernández de Lara, hija del oficial real Julián Fernández Pérez y de Catalina Francisca de Lara. 
Hacendado.

\section{CAMPUZANO POLANCO FERNÁNDEZ DE LARA, Adrián.}

Natural de Santo Domingo, nació el 8 de septiembre de 1754. Fue hijo del hacendado y regidor José Campuzano Polanco Morillo y de Rosa Fernández de Lara. Se casó con su sobrina Rosa Caro Campuzano, hija del coronel Ignacio Pérez Caro y Oviedo y María Magdalena Catalina Campuzano y Fernández de Lara.

Recibió el grado de Bachiller, Licenciado y Doctor en leyes por la Real Universidad de Santo Tomás de Aquino en 10 de enero de 1778, y como abogado con su título correspondiente en 1 de marzo de 1781. Hizo oposición a la Cátedra de Prima de Leyes en concurso de ocho opositores, y después a la de Instituta Justiniano en concurso de cinco, saliendo de ambas nemine discrepante, se le confirió la segunda en noviembre de 1777, para la cuál fue reelegido sin coopositor alguno en febrero de 1783. Después del examen que realizó en la facultad de Cánones en el que también salió nemine discrepante, recibió el grado de Licenciado el 31 de marzo de 1787. Fue en esa Universidad dos veces Fiscal y Consilario, y una vez Vicerrector.

El Arzobispo de la diócesis de Santo Domingo, Isidro Rodríguez le confió el cargo de Promotor Fiscal de la Curia eclesiástica. El cabildo de la ciudad de Santo Domingo le eligió alcalde ordinario de primer voto en 1797, siendo reelegido otra vez en 1798. A través de la Real Cédula de 27 de octubre de 1798 fue aceptado como abogado de los Reales Consejos.

Hacendado.

\section{COCA LANDECHE, Antonio.}

Nacido en Santo Domingo. Sus padres fueron el gaditano Antonio Coca Landeche y Josefa Lucía Bastidas, de la que heredó numerosas propiedades, algunas de las cuales formaban parte de los mayorazgos Dávila y Bastidas, y que él administró hasta su repartición. Le tocó el vínculo Dávila de ahí que fuese conocido como Antonio Dávila Coca Landeche. Tomó por esposa a la criolla Juana Fernández de Oviedo.

De la misma manera que su padre, fue elegido en varios ocasiones como alcalde orinario y de Santa Hermandad en el ayuntamiento de Santo Domingo. En esta institución también desempeñó el empleo de alférez real desde 1754 hasta 1789, año en el que muere. Participó en la elaboración de unas ordenanzas para negros en 1768, junto al regidor José 
Campuzano Polanco, y en las ordenanzas municipales de 1786. Fue miembro de la Junta de Agricultura y consultado en la realización del código negro. Socio Benemérito de la Real Sociedad Bascongada de los Amigos del País (1784-1789).

Hacendado,

\section{CUMULAT, Antonio.}

Natural de la villa de Báscara, Gerona. Fue comerciante en Cataluña desde donde se traslada hacia 1774 a Santo Domingo para ocupar el empleo de factor de la Compañía de Comercio de Barcelona, sustituyendo a Narciso Subirás. En dicho cargo permaneció hasta la extinción de la Compañía en 1786. También se dedicó al corso y participó en la política local, siendo elegido alcalde ordinario en 1786. Obtuvo el grado de capitán de la segunda compañía de milicias urbanas de la ciudad de Santo Domingo. Actuó como intérprete de idiomas de inglés y francés en la expedición a Bayajá. Fue miembro Benemérito de la Real Sociedad Bascongada Amigos del País (1784-1793).

Comerciante-Hacendado.

\section{EMPARÁN Y ORBE, Agustín Ignacio.}

Nació en Azpeitia el 9 de enero de 1748, donde fue bautizado el mismo día. Sus padres fueron José Joaquín de Emparán Zarauz, nacido también en la villa de Azpeitia el 13 de abril de 1725, quién ocupó el cargo de Diputado General de Guipúzcoa y de María Ana Xaviera de Orbe, natural de la villa de Ermúa (nació el 13 de marzo de 1723). José Joaquín y María Ana contrajeron matrimonio en la parroquia de Santiago Apóstol en Ermúa, el 26 de octubre de 1744. Ambas familias pertenecía a la nobleza vasca, que se habían dedicado a la carrera administrativa y eclesiástica. Estudió filosofía y leyes en la Universidad de Valladolid y Salamanca, ciudad esta última en la que obtuvo el grado de Bachiller y Licenciado en Derecho Civil, y donde ejerció como profesor en la Cátedra de Derecho Eclesiástico Antiguo.

Su carrera política la empezó siendo oidor de la Audiencia de Santo Domingo, cargo para el que había sido nombrado el 30 de agosto de 1777, aunque no lo ocupó hasta el año 1779. Se encargó de redactar dos importantes documentos para la vida económica y social de la isla: un código u ordenanzas sobre la población negra que se le llamó Código negro carolino, y un informe sobre el estado de la agricultura y su mejoramiento que terminó en 1785. El 7 de junio de 1787 es nombrado tercer Alcalde de Crimen para la Audiencia de México, trasladándose el 7 de octubre de 1788, pues, durante ese año estuvo 
en Cuba en una comisión contra Rafael de Moncada sobre comercio. El 9 de junio de 1792 llega a Manila para ocupar el cargo de regente para el que había sido nombrado dos años antes, muriendo en su ejercicio en 1801.

Fue miembro Benemérito y de Mérito de la Real Sociedad Bascongada Amigos del País (1783-1793), Vice-recaudador (1786) y Comisionado de la Sociedad (1783 y 1786). El 15 de junio de 1790 se le nombra Caballero de la Real Distinguida Orden Española de Carlos III, y el 27 de noviembre de 1796 Consejero honorario del Consejo de Indias.

\section{ESPAILLAT Y VIROL, Francisco.}

Nació el 29 de mayo de 1734 en el pueblo Masclat, distrito de Gourdon, departamento de Lot, Francia, siendo bautizado al día siguiente. Hijo de Juan Espaillat, herrero y Margarita Virol Lamargot. Hacia 1756 visitó por primera vez la ciudad de Santiago, donde se instaló dedicándose a actividades agropecuarias en las fincas que adquirió en los alrededores de la jurisdicción de dicha ciudad y Montecristi. Se casó en primeras nupcias con Catalina Tabarez Zapata y Morel, y en segundas el 24 de julio de 1786 con Petronila Velilla Sánchez, hija del aragonés Francisco Antonio Velilla y Torres y María Sánchez Moreno y Firpo.

En 1780 es nombrado médico cirujano de las milicias regladas de infantería, caballería y urbanos de Montecristi, Puerto Plata, La Vega y Santiago. En esta última ciudad fue nombrado en 1783 mayordomo, administrador y médico de su hospital militar. En ella también desempeñó el empleo de factor del ramo de tabacos, y el de juez subdelegado de comisos de la región norte. El 17 de agosto de 1787 obtuvo la Carta de Naturaleza. Después de la firma del Tratado de Basilea se trasladó a Puerto Rico con su familia, donde murió.

\section{ESPARZA, Raymundo.}

Nacido en Pamplona, Navarra. Hijo de Bartolomé Esparza y Laura Sastre. Se trasladó a la isla para ocupar el empleo de tesorero de las cajas reales de Santo Domingo. Se dedicó tanto a actividades agropecuarias como mercantiles. Parece que aunque no llegó a casarse contó con numerosas conexiones tanto en la isla como en otras provincias americanas y la Península.

Fue miembro Benemérito de la Real Sociedad Bascongada Amigos del País desde 1783 hasta el 29 de abril de 1786, fecha en la que muere.

Hacendado-Comerciante. 


\section{FAURA, Vicente Antonio.}

Nacido el 16 de abril de 1756 en Santo Domingo. El apellido Faura es originario de Orihuela (Valencia) de donde eran los padres de Vicente Antonio Faura llamados Antonio Faura y Josefa Rodríguez-Agudo. Se casó el 3 de agosto de 1782 con María Mercedes Ramírez Guridi, hija del abogado y relator José Jacinto Ramírez y de Isabel Franco Guridi.

Estudió Leyes durante cinco años en la Universidad de Santo Tomás de Aquino, en cuya facultad recibió los grados de Bachiller, Licenciado, Doctor y el de Bachiller en Cánones. Suplió las Cátedras de Instituta y Vísperas, y en tres ocasiones se opuso a la de Prima de Leyes del Derecho civil, las cuáles regentó durante nueve años. En 1777 fue electo Consiliario Sinodial en la mencionada Universidad, en 1779 fiscal de ella, y en los años de 1780, 1783, y 1784 fue reelegido Consiliario, y en 1785 fue nombrado Vicerrector de la misma. Fue abogado en la Audiencia desde 20 de mayo de 1779, y desde 18 de septiembre de 1787 fue asesor de gobierno del Gobernador de Santo Domingo.

Hacendado.

\section{FERNÁNDEZ PALOMARES, Esteban.}

Nacido en Orán (África), desarrolló un amplio currículo militar como su abuelo Esteban Palomares. El 19 de diciembre de 1769 ingresó en la brigada de marina española en la que sirvió hasta que en 1774 se traslada a Santo Domingo junto con otros militares que fueron asignados para formar parte de los nuevos cuerpos militares que se habían creado en la isla. Esteban Fernández fue incorporado con el grado de subteniente de la onceava compañía del Batallón Fijo. El 22 de noviembre de 1781 fue ascendido a teniente de la segunda de dicho cuerpo, y se le asignó la comandancia en Puerto Plata. Entre 1788 y 1790 estuvo al cargo de la instrucción de cadetes.

Se casó con María Petronila Mañón y Mieses, hija del hacendado y regidor Antonio Mañón de Lara y Ana Teresa Mieses Ponce de León, hija del capitán Francisco Mieses Ponce de León y Olaya María Rodríguez. Al morir Esteban Fernández, Ana Teresa se casó en segundas nupcias con Antonio Ximénez.

Hacendado. 


\section{FERRER ANGULO, Miguel Bernardo Antonio.}

Nació en Cuba el 16 de diciembre de 1726. Sus abuelos y ascendientes por ambas partes ejercieron empleos políticos y militares en la isla de Cuba. Sus padres fueron el capitán y alcalde ordinario Félix Ferrer de Rojas y María de la Concepción Angulo Arias, hija del alférez Leonardo Antonio de Angulo Rojas y Ángela Arias Ramírez. Los abuelos paternos fueron el alférez Miguel Bernardo Ferrer- hijo del que fuese presidente y gobernador interino Pedro Ferrer- y Juana de Toro Rojas.

Pasó a Santo Domingo para continar sus estudios en la universidad y vestir los hábitos clericales, los cuales abandonó al contraer matrimonio con María Belén Castro-Rivera Urdaneta con la que se casó el 16 de agosto de 1744, muriendo en 1784. Obtuvo el título de capitán de infantería del Ejército el 18 de mayo de 1779, y ocupó varios cargos políticos en el ayuntamiento de Santo Domingo como el de regidor y depositario general, el cuál lo renunció en su hijo Miguel. Participó como miembro de la Junta de Agricultura y en la consulta para la elaboración del código negro carolino.

Fue enterrado en el campo Santo de la catedral de la ciudad de Santo Domingo.

Hacendado.

\section{GAZCUE Y OLAIZ, Francisco de Paula.}

Nació en Vera, Navarra. En 1754 pasó a la isla para desempeñar el cargo de contador mayor en las cajas reales de Santo Domingo por fallecimiento de Domingo Ramírez de Arellano. Se casó con Josefa Pueyo y Urríez, hija del regente Andrés Pueyo y Urríes y Josefa Díez. Entre los cuñados que tuvo destaca los oidores Ruperto Vicente Luyando y Beltrán y Nuño Navía Bolaños, y a Julián Joaquín, quien desempeñó la alcaldía mayor de Santiago entre 1770 y 1795.

\section{GURIDI CORONADO, Nicolás.}

Nacido en Santo Domingo. Fue hijo de Antonio Guridi y Echeandia y de Leonor AlarcónCoronado. Fue paje de jinete, soldado arcabucero, alférez y reformado entre 1709 y 1727. En 1725 fue cabo principal de la guardia de Baní, sus puertos y caletas para evitar el comercio ilícito. Luego fue capitán en propiedad de una de las Compañías de dotación de Santo Domingo donde ascendió a coronel del Batallón Fijo de las milicias de dicha ciudad. En 1727 fue elegido alcalde ordinario en el ayuntamiento de Santo Domingo. Estuvo casado en primeras nupcias con Ana Frómesta Balmaceda, hija del relator 
Leonardo José Frómesta y Montejo, y Felipa Balmaceda Rexas y Arteaga. Su segunda mujer fue Beatriz Leos-Echalas, hija de Francisco Javier Leos-Echalas y Juana Coronado. Hacendado.

\section{GURIDI CORONADO, Matías.}

Nacido en Santo Domingo. Era hijo de Antonio Guridi y Echeandia y de Leonor AlarcónCoronado. Se casó en 1726 con María Merced Rivera de la Concha Solano, hija del capitán y secretario de Cámara de la Audiencia de Santo Domingo, José Rivero de la Concha, natural del valle de Carriendo (Santander), y de Ana Solano Garavito.

Fue capitán del Batallón de milicias de la ciudad de Santo Domingo en 1726, y en 1732 de la Compañía de Caballería. Obtuvo el empleo de Alguacil Mayor de la Real Audiencia de Santo Domingo en 1741.

Hacendado.

\section{GURIDI CONCHA, Felipe.}

Nacido en Santo Domingo. Hijo de Matías Guridi y Coronado y de María Merced Rivera de la Concha Solano. Se casó con Ana Buenaventura Leos-Echalas, hermana de Beatriz Leos-Echalas mujer de su tío Nicolás Guridi Coronado.

Su hija María Guridi Leos-Echalas se casó con el regidor del ayuntamiento de Santo Domingo Pedro Fernández de Castro Coca-Landeche, hijo de Lorenzo Fernández Castro y de Antonia Coca-Landeche. Este matrimonio tuvo como hija a Josefa María Fernández Guridi que se casó con su primo Nicolás Leos-Echalas Heredia, hijo de Tomás LeosEchalas Coronado, gobernador de Baní en 1772 y de Ana Heredia de Castro-Coronado, ambos también parientes pero en segundo grado, pues Tomás era sobrino de Ana.

Fue teniente de justicia mayor de los pueblos de Azua, Neiba, San Juan, Banica, Hincha y sus adyacentes entre 1771 y 1783, año en el que muere. En 1763 y 1767 fue elegido alcalde ordinario de segundo voto, y en los años de 1756, 1764, y 1768 alcalde de Santa Hermandad del ayuntamiento de Santo Domingo.

Hacendado. 


\section{GURIDI CONCHA, José.}

Nacido en Santo Domingo. Hijo de Matías Guridi y Coronado y de María Merced Rivera de la Concha Solano. Se casó con Isabel Frómesta y Balmaceda, hija de Leonardo de Frómesta y Montejo relator de la Real Audiencia y Felipa Balmaceda Rexas y Arteaga. Fue abogado y procurador de la Real Audiencia en 1758. En ese mismo año fue Rector de la Universidad de Santo Tomás de Aquino donde realizó sus estudios en Leyes. Fue Alguacil Mayor de la Real Audiencia desde 1762 hasta que muere en 1776. Participó en la política municipal al ser electo en dos ocasiones como alcalde ordinario en 1752 y en 1760, alcalde de Santa Hermandad en 1756 ,1757 y 1761, y regidor perpetuo desde 1753. Hacendado.

\section{GURIDI FRÓMESTA, Nicolás.}

Nacido en Santo Domingo el 7 de mayo de 1755. Fue bautizado el 21 del mismo mes y año, siendo su madrina su tía Beatriz Leos-Echalas. Sus padres fueron el abogado José Guridi Concha e Isabel Frómesta y Balmaceda. Se casó en primeras nupcias con Juana Leos-Echalas y Heredia, hija de José Leos-Echalas y Manuela Heredia de Castro, y en segundas con Teresa Uztáriz y Arranz, hija del gobernador de Puerto Rico Miguel Antonio de Uztáriz, y de Tadea Arranz Martínez de Arizala.

Fue cadete en el regimiento de Infantería de Saboya entre 1773 y 1775. En 1775 fue caballero seminarista en el Real Seminario de Nobles de Madrid. Cuatro años más tarde fue elegido alcalde ordinario de segundo voto en el ayuntamiento de la ciudad de Santo Domingo, y en 1785 obtuvo el empleo de Alguacil Mayor de la Real Audiencia de dicha ciudad. Fue socio Benemérito de la Real Sociedad Bascongada de Amigos del País (1784-1793).

Hacendado.

\section{HEREDIA Y MIESES, José Francisco.}

Nació hacia 1776 en Santo Domingo. Fue hijo del regidor y hacendado Manuel Heredia Serrano Pimentel y de Francisca Justa Mieses Guridi.

Estudió en la Real y Pontificia Universidad de Santo Tomás de Aquino, obteniendo los grados de Bachiller en Cánones en 1792, el de Licenciado en 1793 y el de Doctor en 1794. En ese mismo año obtuvo la Cátedra de Vísperas de Cánones en la mencionada 
Universidad. Fue recibido como abogado por la Real Audiencia de Santo Domingo en 1795, y titulado por el Consejo de Castilla tres años después para ejercer la abogacía tanto en España como en cualquier otra parte de sus reinos. Permaneció en Santo Domingo a pesar de la cesión de la parte occidental de la isla a los franceses, donde en 1801 como Doctor en derecho civil en la Universidad en la que había estudiado, fue profesor para la Cátedra de Prima de Leyes. En 1806 se traslada a Pensacola (Florida Occidental) para desempeñar el cargo que se le había asignado como Asesor del Gobierno e Intendencia de dicha ciudad. En 1809 se muda a Venezuela para ocupar la plaza de oidor en la Audiencia de Caracas, aunque no tomó posesión de él hasta 1812. Entre 1812 y 1816 ejerció en la mencionada audiencia como regente interino. En Caracas se casa con su prima hermana María Merced Heredia y Campuzano, nacida en Venezuela, ya que sus padres habían emigrado a este país tras la cesión de Santo Domingo. En 1817 es designado como alcalde de crimen de la Audiencia de México, adonde se traslada y muere.

\section{HEREDIA SERRANO PIMENTEL, Nicolás.}

Nacido en Santo Domingo. Hijo de Domingo Heredia Castro-Coronado y de Isabel Serrano Pimentel y Paredes, una familia de las principales familias de la ciudad de Santo Domingo, los Heredia. Su padre además de hacendado participó en la política municipal como alcalde ordinario en 1758 y un año después es electo alcalde de Santa Hermandad y visita. Igual que su padre él fue un rico hacendado y en el ayuntamiento también fue alcalde ordinario en 1772 y 1775, y de Santa Hermandad en 1752 y 1771, así como regidor.

Se casó con María Magdalena Campuzano-Polanco Fernández, hija del venezolano y regidor del ayuntamiento de Santo Domingo José Campuzano Polanco Morillo, y de Rosa Fernández de Lara, otra de las principales familias de hacendados de la ciudad de Santo Domingo.

Hacendado.

\section{HEREDIA SERRANO PIMENTEL, Manuel.}

Hermano de Nicolás Heredia Serrano Pimentel, también nació en Santo Domingo. Se casó con Francisca Mieses Guridi, hija de Ana Guridi de la Concha y de Juan Mieses Ponce de León y Pérez Caro. 
Fue capitán de los Reales Ejércitos y capitán de las milicias disciplinadas, y de Urbanos. En el ayuntamiento de Santo Domingo fue alcalde ordinario de segundo voto en 1768, alcalde de Santa Hermandad en 1769, y regidor del ayuntamiento de Santo Domingo. Hacendado.

\section{LECANDA ANDIRENGOECHEA, Andrés.}

Nació el 20 de noviembre de 1737 en la ciudad de Bilbao (Vizcaya), donde fue bautizado el 30 de noviembre de 1737. Hijo de Francisco Fernando de Lecanda y de María Ventura de Andirengoechea y Goicochea, casados el 17 de noviembre de 1729 en Bilbao. Nieto por parte paterna de Juan Lecanda y de María Ventura de Arbolancha, y por parte materna de Felipe de Andirengoechea y de María Josefa de Goicochea. Sus familiares son descendientes de las casas solares de sus apellidos: la de Lecanda en el valle de Llodio, la de Arbolancha de la Iglesia de Begoña, la de Andirengoechea en Mungía y sufragánea de Larranz, y la de Goicochea en la de Sollo.

Llegó a Santo Domingo como paje del gobernador Manuel Azlor y Urríes. Se casó con Gabriela Sánchez Firpo, hija de Domingo Sánchez Moreno y de Rosa Manuela Firpo. Tuvieron diez hijos de los cuáles María Altagracia Raymunda se casó con Joaquín Foxá y Montúfar de Orán, quien había llegado a Santo Domingo como Sargento Mayor del Regimiento de Infantería de Cantabria.

Fue guardalmacén de pertrechos de guerra y artillería y primer Factor de la real renta de tabacos de la ciudad de Santo Domingo, empleo éste último que obtuvo el 1 de enero de 1770. Socio Benemérito de la Real Sociedad Bascongada Amigos del País, 1784-1793. Hacendado.

\section{MAÑÓN DE LARA, Antonio.}

Nació en Santo Domingo. Su padre fue Antonio Mañón, natural de Oriabad (Francia) y de la criolla Angelina de Lara y Mieses. Desempeñó su carrera militar durante veinte años, nueve de ellos como capitán de lanceros hasta que en diciembre de 1769 se formó el cuerpo de milicias regladas al que fue traspasado, y en el que ascendió al grado militar de capitán de Ejército. Fue regidor del cabildo de Santo Domingo, y formó parte de la Junta de Agricultura, así como en colaborador en la consulta que se realizó a algunos hacendados para la elaboración del código negro. 
Estuvo casado con Ana Teresa Mieses Ponce de Léon, hija de Francisco Mieses Ponce de León y Francisca Pérez-Caro Fernández. Fue Socio Benemérito de la Real Sociedad Bascongada Amigos del País, 1784-1793.

Hacendado.

\section{MIESES PONCE DE LEÓN PÉREZ-CARO, Juan.}

Nacido en Santo Domingo el 8 de junio de 1729, era hijo del teniente coronel y capitán de infantería Francisco Mieses Ponce de León Quero, y de Francisca Pérez-Caro y Fernández de Oviedo. Se casó el 30 de octubre de 1748 en la catedral de Santo Domingo con Ana Guridi de la Concha, hija del Alguacil Mayor de la Audiencia Matías Guridi Coronado y de María Merced Rivera de la Concha, con quien tuvo cinco hijos. La familia de su mujer tenía una amplia participación en la vida política, militar, religiosa e universitaria de la ciudad de Santo Domingo. Además se dedicaban a actividades agropecuarias, igual que su familia, también con una amplia participación en las esferas anteriormente citadas. Juan fue alcalde de Santa Hermandad y Visita en 1755, muriendo cuatro años después en 1759.

Hacendado.

\section{PÉREZ CARO Y OVIEDO, Ignacio.}

Natural de Santo Domingo. Sus padres fueron el brigadier Ignacio Francisco Pérez Caro y la criolla Ana María de Oviedo y Castillo Torquemada. Inició carrera militar como cadete hasta alcanzar el grado de capitán y coronel. Se desposó con María Magdalena Catalina Campuzano Fernández de Lara, perteneciente a una importante familia local. Fue uno de los militares consultados para la elaboración del código negro carolino y miembro de la Real Sociedad Bascongada de los Amigos del País (1784-1793).

Entre sus hijos destaca Francisco Xavier que nació el 12 de diciembre de 1773 en la ciudad de Santo Domingo. Estudió en la Universidad de Salamanca donde fue electo rector (1798-1800). También llegó a ocupar varios cargos de la administración metropolitana a principios del siglo XIX como el de vocal para la Junta Suprema Central y Gubernativa por la Provincia de Castilla la Vieja (1808-1810), y ministro de gobierno para consultar a la reina madre durante la minoría de edad de Isabel II (1833-1836). Su hija Rosa contrajo matrimonio con su tío, el abogado Andrían Campuzano Fernández de Lara.

Hacendado. 


\section{PUEYO Y URRÍES, Andrés.}

Nació en Barbastro, Aragón. Era hijo de Gerónimo Pueyo y de Eulalia de Urríes. Estudió filosofía y jurisprudencia en la Universidad de Huesca, donde fue colegial en el Imperial y Mayor de Santiago de dicha Universidad. Después de cuatro años en ella recibió el grado de Bachiller en leyes y estuvo dedicado a la enseñanza, explicando los libros Instituta y materias de ambos derechos. Hizo oposición a una beca de jurisprudencia en el Colegio Mayor en la que fue electo. Más tarde obtuvo el grado de Licenciado y Doctor en jurisprudencia civil. Fue rector en el propio Colegio que estudió, además desempeñó otros empleos como el de secretario y consilario. En varias ocasiones fue padrino en diferentes grados de Bachiller y de Licenciatura y Doctor en la facultad de leyes. En 1734 se le confirió la Cátedra de Digesto Viejo en propiedad y en 1735 y 1736 ejerció las Cátedras de Instituta y de Sexto en esa Universidad. Leyó en oposición a la Canonjías Doctorales de las Iglesias Metropolitanas de Zaragoza, y Catedral de Barbastro, recibiendo universal aplauso de los presentes. Sirvió como corregidor de Baena, y alcalde mayor de la villa de las Brozas.

Se casó con Josefa Díez de Aux y la Marca de la villa de Pertuza (obispado de Huesca, Aragón), hija de Juan Díez de Aux y de Josefa la Marca. En 1755 se le confirió la plaza de oidor de la Audiencia de Santo Domingo, donde se trasladó con su mujer e hijos. Tomó posesión el 9 de enero de dicho año y lo desempeñó hasta 1776. A partir de ese año fue regente en dicha institución hasta que en 1780 se jubiló, y en 1786 muere. Sus hijos se casaron con compañeros de su padre, así como con familias locales de Santo Domingo. Hacendado.

\section{PUEYO Y URRÍES, Julián Joaquín.}

Nació en Barbastro (Aragón) y fue bautizado en dicha ciudad el día 28 de febrero de 1746. Se trasladó de pequeño a Santo Domingo con su padre el oidor Andrés Pueyo y Urríes, donde había sido trasladado, su madre Josefa Díez y sus hermanos. Cursó los estudios menores y mayores de filosofía, teologría, sagrados, cánones y leyes en la Universidad de La Paz. Obtuvo la alcaldía mayor de la ciudad de Santiago, empleo en el que estuvo durante veinticinco años (1770-1795).

Tomó por esposa clandestinamente a Jerónima Tapia y Castro, miembro de la red CastroRivera y Urdaneta, provocando un conflicto entre ésta familia y la suya.

Hacendado. 


\section{RAMÍREZ, José Jacinto.}

Nacido en Santo Domingo. Hijo de Manuel Ramírez y de Úrsula González. Se casó con Isabel Franco Guridi, hija de Luis Franco Acevedo y de Antonia Guridi Coronado.

Fue cadete durante once años en el Batallón Fijo de la plaza de Santo Domingo, desde 1 de junio de 1754 hasta 31 de enero de 1764. Estudió en la Universidad de Gorjón donde regentó las Cátedras de derecho civil y se graduó como Doctor en derecho civil el 1 de mayo de 1766, concediéndosele el título de abogado oficio que desde 1778 ejerció en la Real Audiencia hasta la cesión de la misma. También desempeñó el empleo de relator en la misma institución.

Hacendado.

\section{ROCHA-FERRER LANDECHE, Domingo de la.}

Nacido en Santo Domingo. Sus padres fueron el tesorero de las cajas reales Antonio Francisco de la Rocha-Ferrer y las Barces y la criolla María del Rosario Landeche, hija del capitán Antonio Landeche y Ana María Bastidas, una de las más importantes y poderosas familias de la ciudad de Santo Domingo. Los abuelos paternos fueron Domingo de la Rocha-Ferrer -oidor de la Audiencia de la ciudad de Santa Fé, decano de ella y Teniente General de la ciudad de Cartagena de Indias-, y la asturiana Juana Clemencia de las Barces y Pando.

Estudió leyes en México, siendo admitido como ministro por su audiencia en 1740, y en la de Santo Domingo en 1751. Un año después fue nombrado regidor en el cabildo de la ciudad, cargo que desempeñó hasta 1766, al trasladarse a Yucatán para ejercer su nuevo empleo, el de auditor de guerra. Años más tarde fue oidor de la Audiencia de Guadalajara, y en 1796 fiscal de la de Guatemala, donde muere.

Se casó con su prima hermana Isabel Coca Landeche.

Hacendado.

\section{SÁNCHEZ VALVERDE, Antonio.}

Es una de las figuras intelectuales más importantes de la historia del país del siglo XVIII. Entre sus obras la más relevante se titula Idea del valor de la Isla Española y utilidades que de ella puede sacar su monarquía, y fue publicada en 1785. En este trabajo el autor 
hace una panorámica del pasado colonial, pero se centra fundamentalmente en el siglo XVIII. Periodo sobre el que describe cómo vivían sus habitantes y qué recursos naturales existían en la isla con el propósito de demostrar a la Corona las posibilidades de crecimiento económico de Santo Domingo.

Nacido en Santo Domingo, procedía de una "familia de militares" que había llegado a finales del siglo XVII y principios del siglo siguiente. Sus padres, naturales también de la ciudad de Santo Domingo fueron el agrimensor, y ayudante mayor Juan Sánchez Valverde y Clara de Ocaña, hija del capitán y sargento mayor Andrés de Ocaña, y de Francisca de Frías. Estudió con los padres jesuitas en la Universidad de Santiago de la Paz del Colegio de la Compañía de Jesús de Gorjon, donde se graduó de licenciado en Teología el 23 de diciembre de 1755 y se ordenó sacerdote. En 1756 obtuvo por oposición el Beneficio de la Sacristía Mayor de la Iglesia Parroquial de la ciudad de Bayaguana, donde residían sus padres.

También estudió Derecho civil en la Universidad de Santo Tomás recibiendo el grado de Bachiller el 14 de noviembre de 1758. En esta institución impartió la Cátedra de Instituta. Más tarde, el 22 de noviembre del mismo año, fue nombrado Promotor Fiscal eclesiástico y Defensor de Obras pías de aquel Arzobispado. El 26 de abril de 1759 el Reverendo Arzobispo Felipe Ruiz de Auzmendi le concedió licencia para celebrar el Santo Sacrificio de Misa en toda aquella diócesis. Meses más tarde, el 7 de noviembre del mismo año también se le dio licencia para confesar y predicar el Santo Evangelio, que desempeñó en la capilla de Nuestra Señora del Carmen. El 10 de septiembre de 1763, obtuvo el título de Abogado de los Reales Consejos, y un año después el empleo de racionero eclesiástico en el cabildo de la catedral.

\section{STERLIN DEL MONTE, Tiburcio José.}

Natural de Santo Domingo. Hijo del francés Nicolás Sterling y de Bernarda del Monte y Luna, perteneciente a una familia criolla de Santiago. Bernarda era hija de Tiburcio del Monte y de Ana Luna. Se casó dos veces, una con Dolores Simona Mieses Heredia y la segunda vez con Lorenza Arredondo Castro.

Estudió en la Universidad de Santo Tomás de Aquino donde se graduó en Bachiller en la facultad de derecho civil, y recibió título de abogado de la Audiencia en 15 de septiembre de 1783. En 1789 obtuvo por primera vez el empleo de alcalde ordinario del ayuntamiento de Santo Domingo, y por segunda vez en 1795. En 1793 se comprometió a donar la cantidad de 110 pesos anuales hasta que finalizara la guerra contra los franceses. 
En 1799 fue elegido síndico procurador general de aquella ciudad, empleo que nuevamente ejerció en 1800.

Hacendado.

\section{VEGA, José de la.}

Nació en Plasencia, Cáceres. Durante veinticuatro años y diez meses desarrolló su carrera militar en Santo Domingo. De teniente de una compañía llana de infantería pasó a alférez de las milicias de infantería en 1772, alcanzando el grado de teniente y capitán de infantería de Ejército, por Real Desacho de 30 de agosto de 1783. Con el gobernador Marqués del Socorro- le acompañó en el tratado de límites con Francia, y participó en la guerra de 1780 con Gran Bretaña. También ocupó numerosos cargos civiles en la ciudad de Santo Domingo: segundo factor de la real renta de tabacos (1770), administrador del hospital real y militar de dicha plaza (1778), alcalde ordinario (1788), síndico y procurador general (1790), y secretario de la capitanía general e inspección de ella (1765-1787).

Estuvo casado con Magdalena Velez Carrión, y en segundas nupcias con María Teresa Jover y Aznar, hija del oidor de la Audiencia, Ramón Jover y Joaquina Aznar. Fue Socio Benemérito de la Real Sociedad Bascongada de los Amigos del País (1784-1793).

Hacendado.

\section{VELILLA Y TORRES, Francisco Antonio.}

Natural de Montón, partido de Calatayud en Aragón. Sus padres fueron María Santos y Francisco Velilla. Llegó a Santo Domingo como paje del gobernador Manuel Azlor y Urríes. Ocupó distintos cargos administrativos: guarda mayor y administrador de la real renta de correos de la ciudad de San Fernando de Montecristi, juez subdelegado de comisos de la banda norte, y segundo factor de la renta de tabacos en la ciudad de Santiago. Estuvo casado con la criolla María de la Cruz Sánchez Firpo, hija del canario Domingo de la Cruz Sánchez Moreno y Rosa Manuela Firpo.

Hacendado-comerciante. 
Ruth Torres Agudo

\section{ZÁRRAGA CARO DE OVIEDO, José Antonio.}

Nacido en Santo Domingo, este hacendado era hijo del bilbaíno José Antonio Zárraga y de la criolla Felipa Pérez-Caro y Oviedo. Su mujer, Joaquina Mieses Heredia, pertenecía a una rica familia de hacendados con una activa participación en la vida de la ciudad de Santo Domingo, fundamentalmente en lo político y militar. 


\section{ANEXOS}

\section{Tabla 1. Relación de Presidentes, Gobernadores y Capitanes Generales de Santo Domingo, 1751-1795}

\section{- Francisco Rubio y Peñaranda}

- Años de Mandato, 1751-1759

- Títulos militares: Había servido desde los empleos de cadete, alférez, teniente, ayudante mayor, y capitán del Regimiento de Guardias españolas. En 1758 fue ascendido a Brigadier, Mariscal de Campo, y Comandante militar de Madrid.

\section{- Manuel Azlor y Urríes}

- Años de Mandato, 1759-1771

- Títulos militares: Sirvió los empleos de alférez, teniente y capitán de dragones, y coronel del regimiento de Frisia. Fue promovido a Brigadier en 1760 y a Mariscal de Campo en 1763.

- José Solano y Bote

- Años de Mandato, 1771-1778.

- Títulos militares: Fue guarda marina en Cádiz. Entre 1749 y 1753 realizó estudios de guerra y marina en Francia e Inglaterra. Estuvo comisionado en el establecimiento de los límites entre las posesiones españolas y portuguesas en América, siendo ascendido a capitán de fragata. Fue nombrado en 1763 Gobernador y Capitán General de Caracas, donde permaneció hasta su nombramiento para la de Santo Domingo en 1770. En 1773 fue ascendido a Brigadier y poco después a Teniente General de Armada.

- Isidro Peralta y Rojas

- Años de Mandato, 1778-1785.

- Títulos militares: Inició su carrera militar como capitán del regimiento de infantería de Cataluña, pasando en 1744 al de Navarra, y un año después al de Galicia con destino Niza donde participó en la campaña de Italia. Regresó en 1752, y en 1754 fue nombrado segundo teniente de reales guardias españolas. Participó en la guerra con Portugal regresando de nuevo a Cataluña donde permaneció hasta que en 1768 se le da la gobernación política y militar de Tarifa hasta que en 1778 pasó a Santo Domingo. Fue ascendido a Brigadier el 23 de marzo de 1784, muriendo en el cargo el 26 de septiembre de 1785.

- Manuel González.

- Años de Mandato, 1786-1788.

- Títulos militares: Hacia 1779 ejercía el cargo de Jefe de un Regimiento de Guarnición en La Habana. Ejerció el empleo de Gobernador de la Provincia de Cumaná desde el 16 de septiembre de 1780 hasta el 14 de diciembre de 1782, fecha en que se mudó hacia Caracas para encargarse de su Gobernación, desempeñándolo hasta el 13 de febrero de 1786, cuando se trasladó a la de Santo Domingo. Brigadier.

- Joaquín García Moreno. 
- Años de Mandato, 1789-1801.

- Títulos militares: Inició su carrera militar en 1757 como cadete y luego como subteniente del Real Cuerpo de Artillería. En 1762 es ascendido a ayudante mayor, participando en la campaña de Portugal. Más tarde marchó a La Habana y Puerto Rico para colaborar en la formación de sus milicias, sirviendo en el Regimiento de Toledo donde alcanzó el grado de sargento mayor. Después pasó a Santo Domingo para ayudar a la reorganización de las milicias, siendo ascendido a Comandante en 1771, y Teniente coronel en 1773. Fue comisario de los límites fronterizos con la parte francesa, y como recompensa fue nombrado Teniente de rey, y sargento mayor de la plaza de Santo Domingo en 1780. Antes de ser nombrado oficialmente Gobernador de Santo Domingo ya lo había sido en dos ocasiones aunque interinamente, una en 1785 tras la muerte de Isidro Peralta y Rojas, hasta la llegada de su sustituto, Manuel González. Pero al morir éste volvió a ejercerlo pero por pocos días, pues el oidor decano Pedro Catani fue quién se hizo cargo del gobierno interino. En 1791 fue ascendido a Brigadier y más tarde a Mariscal de Campo. Abandonó la isla una vez entregada la parte española a Toussaint Louverture en 1801, trasladándose a La Habana.

Fuentes: Utrera, F. C. de, Santo Domingo. Dilucidaciones..., op. cit., pp. 154-161. Martín Rebolo, J., Ejército y Sociedad..., op., cit., 34-35. Sevilla Soler, M ${ }^{a}$. R., Santo Domingo..., op., cit., pp. 291-322. Ponce, M., El control de la gestión..., op. cit., vol. I, pp. 395-397. 
Tabla 2. Relación de los escribanos que existen en 1767

\begin{tabular}{|c|c|c|}
\hline Población & Oficio & Poseedor \\
\hline \multirow{5}{*}{ Santo Domingo } & 2 Escribanos de Cámara y gobernación & $\begin{array}{l}\text { Juan Quevedo y Villegas } \\
\text { Juan Rendón Sarmiento }\end{array}$ \\
\hline & $\begin{array}{l}1 \text { Escribano de juzgado de provincia y } \\
\text { de cabildo }\end{array}$ & Esteban López de Urtiaga \\
\hline & 4 Escribanos públicos y de cabildo & $\begin{array}{l}\dot{c} \text { Manuel Benito de Lucas } \\
\text { Antonio García } \\
\text { Diego Sossa } \\
\end{array}$ \\
\hline & $\begin{array}{l}1 \text { Escribano de Real Hacienda, registros } \\
\text { y minas }\end{array}$ & Francisco Martínez de León \\
\hline & 1 Escribano de bienes de difuntos & Vacante \\
\hline Santiago & $\begin{array}{l}2 \text { Escribanos públicos, agregado a uno } \\
\text { de ellos el de cabildo }\end{array}$ & $\begin{array}{l}\text { Bernardo Martínez Valdés } \\
\text { Domingo Sanz de Azcona }\end{array}$ \\
\hline La Vega & 1 Escribano público y de cabildo & José Clemente Montaño \\
\hline Cotuí & Escribano público y de cabildo & No hay \\
\hline Higüey & Escribano público y de cabildo & No hay \\
\hline Bayaguana & Escribano público y de cabildo & No hay \\
\hline Hincha & $\begin{array}{l}2 \text { Escribanos públicos, agregado a uno } \\
\text { de ellos el de cabildo }\end{array}$ & $\begin{array}{l}\text { Bernardo Aybar } \\
\text { Tomás Antonio González }\end{array}$ \\
\hline San Carlos & 1 Escribano público y de cabildo & Miguel González \\
\hline Puerto Plata & 1 Escribano público y de cabildo & Vacante \\
\hline Montecristi & $\begin{array}{l}1 \text { Escribano público y de cabildo, de } \\
\text { Real Hacienda y registros }\end{array}$ & Francisco Figueroa de Cáceres \\
\hline $\begin{array}{l}\text { San Juan de la } \\
\text { Maguana }\end{array}$ & 1 Escribano público y de cabildo & Diego Lorenzo López \\
\hline Azua & 1 Escribano público y de cabildo & José del Rosario \\
\hline Neiba & 1 Escribano público y de cabildo & Jerónimo González \\
\hline Monte Plata & Escribano público y de cabildo & No hay \\
\hline Dajabón & 1 Escribano público y de cabildo & Juan Pablo de la Mota \\
\hline Banica & 1 Escribano público y de cabildo & Santiago Márquez \\
\hline
\end{tabular}

Fuentes: ¿'? (desconocido). El trabajo del escribano de bienes de difuntos era realizado por un escribano público de la ciudad de Santo Domingo. Informe de los oficiales reales, 4 de febrero de 1767. AGI, Santo Domingo, 979. Títulos varios de escribanos. AGI, Santo Domingo, 940. 
Ruth Torres Agudo

Tabla 3. Origen geográfico de los hacendados de Santo Domingo

\begin{tabular}{|c|c|c|}
\hline Hacendado & $\begin{array}{c}\text { Lugar de } \\
\text { nacimiento }\end{array}$ & Fuente \\
\hline Nicolás Guridi y Coronado & Santo Domingo & \multirow[t]{2}{*}{ AGI, Indiferente General, 166} \\
\hline Matías Guridi y Coronado & Santo Domingo & \\
\hline José Guridi y Concha & Santo Domingo & \multirow{3}{*}{ AGI, Santo Domingo, 1036} \\
\hline Felipe Guridi y Concha & Santo Domingo & \\
\hline Nicolás Guridi y Frómesta & Santo Domingo & \\
\hline José Jacinto Ramírez & Santo Domingo & \multirow{2}{*}{ AGI, Santo Domingo, 990} \\
\hline Vicente Antonio Faura & Santo Domingo & \\
\hline $\begin{array}{l}\text { Juan Mieses Ponce de León } \\
\text { Pérez-Caro }\end{array}$ & Santo Domingo & $\begin{array}{l}\text { AchV, Pleitos civiles, La Puerta } \\
\text { Olvidados, } 1378 \\
\end{array}$ \\
\hline $\begin{array}{l}\text { Manuel Heredia Serrano } \\
\text { Pimentel }\end{array}$ & Santo Domingo & \multirow{2}{*}{$\begin{array}{l}\text { Larrazábal Blanco, C., Familias } \\
\text { dominicanas. Santo Domingo, 1978, } \\
\text { vol. IV, pp. 17-18. }\end{array}$} \\
\hline $\begin{array}{l}\text { Nicolás Heredia Serrano } \\
\text { Pimentel }\end{array}$ & Santo Domingo & \\
\hline $\begin{array}{l}\text { José Antonio Zárraga Caro de } \\
\text { Oviedo }\end{array}$ & Santo Domingo & AASD, Acta 948, fol. 207, Libro 11. \\
\hline $\begin{array}{l}\text { Tiburcio José Sterling del } \\
\text { Monte }\end{array}$ & Santo Domingo & AGI, Santo Domingo, 999 \\
\hline Lorenzo Fernández de Castro & Santo Domingo & \multirow{3}{*}{ AGI, Santo Domingo, 949} \\
\hline $\begin{array}{l}\text { Pedro Fernández de Castro } \\
\text { Coca-Landeche }\end{array}$ & Santo Domingo & \\
\hline Nicolás Leos-Echalas Heredia & Santo Domingo & \\
\hline Felipe Frómesta Montejo & Santo Domingo & \multirow{2}{*}{ AGI, Santo Domingo, 1025} \\
\hline José Frómesta Montejo & Santo Domingo & \\
\hline Antonio Álvarez Barba & Salamanca & \multirow{3}{*}{ AGI, Santo Domingo, 933} \\
\hline Antonio Mañón de Lara & Santo Domingo & \\
\hline José Mañón de Lara Mieses & Santo Domingo & \\
\hline Esteban Fernández Palomares & Orán (África) & AGS, SGU, 7290 \\
\hline Antonio Coca Landeche & Santo Domingo & \multirow{3}{*}{ AGI, Santo Domingo, 1095} \\
\hline $\begin{array}{l}\text { Antonio Coca Landeche y } \\
\text { Oviedo }\end{array}$ & Santo Domingo & \\
\hline $\begin{array}{l}\text { Damián Coca Landeche y } \\
\text { Oviedo }\end{array}$ & Santo Domingo & \\
\hline Lorenzo Angulo Medrano & Alfaro (Logroño) & \begin{tabular}{|l|} 
Larrazábal Blanco, C., Familias \\
dominicanas..., op. cit., vol. I, p. 141.
\end{tabular} \\
\hline $\begin{array}{l}\text { Antonio Angulo Coca } \\
\text { Landeche }\end{array}$ & Santo Domingo & \multirow{2}{*}{$\begin{array}{l}\text { Rodríguez Demorizi, E., Milicias de } \\
\text { Santo Domingo (1786-1821). Santo } \\
\text { Domingo, 1978, pp. 70, } 157 \text { y } 359 . \\
\end{array}$} \\
\hline Andrés Angulo Cabrera & Santo Domingo & \\
\hline Francisco Pepín González & Cádiz & \multirow{2}{*}{ Ibidem., pp. 369-381. } \\
\hline Martín José de Miura & Pamplona (Navarra) & \\
\hline Francisco Martínez & Peninsular ( $\dot{\dot{c}}$ ?) & \\
\hline $\begin{array}{l}\text { Domingo de la Rocha-Ferrer } \\
\text { y Landeche }\end{array}$ & Santo Domingo & $\begin{array}{l}\text { Burkholder, M. A., Biographical } \\
\text { dictionary of audiencia ministers in the } \\
\text { Americas: 1687-1821. Westport, 1982, } \\
\text { pp. 291-292. }\end{array}$ \\
\hline $\begin{array}{l}\text { Rodrigo Macedonio de la } \\
\text { Rocha-Ferrer y Coca } \\
\text { Landeche }\end{array}$ & Santo Domingo & $\begin{array}{l}\text { Rodríguez Demorizi, E., Milicias de } \\
\text { Santo Domingo..., op. cit., p. } 30 .\end{array}$ \\
\hline
\end{tabular}




\begin{tabular}{|c|c|c|}
\hline Hacendado & $\begin{array}{c}\text { Lugar de } \\
\text { nacimiento }\end{array}$ & Fuente \\
\hline $\begin{array}{l}\text { José Campuzano Polanco } \\
\text { Morillo }\end{array}$ & Coro (Venezuela) & ARB, leg. 25 (1773-1774) \\
\hline $\begin{array}{l}\text { Adrián Campuzano Polanco } \\
\text { Fernández de Lara }\end{array}$ & Santo Domingo & AGI, Santo Domingo, 929 \\
\hline Ignacio Pérez Caro y Oviedo & Santo Domingo & \multirow[b]{2}{*}{ AGI, Santo Domingo, 960} \\
\hline $\begin{array}{l}\text { Francisco Xavier Caro Oviedo } \\
\text { y Torquemada }\end{array}$ & Santo Domingo & \\
\hline $\begin{array}{l}\text { Miguel Bernardo Antonio } \\
\text { Ferrer Angulo }\end{array}$ & La Habana & \multirow{2}{*}{ AGI, Santo Domingo, 937} \\
\hline Miguel Bernardo Ferrer & Santo Domingo & \\
\hline Antonio Rojas & Peninsular (iं?) & AGI, Santo Domingo, 977 \\
\hline Juan Arredondo Vizcaíno & Santo Domingo & AGI, Santo Domingo, 937 \\
\hline $\begin{array}{l}\text { José Esteban Arredondo } \\
\text { Castro }\end{array}$ & Santo Domingo & AGI, Santo Domingo, 1015 \\
\hline Domingo Lorenzo Zevallos & Canarias & AGI, Santo Domingo, 940 \\
\hline $\begin{array}{l}\text { Antonio Valdemoro y } \\
\text { Alcántara }\end{array}$ & Peninsular ( $\dot{¿} ?)$ & AGI, Santo Domingo, 937 \\
\hline Francisco Tapia y Castro & Santo Domingo & \multirow{2}{*}{ AGI, Santo Domingo, 1021} \\
\hline Gregorio Saviñón & La Habana & \\
\hline Salvador Pí y Piquer & Cataluña & $\begin{array}{l}\text { Oliva Melgar, J. M }{ }^{\mathrm{a}} \text {., Cataluña y el } \\
\text { comercio privilegiado con América en } \\
\text { el siglo XVIII: la Real Compañía de } \\
\text { Comercio de Barcelona en Indias. } \\
\text { Barcelona, 987, p. } 109 . \\
\end{array}$ \\
\hline Pedro Roig y Lluis & Cataluña & \multirow{3}{*}{$\begin{array}{l}\text { Guerrero Cano, Ma } \text {. M.,’Un dominicano } \\
\text { en el colegio de nobles americanos de } \\
\text { Granada. Familia y genealogía de Juan } \\
\text { Clemente Martínez Saviñón.” } \\
\text { Trocadero 8-9 (Cádiz, 1996-1997) pp. } \\
\text { 383-400, p. } 391 \text { y 393. }\end{array}$} \\
\hline $\begin{array}{l}\text { Miguel Jerónimo Martínez de } \\
\text { Venecia Santelices }\end{array}$ & Santo Domingo & \\
\hline Fernando Mauleón & Peninsular ( $\dot{i} ?)$ & \\
\hline $\begin{array}{l}\text { Andrés de Lecanda y } \\
\text { Andirengoechea }\end{array}$ & Bilbao (Vizcaya) & AGI, Santo Domingo, 1011 \\
\hline $\begin{array}{l}\text { Francisco Antonio Velilla y } \\
\text { Torres }\end{array}$ & Montón (Aragón) & \multirow{2}{*}{$\begin{array}{l}\text { Campillo Pérez, J. G., Francisco } \\
\text { Espaillat y el desarrollo del Cibao. } \\
\text { Santo Domingo, 1985, p. } 9\end{array}$} \\
\hline Francisco Espaillat y Virol & Masclat (Francia) & \\
\hline Raymundo de Esparza & Pamplona (Navarra) & AGI, Santo Domingo, 992 \\
\hline $\begin{array}{l}\text { Francisco de Paula Gazcue y } \\
\text { Olaiz }\end{array}$ & Vera (Navarra) & $\begin{array}{l}\text { Larrazábal Blanco, C., Familias } \\
\text { dominicanas..., op. cit., vol. III, p. } 302\end{array}$ \\
\hline Andrés Pueyo y Urríes & Barbastro (Aragón) & \multirow{2}{*}{ AGI, Contratación, 5498,N40 } \\
\hline Julián Joaquín Pueyo y Urríes & Barbastro (Aragón) & \\
\hline Ramón Jover Ferrandiz & Elche (Valencia) & $\begin{array}{l}\text { Burkholder, M. A., Biographical } \\
\text { dictionary..., op. cit., p. } 173 \text {. }\end{array}$ \\
\hline José de la Vega & Plasencia (Cáceres) & $\begin{array}{l}\text { Larrazábal Blanco, C., Familias } \\
\text { dominicanas..., op. cit., vol. IX, p. } 46 .\end{array}$ \\
\hline $\begin{array}{l}\text { Juan Bautista Oyarzábal y } \\
\text { Olavide }\end{array}$ & \begin{tabular}{|l}
$\begin{array}{l}\text { Hendaya (País vasco } \\
\text { francés) }\end{array}$ \\
\end{tabular} & $\begin{array}{l}\text { Zylberberg, M., Une si douce } \\
\text { domination..., op. cit., p. 135-137. }\end{array}$ \\
\hline Antonio Cumulat & Cataluña & $\begin{array}{l}\text { Oliva Melgar, J. Ma., Cataluña y el } \\
\text { comercio..., op. cit., p. } 108 .\end{array}$ \\
\hline José Arata & Génova (Italia) & $\begin{array}{l}\text { Rodríguez Demorizi, E., Milicias de } \\
\text { Santo Domingo..., op. cit., p. } 13 .\end{array}$ \\
\hline
\end{tabular}


Tabla 4. Origen geográfico de los padres de los hacendados criollos

\begin{tabular}{|c|c|c|}
\hline Hacendado & \begin{tabular}{|c|}
$\begin{array}{c}\text { Lugar de nacimiento } \\
\text { del padre }\end{array}$ \\
\end{tabular} & $\begin{array}{c}\text { Lugar de nacimiento de la } \\
\text { madre }\end{array}$ \\
\hline Nicolás Guridi y Coronado & Legazpi (Guipúzcoa) & Santo Domingo \\
\hline Matías Guridi y Coronado & Legazpi (Guipúzcoa) & Santo Domingo \\
\hline José Guridi y Concha & Santo Domingo & Santo Domingo \\
\hline Felipe Guridi y Concha & Santo Domingo & Santo Domingo \\
\hline Nicolás Guridi y Frómesta & Santo Domingo & Santo Domingo \\
\hline José Jacinto Ramírez & $\dot{i} ?$ & $\dot{¿} ?$ \\
\hline Vicente Antonio Faura & Orihuela (Alicante) & Orihuela (Alicante) \\
\hline $\begin{array}{l}\text { Juan Mieses Ponce de León Pérez- } \\
\text { Caro }\end{array}$ & Santo Domingo & Santo Domingo \\
\hline Manuel Heredia Serrano Pimentel & Santo Domingo & Santo Domingo \\
\hline Nicolás Heredia Serrano Pimentel & Santo Domingo & Santo Domingo \\
\hline $\begin{array}{l}\text { José Antonio Zárraga Caro de } \\
\text { Oviedo }\end{array}$ & Bilbao (Vizcaya) & Santo Domingo \\
\hline Tiburcio José Sterling del Monte & Francia & Santo Domingo \\
\hline Lorenzo Fernández de Castro & Santo Domingo & Santo Domingo \\
\hline $\begin{array}{l}\text { Pedro Fernández de Castro Coca- } \\
\text { Landeche }\end{array}$ & Santo Domingo & Santo Domingo \\
\hline Nicolás Leos-Echalas Heredia & Santo Domingo & Santo Domingo \\
\hline Felipe Frómesta Montejo & La Habana & La Habana \\
\hline José Antonio Frómesta Montejo & La Habana & La Habana \\
\hline Antonio Mañón de Lara & Francia & Santo Domingo \\
\hline José Mañón de Lara Mieses & Santo Domingo & Santo Domingo \\
\hline Antonio Coca Landeche & Cádiz & Santo Domingo \\
\hline Antonio Coca Landeche y Oviedo & Santo Domingo & Santo Domingo \\
\hline Damián Coca Landeche y Oviedo & Santo Domingo & Santo Domingo \\
\hline Antonio Angulo Coca Landeche & Alfaro (Logroño) & Santo Domingo \\
\hline Andrés Angulo Coca Landeche & Alfaro (Logroño) & Santo Domingo \\
\hline $\begin{array}{l}\text { Domingo de la Rocha-Ferrer y } \\
\text { Landeche }\end{array}$ & $\begin{array}{l}\text { Cartagena de Indias } \\
\text { (Colombia) }\end{array}$ & Santo Domingo \\
\hline $\begin{array}{l}\text { Rodrigo Macedonio de la Rocha } \\
\text { Coca Landeche }\end{array}$ & Santo Domingo & Santo Domingo \\
\hline José Campuzano Polanco Morillo & Santo Domingo & Santo Domingo \\
\hline $\begin{array}{l}\text { Adrián Campuzano Polanco } \\
\text { Fernández de Lara }\end{array}$ & Coro (Venezuela) & Santo Domingo \\
\hline Ignacio Pérez Caro y Oviedo & Santo Domingo & Santo Domingo \\
\hline $\begin{array}{l}\text { Francisco Xavier Caro Oviedo y } \\
\text { Torquemada }\end{array}$ & Santo Domingo & Santo Domingo \\
\hline $\begin{array}{l}\text { Miguel Bernardo Antonio Ferrer } \\
\text { Angulo }\end{array}$ & La Habana & La Habana \\
\hline Miguel Bernardo Ferrer & La Habana & Santo Domingo \\
\hline Juan Arredondo Vizcaíno & Peninsular (¿?) & Santiago \\
\hline José Esteban Arredondo Castro & Santo Domingo & Santo Domingo \\
\hline Francisco Tapia y Castro & Canarias & Santo Domingo \\
\hline Gregorio Saviñón & La Habana & La Habana \\
\hline $\begin{array}{l}\text { Miguel Jerónimo Martínez de } \\
\text { Venecia Santelices }\end{array}$ & Guadalajara (Toledo) & Santo Domingo \\
\hline
\end{tabular}

Fuentes: ¿? (desconocido). Ver Anexos Tabla 3. 
Anexos

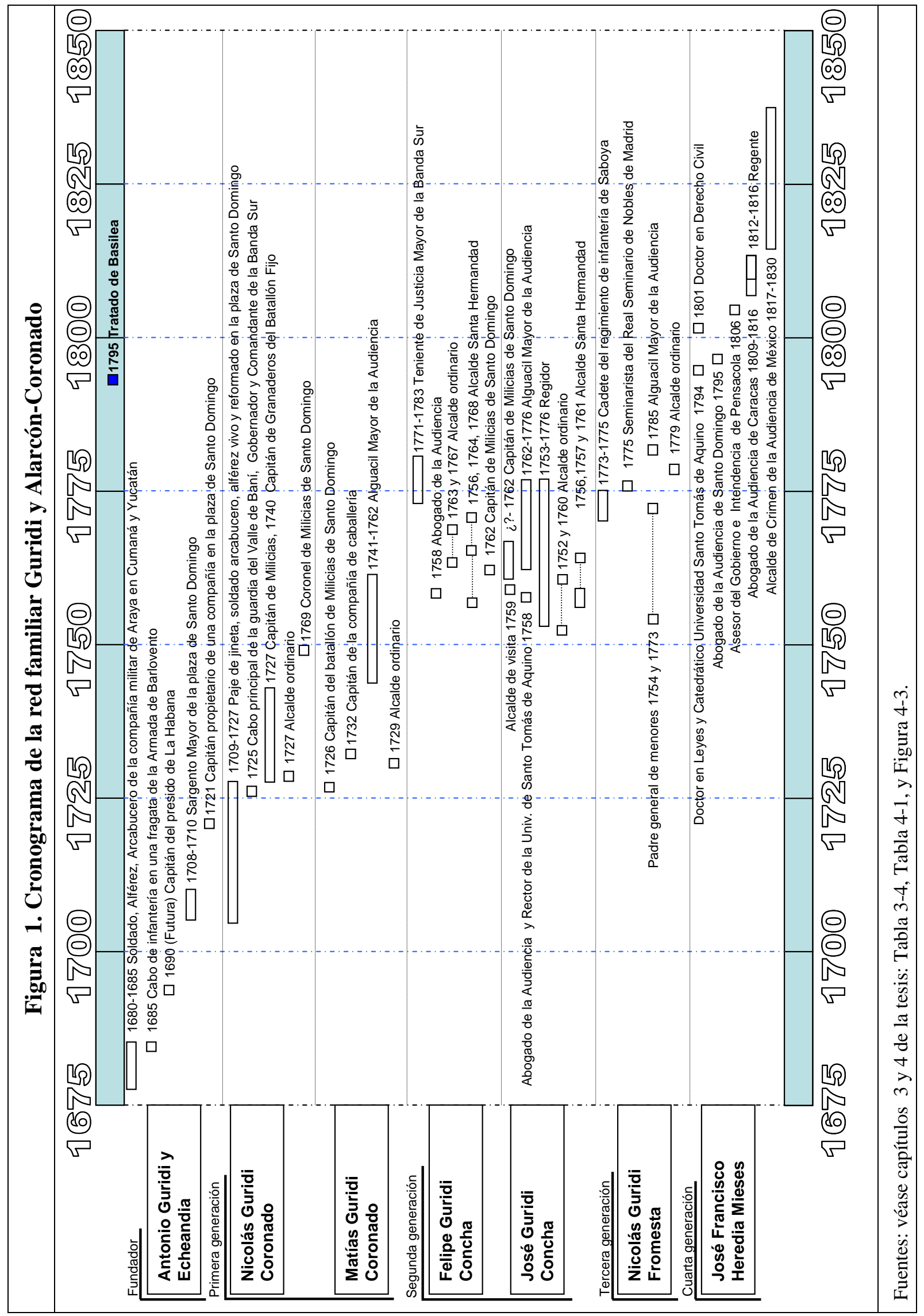


Ruth Torres Agudo

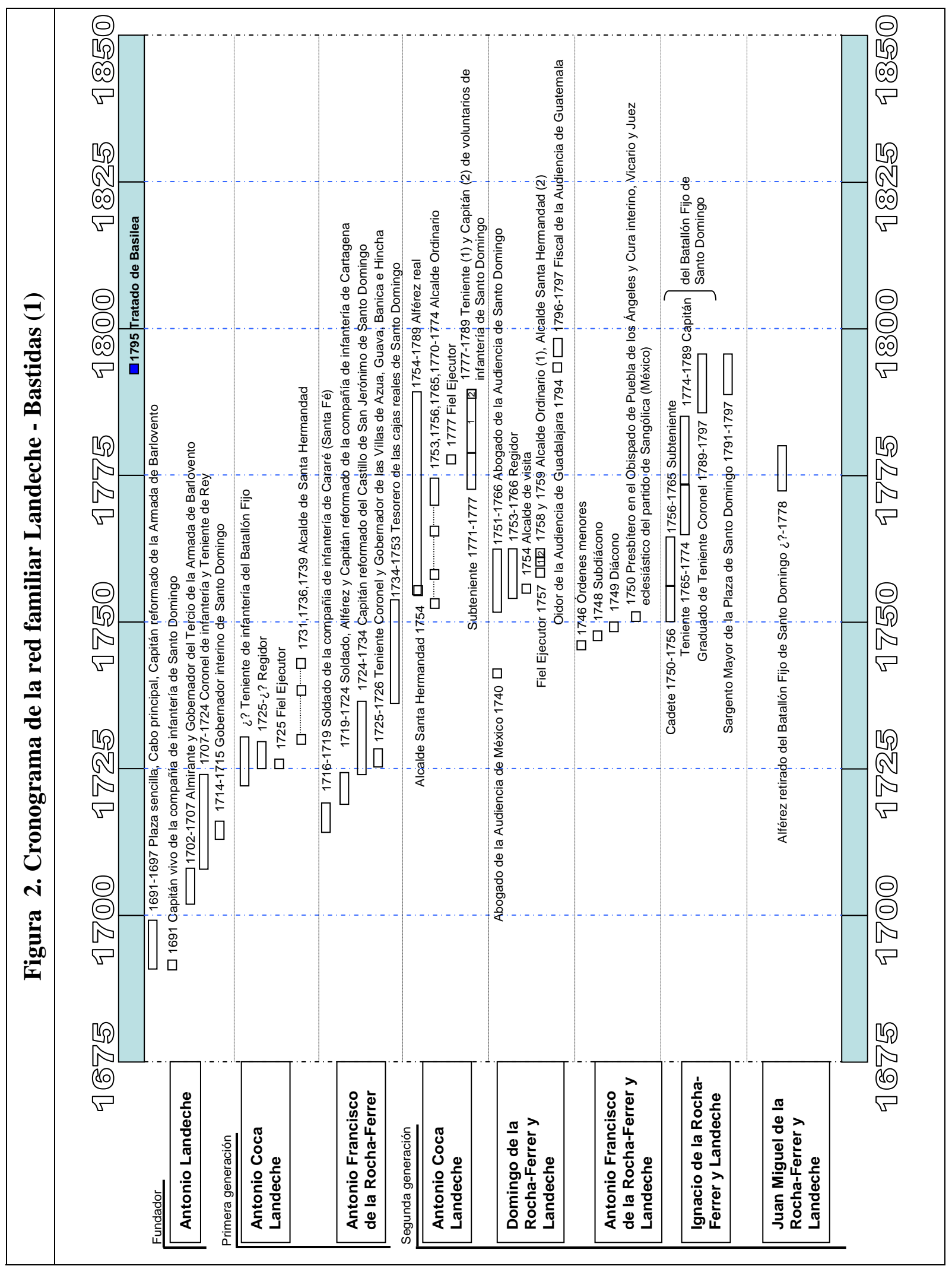


Anexos

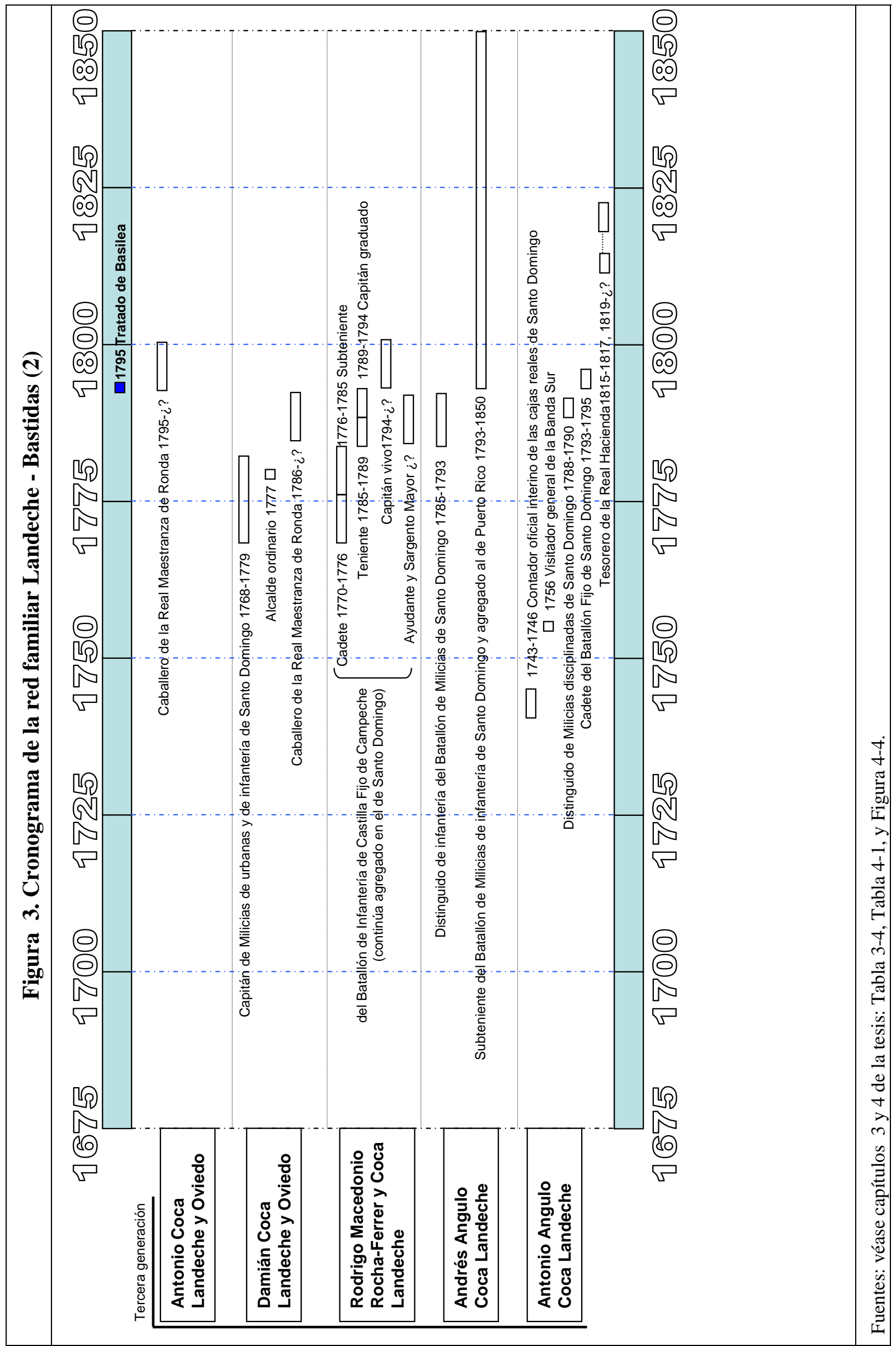


Ruth Torres Agudo

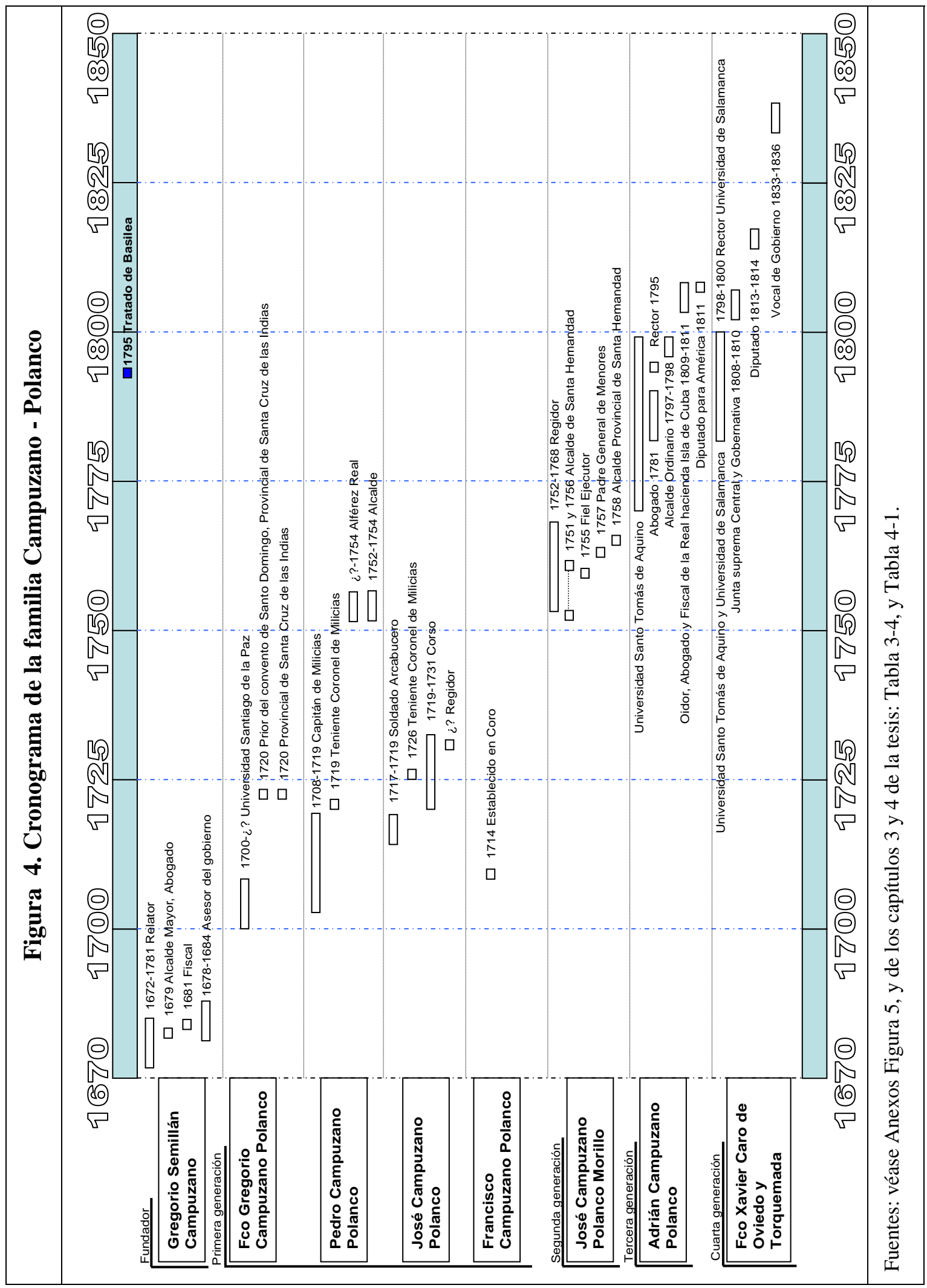


Anexos

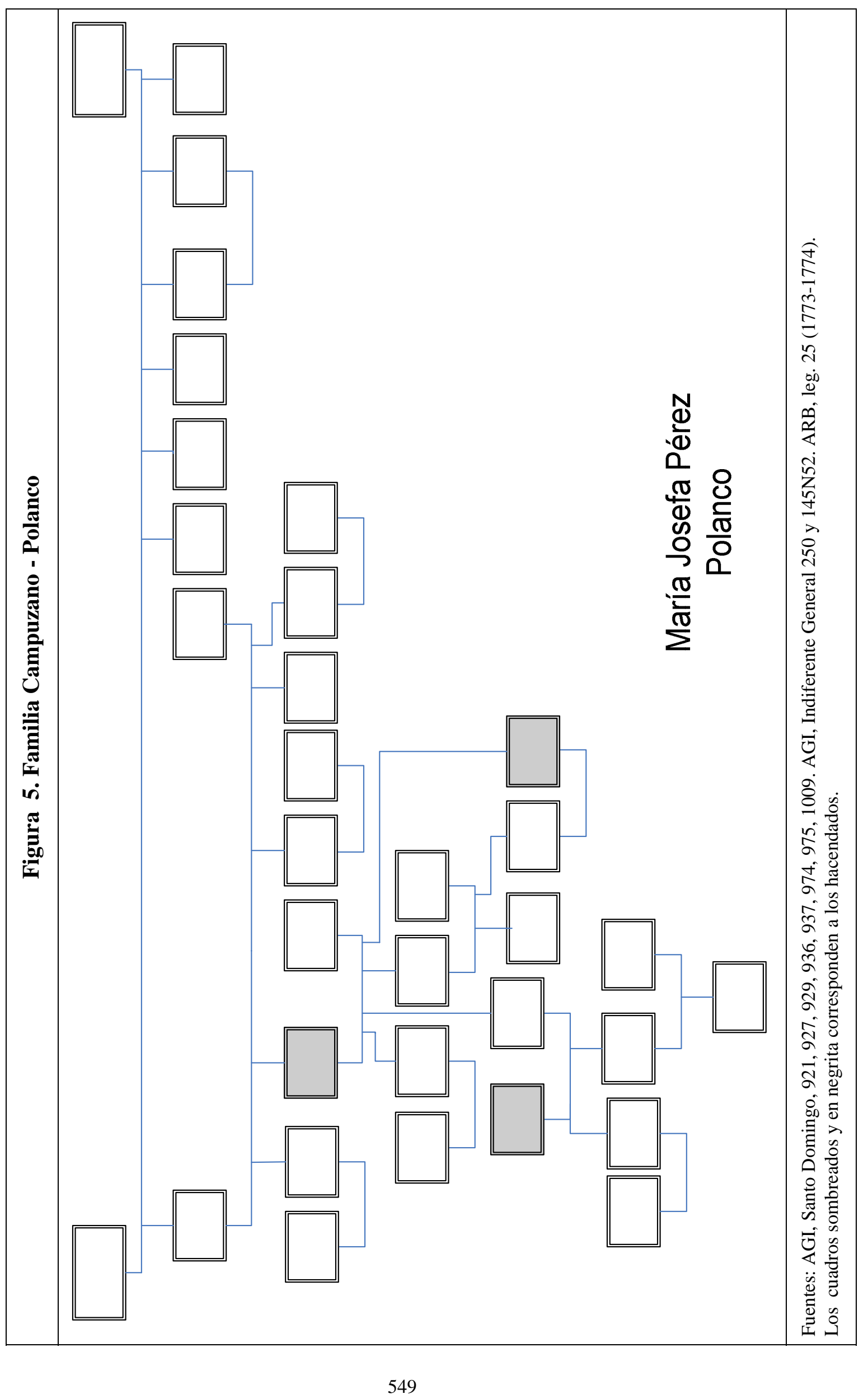


Ruth Torres Agudo

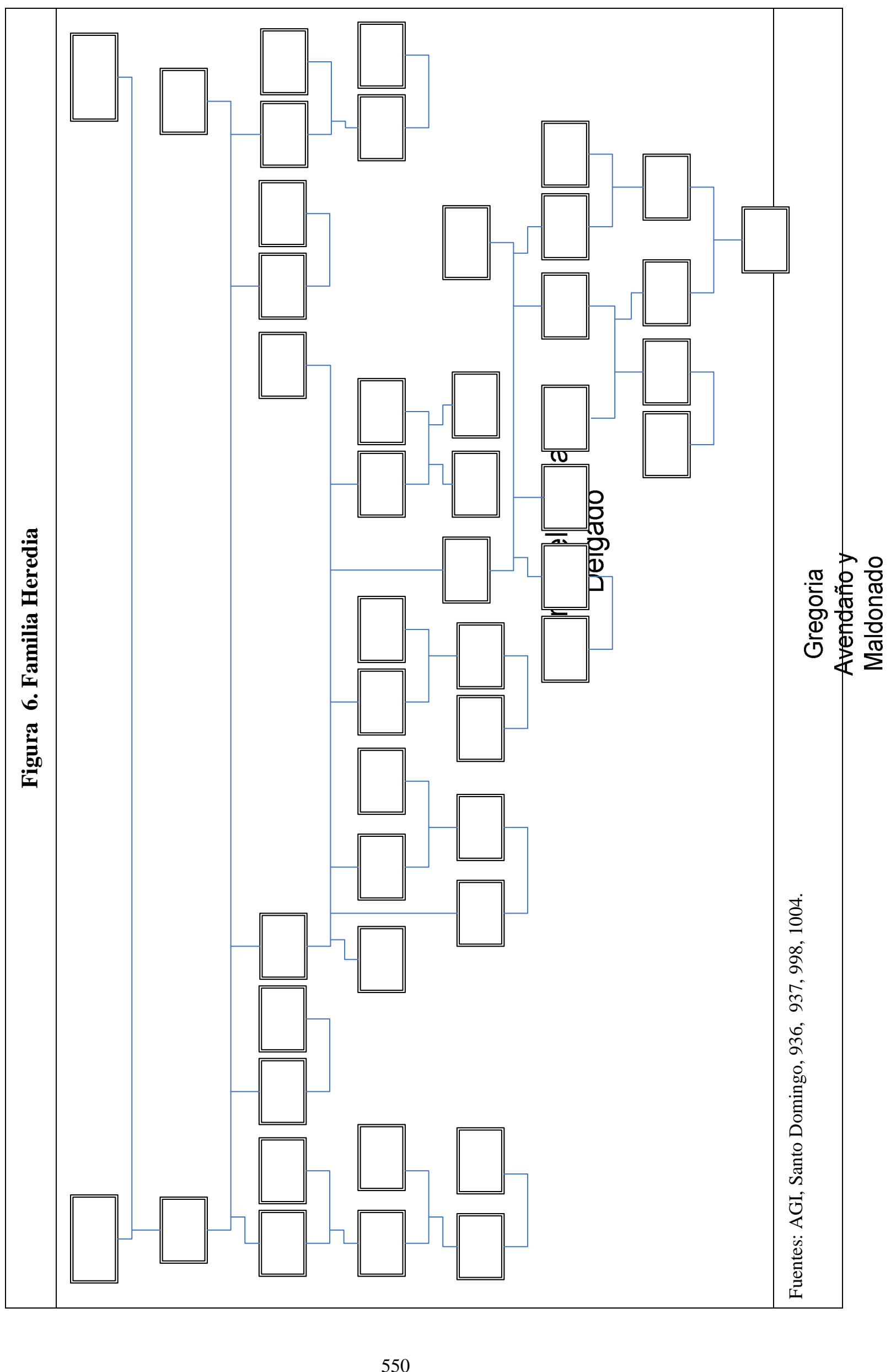


Anexos

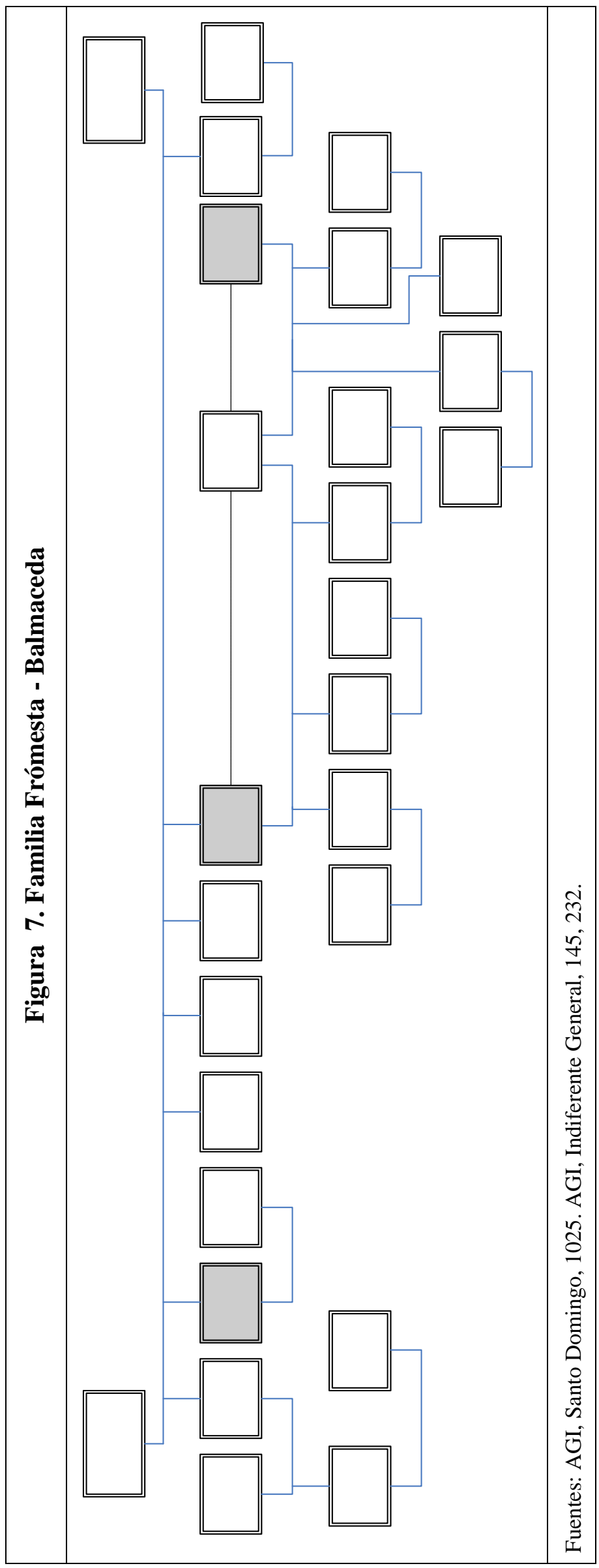

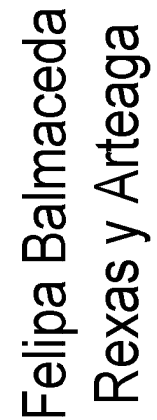


Ruth Torres Agudo
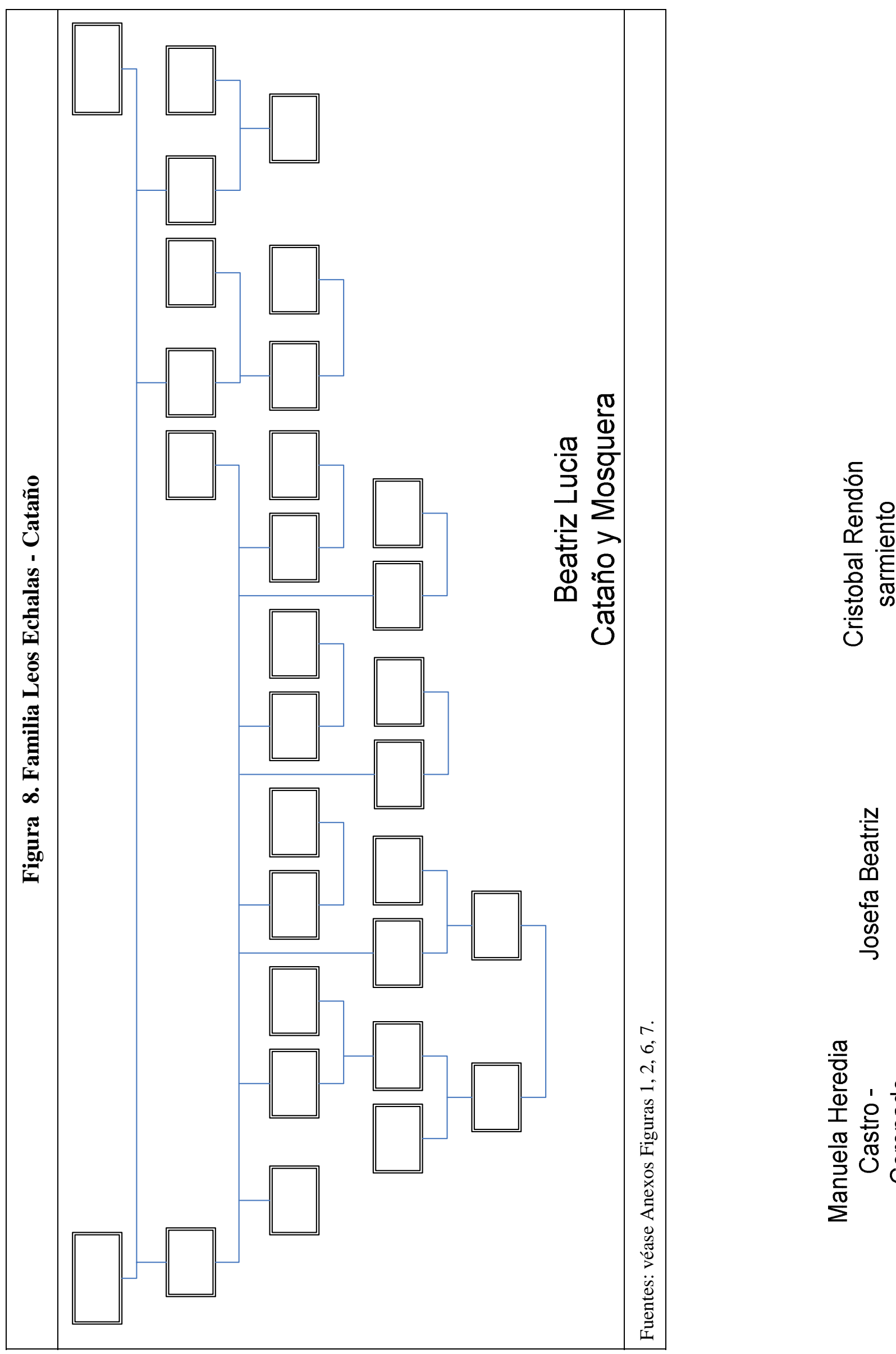

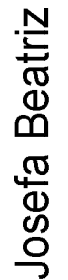

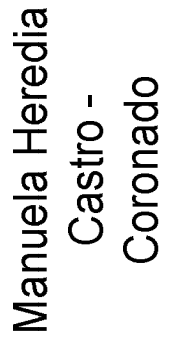


Anexos

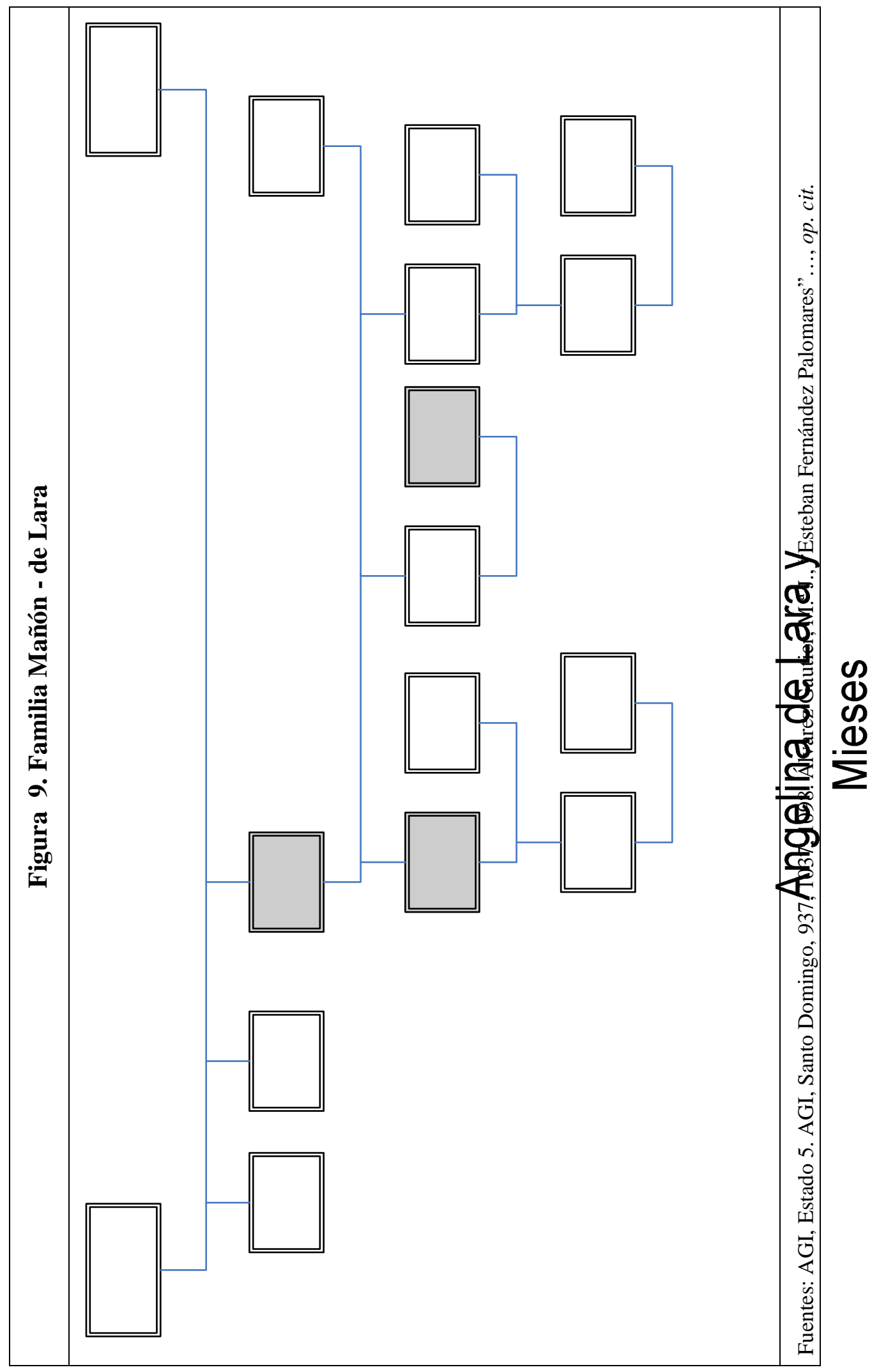


Ruth Torres Agudo

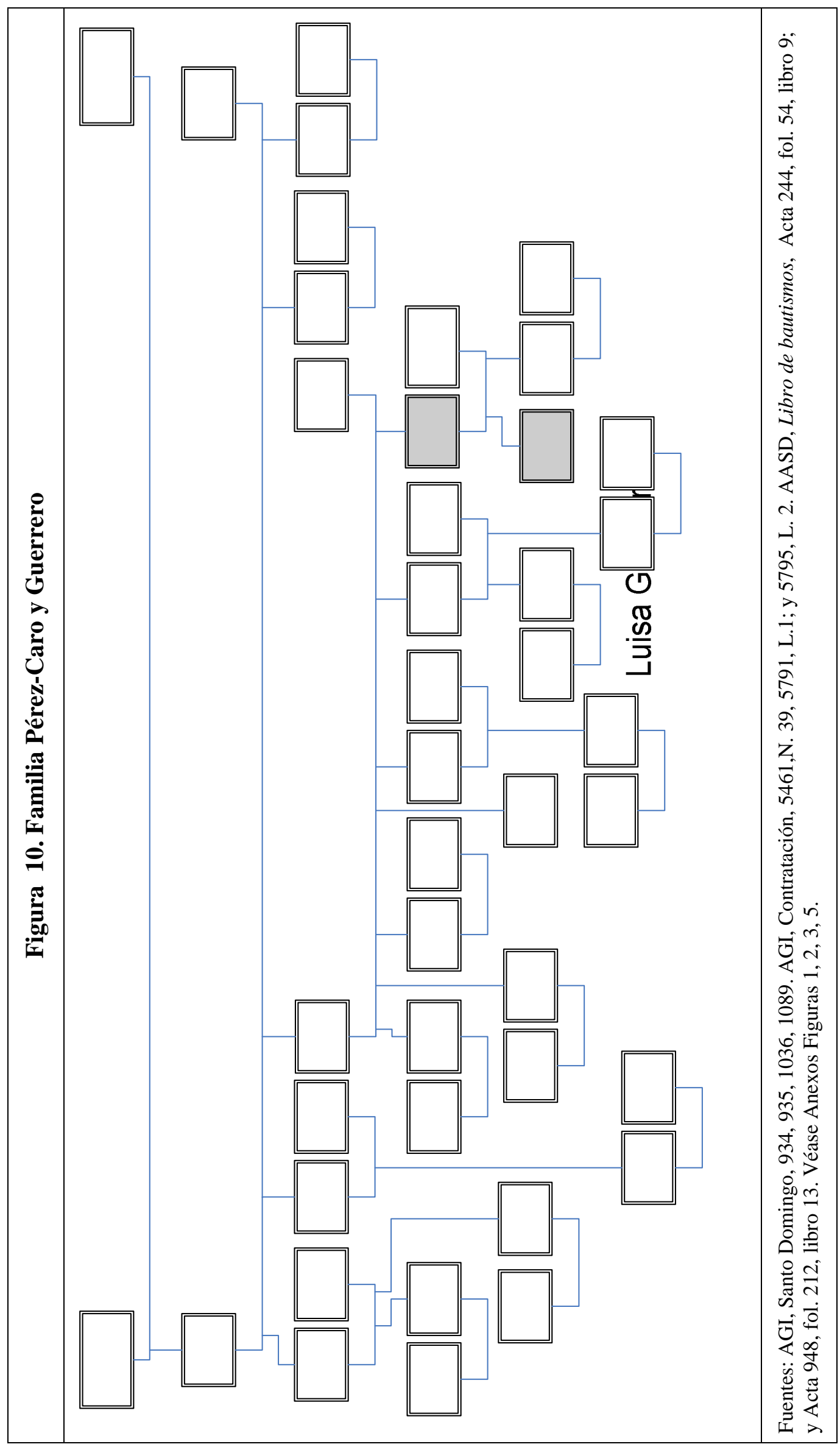

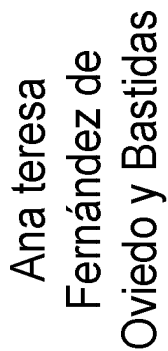


Anexos

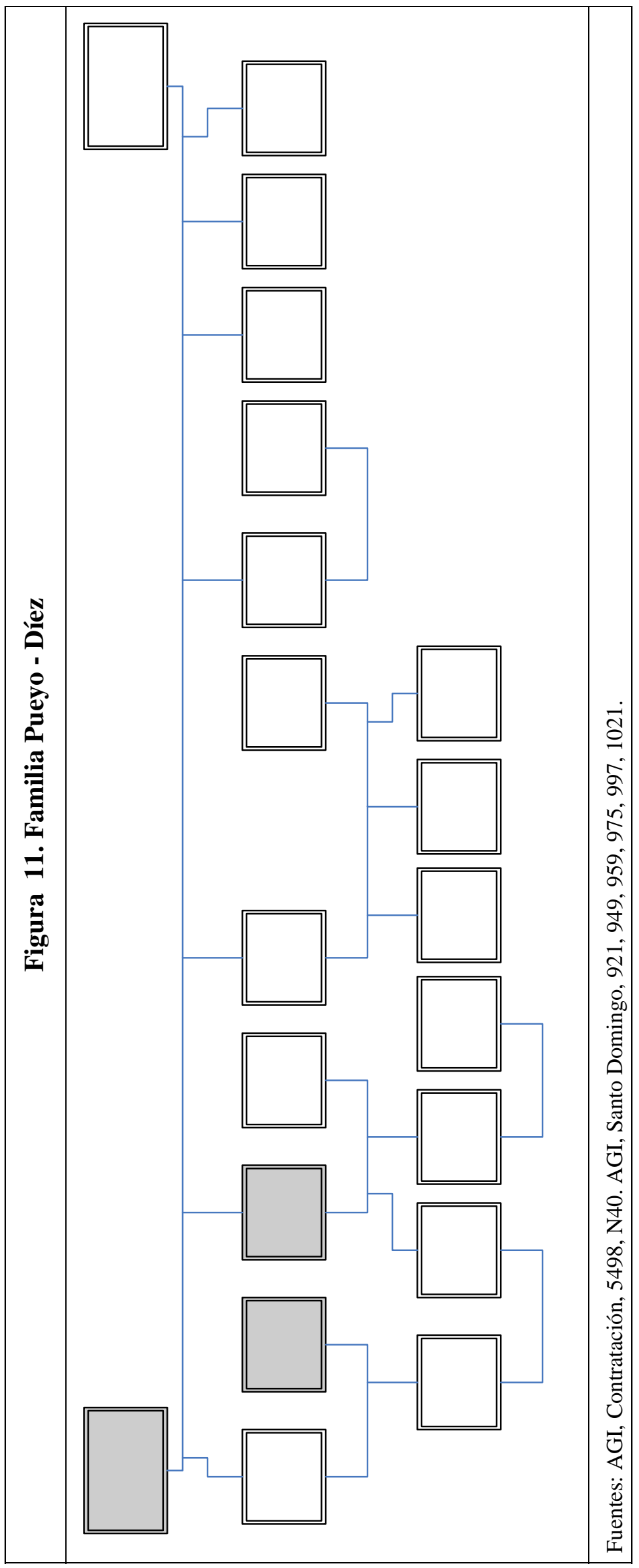

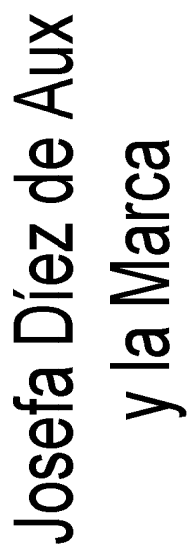


Ruth Torres Agudo

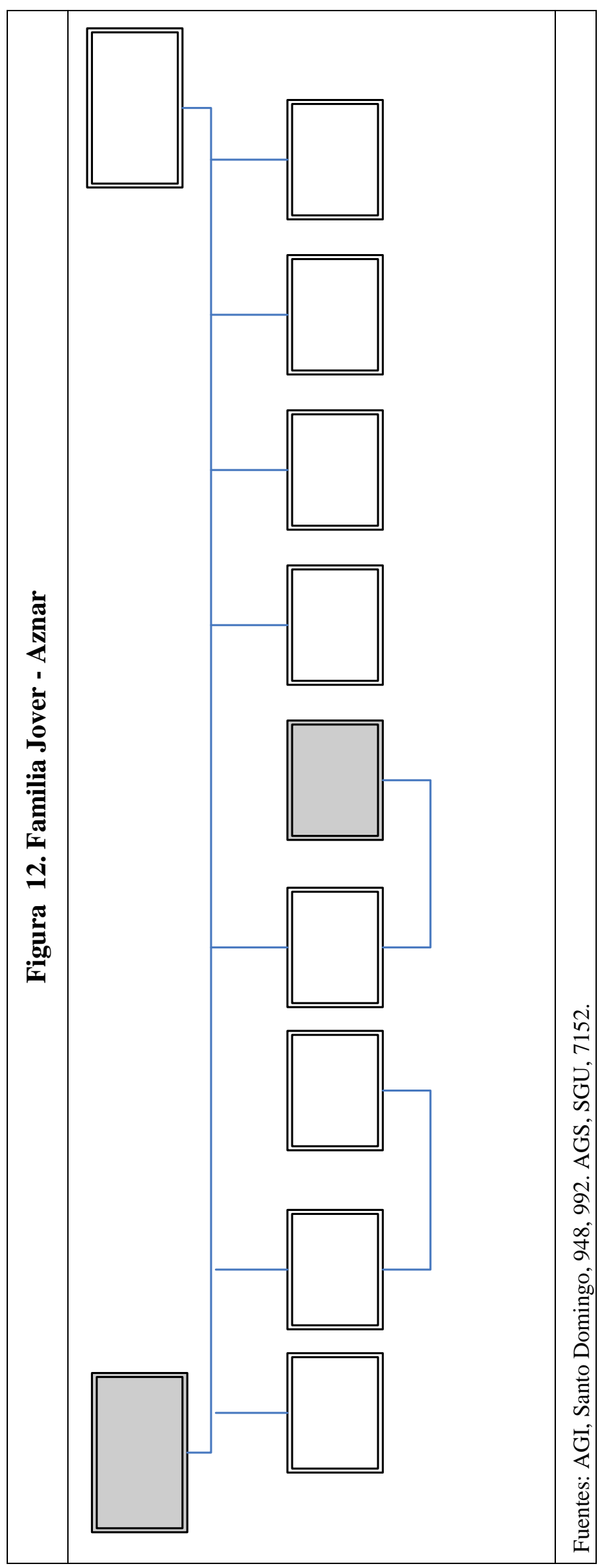

\begin{tabular}{l}
$\frac{1}{\sigma}$ \\
$\frac{N}{\tau}$ \\
$\frac{\sigma}{\sigma}$ \\
$\frac{\bar{\sigma}}{\sigma}$ \\
$\frac{\sigma}{0}$ \\
\hline
\end{tabular} 
Anexos

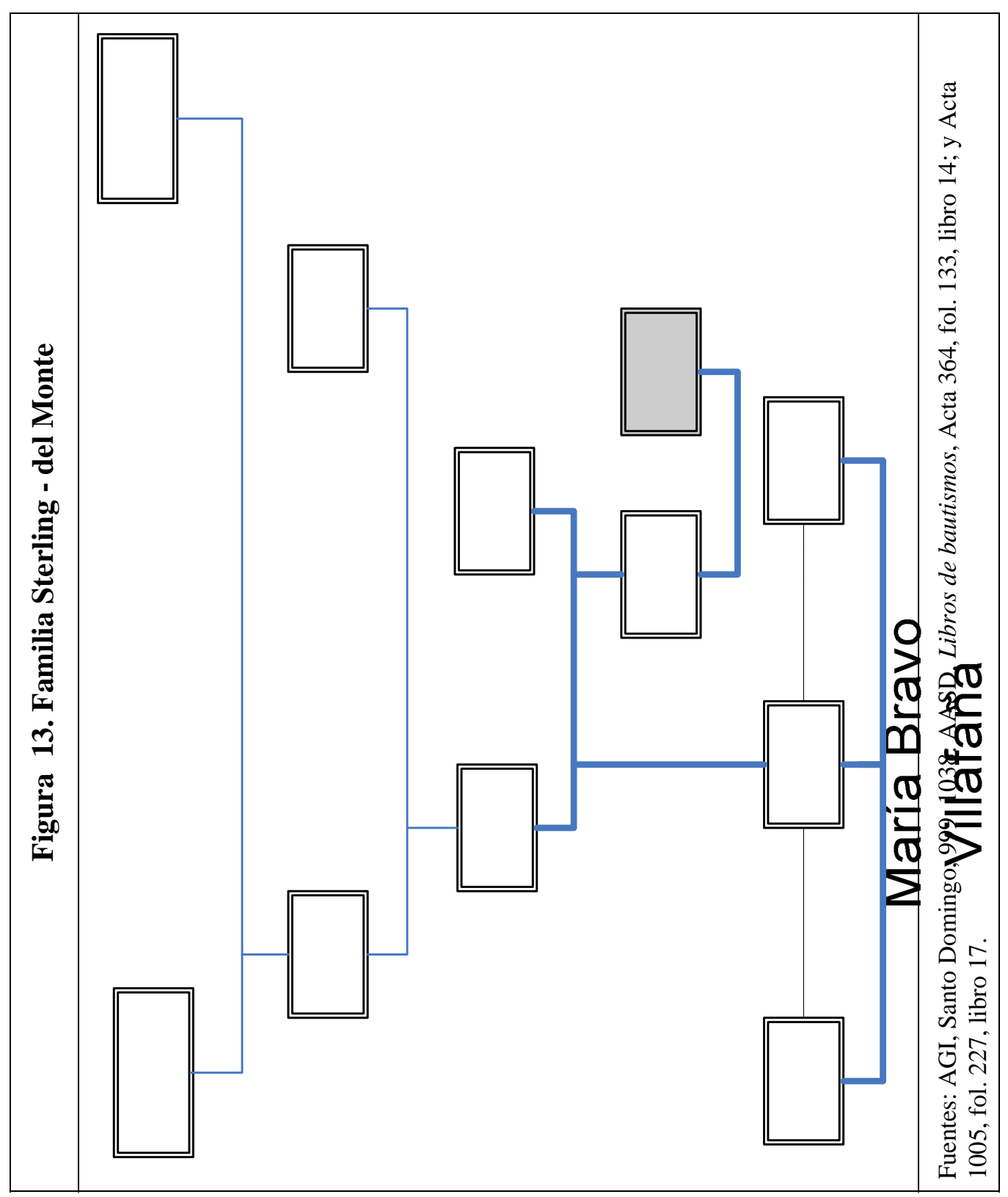


Ruth Torres Agudo

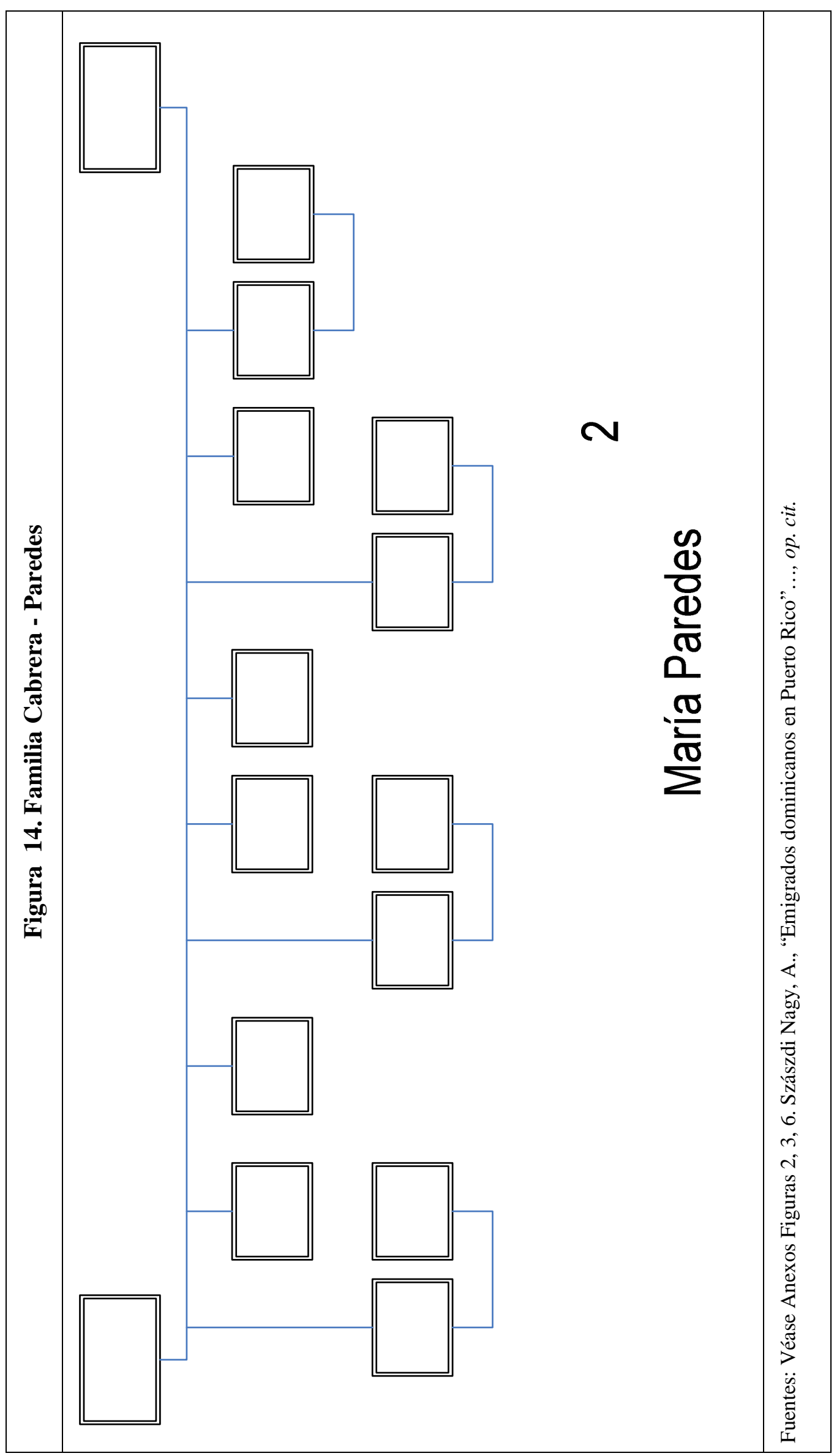




\section{Tabla 5. Biblioteca de Raymundo Esparza ${ }^{1}$}

1. Las leyes de partidas, con cuadernos de pasta picada, 5 ts. (sin identificar) Nota: es un título común a varias obras.

2. Recopilación de Castilla, 3 ts. (sin identificar)

Nota: es un título común a varias obras.

3. Carvajal Lancaster, Isidro de (Obispo de Cuenca), Memorial-ajustado, hecho de orden del Consejo pleno, a instancia de los señores fiscales del expediente consultivo visto remisión de su Magestad a él, sobre el contenido y expresiones de diferentes cartas del rev. Obispo D. Isidro de Carvajal y Lancaster. Joachin de Ibarra, Madrid, 1768.

Expediente del obispo de Cuenca, $1 \mathrm{t}$.

4. Solórzano Pereira, Juan de, Política Indiana. Gabriel Ramírez, Madrid, 1739, II vols.

La política del señor Solórzano, 2 ts.

5. El Atlas, en quarto, 1 t. (sin identificar)

Nota: es un título común a varias obras.

6. Álvarez, Francisco, Noticias del establecimiento y población de las colonias inglesas en la América Septentrional: religión, orden de gobierno, leyes y costumbres de sus naturales y habitantes, calidades de su clima, terreno, frutos... y estado de su industria, artes, comercio y navegación. Antonio Fernández, Madrid, 1778.

Poblacion y establecimiento de las colonias Inglesas, en cuarto, $1 \mathrm{t}$.

7. El arte de medallas, 1 t. (sin identificar)

8. Sabala de tributos del reyno, $1 \mathrm{t}$. (sin identificar)

9. La Garofilduo Real del Perú, 1 t. (sin identificar)

10. Sánchez, Tomás Antonio, Colección de poesías castellanas anteriores al siglo XV: preceden noticias para la vida del primer Marqués de Santillana y la carta que escribió sobre el origen de nuestra poesía. Antonio Sancha, Madrid, 1779, I. vol.

Arte del origen de la poesía, $1 \mathrm{t}$.

11. Bohorquez, Anales de España, 1 t. (sin identificar)

Nota: es un título común a varias obras.

12. Velásquez de Velasco, Luís José, Congeturas sobre las medallas de los Reyes Godos y Suevos de España. Francisco Martínez de Aguilar, Málaga, 1759.

Belasques, Congeturas sobre medallas, $1 \mathrm{t}$.

13. Abru, Presas de mar. (sin identificar)

14. Tosca, Obra trunia, 8 ts. (sin identificar)

15. Pacheco de Narváez, Luís, Nueva ciencia y filosofía de la destreza de las armas. Melchor Sánchez, Madrid, 1672.

Pacheco, Siencia de armas.

16. Tormalario de Cartas, 1 t. (sin identificar)

17. Ugalde, Correccion de tiempos, 1 t. (sin identificar)

18. Mariana, Juan de, Historia general de España. Benito Monfort, Valencia,

II vol.

Mariana, Istoria de España, 2 ts.

\footnotetext{
${ }^{1}$ De los libros que siguen se ofrece, en primer lugar, los datos de la obra ya identificada a través del Catálogo colectivo del patrimonio bibliográfico español, y el de la Biblioteca Nacional, y en segundo lugar, tal como aparece en la documentación. En cuanto a la fecha de las obras, en general hemos procurado citar la primera edición del siglo XVIII teniendo en cuenta que el número del tomo o volumen sea el mismo, y que Raymundo Esparza murió en 1786. En el caso de que en la obra identificada aparezca más volúmenes que en el inventario puede que se deba a que la colección de la obra no esté completa, contando sólo con algunos tomos; o que éstos estuviesen encuadernados cambiando el número de los volúmenes.
} 
19. Gamboa, Francisco Javier de, Comentarios a las ordenanzas de minas dedicados al católico nuestro señor Don Carlos III. Joaquín Ibarra, Madrid, 1761.

Gamboa, De minas, $1 \mathrm{t}$.

20. Sánchez Valverde, Antonio, Idea del valor de la isla Española y utilidades que de ella puede sacar su Monarquía. Pedro Marín, Madrid, 1785.

Historia de la isla de Santo Domingo, 2 ts.

21. Moreri, Luís, El gran diccionario histórico, o miscelánea curiosa de la Historia sagrada y profana, traducida del francés con amplísimas adiciones... relativas a las Coronas de España y Portuga así en el antiguo como en el nuevo mundo por José de Miraval y Casadevante, París, 1753, 10 vols.

Diccionario de Moreri, 1 y 2 ts.

22. Biblia Sacra y una concordantie, 2 ts. (sin identificar)

23. Yarate, Historia Indiana, 1 t. (sin identificar)

24. Curso de química, 1 t. (sin identificar)

25. Curso de pfísica experimental, 2 ts. (sin identificar)

26. Centurión Guerrero de Torres, Manuel, Ciencia de militares: que contiene unos breves principios de geometría, para la perfecta inteligencia de la fortificación, un utilísimo tratado de este arte. Manuel Espinosa de los Monteros, Cádiz, 1757.

Ciencia de militares, $1 \mathrm{t}$.

27. Connellly, Thomas, Gramática que contiene reglas fáciles para pronunciar y aprender metódicamente la lengua inglesa. Imprenta Real, Madrid, 1784.

Gramática inglesa, $1 \mathrm{t}$.

28. Instrucciones de Bielfed, 4 ts. (sin identificar)

29. Quevedo y Villegas, Francisco de, Poesías. IV vols. Quevedo, 4 ts.

30. Florez de Setien y Huidobro, Fray Enrique, Memorias de las Reynas Católicas. Historia genealógica de la Casa Real de Castilla y de León. Tosos los infantes: trages de las Reynas en estampas: y nuevo aspecto de la Historia de España. Antonio Marin, Madrid, 1761, II vols.

Flores, Memorias de los Reyes Católicos, 2 ts.

31. Rodríguez Mohedano, Rafael, Historia literaria de España desde su primera población hasta nuestros días: origen, progresos, decadencia y restauración de la Literatura Española con la vida de los hombres sabios y juicio critico de sus obras. Joaquín Ibarra, Madrid, 1779, II vols. Moedano, Historia literaria, 2 ts.

32. Ataque y sitio de bombas, $1 \mathrm{t}$. (sin identificar)

33. Gueriner, Arte de cocina, 2 ts. (sin identificar)

34. Francisca Inglesa, 1 t. (sin identificar)

35. Historia del parlamento de Inglaterra. (sin identificar)

36. Quinto curso en francés. (sin identificar) Nota: es un título común a varias obras

37. Historia del Conde Zaxe, 1 t. (sin identificar)

38. Hombre de corte en francés. (sin identificar)

39. Huet, Pierre Daniel (Obispo de Arranches), Comercio de Holanda o El gran thesoro historial y politico del floreciente comercio que los holandeses tienen en todos los estados y señorios del mundo. Imprenta Real por Joseph Rodríguez y Escobar, Madrid, 1717, traducido de francés al española por Francisco Xavier de Goyeneche. Comercio de Olanda, 1 t.

40. Comentarios del rezar, 2 ts. (sin identificar)

41. Giustomoamo, Francisco, El Nuevo atlas universal abreviado i Nuevo compendio de los mas curioso de la geographia universal: ilustrado con setenta y siete mapas $i$ figuras y enriquecido con un Breve tratado de la geographia antigua. Jaime Certa, Leon de Francia, 1739, t. III.

Tercer tomo del Atlas abreviado. 
42. Sánchez Valverde, Antonio, Sermones panegíricos y de mysterios. Joaquín Ibarra, Madrid, 1783-1784, II vols.

Valverde, Sermones, $1 \mathrm{t}$.

43. Viajes, 2 ts. (sin identificar)

Nota: es un título común a varias obras

44. Historia de la guerra, 2 y 3 ts. (sin identificar)

Nota: es un título común a varias obras

45. La historia política de Colbert, 1 t. (sin identificar)

46. Rustant, José Vicente, Historia de las turbaciones de Polonia para servir de continuación a las Décadas de la guerra de Prusia. Imprenta de Pantaleón Aznar, Madrid, 1768, I vol, y de la Imprenta de Manuel Martín, Madrid, 1769, vol II.

Décadas de guerra del rey de Prusia, 10 ts.

47. La Rochefoucault, Duque de, Reflexiones, sentencias y máximas morales de la Rochefoucuet, con notas históricas y políticas por Amelot de la Housaye, puestas en nuevo orden y traducidas del francés por Luis de Luque y Leiva. Imprenta del Traductor, Cádiz, 1781.

Amelot, Reflexiones, sentencias y máximas morales.

48. Pluche, M. (Abad), Espectáculo de la naturaleza o Conversaciones acerca de las particularidades de la historia natural, traducido por el padre Esteban de Terreros y Pando. Joachín Ibarra, Madrid, 1757, X vols.

Espectáculo de la naturaleza, en pasta, 10 ts.

49. Feijoo y Montenegro, Benito Jerónimo, Teatro crítico Universal o Discursos varios en todo género de materias. Imprenta del Supremo Consejo de Indias, Madrid, 1959, VIII vols.

Feyjoo, Teatro Crítico, 8 ts.

50. Feijoo y Montenegro, Benito Jerónimo, Cartas eruditas, y curiosas, en que, por la mayor parte se continúa el designio del teatro crítico universal, impugnando o reduciendo a dudosas varias opiniones comunes. Blas Román, Madrid, 1781, V vols.

Feyjoo, Cartas, 5 ts.

51. Apología de Sotomarme. (sin identificar)

52. Historia general de los viajes o Nueva colección de todas las relaciones de los que se han hecho por mar y tierra y se han publicado hasta ahora en diferentes lenguas..., traducida del inglés al francés por el abate Antoine François Prévost d'Exiles, y al castellano por Miguel Terracita. Juan Antonio Lozano, Madrid, 17631791, XLVI vols.

Historias de viajes, 46 ts.

53. El espión de la carta, 8 ts. (sin identificar)

54. Recolección de las ordenanzas militares, 6 ts. (sin identificar)

Nota: es un título común a varias obras

55. Ordenanzas militares del año de veinte y ocho, 2 ts. (sin identificar)

Nota: es un título común a varias obras

56. Díez, Manuel, Llibre de menescalia (en castellano): Libro de albeyteria. Jorge Coci. Leonardo Hutz y Lope Appentegger, Zaragoza, 16 de octubre de 1499, traducida por Martín Martínez de Ampiés.

Libro francés de Abeiteria.

Fuentes: Testimonio de las diligencias del inventario y avaluo de los bienes que quedaron por muerte de Raymundo Esparza, tesorero oficial real de estas cajas de Santo Domingo. AGI, Santo Domingo, 992. 


\section{Tabla 6. Biblioteca de Ramón Jover}

1. El Castexon, 2 ts. (sin identificar)

2. $\quad$ El Alapide, 3 ts. (sin identificar)

3. El Tracio de Regio patronato, 2 ts. (sin identificar)

4. Solórzano Pereira, Juan de, Política Indiana. Gabriel Ramírez, Madrid, 1739, II vols.

Solórzano, Politica Indiana, 2 ts.

5. Saulo, 2 ts. (sin identificar)

6. Las leyes de Castilla con los autos acordados, 3 ts. (sin identificar)

Nota: es un título común a varias obras

7. Recopilación de leyes de los Reynos de las Indias: mandadas imprimir, y publicar por la Magestad Católica el Rey Don Carlos II... ya dividida en quatro tomos. Antonio Balbas, Madrid, 1756, 4 ts.

Las leyes de Indias, 4 ts.

8. Tertuliano, 1 t. (sin identificar)

9. Mateu y Sanz, Lorenzo, D. D., Laurentii et Sanz Iuris consulti Valentini, de Consilio Regiae atque catholicae majestatis... Tractatus de re criminali sive controversiarum. Sumptibus Anisson \& Ioannis Posuel, 1702.

Matheo de re criminali, $1 \mathrm{t}$.

10. El Alamo anales, de Tacito, 1 t. (sin identificar)

11. Blacina, 1 t. (sin identificar)

12. Escritura de Millones, 1 t. (sin identificar)

13. Salcedo, decisiones, 3 ts. (sin identificar)

14. Aristóteles, de moribus, 1 t. (sin identificar)

15. De Republica, 1 t. (sin identificar)

Nota: es un título común a varias obras

16. Arostegui, Idelfonso Clemente de, Concordia Pastoralis super iure Diocesano inter episcopos et praelatos inferiores. Distributa in duas partes. In quipus explicatur conflictos Episcopotum cum Praelatis inferioribus sive nullius, sive intra Dioceseim, tan super universa juris dictione Diocesan, quan super actibus particularibus. Autore eodemque interprete. Compluti, Joseph Espartosa, 1734.

Arostegui, concordia Pastoral, $1 \mathrm{t}$.

17. Carvajal Lancaster, Isidro de (Obispo de Cuenca), Memorial-ajustado, hecho de orden del Consejo pleno, a instancia de los señores fiscales del expediente consultivo visto remisión de su Magestad a él, sobre el contenido y expresiones de diferentes cartas del rev. Obispo D. Isidro de Carvajal y Lancaster. Joachin de Ibarra, Madrid, 1768.

Expediente del obispo de Cuenca.

18. Bula de la cena, 1 t. (sin identificar)

19. Respuesta de España a Francia, 1 t. (sin identificar)

20. Leynes, 1 t. (sin identificar)

21. Dueñas. 1 t. (sin identificar)

22. Cirer y Zerda, Miguel, Propugnáculo histórico-canónico-político-legal: que descubre los fondos de la más preciosa piedra de la Corona de España compuesta con sus antiguos monumentos y Memorias del incontrastable derecho de sus Monarcas a la protección de las iglesias de su Monarquía y al Universal Patronato de los Beneficios de ella: derivado de la católica piedad de sus primeros gloriosos reyes en fundarlas, de sus gloriosas liberalidad enriquecerlas y exudación canónica-legal de la ley XVIII, título V, partida I y sus concordantes sobre el Real Patronato de la corona de España. (s.n) Madrid, 1736. 
Cerer y Cerda, de un propugnaculo, $1 \mathrm{t}$.

23. Instruccion sobre unica contribución. (sin identificar)

Nota: es un título común a varias obras

24. Rey pacifico, 1 t. (sin identificar)

25. Brebiario de politico, en manuscripto, 1 t. (sin identificar)

26. En sal Peregrino, 2 ts. (sin identificar)

27. Pracoica criminal de Jueces, 1 t. (sin identificar)

28. Ignacio Lazarte, 1 t. (sin identificar)

29. Agricultura, 1 t. (sin identificar)

Nota: es un título común a varias obra

30. Papeles en Derecho, 1 t. (sin identificar)

31. Castillo de Magistratibus, 2 ts. (sin identificar)

32. Salcedo, de contravando, 1 t. (sin identificar)

33. De lege, 2 ts. (sin identificar)

34. Gazofilaso, 1 t. (sin identificar)

35. Ribadeneyra y Barrientos, Antonio Joaquín de, Manual Compendio de el Regio Patronato Indiano, para su más fácil uso en las materias conduncentes a la práctica: Dedicado el ey Nuestro Señor D. Fernando VII, el Amado. Antonio Marín, Madrid, 1755.

Riba de Neira, $1 \mathrm{t}$.

36. Abreu vacante de Indias, 1 t. (sin identificar)

37. El Doctor Juan de Miranda, 1 t. (sin identificar)

38. Domínguez Vicente, Joseph Manuel, Ilustración y continuación a la curia Philípica y corrección de las citas que en ella se hallan erradas: Dividido en las mismas cinco partes. Trátase del modo de proceder en los juicios eclesiásticos y seculares, con lo que sobre ello ay hasta ahora dispuesto por Derecho, resuelto por los Doctores antiguos y modernos. Herederos de Juan García Infanzon, Madrid, 1736-1739, III vols.

Domínguez, Ilustración a la Curia, 3 ts.

39. Letras de cambio, $1 \mathrm{t}$.

Nota: es un título común a varias obras

40. Hevia Bolaños, Juan de, Curia Filípica, donde breve y compediosamente e trata de los juicios. Madrid, 1771, 2 vols.

Curia Philipica, $1 \mathrm{t}$.

41. Pax Pragis, 1 t. (sin identificar)

42. Matheu, Practica Criminal, 1 t. (sin identificar)

43. Montel, Practica Criminal, 1 t. (sin identificar)

44. Panexa, 1 t. (sin identificar)

45. Juan Safo, Tratado de procesos criminales, $1 \mathrm{t}$. (sin identificar)

46. Civan Espen, 7 ts. (sin identificar)

47. Petrus de marca, 1 t. (sin identificar)

48. Castillo de Bovadilla, Jerónimo, Política para corregidores y señores de vasallos. Madrid, 1775, 2 ts.

Bobadilla, Politica, 1 t.

49. Juicio Imperial, 1 t. (sin identificar)

50. Torre blanca, $1 \mathrm{t}$. (sin identificar)

51. Concilio Galena, 1 t. (sin identificar)

52. Davila, Enrico Caterino, Historia de las Guerras Civiles de Francia. Juan Bautista Verdussen, Amberes, 1713.

Castelino, guerras de Francia, 1 t.

53. Morales, 1 t. (sin identificar)

54. Conservación de Monarchías, 1 t. (sin identificar)

Nota: es un título común a varias obras

55. Ordenanzas de Intendente, $1 \mathrm{t}$. (sin identificar) 


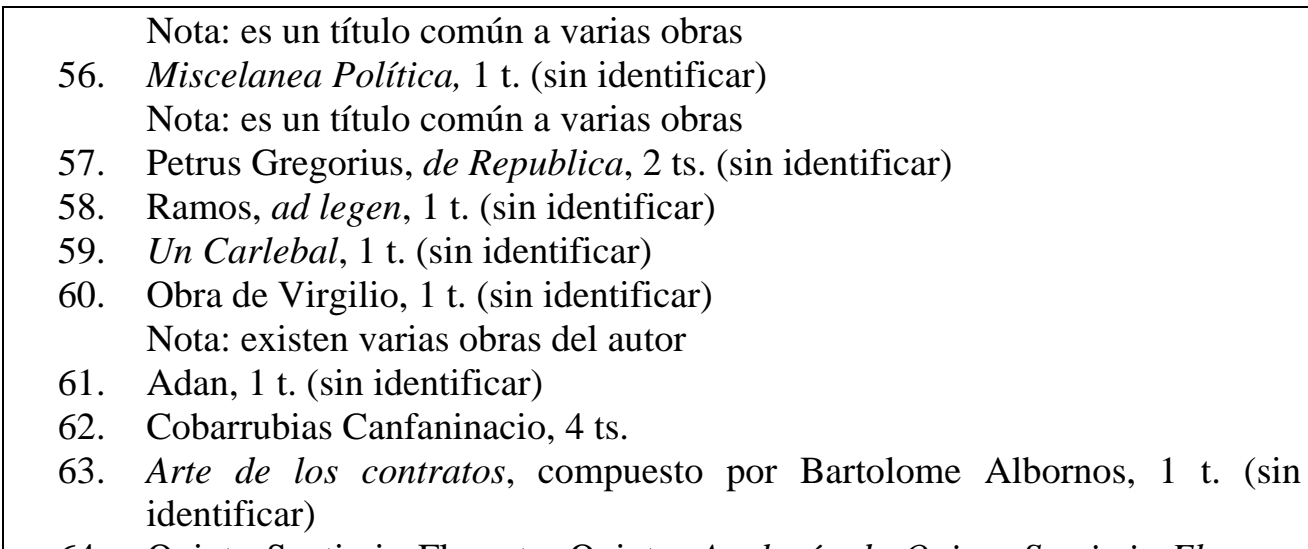

64. Quinto Septimio Florente, Quinto, Apología de Quinto Septimio Florente Tertuliano... contra los gentiles, en defensa de los Cristianos: escrita en Roma año ducientos [sic] de Christo... en el princio de la quinta persecución de la Iglesia i en el año quinto de Septimio Severo emperador. (traducida por Pedro Manero, obispo de Tarazona).

Apología, de Pedro Mareno, $1 \mathrm{t}$.

65. Oyayozores, Francisco, Tratado de levas, quintas y reclutas de gente de guerra; según las Reales ordenanzas, y Cédulas modernas; tomo único; tiene los indices necesarios y al fin la cedula de leva y un Formulario de los Autos que deben hacerse para su execucion. Antonio Marín, Madrid, 1734.

Tratado de lebas, $1 \mathrm{t}$.

66. Marquez, Juan (OSA, Orden de San Agustín), El Gobernador Cristiano. Manuel Martín, Madrid, 1773, 2 ts.

El Gobernador Christiano, 2 ts.

67. Sooto, Juan de (OSA, Orden de San Agustín), Exposición parafrastica del Salterio de David: en diferente género de verso español, con exposiciones varias de varios y gravisimos autores... añadese nuevamente/Alabanza de Dios y de sus santos del mismo autor. Joachin Ibarra, Madrid, 1779.

Exposición parafrastica del Salterio, $1 \mathrm{t}$.

68. Justino Febronis, 1 t. (sin identificar)

69. Guevara Salazar, Antonio de, Epístolas familiares. J. Coci, Zaragoza, 1539 Antonio Guevara Salazar, Epistolas familiares, varios tomos.

70. Richeleieu, Armand Jean du Plessis, Cardenal-duc de, Testamento politico del cardenal duque Richelieu. Primera y segunda parte traducidas de la cuarta impresión que salió en lengua francesa en Ámsterdam el año de 1691 que pone a los pies del Rey Juan de Espinola Baeza Echaburu aviéndolas ilustrado con diversas reflexiones curiosas. Juan García Infanzón imp., Madrid, 1696, 1 t.

Testamento Politico del Cardenal Duque, 1 t.

71. Sabadra, 3 ts. (sin identificar)

72. La Cruz, S. Juana de (monja profesa en el monasterio de San Jerónimo en la ciudad de México), Fama y obras póstumas del fénix de México. Rafael Figueró, Barcelona, 1701.

Sor Juana de Jesús, El Feniz de Mexico, 3 ts.

73. Casiodoro, Magno Aurelio., Magni Aurelii Casiodorii... Vivarienses Abatís opera omnia in duos tomos distributa.../Opera et Studio J.Garetii, Monchi Ordiniss Benedicto. Antonii Groppi, Venteéis, 1729.

Casiodoro, $1 \mathrm{t}$.

74. Mayans y Siscar, Gregorio, Retórica abreviada, escrita para los estudios de Medinasidorni, entonces Conde de Niebla, después destinada para los estudiantes de Oliva. 1734. 
Retorica de Don Gregorio Mayans y Siscas, $1 \mathrm{t}$.

75. Valerio, surresions, $1 \mathrm{t}$. (sin identificar)

76. Delitos, y penas, 1 t. (sin identificar)

77. Sebastián y Latre, Thomas, Relación histórica de los sucesos ocurridos en Zaragoza con motivo del incendio de su Coliseo en la noche de noviembre de 1778. Francisco Moreno, Zaragoza, 1779, 1 t.

Relacion, y sucesos de Zaragoza, $1 \mathrm{t}$.

78. Díaz Salgado, Juan, Sistema physico médico político de la Peste. Su preservación y curación. Para el uso y instrucción de las Diputaciones de Sanidad de este Reyno. Antonio Sanz, Madrid, 1756.

Sistema Phisico de Juan Díaz Salgado, 1 t.

79. Salcedo, reglas para la educación de los reyes, $1 \mathrm{t}$. (sin identificar)

80. Galmace, Antonio, Llave nueva, y universal, para aprender con brevedad, y perfeccion la lengua francesa, sin auxilio de maestro...: dispuesta en tres colunas. Gabriel Ramírez, Madrid, 1748.

Llave de la lengua francesa.

81. Santalla Bustillo, Lorenzo de, Gobierno político de los pueblos de España y el corregidor, alcalde y juez en ellos. Viuda de Eliseo Sánchez, Madrid, 1769, $1 \mathrm{t}$.

Gobierno Politico de los Pueblos, $1 \mathrm{t}$.

82. Magistrado de los anales de España, 1 t. (sin identificar)

83. El sabio más instruido de la naturaleza, 1 t. (sin identificar)

84. Memorial de Don Juan Chumasero y Carrillo, 1 t. (sin identificar)

85. Maravillas de la naturaleza, 1 t. (sin identificar)

86. Concilio Tridentino, 1 t. (sin identificar)

Nota: es un título común a varias obras

87. Marcos Tulio Ciceron, 1 t. (sin identificar)

88. Philipo, de Republica y fidei comisos, 1 t. (sin identificar)

89. Historia y descripción general de los intereses del comercio de todas las naciones de Europa en las cuatro partes del mundo. (traducida del francés por Domingo de Marcoleta) Miguel Escribano, Madrid, 1772-774, 5 vols. Historia del comercio de todas las Naciones, 5 ts.

90. Salazar y Hontiveros, Juan José de, Poesías varias en todo genero de assumptos, y metros: con un epilogo al fin de noticias, y puntos historiales, sobre la provincia de la Rioja, y sucesos de España, con la cronología de sus Reyes, hasta nuestro Don Phelipe Quinto. Juan Saez Ocañuela, Madrid, 1732.

Poesías de Salazar, 1 t.

91. Fénelon, François de Salignac de la Mothe, Diálogo de los muertos, Imp. Miguel de Burgos, Madrid, 1759, 1 vol.

Dialogo de los muertos.

92. Cantos Benítez, Pedro de, Escrutinio de maravedises, y monedas de oro antiguas, su valor, reducción, y cambio a las monedas corrientes: deducido de escrituras, leyes y pragmáticas antiguas y modernas de España. Antonio Marín, Madrid, 1763.

Escrutinio de maravedises, y monedas.

93. Tesauro, Emmanuele (Conte de), Arte de cartas misivas o Méthodo general para reducir al papel quantas materias pide el politico comercio. (traducida al español por Marcelon Migliavaca). Manuel Roman, Madrid, 1723.

Arte de cartas misivas, $1 \mathrm{t}$.

94. Primera parte de las sentencias que hasta nuestros tiempos, para edificación de buenas costumbres. Ioan Álvarez (Juan Álvarez), Coimbra, 1554, $1 \mathrm{t}$. 
Primera parte de las sentencias, $1 \mathrm{t}$.

95. Nieremberg, Juan Eusebio (1595-1658), Obras y días: mañuela de señores y príncipes en que se propone con su pureza y rigor la especulación y ejecución política, económica y particular de todas las virtudes. Viuda de Alonso Martín, Madrid, 1629, 1 t.

Obras y días, $1 \mathrm{t}$.

96. Pradilla Barnuevo, Francisco de la, Suma de las leyes penales. Imprenta del Reyno, Madrid, 1639 (adicionada por Francisco de Barreda y añadido por Ivan Calderón).

Suma de las leyes penales, $1 \mathrm{t}$.

97. Aprobación de los libros de Seneca, 1 t. (sin identificar)

98. El Secretario, 16 discursos, 1 t. (sin identificar)

Nota: es un título común a varias obras

99. Alcaraz y Castro, Isidoro, Breve instrucción del méthodo y práctica de los quatro juicios: ordinario, sumario de partición, executivo y general de concurso de acreedores, anotados con las especies más ocurrentes en los Tribunales. Util para los passantes de las Juntas de Práctica, y Abogadosprincipiantes. Domingo Fernández de Arrojo, Madrid, 1762, 1 t. Instruccion del mhetodo, y practica de los quatro juicios, nombrado el alcaras, 1 t.

100. Politica de Don Andres Picher, 1 t. (sin identificar)

101. Ardemans, Teodoro, Ordenanzas de Madrid y otras diferentes que se practican en las ciudades de Toledo y Sevilla. Francisco del Hierro, Madrid, 1720, $1 \mathrm{t}$.

Ordenanzas de Madrid, $1 \mathrm{t}$.

102. Naufragio de la verdad ilustrada. (sin identificar)

103. Seminario de la Purísia Concepción y San Miguel (Orihuela), Descripción, constituciones y ordenanzas para el régimen y gobierno del colegio de dos seminarios. Antonio Marin, Madrid, 1744, $1 \mathrm{t}$.

Descripsion y ordenanzas, para el regimen y gobierno de seminarios, $1 \mathrm{t}$.

104. Bernardo de Quirós, José (Conde de Prado), Nuevo promotor de la Real Protección: disertación teológica-jurídica, política-regular, y crítica contra el Sr. Salgado y otros, a favor de la autoridad, que según Leyes Canónicas, y Regias, gozan los Reales Tribunales Supremos, para proteger los Regulares oprimidos, y de la acción que éstos tienen a implorar su protección contra las violencias de sus prelados. Eugenio García de Honorato, Salamanca, 1758, 1 t.

Nuevo Promotor de la Real Proteccion, $1 \mathrm{t}$.

105. Mujal y de Gubert, Juan Antonio, Desengaño al público con pura y solida doctrina; Tratado de la observancia y obediencia, que se debe a las leyes, pragmáticas sanciones y Reales Decretos. Francisco Xavier García, Madrid, 1774.

Mujal, Desengaño al publico, $1 \mathrm{t}$.

106. Sanz, Miguel Cayetano, Modo y forma de instruir las causas criminales: obra utilíssima para jueces, Asesores, Abogados, Escribanos y demás curiales de cualesquiera tribunales del Reyno, asi Eclesiasticos como Seculares. Thomás de Santander, Valladolid, 1774, 1 t.

Mhodo y forma de instruir las causas criminales, del Licenciado Miguel Cayetano.

107. Alcaraz y Castro, Isidoro, Breve instrucción del méthodo y practica de los quatro juicios criminales por el contrabando de reales rentas: Primero de aprehensión real en el fraude de tabacos, y demás géneros estancados; segundo, sin real aprehensión, y con reos de peferente por la saca de oro, plata y demás efectos prohibidos extraer del Reino; tercro, por denuncia 
del fraude contra los reales derechos de aduana; y cuarto en rebeldía por el fraude con los reales derechos de millones, anotados con las leyes, reales órdenes, dudas y definiciones más ocurrentes en los Tribunales Subdelegados de rentas. Andrés Ramírez, Madrid, 1765, 1 t.

Instruccion del mhetodo, y practica de los quatro juicios, por Don Isidoro Alacras, y Castro, $1 \mathrm{t}$.

108. Albornos, Castilla politica, 1 t. (sin identificar)

109. Diaz Salgado, Juan, Sistema physico médico político de la Peste. Su preservación y curación. Para el uso y instrucción de las Diputaciones de Sanidad de este Reyno. Antonio Sanz, Madrid, 1756.

Sistema phisico medico politico de la peste, $1 \mathrm{t}$.

110. El suceso acontecido en Saragoza, $1 \mathrm{t}$.

111. Bermúdez de Pedraza, Francisco, El secretario del rey, sus preeminencias, privilegios y grandeza del oficio. Pedro Joseph Alonso y Padilla, Madrid, 1720, $1 \mathrm{t}$.

El secretario del Rey, preeminencias, y privilegios, $1 \mathrm{t}$.

112. León, Fray Luís, Instrucción de la mujer Christiana, 1 t.

Instrucción de la muger cristiana, $1 \mathrm{t}$.

113. Ballexerd, Jacques, Crianza física de los niños desde su nacimiento hasta la pubertad. (traducida al castellano por Patricio de España). Gabriel Ramírez, Madrid, 1765, 1 t.

Crianza phisica de los niños, $1 \mathrm{t}$.

114. Melgarejo Manrique de Lara, Juan, Compendio de contratos públicos, autos de particiones, ejecutivos y de residencias con el género del papel sellado que a cada despacho toca. Antonio Bordaza a costa de Juan de Baeza, Valencia, 1701, 1 t.

Juan Melgarejo, Compendio de contratos publicos, $1 \mathrm{t}$.

115. Obras de Antonio Pérez, 1 t. (sin identificar)

116. Lozano, Juan Antonio, Destierro y azote del libro del duelo. Christoual de la Torre, Zaragoza, 1640, $1 \mathrm{t}$.

Destierro y azotes del duelo, $1 \mathrm{t}$.

117. Siete tomos, en pasta de a quatro. (sin identificar)

118. Cincuenta y siete tomos, en octava, en pasta. (sin identificar)

119. Trece tomos en pasta de a dies, y seis. (sin identificar)

120. La obra de Mayans, 5 ts. en octavo. (sin identificar)

Nota: existen varias obras del autor

121. Ocho tomos, en quatro de pergamino. (sin identificar)

122. Veinte, y nueve tomos, en octava, de pergamino. (sin identificar)

123. Un manuscrito formado en terciopelo carmesí, Gobierno del Peru. (sin identificar)

124. Riera, Agustín Fray, Dialogo sacro de la Santa Madre Católica Iglesia, por medio de una fiel hija suya, con Christo crucificado. Contiene los ocultos mysterios de Dichos Passos del Redemptor en cruz, sepultura y testamento; con meditaciones al pie de los assumptos. Juan Nadal imp., ed Juan Sellent, Barcelona, 1767.

Dialogo de la Santa Madre Iglesia, en pasta.

125. Exercicios de votos de Fray Luis de Granada con meditaciones. (sin identificar)

126. Palafox y Mendoza, Juan de (obispo de Osma), Gemidos del corazón: tiernos afectos, amorosos suspiros y vivos sentimientos de un alma contrita y arrepentida de sus pecados. Viuda de Piferrer, Barcelona, 1775.

Gemidos del corazon, y tiernos afectos.

127. Republica y politica christiana, en pasta pequeño. (sin identificar)

128. Dúchense, Jean Baptiste Philipoteau, Compendio de la Historia de España. 


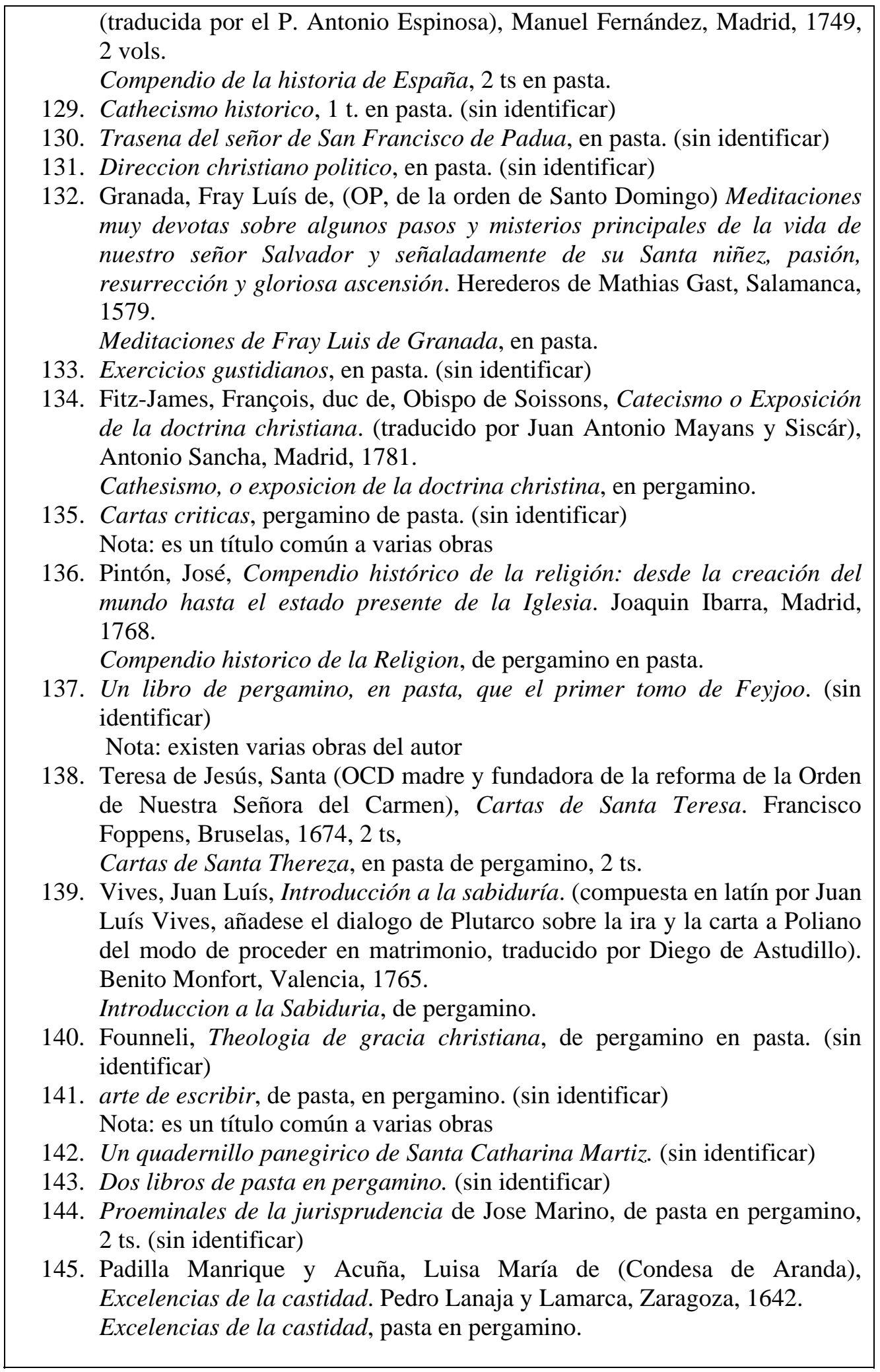

Fuentes: Ramón Jover había muerto en 1785. Ver nota al pie de Anexos Tabla 5. Testimonio de los autos de inventario y avaluo de los bienes que quedaron por fallecimiento de Ramon Jover, oidor que fue de esta Real Audiencia y murio intestado en la ciudad de Santiago de Cuba, 26 de noviembre de 1786. AGI, Santo Domingo, 992. 
Tabla 7. Inventario de las haciendas de José Guridi y Concha, 1773-1774

\begin{tabular}{|c|c|}
\hline \multicolumn{2}{|l|}{ INGENIO SANTA ANA DE LA JAGUA } \\
\hline & $\begin{array}{l}\text { Valor en pesos } \\
\text { y reales }\end{array}$ \\
\hline \multicolumn{2}{|l|}{ ERMITA } \\
\hline Paredes y solar & $276 \$$ \\
\hline Carpintería & $78 \$$ \\
\hline $\begin{array}{l}1 \text { Imagen de busto de Nuestra Señora de Belén con su } \\
\text { corona de plata }\end{array}$ & $10 \$$ \\
\hline $\begin{array}{l}1 \text { Imagen de Nuestra Señora de Santa Ana con diadema } \\
\text { de plata }\end{array}$ & $8 \$$ \\
\hline 1 Imagen de San Francisco Javier & $4 \$$ \\
\hline 1 Lámina de San Miguel & $1 \$$ \\
\hline 1 Lámina de San Javier & $1 \$$ \\
\hline 1 Lámina de Jesús, María y José & 2 rs. \\
\hline 1 Lámina de San José, rota & 3 rs. \\
\hline 1 cruz con un crucifijo de plata & $5 \$$ \\
\hline 1 espejo & 6 rs. \\
\hline 1 niño Jesús de plomo & $2 \$$ \\
\hline 1 Ara consagrada & $1 \$$ y 4 rs. \\
\hline 1 alba, casulla y ornamenta & $6 \$$ \\
\hline 1 cáliz, vinagreras, cuchara y patena & $20 \$$ \\
\hline 1 misal y ritual & 6 rs. \\
\hline 1 capa de coro vieja & $2 \$$ \\
\hline 1 frontal & $1 \$$ y 4 rs. \\
\hline 4 candeleros de metal & $1 \$$ y 4 rs. \\
\hline 1 estandarte de la Virgen & $1 \$$ \\
\hline 1 campanita de bronce & 4 rs. \\
\hline 1 librillo y 1 vaso & $1 \$$ y 3 rs. \\
\hline 1 cajita de concha para las hostias & $1 \$$ y 4 rs. \\
\hline 1 campana & $25 \$$ \\
\hline 1 tarima y mesa de altar & $12 \$$ \\
\hline 1 sagrario, atril y gradas & $10 \$$ \\
\hline 2 mesas con sus cajones & $12 \$$ \\
\hline 1 nicho & $3 \$$ \\
\hline 2 escaños & $12 \$$ \\
\hline 1 silla y 2 confesionarios & $3 \$$ \\
\hline $1 \mathrm{cruz}$ & $1 \$$ \\
\hline \multicolumn{2}{|l|}{ CASA VIVIENDA } \\
\hline Casa grande vivienda & $111 \$$ y 4 rs. \\
\hline \multicolumn{2}{|l|}{ CASAS DE TRABAJO } \\
\hline CASA DE PURGA Y AGUARDIENTERÍA, con cocina & $190 \$$ \\
\hline $\begin{array}{l}1 \text { canoa de guardar el aguardiente de caoba con } 4 \text { varas } \\
\text { de largo y } 1 \text { boca }\end{array}$ & $10 \$$ \\
\hline CASA DE PURGA de piedra, Y CARPINTERÍA & $336 \$$ \\
\hline 1 harifería & $468 \$$ \\
\hline 1 pila de alambique & $20 \$$ \\
\hline 1 peaña de la Santa Cruz & $3 \$$ \\
\hline 1 hornilla del buren & $1 \$$ \\
\hline 3 suelas, 2 llanas, 1 gurbia, 1 formón y 1 barrena & $5 \$$ \\
\hline 2 pilones & $4 \$$ \\
\hline
\end{tabular}




\begin{tabular}{|c|c|}
\hline \multicolumn{2}{|l|}{ INGENIO SANTA ANA DE LA JAGUA } \\
\hline 1 pilón & $1 \$$ \\
\hline 1 alambique maltratado, con sus utensilios & $100 \$$ \\
\hline 1 guayo de cobre & 6 rs. \\
\hline 4 machetes nuevos & $5 \$$ \\
\hline 1 huerta & $16 \$$ y 4 rs. \\
\hline 1 tintero de lejía & $2 \$$ \\
\hline 4 yugos y 2 ejes & $6 \$$ \\
\hline 3 carretas y 3 yugos & $100 \$$ \\
\hline 29 hormas de refinar & $7 \$$ y 2 rs. \\
\hline 2 canoas nuevas & $20 \$$ \\
\hline 1 canoa nueva & $12 \$$ \\
\hline 1 cañoncito para enguijar & $2 \$$ \\
\hline 8 bombas & $31 \$$ \\
\hline 5 espumaderas & $15 \$$ \\
\hline 4 espumaderas viejas en ocho libras de cobre & $4 \$$ \\
\hline 1 fondo de cobre de agro roto & $36 \$$ \\
\hline 1 fondo de cobre de agro asentado & $81 \$$ \\
\hline 1 rejita de ventana que está en la casa de calderas & $3 \$$ \\
\hline 1 fondito de cobre & $13 \$$ \\
\hline 1 fondito de azojar muy maltratado & $30 \$$ \\
\hline CASA DE INGENIO, LA DE CALDERAS y un pozo & $381 \$$ \\
\hline CASA NUEVA DE CALDERAS & $278 \$$ y 2 rs. \\
\hline $\begin{array}{l}1 \text { principio de estufo con } 57 \text { tapias y otras } 157 \text { bien } \\
\text { tratadas }\end{array}$ & $367 \$$ y 4 rs. \\
\hline 30 tapias de una vara de grueso, y 1 pila maltratado & $30 \$$ y 4 rs. \\
\hline $\begin{array}{l}5 \text { tapias nuevas que se levantaron en la casa nueva de } \\
\text { calderas }\end{array}$ & $12 \$$ y 4 rs. \\
\hline La edificación y empañetados de dicha casa & $12 \$$ \\
\hline Por Poner ladrillo de tabla & $4 \$$ \\
\hline 1.150 ladrillos de solado con mezcla de torta y solería & $28 \$$ y 4 rs. \\
\hline Levantar una nueva batería con sus materiales & $75 \$$ \\
\hline $\begin{array}{l}\text { CASA DE CALDERAS, que se levantó nueva con } 4 \\
\text { calderas }\end{array}$ & $80 \$$ \\
\hline 2 pilares que mantienen la canoa de recibir & $1 \$$ y 4 rs. \\
\hline 1 hornito & $5 \$$ \\
\hline $\begin{array}{l}\text { La casa de calderas maltratada por lo que le toca a la } \\
\text { carpintería }\end{array}$ & $70 \$$ \\
\hline 1 canoa de recibir caldos & $2 \$$ \\
\hline La armadura del ingenio con su puente & $80 \$$ \\
\hline La casa de dicho ingenio & $20 \$$ \\
\hline La casa de ingenio, las soleras, cureñotes nuevas & $60 \$$ \\
\hline $\begin{array}{l}\text { El techo de la casa de calderas nuevo, que acaba de } \\
\text { fabricarse }\end{array}$ & $44 \$$ \\
\hline Unas vigas y los barrotes de la casa de calderas nuevos & $4 \$$ \\
\hline $\begin{array}{l}4 \text { piezas de un tendal de poner las espumaderas nuevas y } \\
\text { las bombas }\end{array}$ & $3 \$$ \\
\hline 1 reja de madera para una ventana en la casa de calderas & $2 \$$ \\
\hline 4 alfalgias y dos palos de caoba & $5 \$$ \\
\hline $\begin{array}{l}\text { El juego de ingenios con tres tambores medios guijos, y } \\
\text { sus chumaceras }\end{array}$ & $350 \$$ \\
\hline 7 fondos & $420 \$$ \\
\hline
\end{tabular}




\begin{tabular}{|c|c|}
\hline \multicolumn{2}{|l|}{ INGENIO SANTA ANA DE LA JAGUA } \\
\hline 1 sufridera & $2 \$$ y 4 rs. \\
\hline 3 hierros de herrar & $3 \$$ \\
\hline 3 agujas de hierro de coser los serones del azúcar & 3 rs. \\
\hline 2 fondos maltratados & $40 \$$ \\
\hline \multicolumn{2}{|l|}{ BESTIAS MULARES Y CABALLARES } \\
\hline 7 mulas de buena edad & $385 \$$ \\
\hline 8 mulas viejas & $280 \$$ \\
\hline 7 mulas nuevas & $420 \$$ \\
\hline 4 mulas nuevas & $200 \$$ \\
\hline 3 mulas nuevas & $150 \$$ \\
\hline 1 mula ciega, pero nueva & $30 \$$ \\
\hline 1 mula coja & $25 \$$ \\
\hline 1 caballo entero & $25 \$$ \\
\hline 1 caballo capado & $22 \$$ \\
\hline 1 caballo joven capado & $30 \$$ \\
\hline 1 caballo rucio capado & $25 \$$ \\
\hline 1 caballo bayo capado & $22 \$$ \\
\hline 1 caballo bermejo entero & $25 \$$ \\
\hline 1 caballo castaño capado & $25 \$$ \\
\hline 1 caballo alazano entero & $22 \$$ \\
\hline 1 caballo bermejo entero & $24 \$$ \\
\hline 1 caballo pardo capado & $25 \$$ \\
\hline 1 caballo balluzco tornudo & $24 \$$ \\
\hline 1 caballo alazano entero & $24 \$$ \\
\hline 1 caballo bayo joven y otro castaño & $48 \$$ \\
\hline 1 caballo castaño capado & $22 \$$ \\
\hline 3 caballos & $70 \$$ \\
\hline 1 yegua alazana con un potro de 3 años & $36 \$$ \\
\hline 1 yegua bermeja con un potro de 6 meses & $26 \$$ \\
\hline 1 yegua bermeja con una potranca & $34 \$$ \\
\hline 1 yegua alazana con una potranca & $32 \$$ \\
\hline 1 yegua rucia con un potro & $25 \$$ \\
\hline 1 yegua dorada con un potro & $26 \$$ \\
\hline 1 yegua rucia & $16 \$$ \\
\hline 1 yegua alazana & $20 \$$ \\
\hline \multicolumn{2}{|l|}{ YUNTAS DE BUEYES } \\
\hline 10 yuntas de bueyes & $450 \$$ \\
\hline 2 yuntas de novillos empezados a potrear & $50 \$$ \\
\hline \multicolumn{2}{|l|}{ BURROS } \\
\hline 2 burros flacos y maltratados & $25 \$$ \\
\hline \multicolumn{2}{|l|}{ AVES } \\
\hline 11 gallinas, 5 pollos, 1 gallo y 1 capón & $5 \$$ y 6 rs. \\
\hline 7 patos & $3 \$$ y 4 rs. \\
\hline \multicolumn{2}{|l|}{ OVEJAS } \\
\hline 11 ovejas & $16 \$$ y 4 rs. \\
\hline 12 caballerías y media de tierra & $1.250 \$$ \\
\hline \multicolumn{2}{|l|}{ BARBECHOS } \\
\hline $\begin{array}{l}\text { Barbecho nuevo El Pontón, } 1.800 \text { varas conuqueras (son } \\
18 \text { tareas. La caña de un año) }\end{array}$ & $108 \$$ \\
\hline $\begin{array}{l}\text { Barbecho San Antonio y El Niño, } 6.600 \text { varas } \\
\text { conuqueras (66 tareas. La caña de más de un año) }\end{array}$ & $396 \$$ \\
\hline
\end{tabular}




\begin{tabular}{|c|c|}
\hline \multicolumn{2}{|c|}{ INGENIO SANTA ANA DE LA JAGUA } \\
\hline $\begin{array}{l}\text { Barbecho Los Negros, } 3.000 \text { varas conuqueras (30 } \\
\text { tareas. La caña de } 17 \text { meses) }\end{array}$ & $180 \$$ \\
\hline $\begin{array}{l}\text { Barbecho Charco, } 4.050 \text { varas conuqueras (40 tareas y } \\
\text { media) }\end{array}$ & $243 \$$ \\
\hline $\begin{array}{l}\text { Barbecho nuevo Charco Junco, } 12 \text { tareas (caña de } 11 \\
\text { meses) }\end{array}$ & $72 \$$ \\
\hline \begin{tabular}{|l|} 
Barbecho Las Mujeres, 8 tareas (caña de 11 meses) \\
\end{tabular} & $48 \$$ \\
\hline Barbecho Santa Bárbara, San Ignacio y San Sebastián & $360 \$$ \\
\hline $\begin{array}{l}\text { Barbecho Santo Domingo y Santiago, } 4.550 \text { varas } \\
\text { conuqueras }\end{array}$ & $273 \$$ \\
\hline Barbecho Santo Domingo, 1.800 varas (18 tareas) & $108 \$$ \\
\hline Barbecho Marín, 1.400 varas (15 tareas) & $90 \$$ \\
\hline Barbecho Charco Junco, 1.200 varas & $72 \$$ \\
\hline Barbecho San Xavier, 1.000 varas (10 tareas) & $60 \$$ \\
\hline Barbecho del Platanal Viejo, 15 tareas & $90 \$$ \\
\hline $\begin{array}{l}\text { Barbecho Rosa, } 3.000 \text { varas (30 tareas, cultivadas de } \\
\text { maíz) }\end{array}$ & $80 \$$ \\
\hline 25 tareas de plátano & $100 \$$ \\
\hline 700 árboles de café & $39 \$$ \\
\hline 22 tareas de yuca & $42 \$$ \\
\hline 1.120 árboles de cacao & $560 \$$ \\
\hline \multicolumn{2}{|l|}{ PALIZADAS } \\
\hline $\begin{array}{l}105 \text { varas de palizada de madera, entremetida con } \\
\text { algunos naranjos }\end{array}$ & $12 \$$ y 4 rs. \\
\hline 105 varas de palizada & $52 \$$ y 4 rs. \\
\hline 595 varas de limón & $148 \$$ y 6 rs. \\
\hline 190 varas de palizada de madera y javilla & $47 \$$ y 2 rs. \\
\hline 304 varas de palizada de madera & $38 \$$ \\
\hline 100 varas de javilla & $18 \$$ y 6 rs. \\
\hline $\begin{array}{l}375 \text { varas de palizada de madera y algunos pedazos de } \\
\text { limón }\end{array}$ & $23 \$$ y 6 rs \\
\hline \multicolumn{2}{|l|}{ CORRALES } \\
\hline 2 corrales de encerrar bestias y bueyes & $8 \$$ \\
\hline 1 palomar cubierto de tejamaní ${ }^{2}$ & $20 \$$ \\
\hline 1 corral de ovejas & $6 \$$ \\
\hline \multicolumn{2}{|l|}{ UTENSILIOS } \\
\hline 1 tasajera nueva & $8 \$$ \\
\hline 1 barbacoa de sacar maíz, de palos de caoba labrados & $20 \$$ \\
\hline 1 campanario & $6 \$$ \\
\hline 1 horno de hormas y ladrillos & $25 \$$ \\
\hline 1 horno de quemar cal & $25 \$$ \\
\hline 1.050 hormas buenas & $393 \$$ y 6 rs. \\
\hline 28 hormas & $7 \$$ \\
\hline 411 potes & $51 \$$ y 3 rs. \\
\hline 136 serones nuevos & $34 \$$ \\
\hline 77 serones viejos & $13 \$$ y 6 rs. \\
\hline 121 arganas nuevas & $60 \$$ y 4 rs. \\
\hline 34 arganas viejas & $8 \$$ y 4 rs. \\
\hline
\end{tabular}

${ }^{2}$ Tablitas finas de madera que se utilizaba para cubrir techos. También era conocido como tejamanil. 


\begin{tabular}{|c|c|}
\hline \multicolumn{2}{|c|}{ INGENIO SANTA ANA DE LA JAGUA } \\
\hline 25 aparejos & $12 \$$ y 4 rs. \\
\hline 48 cobijas & $18 \$$ \\
\hline 11 cobijas nuevas & $5 \$$ y 4 rs. \\
\hline 2 gives & $1 \$$ \\
\hline 3 guayos & $6 \$$ \\
\hline 4 cargas de & $4 \$$ \\
\hline 2 botijas & $2 \$$ \\
\hline 1 cana & 6 rs. \\
\hline 4 bateas & $3 \$$ y 4 rs. \\
\hline 3 catres & $4 \$$ y 4 rs. \\
\hline 2 bancos & 6 rs. \\
\hline 2 mesas, una grande con cajón y otra más pequeña & $6 \$$ \\
\hline 1 mesa nueva & $2 \$$ \\
\hline 1 armadura de catre de viento & $1 \$$ y 4 rs. \\
\hline 4 silletas & $3 \$$ \\
\hline 1 silla y 1 ture & $1 \$$ y 6 rs. \\
\hline 1 tinaja & $1 \$$ y 4 rs. \\
\hline 1 alacena & $1 \$$ y 4 rs. \\
\hline 2 cajas de caoba & $6 \$$ \\
\hline 1 libro, Florilegio & $1 \$$ y 4 rs. \\
\hline 2 tablas de caoba & $2 \$$ \\
\hline 4 candados nuevos y 3 viejos & $4 \$$ y 2 rs. \\
\hline$\dot{i}$ ¿' & $1 \$$ y 2 rs. \\
\hline 1 silla de montar con su freno, estribos y cabezadas & $6 \$$ \\
\hline 1 botas de cuero & 4 rs. \\
\hline 1 quitasol & 4 rs. \\
\hline 1 lebrillo de hoja de lata & $1 \mathrm{rs}$. \\
\hline 2 cafeteras, una de cobre y otra de arojar & $1 \$$ y 6 rs. \\
\hline 1 taza de loza & 4 rs. \\
\hline 4 escopetas compuestas de nuevas & $16 \$$ \\
\hline 1 sábana de coleta & $1 \$$ \\
\hline 3 platones y 3 platos de peltre maltratados & $4 \$$ \\
\hline 2 calderos de hierro & $2 \$$ y 2 rs. \\
\hline 1 pailita de cobre & $1 \$$ y 4 rs. \\
\hline 1 almirez & $1 \$$ y 4 rs. \\
\hline 1 paila de cobre grande & $9 \$$ \\
\hline 1 parrilla de hierro compuesta de nueva & $1 \$$ y 4 rs. \\
\hline 2 hojas de sierra & $5 \$$ \\
\hline 2 sierras de trozar & $3 \$$ \\
\hline 5 sierras y 1 serrucho & $11 \$$ y 4 rs. \\
\hline 2 suelas nuevas & $4 \$$ \\
\hline 1 buren de hierro & $10 \$$ \\
\hline 2 azetres nuevos & $16 \$$ \\
\hline 1 azetre viejo & $3 \$$ \\
\hline 2 suelas & $2 \$$ y 4 rs. \\
\hline 3 zachas de labrar nuevas & $6 \$$ \\
\hline 5 escoplos viejos y 2 gubias & $3 \$$ \\
\hline 6 escoplos nuevos y 1 gubia & $5 \$$ \\
\hline $\begin{array}{l}4 \text { barrenas de cuchara, una de gusano y dos de media } \\
\text { escoria }\end{array}$ & $10 \$$ y 4 rs. \\
\hline 7 coas & $3 \$$ y 4 rs. \\
\hline
\end{tabular}




\begin{tabular}{|c|c|}
\hline \multicolumn{2}{|c|}{ INGENIO SANTA ANA DE LA JAGUA } \\
\hline 7 planas de trabajar azúcar & $6 \$$ \\
\hline 1 caldero grande de hierro & $2 \$$ \\
\hline 2 aradores & 3 rs. \\
\hline 1 paila nueva grande & $25 \$$ \\
\hline 1 colador de cobre & $17 \$$ \\
\hline 1 chocolatera o una enfriadora & $3 \$$ \\
\hline 1 yunque & $8 \$$ \\
\hline 1 armadura del juez & $5 \$$ \\
\hline 1 tornillo grande de herrero & $8 \$$ \\
\hline ¿? & $2 \$$ \\
\hline 2 machos & $2 \$$ y 4 rs. \\
\hline 1 martillo de forjar & $1 \$$ \\
\hline 4 pares de tenazas & $2 \$$ \\
\hline 6 tufos & $1 \$$ y 4 rs. \\
\hline 5 claveras & $2 \$$ y 4 rs. \\
\hline 3 limas & $41 / 2$ rs. \\
\hline 4 buriles, 2 punzones y 4 cinceles & $1 \$$ \\
\hline 1 martillo de peña & 4 rs. \\
\hline 1 pan de estaño & 3 rs. \\
\hline 2 martillos nuevos & $1 \$$ y 4 rs. \\
\hline 1 estaca de hierro & $1 \$$ \\
\hline 2 tufos de lanzas & 6 rs. \\
\hline 2 brocas & 4 rs. \\
\hline 1 tufo de hacha & 4 rs. \\
\hline 1 entenada & $1 \$$ \\
\hline 20 libras de acero & $5 \$$ \\
\hline 4 barras de puerta de hierro & $3 \$$ y 2 rs. \\
\hline Garabatos $^{3}$ de hierro & $1 \$$ \\
\hline 2 platinas de hierro con cuatro arrobas & $10 \$$ \\
\hline 1 romana & $14 \$$ \\
\hline 2 pernos de ingenio & $3 \$$ y 2 rs. \\
\hline 32 cuñas de tambor & $4 \$$ \\
\hline 6 coas de azúcar & $3 \$$ \\
\hline 2 pasadores & $1 \$$ \\
\hline 1 plomada de albañil sin cordel & 4 rs. \\
\hline 1 garlopa & $1 \$$ y 4 rs. \\
\hline 1 juntera & 4 rs. \\
\hline 2 argollas de arrastrar & 6 rs. \\
\hline 44 calabozos & $33 \$$ \\
\hline 46 azadas nuevas & $23 \$$ \\
\hline 16 hachas & $24 \$$ \\
\hline 5 hachas viejas & $4 \$$ y 6 rs. \\
\hline 24 azadas viejas & $4 \$$ y 4 rs. \\
\hline 1 cedazo & 2 rs. \\
\hline 1 guariquitel & $3 \$$ \\
\hline 3 prisiones & $3 \$$ \\
\hline 3 pares de grillos & $3 \$$ \\
\hline 3 barras de prisión & $6 \$$ \\
\hline 1 barra grande de prisión & $3 \$$ \\
\hline
\end{tabular}

\footnotetext{
${ }^{3}$ Un tipo de vara larga.
} 
INGENIO SANTA ANA DE LA JAGUA

\begin{tabular}{|c|c|}
\hline 4 moldes de hierro de hacer teja & $1 \$$ y 4 rs. \\
\hline 1 tenazas & $4 \mathrm{rs}$. \\
\hline 1 pico de hierro & 5 rs. \\
\hline 2 pies de cabra de hierro & $5 \$$ \\
\hline 1 bisagras & 4 rs. \\
\hline 1 mandarrias y 2 cuñas & 4 rs. \\
\hline 3 prisiones de la garganta & 3 rs. \\
\hline 2 coitas pequeñas & 4 rs. \\
\hline 2 macetas de apretar azúcar & 4 rs. \\
\hline 1 agua manil & 2 rs. \\
\hline 2 hierros de galafate & $1 \$$ \\
\hline $\begin{array}{l}1 \text { ramada de la hormería, con } 2 \text { tornos, } 1 \text { puerta, } 6 \\
\text { moldes de ladrillo, un par de tapiales, y } 1 \text { puerta de } 2 \\
\text { hojas }\end{array}$ & $20 \$$ \\
\hline ¿? & $2 \$$ y 4 rs. \\
\hline
\end{tabular}

\begin{tabular}{|l|r|r|r|}
\hline \multicolumn{1}{|c|}{ Esclavos } & Casta & $\begin{array}{c}\text { Edad/ } \\
\text { años }\end{array}$ & Valor en pesos \\
\hline Ferenciano Pacheco & & & 280 \\
\hline María Magallanes & & 50 & 150 \\
\hline
\end{tabular}

\begin{tabular}{|l|l|r|r|}
\hline María Magallanes & & 50 & 150 \\
\hline Josefa & Mina & 80 & 25 \\
\hline Anton
\end{tabular}

\begin{tabular}{|l|l|r|r|}
\hline Antonio de Jesús & & 60 & 80 \\
\hline Magdalena & Carabalí & 70 & 70 \\
\hline Juna
\end{tabular}

\begin{tabular}{|c|c|c|}
\hline \begin{tabular}{|l|} 
Juan Bautista \\
\end{tabular} & 80 & 25 \\
\hline Félix del Rosario & 70 & 150 \\
\hline Juan Ignacio de Ayala & 70 & 50 \\
\hline
\end{tabular}

\begin{tabular}{|l|r|r|}
\hline Victoria María & & 50 \\
\hline Felipe Brinón & & 60 \\
\hline
\end{tabular}

\begin{tabular}{|l|l|l|}
\hline Felipe Briñón & & 60 \\
\hline Farcila Franco & Mandinga & 50 \\
\hline María Gallardo & & 80 \\
\hline
\end{tabular}

\begin{tabular}{|l|l|r|}
\hline Petronila de Sierra & & 45 \\
\hline Jerónima, hija de la anterior & & 10 mes \\
\hline Apolinario & Mandinga & 49 \\
\hline Pascio
\end{tabular}

\begin{tabular}{|l|l|r|}
\hline Pascuala Díaz & Criolla & 30 \\
\hline Catalina Brisón & & 30 \\
\hline
\end{tabular}

\begin{tabular}{|l|l|r|r|}
\hline Catalina Brisón & & 30 & 225 \\
\hline Torcuato, marido de la anterior & & 40 & 270 \\
\hline Ignacia, hija de los anteriores & & 5 meses & 30 \\
\hline María Manuela & Nagó & 36 & 275 \\
\hline José, marido de la anterior & Nagó & 39 & 250 \\
\hline Melchor & Mina & 45 & 300 \\
\hline Escolástica Teresa & Criolla & 30 & 225 \\
\hline José Antonio Pilichen & Boruco & 40 & 275 \\
\hline Vicente Muñoz & Mondongo & 40 & 225 \\
\hline Lucrecia & Criolla & 40 & 50 \\
\hline Jaime de Jesús & & 40 & 275 \\
\hline Gregorio Méndez & Boruco & 40 & 250 \\
\hline Vitorina de Ayala & & 25 & 250 \\
\hline Román & & 25 & 270 \\
\hline $\begin{array}{l}\text { Prudencia, mujer del } \\
\text { antecedente }\end{array}$ & Criolla & 25 & 250 \\
\hline
\end{tabular}

${ }^{4}$ Oficial de carpintería y sordo. 
Ruth Torres Agudo

\begin{tabular}{|c|c|c|c|}
\hline \multicolumn{4}{|c|}{ INGENIO SANTA ANA DE LA JAGUA } \\
\hline Manuela, hija de los anteriores & & 1 & 50 \\
\hline Constantino & Criollo & 25 & 270 \\
\hline Apolonia & Criolla & 30 & 250 \\
\hline Casilda, hija de la anterior & & 4 meses & 30 \\
\hline Clara & Criolla & 26 & 260 \\
\hline Casilda Díaz & Criolla & 48 & 150 \\
\hline Casimiro & Criollo & 80 & 40 \\
\hline Juan Servanto $^{5}$ & Boruco & 35 & 125 \\
\hline Agustín de la Concepción & Mandinga & 40 & 225 \\
\hline Rafael & Congo & 25 & 240 \\
\hline Constanza & Criolla & 35 & 250 \\
\hline ¿? & Criolla & 20 & 260 \\
\hline Lorenzo Plasencia & Criollo & 14 & 140 \\
\hline Andrés Pacheco & Criollo & 13 & 130 \\
\hline Borja del Rosario & Criollo & 13 & 130 \\
\hline Marcelo de Ayala & Criollo & 10 & 90 \\
\hline Esteban & Criollo & 12 & 110 \\
\hline Juan Evangelista & Criollo & 9 & 100 \\
\hline Alberto Gallardo & Criollo & 9 & 85 \\
\hline Simpliciano & Criollo & 8 & 103 \\
\hline Romualdo & Criollo & 7 & 70 \\
\hline Alvidoro & Criollo & 14 & 125 \\
\hline Sebastián & Criollo & 8 & 85 \\
\hline Lucas & Criollo & 7 & 65 \\
\hline Nicomedes & Criollo & 16 & 145 \\
\hline Bernardina & Criolla & 20 & 230 \\
\hline Alejo & Criollo & 6 & 60 \\
\hline 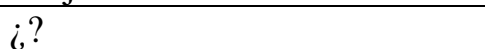 & Criolla & 22 & 250 \\
\hline Águeda & Criolla & 20 & 250 \\
\hline $\begin{array}{l}\text { María Antonia, hija de la } \\
\text { anterior }\end{array}$ & Criolla & $\begin{array}{l}1 \text { año y } \\
4 \text { meses }\end{array}$ & 50 \\
\hline Gracia Gallardo & Criolla & 20 & 150 \\
\hline $\begin{array}{l}\text { Josefa Eduvigi, hija de la } \\
\text { anterior }\end{array}$ & & 2 & 45 \\
\hline Luisa & Nagó & 20 & 235 \\
\hline Eleuteria & Criolla & 20 & 190 \\
\hline Leonor de Plasencia & Criolla & 15 & 135 \\
\hline Creencia & Criolla & 16 & 135 \\
\hline Tomasina Xaviera & Criolla & 15 & 130 \\
\hline María Belén Ramírez & Criolla & 16 & 158 \\
\hline Hindaleza Piluche & Criolla & 14 & 115 \\
\hline Vicente Gallardo & & 10 & 90 \\
\hline Severina & Criolla & 10 & 95 \\
\hline Casimira & Criolla & 10 & 90 \\
\hline Juana de la Cruz & Criolla & 10 & 90 \\
\hline Pelagia & Criolla & 8 & 85 \\
\hline Candida & Criolla & 7 & 60 \\
\hline Marcelina & Criolla & 7 & 75 \\
\hline Blacina Piliche & Criolla & 7 & 75 \\
\hline
\end{tabular}

\footnotetext{
${ }^{5}$ Tiene una pierna hinchada.
} 
Anexos

\begin{tabular}{|c|c|c|c|}
\hline \multicolumn{4}{|c|}{ INGENIO SANTA ANA DE LA JAGUA } \\
\hline Justa & Criolla & 11 & 100 \\
\hline Idefonsa & Criolla & 8 & 75 \\
\hline Lugarda & Criolla & 9 & 75 \\
\hline Marcelina de Ayala & & 16 & 140 \\
\hline Ana Santiago & Criolla & 5 & 65 \\
\hline Gabriel & Criollo & 5 & 65 \\
\hline Luisa de la Concepción & Mondongo & 35 & 225 \\
\hline Julián Caballero & & 44 & 250 \\
\hline Petronila & Criolla & 5 & 60 \\
\hline Andrea & Criolla & 4 & 50 \\
\hline Juana Díaz & Criolla & 4 & 45 \\
\hline Manuel, hijo de Catalina & & 3 & 50 \\
\hline Manuel, hijo de Victorina & & 4 & 50 \\
\hline María Timotea & Criolla & 3 & 45 \\
\hline Pedro de Rojas & Criollo & 45 & 180 \\
\hline Dionisio & Criollo & 13 & 120 \\
\hline Salvadora & Criolla & 9 & 75 \\
\hline Lucía de la Concepción & & 39 & 200 \\
\hline Ignacia Monica & Criolla & 30 & 200 \\
\hline Gordiano & Criollo & 14 & 125 \\
\hline Pablo & Criollo & 35 & 175 \\
\hline Leonardo & Criollo & 2 & 35 \\
\hline Pablo & & 29 & 280 \\
\hline $\begin{array}{l}\text { Micaela Servata, mujer del } \\
\text { anterior }\end{array}$ & & & 250 \\
\hline Ninfa Modesta & & 36 & 250 \\
\hline Clemencia & Criolla & 16 & 170 \\
\hline Eligio & Criollo & 13 & 140 \\
\hline Antonio de la Concepción & & 4 & 70 \\
\hline Tomás Gabriel & & 10 & 150 \\
\hline Domingo & & 9 & 125 \\
\hline Miguel & & 6 & 115 \\
\hline Teresa Custodia & & 3 & 60 \\
\hline María Petronila & Criolla & 57 & 200 \\
\hline
\end{tabular}




\begin{tabular}{|c|c|}
\hline \multicolumn{2}{|c|}{ HATO PIZARRETE } \\
\hline & $\begin{array}{c}\text { Valor en pesos } \\
\text { y reales }\end{array}$ \\
\hline \multicolumn{2}{|l|}{ ANIMALES } \\
\hline 255 reses & $1.530 \$$ \\
\hline 15 yeguas madres & $300 \$$ \\
\hline 19 caballos, 4 capados y el resto enteros & $495 \$$ \\
\hline 5 potros del año pasado & $60 \$$ \\
\hline 4 potros del año pasado & $32 \$$ \\
\hline 1 potra criolla de 2 años & $16 \$$ \\
\hline 5 perros & $20 \$$ \\
\hline 16 puercos y 6 marranitos & $17 \$$ y 4 rs. \\
\hline 25 cabras & $25 \$$ \\
\hline \multicolumn{2}{|l|}{ ESCLAVOS } \\
\hline Juan Ambrosio & $200 \$$ \\
\hline \multicolumn{2}{|l|}{ UTENSILIOS } \\
\hline 1 mesita de caoba & $2 \$$ \\
\hline 2 tarros de ordeñar & $1 \$$ \\
\hline 1 canoa & $1 \$$ y 4 rs. \\
\hline 1 canoa vieja & 2 rs. \\
\hline 2 zachas viejas & $1 \$$ \\
\hline 2 lanzas de mala vida & $1 \$$ \\
\hline \multicolumn{2}{|l|}{ CASAS } \\
\hline Bohío & $20 \$$ \\
\hline Bohío ramada & $8 \$$ \\
\hline \multicolumn{2}{|l|}{ CORRALES } \\
\hline 1 corral de ganado con su chiquero & $25 \$$ \\
\hline TIERRAS DEL HATO & $3000 \$$ \\
\hline Total & 5.755 \$ y 2 rs. \\
\hline
\end{tabular}

\begin{tabular}{|c|c|}
\hline \multicolumn{2}{|c|}{ POTRERO DEL RIO ARRIBA } \\
\hline & Valor en pesos \\
\hline \multicolumn{2}{|l|}{ ANIMALES } \\
\hline 16 yeguas & 320 \\
\hline 3 yeguas criollas de 3 años & 60 \\
\hline 5 yeguas criollas de 9 meses & 40 \\
\hline 1 yegua criolla de año & 12 \\
\hline 1 yegua criolla de 3 años & 16 \\
\hline 1 caballo tornudo & 20 \\
\hline 1 caballo capado & 30 \\
\hline 3 potros (padrotres) & 90 \\
\hline 3 mulas y 2 mulos & 125 \\
\hline 1 burro hechor 6 & 40 \\
\hline $\begin{array}{l}\text { TIERRAS DEL POTRERO comprendidas } \\
\text { entre el Arroyo Iguana y la angostura del } \\
\text { río Nizao quedando en medio las lomas de }\end{array}$ & 500 \\
\hline
\end{tabular}

${ }^{6}$ El burro hechor también llamado padrote "es aquel semental que se destina a las yeguas", en Moreau de Saint-Méry, M. L. E., Descripción de la parte española de Santo Domingo. Ciudad Trujillo, 1944, p. 397. 


\begin{tabular}{|l|r|}
\hline \multicolumn{2}{|c|}{ POTRERO DEL RIO ARRIBA } \\
\hline Bardecia & \\
\hline Total & 1.253 \\
\hline
\end{tabular}

\begin{tabular}{|c|c|}
\hline \multicolumn{2}{|c|}{ HATO DE YAGUETE } \\
\hline & $\begin{array}{l}\text { Valor en pesos } \\
\text { y reales }\end{array}$ \\
\hline \multicolumn{2}{|l|}{ ANIMALES } \\
\hline 153 reses & $918 \$$ \\
\hline 1 caballo blanco tornudo & $25 \$$ \\
\hline 3 yeguas & $60 \$$ \\
\hline 1 potro del año pasado & $8 \$$ \\
\hline 40 cabras & $40 \$$ \\
\hline 1 perra & $4 \$$ \\
\hline \multicolumn{2}{|l|}{ CORRALES } \\
\hline Corral de las cabras & $2 \$$ \\
\hline Corral del ganado & $15 \$$ \\
\hline \multicolumn{2}{|l|}{ ESCLAVOS } \\
\hline $\begin{array}{l}1 \text { esclavo mayoral, Ignacio Javier de } 32 \\
\text { años (criollo) }\end{array}$ & $280 \$$ \\
\hline 1 esclava, Ana de 17 años & $220 \$$ \\
\hline \multicolumn{2}{|l|}{ UTENSILIOS } \\
\hline 2 tarros de ordeñar & $1 \$$ y 4 rs. \\
\hline 1 cocina & $4 \$$ \\
\hline 1 pilón & $1 \$$ \\
\hline \multicolumn{2}{|l|}{ CASAS } \\
\hline $\begin{array}{l}\text { Bohío cobijado de guano y cercado de } \\
\text { caña }\end{array}$ & $6 \$$ \\
\hline TIERRAS DEL HATO & $1.500 \$$ \\
\hline Total & 3.084 \$ y 4 rs. \\
\hline
\end{tabular}

TIERRAS EN LAS MONTERÍAS DEL

RÍO NIZAO y sobre el río Ocoa

\begin{tabular}{|l|r|}
\hline \multicolumn{2}{|c|}{ HATO YABACAO } \\
\hline \multicolumn{2}{|c|}{ ANIMALES } \\
\hline 1.100 reses vacunos & Valor en pesos \\
\hline 70 caballos & 14.400 \\
\hline Total & 500 \\
\hline Fábricas y muebles & $\mathbf{1 4 . 9 0 0}$ \\
\hline Total &
\end{tabular}




\begin{tabular}{|l|r|}
\hline \multicolumn{2}{|c|}{ HATO ARROYO HONDO } \\
\hline \multicolumn{2}{|c|}{} \\
\hline ANIMALES & Valor en pesos \\
\hline Ganado menor y, bestias caballares & 3.000 \\
\hline
\end{tabular}

Fuentes: Certificación del inventario corregida con el expediente original realizada por el escribano Jose Maria Rodríguez, Santo Domingo 12 de noviembre de 1796. AGI, Santo Domingo, 2683. Relacion jurada de Nicolas Guridi y Fromesta del valor actual de las fincas, Santo Domingo terminador año Once Frances. AGI, Ultramar 9. 
Tabla 8. Inventario de las haciendas de Lorenzo Angulo Medrano, 1795

\begin{tabular}{|c|c|}
\hline \multicolumn{2}{|c|}{ INGENIO SANTA ANA DE ENGOMBE } \\
\hline & $\begin{array}{c}\text { Valor en pesos } \\
\text { y reales }\end{array}$ \\
\hline \multicolumn{2}{|l|}{ FUNDO } \\
\hline 9 caballerías de tierra & $2.700 \$$ \\
\hline \multicolumn{2}{|l|}{ IGLESIA } \\
\hline Iglesia de cal y canto con las imágenes y demás adornos & $1.100 \$$ \\
\hline 1 Santísima Cruz & $1 \$$ \\
\hline 2 vinagreras de plata & $4 \$$ \\
\hline 1 platillo y campanilla de metal & $1 \$$ \\
\hline 1 cáliz y patena & $8 \mathrm{rs}$. \\
\hline 1 campana & $26 \$$ \\
\hline 1 campanario & $4 \$$ \\
\hline 2 candeleros de metal & $1 \$$ \\
\hline 1 misal nuevo & $9 \$$ \\
\hline 1 ornamento nuevo & $41 \$$ \\
\hline 1 esterita & $1 \$$ y 4 rs. \\
\hline 4 candeleros dorados & $2 \$$ y 4 rs. \\
\hline 1 frontal nuevo de lienzo pintado & $6 \$$ \\
\hline \multicolumn{2}{|l|}{ CASA VIVIENDA } \\
\hline Casa vivienda de fábrica de piedra de cantería & $4300 \$$ \\
\hline 1 crucifijo & $1 \$$ \\
\hline 1 cama de barandilla & $6 \$$ \\
\hline 2 catres de espalda antiguos & $6 \$$ \\
\hline 2 catres nuevos de armadura & $10 \$$ \\
\hline 2 catres nuevos sin armadura & $8 \$$ \\
\hline 1 tarima & $2 \$$ \\
\hline 3 sillas de brazos & $4 \$$ y 4 rs. \\
\hline 12 sillas de paja & $12 \$$ \\
\hline 3 tures & $2 \$$ y 4 rs. \\
\hline 1 mesa grande de armadura & $2 \$$ y 4 rs. \\
\hline 1 mesa & $4 \$$ \\
\hline 1 mesa con su cajón & 20 rs. \\
\hline 1 mesa maltratada & 12 rs. \\
\hline 1 mesita pequeña & $10 \mathrm{rs}$. \\
\hline 2 candeleros & $1 \$$ \\
\hline 1 calderito & $1 \$$ \\
\hline 1 calderito viejo & $6 \mathrm{rs}$. \\
\hline 1 almirez con su mano & $3 \$$ y 4 rs. \\
\hline $\begin{array}{l}1 \text { cocina con sus anafes, horno, } 3 \text { divisiones y sus } \\
\text { contracimientos }\end{array}$ & $100 \$$ \\
\hline 1 paila de mano & $15 \$$ \\
\hline BOHÍO de mayordomo & $25 \$$ \\
\hline 1 gallinero & $20 \$$ \\
\hline La cerca del patio y hortaliza & $12 \$$ \\
\hline El cercado con 510 varas de palizada firme & $143 \$$ y 6 rs. \\
\hline 1 horno de quemar hormas & $25 \$$ \\
\hline 1 horno de quemar cal & $12 \$$ \\
\hline \multicolumn{2}{|l|}{ CASAS DE TRABAJO } \\
\hline
\end{tabular}




\begin{tabular}{|c|c|}
\hline \multicolumn{2}{|l|}{ INGENIO SANTA ANA DE ENGOMBE } \\
\hline techo de yaguas & \\
\hline Los tendales de tablasón de caobán nuevos con 432 agujeros & $162 \$$ \\
\hline 7 canoas de todos tamaños & $112 \$$ \\
\hline 800 hormas buenas & $300 \$$ \\
\hline 60 hormas maltratadas & $11 \$$ y 2 rs. \\
\hline 400 potes & $65 \$$ \\
\hline LA CASA DE HERRERÍA, de cal y canto, con techo caído & $100 \$$ \\
\hline $\begin{array}{l}1 \text { casa sin techo de paredes de cal y canto que sirve de } \\
\text { aguardentería }\end{array}$ & $175 \$$ \\
\hline 1 alambique grande con su cabezote y culebra & $125 \$$ \\
\hline 1 alambique mistelero con su cabezote y culebra & $38 \$$ y 6 rs. \\
\hline LA CASA DE INGENIO, de cal y canto cubierta de cogollo & $200 \$$ \\
\hline 1 juego del ingenio con su canal & $625 \$$ \\
\hline 1 tambor de bronce de respeto & $200 \$$ \\
\hline 1 espumaderas y bombas de servicio, 6 piezas & $14 \$$ \\
\hline 1 canoa del caldo con su canal & $20 \$$ \\
\hline 1 batería con sus 3 fondos, el de templar de cobre & $600 \$$ \\
\hline 1 fondo de templar pequeño & $30 \$$ \\
\hline $\begin{array}{l}\text { LA CASA DE CALDERAS, de cal y canto, con su techo de } \\
\text { yaguas }\end{array}$ & $300 \$$ \\
\hline 2 canoas grandes de echar melaos & $32 \$$ \\
\hline 3 bagateras para el bagazo & $60 \$$ \\
\hline 26 barriles para cargar mieles & $26 \$$ \\
\hline \multicolumn{2}{|l|}{ ANIMALES } \\
\hline 4 yeguas criollas & $40 \$$ \\
\hline 3 potras criollas & $36 \$$ \\
\hline 1 caballo criollo & $12 \$$ \\
\hline 10 mulas criollas & $210 \$$ \\
\hline 1 burro viejo & $12 \$$ \\
\hline 60 ovejas entre pequeñas y grandes & $90 \$$ \\
\hline 11 reses, entre chicas y grandes & $88 \$$ \\
\hline \multicolumn{2}{|l|}{ YUNTAS } \\
\hline 5 yuntas de bueyes & $200 \$$ \\
\hline 3 vacas paridas & $36 \$$ \\
\hline \multicolumn{2}{|l|}{ CORRALES } \\
\hline 1 corral de ovejas & $12 \$$ \\
\hline 1 corral de vacas & $10 \$$ \\
\hline 1 corral de mulas & $4 \$$ \\
\hline \multicolumn{2}{|l|}{ BARBECHOS } \\
\hline Barbecho Santa Rosa, de caña de hoja, 33 tareas & $231 \$$ \\
\hline Barbecho Carmen, 22 tareas de caña hoja & $52 \$$ y 4 rs. \\
\hline Barbecho San Carlos, 38 tareas de caña soca & $95 \$$ \\
\hline Barbecho San Ramón, 24 tareas de caña soca & $120 \$$ \\
\hline Barbecho San Lorenzo, 23 tareas de caña soca & $46 \$$ \\
\hline Barbecho San Miguel, 35 tareas de caña soca & $52 \$$ y 4 rs. \\
\hline Barbecho San Juan, 25 tareas de caña plantona & $62 \$$ y 4 rs. \\
\hline Barbecho San Pedro, 30 tareas de caña soca & $60 \$$ \\
\hline Barbecho San Andrés, 34 tareas de caña de soca & $68 \$$ \\
\hline Barbecho San Nicolás, 25 tareas de caña plantona & $25 \$$ \\
\hline Barbecho Santa Ana, 24 tareas de caña plantona & $24 \$$ \\
\hline Barbecho Santo Domingo, 18 tareas de caña plantona & $18 \$$ \\
\hline
\end{tabular}




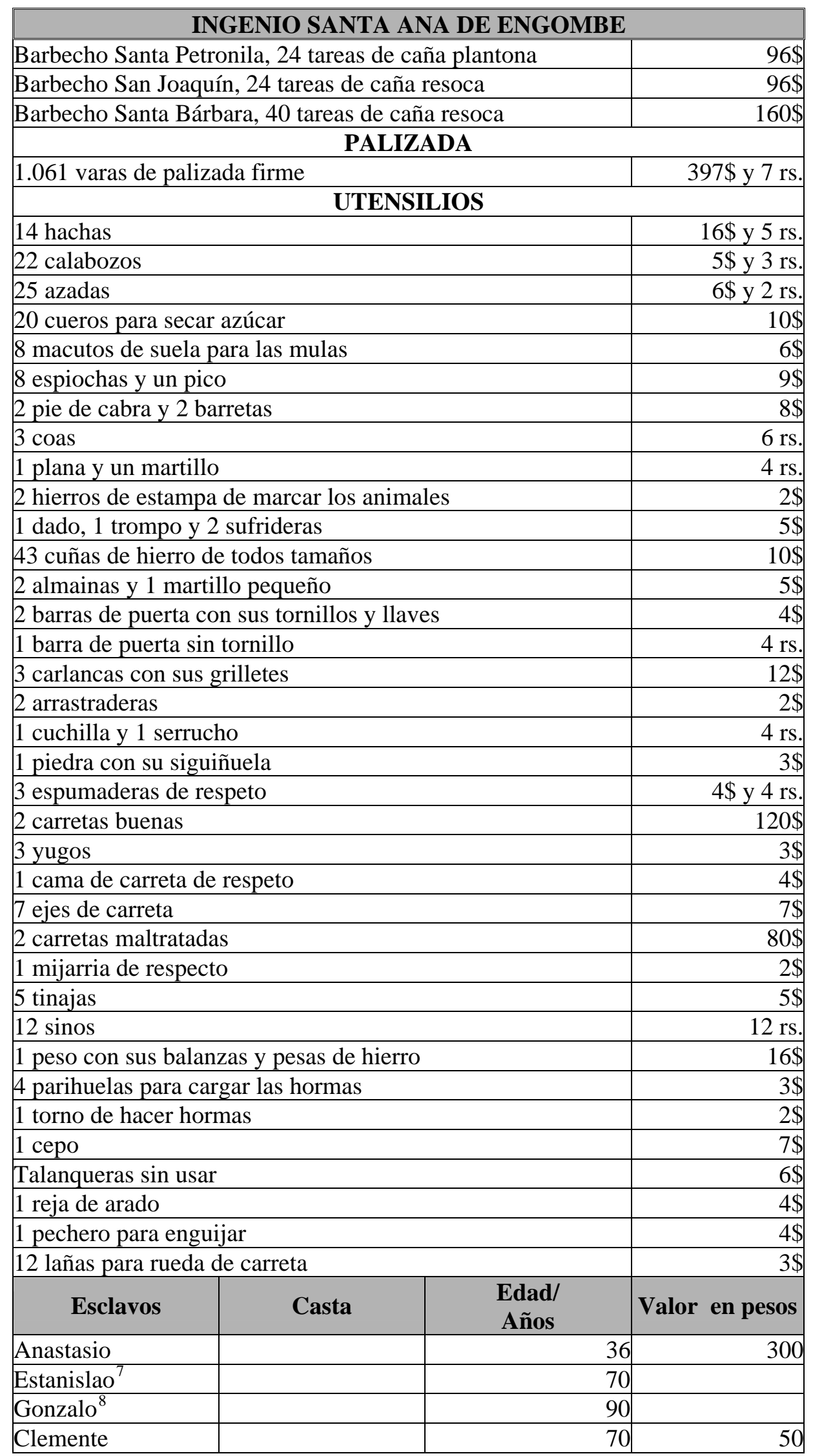

${ }^{7}$ Lisiado y tuerto, no se le dio valor por inútil.

${ }^{8}$ Por inútil no se le dio valor. 


\begin{tabular}{|c|c|c|}
\hline \multicolumn{3}{|c|}{ INGENIO SANTA ANA DE ENGOMBE } \\
\hline Cayetano $^{9}$ & 70 & 60 \\
\hline Valentín $^{10}$ & 50 & 50 \\
\hline Julián ${ }^{11}$ & 50 & 250 \\
\hline Francisco $^{12}$ & 40 & 250 \\
\hline Feliciano $^{13}$ & 40 & 230 \\
\hline Adrián ${ }^{14}$ & 40 & 300 \\
\hline Alfonso & 36 & 270 \\
\hline Bartolo & 40 & 200 \\
\hline Patricio & 33 & 260 \\
\hline José Caro & 40 & 250 \\
\hline Andrés Caro & 35 & 250 \\
\hline Luís & 23 & 250 \\
\hline Eugenio & 19 & 250 \\
\hline José & 17 & 250 \\
\hline Celestino $^{15}$ & 30 & 150 \\
\hline José & 3 & 40 \\
\hline María Francisca & 44 & 240 \\
\hline Catalina & 33 & 270 \\
\hline Isabel & 26 & 250 \\
\hline Ignacia & 45 & 220 \\
\hline Isabel & 54 & 80 \\
\hline Micaela & 70 & 30 \\
\hline Gregoria & 55 & 170 \\
\hline Petrona, con su hijo & 26 & 225 \\
\hline $\begin{array}{l}\text { María de los } \\
\text { Remedios }{ }^{17}\end{array}$ & 25 & 225 \\
\hline $\begin{array}{l}\text { María de los } \\
\text { Dolores }\end{array}$ & 22 & 280 \\
\hline María & 12 & 160 \\
\hline
\end{tabular}

\footnotetext{
${ }^{9}$ Aguardientero, lisiado de las piernas.

${ }^{10}$ Manco de un brazo.

${ }^{11}$ Quebrado, trabaja de albañil y hormero.

${ }^{12}$ Enfermo de una pierna, pero útil.

${ }^{13}$ Quebrado.

${ }^{14}$ Maestro de azúcar.

${ }^{15}$ Quebrado.

${ }^{16}$ Le da ahogo.

${ }^{17}$ Le suele dar gota.
} 


\begin{tabular}{|c|c|}
\hline \multicolumn{2}{|c|}{ ESTANCIA LOS COCOS } \\
\hline & $\begin{array}{c}\text { Valor en pesos } \\
\text { y reales }\end{array}$ \\
\hline \multicolumn{2}{|c|}{ TIERRAS DE LABRANZA } \\
\hline 2 caballerías de tierra & $300 \$$ \\
\hline 2.575 árboles de cacao paridero & $1931 \$$ y 2 rs. \\
\hline 34 palmas de coco & $102 \$$ \\
\hline \multicolumn{2}{|c|}{ PALIZADA } \\
\hline 330 varas de palizada firme & $123 \$$ y 6 rs. \\
\hline \multicolumn{2}{|c|}{ UTENSILIOS } \\
\hline 1 canoa de navegar & $35 \$$ \\
\hline \multicolumn{2}{|c|}{ ESCLAVOS } \\
\hline Fermín, 35 años ${ }^{18}$ & $230 \$$ \\
\hline Luisa & $70 \$$ \\
\hline
\end{tabular}

Fuentes: El inventario fue realizado el 16 de diciembre de 1795, en García Lluberes, L., "Miscelánea histórica. (Extractos de los Cuadernos de Apuntes del Historiador García). El Ingenio Santa Ana de Engonve”. CLÍO 102 (Ciudad Trujillo, 1955) pp. 39-44.

\footnotetext{
${ }^{18}$ Quebrado.
} 
Tabla 9. Inventario de las haciendas de Francisco Espaillat y Virol, 1787

\begin{tabular}{|c|c|}
\hline \multicolumn{2}{|l|}{ INGENIO DE SABANA GRANDE } \\
\hline & Valor en pesos \\
\hline \multicolumn{2}{|l|}{ CASAS } \\
\hline $\begin{array}{l}\text { JUEGO DE INGENIO, } 3 \text { tambores de moler y } 4 \text { mazas que } \\
\text { dan movimiento a las piezas elásticas o de resorte para escupir } \\
\text { el bagazo sin operario. Los avíos y utensilios están fabricados } \\
\text { a la inglesa, y traídos de la colonia francesa en carretas } \\
\text { tiradas de bueyes, con armadura o asiento, y con esclavos que } \\
\text { allanan el camino }\end{array}$ & 3.000 \\
\hline 11 parillas de hierro fundido para las hornallas de las pailas & 550 \\
\hline 6 pailas para cocer & 600 \\
\hline 8 carretas con cadenas y ejes de hierro & 800 \\
\hline $\begin{array}{l}1 \text { alambique de la continencia de } 3 \text { barricas para extraer } \\
\text { aguardiente }\end{array}$ & 500 \\
\hline $\begin{array}{l}\text { CASA DE MOLIENDA, consta de } 22 \text { varas de diámetro de } \\
\text { paredes de cal y piedra por dentro y fuera a la inglesa. Tiene } 7 \\
\text { pies de alto con } 16 \text { pilares de ladrillo y con bóvedas para } \\
\text { introducir la caña y sacar el bagazo. La carpintería es a la } \\
\text { francesa, con madera de caoba, aserrada y labrada con } \\
\text { cubierta de teja de barro }\end{array}$ & 4.000 \\
\hline $\begin{array}{l}\text { CASA DE CALDERAS, con una pared de } 66 \text { varas de largo } \\
\text { con un corredor de } 30 \text { sobre pilares y } 9 \text { varas, dos tercios de } \\
\text { ancho con } 4 \text { de alto sin los cimientos y una profundidad de } \\
\text { cuatro. } 5 \text { pailas asentadas a la inglesa }\end{array}$ & \\
\hline $\begin{array}{l}\text { CASA DE PURGA, con una pila para recibir miel y una } \\
\text { almbiquería separada con } 12 \text { pipas hechas de ladrillos con } \\
\text { mezcla fina de cal y ladrillo molido. Está cubierta toda de teja } \\
\text { de barro sobre carpintería a la francesa y consta de } 13 \\
\text { ventanas, rejas de hierro y } 10 \text { puertas de caoba aseguradas } \\
\text { con panturras }\end{array}$ & 10.000 \\
\hline \multicolumn{2}{|l|}{ TIERRAS DE LABRANZA } \\
\hline 9 barbechos de caña madura de 40 tareas conuqueras & 3.600 \\
\hline 4.000 pies de café, la mitad paridero & 750 \\
\hline 60 tareas conuqueras de platanar & 750 \\
\hline \multicolumn{2}{|l|}{ ANIMALES } \\
\hline 50 mulos de molienda de buen servicio y edad & 3.500 \\
\hline 12 caballos capados de servicio de la hacienda & 480 \\
\hline 30 bestias caballares de raza fina & 1.500 \\
\hline 18 yuntas de bueyes de servicio & 900 \\
\hline \multicolumn{2}{|l|}{ ESCLAVOS } \\
\hline 55 negros grandes de los cuáles 8 son párvulos ${ }^{19}$ & 13.750 \\
\hline Total & 44.680 \\
\hline
\end{tabular}

\footnotetext{
${ }^{19}$ Cada esclavo está valorado en 250 pesos.
} 


\section{INGENIO DE GURABITO}

\begin{tabular}{|c|c|}
\hline \multicolumn{2}{|l|}{ INGENIO DE GURABITO } \\
\hline & Valor en pesos \\
\hline \multicolumn{2}{|l|}{ CASAS } \\
\hline $\begin{array}{l}\text { CASA VIVIENDA,construida de tabla cubierta de teja de } \\
\text { barro y soladura de ladrillo de } 20 \text { varas de largo y } 10 \text { de ancho }\end{array}$ & 600 \\
\hline \multicolumn{2}{|l|}{ CASAS DE TRABAJO } \\
\hline $\begin{array}{l}\text { CASA DE MOLIENDA, de estantería de candelón, cubierta } \\
\text { de yagua, con } 3 \text { pailas y demás utensilios }\end{array}$ & 2.500 \\
\hline $\begin{array}{l}\text { CASA DE CALDERAS, de } 8 \text { varas de ancho, } 16 \text { de largo. } \\
\text { Está construida sobre cimientos de pared y viga entablada de } \\
\text { palma, con cubierta de teja de barro y hornallas de pared }\end{array}$ & 1.100 \\
\hline $\begin{array}{l}\text { Cocina, almacén grande con un cuarto separado, otro almacén } \\
\text { de burenes, el del mayordomo cubierto de yaguas, y la prisión } \\
\text { de pared y tejas }\end{array}$ & 500 \\
\hline \multicolumn{2}{|l|}{ TIERRAS DE LABRANZA } \\
\hline 4 barbechos de caña de todos tiempos & 960 \\
\hline 40 tareas de platanar con 4.000 matas & 500 \\
\hline \multicolumn{2}{|l|}{ PALIZADA } \\
\hline $\begin{array}{l}\text { Cercado que comprende más de media legua de tierra con su } \\
\text { agua, hecha a mano y el correspondiente desmonte }\end{array}$ & 1.500 \\
\hline \multicolumn{2}{|l|}{ ANIMALES } \\
\hline 80 reses & 800 \\
\hline 18 mulas de servicio & 1.260 \\
\hline 55 bestias de todas calidades y edades & 1.250 \\
\hline 5 burros & 75 \\
\hline \multicolumn{2}{|l|}{ ESCLAVOS } \\
\hline 25 negros, todos de servicio y buena edad ${ }^{20}$ & 6.500 \\
\hline Total & 17.545 \\
\hline
\end{tabular}

\section{INGENIO LA ANGOSTURA}

CASA VIVIENDA, con 20 varas de largo y 7 de ancho con corredores por ambos frentes de 3 varas y media de largo y ancho. Forrados la sala y cuarto principal por tablas de madera de caoba aserradas, y labradas sobre cimientos de pared de 2 varas de profundidad; la cubierta de teja de barro con 5 escalones de pared y ladrillo que ocupan su frente y terminan en 2 pilastras de paredes que forman un patio solado de ladrillo con 2 cuadrantes solares de las cuales sale una pared de más de 50 varas de largo y 2 y media de alto formando un cuadro de una vara más alta que el antecedente.

ERMITA, a 30 varas de la casa, es de igual latitud y tiene 7 escalones de ladrillo y mezcla por ambos costados guarnecido de un parral, y de flores de diferentes especies.

${ }^{20}$ Cada esclavo está valorado en 260 pesos. 


\section{INGENIO LA ANGOSTURA}

HOSPITAL, situado ambos lados de la ermita. Mide 17 varas de largo y 7 de ancho sobre cimientos de pared y soladura de ladrillo con cubierta de teja. Tiene un cuarto que es la botica.

ALMACÉN Y FÁBRICA, para recibir los frutos e índigo, con las mismas medidas que el hospital.

CASA PARA SECAR EL AÑIL, de 24 varas de largo y 7 de ancho, de pared cubierta de teja.

PATIO, cerrado de pared y en él un puente con dos paredes de 12 varas de alto y tres de grueso, en sus cimientos de mayor a menor corre 80 varas de largo en donde está hecha una conejera de pared de más de 20 varas de largo, 5 de ancho solada de ladrillo y un trecho cubierto de teja por debajo del cual pasa un arroyo donde nace una pared de 4 varas de grueso y entre 5 y 6 de altura, y de 13 de longitud con el fin de recoger y las aguas para la fábrica del añil

CAÑO, con una compuerta fabricado de mezcla fina de longitud de 140 varas y una profundidad en partes de 7 para tomar los niveles de la conclusión de las aguas a las indigoterías, abovedado y solado 4 Indigoterías fabricada de mezcla fina COCINA, al lado de la casa, de 18 varas de largo y 6 de ancho cubierta de teja con 2 cuartos aforrados de pared y solada de ladrillo

CÁRCEL, de 4 varas de ancho y largo de pared solada de ladrillo y cubierta de teja, surtida de prisiones

GALLINERO, en simetría con los palomares de 20 varas de largo y 6 de ancho cubierto de teja

POZO, de 8 varas de profundidad fabricado de pared con una bomba para atraer el agua que sirve de riego

CASABERA, (lugar común) de 25 varas de largo y 8 de ancho con 2 burenes

FRAGUA Y CARPINTERÍA, con los utensilios de ambos oficios, todo con un largo de 35 varas y 6 de ancho con 3 divisiones. Todo sobre cimientos de pared y cubierto de tablita

\begin{tabular}{|l|r|}
\hline \multicolumn{2}{|c|}{ ANIMALES } \\
\hline 250 reses & 2.500 \\
\hline 50 bestias de buena casta & 2.000 \\
\hline 200 cerdos de crianza & 200 \\
\hline \multicolumn{2}{|c|}{ TIERRAS DE LABRANZA } \\
\hline 1.400 matas de plátano 175 \\
\hline \multicolumn{2}{|c|}{ ESCLAVOS } \\
\hline 8 negros útiles & $\mathbf{1 9 . 1 1 5}$ \\
\hline Total
\end{tabular}


Anexos

\begin{tabular}{|c|c|}
\hline \multicolumn{2}{|l|}{ ESTANCIA LOS CIRUELOS } \\
\hline & Valor en pesos \\
\hline \multicolumn{2}{|l|}{ TIERRAS DE LABRANZA } \\
\hline 10.000 árboles de café & 1.250 \\
\hline 8.000 matas de plátano & 1.000 \\
\hline \multicolumn{2}{|l|}{ UTENSILIOS } \\
\hline $\begin{array}{l}2 \text { hornos , } 1 \text { pila grande de mezcla, cercado y } 2 \text { tamadas } \\
\text { grandes y regular }\end{array}$ & 500 \\
\hline 2 carretas y 2 yuntas de bueyes & 300 \\
\hline \multicolumn{2}{|l|}{ ESCLAVOS } \\
\hline 12 esclavos iguales ${ }^{21}$ & 3.360 \\
\hline 8 esclavos $^{22}$ & 1.920 \\
\hline Total & 8.330 \\
\hline
\end{tabular}

Fuentes: Campillo Pérez, J., Francisco Espaillat..., op. cit., pp. 129-140. Todo lo inventariado procede de esta obra.

${ }^{21}$ Cada esclavo apreciado en 280 pesos.

${ }^{22}$ Cada esclavo apreciado en 240 pesos. 
Tabla 10. Inventario de las haciendas de José de la Vega, 1805

\begin{tabular}{|c|c|}
\hline \multicolumn{2}{|l|}{ INGENIO MATA NARANJO } \\
\hline & \begin{tabular}{|c|} 
Valor en pesos \\
y reales
\end{tabular} \\
\hline \multicolumn{2}{|l|}{ FUNDO } \\
\hline 3 caballerías de tierra & $1.140 \$$ \\
\hline HERMITA & $425 \$$ \\
\hline Campanario con 3 campanas & $97 \$$ \\
\hline Cercado en que están las viviendas y oficinas & $782 \$$ \\
\hline \multicolumn{2}{|l|}{ CASAS } \\
\hline CASA VIVIENDA & $1.110 \$$ \\
\hline Muebles de servidumbre en ella & $110 \$$ \\
\hline \multicolumn{2}{|l|}{ Cocina unida con la aguardentería } \\
\hline CASA DE INGENIO, con la máquina o molino & $1.410 \$$ \\
\hline CASA DE CALDERAS, con su batería & $1.339 \$$ \\
\hline $\begin{array}{l}\text { CASA DE PURGA, con sus tendales, hormas, canoas y } \\
\text { demás utensilios }\end{array}$ & $1.221 \$$ \\
\hline AGUARDENTERÍA, con la cocina a que está unida & $164 \$$ \\
\hline Bagazeras & $60 \$$ \\
\hline Ramada de hormería con horno & $34 \$$ \\
\hline Palomar & $30 \$$ \\
\hline Gallinero & $20 \$$ \\
\hline Ovejería & $54 \$$ \\
\hline Horno para quemar hormas y otro para quemar cal & $170 \$$ \\
\hline Norta con pilas para el agua con su máquina corriente & $600 \$$ \\
\hline Reloj de sol en columna de ladrillo & $6 \$$ \\
\hline \multicolumn{2}{|l|}{ UTENSILIOS } \\
\hline Carretas & $337 \$$ \\
\hline Utensilios sueltos & $90 \$$ \\
\hline Prisiones & $25 \$$ \\
\hline Herramienta de carpintería & $47 \$$ \\
\hline Herramienta de labranza & $47 \$$ \\
\hline Piedra de amolar & $12 \$$ \\
\hline \multicolumn{2}{|l|}{ Aparejos de recua $^{23}$} \\
\hline \multicolumn{2}{|l|}{ ANIMALES } \\
\hline 63 mulas & $3.285 \$$ \\
\hline 2 caballos de silla & $140 \$$ \\
\hline 5 yeguas de cría & $50 \$$ \\
\hline 1 potro & $110 \$$ \\
\hline 2 caballos de carga & $12 \$$ \\
\hline 1 burra & $20 \$$ \\
\hline 1 burro hechor & $80 \$$ \\
\hline 5 vacas & $50 \$$ \\
\hline 37 bueyes & $10 \$$ \\
\hline 4 becerros & $24 \$$ \\
\hline caballeriza & $13 \$$ y 4 rs. \\
\hline \multicolumn{2}{|l|}{ TIERRAS DE LABRANZA } \\
\hline Huerta y frutales con cerca de limón & $63 \$$ y 4 rs. \\
\hline
\end{tabular}

\footnotetext{
${ }^{23}$ Se anotan sin darles avalúo.
} 


\begin{tabular}{|c|c|}
\hline \multicolumn{2}{|l|}{ INGENIO MATA NARANJO } \\
\hline $\begin{array}{l}2.135 \text { varas conuqueras de } 3 \text { varas castellanas, de cerca de } \\
\text { labranzas }\end{array}$ & $300 \$$ y 5 rs. \\
\hline $\begin{array}{l}\text { Los cañaverales que están bajo de dicha cerca viva de javilla } \\
\text { y limón }\end{array}$ & $1.327 \$$ y 4 rs. \\
\hline Labranza de yuca, maíz y batatas, bajo de dicha cerca & $97 \$$ y 4 rs. \\
\hline Potreros para pasto, bajo de la misma & $50 \$$ y 4 rs. \\
\hline $\begin{array}{l}\text { Labranza con } 2.607 \text { árboles de cacao paridero y orqueteado; } \\
309 \text { pies de café; } 3.107 \text { matas de plátanos; árboles de sombrío } \\
\text { de bucar y aguacates contigua a los cañaverales, con } 560 \\
\text { varas conuqueras, que hacen } 1.680 \text { varas castellanas de cerca } \\
\text { de dicha javilla viva que la dividen de ellos por una parte y } \\
\text { por la otra un arroyo }\end{array}$ & $2.921 \$$ y 1 rs. \\
\hline \multicolumn{2}{|l|}{ ESCLAVOS } \\
\hline 34 varones & $8.405 \$$ \\
\hline 16 hembras & $3.685 \$$ \\
\hline 1 muchachos & $60 \$$ \\
\hline 4 muchachas & $460 \$$ \\
\hline 3 esclavos de pecho & $190 \$$ \\
\hline Total & $33.353 \$$ y 6 rs. \\
\hline
\end{tabular}

\begin{tabular}{|l|r|}
\hline \multicolumn{2}{|c|}{ ESTANCIA GUAXIMIA, unida al ingenio } \\
\hline \multicolumn{1}{|c|}{ FUNDO } & $\begin{array}{c}\text { Valor en pesos } \\
\text { y reales }\end{array}$ \\
\hline \multicolumn{1}{|c|}{$380 \$$} \\
\hline $\begin{array}{l}\text { El caballería de tierra } \\
\text { frutales }\end{array}$ & $207 \$$ y 2 rs. \\
\hline Total & $\mathbf{5 8 7 \$}$ y $\mathbf{2}$ rs. \\
\hline
\end{tabular}

\begin{tabular}{|c|c|}
\hline \multicolumn{2}{|c|}{ HATILLO YACÓ } \\
\hline & Valor en pesos \\
\hline \multicolumn{2}{|c|}{ FUNDO } \\
\hline 7 caballerías y media de tierra & 2.350 \\
\hline BOHÍO de vivienda & 25 \\
\hline \multicolumn{2}{|c|}{ ANIMALES } \\
\hline 186 reses de crianza & 1.316 \\
\hline 6 bestias & 150 \\
\hline 17 puercos de crianza & 17 \\
\hline \multicolumn{2}{|c|}{ ESCLAVOS } \\
\hline 2 esclavos & 580 \\
\hline Total & 4.438 \\
\hline
\end{tabular}




\begin{tabular}{|c|c|}
\hline \multicolumn{2}{|l|}{ HATILLO MATA NARANJO } \\
\hline & Valor en pesos \\
\hline \multicolumn{2}{|l|}{ FUNDO } \\
\hline $\begin{array}{l}6 \text { caballerías de tierra, distante cinco leguas al oeste de Santo } \\
\text { Domingo, en la jurisdicción en que está el ingenio }\end{array}$ & 1.560 \\
\hline Total & 1560 \\
\hline \multicolumn{2}{|c|}{ TIERRA EN LA CAMPIÑA DE LA VILLA DEL SEYBO } \\
\hline & Valor en pesos \\
\hline \multicolumn{2}{|l|}{ TIERRA } \\
\hline Una parte de tierra para corte de madera & 35 \\
\hline
\end{tabular}

Fuentes: El inventario fue realizado el 15 de junio de 1805, en Resumen de los vienes que comprende el antecedente abaluo propio del Capitan Joseph de la Vega, 15 de junio de 1805. AGI, Santo Domingo, 964. 
Tabla 11. Relación de licencias de víveres concedidas por el gobernador Manuel Azlor y Urríes, 1760-1771

\begin{tabular}{|c|c|c|c|c|c|}
\hline $\begin{array}{l}\text { Fecha de } \\
\text { licencias }\end{array}$ & $\begin{array}{l}\text { Nombre de la } \\
\text { embarcación }\end{array}$ & $\begin{array}{c}\text { Nombre de la } \\
\text { nación } \\
\text { extranjera }\end{array}$ & $\begin{array}{l}\text { Nombre del } \\
\text { capitán }\end{array}$ & $\begin{array}{c}\mathrm{N}^{0} \mathrm{de} \\
\text { licencias }\end{array}$ & $\begin{array}{l}\text { Vistas Fiscales, } \\
\text { dictamen del } \\
\text { Asesor e informe } \\
\text { de Comisarios }\end{array}$ \\
\hline $\begin{array}{l}28 \text { de julio de } \\
1760\end{array}$ & $\begin{array}{l}\text { Nuestra Señora de la } \\
\text { Luz }\end{array}$ & & Gerardo Carry & 1 & \\
\hline $\begin{array}{l}5 \text { de julio de } \\
1761\end{array}$ & Balandra Santa Rosa & Curazao & Carlos Brisony & 1 & \\
\hline $\begin{array}{l}22 \text { de enero de } \\
1762\end{array}$ & \begin{tabular}{|l} 
Balandra Nuestra \\
Señora de la \\
Misericordia
\end{tabular} & & $\begin{array}{l}\text { Domingo } \\
\text { Sánchez }\end{array}$ & 1 & \\
\hline $\begin{array}{l}23 \text { de enero de } \\
1762\end{array}$ & Balandra Santa Rita & & Ignacio Moreno & 1 & \\
\hline $\begin{array}{l}26 \text { de enero de } \\
1762\end{array}$ & \begin{tabular}{|l|} 
Balandra Juan \\
Nepomuceno
\end{tabular} & & Pedro Coral & 1 & \\
\hline $\begin{array}{l}28 \text { de enero de } \\
1762\end{array}$ & & & Juan Bustamante & 1 & \\
\hline $\begin{array}{l}16 \text { de febrero } \\
\text { de } 1762\end{array}$ & Balandra & & Miguel Parrendo & 1 & \\
\hline $\begin{array}{l}22 \text { de febrero } \\
\text { de } 1762\end{array}$ & & & $\begin{array}{l}\text { Diego Trauca y } \\
\text { Lavastida }\end{array}$ & 1 & $\begin{array}{l}\begin{array}{l}\text { Dictamen del } \\
\text { asesor }\end{array} \\
\end{array}$ \\
\hline $\begin{array}{l}4 \text { de marzo de } \\
1762\end{array}$ & $\begin{array}{l}\text { Balandra Santa } \\
\text { Susana }\end{array}$ & & $\begin{array}{l}\text { Francisco } \\
\text { Aguirre }\end{array}$ & 1 & \\
\hline $\begin{array}{l}22 \text { de marzo } \\
\text { de } 1762\end{array}$ & $\begin{array}{l}\text { Balandra Nuestra } \\
\text { Señora de la Luz } \\
\end{array}$ & & Juan de Burgos & 1 & \\
\hline $\begin{array}{l}17 \text { de abril de } \\
1762\end{array}$ & Balandra o goletas & Curazao & \begin{tabular}{|l|} 
Juan Nicolás \\
Clas
\end{tabular} & 2 & $\begin{array}{l}\text { Dictamen del } \\
\text { asesor }\end{array}$ \\
\hline $\begin{array}{l}14 \text { de mayo de } \\
1762\end{array}$ & $\begin{array}{l}\text { Goleta Santo Cristo } \\
\text { Buen Viajero }\end{array}$ & & Antonio de Rojas & 1 & \\
\hline $\begin{array}{l}9 \text { de junio de } \\
1762\end{array}$ & & Holandés & Jacobo Seot & 1 & \\
\hline $\begin{array}{l}9 \text { de junio de } \\
1762\end{array}$ & & Holandés & Juan Flemen & 1 & \\
\hline $\begin{array}{l}9 \text { de julio de } \\
1762 \\
\end{array}$ & \begin{tabular}{|l|l|} 
Balandra Nuestra \\
Señora de la Luz
\end{tabular} & & Juan de Burgos & 1 & \\
\hline $\begin{array}{l}3 \text { de } \\
\text { septiembre de } \\
1762\end{array}$ & & & $\begin{array}{l}\text { José Clemente } \\
\text { Montaño }\end{array}$ & 1 & \\
\hline $\begin{array}{l}4 \text { de } \\
\text { septiembre de } \\
1762\end{array}$ & & & $\begin{array}{l}\text { Francisco de } \\
\text { Soto }\end{array}$ & 1 & \\
\hline $\begin{array}{l}9 \text { de } \\
\text { septiembre de } \\
1762\end{array}$ & & & José de Vargas & 1 & \\
\hline $\begin{array}{l}14 \text { de } \\
\text { septiembre de } \\
1762\end{array}$ & & & $\begin{array}{l}\text { Juan Bautista } \\
\text { Alemán }\end{array}$ & 1 & \\
\hline $\begin{array}{l}0 \text { de } \\
\text { septiembre de } \\
1762\end{array}$ & & Curazao & $\begin{array}{l}\text { Guillermo la } \\
\text { Reyna }\end{array}$ & 1 & \\
\hline
\end{tabular}


Ruth Torres Agudo

\begin{tabular}{|c|c|c|c|c|c|}
\hline $\begin{array}{l}\text { Fecha de } \\
\text { licencias }\end{array}$ & $\begin{array}{l}\text { Nombre de la } \\
\text { embarcación }\end{array}$ & $\begin{array}{c}\text { Nombre de la } \\
\text { nación } \\
\text { extranjera }\end{array}$ & $\begin{array}{l}\text { Nombre del } \\
\text { capitán }\end{array}$ & $\begin{array}{c}\mathrm{N}^{\circ} \mathrm{de} \\
\text { licencias }\end{array}$ & $\begin{array}{c}\text { Vistas Fiscales, } \\
\text { dictamen del } \\
\text { Asesor e informe } \\
\text { de Comisarios }\end{array}$ \\
\hline $\begin{array}{l}30 \text { de } \\
\text { septiembre de } \\
1762\end{array}$ & & Curazao & Juan Corona & 1 & \\
\hline $\begin{array}{l}13 \text { de octubre } \\
\text { de } 1762\end{array}$ & Balandra la María & Curazao & Carlos Brisony & 1 & \\
\hline $\begin{array}{l}27 \text { de octubre } \\
\text { de } 1762\end{array}$ & $\begin{array}{l}\text { Balandra la Madre } \\
\text { Santísima de la Luz }\end{array}$ & & Juan de Burgos & 1 & \\
\hline $\begin{array}{l}24 \text { de } \\
\text { diciembre de } \\
1762\end{array}$ & & & José de Barrios & 1 & \\
\hline $\begin{array}{l}30 \text { de } \\
\text { diciembre de } \\
1762 \\
\end{array}$ & Balandra la Sirena & & José Imber & 1 & \\
\hline $\begin{array}{l}5 \text { de enero de } \\
1763\end{array}$ & \begin{tabular}{|l|} 
Goleta Nuestra \\
Señora del Rosario
\end{tabular} & & José Blanco & 1 & \\
\hline $\begin{array}{l}5 \text { de enero de } \\
1763\end{array}$ & $\begin{array}{l}\text { Goleta Nuestra } \\
\text { Señora del Rosario }\end{array}$ & & \begin{tabular}{|l} 
Pedro Antonio \\
Betancurt
\end{tabular} & 1 & \\
\hline $\begin{array}{l}18 \text { de enero de } \\
1763\end{array}$ & & & \begin{tabular}{|l} 
Jerónimo \\
Canales
\end{tabular} & 1 & \\
\hline $\begin{array}{l}25 \text { de enero de } \\
1763\end{array}$ & & Holandés & Juan Flemen & 1 & \\
\hline $\begin{array}{l}4 \text { de febrero } \\
\text { de } 1763\end{array}$ & $\begin{array}{l}\text { Goleta Votra } \\
\text { Embarcación }\end{array}$ & & Manuel Valerio & 1 & \\
\hline $\begin{array}{l}23 \text { de marzo } \\
\text { de } 1763\end{array}$ & Barco San Juan & & $\begin{array}{l}\text { Juan Bautista } \\
\text { Alemán }\end{array}$ & 1 & \\
\hline $\begin{array}{l}28 \text { de junio de } \\
1763\end{array}$ & $\begin{array}{l}\text { Balandra la Madre } \\
\text { Santísima de la Luz }\end{array}$ & & Juan de Burgos & 1 & \\
\hline $\begin{array}{l}4 \text { de julio de } \\
1763\end{array}$ & Balandra San Luís & & Antonio de Rojas & 1 & Vista del fiscal \\
\hline $\begin{array}{l}7 \text { de julio de } \\
1763\end{array}$ & & & Santiago Labrose & 1 & \\
\hline $\begin{array}{l}21 \text { de agosto } \\
\text { de } 1763\end{array}$ & & & Francisco Díaz & 1 & \\
\hline $\begin{array}{l}2 \text { de } \\
\text { noviembre de } \\
1763\end{array}$ & \begin{tabular}{|l} 
Balandra Nuestra \\
Señora del Rosario
\end{tabular} & & José Palomino & 1 & \begin{tabular}{|l|} 
Vista del fiscal e \\
informe del guarda \\
almacén
\end{tabular} \\
\hline $\begin{array}{l}25 \text { de } \\
\text { noviembre de } \\
1763\end{array}$ & $\begin{array}{l}\text { Balandra la Madre } \\
\text { Santísima de la Luz }\end{array}$ & & Juan de Burgos & 1 & \\
\hline $\begin{array}{l}19 \text { de } \\
\text { diciembre de } \\
1763\end{array}$ & $\begin{array}{l}\text { Bergantín la } \\
\text { Carolina }\end{array}$ & & Pedro Coral & 1 & \\
\hline $\begin{array}{l}14 \text { de julio de } \\
1764\end{array}$ & $\begin{array}{l}\text { Balandra San José y } \\
\text { las Animas }\end{array}$ & & Pedro Masias & 1 & \\
\hline $\begin{array}{l}20 \text { de julio de } \\
1764\end{array}$ & Balandra San Luís & & Manuel Ramos & 1 & \\
\hline $\begin{array}{l}24 \text { de julio de } \\
1764\end{array}$ & $\begin{array}{l}\text { Bergantín la } \\
\text { Carolina }\end{array}$ & & Pedro Coral & 1 & \\
\hline 1 de agosto de & \begin{tabular}{|l|} 
Balandra la Madre \\
\end{tabular} & & José Pérez de & 1 & \\
\hline
\end{tabular}




\begin{tabular}{|c|c|c|c|c|c|}
\hline $\begin{array}{l}\text { Fecha de } \\
\text { licencias }\end{array}$ & $\begin{array}{l}\text { Nombre de la } \\
\text { embarcación }\end{array}$ & $\begin{array}{c}\text { Nombre de la } \\
\text { nación } \\
\text { extranjera }\end{array}$ & $\begin{array}{l}\text { Nombre del } \\
\text { capitán }\end{array}$ & $\begin{array}{c}N^{0} \text { de } \\
\text { licencias }\end{array}$ & $\begin{array}{l}\text { Vistas Fiscales, } \\
\text { dictamen del } \\
\text { Asesor e informe } \\
\text { de Comisarios }\end{array}$ \\
\hline 1764 & Santísima de la Luz & & Mena & & \\
\hline $\begin{array}{l}4 \text { de } \\
\text { septiembre de } \\
1764\end{array}$ & Balandra el Lobo & Inglés & George Estuar & 1 & Vista del fiscal \\
\hline $\begin{array}{l}22 \text { de octubre } \\
\text { de } 1764\end{array}$ & \begin{tabular}{|l} 
Balandra el \\
Santísimo Cristo \\
\end{tabular} & & Miguel Ferrer & 1 & \\
\hline $\begin{array}{l}24 \text { de octubre } \\
\text { de } 1764\end{array}$ & Balandra & & Antonio Sánchez & 1 & \\
\hline $\begin{array}{l}19 \text { de enero de } \\
1765\end{array}$ & \begin{tabular}{|l} 
Bergantín Nuestra \\
Señora de la Luz
\end{tabular} & & Pedro Coral & 1 & \\
\hline $\begin{array}{l}13 \text { de abril de } \\
1765\end{array}$ & & Inglés & George Estuar & 1 & \\
\hline $\begin{array}{l}16 \text { de abril de } \\
1765\end{array}$ & & & Lorenzo Daniel & 1 & $\begin{array}{l}\text { Vista del fiscal e } \\
\text { informe de } \\
\text { comisarios }\end{array}$ \\
\hline $\begin{array}{l}6 \text { de agosto de } \\
1765\end{array}$ & Balandra Carlos III & & \begin{tabular}{|l} 
Miguel de \\
Arismendi \\
\end{tabular} & 1 & \\
\hline $\begin{array}{l}7 \text { de agosto de } \\
1765\end{array}$ & Balandra San José & & $\begin{array}{l}\text { Juan Miguel de } \\
\text { Paz }\end{array}$ & 1 & \\
\hline $\begin{array}{l}24 \text { de agosto } \\
\text { de } 1765\end{array}$ & $\begin{array}{l}\text { Balandra Nuestra } \\
\text { Señora del Rosario }\end{array}$ & & Pedro Ponte & 1 & \\
\hline $\begin{array}{l}24 \text { de agosto } \\
\text { de } 1765\end{array}$ & Balandra el Lobo & Inglés & George Estuar & 1 & \\
\hline $\begin{array}{l}24 \text { de agosto } \\
\text { de } 1765\end{array}$ & $\begin{array}{l}\text { Balandra Señora de } \\
\text { la Luz }\end{array}$ & & Juan de Burgos & 1 & \\
\hline $\begin{array}{l}26 \text { de } \\
\text { noviembre de } \\
1765 \\
\end{array}$ & \begin{tabular}{|l} 
Goleta Nuestra \\
Señora de las \\
Mercedes \\
\end{tabular} & & \begin{tabular}{|l|} 
Nicolás \\
Violones
\end{tabular} & 1 & \\
\hline $\begin{array}{l}27 \text { de } \\
\text { noviembre de } \\
1765\end{array}$ & Balandra Carlos III & & $\begin{array}{l}\text { Miguel Antonio } \\
\text { Arismendi }\end{array}$ & 1 & \\
\hline $\begin{array}{l}16 \text { de } \\
\text { diciembre de } \\
1765\end{array}$ & \begin{tabular}{|l} 
Balandra Nuestra \\
Señora del Rosario
\end{tabular} & & Pedro Ponte & 1 & \\
\hline $\begin{array}{l}18 \text { de enero de } \\
1766\end{array}$ & $\begin{array}{l}\text { Bergantín Nuestra } \\
\text { Señora de la Luz }\end{array}$ & & Pedro Coral & 1 & \\
\hline $\begin{array}{l}15 \text { de enero de } \\
1766\end{array}$ & \begin{tabular}{|l} 
Balandra Madre \\
Santísima de la Luz
\end{tabular} & & José Palomino & 1 & \\
\hline $\begin{array}{l}17 \text { de febrero } \\
\text { de } 1766\end{array}$ & $\begin{array}{l}\text { Balandra Nuestra } \\
\text { Señora de la Luz }\end{array}$ & & Juan de Burgos & 1 & \\
\hline $\begin{array}{l}11 \text { de junio de } \\
1766\end{array}$ & & & José Zamora & 1 & \\
\hline $\begin{array}{l}7 \text { de julio de } \\
1766\end{array}$ & \begin{tabular}{|l} 
Balandra Nuestra \\
Señora de la \\
Concepción
\end{tabular} & & Antonio Pérez & 1 & \\
\hline $\begin{array}{l}8 \text { de agosto de } \\
1766\end{array}$ & Balandra San Luis & & $\begin{array}{l}\text { Luís Espinosa } \\
\text { Martel }\end{array}$ & 1 & \\
\hline $\begin{array}{l}1 \text { de } \\
\text { septiembre de }\end{array}$ & $\begin{array}{l}\text { Balandra Nuestra } \\
\text { Señora de la Luz }\end{array}$ & & $\begin{array}{l}\text { José Pérez de } \\
\text { Mena }\end{array}$ & 1 & \\
\hline
\end{tabular}


Ruth Torres Agudo

\begin{tabular}{|c|c|c|c|c|c|}
\hline $\begin{array}{l}\text { Fecha de } \\
\text { licencias }\end{array}$ & $\begin{array}{l}\text { Nombre de la } \\
\text { embarcación }\end{array}$ & $\begin{array}{c}\text { Nombre de la } \\
\text { nación } \\
\text { extranjera }\end{array}$ & $\begin{array}{l}\text { Nombre del } \\
\text { capitán }\end{array}$ & $\begin{array}{c}\mathrm{N}^{\circ} \mathrm{de} \\
\text { licencias }\end{array}$ & $\begin{array}{c}\text { Vistas Fiscales, } \\
\text { dictamen del } \\
\text { Asesor e informe } \\
\text { de Comisarios }\end{array}$ \\
\hline \multicolumn{6}{|l|}{1766} \\
\hline $\begin{array}{l}19 \text { de } \\
\text { septiembre de } \\
1766\end{array}$ & $\begin{array}{l}\text { Bergantín el } \\
\text { Caulican }\end{array}$ & & Lorenzo Daniel & 1 & \\
\hline $\begin{array}{l}22 \text { de } \\
\text { diciembre de } \\
1766\end{array}$ & \begin{tabular}{|l|} 
Embarcación \\
Nuestra Señora de la \\
Luz
\end{tabular} & & José Palomino & 1 & \\
\hline $\begin{array}{l}3 \text { de julio de } \\
1767\end{array}$ & \begin{tabular}{|l|} 
Balandra Nuestra \\
Señora de Begoña
\end{tabular} & & Nicolás García & 1 & \\
\hline $\begin{array}{l}5 \text { de agosto de } \\
1767\end{array}$ & $\begin{array}{l}\text { Nuestra Señora de la } \\
\text { Soledad }\end{array}$ & & Pedro Betancurt & 1 & \\
\hline $\begin{array}{l}27 \text { agosto de } \\
1767\end{array}$ & $\begin{array}{l}\text { Nuestra Señora del } \\
\text { Amparo }\end{array}$ & & José Zamora & 1 & \\
\hline $\begin{array}{l}18 \text { de } \\
\text { septiembre de } \\
1767\end{array}$ & \begin{tabular}{|l|} 
Balandra la Madre \\
Santísima de la Luz
\end{tabular} & & Juan de Burgos & 1 & \\
\hline $\begin{array}{l}18 \text { de } \\
\text { septiembre de } \\
1767\end{array}$ & Bergantín & & Lorenzo Daniel & 1 & \\
\hline $\begin{array}{l}18 \text { de } \\
\text { septiembre de } \\
1767\end{array}$ & Barco & & José Zamora & 1 & \\
\hline $\begin{array}{l}19 \text { de } \\
\text { septiembre de } \\
1767\end{array}$ & Bergantín el Galgo & & Pedro Olaeta & 1 & \\
\hline $\begin{array}{l}\text { 24 de marzo } \\
\text { de } 1768\end{array}$ & & & Antonio López & 1 & \\
\hline $\begin{array}{l}12 \text { de julio de } \\
1768\end{array}$ & Balandra la Victoria & & José Coll & 1 & $\begin{array}{l}\text { Informe de } \\
\text { comisarios }\end{array}$ \\
\hline $\begin{array}{l}2 \text { de } \\
\text { septiembre de } \\
1768\end{array}$ & Balandra & & José Palomino & 1 & $\begin{array}{l}\text { Informe de } \\
\text { comisarios }\end{array}$ \\
\hline $\begin{array}{l}9 \text { de } \\
\text { septiembre de } \\
1768 \\
\end{array}$ & Balandra Santa Rosa & & José Laverre & 1 & $\begin{array}{l}\text { Informe de } \\
\text { comisarios }\end{array}$ \\
\hline $\begin{array}{l}10 \text { de } \\
\text { noviembre de } \\
1768\end{array}$ & Balandra San Carlos & & Antonio de Rojas & 1 & \\
\hline $\begin{array}{l}4 \text { de febrero } \\
\text { de } 1769\end{array}$ & Balandra & & José Zamora & 1 & \\
\hline 2 de marzo & \begin{tabular}{|l|} 
Balandra la \\
Voluntad de Dios
\end{tabular} & & Melchor Benites & 1 & \\
\hline 4 de marzo & $\begin{array}{l}\text { Balandra Nuestra } \\
\text { Señora de las } \\
\text { Mercedes }\end{array}$ & & Juan Molina & 1 & \\
\hline 4 mayo & $\begin{array}{l}\text { Balandra la madre } \\
\text { Santísima de la Luz }\end{array}$ & & José Palomino & 1 & \\
\hline $\begin{array}{l}17 \text { de mayo de } \\
1769\end{array}$ & \begin{tabular}{|l} 
Balandra la \\
Esperanza
\end{tabular} & & Felipe Ibáñez & 1 & \\
\hline
\end{tabular}




\begin{tabular}{|c|c|c|c|c|c|}
\hline $\begin{array}{l}\text { Fecha de } \\
\text { licencias }\end{array}$ & $\begin{array}{l}\text { Nombre de la } \\
\text { embarcación }\end{array}$ & $\begin{array}{c}\text { Nombre de la } \\
\text { nación } \\
\text { extranjera }\end{array}$ & $\begin{array}{l}\text { Nombre del } \\
\text { capitán }\end{array}$ & $\begin{array}{c}\mathrm{N}^{\circ} \mathrm{de} \\
\text { licencias }\end{array}$ & $\begin{array}{l}\text { Vistas Fiscales, } \\
\text { dictamen del } \\
\text { Asesor e informe } \\
\text { de Comisarios }\end{array}$ \\
\hline $\begin{array}{l}8 \text { de julio de } \\
1769\end{array}$ & $\begin{array}{l}\text { Balandra Nuestra } \\
\text { Señora del Rosario }\end{array}$ & & $\begin{array}{l}\text { Juan Bautista } \\
\text { Acosta }\end{array}$ & 1 & \\
\hline $\begin{array}{l}5 \text { de agosto de } \\
1769\end{array}$ & & & Felipe Ibáñez & 1 & \\
\hline 8 de agosto & $\begin{array}{l}\text { Goleta Nuestra } \\
\text { Señora de la Caridad }\end{array}$ & & Pedro Pinto & 1 & \\
\hline 8 de agosto & $\begin{array}{l}\text { Balandra Nuestra } \\
\text { Señora del Pilar }\end{array}$ & & $\begin{array}{l}\text { Domingo } \\
\text { Sánchez }\end{array}$ & 1 & \\
\hline 31 de agosto & Balandra & & Jaime Pascual & 1 & \\
\hline $\begin{array}{l}15 \text { de } \\
\text { septiembre }\end{array}$ & Barco & & José Martínez & 1 & \\
\hline $\begin{array}{l}10 \text { de febrero } \\
\text { de } 1770\end{array}$ & \begin{tabular}{|l|} 
Goleta Nuestra \\
Señora la Candelaria
\end{tabular} & & Jaime Jacoisti & 1 & $\begin{array}{l}\text { Informes del } \\
\text { factor y } \\
\text { comisarios }\end{array}$ \\
\hline $\begin{array}{l}24 \text { de julio de } \\
1770\end{array}$ & Balandra San Carlos & & Gerardo Carry & 1 & \\
\hline $\begin{array}{l}1 \text { de agosto de } \\
1770\end{array}$ & $\begin{array}{l}\text { Goleta Nuestra } \\
\text { Señora de } \\
\text { Guadalupe }\end{array}$ & & José Coll & 1 & \\
\hline $\begin{array}{l}18 \text { de octubre } \\
\text { de } 1770\end{array}$ & Balandra San Carlos & & Gerardo Carry & 1 & \\
\hline $\begin{array}{l}3 \text { noviembre } \\
\text { de } 1770\end{array}$ & Balandra la Mariana & & $\begin{array}{l}\text { Francisco } \\
\text { Sasturre }\end{array}$ & 1 & \\
\hline $\begin{array}{l}21 \text { de } \\
\text { noviembre de } \\
1770\end{array}$ & $\begin{array}{l}\text { Goleta Nuestra } \\
\text { Señora de } \\
\text { Guadalupe }\end{array}$ & & José Coll & 1 & \\
\hline $\begin{array}{l}11 \text { de enero de } \\
1771\end{array}$ & $\begin{array}{l}\text { Balandra Nuestra } \\
\text { Señora del Rosario }\end{array}$ & & Pedro Coral & 1 & \\
\hline $\begin{array}{l}29 \text { de enero de } \\
1771\end{array}$ & $\begin{array}{l}\text { Balandra la María } \\
\text { del Agua }\end{array}$ & & Juan Gatell & 1 & \\
\hline $\begin{array}{l}18 \text { de febrero } \\
\text { de } 1771\end{array}$ & Balandra la Mariana & & \begin{tabular}{|l|} 
Francisco \\
Sasturre \\
\end{tabular} & 1 & \\
\hline $\begin{array}{l}20 \text { de marzo } \\
\text { de } 1771\end{array}$ & $\begin{array}{l}\begin{array}{l}\text { Balandra la María } \\
\text { del Agua }\end{array} \\
\end{array}$ & & Juan Gatell & 1 & \\
\hline \multicolumn{4}{|l|}{ Total } & 98 & \\
\hline
\end{tabular}

Fuentes: Relación de entrada de embarcaciones en el puerto de Santo Domingo, 16 de agosto de 1771. AGI, Santo Domingo, 968. 